MARÍA DEL CARMEN CORTÉS ZABORRAS

\title{
LA EXPRESIÓN DEL EROTISMO EN LAS NOVELAS FRANCESAS DE LOS SIG LOS XII Y XIII
}

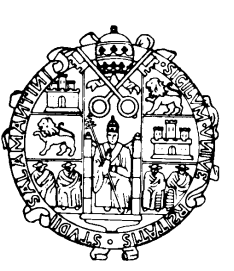

EDICIONES UNIVERSIDAD DE SALAMANCA 


\section{COLECCIÓN VITOR \\ 61 \\ C}

Ediciones Universidad de Salamanca y María del Carmen Cortés Zaborras

$1^{a}$ edición: Diciembre, 2000

I.S.B.N. : 84-7800-900-0

Depósito Legal: S.1560 -2000

Ediciones Universidad de Salamanca

Apartado postal 325

E-37080 Salamanca (España)

Realización:

Nemática, S.L.

Impreso en España - Printed in Spain

Todos los derechos reservados. Ni la totalidad ni parte de este libro puede reproducirse ni transmitirse sin permiso escrito de

Ediciones Universidad de Salamanca

$\kappa$

CEP. Servicio de Bibliotecas

La expresión del erotismo en las novelas francesas

de los siglos XII y XIII [Archivo de ordenador]/María del Carmen Cortés Zaborras. $-1^{a}$ ed.-Salamanca : Ediciones Universidad de Salamanca, 2000

1 disco compacto.-(Colección Vítor ; 61)

Tesis-Universidad de Salamanca, 2000

1. Universidad de Salamanca (España)- Tesis y disertaciones académicas.

2. Novela francesa-Anterior a 1500-Historia y crítica. 3. Erotismo en la literatura

821.133.1-31.09 “11/12”(043.2) 


\section{RESUMEN}

Esta tesis tiene por objeto los enunciados que contienen una cierta dosis de erotismo. El corpus está constituido por cuatro textos literarios en verso: Le roman de Tristan de Béroul, Le chevalier de la Charrete de Chrétien de Troyes, del siglo XII, L'E scoufle de Jean Renart y Le Roman de la Rose de Guillaume de Lorris del siglo XIII.

Cuatro son las preguntas a las que se ha querido responder y que constituyen otros tantos objetivos para el trabajo:

¿Cómo funcionan los elementos formales que permiten expresar las relaciones erótico-amorosas entre los personajes?

¿Cuál es el modo en que se intenta despertar la libido de los receptores de los relatos?

¿Qué elementos coinciden en los cuatro textos o en algunos de ellos y en cuáles divergen?

¿Qué fundamentos ideológicos, culturales y estéticos cimientan la expresión de la sexualidad en los romans?

Para responder a estas preguntas se parte de un análisis morfológico de todas las palabras del corpus. Este análisis permite eliminar la ambigüedad léxica y poner de manifiesto las estructuras sintácticas en las que se insertan los términos escogidos por su carga significativa. Junto a los recursos léxicos y gramaticales se estudian otros fenómenos retóricos como la posición en el verso o los mecanismos de transposición. A la explicación estilística se unen ciertas consideraciones de tipo enunciativo y pragmático. 
La metodología se asienta sobre dos pilares básicos: un minucioso estudio formal y la adopción de criterios y conceptos de los diferentes campos de las humanidades.

El análisis léxico y sintáctico de los términos del registro amoroso se divide en dos grandes apartados: las denominaciones de los individuos implicados en la relación erótica y los componentes de dicha relación: el sentimiento amoroso y la pasión, el deseo, la percepción sensorial, el contacto físico y el placer. 


\begin{abstract}
The object of this thesis concerns the enunciations that contain a certain dose of eroticism. Four literary texts in verse compose the corpus: Béroul's L e Roman de Tristan and Chrétien de Troyes' L e chevalier de la Charrete of the $12^{\text {th }}$ century; Jean Renart's L'E scoufle and Guillaume de Lorris' Le Roman de la Rose of the $13^{\text {th }}$ century.
\end{abstract}

The purposes of the work were to answer these four questions:

1. How do the formal units work in order to express the erotic relations of the characters?

2. How do the Romances try to awaken the receivers' sexual desire?

3. Which are the components shared by the texts and the components in which they differ?

4. Which are the ideological, cultural and aesthetic grounds that underlie the expression of sexuality in the Romances?

The first step of the study is a morphological analysis of all the words in the corpus. This analysis eliminates the lexical ambiguity and reveals the syntactic structures where the terms chosen for their sensual meaning are included. Some other rhetorical resources, such as the position in the verse or the transposition mechanisms, are studied together with the lexical and grammatical ones. Some enunciative and pragmatic considerations join the explanation of the stylistic means.

The methodology rests upon two mainstays: firstly, a thorough formal analysis, and secondly, the application of concepts coming from the different fields of the humanities. 
The lexical and syntactic analysis of the terms expressing love relations is divided into two parts:

-on one hand the denominations of the individuals who are involved in the erotic relationship;

-on the other hand, the components of such relations - love feeling and passion, desire, sensorial perception, physical contact and pleasure- 


\section{TABLA DE CONTENIDO}

INTRODUCCIÓN.

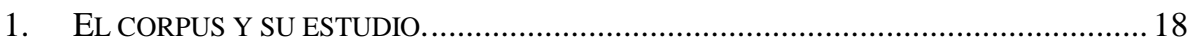

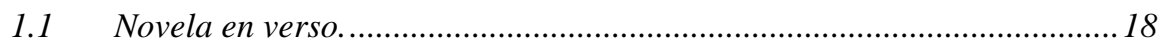

1.2 Los romans elegidos.......................................................................... 21

1.2.1 Le Roman de Tristan de Béroul...............................................................21

1.2.2 Le Chevalier de la Charrete de Chrétien de Troyes. .....................................22

1.2.3 L'Escoufle de Jean Renart..........................................................................23

1.2.4 Le Roman de la Rose de Guillaume de Lorris................................................25

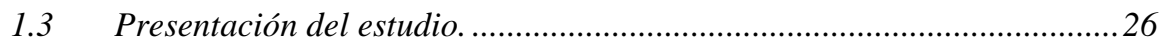

1.3.1 Niveles de análisis y objetivos. ............................................................26

1.3.2 Evolución de la expresión en el corpus....................................................29

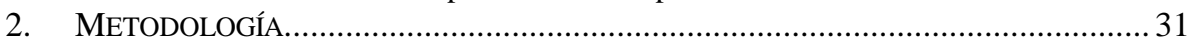

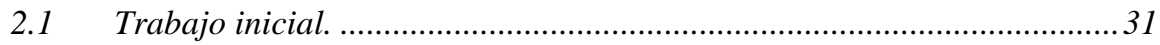

2.2 Utilización de herramientas informáticas.........................................32

2.2.1 Adquisición y edición del corpus........................................................32

2.2.2 Descripción de las etapas del análisis y programas utilizados. ......................35

2.2.2.1 Elaboración de los diccionarios morfológicos.....................................35

2.2.2.2 Análisis morfológico del corpus.....................................................46

2.2.2.3 Determinación de los contextos eróticos. ...........................................52

2.3 Estudio formal del léxico. ..............................................................5 59

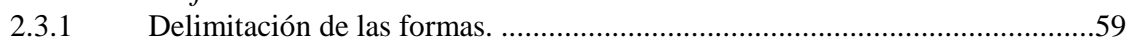

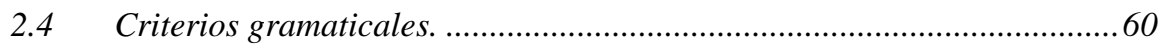

2.4.1 Morfosintaxis tradicional..................................................................60

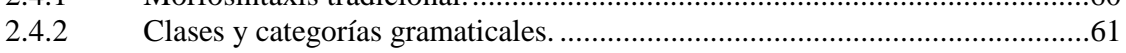

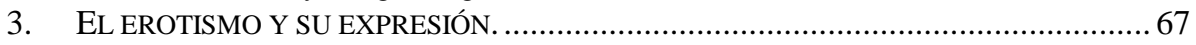

3.1 Aproximaciones al concepto de erotismo.........................................6.67

3.1.1 Definiciones. Lenguaje e ideología..........................................................67

3.1.2 Otros puntos de vista. Ideología y estética.................................................72

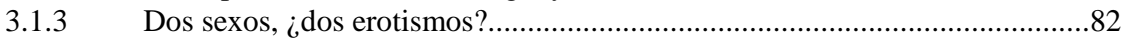

3.1.4 El amor cortés, multiplicidad erótica. ...................................................... 88

Erotismo y actividad textual. .....................................................................99

3.2 Estudio léxico y sintáctico del vocabulario amoroso............................... 104

3.2.1 El sujeto enamorado y el objeto de deseo. Denominaciones........................104

3.2.1.1 La mujer. ............................................................................ 104

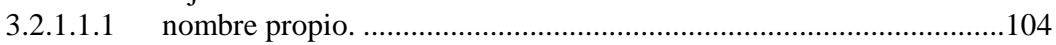

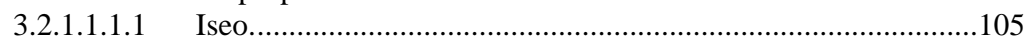

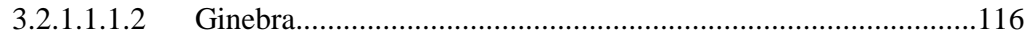

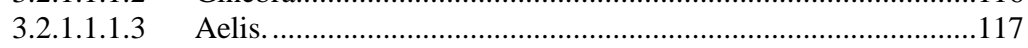

3.2.1.1.2 Reflejo de la estructuración social. ..............................................127

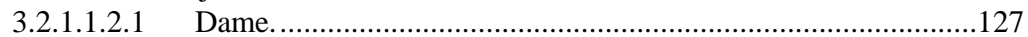

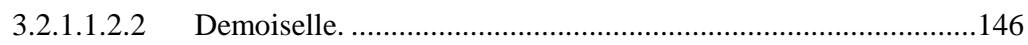

3.2.1.1.2.3 Pucelle y «meschine»........................................................160

3.2.1.1.2.4 Femme, épouse, «oisor» $\mathrm{y}$ «mollier»........................................ 168

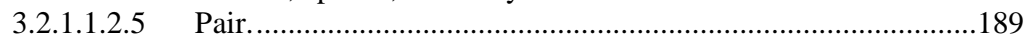

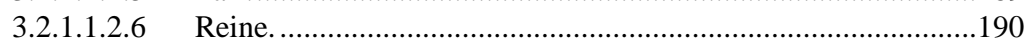

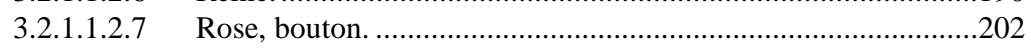

3.2.1.1.3 Expresiones generales relativas a la mujer....................................213

3.2.1.1.3.1 Créature..........................................................................213

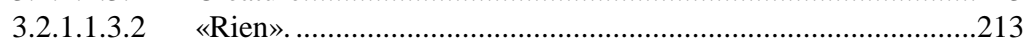

3.2.1.1.4 Términos que denotan una relación amorosa.................................218

3.2.1.1.4.1 Amie, compagne. ..................................................................218 


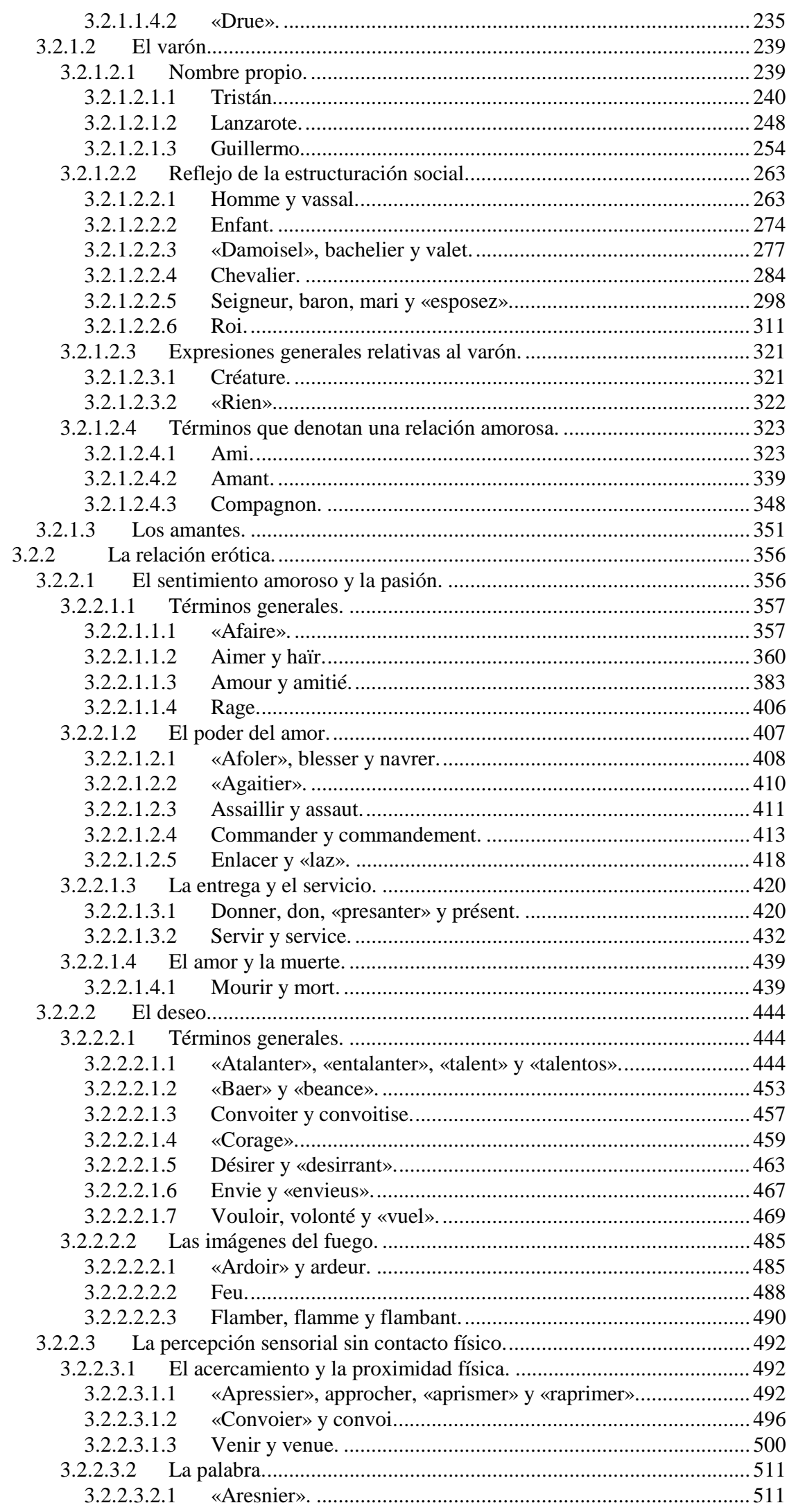




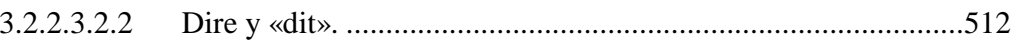

3.2.2.3.2.3 Parler, parole y «parlemant $» \ldots \ldots \ldots \ldots \ldots \ldots \ldots \ldots \ldots \ldots \ldots \ldots \ldots \ldots \ldots \ldots \ldots \ldots \ldots . . . .525$

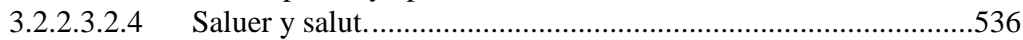

3.2.2.3.3 Los ojos, la mirada y las sensaciones visuales...............................539

3.2.2.3.3.1 «Esgarder», «esgart», «garder», «garde», regarder y regard. .....539

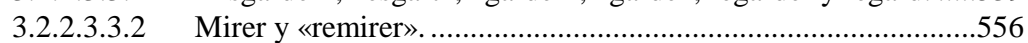

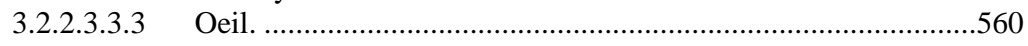

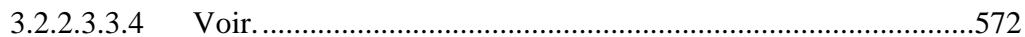

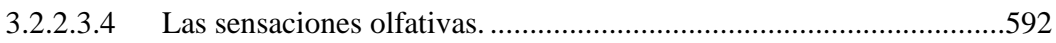

3.2.2.3.4.1 «Basme», flairer, odeur, «oler», «olent» $\mathrm{y}$ «soautume»..............592

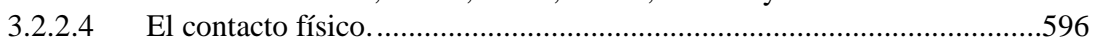

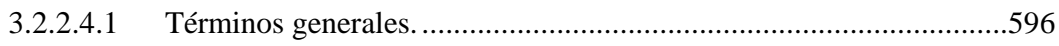

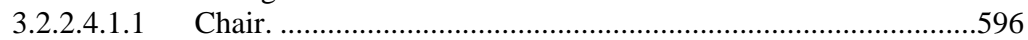

3.2.2.4.1.2 «Adeser», «ajoster», «joster», assembler, rassembler y assemblée.

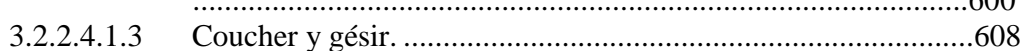

3.2.2.4.1.4 Jouer y jeu............................................................622

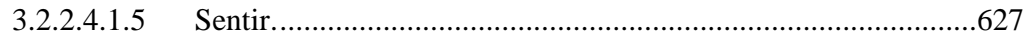

3.2.2.4.1.6 Tenir..................................................................631

3.2.2.4.2 Los brazos y el abrazo. ............................................................637

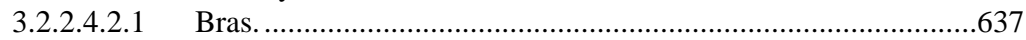

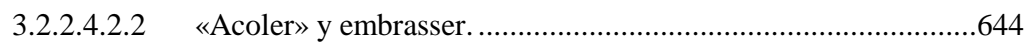

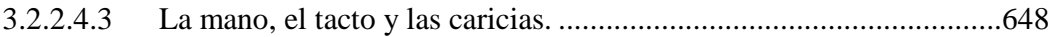

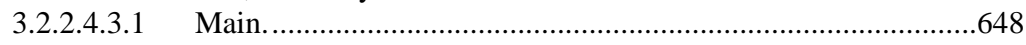

3.2.2.4.3.2 «Ataster», tâter, toucher, attoucher y tact................................656

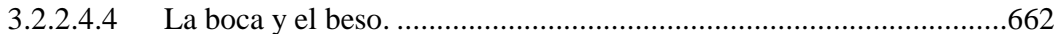

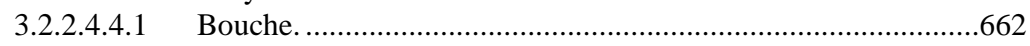

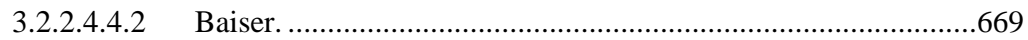

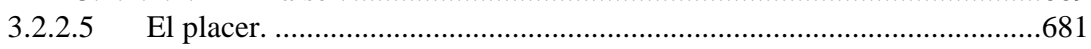

3.2.2.5.1 «Aasier», aise $\mathrm{y}$ «aisement».....................................................682

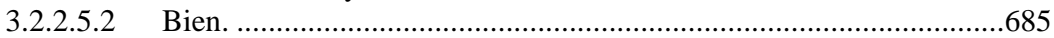

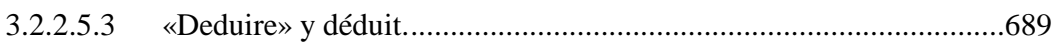

3.2.2.5.4 «Deliter», «delitable»y «delit».........................................................696

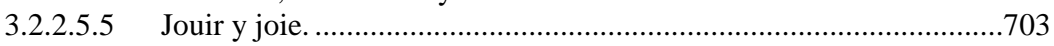

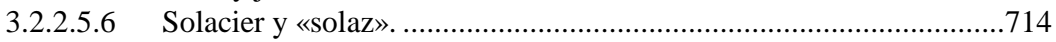

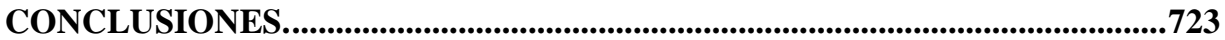

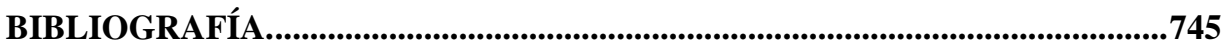




\section{ÍNDICE DE ILUSTRACIONES}

Tabla 1. Estructura de las bases de datos TRISTAN, LANCE, ESCF y ROSA.............35 Tabla 2. Clases gramaticales y claves. Menú presentado por el programa DICO1.PRG

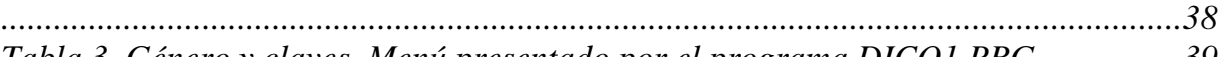

Tabla 3. Género y claves. Menú presentado por el programa DICO1.PRG. .................39

Tabla 4. Número y claves. Menú presentado por el programa DICO1. PRG. ..............39

Tabla 5. Caso y claves. Menú presentado por el programa DICO1.PRG......................39

Tabla 6. Tipo de sustantivo y claves. Menú presentado por el programa DICO1. PRG.

Tabla 7. Tipo de adjetivo y claves. Menú presentado por el programa DICO1. PRG. 40 Tabla 8. Tipo de pronombre y claves. Menú presentado por el programa DICO1.PRG.

Tabla 9. Tipo de forma y claves. Menú presentado por el programa DICO1.PRG......41

Tabla 10. Persona y claves. Menú presentado por el programa DICO1. PRG............41

Tabla 11. Modo y claves. Menú presentado por el programa DICO1.PRG.................42

Tabla 12. Tiempo y claves. Menú presentado por el programa DICO1. PRG. ............42

Tabla 13. Tipo de adverbio y claves. Menú presentado por el programa DICO1.PRG.43 Tabla 14. Tipo de conjunción y claves. Menú presentado por el programa DICO1.PRG.

Tabla 15. Tipo de artículo y claves. Menú presentado por el programa DICO1. PRG.44 Tabla 16. Signo de puntuación y claves. Menú presentado por el programa

DICO1.PRG. 45

Tabla 17. Tipo de participio presente y claves. Menú presentado por el programa

DICO1. PRG.

Tabla 18. Tipo de numeral y claves. Menú presentado por el programa DICO1. PRG.45

Tabla 19. Estructura de las bases de datos que recogen las concordancias. ................47

Tabla 20. Estructura de las bases de datos que recogen los patrones..........................48

Tabla 21. Estructura de las bases de datos que recogen las combinaciones de formas y

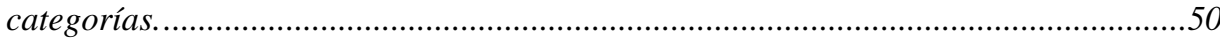

Tabla 22. Nueva estructura de las bases de datos TRISTAN, LANCE, ESCF y ROSA. 51

Tabla 23. Estructura de la base de datos DESTINO.......................................................53

Tabla 24. Estructura de las bases de datos que contienen el comportamiento estilístico

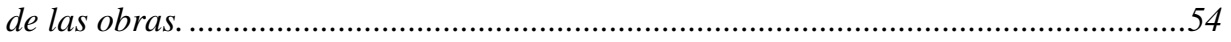

Tabla 25. Estructura de la base de datos que recoge los contextos léxicos y morfosintácticos (GRAM. DBF) ................................................................................56

Tabla 26. Estructura de las bases de datos que recogen las rimas (SALRIM, SALRIMR y SALRIMT) .58

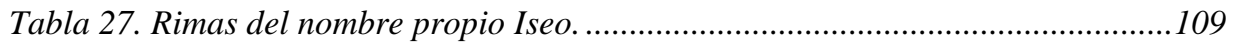

Fig. 1. Comportamiento estilístico del nombre propio Iseo......................................115

Fig. 2. Comportamiento estilístico del nombre propio Ginebra. ................................117

Tabla 28. Rimas del nombre propio Aelis.............................................................. 121

Fig. 3. Comportamiento estilístico del nombre propio Aelis en Escoufle....................126

Tabla 29. Rimas del sustantivo dame ............................................................................ 131

Fig. 4. Comportamiento estilístico del sustantivo dame en Tristan. ............................143

Fig. 5. Comportamiento estilístico del sustantivo dame en Charrete. ..........................144

Fig. 6. Comportamiento estilístico del sustantivo dame en Escoufle ...........................144

Fig. 7. Comportamiento estilístico del sustantivo dame en Rose...............................145 
Tabla 30. Rimas del sustantivo demoiselle .................................................................... 152

Fig. 8. Comportamiento estilístico del sustantivo demoiselle en Charrete.................. 158

Fig. 9. Comportamiento estilístico del sustantivo demoiselle en Escoufle. ..................158

Fig. 10. Comportamiento estilístico del sustantivo demoiselle en Rose. ..................... 159

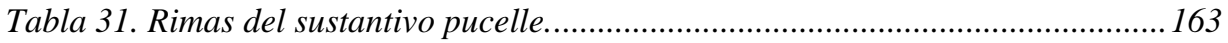

Fig. 11. Comportamiento estilístico del sustantivo pucelle en Charrete ....................... 167

Fig. 12. Comportamiento estilístico del sustantivo pucelle en Escoufle .......................167

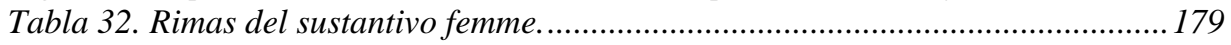

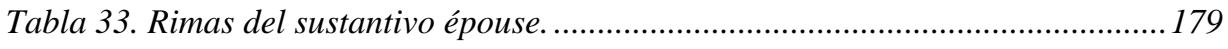

Tabla 34. Rimas del sustantivo «mollier»................................................................ 179

Fig. 13. Comportamiento estilístico del sustantivo femme en Tristan. ........................ 187

Fig. 14. Comportamiento estilístico del sustantivo «mollier» en Tristan. .................... 187

Fig. 15. Comportamiento estilístico del sustantivo femme en Charrete. .......................187

Fig. 16. Comportamiento estilístico del sustantivo femme en Escoufle...................... 188

Fig. 17. Comportamiento estilístico del sustantivo femme en Rose ............................. 188

Tabla 35. Rimas del sustantivo reine ........................................................................ 201

Fig. 18. Comportamiento estilístico del sustantivo reine en Tristan. ..........................201

Fig. 19. Comportamiento estilístico del sustantivo reine en Charrete........................202

Tabla 36. Rimas del sustantivo rose ..................................................................211

Tabla 37. Rimas del sustantivo bouton....................................................................2 211

Fig. 20. Comportamiento estilístico de la denominación rose en Rose.......................2212

Fig. 21. Comportamiento estilístico del sustantivo bouton en Rose .............................2 212

Tabla 38. Rimas del sustantivo créature referido a la mujer....................................213

Fig. 22. Comportamiento estilístico del sustantivo «rien» referido a la mujer en

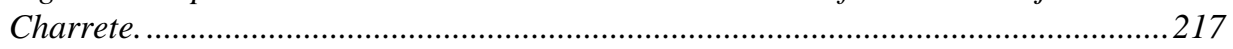

Fig. 23. Comportamiento estilístico del sustantivo «rien» referido a la mujer en

Escoufle................................................................................................... 217

Fig. 24. Comportamiento estilístico del sustantivo «rien» referido a la mujer en Rose.

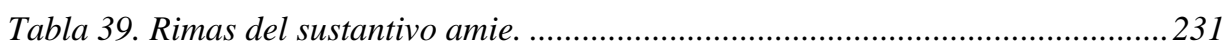

Fig. 25. Comportamiento estilístico del sustantivo amie en Tristan...........................233

Fig. 26. Comportamiento estilístico del sustantivo amie en Charrete ........................233

Fig. 27. Comportamiento estilístico del sustantivo amie en Escoufle ...........................234

Fig. 28. Comportamiento estilístico del sustantivo amie en Rose.................................234

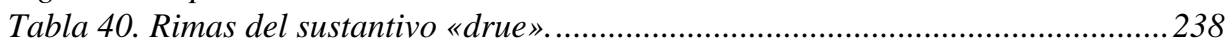

Fig. 29. Comportamiento estilístico del sustantivo «drue» en Tristan. .......................2238

Tabla 41. Rimas del nombre propio Tristán. ............................................................24

Fig. 30. Comportamiento estilístico del nombre propio Tristán en Tristan. ..............247

Tabla 42. Rimas del nombre propio Lanzarote. ......................................................252

Fig. 31. Comportamiento estilístico del nombre propio Lanzarote en Charrete........253

Tabla 43. Rimas del nombre propio Guillermo. ..........................................................260

Fig. 32. Comportamiento estilístico del nombre propio Guillermo en Escoufle. ........262

Tabla 44. Rimas del sustantivo homme.....................................................................2. 272

Fig. 33. Comportamiento estilístico del sustantivo homme en Tristan.........................2 273

Fig. 34. Comportamiento estilístico del sustantivo homme en Charrete. ....................2273

Fig. 35. Comportamiento estilístico del sustantivo homme en Escoufle.....................2273

Fig. 36. Comportamiento estilístico del sustantivo homme en Rose...........................2.274

Fig. 37. Comportamiento estilístico del sustantivo vassal en Rose ............................2.274

Fig. 38. Comportamiento estilístico del sustantivo enfant en Escoufle . ......................2. 277

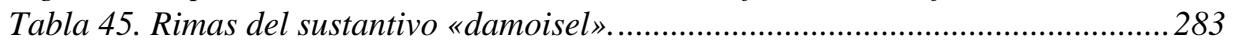

Tabla 46. Rimas del sustantivo bachelier............................................................. 283

Fig. 39. Comportamiento estilístico del sustantivo «damoisel» en Escoufle...............283

Fig. 40. Comportamiento estilístico del sustantivo valet en Escoufle.........................283 
Fig. 41. Comportamiento estilístico del sustantivo bachelier en Rose........................284

Fig. 42. Comportamiento estilístico del sustantivo valet en Rose ...............................284

Tabla 47. Rimas del sustantivo chevalier...............................................................296

Fig. 43. Comportamiento estilístico del sustantivo chevalier en Tristan....................296

Fig. 44. Comportamiento estilístico del sustantivo chevalier en Charrete. .................297

Fig. 45. Comportamiento estilístico del sustantivo chevalier en Escoufle ..................297

Fig. 46. Comportamiento estilístico del sustantivo chevalier en Rose........................297

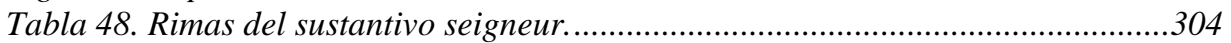

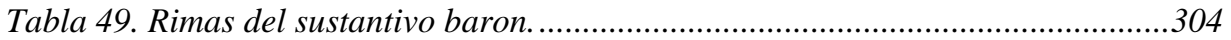

Fig. 47. Comportamiento estilístico del sustantivo seigneur en Tristan. ......................310

Fig. 48. Comportamiento estilístico del sustantivo seigneur en Charrete. ...................310

Fig. 49. Comportamiento estilístico del sustantivo seigneur en Escoufle....................310

Fig. 50. Comportamiento estilístico del sustantivo baron en Escoufle ........................311

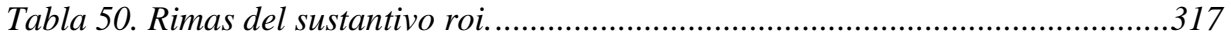

Fig. 51. Comportamiento estilístico del sustantivo roi en Tristan. ..............................320

Fig. 52. Comportamiento estilístico del sustantivo roi en Charrete. ............................320

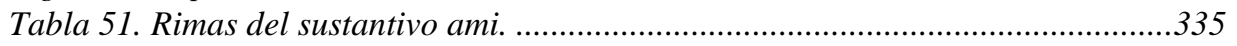

Fig. 53. Comportamiento estilístico del sustantivo ami en Tristan............................337

Fig. 54. Comportamiento estilístico del sustantivo ami en Charrete ..........................338

Fig. 55. Comportamiento estilístico del sustantivo ami en Escoufle.............................338

Fig. 56. Comportamiento estilístico del sustantivo ami en Rose...................................338

Tabla 52. Rimas del sustantivo amant referido al varón. ............................................347

Fig. 57. Comportamiento estilístico del sustantivo amant referido al varón en Escoufle.

348

Fig. 58. Comportamiento estilístico del sustantivo amant referido al varón en Rose. 348

Tabla 53. Rimas del sustantivo compagnon..................................................................350

Fig. 59. Comportamiento estilístico del sustantivo compagnon en Rose......................351

Tabla 54. Rimas del sustantivo amants referido a la pareja.......................................354

Fig. 60. Comportamiento estilístico del sustantivo amants referido a la pareja en

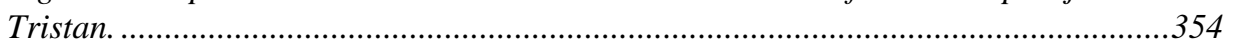

Fig. 61. Comportamiento estilístico del sustantivo amants referido a la pareja en

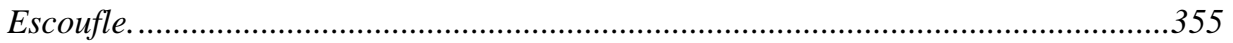

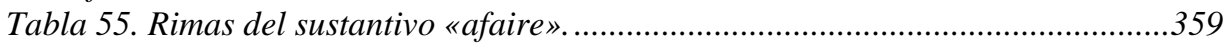

Fig. 62. Comportamiento estilístico del sustantivo «afaire» en el corpus. ....................359

Tabla 56. Rimas del verbo aimer. ............................................................................... 374

Fig. 63. Comportamiento estilístico del verbo aimer en Tristan..................................380

Fig. 64. Comportamiento estilístico del verbo aimer en Charrete...............................380

Fig. 65. Comportamiento estilístico del verbo aimer en Escoufle. .............................381

Fig. 66. Comportamiento estilístico del verbo aimer en Rose. ....................................381

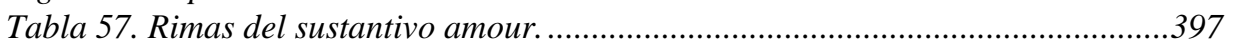

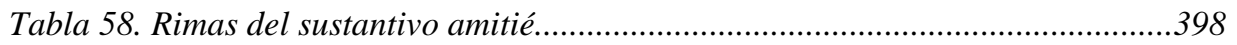

Fig. 67. Comportamiento estilístico del sustantivo amour en Tristan. ......................403

Fig. 68. Comportamiento estilístico del sustantivo amour en Charrete........................404

Fig. 69. Comportamiento estilístico del sustantivo amour en Escoufle. .......................404

Fig. 70. Comportamiento estilístico del sustantivo amour en Rose. ............................404

Fig. 71. Comportamiento estilístico del sustantivo amitié en el corpus......................405

Tabla 59. Rimas del verbo commander y del sustantivo commandement....................416

Fig. 72. Comportamiento estilístico del verbo commander y del sustantivo commandement en Charrete......................................................................................417

Fig. 73. Comportamiento estilístico del verbo commander y del sustantivo

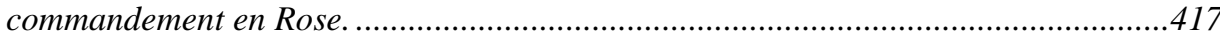

Tabla 60. Rimas del verbo enlacer y del sustantivo «laz»..........................................419 
Fig. 74. Comportamiento estilístico del verbo enlacer y del sustantivo «laz» en Rose.

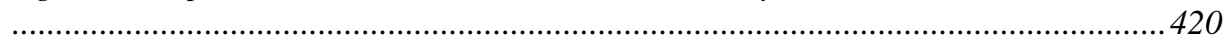

Tabla 61. Rimas del verbo donner y del sustantivo don. ............................................427

Tabla 62. Rimas del verbo "presanter» y del sustantivo présent.................................427

Fig. 75. Comportamiento estilístico del verbo donner y del sustantivo don en Tristan. 430

Fig. 76. Comportamiento estilístico del verbo donner y del sustantivo don en Charrete. 431

Fig. 77. Comportamiento estilístico del verbo donner y del sustantivo don en Escoufle.

Fig. 78. Comportamiento estilístico del verbo donner y del sustantivo don en Rose. 431

Tabla 63. Rimas del verbo servir y del sustantivo service. 436

Fig. 79. Comportamiento estilístico del verbo servir y del sustantivo service en

Charrete....

Fig. 80.Comportamiento estilístico del verbo servir y del sustantivo service en Rose.439

Tabla 64. Rimas del verbo mourir y del sustantivo mort. 442

Fig. 81. Comportamiento estilístico del verbo mourir y del sustantivo mort en Charrete. 443

Fig. 82. Comportamiento estilístico del verbo mourir y del sustantivo mort en Escoufle. 443

Fig. 83. Comportamiento estilístico del verbo mourir y del sustantivo mort en Rose.443 Tabla 65. Rimas de los verbos «atalanter»y «entalanter», del sustantivo «talent» y del adjetivo «talentos».

Fig. 84. Comportamiento estilístico de los verbos «atalanter»y «entalanter», del sustantivo «talent» y del adjetivo «talentos» en Tristan.

Fig. 85. Comportamiento estilístico del verbo «atalanter, del sustantivo «talent» y del adjetivo «talentos» en Charrete. 451

Fig. 86. Comportamiento estilístico de los verbos «atalanter»y «entalanter», del sustantivo «talent»y del adjetivo «talentos» en Escoufle.

Fig. 87. Comportamiento estilístico de los verbos «atalanter»y «entalanter», del sustantivo «talent» y del adjetivo «talentos» en Rose.

Tabla 66. Rimas del verbo «baer»y del sustantivo «beance» en Rose.

Fig. 88. Comportamiento estilístico del verbo «baer»y del sustantivo «beance»en

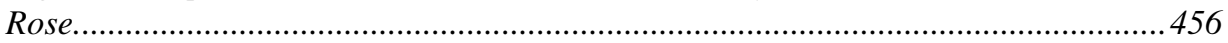

Tabla 67.Rimas del verbo convoiter y del sustantivo convoitise ................................459

Tabla 68. Rimas del sustantivo «corage»................................................................462

Fig. 89. Comportamiento estilístico del sustantivo «corage» en Tristan.....................462

Fig. 90. Comportamiento estilístico del sustantiv «corage» en Charrete.................... 463

Fig. 91. Comportamiento estilístico del sustantiv «corage» en Rose .........................463

Tabla 69. Rimas del verbo désirer y del adjetivo «desirrant»....................................466

Fig. 92. Comportamiento estilístico del verbo désirer y del adjetivo «desirrant»en

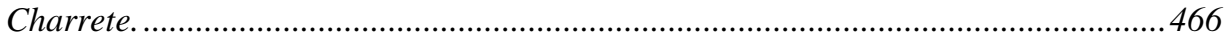

Fig. 93. Comportamiento estilístico del verbo désirer y del adjetivo «desirrant» en Rose.

Tabla 70. Rimas del sustantivo envie y del adjetivo «envieus». ..................................468

Fig. 94. Comportamiento estilístico del sustantivo envie y del adjetivo «envieus» en

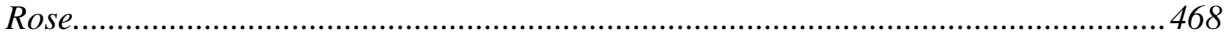

Tabla 71. Rimas del verbo vouloir y de los sustantantivos volonté $y$ «vuel».............477

Fig. 95. Comportamiento estilístico del verbo vouloir y de los sustantivos volonté y «vuel» en Tristan. 482

Fig. 96. Comportamiento estilístico del verbo vouloir y de los sustantivos volonté y «vuel» en Charrete... 
Fig. 97. Comportamiento estilístico del verbo vouloir y de los sustantivos volonté y «vuel» en Escoufle.

Fig. 98. Comportamiento estilístico del verbo vouloir y de los sustantivos volonté y «vuel» en Rose.

Tabla 72. Rimas del verbo «ardoir» y del sustantivo ardeur.

Fig. 99. Comportamiento estilístico del verbo «ardoir» y del sustantivo ardeur en Tristan.

Fig. 100. Comportamiento estilístico del verbo «ardoir» y del sustantivo ardeur en

Rose....

Tabla 73.Rimas del verbo flamber, del sustantivo flamme y del adjetivo flambant....491

Fig. 101. Comportamiento estilístico del verbo flamber, del sustantivo flamme y del adjetivo flambant en Charrete y en Rose.

Tabla 74. Rimas de los verbos «apressier», approcher, «aprismer» $y$ «raprimer»....495

Fig. 102. Comportamiento estilístico de los verbos «apressier», approcher, «aprismer» y raprimer en Tristan, Charrete y Escoufle.

Fig. 103. Comportamiento estilístico de los verbos «apressier», approcher, «aprismer» y raprimer en Rose. 495

Tabla 75. Rimas del sustantivo convoi y del verbo «convoier»...................................498

Fig. 104. Comportamiento estilístico del sustantivo convoi y del verbo «convoier» en

Tristan, Charrete y Escoufle . ......................................................................................499

Fig. 105. Comportamiento estilístico del sustantivo convoi y del verbo «convoier» en

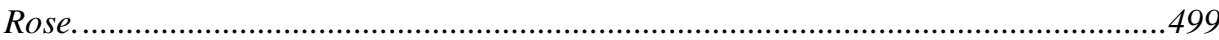

Tabla 76. Rimas del verbo venir y del sustantivo venue ............................................505

Fig. 106. Comportamiento estilístico del verbo venir y del sustantivo venue en Tristan. 509

Fig. 107. Comportamiento estilístico del verbo venir y del sustantivo venue en Charrete. 509

Fig. 108. Comportamiento estilístico del verbo venir y del sustantivo venue en Escoufle. 510

Fig. 109. Comportamiento estilístico del verbo venir y del sustantivo venue en Rose.510 Tabla 77. Rimas del verbo dire y del sustantivo «dit».

Fig. 110. Comportamiento estilístico del verbo dire y del sustantivo «dit» en Tristan.523

Fig. 111. Comportamiento estilístico del verbo dire y del sustantivo «dit» en Charrete.

Fig. 112. Comportamiento estilístico del verbo dire y del sustantivo «dit» en Escoufle.

Fig. 113. Comportamiento estilístico del verbo dire y del sustantivo «dit» en Rose. .524

Tabla 78. Rimas del verbo parler y de los sustantivos «parlemant» y parole. ............531

Fig. 114. Comportamiento estilístico del verbo parler y de los sustantivos parole y

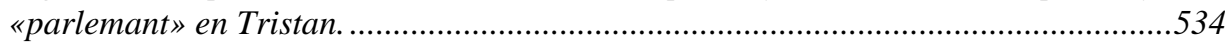

Fig. 115. Comportamiento estilístico del verbo parler y de los sustantivos parole y «parlemant» en Charrete. ........................................................................................534

Fig. 116. Comportamiento estilístico del verbo parler y de los sustantivos parole y «parlemant» en Escoufle ..................................................................................................5. 535

Fig. 117. Comportamiento estilístico del verbo parler y de los sustantivos parole y

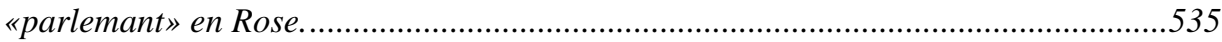
Tabla 79. Rimas del verbo saluer y del sustantivo salut............................................538 Fig. 118. Comportamiento estilístico del verbo saluer y del sustantivo salut en el

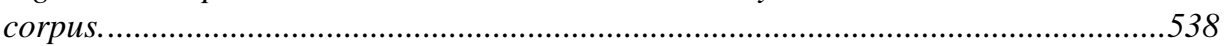
Tabla 80. Rimas de los verbos «esgarder», "garder», regarder y de los sustantivos «esgart», «garde»y regard.................................................................................551 Fig. 119. Comportamiento estilístico de los verbos «esgarder», "garder», regarder y de los sustantivos «esgart», "garde»y regard en Tristan. .554 
Fig. 120. Comportamiento estilístico de los verbos «esgarder», "garder», regarder y de los sustantivos «esgart», «garde»y regard en Charrete. ..............................................55

Fig. 121. Comportamiento estilístico de los verbos «esgarder», "garder», regarder y de los sustantivos «esgart», «garde»y regard en Escoufle ...............................................55

Fig. 122. Comportamiento estilístico de los verbos «esgarder», "garder», regarder y de los sustantivos «esgart», «garde»y regard en Rose.......................................................55

Tabla 81. Rimas de los verbos mirer $y$ «remirer»......................................................559

Fig. 123. Comportamiento estilístico de los verbos mirer $y$ «remirer» en el corpus. 559

Tabla 82. Rimas del sustantivo oeil. ............................................................................5 571

Fig. 124. Comportamiento estilístico del sustantivo oeil en Tristan............................571

Fig. 125. Comportamiento estilístico del sustantivo oeil en Charrete.........................571

Fig. 126. Comportamiento estilístico del sustantivo oeil en Escoufle .........................571

Fig. 127. Comportamiento estilístico del sustantivo oeil en Rose. ..............................572

Tabla 83. Rimas del verbo voir.....................................................................................58

Fig. 128. Comportamiento estilístico del verbo voir en Tristan. .................................590

Fig. 129. Comportamiento estilístico del verbo voir en Charrete. ..............................590

Fig. 130. Comportamiento estilístico del verbo voir en Escoufle ................................591

Fig. 131. Comportamiento estilístico del verbo voir en Rose....................................591

Tabla 84. Rimas del verbo flairer, del adjetivo «olent», y de los sustantivos odeur,

«soautume» $y$ «basme».............................................................................................5 595

Fig. 132. Comportamiento estilístico de los sustantivos «basme», «soautume» y odeur,

del adjetivo «olent» y de los verbos flairer $y$ «oler» en Rose .....................................595

Fig. 133. Comportamiento estilístico del sustantivo chair en el corpus.....................599

Tabla 85.Rimas de los verbos «adeser», «ajoster», «joster», assembler, rassembler y del sustantivo assemblée ........................................................................................................6 605

Fig. 134.Comportamiento estilístico de los verbos «adeser», «ajoster», «joster»,

assembler, rassembler y del sustantivo assemblée en el corpus. ..............................607

Tabla 86. Rimas del verbo coucher. .........................................................................616

Tabla 87. Rimas del verbo gésir. .............................................................................617

Fig. 135. Comportamiento estilístico del verbo coucher en Tristan............................619

Fig. 136. Comportamiento estilístico del verbo coucher en Charrete .........................620

Fig. 137. Comportamiento estilístico del verbo gésir en Tristan...............................620

Fig. 138. Comportamiento estilístico del verbo gésir en Charrete...............................620

Fig. 139. Comportamiento estilístico de los verbos gésir y coucher en Escoufle.......621

Fig. 140. Comportamiento estilístico de los verbos gésir y coucher en Rose..............621

Tabla 88. Rimas del verbo jouer y del sustantivo jeu. .............................................626

Fig. 141. Comportamiento estilístico del verbo jouer y del sustantivo jeu en Charrete.

Fig. 142. Comportamiento estilístico del verbo jouer y del sustantivo jeu en Escoufle.

Fig. 143. Comportamiento estilístico del verbo jouer y del sustantivo jeu en Rose. ..627

Tabla 89. Rimas del verbo sentir. ......................................................................630

Fig. 144. Comportamiento estilístico del verbo sentir en el corpus. ...........................630

Tabla 90. Rimas del verbo tenir...........................................................................6 636

Fig. 145. Comportamiento estilístico del verbo tenir en el corpus...........................636

Tabla 91. Rimas del sustantivo bras. ....................................................................642

Fig. 146. Comportamiento estilístico del sustantivo bras en Charrete........................643

Fig. 147. Comportamiento estilístico del sustantivo bras en Escoufle ........................643

Fig. 148. Comportamiento estilístico del sustantivo bras en Rose .............................643

Tabla 92. Rimas de los verbos «acoler» y embrasser...............................................647

Fig. 149. Comportamiento estilístico de los verbos «acoler» y embrasser en Tristan.647

Fig. 150. Comportamiento estilístico de los verbos «acoler» y embrasser en Escoufle. 
Tabla 93. Rimas del sustantivo main.

Fig. 151. Comportamiento estilístico del sustantivo main en Tristan..........................654

Fig. 152. Comportamiento estilístico del sustantivo main en Charrete. .....................654

Fig. 153. Comportamiento estilístico del sustantivo main en Escoufle.......................655

Fig. 154. Comportamiento estilístico del sustantivo main en Rose...............................655

Tabla 94. Rimas de los verbos «ataster», tâter, toucher, attoucher y del sustantivo tact.

660

Fig. 155. Comportamiento estilístico de los verbos «ataster», tâter, toucher, attoucher y del sustantivo tact en Escoufle ..............................................................................660

Fig. 156. Comportamiento estilístico de los verbos «ataster», tâter, toucher, attoucher y del sustantivo tact en Rose .........................................................................................661

Tabla 95. Rimas del sustantivo bouche. ....................................................................667

Fig. 157.Comportamiento estilístico del sustantivo bouche en Tristan y Escoufle.....668

Fig. 158. Comportamiento estilístico del sustantivo bouche en Charrete. ...................668

Fig. 159. Comportamiento estilístico del sustantivo bouche en Rose ..........................668

Tabla 96. Rimas del verbo y del sustantivo baiser......................................................679

Fig. 160.Comportamiento estilístico del verbo y del sustantivo baiser en Tristan. ...680

Fig. 161.Comportamiento estilístico del verbo y del sustantivo baiser en Escoufle. .680

Fig. 162.Comportamiento estilístico del verbo y del sustantivo baiser en Rose........680

Tabla 97. Rimas del verbo «aasier»y de los sustantivos aise $y$ «aisement»...............684

Fig. 163. Comportamiento estilístico del verbo «aasier» y de los sustantivos aise y

«aisement» en el corpus.......................................................................................685

Fig. 164. Comportamiento estilístico del sustantivo bien en Rose.............................688

Tabla 98. Rimas del verbo deduire y del sustantivo déduit.........................................694

Fig. 165. Comportamiento estilístico del verbo «deduire» y del sustantivo déduit en

Charrete.

.695

Fig. 166. Comportamiento estilístico del verbo «deduire» y del sustantivo déduit en

Escoufle.

Fig. 167. Comportamiento estilístico del verbo «deduire» y del sustantivo déduit en

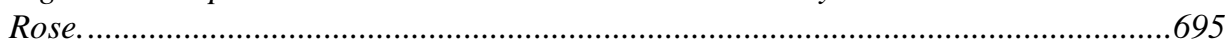

Tabla 99. Rimas del verbo «deliter», del adjetivo «delitable» y del sustantivo «delit».

701

Fig. 168. Comportamiento estilístico del verbo «deliter», del adjetivo «delitable» y del sustantivo «delit» en Charrete ........................................................................................702

Fig. 169. Comportamiento estilístico del verbo «deliter», del adjetivo «delitable» y del sustantivo «delit» en Escoufle ..................................................................................702

Fig. 170. Comportamiento estilístico del verbo «deliter», del adjetivo «delitable» y del

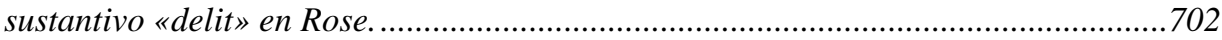

Tabla 100. Rimas del sustantivo joie. ....................................................................... 712

Fig. 171. Comportamiento estilístico del verbo jouir y del sustantivo joie en Charrete.

Fig. 172. Comportamiento estilístico del verbo jouir y del sustantivo joie en Escoufle.

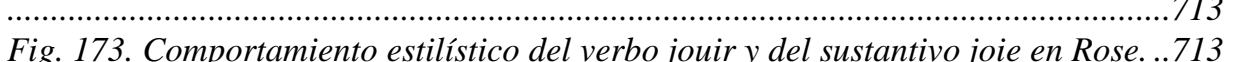

Tabla 101. Rimas del verbo solacier y del sustantivo «solaz»....................................720

Fig. 174. Comportamiento estilístico del verbo solacier y del sustantivo «solaz» en

Charrete y Escoufle.

Fig. 175. Comportamiento estilístico del verbo solacier y del sustantivo «solaz»en

Rose. 


\section{INTRODUCCIÓN.}

El relato de amor y aventuras alcanzó en la segunda mitad del siglo XII una notable estima al desarrollar y extender algunos de los grandes mitos celtas o clásicos armonizándolos con la nueva forma de entender el amor, las relaciones entre los sexos y su plasmación literaria nacida en las cortes del Languedoc. Transcripción del enfrentamiento entre el Texto y la Voz para Zumthor, ${ }^{1}$ el tema del obstáculo erótico de la canso trovadoresca se adaptará a las necesidades de la narración, a la ideología caballeresca y a los diferentes grados de desarticulación del poder propuestos en los relatos.

Aunque para los representantes de la escuela tipológica o robertsoniana la fin' amors no existió jamás, ni en la vida real ni en la literatura, es del todo evidente que entre la caritas cristiana y la cupiditas — representación del pecado-, la sociedad aristocrática, algunos de cuyos individuos pertenecían también a la clase clerical, supo crear una ideología, que por supuesto concernía también a las relaciones entre los sexos, y que implicaba fundamentalmente la búsqueda de un ejemplo de perfección caballeresca y cortesana.

El siglo XIII recogerá este legado pero introducirá variaciones de consecuencias temáticas y formales no desdeñables: los principios económicos y morales de los nuevos grupos sociales con poder se imponen al modelo feudal, el individuo y sus sentimientos pasan a un primer plano y, por fin, los héroes ya no son los caballeros y las damas jóvenes sino adolescentes que descubren el amor.

Creemos que el erotismo, sexualidad que se vela y se desvela, así como el papel que se concede a los receptores en la interpretación del mensaje

1 L a poésie et la voix dans la ávilisation médiévale. Paris: PUF, 1984, p. 33. 
amoroso fueron algunos de los mayores alicientes de las obras que analizamos en este trabajo. Gracias en buena medida a ellas los grupos de poder hicieron atractivos y asimilables modelos sociales, económicos y morales, que en ocasiones eran anacrónicos, en otras novedosos y prácticamente incompatibles con los todavía vigentes, y que tenían, además, otros cauces de transmisión más austeros.

Para intentar determinar cuáles son los modos de expresión del erotismo en las novelas de los siglos XII y XIII pretendemos establecer qué hechos relacionados con él — lingüísticos o no- aparecen en cada obra y cuáles no. Si responden a la tradición literaria y son retomados como meros clichés o suponen una innovación. Y, por fin, qué elementos jurídicos, médicos, de civilización, ideológicos, etc. se encuentran tras ellos. Para alcanzar nuestros objetivos partimos de las formas simples, el léxico y la gramática, y optamos por un estudio cualitativo en el que los contextos son determinantes tanto para la elección de los vocablos como para la identificación de los sentidos. Con respecto a la organización del análisis, agruparemos los términos en dos grandes conjuntos: las denominaciones de los individuos implicados en la relación erótica y los vocablos utilizados para describir los diferentes componentes de dicha relación.

\section{EL CORPUS Y SU ESTUDIO.}

\section{NOVELA EN VERSO.}

Adoptamos la denominación de novela para el género constituido por relatos de ficción rimados en octosílabos pareados. No todos los autores parecen aceptarla y consideran el roman, y fundamentalmente el roman artúrico, 
como un género aparte aunque muy próximo, como un muy probable antecedente de la novela moderna. ${ }^{2}$ Otros, sin embargo, como García Gual, colocan los textos que vamos a estudiar entre las primeras novelas europeas; ${ }^{3}$ nosotros, siguiendo este segundo criterio utilizaremos los términos «novela» y «roman» indistintamente para hablar de las obras que constituyen nuestro corpus.

Si bien en un principio no descartábamos el análisis de novelas en prosa, surgidas a partir de 1210, e incluso pensamos en la posibilidad de comparar las novelas en verso del siglo XII en torno al héroe Tristán y Le Chevalier de la Charrete con las correspondientes reelaboraciones en prosa del siglo XIII, pronto desechamos esta idea por dos motivos fundamentales pero que consideramos de peso. El primero era la magnitud del corpus y el segundo los profundos cambios que la eliminación del armazón del verso y de la rima provocaban desde tres puntos de vista para nosotros fundamentales: el de las relaciones que se establecen entre el discurso narrativo y el discurso de los personajes - desaparición de los discursos directos encadenados sin solución de continuidad, por ejemplo—; el de la sintaxis — periodos más largos y complejos, aumento de las subordinadas- y en el nivel léxico —mayor libertad al desaparecer la rima, disminución de algunas de las innumerables marcas léxicas, como los apelativos, que indicaban el inicio o desarrollo de un discurso directo, compensadas sin embargo con otros recursos como la repetición o la doble marca de introducción discursiva-; fenómenos que en muchos casos provocan que las narraciones en prosa estén más próximas de los cantares de gesta que de los romans compuestos en octosílabos. $^{4}$

\footnotetext{
2 Véase V. Cirlot, La materia cortesana, H istoria de la literatura franœesa, J. del Prado (coord.). Madrid: Cátedra, 1994, p. 86.

3 Primeras novelas europeas. Madrid: Istmo, 1974.

${ }^{4}$ Cf. B. Cerquiglini, L a parole médiévale. Paris: Minuit, 1981, p. 22-127.
} 
Decidimos pues ceñirnos únicamente a las narraciones en verso y aún, dentro del vasto conjunto de los romans versificados en lengua de oill, optamos por restringir el corpus a cuatro que tuviesen en común la presencia en mayor o menor medida de rasgos correspondientes al código cortés reelaborado en el norte de lo que ahora es Francia. La ética y la retórica corteses podían darnos una cierta coherencia en la comparación, pero queríamos que los textos tuviesen elementos heterogéneos que hiciesen posible ver una cierta evolución, un cambio ideológico y estético o bien la existencia en una misma época de concepciones diferentes del erotismo y de su conformación literaria.

Sin embargo creíamos conveniente que la separación temporal entre las obras no fuese excesiva, alrededor de dos generaciones, lo que debía permitir una cierta estabilidad no sólo en lo que concierne a la tradición literaria sino también a la lengua utilizada, dos aspectos que aparecen estrechamente ligados en la época medieval.

Al comparar textos medievales de distintos autores e incluso de un mismo autor percibimos tres tipos de variantes que pueden hallarse relacionadas: las estilísticas, las regionales y las originadas por la intervención de los copistas. Las grafías y el léxico se ven afectados por las diferencias dialectales en un momento en el que las evoluciones paralelas que había sufrido el roman, como se llamaba en la época al conjunto de las lenguas de oil, no habían sido borradas por la influencia del franoois. Los cambios introducidos en la tradición manuscrita contribuyen a acrecentar la heterogeneidad de las grafías pero muy excepcionalmente se ven sometidos a ellos las formas léxicas. Las variantes estilísticas afectan al léxico en general y fundamentalmente a los patrones retóricos al modificarse su sintaxis o alguno de sus componentes léxicos. En nuestro caso sólo consideramos oportuno ocuparnos de las variantes estilísticas sin discriminar si su origen estaba en la «creación» autorial o en las modificaciones introducidas por los copistas y nos atendremos a las ediciones recogidas en las colecciones «Les Classiques 
français du Moyen Age» de la editorial Honoré Champion para tres de los textos y «Textes littéraires français» de la Librairie Droz para el otro.

\subsection{LOS ROMANSELEGIDOS.}

\subsubsection{LE ROMAN DETRISTAN DE BÉ ROUL. ${ }^{5}$}

De las dos versiones que han llegado fragmentariamente hasta nosotros de la leyenda sobre Tristán e Iseo, la versión de Béroul nos parece que ofrece una mayor variedad de registros eróticos, combinando elementos de la estética y la ideología cortesanas con actitudes y voces que no se acomodan a ellas y parecen responder más bien a una corriente arcaica, ${ }^{6}$ naturalista, en la que la sexualidad ha podido ser una fuerza fundamentalmente disgregante de las estructuras de poder en el momento en que éstas coartaban el deseo y la unión carnal.

La obra de Thomas está sin duda más influida por la fin' amors y por la retórica cortés, como muestra, por ejemplo, la aparición de abstracciones personificadas del mismo modo que ocurrirá en las obras de Chrétien, y de repeticiones o juegos de palabras que no encierran una doble intención obscena. La diferencia de tono entre ambas viene además dada, tal como señala Ruiz Capellán, por los episodios que se han conservado de cada fragmento, ${ }^{7}$ ya que mientras Béroul nos muestra a los amantes cuando están juntos en la corte y en el Morrois, de la obra de Thomas conservamos los

\footnotetext{
${ }^{5}$ Béroul, L e Roman de Tristan. Poème du X IIe siède, E. Muret (ed.). Paris: Honoré Champion, 1982. A partir de este momento lo denominaremos Tristan.

${ }^{6}$ R. Ruiz Capellán en la introducción a su traducción de la obra de Béroul habla también de la "sensación de arcaísmo" que no se encuentra en Thomas o en Chrétien aunque se refiere a otros aspectos de la obra. Cf. Béroul, Tristán e Iseo, R. Ruiz Capellán (ed. y trad.). Madrid: Cátedra, 1985, p. 10.

7 Ibid., p. 12.
} 
fragmentos en los que la separación física definitiva se ha consumado y se aproxima el momento fatal de la muerte, por lo que frente al desparpajo y la obscenidad de algunos diálogos encontramos una cierta morosidad de los monólogos cargados de melancolía. Bien es cierto que el texto de Thomas, al igual que ocurre con los otros tres romans analizados, presenta una mayor variedad de historias amorosas, pero el hecho de encontrarse más cercana a las obras de Chrétien nos ha determinado finalmente a adoptar la obra de Béroul.

\subsubsection{LE CHEVALIER DE LA CHARRETE DE CHRÉTIEN DE TROYES. ${ }^{8}$}

De entre los romans conservados de este autor el que narra los amores de Lanzarote y de la reina Ginebra es el más próximo a la concepción depurada del amor cortés como camino de perfección; en él se recoge, además, la necesaria separación entre amor - pasión y matrimonio ideada por los trovadores, aunque se atisbe una cierta ironía en la presentación de las acciones de los personajes.

Mucho se ha escrito sobre el grado de desacuerdo entre Chrétien y Marie de Champagne y en nuestro caso nos inclinamos por la opinión de Jean Frappier, quien considera que no hubo tal, y más bien Chrétien encontró algunas dificultades para trasladar a una obra narrativa las concepciones trovadorescas y feministas de su protectora, recogidas hasta entonces en composiciones líricas. ${ }^{9}$ Desde nuestro punto de vista resulta quizás más interesante el hecho de que no sólo se nos presenta una relación triangular sino varias imbricadas en las que los vértices ocupados por los amantes dan origen a nuevos deseos y obligaciones, tal como ocurre con Meleagant o con

\footnotetext{
${ }^{8}$ Ch. de Troyes, L e Chevalier de la charrete, M. Roques (ed.). Paris: Honoré Champion, 1983. Lo citaremos como Charrete.

${ }^{9}$ Cf. J. Frappier, Chrétien de Troyes. Paris: Hatier, 1957, p. 126-7.
} 
la doncella que libera a Lanzarote de la torre. Solamente hay una noche de amor - en clave mística para algunos ${ }^{10} \mathrm{o}$ tal vez simple sueño erótico y polución nocturna para otros como Accarie—, ${ }^{11}$ pero en el texto de Chrétien se recogen deseos frustrados, celos, ritos y violencia sexual, que por otra parte es una constante en sus obras; ${ }^{12}$ y en el fragmento de Leigni, promesas de nuevas relaciones, alusiones veladas a una amistad homosexual entre Lanzarote y Galván, y la inexplicable unidireccionalidad del amor hasta entonces obsesivamente compartido pero que Lanzarote parece haber olvidado.

A diferencia de las otras novelas de Chrétien de Troyes en las que se muestra más interesado por los conflictos que pueden surgir entre matrimonio y deber caballeresco o bien entre amor, matrimonio y moral, en Charrete amor y deber se funden para lograr la armonía social en el mundo artúrico, hecho éste que junto a los fenómenos enunciados con anterioridad nos han llevado a elegir este roman.

\subsubsection{L'ESCOUFLEDE JEAN RENART. ${ }^{13}$}

Con la llegada del siglo XIII una nueva tendencia amorosa aparece recogida en los textos narrativos, los amores entre un joven, que no tiene por qué ser caballero, y una muchacha virgen casadera. Este es el núcleo de L'E scoufle, obra que nos parece bastante compleja desde muchos puntos de vista y especialmente desde la óptica amorosa. Así, por ejemplo, se nos hace

${ }^{10}$ Cf. J. Ribard, Chrétien de Troyes. Le Chevalier de la Charrete. E ssai d'interprétation symbolique. Paris: Nizet, 1972, p. 125-31.

${ }^{11}$ Cf. M. Accarie, Guenièvre et son chevalier de la charrete: l'orgasme des anges, H ommage à Jean D ufournet. Paris: Champion, 1993, t. I, p. 50-54.

12 Cf. K. Gravdal, Chrétien de Troyes, Gratian, and the Medieval Romance of Sexual Violence, SIG N S, $1992,17,3$, p. $562-82$.

${ }^{13}$ J. Renart, L'E scoufle. Roman d'aventure, F. Sweetser (ed.). París - Ginebra: Droz, 1974. Aludiremos a él con el término E scoufle. 
muy difícil dar una interpretación a los elementos explícitos que la relacionan con la leyenda tristaniana y más concretamente con los textos conservados del siglo XII; ${ }^{14}$ pese a que lo más habitual en una obra medieval sería pensar en una lectura segunda, en una correspondencia voluntaria entre los dos relatos por la que la historia de los amores adúlteros nacidos del bebedizo nos diese alguna clave para la comprensión de los amores recogidos en el texto de Jean Renart, la única relación que encontramos a priori es la de una cierta simpatía hacia los amantes apasionados de la leyenda que se convierten en un ejemplo difícil de seguir para la pareja nacida en el siglo XIII.

$\mathrm{Al}$ margen de esta filiación que sirve de puente entre los dos siglos, podemos considerar esta novela de aventuras como una recopilación casuística de relaciones amorosas. Sería en cierta medida el complemento de la obra de Lorris para comprender los usos amorosos del siglo XIII, herederos, por una parte, de la codificación literaria llevada a cabo en el siglo anterior, y por otra, hijos de una época nueva. En este texto hallamos múltiples historias en clave erótica, algunas de ellas sólo esbozadas: el amor entre jóvenes vírgenes que parece desaparecer con la lejanía y sobre todo con el matrimonio; el amor adúltero; la fidelidad entre esposos casados por conveniencia; las relaciones equívocas entre un hombre casado y una mujer joven y virgen; la atracción ante la belleza femenina y el enamoramiento a primera vista; el falso amor femenino adoptando una postura misógina; los usos codificados del amor caballeresco traspuestos a una pareja de Oriente o la sospecha de la atracción entre mujeres. Esta diversidad, a la que se añaden la descripción de actos amorosos que raramente podemos encontrar en la literatura medieval, el hecho de ofrecer un cambio de mentalidad con respecto a la actividad femenina aquí íntimamente relacionada con los intercambios económicos y el acceso al poder o la ruptura con la novela cortés clásica y su visión de la

\footnotetext{
14 Véase M. R. Blakeslee, Les allusions aux romans de Tristan dans l'oeuvre de Jean Renart: études des sources, Tristan et Iseut, mythe européen et mondial. Göppingen: Kümmerle Verlag, 1987, p. 48-51.
} 
aventura, ${ }^{15}$ inclinaron la balanza a favor de esta obra frente a otras como Le Roman de la Rose del propio Jean Renart o Li biaus desconnëus de Renaut de Beaujeu.

\subsubsection{LE ROMAN DE LA ROSE DE GUILLAUME DE LORRIS. ${ }^{16}$}

El roman de Guillaume de Lorris es sin duda una pieza clave en el desarrollo de la novela cortés ya que retoma las tradiciones fundadoras de esta compleja construcción intertextual, al tiempo que las renueva mediante la asimilación de otras corrientes literarias y la adaptación a una nueva estructuración de la sociedad letrada y laica en las ciudades. Este sutil equilibrio entre tradición y modernidad es la base misma del texto y se manifiesta en numerosos frentes: influencia ovidiana en los temas y en la forma al proclamarse como un arte de amar, el primero en lengua vernácula; preciosismo retórico llevado al extremo gracias a la adopción de la forma alegórica de origen latino; rescate de la aventura que se hace ciudadana e intimista; juego entre la individuación —uso de la primera persona que nos recuerda a los trovadores - y la generalización ejemplar; idolatría hacia la amada, virgen; y, por fin, instrumentalización del texto convertido en el arma definitiva de la seducción.

La actividad creativa de su continuador Jean de Meun, consideremos o no el primer Roman de la Rose como un texto completo, ${ }^{17}$ se aleja

\footnotetext{
15 Cf. C. Cortés Zaborras, Jean Renart. L'Humanisme dans les romans aristocratiques du XIIIe sièle; une esthétique nouvelle, Estudios humanístios en homenaje a L uis Cortés V ázquez, R. Dengler Gassin (ed.). Salamanca: Universidad de Salamanca, 1991, vol. I, p. 149-53.

${ }^{16}$ G. de Lorris, L e Roman de la Rose, T. I, F. Lecoy (ed.). Paris: Honoré Champion, 1983. A partir de ahora nos referiremos a el con el nombre de Rose.
} 
inexorablemente de él. Lo toma como contexto y pre-texto pero ni la estructura que había guardado una sabia proporción entre hechos y enseñanzas, ni el tono de la obra y mucho menos la visión cortés de las relaciones eróticas o de la mujer permanecen. ${ }^{18}$ Es cierto que culmina la aventura del narrador - personaje al penetrar a la amada y que se diversifican de nuevo los registros como ocurría en el caso del Tristan de Béroul. Sin embargo, la negación del código amoroso cortés y la colocación de los amantes en un plano de igualdad ante el instinto, lo alejan en exceso de la línea en la que nos habíamos situado. Por ello hemos restringido nuestro estudio al roman de Guillaume de Lorris.

\subsection{PRESENTACIÓN DEL ESTUDIO.}

\subsubsection{NIVELES DE ANÁLISIS Y OBJETIVOS.}

Hemos partido de la hipótesis de que en buena parte de la literatura amorosa medieval, sea cual sea su adscripción genérica, existen múltiples planos en la presentación del erotismo, que denominamos retórico, fonético y léxico-sintáctico. El hecho de que aparezcan conjuntamente no se debe a

17 Pese a las convincentes razones de R. Lejeune y de K Uitti para afirmar que se trata de un texto cerrado con pleno sentido en sí mismo y perfectamente estructurado, seguimos creyendo que la obra de Guillaume de Lorris está truncada. Y ello por dos razones fundamentales: la primera de orden estructural ya que el autor se ha preocupado de presentarnos las fuerzas antagonistas y ha levantado una construcción defensiva probablemente para que se reanuden los esfuerzos del amante y de los que le ayudan y se oponen a él; la segunda de orden discursivo y retórico pues el amante se dirige en los últimos versos a Bel Accueil, quien en la lógica cortés parece estar obligado a mostrarse de nuevo acogedor ante las muestras de dolor, arrepentimiento y sumisión del enamorado. Cf. respectivamente: A propos de la structure du Roman de la Rose de Guillaume de Lorris, M élanges offerts à F elix L eooy. París: Champion, 1973, p. 346 - 7, Understanding Guillaume de Lorris: the truth of the couple in Guillaumes Romanœ of the Rose, C ontemporary Readings of M edieval L iterature, Guy Mermier (ed.). Ann Arbor: University of Michigan, 1989, p. 58.

18 Cf. W. Calin, Contre la fin'amor? Contre la femme? Une relecture de textes du Moyen Age, Courtly literature: alture and context, K. Busby y E. Kooper (eds.). Amsterdam/Philadelphia: John Benjamins, 1990, p. 75. 
nuestro entender al grado de codificación del impulso sexual que el género, la tradición de un determinado texto, o el autor / autores otorgan a una obra.

Nuestro trabajo consiste fundamentalmente en el análisis de la que podría considerarse como expresión del erotismo en primer grado, es decir, del léxico y de la morfosintaxis de los romans, excluyendo las manifestaciones fonéticas, elaboraciones en segundo grado, menos aparentes, que pretenden pasar más o menos desapercibidas en primera instancia pues se manifiestan a través de los juegos de palabras y de las combinaciones fonéticas y aprovechan la transmisión oral de los textos.

Mientras que el primer nivel corresponde a lo que Zumthor llama superficie lingüística, los recursos sonoros pertenecen a la forma, que engloba a la anterior y que incluye, además, los gestos, la instrumentación o el decorado, ${ }^{19}$ elementos todos ellos difícilmente analizables. La rima, que en principio pertenecería a este estrato, tiene en realidad una filiación múltiple ya que pone en estrecha relación dos palabras desde el punto de vista léxicosemántico pero, además, coarta la composición sintagmática, ${ }^{20}$ debido a la especial estructura lingüística de la poesía, estructura de la que participa la novela en verso. Nosotros nos haremos eco fundamentalmente de su uso en el nivel léxico-semántico y creemos que podemos atribuirle en ocasiones un papel muy importante en la construcción del significado sobrepasando los condicionantes retóricos o el simple adorno formal.

Para abordar el estudio del léxico amoroso creemos que puede resultar interesante la combinación de dos puntos de vista, el onomasiológico y el que llamamos narrativo-estilístico. Con el primero pretendemos determinar qué términos son utilizados para nombrar y describir los entes que están

${ }_{19}$ P. Zumthor, La poésie et la voix..., op. àt., p. 38.

${ }^{20}$ Cf. P. Zumthor, L angue et techniques poétiques à l'époque romane (X Ie - X IIIe sièdes). Paris: Klincksieck, 1963, p. 113. 
directamente o indirectamente implicados en la relación erótica, el juego amoroso y sus consecuencias individuales y colectivas. El estudio narrativoestilístico pretende señalar la distribución del léxico erótico en función de los entes narrativos y de los tipos de discurso.

En cuanto al nivel morfosintáctico nuestro propósito es establecer los modos de encadenación textual, las relaciones sintagmáticas que se establecen entre las unidades y principalmente el grado de recurrencia de las construcciones y funciones sintácticas, así como las variaciones estilísticas individuales que las modifican en los diferentes textos.

En tercer lugar hallamos el plano retórico, tomando este término en el sentido tradicional como el estudio de los recursos estilísticos. En él nos parece interesante destacar no tanto la existencia de una u otra figura, sino el funcionamiento de los nexos intelectuales que se establecen al elaborar ciertas imágenes, teniendo en cuenta que la retórica pretende, tal como afirma Zumthor, exaltar el sentido oculto; ${ }^{21}$ y tomaremos también en consideración la posible evolución de esos nexos en el interior de la tradición literaria. Es del todo evidente que no podremos pasar por alto en muchos casos el estudio de este plano al presentar los resultados de nuestro análisis léxico y sintáctico, aunque esta tarea no será prioritaria ni exhaustiva.

Por encima de estos tres niveles de expresión formal podemos considerar un plano que llamaremos pragmático y del que nos ocuparemos fundamentalmente al estudiar la ideología y la cultura medieval subyacentes a las formas. Partimos al hacer este planteamiento del concepto de pragmalingüística de $\mathrm{H}$. Bühler, quien propone considerar los efectos de la situación sobre las expresiones lingüísticas. ${ }^{22}$ Esto nos permite distinguir dos compartimentos no estancos: el ámbito intra e intertextual, en el que nos

21 P. Zumthor, L ngue, tex te, énigme. Paris: Seuil, p. 234.

22 Cf. Sprachbarrieren und Schulanfang. Weinheim, 1972, p. 21 - 2. 
preguntamos por el funcionamiento de una forma o conjunto de formas a través del prisma de las relaciones amorosas en tanto que relaciones interpersonales en el seno de un relato; un segundo en el que se toman en consideración los fenómenos lingüísticos y literarios en función de aspectos sociales extraliterarios: formas de interacción personal; presiones socioculturales y morales; condiciones y consecuencias de la producción y de la recepción de los textos.

\subsubsection{EVOLUCIÓN DE LA EXPRESIÓN EN EL CORPUS.}

Pretendemos también con nuestro trabajo poner de manifiesto las afinidades y las diferencias que aparecen entre los cuatro textos, observando si se producen cambios formales en diacronía coincidentes con los cambios de mentalidad, o si más bien podemos establecer pares de obras que al menos en apariencia están emparentadas como quizás Tristan-Escoufle por su tratamiento de la pareja ${ }^{23}$ y Lanolot-Rose al mostrarse deudoras de la tradición lírica, o tal vez concluir que tienen su origen en concepciones estilísticas completamente divergentes. Habremos de determinar por lo tanto cuáles son las formas y las estructuras que son comunes a todas ellas, las que no aparecen en alguno de los textos y por fin las pertenecientes a un solo texto.

23 R. Dragonetti señala la existencia de algunos paralelismos entre ambos textos en L e mirage des sources, l'art du faux dans le roman médiéval. Paris: Seuil, 1987, p. 95 - 100. 



\section{METODOLOGÍA.}

\subsection{TRABAJO INICIAL.}

Si bien en un principio nuestra investigación pretendía centrarse en el proceso narrativo de las obras — análisis del punto de vista, de las relaciones entre relato y discurso, los agentes narrativos y los actantes-, pronto nos sentimos atraídos por la expresión lingüística y comenzamos a estudiar las estructuras y las clases gramaticales, un análisis que nos parece recoge una visión más novedosa de las relaciones amorosas en la Edad Media. Esto lo hicimos al comienzo de una forma tradicional, por medio de fichas manuales que recogían formas y contextos. Posteriormente debíamos asignar a cada forma la clase gramatical correspondiente, sin embargo, cuando llevábamos una buena parte de esta tarea realizada y pensando en un análisis sintáctico ulterior, nos dimos cuenta de que las dificultades se hacían cada vez más grandes porque el volumen de material acumulado y más aún la cantidad de combinaciones sintácticas que aparecían era enorme. En ese estadio del trabajo estábamos comenzando a familiarizarnos con algunos útiles informáticos, especialmente los gestores de bases de datos, que podían, si no agilizar el trabajo inicial porque habría que repetirlo, sí permitir que lo hiciésemos de forma mucho más organizada y rigurosa. 


\subsection{UTILIZACIÓN DE HERRAMIENTAS INFORMÁTICAS.}

\subsubsection{ADQUISICIÓN Y EDICIÓN DEL CORPUS.}

Para ayudarnos de un equipo informático en el análisis que pretendíamos llevar a cabo necesitábamos en primer lugar trasladar los textos impresos en papel a un formato asequible para la máquina, lo que nos permitiría un alto grado de automatización en ciertas tareas básicas y lo que era más importante aún, el manejo de una gran cantidad de formas. Sin desdeñar el hecho de que una gran parte del trabajo así realizado para llevar a cabo esta investigación puede sernos de gran utilidad para proseguir estudios sobre la lengua y la literatura medieval desde otros puntos de vista completamente diferentes.

La introducción del corpus en formato electrónico la hicimos utilizando un escáner y mediante un programa de reconocimiento óptico de caracteres (O.C.R.). El siguiente paso consistió en cerciorarnos de que los datos introducidos por este medio correspondían exactamente a los textos del corpus, procediendo a una comparación de ambos y corrigiendo manualmente los errores detectados. Además, eliminamos la numeración de las páginas y de los versos, en el primer caso porque no era un dato que nos interesase y en el segundo porque la numeración debía ser mucho más sistemática y afectar no a cada verso sino a cada forma de cada uno de los textos.

En el caso de Rose la numeración de los versos incorpora en tres ocasiones en la edición impresa la aparición de letras que parecen señalar una interpolación en el manuscrito interrumpiéndose la numeración correlativa y así nos encontramos, por ejemplo, con que hay once versos a los que 
correspondería el número 2074. ${ }^{24}$ La combinación de letras y números se hacía imposible ya que el campo correspondiente de la base de datos era un campo numérico que no aceptaba la inclusión de letras, así pues optamos por la adopción de decimales que hicieran las funciones de aquellas y tenemos para el caso citado los versos que van desde el 2074,00 al 2074,10. También por lo que hace a esta obra la falta de numeración en la edición impresa nos llevó a no considerar las dos líneas iniciales que funcionan como título: ICI COMENCE LE ROUMANZ DE LA ROSE.

Además, debíamos realizar algunos cambios en la presentación del corpus que permitiesen su tratamiento con bases de datos. El primero era la eliminación de las mayúsculas ya que aparecerían como términos distintos los que estuviesen escritos en mayúscula, ya fuese por comenzar una frase tras un punto o porque la edición presentase todas las palabras al comienzo de verso con mayúscula, como es el caso para las utilizadas del Tristan y del E scoufle, y los mismos términos escritos en minúscula. El cambio de mayúsculas por minúsculas en estos casos nos llevó a unificar la edición y tratar del mismo modo los nombres propios, máxime cuando en tres de las obras aparecen abstracciones personificadas o personajes alegóricos cuyos nombres también comienzan con mayúscula. La diferencia entre estos personajes o abstracciones y los personajes históricos o puramente literarios que figuran en los cuatro romans se establece en el momento de la marca secundaria en categorías al aparecer los segundos como nombres propios mientras que los primeros los consideramos nombres comunes aunque en la tradición literaria clásica y medieval aparecen a menudo como sujeto o complemento indirecto de verbos declarativos y de acción.

En la edición de E scoufle eliminamos los corchetes que enmarcaban algunas letras, ciertas palabras e incluso alguna frase, porque aunque no está explicado su uso por el editor se puede suponer que se trata de grafías posibles

\footnotetext{
24 Ocurre lo mismo con el verso 2452 y siguientes, numerados como 2452,00, 2452,01, 2452,02, y con el verso 3098, seguido de otros once versos numerados del 3098,01 al 3098,10.
} 
o más lógicas, bien que aparecen en los manuscritos de apoyo o bien como en el caso de la forma biautrés por tratarse de un error de los copistas. Hemos mantenido pues las formas tal y como aparecen en el texto pero eliminando los signos que entorpeciesen la posterior labor de análisis automatizado. Hemos reservado los corchetes para indicar la falta, no subsanada por el editor, de parte del texto en el interior de un verso o de la totalidad del verso, lo que debe permitir la consideración de construcciones fragmentarias y por lo tanto excepcionales en el momento de realizar el análisis del texto y el establecimiento de patrones sintácticos.

Respecto a los apóstrofos existía la opción de tomarlos como signos de puntuación y que no apareciesen como parte de las formas. Esto planteaba algunos inconvenientes puesto que en E scoufle se encuentra a menudo la forma única ml't en la que no se indica la apócope de un sonido final o inicial y que por lo tanto no puede ser dividida en dos; por otro lado, el presentarlo como signo de desaparición de un sonido y ser incluido en la propia forma permite un análisis más rápido de ciertas formas como 'nn o 'st.

En todos los textos aparecen transcritos los numerales cardinales mediante letras y están precedidos y seguidos de puntos. En este caso sí consideramos a éstos como signos de puntuación aunque no tengan en absoluto la función habitual de representación gráfica del ritmo de la frase.

Por lo que se refiere a los guiones entre formas — dejando de lado las marcas de intervención en estilo directo de un personaje-, tan sólo encontramos en los textos los que sirven para unir dos lexías que conforman una compuesta, por ejemplo passevilenie en Escoufle, en cuyo caso hemos mantenido el guión entre ambas y analizado por lo tanto una sola forma. 


\subsubsection{DESCRIPCIÓN DE LAS ETAPAS DEL ANÁLISIS Y PROGRAMAS UTILIZADOS.}

\subsubsection{ELABORACIÓN DE LOS DICCIONARIOS MORFOLÓGICOS.}

Tras la edición procedimos a exportar el corpus que se encontraba todavía en formato WORDPERFECT 5.1 a cuatro bases de datos -TRISTAN.DBF，LANCE.DBF， ESCF.DBF，ROSA.DBF- con la siguiente estructura para cada registro:

\begin{tabular}{llll}
\hline $\begin{array}{l}\text { NOMBRE DEL } \\
\text { CAMPO }\end{array}$ & TIPO DE DATOS & $\begin{array}{l}\text { LONGITUD DEL } \\
\text { CAMPO }\end{array}$ & DECIMALES \\
\hline FORMA & Caracteres & 50 & 0 \\
RESTO & Caracteres & 130 & 0 \\
RESTO2 & Caracteres & 150 & 0 \\
NVER & Numéricos & 8 & 2 \\
\hline
\end{tabular}

Tabla 1. Estructura de las bases de datos TRISTAN, LANCE, ESCF y ROSA.

En ellas cada una de las formas del texto, incluidos los signos de puntuación, aparece recogida en un registro en el campo «forma» y el verso en el que se encuentra en el campo «nven». Los campos «resto2»y «resto» quedaban reservados para incluir en el primero de ellos todas las posibles clases gramaticales a las que pudiese pertenecer así como las categorías que se le pudiesen atribuir en el sistema de la lengua de la época que nos ocupa. En el segundo aparecerían únicamente las claves correspondientes a las clases gramaticales separadas por once caracteres vacíos, contenido que durante el análisis que presentaremos más abajo sería sustituido por una sola clave que correspondería a la clase gramatical a la que se adscribía cada forma tomando en consideración el contexto. 
Con el fin de determinar el contenido de ambos campos se hacía necesario elaborar en primer lugar un diccionario morfológico en el que quedarían asignados los atributos en lengua para las formas. Para ello podíamos optar por hacer un sólo diccionario para todas las obras o para mayor comodidad crear uno por obra tras hacer un índice en el que sólo apareciese una ocurrencia de cada palabra. Utilizamos para esta labor y para el análisis contextual posterior los programas creados en dBASE III +25 por Jesús Alvarez Polo como parte de su trabajo de investigación para obtener el grado de doctor, ${ }^{26}$ introduciendo algunos cambios ya que no habíamos seguido los mismos criterios a la hora de determinar las clases gramaticales, las categorías no podían ser las mismas pues en su caso el análisis se hacía sobre textos del francés y del español contemporáneos y, por otro lado, la organización textual — numeración de los versos — y el número de textos que conformaban el corpus eran diferentes.

En la elaboración de los diccionarios morfológicos, que llamamos TRISUNI.DBF， LANCUNI.DBF， ESCUNI.DBF y ROSUNI.DBF —recogidos en el CDROM anexo en el subdirectorio D iocionarios morfológioos del directorio Bases de datos - utilizamos el programa DICO.PRG ${ }^{27}$ que presenta una pantalla en la que se pide el nombre de la base de datos que se quiere marcar e invoca un segundo programa DICO1.PRG. Este presenta las formas de la base de datos ordenadas según el código ASCII y ofrece la posibilidad de elegir la clase gramatical que queremos asignar pudiendo repetirse la operación cuantas veces sea necesario hasta caracterizar la forma en lengua, permitiendo así mismo avanzar y retroceder en el diccionario, borrar la selección efectuada, ir a una forma concreta, editar los códigos que se

25 En fases posteriores de nuestro trabajo utilizamos otros programas elaborados con el lenguaje de programación dBASE IV.

${ }^{26}$ Esta tesis doctoral a la que se nos permitió tener acceso antes de su lectura, fue presentada con el título E studio del uso de la preposidiones en la traducción franós-español y defendida en la Universidad de Granada en diciembre de 1997.

27 Todos los programas utilizados pueden ser editados gracias a un editor de textos y pueden ser ejecutados en un gestor de base de datos dBASE III + o superior. 
han otorgado a una forma, o bien abandonar el procedimiento. Este programa, en función de la elección que realizamos en el menú que nos presenta, puede invocar a su vez otros 18 programas permitiendo asignar las diferentes categorías o atributos preestablecidos con antelación según unos criterios a los que nos referiremos más adelante. Todos estos programas aparecen recogidos en el CDROM anexo en el subdirectorio Diocionario morfológio del directorio Programas.

El primer menú que nos presenta el programa ofrece la posibilidad, tal como hemos dicho antes, de determinar la clase o una de las clases gramaticales con la que caracterizamos la forma en cuestión, utilizando el programa CATEG.PRG, que asigna e inscribe una clave según la elección realizada. A continuación presentamos en dos columnas las clases y las claves que podemos encontrarnos:

\begin{tabular}{ll}
\hline CLASE & CLAVE \\
\hline SUSTANTIVO & $\mathrm{S}$ \\
ADJETIVO & $\mathrm{A}$ \\
PRONOMBRE & $\mathrm{P}$ \\
VERBO & $\mathrm{V}$ \\
ETTRE & $\mathrm{E}$ \\
AVOIR & $\mathrm{H}$ \\
ADVERBIO & $\mathrm{D}$ \\
PREPOSICIÓN & $\mathrm{R}$ \\
CONJUNCIÓN & $\mathrm{C}$ \\
PARTICIPIO PRESENTE & $\mathrm{T}$ \\
ARTÍCULO & $\mathrm{J}$ \\
PARTICIPIO PASADO & $\mathrm{O}$ \\
PUNTUACIÓN & $\mathrm{Z}$ \\
EXCLAMACIÓN & $\mathrm{L}$
\end{tabular}


INFINITIVO

NUMERAL
I

$\mathrm{N}$

Tabla 2. Clases gramaticales y claves. Menú presentado por el programa DICO1.PRG

En el caso de que pueda ser un sustantivo el programa DICO1 hace que aparezcan en pantalla otros cinco menús sucesivos con los que determinar los diversos atributos y que invocan a su vez cinco programas diferentes: el género (GENER.PRG), el número (NUMER.PRG), el caso (CASO.PRG), ${ }^{28}$ el tipo de sustantivo (TIPSUS.PRG) y el que denominamos USO en el que se recogen una serie de valores numéricos que hubieran permitido ofrecer una valoración del uso de las formas en un trabajo de tipo estadístico. Aunque este no era en absoluto nuestro propósito lo mantuvimos, asignando en todos los casos el valor 0 , por dos motivos, en primer lugar porque en trabajos posteriores podría ser utilizado y en segundo lugar porque nos daba la posibilidad de añadir un atributo más que no hubiésemos previsto efectuando cambios mínimos en las bases de datos y en los programas. ${ }^{29}$

Para la determinación de cada uno de los atributos se nos ofrecían las siguientes posibilidades, atribuyéndoseles las claves que se consignan al lado:

\section{GENERO CLAVE}

$\begin{array}{ll}\text { NEUTRO } & 0 \\ \text { MASCULINO } & 1 \\ \text { FEMENINO } & 2 \\ \text { COMÚN } & 3\end{array}$

\footnotetext{
${ }^{28}$ Estos tres atributos son comunes a varias clases por lo que aunque los mencionemos en cada una de ellas no volveremos a presentar las posibilidades de elección que se nos ofrecen.

${ }^{29}$ En las agrupaciones de códigos correspondientes a ADJETIVO, PRONOMBRE, VERBO, ÊTRE, AVOIR, y ARTÍCULO, aparece pues un valor 0 en última posición que no reenvía a ningún atributo y al que a partir de ahora no volveremos a referimos.
} 
SIN GÉNERO 4

Tabla 3. Género y claves. Menú presentado por el programa DICO1.PRG.

\begin{tabular}{ll}
\hline NÚMERO & CLAVE \\
\hline SIN NÚMERO & 0 \\
SINGULAR & - \\
PLURAL & + \\
COMÚN & 3
\end{tabular}

Tabla 4. Número y claves. Menú presentado por el programa DICO1. PRG.

\begin{tabular}{ll}
\hline CASO & CLAVE \\
\hline SUJETO & 0 \\
RÉGIMEN & 1 \\
COMÚN & 2 \\
SIN CASO & 3
\end{tabular}

Tabla 5. Caso y claves. Menú presentado por el programa DICO1.PRG.

\begin{tabular}{ll}
\hline TIPO DE SUSTANTIVO & CLAVE \\
\hline NOMBRE COMÚN & 0 \\
NOMBRE PROPIO & 1
\end{tabular}

Tabla 6. Tipo de sustantivo y claves. Menú presentado por el programa DICO1. PRG.

Veamos por ejemplo cómo aparece en el diccionario TRISUNI.DBF el primer sustantivo que encontramos:

\begin{tabular}{lll}
\hline FORMA & \multicolumn{2}{l}{ RESTO } \\
\hline aaisement & $\mathrm{S} 1-110$ & $\mathrm{~S} 1+010$ \\
\hline
\end{tabular}


Nos hallamos ante una forma que sólo puede ser sustantivo, pero que puede ser masculino singular en caso régimen o bien plural en caso sujeto, y se trata de un nombre común.

Si se trata de un adjetivo el programa DICO1 hace que aparezcan en pantalla otros cinco menús sucesivos y que invocan a su vez cinco programas diferentes: GENER.PRG, NUMER.PRG, CASO.PRG, el que determina el tipo de adjetivo (TIPADJE.PRG) y USO. Para los posibles tipos de adjetivos se nos presenta el siguiente menú:

\begin{tabular}{ll}
\hline TIPO DE ADJETIVO & CLAVE \\
\hline CALIFICATIVO & 0 \\
POSESIVO & 1 \\
INDEFINIDO & 2 \\
INTERROGATIVO & 3 \\
VERBAL & 4
\end{tabular}

Tabla 7. Tipo de adjetivo y claves. Menú presentado por el programa DICO1. PRG.

La atribución de las características de los pronombres requería la presentación de siete menús, los ya conocidos que conciernen al género, número, caso y uso y los que presentan el tipo de pronombre (TIPRON.PRG), las posibilidades de contracción del pronombre con otras clases gramaticales apareciendo el pronombre a la izquierda de la forma contracta (TIPFOR.PRG), y la persona (PERSO.PRG), apareciendo como siguen:

\section{TIPO DE PRONOMBRE CLAVE}

$\begin{array}{ll}\text { DEMOSTRATIVO } & 0 \\ \text { RELATIVO } & 1 \\ \text { INDEFINIDO } & 2\end{array}$


INTERROGATIVO 3

PERSONAL 4

Tabla 8. Tipo de pronombre y claves. Menú presentado por el programa DICO1.PRG.

\begin{tabular}{ll}
\hline TIPO DE FORMA & CLAVE \\
\hline SIN CONTRACCIÓN & 0 \\
+ PRONOMBRE & 1 \\
+ VERBO & 2 \\
+ ADVERBIO & 3 \\
+ CONJUNCIÓN & 4 \\
+ ARTÍCULO & 5
\end{tabular}

Tabla 9. Tipo de forma y claves. Menú presentado por el programa DICO1.PRG.

\begin{tabular}{ll}
\hline PERSONA & CLAVE \\
\hline SIN PERSONA & 0 \\
PRIMERA & 1 \\
SEGUNDA & 2 \\
TERCERA & 3
\end{tabular}

Tabla 10. Persona y claves. Menú presentado por el programa DICO1. PRG.

En los casos en que se tratase de un verbo, o de être o de avoir, los atributos que les podríamos asignar serían los mismos utilizando para ello cinco programas: el que define el modo verbal (MODO.PRG), el que determina el tiempo verbal (TIEMPO.PRG) y otros ya presentados anteriormente, que son PERSO.PRG, NUMER.PRG y USO.

MODO CLAVE

IN DICATIVO 0 


\section{SUBJUNTIVO 1}

Tabla 11. Modo y claves. Menú presentado por el programa DICO1.PRG.

\begin{tabular}{ll}
\hline TIEMPO & CLAVE \\
\hline PRESENTE & 0 \\
IMPERFECTO & 1 \\
PASADO & 2 \\
FUTURO & 3 \\
CONDICIONAL & 4 \\
IMPERATIVO & 5
\end{tabular}

Tabla 12. Tiempo y claves. Menú presentado por el programa DICO1. PRG.

La clase de los adverbios puede recibir cuatro atributos cuya determinación se hace mediante los programas siguientes: GENER.PRG, NUMER.PRG, TIPADVE.PRG para definir el tipo de adverbios y TIPFOR.PRG para las contracciones con otras clases en que el adverbio aparezca en la posición izquierda:

\begin{tabular}{ll}
\hline TIPO DE ADVERBIO & CLAVE \\
\hline MODO & 0 \\
DUDA & 1 \\
LUGAR & 2 \\
CANTIDAD & 3 \\
AFIRMACIÓN & 4 \\
NEGACIÓN & 5 \\
TIEMPO & 6 \\
PRONOMINAL & 7 \\
COMPARACIÓN & 8 \\
INTERROGATIVO & 9
\end{tabular}




$\begin{array}{ll}\text { COORDINACIÓN } & \$ \\ \text { INTENSIDAD } & \& \\ \text { DE FRASE } & * \\ \text { RELATIVO } & i \\ \text { EXCLAMATIVO } & !\end{array}$

Tabla 13. Tipo de adverbio y claves. Menú presentado por el programa DICO1.PRG.

Para la clase de las preposiciones se presentan tres menús correspondientes al género (GENER.PRG), al número (NUMER.PRG) y a las posibilidades de contracción de la preposición con otras clases gramaticales (TIPFOR.PRG). Ya que los dos primeros atributos pueden causar extrañeza debemos decir aquí que las preposiciones que, al igual que posteriormente las conjunciones, no están contractas van siempre marcadas como sin género y sin número (es el caso para a, por ejemplo, que aparece marcada como R400), y lo que se marca con estos atributos en realidad son los correspondientes a la segunda forma de la contracción cuando sí puede poseer las categorías de género y número.

En cuanto a las conjunciones, su caracterización se hace mediante cuatro programas: GENER.PRG, NUMER.PRG, TIPCON.PRG, que define el tipo de conjunción, y TIPFOR.PRG.

TIPO DE CONJUNCION CLAVE

$\begin{array}{ll}\text { COPULATIVA } & 0 \\ \text { CAUSAL } & 1 \\ \text { CONSECUTIVA } & 2 \\ \text { ADVERSATIVA } & 3 \\ \text { DISYUNTIVA } & 4 \\ \text { EXPLICATIVA } & 5\end{array}$


FINAL 6

CONCESIVA 7

TEMPORAL 8

COMPARATIVA 9

CONDICIONAL \$

Tabla 14. Tipo de conjunción y claves. Menú presentado por el programa DICO1.PRG.

El programa DICO1.PRG invoca cinco programas para definir los atributos de la clase de los artículos: GENER.PRG, NUMER.PRG, CASO.PRG, TIPART.PRG, que presenta los tipos de artículos, y USO.

\begin{tabular}{ll}
\hline TIPO DE ARTÍCULO & CLAVE \\
\hline DETERMINADO & 0 \\
INDETERMINADO & 1 \\
DEMOSTRATIVO & 2 \\
POSESIVO & 3
\end{tabular}

Tabla 15. Tipo de artículo y claves. Menú presentado por el programa DICO1. PRG.

Para determinar los tipos de signos de puntuación utilizamos el programa SIGPUN.PRG:

\begin{tabular}{ll}
\hline SIGNO DE PUNTUACION & CLAVE \\
\hline TODOS & 0 \\
COMA & 1 \\
COMILLAS & 2 \\
GUIÓN & 3 \\
SUBRAYADO & 4 \\
PORCENTAJE & 5 \\
INTERROGANTE & 6
\end{tabular}


Tabla 16. Signo de puntuación y claves. Menú presentado por el programa DICO1.PRG.

Los infinitivos se caracterizan mediante los programas NUMER.PRG y CASO.PRG; los participios pasados gracias a GENER.PRG, NUMER.PRG y CASO.PRG; y los participios presentes pueden aparecer con cuatro atributos: género, número, caso y tipo de participio presente, utilizando para ello el programa TIPPRES.PRG.

\section{TIPO DE PART. PRESENTE CLAVE}

$\begin{array}{ll}\text { PARTICIPIO } & 0 \\ \text { GERUNDIO } & 1\end{array}$

Tabla 17. Tipo de participio presente y claves. Menú presentado por el programa DICO1. PRG.

Finalmente a los numerales les hemos asignado tres tipos de atributos, el género, el caso y el tipo de numeral con TIPNUM.PRG.

\section{TIPO DE NUMERAL CLAVE}

$\begin{array}{ll}\text { ORDINAL } & 0 \\ \text { CARDINAL } & 1\end{array}$

Tabla 18. Tipo de numeral y claves. Menú presentado por el programa DICO1. PRG. 


\subsubsection{ANÁLISIS MORFOLÓGICO DEL CORPUS. ${ }^{30}$}

Una vez completados los cuatro diccionarios procedimos a traspasar las marcas que habíamos atribuido a cada forma a las palabras de los textos, rellenando así el campo RESTO2 de las bases de datos, y sólo las claves correspondientes a las clases gramaticales fueron trasladadas al campo RESTO. Tras ello pasamos ya a realizar el análisis morfológico de todas las palabras. En un primer momento hicimos una asignación manual de las clases gramaticales para que los programas de análisis automatizado pudiesen partir de datos fiables; para ello analizamos en cada texto unas tres mil formas tomadas al comienzo, hacia la mitad del texto y al final.

$\mathrm{Al}$ terminar este análisis ejecutamos los que llamamos programas de aprendizaje APRENT.PRG para TRISTAN.DBF, APRENL.PRG para LANCE.DBF, APRENE.PRG para ESCF.DBF y APRENG.PRG para ROSA.DBF. Con estos programas se toman tres datos: las concordancias de dos palabras, los patrones constituidos por cinco categorías seguidas, así como las categorías asignadas para cada forma, y se actualizan las bases de datos correspondientes — de las que hablaremos a continuación— cada vez que se lleva a cabo un análisis, ya sea manual o automático, y en este último caso, una vez que éste ha sido corregido manualmente, para que los programas de análisis que presentaremos a continuación puedan realizar paulatinamente un trabajo con menos errores. Los cuatro programas de aprendizaje utilizan en la parte correspondiente al establecimiento de concordancias una base de datos auxiliar CONAUX.DBF y dos índices IUFORCON.NDX e IFORCON.NDX, siendo estos últimos creados por el propio programa al ejecutarse.

\footnotetext{
${ }^{30}$ Los programas que presentamos en este apartado aparecen recogidos en el subdirectorio A nálisis y aprendizaje del directorio Programas del CDROM anexo. Las bases de datos a las que vamos a hacer referencia están en el subdirectorio A nálisis y aprendizaje del directorio Bases de datos. Los índices se pueden encontrar en el directorio Indios.
} 
El proceso ya automatizado constaba de tres fases: análisis automático, correcciones manuales y aprendizaje automático, y sólo podía ser realizado fragmentando las bases de datos que contenían los textos completos, por ello procedimos a subdividirlas en bases de datos parciales de aproximadamente mil formas que unificábamos al final de todo el proceso. ${ }^{31}$ El análisis automatizado se hace mediante cuatro programas ANALIT.PRG — correspondiente a la base de datos TRISTAN.DBF—, ANALIL.PRG, que analiza la base de datos LANCE.DBF, ANALIE.PRG, que corresponde a la base de datos ESCF.DBF, y ANALIG.PRG, que analiza la base de datos ROSA.DBF.

Los cuatro programas utilizan cada uno de ellos tres bases de datos auxiliares a las que hemos hecho referencia en la fase de aprendizaje; en una se recogen las concordancias, es decir, se forman pares de formas, apareciendo cada una de ellas en un registro como primera forma y en otro como segunda. Estas bases de datos llamadas CONCORT.DBF, CONCORL.DBF, CONCORE.DBF Y CONCORG.DBF tienen la estructura que presentamos a continuación:

\begin{tabular}{lll}
\hline $\begin{array}{l}\text { NOMBRE } \\
\text { DEL CAMPO }\end{array}$ & $\begin{array}{l}\text { TIPO DE } \\
\text { DATOS }\end{array}$ & $\begin{array}{l}\text { LONGITUD } \\
\text { DEL } \\
\text { CAMPO }\end{array}$ \\
\hline FORMA & Caracteres & 33 \\
CATEG & Caracteres & 1 \\
FORSIG & Caracteres & 33 \\
CATSIG & Caracteres & 1 \\
NUMOC & Numéricos & 5 \\
TOCAM & Caracteres & 68 \\
\hline
\end{tabular}

Tabla 19. Estructura de las bases de datos que recogen las concordancias.

En ellas además del campo FORMA y el campo CATEG en el que se recoge la clase gramatical que se le ha asignado a la forma en el contexto, aparecen la forma siguiente FORSIG y la clase correspondiente en CATSIG,

31 TRISTAN.DBF: TRIS1.DBF — TRIS33.DBF; LANCE.DBF: LANCE1.DBF — LANCE50.DBF; ESCF.DBF: ESCF1.DBF — ESCF66.DBF; ROSA.DBF: ROSA1.DBF — ROSA27.DBF 
el número de ocurrencias totales de la combinación de los cuatro datos en NUMOC y finalmente el campo TOCAM en el que aparecen los cuatro datos ordenados y separados por el signo \#. Este campo sirve para crear el índice correspondiente a cada base de datos que utilizan tanto el programa de aprendizaje como el programa de análisis, y que son: ITOCCNCT.NDX para CONCORT.DBF, ITOCCNCL.NDX para CONCORL.DBF, ITOCCNCE.NDX para CONCORE.DBF e ITOCCNCG.NDX para CONCORG.DBF.

Tomemos como ejemplo el primer registro de la base de datos CONCORG.DBF:

\begin{tabular}{llllll}
\hline FORMA & CATEG & FORSIG & CATSIG & NUMOC & TOCAM \\
\hline $\mathrm{a}$ & $\mathrm{H}$ & $\mathrm{se}$ & $\mathrm{C}$ & 2 & $\mathrm{a}$ \\
\hline
\end{tabular}

El segundo grupo de bases de datos auxiliares recoge los patrones gramaticales, tomando grupos de 5 clases y estableciendo las combinaciones y apariciones de las diferentes clases gramaticales, y son PATT.DBF (índice: ITOPPATT.NDX) correspondiente a TRISTAN.DBF, PATL.DBF (índice: ITOPPATL.NDX) para LANCE.DBF, PATE.DBF (índice: ITOPPATE.NDX) que corresponde a ESCF.DBF, y finalmente PATG.DBF (índice: ITOPPATG.NDX) para ROSA.DBF. Todas ellas presentan la estructura siguiente:

\begin{tabular}{llll}
\hline $\begin{array}{l}\text { NOMBRE DEL } \\
\text { CAMPO }\end{array}$ & TIPO DE DATOS & $\begin{array}{l}\text { LONGITUD DEL } \\
\text { CAMPO }\end{array}$ & DECIMALES \\
\hline L1 & Caracteres & 1 & 0 \\
L2 & Caracteres & 1 & 0 \\
L3 & Caracteres & 1 & 0 \\
L4 & Caracteres & 1 & 0 \\
L5 & Caracteres & 1 & 0 \\
NUM & Numérico & 5 & 0 \\
PORC & Numérico & 8 & 6 \\
TOPA & Caracteres & 9 & 0 \\
& & & \\
\hline
\end{tabular}

Tabla 20. Estructura de las bases de datos que recogen los patrones. 
En los campos L1, L2, L3, L4 y L5 se recogen las claves de las cinco clases gramaticales que aparecen combinadas, en NUM el número de veces que en el texto en cuestión aparece dicha combinación, en PORC el porcentaje de aparición, dato que permite al programa de análisis otorgar un determinado peso a la combinación para determinar la clase gramatical de la forma que está analizando, y en el campo TOPA encontramos las cinco claves separadas por el signo \#, sirviendo este campo para crear el índice al que hemos hecho referencia en el párrafo anterior para cada base de datos.

En este caso vamos a tomar como ejemplo el registro $n^{\circ} 4$ de la base de datos PATL.DBF:

\begin{tabular}{llllllll}
\hline L1 & L2 & L3 & L4 & L5 & NUM & PORC & TOPA \\
\hline C & J & S & R & S & 17 & 0,033337 & C\#J\#S\#R\#S
\end{tabular}

En tercer lugar hablaremos de las bases de datos que recogen las diferentes clases gramaticales asignadas para cada forma en el texto. Son FORCAT.DBF (índice: IFORFORT.NDX) para TRISTAN.DBF, FORCAL.DBF (índice: IFORFORL.NDX) para LANCE.DBF, FORCAE.DBF (índice: IFORFORE.NDX) para ESCF.DBF y FORCAG.DBF (índice: IFORFORG.NDX) para ROSA.DBF; y presentan la estructura:

\begin{tabular}{llll}
\hline $\begin{array}{l}\text { NOMBRE DEL } \\
\text { CAMPO }\end{array}$ & $\begin{array}{l}\text { TIPO DE } \\
\text { DATOS }\end{array}$ & $\begin{array}{l}\text { LONGITUD DEL } \\
\text { CAMPO }\end{array}$ & DECIMALES \\
\hline FORMA & Caracteres & 33 & 0 \\
NUMOC & Numérico & 6 & 0 \\
CA1 & Caracteres & 1 & 0 \\
CA2 & Caracteres & 1 & 0 \\
CA3 & Caracteres & 1 & 0 \\
CA4 & Caracteres & 1 & 0 \\
CA5 & Caracteres & 1 & 0 \\
CA6 & Caracteres & 1 & 0 \\
N1 & Numérico & 5 & 0 \\
N2 & Numérico & 5 & 0 \\
N3 & Numérico & 5 & 0 \\
N4 & Numérico & 5 & 0
\end{tabular}




\begin{tabular}{llll} 
N5 & Numérico & 5 & 0 \\
N6 & Numérico & 5 & 0 \\
PO1 & Numérico & 8 & 6 \\
PO2 & Numérico & 8 & 6 \\
PO3 & Numérico & 8 & 6 \\
PO4 & Numérico & 8 & 6 \\
PO5 & Numérico & 8 & 6 \\
PO6 & Numérico & 8 & 6 \\
\hline
\end{tabular}

Tabla 21. Estructura de las bases de datos que recogen las combinaciones de formas y categorías.

En ellas encontramos el campo FORMA que es utilizado para crear el índice del que se valen los programas de análisis y aprendizaje, el número de ocurrencias totales de la forma en el texto en NUMOC, las diferentes clases que se le han asignado en el texto en CA1 a CA6, el número de ocurrencias totales para cada una de las asignaciones morfológicas en $\mathrm{N} 1$ a $\mathrm{N} 2$ y el porcentaje que cada una de las asignaciones presenta en PO1 a PO6; tal como podemos ver en el primer registro de FORCAE.DBF, en el que se recoge la forma que, con 871 ocurrencias en la base de datos ESCF.DBF, funcionando como pronombre en 198 ocasiones, como conjunción en 580 y como adverbio en 93 ocasiones:

\begin{tabular}{ll}
\hline CAMPO & \\
\hline F0RMA & que \\
NUMOC & 871 \\
CA1 & P \\
CA2 & C \\
CA3 & D \\
N1 & 198 \\
N2 & 580 \\
N3 & 93 \\
P01 & 22,73249 \\
P02 & 66,59013
\end{tabular}




PO3 10,67738

Los datos que se recogen en estas bases de datos auxiliares no sólo son meras herramientas en el proceso de asignación de clases sino que pueden sernos muy útiles para obtener datos sobre la composición textual en su conjunto o sobre el uso de algunos vocablos, clases gramaticales, esquemas lingüísticos, preferencias estilísticas y su evolución en los diferentes textos. Por ello creemos que es un material que además de ayudarnos en la investigación que presentamos pueden dar pié a futuros trabajos sobre el corpus.

Una vez completado el análisis procedimos a reducir la longitud del campo RESTO por lo que ahora sólo puede contener un único carácter, quedando la estructura de las bases de datos como sigue:

\begin{tabular}{llll}
\hline $\begin{array}{l}\text { NOMBRE DEL } \\
\text { CAMPO }\end{array}$ & $\begin{array}{l}\text { TIPO DE } \\
\text { DATOS }\end{array}$ & $\begin{array}{l}\text { LONGITUD DEL } \\
\text { CAMPO }\end{array}$ & DECIMALES \\
\hline FORMA & Caracteres & 50 & 0 \\
RESTO & Caracteres & 1 & 0 \\
RESTO2 & Caracteres & 150 & 0 \\
NVER & Numéricos & 8 & 2 \\
\hline
\end{tabular}

Tabla 22. Nueva estructura de las bases de datos TRISTAN, LANCE, ESCF y ROSA.

Tomemos como ejemplo el primer registro de la base de datos ROSA.DBF:

\begin{tabular}{lllrr}
\hline FORMA & RESTO & REST 02 & NVER \\
\hline aucunes & $\mathrm{A}$ & $\mathrm{A} 2+220$ & $\mathrm{P} 2+22000$ & 1,00 \\
\hline
\end{tabular}




\subsubsection{DETERMINACIÓN DE LOS CONTEXTOSERÓTICOS. ${ }^{32}$}

El tema de nuestro trabajo requería que delimitásemos dentro del corpus cuáles eran las formas y cuáles eran los contextos que íbamos a estudiar con más detalle para descubrir los entresijos del discurso amoroso en los textos que habíamos elegido. Una vez realizado el análisis morfológico pretendíamos determinar la utilización del léxico y en qué grupos sintácticos este léxico aparecía. Para ello debíamos realizar una selección de cada una de las ocurrencias del vocabulario que considerásemos portadora o cuando menos coadyuvante en la transmisión de los contenidos eróticos, teniendo en cuenta no sólo este estudio sino trabajos posteriores que nos permitiesen ofrecer una visión más amplia y completa del erotismo medieval. Es decir, tomaríamos no sólo las palabras léxicas sino también las palabras gramaticales, partiendo de la hipótesis de que podían ser tanto o más importantes que las primeras en la formación de esquemas sintácticos fijos, sin olvidarnos de que adverbios, conjunciones o preposiciones pueden variar significativamente el valor de las primeras.

La automatización de la selección léxica nos llevó a optar por dos tipos de búsquedas que quedarían reflejadas en el programa creado a tal efecto, una por palabras y otra por lexemas. El programa, llamado BUSFOR.PRG, una vez introducido el término o el lexema que queremos encontrar, lo presenta con un contexto de 19 formas anteriores y posteriores y ofrece la posibilidad de seleccionar o no la forma concreta pasando después a la siguiente y así sucesivamente para los cuatro textos. Según sean términos o lexemas, las formas elegidas pasan a engrosar dos bases de datos DESTIN.DBF y DESTINL.DBF que a la postre se convertirán en una sola, DESTINO.DBF, con la estructura:

\footnotetext{
32 Los programas que aparecen en este apartado se encuentran en el subdirectorio L éxiø y œntex tos del directorio Programas, y las bases de datos en el subdirectorio L éx io y ontex tos del directorio Bases de datos.
} 


\begin{tabular}{llll}
\hline NOMBRE DEL & TIPO DE & LONGITUD & DECIMALE \\
CAMPO & DATOS & DEL CAMPO & S \\
\hline FORMA & Caracteres & 50 & 0 \\
CATEG & Caracteres & 1 & 0 \\
BD & Caracteres & 10 & 0 \\
NVER & Numérico & 8 & 2 \\
NREG & Numérico & 6 & 0 \\
FOCA & Caracteres & 52 & 0 \\
\hline
\end{tabular}

Tabla 23. Estructura de la base de datos DESTINO.

En ellas, además de recogerse la forma en cuestión y la clase que le habíamos asignado en el análisis en el campo CATEG, aparece el nombre del texto al que pertenece - Tristan, Charrete, E scoufle, Rose - en el campo BD, el número de verso en NVER, el número de registro o número de forma en el texto, en NREG, y en el campo FOCA la combinación de la forma y la clase gramatical separadas por el signo \#. Este último campo nos permitirá organizar el léxico recurriendo a los índices, pero tomando en consideración la morfología y por lo tanto eliminando en gran medida los problemas que podía causarnos la homografía.

Sin embargo no todas las formas de los textos pudieron ser seleccionadas de esta forma ya que la numeración especial que hemos señalado más arriba para algunos versos de Rose no aparecía reflejada en las nuevas bases de datos con lo que se falseaban los resultados provocando, además, el mal funcionamiento del programa de determinación de contextos que haríamos correr después. Ello nos llevó a eliminar de la base de datos DESTINO.DBF las formas recogidas de esos versos y crear con ellas otra DESTINR.DBF para cuyas formas debimos extraer los contextos manualmente. A la postre y una vez ejecutado el programa que sirve para determinar los contextos automáticamente, DESTINR.DBF pasaría a incluirse en DESTINO.DBF, tal y como aparece en el CDROM anexo.

A modo de ejemplo mostramos el primer registro de esta base de datos: 


\begin{tabular}{llllll}
\hline FORMA & CATEG & BD & NVER & NREG & FOCA \\
\hline $\mathrm{a}$ & $\mathrm{H}$ & Tristan & 263.0 & 1866.0 & $\mathrm{a \# H}$ \\
\hline
\end{tabular}

En este punto, antes de pasar a definir los contextos léxicos y gramaticales de las formas que habían sido elegidas, debíamos establecer los contextos estilísticos que permitiesen determinar para cada forma cuál era la entidad narrativa en cuyo discurso se recogía y por otra parte qué tipo de discurso — directo, indirecto, indirecto libre o narración- había sido utilizado en cada ocasión. Para ello creamos cuatro bases de datos DISCURST.DBF, DISCURSL.DBF, DISCURSE.DBF y DISCURSG.DBF que tienen el siguiente formato:

\begin{tabular}{lll}
\hline NOMBRE DEL & TIPO DE & LONGITUD DEL \\
CAMPO & CAMPO & CAMPO \\
\hline NVER & Caracteres & 15 \\
DISC & Caracteres & 1 \\
PERS & Caracteres & 15 \\
\hline
\end{tabular}

Tabla 24. Estructura de las bases de datos que contienen el comportamiento estilístico de las obras.

En ellas recogimos en el campo NVER separados por un guión los números de los versos donde considerábamos que comenzaba y acababa cada una de las intervenciones en un estilo determinado, en DISC el estilo de la intervención con las siguientes claves: $\mathrm{N}$ para la narración, D para el estilo directo, I para el estilo indirecto y L para el indirecto libre; y en PERS el nombre que le habíamos asignado a cada uno de los personajes, teniendo en cuenta que cuando no aparece un personaje identificado por el nombre propio o por un nombre común que sirva para distinguirlo suficientemente lo incluíamos con la denominación «gens», utilizando en todos los casos, excepto para el narrador, una de las grafías del nombre que aparecía en la obra que tratábamos o el nombre utilizado por los editores de las obras en las páginas introductorias. 
El siguiente paso, una vez elegidas las formas y definidos los comportamientos estilísticos para las obras en su totalidad, debía recoger el contexto léxico y morfosintáctico en el que aparecían así como las características narrativas de aquéllas. En un principio pensamos no establecer un contexto fijo y determinar para cada forma uno específico; para ello comenzamos a utilizar un programa que de nuevo presentaba la forma en pantalla, permitiendo retroceder y avanzar antes de especificar cuántas formas por delante y cuántas formas por detrás escogíamos. Sin embargo, muy pronto, se mostró un proceso excesivamente lento teniendo en cuenta que habíamos de delimitar las formas adyacentes para más de 30.000 registros. Así pues decidimos realizar un programa en el que el contexto fuese fijo y el proceso se hiciese automáticamente para todas las formas, con la excepción ya hecha de las recogidas en DESTINR.DBF. Este programa, que tiene el nombre CONTEXTO.PRG, toma la forma, el verso en que se encuentra, cuatro versos por delante y dos versos por detrás. La decisión de adoptar este contexto no fue aleatoria ya que hicimos manualmente algunas pruebas y los contextos que adoptábamos estaban formados por menos formas pero en una ocasión llegamos a tomar los cuatro versos precedentes; lo mismo ocurría con el contexto posterior, ya que nos pareció prudente optar por los dos versos siguientes. Todo ello, evidentemente, en el caso de que la forma en cuestión no se encontrase antes del quinto verso del comienzo o en los dos últimos versos de una de las obras, hecho que había que contemplar para que el programa funcione correctamente. Los resultados de ejecutar este programa se almacenan en una base de datos que llamamos GRAM.DBF, cuya estructura es como sigue:

\begin{tabular}{lll}
\hline $\begin{array}{l}\text { NOMBRE DEL } \\
\text { CAMPO }\end{array}$ & TIPO DE DATOS & $\begin{array}{l}\text { LONGITUD DEL } \\
\text { CAMPO }\end{array}$ \\
\hline FORMA & Caracteres & 50 \\
CATEG & Caracteres & 1 \\
DISC & Caracteres & 1 \\
PERS & Caracteres & 22 \\
FOCA & Caracteres & 52 \\
NREG & Numérico & 5 \\
CTXT & Memo & 10
\end{tabular}




\begin{tabular}{lll} 
CTXTCAT & Caracteres & 130 \\
NVERSO & Caracteres & 17 \\
BD & Caracteres & 10 \\
REGBD & Caracteres & 20 \\
\hline
\end{tabular}

Tabla 25. Estructura de la base de datos que recoge los contextos léxicos y morfosintácticos (GRAM. DBF).

En ella se recogen además de la forma, la clase asignada en CATEG, la combinación de ambas en FOCA, el número de registro en NREG, el contexto léxico en CTXT que es un campo de tipo Memo, de longitud variable, aunque la longitud del campo se fija automáticamente a 10 bytes, y que sirve para guardar texto, pudiendo contener un número ilimitado de bytes en las bases de datos dBASE IV — mientras que el contenido de los otros tipos de campos es como máximo de 254 caracteres—, almacenándose los datos en un fichero auxiliar especial, en este caso GRAM.DBT, en el que podemos introducirnos para poder ver o modificar los datos que contiene colocando el cursor sobre él y pulsando Ctrl-Home o Ctrl-Inicio. En este campo los versos aparecen separados con el signo \$ y la forma sobre la que se ha constituido el contexto enmarcada por el signo \#. Estos signos serán utilizados después, una vez enviado el contenido de la base de datos al procesador de texto con el que redactamos este texto para poder realizar operaciones de búsqueda y sustitución que nos permitan colocar en columnas los versos y subrayar la forma elegida. En el campo CTXTCAT se guardan las claves morfológicas correspondientes a las formas del campo CTXT, utilizándose los mismos signos para marcar el cambio de verso y para marcar la clase asignada a la forma de la que se presenta el contexto. Así mismo aparece recogido el número de registro de la base de datos correspondiente -Tristan, Charrete, Escoufle o Rose-, por último aparecen combinados el número de registro y el nombre de la base de datos separados por el signo \# para poder crear índices. Los campos DISC y PERS quedaban vacíos pues no hubiera sido una tarea fácil determinar automáticamente a partir de las bases de datos que habíamos elaborado cuáles eran sus contenidos para cada forma 
concreta, teniendo en cuenta que en algunos versos se mezclaban dos o más intervenciones o estilos distintos. Esta tarea la realizamos pues manualmente tomando como referencia las bases de datos mencionadas más arriba.

Presentamos ahora el primer registro de esta base de datos:

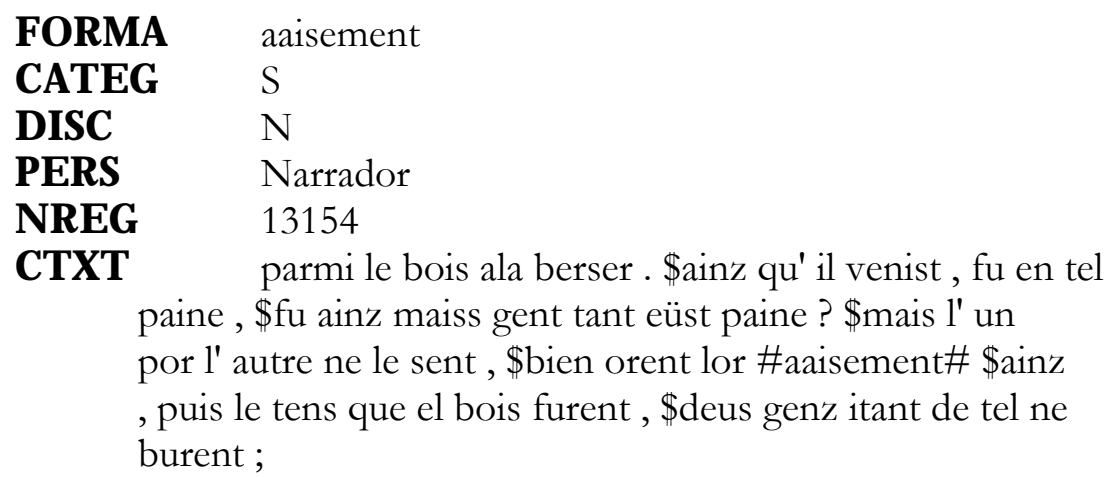

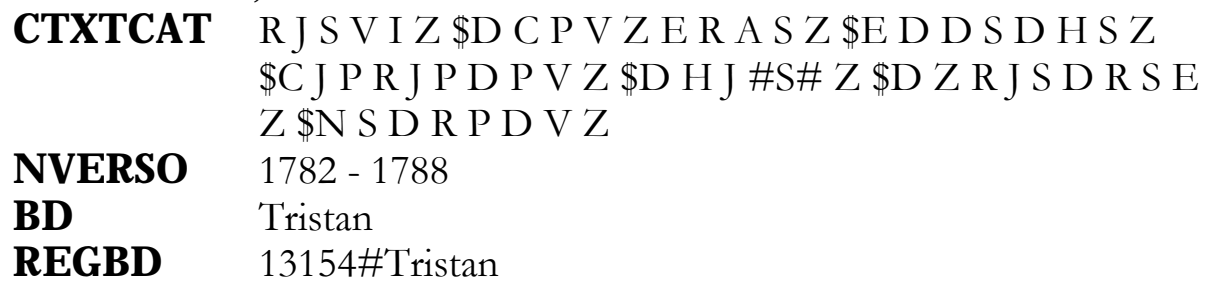

La selección de las rimas, que nos debían aportar datos sobre una parte de los imperativos formales que habían podido determinar el uso de una forma léxica frente a otras y que podían ser testimonio de las relaciones y evocaciones temáticas así como de los juegos sonoros en torno a algunos vocablos, sí la realizamos automáticamente a partir de los elementos que habíamos escogido y que se encuentran en DESTINO.DBF gracias al programa RIMA.PRG. Como había ocurrido para recoger los contextos léxicos y gramaticales de las formas elegidas, la numeración de algunos versos de Rose nos obligó a trabajar manualmente con las formas que se encontraban en ellos y a almacenar estos datos en una base de datos especial que después unificaríamos con la resultante de la búsqueda automatizada. El programa RIMA.PRG funciona básicamente como sigue: comprueba si la forma sobre la que está el puntero en DESTINO.PRG está a final de verso, si es así y el número de verso es impar busca hacia adelante hasta llegar a la última forma 
del verso siguiente, almacenando los datos de ambas formas que nos interesan y que después señalaremos; si por el contrario el verso es par busca hacia atrás hasta encontrar la última forma del verso anterior recogiendo así mismo los datos de ambas; esto en el caso de que la última forma de los versos no esté marcada con el código $Z$ que indica que se trata de un signo de puntuación, lo que hace retroceder el puntero una forma o varias formas hasta encontrar una que no esté marcada con este código. Los resultados se guardan en dos bases de datos llamadas SALRIM.DBF para la búsqueda automática y SALRIMR.DBF para la búsqueda manual, unificándose posteriormente en una sola SALRIMT.DBF, que aparece en el CDROM anexo, teniendo las tres la misma estructura:

\begin{tabular}{llll}
\hline $\begin{array}{l}\text { NOMBRE DEL } \\
\text { CAMPO }\end{array}$ & $\begin{array}{l}\text { TIPO DE } \\
\text { CAMPO }\end{array}$ & $\begin{array}{l}\text { LONGITUD DEL } \\
\text { CAMPO }\end{array}$ & DECIMALES \\
\hline FORMA & Caracteres & 50.0 & 0.0 \\
CATEG & Caracteres & 1.0 & 0.0 \\
BD & Caracteres & 10.0 & 0.0 \\
NVER & Numérico & 8.0 & 2.0 \\
RIMA & Caracteres & 50.0 & 0.0 \\
CATEG2 & Caracteres & 1.0 & 0.0 \\
NVER2 & Numérico & 8.0 & 2.0 \\
DISC & Caracteres & 1.0 & 0.0 \\
PERS & Caracteres & 22.0 & 0.0 \\
TODO & Caracteres & 60.0 & 0.0 \\
\hline
\end{tabular}

Tabla 26. Estructura de las bases de datos que recogen las rimas (SALRIM, SALRIMR y SALRIMT)

En ellas se recoge la forma y la clase que se le ha asignado en CATEG —en las tablas que presentaremos en el cuerpo de este trabajo aparecerá con el nombre CA por cuestiones de espacio al presentar las tablas—, el nombre de la base de datos en $\mathrm{BD}$ y el número de verso en NVER — así mismo lo veremos en adelante como NV—, la forma con la que rima en RIMA, y la clase gramatical a la que ha sido adscrita en CATEG2 —CA2 en adelante—, el número de verso correspondiente a esta segunda forma en NVER2 (NV2), el tipo de discurso en el que aparece en DISC —D en las tablas que recogeremos más adelante-, el nombre del personaje en 
cuyo discurso se encuentra la primera forma, es decir, la que nos sirve para establecer la rima, o bien la palabra Narrador si se trata de la narración o de una intervención en estilo directo de este en PERS, y finalmente en el campo TODO se recogen la forma, el nombre de la base de datos y el número de verso separados por el símbolo \#, datos que nos servirán para indizar la base de datos.

Incluimos a continuación el primer registro de esta base de datos:

$\begin{array}{ll}\text { FORMA } & \text { aaisement } \\ \text { CATEG } & \text { S } \\ \text { BD } & \text { Tristan } \\ \text { NVER1786 } & \\ \text { RIMA } & \text { sent } \\ \text { CATEG2 } & \text { V } \\ \text { NVER2 } & 1785 \\ \text { DISC } & \text { N } \\ \text { PERS } & \text { Narrador } \\ \text { TOD0 } & \text { aaisement\#Tristan\#1786 }\end{array}$

\subsection{ESTUDIO FORMAL DEL LÉXICO.}

\subsubsection{DELIMITACIÓN DE LAS FORMAS.}

El estudio del léxico amoroso podría hacerse sobre un grupo restringido de clases gramaticales, tomando en consideración aquéllas que se caracterizan por poseer un contenido léxico y excluyendo las llamadas formas gramaticales, es decir aquéllas que sirven para establecer relaciones sintácticas como preposiciones y conjunciones y las que son utilizadas como actualizadores discursivos o como marcas enunciativas: artículos, pronombres, adjetivos no calificativos, numerales así como algunos adverbios. Optamos 
por una visión más global que conlleva la observación del funcionamiento de algunas clases gramaticales como complemento al análisis de otras.

Los sustantivos, los adjetivos calificativos y los verbos aparecerán parcialmente lematizados, es decir, vamos a presentar como elemento de referencia el caso régimen del singular, pero no unificaremos las formas en función de la categoría del género; en el caso de los verbos aparecerá sólo el infinitivo.

\subsection{CRITERIOS GRAMATICALES.}

\subsubsection{MORFOSINTAXIS TRADICIONAL.}

Con el fin de definir los atributos que iban a marcar gramaticalmente las formas consideramos oportuno adoptar los criterios y la nomenclatura de la gramática tradicional con muy ligeras modificaciones, pese a que somos conscientes de que la división en partes de la oración a la que aquélla procede resulta en ocasiones equívoca o poco ajustada al funcionamiento discursivo de la lengua, y que las definiciones que se han dado suelen ser poco homogéneas.

Dos motivos fundamentales nos llevaron a tomar esta postura: el hecho de que aunque las escuelas y las clasificaciones que éstas hacen de los fenómenos lingüísticos, aparecen, se modifican y a menudo pasan de moda, prácticamente todos poseemos el bagaje de la gramática tradicional; y en segundo lugar, y como razón principal, se encuentra el hecho de que, salvo excepciones, la mayor parte de los lingüistas que se ocupan de la lengua medieval utilizan también las estructuras tradicionales y así se recoge en las gramáticas, manuales y artículos referidos al conjunto de dialectos que formaban la lengua de oill. De igual modo los diccionarios históricos y 
particularmente de la lengua medieval, así como los glosarios que encontramos en las ediciones de los textos que analizamos, responden a una terminología gramatical convencional.

Algunos fenómenos que la lingüística actual da por sentados pero que no eran en absoluto contemplados por la gramática convencional como, por ejemplo, la existencia en el seno de la clase gramatical de los adverbios de los llamados adverbios de frase, distinción cuya base no es semántica sino funcional, los hemos incluido en la descripción de los atributos secundarios asignados durante el proceso de creación de los diccionarios morfológicos. En el caso de los adverbios a los que nos referimos porque muchos de ellos no podrían ser identificados más que por esa cualidad y no por su contenido semántico.

\subsubsection{CLASESY CATEGORÍAS GRAMATICALES.}

Si excluimos los signos de puntuación, que hemos introducido en el programa de análisis para mayor comodidad al marcar las formas, hemos considerado en el seno de las clases gramaticales tradicionales el nombre, que hemos llamado sustantivo, el verbo, el artículo, el adjetivo, el pronombre, el adverbio, la preposición, la conjunción y la interjección, que hemos denominado exclamación.

En algunas de ellas introdujimos variaciones respecto a la asignación tradicional que debían permitirnos una mejor comprensión de la estructura formal de los textos, adoptando una posición ecléctica al hacer nuestras las aportaciones de numerosos estudiosos de la lengua medieval a la clasificación y estructuración de los paradigmas gramaticales.

En el caso de los verbos, hemos hecho dos tipos de distinciones, en

primer lugar entre los verbos que pueden funcionar como auxiliares - être y 
avoir - y el resto, incluidos los llamados semi-auxiliares; esta distinción debe permitirnos establecer con mayor facilidad los tiempos compuestos en una sucesión $\mathrm{H} / \mathrm{E}+(\mathrm{nF})+\mathrm{O}$, y la aparición de la voz pasiva en sucesiones del tipo $\mathrm{E}+(\mathrm{nF})+\mathrm{O}$; a esto se añade que en la selección del léxico amoroso las ocurrencias de estos verbos actuando como auxiliares no las hemos señalado, por lo que cuando aparezcan como núcleo de un contexto los identificaremos como formas con un semantismo completo. Por otro lado distinguimos entre las formas personales y las formas no personales, identificando en este caso el infinitivo, el participio presente y el participio pasado. En lo que concierne al infinitivo por dos razones: su aparición en perífrasis verbales dependiendo de otras formas verbales y su substantivación. Los participios presentes, entre los que hemos distinguido ya en el análisis entre participio y gerundio, fundamentalmente por su capacidad de conversión en una palabra gramatical y en menor grado de substantivación. En cuanto a los participios pasados, además de lo señalado para los tiempos compuestos, nos parecía necesario por el uso adjetivo que la lengua medieval hacía de ellos, mucho más abundante que en la actualidad, pues muchas formas que ahora son consideradas adjetivos plenos eran en la Edad Media participios que podían tener funciones adjetivas. En estos y otros casos de cambio funcional lo que nos interesaba era incluir la forma en la clase a la que se adscribía originalmente y después al analizar las estructuras sintácticas, ver cómo funcionaba discursivamente.

En el seno de la clase que hemos llamado artículo, siguiendo la clasificación que hacen tanto Geneviève Hasenohr como Gérard Moignet, ${ }^{33}$ hemos incluido además de los definidos e indefinidos, los posesivos y los demostrativos, que la gramática tradicional consideraba adjetivos. Hemos excluido los partitivos ya que las formas del masculino y del plural son formas contractas y en esos casos hemos optado por clasificar el conjunto según la

\footnotetext{
33 Véanse sus Introduction à l'ancien français de Guy Raynaud de Lage. Paris: SEDES, 1993 en las partes correspondientes a los posesivos y los demostrativos, y $\mathrm{G}$ rammaire de l'ancien français. Paris: Klincksieck, 1984 en la parte consagrada a los pronominales, respectivamente.
} 
clase de la primera forma, en este caso una preposición, ${ }^{34}$ y en la asignación de atributos aparece como una forma contracta con artículo y se marca el género y el número, en el caso del femenino aparecerá por lo tanto la sucesión $\mathrm{R}+\mathrm{J}$

[Prep. + Art.]. Por otra parte Louis Kukenheim señala una aparición tardía para el sentido partitivo, hacia el siglo XIV, cuando el artículo definido comenzaba a perder su valor demostrativo. ${ }^{35}$

Es evidente que los cambios introducidos en la clase de los artículos modifica substancialmente la clase de los adjetivos, aunque en ella se incluyen lo que tradicionalmente eran pronombres posesivos, además de los indefinidos e interrogativos, según la distinción que hace Gaston Zink al incluirlos entre los que llama adjetivos pronominales. ${ }^{36}$ Para establecer la diferencia entre participio presente y adjetivo verbal nos hemos basado en la distinción que realiza Philippe Ménard ${ }^{37}$ para las construcciones perifrásticas construidas con el verbo être, en función de que se trate de un estado permanente o durable, en ocasiones de una cualidad, siendo entonces adjetivo, o bien de que sea un proceso que se desarrolla en el presente de la narración.

$\mathrm{Al}$ definir los tipos de adverbios hemos combinado dos criterios, los semánticos y los funcionales. Las marcas funcionales responden a adverbios que actúan generalmente como modificadores frásticos o como marcas de la enunciación, como por ejemplo los que hemos denominado adverbios de coordinación, los cuales coinciden prácticamente con los que Ménard llama "de liaison", 38 mientras que los que son caracterizados semánticamente, respondiendo a la clasificación tradicional, suelen funcionar como modificadores de otras clases gramaticales. Entre los adverbios también

\footnotetext{
${ }^{34}$ G. Moignet, op. at., p. 15, habla de partícula y no de preposición.

${ }_{35}$ Cf. G rammaire historique de la langue française. L es parties du discours. Leyde: Universitaire Pers Leiden, 1967, p. 21.

36 Véase su M orphologie du français médiéval. Paris: PUF, 1994, p. 105 y 124-129.

37 Syntax e de l'ancien français. Bordeaux: Sobodi, 1976, p. 171.

38 0p. at., p. 273-5.
} 
encontraremos muchas de las formas que A.-J. Greimas denomina "motphrase" o partícula, como es el caso para nenil, por ejemplo, ${ }^{39}$ que sin embargo Gaston Zink recoge entre los adverbios. ${ }^{40}$ Respecto a las formas i y en, adverbios de lugar en primera instancia, los consideramos adverbios pronominales ya que como indica Moignet ${ }^{41}$ en tanto que adverbios poseían usos muy cercanos a los de los pronombres personales.

En el caso de las preposiciones el criterio distribucional debería ser, en principio, definitivo, sin embargo, por cuestiones derivadas de la composición textual y fundamentalmente de la consecución de la rima encontramos morfemas que consideramos preposiciones desde un punto de vista funcional, pero que se encuentran detrás del sintagma nominal al que parecen poner en relación con un sintagma precedente, habiendo por ello de desechar su clasificación entre los adverbios, pese a que se den muchos casos de homonimia.

Los problemas que hemos señalado más arriba derivados de la adopción de las categorías gramaticales tradicionales afectan especialmente a las conjunciones y particularmente a aquellas cuya función estaría entre la subordinación y la coordinación. Nos referimos a las que introducen una proposición completiva, ya sea sujeto o COD, y que hemos incluido entre las conjunciones copulativas, aunque habíamos considerado la posibilidad de crear un nuevo tipo que sería la conjunción completiva.

En el caso de algunas formas, ciertas clases a las que pueden adscribirse según el uso que en los textos se hace de ellas no aparecen en los diccionarios ni en los manuales, cuando esto ocurría hemos añadido en el

\footnotetext{
${ }^{39}$ Esta denominación la hallamos en algunas entradas de su D idionnaire de l'andien français. Paris: Larousse, 1980, cf. p. 435 para este caso concreto. Hemos creído que la palabra "partícula", utilizada por muchos autores para algunas formas no podía ser conservada, dada su indefinición y por el hecho de que se aplica a formas de origen muy diverso y con funciones muy distintas, habiendo optado por incluirlas en una u otra clase, generalmente adverbio, conjunción o preposición.

40 M orphologie du français médiéval. Paris: P.U.F., 1994, p. 238.

41 0p. ait., p. 147.
} 
diccionario la clase o clases que no aparecían en las obras de referencia. Esto ocurre entre otras palabras con travers que es considerada adjetivo, sustantivo o verbo pero no preposición, uso que de hecho existe en la lengua contemporánea y que nosotros hemos incorporado, así en E scoufle (v. 1481): S'en vont travers chans ambedui; para otras formas como ocurre con $\infty \mathrm{m} /$ con, que puede ser tanto preposición, como adverbio o conjunción, salvo en las ocurrencias en las que tiene un uso que corresponde claramente con el recogido en las gramáticas o en los diccionarios, hemos utilizado un criterio sintáctico para su adscripción a una determinada clase gramatical, y en el caso concreto de esta forma la hemos marcado como una preposición cuando combina dos sintagmas, como un adverbio cuando modifica un sintagma nominal y como conjunción cuando introduce una proposición subordinada.

En un segundo nivel, tanto para los adverbios como para las preposiciones y las conjunciones, la distinción de sus valores contextuales basándonos en relaciones logico-semánticas no siempre es posible, ya que las fronteras entre algunos de ellos son porosas cuando no borrosas, y de hecho existen numerosos morfemas polisémicos y polivalentes para los cuales no siempre es evidente una adscripción.

Por lo que se refiere a las denominadas locuciones - conjuntivas, preposicionales o adverbiales — hemos optado por considerar cada uno de sus elementos por separado incluyéndolo en su clase de origen, como es el caso para ainz que $(\mathrm{D}+\mathrm{C}){ }^{42}$ en primer lugar porque no sabemos hasta qué punto en el época se tenía conciencia de un grupo inequívocamente solidario, y de hecho aparecen en el corpus ejemplos en los que los separa un sintagma o una proposición. Sin embargo no hemos dividido en ningún caso formas que ya aparecen soldadas aunque en un principio fuesen locuciones y en ese caso las hemos clasificado según la clase en la que se podían adscribir en la época

42 Algunos autores como Ménard, op. at., p. 218 la consideran simplemente conjunción. 
según su función habitual, tal es el caso por ejemplo para malgré que incluimos entre las preposiciones.

Para terminar estos comentarios referidos a las clases gramaticales señalaremos la consideración de otra nueva clase que es la de los numerales tal como hacen muchos de los autores a los que hemos aludido hasta aquí. 43 Por otra parte su inclusión dentro de las clases de los sustantivos, y más probablemente en nuestros textos de los adjetivos o de los pronombres puede ser deducida de su funcionamiento sintáctico.

Por lo que hace a las categorías gramaticales sólo queremos señalar que la distinción entre caso sujeto y caso régimen resulta bastante imperfecta ya que las diferencias formales que se dan entre los casos responden generalmente a los casos nominativo y acusativo latinos, aunque también podamos encontrar el dativo, como ocurre para los demostrativos, y por otro lado las funciones lógicas que ambos casos pueden tener son muy variadas y se encuentran así enormemente simplificadas; el hecho de hacerlo así, como ya nos ha ocurrido antes, se debe a que la mayor parte de los lingüistas así lo hacen, a excepción de Kukenheim, quien critica esta postura. ${ }^{44}$

\footnotetext{
43 Gaston Zink, op. cit., p. 55-64 habla de "les termes de numération" y de los numerales en L'ancien francais. Paris: PUF, 1990, p. 42 ; Moignet se refiere a los numerales en su G rammaire de l'ancien français, op. at., en múltiples páginas; así como Ménard, op. at., p. 112-7; Kukenheim, op. at., p. 32-3 presenta el "nom de nombre" del mismo modo que Nyrop en el tomo II de su Grammaire historique de la langue française, Copenhague: Gyldendal, p. 350-69; y Hasenohr incluye el numeral entre los determinantes del sustantivo, op. dit., p. 36-7

44 Véase G rammaire historique de la langue française. L es parties du discours, op. at., p. 6, y en el volumen titulado L es syntagmes, Leyde: Universitaire Pers Leiden, 1968, p. 5.
} 


\section{EL EROTISMO Y SU EXPRESIÓN.}

\subsection{APROXIMACIONES AL CONCEPTO DE EROTISMO.}

\subsection{DEFINICIONES. LENGUAJE E IDEOLOGÍA.}

Herramienta social e individual, el lenguaje aparece siempre marcado por la subjetividad del colectivo o del hombre, pero esta cualidad se hace aún más evidente cuando se abordan ciertos temas que pertenecen a la historia del instinto, por ende del tabú y casi inevitablemente en algunas sociedades de la moralidad, lo que hace que se presenten altamente ritualizados en las prácticas sociales, codificados, manipulados y ocultados por y en el discurso. La sexualidad, el erotismo y el amor, los tres lados de un mismo triángulo, son quizá los fenómenos que mayor y «mejon» regulación han sufrido a lo largo de la historia, siendo precisamente la época medieval la que modeló la conciencia sexual del llamado mundo occidental elaborando innumerables tabús que han perdurado hasta nuestros días; ${ }^{45}$ y en el plano discursivo, si exceptuamos lo tocante a la escatología, aquello que más ahínco ha puesto nuestra sociedad en velar y edulcorar. ${ }^{46} \mathrm{Y}$ así el término «erotismo» escapa a la objetividad, se

45 Cf. J. A. Brundage, L aw, Sex and Christian Society in M edieval E urope. Chicago: The University of Chicago Press, 1987, passim.

46 Michel Foucault ha descrito el paradójico proceso de marginación de la referencia a la sexualidad, negada como fuente de placer, llevado a cabo a partir del siglo XVII en Historia de la sex ualidad. 1. La voluntad de saber. Madrid: Siglo XXI, 1987. 
escurre entre el deseo y la experiencia de los que intentan definirlo, haciéndose casi imposible evitar, no sólo el legado cultural, educacional o social que ha moldeado y moldea nuestras mentes, sino también las trampas, los subterfugios del lenguaje, y ello fundamentalmente porque el erotismo es tanto o más un fenómeno psíquico que físico. De hecho los aspectos objetivos y los aspectos fantásticos del amor, en un sentido amplio que incluiría el erotismo y el placer carnal, aparecen paradójica e intrínsecamente unidos entre sí por su origen común, que es lo imaginario, fuente de todo deseo. 47

Las diferentes acepciones del sustantivo «érotisme», forma de reciente aparición en la lengua, y del adjetivo «érotique» del que deriva, nos permiten tomarlos en un sentido lato, siendo todo aquello relacionado con el amor —aunque esta acepción haya caído en desuso-, 48 y en otro estricto como aquello que toca al deseo y al placer sexuales. Así en el Trésor de la langue française está recogido el sentido "impulsion à aimer, tendance vive à l'amour", y el más usual en el que aparece una idea explícita de sensualidad o sexualidad como

tendance plus ou moins prononcée à l'amour (sensuel, sexuel), goût plus ou moins marqué pour les plaisirs de la chair,

del que derivan otros usos más concretos aunque todos tomen como base la referencia a la sensualidad carnal. ${ }^{49}$ De igual manera el D RA E hace referencia explícita al amor sensual y a aquello que lo excita, ${ }^{50}$ mientras Julio Casares retoma los dos significados básicos a los que aludíamos para el sustantivo en

\footnotetext{
47 Cf. R. Nelli, É rotique et divilisations, Paris: Weber, 1972, p. 12.

48 El étimo griego erôtik os poseía ya este significado, aunque la palabra erôs, erôtos en la que tenía su origen, se refería también al deseo sexual. Véase para lo que concierne a la historia de estas palabras en francés el D ictionnaire historique de la langue française, Alain Rey (dir.). Paris: Dictionnaires le Robert, 1992, p. 716.

49 Paris: CNRS, 1980, vol. VIII, p. 90.

50 D icionario de la lengua española. Madrid: Real Academia Española, 1992, p. 610.
} 
francés, aunque señalando un matiz intensivo: "Pasión fuerte de amor. | Exageración del instinto carnal." 51

$\mathrm{El} \mathrm{G}$ rand L arousse de la L angue française introduce para ambos términos un sentido claramente peyorativo que en el TL F sólo aparecía apuntado como una posibilidad contextual. «Érotique» es también aquello que "choque la pudeur et la morale par son caractère licencieux", y «érotisme» es definido como

goût excessif pour tout ce qui concerne l'amour physique; exagération pathologique des préoccupations d'ordre sexuel.52

María Moliner también señala para el adjetivo «erótico» la posibilidad de que posea un sentido peyorativo "implicando exageración morbosa del aspecto sexual". 53

El término «amon», al que reiteradamente se refieren estas definiciones, y de hecho el único utilizado durante siglos, y áun hoy en algunos diccionarios, para hablar de la atracción física o/e intelectual restringida al otro sexo, se entiende como la

inclination envers une personne, le plus souvent à caractère passionnel, fondée sur l'instinct sexuel mais entraînant des comportements variés, ${ }^{54}$

o bien, como eufemismo para nombrar las relaciones sexuales.

51 D icionario ideológico de la lengua española. Barcelona: Gustavo Gili, 1992, p. 346.

52 Paris: Larousse, 1972, vol. 2, p. 1719. Esta última acepción es, de hecho, la única que recoge Paul Robert en su D idionnaire alphabétique et analogique de la langue française. Paris: Le Robert, 1978, p. 612.

53 D iccionario de uso del español. Madrid: Gredos, 1986, vol. I, p. 1167.

54 L e Petit Robert. Paris: Dictionnaires le Robert, 1985, p. 61. 
Con respecto a la pasión, sentimiento violento, desordenado y difícilmente controlable que produce dolor al tiempo que placer, el TL F entre otras muchas acepciones recoge ésta referida a los sentimientos:

Amour violent et exclusif inspiré par une personne et dégénérant parfois en obsession, ${ }^{55}$

a lo que se añade el ser un sentimiento duradero. ${ }^{56}$

Por otro lado, y desde la perspectiva del análisis de creaciones artísticas, nuestra tarea se complica al intentar delimitar la extensión de erotismo frente a otros conceptos como el de pornografía u obscenidad. Así L e Robert define el adjetivo «obscène» como aquello que

révolte, offense ouvertement la pudeur; qui présente un caractère très choquant de crudité et de trivialité,

y puntualiza "obscène se dit surtout en parlant des questions sexuelles". ${ }^{57} \mathrm{El}$ TLF define igualmente el sustantivo «obscénité» como el "caractère de ce qui offense ouvertement la pudeur dans le domaine de la sexualité" y señala la transferencia metonímica por la que en plural se designa toda

parole, action, image, objet qui offense ouvertement la pudeur dans le domaine de la sexualité. ${ }^{58}$

En estrecha relación con estos términos aparece el sustantivo «pornographie», que ha perdido su primer sentido, didáctico, como tratado sobre la prostitución, para hacer referencia a

\footnotetext{
55 Op. at., vol. XII, p. 1137. Con este sentido aparece en la lengua francesa por primera vez en el s. XVI, cf. D ictionnaire historique de la langue francaise, op. at., p. 1443.

56 L e Robert, op. at., vol. V, p. 39.

57 Op.at., vol. IV, p. 691.

58 Op. at., vol. XII, p. 356.
} 
une représentation (par écrits, dessins, photos...) de choses obscènes. Par extension, il désigne la représentation directe et concrète de la sexualité, de manière délibérée, en littérature, dans les spectacles,

y se añade que esta palabra y sus derivados conservan, a pesar de la caída de los tabúes y de las autorizaciones administrativas, un carácter transgresor que las oponen a los términos «erotismo», «erótico» y «licencioso» al tiempo que las acercan a lo obsceno. ${ }^{59}$ El TLF introduce también el sentido de intencionalidad deliberada, pero en lo que se refiere al efecto de excitación sexual del público receptor de una obra artística. ${ }^{60}$

Si nos atenemos a estas definiciones casi ninguno de los conceptos que nos ocupan puede ser considerado universal y acrónico, y sí más bien plurales, y en muchos casos contradictorios, por lo que llegados a este punto cabe preguntarse en qué medida lo que en la actualidad es excesivo, ofensivo o hiriente - siempre en función del individuo— lo era para los hombres o las mujeres de la Edad Media, máxime si tenemos en cuenta que las condiciones de la vida cotidiana diferían enormemente de las de épocas posteriores y que los contactos visuales y carnales, más o menos furtivos, eran moneda corriente en todos los ámbitos de la sociedad, quizá con la salvedad de los claustros e iglesias. Por ello consideramos oportuno incluir dentro de lo erótico todo aquello que va desde la simple alusión al amor hasta cualquier manifestación de la unión carnal, descripción o referencia al cuerpo de los amantes. Nos interesarán por tanto en nuestro trabajo, no sólo los elementos que se definan dentro de la tradición del amor cortés sino también los que pudieran engarzarse en las tradiciones anticorteses que hoy se podrían calificar de obscenas.

\footnotetext{
59 D ictionnaire historique de la langue française, op. at., p. 1582.

60 Op. at., p. 785.
} 


\subsubsection{OTROS PUNTOS DE VISTA. IDEOLOGÍA Y ESTÉTICA.}

Retomemos el intento de definición de erotismo desde las perspectivas filosófica, psicológica, sociológica, histórica y literaria. Comencemos con la definición que abre el Traité de l'amour courtois de André le Chapelain, un texto clave para la comprensión del amor en la época que nos ocupa, no tanto como instigador de determinados usos eróticos, máxime si tenemos en cuenta que durante el siglo XIII fue considerado como una representación hiperbólica y por lo tanto paródica del amor cortés; ${ }^{61}$ sino como recopilación y sistematización de los que podríamos considerar metatextos corteses producidos en las cortes de las regiones de Oc y de Oil, puntas del iceberg ideológico, social y literario cuya influencia está presente en diferentes grados en las obras que forman nuestro corpus; sin perder de vista que al mismo tiempo representa un código sexual adaptado a la nueva doctrina que la Iglesia elaboró en torno al matrimonio: ${ }^{62}$

L'amour est une passion naturelle qui nait de la vue de la beauté de l'autre sexe et de la pensée obsédante de cette beauté. On en vient à souhaiter par-dessus tout de posséder les étreintes de l'autre et à désirer que, dans ces étreintes, soient respectés, par une commune volonté, tous les commandements de l'amour. ${ }^{63}$

${ }^{61}$ Cf. A. Karnein, La réception du D eA more de André le Chapelain au XIIIe siècle, Romania, CII, 1981, p. 326.

62 Duby retoma en su libro Mâle Moyen A ge. D e l'amour et autres essais. Paris: Flammarion, 1988, p. 79, el análisis de Rüdiger Schnell sobre la obra de André Le Chapelain, quien ha mostrado que:

Un tel code était nécessaire pour comprimer la brutalité, la violence dans ce progrès que j'évoquais vers la civilité. On attendait que ce code, ritualisant le désir, orientât vers la régularité, vers une sorte de légitimité, les insatisfactions des époux, de leurs dames, et surtout de cette foule inquiétante d'hommes turbulents que les usages familiaux contraignaient au célibat.

Se trata además de una obra redactada muy probablemente entre el último cuarto del s. XII y la primera mitad del siglo XIII con lo que coincide temporalmente con los romans que analizamos. Cf. A. le Chapelain, Traité de l'amour wurtois, C. Buridant (ed.). Paris: Klincksieck, 1974, p. 11.

63 Ibid., p. 47. 
Reconocemos algunos de los elementos que habían aparecido en las definiciones más arriba recogidas — deseo obsesivo, pasión, contacto físico-, a estos se añaden otros que son un reflejo del contexto ideológico-cultural, deudor de las tradiciones griega y latina, fundamentalmente platónica y ovidiana —origen visual, atracción por la belleza, personificación del amor, complacencia mutua - y que tendremos ocasión de estudiar en los romans. Aunque quizá el más importante desde el punto de vista de la relación amorosa y de su transcripción literaria sea la alusión al otro, opuesto y complementario, el único objeto de la semiosis erótica, ya que pese a Narciso "l'érotisme est en tout cas le discours conscient de l'Autre". 64

Para George Bataille el erotismo, actividad o cualidad específicamente humana, constituye una búsqueda psicológica independiente de la actividad sexual animal con función procreativa; y está, por otra parte, inexcusablemente dominada por la violencia y la violación, la vergüenza, la fealdad, el asco y la putrefacción, haciéndose eco de la relación agustiniana entre el nacimiento - y por extensión la concepción y los órganos sexuales externos—, y la eliminación de materiales impuros, la orina y las heces; y más fundamentalmente por la lucha entre dos contrarios, la discontinuidad inherente a la especie humana frente a la atracción de la muerte, a la disolución del ser representada en la vida cotidiana por el orgasmo. ${ }^{65}$ Es muy probable que la asociación entre amor y muerte, y fundamentalmente entre mujer y muerte, hinque sus raíces en las antiguas teogonías en las que se realizaba la identidad primordial entre muerte y fertilidad, por la que las diosas del amor lo eran al tiempo de la muerte como es el caso para Afrodita y para todas las diosas maternales de los pueblos orientales. ${ }^{66}$ Baudrillard retoma estas creencias ancestrales cuando mantiene que el desgarro de la muerte sólo

\footnotetext{
${ }^{64}$ M. Zéraffa, Érotique/Esthétique, Revue d’E sthétique, 1978, 1-2, p. 124.

65 Véase su obra L 'É rotisme. Paris: Minuit, 1985, en las páginas 12-23; 36-7; 64-5 y 160-1.

66 Cf. S. Freud, P sioanálisis aplicado y Técnica psioanalítica. Madrid: Alianza, 1974, p. 29.
} 
es posible en el paroxismo de la seducción como manifestación suprema de la feminidad, mientras que a diferencia de Bataille, lo considera incompatible con la búsqueda del placer sexual correspondiente a la libido masculina. ${ }^{67}$

Todos los fenómenos a los que hace referencia Bataille se encuentran estrechamente relacionados con la noción de pecado, idea obsesiva entre los moralistas — redactores de penitenciarios, canonistas y decretistas - de la Alta Edad Media, al igual que entre los Padres de la Iglesia, para muchos de los cuales incluso entre los esposos la unión y la procreación llevaban aparejada la falta, siendo ésta grave, ya que se cometía adulterio, al amar demasiado ardientemente al cónyuge. ${ }^{68}$ Es más, para la ortodoxia religiosa de gran parte de la Edad Media

non seulement la pulsion sexuelle est lue comme effet de la concupiscence, mais l'attrait amoureux dans ce qu'il y a d'irrationnel est lui-même condamné. ${ }^{69}$

El rechazo del placer, fundamentalmente sexual, tiene su origen en una larga tradición neoplatónica retomada por la patrística que consideraba que la unión carnal hacía caer al hombre en la pura animalidad. ${ }^{70}$ Estas ideas impulsaron la aparición de variadas y muy matizadas recopilaciones de los innumerables pecados y las faltas contra la pureza que podían cometer los

67 Véase L a seducción. Madrid: Cátedra, 1986, p. 47.

${ }^{68} \mathrm{~J}$. L. Flandrin, Un temps pour embrasser. A ux origines de la morale sex uelle occidentale, V IeX e s. Paris: Seuil, 1983, fundamentalmente en las páginas 87 y 116. A conclusiones algo diferentes ya que parte también de textos de vulgarización teológica pero de los siglos XII y XIII que contemplan una mejor comunicación entre los esposos, llega Michael M. Sheehan en Maritalis Affectio Revisited, The Olde D aunc. L ove, Friendship, Sex, and M arriage in the M edieval W orld, R.R. Edwards y S. Spector (eds.). Albany: State University of New York Press, p. 33-43. La evolución de las ideas agustinianas con respecto al matrimonio, el pecado y el sexo, que están en el origen de estos cambios aparece claramente expuesta por Elizabeth A. Clark en "Adam's Only Companion": Augustine and the Early Christian Debate on Marriage, ibid., p. 15-31.

${ }^{69}$ J. L. Flandrin, L e sex e et l'O cadent. É volution des attitudes et des comportements. Paris: Seuil, 1986, p. 106.

70 Cf. J. Delumeau, L e péché et la peur. La alpabilisation en 0 acident, X IIIe - X V IIIe sièdes. Paris: Fayard, 1983, p. 22. 
esposos así como de sus irremediables penitencias y castigos terrenos e incluso divinos. $^{71}$

El cristianismo, tal como apunta Marguerite Yourcenar, intenta conseguir la desacralización de la sensualidad, con la excepción del matrimonio, a la vez que la acompaña de un sinnúmero de prohibiciones y de reglamentaciones que amoldan los sentidos a los dictados del espíritu o del alma. ${ }^{72}$ Frente a esta tendencia represiva hallamos las reacciones de algunos de los movimientos heréticos medievales, y especialmente, por la influencia indudable que tuvo sobre la elaboración del código erótico cortés, la herejía cátara. ${ }^{73}$ Así bajo el influjo de las concepciones neo-maniqueas, ${ }^{74}$ la ideología cortés rechaza también el amor en el seno del matrimonio, no tanto por pecaminoso sino por la imposibilidad de la existencia de éste fuera de la libertad compartida por los amantes. ${ }^{75}$ Köhler apunta una tesis sociológica, que no tiene por qué excluir las razones religiosas o ideológicas, para el rechazo manifiesto de los trovadores hacia el amor entre esposos: consideraban el amor conyugal un peligro para la sociedad porque robaba a la esfera pública parte de las energías necesarias para su buen funcionamiento. ${ }^{76}$ Tesis que parece reforzar el hecho de que los autores corteses considerasen nefasta la unión del deseo y del matrimonio para los linajes aristocráticos, ${ }^{77}$ estableciéndose así una estrecha relación entre el amor cortés y el naturalismo

71 Cf. J. A. Brundage, op. at., particularmente en lo que se refiere a las concepciones más rigoristas, p. 1856, 260-2 y 282-3.

72 M. Yourcenar, Sur quelques thèmes érotiques et mystiques de la Gita-Govinda, Le Temps, œ grand salpteur. Paris: Gallimard, 1983, p. 116-7.

${ }^{73}$ R. Nelli, La vie quotidienne des Cathares du Languedoc au X IIIe siède. Paris: Hachette, 1984, p. 58 y 87 fundamentalmente. Véase también A. Brenon, L es femmes cathares, Paris: Perrin, 1992, p. 67-69.

${ }^{74}$ F. Decret, Mani et la tradition manichéenne. Paris: Seuil, 1974, p. 164-9.

75 Cf. Le Chapelain, op. ait., p. 111-2.

76 Véase L'aventure chevaleresque, Paris: Gallimard, 1974, p. 164.

77 Cf. H. Bloch, E tymologie et généalogie. Une anthropologie littéraire du M oyen A ge français. Paris: Seuil, 1989, p. 175. 
al disociar el acto sexual de la procreación. ${ }^{78}$ Esta postura por la que la relación entre individuos pasa a un primer plano es la que el cristianismo había intentado desterrar ya desde la Antigüedad para justificar únicamente la procreación controlada en el seno de la familia que permitiese la cohesión y la perpetuación de la sociedad cristiana. ${ }^{79} \mathrm{La}$ culminación del proceso de sacralización del matrimonio, absolutamente disociado del placer, llega en el último tercio del siglo XII al convertirse en un sacramento, y pasa a ser el mejor modo de fiscalizar la renovación social. ${ }^{80}$

Es precisamente el mito medieval del adulterio, la historia por excelencia del triángulo - en el que convergen también el incesto, la reincidencia, la falta de arrepentimiento y el conocimiento público-, los relatos de los amores de Tristán y de la reina, los que llevan a Denis de Rougemont a alinearse con la posición de Bataille afirmando que sólo es posible enunciar

l'amour mortel, c'est-à-dire, ... l'amour menacé et condamné par la vie même... c'est moins l'amour comblé que la passion d'amour. Et passion signifie souffrance. ${ }^{81}$

Es cierto que por su naturaleza profundamente antisocial el amor pasión medieval sólo puede encontrar satisfacción aceptable en el ámbito de lo imaginario, en el sueño o en la muerte, pero no compartimos la idea de la restricción de la diégesis a esa búsqueda desesperada de lo absoluto. ${ }^{82} \mathrm{Y}$ ello porque pese a que algunos de los componentes marcados negativamente

\footnotetext{
78 Cf. M.-O. Métral, L e M ariage. L es hésitations de l’0 ơddent. Paris: Aubier-Montaigne, 1977, p. 139.

79 Jean-Louis Flandrin, La réglementation du commerce conjugal dans les pénitentiels: Réflexion sur ses effets possibles et son application, L a ondición de la mujer en la E dad M edia, Actas del Coloquio HispanoFrancés. Serie Casa de Velazquez. Madrid: Univ. Complutense, 1986, p. 87.

80 Véase en este sentido G. Duby, L es trois ordres ..., op. at., p. 285 y 297 fundamentalmente.

81 D. de Rougemont, L'A mour et l'0 oddent, Paris: Plon, 1979, p. 16.

82 Véase otra definición del amor-pasión en R. Nelli, L 'amour et les mythes du coeur, suivi de L e corps féminin et l'imaginaire. Paris: Hachette, 1975, p. 38-9.
} 
aparecen en nuestro corpus y en muchos otros textos medievales, literarios o no, la visión de los moralistas medievales, de Bataille así como la de Rougemont, parece en extremo pesimista, olvidando las manifestaciones de alegría, bienestar o ternura relacionadas con el amor, el erotismo y el placer. En efecto, al menos por lo que se refiere a las manifestaciones escritas y artísticas en general, en el siglo XII se produjo un cambio radical en cuanto a la comprensión de las relaciones entre los sexos: hace su aparición un sentimiento caracterizado por la ternura, el abandono de la brutalidad masculina y de la sumisión de la mujer, ${ }^{83}$ aunque ciertos cambios en la actitud amorosa se habían producido ya en época romana, llegándose a aceptar el que la mujer tomase la iniciativa en la relación heterosexual. ${ }^{84}$ Esta tímida revolución ideológica, uno de cuyos hitos es la obra de Hildegarda de Bingen, donde se llega hasta evocar la belleza del acto sexual, va acompañada de una progresiva aceptación del cuerpo no como símbolo sino como realidad impregnada de la belleza divina, y en el siglo XIII del redescubrimiento del poder seductor del cuerpo femenino tomado en su individualidad. Ello no impide que en la mayor parte de los escritos se condene el hecho de desvelar el cuerpo ante el amante y Robert de Blois prevenga contra el enfriamiento de la pasión masculina al ver el cuerpo desnudo de la mujer. ${ }^{85}$ Quizá debiéramos hablar más bien de un minoritario cambio de mentalidad que afectó a una elite de la que también formaban parte algunos intelectuales monásticos como Bernard de Clairvaux o Hugues de Saint Victor; de hecho este último se acercó a las tesis del amor cortés al concebir el matrimonio no como una institución al servicio de las relaciones de parentesco sino de la ternura y de la

\footnotetext{
83 Véase en este sentido el interesante artículo de P. Dinzelbacher, Pour une histoire de l'amour au moyen âge, L e Moyen Â ge, no 2, 1987, p. 223-40; así como el ensayo de Erik Kooper, Loving the Unequal Equal: Medieval Theologians and Marital Affection, The Olde D aunœ. L ove, Friendship, Sex, and Marriage in the Medieval W orld, op. at., p. 44-56, donde estudia los puntos de vista adoptados por la Iglesia de los siglos XII y XIII respecto de la convivencia conyugal, con una particular atención para las relaciones entre los escritos de los teólogos y las ideas expuestas por Jean de Meun.

${ }^{84}$ Cf. D. Gourevitch, Le mal d'être femme. La femme et la médecine dans la Rome antique. Paris: Les Belles Lettres, 1984, p. 74.

85 Cf. J.-C. Bologne, Histoire de la pudeur. Paris: France Loisirs, 1986, p. 54; así como J.-C. Schmitt, La raison des gestes dans l'0 coident médiéval. Paris: Gallimard, 1990, p. 227.
} 
intimidad de los esposos. ${ }^{86}$ A pesar de todo los contactos violentos entre los sexos perdurarán, en cierto modo institucionalizados o cuando menos muy arraigados en los usos sociales durante siglos, tal como nos recuerdan los pasajes de rudeza sexual plasmados en la literatura medieval castellana, reflejo de la violencia general de la época y del desprecio por el sentimiento amoroso. ${ }^{87}$ Es más, nos atrevemos a poner en tela de juicio con Adeline Rucquoi la evolución de las relaciones de poder entre los sexos incluso en el nivel simbólico, ya que en la literatura cortés

la mujer aparece como el «ser amado» al cual rinde su homenaje el amante; «ser amado» - $\mathrm{y}$ no «ser que ama» que se convierte en un ser pasivo, inexistente, objeto del amor del poeta. ${ }^{8}$

$\mathrm{Al}$ igual que en la época medieval, la comprensión de los fenómenos eróticos por parte de los pensadores contemporáneos dista mucho de ser unánime y podemos leer opiniones encontradas. Francesco Alberoni convierte la oposición irreductible del erotismo según Bataille en un proceso dialéctico entre continuidad y discontinuidad y por lo tanto anula la negación, la pérdida y la descomposición infinita del ser en el otro y en la muerte. ${ }^{89} \mathrm{Y}$ Kristeva convierte el amor en una exquisita mezcla de contrarios,

\footnotetext{
86 Muy esclarecedores resultan en este sentido los estudios de Jean Leclercq en torno a la figura de Bernard de Clairvaux, L 'amour vu par les moines au X IIe siède. Paris: Cerf, 1983 y en especial L e M ariage vu par les moines. Paris: Cerf, 1983 y L a F emme et les femmes dans l'oeuvre de saint Bernard. Paris: Téqui, 1983. George Duby hace igualmente referencia al cambio incubado en los monasterios cistercienses en su obra Mâle M oyen Â ge..., op. at., p. 34-5. Por su parte Métral recoge las reflexiones que al comienzo del siglo XII hace sobre el matrimonio Hugues de St. Victor en L e M ariage, op. at., p. 149-51.

87 Cf. J. Victorio cf. El amor y el erotismo en la Literatura Medieval. Madrid: Editora Nacional, 1983, p. 22 y ss.; así mismo R. Nelli se hace eco de la promiscuidad que existía en los castillos medievales y que propiciaba las violaciones, cf. La vie quotidienne, op. at., p. 81-2. Véase también M. Wade Labarge, La mujer en la E dad Media. Madrid: Nerea, 1988, p. 47; y para la evolución de la historia cotidiana hasta la época contemporánea J. L. Flandrin, L e sex e et l'0 cident, op. at., p. 284 y L es A mours paysannes: A mour et sex ualité dans les campagnes de l'ancienne F ranœ. X V Ie X IX e s. Paris: Gallimard, 1975, passim.

88 Historia de un tópico: La mujer en la Edad Media, H istoria 16, 1978, 21, p. 113.

89 L 'érotisme. Paris: Ramsay, 1987, p. 30.
} 
de possession destructrice et d'idéalisation, crête entre le désir qui est un flux et l'interdit qui met des frontières..$^{90}$

Sin embargo Claude Elsen, desde una perspectiva ciertamente poco positiva, enfrenta amor y amor físico — sentimiento y unión voluntarios, perdurables y sublimes-, y erotismo, que define como

une dépersonnalisation de l'amour, une aventure solitaire, où l'Autre n'est qu'un «objet» de désir et de plaisir. ${ }^{91}$

También Nelli discrimina en primer lugar el "anti-amour" —unidireccional, sin posibilidad de ser correspondido_-, del amor mutuo. La disección de la sensualidad compartida le permite distinguir a su vez entre el amor, en el que la comunión de los corazones antecede y da paso a la consecución del placer, y el erotismo, caracterizado por la preexistencia del placer que da origen al amor; ${ }^{92}$ la pasión se erige así en punto de confluencia de ambas vivencias, eliminando sin duda las estridencias de la fatalidad que la definición de pasión recogida más arriba nos daba como inherentes al concepto y de las que Denis de Rougemont se hacía eco. No es tanto la distinción genética secundaria como la distinción cualitativa inicial la que acerca a Nelli a planteamientos rigoristas, de los que su obra parece pretender distanciarse, al enajenar los placeres solitarios, los encuentros fugaces y la búsqueda no correspondida.

En esta tremenda ruptura histórica entre sexo y amor consiste para García Calvo el pecado contra el amor,

\footnotetext{
90 J. Kristeva, H istoires d'amour, Paris: Denoël, 1983, p. 79.

${ }^{91} \mathrm{H}$ omo erotiaus. E squisse d'une psychologie de l'érotisme. Paris: Gallimard, 1953, p. 131-2.

92 R. Nelli, É rotique et ávilisations, op. at., p. 21.
} 
esta insistencia en la separación entre lo que es Amor de veras y lo que es sexo es justamente el fundamento de todas las nuevas y más poderosas formas de represión. ${ }^{93}$

M. Jiménez desde un punto de vista similar niega la existencia de la pornografía, término perteneciente al código lingüístico de la ideología represiva, pues no tiene razón de ser fuera de las convenciones artificiales y arbitrarias, generalmente morales y religiosas, que autorizan a emitir juicios de valor peyorativos sobre la sexualidad ajena. ${ }^{94}$

Y de la represión surge la dominación, fundamentalmente de la mujer, ${ }^{95}$ aunque no exclusivamente, pues la condena de la sumisión a los placeres pecaminosos del sexo no sólo tiene propósitos espirituales sino que sirve a otros fines. A comienzos del siglo XI, por ejemplo, permitió sentar uno de los pilares ideológicos del orden feudal al justificar biológicamente la servidumbre de los laicos, y aunque a mediados del siglo XII se considerará el acto sexual sólo como una mácula necesaria de la que los cónyuges podrán liberarse mediante la intercesión de los clérigos, se constituye de nuevo el abismo entre castidad y matrimonio como criterio fundamental para una nueva división en dos grandes grupos sociales. ${ }^{96}$ A esta secular voluntad del poder, religioso y/o profano, de someter a la mayoría se une el miedo al sexo femenino ${ }^{97}$ para conformar el núcleo represivo fundamental que ha marcado la vida cotidiana y las representaciones artísticas de la sociedad patriarcal y patrilinear. El abandono de la doble linearidad familiar y la consolidación de la patrilinearidad entre los grupos privilegiados de la sociedad también se

\footnotetext{
93 Los dos sexos y el sexo: las razones de la irracionalidad, Filosofía y sex ualidad, F. Savater (ed.). Barcelona: Anagrama, 1988, p. 36.

94 L'agonie d'Eros. Spectacle et Spéculation. Revue d’E sthétique, 1978, 1-2, p. 215.

95 Tal como afirma Graciano en su D ecretum: "Nulla est mulieris potestas, sed in omnibus uiri dominio subsit”, rúbrica a C. 33 q. 5 c. 17, citado por J. A. Brundage, op. dit., p. 255.

96 Cf. G. Duby, L es trois ordres ou l'imaginaire du féodalisme. Paris: Gallimard, 1978, p. 70 y 256.

97 A. García Calvo, op. cit., p. 37 y ss.
} 
llevaron a cabo durante el siglo XI y la primera mitad del siglo XII bajo la influencia de las reglamentaciones matrimoniales de la Iglesia, y con la consiguiente marginación de los miembros femeninos de la familia. ${ }^{98}$

Así pues la historia de las relaciones entre los sexos en Occidente desde la época medieval se dibuja como un enfrentamiento desigual entre dos tendencias, una moralista y represora en la que se combinan la realidad de la violencia y la angustia del pecado para atenazar a los individuos y conducir el rebaño social, y otra positiva en dos sentidos pues reúne un cierto optimismo al optar por la igualdad en las relaciones heterosexuales con un cierto pragmatismo al intentar poner remedio a la infelicidad, y en segunda instancia y no siempre de manera consciente a la infidelidad, mediante el mutuo consentimiento y el respeto mutuo.

Mención aparte merecen las relaciones homosexuales, que en gran medida correspondían a los contactos sexuales propios de la juventud para individuos que en la edad adulta serían heterosexuales o bisexuales. De ellas sólo hallamos algunos atisbos en la literatura vernácula y sospechas en nuestro corpus, pese al florecimiento de textos latinos que cantaban la belleza masculina y el amor entre hombres. El progresivo rechazo y la represión de relaciones aceptadas y en ocasiones fomentadas socialmente por la confluencia de varias tradiciones — la germánica y la clásica para la homosexualidad masculina y la que llamaremos «intimista» para la femenina-, se consolidaron, no tanto debido a condenas expresas, aunque las hubo, sino como consecuencia indirecta de la imposición del matrimonio como único marco adecuado y aceptable para las relaciones sexuales. Es lo que se desprende por ejemplo de los furibundos ataques de Saint Bernard de Clairvaux contra los herejes del Languedoc:

98 Cf. J. A. Brundage, op. at., p. 227. 
Excluez de l'Eglise le mariage honnête et le lit sans souillure, vous la verrez envahie par les concubinaires, les incestueux, les épancheurs de sperme, les voluptueux, les homosexuels, en un mot toutes les espèces de l'immonde.99

\subsubsection{DOS SEXOS, ¿DOS EROTISMOS?}

Mme de Rosemonde rechaza la posibilidad del placer femenino a través de los sentidos y lo hace depender de la racionalización de la servidumbre sensual a la que los códigos ideológicos dominantes han sometido a la mujer, negando su propia naturaleza:

L'homme jouit du bonheur qu'il ressent, et la femme de celui qu'elle procure. ${ }^{100}$

El proceso por el que el erotismo se hacía antropocéntrico y se alejaba de la unión cósmica aún presente en los ritos dionisíacos, al tiempo que el «aburguesamiento» general de la mente colectiva que reduce a la mujer a ser madre y ama de casa y que se manifiesta ya en la segunda mitad del siglo $\mathrm{XIII},{ }^{101}$ sin que podamos pasar por alto que en los siglos anteriores la mujer tampoco tenía existencia social en el sentido de que los ideólogos de la feudalidad no le asignaban ni oficio, ni función y por lo tanto no era incluida en ningún grupo, ni siquiera entre los siervos, ${ }^{102}$ han erigido un único sujeto erótico, el masculino, condenando a la mujer a la periferia de la sensualidad, por exceso — mujer lúbrica y prostituta — o por defecto — mujer frígida—. De hecho durante el siglo XII se disocia drásticamente a los esposos en la

${ }_{99}$ LX V Ie sermon sur le Cantique des Cantiques, citado por G. Duby, Saint Bernard, l'art aistercien. Paris: Flammarion, 1979, p.154.

${ }^{100}$ Ch. de Laclos, L es liaisons dangereuses. Paris: Flammarion, 1981, p. 298.

${ }^{101}$ Cf. A. Rucquoi, op. at., p. 113 y M.-M. Rivera Garretas, Formas femeninas de sexualidad en la Europa prefeudal y feudal, $\mathrm{H}$ ijas de A frodita. L a sex ualidad femenina en los pueblos del M editerráneo, A. Pérez Jiménez y G. Cruz Andreotti (eds.). Madrid: Ed. Clásicas, p. 223.

102 Véase G. Duby, L es trois ordres..., op. at., p. 78. 
consumación del «debitum»: mientras que el marido puede gozar del placer que le depara el contacto con su mujer, inerte, fría, y puede sentir la pasión fuera del matrimonio, la esposa debe tender a gozar espiritualmente transformando la rudeza del coito en comunión con la divinidad. ${ }^{103}$

Aunque no parece haber acuerdo en cuanto a que el desprecio hacia la mujer fuera un sentimiento compartido por toda la sociedad medieval, ya que en las artes plásticas hallamos representaciones que son sin duda reflejo de la importancia que se daba a la participación de la mujer en la vida del grupo, ${ }^{104}$ existió una muy arraigada concepción misógina entre los intelectuales medievales, ${ }^{105}$ que dio paso en los círculos eclesiásticos a un discurso autoritario y represivo, quizá como rechazo de un hipotético y remoto dominio matriarcal, ${ }^{106}$ o bien del papel preponderante que en las religiones precristianas o naturalistas poseían algunas mujeres, tal como señala Cheverny para la sociedad celta, en la que las mujeres podían ser educadoras, magas, guerreras, profetas, o iniciadoras en el placer, en la fuerza y el poder como lo fue la reina Ginebra para los caballeros artúricos; ${ }^{107}$ o como medio de control del poder para evitar la igualdad en las relaciones heterosexuales; sin que estas tres posibles causas se excluyan entre sí. Este discurso al que aludíamos provocó el enraizamiento progresivo en la mentalidad colectiva del miedo a la mujer y a su capacidad sexual, a lo que contribuyó sin duda una cierta visión negativa de la Belleza que persistía en el seno de la Iglesia conviviendo con la idea de un origen divino indudable y que permitió la coexistencia del deseo y

\footnotetext{
${ }^{103}$ Cf. G. Duby, Mâle M oyen A ge..., op. at., p. 42-5.

${ }^{104}$ Cf. J. M. Azcárate Ristori, La mujer en el arte medieval español: introducción, L a ondioón de la mujer en la E dad M edia, op.at., p. 403.

105 Véase el interesante trabajo de M.-T. d'Alverny, Comment les théologiens et les philosophes voient la femme, CCM, II, 20, 1977, p. 105-29, así como M. Wade Labarge, op. at., p. 142-3.

${ }^{106}$ Julien Cheverny pone en estrecha relación algunos mitos griegos y el mito del pecado original con el terror de la dominación femenina y el fin de la supremacía del matriarcado, en Sex ologie de l'0 ocident. Paris: Hachette, 1976, p. 19-25.

${ }_{107}$ Ibid., p. 108.
} 
del terror respecto de la feminidad. ${ }^{108}$ Durante toda la Edad Media se exageró el deseo sexual de la mujer, ser esencialmente lujurioso, amoral y pecaminoso, portadora de las fuerzas demoníacas; de este supremo defecto $-\mathrm{y}$ de su capacidad para dislocar la patrilinearidad — surgieron como corolario todos los otros defectos que secularmente se le han achacado. ${ }^{109}$

Sin embargo, parece ser que sólo el hombre ha desarrollado o por lo menos ha utilizado instintivamente la poliformidad del deseo, es decir la capacidad de desear a varias mujeres —u hombres tendríamos que añadircasi al tiempo, "correspondant à ses goûts momentanés, à des besoins passagers de sa sensibilité."110 Quizá esta característica del deseo masculino tenga en sus raíces las peculiaridades erógenas del hombre, que Alberoni recoge confrontándolas con las femeninas:

Il faut ajouter que les femmes semblent plus sensibles que les hommes à la musique, au rythme et aux sons. L'érotisme masculin est visuel et génital; l'érotisme féminin est, quant à lui, plus tactile, musculaire, auditif, lié à l'odorat, à la peau, au contact. ${ }^{111}$

Esta poliformidad erótica de la especie a la que nos atreveríamos a dar una filiación natural, deudora del instinto sexual puramente animal, parece también evocar un tempo sensual difícilmente conciliable y que ha restringido

\footnotetext{
${ }^{108}$ Cf. D. Regnier-Bohler, Femme $\backslash$ Faute $\backslash$ Fantasme. La ondición de la mujer en la E dad M edia, op. at., p. 476; H. Rey-Flaud, L a nérrose courtoise. Paris: Navarin, 1983; D. Poirion, Résurgenoes, mythe et littérature à l'âge du symbole, X IIe siède. Paris: PUF, 1986, p. 13 y 218.

${ }^{109}$ Véase entre otros, Pedro M. Cátedra García, La mujer en el sermón medieval (a través de textos españoles), L a ondición de la mujer en la E dad M edia, op. at., p. 43 y ss.

${ }^{110}$ R. Nelli, L 'amour et les mythes du coeur, op. cit., p. 31.

1110 p. at., p. 10. La obra de Sade representa el paroxismo de esta sensualidad masculina dominada por la visión, el resto de los sentidos son absolutamente inexpresivos, se representan sin matices o simplemente se olvidan.

El propio Alberoni establece otras distinciones entre el erotismo masculino y el femenino, algunas de ellas difícilmente aceptables, como ocurre con la que presenta en el hombre la atracción por la belleza mientras que para la mujer adquieren una importancia igual o mayor la posición social y el poder; ibid. p. 35 .
} 
el placer femenino. La homogeneización de la búsqueda del placer, la adaptación fundamentalmente de la sensualidad del hombre a la de la mujer, es una evolución irreversible pero lenta, con épocas de retroceso y de anuncios inesperados del futuro, a la que las diferentes culturas han respondido mediante la condena o por el contrario mediante la reglamentación de la búsqueda compartida, tal y como ocurrió con las prescripciones amorosas, por lo menos de orden teórico, en los ámbitos trovadoresco y cortés. ${ }^{112}$

García Calvo reflexiona sobre otro punto de ruptura entre ambos sexos, la imaginación erótica y en particular la imaginación como fuente de placer. Frente a la masculina, consciente, visual y fragmentaria se encuentra la femenina, desdibujada, preparada por el poder para grabar sólo la imagen de un hombre. ${ }^{113}$ Es más, el hombre parece poder imaginar a la mujer en actitudes bien definidas, generalmente estáticas, receptivas, acostada o inmóvil, ${ }^{114}$ mientras que la mujer parece no hacerse ninguna representación que incite a la unión, que sea sexualmente simbólica, del cuerpo masculino.

Es indudable que estas formas de imaginar el sexo y de adentrarse en el placer tanto de orden fisiológico como cultural han dejado sus huellas en la representación erótica literaria medieval y más concretamente en nuestro corpus. Hallaremos pues rastros de esas diferencias, si bien la tendencia dominante, la libido masculina, parece acaparar los espacios expresivos de los romans, desafiando los supuestos de eliminación de los tópicos negativos que afectaban a la mujer y de exaltación de la sensualidad femenina frente a la masculina que se le atribuían a la cultura cortés.

\footnotetext{
${ }^{112}$ Esta idea está presente en la Introducción de R. Nelli a su obra É rotique et áilisations, culminando su reflexión con una referencia a la época contemporánea y a la resolución de la lucha entre los sexos, todavía imperfecta pues no afecta a todos los individuos: "L'unité du plaisir, la résorption de la dyade hédonique, paraitt bien avoir été le but suprème de la nature." 0 p. ait., p. 27.

${ }^{113} 0$ p. at., p. 44 y ss.

${ }^{114}$ Cf. R. Nelli, L e corps féminin et l'imaginaire, op. at., p. 208.
} 
La seducción — manifestación del deseo y búsqueda del otro- es uno de los aspectos más interesantes de la actividad erótica, y sobre ella las opiniones están divididas con respecto al sujeto seductor dominante. Mientras que Ovidio al consagrarle su A rs amatoria habla fundamentalmente al seductor —ente activo- y pretende guiar su esfuerzo para conseguir la mujer que encanta sus sentidos; la seducción queda reservada a la mujer en opinión de Alberoni, ${ }^{115}$ reduciéndose el juego amoroso femenino a una activa pasividad que lleva a la mujer a convertirse en un objeto de deseo para el hombre. ${ }^{116}$ En su ensayo sobre la seducción, Baudrillard analiza la naturaleza de ambas seducciones, no como complementarias sino como radicalmente opuestas. Afirma que frente a la libido masculina — tal como la identificó Freud— y su manifestación seductora artificial, estratégica, ${ }^{117}$ se erige la seducción femenina, natural, inconsciente, que representa

el dominio del universo simbólico, mientras que el poder (masculino) representa sólo el dominio del universo real. ${ }^{118}$

Ya sea masculina o femenina, la seducción está caracterizada esencialmente por ser la apariencia frente a la verdad, la indistinción frente a la certeza, y esta capacidad para invertir el orden se torna fundamental en el desarollo narrativo de nuestros romans. Sin embargo, y en contra de las tesis de Baudrillard, la mujer aparece en la época medieval como la gran maestra de la estrategia engañosa voluntaria — esta idea entonces generalizada ha perdurado hasta hoy-, y utiliza los mismos recursos del seductor masculino, subterfugios del acto y de la palabra con fines extraños al amor. Ya los autores griegos habían descrito la actividad seductora como un arma femenina tanto como masculina en la que hechos y palabras engañosos confluían para lograr

\footnotetext{
1150 p. cit., p. $54-60$.

${ }^{116}$ C. Elsen, op. at., p. 104-6.

1170 p. ait., p. $95-6$.

118 Ibid., p. 14-8.
} 
el amor del otro. Entre otros Jenofonte en sus tratados L os memorables (III, 11, 5 - 18) recoge la lección de Sócrates a la cortesana Teodotes, quien de aprendiz de seducción pasa a seductora del maestro.

Desconocemos en qué medida la naturaleza representada por el instinto de conservación de la especie con la contribución indudable de la búsqueda del placer, y hasta qué punto el desarrollo social con su carga de miedos, tabús, luchas por el poder o deseo de armonía, han contribuido en la conformación de las formas de buscar, sentir y practicar la actividad sexual, pero nos parece fuera de toda duda que las diferencias existen y que de nuevo, en las diferentes civilizaciones y a lo largo de la historia, dos tendencias han existido, coexistido y en ocasiones se han confrontado violentamente. Una ha buscado profundizar las diferencias creando un abismo entre los sexos y negando el placer cuando menos a uno de ellos, y otra por el contrario ha pretendido acercarlos puenteando las distancias y dando relieve a las fuerzas de homogeneización social. 


\subsubsection{EL AMOR CORTÉS, MULTIPLICIDAD ERÓTICA.}

Entre las manifestaciones de lo que se ha dado en llamar amor cortés, ${ }^{119}$ esencialmente un arte de amar para Moshé Lazar, ${ }^{120}$ encontramos una multiplicidad de matices eróticos que responden no tanto a movimientos colectivos como a impulsos individuales. Su distinción resulta sin embargo compleja al aparecer constreñidos por el armazón de la tradición literaria, fundamentalmente en lo que se refiere a los cánones estéticos y al uso de los recursos expresivos, así como por los preceptos del género al que se adscriben los textos; sean poemas líricos, romans, fabliaux, lais o pastourelles, en todos se encarna el inmemorial conflicto entre los sexos, los intentos de acercamiento de las sensualidades masculina y femenina tenazmente alejadas en el Occidente medieval, y el desgarro producido por la violencia sexual y la doctrina de la Iglesia.

Los textos paródicos y particularmente los fabliaux representan en negativo la estructura del discurso cortés, del Texto, ${ }^{121}$ que en gran medida por su enunciación eufemística del mundo y de las relaciones entre los sexos, fue la fuente de vida, Huevo de plata de la literatura medieval, como el otro

\footnotetext{
119 Adoptamos esta denominación propuesta en el siglo pasado por Gastón Paris por ser la que en nuestra opinión se adapta mejor a la variedad de formas que el amor aristocrático y cultivado de los roman adopta, aunque autores como Brault hayan propuesto otras traducciones para la expresión «fin' amors», tales como «amour vrai», «amour achevé» o «pur amour», cf. J. Brault, Le secret d'amour dans la lyrique courtoise, L'érotisme au moyen âge, Bruno Roy (dir.). Montréal: Éditions de l'Aurore, 1977, p. 26; y Matoré, siguiendo a Frappier, propone hacer la distinción entre "l'amour courtois, sentiment élevé qui spiritualise la femme" y "la 'fine amor' qui est la «passion adultère»". Le vocabulaire et la société médiévale, Paris: PUF, 1985, p. 180, n. 5.

${ }^{120}$ M. Lazar, A mour courtois et fin'amors dans la littérature du X IIe siède. Paris: Klincksieck, 1964, p. 23.

${ }^{121}$ Cf. J. -Ch. Huchet, De la perversion en littérature. Poétique, XVIII, 71, 1987, p. 283 y 289. Así ocurre también con la reescritura que hace Jean Renart de los temas y convenciones corteses así como de su enfrentamiento con los hábitos eróticos ciertamente rudos de la nobleza feudal. Cf. C. Cortés Zaborras, «Cortoisie fere». Une approche au Lai de l'ombre, A nales de filología franosa, 3, 1989, passim. Por lo que se refiere al tratamiento de la mujer en el género cómico, Pierre Gallais en D ialectique du réait médiéval. Chrétien de Troyes et l'hex agone logique. Amsterdam: Rodopi, 1982, p. 302, nos recuerda que se le niega permanentemente el derecho a una existencia autónoma en tanto que objeto de deseo: “... elle y est niée en tant qu'autre, en tant que membre d'un couple dont les deux moitiés seront différentes et complémentaires."
} 
Eros, origen de toda existencia en la cosmogonía órfica. Si descartamos estos géneros menores y nos acercamos al corpus axial del fenómeno cortés podemos hablar de dos grandes corrientes, no sólo literarias sino también éticas y eróticas:

Una corriente que llamamos lírica, cuyos valores son esencialmente morales y estéticos y sólo en segunda instancia sociales, representada fundamentalmente por la chanson d'amour en lengua d' $0 c$ y ya como un ejercicio de retórica en lengua d'oil. Desde el comienzo la homogeneidad creativa renovada mediante un uso sutil de la connotación no lleva aparejada la homogeneidad erótica: mientras Conon de Béthune canta el deseo de pecar, Jauffré Rudel o Marcabru — moralista estricto—, anhelan la armonía espiritual que otorga el amor puro. ${ }^{122}$

La otra tendencia, sin duda influida por la primera en los niveles expresivos y en alguno de los ámbitos de la ética amorosa, y en cuya elaboración intervienen fundamentalmente componentes sociales, está constituida por muchos de los textos narrativos de los siglos XII y XIII en verso y en prosa.

El roman, heredero de dos tradiciones, lírica y guerrera, se convierte así en el instrumento ideal para intentar la humanización del orden feudal "en opposant la réalité vécue des sentiments au code abstrait de l'amour courtois". ${ }^{123}$ Las historias de amor que encandilaban al público medieval adoptan el código caballeresco caracterizado por "sa virilité et son réalisme en matière érotique (l'acte sexuel doit avoir lieu)",124 manteniendo sólo ocasionalmente puntos de contacto con el otro código erótico, el amor trovadoresco. Duby hace mención del proceso mediante el cual la caballería

\footnotetext{
${ }^{122}$ Cf. W. Kellermann, L'éclosion du lyrisme occidental: l'amour vénération, E ntretiens sur la renaissanœ du X IIe siède. M. de Gandillac y E. de Jeauneau (dir.). Paris/La Haye: Mouton, 1968, p.383; M. Fehrer, L'amour le plus éprouvant, Magazine littéraire, no 267-268, 1989, p. 19-20.

${ }^{123}$ M. Zéraffa, Roman et société. Paris: PUF, 1976, p. 100.

${ }^{124}$ M.-O. Métral, op. at, p. 115.
} 
conculca la moral cristiana y la debida templanza de los trovadores: de entre los juegos que se proponían a los jóvenes

ceux de l'amour ont, durant tout le XIIe siècle, élargi sans cesse leur domaine. Défiant l'exhortation des prêtres à la continence, la chevalerie n'a cessé de s'érotiser. ${ }^{125}$

En el seno del roman también conviven interpretaciones diversas de la realidad erótica y de los sujetos tipificados del amor cortés: Erec y Enide consiguen eliminar los obstáculos que se oponen a la liberación del deseo compartido mediante la transgresión de los códigos caballerescos y corteses; de hecho, parece que Chrétien, excepto en Le Chevalier de la dharrete, donde Lanzarote encarna al perfecto fin amant y Ginebra se entrega a él según los preceptos del código cortés, pretendió en sus obras poner de manifiesto las insuficiencias de la cortesía, especialmente en lo que concierne a la disociación entre amor y matrimonio. ${ }^{126}$ Liénor, hermana de Guillaume de Dole, debe reivindicar su virginidad — un valor en alza en la literatura del siglo XIII que era despreciado por los trovadores - frente a la figura hipertrófica del lausengier; mientras que la pureza idílica de Floire y de Blancheflor pretende rehabilitar el amor y recuperar la fe en sus infinitas bondades. Pocas narraciones cortesanas conjugan armoniosamente el ideal de perfección caballeresco y el código del amor cortés y en muchos casos se trata de discursos que se encuentran en la periferia del movimiento, adoptando y adaptando según las necesidades temáticas o ideológicas la tópica, los preceptos éticos o las convenciones amorosas corteses.

Ambas corrientes parecen confluir en un cierto manierismo ya durante el siglo XII que afecta a las relaciones sociales en el espacio cortesano, puesto que la cortesía se convierte en una especie de gimnasia individual que

\footnotetext{
${ }^{125}$ Mâle M oyen A ge..., op. àt., p. 91.

${ }^{126}$ Cf. M. Zéraffa, Roman et société, op. at., p. 100; S. Gallien, La conception sentimentale de Chrétien de Troyes. Paris: Nizet, 1975, p. 14-5.
} 
pretende conseguir el más alto grado de refinamiento y la mejor reputación posible entre los miembros de la corte —véase por ejemplo ya en sus comienzos la actitud de Gauvain—, ${ }^{127}$ algo que parece dar la razón a Duby en su convencimiento de que el amor cortés no es sino una elaboración literaria y que su hipotética transposición a la vida real de la aristocracia debió ser

un simulacre mondain, un vêtement de parade jeté sur la vérité des attitudes affectives. ${ }^{128}$

Y en mayor medida determinará la evolución de la composición literaria, ya que

la courtoisie, passant de l'état de forme structurante à l'état de formule structurée, tombe aux mains des doctes, des faiseurs de manuels du bien-vivre, et devient une espèce de jouet pour une aristocratie dont l'avenir va s'assombrissant. ${ }^{129}$

De hecho los más antiguos trovadores ya auguraban el rápido declinar del ideal al que tendían, copado por los seniores y las damas inconstantes en el declive de la aristocracia del espíritu.

Dos de las diferencias fundamentales entre ambas corrientes radican:

- En la posición de la primera instancia enunciadora con respecto al objeto de deseo, a la Dama o a sus avatares. En la tendencia lírica el poeta está, o debería estar, substancialmente implicado en el combate amoroso que se hace poema, el deseo es texto; mientras que en la corriente caballeresca autor/narrador y amador —en este caso un personaje- son entes completamente diferenciados, y el amor está en el texto, utilizado generalmente como vehículo de los ideales feudales o de la moral oficial de la

${ }^{127}$ Cf. R. Dragonetti, L a technique poétique des trouvères dans la chanson ourtoise. Genève: Slatkine Reprints, 1979, p. 103. Véase también J. Cheverny, op. at., p. 106.

${ }^{128}$ M âle M oyen A ge...., op. at., p. 46.

${ }^{129}$ J. Brault, Le secret d'amour dans la lyrique courtoise, L 'érotisme au M oyen A ge, op. ait., p. 26. 
Iglesia, ajenos a su naturaleza y a su evolución natural. Algunas obras, sin embargo, como los poemas de Guillaume d'Aquitaine y el Roman de la Rose de Guillaume de Lorris, ponen de manifiesto la existencia de textos híbridos durante todo el período cortés.

- En la forma en que se presenta a la mujer. Los trovadores mantenían en secreto el nombre de la amada y siguiendo los dictados de la retórica no dibujaban al personaje en su individualidad sino como símbolo ejemplar, como arquetipo. Para ellos describir era ante todo dar, "au moyen d'hyperboles, une image idéale exaltante ou déprimante de l'objet". ${ }^{130}$ En los textos narrativos, se recogen sus acciones y se reproducen sus palabras; es más, en ocasiones, tal como señala Pauphilet se otorga a la mujer una cierta supremacía como motor de la acción, en su opinión como uno de los logros naturales de la cortesía, ${ }^{131}$ sin embargo esa impulsión femenina del desarrollo de los relatos es sobre todo evidente en las obras que intentan hacer una crítica o incluso parodiar velada o abiertamente los modelos corteses. ${ }^{132}$

Dicho esto y para clarificar desde el comienzo nuestra postura respecto a las representaciones literarias del amor cortés debemos señalar que no nos parece adecuado intentar hallar en los textos representación alguna de búsqueda explícita de la divinidad, de unión mística que trascienda el encuentro entre los amantes, tal como hace Georgette Kamenetz para Le Roman de la Rose. ${ }^{133}$ Bien es cierto que el hecho de anhelar la perfección individual mediante la relación amorosa y el de aproximarse a la belleza como

\footnotetext{
${ }^{130}$ R. Dragonetti, L a technique poétiques..., op. ait., p. 250.

131 A. Pauphilet, L e legs du M oyen A ge. Paris: Librairie d'Argences, 1950, p. 247.

${ }^{132}$ Véase en el caso de A ucassin et N iolette, C. Cortés Zaborras, Análisis del código espacial en un texto narrativo del siglo XIII, A das del IV Simposio internacional de la A sociación andaluza de Semiótica, P. Moraleda García y A. Sánchez Fernández (eds.). Córdoba: Universidad de Córdoba, 1992 (microfichas). En la chantefable se invierten los valores simbólicos otorgados a los espacios y a las acciones de los personajes femeninos y masculinos desencadenándose una confusión sexual que sólo los lazos matrimoniales lograrán superar.

${ }^{133}$ Véase La Promenade d'Amant comme expérience mystique, E tudes sur le Roman de la Rose, J. Dufournet (ed.). Paris: Champion, 1984, passim.
} 
absoluto estético mediante la contemplación de la mujer y el éxtasis sensual componen un trasfondo ético que puede llevar a error. A todo esto hay que añadir que a menudo la literatura profana medieval utiliza los recursos expresivos — términos, imágenes y estructuras retóricas- de la literatura religiosa. ${ }^{134}$ Existen también notables divergencias que permiten a Davy afirmar que el amor cortés es independiente de la tradición mística medieval:

Les mystiques et les artistes se réfèrent à la Bible et aux Pères de l'Eglise. Par contre la fin'amors se représente comme un véritable art d'aimer qui s'apparente à la pensée hispano-arabe. ${ }^{135}$

La voluntad última de los creadores corteses parece ser la exaltación de las relaciones heterosexuales — en el seno del matrimonio o fuera de él en función de los dictados ideológicos y sociales-, y la consecución perfecta del placer compartido, aunque no siempre cuenten con la voluntad femenina. Tal como afirma Yves Lefèvre sobre la obra de Guillaume d'Aquitaine "l'érotisme y garde tous ses droits", ${ }^{136}$ comprendiendo erotismo en el sentido en el que lo hace R. Nelli, unión de los cuerpos para lograr el placer, que precede o no al amor, y que para Javelet representa un homenaje indecente al amor carnal. ${ }^{137}$ El culto a la dama sólo es parcialmente, nos atreveríamos a decir incluso secundariamente, el culto a su espíritu:

C'est une révolte du monde contre le royaume du ciel. Le «fin amour», par son essence, est anti-chrétien. ${ }^{138}$

\footnotetext{
${ }^{134}$ Cf. J. Brückmann y J. Couchman, Du Cantique des Cantiques aux Carmina Burana: amour sacré et amour érotique, L 'érotisme au moyen âge, op. ait., p. 48.

${ }^{135}$ M.-M. Davy, Initiation à la symbolique romane (XIIe siècle). Paris: Flammarion, 1988, p. 262.

${ }_{136}$ H istoire mondiale de la Femme. T. II: D e l'0 cadent des Celtes à la Renaissanœ. Paris: Nouvelle Librairie de France, 1966, p. 93.

${ }^{137}$ R. Javelet, L'amour spirituel face à l'amour chrétien, E ntretiens sur la Renaissance du X IIe siède. Paris / La Haye: Mouton, 1966, p. 309.

${ }^{138} \mathrm{H}$ istoire mondiale de la Femme, op. at., p. 93.
} 
El amor cortés tampoco es amor platónico en el sentido que le otorgará Marsilio Ficino en el siglo XV, un amor cuya única herramienta en la construcción del placer —sin duda intelectual y masculino- es la contemplación de la belleza en el ser amado. Esta sacralización de la mujer que impide el placer transmitido por el tacto puede considerarse como una evolución comprensible del amor cortés si tomamos en consideración los problemas sanitarios que padeció Europa al final de la Edad Media; está muy lejos del supremo bien al que aspiran los trovadores y los personajes de los romans: el contacto de los cuerpos desnudos y la penetración de la amada, y ello incluso en el caso en que aceptásemos que el adulterio era simbólico, una metáfora que nunca se llevaba a la práctica ${ }^{139}$ puesto que el deseo hubiera pervivido entre los amantes leales. Métral, en su distinción entre erotismo cortés y caballeresco, descarta la posibilidad del coito en el primero, y justifica esta tesis por la posibilidad que el asag probatorio ofrece a la mujer de llegar al orgasmo, imposible por otra parte en las relaciones conyugales; ${ }^{140}$ sin embargo no se puede descartar totalmente el que el asag también pudiese comportar la penetración vaginal sin emisión seminal, a pesar de lo que afirman los poetas durante el siglo XII; de hecho ya a comienzos del siglo XIII Raimon de Miravall, sin duda influido por el amor caballeresco, disloca absolutamente la ascesis abocada a no llegar jamás al feit, proclamando que

el jazer debe preceder a todas las demás señales de dilección, platónicas u honoríficas. ${ }^{141}$

"E cortesia es d'amar" según canta Marcabru, ${ }^{142}$ pero ¿de qué amor se trata? Del amor que profesan los jóvenes y los poetas por las lejanas damas, del supuesto amor que esconde el deseo puramente carnal de muchos

\footnotetext{
${ }^{139}$ P. G. Beltrami, Chrétien de Troyes, l'amour, l'adultère. Remarques sur le Chevalier de la Charrete, A des du X IV e Congrès international arthurien. Rennes: Presses Universitaires, 1985, p. 62-3.

${ }^{140}$ Op. at., p. 138.

${ }^{141} \mathrm{~J}$. M. Bermejo, L a vida amorosa en la época de los trovadores. Madrid: Temas de hoy, 1996, p. 113-4.

${ }^{142} \mathrm{XV}, 20$, citado por R. Dragonetti, L a technique poétique..., op. ait., p. 407.
} 
caballeros, señores y vanos poetas, o del amor natural inocentemente compartido por dos héroes adolescentes. Parece ser que para los trovadores no existía duda alguna, el amor - adoración ${ }^{143}$ por la dama era el único capaz de satisfacer plenamente las aspiraciones espirituales y físicas del amante, cuyas cualidades eran juventud, discernimiento, liberalidad, mesura, fidelidad, nobleza en suma. Nobleza que no era estrictamente de sangre sino una nobleza intrínseca, del corazón, la nobleza del alma que Mathieu de Vendôme retoma del poeta Claudiano ${ }^{144}$ y que se expresa gracias a la perfección de la cortesía. ${ }^{145}$ Este amor descartaba las estridencias y surgía en el justo medio entre el deseo y lo vedado, entre la realidad y lo imaginado, entre lo posible y lo imposible, entre el vicio y la virtud. ${ }^{146}$ La relación de los trovadores con la dama se va a mantener en la literatura caballeresca aunque matizada, diluida en muchas ocasiones por una sensualidad masculina más exigente, cada vez más cercana de los intereses dinásticos y de la realidad social.

El terrible lado oscuro de la $\mathrm{D}$ ame, de ese mito poético que encierra el placer supremo, reaparece cuando se torna femme, venal, inconstante, lujuriosa y no merece el título de dama ni el terrible sufrimiento de la espera. ${ }^{147}$ Pero la Dama es el día, la luz, la Belleza ${ }^{148}$ y por ello el poeta le consagra incansable sus rimas, deseoso de rendirla al servicio del Amor. A esta

\footnotetext{
${ }^{143}$ G. M. Cropp en L e vocabulaire courtois des troubadours à l'époque dassique. Genève: Droz, 1975, p. 406, n. 80, nos aclara: "Le verbe «azoran», adorer, que l'on a emprunté sans doute à la langue religieuse, est d'un emploi restreint. L'amour courtois comporte de la vénération, mais sans aboutir à l'idolâtrie."

${ }^{144}$ Citado por E. Faral en A rts poétiques du X IIe et X IIIe siède. Recherches et doauments sur la technique littéraire du M oyen A ge. Paris: Champion, 1924, p. 116: "Virtute decet, non sanguini, niti: Nobilitias animi sola est atque unica virtus".

${ }^{145}$ Cf. R. Dragonetti, L a technique poétique..., op. cit., p. 84-5. F. de Casas Fernández reseña en La lírica. H istoria de la Literatura franoesa. J. del Prado (coord.). Madrid: Cátedra, 1994, p. 154, las virtudes corteses establecidas por Marcabru: "El jovens, juventud de espíritu, y su hermana la largueza, la liberalidad, que desaparecen si falla la lealtad. La conoissensa, poder de discernir entre lo auténtico y lo falso, la mezura, que exige del comportamiento de cada individuo que se ajuste al orden establecido para todo lo creado. Cuando no se guarda mezura se pierde el sen, la capacidad de actuar de forma justa y razonable"

${ }^{146}$ Cf. M.-O. Métral, op. ait., p. 118.

${ }^{147}$ Cf. R. Dragonetti, Techniques poétiques..., op. ait., p. 49 y 78.

${ }^{148}$ Matthieu de Vendôme señala que en las alabanzas a la dama se debía insistir en su belleza: «Amplius, in femineo sexu approbatio formae debet ampliarì. E. Faral, op. at., p. 134.
} 
virtud natural se unen muchas otras de carácter moral y social hasta componer en un largo proceso poético el símbolo que fue para los trovadores:

bonne, débonnaire, bienveillante, elle apparait pleine de vaillance, de sens, d'honneur et de sagesse; sa courtoisie n'est pas moins parfaite, car elle est accueillante, avenante, et son langage simple et châtié charme ceux qui l'écoutent, car elle est bien apprise et de grand savoir pour ce qui regarde les choses du coeur; ... son maintien empreint de simplicité, de discrétion et de noblesse. ${ }^{149}$

El término dame va a designar invariablemente a la amada, sin embargo con la evolución del derecho en cuanto a las transmisiones patrimoniales y con los cambios introducidos en el «mercado matrimonial» por la doctrina de la Iglesia, la dama — en tanto que objeto amoroso- pasa de ser una mujer casada y noble a ser una joven virgen perteneciente a la nobleza, ${ }^{150}$ con la consiguiente anulación progresiva de la distancia necesaria para exacerbar el deseo de lo prohibido en el amador, que a lo sumo se transmuta en distancia geográfica. ${ }^{151}$ Quizá la clave para comprender el mantenimiento de esta denominación no sea exclusivamente deudora de la tradición literaria sino que también pueden haber intervenido factores socioeconómicos, la mujer poseedora de tierras permitía soñar a los jóvenes con la señoría, con el poder y la estabilidad, tal como se puede deducir de las conclusiones del estudio sobre actas legales que lleva a cabo Dyggve, retomadas por Dragonetti:

Presque chaque fois que l'on rencontre une femme avec la qualification de dame de tel lieu, il s'agit d'une terre provenant de sa famille à elle et qu'elle avait eue personnellement en héritage. 152

\footnotetext{
${ }^{149}$ R. Dragonetti, L a technique poétique..., op.ait., p. 252-3.

${ }^{150}$ Cf. A. Grisay et alii., Les dénominations de la femme dans les anciens textes littéraires français. Gembloux: Duculot, 1969 , p. 118 - 37.

${ }^{151}$ Cf. J.-Ch. Huchet, De la perversion en littérature, Poétique, XVIII, 71, 1987, p. 281.

${ }^{152} \mathrm{~L}$ a technique poétique..., op. at., p. 324.
} 
El roman recoge todas las posibles figuras de la joven y las confronta cada vez más abiertamente a la de la dama para recrear el complejo itinerario del juego amoroso hecho de sueños eróticos y anhelos de justicia social; cuando los autores hablan de pucle o demoisele se refieren a diversos modos de ser o actuar de la mujer soltera: 1. Muchacha de buena familia errante en el bosque. 2. Doncella que es abiertamente amiga, esto es, amante de un caballero. 3. Una virgen en sentido estricto. 4. Una muchacha preparada para el matrimonio: una joven casadera; siendo todos ellos imaginarios. ${ }^{153}$ Desde los primeros relatos artúricos las doncellas, dotadas de una gran belleza y cortesía, llegaban a la corte para solicitar ayuda o participar en los juegos cortesanos, en su mayor parte con una intencionalidad erótica, y ofrecían a los hombres maravillados el sueño de la sensualidad y tal vez el placer:

\author{
Tex puceles soelent venir \\ ça en arrier, por esbaudir \\ a la court le bon roi Artu», \\ font cil qui tienent a vertu \\ ou a mout bel enchantement. ${ }^{154}$
}

${ }^{153}$ Cf. J. E. Ruiz Domenec, L a mujer que mira. Crónicas de la cultura cortés. Barcelona: Quaderns Crema, 1986, p. 71.

${ }^{154}$ J. Renart, L e Roman de la Rose ou de G uillaume de D ole, Félix Lecoy (ed.). Paris: Honoré Champion, 1979, v. 4617-21. 
Durante el siglo XIII, la mujer soltera tiene el papel de despertar en el hombre los deseos inmateriales e inconfesados de la pubertad así como las aspiraciones sociales de aquéllos para los que la guerra, la rapiña y la violencia ya no pueden ser el único modo de vida en tierra cristiana. Y ello pese a que el tabú popular de la virginidad sólo alcanzó las capas aristocráticas de la sociedad a comienzos de siglo, una vez que el discurso eclesiástico había logrado sublimarlo, convirtiendo el himen

en un precinto social que mantiene pura a la mujer, ajena a toda contaminación con el sexo masculino. ${ }^{155}$

Los seniores ofrecen el reparto de bienes a cambio del respeto hacia el juego matrimonial para que los jóvenes dejen de vagar en busca de mujeres casadas o viudas, lo que se convierte en una máxima en boca del senescal en el Roman de la Rose de Jean Renart, genuino representante de este grupo al que la narrativa cortés pretende marginar y denigrar:

\section{Bien prent terre et avoir li hom \\ qui la prent bone et sage et bele \\ et de bon lignage et pucele. ${ }^{156}$}

Se pretende que se asienten junto a una esposa virgen a la que ya no llamarán amie, ${ }^{157}$ pues este término se reserva para los usos amorosos, designando a la amante, y procura evitarse cuando se habla de la mujer legítima. Con ello podemos también observar que la presión de la realidad social multiplica los modelos femeninos, a la par que diversifica los términos

\footnotetext{
${ }^{155}$ J. E. Ruiz Domenec, op. at., p. 78-80. Para Matoré las dos acepciones de la palabra puœlle, mujer joven y virgen, estaban muy probablemente estrechamente unidas en una civilización en la que debía llegar virgen al matrimonio, op. at., 1985, p. 47.

${ }^{156} \mathrm{~J}$. Renart, L e Roman de la Rose ou de G uillaume de D ole, op. ait., v. 3522-4

${ }^{157}$ Cf. J. E. Ruiz Domenec, op. at., p. 81; y A. Duplat, Étude stylistique des apostrophes adressées aux personnages féminins dans les romans de Chrétien de Troyes, CCM, XVII, 1974, p. 141.
} 
con los que se habla de o a la mujer en función del estadio en el que se encuentra y de su relación con el que se dirige a ella.

Podemos así concluir que mediante la conciliación de la exaltación de la mujer con su control y gracias al establecimiento del matrimonio como medio de acceso masculino al placer y al poder — sin olvidar su papel como instrumento de orden sociaŁ, se llega a la disolución de la gran contradicción impuesta por la estética cortés a través de las canciones de amor de los trovadores y de las primeras novelas caballerescas.

\subsubsection{EROTISMO Y ACTIVIDAD TEXTUAL.}

La literatura como cualquier otra manifestación artística revela los objetos de deseo de la sociedad que la engendra y en la que se difunde gracias a una fusión alquímica entre ficción y realidad. Sin embargo al ser esencialmente la plenitud que contiene todas las virtualidades no pretende describir la sociedad, sino que más bien forma parte de ella. La novela va más allá de ser un reflejo de la vida; producto acabado de la simbiosis entre lo real y lo imaginario tiene para Zéraffa una función reveladora de los aspectos latentes, inconfesados e inconfesables de la vida social, económica y psicológica, convirtiéndose en búsqueda y expresión de una esencia. ${ }^{158}$ Es en palabras de Jacques Le Goff:

la part inquiète d'elle-même, sa morne moitié d'ombre, son cri d'angoisse, son effort pour se rassurer. ${ }^{159}$

La sexualidad a su vez utiliza los códigos semióticos para convertirse en texto erótico, cargándolo de los fantasmas y deseos individuales o colectivos; mediante la obra literaria el gesto, la palabra y la situación

\footnotetext{
${ }^{158}$ Cf. M. Zéraffa, Roman et société, op. ait., p. 12.

${ }^{159}$ Prefacio a L 'aventure chevaleresque, op. ait., p. XIV.
} 
adquieren ese significado segundo, connotado, evocador de otras realidades, de otras vivencias, que caracteriza el erotismo. ${ }^{160}$

Frente al erotismo, que como todo sistema connotativo desarrolla una actividad semiológica, al tiempo icónica y semántica, relacionada a la vez con el instinto y sus manifestaciones sensuales primarias y con las elaboraciones culturales secundarias, una actividad que es síntoma de la existencia de un código común al autor, al texto y a su auditorio, ${ }^{161}$ y cuya función es lograr el placer intelectual, se encuentra la pornografía, cuyo discurso es puramente denotativo y tiende a conseguir el placer físico. ${ }^{162}$

El placer intelectual a la vez estético y erótico de la creación de los textos medievales así como de su recepción, si tenemos en cuenta la definición del relato amoroso como una estructura orgásmica, como "une voyure", ${ }^{163}$ descansa permanentemente sobre un principio metonímico ${ }^{164}$ ya que prevalece la parte por el todo, lo entredicho por lo explícito; el discurso queda voluntariamente abierto al descubrimiento del destinatario, y más allá a la identificación de sus experiencias eróticas y narrativas con las que actualiza o vela el propio texto; forma y contenido son intertexto, de lo literario y de la vida.

Rara vez el roman da algo más que alusiones indirectas —anuncios, imágenes, intervenciones del narrador en las que se dirige al narratario- de la unión sexual de los amantes, algo que resulta comprensible si tenemos en cuenta la nobleza del género y el funcionamiento general del motivo sexual que por su carácter "irracional y transgresor y por su privacidad" ha

\footnotetext{
${ }^{160}$ M. Chlvmsky, Esthéticité, érotisme et pornographie, Revue d’E sthétique, 1978, 1-2, p. 207.

${ }^{161}$ Cf. P. Zumthor, E ssai de poétique médiévale, Paris: Seuil, 1972, p. 112.

${ }^{162}$ M. Chlymsky, op. cit., p. 196.

${ }^{163}$ Ch. Grivel, La place d'amour, Le Réat amoureux; Colloque de Cerisy, Seyssel: Champ Vallon, 1984, p. 102.

${ }^{164} \mathrm{El}$ carácter metonímico de la obra erótica ha sido puesto de relieve por M. Zéraffa, Érotique /Esthétique, op. at., p. 122.
} 
encontrado siempre muchas dificultades para ser incluido en el discurso escrito. ${ }^{165}$ La consecuencia más llamativa por lo que se refiere al nivel retórico de la narrativa cortés es la sobreexplotación del tabú ético — palabra prohibida cuyo designado también lo está - y del eufemismo — sugestión de una idea cuya expresión directa resultaría malsonante o ruda-, es decir, un ocultamiento de origen social que desaparece con el lenguaje «natural» de los fabliaux o de Jean de Meun. ${ }^{166}$

De esa forma el deseo, concupiscencia de lo que está ausente para Bernardo de Claraval, ${ }^{167}$ es el deseo del texto, de la narración de los hechos que han ocurrido pero que no se cuentan y de los que sólo se puede conocer el antes, quizá el después, nunca el durante en su plenitud. Ya Ovidio, tras ser duramente criticado por lo explícito de sus composiciones, declina hacer una descripción del acto de Venus y pide al receptor de su obra que utilice su imaginación. ${ }^{168} \mathrm{El}$ amor, el sexo y su plasmación literaria se distancian a la vez que se acercan en un movimiento paradójico tras el que la verdad y la mujer permanecen siempre ocultas, desconocidas. El relato mítico en tercera o en primera persona recupera así, cuando la lógica de la narración parece exigir lo contrario, lo que para Michel Zink es la representación medieval del amor: exaltación del deseo en su esencia, exacerbamiento de éste porque queda permanentemente insatisfecho y por los innumerables obstáculos que se le oponen. ${ }^{169}$

$\mathrm{Al}$ igual que las relaciones sexuales cotidianas tendentes a satisfacer el deseo masculino, el discurso literario queda en la Edad Media monopolizado

\footnotetext{
165 A. Firpo, Las concubinas reales en la Baja Edad Media castellana, La condicón de la mujer en la E dad M edia, op. at., p. 336.

${ }^{166}$ Cf. D. Poirion, Les mots et les choses selon Jean de Meun, Information littéraire, XXVI, 1, 1974, p. 8.

${ }^{167} \mathrm{Q}$ u'il faut aimer D ieu, citado por J. Leclercq, L'amour vu..., op. cit., p. 70.

${ }^{168}$ Véase L es Remèdes à l'amour. Paris: Gallimard, 1988, p. 145.

${ }^{169} \mathrm{M}$. Zink, La tristesse du coeur dans le Livre du Cuer d'Amours espris de René d'Anjou, Le Réat amoureux; Colloque de Cerisy, op. at., p. 33-4.
} 
por el hombre y se convierte en sustituto inmaculado de la generación sexual imperfecta por ser en última instancia femenina. El clérigo, fundamentalmente, deviene así el recreador de la obra divina, ${ }^{170}$ de la palabra, del texto, de la Belleza, en suma, como atributo de la divinidad. Depositario de la realidad ${ }^{171}$ e intrínsecamente veraz, el discurso escrito masculino intenta conjurar el lenguaje del pecado enraizado en la naturaleza femenina, ${ }^{172}$ elaborado mediante los recursos expresivos de la oralidad, los silencios, los gestos, las entonaciones que permiten el engaño, la manifestación de sentidos que aparentemente no son transmitidos por los significantes. Sin embargo, los textos medievales reproducen y obligatoriamente requieren para su transmisión el uso de tales recursos, en ocasiones sutilmente utilizados como medio de subversión del orden ¿social, sexual y literario?

Los romans conforman dos redes semióticas paralelas: una interna combinando las posibilidades que los diferentes códigos, desde los formales a los pragmáticos, ofrecen a los autores, sin que podamos pasar por alto el hecho de que según los principios de la retórica y en el conjunto de la literatura medievales, el fondo y la forma constituían una sola unidad funcional que nosotros diseccionamos en nuestro análisis; ${ }^{173}$ y otra externa en la que dominan las relaciones de toda índole dentro del propio género o a través de los diferentes géneros — reelaboraciones, reutilización de temas, presentación de tesis contrarias a las de otros textos, recuperación del material retórico y formal, o simples alusiones_- fenómenos de intertextualidad que se entretejen en el conjunto de la producción oral y escrita de la época medieval como un eslabón más de la omnipresente tradición.

\footnotetext{
${ }^{170}$ Cf. D. Poirion, Résurgenœs..., op. ait., p. 16.

${ }^{171}$ Cf. B. Stock, Medieval Literacy, Linguistic Theory, and Social Organization, N.L.H ., XVI, 1, 1984, p. 23.

${ }^{172}$ Cf. Cheverny, op. at., p. 21 así como P. Zumthor, La poésie et la voix dans la ávilisation médievale. Paris: PUF, 1984, p. 60.

${ }^{173}$ Véase en cuanto al texto fundacional de la retórica medieval, N oces de Philologie et de Merare de Martianus Capella, R. Dragonetti, L e mirage des souros...., op. at, p. 49 - 50.
} 
La expresión de la sensualidad natural o codificada en un arte de amar, recurre durante la época medieval a estas dos estructuras en permanente mutación para manifestarse en el roman, que como conjunto de signos se asienta sobre el cambio, la ambigüedad y la contradicción. 


\subsection{ESTUDIO LÉXICO Y SINTÁCTICO DEL VOCABULARIO AMOROSO.}

\subsubsection{EL SUJETO ENAMORADO Y EL OBJETO DE DESEO. DENOMINACIONES.}

\subsubsection{LA MUJER.}

Entre los personajes femeninos que hemos seleccionado en nuestro corpus distinguiremos tres grandes tipos: aquéllos que son identificados gracias al nombre propio y a los que generalmente se hace referencia mediante otros apelativos, ya sean nombres comunes $\mathrm{u}$ otras clases gramaticales sustantivadas; aquéllos cuya identificación puede ser común a otros pero resultan caracterizados por atributos específicos que los diferencian en el contexto; y por fin los que son difícilmente identificables singularmente y que conforman una masa de personajes corales, cuyo valor erótico radica fundamentalmente en su abundancia.

\subsection{NOMBRE PROPIO.}

En nuestros textos encontramos pocas mujeres a las que se identifique por su nombre. ${ }^{174} \mathrm{El}$ sexo femenino, por un imperativo heredado de la poesía amorosa, es secreto y anónimo y se identifica sólo con sus cualidades sociales, estéticas y morales, de ahí que en Rose, cuya concepción

${ }^{174}$ Excluimos en este apartado los nombres de los personajes alegóricos de Rose, y los de los personajes literarios citados en E scoufle (Iseo, Brangien, Elena de Troya, Tisbe) y en el propio Rose (la ninfa Eco). 
está en muchos sentidos más cerca de las obras líricas corteses, se mantenga celosamente oculto el nombre de la amada, al que sólo el narrador alude metafóricamente en una de sus intervenciones en estilo directo: "el doit estre

Rose clamee" (Rose, 44).

El género novelesco, sin embargo, exigía una cierta individualización de los personajes, una ruptura con el trasfondo en este punto realista de la lírica que, quizá muy a pesar de sus creadores, defendía los intereses genealógicos velando la identidad de la adúltera. ${ }^{175}$

\subsection{Iseo.}

Tristán es el único amante que pronuncia el nombre de la amada sin recato ante terceros, sin anteponer el rango. Hay una única excepción: “... destruire veut et moi et la roïne Yseut." (Tristan, 2117 - 2118), una vez que el soberano en su visita al bosque de Morrois había recuperado simbólicamente a la esposa y a la reina.

El uso del simple nombre de la amada parece natural ante Governal y Brangien pues son las personas más allegadas a los amantes y les ayudan en su constante desafío al marido y a la corte. En estos casos se asocia el nombre de Iseo con reacciones espontáneas del amante, de dolor, rabia e impotencia ante la inminente muerte de la reina o de gozo por los placeres que le esperan de nuevo en la cámara que le había sido vedada:

qant n'ai Yseut, rien ne me vaut.

Dolent! le saut que orainz fis!

Que dut ice que ne m'ocis?

\footnotetext{
175 No creemos entrar en contradicción con H. Bloch cuando califica con razón el trobar dus como lírica nominalista construida mediante un encadenamiento de substituciones metafóricas con las que se hacía eco de los desarreglos sexuales, genealógicos y económicos de los grupos nobles. Cf. É tymologie et généalogie..., op. ait., p. 146 - 159.
} 
Ce me peüst estre mot tart.

Eschapé sui! Yseut, l'en t'art!

Tristan, 982 - 986

\author{
Brengain a par les braz saisie, \\ acole la, Deu en mercie: \\ [d'or en avant avra loisir] \\ d'estre o Yseut a son plaisir. \\ Tristan, $531-536$
}

Sin embargo se expresa con la misma familiaridad cuando el propio rey Marco está presente aunque sea como el convidado de piedra en un encuentro amañado, ante los barones de la corte o ante Ogrin el ermitaño:

ne vos en qier mentir deus moz.

Yseut, por Deu, de moi pensez

Tristan, $216-217$

- Sire , j'am Yseut a mervelle,
si que n'en dor ne ne somelle

Tristan, $1400-1401$

El nombre puede ir seguido, como en el ejemplo que proponemos, de uno o más epítetos —adjetivos o sintagmas calificativos, semejantes a las fórmulas épicas - Este caso de epitetismo nos muestra la habilidad con la que utiliza Béroul la retórica para conseguir los fines de la pasión. El objetivo de los epítetos, como el de Tristán en todo el pasaje y en realidad en toda la obra, es seguir engañando al marido y estar junto a la reina. Para conseguirlo esconde su amor tras la adoración infinita, aunque lejana, que los trovadores mostraban por sus damas, recuperando a la vez la expresión del rango, 
elemento característico de la calificación y de la denominación en los romans de esta época.

\author{
«Ahi! Yseut, fille de roi, \\ franche, cortoise, en bone foi \\ par plusors foiz vos ai mandee \\ Tristan, $101-103$
}

Podemos observar que en los textos, además de representarse una determinada organización social, se construyen dos planos simbólicos, el de los modelos o substancias —en este caso la Dama- y el del propio lenguaje, tomando este como un conjunto organizado de clases y categorías combinadas en sintagmas, cuyo valor representativo va más allá del valor sígnico.

Desde esta perspectiva la de Tristán no es la única ruptura del orden socio-simbólico asociada al nombre de la reina. Otros personajes también lo ponen en relación con el placer del sexo. Indirectamente, como Governal al precisar "Yseut ta drue" (Tristan, 1003), o como el ermitaño, quien inocentemente propone un hipotético regreso de Tristán tras el exilio voluntario no solamente junto al rey sino también junto a Iseo: "revien a lui et a Yseut" (Tristan, 2675).

Más explícitas y por eso mismo más transgresoras, aunque curiosamente pretendan restablecer el orden, son las acusaciones de los barones traidores:

Qar, en un gardin, soz une ente, virent l'autrier Yseut la gente ovoc Tristran en tel endroit que nus hon consentir ne doit

Tristan, $589-592$ 
Estas tienen como consecuencia no sólo el castigo de los amantes, sino algo más peligroso para el Texto, el público conocimiento de las relaciones adúlteras que debían permanecer secretas pero corren de boca en boca y con ellas el nombre de la reina:

$$
\begin{aligned}
& \text { Li criz live par la cité } \\
& \text { qu'endui sont ensenble trové } \\
& \text { Tristran et la roïne Iseut } \\
& \text { et que li rois destruire eus veut. }
\end{aligned}
$$

Tristan, $828-830$

La última consecuencia de la puesta en común de lo íntimo, de lo que atañía sólo a dos, a lo sumo a tres, es la propuesta orgiástico-macabra del leproso. Sus palabras resultan morbosas, francamente obscenas, menos por el sentido del adjetivo conmune que por la evocación del suplicio sexual, cuyos ecos resuenan en los miembros purulentos y monstruosos del sadismo:

Veez, j'ai ci conpaignons cent:

Yseut nos done, s'ert conmune.

Tristan, $1192-1193$

El nombre de Iseo resulta desestabilizador para el modelo erótico cortés en muchas de las ocurrencias relacionadas con el adulterio, y sigue siéndolo en el discurso del esposo al sugerir el amor y el deseo: "Hastez le brief: mot sui destroiz mot a ne vi Yseut la gente" (Tristan, 2642 - 2643).

El estudio de las rimas en las que aparece Iseo - recogidas a continuación, ${ }^{176}$ y sin tener en cuenta el par Yseut/ seut ya que una sola ocurrencia no nos parece representativa - nos aporta nuevos datos sobre el

\footnotetext{
176 Las claves que asignamos en las tablas y en la descripción morfosintáctica de los versos, las mismas que utilizamos en la elaboración de los diccionarios y en el análisis, se encuentran en la tabla 2.
} 
papel que desempeña la reina en la obra de Béroul así como sobre la distancia que la separa de la Dama cortés.

\begin{tabular}{llllllll}
\hline FORMA & CA & NV & RIMA & CA2 & NV2 & D & PERS \\
\hline Yseut & S & 3775 & Seut & V & 3776 & D & Tristan \\
Yseut & S & 607 & Veut & V & 608 & D & Félons \\
Yseut & S & 2118 & Veut & V & 2117 & D & Tristan \\
Yseut & S & 2659 & Veut & V & 2660 & N & Narrador \\
Yseut & S & 2674 & veut & V & 2673 & D & Ogrin l'ermite \\
Iseut & S & 829 & veut & V & 830 & I & Gens \\
\hline
\end{tabular}

Tabla 27. Rimas del nombre propio Iseo.

Por un lado se trata de una mujer tremendamente activa, de un actor fundamental en el desarrollo del entramado del relato. Por otra parte todo apunta a que su voluntad es soberana, y ello pese a que las formas del verbo voloir tienen como sujeto de la proposición a Marco, dato que interpretamos como una nueva ironía sobre las relaciones en el triángulo amoroso. Los trovadores también cantaban la voluntad soberana de la Dama pero en su caso solía tener tintes negativos, la mujer los rechazaba y no aceptaba su sometimiento como prueba de amor, o bien el querer de la dama, su entrega, era una hipótesis realizable en un futuro indeterminado.

Desde el punto de vista de la organización textual también cabe destacar el que el nombre propio de Iseo aparezca en numerosas ocasiones al comienzo del verso, posición que sin lugar a dudas contribuye a resaltar su papel, sobre todo en el discurso del narrador, donde funciona fundamentalmente como sujeto de proposiciones independientes; por el contrario, cuando el nombre aparece coordinado al de sus amantes, el rey o Tristán, aparece sistemáticamente en segundo lugar, algo que podemos interpretar como un signo de la posición social secundaria, de la dependencia femenina con respecto al elemento masculino: "ne jamais jor ne mescroira Tristran d'Iseut” (Tristan, 295 - 296); “du roi Marc et d'Iseut sa per referoit sordre mortel gerre" (Tristan, 4447 - 4448); "destruire veut et moi et la roïne Yseut" (Tristan, 2117 - 2118). Encontramos muy pocas excepciones y una de 
ellas $^{177}$ creemos viene dada por la rima enfanz / Tristranz, puesto que la fórmula que contiene enfanz suele siempre aparecer en el orden que nos encontramos aquí:

$$
\begin{aligned}
& \text { qu'omes que femes que enfanz; } \\
& \text { que por Yseut, que por Tristranz, } \\
& \text { mervellose joie menoient } \\
& \text { Tristan, } 2959 \text { - } 2961
\end{aligned}
$$

Por lo que concierne a las funciones gramaticales en las que se integra la denominación Iseo, ya hemos destacado su uso como sujeto en el discurso narrativo donde también actúa como complemento de objeto directo o aposición al sustantivo que funciona como tal: "Iseut apele bonement" (Tristan, 2777); “en ses deduiz Yseut en meine" (Tristan, 4269); “qant or verra passer s'amie, Yseut' (Tristan, 3694 - 3695). Lo encontramos así mismo en algunas ocurrencias que funcionan como complemento de objeto indirecto: "qui pardonne a Yseut son mautalent" (Tristan, 2659 - 2660), apareciendo en contadas ocasiones de igual modo que la de atributo que hallamos en el discurso de Tristán en su disfraz de leproso: “- Qui est ele? - La bele Yseut." (Tristan, 3775); también funciona como complemento circunstancial introducido por preposición: "le rai qui sor Yseut decent" (Tristan, 2041) o como complemento atributivo del nombre: "uns rais decent desor la face Yseut”' (Tristan, 1827 - 1828).

El complemento atributivo es, junto al uso vocativo del nombre propio, la función más abundante en el discurso de los personajes, y puede ir precedido por una preposición: “asez orras d'Iseut novele” (Tristan, 995), o bien construirse como un genitivo: "por l'amour Yseut m'amie" (Tristan, 3601); “du doi Yseut l'anel, le buen, en a porté” (Tristan, 2109 - 2110).

177 La otra es la que aparece en los versos ya citados 590 - 591. 
Los vocativos, como ya hemos visto en algunos ejemplos anteriormente, se encuentran sin excepción en el discurso directo de Tristan, acompañados a menudo por varios epítetos: "Yseut, franche, gente façon" (Tristan, 2261); o bien de expresiones exclamativas que suelen reforzar el tono suplicante o de queja del enamorado: "Yseut, por Deu, de moi pense" (Tristan, 217); "Yseut, par cest mien chief le bloi” (Tristan, 212).

Respecto a la sintaxis proposicional podemos decir que predomina la construcción activa, si bien encontramos ejemplos en los que Iseo se incluye en construcciones pasivas, siempre como sujeto pasivo; todas ellas están en el discurso de los personajes, ya sea en estilo indirecto: “qu'endui sont ensenble trové Tristran et la roïne Iseut” (Tristan, 828 - 829), ya en estilo directo: “par quoi'st destruite Yseut ta drue" (Tristan, 1003);

$$
\begin{aligned}
& \text { si que Yseut fust acordee } \\
& \text { o le roi Marc, qui'st esposee }
\end{aligned}
$$

Tristan, $2191-2192$

De los usos discursivos frente a los narrativos podemos concluir que, si exceptuamos algunos de los vocativos, en las intervenciones de los personajes, el nombre propio Iseo evoca una situación dependiente o secundaria en el relato y en la historia. Pero ya hemos visto que esta posición contrasta con la preponderancia que le otorgan tanto el discurso del narrador como los aspectos formales del texto.

En cuanto a las relaciones sintácticas que se establecen entre las frases en las que aparece la denominación Iseo y las oraciones contiguas señalaremos simplemente aquéllas que dependen de otras, es decir, sólo nos ocuparemos aquí de las proposiciones subordinadas. 
Las proposiciones subordinadas completivas son introducidas por la conjunción que: ${ }^{178}$

que tu seras aseürez

qu'Yseut te tienge loiautez

Tristan, 2903 - 2904

En este ejemplo el modo subjuntivo del verbo tenir no se debe a la cualidad virtualizante del verbo que rige la proposición, lo que es habitual en francés medieval, ${ }^{179}$ responde más bien al posicionamiento del emisor, en este caso los barones felones, con respecto a las actividades amorosas de Iseo, planteando la fidelidad como algo dudoso.

Entre las proposiciones relativas encontramos sólo proposiciones adjetivas; distinguimos las determinativas, de las que hay un ejemplo, ${ }^{180} \mathrm{y}$ las apositivas, más abundantes: ${ }^{181}$

en sa main tint un vert jarri
et fiert Yvain, qui Yseut tient.

Tristan, $1260-1261$

a la chanbre painte s'en vont,

la ou li rois et Yseut sont

Tristan, 549 - 550

tresque li troi felon larron

par quoi'st destruite Yseut ta drue

Tristan, $1002-1003$

\footnotetext{
178 Véase Tristan v. 828 - 829, 1653 - 1654.

179 Cf. Moignet, op. at., p. 213 - 8.

$180 \quad$ le rai qui sor Yseut decent

covre des ganz mot bonement

Tristan, 2041 - 2042

181 Véase también Tristan v. 2659 - 2661.
} 
Por lo que se refiere a este ejemplo queremos señalar que el pronombre relativo sólo se utiliza excepcionalmente con un antecedente que designa a personas, y ello casi siempre en el caso en el que el verbo de la proposición relativa implique el uso de la palabra. ${ }^{182}$ Nos encontramos pues con un uso excepcional del pronombre relativo, a no ser que considerásemos que en este contexto el verbo destruire no sólo alude a la muerte en la hoguera, sino al origen de la destrucción de Iseo, a la maledicencia de los nobles.

Por lo que hace a las proposiciones subordinadas circunstanciales el texto nos ofrece dos tipos:

- De causa:

qar, en un gardin, soz une ente, virent l'autrier Yseut la gente

Tristan, $589-590$

En el siguiente ejemplo la conjunción puede expresar tanto el tiempo como la causa, inclinándonos más bien por este segundo valor semántico:

Ha! Las, dolent, et moi que chaut?

Qant n'ai Yseut, rien ne me vaut.

Tristan, $981-982$

- De tiempo:

qant or verra passer s'amie,

Yseut, qui a la crine bloie, que ele an ait en son cuer joie

Tristan, 3694 - 3696

${ }^{182}$ Cf. Moignet, op. at., p. 161. 


\author{
a Deu vo je que jel feroie \\ mot volentiers, se je pooie, \\ si que Yseut fust acordee \\ o le roi Marc (...)
}

Tristan, 2189 - 2192

a lui tot sol la cuvertise

que Tristran fist, quant il l'ot prisse

Yseult la bele o le cler vis

Tristan, 1945 - 1947

En este último ejemplo podríamos leer dos versiones de los planes de Tristán para reconciliar a Iseo con el rey, pudiendo ambas coexistir como un doble sentido. La locución conjuntiva si que [Adv. + C onj.] puede tener un sentido temporal, evocando un proceso ulterior y también un valor consecutivo: la consecuencia esperada de mantenerse alejado de Iseo sería la reconciliación de ésta. Ambos valores se construyen con subjuntivo por lo que el criterio formal no nos ayuda a distinguirlos; sin embargo el sentido que otorga la temporal creemos que se ajusta más, no sólo a la tónica general del discurso de Tristán referido a Iseo caracterizado por la transgresión del orden social, sino también a los acontecimientos posteriores; es decir, Tristán, arrepentido de haber sacado a Iseo de la corte del rey, se propone intentar su restitución y para ello desearía dejarla en paz, leemos, desearía no mantener relaciones carnales, hasta que el rey Marco la aceptase de nuevo. 


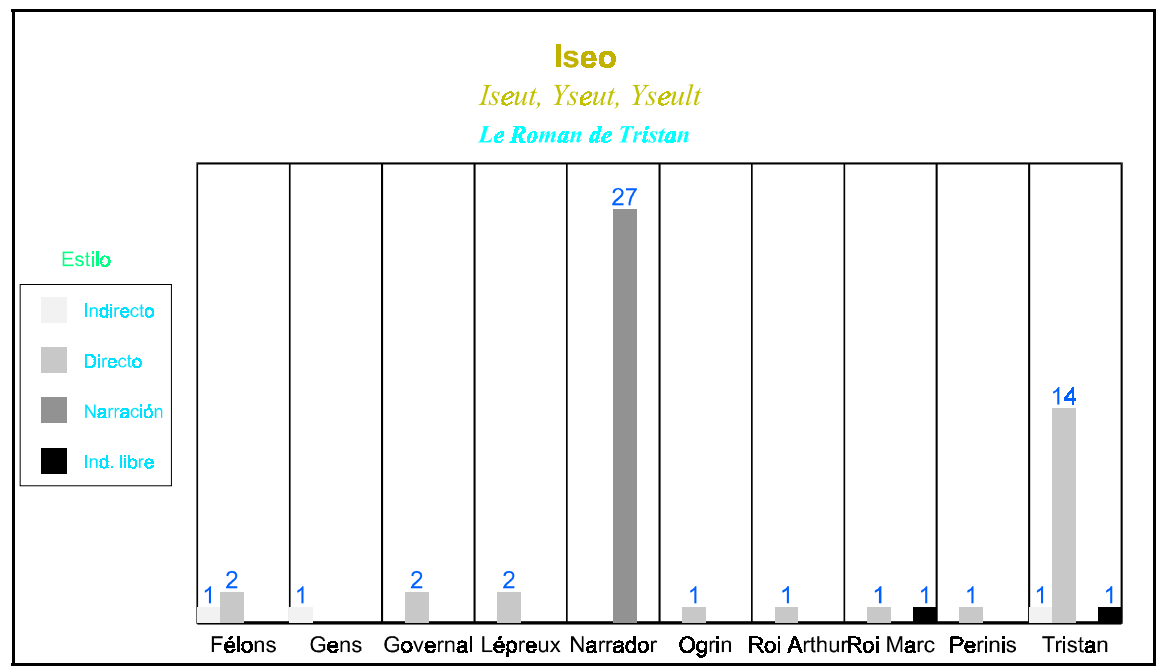

Fig. 1. Comportamiento estilístico del nombre propio Iseo.

En este gráfico se recogen las ocurrencias del nombre propio que acabamos de estudiar en función de los entes narrativos en cuyo discurso aparece y del estilo utilizado. No lo hemos elaborado con la intención de realizar un estudio estadístico, pretendemos simplemente mostrar visualmente las diferencias o similitudes que se dan en el uso de los nombres propios en este caso y de otros elementos léxicos más adelante.

Podemos observar dos fenómenos sumamente interesantes para la comprensión del manejo de la leyenda hecho por Béroul. Por un lado el discurso narrativo relacionado con el erotismo utiliza en gran medida el nombre propio de la reina como pivote donde se insertan los diferentes puntos de vista sobre la sexualidad, por otro la práctica totalidad de los personajes masculinos del fragmento se refieren a ella desterrando el tabú que debería proteger la identidad de la adúltera. Con ello se recrea el mito de la amante no sobre las premisas del discurso cortés generalizador y secretista sino sobre el individuo, la gran fuerza destructora del orden medieval, máxime cuando se trata de una mujer poderosa que puede tomarse como ejemplo. 


\subsection{Ginebra.}

El tratamiento que se da al nombre propio de la amada de Lanzarote en Charrete es completamente diferente al de Tristan y creemos que sigue la doctrina cortés. Lo encontramos únicamente en dos ocasiones, en ambas precedido del sustantivo reïne y en ninguno de los dos casos se liga a la reina directamente con el sexo, pues aunque la reflexión de Lanzarote surge ante la visión de una violación, el recuerdo de Ginebra lo lleva a desbaratar la acción de los violadores. Sí está relacionado sin embargo con la búsqueda y la liberación emprendidas por Lanzarote al que ya hemos identificado como su enamorado aunque desconozcamos aún si el amor del pretendiente es correspondido.

Meüz sui por si grant afeire
con por la reïne Guenievre.

Charrete, 1098 - 1099

Car tu sez bien certainnemant

qu'il quiert la reïne Ganievre

Charrete, $3206-3207$

Pese a la aparición del nombre de pila, la distancia física y sentimental entre amador y amada se nos antoja enorme; nos hallamos ante la situación tópica presentada por los cánones caballerescos que han cambiado las formas del antiguo proceso de conquista amorosa, en el que entre el tormento y la dicha tan sólo podían mediar la palabra y la Retórica. La caballería en cambio va a utilizar la fuerza, el valor guerreros y la defensa de la paz, ${ }^{183}$ como armas para atraer a la amada y conseguir su estima.

${ }^{183}$ La ideología caballeresca asimila la primitiva paix de D ieu al transformar la función puramente guerrera en una profesión cargada de rigor moral en el último cuarto del siglo XII, cf. G. Duby, L es trois ordres ou l'imaginaire du féodalisme. París: Gallimard, 1978, p. 352- 60. 
Poco podemos decir desde el punto de vista sintáctico. Solamente señalar la aparición de una proposición completiva en la que el nombre propio tiene la función de complemento de objeto directo; en el discurso de Lanzarote se trata de una proposición independiente construida en forma pasiva y con un complemento agente doble, aunque sólo formalmente ya que creemos que se trata de una falsa comparación, y en realidad el sintagma que contiene el nombre propio funciona como una aclaración que persigue probablemente mantener la distancia entre Lanzarote y Ginebra, entre la actividad heroica del enamorado y su verdadera causa.

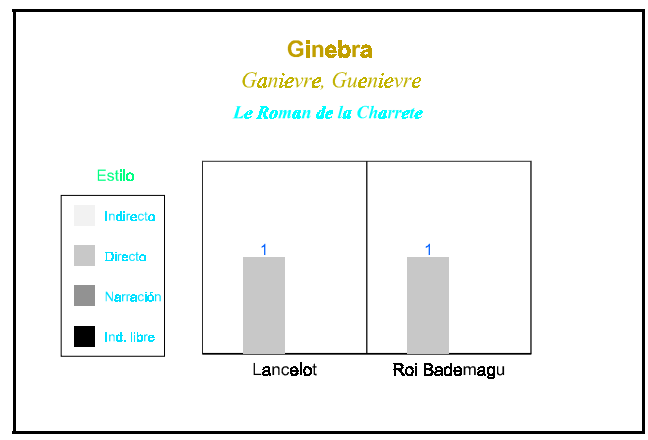

Fig. 2. Comportamiento estilístico del nombre propio Ginebra.

\subsection{Aelis.}

Algo muy similar ocurre con Aelis en E scoufle aunque su nombre aparece en varios contextos puesto en relación directa o indirecta con su belleza, la atracción que ejerce sobre los hombres, así como con sus cualidades morales:

Cuidiés vous c'aucuns ne s'abuist

en esgardant bele Aelis?

Escoufle, 8212 - 8213

cel jor fu la bele Aelis

ml't esgardee de maint home.

Escoufle, 8814 - 8815 
ke il n'a si preu ne si biele,

(... ) s'a non biele Aelis de Toul.

Escoufle, 5952 - 5955

También se relaciona con el amor, y especialmente en el discurso del narrador con su pareja:184 " $k$ 'encore fust bele Aelis çaiens, se Guilliaumes i fust" (Escoufle, 4112 - 4113) o bien con la promesa del matrimonio hipergámico:

et si voel qu'il ait a oisor
ma fille Aelis que voi la.

Escoufle, 2152 - 2153

quant a tele honor est eslis

vos fix qu'il avra Aelis.

Escoufle, 2195 - 2196

Mas por lo que se refiere a su enamorado el nombre de la amada es un tabú que sólo puede ser roto con un grito desesperado cuando está en completa soledad:

Il brait et crie comme uns ors se se fiert del poing sor le pis

et huce en haut: «Hé! Aelis,

ma douce, ou estes vos alee?

Escoufle, 5122 - 5125

O cuando, tras siete largos años de búsqueda infructuosa, deseoso de obtener fondos para continuarla, cuenta sus peripecias en el castillo de Saint Gilles, rindiendo homenaje a la amada con el largo silencio que precede la emisión de tan dulce nombre. 
«Comment ot vostre amie a non,

fait la contesse, biaus amis?»

Ml't a le non a nommer mis

ki ml't estoit biaus et eslis.

Fait il: «Ele ot non Aelis

la pucele qui tant m'ama.»

Escoufle, 7680 - 7685

La causa de ese silencio está en la identificación del nombre y del ser — ambos perfectos en su belleza, deseados y venerados—; relación entre belleza física y belleza del nombre que Aelis establece explícitamente refiriéndose a Isabel. ${ }^{185}$ Creemos que esta identificación está muy cerca del concepto de suposición propuesto por Ockham, es decir, de la capacidad de los signos lingüísticos para ocupar el lugar de las cosas en el discurso. Éste es un cambio sustancial con respecto al realismo cortés primitivo, a ese realismo moderado como lo será el tomista por el que un concepto, una idea de perfección surgía teniendo como origen una realidad múltiple o vaga, muchas veces deseada, soñada, de la que creían sentirse enamorados sus cantores. Incluso si pensamos que la lírica trovadoresca era una mística del Texto y la dama imagen de la perfección artística.

Esta modificación se ve corroborada por la insistencia con la que un joven admirado ante la belleza de Aelis y atraído por ella, le pregunta por su origen y sobre todo por su nombre, el mejor pago, dice, para los servicios que le ha prestado: "de vostre non avroie je ml't grignor joie que des besans" (Escoufle, 4856 - 4858); curiosa recompensa, por otra parte, en un relato en el que el dinero y los bienes materiales cobran una singular y creciente importancia. Con él el deseo se sublima en la voluptuosidad del signo

184 También v. 1763 - 66; 1933; 1943; 8491 - 8495; 8528 - 8533; 8911 - 8913.

185 «Si m'ait Diex, cis nons est biax. S’en devés Dieu grant guerredon quant il et de vis et de non vos a soufert a estre bele.» (Escoufle, 5298 - 5301). 
lingüístico que es un trasunto del ser de carne y hueso; pero el placer será menor del esperado, pues Aelis, como Lanzarote, sólo consiente en entregarle una verdad a medias sobre su identidad y sobre su historia.

Las rimas nos aportan otras informaciones sobre la carga expresiva del nombre propio de Aelis, concordando con las grandes unidades temáticas de la historia. La más abundante es lis (lecho), el centro de los espacios interiores dominados por la heroína, lugar de encuentro y agasajo, de descanso y caricias y del juego amoroso o delis; también promesa de ascenso social para Guillaume que parece confirmarse con la rima eslis (elegido, perfecto), vocablo que en los contextos en los que aparece se refiere a los amantes, a Guillaume y al nombre de Aelis, o lo que es lo mismo, a la amada. Las rimas con la forma empereïs / emperenis nos recuerdan que por su nacimiento Aelis está destinada a la soberanía sobre el imperio, y que ni el amor ni la aventura podrían doblegar las firmes estructuras de la sociedad feudal.

\begin{tabular}{llllllll}
\hline FORMA & CA & NV & RIMA & CA2 & NV2 & D & PERS \\
\hline Aelis & S & 4112 & banis & O & 4111 & D & Pucelles \\
Aelis & S & 2510 & cris & S & 2509 & N & Narrador \\
Aelis & S & 4098 & cris & S & 4097 & D & Pucelles \\
Aelis & S & 3614 & defuïs & O & 3613 & N & Narrador \\
Aelis & S & 2374 & delis & S & 2373 & N & Narrador \\
Aelis & S & 7405 & delis & S & 7406 & N & Narrador \\
Aelis & S & 8814 & dis & S & 8813 & N & Narrador \\
Aelis & S & 7740 & empereïs & S & 7739 & D & Comte de St. Gilles \\
Aelis & S & 7957 & empereïs & S & 7958 & N & Narrador \\
Aelis & S & 8521 & empereïs & S & 8522 & N & Narrador \\
Aelis & S & 1766 & empereris & S & 1765 & N & Narrador \\
Aelis & S & 4030 & empereris & S & 4029 & N & Narrador \\
Aelis & S & 4151 & empereris & S & 4152 & N & Narrador \\
Aelis & S & 1943 & eslis & O & 1944 & N & Narrador \\
Aelis & S & 2196 & eslis & O & 2195 & D & Empereur \\
Aelis & S & 7684 & eslis & O & 7683 & D & Guillaume \\
Aelis & S & 8576 & eslis & O & 8575 & N & Narrador \\
Aelis & S & 3276 & lis & S & 3275 & N & Narrador \\
Aelis & S & 4309 & lis & S & 4310 & N & Narrador \\
Aelis & S & 4885 & lis & S & 4886 & N & Narrador \\
Aelis & S & 5647 & lis & S & 5648 & N & Narrador \\
Aelis & S & 5751 & lis & S & 5752 & N & Narrador \\
Aelis & S & 7025 & lis & S & 7026 & N & Narrador \\
Aelis & S & 8219 & lis & S & 8220 & N & Narrador \\
Aelis & S & 8533 & lis & S & 8534 & N & Narrador \\
Aelis & S & 1933 & partis & O & 1934 & N & Narrador
\end{tabular}




\begin{tabular}{llllllll} 
Aelis & S & 5124 & pis & S & 5123 & D & Guillaume \\
Aelis & S & 8064 & ploureïs & S & 8063 & D & Dame de St. Gilles \\
Aelis & S & 4174 & salis & O & 4173 & D & Empereur \\
Aelis & S & 2008 & samis & S & 2007 & N & Narrador \\
Aelis & S & 8345 & samis & S & 8346 & N & Narrador \\
Aelis & S & 9089 & samis & S & 9090 & D & Narrador \\
Aelis & S & 8213 & soneïs & S & 8214 & N & Narrador \\
Aelis & S & 8913 & treslis & A & 8914 & N & Narrador \\
\hline
\end{tabular}

Tabla 28. Rimas del nombre propio Aelis.

Las rimas con el nombre Aelis parecen confirmar el papel secundario que la ideología caballeresca de comienzos de siglo pretendía para la mujer. Antes del matrimonio ella también puede gozar de los placeres carnales siempre que permanezca virgen y podríamos añadir bella, pero a la postre se ha convertido en un mero instrumento para llegar hasta el placer y el poder.

Ya hemos apuntado la relación que se establece entre Aelis y la belleza, un vínculo que se muestra obsesivo en el análisis de los patrones sintácticos de la narración. Dos de ellos "bele Aelis" [A dj. + Sust.] y "la bele Aelis" [A rt. + A dj. + Sust.] se repiten en todas las posiciones del verso, reproduciendo los esquemas de muchas composiciones líricas que ya habían lexicalizado estas fórmulas y quizá contribuido en gran medida a vaciarlas de contenido semántico convirtiéndolas en un mero adorno. $\mathrm{Al}$ comienzo del verso, situación en la que los encontramos muy a menudo, estos sintagmas relegan el nombre propio a una posición secundaria. ¿Qué efecto querría conseguir Renart sobre su audiencia? Se trata simplemente de un mero adorno, o tal vez se hacía eco de la larga tradición platónica, aunque el conjunto del texto sea heterodoxo, o más bien alinearlo con la nueva imagen del cuerpo y especialmente del cuerpo femenino. Esta interpretación podría satisfacernos pero creemos que, además, persigue reincidir en la idea que nos apuntaban las rimas. Frente a Iseo, que a menudo aparecía al comienzo del verso, es raro encontrar el nombre de Aelis en esa posición, sólo cuatro apariciones en los discursos en estilo directo de Amor y Razón, es decir Aelis, 
la emperatriz o el burgués, cuyos contextos están relacionados con la fuga y la búsqueda, ${ }^{186}$ subconjuntos temáticos en los que la actividad de la heroína pasa a un primer plano, ocupando el espacio indefinido, exterior, en el que todo es posible, fuera del control de la corte imperial, de los lazos matrimoniales y del condado de Normandía.

Otros grupos sintagmáticos consolidan la tendencia a relegar el nombre propio a una posición secundaria incluso en los usos como vocativo: [Verbo + Sust.]: "fait Aelis" (Escoufle, 5456, 5673, 7217); "velt Aelis" (Escoufle, 5295); [C onj. + Sust.]: “et Aelis” (Escoufle, 2015, 2093); [Art. + Sust. + Sust.]: "ma fille Aelis" (Escoufle, 2153). Estas dos últimas estructuras aparecen en mayor medida en el centro o al final de verso: “la contesse Aelis" (Escoufle, 8345), “me dame Aelis” (Escoufle, 8521, 8532, 8913). Los grupos [Conj. + Sust.], [Conj. + Adj. / Art. + Sust.] y [Prep. + Sust.] colocan sistemáticamente a Aelis formando pareja con su enamorado declarado, con Isabel y el conde de Saint Gilles, con los que tiene una amable y sensual relación, o con otras mujeres.

$\begin{array}{cc}\text { del } \underline{\text { damoisel et d'Aelis }} & \text { R S C R S } \\ \text { Escoufle, } 2008 & \\ \text { de } \underline{\text { Guilliaume }} \text { ne d'Aelis } & \text { R S C R S } \\ \text { Escoufle, 1943 } & \\ \text { entre Guilliaume et Aelis } & \text { R S C S } \\ \text { Escoufle, } 2374187 & \\ \text { entre Aelis et } \underline{\text { Ysabel }} & \text { R S C S } \\ \text { Escoufle, 6032 } & \\ \text { et le } \underline{\text { conte }} \text { et bel Aelis } & \text { C J S C A S } \\ \text { Escoufle, } 8219 & \end{array}$

186 De hecho otro de los grandes temas de la obra como nos han mostrado algunas de las formas aparecidas en las rimas que hemos comentado antes.

187 También Escoufle 2510 y 3614. 


\section{bele Aelis et ses puceles $\quad$ A S C J S}

Escoufle, 1928

Como podemos observar Aelis queda en la rima en todas las ocurrencias en las que la pareja es un varón, ocupando la segunda posición del sintagma o el segundo sintagma del verso, por el contrario pasa al comienzo del verso cuando son mujeres. La construcción social de los géneros deja a Aelis, hija de emperador, por debajo de cualquier hombre y mantiene la jerarquía entre las mujeres.

Por otra parte nos llama poderosamente la atención que un texto en gran medida caracterizado por la complejidad sintáctica y por dibujar una imagen renovada de la mujer y de sus relaciones amorosas, en ruptura con las ataduras económicas y sociales, codifique de forma tan sistemática los contextos léxicos y sintácticos en los que aparece el nombre propio de la heroína.

El análisis sintáctico nos presenta el nombre propio mayoritariamente en la función de sujeto - compartida en ocasiones- de verbos declarativos y de otros cuyas acciones sirven para expresar las cualidades sociales y en menor grado la sensualidad de Aelis:

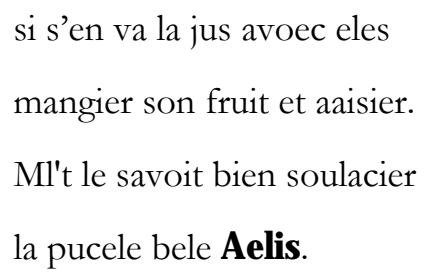

Escoufle, 7022 - 7025

toute l'assamblee ki fu

i fist Aelis la cortoise

Escoufle, 7042 - 7043 
de robes, de joiaus d'argent

dona tant la bele Aelis

Escoufle, 7056 - 7957

En las construcciones pasivas es sujeto y de nuevo observamos a Aelis a la sombra del que ya es su marido y reinará sobre el imperio por ella o como un objeto de deseo colectivo:

ne cuic c'onques nasqui de mere

.i. rois qui plus fust honerés.

Quant il fu au mostier menés, ausi fu me dame Aelis.

Escoufle, 8910 - 8913

Ml't est esgardee et prisie

de ciaus de la cort Aelis.

Escoufle, 5646 - 5647

cel jor fu la bele Aelis

ml't esgardee de maint home

Escoufle, 8813 - 8814

En la función de complemento de objeto directo cabe destacar su uso con el verbo avoir en las construcciones avoir [a oisor] ${ }^{188}$ y avoir [a non]: "s'a non biele Aelis de Toul" (Escoufle, 5955), 189 así como con el verbo esgarder que acabamos de ver en su formulación pasiva: "en esgardant bele Aelis” (Escoufle, 8213).

\footnotetext{
${ }^{188}$ Escoufle 2152 - 2153, 2196.
}

189 También Escoufle 7684. 
Como complemento atributivo del nombre, con o sin preposición y como complemento preposicional con función circunstancial sobresalen en primer lugar los usos en los que el nombre propio aparece coordinado al de su amante: “del damoisel et d'Aelis estoit ml't bele l'assamblee” (Escoufle, 2007 2008),

$$
\begin{aligned}
& \text { ainc puis ne furent a celee } \\
& \text { lor parlemens ne lor delis } \\
& \text { entre Guilliaume et Aelis }
\end{aligned}
$$

Escoufle, 2372 - 2374

y en segundo lugar la insistencia en una de las virtudes corteses más apreciadas y loadas en E scoufle, la largueza: "ne vous aroie hui conté preu des dons la contesse Aelis” (Escoufle, 8344 - 8345).

Desde el punto de vista de la sintaxis proposicional la coordinación reproduce los mismos esquemas que hemos encontrado en o entre los sintagmas, se menciona a Aelis siempre en la segunda proposición mientras que en la primera se halla Guillermo, su enamorado: "voel je de Guilliaume faire (...) et si voel qu'il ait a oisor ma fille Aelis” (Escoufle, 2150 - 2153). La utilización de las subordinadas nos muestra el nombre propio fundamentalmente en proposiciones circunstanciales, consecutivas, ${ }^{190}$ condicionales, ${ }^{191}$ y comparativas, cuya finalidad es intensificar las virtudes de Aelis: "et u siecle n'avoit tel feme com estoit me dame Aelis" (Escoufle, 8520 - 8521), "n’il n'ert si vaillant dame nee comme estoit me dame Aelis" (Escoufle, 8532 - 8533).

Las relativas y las completivas ${ }^{192}$ son menos abundantes. Entre las primeras destacamos la que encontramos en el discurso directo del narrador

\footnotetext{
${ }^{190}$ Escoufle, 2195 - 2196, 5796 - 5797.

191 Escoufle, 4150 - 4151.

192 Escoufle, 2152 - 2153, 4308 - 4309, 5750 - 5751.
} 
quien al final de la obra, y a pesar de la constante supeditación de Aelis a los varones que aparecen en el texto y más concretamente al que sería su esposo, sitúa las andanzas de la joven heredera, una vez separada de su amante, como centro argumental:

$$
\begin{aligned}
& \text { mais cil qui ont le livre lit } \\
& \text { i ont mainte bele aventure } \\
& \text { trovee et la mesaventure } \\
& \text { qui avint la bele Aelis } \\
& \text { par l'aumosniere de samis } \\
& \text { ke li escoufles emporta }
\end{aligned}
$$

Escoufle, 9086 - 9091

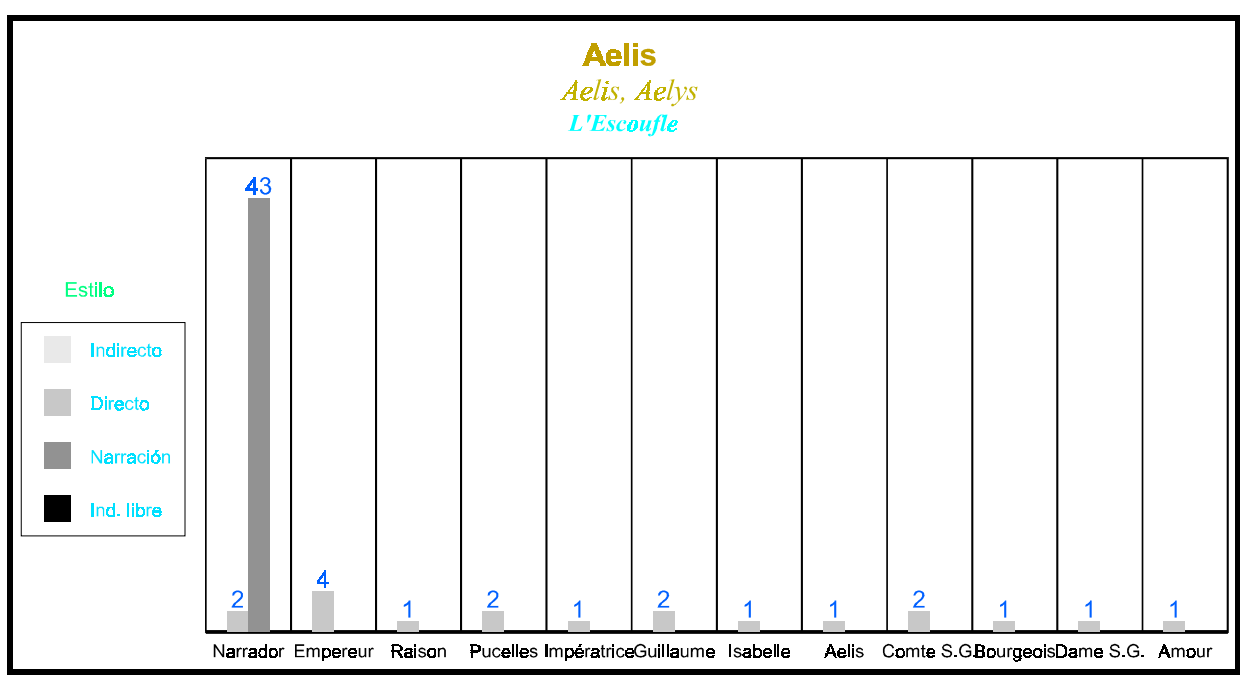

Fig. 3. Comportamiento estilístico del nombre propio Aelis en Escoufle.

Jean Renart plantea en principio un tratamiento estilístico del nombre propio de su heroína muy similar al realizado por Béroul, al tiempo que el discurso del enamorado Guillermo entronca en parte la concepción de la amada con la elaborada por la lírica cortés de la que se hacía eco Chrétien de Troyes. El uso narrativo y discursivo, a excepción de la filiación que acabamos de apuntar, refuerza la idea de independencia que nos ofrece el 
relato de las aventuras de Aelis, especialmente al observar que el resto de los personajes femeninos y ella misma o las abstracciones que representan su vida mental, también pronuncian su nombre. Una notable diferencia con respecto al uso que en Tristan se hace del nombre propio de la amada es su aparición en el discurso directo del narrador, con lo que el acercamiento a los receptores de la vida de Aelis en tanto que individuo puede ser considerado mayor. Todo ello, sin embargo, queda coartado por la enorme formalización sintácticoformularia del nombre propio, apenas existente para la denominación Iseo.

\subsubsection{REFLEJO DE LA ESTRUCTURACIÓN SOCIAL.}

\subsection{Dame.}

El apelativo dame, que no fue muy utilizado por los trovadores, ${ }^{193}$ conserva en principio en la novela caballeresca los dos significados básicos que aquéllos habían mezclado:

a. el de hallarse en una posición social privilegiada que le permitía ejercer el poder o una parte del poder, y que encontramos en la utilización metafórica que del sustantivo hace el narrador en Rose. "Chasteez, qui dame doit estre et des roses et des boutons" (Rose, 2830 - 2831).

b. el de poseer el corazón del enamorado y dominar sus sentidos y emociones.

Encontramos, sin embargo, en nuestros textos algunas modificaciones substanciales que son consecuencia del cambio de género con la consiguiente aparición de un narrador, generalmente en tercera persona, que utiliza el apelativo con su carga social y le da un valor general, por lo demás

${ }^{193}$ Cf. G. M. Cropp, L e vocabulaire courtois des troubadours de l'époque dassique. Ginebra: Droz, 1975, p. 37. 
bastante común y que se extiende paulatinamente: la dama es la mujer casada y mientras en Charrete se trata de una mujer perteneciente a la nobleza o esposa de un caballero, en Escoufle la generalización es ya completa y el narrador se refiere a la mujer de un burgués, es decir, la dama es ya aquella mujer que ejerce la administración de una casa. ${ }^{194} \mathrm{El}$ mismo uso puramente social se ve reflejado en los discursos de los hombres y mujeres de la corte e incluso en el discurso directo de la condesa de Saint Gilles para referirse a su rival, la amante de su esposo:

$$
\begin{aligned}
& \text { «Cil ne me menti mie } \\
& \text { ki me conta que vos amés } \\
& \text { la dame por cui vos portés } \\
& \text { l'aumosniere et le tissu tel.» } \\
& \text { Escoufle, } 5912 \text { - } 5915
\end{aligned}
$$

La novela entraña generalmente la diversificación y amplificación de los personajes y entre ellos la figura del marido, que quedaba oculto o era simplemente un obstáculo en la poesía. Y tanto en Tristan como en Charrete el marido está por añadidura enamorado de su esposa aunque este sentimiento se ponga de manifiesto pocas veces y nunca en su propio discurso. ${ }^{195}$ Esto lleva consigo el que los reyes se dirijan a Iseo o a Ginebra ${ }^{196}$ mediante este apelativo, de igual forma que lo harán sus amantes, aunque en el caso del esposo en Tristan existe una gran diferencia entre ambos, ya que mientras el amante también utiliza el nombre propio para dirigirse a la reina, tal como hemos visto más arriba, el rey sólo usa el título dame, que parece marcar cierta distancia entre los esposos, incluso en la intimidad de la alcoba. ${ }^{197}$

\footnotetext{
194 También Escoufle, 6336 y 6338. Este uso no aparece recogido por A. Grisay, quien presenta la oposición mujer noble casada o soltera / burguesa, cf. op. at., p. 123 - 4.

195 Del amor de los reyes sólo nos dan fe el narrador o un rival celoso como Meleagant; cf. Charrete, 4857 y 5357; Tristan, 2520 .

196 Charrete, 116, 122, 6182.

197 Tristan, 399, 476, 3217.
} 
El conde de Saint Gilles es el único personaje de nuestro corpus al que observamos junto a la amante y junto a la esposa y sus palabras confirman la coexistencia de dos usos del vocablo dame en los discursos directos de las novelas: se utiliza como vocativo tanto para dirigirse a la esposa ${ }^{198}$ —uso social atenuado, pues ésta se encuentra legalmente supeditada al marido, al que puede asociarse el contenido puramente sentimenta—, como en el cortejo de la partenaire adúltera —el uso amoroso es predominante y sólo en ocasiones la superioridad social se mantiene, lo que no ocurre en este caso concreto-:

$$
\begin{aligned}
& \text { Dame, vos chevaliers, vostre hom, } \\
& \text { fait li quens, s'en devroit raler }
\end{aligned}
$$$$
\text { Escoufle, } 5886 \text { - } 5887
$$

Por lo que concierne a los héroes de nuestras novelas, el uso del vocablo dame, mayoritariamente en función de vocativo, responde al patrón definido por la tradición cortés si bien en Escoufle es donde se aprecia claramente la extensión en el sentido amoroso a la mujer que no está casada y se toma en ocasiones como sinónimo de amada, reforzado por la rima con ame $^{199}$ — espacio de los sentimientos más sublimes— sin que subsista en absoluto la distancia social:

Lasse! Il disoit qu'il m'amoit tant; lasse! Il disoit j'ere sa dame

Escoufle, 5361 - 5362

\footnotetext{
198 Escoufle, 5914, 6337.

199 Uno de los motivos que nos han hecho pensar en una relación lésbica entre Aelis e Isabel: fu puis en cambrë o sa dame: toutes sont.j., et cors et ame. Ne lor membre mais de Guilliaume Escoufle, 6167 - 6169
} 
Una distancia que se restablecía en el discurso de Lanzarote al integrar la forma reïne:

$$
\begin{aligned}
& \text { que je me deüsse estre ocis } \\
& \text { des que ma dame la reïne } \\
& \text { me mostra sanblant de haïne } \\
& \text { Charrete, } 4336 \text { - } 4338
\end{aligned}
$$

El término dame posee en Rose un valor erótico que no se encontraba tan claramente en los otros textos y que se manifiesta tanto en el discurso del narrador — en estilo directo o en la narración- como en el de Venus. ${ }^{200}$ Viene dado no sólo por el sentido denotado del contexto: se habla de las mujeres adúlteras o potencialmente adúlteras que hacen sufrir a sus amantes: "dames (...), qui vers vos amis mesprenez; car se vos les lessiez morir" (Rose, 1505 - 1506); que son engañadas por los falsos enamorados: "qui vont les dames traïssant" (Rose, 2538) o que se han abandonado a la lujuria empujadas por la diosa Venus: "ele tint un brandon flanbant en sa main destre, dont la flame a eschaufee mainte dame.” (Rose, 3406 - 3408); sino, y principalmente, por la disolución de lo particular en lo general haciendo emerger un continuo de placeres posibles que corresponden al orden simbólico cortés. El Tristan participa excepcionalmente en esta operación que pretende universalizar la sensualidad y lo hace a través de los caballeros de la Mesa Redonda, garantes de la justicia divina y real en materia de sexo, y espejo de las cualidades caballerescas, guerreras y corteses. Por lo que deducimos del texto prefieren las relaciones sexuales con mujeres casadas, contactos furtivos y secretos y quizá por ello con mayor carga erótica, a los que otorgan un gran valor pues son el precio - recompensa o castigo- de los enfrentamientos armados, un tema que se hará obsesivo en la obra de Chrétien:

200 Rose, 3437. 


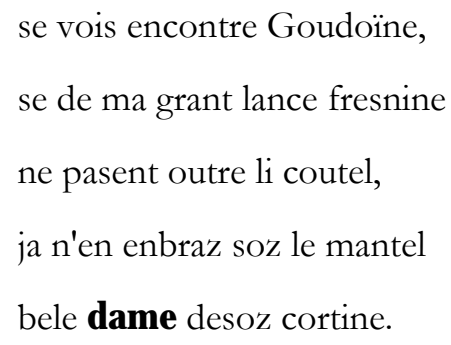

Del estudio de las rimas destacamos el valor político y genealógico en su asociación con roialme retomando el principal obstáculo para los amores de Aelis y Guillermo.

\begin{tabular}{lllllllll}
\hline FORMA & CA & BD & NV & RIMA & CA2 & NV2 & DISC & PERS \\
\hline dame & S & Charrete & 4862 & ame & S & 4861 & $\mathrm{D}$ & Keu \\
dame & S & Escoufle & 4027 & ame & S & 4028 & D & Ális \\
dame & S & Escoufle & 5117 & ame & S & 5118 & D & Guillaume \\
dame & S & Escoufle & 5363 & ame & S & 5364 & I & Guillaume \\
dame & S & Escoufle & 6169 & ame & S & 6170 & N & Narrador \\
dame & S & Escoufle & 8669 & ame & S & 8670 & N & Narrador \\
dame & S & Rose & 1442 & ame & S & 1441 & N & Narrador \\
dame & S & Escoufle & 3495 & feme & S & 3496 & I & Chevalier \\
dame & S & Charrete & 3749 & flame & S & 3750 & N & Narrador \\
dame & S & Rose & 3408 & flame & S & 3407 & N & Narrador \\
deme & S & Escoufle & 8924 & geme & S & 8923 & N & Narrador \\
dame & S & Escoufle & 8608 & roialme & S & 8607 & I & Barons \\
dame & S & Escoufle & 1681 & roiame & S & 1682 & I & Empereur \\
dame & $\mathrm{S}$ & Escoufle & 8868 & roiame & S & 8867 & N & Narrador \\
\hline
\end{tabular}

Tabla 29. Rimas del sustantivo dame.

Ya hemos señalado que la función preferente de este sustantivo es la de vocativo, siendo así incluso en una intervención del narrador en Rose. En su mayoría se trata de un uso descarnado al comienzo del verso, aunque encontramos ocurrencias en las que el tono patético del discurso directo, ya sea del rey Arturo o de Guillermo, introduce modificaciones en el sintagma agregándose un posesivo y/o un adjetivo calificativo: "alez a lui, ma dame chiere" (Charrete, 122); “douce dame” (Escoufle, 3432). Sin embargo también aparece realizando otras funciones, fundamentalmente la de sujeto, con la excepción de Tristan donde esta denominación no la cumple nunca. 
En Charrete el sustantivo en singular, precedido de un posesivo en primera o en tercera persona hace referencia a la reina Ginebra; 201 pero no es esto lo que más nos llama la atención sino la repartición de estos sujetos en función del tipo de proposición, así en la primera parte de la novela en la que la reina se encuentra en poder de Meleagant, lo encontramos sistemáticamente en proposiciones subordinadas, completivas: "ne sai ou ma dame est anclose" (Charrete, 2138); "a Lancelot vient la novele que morte est sa dame et s'amie" (Charrete, 4250 - 4251); o circunstanciales: "des que ma dame la reïne me mostra sanblant de haïne" (Charrete, 4337 - 4338). Por el contrario en la segunda parte del relato, una vez que la reina se encuentra de nuevo en la corte, las proposiciones en las que dame se encuentra en un sintagma sujeto son oraciones o bien principales o bien independientes: "sire, ma dame la reïne par moi vos mande" (Charrete, 5652 - 5653); "Or vos mande ma dame, sire" (Charrete, 5888). Cuando el sustantivo es plural y denomina a las mujeres casadas de la corte del rey Arturo, el sujeto es siempre múltiple, integrándose pues en una enumeración: "por ce que la reïne i fust et les dames et les puceles" (Charrete, 5582 - 5583); “es loges refu la reïne et les dames et les puceles" (Charrete, 5766 - 5767); “et as fenestres revont maint chevalier, dames et puceles" (Charrete, 6981 - 6982).

En E scoufle la determinación del sustantivo dame en función sujeto se reparte entre los posesivos cuando se denomina a la heroína: "s'il eüst tant de boines mors en moi com ma dame i cuidoit" (Escoufle, 5568 - 5569); “et

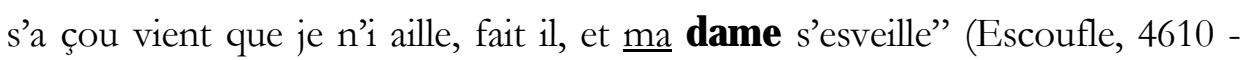
4611); "a la biauté dont lor dame ere" (Escoufle, 8827); "les damoiseles et lor dame s'en vont es cambres atillier" (Escoufle, 8868 - 8869); “u 뜨 damë herberja" (Escoufle, 6393); y el artículo definido cuando se trata de otra mujer — la condesa o la amante de Saint Gilles, ambas casadas—: "ml't le vit envoisiement la dame qui nel haoit mie” (Escoufle, 5832 - 5833); "a dame ki

\footnotetext{
201 Una sola excepción en la narración donde el posesivo pasa a ser un definido refiriéndose a la mujer del senescal cuando pide a Lanzarote que la ame: "fet la dame tot an rïant”, Charrete, 5485.
} 
ml't fu cortoise li a respondu comme sage" (Escoufle, 5916 - 5917); "ke la dame li laist et sueffre son voloir sans dire folie” (Escoufle, 5926 - 5927); “Diex, fait la dame” (Escoufle, 5958). ${ }^{202}$ Sin artículo el sustantivo adquiere un valor general: "que dame ne fait son mantel qui tient le nés el sebelin" (Escoufle, 8484 - 8485). En esta obra también funciona como aposición al sujeto pronominal: "ele m'avoit son cuer rendu au doner, ma dame, m'amie" (Escoufle, 4614 - 4615) o precede al nombre propio en el sintagma sujeto: “com estoit me dame Aelis" (Escoufle, 8521); "comme estoit me dame Aelis" (Escoufle, 8533).

Este último papel es así mismo asumido por el sustantivo en Rose: "la parole a premiere mise, seue merci, dame Franchise” (Rose, 3239 - 3240);203 donde desaparece la expresión de la dependencia mediante los posesivos puesto que en ningún momento el sustantivo en función sujeto se refiere a la amada, y por el contrario priman la indeterminación: "et une dame lor chantoit" (Rose, 727); “c'une dame mout envoisie me tresvit” (Rose, 777 778); "que por ce dist une dame qui mout amot" (Rose, 2662 - 2663); y en menor medida, la designación contextual: "cele dame avoit non Biautez" (Rose, 992), la cuantificación: "qui maint home par mi le monde et mainte dame a fet amer" (Rose, 1736 - 1737) o la actualización contextual: “tant que me vit ensi maté la dame de la haute engarde” (Rose, 2956 - 2957).

Por otra parte, dame es también en numerosas ocasiones sujeto de formas verbales unipersonales con un valor existencial: “il n'est dame ne chastelaine que je ne tenise a vilaine" (Rose, 3437 - 3438), que puede servir para expresar la excepcionalidad de la mujer sobre la que se habla: “il n'ot dame de tel renon, je cuit, en la crestïenté" (Escoufle, 8510 - 8511), ${ }^{204}$ o para realzar mediante la indeterminación verbal la abundancia de mujeres, siendo a

\footnotetext{
202 Sólo hay un ejemplo en plural funcionando como sujeto: “en acolant l'ont desliie les dames qui prenent congié”, Escoufle, 8720 - 8721.

${ }^{203}$ La misma fórmula sirve como vocativo en el discurso del amante: “dame Oiseuse”, Rose, 619.

204 También Escoufle, 8532 - 8533.
} 
menudo acompañada la denominación de adjetivos o sintagmas que intensifican el valor erótico expresado mediante la cantidad: "dames $\mathrm{i}$ ot de toz sens pointes" (Rose, 919);

\author{
beles dames o simples chieres, \\ ot plus de mil monté as estres, \\ as huis, as soliers, as fenestres. \\ Escoufle, 544 - 546
n'ot il a .j. chevalier faire
tant de dames de haut afaire

Escoufle, 7909 - 7910

\begin{abstract}
si ot avoec aus, ce me sanble, mainte bele dame cortoise
\end{abstract}

Charrete, 38 - 39

De entre las funciones restantes en las que encontramos este sustantivo sigue en importancia la de complemento de objeto directo, no sólo por el número de ocurrencias sino también por el valor sexual que otorgan los contextos y fundamentalmente el sentido del núcleo verbal del que depende la denominación dame. Algunos verbos poseen una carga erótica atenuada: veoir, mener, oceïr, desfendre, querre, apeler o adestrer, mientras que otros como embracier (Tristan, 3480 - 3481), doner (Escoufle, 1681), prendre [a feme] (Escoufle, 3495 - 3496), amer (Escoufle, 5911 - 5912), avoir (Escoufle, 8608), metre [a merci] (Rose, 1824 - 1825), eschaufer (Rose, 3408) o traïre (Rose, 2538) manifiestan una erotización del cuerpo femenino que se nos muestra anhelante, deseado y poseído; observamos sin embargo que en Charrete no se registra este proceso. 
En tanto que complemento de un sustantivo lo hallamos solamente en el texto de Jean Renart, precedido por la preposición a sugiriendo la pertenencia: "li quens de mon signor Saint Gile qui estoit a la dame amis" (Escoufle, 5828 - 5829); por la preposición de: “ainc de dames ne de puceles si grans plentés ne fu veüe" (Escoufle, 1734 - 1735); o sin preposición: "pour l'amour lor dame qu'il a” (Escoufle, 8785).

Como complemento del verbo aparece introducido también por varias preposiciones. Avuec: "se onques jui avoec ma dame" (Charrete, 4862); 0: "fu puis en cambrë o sa dame" (Escoufle, 6169); a: "s'il vos pooit anuit avoir a dame” (Escoufle, 4938 - 4939), “a une dame de haut pris se fu de mout pres ajostez" (Rose, 990 - 991); y en aposición a un complemento introducido por devant: "et totevoies s'arestoit, devant la reïne sa dame" (Charrete, 3748 - 3749).

Respecto de las proposiciones subordinadas ya nos hemos referido más arriba parcialmente al uso que había hecho Chrétien, nos interesaremos ahora por el resto de las ocurrencias de Charrete y por el tratamiento que se hace en los otros textos.

a. Proposiciones completivas:

Mientras que Béroul no introduce el sustantivo dame en ninguna subordinada completiva, Chrétien hace el uso restringido que ya hemos señalado, ${ }^{205}$ y Lorris ciñe también su utilización a dos ocurrencias, construyendo una de las dos proposiciones con un infinitivo en parataxis:

$$
\begin{aligned}
& \text { qui maint home par mi le monde } \\
& \text { et mainte dame a fet amer }
\end{aligned}
$$

Rose, 1736 - 1737

\footnotetext{
205 Añadimos a las ya mencionadas una interrogativa introducida por la conjunción se dependiente de un verbo declarativo en los versos 351 - 353 .
} 


$$
\begin{aligned}
& \text { si me sovient que por ce dist } \\
& \text { une dame qui mout amot } \\
& \text { en sa chançon un cortois mot }
\end{aligned}
$$

Rose, 2662 - 2664

Jean Renart, quien concede un gran peso a los verbos declarativos, a los que contienen el sentido de una promesa que se desarrollará con un acto legal, así como a los que indican un conocimiento de las circunstancias sociales o personales del individuo, introduce varias proposiciones completivas ya sea mediante la conjunción que, ya sea sin que medie ningún nexo: 206

$$
\begin{aligned}
& \text { qu'il li a creanté } \\
& \text { qu'il li donra la riche dame } \\
& \text { Escoufle, } 1680-1681^{207} \\
& \text { et si li prient et comandent } \\
& \text { k'il s'en voist, s'avra le roialme, } \\
& \text { puis qu'il sevent qu'il a la dame } \\
& \text { Escoufle, } 8606-8608
\end{aligned}
$$

b. Proposiciones relativas:

En Tristan, como ocurría con las proposiciones que acabamos de estudiar, no se presenta ninguna ocurrencia del sustantivo dame inserta en una proposición relativa, y en Charrete tan sólo observamos un ejemplo en el que la relativa es explicativa, estableciendose así una relación laxa entre caballero y dama, la misma que se establecerá entre Lanzarote y la joven enamorada a la que conducirá como hace Meleagant con Ginebra:

\footnotetext{
206 Escoufle, 5363.

207 También Escoufle, 3495 - 3496, 5911 - 5912, 5925 - 5926.
} 


$$
\begin{aligned}
& \text { (...) et devant venoit } \\
& \text { uns granz chevaliers qui menoit } \\
& \text { une bele dame a senestre }
\end{aligned}
$$

Charrete, 557 - 559

Los textos del siglo XIII introducen a menudo el sustantivo dame en proposiciones de este tipo. Las explicativas aparecen en muy contadas ocasiones:

$$
\begin{aligned}
& \text { li autres biens est Douz Palers, } \\
& \text { qui a fet a mainz bachelers } \\
& \text { et a maintes dame secors }
\end{aligned}
$$

Rose, 2657 - $2659^{208}$

mientras que las especificativas, que mantienen una relación más estrecha y necesaria con el antecedente, son relativamente abundantes en ambos textos. Incluimos también entre estas un caso en el que el nexo es una expresión copulativa, pero que funciona como una variante expresiva que evita la repetición del relativo:

$$
\begin{aligned}
& \text { c'est cil qui les amanz justise } \\
& \text { et qui abat l'orgueil de gent, } \\
& \text { et si fet dou seignor sergent } \\
& \text { et les dames refet baesses }
\end{aligned}
$$

$$
\text { Rose, } 866-869
$$

Al igual que en este caso, muchos de los antecedentes cuya determinación restrictiva se lleva a cabo mediante la proposición relativa son pronombres demostrativos o indefinidos; y aunque no sea considerado como un indefinido en las gramáticas, el sustantivo chose sin determinación, que

208 También Escoufle, 5828 - 5829 y Rose, 2830 - 2831, 3407 - 3408. 
aparece en uno de los ejemplos que recogemos a continuación, podría ser también aquí tomado como tal: 209

$$
\begin{aligned}
& \text { fai, se tu puez, chose qui plaise } \\
& \text { as dames et as demoiseilles } \\
& \text { Rose, } 2107 \text { - } 2108 \\
& \text { onques ne l'oï, je cuit, un } \\
& \text { ki ne fust liés de la novele } \\
& \text { de tel seignour et de si bele }
\end{aligned}
$$

dame com Diex lor a donés.

Escoufle, 8228 - 8231

n’i a nul qui la dame voie

et ses puceles qui ne die

$$
\text { Escoufle, } 8676-8677
$$

il n'est nule qui plus tost mete

a merci dame ou damoiseile

$$
\text { Rose, } 1824 \text { - } 1825
$$

Vemos, por otra parte, que los modos subjuntivo e indicativo responden a los usos normales en las proposiciones relativas, y que al menos en estos ejemplos ninguno de los dos textos se ha visto afectado por la tendencia a abandonar el indicativo que se impuso durante este siglo. ${ }^{210} \mathrm{El}$ subjuntivo es el modo habitual cuando el antecedente se encuentra en una oración negativa o cuando se presenta un proceso virtual, mientras que cuando está actualizado se impone el indicativo:

\footnotetext{
209 Tan sólo en un ejemplo hay un antecedente sustantivo al que no afecte un posible fenómeno de cambio de clase gramatical:

mais nule riens ne s'apareille

a la biauté dont lor dame ere

Escoufle, 8826 - 8827
} 
quant cil ki ma dame ont atainte

ne nos ataindrent ambedeus

Escoufle, 5146 - 5147

a ce sont bien cil parissant
qui vont les dames traïssant

Rose, 2537 - 2538

c. Proposiciones circunstanciales:

De nuevo son los textos del siglo XIII los que integran más a menudo el sustantivo dame en proposiciones subordinadas, y así por ejemplo las causales, introducidas por la conjunción que, sólo aparecen en ellos. ${ }^{211}$ No obstante también las encontramos en Tristan y en Charrete; así ocurre con una proposición final en la que la locución conjuntiva por ce que [Prep. + Pron. + Conj.] sirve para incorporar a las mujeres de la corte — la reina, las damas y las muchachas jóvenes- como espectadoras de excepción de los juegos deportivos y plenos de erotismo de los caballeros 212 —aunque parece ser que en la realidad tenían funciones endógenas al estar orientados a suplir o preparar la guerra y a redistribuir parcialmente las riquezas entre los grupos masculinos - Lo que se pretende conseguir en la ficción es que aquellas los observen — transponiéndose así la sensualidad masculina sobre la femenina— antes de elegir la pareja que podrá poseerlas.

\section{- Consecutivas:}

Respecto de este tipo de subordinadas circunstanciales cabe señalar para el conjunto de los casos con los que nos encontramos que la proposición

\footnotetext{
${ }^{210}$ Cf. Hasenohr, op. at., p. 229.

${ }^{211}$ Cf. Escoufle, 6166 - 6169; Rose, 1164 - 1166.

${ }^{212}$ Charrete, 5581 - 5583.
} 
principal implica la noción de intensidad o de cantidad introducida por los adverbios correlativos referida a un elemento sustantivo, nunca a un proceso expresado por un verbo.213 Por otra parte Béroul, probablemente por condicionamientos métricos, elimina la conjunción que introduce la subordinada de forma sistemática durante la época medieval.

$$
\begin{aligned}
& \text { Sire, en nos a si grant ardor } \\
& \text { soz ciel n’a dame qui un jor } \\
& \text { peüst soufrir nostre convers } \\
& \text { Tristan, } 1195 \text { - } 1197
\end{aligned}
$$

\section{- Condicionales:}

Podemos observar diferentes efectos expresivos en función de los tiempos y modos que se combinan en la proposición principal y en la subordinada introducida sistemáticamente por la conjunción $\mathbf{s e .}$

En Tristan la mala fe de los barones traidores nos hace distinguir un valor potencial para la hipótesis expresado mediante el imperfecto de indicativo en la prótasis y el condicional en la apódosis, al tiempo que se establece una relación temporal de anterioridad — reforzada por el adverbio puis-:

$$
\begin{aligned}
& \text { qui puis garant li porteroient, } \\
& \text { se li felon de rien greignoient } \\
& \text { a la dame de loiauté } \\
& \text { Tristan, } 3361 \text { - } 3363
\end{aligned}
$$

Para proclamar su inocencia Keu apela a la justicia divina, algo común en la época medieval y que todavía se mantiene en expresiones actuales pero que entonces poseía valor probatorio, sin embargo la expresión

213 Cf. Charrete, 4319 - 4321 y Escoufle, 8923 - 8925. 
de los hechos hipotéticos que se ofrecen como irreales y de la consecuencia recogida en la apódosis no responde a la forma habitual. El presente de subjuntivo en la principal se debe aquí a la virtualidad temporal en la que no se distingue claramente entre el presente y el futuro, ${ }^{214}$ mientras que la irrealidad del placer que se les achaca a él y a la reina no se deduce del modo de la prótasis sino más bien de la combinación del adverbio negativo con el tiempo pasado del verbo:

$$
\begin{aligned}
& \text { ne me face pardon a l'ame, } \\
& \text { se onques jui avoec ma dame }
\end{aligned}
$$

Charrete, 4861 - 4862

También en E scoufle la negación en la apódosis provoca un cambio en el modo verbal, aquí reflejado en la subordinada relativa especificativa, pasando del condicional, es decir, de una forma del indicativo al imperfecto del subjuntivo, cuando lo que se expresa es una hipótesis verosímil sobre el deseo masculino y la capacidad de atracción sexual o cuando menos social de Aelis:

$$
\begin{aligned}
& \text { n’i a nul qui presist escange } \\
& \text { por vos, richece ne avoir, } \\
& \text { s'il vos pooit anuit avoir }
\end{aligned}
$$

a dame, a amie $u$ a oste

Escoufle, 4938 - 4939

\section{- Temporales:}

Las tres subordinadas temporales que hemos encontrado parecen confirmar algunas de las características del comportamiento de los enamorados, Lanzarote y el amante - narrador de Rose, con respecto no tanto a la mujer, sino más bien al sentimiento amoroso, que se encuentra en estadios diferentes.

${ }^{214}$ Cf. Moignet, op. at., p. 252. 
Lanzarote, poseído por el deseo, actúa de forma impulsiva durante todo el relato y paradójicamente sólo se controla en presencia de la dama; sin embargo, la noticia de su muerte le hace lamentar no haber seguido, en el mismo instante en que se vio rechazado, la fuerza incontrolada de su pasión que lo hubiera conducido a la autodestrucción.

que je me deüsse estre ocis

des que ma dame la reïne

me mostra sanblant de haïne

Charrete, 4336 - 4337

Por el contrario el amante de R ose, que acaba de despertar al amor, se nos aparece en la primera parte de la novela —antes de haber fijado su atención en una joven - rosa - expectante ante las reacciones femeninas, representadas en este caso por la acogida amable de Cortesía y dubitativo, a merced de las fuerzas contrarias que luchan en su interior, por un lado las que calificaríamos de sociales, adquiridas con la educación como la Razón que pretenderá imponerse en este caso, y por otro las instintivas que lo ofuscan y le impiden salir de la red echada por su propio deseo.

\author{
la querole ilec en estant \\ regardai juques a itant \\ c'une dame mout envoisie \\ me tresvit (...) \\ Rose, 775 - 778 \\ en cest point ai grant piece esté, \\ tant que me vit ensi maté \\ la dame de la haute engarde \\ Rose, 2956 - 2957
}




\section{- Comparativas:}

Como tendremos ocasión de ver, el estilo de Jean Renart está caracterizado en gran medida por el establecimiento casi constante de comparaciones: ya sea entre lo que se espera y la realidad, como es el caso en el primer ejemplo donde la estructura comparativa canónica de igualdad se ve contrarrestada por la hipotética irreal, ya sea enfrentando la realidad individual a un conjunto que representaría la perfección pero que generalmente se ve superado por aquélla mediante la expresión de una relación de superioridad o bien rompiendo gracias a la negación un esquema formal que expresaría la igualdad:215 "s'il eüst tant de boines mors en moi com ma dame i cuidoit" (Escoufle, 4568 - 4569), "plus bel tenoit par les enarmes l'escu devant lui en cantel que dame ne fait son mantel" (Escoufle, 8482 - 8484).

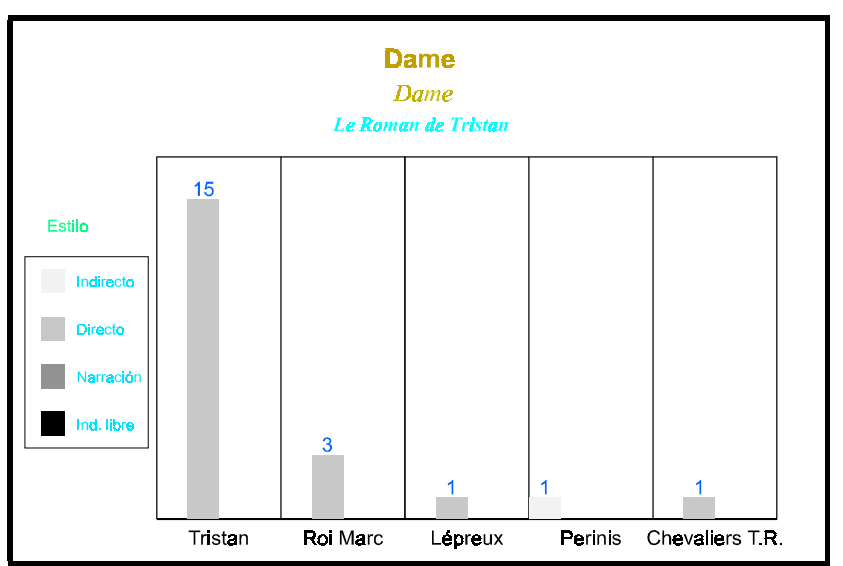

Fig. 4. Comportamiento estilístico del sustantivo dame en Tristan.

${ }^{215}$ Cf. los versos ya citados en Escoufle, 8520 - 8521, 8532 - 8533. 


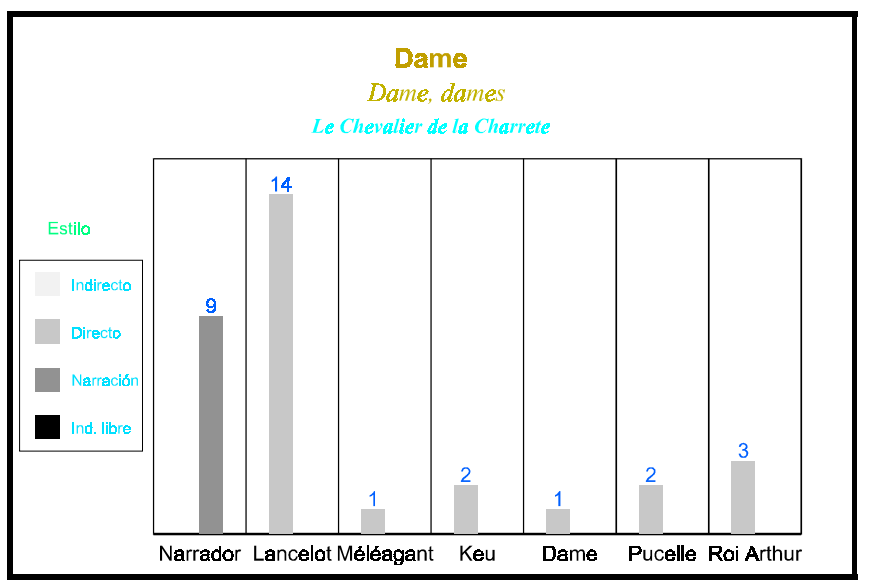

Fig. 5. Comportamiento estilístico del sustantivo dame en Charrete.

\section{Dame}

Dame, damë, deme, dames

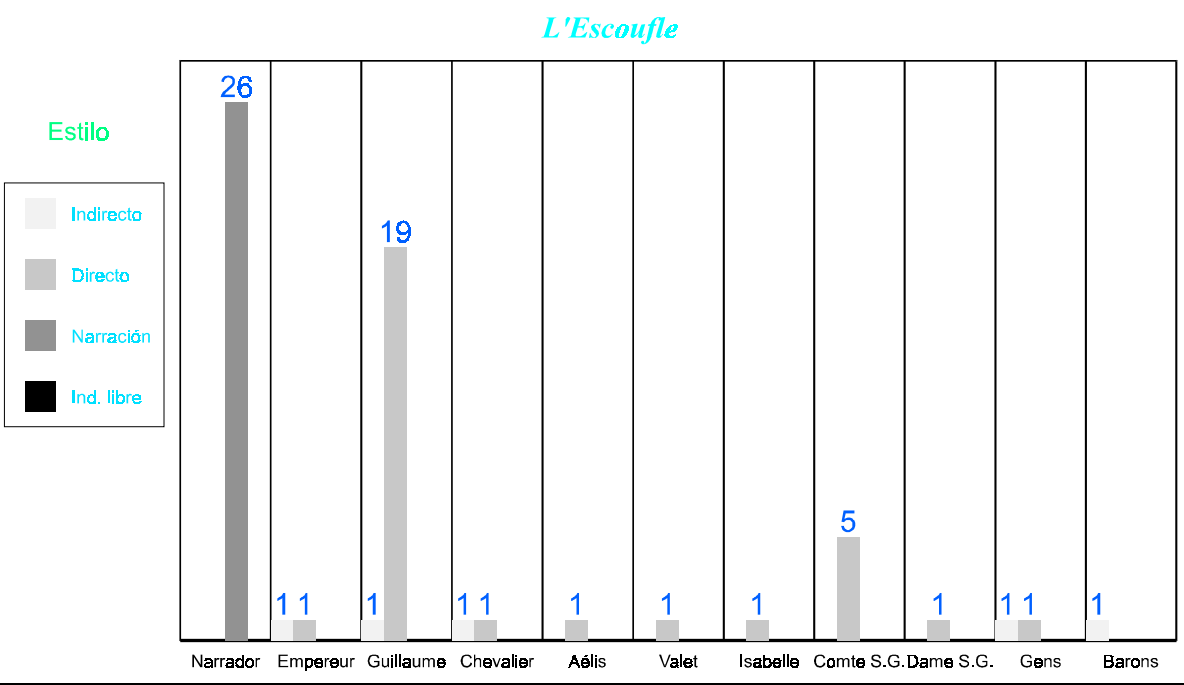

Fig. 6. Comportamiento estilístico del sustantivo dame en Escoufle. 


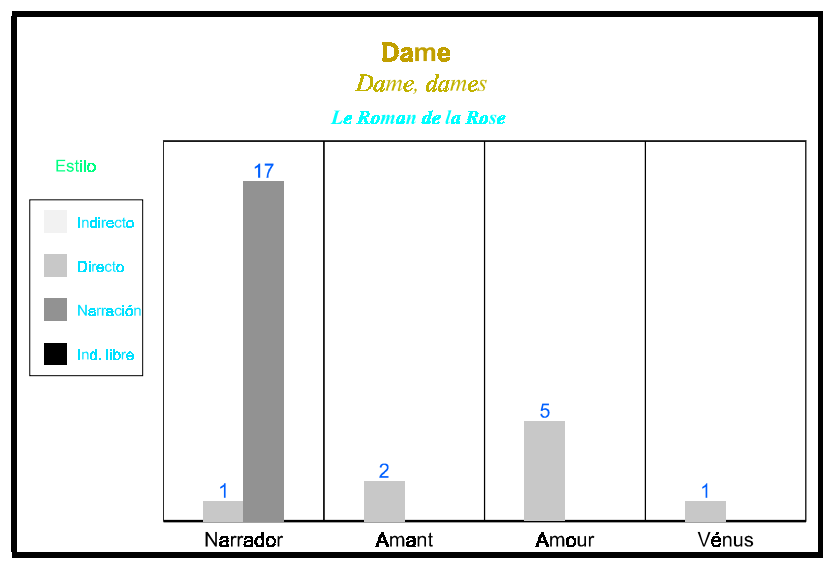

Fig. 7. Comportamiento estilístico del sustantivo dame en Rose.

La descripción estilística representada gráficamente nos pone a la vista las diferencias notables que existen en el corpus con respecto a una denominación que la novela generaliza. En Tristan el uso como vocativo dominante recupera paradójicamente la distancia establecida por el sentido etimológico y recogida por la lírica, si bien reposa en gran medida sobre las bases de un discurso irónico que trivializa este fenómeno gracias a la connivencia de los receptores. Chrétien, quien reduce las ocurrencias como apóstrofe y revigoriza el dúo semántico formado por la superioridad social y la superioridad amorosa en el discurso directo de Lanzarote, sienta también las bases para la generalización posterior merced a la utilización narrativa. En las obras del siglo XIII la denominación se emplea continuamente olvidando las rígidas estructuras que la encorsetaban, al amparo de los cambios en los usos eróticos que llevan a Guillermo a hablar de o a su enamorada como lo hacían los amantes del siglo XII pese a ser virgen, si bien las distancias sociales se mantienen; cambios a los que se suma el reflejo literario de la importancia creciente de la burguesía y que hacen del término dame en Rose un sinónimo de femme. En este roman observamos, además, que junto a la utilización hecha por el narrador, quien también se muestra aquí maestro del amor mediante el uso del estilo directo, los personajes - Amant, Amour y Vénus— pertenecen todos a la facción favorable a las relaciones amorosas o abiertamente a la carnalidad, aunque el análisis precedente ha hecho aparecer 
una cierta visión negativa, no carente de rasgos misóginos que se hace eco de las críticas de los suspirantes en lengua d'oc hacia las damas excesivamente ariscas o lascivas.

\title{
3.2.1.1.2.2 Demoiselle.
}

Creemos que en nuestro corpus podemos identificar este vocablo con la mujer joven y casadera, aunque ello no signifique que se trata de una virgen, especialmente en Charrete ya que la violación o la entrega complaciente de una joven son moneda corriente en el mundo artúrico a tenor de lo que deducimos de las aventuras de Lanzarote y de otros personajes de los romans de Chrétien. En general se trata también de la hija de un noble o de un caballero que se encuentra en la corte acompañando y sirviendo a la reina o a la señora de un castillo tal como recuerda Iseo en la única ocurrencia que aparece en el texto de Béroul:

\author{
Les damoiseles des anors, \\ les filles as frans vavasors \\ deüse ensenble o moi tenir \\ en mes chanbres, por moi servir, \\ et les deüse marïer \\ et as seignors por bien doner.
}

Tristan, 2211 - 2216

o ella misma posee un recinto fortificado en el que ofrece hospitalidad al caballero en busca de aventuras, ${ }^{216}$ o bien, y sólo como una hipótesis no demostrable, en Rose es la hija de una adinerada familia burguesa. En cualquier caso es una promesa de mejora social ascendiendo uno o varios peldaños en la escala de la nobleza o de la ciudadanía, aumentando el patrimonio o el poder

${ }^{216}$ Charrete, 951 - 952, 430 - 431. 
gracias a la multiplicación de las relaciones sociales. Y ya que ningún texto dice lo contrario podemos suponerles a todas belleza, bondad, generosidad, y otras muchas cualidades corteses: "molt avenant, bien acesmee et bien vestue (...) sage et bien afeitiee" (Charrete, 934 - 937) como las que definen a las damiselas hospitalarias de Charrete.

Chrétien expone a estas jóvenes como la figura erótica por excelencia y la única que parece tener una proyección extradiegética, pues es tal su abundancia y es tal la recurrencia del término que las designa, que son el único sueño al que pueden aspirar los hipotéticos receptores de la obra. En gran medida la tensión del relato se mantiene por el continuo aparecer de nuevas mujeres solitarias o en prometedores grupos que se arremolinan en torno al héroe o buscan un marido: "dames et dameiseles gentes i rot tant que mervoille fu.” (Charrete, 5524 - 5525). Galván y Lanzarote las encuentran por doquier — de hecho en función de complemento objeto directo el sustantivo depende sobre todo de los verbos ancontrer y trover-, acompañadas de otras jóvenes vírgenes dispuestas a servirlos y agasajarlos, a sentarlos junto a ellas en la mesa, y a ofrecerles una cama reparadora o un lecho donde abandonarse al placer incluso aunque el caballero las rechaza: "par force covient que il s'aut couchier avoec la dameisele” (Charrete, 1210 1211). Es cierto que no todos pueden conseguirlas pues buscan la perfección caballeresca en aquel que logre su cuerpo

(...) et si prandront ces cui le jor seroit l'enors

les dameiseles a seignors

Charrete, 5728 - 5730

y se muestran a menudo caprichosas, pero ¿qué caballero no se sentiría capaz de lograr tan preciada recompensa? Así pues en Charrete devienen un señuelo para mejorar el comportamiento social y militar de los jóvenes que buscan un 
lugar en la sociedad cambiante del siglo XII que necesita reconducir y apaciguar las fuerzas masculinas excedentarias. Dos sistemas de convivencia se encuentran recogidos y en cierta medida enfrentados en el roman en torno a la figura de la demoiselle, por un lado el orden antiguo dominado por el más fuerte en la batalla y que se lleva como botín de guerra a la mujer conquistada o reconquistada sin apelación, para hacer con ella lo que le plazca fuera de los marcos sociales que pretendían imponer los señores y la Iglesia; por otro lado el orden nuevo en el que la corte organiza luchas rituales por iniciativa femenina tras las que, siempre que el campeón sea del agrado de la mujer, se consumará la unión consagrada por el matrimonio.

L 'E scoufle mantiene el uso general del vocablo que hemos señalado más arriba con dos particularidades, por un lado la extracción social ya no es determinante y cualquier mujer joven, particularmente en el discurso directo de los personajes puede ser así denominada, ${ }^{217}$ por otro la heroína es aquí también una joven heredera a la que tanto el narrador desde su infancia — desde que tenía tres años, en el momento en que llega el que será su esposo a la corte—, como los barones cortesanos —incluso cuando ya está casada —, 218 los personajes episódicos o el propio enamorado denominan damoisele: "ou es ce que ma damoisele me mande?" (Escoufle, 3346 3347). Guillermo así se dirige a ella: "or tost, ma damoisele, vestés ceste robe nouvelle; ostés cest bon bliaut de Sire" (Escoufle, 3989 - 3991), e incluso cuando nadie lo oye recurre a esta denominación que mantiene la distancia jerárquica que habían establecido los trovadores: “ml't sui fox quant je lais ma damoisele en tel maniere." (Escoufle, 4596 - 4597).

Renart utiliza el vocablo como una fórmula de cortesía para marcar una especial deferencia del que habla y como el substituto perfecto de la dama. Podemos afirmar que en este texto se ha producido ya el cambio de

\footnotetext{
${ }^{217}$ Cf. Escoufle v. 5038 en el que Aelis usa la fórmula "douce damoisele" para hablar a Isabel. ${ }^{218}$ Cf. Escoufle v. 8561, 8581.
} 
objeto erótico para los jóvenes que prefiguraba Charrete aunque en su caso los preceptos corteses clásicos habían obligado a Chrétien a mantener la figura primordial de la dama y la relación triangular. Un cambio que parece corroborar el uso que de los términos demoiselle y dame hace un noble a la vieja usanza como el conde de Saint Gilles al saber que Aelis no es una simple joven de noble cuna sino la heredera del imperio: "ne l'apele mais damoisele li quens, mais dame, par cierté" (Escoufle, 8362 - 8373).

Por el contrario Rose mantiene todavía una cierta indecisión, pues aunque, como veremos más adelante, el enamorado prefiere las mujeres jóvenes y el dios Amor suele elegirlas para hacerlas caer en sus redes:

et fist ses laz environ tendre et ses engins i mist por prendre

demoiseilles et demoisiaus, qu'Amors si ne velt autre oisiaus.

Rose, 1589 - 1592

él mismo aconseja a su pupilo que intente agradar a todas las mujeres ${ }^{219}$ por igual, sean damas o señoritas, con la finalidad implícita de conseguir su amor o cuando menos sus favores:

fai, se tu puez, chose qui plaise

as dames et as demoiseilles,

si qu'eus oient bones noveles

de toi dire et raconter

Rose, 2108 - 2111

\footnotetext{
${ }^{219}$ Esta universalización del objeto amoroso aparece claramente expresada gracias al sustantivo femme: toutes fames ser et honore, en aus servir poine et labeure
} 
En el discurso del narrador se asocia de nuevo el término con la belleza física realzada por las ropas y el tocado: “.ii. demoiselles mout mignotes, qui estoient en pures cotes et trecies a une trece” (Rose, 757 - 759); con ello se pretende acercar las abstracciones con formas de mujer a la imaginación de los receptores de la obra aprovechando también para generalizar y presentar a todas las mujeres como posible objeto de deseo:

car nule robe n'est plus bele de sorquenie a demoiseile; fame est plus cointe et plus mignote en sorquenie que en cote.

Rose, 1215 - 1218

La justificación para la indeterminación a la que hemos hecho referencia podemos quizá encontrarla en la contradicción que se crea al intentar por un lado transcribir el código amoroso cortés y al adoptar por otro el nuevo ideal de amada.

El estudio de las rimas confirma por una parte la coincidencia de las tres obras - E scoufle, Rose y Charrete - respecto del rasgo fundamental de la belleza en una época en la que las condiciones de vida —alimentación, enfermedades, condiciones sanitarias— ofrecían pocas posibilidades al común de los mortales de mantenerla, si se poseía, más allá de la primera juventud, a lo que se une el hecho de que desde finales del siglo XII y en especial en el siglo XIII la reflexión filosófica se centra en gran medida en la estética. ${ }^{220}$ Por otra parte resultan significativos dos datos desde un punto de vista cuantitativo: en Charrete donde encontramos un gran número de ocurrencias del vocablo — tal como se puede observar en el gráfico que presentamos más abajo- las apariciones al final del verso son relativamente escasas si las

220 Cf. E. de Bruyne, É tudes d'esthétique médiévale. Ginebra: Slatkine Reprints, 1975, t. III, p. 5-8. 
comparamos con las otras dos obras en las que los recursos de la sonoridad y de la asociación léxica han sido utilizados en mayor medida para resaltar estas formas. Hemos de llamar la atención sin embargo sobre la repetición de la rima con pucele en Charrete ya que pone de relieve dos cosas:

a. la virginidad comienza a imponerse como una característica importante de la mujer amada aunque el hecho de que se unan explícitamente como obedeciendo a una norma parece indicar que la relación todavía tiene fisuras y que no ha invadido el inconsciente;

b. las damiselas solían estar acompañadas de otras jóvenes que las servían y que con su presencia hacían más atrayente la situación que se presentaba al público y sobre todo al público masculino.

En E scoufle la rima con el término nouvele [Sust.] que también se encuentra en Rose reafirma a nuestro entender la importancia del tema de la búsqueda de la amada que habíamos comentado a propósito del nombre propio, lo que a su vez podemos interpretar con respecto a Charrete, donde la acción de buscar es el motivo fundamental de la obra $-\mathrm{y}$ especialmente la busca de Ginebra-, como un nueva prueba del destronamiento de la dama.

\begin{tabular}{lllllllll}
\hline FORMA & CA & BD & NV & RIMA & CA2 & NV2 & D & PERS \\
\hline dameisele & S & Charrete & 1211 & apele & V & 1212 & N & Narrador \\
damoisele & S & Escoufle & 5038 & apele & V & 5037 & N & Narrador \\
dameisele & S & Charrete & 458 & bele & A & 457 & N & Narrador \\
damoisele & S & Escoufle & 2997 & bele & A & 2998 & N & Narrador \\
damoisele & S & Escoufle & 8372 & bele & A & 8371 & N & Narrador \\
demoiseile & S & Rose & 1216 & bele & A & 1215 & N & Narrador \\
damoiseles & S & Escoufle & 227 & beles & A & 228 & N & Narrador \\
damoisele & S & Escoufle & 7597 & cele & P & 7598 & D & Guillaume \\
dameisele & S & Charrete & 636 & ele & P & 635 & N & Narrador \\
dameiseles & S & Charrete & 5362 & eles & P & 5361 & N & Narrador \\
damoisele & S & Escoufle & 4514 & enoisele & V & 4513 & N & Narrador \\
damoisele & S & Escoufle & 2795 & nouvele & S & 2796 & D & Traîtres \\
damoiseles & S & Escoufle & 5609 & nouveles & S & 5610 & N & Narrador \\
damoisele & S & Escoufle & 3989 & nouvelle & A & 3990 & D & Guillaume \\
damoisiele & S & Escoufle & 7945 & novele & A & 7946 & N & Narrador \\
damoiseles & S & Escoufle & 7755 & noveles & S & 7756 & N & Narrador \\
damoiselles & S & Rose & 3558 & noveles & S & 3557 & D & Honte \\
demoiseilles & S & Rose & 2109 & noveles & S & 2110 & D & Amour
\end{tabular}




\begin{tabular}{lllllllll} 
damoisele & S & Escoufle & 1963 & oisele & V & 1964 & N & Narrador \\
dameisele & S & Charrete & 1390 & pucele & S & 1389 & D & Lancelot \\
dameisele & S & Charrete & 1706 & pucele & S & 1705 & D & Lancelot \\
dameiseles & S & Charrete & 1636 & puceles & S & 1635 & N & Narrador \\
dameisele & $\mathrm{S}$ & Charrete & 479 & querele & S & 480 & I & Lancelot \\
dameisele & S & Charrete & 1428 & sele & S & 1427 & N & Narrador \\
\hline
\end{tabular}

Tabla 30. Rimas del sustantivo demoiselle.

La determinación del sustantivo demoiselle es uno de los rasgos sintácticos más habituales en Charrete y sobre todo en E scoufle donde incluso el vocativo se encuentra precedido por un posesivo; el grupo [A rt. + Sust.]: "une damoisele", "la damoisele", "ma damoisele" conlleva también la desaparición de la denominación de la primera posición del verso en E scoufle donde hay una sola ocurrencia en su uso como vocativo:

font tuit li voisin: «Qu'es ce? Avoi!

Damoisiele, irés ent vos donques?

Escoufle, 6064 - 6065

Chrétien sin embargo parece buscar esta posición privilegiada para los vocativos con los que Lanzarote o Galván interpelan o agradecen su ayuda a las jóvenes, por lo que llega a interrumpir el periodo para intercalarlo en esa posición cuando lo más habitual es encontrarnos con el vocativo al comienzo de la intervención en estilo directo:

Se vos rien nule amez de cuer,

dameisele, de par celi

vos conjur et requier et pri

Charrete, 1404 - 1406

et cil respont: «Sainne et heitiee,

dameisele, vos face Dex.»

Charrete, 938 - 939 
Lorris mantiene sistemáticamente la indeterminación del sustantivo pues siempre que alude a este grupo definido por la edad y por la calidad social y sexual lo hace en un sentido general: "car nule robe n'est plus bele de sorquenie a demoiseile” (Rose, 1215 - 1216), a menudo en coordinación con otros grupos complementarios:221 “de vallez et de damoiselles” (Rose, 8558), “demoiseilles et demoisiaus" (Rose, 1591).

A excepción de Rose donde el sustantivo no funciona nunca como sujeto, esta es la función dominante en la narración de Charrete y E scoufle. En el primer texto lo es de tres grandes grupos de verbos si tomamos en consideración su semantismo y el contexto, los verbos enunciativos: conter, ${ }^{222}$ respondre, ${ }^{223}$ dire,${ }^{224}$ redire, ${ }^{225}$ conoistre: "ne cuidiez pas que le porcoi la dameisele l'an conoisse" (Charrete, 1446 - 1447), los de percepción y conocimiento: entendre, oir, ${ }^{226}$ percevoir, ${ }^{227}$ veoir,, 228 conoistre $^{229}$ y apercevoir: "bien l'aparçoit la dameisele, et bien le voit" (Charrete, 1265 1266) o savoir, ${ }^{230}$ y los que aluden a la amable acogida que dispensan a los caballeros: saluer, ${ }^{231}$ couchier, $^{232}$ seoir, ${ }^{233}$ prendre, ${ }^{234}$ apareillier, ${ }^{235}$ aporter $^{236}$ o faire:

\footnotetext{
221 Sólo encontramos un ejemplo en el que utiliza el artículo definido pero aún en ese caso se mantienen las dos características de las que hablamos, generalización y coordinación: "as dames et as demoiseilles" (Rose, 2109).

222 Charrete, 636.

${ }^{223}$ Charrete, 679 .

${ }^{224}$ Charrete, 912 - 913, 1512, 5993, 6049 - 6051

225 Charrete, 1188,

226

la dameisele que o li

li chevaliers amenee ot

les menaces antant et ot

Charrete, 888 - 890

227 Charrete, 1357.

228 Charrete, 1428.

${ }^{229}$ Charrete, 1512.

${ }^{230}$ Charrete, 6049.

231 Charrete, 936.
} 
et lors corteisie et proesce

fist la dameisele et largesce

Charrete, 585 - 586

car molt lor i fist grant enor

et conpeignie boene et bele, tote la nuit, la dameisele

Charrete, 456 - 458

$\mathrm{Al}$ papel que ya habíamos señalado de amables anfitrionas se une el de testigo de las actividades masculinas y aún el de mediadoras en los conflictos que surgen entre los caballeros ya que en este texto demuestran conocer los deseos y comportamientos de los hombres adelantándose a estos para provocar o apaciguar sus enfrentamientos en función de sus propios intereses, y conducen gracias principalmente a la palabra las previsibles reacciones varoniles.

Las acciones sociales y amorosas de las que es sujeto el sustantivo demoiselle en Escoufle son muy diferentes y parecen mostrar una menor actividad de las jóvenes —aunque en contadas ocasiones se exprese la

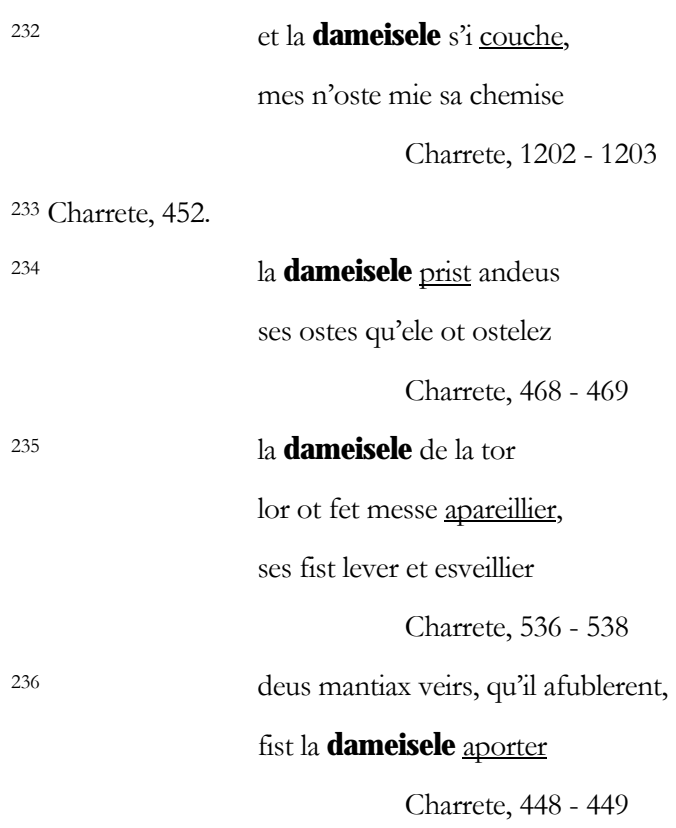


voluntad de la amada con los verbos mander y voloir-, puesto que por un lado algunas ocurrencias en función sujeto se encuentran en el discurso directo de Guillermo y por otro predominan los verbos que reflejan una preocupación por el aspecto externo y el vestido:

\author{
pour movoir et la damoisiele \\ lorains et sambue novele \\ ot tele com il li convint
}

Escoufle, 7945 - 7947

Les damoiseles et lor dame

s'en vont es cambres atillier.

Escoufle, 8868 - 8869

los que expresan la entrega de objetos al varón, objetos que son símbolo de la propia cesión: “quant la damoisele m'ot fait le don qui si ert bons et biaus" (Escoufle, 7588 - 7589), ${ }^{237}$ o el sueño confiado bajo la tutela del enamorado que les traerá a ambos la desventura:

tout en jouant laste et soumaus

fist endormir ma damoisele

Escoufle, 7596 - 7597238

El enamorado asume en gran medida la responsabilidad de las actividades de la pareja y abandona o toma posesión de la joven noble sin que ella pueda intervenir para remediarlo como ocurría en el texto de Chrétien,

\footnotetext{
${ }^{237}$ Véase también: que ke ma damoisele sist

lés moi sour l'erbe et sour la flor,

iluec me fist don de s'amour

Escoufle, 7576 - 7578

238 También Escoufle, 4538 - 4539.
} 
hecho que parece confirmar el uso del sustantivo demoiselle en función de complemento de objeto directo:

\begin{abstract}
fait il: «Ml't sui fox quant je lais
ma damoisele en tel maniere.
\end{abstract}

Escoufle, 4596 - 4597

k'il a la damoisele prise
qui tant est bele et bien aprise

Escoufle, 8327 - 8328

Los usos como complemento preposicional con valor circunstancial o como complemento atributivo del nombre tienen menor relevancia en la obra de Chrétien aunque no podemos pasar por alto el complemento introducido por avoec: "couchier avoec la dameisele" (Charrete, 1211). En E scoufle sin embargo confirman las ideas de dependencia y sumisión que hemos expresado, ya que la denominación en tanto que complemento del nombre nos habla de la relación matrimonial que se establece entre Aelis y Guillermo (Escoufle, 2574 - 2575 y 8580 - 8581) a pesar de la disparidad social que debería impedirla: "il ne deüst pas estre mains gentix de vostre damoisele" (Escoufle, 2794 - 2795). En otros contextos, precedido por una preposición, se nos muestran los intentos por difuminar dichas diferencias desde la infancia:

\title{
On enmaine l'enfant mangier \\ en la chambre a la damoisele
}

Escoufle, 1962 - 1963

Sire, fait il, jou fui .v. ans

en la cambre l'empereïs

o ma damoisiele norris

Escoufle, 7502 - 7504 
La sintaxis proposicional nos muestra el sustantivo con preferencia en oraciones independientes, y entre las subordinadas se hallan sobre todo las circunstanciales, expresándose una relación causal al tiempo que explicativa por medio de que: "qu'a desdaing et a despit tint la deffanse a la dameisele" (Charrete, 478 - 479);239 datando una acción con respecto a otra posterior gracias a la locución tant que [A dv. + $\mathbf{C}$ onj.]: "puis si s'an va tant que de bas vespre trova une dameisele venant" (Charrete, 931 - 933), o la concomitancia de dos procesos con quant (Charrete, 1357 - 1359, 1428 1429 y Escoufle, 4596 - 4597, 7588), con que ke [C onj. + C onj.] (Escoufle, 7576 - 7578) o con quanque: "quanqu'il paist et enoisele de la douçor la damoisele" (Escoufle, 4513 - 4514); expresando el modo y la consecuencia con tex ... que [Adj. + $\mathbf{C}$ onj.]: "les costumes et les franchises estoient tex, a cel termine, que dameisele ne meschine" (Charrete, 1302 - 1304) o la intensidad y la consecuencia con tant ... que [Adv. + C onj.] (Escoufle, 8326 - 8327).

Entre las completivas cabe destacar aquellas que funcionan como complemento directo de un verbo que expresa una obligación del caballero con respecto a la joven (Charrete, 1210 - 1211) o de un verbo de percepción como veoir.

\section{Cil voit que molt vileinemant tenoit la dameisele cil}

Charrete, 1080 - 1081

Las subordinadas relativas que contienen este sustantivo tienen como característica principal el que los antecedentes del relativo -que a su vez funciona siempre como sujeto de la proposición dependiente- son siempre hombres, caballeros: “«Sire, veïstes vos un chevalier, dites le nos, qui

239 La misma relación se expresa mediante la conjunción de coordinación car en Charrete, v. 456 - 458 y en Rose, v. 1215 - 1216. 
une dameisele mainne?» (Charrete, 1961 - 1963), cortesanos: “dui de ciaus qui grant joie en ont de la venue as damoiseles" (Escoufle, 5608 - 5609), o el enamorado de Aelis (Escoufle, 8580 - 8581):240

que li damoisiaus vit et raine

qui doit avoir l'onour du raine

pour no damoisele (...)

Escoufle, 8559 - 8561

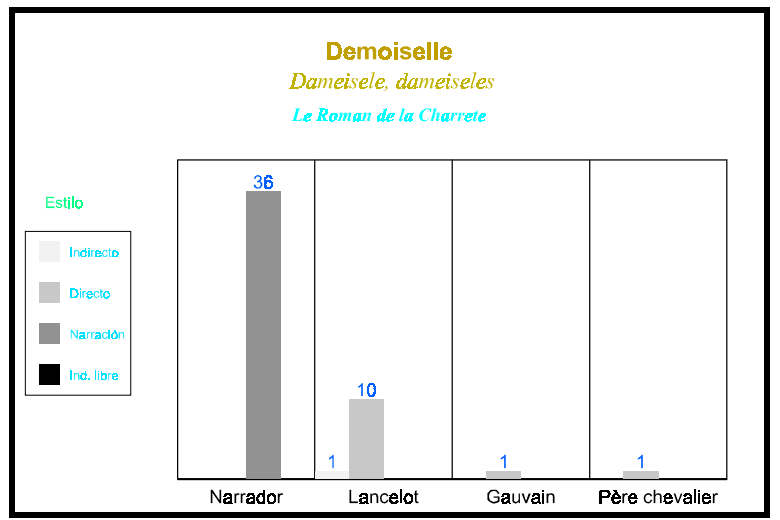

Fig. 8. Comportamiento estilístico del sustantivo demoiselle en Charrete.

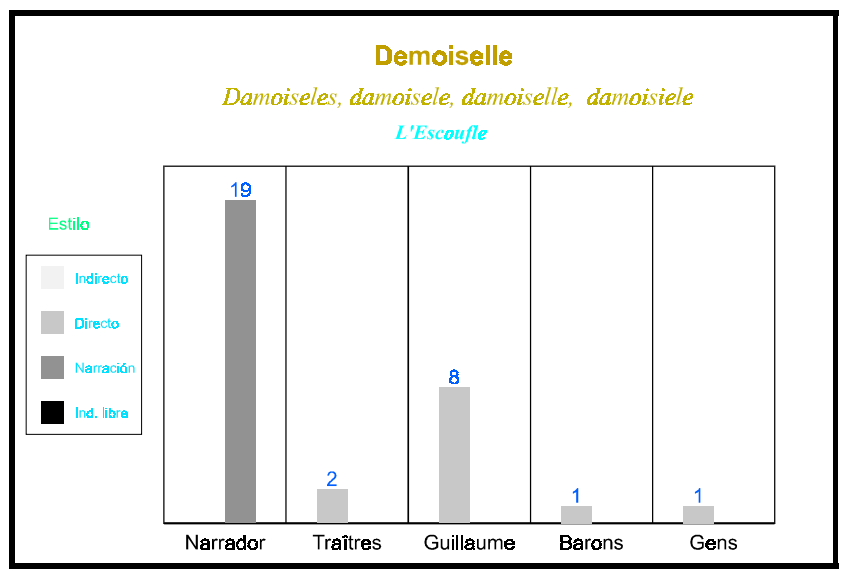

Fig. 9. Comportamiento estilístico del sustantivo demoiselle en Escoufle.

240 A excepción de un ejemplo que ya hemos citado más arriba al estudiar la denominación dame perteneciente a Rose, v. 2108 - 2109. 


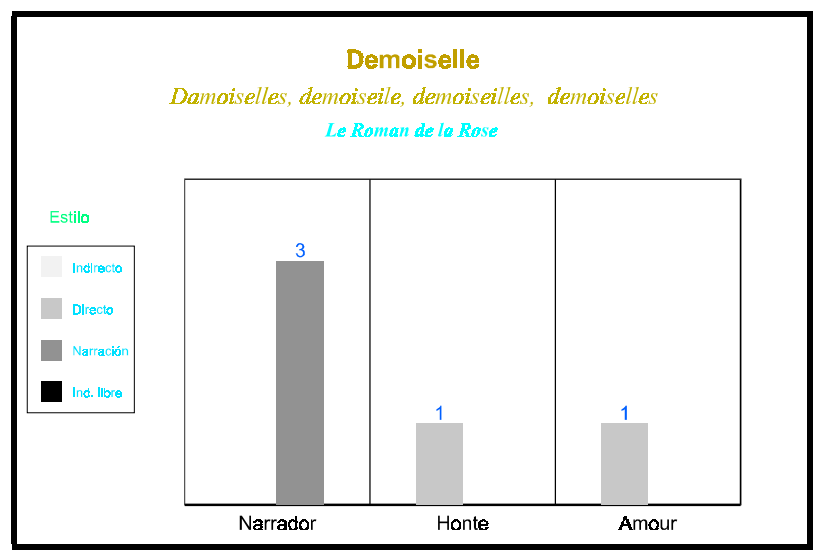

Fig. 10. Comportamiento estilístico del sustantivo demoiselle en Rose.

Chrétien de Troyes, gran defensor de las bondades del matrimonio cuando el amor de los esposos se hace compatible con las obligaciones sociales del varón, consigue introducir parte de esta ideología en la historia del adulterio de la reina Ginebra. Para ello, gracias fundamentalmente al discurso narrativo, abre las expectativas de un nuevo mercado erótico más provechoso social y económicamente y menos exigente física y psicológicamente para el varón. El discurso directo de Lanzarote también contribuye a ello, pues las relaciones del paladín de la reina, que apenas osaba dirigirse a ésta, son mucho más fáciles con las jóvenes que se le acercan, le dan su ayuda y le prometen su amistad y su cuerpo. En E scoufle, donde ya se ha verificado la conquista por parte de las jóvenes vírgenes del lugar excelso ocupado por la mujer noble casada, la denominación comparte sus usos con el sustantivo dame, lo que atestiguan las ocurrencias en el discurso directo del enamorado Guillermo. No ocurre lo mismo en Rose, obra en la que la escasa presencia de la denominación tiene probablemente dos causas: para hacer referencia a la joven de la que se enamora el protagonista del relato se prefiere la denominación metafórica, y tal vez como muestra de la influencia cortés, el discurso sobre las doncellas es periférico. 


\title{
3.2.1.1.2.3 Pucelle y «meschine».
}

El término pucelle conserva en la mayor parte de las ocurrencias de nuestro corpus su sentido etimológico, es decir, muchacha joven y por ello inocente como la que supuestamente requiere la presencia del rey Marco. ${ }^{241} \mathrm{Se}$ une a la indicación cronológica la pertenencia a una familia noble, como sucede en una de las dos ocurrencias de Rose, 242 lo que lo hace en la mayor parte de los casos sinónimo de demoiselle. Sin embargo, también puede aparecer con el sentido de sirvienta o señorita de compañía y especialmente en aquellos contextos en los que ambos términos aparecen coordinados:

\author{
an cele pree avoit puceles \\ et chevaliers et dameiseles \\ Charrete, $1635-1636^{243}$
}

\begin{abstract}
En cel borc maint et sa pucele
qu'ele a o li cortoise et preu.
\end{abstract}

Escoufle, 5864 - 5865

En cualquier caso podemos hacer la misma lectura que para demoiselle — coincidencia que se da también en las palabras con las que se encuentra en las rimas- y considerar que pucelle es un testigo en Charrete así como en Escoufle de la importancia que ha cobrado la mujer joven y en segunda instancia virgen al final del siglo XII y principios del XIII. Estos dos

\footnotetext{
241 " $\mathrm{Li}$ rois respont: «Ne sai novele, mais mandé m’a une pucele que j’alle tost a lié parler. bien me mande n’i moigne per." (Tristan, 1928 - 1932)

242

(...) et les faus pledeors

ont maintes foiz par lor faveles

as demoisiaus et au puceles

lor droites heritez tolues

Rose, 184 - 187

${ }^{243}$ También 431 - 433.
} 
atributos podrían no ser todavía absolutamente interdependientes pero el proceso de trabazón se aproxima a la estabilidad. De hecho encontramos cuatro ocurrencias en que se ha producido un cambio de clase gramatical —el sustantivo pasa a ser adjetivo- que lleva consigo una restricción semántica adquiriendo el significado que posee en la lengua actual, que, sin embargo, los diccionarios de francés medieval no recogen:

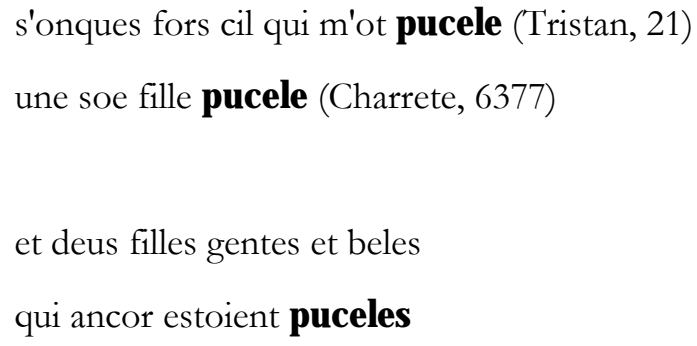

Charrete, 2049 - 2050

Si est reson qu'il te redie se s'amie est pucele ou non

Rose, $2688-2689$

Pero de nuevo lo más interesante desde el punto de vista de la expresión erótica es el factor cantidad que reaparece en Charrete: "totes les puceles estrenges del rëaume le roi Artu" (Charrete, 3526 - 3527), y se inaugura en E scoufle.

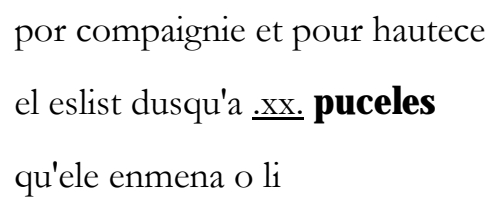

Escoufle, 8660 - 8662

Y si la acumulación sucesiva de unidades caracterizadas por la belleza física constituía la piedra de toque de la aptitud del nuevo modelo femenino para despertar la libido masculina, la posición social parece 
perfilarse en Escoufle como uno de los mecanismos que debe despertar el deseo femenino o cuando menos hacer que el común de las mujeres se predisponga a entregarse a los hombres pertenecientes a la nobleza.

$$
\begin{aligned}
& \text { On tenoit ml't a grant fierté } \\
& \text { ce qu'ele menoit tant puceles; } \\
& \text { pour ce qu'eles erent si bieles } \\
& \text { les adestrent et duc et conte. }
\end{aligned}
$$$$
\text { Escoufle, } 8820 \text { - } 8823
$$

La evolución con respecto a la exquisita selección que las mujeres hacían en Charrete es manifiesta siguiendo la tendencia normal de los cambios en el seno de las clases altas, nobleza y caballería, que se habían concluido con anterioridad en la sociedad real. Como consecuencia de ellos los méritos individuales habían perdido su peso en favor de la transmisión familiar; un proceso del que encontramos un magnífico ejemplo en la historia de Guillermo y de su padre el conde Ricardo de Normandía.

Respecto de las palabras que riman con el sustantivo señalar la coincidencia con las de demoiselle si bien aumenta el número de ellas y particularmente las asociaciones que se hacen con el adjetivo bele, siendo en Charrete sintomático de un intento de suplir una situación social poco favorable con el atractivo de la belleza, y con el pronombre cele en E scoufle donde todo apunta a una solución de compromiso para colocar la denominación que nos ocupa en la prominente situación del final del verso.

\begin{tabular}{lllllllll}
\hline FORMA & CA & BD & NV & RIMA & CA2 & NV2 & D & PERS \\
\hline pucele & S & Escoufle & 5268 & ancele & S & 5267 & D & Isabelle \\
pucele & S & Escoufle & 3378 & bele & A & 3377 & N & Narrador \\
pucele & S & Escoufle & 5302 & bele & A & 5301 & N & Narrador \\
pucele & S & Escoufle & 5413 & bele & A & 5414 & N & Narrador \\
pucele & S & Escoufle & 5611 & bele & A & 5612 & I & Valet \\
pucele & S & Escoufle & 5864 & bele & A & 5863 & D & Dame Montp. \\
Pucele & S & Rose & 523 & bele & A & 524 & N & Narrador \\
puceles & S & Charrete & 433 & beles & A & 434 & N & Narrador \\
puceles & S & Charrete & 5583 & beles & A & 5584 & N & Narrador
\end{tabular}




\begin{tabular}{|c|c|c|c|c|c|c|c|c|}
\hline puceles & S & Charrete & 5715 & beles & A & 5716 & $\mathrm{~N}$ & Narrador \\
\hline puceles & S & Charrete & 6981 & beles & A & 6982 & $\mathrm{~N}$ & Narrador \\
\hline pucele & S & Escoufle & 5996 & biele & $\mathrm{A}$ & 5995 & $\mathrm{~N}$ & Narrador \\
\hline puceles & S & Escoufle & 8821 & bieles & A & 8822 & $\mathrm{~N}$ & Narrador \\
\hline pucele & S & Charrete & 1059 & cele & $\mathrm{P}$ & 1060 & $\mathrm{~N}$ & Narrador \\
\hline pucele & S & Escoufle & 2297 & cele & $\mathrm{P}$ & 2298 & $\mathrm{I}$ & Barons \\
\hline pucele & S & Escoufle & 3368 & cele & $\mathrm{P}$ & 3367 & $\mathrm{~N}$ & Narrador \\
\hline pucele & $S$ & Escoufle & 4073 & cele & $\mathrm{P}$ & 4074 & $\mathrm{~N}$ & Narrador \\
\hline pucele & S & Escoufle & 4765 & cele & $\mathrm{P}$ & 4766 & $\mathrm{~N}$ & Narrador \\
\hline pucele & S & Escoufle & 6262 & cele & $\mathrm{P}$ & 6261 & $\mathrm{D}$ & Bourgeois \\
\hline pucele & S & Escoufle & 6415 & cele & $\mathrm{P}$ & 6416 & $\mathrm{~N}$ & Narrador \\
\hline pucele & S & Escoufle & 8021 & cele & $\mathrm{P}$ & 8022 & D & Gens \\
\hline pucele & S & Escoufle & 8147 & cele & $\mathrm{P}$ & 8148 & $\mathrm{D}$ & Comte S. G. \\
\hline puceles & $S$ & Escoufle & 7801 & celes & $\mathrm{P}$ & 7802 & $\mathrm{~N}$ & Narrador \\
\hline puceles & $\mathrm{S}$ & Escoufle & 8661 & celes & $\mathrm{P}$ & 8662 & $\mathrm{~N}$ & Narrador \\
\hline pucele & S & Charrete & 1705 & dameisele & $S$ & 1706 & $\mathrm{~N}$ & Narrador \\
\hline puceles & S & Charrete & 1635 & dameiseles & S & 1636 & $\mathrm{~N}$ & Narrador \\
\hline puceles & S & Escoufle & 7977 & damoisieles & S & 7978 & $\mathrm{~N}$ & Narrador \\
\hline puceles & S & Charrete & 5767 & eles & $\mathrm{P}$ & 5768 & $\mathrm{~N}$ & Narrador \\
\hline puceles & S & Escoufle & 7021 & eles & $\mathrm{P}$ & 7022 & $\mathrm{~N}$ & Narrador \\
\hline puceles & S & Rose & 186 & faveles & S & 185 & $\mathrm{~N}$ & Narrador \\
\hline pucele & $S$ & Tristan & 1932 & novele & S & 1931 & $\mathrm{D}$ & Roi Marc \\
\hline pucele & $\mathrm{S}$ & Escoufle & 2955 & novele & S & 2956 & $\mathrm{~N}$ & Narrador \\
\hline pucele & S & Escoufle & 5477 & novele & S & 5478 & $\mathrm{~N}$ & Narrador \\
\hline puceles & $S$ & Charrete & 53 & noveles & S & 54 & $\mathrm{D}$ & Méléagant \\
\hline puceles & S & Charrete & 3490 & noveles & S & 3489 & $\mathrm{~N}$ & Narrador \\
\hline puceles & S & Escoufle & 6057 & noveles & S & 6058 & $\mathrm{~N}$ & Narrador \\
\hline puceles & S & Escoufle & 7988 & noveles & $\mathrm{S}$ & 7987 & $\mathrm{~N}$ & Narrador \\
\hline puceles & S & Escoufle & 9009 & noveles & A & 9010 & $\mathrm{~N}$ & Narrador \\
\hline puceles & $S$ & Escoufle & 1734 & vïeles & $\mathrm{S}$ & 1733 & $\mathrm{~N}$ & Narrador \\
\hline
\end{tabular}

Tabla 31. Rimas del sustantivo pucelle.

El análisis del comportamiento sintáctico del sustantivo nos revela un cambio significativo con respecto a la denominación demoiselle con la que desde el punto de vista semántico presentaba bastantes semejanzas: sólo se encuentran dos ocurrencias en todo el corpus funcionando como vocativo, concretamente en el discurso directo de Lanzarote para dirigirse a la que se nos presentará como hija del rey Bademagu y hermana de Meleagant: "Cil qui volantiers l'ot oïe li respont: «Dex vos beneïe, pucele, et doint joie et santé.” (Charrete, 2793 - 2795) 244

${ }^{244}$ Y Charrete, 6582. 
Este uso podría considerarse como una simple variación estilística o un recurso formal para cuadrar la métrica del verso si no fuera por tres razones: porque a esta joven de ilustre cuna se la nombra siempre con este apelativo, con un sintagma que recuerda su filiación o también en boca de Lanzarote llamándola amie: "se ne fust une moie amie, une pucele" (Charrete, 6876 - 6877); porque el caballero obsesionado con su dama la escucha con agrado desde el primer momento, cosa que no había ocurrido hasta este encuentro excepto cuando las jóvenes le proporcionaban información sobre Ginebra, aunque quizá sea porque en su saludo sabe atraer la atención del de la carreta aludiendo al disfrute de la amada; y porque tras rescatarlo de la torre se establece entre ellos un vínculo que parece ir más allá de la simple amistad. Pensamos que Chrétien pone los cimientos para que el continuador de su novela construya una salida a la sexualidad de Lanzarote dentro de los nuevos cánones sociales: la virgen salvadora frente a la dama que produce placer y también mucho dolor y cuyo amor es la causa latente de su encierro y alejamiento de la corte, la joven que le permite recuperar su dignidad y su fuerza y que podría ofrecerle un futuro estable y socialmente mejorado. Evidentemente se trata de una interpretación que nos aleja completamente de los márgenes corteses clásicos que se le habían impuesto a Chrétien y que parece estar en contradicción con el entramado simbólico por el que el reino de Bademagu representaría el otro mundo, pero creemos que no debemos descartarla pues apunta en la misma dirección que los usos que hemos observado para demoiselle.

Junto a este uso excepcional del sustantivo que nos ocupa cabría destacar el hecho de que en plural aparezca en bastantes ocasiones como uno de los elementos de una enumeración precedido o no de un determinante, siendo más habitual en Charrete que en Escoufle aunque también aquí lo encontraremos y prefiriéndose en estos casos a demoiselle del que existen menos ocurrencias en esta situación:

et d'uns et d'autres amassez

$\underline{\text { chevaliers }}$ et dames senees, 
et puceles del païs nees
Charrete, $3574-3576$

et as fenestres revont maint

chevalier, $\underline{\text { dames }}$ et puceles

Charrete, 6980 - 6981

pour le congié, querre les dames

et les puceles et les fames

as vavasors qui ml't l'amerent

Escoufle, 8651 - 8653

tant $i$ ot a cel'assamblee

chevaliers, puceles et $\underline{\text { dames }}$

Escoufle, $8902-8903$

La calificación también distingue pucelle de demoiselle ya que mientras que es excepcional la aparición de adjetivos junto a este último y no hay rastro de ningún participio pasado en función adjetiva, es relativamente común encontrar tales clases gramaticales en torno al primero: "la gentix pucele honeree" (Escoufle, 3994 y 5465), "li cuers a la gentil pucele" (Escoufle, 5413), "o la france pucele" (Escoufle, 5477), "la bele pucele bloie" (Escoufle, 6132).

La función que más frecuentemente desempeña en los contextos que hemos elegido es la de sujeto en oraciones independientes o principales coincidiendo en gran medida los verbos con los que habíamos señalado para demoiselle. Cabría destacar, sin embargo, las acciones de la doncella que rescata a Lanzarote al mostrarse más cuidadosa y afectiva en su hospitalidad que las que antes lo habían acogido: 
la pucele soëf le couche,

puis le baigne, puis le conroie

Charrete, $6662-6663$

Así como algunas de las acciones de Aelis cuya sensualidad invita al placer en la habitación de las doncellas del castillo de Saint Gilles o al recostarse sobre la hierba en el ya tradicionalmente incitante loaus amoenus:

la pucele s'est estendue

as flouretes et au deduit

Escoufle, 4412 - 4413

En Charrete se nos muestra el sustantivo en función de complemento de objeto directo dependiendo de verbos como amer (Charrete, 1675), baisier y acoler (Charrete, 6678); sin embargo también lo encontramos en contextos eróticos que nos ofrecen un aspecto menos trivial de los usos amorosos artúricos y a los que ya hemos hecho referencia, como es el hecho de que la mujer se convierta en un objeto de intercambio que el más poderoso puede tomar y que el débil debe ceder al aparecer como complemento de los verbos retenir (Charrete, 1712 - 1713), rendre: “et si li covendra, mau gré suen, la pucele randre" (Charrete, 1788 - 1789). En E scoufle se refuerza esta tendencia pero se cambian las condiciones básicas para pujar en el mercado del sexo femenino ya que se abandonan los requisitos de la fuerza física, la destreza guerrera y la virtud caballeresca, quizá más equitativos para el individuo, por los de la nobleza de cuna y la voluntad del padre y de la corte: "quant il a si bas home alie par mariage la pucele" (Escoufle, 2296 - 2297). En cualquier caso, en esta obra, la autonomía de la mujer que huye con su amante por voluntad propia pronto queda diluida — de hecho la legislación consideraba estas acciones siempre como un rapto en el que el varón era culpable de atentar contra los bienes familiares—, ${ }^{245} \mathrm{y}$ como en el caso de

${ }^{245}$ Cf. M. Rodríguez Gil, Las posibilidades de actuación jurídico-privadas de la mujer soltera medieval, L a condición de la mujer en la E dad M edia, op. cit., p. 109 - 111. 
Charrete es siempre el hombre el que conduce a la doncella hacia un destino más o menos incierto: "li quens enmaine la pucele a son cousin" (Escoufle, 8021 - 8022), "que cil estoit teus chevaliers qui la pucele en ot menee" (Escoufle, 8530 - 8531); una tendencia que solamente se invierte cuando Aelis se procura una acompañante de muy baja cuna o cuando es ya una dama, condesa de Normandía y futura emperatriz, y puede a su vez llevar a nuevas tierras y probablemente a altos lechos a jóvenes doncellas, hijas de los mejores hombres del condado. ${ }^{246}$

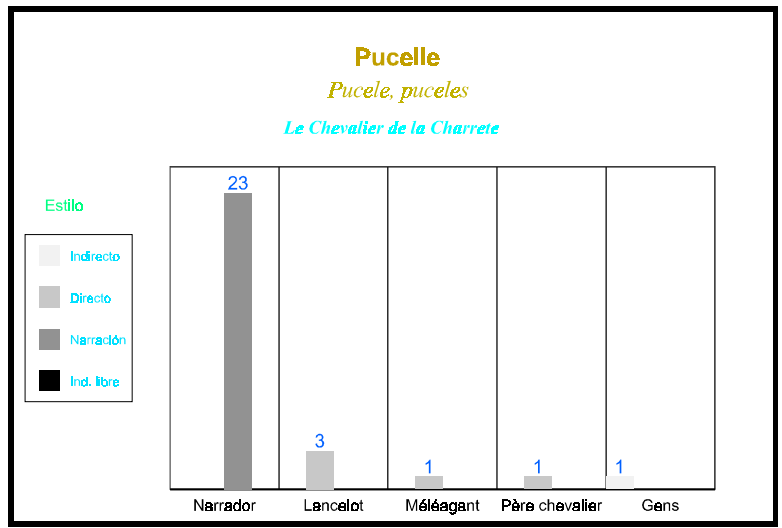

Fig. 11. Comportamiento estilístico del sustantivo pucelle en Charrete.

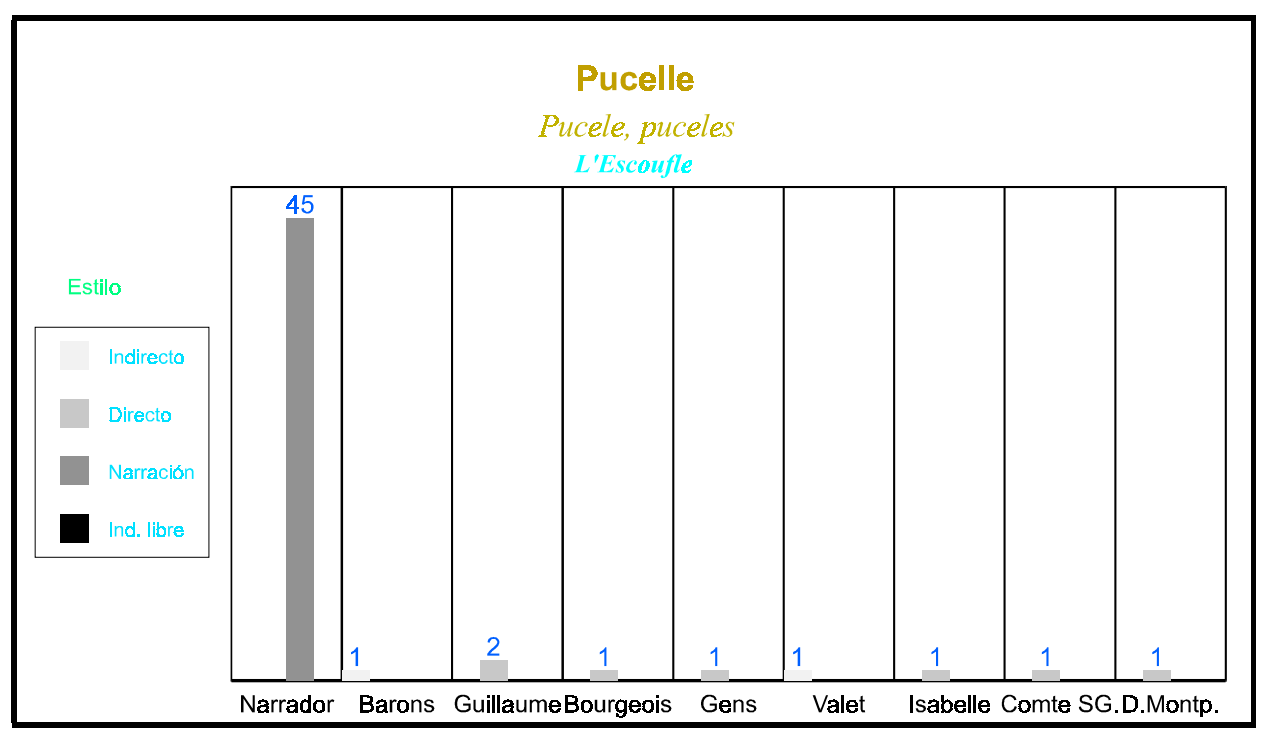

Fig. 12. Comportamiento estilístico del sustantivo pucelle en Escoufle.

${ }^{246}$ Escoufle, 8661 - 8662, 8820 - 8821. 
La observación de los datos que nos presentan estos gráficos sostiene la generalización del nuevo modelo de amada y aún en mayor medida la tesis de una sustitución como variante estilística en el discurso narrativo del sustantivo demoiselle.

Meschine tiene en lengua y así se presenta en nuestro corpus las mismas posibilidades significativas que pucelle aunque sobre este término no ejerció su influencia el tabú de la virginidad pudiendo aludir a cualquier mujer joven, noble como la ninfa Eco en Rose: “ensi si out de la meschine qu'il avoit devant escondite son guerredon et sa merite” (Rose, 1502 - 1504); o mujer del pueblo como colegimos de su aparición junto a demoiselle: "que dameisele ne meschine, se chevaliers la trovast sole" (Charrete, 1304 - 1305).

\subsection{Femme, épouse, «oison» y «mollien».}

Grisay señala que el vocablo femme posee dos rasgos semánticos fundamentales: ser hembra y pertenecer al género humano, ${ }^{247}$ ambos establecidos sobre una base biológica; en nuestro corpus figuran efectivamente ocurrencias de este término que se integran en el registro natural si bien con algunas particularidades contextuales. A ellos se añadió otro que podremos considerar en principio secundario y que es de orden social: estar unida en matrimonio, legítimamente, a un hombre. Este uso tiene un papel dominante en nuestro corpus, sobre todo en E scoufle donde ya hemos señalado la importancia de las estructuras dinásticas así como de las luchas de poder cuyo telón de fondo es la renovación del orden simbólico que regula la oposición endogamia/exogamia entre las castas guerrera y cortesana. ${ }^{248}$

\footnotetext{
247 0p. dit., p. 56.

${ }^{248}$ F. Cardini habla de una "mentalidad exogámica" que en los siglos XII y XIII empujará a desarrollar el amor cortés como marco de los sueños de elevación social mediante el matrimonio y el asentamiento para los grupos de jóvenes pertenecientes a la pequeña aristocracia que vagaban fuera de los territorios donde habían nacido, cf. El guerrero y el caballero, en El hombre medieval, J. Le Goff (ed.). Madrid: Alianza, 1990, p. 102.
} 
Además comparte el mismo rasgo restrictivo con los otros tres términos que estudiamos en este apartado por lo que hallamos una cierta diversificación expresiva. Dos de ellos, mullier y oisor, habían caído en desuso o estaban en franca decadencia y es probable que se utilicen en los textos por condicionamientos formales ya que mullier se presenta en la rima en cinco de sus seis ocurrencias y oisor en una de las dos que aparecen en E scoufle.249 $\mathrm{Y}$ en este segundo caso habría que agregar los estilísticos al conferir un tono arcaizante y ceremonioso al discurso del emperador en el momento, y sólo entonces, en el que ofrece a su hija en matrimonio:

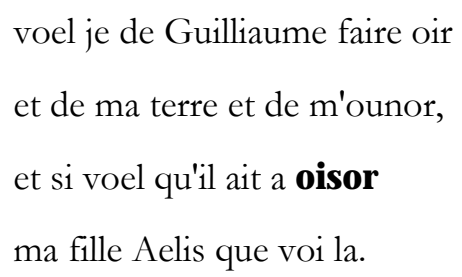

voel je de Guilliaume faire oir et de ma terre et de m'ounor, et si voel qu'il ait a oisor ma fille Aelis que voi la.

Escoufle, 2150 - 2153

(...) n'en doutés mie que il n'ait ma fille et m'amie

a oisor, ce sachiés de voir.

Escoufle, 2173 - 2175

Los cuatro vocablos a los que nos referimos suelen aparecer en fórmulas o en agrupaciones variables que no encontraremos para los equivalentes masculinos y que revelan sistemáticamente la supeditación de la mujer al hombre, sea el esposo, el padre o el señor, en nuestro caso el emperador.

En ellas el término que presenta lo que ahora conocemos como estado civil funciona como complemento preposicional del verbo cuyo sujeto es el varón y cuyo complemento directo es la mujer en cuestión:

249 Ounor - oisor, v. 2151 - 2152. 
1. Avoir $+\mathrm{a}+$ oisor/femme

li vavasors avoit a fame
une bien afeitiee dame

Charrete, 2045 - 2046

si li mande por voir qu'il viaut

que li quens Richars l'ait a fame.

Escoufle, 1695 - 1701

et qu'il se lairoient ains traire

les dens, ains qu'il l'eüst a fame.

Escoufle, 2754 - $2755^{250}$

2. Prendre $+\mathrm{a}+$ mollier $/$ femme

$\mathrm{k}^{\prime}$ il avoit une haute dame

en ceste terre prise a feme

Escoufle, 3495 - 3496

» Rois, tu la preïs a mollier.

» $\mathrm{Si}$ que virent ti chevalier.

Tristan, 2563 - 2564

\section{Doner $+\mathrm{a}+$ femme}

puis li dona li emperere

a feme la dame de Jenvres

Escoufle, 7488 - 7489

250 También Escoufle 2947. 
4. Reçoivre + com + [posesivo] + femme

(...) de vostre main

la reçui je comme ma feme

Escoufle, 3044 - 3045

El posesivo tiene un papel fundamental como marca de las relaciones unidireccionales dominantes en el matrimonio tal como nos muestra el texto de Tristan donde los sustantivos mollier y femme van siempre precedidos, con dos excepciones, ${ }^{251}$ de un artículo posesivo, ya sea en el discurso del rey: "qu'il veut faire dedenz un ré ardoir son nevo et $\underline{\text { sa }}$ feme" (Tristan, 882 - 883); en el de Tristán: “que il me donst itel corage que je lais a mon oncle sa feme en pais" (Tristan, 2186 - 2188); en el del leproso: “tu veus faire justise, $\underline{\text { ta }}$ feme ardoir en ceste gise” (Tristan, 1165 - 1166); o en la propia narración: "son oncle, qui a fait tel tort, $\underline{\text { sa }}$ feme mise a tel descort" (Tristan, 2197 - 2198).

También lo encontramos en construcciones en las que los términos a los que nos referimos aquí funcionan como complemento directo o atributo, precedido por un posesivo, adquiriendo el conjunto un sentido particular:

\section{Prendre + [posesivo] + femme}

n'ainc la ou rois Mars prist Yseut

n'ot tant de joie com la eut

ou li quens Richars prist sa feme.

Escoufle, $1715-1717$

s'ele espargnast le conte tant

que ses fiex eüst pris sa feme

Escoufle, 2412 - 2413

251 Tristan 75 y 2563. 
En Tristan esta construcción expresa la readmisión de la reina y esposa en la corte, y en el lecho, después de haber sido repudiada y de haber sufrido el largo exilio junto a Tristán: "au loement de ses vasaus preïst sa feme la cortoise" (Tristan, 2402 - 2403); "n'i a baron de Cornoualle ne die: "Rois, ta feme pren" (Tristan, 2624 - 2625). No podemos saber si en E scoulle en el verso 1715 que acabamos de citar y en el que aparece el mismo verbo, se hace referencia a la desbordante alegría del retorno de Iseo o bien a las nupcias con el rey para las que se utiliza la construcción [prendre + a + mollier] recogida más arriba.

\title{
2. Estre + [posesivo] + espouse $/$ femme.
}

\author{
et l'une est de l'autre jalouse \\ si con s'ele fust ja s'espouse
}

Charrete, $6017-6018$

En las construcciones atributivas, la referencia a la mujer ocupa el sintagma sujeto y podría parecer que la sumisión a la que hemos hecho referencia se ha disipado. No creemos que sea así ya que la presencia del posesivo es suficiente en este caso para marcarla, máxime si tomamos en consideración el único ejemplo en el que un hombre aparece en una construcción sintáctica y semánticamente similar, en la que sin embargo el léxico y el encadenamiento sintagmático contribuyen a poner de relieve la supremacía masculina:

$$
\begin{aligned}
& \text { Comment! J'arai d'ami le non } \\
& \text { et vo sire ert amis et sire? }
\end{aligned}
$$

Escoufle, 5842 - 5843

En otro orden de cosas la combinación redundante fame espouse, única en el corpus y variante del grupo fame espousee, se utiliza como en otros textos medievales para reforzar la noción de legitimidad: 
Donne doit ma bele fille estre

proçainement $\underline{\mathrm{sa}}$ feme espouse?

Escoufle, 2710 - 2711

En Escoufle sirve para que el emperador justifique ante la corte la intimidad en la que viven Guillermo y Aelis antes de su matrimonio. Convivencia por otro lado plenamente avalada por una costumbre que pervivirá en las capas populares de la sociedad hasta el siglo XVII y que permitía el conocimiento mutuo de los futuros esposos pese a que la Iglesia intentase restringirla. En este roman no son razones religiosas o morales las que esgrimen los barones traidores para suprimirla, sino que reaparecen las imposiciones genealógicas pues la intimidad cotidiana suponía un grave riesgo para la virginidad — sin que este motivo se presente explícitamente en su discurso- y por lo tanto para un posible matrimonio endogámico, es decir, dentro del mismo estrato de la nobleza.

Siempre en E scoufle nos llama la atención la combinación amor matrimonio gracias a los pares léxicos: feme / amis, feme / amie. Esta unión es poco frecuente puesto que los pares o tríos de formas sirven para reforzar la legitimidad de la unión, tal como hemos visto más arriba; es más esta relación de índole amorosa no durará mucho ya que una vez reintegrada la pareja en la sociedad noble, ante la perspectiva de la unión legalmente reconocida - la unión de hecho o cuando menos el consentimiento mutuo que la Iglesia intentaba imponer como base del matrimonio, especialmente entre los grupos sociales más elevados, está presente en el segundo ejemplo—, y tras una noche de amor de la que nada se nos dice pero que no tendrá secuelas, las relaciones entre los enamorados se entibiarán y ya tan sólo tendrán en común las frías etiquetas de los títulos de nobleza compartidos.

cele qui dut estre sa feme

ne set mot qu'il soit ses amis

Escoufle, 7370 - 7371 


$$
\begin{aligned}
& \text { cele qui sist delés le conte, } \\
& \text { qui estoit sa feme et s'amie }
\end{aligned}
$$

Escoufle, 7498 - 7499

La ausencia de artículo posesivo da al sustantivo un valor general:

\section{- Doner femme.}

Siguiendo con su tendencia de hacer explícitos aquellos mensajes que otros autores ocultan tras un entramado simbólico, Jean Renart reúne en un plano de igualdad las dos máximas aspiraciones, probablemente poco latentes, de muchos caballeros de la época, conseguir tierras y una mujer. Pero, puesto que las posibilidades de conquista y reparto se estaban extinguiendo en los territorios que hoy conforman el norte de Francia — de ahí las expediciones de los cruzados a Tierra Santa y a los territorios del sur con la excusa de acabar con la herejía cátara, y más tarde los trabajos mercenarios para el imperio bizantino contra los turcos - la solución más cómoda y placentera es la propuesta en las obras de ficción: los esponsales y posterior matrimonio con una señora soltera o viuda o con una heredera, ${ }^{252}$ que también se dio en la realidad de la época al obligarse de hecho a las herederas de las tierras meridionales de Provenza a contraer matrimonio con nobles vasallos del rey de Francia. ${ }^{253}$

$$
\begin{aligned}
& \text { Et bien sache ki c'onques l'oie } \\
& \text { que je vos donrai feme et terre }
\end{aligned}
$$

Escoufle, 1670 - 1671

\footnotetext{
${ }^{252}$ Cf. R. Fossier, La femme dans les sociétés occidentales, CCM, n 2 - 3, vol. XX, 1977, p. 99.

253 Según los Estatutos de Pamiers recogidos por P. Labal, "las viudas y herederas nobles «que poseyeran castra y fortificaciones» no podrán contraer matrimonio con «un indígena de esta tierra hasta dentro de diez años sin la autorización del conde. Pero pueden casarse con los franceses que quieran sin requerir el consentimiento»." L os cátaros: herejía y crisis sodial. Barcelona: Grijalbo Mondadori, 1995, p. 180.
} 
Hasta ahora femme y sus sinónimos no nos han permitido observar más que relaciones de dependencia ya fueran contractuales o de franca posesión. Sólo los amores de Guillermo y Aelis nos han dejado entrever, o por mejor decir suponer, los contactos carnales que como regla son inherentes a la comunidad matrimonial. Mas será una mujer poco ejemplar, muy alejada del modelo de perfección cortés, mentirosa y traicionera, la que exhiba su deseo y aproveche el placer que proporciona a su marido para hacer su voluntad:

\section{L'empereris l'acole et baise et puis les ex et puis la face: samblant fait qu'ele velt que face de li com de sa feme chiere.} He! Dix, cis samblans, ceste chiere, n'est pas amors, ains est losenge.

Escoufle, 2872 - 2877

Es el único caso en que un adjetivo que califica la relación entre esposo y esposa acompaña al sustantivo femme convirtiéndose a nuestro parecer en la forma léxica que delimita la extensión de la expresión dándole un sentido claramente erótico. Y de nuevo aquí llama nuestra atención el que a pesar de ser la mujer la que incita y excita al varón a realizar la cópula, es él en última instancia el único agente del acto carnal. Le deja a ella los prolegómenos y las caricias posteriores al coito, aunque tampoco éstas serán fruto de la pasión o el amor sino de su victoria sobre la voluntad del emperador. Esta noche de seducción en que la mujer muestra su peor faceta, incluso más nociva que el adulterio por lo que concierne a nuestros relatos, será fatal y tendrá dos consecuencias en las que se implican lo erótico y lo genealógico: la fuga de Guillermo y Aelis o según las leyes de la época el rapto de la joven, y la repugnancia moral y física del emperador por su esposa a la que rechaza expresando el final de su atracción: "mais por nul avoir ne li pot puis sa feme plaire.” (Escoufle, 4232 - 4233). 
El sustantivo femme en su sentido general aparece en dos usos que tienen una relación con el amor o el deseo sexual. En primer lugar forma parte de frases proverbiales, ${ }^{254}$ como la utilizada por el caballero enamorado cuya pasión, representada por los verbos ardoir et anflamer, aumenta con los obstáculos: “car qui blasme, bien le savez, son voloir a home n'a fame, plus en art et plus en anflame.” (Charrete, 1758 - 1760); o la que evoca Meleagant al creer que sólo él es privado del goce del cuerpo de Ginebra y otros lo obtienen pese al cuidado con el que se la vigila: "bien est voirs que molt se foloie qui de fame garder se painne, son travail i pert et sa painne; qu'ainz la pert cil qui plus la garde" (Charrete, 4758 - 4761).

En segundo lugar y sólo en los textos del siglo XIII observamos en la narración una determinación intensiva, superlativa, que otorga a los personajes femeninos, ya sea Aelis o algunas de las abstracciones de Rose, el máximo esplendor y la posesión de la nobleza suprema. Guillaume de Lorris toma en consideración sobre todo la belleza física, ${ }^{255}$ de una manera estereotipada, reutilizando los clichés puestos a punto por la narrativa, que también se encuentran en Escoufle, y que parten de una visión global de la mujer: "ele fu une clere brune, gente ert et bele et avenant, je ne sai fame mieuz pleisant” (Rose, 1238 - 1240). Pero también lo hace a partir de la anatomía femenina: "il n'esteüst en nule terre nul plus bel cors de fame querre" (Rose, 547 - 548), que describe esporádicamente cargada de sensualidad al evocar la combinación de las percepciones visual y táctil, y con el realismo que le otorgan las contraposiciones de elementos desagradables relacionados con la enfermedad, la pobreza y probablemente la vejez:

le col ot de bone moison,

la char plus soëf que toison,

\footnotetext{
254 También hay una exclamación que sería asimilable en cierta medida a éstas: "Ahi! ahi! feme que fame com le set ore bien atraire!” (Escoufle, 2880 - 2881)

255 Apunta también algunas cualidades corteses pero parecen interesarle menos. En el caso de Richesse también apela al superlativo para referirse a la riqueza de sus adornos: "onc fame plus riche ne ceint" (Rose, 1066)
} 
si n'i ot bube ne malem:

n'avoit jusqu'en Jerusalem

fame qui plus bel col portast;

polis ert et soés au tast.

Sa gorge estoit autresi blanche

Rose, $537-543$

Miembros que el narrador dice recordar y cuya imaginación le produce una sensación placentera:

$$
\begin{aligned}
& \text { mout grant douçor au cuer me touche, } \\
& \text { si m'aït Dex, quant il me menbre } \\
& \text { de la façon de chascun menbre, } \\
& \text { qu'il n'ot si bele fame ou monde } \\
& \text { Rose, } 1010 \text { - } 1013
\end{aligned}
$$

Aelis también supera a todas las mujeres en belleza física: "Il n'est feme qui cesti vaille, fait cascuns, de cors et de vis." (Escoufle, 6013 6014). ${ }^{256}$ Aunque los rasgos más interesantes puestos de relieve por estas construcciones son los que se refieren a sus conocimientos, obligaciones femeninas y pequeños placeres para los que la rodean y de los que "ele en $\underline{\text { set }}$ plus c'une autre feme" (Escoufle, 2071)257, habilidades tanto manuales

256 Iseo también se convierte en punto de referencia para cantar las alabanzas de Aelis, adoptando Renart la técnica panegírica del "sobrepujamiento" estudiada en la tradición clásica y medieval por Curtius, L iteratura europoea y E dad M edia L atina. Madrid: F.C.E., 1984, vol. 1, p. 235 - 239:

$$
\begin{aligned}
& \begin{array}{l}
\text { ne puis le tans } \text { Yseut la blonde } \\
\text { ne fu mais vostre pers veüe } \\
\text { Escoufle, } 3449
\end{array}-3450 \\
& \text { pour veoir celi cui Ysiels } \\
& \text { ne sambla onques de biauté } \\
& \text { Escoufle, } 8848 \text { - } 8849
\end{aligned}
$$

257 También Escoufle 5480, 5511, 5512 - 5513, 5822 - 5823, 6017 y 5459 - 5461 donde es la propia Aelis en estilo directo la que pondera sus cualidades: "k'il n'est feme ki tant en sache: d'orfrois, de çainture, d'atache, de ce faire ai je tot le pris." 
- bordar, coser o lavar cabezas - como artísticas e intelectuales — narrar historias o cantar-; también a su bondad y piedad religiosa que contrastan con su riqueza: "avuec le grant avoir qu'ele eut n'iert il si boine feme lors" (Escoufle, 1500 - 1501). Todo lo cual hace de ella la más perfecta de entre los laicos y la más querida entre propios y extraños:

\author{
ne cuit pas que il fust feme onques \\ $\underline{\text { si amee d'estraignes gens }}$
}

Escoufle, 6066 - 6067

et u siecle n'avoit tel feme
com estoit me dame Aelis

Escoufle, 8520 - 8521

Los pares de rimas son prácticamente idénticos a los de dame - lo que es lógico si tenemos en cuenta la coincidencia de los sonidos y el hecho de que la dama solía ser una mujer casada—. Podemos destacar la asociación feme / reigne en Tristan que no se daba con dame; la interpretación de este juego formal nos parece más compleja que en E scoufle, si bien es cierto que la frágil estabilidad de las relaciones feudales en el reino depende en varias ocasiones de las acciones y de las palabras de la reina. Respecto a espouse y a mollier encontramos pares muy sugerentes como los formados con jalouse $y$ chevalier o baillier y essilier pero el hecho de que aparezca una única asociación no nos permite aventurar ninguna interpretación desde un punto de vista temático o retórico.

\begin{tabular}{lllllllll}
\hline FORMA & CA & BD & NV & RIMA & CA2 & NV2 & D & PERS \\
\hline fame & S & Escoufle & 2755 & ame & S & 2756 & I & Traîtres \\
fame & S & Escoufle & 2880 & ame & S & 2879 & N & Narrador \\
feme & S & Escoufle & 2423 & ame & S & 2424 & N & Narrador \\
feme & S & Escoufle & 3045 & ame & S & 3046 & D & Guillaume \\
fame & S & Charrete & 1759 & anflame & V & 1760 & D & Chevalier \\
feme & S & Tristan & 3067 & cane & S & 3068 & D & Roi Marc \\
fame & S & Charrete & 2045 & dame & S & 2046 & N & Narrador
\end{tabular}




\begin{tabular}{lllllllll} 
fame & $\mathrm{S}$ & Charrete & 2511 & dame & $\mathrm{S}$ & 2512 & $\mathrm{~N}$ & Narrador \\
fame & $\mathrm{S}$ & Escoufle & 1699 & dame & $\mathrm{S}$ & 1700 & $\mathrm{I}$ & Empereur \\
fame & $\mathrm{S}$ & Escoufle & 5254 & dame & $\mathrm{S}$ & 5253 & $\mathrm{D}$ & Mère Isabelle \\
feme & $\mathrm{S}$ & Escoufle & 1778 & dame & $\mathrm{S}$ & 1777 & $\mathrm{~N}$ & Narrador \\
feme & $\mathrm{S}$ & Escoufle & 2947 & dame & $\mathrm{S}$ & 2948 & $\mathrm{D}$ & Traîtres \\
feme & $\mathrm{S}$ & Escoufle & 3496 & dame & $\mathrm{S}$ & 3495 & $\mathrm{I}$ & Chevalier \\
feme & $\mathrm{S}$ & Escoufle & 6017 & dame & $\mathrm{S}$ & 6018 & $\mathrm{~N}$ & Narrador \\
feme & $\mathrm{S}$ & Escoufle & 7370 & dame & $\mathrm{S}$ & 7369 & $\mathrm{~N}$ & Narrador \\
feme & $\mathrm{S}$ & Escoufle & 8284 & dame & $\mathrm{S}$ & 8283 & $\mathrm{~N}$ & Narrador \\
feme & $\mathrm{S}$ & Escoufle & 8350 & dame & $\mathrm{S}$ & 8349 & $\mathrm{~N}$ & Narrador \\
feme & $\mathrm{S}$ & Escoufle & 8520 & dame & $\mathrm{S}$ & 8519 & $\mathrm{~N}$ & Narrador \\
femes & $\mathrm{S}$ & Escoufle & 150 & dames & $\mathrm{S}$ & 149 & $\mathrm{~N}$ & Narrador \\
fames & $\mathrm{S}$ & Escoufle & 8652 & dames & $\mathrm{S}$ & 8651 & $\mathrm{~N}$ & Narrador \\
feme & $\mathrm{S}$ & Escoufle & 8899 & deme & $\mathrm{S}$ & 8900 & $\mathrm{~N}$ & Narrador \\
feme & $\mathrm{S}$ & Tristan & 287 & reigne & $\mathrm{S}$ & 288 & $\mathrm{~L}$ & Roi Marc \\
feme & $\mathrm{S}$ & Tristan & 883 & reigne & $\mathrm{S}$ & 884 & $\mathrm{~N}$ & Narrador \\
feme & $\mathrm{S}$ & Tristan & 1115 & reigne & $\mathrm{S}$ & 1116 & $\mathrm{D}$ & Dinas \\
feme & $\mathrm{S}$ & Tristan & 4124 & reigne & $\mathrm{S}$ & 4123 & $\mathrm{~N}$ & Narrador \\
feme & $\mathrm{S}$ & Escoufle & 2071 & roiame & $\mathrm{S}$ & 2072 & $\mathrm{~N}$ & Narrador \\
feme & $\mathrm{S}$ & Escoufle & 1717 & roiaume & $\mathrm{S}$ & 1718 & $\mathrm{~N}$ & Narrador \\
\hline
\end{tabular}

Tabla 32. Rimas del sustantivo femme.

\begin{tabular}{lllllllll}
\hline FORMA & CA & BD & NV & RIMA & CA2 & NV2 & D & PERS \\
\hline espouse & S & Charrete & 6018 & jalouse & A & 6017 & N & Narrador \\
espouse & S & Escoufle & 2711 & espouse & V & 2712 & D & Empereur \\
\hline
\end{tabular}

Tabla 33. Rimas del sustantivo épouse.

\begin{tabular}{lllllllll}
\hline FORMA & CA & BD & NV & RIMA & CA2 & NV2 & D & PERS \\
\hline mollier & S & Tristan & 75 & chier & A & 76 & D & Iseut \\
mollier & S & Tristan & 2563 & chevalier & S & 2564 & D & Tristan \\
mollier & S & Tristan & 2746 & huchier & I & 2745 & N & Narrador \\
mollier & S & Tristan & 3127 & ballier & I & 3128 & D & Roi Marc \\
mollier & S & Tristan & 4279 & essillier & I & 4280 & D & Félons \\
\hline
\end{tabular}

Tabla 34. Rimas del sustantivo «mollier».

En cuanto al funcionamiento sintáctico cabe recordar en primer lugar los usos como complemento atributo, ya del sujeto, construido sin preposición y dependiendo del verbo estre, ya del complemento de objeto directo, introducido por una preposición y acompañando a otros verbos, con el sentido de «esposa»; en contadas ocasiones el sustantivo femme tiene en esta función el valor más general de «mujer» coincidiendo en las descripciones de la calidad social de la dama, en estrecha relación con el uso superlativo 
mencionado más arriba para los textos del siglo XIII: “ml't par pert estre haute fame” (Escoufle, 5254); “rice fame sui et poissanz” (Rose, 582).

Más abundantes son los usos como complemento de objeto directo en los que éste no sirve para otorgar el sentido de «desposan» al verbo del que depende. En Tristan estas construcciones nos muestran de nuevo una marcada relación de dependencia de la mujer con respecto al varón. Este puede abandonarla y retomarla, tanto si se trata del amante (Tristan, 2188 y 2198) como del esposo, quien a su vez está a expensas de sus vasallos: "au loement de ses vasaus preïst sa feme la cortoise" (Tristan, 2402 - 2403), "n’i a baron de Cornoualle ne die: «Rois, ta feme pren” (Tristan, 2624 - 2625), e incluso puede acabar con su vida como nos muestran las ocurrencias construidas con el verbo ardoir (Tristan, 883 y 1166). Mientras que la relación de absoluta dependencia aparece atenuada en Escoufle al encontrarse en construcciones convencionales evocando la asistencia a reuniones cortesanas que también hallamos en la obra de Béroul, 258 o quedar oculta antes del matrimonio porque en el discurso directo de caballeros y clérigos se presenta como imprescindible el amor de la mujer para que el hombre pueda poseerla legalmente:

$$
\begin{aligned}
& \text { Cuidiés vous dont que s'el n'amast } \\
& \text { cest home, qu'il peüst avoir } \\
& \text { si bele feme? Nenil voir. }
\end{aligned}
$$$$
\text { Escoufle, } 8252 \text { - } 8254
$$

En Rose no queda ningún rastro de la subordinación entre amantes, no así por lo que se refiere a las familias y a la sociedad, dejando paso al servicio del varón a la mujer, ya sea directo: "toutes fames ser et honore" (Rose, 2103), ya indirecto al enfrentarse a los que la calumnian como Male Bouche:259

\footnotetext{
258 Véase Tristan, 4123 - 4124 y Escoufle, 8651 - 8653, 8898 - 8899.

259 Véase Rose, 3884.
} 
et se tu oz nul mesdisanz

qui aille fame despisant,

blasme le et di qu'il se taise

Rose, 2105 - 2107

Funcionando como sujeto, el sustantivo femme se encuentra principalmente en E scoufle en las frases que hemos calificado de intensivas, en ellas el verbo suele ser un impersonal. Estas se reproducen en Rose, donde encontramos una interesante excepción que recuerda bajo forma de mandamiento en el discurso directo del dios Amor uno de los anhelos fundadores de la poética y de la erótica de los trovadores, la dulce acogida de la dama:

\author{
Bien doit fame aucune pitié \\ avoir de celui qui endure \\ tel mal por lui, se mout n'est dure.
}

Rose, 2518 - 2520

En los textos del siglo XII creemos digno de destacar que ninguno de los términos funciona como sujeto en Charrete y sólo en dos ocasiones lo hacen femme y mollier en Tristan, en ambas ligados a la unión adúltera con un valor universal, aunque en el primer caso el término posee su sentido más general en el discurso directo de Ogrin, quien hace equivalentes la unión del hombre y de la mujer y el pecado: "qant home et feme font pechié" (Tristan, 2345), y en el otro, el sentido inequívocamente restringido del vocablo es utilizado por Iseo, citando unas supuestas palabras de su madre en estilo indirecto con el fin de justificar mediante el vínculo matrimonial su equívoco cariño por Tristán:

et disoit ce, que ja mollier

n'en avroit ja son seignor chier

qui les parenz n'en amereit

Tristan, $75-77$ 
Por lo que se refiere a la sintaxis proposicional destacaremos el elevado número de subordinadas en las que encontramos estos sustantivos frente a los términos estudiados hasta ahora que apreciábamos en un mayor número de ocasiones en proposiciones principales o independientes.

- Proposiciones relativas:

El vocablo femme que hemos visto funcionar más arriba como antecedente de subordinadas relativas con un valor al tiempo restrictivo y superlativo, aparece también en el seno de este tipo de proposiciones siendo de destacar el que en los textos del siglo XII el pronombre relativo no tiene antecedente, conformando las llamadas relativas indefinidas o sustantivas: ${ }^{260}$

$$
\begin{aligned}
& \text { Beaus oncles, poi me deconnut } \\
& \text { qui de ta feme me mescrut } \\
& \text { Tristan, } 251 \text { - } 252 \\
& \text { car qui blasme, bien le savez, } \\
& \text { son voloir a home n'a fame, } \\
& \text { plus en art et plus en anflame } \\
& \text { Charrete, } 1758 \text { - } 1760 \\
& \text { bien est voirs que molt se foloie } \\
& \text { qui de fame garder se painne } \\
& \text { Charrete, } 4758 \text { - } 4759
\end{aligned}
$$

En E scoufle, por el contrario, las proposiciones relativas son adjetivas, con la particularidad de que entre ellas encontramos varias en las que el antecedente es un pronombre demostrativo que representa a Aelis en una variante estilística de referencia, propia de la narración:

\footnotetext{
260 Encontramos también proposiciones relativas referidas a un antecedente con valor adjetivo, cf. Tristan, 4124 y 3126 - 3127 para el vocablo mollier: “que vos ö̈stes l'escondit que mes niés fist de ma mollier".
} 
cele qui dut estre sa feme

ne set mot qu'il soit ses amis

Escoufle, 7370 - 7371

cele qui sist delés le conte,

qui estoit sa feme et s'amie,

el nel connoist encore mie

Escoufle, 7498 - 7500

\section{- Proposiciones completivas:}

En E scoufle las proposiciones completivas en las que aparecen estos sustantivos recogen, al igual que muchas de las relativas, las construcciones que magnifican las virtudes de Aelis. En Tristan, introducidas o no por una conjunción, y a excepción de la ya señalada en la que Iseo retoma el discurso materno sobre el amor familiar, tienen como características fundamentales el depender de verbos de discurso, de pensamiento o de voluntad ${ }^{261}$ cuyo sujeto es el rey Marco y el funcionar como complemento de objeto directo. Estas podrían confirmar la tendencia del esposo a enseñorearse del destino de la mujer, aunque también encontremos ejemplos en los que esa voluntad se ve cuando menos distraída y reconducida por los engaños de los amantes: "en son cuer dit or croit sa feme et mescroit les barons du reigne" (Tristan, 287 288)

$$
\begin{aligned}
& \text { li rois lor a dit et monstré } \\
& \text { qu'il veut faire dedenz un ré } \\
& \text { ardoir son nevo et sa feme }
\end{aligned}
$$

Tristan, $881-883$

\footnotetext{
261 En este caso el infinitivo puede también constituir el núcleo verbal de una perífrasis funcionando entonces el verbo voloir como un auxiliar modal.
} 
pensez que de si franche feme,

qu'il amena de lointain reigne,

que lui ne poist s'ele est destruite?

Tristan, 1115 - 1117

«Sire, tu veus faire justise,

ta feme ardoir en ceste gise

Tristan, $1165-1166$

par Cornoualle fait huchier

li rois s'acorde a sa mollier

Tristan, $2745-2746$

- Proposiciones circunstanciales:

De entre las proposiciones subordinadas circunstanciales las más abundantes son las que expresan temporalidad. Las encontramos tanto en Tristan como en E scoufle, si bien en esta obra aparece un caso en el que la locución conjuntiva ainz que [A dv. + $\mathbf{C}$ onj.] se encuentra ya en una fase de transición hacia la expresión de la comparación, evolución que Ménard data a mediados del siglo XIII:262

et qu'il se lairoient ains traire

les dens, ains qu'il l'eüst a fame

Escoufle, 2754 - 2755

En Tristan las temporales introducidas por quant representan el momento en el que se comete el adulterio: "a Segoçon, qu'il escolla qant o sa feme le trova" (Tristan, 279 - 280). ${ }^{263}$ Mientras que en Escoufle, las

262 Op. at., p. 218.

263 También 2345 . 
conjunciones temporales datan la acción con respecto a otra ulterior que no es otra que el matrimonio de Aelis y de Guillermo, en un proceso que se augura sembrado de los obstáculos que los cortesanos interponen para su celebración:

$$
\begin{aligned}
& \text { s'ele espargnast le conte } \underline{\operatorname{tant}} \\
& \text { que ses fiex eüst pris sa feme }
\end{aligned}
$$

Escoufle, 2422 - 2423

Las proposiciones causales se diferencian en sus características formales y estilísticas en función de la época del texto, aunque el distanciamiento no afecta a las cualidades expresivas, pues en todas se apunta una explicación a lo dicho en la proposición principal. Así mientras Béroul utiliza la conjunción car, que se ha descrito como más intelectual y literaria: “a grant mervelle s'en esjot, qar sa feme forment amot" (Tristan, 2519 - 2520), los textos del siglo XIII ${ }^{264}$ prefieren la conjunción que, considerada más familiar, ${ }^{265}$ aunque quizás lo hagan por cuestiones puramente métricas ya que permite la elisión:

«Dame, fait il, je vos en rent moi et mon cuer en guerredon, k’ainc mais feme ne fist tel don a nul home de mon afaire.»

Escoufle, 4498 - 4501

bien sachiés que jou referoie joiaus de fil d'or et de soie;

k'il n'est feme ki tant en sache:

d'orfrois, de çainture, d'atache

Escoufle, 5457 - 5460

\footnotetext{
${ }^{264}$ Cf. Rose, 1013: "qu'il n'ot si bele fame ou monde"

265 Cf. Ménard, op. at., p. 211.
} 
Entre las hipotéticas encontramos un ejemplo que podríamos encuadrar también en el dominio de las explicativas, introducido por la locución come si [Adv. + C onj.]: “et l’une est de l'autre jalouse si con s'ele fust ja s'espouse" (Charrete, 6017 - 6018), y en Escoufle una que podríamos considerar canónica si no fuera por la aparición de una coordinación que une dos hipotéticas, combinando el dominio de lo sobrenatural y de lo puramente físico, aunque en realidad la segunda hipótesis depende en la mentalidad cristiana de la primera: "encore iert il sire de Rome, se Dieu plaist, et sa feme vit" (Escoufle, 7926 - 7927); aquí también nos parece interesante el hecho de que pese al matrimonio legalizado y consumado la dependencia en la mejora social se mantenga y sea necesario que la heredera legítima esté en vida para que el cónyuge pueda acceder al trono, si bien esta será la única ventaja de la mujer, quien deberá quedar a la sombra de su esposo en lo que a cuestiones políticas se refiere.

Cerraremos este recorrido por las proposiciones subordinadas en las que se encuentran los sustantivos que ahora nos ocupan con las comparativas y las consecutivas de las que sólo hallamos un caso. En E scoufle del primer tipo: “k'ele en set plus c'une autre feme" (Escoufle, 2071), que como se puede observar se encuentra en la línea que ya hemos señalado para otros fenómenos sintagmáticos que afectan a la denominación femme en esta obra, el obsesivo encumbramiento de Aelis. En cuanto a la consecutiva la hallamos en Tristan donde se presenta una construcción habitual para este tipo de proposiciones: [A dj. + Sust. + Conj.] introduciendo probablemente un valor intensivo: "que il me donst itel corage que je lais a mon oncle sa feme en pais" (Tristan, 2186 - 2188). 


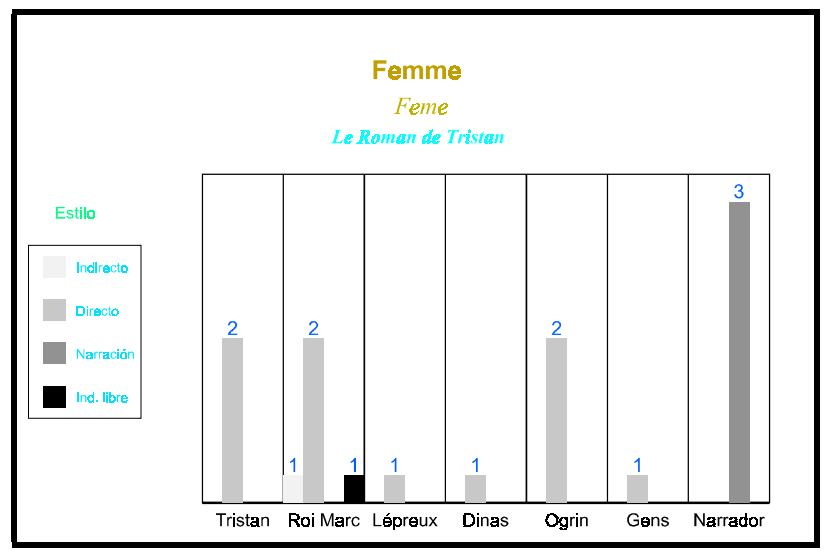

Fig. 13. Comportamiento estilístico del sustantivo femme en Tristan.

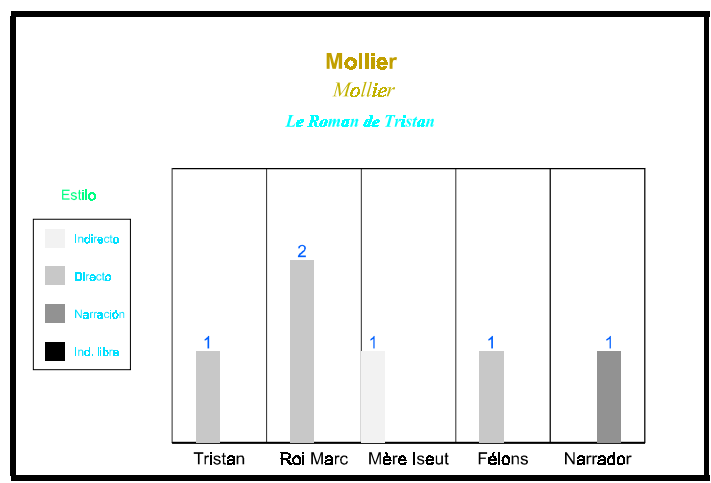

Fig. 14. Comportamiento estilístico del sustantivo «mollier» en Tristan.

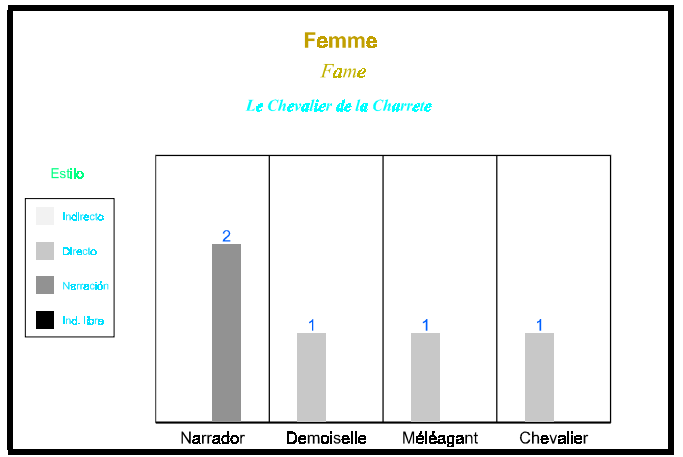

Fig. 15. Comportamiento estilístico del sustantivo femme en Charrete. 


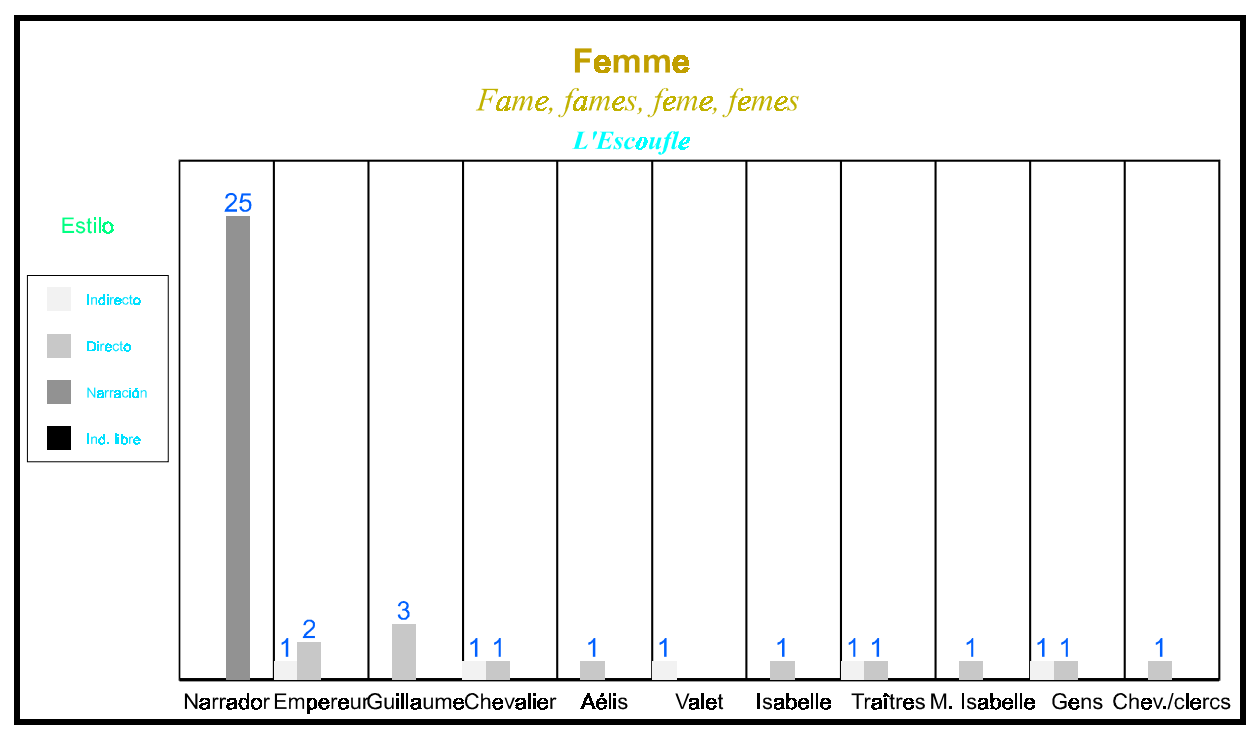

Fig. 16. Comportamiento estilístico del sustantivo femme en Escoufle.

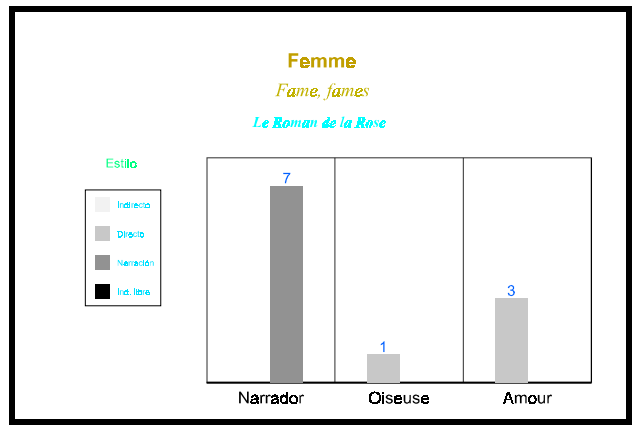

Fig. 17. Comportamiento estilístico del sustantivo femme en Rose.

En la obra de Béroul las denominaciones femme y mollier sirven para designar a la esposa, de ahí que junto al narrador, sean los componentes masculinos del triángulo amoroso los que más asiduamente se refieran a Iseo con este nombre, reclamando sus derechos el rey, o recordándoselos irónicamente o con arrepentimiento Tristán; junto a ellos Ogrin, que se hace valedor del sacramento y pretende borrar el pecado, o bien los individuos que reivindican el orden social. La intervención en estilo directo del barón Dinas de Lidan inaugura en nuestro corpus la larga lista de ocurrencias con función laudativa que nos muestran los textos del siglo XIII, de manera insistente, aunque no exclusiva, en el discurso narrativo. La misoginia también encontrará eco gracias al valor general que posee el sustantivo femme en el 
discurso de Meleagant, recurriendo a la tradición aforística, así como en la narración de los romans del siglo XIII.

\subsection{Pair.}

Tan sólo hallamos este término en Tristan y de las cuatro ocurrencias observadas tres se refieren a Iseo y otra a cada uno de los amantes indistintamente. ${ }^{266}$ Cuando nombra a la reina lo hace ya como amante de Tristan: “Ja, por toz ceus de Tintajol, (...) qu'il n'en tenist piece a sa per, ne laisast il qu'il n’i alast”' (Tristan, 1040 - 1043), añadiendo al sentido básico del igual los valores afectivos del que ama y sufre por amor con igual intensidad, poco antes de que el bosque los una en las mismas condiciones de vida; ya como esposa. "du roi Marc et d'Iseut sa per" (Tristan, 4448). En los dos ejemplos en los que esto ocurre no parece que quede ningún resto de la carga sentimental, máxime cuando uno de ellos pertenece al discurso que prefigura en estilo indirecto libre el juramento de exculpación de Iseo: “envers son oncle et vers sa per' (Tristan, 4196) elevándola de nuevo y sin ningún género de dudas al rango que por su nacimiento y por su matrimonio le corresponde; un lugar privilegiado del que los traidores podrían apearla si pudiesen airear de nuevo sus relaciones con Tristán:

s'il en peüst vis eschaper, du roi Marc et d'Iseut sa per referoit sordre mortel gerre.

Tristan, 4447 - 4449

En cualquier caso sí se opera un notable cambio con respecto a los términos analizados más arriba referidos a la esposa, en los que observábamos un permanente avasallamiento de ésta, siendo aquí más bien la compañera, la

266 "car amors ne se puet celer: sovent cline l'un vers son per, sovent vienent a parlement" (Tristan, 575 577). 
que comparte cama y honores con el esposo. La denominación per presenta una de las caras de la renovada institución conyugal que pretendía colocar a los esposos en un plano de igualdad al tiempo que establecía una estricta jerarquía en la que la mujer aceptaba su sumisión. ${ }^{267}$

\subsection{Reine.}

En Charrete reine es el término más común para hablar de Ginebra ligado principalmente a cuatro subconjuntos temáticos:

- La mujer como moneda de cambio masculina, un objeto —complemento de objeto directo en la sintaxis— que se puede entregar: "la reïne que je voi ci m'avez otroiee a baillier" (Charrete, 176 - 177), ${ }^{268}$ reclamar: "bien set c'or li ert chalongiee la reïne” (Charrete, 3160 - 3161), conquistar: "s'il ne conquiert vers toi la reïne an bataille" (Charrete, 3238 - 3239) o devolver: "si li rant quite la reïne" (Charrete, 3197), ${ }^{269}$ vinculado estrechamente con el honor masculino y con la palabra dada. En este conjunto temático el valor erótico de la reina quedaría muy difuminado, si no fuera porque sospechamos que ella también deberá soportar el peso de la costumbre de Logres. Es cierto que en el texto sólo se nombra a pucelles y demoiselles como las víctimas potenciales del rapto y la violación posterior, ${ }^{270}$ pudiendo quedar excluidas las mujeres casadas; sin embargo, más tarde se nos dirá que Ginebra se ve libre de la lujuria de su enamorado

\footnotetext{
${ }^{267}$ Cf. G. Duby y Ph. Ariès, De l'Europe féodale à la Renaissance, H istoire de la vie privée, G. Duby (dir.). París: Seuil, 1985, p. 150.

${ }^{268}$ En el discurso de Meleagant en los versos 72 - 73.

${ }^{269}$ Y Charrete, $3201-3202$ y 3440.

270 La aparición del verbo esforcier "et, s'il l'esforçast”" (Charrete, 1309) que había servido para describir la violación de la anfitriona de Lanzarote anteriromente: "celui qui esforçoit s'ostesse” (Charrete, 1153), y es el más habitual para denominar la violación en los textos medievales no deja ninguna duda al respecto. Véase para el uso de este verbo K. Varty y D. Buschinger, Le viol dans l'Y sengrinus, les branches II-Va et la branche I du Roman de Renart, et dans le Reinhart Fuchs d'Heinrich der Glichezare, A mour, mariage et transgressions au M oyen A ge. Göppingen: Kümmerle Verlag, 1984, p. 422, nota 1.
} 
Meleagant sólo gracias a los cuidados del rey Bademagu. ${ }^{271}$ Respecto al origen de la costumbre nos queda la duda de si la violenta práctica por la que un caballero —en este caso Meleagant — al ganar a una mujer conducida por otro — aquí Keu— puede hacer de ella su voluntad impunemente: "sa volenté an poïst faire sanz honte et sanz blasme retraire" (Charrete, 1315 - 1316), es el reflejo de sucesos reales o si se trata de una invención de Chrétien. En cualquier caso creemos que es una argucia para incrementar la tensión en la fibra de la sensualidad masculina alimentada de violencia: violaciones, raptos y justas, y aderezada con el retrato de bellas presas.

- La búsqueda, cuyo fin último es el restablecimiento del orden social, de las estructuras corteses, y si tomamos la corte de Arturo como el centro del mundo caballeresco, la restauración del orden universal en el que la reina debe encontrarse en la corte junto a su esposo, pues sin ella la vida social femenina y especialmente las estructuras familiares de todo el reino se resienten. En segundo plano queda la persecución de la amada aunque sea el amor el que dé alas y fuerzas al enamorado para superar todas las pruebas a las que se enfrenta intentando perder el menor tiempo posible:

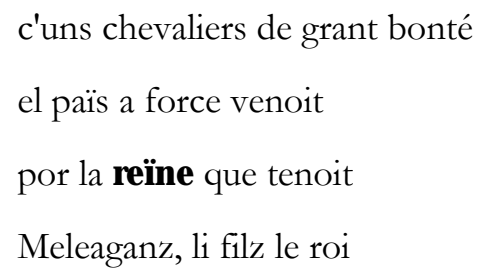

De hecho, Galván, movido solamente por motivos sociales, imprime un ritmo más lento a su caza.

271 Maddox en su estudio sobre la costumbre en Chrétien cree también que la de Logres afecta no sólo a las solteras sino a las casadas e incluso a la que está por encima de todas ellas, a la mujer del rey Arturo. The A rthurian Romanos of Chrétien de Troyes. 0 nœe and future fictions. Cambridge: C.U.P.,1991, p. 40. 
- Los encuentros de los enamorados en los que incluimos las tentaciones suicidas, los remordimientos y las quejas de ambos como consecuencia de la primera visita de Lanzarote a la reina y preludio de las entrevistas posteriores. A diferencia de los dos anteriores la reina tiene las riendas de la acción y en el discurso del narrador o de Lanzarote el sustantivo pasa a ser sujeto o complemento indirecto de verbos del registro amoroso o cuyo valor contextual está muy próximo, como atalenter. "que, s'a la reïne atalante, avoec li leanz anterra" (Charrete, 4598 - 4599), requerre: "quant la reïne an gré requialt sa conpaignie et son solaz" (Charrete, 4670 - 4671), estre [tart]: "et molt est la reïne tart que sa joie et ses amis veingne" (Charrete, 4424 - 4425), pleire: "qu'il ne dit rien que molt ne pleise la reïne" (Charrete, 4470 4471), estandre [ses bras], anbracier o anlacier.

et la reïne li $\underline{\text { estant }}$

$\underline{\text { ses bras ancontre, si l'anbrace, }}$ estroit pres de son piz le lace

Charrete, 4654 - 4656

En esta actividad de la reina podrían confluir las dos corrientes que observamos en las formas del erotismo medieval: por un lado la adopción de un papel dominante de la dama según los mandamientos corteses, por otro, la búsqueda del adulterio por parte de Ginebra para compensar la falta de satisfacción sexual — fenómenos de frustración y de compensación habituales en los fabliaux — , ya que está casada con Arthur, cuyo papel es el de viejo de la corte, de rey consagrado a guardar y conservar las viejas costumbres.

Podemos destacar que en ningún caso Lanzarote, a diferencia de lo que veremos en Tristan, utiliza la denominación reine como vocativo para dirigirse a Ginebra, mostrando una adoración absoluta por la persona de la amada, una de cuyas muestras es la rima con la forma verbal ancline. 
- La falta sexual. De nuevo el vocablo reine es reintegrado mayoritariamente en el universo masculino caracterizado por el discurso polémico con el que se cierra el círculo de la opresión de la mujer. Esta aparece sometida a los celos, un mecanismo de defensa íntimamente relacionado con la sexualidad en su estadio más irracional aunque con un trasfondo social, y a la presión ideológica de los señores que pretenden salvaguardar la pureza de la linea patrilinear y exigen la fidelidad de la esposa. Lo peculiar de este suceso es que sea Meleagant, el enamorado despechado, quien exija los derechos masculinos y no el marido. La reina apenas si puede ejercer su derecho a ser defendida por su campeón: "la reïne mandé ot tot celeemant Lancelot" (Charrete, 4901 - 4902), y salir airosa del trance que la precipitaba a la deshonra: "se Kex son outrage conpere, si que la reïne $\mathrm{i}$ ait honte." (Charrete, 4850 - 4851), temiendo al igual que otras muchas mujeres convertirse en mujer pública. ${ }^{272}$

La repartición de las funciones sintácticas del término también responde en gran medida a esta repartición temática, tal como acabamos de apuntar para los subconjuntos primero y tercero. Las funciones que asume en este último grupo — sujeto y complemento indirecto, cuando se trata de oraciones en voz activa—, se extienden a otra situación bien definida: la reina se encuentra en la corte junto a su esposo antes del reto de Meleagant: "et si $\underline{\mathrm{fu}}$ la reïne ansanble" (Charrete, 37) o una vez que ha regresado después de haber sido liberada por Lanzarote: "ce que la reïne vialt" (Charrete, 5647), "la reïne par moi vos mande" (Charrete, 5652 - 5653), "la reïne n’i est ele a cele joie qu'an demainne" (Charrete, 6820 - 6821), "por ce qu'a la reïne plot" (Charrete, 5662). Los complementos preposicionales, introducidos por la preposición por se hallan relacionados con la conquista y la búsqueda de la reina, que se confirma como motor fundamental de la aventura del caballero

\footnotetext{
272 El mismo castigo con el que soñaba el leproso Yvain en Tristan y que sospecha Aelis al verse abandonada: "m'ont il ici seule laissie com une fole menestrel" (Escoufle, 4672 - 4673)
} 
enamorado, ya sea Lanzarote o Meleagant, ${ }^{273}$ y en una ocasión con la vida social y los usos matrimoniales restablecidos al reintegrarse la reina a la corte: “don ja un tot seul n’i eüst se por la reïne ne fust" (Charrete, 5519 - 5520). Excepcionalmente la preposición devant retoma la temática de la adoración de la dama que llega incluso a perturbar la actividad guerrera del perfecto enamorado:

$$
\begin{aligned}
& \text { ensi Lanceloz molt sovant } \\
& \text { le menoit arriers et avant } \\
& \text { par tot la ou boen li estoit, } \\
& \text { et totevoies s'arestoit, } \\
& \text { devant la reïne sa dame }
\end{aligned}
$$$$
\text { Charrete, } 3745 \text { - } 3749
$$

En Tristan creemos que las apariciones de reine responden en su mayoría a condicionamientos estilísticos y formales: la variación de las formas para evitar la repetición en contextos próximos, la combinación con ciertos adjetivos, que puede deberse a motivos métricos, y la facilidad de las rimas. Acaso, podemos aventurar un predominio de esta denominación en las situaciones en las que su figura aparece ligada a la del rey y su honor, como ocurre con la escena del solazoso encuentro en el lecho:

$$
\begin{aligned}
& \text { Ha! Dex, qel duel que la roïne } \\
& \text { n'avot les dras du lit ostez! } \\
& \text { Ne fust la nuit nus d'eus provez. } \\
& \text { Tristan, } 750-752^{274}
\end{aligned}
$$

con el descubrimiento de los amantes en la choza del Morois, cuyo relato conlleva variaciones en función de la proximidad del amante cuyo punto de

\footnotetext{
273 Cf. v. 1099, 2133, 3642, 4807.

${ }^{274}$ También Tristan, 697 - 699, 765 - 766, 744 - 745, 800 - 802 y 807.
} 
vista se adopta, Tristán o el rey: “Tristan avoc s’amie dort” (Tristan, 1851) / “je te merrai la ou il dort, et la rö̈ne ensenble o lui." (Tristan, 1890 - 1891); o con la justificación y juramento ante las cortes de Marco y de Arturo: "li terme aprime de soi alegier la roïne" (Tristan, 3564 - 3565).

La función sintáctica que más nos llama la atención de los sintagmas en los que se integra el sustantivo en esta obra es la de complemento preposicional, repartida en dos grandes grupos: los sintagmas introducidos por de en contextos donde se nos presentan algunos de los aspectos del conflicto entre los amantes y los felones: “onques cil n'orent nul jor sen qui ce distrent de la roïne" (Tristan, 2626 - 2627), "Sire, merci de la roïne” (Tristan, 1096), "Sire, por Deu, de la roïne aiez pitié" (Tristan, 797 - 798); y los que expresan una idea de compañía en la que se incluyen también los encuentros sexuales ilícitos: "que pris eüse drüerie o la rö̈ne par folie" (Tristan, 801 - 802), mediante las preposiciones o, a y ensenble: "Tristran s'asist o la rö̈ne" (Tristan, 1293), “Tristran s'en voit a la roïne” (Tristan, 1271), “ Tristran estoit el bois aval o la reïne et Governal” (Tristan, 1531 - 1532)

$$
\begin{aligned}
& \text { le roi par bien salu mandez } \\
& \text { en bois estes o la roïne }
\end{aligned}
$$

Tristan, $2360-2361$

$$
\begin{aligned}
& \text { por qui consel estoit li rois } \\
& \text { meslez ensenble la roïne }
\end{aligned}
$$

Tristan, $1682-1683$

El análisis de la sintaxis proposicional nos muestra este sustantivo casi por igual en proposiciones independientes - yuxtapuestas y coordinadas - o principales y en proposiciones subordinadas, aunque solamente presentaremos aquí con detalle estas últimas. 
- Proposiciones relativas:

Las proposiciones introducias por el adverbio ou nos recuerdan la asociación entre la mujer y el espacio cerrado representado por la torre y la ventana por una parte: "mes ferant, vers la tor le chace, ou la reïne ert apoiee" (Charrete, 3738 - 3739), "s'an est vers la chanbre tornez ou la reïne se gisoit" (Charrete, 4746 - 4747), y entre la mujer y la aventura, guerrera o amorosa, dibujada en un espacio indefinido y misterioso, a menudo desconcertante como lo será el amor de la dama: "Isnelemant s'an vont par la ou la reïne orent veüe" (Charrete, 598 - 599), "Ses cuers adés cele part tire ou la reïne se remaint" (Charrete, 4692 - 4693). En este caso el predominio de las relativas de lugar parece reforzar la sensación de que la reina antes que como amante o simplemente como mujer es vista como un engranaje en el juego social y que como tal es el espacio que ocupa o debería ocupar lo que le otorga su alto valor.

Béroul por el contrario prefiere las relativas adjetivas que tienen como antecedente a los barones traidores que han buscado la destrucción de los amantes: "a un des trois por qui consel estoit li rois meslez ensenble la rö̈ne” (Tristan, 1681-1683), "cil n’orent nul jor sen qui ce distrent de la rö̈ne" (Tristan, 2626 - 2627), "li felon prendront colee, qui la roïne ont quis meslee" (Tristan, 3497 - 3498).

- Proposiciones completivas:

Las proposiciones infinitivas aparecen subordinadas a verbos de percepción: "vez la roïne chevauchier un malade qui seut clochier" (Tristan, 3943 - 3944), o de consentimiento: "lors ne lessa mie cheoir la reïne ses ialz vers terre" (Charrete, 4460 - 4461). Mientras que en Charrete las interrogativas indirectas introducidas por la conjunción se: "car me di se tu as veü par ici passer ma dame la reïne" (Charrete, 351 - 353) o por el adverbio ou: "qu'ele lor die ou la reïne an est menee" (Charrete, 610 - 611) que dependen de 
verbos de dicción, nos muestran las pesquisas de los caballeros para encontrar a la reina.

Las introducidas por la conjunción que funcionan como complemento de objeto directo de verbos de conocimiento: "li chevaliers de la fenestre, conut que c'estoit la reïne" (Charrete, 560 - 561), "bien set ćor li ert chalongiee la reïne” (Charrete, 3160 - 3161), "tu sez bien certainnemant qu'il quiert la reïne Ganievre” (Charrete, 3206 - 3207); o de dicción: “qu’an li avoit dit et conté ćuns chevaliers de grant bonté el païs a force venoit por la reïne" (Charrete, 2117 - 2220), "en son cuer dist qu'il parleroit a la rö̈ne" (Tristan, 697 - 698), "mandez par brief que la röne vos ameint ci a brief termine" (Tristan, 2637 - 2638), "cil li prie que a la reïne le maint” (Charrete, 3926 - 3927). En los dos últimos ejemplos podemos observar los matices introducidos por las diferencias sociales entre los interlocutores y el medio utilizado para la transmisión del mensaje. El adverbio interrogativo comment se utiliza para expresar el modo en el que se ha realizado la acción contada en la subordinada con el propósito de acrecentar la estima que el rey Arturo siente por Lanzarote: "assez fu qui li sot retraire (...) comant par lui sont recovré la reïne et tuit si prison" (Charrete, 4346 - 5349).

Encontramos también construcciones paratácticas en el discurso directo o indirecto libre donde la sensación de vivacidad se logra a menudo con la desaparición de la conjunción que: "la reïne, ce croi, querez" (Charrete, 3345), "le roi par bien salu mandez en bois estes o la roïne" (Tristan, 2360 - 2361).

- Proposiciones circunstanciales:

Estas subordinadas, mucho más habituales en el texto de Chrétien, se reparten entre las comparativas, ${ }^{275}$ las consecutivas ${ }^{276}$ y las causales. En

275 meüz sui por si grant afeire

con por la reïne Guenievre

Charrete, 1098 - 1099 
estas observamos la homogeneidad de la expresión lógica por lo que se refiere al término reine tanto en los complementos preposicionales como en las proposiciones encabezadas por conjunciones o locuciones conjuntivas. La reina es el origen de las acciones amorosas: "n'a pooir que il l'an remaint, que la reïne tant li plest" (Charrete, 4694 - 4695) y sociales de Lanzarote, incluso de las más impropias para un valeroso caballero como son las muestras de cobardía en el torneo de Noauz:

$$
\begin{aligned}
& \text { ne fist s'au pis non que il pot } \\
& \text { por ce qu'a la reïne plot } \\
& \text { Charrete, } 5661 \text { - } 5662
\end{aligned}
$$

Y en mayor número las hipotéticas donde se nos presentan las condiciones en las que Lanzarote debe recuperar a la reina frente al poco virtuoso Meleagant:

$$
\begin{aligned}
& \text { ce sez tu bien que hontes iert } \\
& \text { au chevalier, } \underline{\text { sil }} \text { ne conquiert } \\
& \text { vers toi la reïne an bataille } \\
& \text { Charrete, } 3237 \text { - } 3239
\end{aligned}
$$

se tu la reïne li ranz,

criens an tu avoir desenor?

Charrete, 3440 - 3441

así como las imposiciones contradictorias con las que la reina, caprichosa y obstinada como muchas otras de las mujeres que encontramos en los textos medievales, coarta las reacciones del amado: "Lanceloz molt se demantast se la reïne l'escoutast" (Charrete, 3965 - 3966), "śa la reïne atalante, avoec li leanz anterra” (Charrete, 4598 - 4599), “que ancor «au noauz» le face, śavoir

276 Charrete, 3877 - 3878 y 4848 - 4851. 
vialt l'amor et la grace la reïne (Charrete, 5853 - 5855). En Tristan las hipotéticas nos presentan los dos polos entre los que se encuentra la reina una vez acabado el efecto del filtro que la unía mágicamente a Tristán, por un lado los intentos de éste por reintroducirla en la corte junto al marido y por hacer olvidar su comportamiento antisocial:

\section{s’or poïons consel trover \\ de la rö̈ne racorder}

Tristan, $2305-2306$

por otro la implacable legalidad esgrimida por los barones desleales, quienes utilizan la construcción hipotética como un medio para atenuar ante el marido cansado ya de sus sospechas el recuerdo del adulterio:

$$
\begin{aligned}
& \text { se la roïne a esté fole, } \\
& \text { el n'en fist onques escondit }
\end{aligned}
$$

Tristan, $3041-3042$

Y si la importancia del espacio ocupado por la reina se ponía de manifiesto gracias al uso de las subordinadas relativas, algo similar ocurre con el tiempo. Las subordinadas temporales se encuentran dentro del subconjunto temático que podíamos llamar «del adulterio» ${ }^{277}$ y de nuevo vemos cómo la vida de Lanzarote sigue el ritmo impuesto por la reina antes y después del retorno de ésta a la corte:

$$
\begin{aligned}
& \text { si coiz qu'il n’i tost, n'esternue, } \\
& \text { tant que la reïne est venue }
\end{aligned}
$$

Charrete, 4577 - 4578

\footnotetext{
277 Una sola proposición hace referencia al regreso a la corte de la reina y al efecto que causa sobre su esposo, Charrete, 5303 - 5305.
} 
quant Lanceloz voit la reïne

qui a la fenestre s'acline

Charrete, 4583 - 4584

or a Lanceloz quan qu'il vialt

quant la reïne an gré requialt

sa conpaignie et son solaz

Charrete, 4669 - 4671

quant la reïne point n'an voit,

talanz li prist qu'ele l'anvoit

les rans cerchier tant qu'an le truisse

Charrete, 5829 - 5831

$\mathrm{Al}$ observar las rimas, y por mucho que algunos emparejamientos se repitan, no podemos establecer relaciones semánticas suficientemente estables entre ellas, sin embargo, sí creemos oportuno señalar que mientras en Tristan se prefieren las rimas con elementos sustantivos, en Charrete hay un predominio de formas verbales. Por otro lado, y dado que en muy contadas ocasiones el término reine se halla en la primera posición del verso, la aparición en la rima le confiere formalmente un realce que casa con la importancia social, narrativa y erótica de los personajes.

\begin{tabular}{lllllllll}
\hline FORMA & CA & BD & NV & RIMA & CA2 & NV2 & D & PERS \\
\hline rë̈ne & S & Charrete & 4583 & acline & V & 4584 & N & Narrador \\
rë̈ne & S & Charrete & 4651 & ancline & V & 4652 & N & Narrador \\
reïne & S & Charrete & 3849 & anterine & A & 3850 & D & Roi Bademagu \\
rë̈ne & S & Charrete & 3197 & atë̈ne & S & 3198 & D & Roi Bademagu \\
rö̈ne & S & Tristan & 1096 & beauveisine & S & 1095 & D & Dinas \\
rö̈ne & S & Tristan & 2179 & cortine & S & 2180 & D & Tristan \\
rö̈ne & S & Tristan & 1293 & cuisine & S & 1294 & N & Narrador \\
rö̈ne & S & Tristan & 2591 & decepline & S & 2592 & D & Tristan \\
rö̈ne & S & Tristan & 2256 & desertine & S & 2255 & D & Tristan \\
rö̈ne & S & Tristan & 797 & encline & V & 798 & D & Tristan
\end{tabular}




\begin{tabular}{|c|c|c|c|c|c|c|c|c|}
\hline roïne & $S$ & Tristan & 3327 & encline & $\mathrm{V}$ & 3328 & $\mathrm{~N}$ & Narrador \\
\hline reïne & S & Tristan & 2027 & esmeraudine & A & 2028 & D & Roi Marc \\
\hline roïne & S & Tristan & 750 & farine & $\mathrm{S}$ & 749 & $\mathrm{D}$ & Narrador \\
\hline reïne & S & Charrete & 561 & fine & $\mathrm{V}$ & 562 & $\mathrm{~N}$ & Narrador \\
\hline reïne & S & Charrete & 4430 & fine & $\mathrm{V}$ & 4429 & $\mathrm{~N}$ & Narrador \\
\hline reïne & S & Charrete & 5355 & fine & V & 5356 & $\mathrm{~N}$ & Narrador \\
\hline roïne & S & Tristan & 3565 & fine & V & 3566 & $\mathrm{~N}$ & Narrador \\
\hline roïne & S & Tristan & 420 & frarine & A & 419 & D & Iseut \\
\hline roïne & $S$ & Tristan & 1350 & Frocine & S & 1349 & $\mathrm{~N}$ & Narrador \\
\hline roïne & S & Tristan & 1271 & gaudine & S & 1272 & $\mathrm{~N}$ & Narrador \\
\hline roïne & S & Tristan & 2389 & gaudine & S & 2390 & $\mathrm{D}$ & Ogrin l'ermite \\
\hline roïne & S & Tristan & 3473 & Godoïne & $\mathrm{S}$ & 3474 & $\mathrm{D}$ & Chevaliers T. R. \\
\hline reïne & S & Charrete & 4337 & haïne & $\mathrm{S}$ & 4338 & $\mathrm{D}$ & Lancelot \\
\hline roïne & S & Tristan & 774 & haïne & S & 773 & $\mathrm{~N}$ & Narrador \\
\hline roïne & $S$ & Tristan & 807 & haïne & $S$ & 808 & $\mathrm{~N}$ & Narrador \\
\hline roïne & S & Tristan & 2744 & hermine & $\mathrm{S}$ & 2743 & $\mathrm{~N}$ & Narrador \\
\hline reïne & S & Charrete & 1972 & marbrine & A & 1971 & $\mathrm{D}$ & Moine \\
\hline roïne & S & Escoufle & 6355 & medecine & $\mathrm{S}$ & 6356 & $\mathrm{~N}$ & Narrador \\
\hline roïne & $S$ & Tristan & 2627 & oïe & $\mathrm{O}$ & 2628 & $\mathrm{D}$ & Gens \\
\hline reïne & $S$ & Charrete & 353 & orine & $\mathrm{S}$ & 354 & $\mathrm{D}$ & Lancelot \\
\hline roïne & $S$ & Tristan & 565 & orine & $\mathrm{S}$ & 566 & $\mathrm{D}$ & Tristan \\
\hline roïne & S & Tristan & 1683 & ravine & $\mathrm{V}$ & 1684 & $\mathrm{~N}$ & Narrador \\
\hline roïne & S & Tristan & 2361 & saisine & $\mathrm{S}$ & 2362 & $\mathrm{~L}$ & Tristan \\
\hline roïne & S & Tristan & 2731 & saisine & $\mathrm{S}$ & 2732 & $\mathrm{~N}$ & Narrador \\
\hline reïne & S & Charrete & 2133 & sarradine & A & 2134 & D & Chevalier \\
\hline roïne & $S$ & Tristan & 2637 & termine & $\mathrm{S}$ & 2638 & D & Gens \\
\hline reïne & S & Charrete & 5652 & veisine & $\mathrm{S}$ & 5651 & D & Pucelle \\
\hline
\end{tabular}

Tabla 35. Rimas del sustantivo reine.

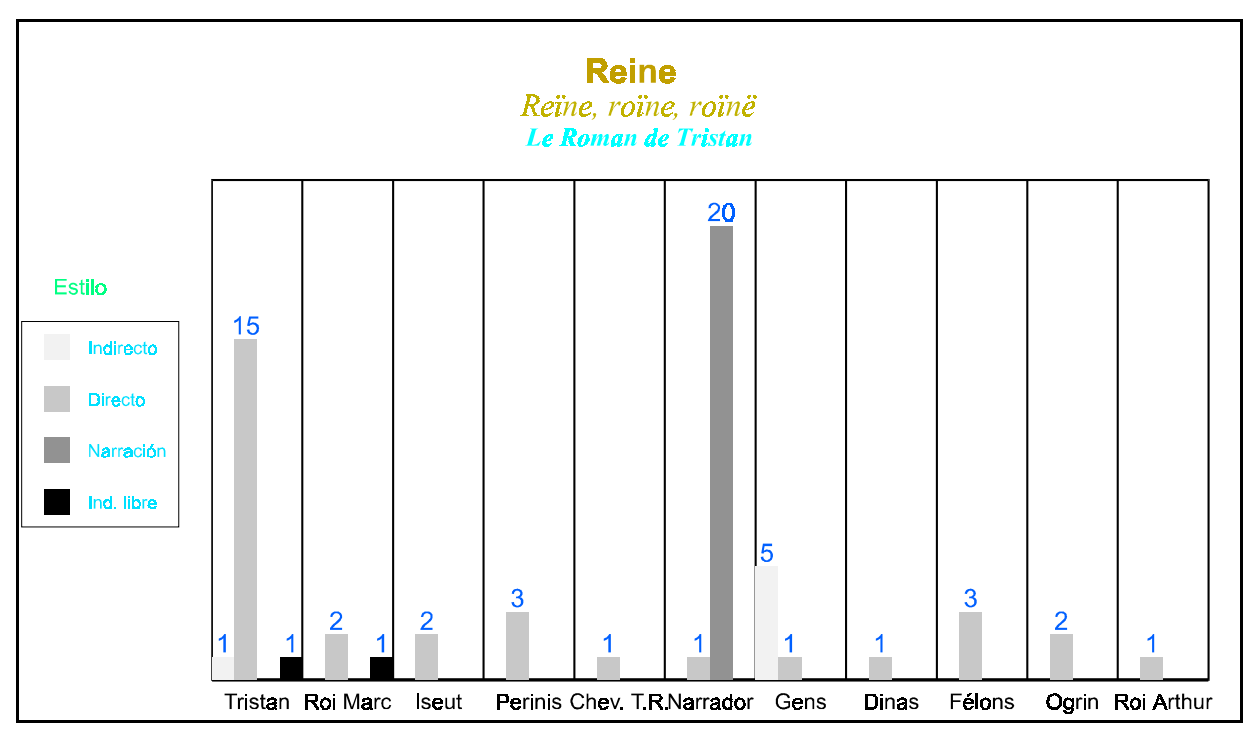

Fig. 18. Comportamiento estilístico del sustantivo reine en Tristan. 


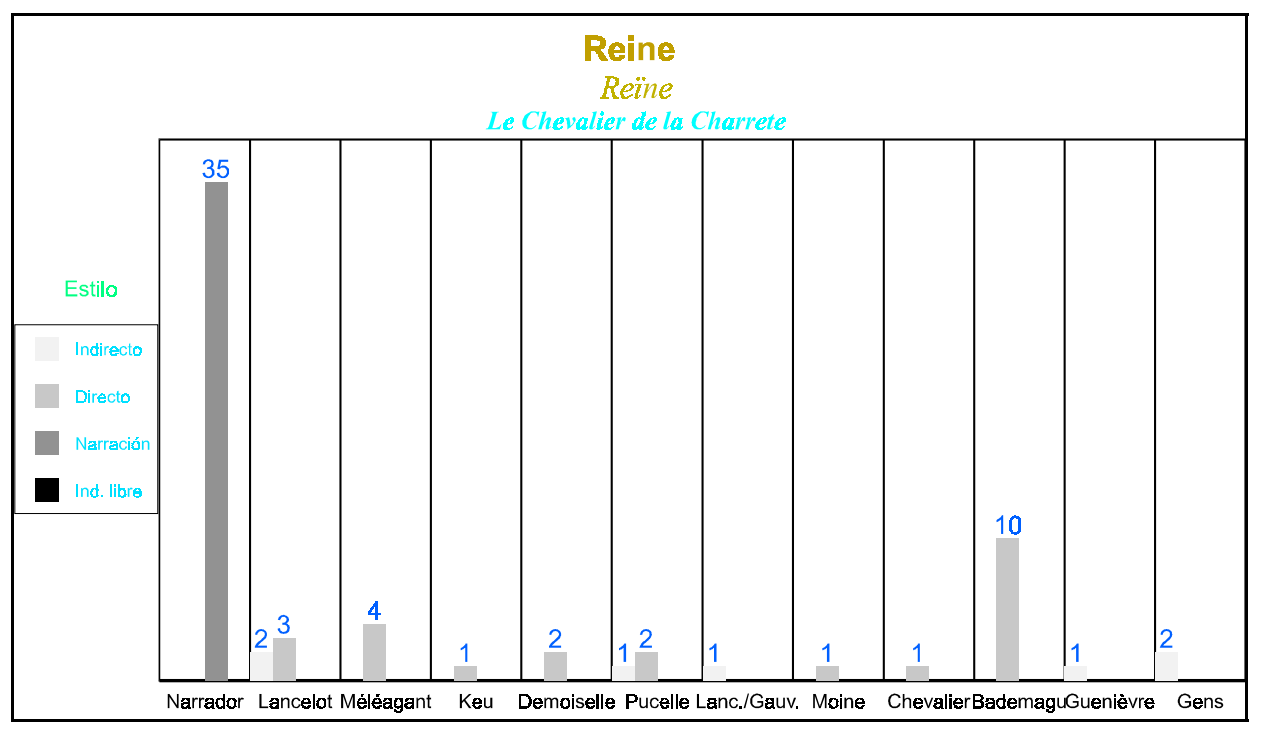

Fig. 19. Comportamiento estilístico del sustantivo reine en Charrete.

Las diferencias más llamativas tras la comparación de los dos gráficos resultan de los usos hechos por los amantes: mientras Tristán se refiere a la reina una vez que el filtro ha dejado de surtir efecto y desea restituirla al rey, Lanzarote, siempre comedido al hablar de Ginebra, pregunta por ella, se atormenta en un monólogo o supedita su deseo al de ella sólo hasta el momento en que se unen en la cama, a partir de ese instante no volverá a nombrarla. Por otro lado, en el roman de Chrétien Ginebra es ante todo reina, de ahí que en comparación con otras denominaciones anteriormente estudiadas se observe un gran número de ocurrencias de este término tanto en la narración como en el discurso de los personajes.

\subsection{Rose, bouton.}

La metamorfosis de rosa a mujer comienza en la comparación y llega a su plenitud en la metáfora del discurso alegórico. Cuando alcanza este estado de madurez expresiva adopta formas diversas, desde una mujer cualquiera a la bella entre las bellas, pasando por la dama y la joven doncella figurada por el inmaduro capullo. 
En E scoufle descubrimos un estado intermedio entre las comparaciones ya tópicas y la metáfora multiforme que encontramos en Rose. El mecanismo que integra dentro de la esfera de lo metafórico la construcción comparativa, cuya característica esencial es que los dos términos están presentes en el enunciado, pasa por reutilizar los modelos comparativos tradicionales de los que encontramos algunas muestras en E sooufle y añadir un grado de abstracción. Es decir, se pasa de comparar a Aelis con todas las mujeres y con las rosas en construcciones intensivas convencionales a transformar las mujeres en flores y comparar a Aelis de nuevo en forma superlativa para que resulte ser la más bella de las flores.

\section{Ceste est de totes flors la rose}

u nature a mis tant biauté

Escoufle, $8296-8297$

La rosa entre las bellas es en la obra de Lorris la substancia esencial de la amada cortés, que se caracteriza por su perfección y por el anonimato; sin embargo, la confusión creada por la reunificación de las denominaciones para la mujer va aún más lejos en el desarrollo del fenómeno cortés. De nuevo se reivindica el discurso eufemístico con que se inauguraba la poesía de los trovadores, por el que el individuo se escondía tras el frío nombre de dama y los clichés con que era atribuido, pero aquí se llega hasta hacer coincidir el objeto de deseo con el objeto erótico primordial, la mujer como género. Sólo Jean de Meun franqueará la puerta del tabú al identificar en una compleja estructura metonímica la fuente del deseo erótico cortés, los órganos genitales femeninos, el coño al que se canta en las composiciones burlescas y que será rosa dos siglos más tarde. ${ }^{278}$

El siglo XIII es el siglo de la rosa, el del florecimiento del símbolo en el pensamiento místico, en la piedra gótica, y también en la frívola literatura

278 Guiraud recoge en la entrada rose: " $1^{\circ}$ «sexe de la femme»; $2^{\circ}$ «virginité» (FEW XV - XXe s.)". D ictionnaire historique, stylistique, rhétorique, étymologique de la littérature érotique. Paris: Payot, 1978, p. 555. 
cortés. Esta aprovecha la moda para hacer de la rosa algo banal, un adorno retórico con el que renovar el mito de la dama. Lo que era símbolo es aquí un simple signo o en todo caso el símbolo del símbolo recreado en el siglo XII y que apenas se modifica con la personificación de la rosa. Es más, Lorris acomoda el recurso formal al nuevo canon impuesto por la propaganda clerical y aristocrática, en parte gracias al culto mariano y a la rosa símbolo de la Virgen María. La desfloración se ha quitado de encima el peso del tabú que la relacionaba con las oscuras e impuras fuerzas del sexo femenino y el imaginario sexual se reconstituye con prometedoras fuentes de placer en las que la pureza y la iniciación sexual de la mujer constituyen los principales atractivos. Sin desearlo los moralistas habían dado un aliciente más al mito de la virginidad al sacralizar la pureza femenina, pues la transgresión parece dar nuevos bríos al deseo y al placer sexuales.

“Cueillir la rose" permanece en la lengua con el sentido de desvirgar al igual que "cueillir la fleur", ${ }^{279}$ aunque en nuestro roman el enamorado no consiga su propósito. En Rose el narrador utiliza el término rose con el sentido más general de femme para hablar de las mujeres, que casi siempre en grupos: “choisi rosiers chargiez de roses” (Rose, 1614) 280 aparecían en su sueño, ramilletes que lo deleitaban con su belleza y su exquisito olor, cuando su deseo no tenía un referente preciso y sólo era una fuerza que empujaba sus ojos a contemplarlas y conseguir así una suave sensación placentera todavía lejana de la dulce obsesión del amor. Las mismas que lo invitan a acercarse para que descubra el sensual olor de la rosa - mujer. Bel Accueil con su amistosa acogida nos muestra el coqueteo de las mujeres, sus casi imperceptibles insinuaciones, su deseo de agradar al hombre aunque quieren evitar una excesiva confianza:

\footnotetext{
279 Ibid., p. 263.

280 “des roses i ot grant monciaus, ausi beles n'avoit soz ciaus" (Rose, 1635 - 1636).
} 


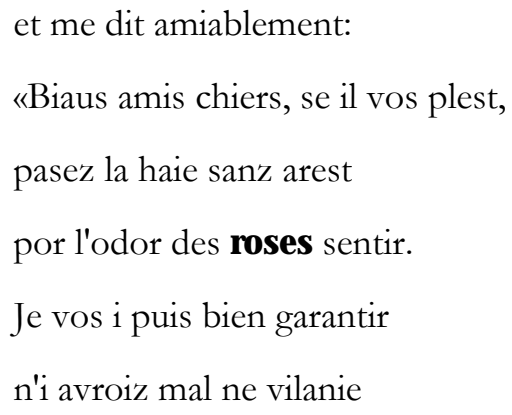

Poco después la intrusión de los aliados de la honestidad aislará a las rosas en un intento por evitar la lujuria:

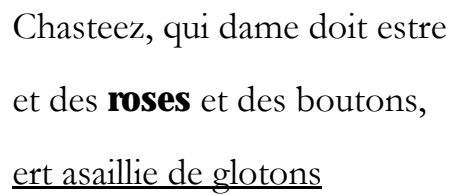

y a partir de ese momento el sustantivo rose, solo o en compañía de bouton, aparece asociado al robo, léase rapto, violación o unión sexual, y a los intentos para evitarlo. Los verbos garder, ${ }^{281}$ desfendre, ${ }^{282}$ clore, ${ }^{283}$ se oponen a tendre [la main], ${ }^{284}$ espier, $^{285}$ emporter $^{286}$ o embler $^{287}$ muy a menudo en proposiciones subordinadas relativas cuyos antecedentes son ya los amantes, ya las fuerzas que intentan impedir la corrupción de las mujeres:

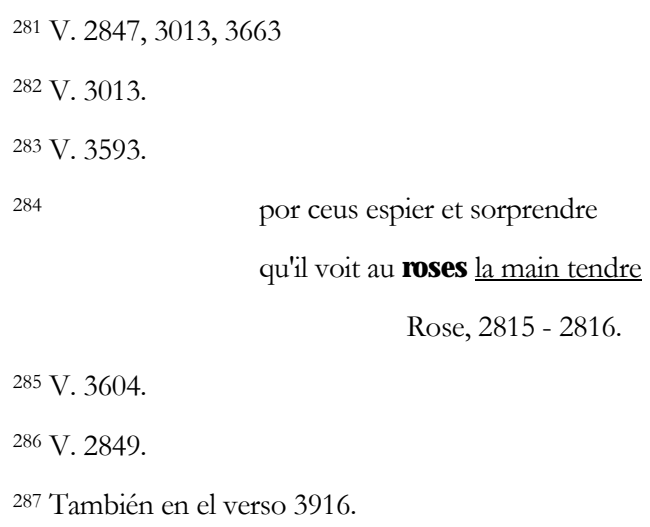




$$
\begin{aligned}
& \text { et Venus l'avoit envaïe, } \\
& \text { qui nuit et jor sovent li emble } \\
& \text { boutons et roses tot ensemble }
\end{aligned}
$$

Rose, 2834 - 2836

Los amantes desaprensivos, tanto como las barreras sociales y el excesivo pudor, son el lado oscuro de la seducción, el freno para la iniciación sexual masculina y femenina. Aparentemente nos encontramos ante los obstáculos de los comienzos de la cortesía pero algunas cosas han variado —incluso si nos olvidamos aquí de la virginidad—, y ello debido fundamentalmente a la presión de la moral cristiana. Las diferencias jerárquicas entre el suspirante y la dama están latentes mientras se desarrollan hipertróficos los obstáculos morales que salvaguardan el matrimonio y la virginidad como bienes sociales en todos los estratos de la población.

El enamoramiento, el lado amable en el despertar de la sexualidad, también gira en torno a la rosa, una y trina: rose, rousete, bouton, y que sólo encontramos en los discursos del narrador, del amante y excepcionalmente de Bel Acueil. Creemos que esta variedad de denominaciones corresponde a la aparecida en Escoufle con los términos dame, pucelle y demoiselle. La frecuencia de aparición de bouton es sensiblemente mayor que la de rose $\mathrm{y}$ las dos ocurrencias de rousete nos hacen ver esta forma como un recurso métrico; aunque no son estas diferencias cuantitativas las que nos interesan, bien pueden ser una nueva muestra de la evolución del deseo masculino. De hecho, cuando en el texto rose y bouton todavía representaban diferentes grupos de edad el narrador nos mostraba las preferencias del amante, la radiante belleza de la juventud que todavía tardará en marchitarse:

$$
\begin{aligned}
& \text { les roses overtes et lees } \\
& \text { sont en un jor toutes alees, } \\
& \text { et li bouton durent tuit frois } \\
& \text { a tot le moins .ii. jors ou trois } \\
& \text { Rose, } 1643 \text { - } 1646
\end{aligned}
$$


Lo que realmente nos llama la atención son las diferentes calidades de algunos de los contextos en los que aparecen uno y otros términos. Mientras bouton y rousete son sujeto u objeto de verbos que indican atracción física o sentimental: atalanter, ${ }^{288}$ abelir, ${ }^{289}$ seoir, ${ }^{290}$ metre [son cuer], ${ }^{291}$ tendre, ${ }^{292}$ aler / marchier [vers], ${ }^{293}$ o beoir.

mes vers le bouton me traioit

li cuers, qui aillors ne beoit

Rose, 1725 - 1726

quant il me vit a li paler

dou bouton a qui je beoie

Rose, 3102 - 3103

de formas que expresan el acercamiento e incluso el contacto del amante con la rosa pero sólo como deseo u opción que no se ha consumado, como aprochier $_{\mathrm{y}}$ atouchier $\mathrm{o}$ ataindre:

$$
\begin{aligned}
& \text { sovent me semont d'aprochier } \\
& \text { vers le bouton et d'atouchier } \\
& \text { au rousier qui estoit chargié }
\end{aligned}
$$$$
\text { Rose, } 2855 \text { - } 2857
$$

\footnotetext{
288 V. 1779: "vers le boton qui m'atalante."

289 V. 3207.

290

ce bouton, qui plus me seoit

que nul des autres ne fessoit

Rose, 1685 - 1686

291 fors par le bouton ou j'avoie

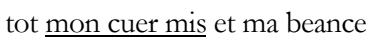

Rose, 2756 - 2757.
}

292 V. 1795: "vers la rousete ou mes cuers tent"

293 V. 1753 y $1793-1795$. 


$$
\begin{aligned}
& \text { (...) qu'onques n'oi } \\
& \text { pooir de passer l'espinoi } \\
& \text { si qu'au bouton peüse ateindre }
\end{aligned}
$$

$$
\text { Rose, } 1797 \text { - } 1799
$$

si vos di que mout m'agrea

dont je me poi si pres remaindre

que au bouton peüse ateindre.

Rose, 2804 - 2806

En ellos también puede quedar implícita la idea de contacto sexual: “se le bouton ne me bailliez" (Rose, 2887) y de violencia: "se le bouton aviez osté" (Rose, 2896), que creemos acercan el sentido de bouton a uno de los que ahora tiene en el registro erótico: sexo de la mujer. ${ }^{294}$ Hechos que, aunque permanecen en el ámbito de lo irrealizado, provocan el rechazo de ésta, no demasiado atraída por una entrega rápida y sí más bien por un largo cortejo. Con todo ello podemos pensar que el joven amante se ve abocado a cumplir las reglas impuestas por el código cortés y no lo hace por voluntad propia.

O bien aparecen asociados a sustantivos y verbos que conciernen dos sentidos, la vista y el olfato: rendre odor ${ }^{295}$ basme, ${ }^{296}$ flairer, ${ }^{297}$ sentir y veoir.

mout bel me fu dont je estoie

si pres que dou boton $\underline{\text { sentoie }}$

\footnotetext{
${ }^{294}$ Cf. Guiraud, op. at., p. 188.

295

vers le bouton m'en vois errant

qui miaudre odor des autres rent

Rose, 2801 - 2802

${ }^{296}$ V. 2767: "dou bouton qui eut mieuz de basme"

297 je me començai lors a traire

vers le bouton qui souëf flaire

Rose, $1731-1732$
} 
la douce odor qui en issoit

Rose, 1803 - 1805

Bel Acueil m'ot mout bien servi

quant le bouton de si pres $\underline{\text { i }}$

Rose, 2807 - 2808

En todos estos casos el amante todavía se siente embargado por la alegría y sólo aflora una débil inquietud que lo empuja a acercarse al capullo cada vez más cercano, angustia que la dulce acogida de las mujeres disipará.

Por el contrario rose, pese a hallarse también como sujeto del verbo flairer. "de la rose qui soëf flaire" (Rose, 3371) o como complemento de los verbos aler [vers] ${ }^{298}$ y veoir.

(...) tuit li membre

me fremissent quant il me menbre

de la rose que je soloie

veoir de pres quant je voloie

Rose, 3751 - 3754

está relacionada con un paso más en el camino del amante, con el contacto físico representado por el beso:

un besier douz et savoré

pris de la rose erraument

Rose, 3460 - 3461

por el tacto, o por el gusto:

qu'encor ai ge ou cuer enclose

la douce savor de la rose

Rose, 3759 - 3760

298 V. 3222. 
con el cambio de la rosa, más alta: "la rose auques s'eslargissoit par amont" (Rose, 3343 - 3344) y con formas más redondeadas, ${ }^{299}$ es decir, con el desarrollo físico de ambos que acrecienta el deseo y la osadía del amante; $300 \mathrm{y}$ por fin, con el recuerdo y con la pena producida por la distancia y los obstáculos al amor, expresada en su gran mayoría mediante proposiciones subordinadas circunstanciales de tiempo:

$$
\begin{aligned}
& \text { (...) j'ai mainz anuiz } \\
& \text { sosferz et maintes males nuiz } \\
& \text { puis que j'oi la rose besie }
\end{aligned}
$$$$
\text { Rose, } 3473 \text { - } 3475
$$

mar touchai la rose a mon vis

et a mes ieuz et a ma bouche,

s'amors ne sueffre que g'i touche

$$
\text { Rose, } 3764 \text { - } 3766
$$

Vemos pues que la diversidad en las denominaciones parece responder no al azar sino a una voluntad estilística relacionada con la evolución de las relaciones entre el amante y la amada corteses. Podríamos decir que se adopta la denominación más noble para la mujer, rose - dame, en el momento en que el amante ha sido aceptado por ella, al otorgarle el beso, y se halla en la estrecha senda que lo conducirá a obtener el don más preciado. Camino en el que encuentra no sólo la oposición de los círculos familiares de la joven o de la sociedad bajo la forma de habladurías, sino también la de ella misma todavía atenazada por el pudor y quizá temerosa de un amor fingido o poco constante.

\footnotetext{
$299 \quad$ si con j'oi la rose apressie,

un poi la trovai engroisie

Rose, 3339 - 3340
} 
Los espacios figurados en Rose, los espacios de la mujer, del sexo femenino y del corazón del enamorado son cerrados, a menudo herméticos por impenetrables y misteriosos, y encuentran su reflejo en la rima de los participios pasados enclose y descloses, este último en un contexto negativo. Es más, todo parece tender a construir ese mundo concéntrico, angustioso para el enamorado y claustrofóbico para la rosa, incluso la forma de los versos, que suele recluir las dos denominaciones en el interior evitando las posiciones inicial y final.

\begin{tabular}{lllllllll}
\hline FORMA & CA & BD & NV & RIMA & CA2 & NV2 & D & PERS \\
\hline rose & S & Escoufle & 8296 & cose & S & 8295 & N & Narrador \\
roses & S & Rose & 1614 & choses & S & 1613 & N & Narrador \\
roses & S & Rose & 3593 & descloses & O & 3594 & D & Jalousie \\
rose & S & Rose & 3348 & enclose & O & 3347 & N & Narrador \\
rose & S & Rose & 3760 & enclose & O & 3759 & N & Narrador \\
rose & S & Rose & 3969 & enclose & O & 3970 & N & Narrador \\
rose & S & Rose & 3222 & ose & V & 3221 & N & Narrador \\
rousete & S & Rose & 1753 & violeite & S & 1754 & N & Narrador \\
\hline
\end{tabular}

Tabla 36. Rimas del sustantivo rose.

\begin{tabular}{lllllllll}
\hline FORMA & CA & BD & NV & RIMA & CA2 & NV2 & D & PERS \\
\hline boton & S & Rose & 3916 & gloton & S & 3915 & N & Narrador \\
boutons & S & Rose & 2831 & glotons & S & 2832 & N & Narrador \\
boutons & S & Rose & 1664 & jons & S & 1663 & N & Narrador \\
boton & S & Rose & 3663 & mouton & S & 3664 & D & Honte \\
\hline
\end{tabular}

Tabla 37. Rimas del sustantivo bouton.

300 Para K. Uitti el bouton no posee características del género femenino, es más, los versos 1655 - 1674 describen, a su parecer, un falo con apariencia de rosa. Cf. Understanding Guillaume de Lorris... , op. at., p. 62 - 3. 


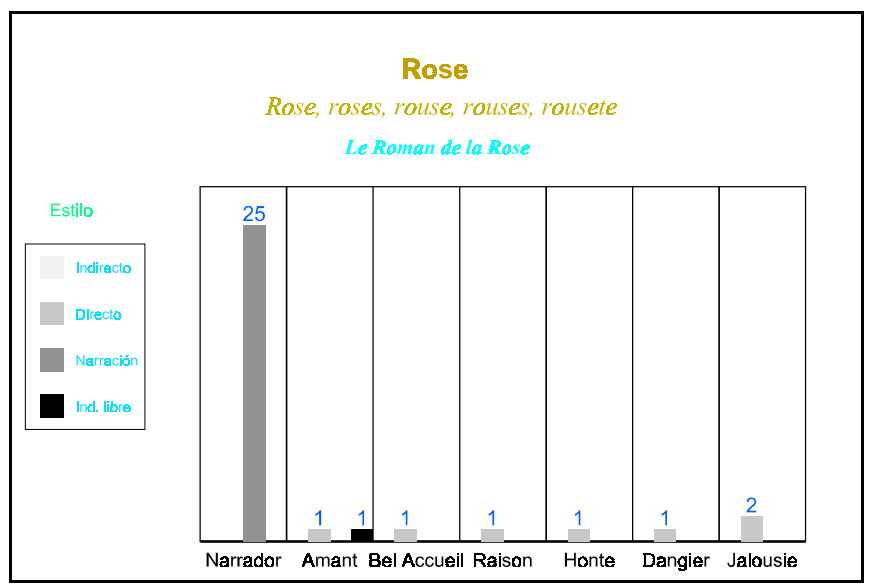

Fig. 20. Comportamiento estilístico de la denominación rose en Rose.

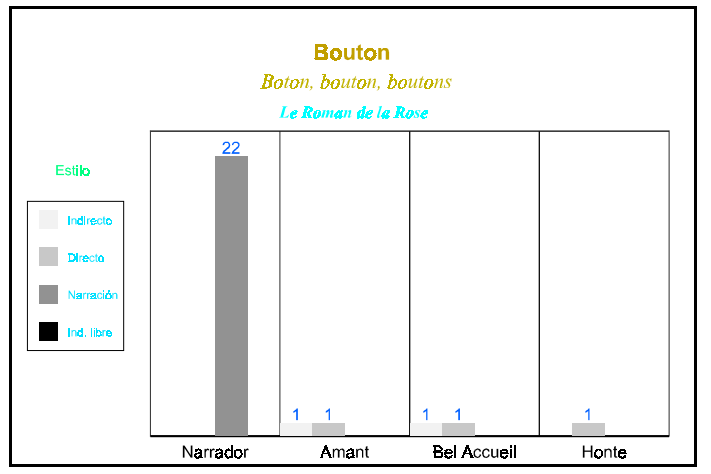

Fig. 21. Comportamiento estilístico del sustantivo bouton en Rose.

Más que las ocurrencias en la narración en primera persona o en los discursos directos o indirectos de Bel Accueil y de Amant, merecen ser comentadas brevemente las que se encuentran en las alocuciones de los defensores de la moral sexual. Honte se refiere conjuntamente a los dos avatares de la mujer, pues en ambos estados deben poseer el pudor que las hará virtuosas, pero Jalousie, Dangier y Raison aluden a la mujer núbil que debe ser protegida para que su virginidad y su buen nombre queden intactos, en espera de ser consagrados al matrimonio. 


\subsubsection{EXPRESIONES GEN ERALES RELATIVAS A LA MUJER.}

\subsection{Créature.}

Los textos del siglo XIII recurren a esta forma aunque en coordenadas contextuales completamente diferentes, mientras que en $\mathrm{E}$ sooufle retoma la figura de Aelis — siempre acompañada de adjetivos de valoración positiva: gentil ${ }^{301}$ franche, ${ }^{302}$ bele ${ }^{303}$ en construcción ponderativa-, en Rose se encuentra rodeada de adjetivos cuyo valor axiológico es negativo, ya sea por su significado denotativo ya sea por los matices contextuales, entre los que destaca el otorgado por el verbo sembler, y se refiere a dos de los vicios anticorteses, según Lorris, la maldad o villanía y la hipocresía religiosa. ${ }^{304}$

En ambos textos los imperativos formales tienen un gran peso en el uso de esta forma ya que en todos los casos la encontramos en la rima.

\begin{tabular}{lllllllll}
\hline FORMA & CA & BD & NV & RIMA & CA2 & NV2 & D & PERS \\
\hline creature & S & Escoufle & 8540 & aventure & S & 8539 & D & Barons \\
criature & S & Rose & 413 & aventure & S & 414 & N & Narrador \\
creature & S & Escoufle & 5856 & çainture & S & 5855 & L & Dame Montpellier \\
creature & S & Escoufle & 5162 & cure & S & 5161 & N & Narrador \\
criature & S & Rose & 160 & faiture & S & 159 & N & Narrador \\
creature & S & Escoufle & 5556 & mesure & S & 5555 & D & Isabelle \\
\hline
\end{tabular}

Tabla 38. Rimas del sustantivo créature referido a la mujer.

\subsection{2 «Rien».}

Esta denominación, como la anterior, ofrece una visión difuminada de la mujer y la convierte en un ser indefinido del que no se nos da a conocer

\footnotetext{
301 Escoufle, v. 5162 y 5556.

302 Escoufle, v. 5856.

303 Escoufle, v. 8540.

304 Rose, v. 160 - 162 y 412 - 415.
} 
ni la edad, ni la situación social, ni siquiera el grado de intimidad que mantiene con el amado. Por otra parte, y al contrario que creature, rien en los casos en los que pertenece a la clase de los sustantivos — puede ser también pronombre y adverbio en nuestros textos — no aparece nunca a final de verso por lo que las formas asociadas en la rima no nos pueden dar ninguna pista sobre las posibles afinidades temáticas. Creemos sin embargo que las principales características del funcionamiento textual de rien como denominación de la mujer amada vienen dadas por las relaciones sintagmáticas en las que participa y de las consecuencias que estas tienen en el plano retórico. De todos los ejemplos en los que rien hace referencia a la amada sólo dos no presentan un esquema comparativo o ponderativo. ${ }^{305} \mathrm{El}$ resto de las ocurrencias las hallamos en tres tipos de construcciones que acaparan esta denominación en los tres romans en los que aparece, Charrete, E scoufle y Rose:

- Como antecedente de una frase de relativo caracterizada en todos los casos por incluir un verbo del registro amoroso en grado superlativo, en ella el relativo funciona habitualmente como objeto directo o complemento preposicional y sólo excepcionalmente como sujeto. En Charrete este uso está reservado a los discursos de los personajes:

\section{Plus aimer.}

quant la rien voit que il plus ainme (Charrete, 1548)

que la rien que plus aim li doingne (Charrete, 3279)

la rien que plus ainme an cest monde (Charrete, 4857)

la rien el mont qu'il plus amot (Escoufle, 6611)

la rien el mont qui plus m'amot (Escoufle, 7629)

de la riens que il plus amot (Escoufle, 5078)

\footnotetext{
305 "la france riens, la debonaire" (Escoufle, 5284)

“mauvaise riens, qu'aten je tant?” (Escoufle, 3941)
} 
Plus voleir, avoir joie y doloir.
(...) la riens que je plus vuel,
don moins ai joie, et plus me duel,
soit bien veignanz, don qu'ele veingne
Charrete, 1551 - 1553

tes cuers si grant joie ait
de la rien que il plus voldroit

Charrete, 2928 - 2929

quant la rien a que il plus vialt (Charrete, 5357)

\section{Plus estre.}

fors de tant qu'el li rementoit

la rien dont il plus li estoit

Escoufle, 6409 - 6410

\section{Plus deliter.}

(...) Dex te mete,

chevaliers, joie el cuer parfite,

de la rien qui plus te delite

Charrete, 2790 - 2792

\section{Plus covoiter.}

Bel Acueil li avez toloite, que c'est la rien que plus covoite

Rose, 3281 - 3282 


\section{Tant plaire.}

Se trata del único caso en el que el sustantivo rien no está actualizado por el artículo determinado debido a que ya no se trata exclusivamente de la amada sino que ésta ha pasado a formar parte de un conjunto del que se distingue tras la comparación:

$$
\begin{aligned}
& \text {.j. rai del soleil sor la face, } \\
& \text { n'est riens el mont qui tant li place }
\end{aligned}
$$$$
\text { Escoufle, } 603 \text { - } 604
$$

- En Escoufle, con el mismo sentido que acabamos de señalar en el último ejemplo, aparece modificado por un adjetivo al que se le otorga de nuevo un valor intensivo y al que el contexto, fundamentalmente gracias a los adverbios, sobrepone la exclusión.

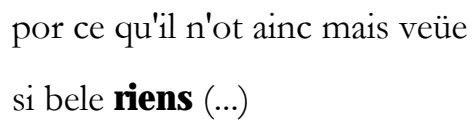

Escoufle, 4811 - 4812

$$
\begin{aligned}
& \text { ainc puis que fu fais Monpelliers } \\
& \text { si bele riens ne fu veüe } \\
& \text { Escoufle, } 5484-5485 \\
& \text { (... ) ainc ne veïstes } \\
& \text { si dolante riens par samblant }
\end{aligned}
$$

Escoufle, 3716 - 3717

- En una construcción que llamaremos excluyente, rien, precedido o seguido de nule, adopta un valor muy general. Significa mujer — excluida la 
amada - o incluso ser humano, y representa todo aquello a lo que se anteponen Ginebra o la rosa, o aquello a lo que la heroína Aelis supera en belleza: "mais nule riens ne s'apareille a la biauté dont lor dame ere" (Escoufle, 8826 - 8827)

ne set ou va, ne set don vient;

de rien nule ne li sovient

fors d'une seule, et por celi

a mis les autres en obli

Charrete, $718-722$

ce est ma mort, ce est ma vie, de nule rien n'ai plus envie.

Rose, $2889-2890$

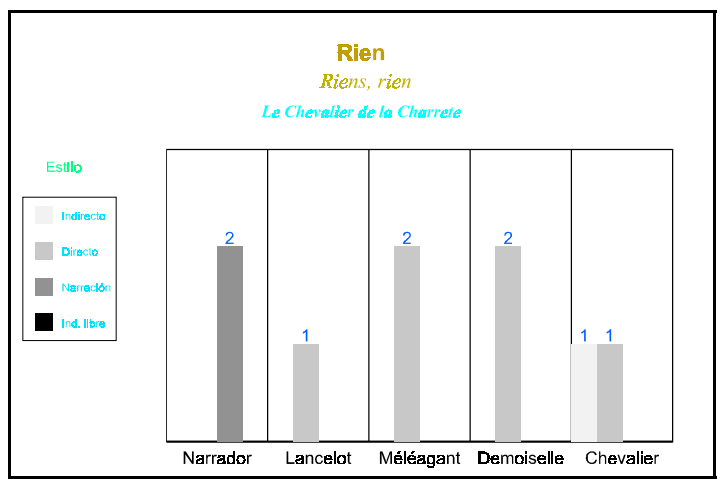

Fig. 22. Comportamiento estilístico del sustantivo «rien» referido a la mujer en Charrete.

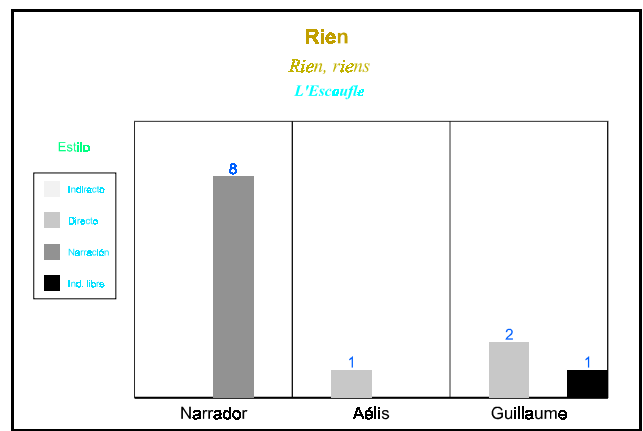

Fig. 23. Comportamiento estilístico del sustantivo «rien» referido a la mujer en Escoufle. 


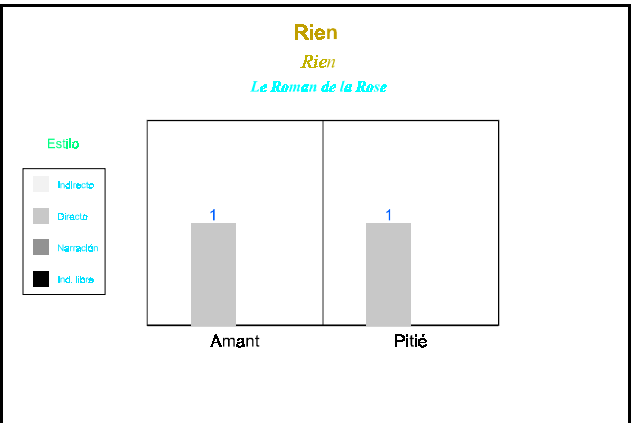

Fig. 24. Comportamiento estilístico del sustantivo «rien» referido a la mujer en Rose.

Chrétien y Lorris, quienes se sirven preferentemente de las construcciones más estrechamente relacionadas con la expresión del amor y aun del deseo apasionado, recurren al sustantivo rien en las intervenciones discursivas. En Escoufle, por el contrario, abundan las construcciones ponderativas que esperaríamos encontrar en la narración pero que se extienden a las intervenciones de Aelis y de Guillermo.

\subsection{TÉRMINOS QUE DENOTAN UNA RELACIÓN AMOROSA.}

\subsection{Amie, compagne.}

Amie es sin lugar a dudas la denominación amorosa por excelencia debido a dos causas fundamentales, en primer lugar porque ya en latín pertenecía al registro afectivo del que derivó al registro amoroso al encontrarse a menudo en contextos eróticos; 306 en segundo lugar por su versatilidad o amplitud dentro de este registro ya que puede significar tanto amada - con la que se comparte o no una cierta intimidad pero sin que se

\footnotetext{
306 En Charrete v. 2916 encontramos el antónimo anemie aunque no podemos precisar si el odio que se desprende de esta denominación y de las palabras de quien así es llamada tiene su origen en una afrenta relacionada con el sexo. Sin embargo, en E sooufle el término tiene un claro contenido amoroso en el discurso de Amour, personificación de los sentimientos de Aelis, ya que se le reprocha a ésta el que no reconozca a su enamorado pese a sentirse atraída por él y pese a la narración de sus venturas y desventuras que éste lleva a cabo. La asociación con un adjetivo en apariencia redundante sitúa el sustantivo en las coordenadas corteses: "si est, desloiaus anemie" (Escoufle, 7558).
} 
haya consumado la unión sexual- como amante. Frente a las denominaciones que hemos estudiado hasta el momento tenía dos ventajas: la de abolir las diferencias sociales y la distancia que el juego amoroso cortés establecía entre los enamorados, y la de reforzar el sentido erótico de aquellas con las que aparece relacionada sintácticamente: "qui estoit sa feme et s'amie" (Escoufle, 7499); “que morte est sa dame et s'amie" (Charrete, 4251), "ele m'avoit son cuer rendu au doner, ma dame, m'amie" (Escoufle, 4614 4615). ${ }^{307}$ Hemos de pensar, sin embargo, que dame y amie poseen, por lo menos en E scoufle, sentidos claramente distintos aunque pertenezcan al mismo registro, tal como se deduce de las palabras de Isabel a Aelis a propósito de la buena acogida que sin duda tendría su presencia entre los hombres de la ciudad:

$$
\begin{aligned}
& \text { n'i a nul qui presist escange } \\
& \text { por vos, richece ne avoir, } \\
& \text { s'il vos pooit anuit avoir } \\
& \text { a dame, a amie u a oste. }
\end{aligned}
$$

Escoufle, 4936 - 4939

En esta construcción atributiva ${ }^{308}$ queda clara la connotación sexual de amie que adopta el sentido de amante, mujer con la que se tienen relaciones sexuales ocasionales o habituales, mientras que dame parece tener un sentido que, aunque cargado de erotismo, no implica la unión sexual y parece expresar el cortejo, las atenciones de un suspirante cortés.

\footnotetext{
307 La coordinación de los dos sintagmas parece haberse convertido en un recurso retórico ideal para expresar las relaciones corteses hasta el extremo de que la encontramos en un contexto en que no responde al registro amoroso y ha pasado a formar parte de la cortesía entendida como buenas maneras; esto ocurre en una intervención del conde Ricardo al anunciarse el compromiso de su hijo con Aelis a la que dice: "vos estes ma dame, m'amie" (Escoufle, 2362).

308 Moignet considera este tipo de complemento introducido por la preposición a "une sorte d'attribut avec des verbes signifiant «tenin», «considéren», «connaitre», «témoignen», etc.". G rammaire de l'ancien français. Paris: Klincksieck, 1984, p. 296.
} 
Hemos visto que a las causas de orden semántico se añaden otras de tipo estilístico y sintáctico no menos a tener en cuenta. Entre estas se encuentra la posibilidad de utilizar los artículos posesivos correspondientes a las tres personas, a diferencia por ejemplo de dame para la que se reservan la primera y la tercera persona. Con ello se consigue expresar la posesión en los discursos directos que no son pronunciados por el propio enamorado, tal como podemos observar en Tristan, en E scoufle y en el discurso de Amor en Rose sobre una hipotética amiga: "Ves ci t'amie" (Tristan, 1236), "conment ce te donna t'amie" (Tristan, 3770); “comment ot vostre amie a non” (Escoufle, 7680), "jou sui Aelis vostre amie" (Escoufle, 7700); "qu'i te soviengne que trop est t'amie lointaigne” (Rose, 2287 - 2288), “si n'avras pas peor qu'il muse a t'amie ne qu'il t'en ruse" (Rose, 2691 - 2692).

De hecho la noción de posesión se hace casi obsesiva en los contextos en los que aparece el sustantivo amie. La misma insistencia con la que se expresaba la posesión de la esposa pero que creemos se debe interpretar aquí no tanto como un signo de sumisión y dependencia, sino como el refuerzo de la intensidad amorosa inherente a la denominación. Éste se lleva a cabo mediante la utilización del artículo posesivo —el recurso más abundante—, del adjetivo posesivo —que permite la utilización del posesivo incluso en una llamada acompañando al vocativo: "la moie amie, Husdent vos doins par drüerie" (Tristan, 2724 - 2725)—, o del verbo avoir. "com est rois qui a tele amie” (Escoufle, 3365).

Tal como nos dice el narrador de Rose el hecho de poseer una amiga a la que se desea es el mayor placer al que se puede aspirar:

$$
\begin{aligned}
& \text { qu'il n'est nus graindres paradis } \\
& \text { d'avoir amie a son devis }
\end{aligned}
$$$$
\text { Rose, } 1297 \text { - } 1298
$$ 
$\mathrm{Y}$ en todos los romans el término sirve para denominar a la mujer amada a excepción del «hipererotizado» Charrete donde amie es también la mujer a la que se le presta un servicio y a la que el caballero queda ligado por una promesa — su aparición queda caracterizada formalmente por el uso del artículo indefinido: "parlez a une vostre amie" (Charrete, 6539)—,309 o aquélla que reclama los servicios sexuales del varón, "cele qui se fet s'amie" (Charrete, 1051), lo que otorga al término un sentido que calificaremos como fuerte dentro del registro erótico, al que se añade el hecho de que sea ella la que obligue al hombre a satisfacer sus deseos gracias a dos recursos que todavía se permite utilizar a la mujer, la palabra y las costumbres corteses, en este caso una típicamente artúrica, el don contraignant. En E scoufle y en Rose encontraremos este mismo sentido en el que no caben dudas sobre la naturaleza de las relaciones entre varón y hembra aunque en el primer caso tengamos que entender que no existe penetración de la amada pues más tarde seguirá llamándola pucelle:

La damoisele velt qu'il face
de li com de s'amie chiere

Escoufle, 4046 - 4047310

que tu tendras cele au cler vis

entre tes braz trestote nue

ausi con s'el fust devenue

dou tot t'amie et ta compaigne

Rose, 2426 - 2429

Curiosamente será también en Charrete, texto en el que se utiliza más libremente el sustantivo amie para hablar de las vírgenes con las que los

\footnotetext{
309 También Charrete v. 6876: "une moie amie".

310 Obsérvese el paralelismo sintáctico y léxico que existe entre esta construcción y la que se refiere a femme que hemos comentado más arriba.
} 
caballeros se encuentran en sus andanzas, donde el enamorado hace una reflexión a la vez sentimental y metalingüística sobre el término: sus dudas sobre el amor que hacia él profesa Ginebra lo llevan a preguntarse si puede otorgarle el nombre de amie. Esto nos aclara un poco más el uso que en esta obra se hace del término y que parece responder no tanto al amor, el deseo o la atracción sentidos por el hombre —excluimos aquí algunos vocativos que son simplemente fórmulas de cortesía— sino más bien a los mismos sentimientos y emociones en la mujer:

$$
\begin{aligned}
& \text { ne sai comant je die, las! } \\
& \text { Ne sai se die «amie } » \text { ou non, } \\
& \text { ne li os metre cest sornon }
\end{aligned}
$$$$
\text { Charrete, } 4362 \text { - } 4364
$$

El narrador de Escoufle introduce también una reflexión de las mismas características sobre las denominaciones ami y amie aunque con una finalidad totalmente diferente, que en cualquier caso es igualmente interesante a nuestros ojos. El placer que sienten los enamorados tiene su origen no sólo en las sensaciones físicas y en los sentimientos sino también en el discurso, en el uso de ciertas palabras claramente connotadas eróticamente para ellos aunque no lo estén para los que los rodean. Hemos visto más arriba a propósito del uso del nombre propio la identificación nombre - ser que aquí se complementa con la identificación nombre - sentimientos del ser:

$$
\begin{aligned}
& \text { que cis nons lor plaist ja « } \underline{\underline{a m i s} »:} \\
& \text { dous nons est d'ami et d'amie } \\
& \text { Escoufle, } 1984-1985
\end{aligned}
$$

Si adoptamos el criterio del funcionamiento sintáctico nos encontramos con notables coincidencias y también con interesantes diferencias entre los romans que estudiamos. 
En Tristan amén de algunos casos en los que el sintagma en el que se incluye el sustantivo amie funciona como sujeto pasivo, ${ }^{311}$ complemento del nombre 312 o como aposición al nombre propio:313 "por l'amour Yseut m'amie" (Tristan, 3601), ${ }^{314}$ las construcciones predominantes son el sintagma preposicional generalmente con una función circunstancial — principalmente en la narración—, el vocativo en el discurso directo del enamorado, así como la función de objeto directo.

Los sintagmas preposicionales a los que aludimos expresan en Tristan la compañía mediante las preposiciones $\mathbf{0}$ y avec, de igual modo que en E scoufle o en Rose donde como veremos también encontramos otros valores circunstanciales: "il amast bien en .j. plus lait la nuit gesir avoec s'amie" (Escoufle, 3110 - 3111), “car tuit li plusor s'en aloient o lor amies ombroier” (Rose, $1290-1291)$

\section{(... ) Deu en mercie que plus n'i out fait o s'amie \\ Tristan, $383-384$}

Tristran chevauchë o s'amie (Tristan, 2770)

Tristran avoc s'amie dort (Tristan, 1851)

et quant il est avoec s'amie (Escoufle, 2026)

remest a cort avoec s'amie (Escoufle, 2647)

\footnotetext{
311 “ainz que getee i soit m'amie" (Tristan, 1021).

312 Tristan v. 3027.

313 En E scoufle también encontramos este uso como aposición del sustantivo amie: "qui dut estre Tisbé s'amie?” (Escoufle, 6369); “jou sui Aelis vostre amie” (Escoufle, 7700).

${ }^{314}$ La construcción también puede ser invertida y el nombre propio aparecer como aposición explicativa del sustantivo amie: "qant or verra passer s'amie, Yseut" (Tristan, 3694 - 3695).
} 
Mediante el uso de preposiciones que tienen un contenido locativo encontramos algunas variantes con respecto a esta idea de compañía que queda implícita y sobre la que se cierne el fantasma de la dolorosa separación de los amantes prefigurada en E scoufle en el episodio de la muerte del conde Ricardo de Normandía.

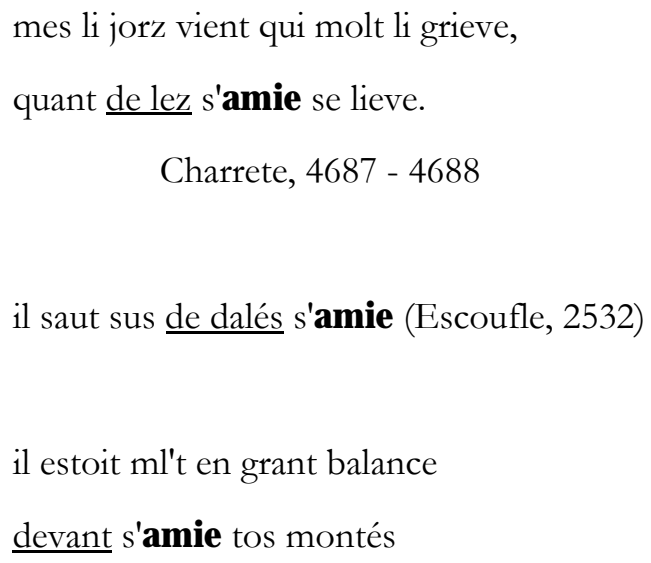

Escoufle, 5178 - 5179

La amiga es también la causa de los actos del enamorado cuando aparece en un sintagma introducido por la preposición por, tanto en Charrete como en E scoufle, a diferencia de Tristan donde las únicas causas eficientes son el filtro o las intrigas de los barones traidores. Por otro lado creemos que es interesante señalar cuáles son las acciones que se justifican de este modo ya que tanto en una como en otra obra los enamorados cometen actos descabellados: Lanzarote monta en la ignominiosa carreta de la que tomará su sobrenombre, Guillermo besa en un estado de delirio el cuerpo del burro que había sido de su amada, y el jefe del ejército turco promete enfrentarse en un combate singular a un paladín de las tropas cristianas, un acto tan inconsciente según la lógica del texto como los ya mencionados. Creemos que se deja 
traslucir una idea que Amor y Razón —desde ópticas y con fines contrapuestos- expresarán claramente en Rose y que también está presente en los discursos de los moralistas y los físicos medievales: el deseo erótico o si se quiere la concupiscencia, conlleva graves trastornos físicos $\mathrm{y}$ fundamentalmente psíquicos que evitan que el hombre haga un uso correcto de su razón.

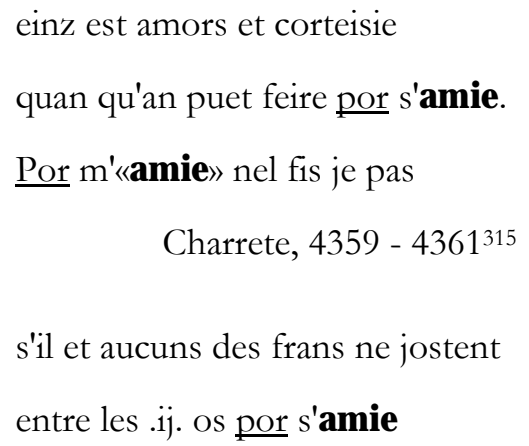

Escoufle, 6298 - 6299

En Rose encontramos un ejemplo en el que la amada es el motor de un comportamiento digno y podríamos decir ejemplar desde la óptica de la ética caballeresca, sin embargo también aquí parece estar fuera de lugar porque esta forma de vivir y sobre todo de amar aparece totalmente superada en el roman y podemos interpretar estos actos de amor como anacrónicos:

$$
\begin{aligned}
& \text { ou il ot fete por s'amie } \\
& \text { mainte joste et mainte estormie }
\end{aligned}
$$$$
\text { Rose, } 1183 \text { - } 1184
$$

\footnotetext{
315 Cuando es la mujer la que efectivamente lleva a cabo una acción el sintagma que expresa esta circunstancia no va introducido por ninguna preposición: "la menasse ancor dure vie se ne fust une moie amie" (Charrete, 6875 - 6876)
} 
Por lo que hace a los vocativos, tanto el amante como el marido utilizan este sustantivo para mostrar a Iseo su amor. Sólo en una ocasión hallamos el sustantivo amie como único miembro del sintagma: "e li a fait li rois: «Amie (...)” (Tristan, 3185) y se prefiere el uso de grupos asociativos que siguen los siguientes esquemas: [Adj. + Sust.] y $[\mathbf{A r t .}+\mathbf{A d j}$. +

\section{Sust.]}

ge vos dorrai ma drüerie, vos moi la vostre, bele amie

Tristan, $2687-2688^{316}$

non fera il, ma chiere amie (Tristan, 2837)

ma chiere amie, que avez? (Tristan, 3175)

En C harrete, donde también aparece en una sola ocasión aislado, ${ }^{317}$ se introducen nuevas combinaciones léxicas y compositivas gracias a la estructura [Adj. + Sust. + Adj.]:

dolce amie (Charrete, 708)

or, douce amie deboneire,

par amors si vos prieroie

Charrete, $6876-6877$

L'E scoufle recurre a los agrupamientos del Tristan o combina los esquemas y los términos aparecidos en esta obra y en Charrete.

car je pens, douce amie chiere (Escoufle, 3394)

\footnotetext{
316 Ttambién v. 2223, 2692.

317 Charrete v. 6680.
} 


$$
\begin{aligned}
& \text { vostre douçors, vostre amistié, } \\
& \text { certes, mar vi jou, bele amie }
\end{aligned}
$$

Escoufle, 3466 - 3467

Encontramos ejemplos en todos los textos en los que el sintagma que contiene el sustantivo amie funciona como objeto directo, como objeto indirecto y como atributo, un hecho que nos parece del todo normal si tomamos en consideración el que el enamorado aparezca generalmente como el sujeto de las actividades eróticas y la definición de la pareja se hace tomándolo a él como referencia:

\author{
mot est dolenz qui pert s'amie (Tristan, 2682) 318 \\ quant je li lesserai m'amie (Charrete, 1725) ${ }^{319}$ \\ ne li plaist tant comme s'amie (Escoufle, 3741) ${ }^{320}$
}

li feus si est ce qu'i remire

s'amie qui le fet defrire

$$
\text { Rose, } 2341-2342321
$$

et molt fet tost et volentiers,

la ou il est amis antiers,

ce qu'a s'amie doie plaire

Charrete, 3799 - 3801322

il nes laist pas morir de fain,

lui ne son oste ne s'amie

Escoufle, 4258 - $4259^{323}$

\footnotetext{
318 También en los versos 1236 y 3762.

319 También v. 1820.

${ }^{320}$ En E sooufle los ejemplos son muy abundantes: v. 3969, 4691, 5087, 6399, 6412, 6464, 6961, 7419, 7423, 7651, 7867, 9097.

321 Así mismo v. 1298, 2548, 2692.

322 También tiene una función de objeto indirecto en el verso 6539.
} 


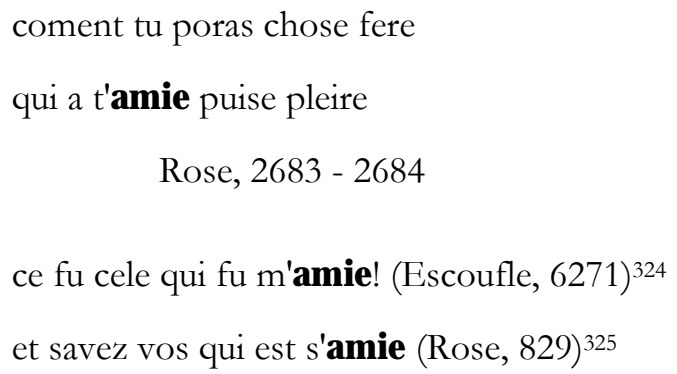

Partiendo de lo que acabamos de observar parecería lógico que la amiga no cumpliese la función sujeto o lo hiciese en pocos casos. Así es efectivamente por lo que concierne a los textos del siglo XII donde, como ya hemos señalado, sólo hemos encontrado un caso en que aparece como sujeto pasivo y por lo tanto no la podemos considerar como verdadero agente. Tampoco en Rose encontramos muchos ejemplos, si bien desde un punto de vista lógico debemos considerar también una ocurrencia en la que funciona como complemento agente:

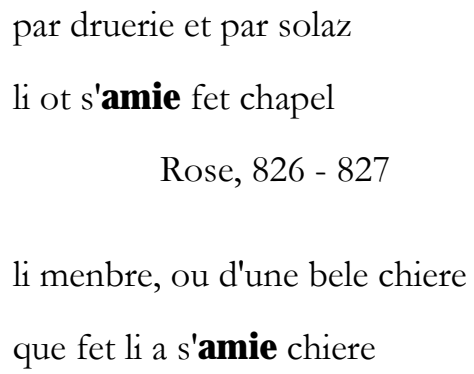

li chevaliers fu biaus et genz

et as armes bien acesmez

et de s'amie bien amez

\footnotetext{
323 También v. 4323.

${ }^{324}$ Funciona así mismo como atributo en el verso 7499.

325 También v. 2429.

326 Del mismo modo los versos 1288 y 2689.
} 
Sin embargo, Aelis, cuyo protagonismo cuando está alejada de Guillermo es mucho mayor que el de éste, también lo conserva en su papel de amiga e incluso impera en la vida cotidiana de su enamorado mientras permanecen separados:

(...) en tante povre couce

m'a fait gesir ma douce amie

Escoufle, $6440-6441$

Por otra parte observamos que la amiga reina en los espacios cerrados y que conserva un cierto dominio sobre la palabra al igual que veíamos en Charrete:

et la cambre ou s'amie maint (Escoufle, 3207)

que s'amie dist qui aproche (Escoufle, 3547)

quanque s'amie ot commandé (Escoufle, 3665)

laiens u s'amie ot esté (Escoufle, 6404)

Y lo que es aún más importante desde nuestro punto de vista, controla los placeres que quiere conceder al enamorado reservando celosamente su virginidad:

$$
\begin{aligned}
& \text { (...) fors d'un } \\
& \text { que s'amie li garde et serve }
\end{aligned}
$$

Escoufle, 2376 - 2377

Otra función inexistente en los textos del siglo XII, el complemento atributivo del sustantivo, ya sea introducido por la preposición de, ya sea en forma de yuxtaposición como resto de la antigua relación mediante el genitivo, ofrece a la amiga un nuevo resquicio para recuperar el centro del universo amoroso, si bien su cuerpo sólo ocupa una vez este espacio, en Rose y como una pura hipótesis, un deseo del enamorado que posiblemente no se haga nunca real: 


$$
\begin{aligned}
& \text { la mort ne me greveroit mie, } \\
& \text { se ge moroie es braz m'amie }
\end{aligned}
$$

$$
\text { Rose, } 2449 \text { - } 2450
$$

El resto de las ocurrencias se refieren al mundo femenino de manera indirecta al evocar de nuevo la naturaleza privada del espacio cerrado: "ki es chambres s'amie" (Escoufle, 2828), "vers la meson t'amie" (Rose, 2501), o los sentimientos y las virtudes corteses: "pour l'onour de s'amie" (Escoufle, 8440 - 8441), "la douçor et l'amor s'amie”" (Escoufle, 7283), "l'amors s'amie li enorte k'il soit prex et frans et hardis" (Escoufle, 1164 - 1165), "k'il me ramentoit la doçor de m'amie que j’ai perdue" (Escoufle, 7238 - 7239).

En cuanto a las rimas haremos algunas observaciones que merecen ser destacadas, por una parte el elevado número de apariciones al final de verso, particularmente en E scoufle y la repetición de la rima con el adverbio mie tanto en esta obra como en Charrete, que nos muestra la tendencia a la aparición del sustantivo en contextos formalmente negativos -aunque examinados estos no nos parece que podamos sacar conclusiones sobre una visión pesimista de las relaciones de pareja-; por otro lado señalaremos que Tristan es la única obra en la que las rimas de amie: drüerie, folie, lecherie, ponen de relieve el sentido erótico del término, máxime cuando se trata de una mujer casada, así como la intención transgresora de las relaciones carnales fuera del matrimonio.

\begin{tabular}{lllllllll}
\hline FORMA & CA & BD & NV & RIMA & CA2 & NV2 & D & PERS \\
\hline amie & S & Tristan & 3185 & ancesorie & S & 3186 & D & Roi Marc \\
amie & S & Charrete & 4360 & corteisie & S & 4359 & D & Lancelot \\
amie & S & Tristan & 1236 & crie & V & 1235 & D & Governal \\
amie & S & Escoufle & 7867 & demie & A & 7868 & N & Narrador \\
amie & S & Tristan & 2682 & departie & S & 2681 & D & Tristan \\
amie & S & Escoufle & 7876 & desdormie & O & 7875 & N & Narrador \\
amie & S & Tristan & 2688 & drüerie & S & 2687 & D & Tristan \\
amie & S & Tristan & 2725 & drüerie & S & 2726 & D & Tristan \\
amie & S & Rose & 2501 & endormie & O & 2502 & D & Amour \\
amie & S & Tristan & 3601 & esbaudie & S & 3602 & D & Tristan \\
amie & S & Escoufle & 2026 & escremie & S & 2025 & N & Narrador \\
amie & S & Rose & 1183 & estormie & S & 1184 & N & Narrador \\
amie & S & Tristan & 2837 & folie & S & 2838 & D & Tristan \\
amie & S & Tristan & 3694 & lecherie & S & 3693 & N & Narrador
\end{tabular}




\begin{tabular}{|c|c|c|c|c|c|c|c|c|}
\hline amie & $\mathrm{S}$ & Escoufle & 8088 & liue & $S$ & 8087 & $\mathrm{~N}$ & Narrador \\
\hline amie & S & Tristan & 3027 & maudie & V & 3028 & $\mathrm{~N}$ & Narrador \\
\hline amie & S & Tristan & 384 & mercie & $\mathrm{V}$ & 383 & $\mathrm{~N}$ & Narrador \\
\hline amie & $\mathrm{S}$ & Tristan & 3770 & mie & $\mathrm{D}$ & 3769 & $\mathrm{D}$ & Roi Marc \\
\hline amie & S & Charrete & 708 & mie & $\mathrm{D}$ & 707 & $\mathrm{D}$ & Lancelot/Gauvain \\
\hline amie & S & Charrete & 1051 & mie & $\mathrm{D}$ & 1052 & $\mathrm{~N}$ & Narrador \\
\hline amie & S & Charrete & 1402 & mie & $\mathrm{D}$ & 1401 & $\mathrm{~N}$ & Narrador \\
\hline amie & S & Charrete & 1725 & mie & $\mathrm{D}$ & 1726 & $\mathrm{D}$ & Chevalier \\
\hline amie & S & Charrete & 4251 & mie & $\mathrm{D}$ & 4252 & $\mathrm{~N}$ & Narrador \\
\hline amie & $\mathrm{S}$ & Charrete & 6539 & mie & $\mathrm{D}$ & 6540 & $\mathrm{D}$ & Demoiselle \\
\hline amie & S & Escoufle & 1171 & mie & $\mathrm{D}$ & 1172 & $\mathrm{~N}$ & Narrador \\
\hline amie & S & Escoufle & 1985 & mie & $\mathrm{D}$ & 1986 & $\mathrm{~N}$ & Narrador \\
\hline amie & S & Escoufle & 2061 & mie & $\mathrm{D}$ & 2062 & $\mathrm{~N}$ & Narrador \\
\hline amie & S & Escoufle & 2094 & mie & $\mathrm{D}$ & 2093 & $\mathrm{~N}$ & Narrador \\
\hline amie & S & Escoufle & 2362 & mie & D & 2361 & $\mathrm{D}$ & Comte Richard \\
\hline amie & $\mathrm{S}$ & Escoufle & 2532 & mie & D & 2531 & $\mathrm{~N}$ & Narrador \\
\hline amie & $\mathrm{S}$ & Escoufle & 2647 & mie & $\mathrm{D}$ & 2648 & $\mathrm{~N}$ & Narrador \\
\hline amie & S & Escoufle & 3111 & mie & D & 3112 & $\mathrm{~N}$ & Narrador \\
\hline amie & S & Escoufle & 3341 & mie & D & 3342 & $\mathrm{~N}$ & Narrador \\
\hline amie & S & Escoufle & 3365 & mie & $\mathrm{D}$ & 3366 & $\mathrm{D}$ & Valet \\
\hline amie & S & Escoufle & 3467 & mie & $\mathrm{D}$ & 3468 & $\mathrm{D}$ & Guillaume \\
\hline amie & S & Escoufle & 3741 & mie & $\mathrm{D}$ & 3742 & $\mathrm{~N}$ & Narrador \\
\hline amie & S & Escoufle & 3763 & mie & $\mathrm{D}$ & 3764 & $\mathrm{~N}$ & Narrador \\
\hline amie & S & Escoufle & 4259 & mie & $\mathrm{D}$ & 4260 & $\mathrm{~N}$ & Narrador \\
\hline amie & S & Escoufle & 4323 & mie & D & 4324 & $\mathrm{~N}$ & Narrador \\
\hline amie & S & Escoufle & 4615 & mie & $\mathrm{D}$ & 4616 & $\mathrm{D}$ & Guillaume \\
\hline amie & S & Escoufle & 4691 & mie & D & 4692 & D & Aélis \\
\hline amie & $\mathrm{S}$ & Escoufle & 5087 & mie & D & 5088 & $\mathrm{~N}$ & Narrador \\
\hline amie & S & Escoufle & 5834 & mie & D & 5833 & $\mathrm{~N}$ & Narrador \\
\hline amie & S & Escoufle & 5909 & mie & D & 5910 & $\mathrm{~N}$ & Narrador \\
\hline amie & S & Escoufle & 6209 & mie & D & 6210 & $\mathrm{~N}$ & Narrador \\
\hline amie & S & Escoufle & 6271 & mie & D & 6272 & D & Guillaume \\
\hline amie & S & Escoufle & 6299 & mie & D & 6300 & $\mathrm{~N}$ & Narrador \\
\hline amie & S & Escoufle & 6369 & mie & $\mathrm{D}$ & 6370 & $\mathrm{~N}$ & Narrador \\
\hline amie & $\mathrm{S}$ & Escoufle & 6441 & mie & D & 6442 & D & Guillaume \\
\hline amie & S & Escoufle & 6961 & mie & D & 6962 & D & Guillaume \\
\hline amie & S & Escoufle & 7283 & mie & D & 7284 & $\mathrm{~N}$ & Narrador \\
\hline amie & S & Escoufle & 7423 & mie & D & 7424 & $\mathrm{~N}$ & Narrador \\
\hline amie & $\mathrm{S}$ & Escoufle & 7457 & mie & D & 7458 & $\mathrm{~N}$ & Narrador \\
\hline amie & S & Escoufle & 7499 & mie & D & 7500 & $\mathrm{~N}$ & Narrador \\
\hline amie & S & Escoufle & 7651 & mie & D & 7652 & D & Guillaume \\
\hline amie & S & Escoufle & 7700 & mie & D & 7699 & D & Aélis \\
\hline amie & S & Escoufle & 9097 & mie & $\mathrm{D}$ & 9098 & $\mathrm{~N}$ & Narrador \\
\hline amie & S & Rose & 829 & mie & $\mathrm{D}$ & 830 & $\mathrm{~N}$ & Narrador \\
\hline amie & $\mathrm{S}$ & Rose & 2450 & mie & $\mathrm{D}$ & 2449 & $\mathrm{D}$ & Amant \\
\hline amie & $\mathrm{S}$ & Tristan & 1021 & ocie & V & 1022 & $\mathrm{D}$ & Tristan \\
\hline amie & S & Tristan & 2770 & praerie & S & 2769 & $\mathrm{~N}$ & Narrador \\
\hline amie & S & Escoufle & 6464 & prie & V & 6463 & I & Mère Isabelle \\
\hline amie & S & Tristan & 3762 & vie & $\mathrm{S}$ & 3761 & $\mathrm{D}$ & Tristan \\
\hline amie & $\mathrm{S}$ & Charrete & 6876 & vie & S & 6875 & $\mathrm{D}$ & Lancelot \\
\hline
\end{tabular}

Tabla 39. Rimas del sustantivo amie. 
Las proposiciones subordinadas circunstanciales nos ofrecen algunas constantes que afectan cuando menos a tres de los textos. En Charrete, E swufle y Rose predominan las proposiciones subordinadas hipotéticas: “n’avrai je puis nule fiance, ne an m'espee, n'en ma lance, quant je li lesserai m'amie" (Charrete, 1723 - 1725), "la menasse ancor dure vie se ne fust une moie amie" (Charrete, 6875 - 6876), “et dist jamais n’iert honerés (...) ślil et aucuns des frans ne jostent entre les .ij. os por s'amie” (Escoufle, 1168 - 1171), “jamais ne me tenrai a preu s'orendroit ne revois arriere aprés ma douce amie chiere" (Escoufle, 5178 - 5180), "ausi con s'el fust devenue dou tot t'amie et ta compaigne" (Rose, 2428 - 2429), "la mort ne me greveroit mie, se ge moroie es braz m'amie" (Rose, 2449 - 2450). Por otra parte hallamos proposiciones temporales en las que se incluye el sustantivo amie en Tristan, Charrete y E scoufle. "ainz que getee i soit m'amie, ceus qui la tienent nen ocie" (Tristan, 1021 - 1022), "et quant il est avoec s'amie, ml't la set servir de biax dis" (Escoufle, 2026 - 2027). La expresión del tiempo puede ir acompañada de un matiz causal: "mes li jorz vient qui molt li grieve, quant de lez s'amie se lieve" (Charrete, 4687 - 4688), “ml't est liés quant il voit l'engin et s'amie qui s'en avale" (Escoufle, 3968 - 3969).

Los textos del siglo XIII introducen, además, la comparación como recurso para expresar el grado de atracción de la amiga sobre el enamorado: "mere ne parens ne amis ne li plaist tant comme s'amie" (Escoufle, 3740 3741) o la conveniencia de la armonía en las características físicas —representadas aquí por la edad—y afectivas de los enamorados: "si estoit bien d'autel aage con s'amie, et d'autel courage" (Rose, 1275 - 1276), aspectos que no habían tenido en cuenta ni Béroul ni Chrétien.

En cuanto a las proposiciones relativas sólo consideramos destacable el hecho de que sean especialmente abundantes en Escoufle donde encontramos varios ejemplos en los que el antecedente del pronombre relativo es un pronombre que se refiere a Aelis y el sintagma en el que se encuentra la denominación amie funciona como atributo: “«Aelis.» - «Las, 
caitis, dolens! Ce fu cele qui fu m'amie!” (Escoufle, 6270 - 6271), “cele qui sist delés le conte, qui estoit sa feme et s'amie" (Escoufle, 7498 - 7499); y donde, al igual que ocurría en Charrete para el sustantivo reine, las relativas introducidas por un adverbio de lugar parecen indicarnos el valor que se le concede al espacio ocupado por la mujer amada, especialmente cuando el amante ya no puede gozar de su presencia: "por regarder la sale et l'estre et la cambre ou s'amie maint" (Escoufle, 3206 - 3207), "et vient el pré tot a droiture ou il avoit laissié s'amie" (Escoufle, 5086 - 5087), "laiens u s'amie ot esté trueve la vielle et noient plus” (Escoufle, 6404 - 6405).

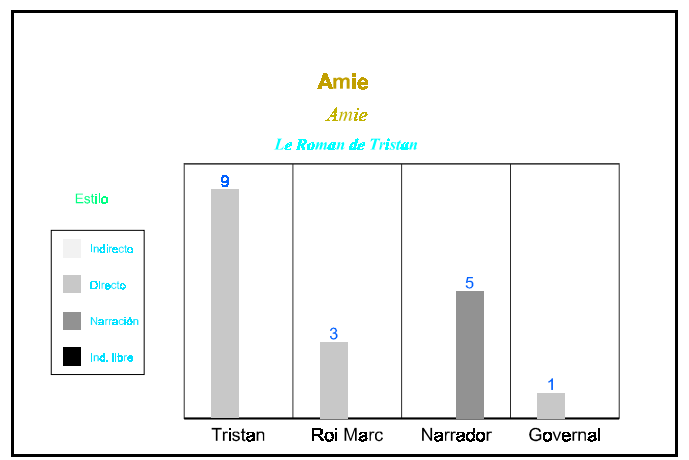

Fig. 25. Comportamiento estilístico del sustantivo amie en Tristan.

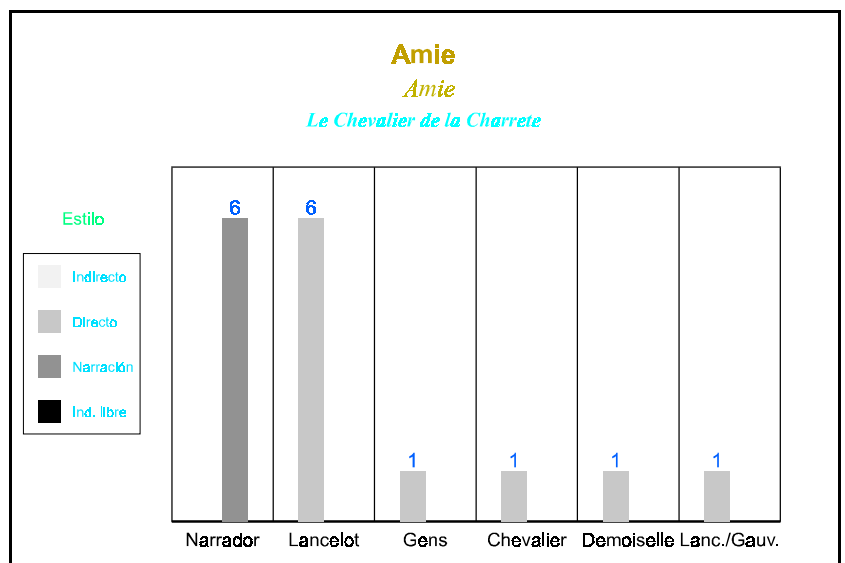

Fig. 26. Comportamiento estilístico del sustantivo amie en Charrete. 


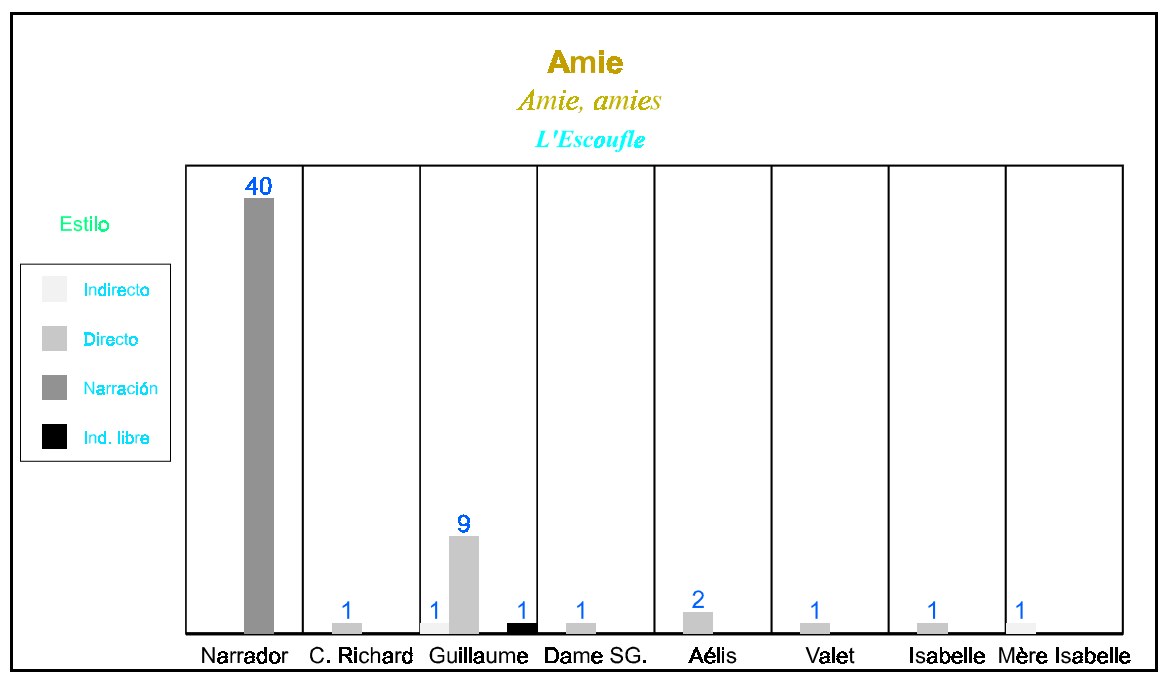

Fig. 27. Comportamiento estilístico del sustantivo amie en Escoufle.

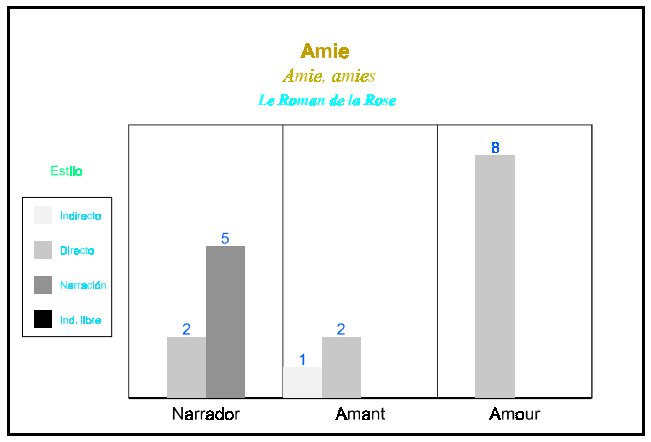

Fig. 28. Comportamiento estilístico del sustantivo amie en Rose.

Una cierta concordancia en el comportamiento estilístico de la denominación amie viene dada por los usos compartidos de la narración y el enamorado en cada roman, teniendo en cuenta que Amor en Rose se apropia muchas veces de la función de un narrador en tercera o en primera persona dentro de sus largos monólogos. Ahora bien, conviene que hagamos alguna advertencia: los vocativos, comunes en este caso a los textos del siglo XII, no tienen el mismo alcance en una y otra obra, pues al ser Iseo quien se nombra en Tristan, el término adquiere un contenido restringido, es la mujer a la que se ama dentro o fuera del matrimonio; por el contrario, Lanzarote lo usa libremente para dirigirse a las jóvenes que encuentra en su camino con valores que van desde el afecto a la simple urbanidad y, sin embargo, le embargan las 
dudas cuando en un monólogo asignaa Ginebra tal denominación, en esa ocasión comprendida dentro del registro amoroso. En E sooulle se produce una neta inversión del peso otorgado a los usos discursivos generales y los narrativos al aumentar enormemente estos últimos. De esta desproporción podemos extraer dos consecuencias: en primer lugar el que la narración de los acontecimientos que incumben a los enamorados toma preferentemente como eje al varón, aunque este se nos muestre obsesionado por su amada, y en segundo lugar el que Guillermo siga dibujándose, al menos en los modos discursivos, como un amador caballeresco.

El sustantivo compagne nos presenta algunas dudas ya que sólo nos atrevemos a afirmar que tiene un contenido erótico en la ocurrencia que encontramos en Rose formando par con amie: "dou tot t'amie et ta compaigne” (Rose, 2429). Aquí aporta en nuestra opinión nuevos matices al vocablo que acabamos de comentar: se trata de la mujer que lo comparte todo con el amante, sobre todo su cuerpo pero también las penas y alegrías que tanto preocupan al joven enamorado en este roman. Este mismo sentido es el que le otorgamos a las dos ocurrencias que hallamos en E scoufle 327 aunque no queda del todo claro que existan relaciones carnales entre Isabel y Aelis; quizá sólo las una un gran afecto que nació la primera noche al compartir lecho y confidencias.

\subsection{2 «Dne».}

Este es el único término que nombra sin ambages a la amante y, sin embargo, ya había caido en desuso en el último cuarto del siglo XII. La noble materia caballeresca no podía aceptar la connotación misógina que lo empañaba. Ya en los trovadores la falsa drue es la mujer engañada; será también la mujer que se somete a los deseos del varón o que ofrece

\footnotetext{
327 "k'ele vuelle estre sa compaigne" (Escoufle, 5277), "or a la bele grant fiance en ce qu'ele a tele compaigne" (Escoufle, 5304 - 5305).
} 
voluntariamente su cuerpo a la vez que su amor. La dominación ejercida por el elemento masculino de la pareja, noción de base heredada del origen feudal del sustantivo, desacreditó esta forma al considerarla opuesta a la ética del amor cortés. ${ }^{328}$

El marco tradicional del locus amoenus se apoderará en el siglo XIII de drue $^{329}$ aprovechando la rima con el adjetivo que califica a embe:

$$
\begin{aligned}
& \text { entor les ruisiaus et les rives } \\
& \text { des fontaines cleres et vives } \\
& \text { poignoit l'erbe freschete et drue: } \\
& \text { ausi i pooit l'en sa drue } \\
& \text { couchier come sus une coute, } \\
& \text { car la terre est et douz et moute. }
\end{aligned}
$$$$
\text { Rose, } 1389 \text { - } 1394
$$

tot entor li, sor l'erbe drue.

Ml't est garis qui a tel drue

Escoufle, 4419 - 4420

La construcción impersonal refuerza la capacidad de evocación de ambas ocurrencias. En Rose la tradición literaria entreteje con enbe y coute el mensaje con el que se invita al goce: pensad en la mullida hierba y las acogedoras colchas en las que los caballeros de los relatos poseen a sus

\footnotetext{
328 A. Grisay, op. at., p. 151 - 3.

${ }^{329}$ Como observamos en el lai D esirré compuesto a comienzos del siglo XIII, recogido por Grisay, ibid.. p. 150:

Li chevaliers n'est pas vilain:

A pié descient, si la salue,

Il en voudra fere sa drue;

Sor l'erbe fresche l'a couchiée
}

Desirré, 144 - 147 
amantes, imaginad el paraiso de Deduit y soñad que acostáis en ellos a vuestra drue. Es un sueño más asequible, más cercano a lo cotidiano que el que se nos presenta en E soufle. En esta obra la generalización —con una fórmula muy próxima al proverbio- recuerda a los receptores de la obra que ellos también pueden desear, pueden aspirar a poseer una mujer bellísima, heredera de un imperio, capaz de abandonarlo todo por un enamorado al que entrega su cuerpo y guarda su virginidad. Por los resquicios de este sueño tejido en los comienzos del siglo XIII entrevemos el deseo masculino sojuzgado hasta entonces por la cortesía: el deseo de poseer, de dominar al objeto que se toma por la fuerza y a la mujer despojada de su envoltura mítica, sedienta de placeres. Un anhelo que resurge, para que nadie se lleve a engaño, con la palabra rechazada. Y todavía drue, casi extinta, consigue apoderarse de una nueva y ardiente visión de lo femenino, le aporta la certidumbre del placer, la misma que todos intuían en el Tristan de Béroul por ejemplo. En E sooufle los caballeros, barones y burgueses llevan a sus hijas y a sus mujeres a las celebraciones y actos públicos, mientras que en la Landa Blanca, convocados a la corte para oir a Iseo, “maint chevalier i out sa drue” (Tristan, 4086). Aquí el sustantivo drue es sólo un figurante evocador pero con Iseo se eleva hasta el mito. Al pedir protección a Tristán le recuerda la profunda relación que los une: "gel prié, qui sui ta chiere drue" (Tristan, 2815); esta rotunda definición de sí misma aporta un sentido nuevo al término, es al tiempo la mujer que ama y es amada, la que posee y es poseída, con ella se unen el viejo sentido de drue en su faceta más amable y la ética cortés. De hecho en Tristan el término aparece revalorizado en todos sus contextos, incluso en la boca del espía que vende la intimidad de los amantes:

pendre m'otroi ou essillier, se ne vos mostre apertement Tristran, la ou son aise atent de parler o sa chiere drue

Tristan, 4280 - 4283 
$\mathrm{Al}$ resto de las ocurrencias de drue se les reservan los contextos más cargados de afectividad, los más gozosos, como el encuentro espiado: "quant out oï parler sa drue, sout que s'estoit aperceüe" (Tristan, 97 - 98) el retorno de Tristán a la habitación del rey, ${ }^{330}$ o la llegada al escondite del enamorado de las “noveles de sa drue" (Tristan, 3322), y también el más dramático cuando Tristán contempla impotente cómo van a quemar a su amante y se prepara para la venganza. 331

No podemos pasar tampoco por alto que esta forma aparece sólo una vez fuera de la rima y que por lo tanto las presiones formales han podido imponerse al elegirlo en el paradigma de las denominaciones para cubrir el difícil emparejamiento con las formas femeninas de los participios pasados.

\begin{tabular}{lllllllll}
\hline FORMA & CA & BD & NV & RIMA & CA2 & NV2 & D & PERS \\
\hline drue & S & Tristan & 97 & aperceüe & O & 98 & N & Narrador \\
drue & S & Escoufle & 4420 & drue & A & 4419 & N & Narrador \\
drue & S & Rose & 1392 & drue & A & 1391 & N & Narrador \\
drue & S & Tristan & 4283 & mue & S & 4284 & D & Félons \\
drue & S & Tristan & 1003 & receüe & O & 1004 & D & Governal \\
drue & S & Tristan & 2815 & retenue & O & 2816 & D & Iseut \\
drue & S & Tristan & 538 & tenue & O & 537 & D & Brangien \\
drue & S & Tristan & 3322 & venue & S & 3321 & N & Narrador \\
drue & S & Tristan & 4086 & vestue & O & 4085 & N & Narrador \\
\hline
\end{tabular}

Tabla 40. Rimas del sustantivo «drue».

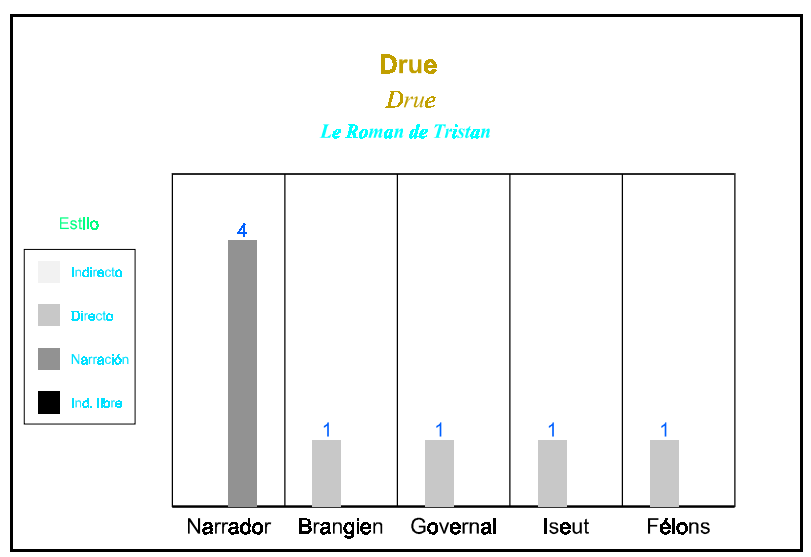

Fig. 29. Comportamiento estilístico del sustantivo «drue» en Tristan.

\footnotetext{
330 Tristan, v. 538.

331 Tristan, v. 1003.
} 


\subsubsection{El VARón.}

Los personajes masculinos que hemos seleccionado en nuestro corpus pueden ser clasificados en tres grandes tipos: aquéllos a los que, al igual que a sus amadas, se les llama mediante el nombre propio y a los que se hace referencia con otros apelativos, generalmente nombres comunes; aquéllos cuya identificación puede ser común a otros pero aparecen diferenciados en el contexto; y finalmente los que forman grupos de personajes imposibles de identificar individualmente.

\subsection{NOMBRE PROPIO.}

$\mathrm{Al}$ igual que en el caso de los personajes femeninos pocos son los masculinos a los que se denomina con el nombre de pila, aunque sí es más frecuente encontrarlos, tal como ocurre con los caballeros que participan en el torneo de Noauz. Sin embargo, al igual que sucedía entre las mujeres, suele ser más común que aparezcan como comparsas, de hecho es así con los que acabamos de nombrar, o bien que se los designe mediante el título que ostentan.

En este apartado sólo recogemos a los amantes que llamaremos «oficiales». Los nombres de los esposos de Iseo y de Ginebra suelen ir precedidos del sustantivo roi, que trataremos más adelante. Por otro lado, el enamorado desdeñado por la reina Ginebra se suele mostrar como la antítesis de Lanzarote y sólo haremos referencias a él en comparación con éste, teniendo también en cuenta que nos detendremos en su figura al tratar el sustantivo chevalier. 


\subsection{Tristán.}

Desde los primeros versos del texto conservado de Béroul, el nombre propio del amigo, del amante, queda monopolizado por el discurso de la reina en estilo directo o en estilo indirecto libre, ya sea en enunciados claramente mendaces o absolutamente ciertos pero que ella presenta como irreales si está ante su esposo o ante la corte: “qar tu penses que j’aim Tristrain par puterie et par anjen" (Tristan, 406 - 407). En algunos de ellos mezcla con un atrevimiento irrespetuoso el sexo adúltero o más bien incestuoso, el amor familiar y el respeto feudal, y sugiere en ocasiones un cierto distanciamiento al hacerlo preceder por el tratamiento sire, inexistente en la intimidad: 332

Tristran, certes, li rois ne set que por lui par vos aie ameit; por ce qu'eres du parenté Tristan, $69-71$ oiez de qoi on vos apele: que Tristran n'ot vers vos amor de puteé ne de folor, fors cele que devoit porter envers son oncle et vers sa per.

Tristan, 4192 - 4196

\footnotetext{
332 Aunque en menor grado sigue la misma tendencia que habíamos señalado en el discurso de Tristán refiriéndose a ella:

Sire Tristran, por Deu le roi,

si grant pechié avez de moi

qui me mandez a itel ore!

Tristan, 5 - 7

li rois pense que par folie,

sire Tristran, vos aie amé

Tristan, 20 - 21
} 
Y ello porque la sociedad, quizá deberíamos decir la sociedad aristocrática, sólo creía posibles dos tipos de relaciones entre hombres y mujeres: el trato en el que no intervenía en absoluto el deseo sexual o si lo hacía no existía el contacto carnal, o bien los encuentros instintivos dominados por la animalidad en los que era impensable el afecto y la ternura. Béroul expresa explícitamente esa búsqueda instintiva de los cuerpos —mediante expresiones indudablemente peyorativas—, por boca de Iseo al referirse a sí misma o en la formulación en estilo indirecto libre del juramento de lealtad pronunciado por el propio rey Arturo en el que pide a la reina que atestigüe sobre la naturaleza del deseo del enamorado; pero al tiempo parece dar paso implícitamente a una tercerca vía en la que el sentimiento amoroso se une al deseo de los cuerpos.

La visión excluyente generalizada es la que alimenta la burla constante de los amantes y el juramento obsceno de la reina que analizaremos más adelante y la que marca muchos de los contextos en los que aparece el nombre propio del héroe en el discurso de los personajes de la corte; del rey Marco que seguirá permitiéndoles la dulce y arriesgada intimidad de la cámara: “ne jamais jor ne mescroira Tristran d'Iseut” (Tristan, 295 - 296), o que se hace eco de las continuas dudas sobre la honestidad de Iseo: "n'as fait de Tristran escondit" (Tristan, 3223), y fundamentalmente de los felones, voyeurs y justicieros impenitentes que asocian de forma invariable el nombre de Tristán al engaño: "Tristran set mot de Malpertuis" (Tristan, 4286) y a las relaciones sexuales con la reina caracterizadas por el exceso y el libertinaje:

Lors devisent li qeus d'eus trois

ira premier voier l'orlois

que Tristran an la chanbre maine

o celié qui seue est demeine.

Tristan, 4337 - 4340 
se Tristran l'aime folement,
a lui vendra a parlement

Tristan, $661-662^{333}$

La tercera vía se traza mediante el discurso de Iseo en la intimidad, en el que predomina el uso vocativo: “"Tristran,» fait ele, «quel damage qu'a si grant honte estes liez!” (Tristan, 904 - 905), precedido o seguido por el sustantivo ami, 334 especialmente cuando el filtro ha dejado de surtir su efecto, como si a partir de ese momento la relación entre ambos necesitase ser vivificada mediante la palabra definitoria del nuevo amor. El lenguaje, de hecho, es uno de los pocos lazos que les estará permitido mantener durante un periodo incierto. También se muestra de manera inequívoca ante Ogrin una vez transcurridos los tres años en los que la inexplicable pasión que los unía les permite por fín ser conscientes de sus sentimientos:

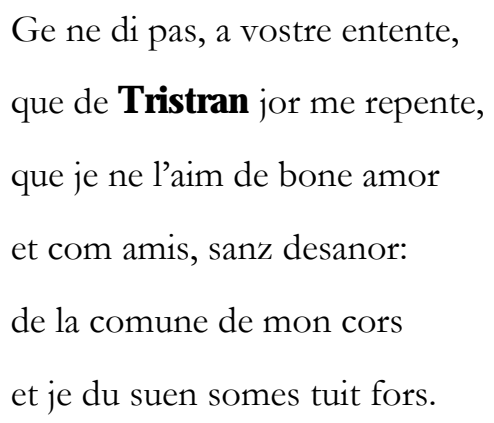

Tristan, $2325-2330$

Aunque de difícil interpretación ya que es extremadamente ambiguo y contradictorio con la continuación de la historia, este pasaje no nos parece una muestra más de las mentiras entretejidas por los amantes para salvarse y continuar juntos. Creemos que responde más bien a la lógica del fin del deseo físico irrefrenable — un final confirmado por las escenas de remordimientos y temores de los amantes y del sueño espiado por el marido- que los lleva a

\footnotetext{
333 También v. 590 - 593, 655 - 657, 3047 - 3048, 4282 - 4283.

334 Tristan 1587, 2217, 2285, 2288, 2707 y 2794.
} 
desear de nuevo la vida en sociedad. El final de la comune no es, y tanto Iseo como Ogrin lo saben, el final del adulterio, sino el comienzo de una relación controlada que quizá les permita gozar de la presencia del otro y de sus cuerpos sin exponerse inconscientemente a las miradas de los cortesanos y a la deshonra.

Esta tercera forma de entender la unión entre un hombre y una mujer también se define en las intervenciones del narrador en torno al nombre de Tristan. Éste es sujeto de enunciados donde se muestra el final de la concupiscencia: "Tristran ses braies ravoit" (Tristan, 1810), "Tristran avoc s'amie dort" (Tristan, 1851), "Tristran se couche et trait s'espee, entre les deux chars l'a posee" (Tristan, 1805 - 1806), o el cariño que siente hacia Iseo, gestos que curiosamente se hacen más abundantes desde el final del efecto del bebedizo: "Tristran gesoit en sa fullie, estroitement ot enbrachie la roïne" (Tristan, 1673 - 1675), “Tristran l'acole” (Tristan, 1795), “Tristran en bese la roïne, et ele lui, par la saisine" (Tristan, 2731 - 2732).

Desde un punto de vista formal cabe destacar el claro predominio de la denominación al comienzo del verso que coincide en gran medida con los usos gramaticales como vocativo - aunque con esta función también puede aparecer en el interior del verso- y como sujeto. Por el contrario las rimas no son muy abundantes y son menos expresivas que las que encontrábamos para su pareja, aunque nos llaman la atención dos sustantivos, ahan en el discurso del narrador, quien a menudo se muestra preocupado por el destino de los amantes y particularmente por los sufrimientos que la pasión les lleva a soportar; y anjen en el discurso de Iseo, puesto que el sustantivo podría ser considerado uno de los distintivos de la leyenda del héroe como observamos en E scoufle. 335

335 “Ml’t orent deduit par engien”, Escoufle, 3136. 


\begin{tabular}{lllllllll}
\hline FORMA & CA & BD & NV & RIMA & CA2 & NV2 & D & PERS \\
\hline Tristran & S & Tristan & 3289 & ahan & S & 3290 & N & Narrador \\
Tristran & S & Tristan & 2144 & an & S & 2143 & N & Narrador \\
Tristran & S & Tristan & 3136 & an & S & 3135 & D & Roi Marc \\
Tristrain & S & Tristan & 407 & anjen & S & 408 & D & Iseut \\
Tristrans & S & Tristan & 467 & corneualans & S & 468 & L & Roi Marc \\
Tristran & S & Tristan & 2848 & Dinan & S & 2847 & N & Narrador \\
Tristranz & S & Tristan & 2960 & enfanz & S & 2959 & N & Narrador \\
Tristran & S & Tristan & 3561 & Lidan & S & 3562 & N & Narrador \\
\hline
\end{tabular}

Tabla 41. Rimas del nombre propio Tristán.

En función de complemento de objeto directo Tristan aparece en un conjunto temático bien definido: el conflicto que sus relaciones con la reina provoca en la corte y las consecuencias que tiene para él mismo. En este caso el nombre propio depende de los verbos mescroire, ${ }^{336}$ menacier, ${ }^{337}$ prendre, ${ }^{338}$ mesler, ${ }^{339}$ chacier,, 340 mostrer, ${ }^{341}$ cuyos sujetos son invariablemente el rey Marco y los felones de la corte, los barones o los espías que les venden información sobre las actividades de los amantes. En menor medida lo encontramos como complemento de verbos cuyo sujeto es Iseo: “jaim T ristrain” (Tristan, 407) o el filtro:

\author{
Tant con durerent li troi an, \\ out li vins si soupris $\mathbf{T}$ ristran \\ et la roïne ensenble o lui \\ que chascun disoit: «Las n’en sui.» \\ Tristan, 2143 - 2146
}

El estudio de la sintaxis proposicional nos muestra este nombre propio en gran medida en proposiciones independientes o principales donde

\footnotetext{
336 Tristan 296.

337 Tristan 770 .

338 Tristan 806.

339 Tristan 1721

340 Tristan 3136.

341 Tristan 4282.
} 
funciona principalmente como sujeto o como aposición a un pronombre cuyas funciones son las de complemento de objeto directo o indirecto: "je vos di bien, Tristran, a fais, certes, je n'i vendroie mie" (Tristan, 18 - 19), aunque también lo hallamos en proposiciones subordinadas.

Las subordinadas circunstanciales están representadas por las causales introducidas mediante la conjunción car $^{342}$ y las hipotéticas introducidas por la conjunción se. Estas últimas formulan una condición sobre la que el locutor no nos da su parecer en el discurso directo de los personajes que traicionan a los amantes, el enano Frocín y el espía de los barones, con lo que deja que sean sus interlocutores los que saquen las conclusiones pertinentes y actúen en consecuencia:

$$
\begin{aligned}
& \text { se Tristran l'aime folement, } \\
& \text { a lui vendra a parlement } \\
& \text { Tristan, } 661 \text { - } 662
\end{aligned}
$$

Pendre m'otroi ou essillier, se ne vos mostre apertement

Tristran, la ou son aise atent de parler o sa chiere drue.

Tristan, $4280-4283$

de moi faciez en un feu cendre, (...) se n'i veez Tristran venir

Tristan, $4288-4291$

o bien un hecho pasado del que hay constancia que no se ha realizado en la narración: "Ja, se Tristran ice seüst que escondire nul leüst, mex se laisast vif depecier" (Tristan, 809-811). 
De entre las proposiciones subordinadas relativas podemos destacar aquéllas en las que el pronombre relativo funciona como complemento de objeto directo $\mathrm{y}$, especialmente, las especificativas que tienen como antecedente un sustantivo cuyo referente son las relaciones amorosas ilícitas o la traición de uno u otro bando —amantes o felones-, fenómenos de naturaleza antisocial y cuya conexión es evidente: "vit les braies que Tristran out" (Tristan, 2000)

$$
\begin{aligned}
& \text { Li rois a fait sa sele metre, } \\
& \text { s'espee çaint, sovent regrete } \\
& \text { a lui tot sol la cuvertise } \\
& \text { que Tristran fist, quant il l'ot prisse }
\end{aligned}
$$$$
\text { Yseult la bele o le cler vis }
$$$$
\text { Tristan, } 1943 \text { - } 1947
$$

$$
\begin{aligned}
& \text { ira premier voier l'orlois } \\
& \text { que Tristran an la chanbre maine }
\end{aligned}
$$

Tristan, $4338-4339$

$$
\begin{aligned}
& \text { ne se gaitoit de la } \underline{\text { rancune }} \\
& \text { que il avoit a Tristran fait }
\end{aligned}
$$

Tristan, $1698-1699$

Las proposiciones completivas cuya función es la de complemento de objeto dependen de verbos declarativos: dire, ${ }^{343}$ mander $^{344}$ y escondire; este último, aunque expresa en un principio el hecho de justificarse o defenderse, en el caso de Iseo la justificación se hará mediante el lenguaje:

\footnotetext{
342 Tristan 406 - 408 y 588 - 591.

343 Tristan $2325-2326$.

344 Tristan 4347 - 4349.
} 
“qu'il vuelent bien s'en escondie qu'o Tristran n'ot sa drüerie” (Tristan, 3047 - 3048); de pensamiento u opinión, referidos al conocimiento de las relaciones ilícitas: penser. "li rois pense que par folie, sire Tristran, vos aie amé" (Tristan, 20 - 21), y savoir: “demain savront con Tristran sert” (Tristan, 4344)

s'or savoit ceste chevauchie,

cel sai je bien que ja resort,

Tristran, n'avreie contre mort

Tristan, $184-186$

o de sintagmas que expresan temor, construcción en la que la subordinada adquiere una función cercana al complemento de nombre: "grant poor a Yseut la gente Tristran por lié ne se repente” (Tristan, 1651 - 1652)

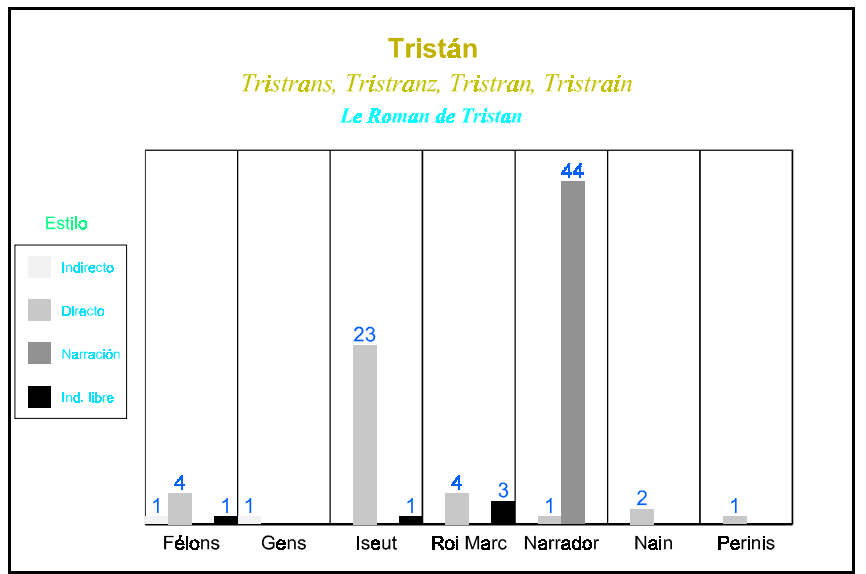

Fig. 30. Comportamiento estilístico del nombre propio Tristán en Tristan.

Tal como habíamos apuntado para el nombre propio de Iseo, una gran parte del peso de la leyenda recae sobre la identificación inequívoca del amante y de sus acciones, reales o simuladas. Por otra parte la definición, la evolución y la apariencia externa de las relaciones entre ambos enamorados vienen en gran medida determinadas por las intervenciones discursivas de Iseo en las que Tristan es vocativo, sujeto o complemento de objeto directo. El resto de las ocurrencias se reparten desigualmente entre los personajes que se 
oponen al adulterio y los que ayudan o compadecen a los amantes, y es especialmente notable la presencia del discurso indirecto e indirecto libre que colocan sus voces en un segundo plano.

\subsection{Lanzarote.}

No cabe duda de que el largo anonimato del héroe y la revelación de su nombre por la reina Ginebra, quien oculta su afecto tras una expresión dubitativa y otra excesivamente anodina: "Lanceloz del Lac a a non li chevaliers, mien escïant" (Charrete, 3660 - 3661), son un recurso que va más allá de la consecución de un golpe de efecto intra y extradiegético. Creemos que, además de otros fines de tipo estilístico y narrativo, en la utilización del sobrenombre o del sustantivo que define la clase social, a la vez dependientes de una larga tradición y de una voluntad innovadora por parte de Chrétien, confluyen varias causas de carácter erótico. Quizá la más importante sea la feminización del personaje, un fenómeno que apoyan otros pasajes de la obra como el paso del puente de la Espada. Bajo este puente Lanzarote encuentra un agua profunda y peligrosa, y para franquearlo debe abandonar sus atributos guerreros, caballo y armas. ${ }^{345}$ A este desnudo viril se añaden la castración simbólica de las heridas sufridas por el filo de la espada horizontal, el debilitamiento y la pérdida de sangre, que se producirá también en el paso por la ventana hasta la cama de Guenièvre, un nuevo espacio femenino imbricado. El amor cortés conlleva inevitablemente, por la aproximación necesaria de los contrarios para un encuentro sexual ideal, la masculinización de la mujer y la feminización del hombre. Éste adopta características que correspondían tradicionalmente a aquélla, cuando menos en el plano arquetípico y que habían servido para estructurar la sociedad en función de la división sexual. Así el hombre se hace sumiso, extremadamente fiel — no sólo física sino

\footnotetext{
345 L. Harf Lancner analiza este rito de paso al mundo femenino en el pasaje en el que se trata el tema del «mundo al revés» en el L anœlot en prosa; cf. Le Val sans Retour ou la prise du pouvoir par les femmes, A mour, mariage et transgressions, op. at., p. 188.
} 
también mentalmente, concentrando su deseo en una sola mujer-y fundamentará sus actuaciones sociales en el amor, dejando a un lado los intereses dinásticos y genéticos. En esta obra, además, se transfiere al hombre el secreto que rodea la identidad de la dama, una incógnita que unida a su valor lo hace más deseable. Esta mutación podemos observarla en la primera parte de la novela hasta su llegada al reino de Bademagu y en el episodio del torneo de Noauz, en el que sus nobles oponentes plenamente identificados por nombres, origen familiar, actitudes y emblemas son rechazados por las doncellas y menos admirados por los caballeros que inactivos contemplan los combates. De hecho ya hemos observado que los personajes femeninos de Charrete no son identificados por su nombre de pila, con la sola excepción de Ginebra, y éste se convierte en uno de los alicientes eróticos de la obra. Sin embargo, se produce en Charrete un fenómeno aparentemente contradictorio con lo que acabamos de exponer: el sometimiento absoluto a los dictados del amor y la ocultación del nombre del héroe llevan consigo un grave envilecimiento social — pérdida del caballo y subida a la carreta— que da origen al sobrenombre, traducido con una incomprensible rapidez en un rechazo que sólo desaparecerá tras notables esfuerzos por su parte, y, al contrario, sus grandes hazañas quedarán difuminadas por el anonimato. Probablemente la explicación se halle en el hecho de que la verdadera exaltación del héroe quedaba reservada a la reina - amante y que en cierta medida ésta debía hacerlo renacer a la sociedad y al sexo, hacerlo beneficiario de la nombradía que por méritos propios le correspondía y que tan importante era en el mundo artúrico. ${ }^{346}$

Con respecto a la utilización morfosintáctica del nombre propio nos parece reseñable el hecho de que sólo las mujeres lo utilicen como vocativo y que ésta sea la única función que aparezca en sus discursos, mayoritariamente en caso régimen como se impuso a partir de la segunda mitad del siglo XII

\footnotetext{
346 R. Caillois nos recuerda que nombrar, al igual que tocar, son prerrogativas de aquel que posee el poder en L 'H omme et le sacré. París: Gallimard, 1988, p. 122 - 3.
} 
aunque excepcionalmente encontramos una ocurrencia en caso sujeto: "Lanceloz, je sui por vos querre de loing venue" (Charrete, 6568 - 6569). Incluimos también entre ellos el bautizo de Ginebra en el que formalmente aparece en función de complemento de objeto directo pero lógicamente tiene un papel identificativo.

Frente a esto el contacto verbal de las mujeres con Meleagant no será nunca directo y Ginebra hablará siempre de él a otros hombres, interponiendo un escudo protector entre su raptor y ella misma, ya sea a Lanzarote: "Lancelot, ceste honte m'a ci Meleaganz amise" (Charrete, 4918 4919), Arturo: “C'est Meliaganz qui me prist el conduit Kex le seneschal" (Charrete, 6178 - 6179) o Bademagu:

$$
\begin{aligned}
& \text { et dit au roi que ele avra } \\
& \text { un chevalier qui desfandra } \\
& \text { le seneschal de ceste chose } \\
& \text { vers Meleagant, se il ose. }
\end{aligned}
$$

Charrete, 4903 - 4906

En el discurso narrativo el nombre propio se reparte en cuatro funciones: sujeto, complemento de objeto directo, complemento preposicional con valor circunstancial y, en una de las pocas intervenciones en que el narrador implica al auditor, es régimen de una construcción de presentación, con la que se pone de relieve la confusión en la que las contradictorias reacciones femeninas sumen al enamorado: " $\underline{E z}$ vos Lancelot trespansé" (Charrete, 3960). La función sujeto nos muestra a un enamorado extremadamente pasivo, que utiliza la vista: “et Lanceloz jusqu'a l'antree des

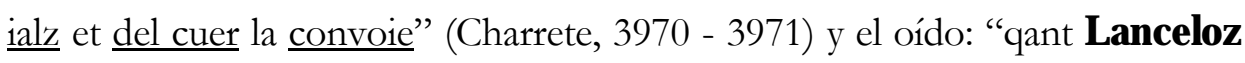
s'oï nomer" (Charrete, 3669), que se postra ante el rey Bademagu agradecido por la iniciativa de este al conducirlo ante la amada, que se ve obligado a actuar sometido a la voluntad de aquélla: "Donc le dut bien Lanceloz faire, 
qui plus ama que Piramus" (Charrete, 3802 - 3803), y que logra la felicidad cuando la reina lo llama a su lado después de haberlo rechazado y de haber fallado en su intención de matarse:

$$
\begin{aligned}
& \text { Or a } \mathbf{L} \text { anceloz quan qu'il vialt } \\
& \text { quant la reïne an gré requialt } \\
& \text { sa conpaignie et son solaz } \\
& \text { Charrete, } 4669 \text { - } 4671
\end{aligned}
$$

Aunque a la postre, la condición masculina triunfa en la referencia eufemística al placer sexual que resume la noche de amor tras la que Lanzarote abandona a regañadientes la habitación de la reina, obligado esta vez por el qué dirán:

\author{
Molt ot de joie et de deduit \\ Lanceloz, tote cele nuit. \\ Charrete, 4685 - 4686 \\ Molt śan part Lanceloz destroiz,
plains de sopirs, et plains de lermes. \\ Charrete, 4702 - 4703
}

En las dos ocurrencias en las que aparece como complemento de objeto directo observamos que el sujeto de los verbos mander, baisier y conjoïr es la reina, quien adapta su actuación con respecto al enamorado en función de la situación en la que se encuentra, aunque mantiene siempre la discreción que requiere la transformación que el amante cortés sufre al estar próximo a su amada y no tanto el adulterio en sí pues con otros caballeros como Gauvain y Keu actúa de forma muy espontánea, lo que le hubiera permitido una cierta familiaridad con el que había sido su salvador: 
Ou est donc li cuers? Il beisoit

et conjoïssoit Lancelot.

Charrete, 6830 - 6831

Lanzarote es la causa de los sufrimientos de Ginebra, torturada por haberlo perdido, lo que la aleja en cierta medida de las lejanas y altivas damas trovadorescas: "por Lancelot a le cuer vain" (Charrete, 5200)

$$
\begin{aligned}
& \text { que por Lancelot duel avoit } \\
& \text { tel, don noveles ne savoit, } \\
& \text { que la color en a müee }
\end{aligned}
$$

Charrete, 5245 - 5247

pero también lo es de las congregaciones multitudinarias en la corte, deseosos como están todos de ver luchar al valeroso caballero que durante tanto tiempo ha estado perdido:

et as fenestres revont maint chevalier, dames et puceles, por Lancelot, gentes et beles.

Charrete, 6980 - 6982

La composición textual presenta en muy pocas ocasiones el nombre propio al comienzo o al final del verso como podemos ver en la tabla de rimas correspondiente, y se prefiere para él la segunda posición del verso en construcciones de tipo: [Prep. + Sust.], [C onj. + Sust.], [Adv. + Sust.] o [Interj. + Sust.].

\begin{tabular}{lllllllll}
\hline FORMA & CA & BD & NV & RIMA & CA2 & NV2 & D & PERS \\
\hline Lancelot & S & Charrete & 6831 & celot & V & 6832 & N & Narrador \\
Lancelot & S & Charrete & 3942 & mot & S & 3941 & D & Roi Bademagu \\
Lancelot & S & Charrete & 3666 & ot & V & 3665 & D & Pucelle \\
Lancelot & S & Charrete & 4902 & ot & H & 4901 & N & Narrador \\
\hline
\end{tabular}

Tabla 42. Rimas del nombre propio Lanzarote. 
Pocas son las proposiciones subordinadas en las que se encuentra el nombre propio del Caballero de la Carreta, una sola completiva: "de rechief vient a la reïne que Lanceloz ocis se fust por li, se feire li leüst." (Charrete, 4430 - 4432) y, entre las circunstanciales, una causal introducida por la conjunción que ${ }^{347}$ y dos temporales introducidas por la conjunción quant: "quant Lanceloz voit son eise, qu'il ne dit rien que molt ne pleise la reïne" (Charrete, 4469 - 4471). ${ }^{348}$

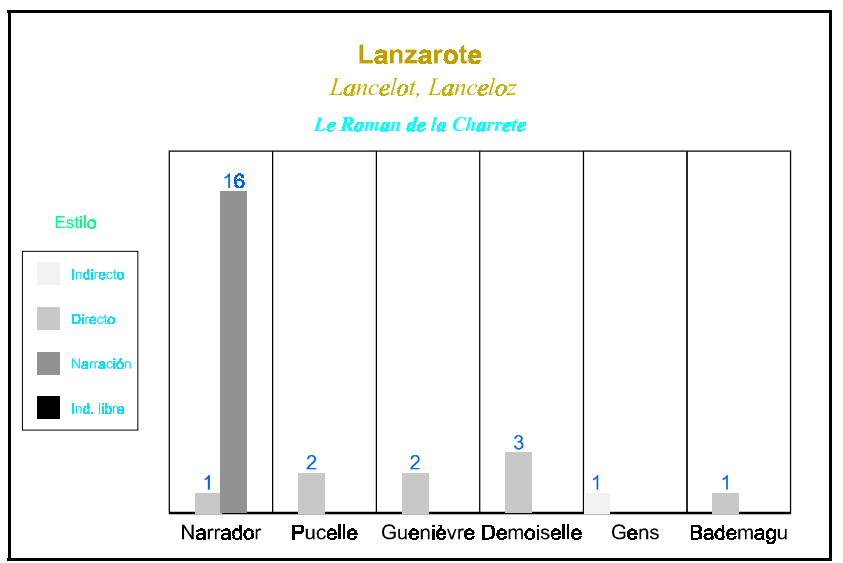

Fig. 31. Comportamiento estilístico del nombre propio Lanzarote en Charrete.

Quizá lo más destacable del comportamiento estilístico de este nombre propio, máxime si lo comparamos con Tristan, sean la apropiación que de él hace el discurso femenino así como el huidizo discurso de Ginebra. Estos hechos lo colocan en una situación contradictoria al ser índice, por un lado, del deseo que despierta entre las mujeres y por otro, de las fuertes convenciones que pretendían hacer prevalecer los que veían en la cortesía un aliado socio-político. Esta aparente contradicción nos lleva a concluir que, al menos en la utilización del nombre propio del héroe, Charrete se ofrece como uno de los paradigmas del género caballeresco, que ha surgido de la profunda remodelación textual, erótica y social operada sobre la lírica cortés.

\footnotetext{
347 Charrete 5245.

348 También Charrete 3669.
} 


\title{
3.2.1.2.1.3 Guillemo.
}

Guillermo es hijo de héroe, pero sólo tomará las armas para entrenarse en su infancia con el fin de fortalecer su cuerpo y su espíritu y al ser armado caballero en un rito vacío ya de contenido. Este, sin embargo, le proporcionará la prestancia necesaria para acceder al condado heredado de su padre y al imperio que le otorgan sus nupcias y la gloria de su progenitor. El amante y sus peripecias parecen haberse impuesto definitivamente al guerrero:

\author{
Vous savés bien que ceste terre \\ doit estre leur et li roiaumes: \\ que li fius le conte, Guilliaumes, \\ en fu revestus par le pere \\ quant il tenoit encor l'empere.
}

Escoufle, 8550 - 8554

Quizá irónicamente, pues no conoceremos ninguna hazaña bélica del joven, su nombre se asocia en la rima a hiaume elemento característico de los caballeros y de su fuerza en la primera parte de la obra así como de la vida palaciega de aquéllos en los episodios italianos. El recorrido vital del pusilánime enamorado será casi del todo opuesto al de su amada Aelis. Mientras esta huye del yugo cortesano y de la institución matrimonial al salir del palacio paterno, Guillermo, que había llevado una existencia marcada por las mujeres, sale empujado de ella. Sólo acatando la férrea voluntad de Aelis se dispone a liberarse y liberarla mediante el rapto, y a reclamar para sí las tierras de Normandía a las que su padre no pudo regresar. En un primer momento la cuidada formación al lado de la heredera del imperio lo ayudarán en el servicio y agasajo de su prometida: "Guilliaume, que si li seut porchacier ostel bel et bon” (Escoufle, 4870 - 4871), pero demasiado pronto su inmadurez lo llevará a cometer un error irreparable que lo despeñará a la soledad, la pobreza, la enfermedad, al duro trabajo manual y al ahorro, y lo convertirá en un 
antihéroe al situarlo en los antípodas del hombre noble y del amante cortés. Resulta curioso que se nos presente como tal cuando los héroes caballerescos que lo habían precedido, y de los que tenemos claros ejemplos en Tristán y Lanzarote también habían pasado por momentos de infortunio y de deshonra social, sin que los receptores sean conscientes de que exista una denigración real del héroe. Creemos que dos de los factores principales para que nos cause esa impresión son: por un lado, la preferencia narrativa por las aventuras de la bella una vez que ambos salen del palacio del emperador, y, sobre todo, la dejación que hace Aelis de sus derechos eróticos sobre Guillermo, representada por el olvido y el continuo agasajo que recibe de otros hombres a los que sirve y entretiene a cambio de renombre y bienes materiales, en lo que puede representar el fin de una cierta concepción del amor, excesivamente monolítica y obsesiva, en gran medida de espaldas a la realidad.

Sin embargo, el nombre propio del enamorado apenas está asociado con estas terribles vicisitudes, tan sólo en el punto en el que Aelis se cree irremediablemente abandonada y le reprocha sus acciones, crítica que retomará el narrador:

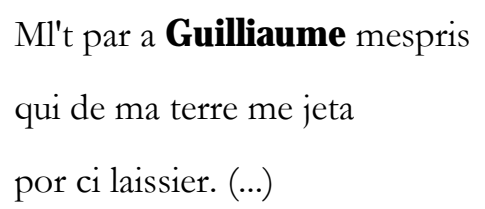

Escoufle, 5286 - 5287

cuando acompañada de Isabel y cansada de buscarlo, simplemente lo olvida - una reacción que cuadra escasamente con las convenciones amorosas que atañen a los personajes femeninos en los romans - "ne lor membre mais de 
Guilliaume" (Escoufle, 6171); al haber devorado el corazón del pájaro que los había separado ${ }^{349} \mathrm{y}$, por fín, cuando a punto de recobrar a la amada, no puede reconocerla y piensa tan sólo en ganar el dinero suficiente para reemprender su búsqueda:

$$
\begin{aligned}
& \text { (... ) et Guilliaumes qui solt } \\
& \text { s'amie querre a tel souffraite, } \\
& \text { et pense s'il li avoit faite } \\
& \text { itel aïe com il li dist } \\
& \text { qu'il n’i aroit ja plus respit } \\
& \text { Escoufle, } 7480-7484
\end{aligned}
$$

Una gran parte de las ocurrencias del nombre propio se encuentran repartidas en dos grandes grupos temáticos íntimamente relacionados. Uno de ellos absolutamente positivo — la vida gozosa de los amantes en la corte imperial y en la de Saint Gilles—-, y la otra cara de la moneda, el matrimonio desigual que, sin embargo, se hacía eco de las recomendaciones de la Iglesia —libertad de elección y amor entre los futuros cónyuges—: "comment est hui primes venue avant la parole de vostre enfant que Guilliaume aime" (Escoufle, 2886 - 2889). Una promesa de matrimonio en torno a la cual se teje una trama cortesana para impedir que se cumpla; hechos que permitirán el relanzamiento del relato y la iniciación y madurez, sensual y económica para Aelis y vital para Guillermo.

En ambos casos Guillaume se encuentra constantemente asociado a su amada, cuyo nombre, como hemos señalado más arriba, queda supeditado al del varón. Sin embargo, la substitución pronominal del primero trastoca ese orden y coloca Guillaume en la rima: "tos li deduis ert d'un roiame en estre o li et o Guilliaume" (Escoufle, 2072 - 2073). Se construye de este modo el enfrentamiento dialéctico entre el rey y los cortesanos que se oponen al enlace

${ }^{349}$ Escoufle, 6920 y 7013 - 7015. 
entre los enamorados y por ende a la intimidad en la que conviven desde que eran niños:

car nos dites de quel aconte

est Guilliaumes, li fix le conte,

adés es chambres vostre fille

Escoufle, 2701 - 2703

et dist jamais n'iert aliie

a Guilliaume par mariage

Escoufle, 2906 - 2907

o bien las referencias, como es habitual poco claras y determinadas, a los juegos y placeres de los enamorados:

Et Guilliaume, le debounaire,

et Aelis qu'il ne het mie

s'en vont com amis et amie

Escoufle, 2092 - 2094

Ainc puis ne furent a celee

lor parlemens ne lor delis

entre Guilliaume et $\underline{\text { Aelis }}$

Escoufle, 2372 - 2374

Tuit servent Guilliaume et onourent

et la pucele qui le baise

Escoufle, 7730 - 7731

De Guilliaume ne de s'amie

ne sai or comment il lor fu, car cil qui siet tranlant au fu se caufe volentiers de prés

Escoufle, 7876 - 7879 
En el discurso directo de Aelis encontramos una cierta similitud con el uso que habíamos observado para el nombre propio de la enamorada en boca de Guillermo. Éste parece reflejar el acuerdo perfecto entre ambos, así como un cierto respeto de las convenciones corteses que hemos analizado también en lo tocante a Ginebra y Lanzarote, y una cierta tendencia de Jean Renart a equilibrar las relaciones entre el hombre y la mujer rompiendo con algunas reglas sociales y literarias, intento que será a la postre fallido. En este caso el nombre del enamorado se convierte casi en objeto de culto para Aelis antes del paréntesis burgués al que nos hemos referido: " $\mathrm{Li}$ nons de Guilliaume et li deus li est tos jors el cuer escris” (Escoufle, 4724 - 4726), y sólo lo nombrará en completa soledad o en la intimidad para reclamar su presencia ante un joven servidor que le es fiel, en su faceta de miembro dominante de la pareja, al tiempo como heredera del simbolismo de la dama cortés y como muestra de una efectiva superioridad social una vez rotos los lazos matrimoniales y en espera de la recuperación de éstos mediante el rapto: “va a l'ostel plus que le pas por Guilliaume, si le m'amaine: je voel savoir quel vie il maine" (Escoufle, 3326 - 3328); en el vergel cuando no lo ve a su lado: "Ml't bel l'apele par son non: «Guilliaume!» et cil ne li dit mot." (Escoufle, 4654 - 4655); al reprocharle su abandono; y desnuda en su lecho al recordar las caricias que tantas veces la habían hecho gozar hasta esa noche, en uno de los pasajes más sensuales del roman:

(...) Ele s'est nue levee en son lit en estant.

Entre ses dens a dit itant:

«Ahi! Guilliaumes, biax amis

Escoufle, 3280 - 3283

El uso como vocativo queda muy restringido: junto a las dos ocurrencias mencionadas se halla la que encabeza el discurso del emperador al prohibir la entrada a Guillermo en la habitación de las doncellas. ${ }^{350}$ En

350 Escoufle, 3016. 
función de sujeto lo encontramos en dos estructuras diferentes, una convencional en caso nominativo que ocupa preferentemente una de las tres posiciones iniciales del verso tanto en activa: "or sachiés que richement robe Guilliaumes la maison le roi” (Escoufle, 3986 - 3987) como en pasiva: “ceus puist mangier li leus du bos par cui Guilliaumes fu banis!” (Escoufle, 4110 4111), y la otra formando pareja con Aelis, en la que suelen presentarse ciertas anomalías formales al ir precedido de una preposición y en caso régimen:

\author{
Entre Guilliaume et Aelis \\ devisent bien tot lor afaire \\ Escoufle, 3614 - 3615 \\ Entre Guilliaume et Aelis \\ sont lés la biere d'une part \\ Escoufle, 3510 - 3511
}

Como complemento de objeto directo depende de verbos como aimer, 351 senvir y honorer, 352 eslire: "k'il a sor tos autres eslit Guilliaume" (Escoufle, 2288 - 2289), mesler. "cil qui Guilliaume orent mellé a lui li ont tolu sa fille" (Escoufle, 4122 - 4123), honir, metre [fors]: “il se porront mix entremetre de Guilliaume honir et $\underline{\text { metre }}$ fors de l'onor l'empereor" (Escoufle, 2681 - 2683) y queme: "quis ont Guilliaume en Normendie" (Escoufle, 5345). ${ }^{353}$ En función de complemento de objeto indirecto lo hace

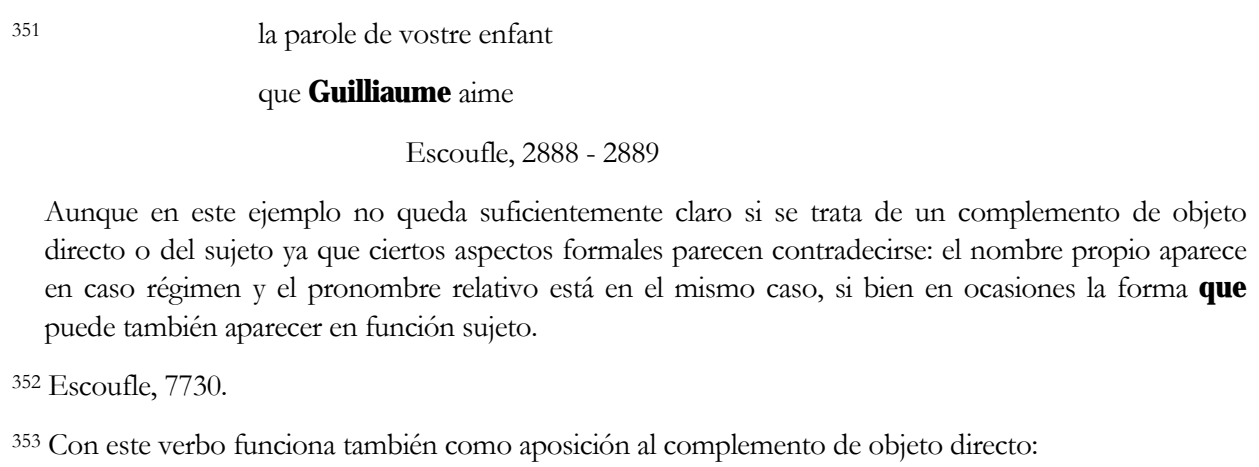

Aunque en este ejemplo no queda suficientemente claro si se trata de un complemento de objeto directo o del sujeto ya que ciertos aspectos formales parecen contradecirse: el nombre propio aparece en caso régimen y el pronombre relativo está en el mismo caso, si bien en ocasiones la forma que puede también aparecer en función sujeto.

352 Escoufle, 7730.

${ }^{353}$ Con este verbo funciona también como aposición al complemento de objeto directo:

Guilliaume le gentil, le preu,

$\mathrm{u}$ le ferai je jamais querre

Escoufle, 5159 - 4160 
de los siguientes: porter [honor]: “des ore est mais raisons c'on port a Guilliaume grignor honor" (Escoufle, 2344 - 2345), doner, 354 aliier, 355 renoveler: "ml't renovele li pensés a Guilliaume" (Escoufle, 6675), faire, con el que se hace referencia al lecho en el que descansará en el castillo de Saint Gilles cerca de Aelis: “on ne fist pas celui plus lait a oés Guilliaume son ami” (Escoufle, 7862 - 7863). Si exceptuamos el verbo aimer - del que hemos señalado como dudosa la función del nombre propio como objetoel resto de los verbos mencionados jalonan las grandes etapas en la vida de Guillermo, los honores y la desgracia asociados al matrimonio con la heredera del imperio y la pérdida del contacto con la sociedad noble y con el sexo femenino, apenas restablecida por la compra de un caballo, símbolo de clase así como de la búsqueda, y probablemente de la virilidad que pronto recobrará. Junto a ellas o, por mejor decir, por encima de todas ellas, se perfila el tema fundamental de la novela en sus dos partes: la consecución de tierras que incrementa con el patrimonio el poder del linaje y lo acerca en lo posible a la realeza —obsesión que se plasma en las rimas con roiaume-, la cual ya era del todo imposible alcanzar mediante la actividad guerrera directa, método que había sido sustituido por las uniones matrimoniales en las que pronto intervendrá un nuevo factor, el dinero. Éste ya está presente en la obra como elemento de intercambio erótico en las ciudades, pero no es aún en el imaginario noble la llave para un matrimonio ventajoso.

\begin{tabular}{lllllllll}
\hline FORMA & CA & BD & NV & RIMA & CA2 & NV2 & D & PERS \\
\hline Guilliaume & S & Escoufle & 2073 & hiaume & S & 2074 & N & Narrador \\
Guilliaumes & S & Escoufle & 2972 & hiaumes & S & 2971 & N & Narrador \\
Guilliaume & S & Escoufle & 6171 & roialme & S & 6172 & N & Narrador \\
Guilliaume & S & Escoufle & 2722 & roiaume & S & 2721 & D & Traîtres \\
Guilliaumes & S & Escoufle & 8552 & roiaumes & S & 8551 & D & Barons \\
\hline
\end{tabular}

Tabla 43. Rimas del nombre propio Guillermo.

Las proposiciones subordinadas completivas en las que aparece el nombre propio dependen de dos tipos de verbos desde el punto de vista

\footnotetext{
354 Escoufle, 2721 - 2722

355 Escoufle, 2906 - 2907.
} 
lógico: los de dicción que presentan los discursos y enfrentamientos del emperador y de los cortesanos en torno a la conveniencia o no de que Guillermo se convierta en el esposo de Aelis, y los verbos de conocimiento, en tres intervenciones del narrador, ${ }^{356}$ una de ellas en estilo directo en la que recuerda a los receptores de la obra el delito contra la propiedad familiar cometido por Guillermo al huir con Aelis pese a ser ella la promotora del rapto. 357

Las proposiciones subordinadas circunstanciales recogen varias hipotéticas introducidas por la conjunción se en las que la unión legítima de los amantes se presenta como un factor desestabilizador para la monarquía, y aunque la transgresión desde el punto de vista moral es inexistente a diferencia de lo que ocurría en Tristán, se considera o al menos se presenta igual de peligrosa desde el punto de vista del funcionamiento de la autoridad y de los lazos entre los diferentes grupos de la nobleza: “n'avroit pais en vostre roiaume s'on donoit vo fille Guilliaume” (Escoufle, 2721 - 2722)

\section{Trop kerroit ja de roiste tertre \\ vostre grant terre et vostre empire}

se Guilliaumes en estoit sire, et nos honi et damagié.

Escoufle, 2740 - 2743

aunque como ocurría en la obra de Béroul el mayor problema para la integridad de la paz, de la familia y del buen gobierno era la separación de los amantes pues llevaba aparejados el exilio, la deshonra y el dolor para los que no habían sabido retenerlos: "K'encore fust bele Aelis çaiens, se Guilliaumes i fust." (Escoufle, 4112 - 4113).

Las proposiciones temporales nos presentan los momentos, muy distantes, en los que Guillermo es plenamente aceptado en el grupo

\footnotetext{
356 Escoufle, 5286 - 5287 y 7876 - 7877.

357 Escoufle, 3986 - 3987.
} 
aristocrático, en el nacimiento y el renacimiento a la vida noble; tras la formación teórica en palacio: "et quant Guilliaumes ot .x. ans, ml't fu a cort de tos amés" (Escoufle, 2040 - 2041) y tras la verdadera iniciación en el mundo del trabajo: "quant la bele ot oï le non de Guilliaume qui tant l'amoit" (Escoufle, 7280 - 7281).

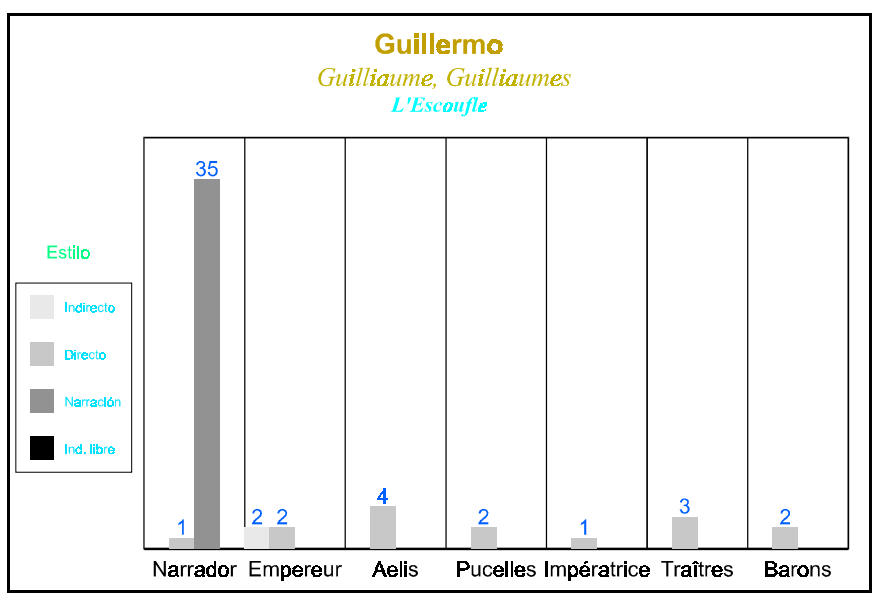

Fig. 32. Comportamiento estilístico del nombre propio Guillermo en Escoufle.

El modo en el que se reparten las ocurrencias del nombre propio del héroe en E sooufle lo hace deudor de las dos tendencias observadas hasta ahora en nuestro corpus. Por un lado, la narración y las intervenciones de los que apoyan o rechazan su matrimonio hasta su salida de la corte imperial hacen que se acerque a Tristán. Por otro, fiel a la tradición caballeresca más próxima de la cortesía primitiva en cuanto a las manifestaciones sentimentales, representada por Charrete, Renart evita en lo posible que Aelis pronuncie el nombre de su amante, con ello salvaguarda el secreto de sus amores y reserva el nombre propio para circunstancias marcadamente patéticas. 


\subsection{REFLEJO DE LA ESTRUCTURACIÓN SOCIAL.}

\subsection{Homme y vassal.}

Las características semánticas del vocablo homme responden en primer término, tal como ocurría en el caso de femme a dos rasgos principales fundamentados en consideraciones biológicas: pertenecer al género humano y ser una criatura racional de sexo masculino, uno de carácter general y el segundo de carácter particular y por lo tanto independientes. Así puede observarse en los romans que hemos analizado, aunque, como veremos, las peculiaridades de los usos del vocablo vienen en gran medida dadas por los aspectos sintácticos y retóricos del contexto. A los dos rasgos mencionados podemos añadir otro cuyo origen es social, aunque en este caso es indudablemente de orden secundario, a diferencia de lo que ocurría para femme: mantener una relación de dependencia con respecto a un señor en el sistema feudal. Este rasgo, que en principio no tenía nada que ver con el erotismo, va a ser aprovechado por la literatura medieval para elaborar o adaptar una parte del ideario cortés. Así en estado bruto lo hallamos en Rose, donde el amante reconoce a Amor como su único señor, quien a su vez lo acepta como vasallo en pago a sus indudables virtudes, promesas de futuros desvelos y servicios: "ainz doit estre cortois et frans cui ge ensint a home prans" (Rose, 1937 - 1938), todo lo cual reproduce el ritual del beso que sellaba el vasallaje:

$$
\begin{aligned}
& \text { Atant devins ses hom mains jointes, } \\
& \text { et sachiez que mout me fis cointes } \\
& \text { dont sa bouche baisa la moie }
\end{aligned}
$$

$$
\text { Rose, } 1953 \text { - } 1955
$$

Esta transposición metafórica tardía, propiciada por una reelaboración erótica de las relaciones feudales en los primeros tiempos de la 
cortesía, da lugar en Rose a dos usos desvirtuados del término vassal. Éste en principio servía para denominar al noble que ayudaba a su señor en la guerra según la costumbre, pero su sometimiento era relativo y surgido de un acatamiento voluntario; $y$, como vocativo, para dirigirse a un hombre joven del mismo rango. ${ }^{358}$ En el discurso de Amor el vocativo traduce la violencia con la que irrumpe el instinto sexual en el joven, representada alegóricamente por la violencia física que ya le ha infligido la personificación del dios y el avasallamiento dialéctico con el que terminará de someterlo, imagen a su vez de la reelaboración intelectual del deseo; y todo ello mucho antes de que el que acaba de caer en sus redes esté en disposición de servirle tras la ceremonia de vasallaje a la que nos hemos referido:

\footnotetext{
Vasaus, pris estes, rien n’i a de destorner ne de desfendre, ne fai pas dangier de toi rendre.
}

Rose, 1882 - 1884

En el discurso de Dangier - personaje que puede ser interpretado como el rechazo pudoroso de la mujer o como el celo de los que la rodeanel término adquiere un valor peyorativo en el que se conjugan algunos de los conceptos básicos de la estructura amorosa cortés: la condena de una excesiva rapidez en el acercamiento de los sexos, familiaridad o intimidad que puede acarrear graves consecuencias sociales para la joven y que, al tiempo, parece transgredir las normas que pretendían armonizar la sensualidad masculina y femenina; en segundo lugar la sumisión social y/o sexual, rasgo aquí secundario y derivado del discurso de Amor.

Bel Acueil, por quoi amenez entor ces rosiers ce vassaut?

Rose, 2910 - 2911

${ }^{358}$ Cf. A.-J. Greimas, op. at., p. 655. 
Vos li cuidiez bonté fere,

et il vos quiert honte et contraire.

Fuiez, vassaus, fuiez de ci!

Rose, 2917 - 2919

Este sometimiento vertebró los discursos amorosos herederos de la fin' amors y dio origen a un nuevo rasgo semántico para el término homme: mantener una relación amorosa con una mujer a la que no se está unido por los lazos matrimoniales. Se trata de un uso ya tradicional en la retórica cortés que calca, al menos en lo discursivo, la sumisión del vasallo con respecto al señor feudal, aquí la dama. El indudable efecto transgresor del orden social y fundamentalmente sexual que dicho uso había podido tener, sin entrar en consideraciones morales: a. por el trastrocamiento del orden de prelación masculino - femenino en cualquier ámbito de la vida; b. por el debilitamiento subsecuente de los lazos sociales masculinos; c. por la tendencia a la confluencia de la poligamia masculina y de la monogamia femenina tradicionales en una poligamia compartida aunque restringida a los esposos y a un solo amante; d. por la introducción de los sentimientos como bases indiscutibles del adulterio potencial o consumado; e. por el desmembramiento del estricto ordenamiento genealógico; f. por la ruptura de las tendencias endogámicas; se halla amortiguado en la tradición novelesca tal como nos muestran las ocurrencias que encontramos en Escoufle. Una de ellas contraviene el uso regular por dos motivos: la mujer a la que se somete el enamorado - vasallo es soltera y la dependencia sobreviene por un cambio inesperado en sus relaciones, no se encuentra en la génesis de la relación, tal como parece mostrarnos el adverbio or, a ello se añade el hecho no desdeñable de que huem aparece en más ocasiones en la rima con Rouen, y por lo tanto podemos suponer un factor estríctamente formal para explicar la atribución definitoria en el discurso de Guillermo:

«Dame, fait il, or sui vostre huem.

Or ai plus que n'a quens ne rois.

Escoufle, 3538 - 3539 
La segunda ocurrencia, que aparentemente responde a una relación perfectamente acorde con el adulterio cortés, se queda en una simple fórmula de afecto sin que subyazca un verdadero vínculo de vasallaje por parte del conde de Saint Gilles, al que hemos oído increpar a su amada en un arrebato de celos. Esta impresión de vaciedad se ve reforzada por la yuxtaposición del sintagma vos chevaliers, una variante que recapitula el trato amoroso privilegiado por la literatura en los cincuenta años precedentes a la obra de Renart en su pretensión, ya entonces caduca, de reconducir y rentabilizar las fuerzas excedentes de los jóvenes guerreros:

\author{
«Dame, vos chevaliers, vostre hom, \\ fait li quens, s'en devroit raler, \\ car je criem que le malparler \\ Escoufle, 5886 - 5888
}

En cuanto a los dos rasgos principales que hemos dicho caracterizan el vocablo nos ha resultado en ocasiones imposible determinar si una ocurrencia respondía a uno u otro pues podía hacer referencia a cualquier persona o solamente a un varón, sin que el contexto semántico y formal nos ayudase a delimitar su alcance, especialmente en E scoufle y en Rose: "en sa veüe se peüst bien uns hom mirer” (Escoufle, 4812 - 4813). Bien es cierto que en muchos casos la duda quedaría despejada si pensásemos que ciertas actitudes y sentimientos amorosos como el extremo dolor podían quedar reservados al varón, apreciación que se nos viene abajo si tomamos en consideración las reacciones de Iseo, Ginebra o Aelis al creer muertos o al pensar haber perdido para siempre a sus amantes. En Tristan esta dificultad no se presenta y con el significado de «varón» sirve para que Iseo reafirme su amor y fidelidad sexual hacia el marido, quien según la Iglesia y la sociedad es Marc, aunque el término seignor con el que supuestamente se refiere a éste bien puede ser aplicado también al que la desvirgó y por lo tanto se convirtió según la costumbre en su verdadero esposo: 
Mex voudroie que je fuse arse,

aval le vent la poudre esparse,

jor que je vive que amor

aie o home qu'o mon seignor

Tristan, $35-38$

Con ello el verdadero adulterio se produjo tras las ceremonias de matrimonio al acostarse con el rey, tras haber sido empujada a una poligamia de hecho que se vislumbra en el lenguaje figurado del leproso - Tristán cuando le cuenta al rey que su enfermedad, aquí de transmisión sexual, procedía del marido de su amiga, así como en la evocación obscena que hace Iseo de aquel que la llevó a horcajadas para conseguir que llegase inmaculada al juramento de la Blanca Landa:

qu'entre mes cuises n'entra home,

fors le ladre qui fist soi some

Tristan, $4205-4206$

En Rose las exigencias extremas del dios Amor y la inexperiencia del enamorado se transmutan en oraciones -independientes o subordinadas completivas — introducidas mediante el adverbio coment con valor al tiempo exclamativo e interrogativo en las que el sustantivo homme creemos representa al hombre enamorado, y ello porque, aunque se hace referencia en la obra al dolor que invade a la mujer enamorada cuando nos son narradas las aventuras de la desdichada Eco, el discurso de Amor parece centrarse en el servicio y sufrimientos del enamorado para que la mujer elegida lo acepte y le entregue su amor y su cuerpo, y que lo llevarán probablemente a la ruina, la desesperación, la enfermedad y posiblemente la locura:

Coment vit hom et coment dure qui est em poine et en ardure, 


$$
\begin{aligned}
& \text { en duel, en soupirs et en lermes } \\
& \text { et en toz poinz et en toz termes } \\
& \text { est en sousi et en esveil? } \\
& \text { Si m'aïst Dex, mout me merveil } \\
& \text { coment hom, s'il iere de fer, } \\
& \text { puet un an vivre en tel enfer. }
\end{aligned}
$$

Rose, 2573 - 2580

En cualquier caso creemos que resulta más interesante un análisis de las estructuras en las que aparece el sustantivo que la dilucidación de su sentido más o menos concreto. Las más abundantes son las que expresan nociones de ponderación o de énfasis, si bien predominan en las dos novelas del siglo XIII y sólo aparecen excepcionalmente en Charrete, tal es el caso de las construcciones negativas con valor generalizante y excluyente, sin lugar a dudas las más frecuentes. Entre ellas encontramos dos ejemplos casi coincidentes por su sentido —expresión del amor superlativo de los héroes masculinos—y uso de referentes literarios, aunque la variación viene dada por estos últimos:

$$
\begin{aligned}
& \text { Donc le dut bien Lanceloz faire, } \\
& \text { qui plus ama que Piramus, } \\
& \text { s'onques nus hom pot amer plus } \\
& \text { Charrete, } 3802-3804
\end{aligned}
$$

Or n'ama mais en tel maniere

nus hom ja; si fist viaus Tristrans.

Escoufle, 6352 - 6353

En E scoufle predomina este tipo de construcciones donde se niega el verbo - ya de la proposición principal, ya de la subordinada en la que aparece 
el sustantivo homme- y el sustantivo se halla precedido por el adjetivo indefinido nul, a lo que se añaden uno o varios adverbios temporales negativos, y en las descripciones de la esencia o del estado del personaje el uso del comparativo de superioridad:

Et bien sachiés, se il tant vit

k'il soit chevaliers, ains ne vit

nus hom plus hardi ne plus preu.

Escoufle, 2767 - 2769

k'il ñ'est nus hom plus a malaise,

et el n'est mie ml't a aise

Escoufle, 3475 - 3476

k'ainc mais feme ne fist tel don

a nul home de mon afaire

Escoufle, 4500 - 4501

Jamais ne cuit que nus hom voie

si tres bele rien a cheval

Escoufle, 7991 - 7992

Guillaume de Lorris prefiere la combinación de múltiples elementos frente a la estandarización de Jean Renart con lo que puede aparecer el adjetivo indefinido, ${ }^{359}$ y junto a la negación del verbo encontrarse adverbios

\footnotetext{
359 En algún caso parecen un calco de las utilizadas por Renart como ocurre con la descripción de Deduit, similar a una de las de Guillermo en E soufle.

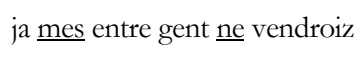


temporales negativos como mes y onques y adjetivos que refuerzan el valor general del sustantivo como mortel y nez: "nou voudroie avoir deserté dou rosier qui l'a aporté por nul home vivant, tant l'ains." (Rose, 2901 - 2903). Estas construcciones se hallan fundamentalmente en la descripción inicial del jardín y de los que en él se solazan y con menor frecuencia en el discurso de Amor:

$$
\begin{aligned}
& \text { que mes si douce meloudie } \\
& \text { ne fu d'ome mortel oïe }
\end{aligned}
$$$$
\text { Rose, } 665 \text { - } 666
$$

car tel joie ne tel deduit

ne vit mes hom, si com je cuit

Rose, 473 - 474

$$
\begin{aligned}
& \text { dont si tres beles genz pooient } \\
& \text { estre venu, que il sembloient } \\
& \text { tot por voir angres empenez: } \\
& \text { si beles genz ne vi hom nez. }
\end{aligned}
$$

$$
\text { Rose, } 721-724
$$

\section{Onques voir tex respons ñissi}

d'ome vilain mal enseignié

Rose, 1928 - 1929

El valor contextual ponderativo o enfático en que se encuentra inmerso el sustantivo homme puede venir dado por la introducción de construcciones consecutivas que sirven para expresar la grandeza o bajeza de las acciones que se le atribuyen a un hombre en particular - Lanzarote o Keu—y que encontramos solamente en Charrete. 
Certes vos avez trop mespris

d'ome qui tant vos a servie

qu'an ceste oirre a sovant sa vie

por vos mise an mortel peril

Charrete, 3950 - 3953

Certes, Kex n'est mie tex hom

qu'il me requeïst tel outrage

Charrete, 4844 - 4845

O bien en proposiciones exclamativas como las que se recogen en Escoufle, sean proposiciones subordinadas completivas o proposiciones independientes coordinadas:
et s'ama toustans par amors,
ki le faisoit hardi et preu.
Ne vos avroie hui conté preu
quels hom il fu, car ne porroie
Escoufle, 108 - 111
Ja n'est il nule autre seconde
a cesti, et tex hom l'avroit!

Escoufle, $2724-2725$

Quizá la característica sintagmática más notable que podamos deducir de las ocurrencias observadas es una imperiosa necesidad de determinar o de calificar el término homme, que por otra parte apenas es puesto de relieve por la organización estructural del verso al no ocupar nunca la primera posición y aparecer en contadas ocasiones en las rimas. 


\begin{tabular}{lllllllll}
\hline FORMA & CA & BD & NV & RIMA & CA2 & NV2 & D & PERS \\
\hline home & S & Tristan & 4205 & some & S & 4206 & D & Iseut \\
hom & S & Charrete & 4844 & livreison & S & 4843 & D & Guenièvre \\
home & S & Escoufle & 8815 & Rome & S & 8816 & N & Narrador \\
hom & S & Escoufle & 5886 & raison & S & 5885 & D & Comte S. G. \\
homes & S & Escoufle & 5509 & disomes & V & 5510 & N & Narrador \\
huem & S & Escoufle & 3538 & Rueem & S & 3537 & D & Guillaume \\
home & S & Rose & 801 & pome & S & 802 & N & Narrador \\
home & S & Rose & 2101 & nome & V & 2102 & D & Amour \\
\hline
\end{tabular}

Tabla 44. Rimas del sustantivo homme.

La determinación, como ya hemos apuntado, suele ser negativa e indefinida, aunque también recurren a los demostrativos: "cuidiés vous dont que s'el n'amast cest home" (Escoufle, 8252 - 8253), y a otros indefinidos como maint: "que maintenant ou laz cheï qui maint home a pris et traï" (Rose, 1611 - 1612), o autre: "se je veoie autre home avoir ceste honor et vos et l'avoir"' (Escoufle, 3517 - 3518). La calificación se lleva a cabo por medios diversos, una proposición relativa: “ja mar arés doute d'ome qui en la vile viengne" (Escoufle, 5724 - 5725), “ausi com hom qui a peor" (Rose, 2282), un adjetivo indefinido como tel, un adjetivo calificativo: “amor n'a cure d'ome morne" (Rose, 2166), "si vit de ce qu'ele desert a laver les chiés as haus homes" (Escoufle, 5508 - 5509), "et quant joines hom fet folie" (Rose, 3000), un complemento atributo o circunstancial con valor atributivo: "que hom va plus bel et plus droit" (Escoufle, 2023), una construcción comparativa: "l'espee prent com home iriez" (Tristan, 2080), e incluso mediante la predicación verbal: “onques hom rien d'amer ne sot cui il n'abelist a doner" (Rose, 2204 - 2205). Nos da la impresión de que con todo ello lo que se pretende es dar una cierta fijeza al concepto - excepto en las referencias más generales - aun en su variedad, buscar la integridad lingüística, una marca que permita identificar a los individuos a la vez que se crea un universo masculino absolutamente maniqueo. En él se enfrentan los traidores a los fuertes y honrados, los ricos y poderosos a los débiles, los villanos a los corteses, los que tienen derecho a amar frente a los que nunca serán amados; una estrategia que apenas será utilizada con respecto a las mujeres, cuya afiliación parece 
quedar borrada por la omnipresente belleza y por la inevitable atracción sexual ejercida sobre el varón.

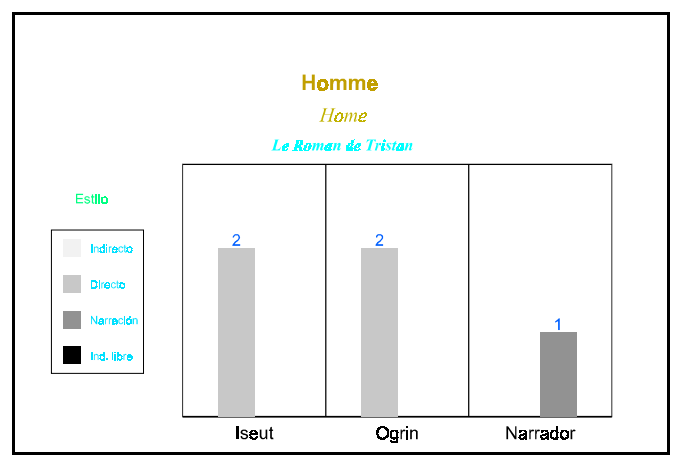

Fig. 33. Comportamiento estilístico del sustantivo homme en Tristan.

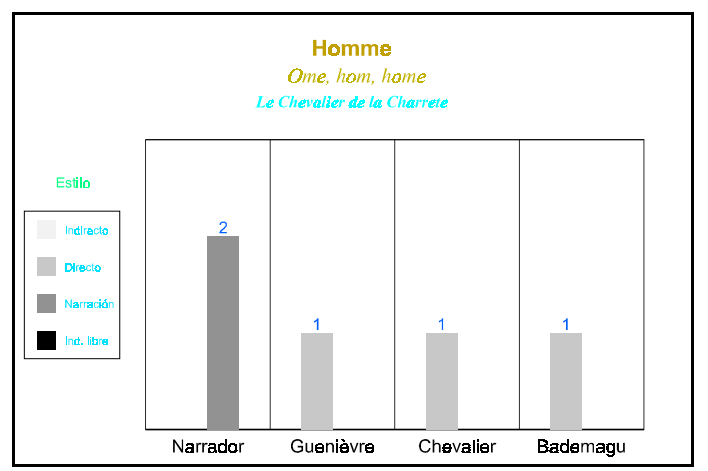

Fig. 34. Comportamiento estilístico del sustantivo homme en Charrete.

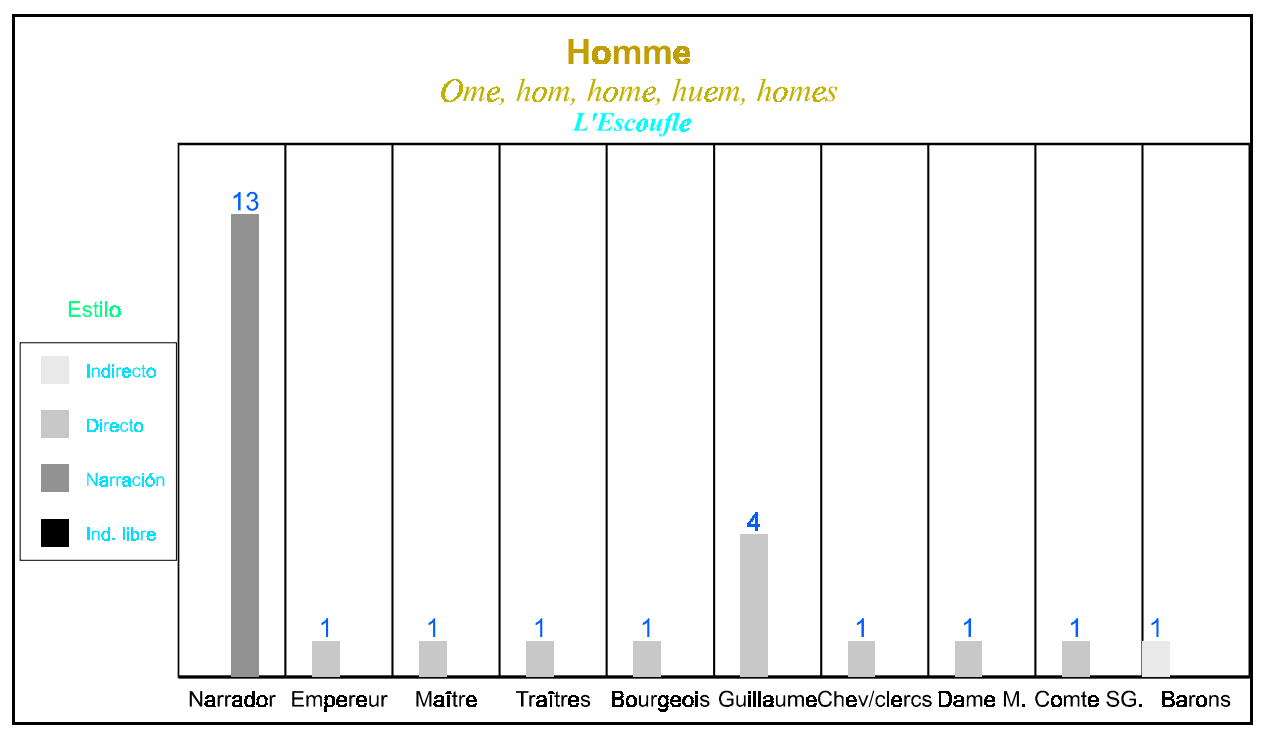

Fig. 35. Comportamiento estilístico del sustantivo homme en Escoufle. 


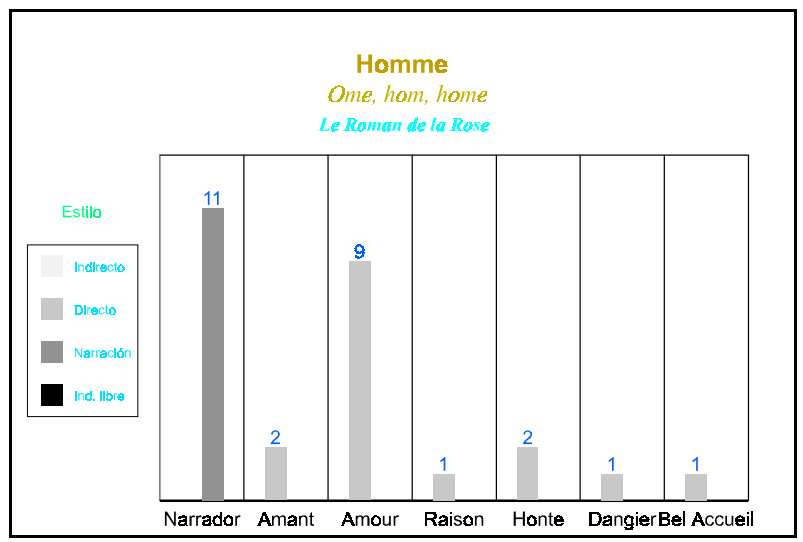

Fig. 36. Comportamiento estilístico del sustantivo homme en Rose.

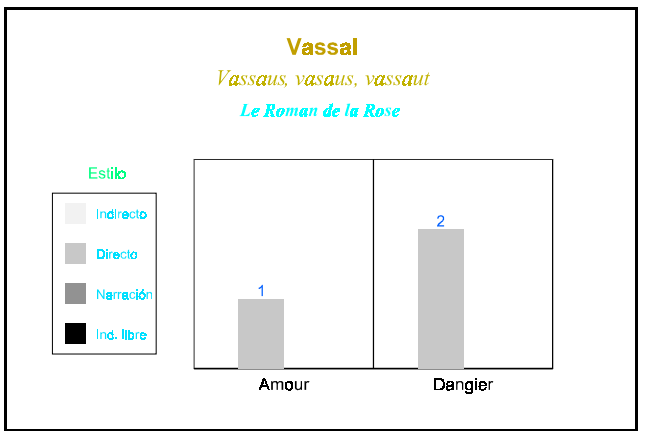

Fig. 37. Comportamiento estilístico del sustantivo vassal en Rose.

La intensificación del uso de las construcciones comparativas y superlativas, así como el desarrollo de las transposiciones del vocabulario feudal han incrementado sobremanera los usos narrativos y discursivos del sustantivo homme en los textos del siglo XIII. En Tristan y Charrete quedaba reservado generalmente para ocasiones muy particulares en las que, partiendo del sentido más general del término, se pretendía llegar a hablar de un individuo bien identificado por el contexto, como ocurre en las intervenciones de Iseo, Ginebra, el rey Bademagu o incluso de Ogrin.

\subsection{Enfant.}

La niñez es un valor en alza en la novela del siglo XIII: es como si una vez sobrepasada la gran época de los mitos guerreros y de los amores 
adúlteros inesperadamente fieles, el amor sólo pudiera refugiarse en la inocencia y pureza infantiles, al menos supuestas por los adultos, así como en el vigor sexual de los púberes a los que Venus encuentra más dignos de ser amados. Se convierte así la infancia en una virtud que no sólo iguala sino que ensalza las cualidades físicas y sociales tradicionalmente requeridas para gozar de los favores del sexo femenino:

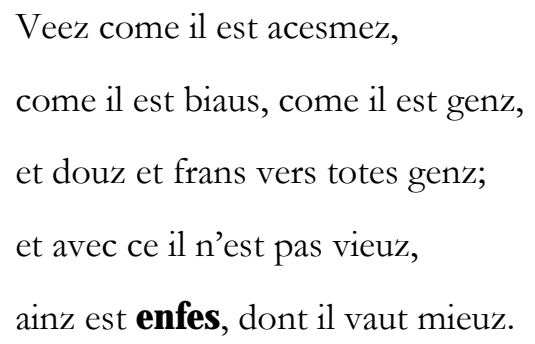

Por otra parte, la infancia llega a ser la época privilegiada para manifestar la angustia producida por las tensiones genealógicas. Esta se había agudizado por la mitificación de las relaciones extramatrimoniales y por la entrada del dinero en los circuitos matrimoniales, y se vuelve contra Guillermo en E scoufle, objeto de las iras de los que se erigen en guardianes de la pureza de clase: "li traïtor, li losengier qui l'enfant heent durement" (Escoufle, 2920 2921). También creemos que en todo esto se hace notar la influencia de las enseñanzas de la Iglesia que pretende crear una cultura del matrimonio como patrón organizador de la sociedad laica y para ello debe recurrir a fomentar una idealización de las actividades de los linajes nobles y conseguir parejas estables. Toman para ello como punto de partida por un lado la realidad social, la unión al menos nominal de los niños pertenecientes a dos familias con intereses yuxtapuestos, y por otro una cierta ideología amorosa que hiciese a las familias más proclives a atender los diversos requerimientos de la Iglesia más alla de sus propios intereses. 
También es la época de la iniciación sexual en la que el deseo se mueve entre lo múltiple y lo singular empujado por los arrebatos de los sentidos, en la que mientras dura un enamoramiento, que puede ser fugaz, no se dejan resquicios a la duda o a la razón para modular las acciones. Se convierte así en la edad dorada de la cortesía llevada a sus extremos: amor doloroso pero siempre proclive a la alegría del que no tiene otras preocupaciones, sin contacto físico o tan furtivo que apenas se le concede la existencia pero suficiente para mantener el deseo, sin que las barreras sociales importen pero bajo la estricta vigilancia de las familias.

Todo ello no podía dejar exenta de contradicciones la evocación de las actividades de las que son sujeto los niños — casi invariablemente varones_. 360 A la vez héroes duchos: "Ainc mais nus enfes de .xii. ans ne seut tant comme cis set ja." (Escoufle, 4268 - 4269) y enamorados inmaduros: “et uns enfes de son eage ne bee pas a faire sens" (Escoufle, 5384 - 5385), se dejan llevar, como Narciso, por apariencias y por impulsos: “car ses ombres l'avoit traï, qu'il cuida voair la figure d'un esfant bel a desmesure" (Rose, 1484 - 1486). Impulsos innegablemente nefastos para el verdadero amor, el amor al otro, casi idéntico pero complementario como nos dice Jean Renart al describir a los amantes fugitivos: “.ii. enfans tous d'une faiture encontrés et tos d'un eage" (Escoufle, 4220 - 4221). ${ }^{361}$

\footnotetext{
360 Solamente en una ocasión la pareja formada por Aelis y Guillermo actúa llevada por la despreocupación y ello por su falta de experiencia ante la muerte, cf. Escoufle 2404 - 2406, insistiéndose en otro lugar en su conocimiento de la vida:

$$
\text { ainc dui enfant de lor eage }
$$$$
\text { ne s'en alerent si par sens }
$$$$
\text { Escoufle, } 4240 \text { - } 4241
$$

361 El sustantivo también hace en plural referencia a los dos enamorados en otras ocasiones, véanse los versos 1973, 2315, 2329, 2381, 4121, 4238 y 4348.
} 


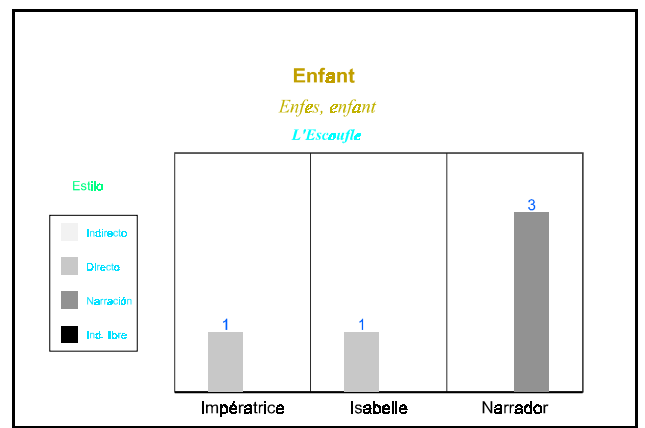

Fig. 38. Comportamiento estilístico del sustantivo enfant en Escoufle.

\subsection{3 «Damoisel», bachelier y valet.}

Estos tres vocablos, presentes tan sólo en los textos del siglo XIII, añaden valores diversos al componente cronológico básico que encontrábamos en el anteriormente tratado. Damoisel, evoca la pertenencia a un grupo social superior, claramente definido en E scoufle - noble de cuna y aspirante a caballero— 362 y muy difuminado en Rose, donde hace referencia a los que tienen el privilegio de enamorarse, es decir, poseen una nobleza de espíritu inevitablemente acorde con una cierta posición social que los separa de la villanía: "Narcisus fu uns demoisiaus qui Amors tint en ses raisiaus" (Rose, 1437 - 1438), 363 y al propio Deduit, el señor del jardín en el que penetra el amante. Tal como observamos en E scoufle cuando Guillermo ya es caballero, conde y marido de Aelis: "li damoisiaus vit et raine" (Escoufle, 8559), la acepción política puede prevalecer sobre la cronológica, y ello hace que se redunde en el primer rasgo, la juventud, recurriendo a la calificación mediante un epíteto al concluir en una proposición subordinada causal la descripción del anfitrión de los enamorados:

\footnotetext{
$362 \quad$ li damoisel qui furent droit

sor les degrés, devant la sale

Escoufle, 5592 - 5593
}

363 También Rose, 1591. 
se petiz peuls filoges non,

car il ert joines demoisiaus

Rose, $816-817$

La misma insistencia con la que se caracteriza al amigo de Jeunesse para el que se echa mano no sólo del adjetivo en función atributo, sino del tópico del emparejamiento armonioso mediante dos construcciones comparativas paralelas, y se abunda inevitablemente en el rasgo definitorio del término valet en esta época:

\author{
Li valez fu joines et biaus, \\ $\underline{\text { si estoit bien d'autel aage }}$

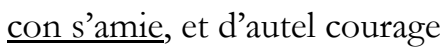 \\ Rose, 1274 - 1276
}

Valet parece ser una forma alternativa de dos sílabas que no introduce ninguna variación semántica con respecto a damoisel ${ }^{364}$ y que permite, por ejemplo, la coordinación de los sintagmas en los que aparecen denominaciones de ambos sexos, mientras que la forma de tres sílabas exigía la yuxtaposición, con la que se daba un ritmo excesivamente forzado a la frase: “de raconter fauses noveles de vallez et de damoiselles" (Rose, 3557 - 3558). Lorris también prefiere esta denominación cuando se describen las cualidades físicas y/o sociales del joven en el mismo verso, mediante dos adjetivos coordinados: "dames i ot de toz sens pointes, et vallez envoisiez et cointes" (Rose, 919 - 920), "un vallet bel et avenant" (Rose, 2774), o gracias a un adjetivo que indica la abundancia de la cualidad expresada mediante un complemento preposicional: “un valet de grant biauté plain” (Rose, 1108).

En la obra de Renart damoisel reúne tres subconjuntos temáticos relacionados con el amor y el deseo sexual. En el primero se define a

364 Véanse por ejemplo en Escoufle los versos 4428, 4935 y 6567. 
Guillermo como la pareja perfecta para la heredera del imperio, todavía una niña, adoptando expresiones formularias: "l'en mena la dame et s'amie par grant chierté, le damoisel. Ainc mais ne si preu ne si bel ne vit nus hom venir a cort” (Escoufle, 1950 - 1953), “del damoisel et d'Aelis estoit ml't bele l'assamblee" (Escoufle, 2008 - 2009). Se hace depender el futuro de la pareja de la voluntad del emperador, ${ }^{365}$ cuyo verdadero deseo, la mejora genética de la estirpe, se pone de manifiesto en la metáfora agrícola propuesta por el narrador:

$$
\begin{aligned}
& \text { L'emperere n'aime tant rien } \\
& \text { com le damoisel et la fille, } \\
& \text { et c'est por la boine semille } \\
& \text { u il les voit asemillier }
\end{aligned}
$$

Escoufle, 2102 - 2105

En el segundo, Guillermo sigue siendo el protagonista como núcleo masculino del gineceo en el que ejercita la sensibilidad erótica primordial, la que tiene su origen en la visión:

$$
\begin{aligned}
& \text { le damoisel qui ne s'en garde, } \\
& \text { ki es chambres s'amie garde } \\
& \text { les puceles qui font karoles }
\end{aligned}
$$

Escoufle, $2827-2829$

y como partenaire erótico de Aelis, siempre sumiso tras la huida del palacio paterno, en contextos en los que la sexualidad pasa a un segundo plano oculta tras la alimentación, un tema que se retoma incesantemente en esta parte de la novela y que parece funcionar a la vez como construcción metonímica de las necesidades físicas y como figuración metafórica de los deseos eróticos: “Li damoisiax li fait son sés de tot comme ses dous amis." (Escoufle, 4460 -

365 Escoufle, 2214 - 2217, 2941 - 2943, 4155 - 4157. 
4461). En este subconjunto aparece una cierta contradicción con respecto al héroe, por un lado sirve satisfactoriamente a su amante, por otro se halla siempre desprevenido o indeciso, incapaz de sobreponerse tras la desgracia turbado como está por la pasión amorosa:

Li damoisiax ne set que faire, k'amors le destraint et encauce.

Escoufle, 3202 - 3203

Ml't est pensis li damoisiaus

por ce qu'il crient que ne s'esvelt.

Ne set le quel voloir il velt

Escoufle, 4624 - 4626

En el tercero el damoisel Guillermo, en un principio único beneficiario de los favores de la joven dama, representados por los objetos preciosos o joiaus que ella misma manufactura, debe compartirlos con otros hombres que pueden pagar por ellos:

Ele a lués droit la grace eüe

des chevaliers, des damoisiaus.

C'est par son sens et ses joiaus

k'ele fait tex comme il devisent.

Escoufle, 5486 - 5489

y si bien en su emparejamiento con Guillermo la relación joiel - actividad sexual se establecía en el plano simbólico, aquí se juega claramente con el equívoco, haciendo de los objetos preciosos un indicio y dejando abierta la puerta a una interpretación puramente erótica — Tristan el leproso nos ofrece un ejemplo del sentido sexual del término: "o lié faisoie mes joiaus" (Tristan, 3772)—. Según ésta las actividades manuales de Aelis producirían un placer 
físico entre los que la visitan y pagan sin regatear lo que les pide. Se establece así un doble circuito entre dos conjuntos significantes jerarquizados, el metafórico, que depende del amor y exige entrega física y espiritual a cambio del don femenino, acorde con la ideología aristocrática feudal, y el metonímico, que responde a necesidades de subsistencia individual y social y se inserta en el circuito monetario donde las relaciones contractuales en el plano simbólico pueden suspenderse a voluntad.

Si tomamos en consideración las funciones que desempeñan los sintagmas en los que se inserta la denominación masculina damoisel, observamos en primer lugar que la función de complemento de objeto directo se reserva en E scoulle para el primer subconjunto temático relacionado con los problemas genealógicos: "L’emperere qui ml't amot le damoisel et la besoigne ne bee pas a faire aloigne" (Escoufle, 2214 - 2216), mientras en Rose la única ocurrencia nos presenta las presas favoritas del dios Amor: "et fist ses laz environ tendre et ses engins i mist por prendre demoiseilles et demoisiaus" (Rose, 1589 - 1591). En esta obra las dos ocurrencias restantes funcionan como complemento atributo mientras que en Escoufle se da un claro predominio de la función sujeto, si bien son minoritarios los contextos en los que se nos muestra la relación amorosa o los signos de ternura que de ella se derivan:

\section{Li damoisiax cui pas ne poise \\ li met la robe sous son chief}

Escoufle, 4520 - 4521

\section{Li damoisiax s'est acostés}

lés li, si l'a par la main prise

Escoufle, $2322-2323$

Por el contrario se insiste en la desgracia y los sufrimientos que sobre él se ciernen, fruto del amor y de la falta de experiencia. El cambio en el modelo erótico masculino que pasa del joven caballero del siglo XII al muy 
joven aspirante a caballero o al joven burgués del siglo XIII, y del modelo único o bifronte a la multiplicidad acorde con la vida ciudadana, carga con el lastre tradicional de la ascesis amorosa, aunque cambian las causas sociales que la originan. Una vez desaparecido el adulterio como impedimento a la vez que acicate, se adopta la inexperiencia y la dificultad para controlar el deseo como principios básicos del desarrollo narrativo: "del grant duel et de la mervelle ke avoit fait li damoisiaus” (Escoufle, 6980 - 6981)

\section{Dex! Tans contraires, Dex! Tans $\underline{\text { deus }}$}

li damoisiaus ot li proçains!

Escoufle, 6182 - 6183

Por lo que se refiere a bachelier, cuyo uso queda restringido a Rose, la justificación como variante formal de damoisel sólo sería válida en las dos ocurrencias que aparecen al final de un verso, ${ }^{366}$ mientras que en otra entrevemos la reafirmación de uno de los rasgos complementarios ya mencionados: ser un aprendiz que ayuda al señor en las tareas caballerescas; en este caso al sostener las flechas del dios Amor y ayudarle a descubrir a las víctimas potenciales:

Icil bachelers regardoit

les queroles, et si gardoit

au dieu d'Amors .ii. ars turquois

Rose, 907 - 909

\footnotetext{
$366 \quad$ Li autres biens est Douz palers,

qui a fet a mainz bachelers

et a maintes dame secors

Rose, 2657 - 2659

si avient bien a bacheler

que il sache de vieler,

de citoler et de dancier
}

Rose, 2195 - 2197 


\begin{tabular}{lllllllll}
\hline FORMA & CA & BD & NV & RIMA & CA2 & NV2 & D & PERS \\
\hline damoisiax & S & Escoufle & 5605 & aviaus & S & 5606 & N & Narrador \\
damoisel & S & Escoufle & 1951 & bel & A & 1952 & N & Narrador \\
damoisiaus & S & Escoufle & 4624 & joiaus & S & 4623 & N & Narrador \\
damoisiaus & S & Escoufle & 5487 & joiaus & S & 5488 & N & Narrador \\
demoisiaus & S & Rose & 817 & oisiaus & S & 818 & N & Narrador \\
demoisiaus & S & Rose & 1591 & oisiaus & S & 1592 & N & Narrador \\
damoisiaus & S & Escoufle & 6981 & oissiaus & S & 6982 & N & Narrador \\
damoisiaus & S & Escoufle & 6894 & rainciaus & S & 6893 & N & Narrador \\
demoisiaus & S & Rose & 1437 & raisiaus & S & 1438 & N & Narrador \\
\hline
\end{tabular}

Tabla 45. Rimas del sustantivo «damoisel».

\begin{tabular}{lllllllll}
\hline FORMA & CA & BD & NV & RIMA & CA2 & NV2 & D & PERS \\
\hline bacheler & S & Rose & 2195 & vïeler & I & 2196 & D & Amour \\
bachelers & S & Rose & 2658 & palers & I & 2657 & D & Amour \\
\hline
\end{tabular}

Tabla 46. Rimas del sustantivo bachelier.

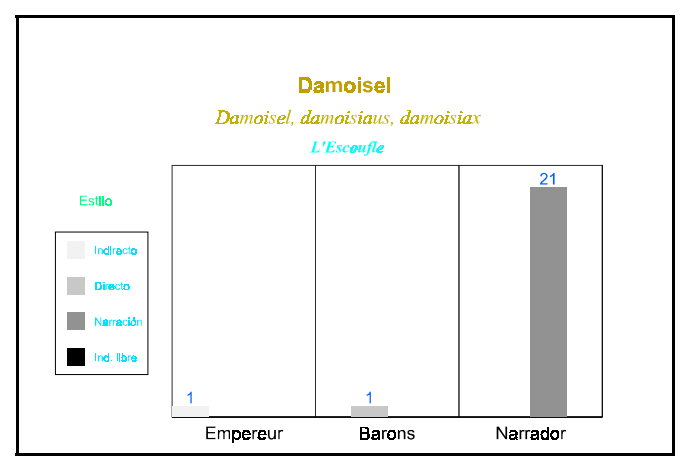

Fig. 39. Comportamiento estilístico del sustantivo «damoisel» en Escoufle.

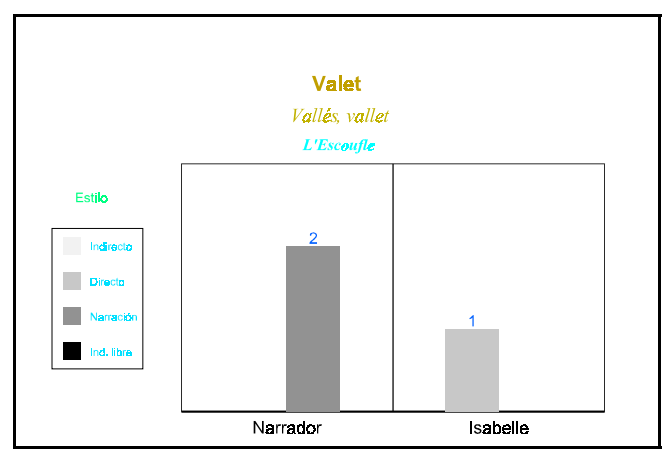

Fig. 40. Comportamiento estilístico del sustantivo valet en Escoufle. 


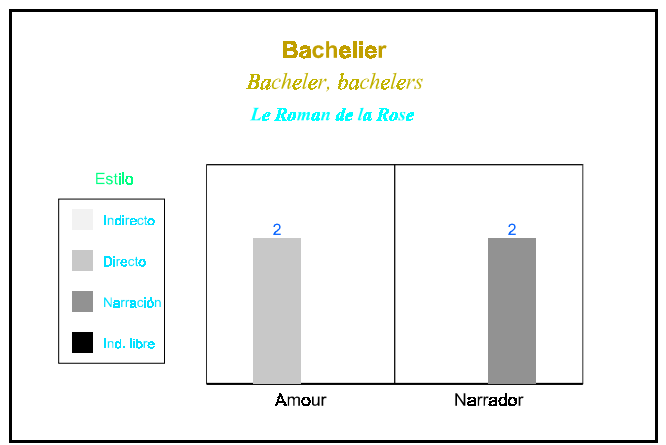

Fig. 41. Comportamiento estilístico del sustantivo bachelier en Rose.

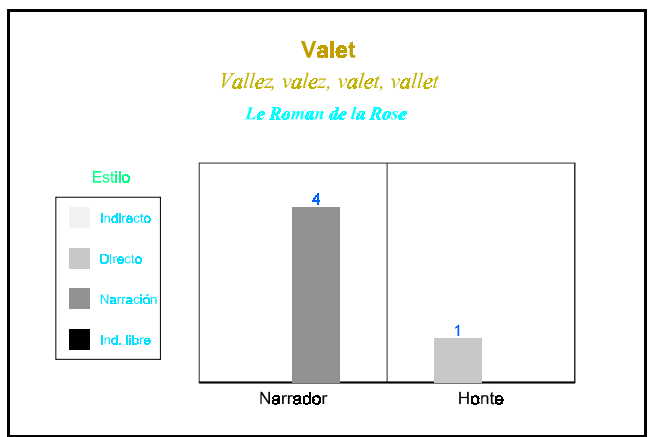

Fig. 42. Comportamiento estilístico del sustantivo valet en Rose.

El recurso a estas denominaciones, prácticamente monopolizado por la narración, pretende, junto a la caracterización de los personajes y como resultado de ésta, afianzar el nuevo modelo de héroe masculino más acorde con los renovados intereses aristocráticos y con las aspiraciones de las grupos urbanos más favorecidos.

\subsection{Chevalier.}

Las obras de Chrétien constituyen un punto de referencia en el ordenamiento simbólico de la caballería y en general de la baja nobleza, lo que le lleva a una reducción máxima de la compleja gradación social masculina limitándola a unos cuantos grupos: reyes, caballeros, aspirantes a caballeros, vavasseurs y sirvientes. Dentro de ese ordenamiento también se encuentran los códigos sexuales que, en gran medida enfrentados entre sí, pretenden 
conseguir la regulación de los comportamientos, una reglamentación tácita que quiere ser objetiva y que se halla sometida a fuerzas coercitivas de origen natural o sociohistórico como las estructuras familiares o las diferencias biológicas entre los sexos.

En Charrete se adopta el modelo trovadoresco con evidentes matizaciones caballerescas y se otorga a cada uno de los grupos mencionados un papel en relación con el sexo femenino: los sirvientes y los aspirantes a caballero no muestran ninguna inclinación por el sexo femenino; a los vasallos y caballeros en su condición de maridos se les supone una relación sujeta a las reglas eclesiásticas, de igual modo que al rey Arturo; en cuanto a los caballeros solteros tropezamos con dos tipos bien diferenciados; por un lado se encuentra Lanzarote cuya actuación significante: acciones, gestos, palabras, e incluso reacciones físicas, se acomodan al modelo cortés, por otro los que como Meleagant siguen pautas de conducta que se podrían considerar como precorteses, sobre las que, sin parar mientes en el deseo femenino, imperan la fuerza y la habilidad guerreras a duras penas coartadas por la autoridad señorial y paterna. En general se caracterizan por un orgullo desmedido que termina por hacerlos aparecer como meros bravucones:

De ce me puis je bien vanter qu'il n'a, tant con la mers aceint, chevalier, ou il en a meint, nul si boen cui je la leissasse Charrete, $1732-1735$

Mención aparte merecen los caballeros dependientes de la que se ha dado en llamar «joven enamorada», quienes, sometidos a la voluntad de ésta y con el fin de despertar la lujuria de Lanzarote, al que obligan a presenciar una violación: “chevaliers, (...) se de sor moi cestui ne m'ostes, il me honira, veant toi” (Charrete, 1071 - 1073), manifiestan una sexualidad tosca, impúdica, dominada por el instinto: 


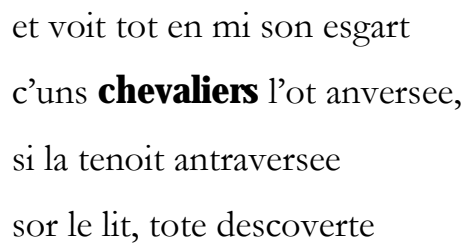

Meleagant es el único caballero del que se nos presenta la descripción física, somera y estereotipada pero suficiente para ensalzar la fuerza y la capacidad de sufrimiento del enardecido contrincante que será Lanzarote. Del aspecto de este último sólo nos dan cuenta los adjetivos bel y gent, aunque en belleza como en virtud supere a todos los demás: "et qui trestoz les assanblast si bel ne si gent n’i veïst” (Charrete, 2620 - 2621). De Meleagant se habla según tres puntos de vista diferentes en dos tipos de discurso. El narrador asume la presentación del punto de vista de Galván y del propio Lanzarote que lo observan desde lejos: "et devant venoit uns granz chevaliers qui menoit une bele dame a senestre" (Charrete, 557 - 559); en el discurso de una de las doncellas se añade una apreciación subjetiva no exenta de admiración: "Meleaganz, uns chevaliers molt forz et granz" (Charrete, 637 - 638), que será retomada por el propio narrador poco antes de dar paso a su calidad moral, es decir, a aquello que lo hace vulnerable ante Lanzarote y que le impide no sólo ser el mejor de los caballeros, sino amar y ser amado de la misma forma que aquel:

(...) mes il estoit

tex chevaliers qu'il ne dotoit nul home, tant fust forz ne fiers.

Nus ne fust miaudres chevaliers, se fel et deslëaus ne fust; mes il avoit un cuer de fust

Charrete, 3161 - 3166

El de la carreta es sin lugar a dudas el más perfecto de los caballeros, la fortaleza física y mental que lo caracterizan tienen su origen en la excelencia 
de sus cualidades morales y sociales, que de hecho comparte con Galván: "Li chevalier congié ont pris come cortois et bien apris a la dameisele" (Charrete, 591 - 593), y que en los discursos de los personajes se traduce en la incorporación del adjetivo franc junto al vocativo, 367 en la aparición de un sintagma preposicional con valor circunstancial: "chevaliers, par ta franchise” (Charrete, 913), y en mayor grado, de construcciones comparativas o superlativas que lo colocan muy por encima del común de los caballeros: "et plus les mainnent leidemant por le bien feire seulemant d'un seul chevalier, (...), que por toz les autres ansanble" (Charrete, 2429 - 2432), "Meliaganz, ainz le crient molt, c'onques chevalier si estolt n'acointa mes ne ne conut" (Charrete, 3729 - 3731), "cestui qui est a devise li miaudres chevaliers del monde" (Charrete, 3218 - 3219), y muy lejos del alcance de las doncellas que desearían tomarlo por esposo: "que por biauté ne por avoir deignast nule d'eles avoir cil chevaliers, que trop est prouz" (Charrete, 5999 - 6001). Entre estas expresiones laudatorias merecen ser destacadas las que han sido construidas como proposiciones completivas dependientes de un verbo de dicción y que hallamos en un fragmento narrativo bien definido: tras haber levantado la losa que cubría la que sería su tumba y antes de encaminarse al puente de la espada; un pasaje que está caracterizado por la práctica desaparición de la ayuda femenina que había marcado la fase inicial de la búsqueda. Con ellas se pone de relieve un fenómeno primordial en los relatos artúricos, la importancia de la fama que acompaña o precede a un caballero —en el caso de Lanzarote había sido gravemente menoscabada por el incidente de la carreta—368 y que en buena medida será recompensada sexualmente:

\footnotetext{
367 Charrete, v. 2896 y 5072, aunque en este último la intención de uno de los servidores de Meleagant es agasajarlo para poder separarlo de sus acompañantes.

368 s'ot molt li chevaliers de lui

vilenies et despit dire.

Tuit demandent: «A quel martire

sera cist chevaliers randuz?
}

Charrete, 408 - 411 


\begin{abstract}
qu'il n'a tel chevalier vivant
tant con vantent les quatre vant

Charrete, 1953 - 1954

c'onques tel chevalier ne vit,

ne nus a lui ne s'aparoille.
\end{abstract}

Charrete, 2240 - 2241

\begin{abstract}
an tant con dure toz li mondes,
ne fust uns chevaliers trovez,

tant soit de proesce esprovez,

qui cest chevalier resanblast;

Charrete, 2616 - 2619

c'uns chevaliers de grant bonté

el pais a force venoit
\end{abstract}

Charrete, 2118 - 2119

Estas virtudes están indudablemente relacionadas con el excelso sentimiento amoroso que le impulsa a eludir cualquier contacto físico con una mujer y a saltarse incluso ciertas normas de convivencia cortesana:

\author{
Au chevalier fu bel et buen, \\ quant ele tant nel vost atendre \\ que il li eidast a descendre.
}

Charrete, $1006-1008^{369}$

Sin embargo, la naturaleza enajenante de su pasión: "li chevaliers n'a cuer que un et cil n'est mie ancor a lui einz est comandez a autrui" (Charrete, 1228 - 1230) provoca en Lanzarote estados de ensimismamiento: "n'ancor ne se remuet ne lasse li chevaliers de son panser" (Charrete, 736 -

369 Así mismo v. 1262 - 1263. 
737), de estupor, de duda, e incluso de pasividad guerrera, que desembocan invariablemente en un sentimiento de vergüenza: "tant que la bataille a ce monte qu'an son cuer en a molt grant honte li chevaliers de la charrete" (Charrete, 865 - 867) que le hace reaccionar y renovar sus esfuerzos, los cuales, a su vez, se inspiran en el deseo de ser digno del amor de la reina.

La denominación chevalier referida a Lanzarote funciona preferentemente como complemento de objeto directo de verbos como avoir. "ele avra un chevalier qui desfandra le seneschal" (Charrete, 4903 - 4905), veoir. "Veez le chevalier, veez, qui fu menez sor la charrete" (Charrete, 1667 - 1668); como complemento de objeto indirecto de verbos como dire (Charrete, 1034, 2789), grever (Charrete, 1262) o doner. "por ce que Dex force et vertu donast contre son aversaire au chevalier" (Charrete, 3528 3530); y como sujeto de tres tipos de verbos:

a. Verbos de dicción como dire, ${ }^{370}$ faire,,${ }^{371}$ o respondre, ${ }^{372}$ en los que creemos ver un nuevo rasgo femenino en la forma de caracterizar al héroe, máxime al concentrarse en los primeros versos de la obra donde es mayor la indefinición del personaje.

b. Verbos en los que subyacen las ideas de acción o de movimiento, ya sean físicos, relacionados con la búsqueda de la amada o la violencia que usada contra otros caballeros tiene como fin ayudar a las doncellas o a la propia reina: s'en aller (Charrete, 299 - 300), avancer. "li chevaliers a pié, sanz lance, aprés la charrete s'avance" (Charrete, 345 - 346), tenir [sa voie] (Charrete, 360 - 361), mesfaire: “qu'a cist chevaliers meffet que tu mainnes come contret?" (Charrete, 439 - 440), descendre: "einz fet le chevalier descendre de la charrete" (442 - 443), s'arester (Charrete, 1097), conduire: “que cist chevaliers me conduit" (Charrete, 1581), venir(Charrete, 541, 1704,

\footnotetext{
${ }^{370}$ V. 350, 683, 1097, 1418.

371 V. 1291, 1387.

372 V. 476, 2136.
} 
2118), s'en tomer (Charrete, 1829), anbatre (Charrete, 2295), prendre: “et li chevaliers prant la hache" (Charrete, 1167), "li chevaliers la teste prant par les chevox" (Charrete, 2925 - 2926), passer (Charrete, 3156), adrescer (Charrete, 5966); ya figurados: removoir (Charrete, 736 - 737), aramir (Charrete, 3637 - 3638), recevoir y prendre:

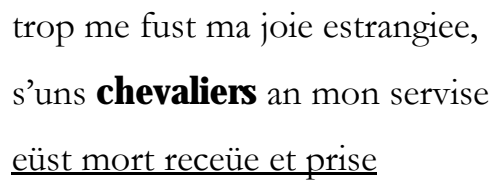

c. Verbos o expresiones que presentan un sentimiento del propio Lanzarote: haer. "se tu tant te hez con cist chevaliers qui ci siet" (Charrete, 384 - 385), avoir [honte] (Charrete, 866 - 867), avoir [cuer] (Charrete, 1228), blasmer y reter (Charrete, 2717 - 2718); o de otros hacia él, en este caso mediante el verbo pleire: "mes quatre tanz a toz pleisoit li chevaliers qu'il ne conoissent." (Charrete, 5632 - 5633)

$$
\begin{aligned}
& \text { neïs li chevaliers vermauz } \\
& \text { plot as dames, et as puceles, } \\
& \text { aus plus gentes et aus plus beles } \\
& \text { Charrete, } 5714 \text { - } 5716
\end{aligned}
$$

En cuanto a la sintaxis proposicional, amén las proposiciones completivas, de las que ya hemos citado varios ejemplos, cabe señalar la abundancia de subordinadas circunstanciales, y entre ellas las temporales, las consecutivas y las causales.

Chrétien utiliza las consecutivas y las causales como uno de los métodos para magnificar las cualidades de Lanzarote: "cui si granz enors i avint qu'ainz n'ot si grant nus chevaliers" (Charrete, 5328 - 5329), "que il a vaincuz et passez trestoz les chevaliers del monde" (Charrete, 5990 - 5991), o bien para realzar la vistosidad y fiereza de los combates: “car deffandre le 
covenoit, que li chevalier sus li vienent" (Charrete, 1170 - 1171), y en especial del torneo de Noauz, casi una feria de maridos, donde se reúnen innumerables caballeros:

\author{
Si sont plainnes les praeries \\ et les arees et li sonbre, \\ que l'an n'en puet esmer le nonbre \\ des chevaliers, tant en i ot
}

Charrete, 5608 - 5611

Las conjunciones temporales datan un proceso con respecto a otro posterior: "tant qu'il revit par avanture le chevalier tot seul a pié" (Charrete, 316 - 317), "par mi les rans s'est avoiee tant qu'ele vit le chevalier" (Charrete, 5850 - 5851), 373 o expresan la simultaneidad de dos procesos: "quant il i trueve seant le chevalier, si s'an mervoille" (Charrete, 380 - 381) en dos de las situaciones de búsqueda, no de la reina sino del propio Lanzarote, al comienzo del relato y durante el torneo de Noauz; o bien lo ponen en relación con un proceso anterior para convertirlo en un recurso laudatorio:

Des lores que je conui primes

chevalier, un seul n'an conui

que je prisasse, fors cestui,

la tierce part d'un angevin

Charrete, 1270 - 1273

$\mathrm{Al}$ contrario de lo que ocurre en el roman de Chrétien, el caballero se nos presenta en los otros tres como un mero figurante. En Tristan son los testigos de la boda del rey con Iseo, ${ }^{374} \mathrm{O}$ bien están presentes con sus esposas o amantes en las reuniones multitudinarias de la corte. ${ }^{375}$ Renart recurre a la

\footnotetext{
373 También v. 5886.

374 "si que virent ti chevalier" (Tristan, 2564).

375 Tristan, v. 4086 y 4123 - 4124.
} 
estrategia preferida de Chrétien, la exageración del número, ${ }^{376}$ para engrandecer el papel del grupo en la sociedad. Desde el punto de vista del erotismo, este gran número de varones dispuestos a buscar una esposa con quien asentarse y una amiga con quien disfrutar de los placeres sensuales e intercambiar bellos y ricos objetos es un señuelo para las mujeres que escuchan el relato; de hecho, al final de la obra, la unión de los dos grupos más numerosos y ensalzados se ha hecho ya efectiva pues chevaliers y puceles - a imagen de Guillermo y Aelis y en sustitución de su unión excesivamente regulada — han forjado "maintes amors noveles" (Escoufle, 9010) en sus encuentros galantes. Sin embargo, incluso el conde Ricardo, loado en la más pura tradición caballeresca: "bons chevaliers fu et ml't biax et frans et larges, et cortois" (Escoufle, 94 - 95), “n'ainc n'ot tel chevalier a Troie" (Escoufle, 112), "quel chevalier et quel preudome! Ainc puis le tans Cesar de Rome ausi bons bers ne fu veüs” (Escoufle, 1021 - 1023), tiene un papel secundario en Escoufle. Sus hazañas guerreras que le valdrán tantas alabanzas como las políticas, entre las que destaca su habilidad para dar estabilidad territorial y económica a sus vasallos: "maint chevalier fist de noient riche et manant en son eage par biax dons et par mariage" (Escoufle, 80 - 82), sirven sólo a la causa del hijo, quien sin lugar a dudas sacará un magnífico partido de la vida y milagros de su progenitor. De hecho, al igual que ocurre con los caballeros de Rose, emparejados con Largesse y con Courtoisie: "la vaillant, la sage, tint un chevalier dou lignage le bon roi Artu de Bretaigne” (Rose, 1173 - 1175),

\section{A li se tint un chevaliers,}

acointables et biau paliers,

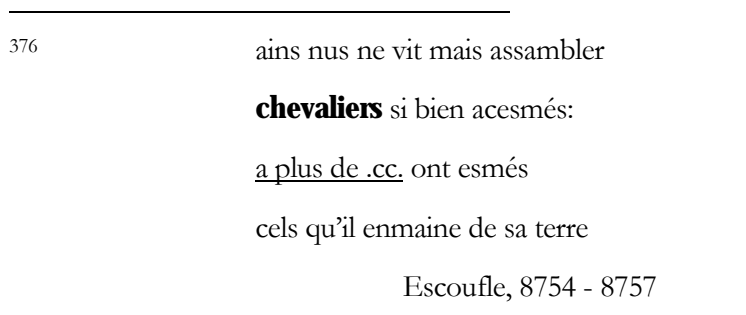


qui bien sot fere honor a genz.

Li chevaliers fu biaus et genz

et as armes bien acesmez

et de s'amie bien amez

Rose, 1243 - 1248

el conde es más bien el representante de una época que se ha extinguido y de la que ya sólo quedan recuerdos gloriosos, torneos en los que se combate sólo para impresionar a la amada y buenas maneras cortesanas, que deberán ser tomadas como ejemplo por el enamorado imitando a Galván: "soies cortois et acointables, de paroles douz et resnables" (Rose, 2087 - 2088). En este sentido resulta especialmente curioso el emparejamiento que hace Lorris en la rima con el sustantivo paliers; este parece exagerar el valor de una de las cualidades de los caballeros, probablemente la menos adecuada a su verdadera esencia, tal como observamos en la caracterización de Lanzarote, quien pierde progresivamente el gusto a la palabra y se concentra en las obras que lo alzarán a la gloria social y amorosa. Más aún será uno de los principales reproches contra los caballeros poco ejemplares: Bademagu criticará a su hijo más por su falta de modestia que por su orgullo, y Lorris describirá a Keu, el peor de los caballeros artúricos, destacando el mal uso de la palabra:

$$
\begin{aligned}
& \text { autretant ot de blasme Keus, } \\
& \text { por ce qu'i fu fel et crueus, } \\
& \text { remponieres et mal paliers } \\
& \text { desor toz autres chevaliers }
\end{aligned}
$$

Rose, 2083 - 2086

Por otra parte, los caballeros contemporáneos de Guillermo y Aelis en E scoufle tienen, como otros grupos masculinos, una única función, la de admirar a la heroína y disfrutar de su compañía en Montpellier o en la corte de Saint Gilles: 


\begin{abstract}
N'i a chevalier qui mot sont, ains l'esgardent a grant merveille, qu'ele est si bele a la candeille
\end{abstract}

Escoufle, 5742 - 5744

\author{
qui de biauté et d'oevre vaint \\ toutes celes de Montpellier. \\ «Tuit li clerc et li chevalier \\ o li sont por deduire adés.»
}

Escoufle, 5942 - 5945

También se cuentan, sin embargo, entre los difamadores potenciales de las actividades en apariencia poco honestas de Aelis, quien en cierto modo compra la ayuda de la dama de Montpellier para preservarse de la maledicencia masculina, y mantener intacta la fama que ha alcanzado en la ciudad, un prestigio que le permite vivir de forma independiente y suficientemente holgada. Quizá porque las clases altas, generalmente ociosas, contasen entre sus miembros muchas malas lenguas, o quizá porque las repercusiones sociales y económicas de sus habladurías fuesen más graves:

\footnotetext{
s'il avenoit, par aventure,

k’aucuns nos eüst fait laidure,

ou par folie ou par outrage

ou par hautece de lignage,

ki fust chevaliers ou frans hom
}

Escoufle, 5715 - 5719

En cuanto a Guillermo los augurios del emperador sobre su futura caballería están todavía anclados en el orden guerrero y retoman los adjetivos propios de éste: "se il tant vit k'il soit chevaliers, ains ne vit nus hom plus hardi ne plus preu" (Escoufle, 2766 - 2768). Sin embargo, los nuevos tiempos 
se infiltran en el antiguo orden reconstruyendo miméticamente la imagen masculina sobre la femenina y sustentándola por tanto en la estética, la belleza es el compendio físico de todas las virtudes y la prueba indiscutible de la nobleza heredada:

\author{
que li bons quens Richars est mors. \\ C'est damages, mais li confors \\ est ml't tres biax et li restors: \\ cist chevaliers a cest biau cors \\ est ses fix, ce n'est mie doute.
}

Escoufle, 8141 - 8145

Belleza que merece ser observada y admirada como la femenina y que concita ojos y deseos como ella, sin que quepa duda sobre los destinatarios de tal espectáculo. A diferencia de Charrete donde el atractivo del caballero despertaba pasiones en ambos sexos, unas explícitamente sexuales, otras veladamente eróticas si tomamos en consideración las relaciones entre hombres, aquí sólo se pone de relieve a las mujeres creando una suma de estímulos encadenados tanto en el interior como en la recepción de la narración:

$$
\begin{aligned}
& \text { puis que Troie la grans fu arse } \\
& \text { n'ot il a .j. chevalier faire } \\
& \frac{\text { tant de dames de haut afaire }}{\text { ne tante pucele de pris. }} \\
& \text { Escoufle, } 7908-7911
\end{aligned}
$$

Por lo que se refiere a la estructura externa y a los recursos formales de los romans podemos poner de relieve tres hechos: existe tan sólo una ocurrencia que ocupe la primera posición del verso, en E scoufle, y que coincide con la hipérbole heredada de Chrétien, y se prefiere la segunda posición 
haciendo que sea precedido por un adjetivo, generalmente indefinido como maint, o un artículo, de preferencia demostrativo; también hay relativamente pocas formas al final de verso y en muchos casos parecen deberse únicamente a necesidades formales sin que intervengan otros criterios retóricos.

\begin{tabular}{lllllllll}
\hline FORMA & CA & BD & NV & RIMA & CA2 & NV2 & D & PERS \\
\hline chevalier & S & Charrete & 3697 & Apareillier & I & 3698 & D & Pucelle \\
chevalier & S & Charrete & 178 & Baillier & I & 177 & D & Keu \\
chevaliers & S & Escoufle & 8530 & Ciers & A & 8529 & N & Narrador \\
chevalier & S & Charrete & 5851 & Conseillier & I & 5852 & N & Narrador \\
chevalier & S & Charrete & 306 & Destrier & S & 305 & N & Narrador \\
chevalier & S & Charrete & 3653 & eidier & I & 3654 & D & Pucelle \\
chevaliers & S & Escoufle & 1809 & escuiers & S & 1810 & N & Narrador \\
chevalier & S & Charrete & 1034 & mangier & S & 1033 & N & Narrador \\
chevalier & S & Charrete & 3261 & mestier & S & 3262 & D & Bademagu \\
chevalier & S & Charrete & 3486 & Monpellier & S & 3485 & N & Narrador \\
chevalier & S & Escoufle & 5944 & Montpellier & S & 5943 & D & Comte SG \\
chevaliers & S & Rose & 1243 & paliers & S & 1244 & N & Narrador \\
chevaliers & S & Rose & 2086 & paliers & S & 2085 & D & Amour \\
chevaliers & S & Escoufle & 4933 & volentiers & D & 4934 & D & Isabelle \\
\hline
\end{tabular}

Tabla 47. Rimas del sustantivo chevalier.

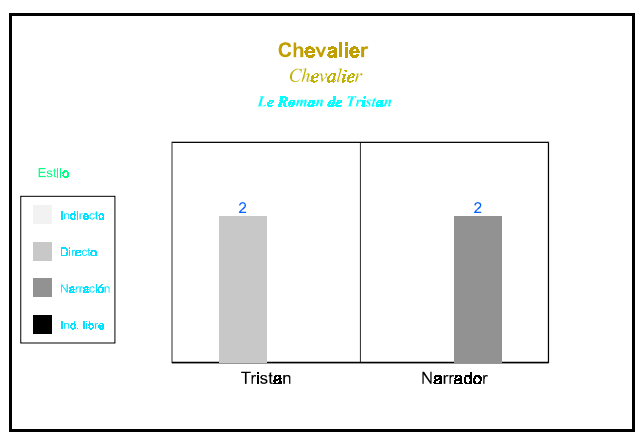

Fig. 43. Comportamiento estilístico del sustantivo chevalier en Tristan. 


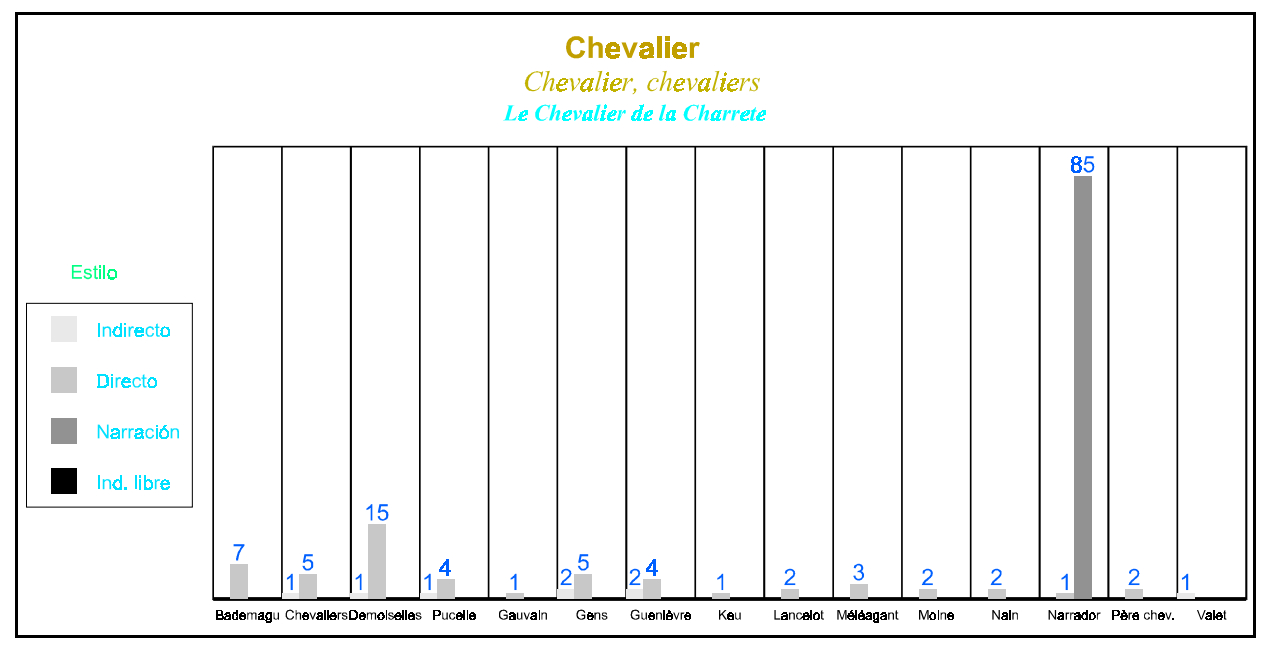

Fig. 44. Comportamiento estilístico del sustantivo chevalier en Charrete.

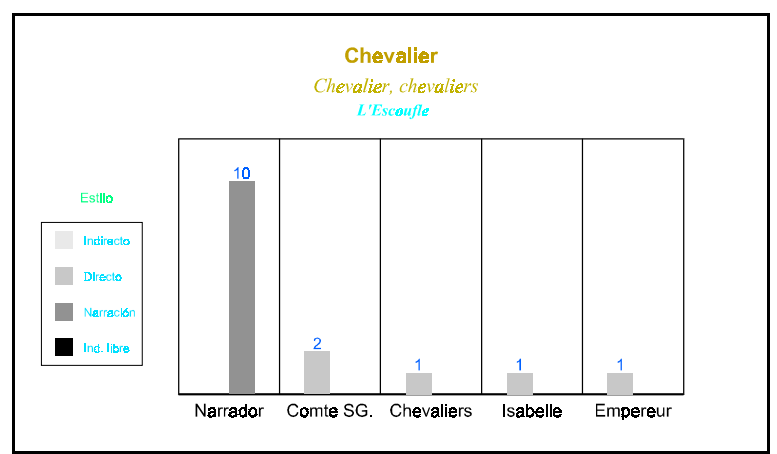

Fig. 45. Comportamiento estilístico del sustantivo chevalier en Escoufle.

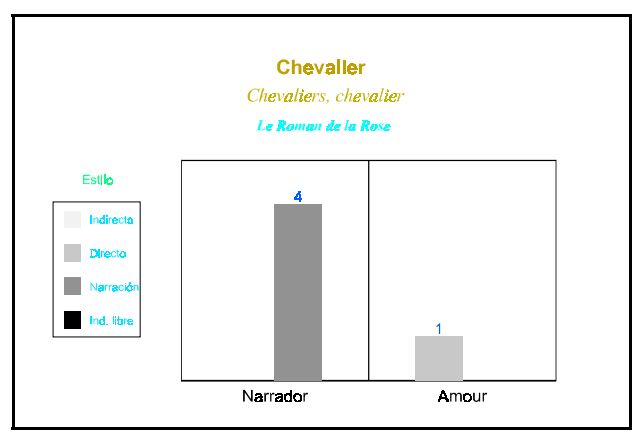

Fig. 46. Comportamiento estilístico del sustantivo chevalier en Rose.

Estos gráficos ilustran las notables diferencias existentes entre Charrete y el resto de los romans a las que nos hemos referido anteriormente. El texto de Chrétien nos muestra al caballero como el representante de una clase 
guerrera simplificada compuesta por dos grupos bien diferenciados a los que saca una indudable rentabilidad narrativa: los buenos y los malos caballeros. La presencia enfrentada de ambos se convierte en el eje de la narración, y sin duda alguna también en el referente obligado de los discursos de los personajes sobre las cualidades físicas, morales o sociales y sobre las actividades idealizadas y erotizadas del grupo. En los textos del siglo XIII la caballería se convierte en un elemento casi residual que, a imagen de la pequeña nobleza del sur de Francia, comparte la vida ciudadana con otros grupos que se igualan con ella o podrían incluso llegar a aventajarla en nobleza, como inferimos de la enumeración de Isabelle: "Mais laiens en cele cité a gens de grant nobilité: borgois et clercs et chevaliers”' (Escoufle, 4931 4933).

\subsection{Seigneur, baron, mari y «esposez».}

En las ocurrencias que encontramos de seigneur podemos determinar cuatro usos relativamente dependientes entre sí pues todos derivan de la noción de potestad ya sea en el ámbito público o en la esfera íntima. El primero de ellos, general y poco alejado del valor básico, la ostentación del poder feudal que solía entrañar la posesión o cuando menos el usufructo de una construcción defensiva o señorial: “k'il n’a cité jusc'a Amiens, chastel ne vile ne manoir, se vos i daigniés manoir, que ml't n'en fust li sires liés" (Escoufle, 4926 - 4929) se utiliza empero en contextos que poco tienen que ver con los bienes materiales, y que tienden más bien a reafirmar el orden jurídico y la regulación moral a la que apelan las relaciones señor / vasallo, ya sea en el plano político: "por faire signor et de sa fille et de s'onor" (Escoufle, 2289 - 2290). Este se ve reforzado, excepto en Rose, por el frecuente emparejamiento en las rimas con el sustantivo onor, ya en el plano metafórico del amor, a menudo en compañía de otros términos como maître, en Charrete. "li cuers qui plus est sire et mestre et de plus grant pooir assez" (Charrete, 3976 - 3977) o en Rose: "mout liez dont tu as si bon mestre et seignor de si 
haut renon" (Rose, 1942 - 1943). Renart, sin embargo, reconstituye la metáfora sobre la base del derecho de posesión que el señor gozaba, no sólo sobre los bienes inmuebles y sobre las tierras sino también sobre la propia persona del que se hallaba bajo su poder, y ello para desvelar los derechos que disfruta el joven Guillermo sobre el cuerpo de Aelis y los placeres que éste puede proporcionarle, aunque salvaguarda el que socialmente se había convertido en el más preciado, la desfloración, a la que sólo puede aspirar el marido. Este, en el relato, no sólo obtendrá el placer de la penetración de la mujer y su plena posesión, sino que, gracias a la unión matrimonial accederá al verdadero señorío. Se muestra, además, explícitamente el nexo entre sexo y poder que habitualmente queda oculto:

$$
\begin{aligned}
& \text { Tot lor delit sont mais commun, } \\
& \text { de toz est cil sire, fors d'un } \\
& \text { que s'amie li garde et serve } \\
& \text { jusqu'a tant que sa gens le serve } \\
& \text { comme signor et comme roi. }
\end{aligned}
$$

Escoufle, 2375 - 2379377

En Rose Amor recurre a la misma imagen para poner de relieve la íntima relación que existe entre el espíritu y el cuerpo, ambos sumisos a la voluntad del amante:

$$
\begin{aligned}
& \text { Il est assez sire dou cors } \\
& \text { qui a le cuer en sa comande } \\
& \text { Rose, } 1994 \text { - } 1995
\end{aligned}
$$

Otro uso, particular y muy extendido en los contextos analizados, es el que restringe el papel del señor al de marido. ${ }^{378}$ En algunos casos como en

\footnotetext{
377 También en el discurso directo de Aelis tras evocar claramente las partes de su cuerpo y las caricias de su amante: “si m’ait Diex, poi pris mon sens se vos n'en estes par tans sire.” (Escoufle, 3288 - 3289).
} 
el discurso de la reina Iseo o en algunas ocurrencias en E scoulle, la relación conyugal, que debería tender a un acercamiento de los esposos, se mantiene todavía en un segundo plano en provecho de la idea de autoridad: "Sire, jos tien por mon seignor, et il est vostre niés" (Tristan, 424 - 425), que puede verse formalmente reforzada por la aparición en el mismo verso del término man: “ne seront ouan marïees, n'a mari n'a seignor donees" (Charrete, 6005 6006). La inestabilidad semántica a la que acabamos de referirnos se halla fundamentalmente en el discurso femenino en estilo indirecto o directo, mientras que los discursos masculinos delimitan ambos usos. El artículo posesivo y la construcción apositiva sirven para definir la relación marital en boca de Tristán: "Vez la le roi, vostre seignor" (Tristan, 2781), del rey Arturo: "ge prié le roi vostre seignor" (Tristan, 4257), del conde Ricardo: "Li quens se sire ausi li mande" (Escoufle, 1821), o de los barones romanos: "com li quens Guilliaumes se sire” (Escoufle, 8545), así como en el equívoco juramento de la reina destinado dentro del relato a una audiencia masculina, o por mejor decir ideológicamente masculina, especialmente sensible, dadas las circunstancias, a un discurso regido por sus propias normas: "du ladre, du roi Marc, mon sire" (Tristan, 4213).

El vocablo baron, exclusivo de Escoufle, posee dos sentidos claramente definidos: por una parte designa a los nobles más próximos al emperador y por otra, incluso cuando no va precedido por un posesivo, al esposo, al que no siempre hemos de suponer una ascendencia noble: "cascune ostesse se conseille priveement a son baron” (Escoufle, 4278 - 4279)

\author{
k'il le jura et si baron \\ que sa fille avroit a baron \\ le damoisel, et or le nie.
}

Escoufle, $2941-2943$

\footnotetext{
378 Escoufle, v. 2624, 8513, 5837, 5705, 3419, 2833; Tristan, v. 76, 3771, 3204, 3164, 3416, 2258; Charrete, v. 5730 .
} 


$$
\begin{aligned}
& \text { Ja tant com j’aie el cors la vie, } \\
& \text { se je ne l'ai, n'arai baron. }
\end{aligned}
$$

Escoufle, 3240 - 3241

Es muy probable que la aparición de esta forma responda a condicionamientos formales ya que excepto en dos ocasiones las ocurrencias se encuentran al final del verso.

Mani, exclusivo de Charrete, y esposez, utilizado únicamente en aposición para hacer referencia al rey Marco: "et li rois Marc mes esposez" (Tristan, 4208), sólo poseen este segundo sentido y para ellos también cabe dar una justificación como variante estilística de seigneur o como alternativa formal al final del verso: "l'anhatine ensi departi c'onques nule n'an prist mari.” (Charrete, 6055 - 6056). Quizá en el caso del participio sustantivado esposez podamos distinguir un cierto matiz legalista al designar al marido según los ritos matrimoniales frente al equívoco que hemos señalado en lo tocante a la contradicción creada por los usos tradicionales, la unión de hecho en contraposición a los usos eclesiásticos renovados que intentan imponer la unión de derecho. Hipótesis que parece quedar avalada por la situación de enunciación, el juramento en la Blanca Landa y por la dependencia sintáctica, pues en ambos casos se encuentra en una proposición completiva dependiente de los verbos jurer y aseürer que constituyen un acto performativo en el discurso directo de Iseo en primera persona, y de los verbos jurer y metre en vo en el discurso indirecto reproducido por los que allí se encontraban:

Or escoutez que je ci jure, de quoi le roi ci aseüre: (...) et li rois Marc mes esposez.

Tristan, 4199 - 4208

Ele a juré et mis en vo

qu'entre ses cuises nus n'entra 


\section{$(\ldots)$ \\ et li rois Marc, ses esposez.}

Tristan, 4226 - 4230

También merecen algún comentario los contextos negativos en los que aparece el sustantivo mari: "que s'an cestui ne se marïent ne seront ouan mariees, ñ'a mari n’a seignor donees" (Charrete, 6004 - 6006), “ne se marieront ouan: quant celui n'ont qu'eles voloient, (...) c'onques nule n'an prist mani." (Charrete, 6052 - 6056). Mientras que en Tristan y en E sooufle parece aceptarse el matrimonio como un mal menor para la convivencia de los amantes, Charrete se nos aparece tanto como la novela del adulterio en la que los maridos poco tienen que decir, como el roman del celibato. La excepcionalidad y la fidelidad de Lanzarote arrastran a las jóvenes casaderas a una inaudita ruptura colectiva del orden genealógico así como del tan necesario intercambio económico. La sociedad noble debe arrostrar así los peligros de dos fuerzas disolventes, la infidelidad conyugal, que a la postre será la causa del fin del mundo artúrico, y la soltería, que tiene tanto su origen como una posible consecuencia en la anterior.

Tras la separación de los amantes se instaura en E scoufle un discurso equívoco en torno a la sexualidad de Aelis y a sus relaciones, tanto con hombres como con mujeres. Mientras ambos se hallaban juntos no existía ninguna fisura en la entrega de Aelis, quien daba así pleno sentido a la máxima enunciada por Amor: su cuerpo y su espíritu pertenecían a su futuro marido. Sin embargo, la vida independiente, la distancia y el trato con otros hombres fuera del ámbito de la familia y del estricto orden jerárquico, la llevan a prodigar sus encantos, con lo que multiplica los beneficiarios de su cuerpo y de su espíritu, y modificando profundamente el sentido del término seigneur. Éste pasa, precedido por un adverbio comparativo, a ser el equivalente de amante:

Du castel se sont fors issu

plus de .l. por s'amor. 


\section{A cascun comme a son seignour}

prent congié par beles paroles.

Escoufle, 6082 - 6085

en una confusión que la astuta Iseo había dejado entrever amparándose en la duplicidad jurídica a la que ya hemos hecho referencia: "jor que je vive que amor aie o home qu'o mon seignor" (Tristan, 37 - 38), y que también se había producido al evocar las supuestas relaciones amorosas entre la dama de Montpellier y su marido: "vo sire iert amis et sire" (Escoufle, 5843), relaciones que serían acordes con la ideología erótica y matrimonial que se intenta imponer en esta época pero que romperían con la concepción cortés del amor adúltero.

En caso sujeto con función de vocativo aparece como una forma de tratamiento respetuoso, en la posición inicial del verso — salvo contadas excepciones-: "Sire, alez vos la fors deduire" (Charrete, 1035) en la que se han perdido una gran parte de los componentes denotativos del término — si bien las esposas lo utilizan para dirigirse al marido y también Tristán para hablar a su señor, al rey Marco-, al tiempo que se han desarrollado algunos aspectos connotativos de orden enunciativo. La dependencia de la situación de comunicación es en ocasiones muy acusada como podemos observar en las ocurrencias que en el discurso de Iseo hacen referencia a Tristán: sólo lo utiliza durante el encuentro espiado, bien solo, bien seguido del nombre propio: "Sire Tristran" (Tristan, 5), 379 o precedido del adjetivo beau (Tristan, 181), ${ }^{380}$ y también una vez acabado el efecto del filtro.

\footnotetext{
379 También v. 21, 85.

380 También v. 2709.
} 


\begin{tabular}{lllllllll}
\hline FORMA & CA & BD & NV & RIMA & CA2 & NV2 & D & PERS \\
\hline seignor & S & Tristan & 38 & amor & S & 37 & D & Iseut \\
seignor & S & Tristan & 4257 & amor & S & 4258 & D & Roi Arthur \\
seignour & S & Escoufle & 6084 & amor & S & 6083 & N & Narrador \\
seignor & S & Tristan & 424 & anor & S & 423 & D & Iseut \\
seignor & S & Tristan & 2258 & anor & S & 2257 & D & Tristan \\
sire & S & Escoufle & 5705 & consire & V & 5706 & N & Narrador \\
seignor & S & Tristan & 91 & demor & V & 92 & D & Iseut \\
sire & S & Escoufle & 5843 & descire & V & 5844 & D & Comte S. G. \\
sire & S & Tristan & 86 & dire & I & 85 & D & Iseut \\
sire & S & Tristan & 426 & dire & I & 425 & D & Iseut \\
sire & S & Escoufle & 8545 & dire & I & 8546 & D & Barons \\
sire & S & Escoufle & 2742 & empire & S & 2741 & D & Traîtres \\
seignors & S & Charrete & 5730 & enors & S & 5729 & N & Narrador \\
seignor & S & Tristan & 359 & error & S & 360 & D & Iseut \\
sire & S & Tristan & 4212 & escondire & I & 4211 & D & Iseut \\
signor & S & Escoufle & 2833 & honor & S & 2834 & D & Impératrice \\
sire & S & Tristan & 181 & ire & S & 182 & D & Iseut \\
sire & S & Escoufle & 3419 & ire & V & 3420 & D & Guillaume \\
seignor & S & Tristan & 2781 & onor & S & 2782 & D & Tristan \\
signor & S & Escoufle & 2289 & onor & S & 2290 & I & Empereur \\
sire & S & Escoufle & 3289 & Sire & S & 3290 & D & Aélis \\
sire & S & Escoufle & 4727 & Sire & S & 4728 & D & Aélis \\
\hline
\end{tabular}

Tabla 48. Rimas del sustantivo seigneur.

\begin{tabular}{lllllllll}
\hline FORMA & CA & BD & NV & RIMA & CA2 & NV2 & D & PERS \\
\hline baron & S & Escoufle & 2942 & baron & S & 2941 & I & Empereur \\
baron & S & Escoufle & 3241 & baron & S & 3242 & D & Aélis \\
baron & S & Escoufle & 4279 & baron & S & 4280 & N & Narrador \\
barons & S & Escoufle & 2774 & barons & S & 2773 & D & Traîtres \\
barons & S & Escoufle & 8580 & barons & S & 8579 & N & Narrador \\
baron & S & Escoufle & 5568 & don & S & 5567 & D & Aélis \\
baron & S & Escoufle & 5676 & façon & S & 5675 & N & Narrador \\
barons & S & Escoufle & 5701 & lyons & S & 5702 & N & Narrador \\
baron & S & Escoufle & 5707 & non & D & 5708 & N & Narrador \\
baron & S & Escoufle & 5841 & non & S & 5842 & D & Comte S. G. \\
\hline
\end{tabular}

Tabla 49. Rimas del sustantivo baron.

Respecto al funcionamiento de los sintagmas en los que intervienen estas denominaciones nos llama poderosamente la atención el hecho de que no se prodiguen los sujetos y que cuando asumen ese papel lo hagan con respecto al verbo estre. ${ }^{381}$ Expresan un estado que implica generalmente una

\footnotetext{
381 Encontramos algún otro verbo como prendre: "mes amis est trovez, mes sires l’a pris" (Tristan, 3163 - 3164), iraistre: "Dex i a fait vertuz, qant mes sires s'est irascuz" (Tristan, 3203 - 3204), porter. "uns tex com ses sire le porte" (Escoufle, 5837) o avoir: "puis qu'ele la velt doner, donques la devroit avoir ses barons" (Escoufle, 5700 - 5701).
} 
redefinición del propio sujeto ya como amigo de la esposa, como esposo o como conde el que había sido amante en E scoufle, ya como leproso - cornudo en Tristan: "Dans rois, ses sires ert meseaus" (Tristan, 3771), donde por otra parte podemos observar un juego a partir de las estructuras apositivas que caracterizaban al rey como esposo de Iseo: si obviamos el signo de puntuación podríamos tener en cuenta dos elocuciones distintas, la que nos propone el editor en la que el primer sintagma funciona como vocativo y otra en la que “ses sires" funcionaría como aposición al sujeto y llevaría aún más lejos la burla de Tristán.

Como atributo también suele ser utilizado en E soufle, donde están la mayor parte de las ocurrencias con esta función, como redefinidor hipotético del enamorado — la irrealidad viene dada por el uso del subjuntivo y del pasado-, quien debería ser esposo, amante y rey. Con ello se ponen de nuevo de manifiesto las contradicciones provocadas por la pervivencia de las antiguas costumbres junto a los ritos modernos:

Li rois tos seus a ce s'aert que Guilliaumes soit sire et rois.

Escoufle, 2778 - 2779

(...) Encor me dist il ore

k'il m'estoit et sire et amis

Escoufle, 4698 - 4699

Certes, encor cuidoie g’ier

que je deüsse estre vos sire.

Hom qui ce pert, que puet s'il s'ire,

et qui tos biens laist et trespasse?

Escoufle, 3418 - 3421 
Los sintagmas preposicionales que funcionan como complementos circunstanciales presentan paradójicamente la supeditación del varón, ya sea a la mujer, de cuya voluntad depende la unión matrimonial: "si prandront ces cui le jor seroit l'enors les dameiseles a seignors" (Charrete, 5728 - 5730) o la estabilidad de la pareja y de la corte: "la roïne s'est acordee o son seignor" (Tristan, 3415 - 3416), ya a los hombres que lo rodean, sea el padre o los felones:

$$
\begin{aligned}
& \text { Mais l'en puet home desveier, } \\
& \text { faire mal faire et bien laisier: } \\
& \text { si a l'on fait de mon seignor. }
\end{aligned}
$$

Tristan, 89 - 91

Las proposiciones subordinadas relativas en las que aparece el sustantivo seigneur — con un sentido general o con el significado de «marido»— se caracterizan por tener como antecedentes expresiones de lugar, espacios que lo identifican con el poder político:

$$
\begin{aligned}
& \text { et la pitiés et la dolors } \\
& \text { ne la laist pas monter en l'estre } \\
& \text { dont ses bons sires soloit estre } \\
& \text { tous connestables et baillius }
\end{aligned}
$$

Escoufle, 2622 - 2625

Aquéllas en las que se encuentra el sustantivo baron tienen, merced al pronombre celui que funciona como antecedente, un valor determinativo: “a celui qui estoit barons la damoisele" (Escoufle, 8580 - 8581). En uno de los casos éste es muy impreciso, pues frente al amante, del que se nos dejan entrever algunos rasgos psicológicos deducibles de su comportamiento, del señor de Montpellier tan sólo conocemos la divisa, símbolo inicialmente de su poder pero también de las faltas contra la fidelidad conyugal y por lo tanto contra su honor al pasar a manos de su rival: 
Bien connut que ce fu des armes

celui qui ert barons s'amie

Escoufle, 5908 - 5909

Una clasificación semántica de las proposiciones de las que dependen las subordinadas completivas nos muestra la vinculación de las denominaciones que nos ocupan con verbos declarativos en el discurso indirecto como jurer (Escoufle, 2942), prier. "et il autretant me priout que l'acordase a mon seignor' (Tristan, 358 - 359), o el más abundante dire;382 de verbos de conocimiento como veoir. "quant li quens voit qu'il puet avoir les joiaus et qu'el nes tient pas de son baron" (Escoufle, 5872 - 5874); de verbos de creencia como cuidier (Escoufle, 3419); de verbos introductores de un acontecimiento como la forma impersonal de venir, tras la que debería aparecer normalmente el indicativo pero que en el ejemplo que encontramos en E scoufle el subjuntivo de la subordinada reincide en la precaria situación del que se prefiguraba como marido de Aelis y heredero del imperio: "s'a çou vient que ma fille l'ait a signor" (Escoufle, 2832 - 2833); o verbos de voluntad como aerdre: "li rois tos seus a ce s'aert que Guilliaumes soit sire et rois" (Escoufle, 2778 - 2779).

Si exceptuamos una proposición consecutiva en Charrete 383 con la que se da por finalizado el torneo de Noauz y se disipan las esperanzas de los caballeros que habían participado en él de conquistar una esposa, tan sólo encontramos subordinadas circunstanciales en Escoufle, y estas son de dos tipos:

\section{- Comparativas:}

$\mathrm{El}$ adverbio comme, que expresa una relación de igualdad, sirve para identificar la potestad del marido con la limosnera bordada por Aelis para la

\footnotetext{
382 Tristan v. 75; Charrete v. 6003; Escoufle v. 2287, 4698.

${ }^{383}$ En el verso 6056 ya citado.
} 
dama de Montpellier. Marido y señor en el que la joven, formada en la nueva ideología que hace coincidir amor y matrimonio, cree erróneamente ver también al amante. Este error, que entraña una profunda y poco realista divergencia ideológica entre generaciones — de hecho ya hemos señalado la turbia relación de la propia Aelis con sus admiradores y complacidos clientes también expresada mediante una comparativa de igualdad matizada por una hipotética irreal no explícita: "A cascun comme a son seignour" (Escoufle, 6084)—, provocará no sólo los celos del amante sino también los de la condesa de Saint Gilles, y a la postre la reconducción del relato y de Aelis hacia cauces más aceptables socialmente y hacia el matrimonio:

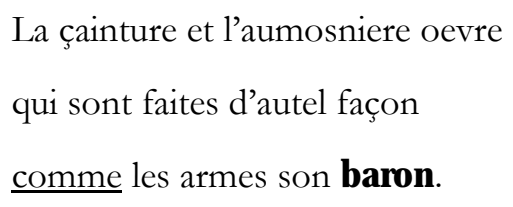

La desigualdad entre los elementos comparados se expresa así mismo mediante el adverbio comme precedido en la principal por una negación y un intensivo para engrandecer la figura de Guillermo una vez que el matrimonio con Aelis lo hace digno del imperio:

et c'on ne conte $\underline{\text { si preudome }}$ com li quens Guilliaumes se sire.

Escoufle, 8544 - 8545 
O bien de forma más habitual mediante el adverbio plus que precede a otro adverbio o a un adjetivo en correlación con el adverbio que, para informarnos sobre la clara disociación entre el marido y el amante, el único que parece avivar la llama de la pasión en la dama de Montpellier:

$$
\begin{aligned}
& \text { Ml't li est ore plus prés trais } \\
& \text { du cuer ses amis que se sire, } \\
& \text { et plus dolente s'en consire } \\
& \text { de son ami que del baron }
\end{aligned}
$$

Escoufle, 5704 - 5707

\section{- Hipotéticas:}

Dos son las proposiciones que encontramos con este sentido. En una de ellas se nos muestra la determinación que caracteriza a Aelis, quien apenas separada de su enamorado decide jugar la baza de su inteligencia, una constante entre nuestras heroínas, para poder gozar de nuevo de los placeres que aquel le procuraba: “Si m'aït Diex, poi pris mon sens se vos n'en estes par tans sire" (Escoufle, 3288 - 3289). En la otra el término seigneur conserva su valor político, aunque en el relato debía derivar obligatoriamente de la relación matrimonial, mientras que la correlación temporal entre principal y subordinada nos muestra cómo la hipótesis de la señoría del héroe puede condicionar el futuro del imperio según las predicciones de los barones envidiosos:

trop kerroit ja de roiste tertre vostre grant terre et vostre empire

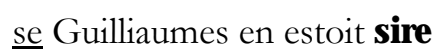

Escoufle, 2740 - 2742 


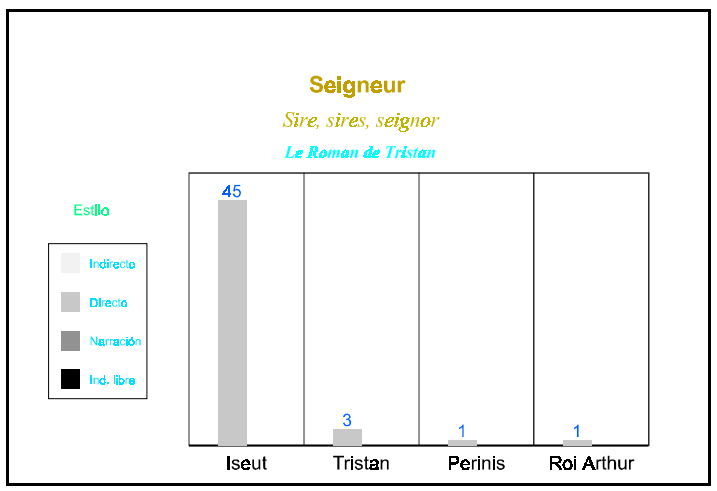

Fig. 47. Comportamiento estilístico del sustantivo seigneur en Tristan.

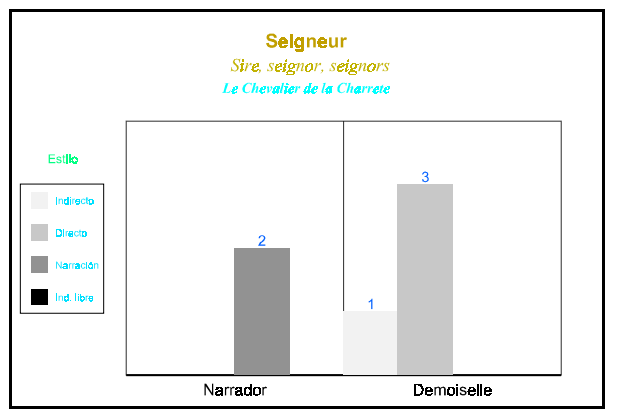

Fig. 48. Comportamiento estilístico del sustantivo seigneur en Charrete.

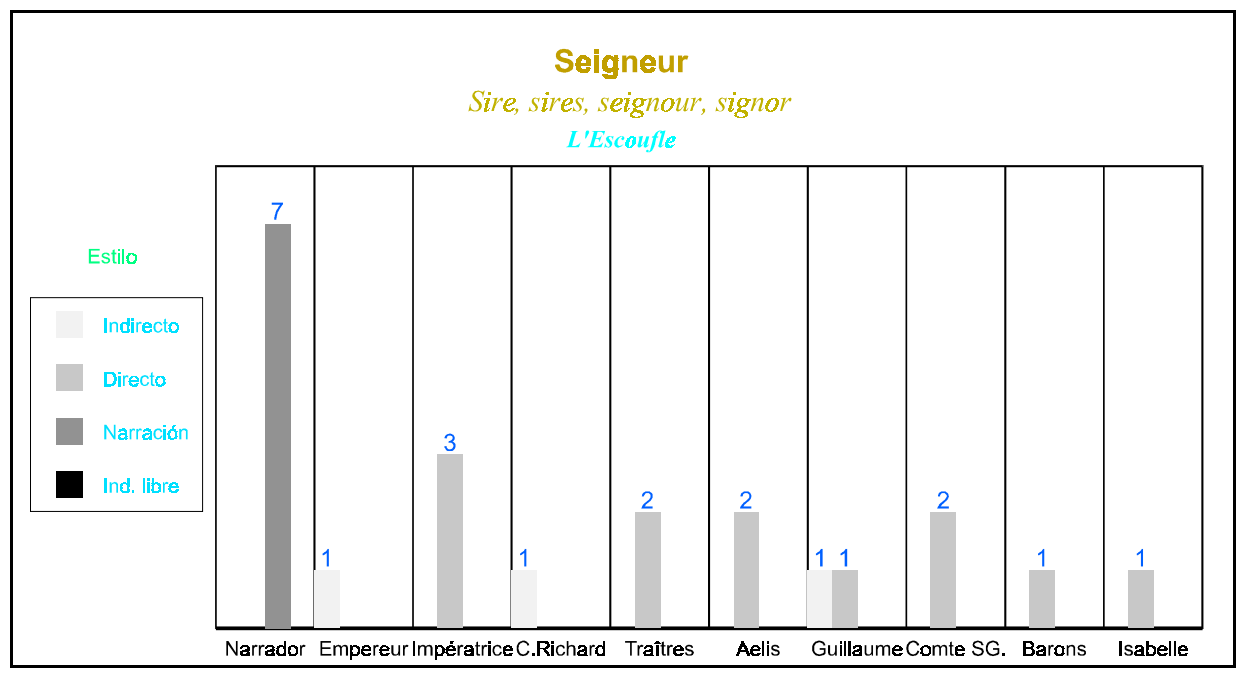

Fig. 49. Comportamiento estilístico del sustantivo seigneur en Escoufle. 


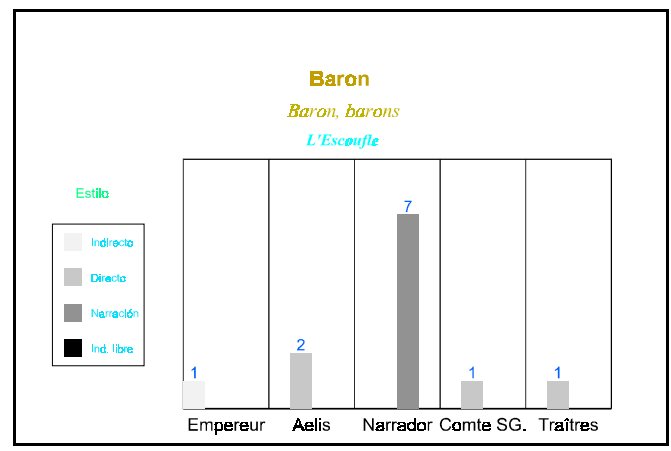

Fig. 50. Comportamiento estilístico del sustantivo baron en Escoufle.

Las carencias narrativas que observamos en Tristan constituyen uno de los goznes del texto: el narrador, al inhibirse ante el conflicto permanente entre matrimonio y adulterio, permite una comprensión múltiple, abierta, de los derechos de unos y otros sobre la persona de la reina, y lo que es aún más interesante a nuestros ojos, hace posible que sea ella la que manifieste sus inclinaciones sentimentales o su inteligencia, perpetuando así la transgresión. Poco parecen preocupar las cuestiones matrimoniales a Chrétien en Charrete si tomamos estas denominaciones como índice, y en todo caso las supedita a la elaboración de las cualidades únicas del héroe; mientras que en E scoufle, la extracción, los intereses o los sentimientos de los personajes modifican los valores de los términos a los que nos referimos, y hacen prevalecer los aspectos feudales, los contractuales o los dinásticos, no sólo en las intervenciones discursivas de aquéllos sino en la propia narración.

\subsection{Roi.}

El rey se nos aparece en los contextos seleccionados de la obra de Béroul como un hombre despreciable, aunque el conjunto del texto nos dé una visión más compleja y matizada. De hecho ni Tristán ni Iseo ahorran calificaciones que lo desvalorizan aunque las camuflen tras el juego retórico de la interrogación figurada: "Dex! Porquoi est li mis si fol? (Tristan, 127) o de la ironía: 


$$
\begin{aligned}
& \text { mot est cortois li rois, mi sire; } \\
& \text { ja nu pensast nul jor par lui } \\
& \text { q’en cest pensé fuson andui. } \\
& \text { Tristan, } 86 \text { - } 88
\end{aligned}
$$

Sus defectos derivan de la falta de ecuanimidad, aprovechada por la reina ${ }^{384}$ y por sus allegados ${ }^{385}$ para justificar la permanencia del amante en las inmediaciones de la corte y para encontrar un respaldo institucional, y casi podríamos decir moral si tomamos en consideración la construcción intertextual de la corte artúrica, a la infidelidad conyugal. El adulterio y las contradicciones subsecuentes entre el hombre —esposo y pariente- y el monarca, llevan a Marco a mostrar una actitud indecisa y sumisa o muy violenta: "li rois destruire eus veut" (Tristan, 830), "mot est li rois acoragiez de destruire: c'es granz pechiez" (Tristan, 1951 -1952), ${ }^{386}$ así como a la dejación de sus derechos sobre la esposa al entregarla a los leprosos: "li rois li done, et cil la prent" (Tristan, 1223) en una escena que reproduce en negativo el ritual por el que Tristán la obtuvo al enfrentarse a la bestia del Valle del Infierno y la entregó al rey, ${ }^{387}$ y que volverá a repetirse tras el exilio en el Morrois. El propio ejercicio de la autoridad le perjudica en su calidad de esposo: "li mois li a doné congié d'estre a la chanbre" (Tristan, 569 - 570) y termina irremediablemente socavando la estabilidad de su reinado. Ello provoca un fuerte desprestigio de la figura del rey, predominante como sujeto

\footnotetext{
384 “conment li rois sera vers moi, iriez ou voirs" (Tristan, 2813 - 2814).

385 Es el caso de la descripción que de él hace Perinís en la corte del rey Arturo: "li rois n’a pas coraige entier, senpres est ci et senpres la" (Tristan, 3432 - 3433).

386 En este sentido encontramos los verbos haer (Tristan, 203), menacier (Tristan, 770 y 1949) у mesfaire (Tristan, 1950) o la expresión estre iniez (Tristan, 1029).

387 » le grant serpent cresté ocis,

» par qoi ele me fu donee.

»Amenai la en ta contree.

» Rois, tu la preïs a mollier

Tristan, $2560-2564$
} 
activo si tomamos en consideración la función sintáctica de las denominaciones estudiadas. La observación del término roi en esta función nos ofrece aún nuevas perspectivas sobre el descrédito que lo persigue, plasmado merced a los verbos de conocimiento y de percepción. La abundancia de éstos contrasta llamativamente con lo erróneo de sus conclusiones y con la facilidad con la que los amantes hacen que se modifiquen sus opiniones y sus sentimientos, valiéndose, bien es cierto, del apego que siente el monarca por las apariencias, ya sean gestos, actitudes o palabras. Entre los verbos de conocimiento encontramos penser. "li rois pense que par folie, sire Tristran, vos aie amé” (Tristan, 20 - 21); savoir. "s'or en savoit li rois un mot, mon cors seret desmenbré tot" (Tristan, 65 - 66), "li rois ne set que por lui par vos aie ameit" (Tristan, 69 - 70); oïr. "s'un mot en puet li rois ö̈r que nos fuson ça asenblé, il me feroit ardoir en ré" (Tristan, 190 - 192) o deconoistre: “onques li rois ne s'aperçut ne mon estre ne desconnut" (Tristan, 367 - 368); y entre los de percepción aperçoivre, veoir. “que li mois n'a chose veüe qui ne puise estr'en bien tenue" (Tristan, 375 - 376) y entendre: "li rois (...) out l'asenblee bien veüe et la raison tote entendue" (Tristan, 258 - 260). Tan sólo en una ocasión la percepción es clara: "li rois choisi el lit le sanc" (Tristan, 767) y aunque la interpretación de los indicios podría ser dudosa, tal como ocurre en la cama de Ginebra, el rey no vacila en considerar la sangre como una prueba inequívoca del adulterio, probablemente porque está acompañado de los barones felones y adopta su punto de vista.

Nada se nos dice sobre la sensualidad del monarca pero sí debemos asignarle un papel central en el entramado erótico de la leyenda. En primer lugar porque es la clave de los amores prohibidos al interponerse entre la pareja natural reclamando para sí los placeres que debían pertenecer a los jóvenes. De hecho en las diferentes versiones del juramento de la reina se insiste sobre la actividad sexual del rey y se la equipara a la del sobrino adúltero: "fors du roi et de son nevo" (Tristan, 4225). También porque en 
ocasiones actúa con excesiva tibieza y parece consentir los encuentros de los amantes, ${ }^{388}$ siendo como es su cama el lugar idóneo para la unión sexual de Tristán y de la reina, tal como se expresa en los contextos en que el sustantivo funciona como complemento atributivo del nombre construido con o sin preposición:

et plusors foiz les ont veüz
el lit roi Marc gesir toz nus

Tristan, $593-594$

entre son lit et cel au roi

avoit bien le lonc d'une lance.

Trop out Tristran fole atenance

Tristan, $694-696$

les piez a joinz, esme, si saut,

el lit le roi chaï de haut

Tristan, $729-730$

Aún más, la autoridad congregada en su figura, mayor que la de un marido cualquiera, refuerza el poder erótico de la interdicción, renovado

388 Como deducimos de algunas omisiones y acciones presentadas por el narrador:

Tristran vait a la chanbre et vient;

nule cure li mis n'en tient.

Tristan, $571-572$

tes niés s'entraiment et Yseut,

savoir le puet qui c'onques veut;

et nos nu volon mais sofrir.»

Li mis l'entent, fist un sospir,

$\underline{\text { son chief abesse vers la terre, }}$

ne set qu'il die, sovent erre.

Tristan, 607 - 612 
gracias al uso del vocativo que a menudo aparece combinado con verbos como prendre o rendre. De este modo los traidores, los consejeros leales o el propio Tristán se dirigen al rey instándole para que haga valer sus derechos, el de cobrar la vida de los adúlteros mediante el verbo prendre en sentido figurado: “Rois s'or n'en prens aspre venjance, n'as droit en terre, sanz doutance." (Tristan, 1903 - 1904) o el de recuperar a la esposa mancillada y repudiada, con lo que se recrea la atmósfera más propicia para un relanzamiento del triángulo amoroso, atractivo fundamental de la leyenda:

$$
\begin{aligned}
& \text { n’i a baron de Cornoualle } \\
& \text { ne die: «Rois, ta feme pren. }
\end{aligned}
$$

Tristan, $2624-2625^{389}$

«Rois, ge te rent Yseut, la gente:

hon ne fist mais plus riche rente.

Tristan, $2851-2852$

Este mismo verbo aparece con el sustantivo rois en función de complemento de objeto indirecto incidiendo en la idea del monarca como beneficiario del que se nos ofrece como un bien mueble, la reina, quien es capaz de satisfacer las necesidades de sus dos compañeros con la sola condición de gozar de su amante:

$$
\begin{aligned}
& \text { - Tu me conduiz, si me veuz rendre } \\
& \text { au roi, par le consel Ogrin }
\end{aligned}
$$$$
\text { Tristan, } 2808-2809
$$

El rey Arturo tiene un papel mucho menos relevante en la historia del adulterio de la reina Ginebra, si bien cabe destacar dos aspectos que influirán en el desarrollo de la novela y en la conformación de los amores de la

${ }^{389} \mathrm{El}$ rey también es sujeto de los verbos prendre y reçoivre en un fragmento en estilo indirecto libre: "li mois la roïne prent” (Tristan, 2667), “est li mis prest de lié reçoivre.” (Tristan, 2676). 
reina, de Lanzarote y del advenedizo Meleagant. Por una parte, su estricta observancia de las costumbres cortesanas lo obligan a entregar a su esposa para que corra una suerte incierta, y tal como hemos apuntado anteriormente esta cesión puede llevar a un tercero a disfrutar carnalmente de la reina: "li rois li baille et cil l'an mainne" (Charrete, 196). Supedita así el poder regio a los caprichos de sus caballeros, y se hace en gran medida equiparable a Marco, por mucho que se separe de su esposa con disgusto:

$$
\begin{aligned}
& \text { au roi poise, et si l'an revest, } \\
& \text { car einz de rien ne se desdist, } \\
& \text { mes iriez et dolanz le fist } \\
& \text { Charrete, } 180-182
\end{aligned}
$$

Por otro lado, individualizado pero en la misma medida que el resto de los cortesanos, el rey es el principal obstáculo para que Ginebra manifieste abiertamente sus sentimientos hacia el reaparecido Lanzarote:

$$
\begin{aligned}
& \text { li rois, li autre, qui la sont, } \\
& \text { qui lor ialz espanduz i ont, } \\
& \text { aparceüssent tost l'afeire } \\
& \quad \text { Charrete, } 6837 \text { - } 6839
\end{aligned}
$$

Poco nos aportan las rimas con el término roi, pues las mínimas repeticiones que hallamos, como las de los sustantivos foi y esfroi, responden más bien a condicionantes formales, y tan sólo el pronombre soi podría haber servido para impulsar las diferencias que separan al rey de Tristán.

\begin{tabular}{lllllllll}
\hline FORMA & CA & BD & NV & RIMA & CA2 & NV2 & D & PERS \\
\hline rois & S & Tristan & 1029 & borjois & S & 1030 & D & Governal \\
roi & S & Tristan & 1812 & doi & S & 1811 & N & Narrador \\
roi & S & Tristan & 694 & esfroi & S & 693 & N & Narrador \\
roi & S & Tristan & 1721 & esfroi & S & 1722 & N & Narrador \\
roi & S & Tristan & 56 & foi & S & 55 & D & Iseut \\
roi & S & Tristan & 568 & foi & S & 567 & N & Narrador \\
rois & S & Tristan & 203 & hernois & S & 204 & D & Tristan \\
roi & S & Tristan & 109 & moi & P & 110 & D & Tristan
\end{tabular}




\begin{tabular}{lllllllll} 
roi & S & Tristan & 2950 & soi & P & 2949 & N & Narrador \\
roï & S & Tristan & 2774 & soi & P & 2773 & N & Narrador \\
rois & S & Tristan & 1682 & trois & N & 1681 & N & Narrador \\
rois & S & Tristan & 2813 & voirs & A & 2814 & D & Iseut \\
\hline
\end{tabular}

Tabla 50. Rimas del sustantivo roi.

$\mathrm{El}$ análisis de las proposiciones subordinadas en las que aparece el sustantivo roi nos muestra en la obra de Béroul un predominio de las completivas y las circunstanciales. Las relativas, menos frecuentes, están introducidas por el adverbio ou reforzado con la: "a la chanbre painte s'en

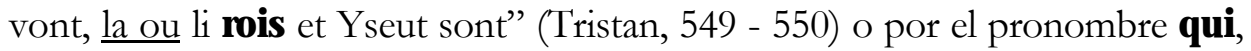
que representa la forma del caso régimen cui precedido por una preposición con la que se introduce un matiz causal:

c'erent li chien a un des trois

por qui consel estoit li rois

meslez ensenble la roïne.

Tristan, $1681-1683$

En la obra de Chrétien tan sólo hallamos una proposición subordinada relativa que contenga la denominación que nos ocupa. En este caso el pronombre relativo qui cumple su función habitual de sujeto:

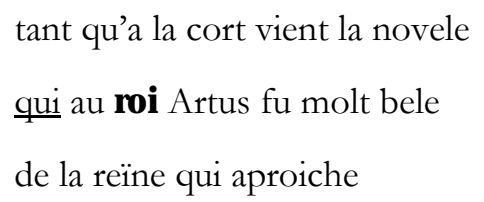

Charrete, 5303 - 5305

Podemos clasificar las proposiciones completivas, todas ellas complemento de objeto directo, en función de la aparición de la conjunción que o de la omisión de esta. En ambos casos los verbos introductores pueden ser de conocimiento como savoir: "bien sai que mot me het li mois." (Tristan, 203), y verbos de dicción o locuciones equivalentes, jurer. "qu'entre mes 
cuises n'entra home, (...) et li rois Marc mes esposez.” (Tristan, 4205 - 4208); dire: "et je li dis que grant folie avoit requis, que je a lui mais ne vendroie ne ja au roi ne parleroie." (Tristan, 361 - 364); li criz lever. "li criz live par la cité qu'endui sont ensenble trové (...) et que li rois destruire eus veut”' (Tristan, 827 - 830) y huchier. "par Cornoualle fait huchier li rois s'acorde a sa mollier" (Tristan, 2745 - 2746).

En cuanto a las subordinadas circunstanciales observamos cuatro tipos: causales, consecutivas, temporales y condicionales.

- Causales: Introducidas por las conjunciones quar y que, o la locución conjuntiva por ce que [Prep. + Pron. + Conj.]

$$
\begin{aligned}
& \text { n’i voi or point de ton pooir, } \\
& \text { quar vers toi est iriez li rois }
\end{aligned}
$$$$
\text { Tristan, } 1028 \text { - } 1029
$$

qar j’ai tel duel ćonques le roi out mal pensé de vos vers moi

$$
\text { Tristan, } 109-110
$$

$$
\begin{aligned}
& \text { quar grant poor avoit de soi, } \\
& \text { por ce qu'il out mesfait au roï. }
\end{aligned}
$$

Tristan, $2773-2774$

- Hipotéticas: Invariablemente introducidas por la conjunción se, pueden eliminar cualquier relación cronológica al construirse en imperfecto de subjuntivo:

$$
\begin{aligned}
& \text { bele amie, se je peüse, } \\
& \text { par consel que je en eüse, } \\
& \text { faire au roi Marc acordement } \\
& \text { Tristan, } 2223 \text { - } 2225
\end{aligned}
$$


expresar la probabilidad mediante una construcción en la que se combinan el imperfecto de indicativo y el condicional:

$$
\begin{aligned}
& \text { S'or en savoit li rois un mot, } \\
& \text { mon cors seret desmenbré tot, } \\
& \text { et si seroit a mot grant tort; }
\end{aligned}
$$$$
\text { Tristan, } 65-67
$$

o bien en una construcción asimétrica el presente de indicativo en la prótasis y el condicional en la apódosis:

$$
\begin{aligned}
& \text { s’un mot en puet li rois oïr } \\
& \text { que nos fuson ça asenblé, } \\
& \text { il me feroit ardoir en ré }
\end{aligned}
$$

Tristan, 190 - 192

- Consecutivas: Introducidas por la locución si que [Adv. +

Conj.] o por la conjunción que sin que la consecuencia se exprese claramente:

$$
\begin{aligned}
& \text { si que Yseut fust acordee } \\
& \text { o le roi Marc, qui'st esposee } \\
& \text { Tristan, } 2191-2192 \\
& \text { qant il vos a fait desevrer } \\
& \text { du parlement sanz plus outrer, } \\
& \text { que li rois n'a chose veüe }
\end{aligned}
$$

Tristan, $373-375$

- La proposición temporal introducida por qant sitúa en el tiempo la acción de la subordinada completiva introducida por que y no la acción de la principal, con ello supedita la permanencia de Tristán oculto cerca de la corte 
a su restablecimiento como reina, y se vuelve a la situación inicial del fragmento:

Gel prié, qui sui ta chiere drue,

qant li rois m'avra retenue,

que chiés Orri le forestier

t’alles la nuit la herbergier

Tristan, $2815-2818$

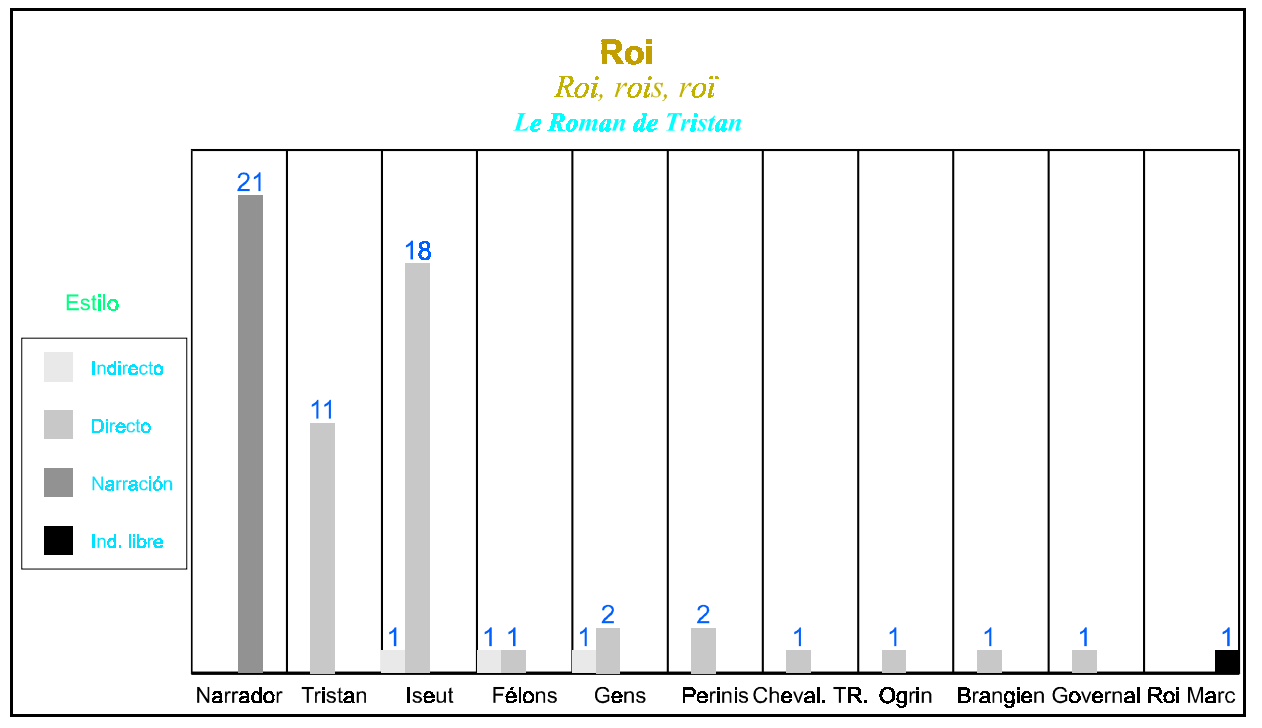

Fig. 51. Comportamiento estilístico del sustantivo roi en Tristan.

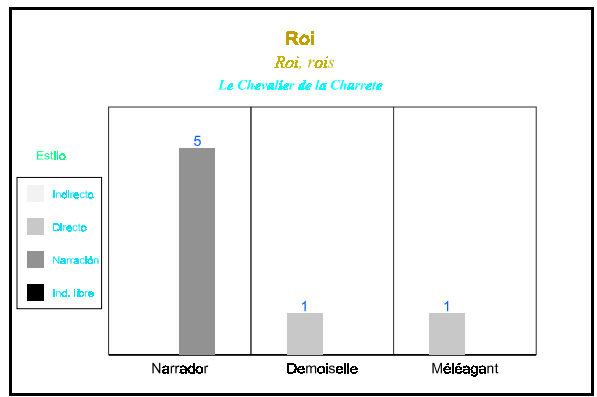

Fig. 52. Comportamiento estilístico del sustantivo roi en Charrete.

Resulta curioso observar la gran disparidad de los papeles asignados al marido cuando ambos romans narran la historia de un adulterio. 
Probablemente Chrétien pretendía evitar que se amancillase su recreación de la corte de Arturo y que la imagen del propio rey se viese ajada por los abusos sexuales que, como se comprobará en las reelaboraciones tardías del mito, serán la causa de su ruina y de su muerte. Para ello se sirvió del recurso narrativo no sólo habitual sino más provechoso en el conjunto de sus obras, la aventura, que alejaba el caos del centro del universo artúrico para restituirse sus protagonistas tan sólo cuando el orden había sido alcanzado de nuevo. Por el contrario Béroul reitera con complacencia lo ambiguo de la relación que se establece en la corte del rey Marco, y es especialmente significativo el hecho de que Tristán e Iseo aludan con asiduidad a él como representación del poder y de la moral que quebrantan.

\subsection{EXPRESIONES GENERALES RELATIVAS AL VARÓN.}

\subsection{Créature.}

Chrétien hace un uso muy particular de esta forma ya que habitualmente aparece como denominación femenina, e incluso a partir de su significado de mujer pasará a tener a partir del siglo XVII el de cortesana debido a su utilización generalizada en contextos eróticos. ${ }^{390}$ Él la aplica a Lanzarote —nueva manifestación de la feminización del héroe—, tal como ocurrirá después en Escoufle, en una construcción ponderativa en la que se acumulan los adjetivos apreciativos:

certes trop i avroit grant perte,

se criature si aperte,

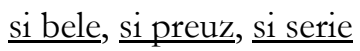

Charrete, 6369 - 6371

${ }^{390}$ Cf. Guiraud, op. at., p. 259. 


\subsection{2 «Rien».}

Aunque este sustantivo se refiera en mucha menor medida al varón que a la mujer, las construcciones en las que aparece son muy similares y expresan, sin excepción, la comparación o la ponderación. Lo encontramos tan sólo en dos novelas, Charrete y E sooufle, y a excepción de un ocurrencia en la narración, queda reservado para el discurso directo de los personajes, generalmente femeninos.

- Como antecedente de una frase de relativo que contiene un verbo de sentimiento — amor u odio- en grado superlativo, en la que el relativo funciona como objeto directo:

\section{Aimer miex.}

se Diex de la riens que j’aim miex me doinst joïr a nul jor mais Escoufle, 4952 - 4953

Plus haer.

con li miens cuers a or androit de la rien que je plus haoie.

Charrete, 2930 - 2931

- Con un valor muy general — también podría referirse a una mujer - acompañado por el adjetivo indefinido nule en el discurso de Lanzarote, con la función de complemento de objeto directo de la expresión aimer de cuer que parece indicar un cierto grado de perfección amorosa y nos sitúa de nuevo en un contexto superlativo:

Se vos rien nule amez de cuer,

dameisele, de par celi 
vos conjur et requier et pri

Charrete, 1404 - 1406

- En una comparación de superioridad con carácter excluyente en la que rien representa el elemento referencial general al que el comparado supera en sus acciones, aquí la de amar: "quant ele ot que cil la nomma qui plus l'aime que niens qui vive" (Escoufle, 7686 - 7687), o bien se refiere al sujeto comparado por sus cualidades en una comparación generalizada: “que c'est la plus desleax nien qui onques fust ne ja mes soit”' (Charrete, 2814 - 2815).

\subsection{TÉRMINOSQUE DENOTAN UNA RELACIÓN AMOROSA.}

\subsection{Ami.}

A excepción de Rose, donde el sustantivo ami se ve en gran medida relegado por la denominación amant, los otros romans lo adoptan mayoritariamente, en la estela de los trovadores, para hacer referencia al enamorado. Aunque, como ya hemos señalado para el término amie, puede adoptarse el punto de vista femenino y llamar de este modo al hombre por el que una mujer se siente atraída o del que está enamorada; así ocurre en Charrete con la doncella que exige a Lanzarote sus servicios sexuales a cambio de su hospitalidad (Charrete, 1020) o con la hija del rey Bademagu (Charrete, 6696), y en E scoufle al aludir el celoso conde de Saint Gilles a la supuesta relación que su amada mantiene con su esposo (Escoufle, 5843).

Desde la perspectiva del funcionamiento sintáctico resulta llamativo el hecho de que la función sujeto, en la que aparece siempre el sustantivo precedido por un artículo posesivo, sea minoritaria en los textos y que en la mayoría de los casos la acción enunciada por el verbo correspondiente sólo tenga una relación indirecta con el amor, hecha excepción de la presentación del afectuoso amigo íntimo de Jeunesse: 
ses amis fu de lui privez

en tel guise qu'i la bessoit

toutes les foiz qu'il li plessoit

Rose, $1266-1268^{391}$

En Tristan el sustantivo es sujeto activo de los verbos eschaper. “que ses amis est eschapez" (Tristan, 1047) y seoir. "sor la mote sist ses amis" (Tristan, 3826) y sujeto paciente del verbo trover. "mes amis est trovez" (Tristan, 3163 - 3164). En Charrete el verbo venir sirve en el discurso de Ginebra para expresar el acercamiento del amante en un acto de sometimiento público: "quant mes amis devant moi vint" (Charrete, 4198) o el deseo de entregarse a él, al tiempo que lo identifica con el placer y la alegría amorosos mediante la coordinación de los sintagmas:

$$
\begin{aligned}
& \text { et molt est la reïne tart } \\
& \text { que sa joie et ses amis veingne }
\end{aligned}
$$

Charrete, 4424 - 4425

Mientras que, Lanzarote — sea en estilo directo o bien en el discurso narrativo, donde excepcionalmente desaparece el artículo posesivo para marcar la generalización — tiende a despersonalizarse, a esconderse utilizando la tercera persona tras la tipología creada por la tradición literaria que había concebido un prototipo de enamorado con el que se identifica plenamente. El personaje se pliega de esta forma a la ideología dominante que oculta al individuo tras el grupo y condena el pecado de orgullo, en una nueva muestra de la perfección del caballero y del amigo:

$$
\begin{aligned}
& \text { (...) si li conjure } \\
& \text { come cil qui ne cuidoit mie }
\end{aligned}
$$

\footnotetext{
${ }^{391}$ En Rose tan sólo encontramos otro ejemplo en el que ami es sujeto, también en la presentación de la corte de Deduit, apuntándose la homogeneidad de una de las parejas: "d’un samit, qui toz ert dorez, fu ses cors vestuz et parez, de quoi ses amis avoit robe” (Rose, 859 - 861)
} 
qu'amie ami, n'amis amie

doient parjurer a nul fuer

Charrete, 1400 - 1403

et tote voie ses amis

fist ce don maint li ont amis

por li honte et reproche et blasme

Charrete, 4379 - 4381

Jean Renart mediante el sustantivo ami en función de sujeto nos muestra a un enamorado supeditado a los que lo rodean, obligado moralmente a corresponder al amor que le muestra Aelis: "ml't la doit amer ses amis quant ele ensi por lui s'en emble" (Escoufle, 3879 - 3880), ${ }^{392}$ y alejado físicamente de la amada, que es en realidad la que ejecuta las acciones de las que se beneficiará su amigo:

$$
\begin{aligned}
& \text { Ele a bien son cuer afichié } \\
& \text { que ses dous amis, s'ele vit, } \\
& \text { avra, l'anel qu'il ainc ne vit } \\
& \text { et l'aumosniere tot ensamble }
\end{aligned}
$$

Escoufle, 3838 - 3841

A esto se suma un distanciamiento discursivo provocado por el desarrollo de abstracciones personificadas: Amor y Razón recogen las dudas que le plantean a Aelis el abandono de la protección familiar y del código moral que pretendía salvaguardar su virginidad, así como la presión cortesana para que se ciña a la reglamentación matrimonial no escrita que antepone los intereses políticos y económicos a los sentimientos amorosos:

\section{Lairoit on son ami manoir avuec, se ele estoit remese?}

Escoufle, 3917 - 3918

392 Aquí hemos asignado un valor causal a la conjunción quant, cf. P. Ménard, op. ait., p. 212. 
Bien es cierto que siguiendo las consignas de su joven compañera regresa a su lado para ayudarla a fugarse, tal como nos muestran los verbos revenir (Escoufle, 3788) y venir queme: "mes amis m'est venue querrë" (Escoufle, 3954 - 3955), y que después le da muestras de su amor con pequeños gestos que pretenden evitarle las molestias de la vida en el incómodo mundo exterior a la corte, a los que ella corresponde con otros cargados de voluptuosidad: "quant la bele a en .j. lieu mors, si done a mordre son ami” (Escoufle, 4450 - 4451)

$$
\begin{aligned}
& \text { et ses dous amis li acource } \\
& \text { son estrier, puis si la remonte } \\
& \text { Escoufle, } 4006-4007 \\
& \text { et ses amis } \underline{\text { a acosté }} \\
& \text { le soleil, qu'il li velt faire ombre } \\
& \text { Escoufle, } 3540 \text { - } 3541
\end{aligned}
$$

En nominativo plural designa también a los enamorados, en este caso probablemente nobles con pocos recursos que cortejaban a las hijas de otros nobles normandos con el fin de contraer nupcias con ellas. Estos quedarán atrás, con lo que quedará al descubierto la otra cara del juego matrimonial evocado en la mayor parte de las novelas, pues aquí es la mujer la que puede beneficiarse económica y socialmente de un matrimonio ventajoso aunque ello implique el alejamiento de los territorios familiares, el servicio directo a una dama y por supuesto la supeditación de los sentimientos a los intereses sociales:

Les meres pleurent qui convoient lor filles que la dame enmaine, mais plus ara en son demaine terres et fiex toute la pire, 
se Diex rent au conte l'empire, que n'ont ore tuit si ami.

Escoufle, 8688 - 8693

Al funcionar como complemento atributo, se modifica el alcance semántico del nominativo singular amis —o la variante ami al servicio de la rima- según algunas variables de orden sintáctico, estilístico o retórico. En el diálogo espiado la reina Iseo camufla la relación amorosa bajo los sentimientos amistosos del que le debe la vida, haciendo desaparecer cualquier tipo de actualización del sustantivo y evocando el origen de la amistad mediante el imperfecto de indicativo, lo que parece relegarla al pasado y desvincularla del presente:

$$
\text { (...). Je vos gari. }
$$

Se vos m'en eriez ami,

n'ert pas mervelle, par ma foi!

Tristan, 53 - 55

En Charrete la desaparición de los artículos y la calificación mediante el adjetivo antiers define al amigo, no en función de la amada, de la que todavía desconocemos la identidad, sino de su propia idealidad al permanecer su cuerpo y su espíritu imperturbables, fieles y sometidos a una única mujer:

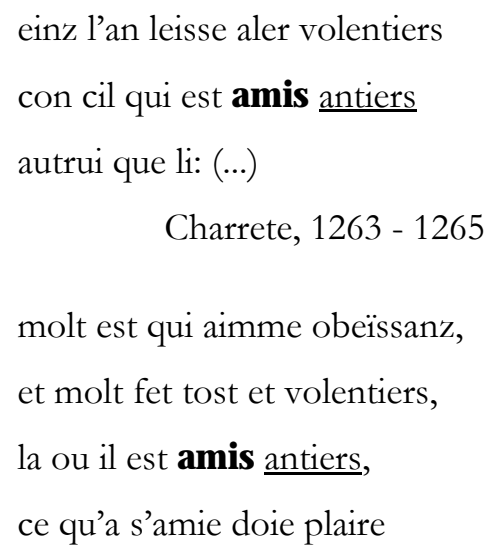

Charrete, 3798 - 3801 
Una variante de esta fórmula se encuentra en el texto de Lorris aunque en este caso la pareja queda identificada y reaparece el posesivo. Aquí el adjetivo hace hincapié en otra de las virtudes corteses, la sinceridad del amigo, que ya había reclamado para sí Lanzarote: “ami verai”” (Charrete, 4368)

$$
\begin{aligned}
& \text { Richece tint par mi la main } \\
& \text { un valet de grant biauté plain } \\
& \text { qui fu ses amis } \underline{\text { veritex. }}
\end{aligned}
$$$$
\text { Rose, } 1107 \text { - } 1109
$$

En E scoufle el sustantivo en función de atributo, no de un sujeto de persona, ya fuese bajo la forma del nombre propio del amante o de un pronombre personal, sino referido al sustantivo corps, evoca en el discurso de la esposa del conde Richard la unión sexual, el deseo físico mutuo en paralelo a la armonía de sus espíritus:

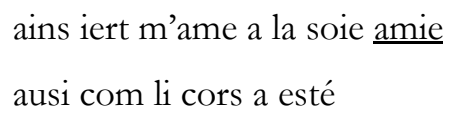

Escoufle, 2460 - 2462

Por fin, precedido de un artículo o de un adjetivo posesivo define en el discurso del hombre — Guillermo o el conde de Saint Gilles—, del narrador, de Razón o de Aelis a aquel del que está enamorada una mujer: "se je ne fuisse ses amis, cil dous regars ne peüst estre” (Escoufle, 3167 - 3168), “a cel regart m’aperçui lors que g'ere ses amis sans doute.” (Escoufle, 3174 3175), 393 “Amors, et comment savés vous que c'est ses amis?” (Escoufle, 7560 - 7561), "biau frere, cui j’acol, estes vous donc li miens amis?" (Escoufle, 7694 - 7695); y en menor medida, sin artículo, al construirse con un complemento atributivo del nombre, al hombre enamorado de una mujer: "li quens de mon signor Saint Gile qui estoit a la dame amis" (Escoufle, 5828 $5829)$.

393 Cf. Escoufle, 5843 
En el discurso de Aelis cuando se cree abandonada la perspectiva cambia y amis, sin artículo, con un valor general en el primer ejemplo que citamos o bien particular al retomar en estilo indirecto las palabras de Guillermo, se refiere al que se dice enamorado pero miente, una de las figuras más criticadas en las composiciones de los trovadores: ' $k$ ’il n'est mie amis qui s'amie guerpist ensi” (Escoufle, 4691 - 4692), “encor me dist il ore k'il m’estoit et sire et amis" (Escoufle, 4698 - 4699).

En pocos casos son asumidas por la denominación ami las funciones de objeto directo, de objeto indirecto, ${ }^{394}$ o de complemento preposicional.

Como complemento de objeto directo lo encontramos dependiendo de los verbos aprismer. "ele aprisme son ami" (Tristan, 3); garder. "qui garder durent mon ami” (Tristan, 1057); oublier (Escoufle, 7285); regreter (Escoufle, 7335); beisier. "ele ot la bouche petiteite et por beisier son ami prete" (Rose, 850); clamer. "mes ami verai me clamast" (Charrete, 4368); apeler: "la damoisele ne laist mie por sa maistre ne por sa mere que ne l'apiaut ami ou frere" (Escoufle, 1986 - 1988), "l'a apelé «biax dous amis» (Escoufle, 3635); celer: "or oiés com el l'en desvoie celant l'ami sos les amis" (Escoufle, 7320 - 7321). Observamos de nuevo en Charrete y en Escoufle una gran preocupación por la manifestación o la ocultación discursiva del amor como síntoma inequívoco de la pasión, tema este que se desarrollará en la obra del siglo XIII gracias a la aparición del sustantivo ami en sintagmas preposicionales introducidos por de dependientes del sustantivo nom: “c'uns faus souspirs et .j. senglous la prent enmi le non d'ami”' (Escoufle, 1996 1997). .395

A diferencia del sustantivo en su forma femenina, no existe ninguna preposición que se utilice mayoritariamente para introducir los sintagmas en

\footnotetext{
394 Tan sólo hay dos ocurrencias en Escoufle, dependiendo de los verbos doner "la dame l'a ja son ami donee"(Escoufle, 5698 - 5699) y faire (Escoufle, 7863).

395 Véanse también los versos 1985, 5842 y 7324.
} 
los que interviene el amigo, sin embargo, queremos poner de relieve algunos usos que nos muestran en unos y otros textos la intimidad en la que viven los amantes, o bien al amigo como causa o fin de las acciones o del dolor femeninos. Así la preposición sor en Tristan traduce la idea de proximidad espacial: "somel li prist, dormir se vot, sor son ami dormir se vot" (Tristan, 1301 - 1302), mientras que en E soufle la misma idea viene expresada por o: "s'il me laissast, si com je suel, estre çaiens o mon ami” (Escoufle, 3900 3901), o bien por a cuando implica un movimiento: "bele et ja vendras la desous a ton douç ami” (Escoufle, 3948 - 3949), “ki ml't par tans s'ert descoucie por aler a son douç ami." (Escoufle, 4080 - 4081). Mientras, com introduce un complemento de identidad en Tristan: "ge ne di pas, (...) que je ne l'aim de bone amor et com amis" (Tristan, 2325 - 2328) y en E scoufle sirve para evocar el modo en que se comportan los verdaderos amantes o las parejas de enamorados, y deja de nuevo la puerta abierta a una intervención activa por parte del receptor de la obra apelando a sus vivencias:

li damoisiax li fait son sés

de tot comme ses dous amis

Escoufle, 4460 - 4461

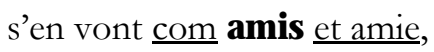

deduisant parmi le vergier,

et font samblant de fruit mangier.

Escoufle, 2094 - 2096

La preposición por introduce la causa en el monólogo de la atormentada Ginebra, quien prefiere el dolor de la separación a la muerte que acaba con el sufrimiento: "malveise est qui mialz vialt morir, que mal por son ami sofrir" (Charrete, 4239 - 4240), y en el discurso de Aelis cuando recuerda a su amante: "et qui ml't li prie et enorte que li die pour qu'ele plore.(...) et c'est pour son ami le gent" (Escoufle, 7340 - 7344);396 o bien presenta al

$396 \mathrm{Al}$ igual que en Escoufle, 7317. 
beneficiario de las primorosas labores femeninas, muestra material del amor que por él profesa: “ce dient les letres d'entor qu'elle ot faites por son ami” (Escoufle, 1158 - 1159).

Como vocativo puede presentarse tanto al comienzo del verso como en la rima, donde más que a efectos de sentido parece deber este uso a exigencias formales. Tristan y Escoufle son las novelas que con mayor reiteración acuden a esta función, muy escasamente utilizada por Chrétien y Lorris. Formalmente puede aparecer solo, ${ }^{397}$ seguido del nombre propio: “Amis Tristan” (Tristan, 1587, 2217, 2285, 2707, 2792) o en aposición a este: “Tristan, ami” (Tristan, 2288), así como acompañado de un adjetivo posesivo: "El buen celier, soz le boron, seras entrez, li miens amis.” (Tristan, 2828 2829), "li miens amis, que Dex t'enort!" (Tristan, 2832), o de uno o varios adjetivos calificativos. Estos constituyen patrones sintácticos y léxicos bien definidos que se repiten sin apenas variaciones en las diferentes novelas. Quizá lo más destacable dentro de estas estructuras que detallamos a continuación sea el predominio de adjetivos de una sola sílaba que pueden incluso haber dado lugar a una lexicalización del grupo. Si las comparamos con las que se formaban en torno al sustantivo femenino observamos una mayor diversificación así como una intensificación del uso, hechos que podrían responder a la voluntad por parte de los autores — exceptuando a Lorris pues en Rose se encuentran en los discursos de Bel Accueil y del Amant- de dotar a los personajes femeninos de mayor expresividad en el terreno afectivo:

\section{1. [Adj. + Sust.]}

\section{Beaus amis}

$$
\begin{aligned}
& \text { qui m'oceïst, si garisiez, } \\
& \text { ce fust grant joie, beaus amis; }
\end{aligned}
$$

\footnotetext{
397 Tristan, 1791, 2265, 2497, 2723, 2806, 4453. Charrete, 1020, 4498. Escoufle, 3552, 4372, 4482, 5858, 7698. Rose, 3377
} 
encore en fust vengement pris

Tristan, $906-908$

$\underline{B i a x}$ amis, fait ele, biau frere (Escoufle, 1855)

$\underline{B i a x}$ amis, biax frere, biax sire (Escoufle, 4727)

Comment, fait ele, biax amis (Escoufle, 3520)

«Ahi! Guilliaumes, biax amis,

tantes foïes avés mis

vos beles mains, qui si sont blanches

Escoufle, 3283 - 3285

\section{Dous amis}

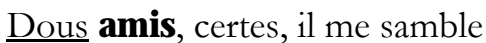
que dame sui ja de Rueem

Escoufle, 3536 - 3537

Dous amis, foi que je vos doi, la chose vait tot autrement.

Escoufle, 5850 - 5851

\section{2. [Adj. + Sust. + Adj.]}

\section{Beaus amis douz}

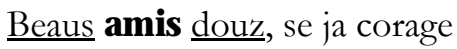
vos ert venuz de repentir, or ne peüst mex avenir.

Tristan, 2270 - 2272 
Dous amis debonaire. Este agrupamiento, que rompe la regla de los monosílabos, corresponde exactamente al equivalente femenino que había sido utilizado en Charrete.

Ahi! Dous amis debounaire,

por coi nos a on desevrés?

Escoufle, 3214 - 3215

\section{Beaus amis chiers}

«Biaus amis chiers, se il vos plest, pasez la haie sanz arest por l'odor des roses sentir.

Rose, 2781 - 2783

\section{3. [Adj. + Adj.+ Sust.]}

\section{Beaus douz amis}

(...) beaus douz amis.

qant gel verrai, ce m'est avis,

menberra moi de vos sovent.

Tristan, $2699-2701$

Por Deu vos pri, beaus douz amis, que ne partez de cest païs

Tristan, $2811-2812$

Biaus dous amis, malgré tos ciaus qui nos cuident despareillier

Escoufle, 3602 - 3603398

398 "Ele li dist: «Vo boine mere, biax dous amis, me salués.” (Escoufle, 3638 - 3639), «Biax dous amis, fait ele, la voel je descendre por mangier.» (Escoufle, 4403 - 4404) 
Hai! Bel Acueil, biau douz amis,

se vos estes em prison mis,

gardez moi seviaus vostre cuer

Rose, 3975 - 3977

\section{Beaus chiers amis}

li cors giront el bois, sovin,

beau chiers amis, et g'en ai dote

Tristan, 2824 - 2825

\section{4. [Adj. + Adj. + Sust. + Adj.]}

\section{Beaus dolz amis chiers}

Lancelot, biax dolz amis chiers,

fet la pucele, jel vuel bien;

Charrete, 6696 - 6697

E scoufle es el texto en el que más se aprovechan las posibilidades que ofrece la colocación en la rima del sustantivo ami. Junto a la nada desdeñable posición relevante en la composición formal del verso lo asocia a términos que refuerzan su expresividad. Es el caso para el emparejamiento con la interjección aimi que evoca un gran desánimo o un profundo dolor, cuyo comienzo coincide con los primeros síntomas de traición contra el amigo de Aelis; así mismo, el término demi, ya sea sustantivo o adjetivo, generalmente en proposiciones negativas, engrosa la sensación de veracidad en la expresión de los sentimientos amorosos. Por el contrario la rima más repetida, la que se establece con el participio pasado mis, no responde en apariencia a una voluntad retórica sino más bien a una simple comodidad formal. 


\begin{tabular}{|c|c|c|c|c|c|c|c|c|}
\hline FORMA & CA & BD & NV & RIMA & CA2 & NV2 & D & PERS \\
\hline ami & $\mathrm{S}$ & Escoufle & 2705 & aimi & $\mathrm{L}$ & 2706 & $\mathrm{D}$ & Traîtres \\
\hline ami & $\mathrm{S}$ & Escoufle & 3949 & aimi & $\mathrm{L}$ & 3950 & D & Amour \\
\hline ami & $\mathrm{S}$ & Escoufle & 4081 & aimi & $\mathrm{L}$ & 4082 & $\mathrm{~N}$ & Narrador \\
\hline ami & $\mathrm{S}$ & Escoufle & 8693 & aimi & $\mathrm{L}$ & 8694 & $\mathrm{~N}$ & Narrador \\
\hline amis & $S$ & Tristan & 3826 & ainemis & $\mathrm{S}$ & 3825 & $\mathrm{~N}$ & Narrador \\
\hline amis & $S$ & Charrete & 4379 & amis & $\mathrm{O}$ & 4380 & D & Lancelot \\
\hline amis & $\mathrm{S}$ & Tristan & 2699 & avis & $\mathrm{S}$ & 2700 & D & Iseut \\
\hline ami & $\mathrm{S}$ & Escoufle & 1159 & demi & $\mathrm{S}$ & 1160 & $\mathrm{~N}$ & Narrador \\
\hline ami & $\mathrm{S}$ & Escoufle & 1997 & demi & $\mathrm{S}$ & 1998 & $\mathrm{~N}$ & Narrador \\
\hline ami & $S$ & Escoufle & 3901 & demi & A & 3902 & D & Aélis \\
\hline ami & $S$ & Escoufle & 4451 & demi & $\mathrm{S}$ & 4452 & $\mathrm{~N}$ & Narrador \\
\hline ami & $\mathrm{S}$ & Escoufle & 5423 & demi & $\mathrm{S}$ & 5424 & D & Aélis \\
\hline ami & $\mathrm{S}$ & Escoufle & 7863 & demi & $\mathrm{S}$ & 7864 & $\mathrm{~N}$ & Narrador \\
\hline ami & $\mathrm{S}$ & Tristan & 3 & devanci & $\mathrm{O}$ & 4 & $\mathrm{~N}$ & Narrador \\
\hline ami & $\mathrm{S}$ & Escoufle & 2549 & enmi & $\mathrm{R}$ & 2550 & D & Aélis \\
\hline ami & $\mathrm{S}$ & Escoufle & 7285 & enmi & D & 7286 & $\mathrm{~N}$ & Narrador \\
\hline ami & $\mathrm{S}$ & Tristan & 54 & gari & V & 53 & D & Iseut \\
\hline ami & $S$ & Tristan & 160 & merci & $\mathrm{S}$ & 159 & D & Tristan \\
\hline ami & $S$ & Tristan & 1057 & merci & $\mathrm{S}$ & 1058 & D & Iseut \\
\hline ami & $\mathrm{S}$ & Tristan & 2288 & merci & $\mathrm{S}$ & 2287 & D & Iseut \\
\hline ami & $\mathrm{S}$ & Escoufle & 5698 & mi & $\mathrm{S}$ & 5697 & $\mathrm{~N}$ & Narrador \\
\hline ami & $\mathrm{S}$ & Escoufle & 7324 & mi & $\mathrm{S}$ & 7323 & $\mathrm{~N}$ & Narrador \\
\hline amis & $\mathrm{S}$ & Charrete & 1020 & mis & $\mathrm{O}$ & 1019 & D & Demoiselle \\
\hline amis & $\mathrm{S}$ & Escoufle & 1984 & mis & $\mathrm{O}$ & 1983 & $\mathrm{~N}$ & Narrador \\
\hline amis & $\mathrm{S}$ & Escoufle & 2363 & mis & $\mathrm{O}$ & 2364 & D & C. Richard \\
\hline amis & $\mathrm{S}$ & Escoufle & 3168 & mis & $\mathrm{O}$ & 3167 & D & Guillaume \\
\hline amis & $S$ & Escoufle & 3283 & mis & $\mathrm{O}$ & 3284 & D & Aélis \\
\hline amis & S & Escoufle & 3635 & mis & $\mathrm{O}$ & 3636 & D & Aélis \\
\hline amis & $\mathrm{S}$ & Escoufle & 3788 & mis & $\mathrm{O}$ & 3787 & $\mathrm{~N}$ & Narrador \\
\hline amis & $\mathrm{S}$ & Escoufle & 3880 & mis & $\mathrm{O}$ & 3879 & $\mathrm{~N}$ & Narrador \\
\hline amis & $\mathrm{S}$ & Escoufle & 4461 & mis & $\mathrm{O}$ & 4462 & $\mathrm{~N}$ & Narrador \\
\hline amis & $\mathrm{S}$ & Escoufle & 4699 & mis & $\mathrm{O}$ & 4700 & I & Guillaume \\
\hline amis & $\mathrm{S}$ & Escoufle & 4747 & mis & $\mathrm{O}$ & 4748 & $\mathrm{~N}$ & Narrador \\
\hline amis & $\mathrm{S}$ & Escoufle & 5829 & mis & $\mathrm{O}$ & 5830 & $\mathrm{~N}$ & Narrador \\
\hline amis & $\mathrm{S}$ & Escoufle & 7317 & mis & $\mathrm{O}$ & 7318 & D & Aélis \\
\hline amis & $\mathrm{S}$ & Escoufle & 7321 & mis & $\mathrm{O}$ & 7322 & $\mathrm{~N}$ & Narrador \\
\hline amis & $\mathrm{S}$ & Escoufle & 7371 & mis & $\mathrm{O}$ & 7372 & $\mathrm{~N}$ & Narrador \\
\hline amis & $\mathrm{S}$ & Escoufle & 7561 & mis & $\mathrm{O}$ & 7562 & D & Raison \\
\hline amis & $\mathrm{S}$ & Escoufle & 7695 & mis & $\mathrm{O}$ & 7696 & D & Aélis \\
\hline amis & $\mathrm{S}$ & Rose & 3975 & mis & $\mathrm{O}$ & 3976 & $\mathrm{~L}$ & Amant \\
\hline amis & $\mathrm{S}$ & Tristan & 2811 & païs & $\mathrm{S}$ & 2812 & D & Iseut \\
\hline amis & $\mathrm{S}$ & Tristan & 2829 & Perinis & $\mathrm{S}$ & 2830 & D & Iseut \\
\hline amis & $\mathrm{S}$ & Tristan & 907 & pris & $\mathrm{O}$ & 908 & D & Iseut \\
\hline amis & $\mathrm{S}$ & Tristan & 3163 & pris & $\mathrm{O}$ & 3164 & D & Iseut \\
\hline amis & $\mathrm{S}$ & Escoufle & 3520 & promis & $\mathrm{O}$ & 3519 & D & Aélis \\
\hline
\end{tabular}

Tabla 51. Rimas del sustantivo ami.

El estudio de las proposiciones subordinadas nos muestra una gran diferencia cuantitativa en las diferentes obras, en primer lugar porque tanto en 
Charrete como en Rose la denominación se utiliza en pocas ocasiones. En este último roman tan sólo encontramos subordinadas relativas, sin antecedente, aunque se designa a una persona concreta: "Mout sui, fet ele, a bone escole, qui de mon ami me parole" (Rose, 2665 - 2666), o con antecedente: "Dames, cest essample aprenez, qui vers vos amis mesprenez" (Rose, 1505 - 1506). Por lo que hace a Tristan el escaso número de subordinadas se debe con toda probabilidad a la gran abundancia de apóstrofes.

Jean Renart, en cuya obra ya hemos observado una tendencia a la complejidad sintáctica, se inclina en este caso por las subordinadas completivas y las circunstanciales. La aparición de las primeras parece deberse por un lado a las observaciones sobre la elaboración del discurso amoroso y particularmente a la adopción de determinadas denominaciones. Por otro a cuestiones que derivan de la construcción de la historia, ya que las separaciones de los amantes provocan repetidas reflexiones de Aelis y del narrador sobre las causas de aquellas, las promesas de amor del enamorado y sus propios sentimientos, mientras que el tiempo transcurrido desde su separación hace surgir dudas sobre la identidad de Guillermo: "cele qui dut estre sa feme ne set mot qu'il soit ses amis” (Escoufle, 7370 - 7371),

\footnotetext{
- «Si est, desloiaus anemie, fait Amors, «c'est il voirement.» Fait ses sens: «Amors, et comment savés vous que c'est ses amis?» Ce que cele en doute ra mis en son cuer .j. grant descorde.
}

Escoufle, 7558 - 7563

Una clasificación semántica de las proposiciones subordinadas circunstanciales del corpus nos muestra cinco tipos: 
- Temporales que expresan la simultaneidad de la acción con la expresada por la principal: "com ele aprisme son ami, oiez com el l'a devanci” (Tristan, 3 - 4); "de coi me sovint, quant mes amis devant moi vint" (Charrete, 4197 - 4198).

- Hipotéticas introducidas por se que expresan un hecho cuya realidad no se cuestiona: “se vos m'en erïez ami, n'ert pas mervelle” (Tristan, 54 - 55) o bien presentan un hecho contrario a la realidad: "se je ne fuisse ses amis, cil dous regars ne peüst estre" (Escoufle, 3168 - 3169).

- Causales: "Nel doi pas tenir por amant, k’il n'est mie amis qui s'amie guerpist ensi." (Escoufle, 4690 - 4692);

$$
\begin{aligned}
& \text { c'est la riens par k'il seüst miex } \\
& \text { li quex des nons li fust plus dols, } \\
& \text { ćuns faus souspirs et .j. senglous } \\
& \text { la prent enmi le non d'ami }
\end{aligned}
$$

Escoufle, 1994 - 1997

- Comparativas de superioridad: "Malveise est qui mialz vialt morir, que mal por son ami sofrir." (Charrete, 4239 - 4240); "mais plus ara en son demaine terres et fiex toute la pire, (...) que n'ont ore tuit si ami." (Escoufle, 8690 - 8693); y de igualdad: "ausi com li cors a esté amis au sien” (Escoufle, 2461 - 2462).

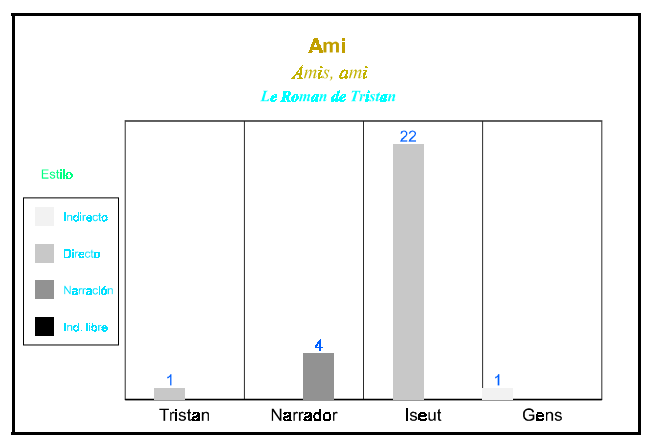

Fig. 53. Comportamiento estilístico del sustantivo ami en Tristan. 


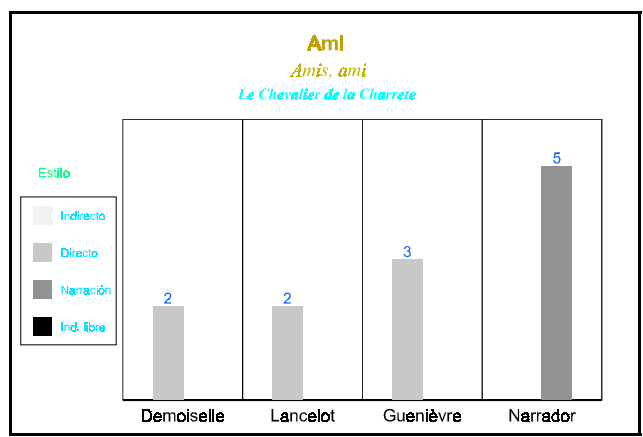

Fig. 54. Comportamiento estilístico del sustantivo ami en Charrete.

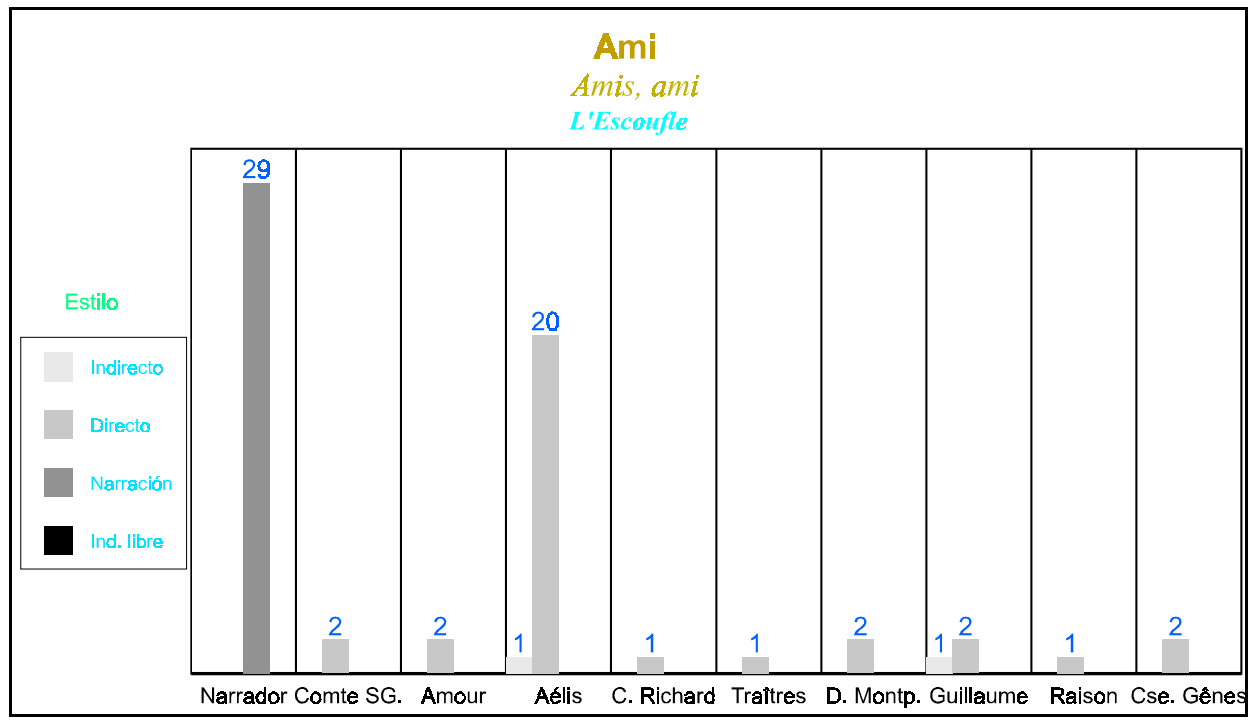

Fig. 55. Comportamiento estilístico del sustantivo ami en Escoufle.

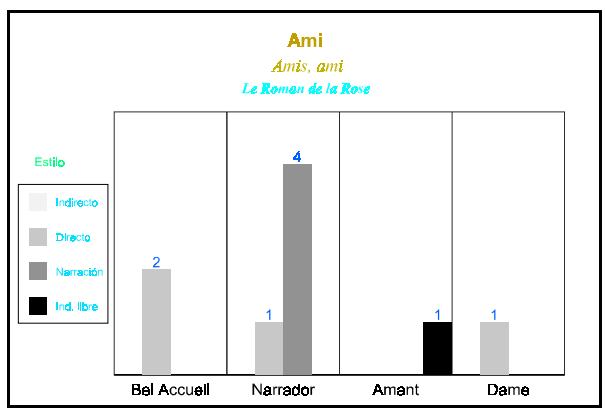

Fig. 56. Comportamiento estilístico del sustantivo ami en Rose.

Béroul, como suele ser habitual en su obra, reserva el uso de las denominaciones más expresivas desde el punto de vista amoroso para el discurso de los enamorados, y en este caso podemos observar cómo Iseo manifiesta con intensidad sus sentimientos. Por el contrario, en E sooufle se 
prefiere la narración y la especulación en el discurso de los personajes sobre las relaciones amorosas a una expresión más espontánea. El mismo espíritu especulativo se advierte en Charrete, mientras en Rose los vocativos y atributos que complementan las descripciones de las parejas del jardín de Deduit dejarán paso a la supuesta voz de una dama que recuerda a su amante, hecho muy excepcional pues en esta obra se silencia sistemáticamente el discurso de las mujeres.

\subsection{Amant.}

El sustantivo amant, perteneciente sin duda alguna al registro amoroso y específicamente al registro erótico-sexual en muchas de las novelas caballerescas, hinca sus raíces en las tradiciones latina y trovadoresca. Ya en éstas parece existir una cierta preferencia por utilizarlo en masculino como sinónimo de amigo y en plural para hablar en general de los varones que muestran signos de enamoramiento, sea este real o ficticio, así como para referirse a la pareja de enamorados. Dejaremos por ahora el estudio de este segundo uso del plural para ocuparnos de él en otro apartado. Por lo que se refiere a nuestro corpus el término encuentra una mayor aceptación entre los autores del siglo XIII, si bien tanto unos como otros se sirven de él como alternativa a ami en gran medida por motivos formales puesto que lo encontramos en el contexto próximo de aquel: "nel doi pas tenir por amant, k'il n'est mie amis qui s'amie" (Escoufle, 4690 - 4691) y a menudo en la rima, tal como ocurre en la única ocurrencia de Tristan: "ne me tendra ne face errant le mandement de mon amant" (Tristan, 2799 - 2800) o en el excepcional emparejamiento amies - amans:

mais li felon jalous i visent

as amies et as amans,

mais amors est si porveans

Escoufle, 9018 - 9020 
En Rose parece, sin embargo, prevalecer una especialización estilística ya que la denominación ami queda reservada a los apóstrofes, para la descripción de los integrantes del corro al que es invitado el joven cuando entra en el jardín, o bien, en tercer lugar, asociada al sustantivo dame y precedida por un artículo posesivo; mientras que amant será el término utilizado con un valor particular por Venus y Franchise para interceder por el joven enamorado de la rosa, siempre precedido de un artículo demostrativo y dentro de un sintagma preposicional: "Dangier, se Dex m'ament, vos avez tort de cest amant" (Rose, 3241 - 3242), "trop vos estes de cel amant, Bel Acueil, grant piece esloigniez" (Rose, 3312 - 3313),

$$
\begin{aligned}
& \text { Por quoi vos fetes vos, biau sire, } \\
& \text { vers cest amant si dangereus } \\
& \text { d'avoir un bessier doucereus? }
\end{aligned}
$$$$
\text { Rose, } 3424 \text { - } 3426
$$

y con un sentido general por el narrador, por Amor en su adoctrinamiento, así como por otros personajes como Eco, Bel Accueil o el propio amante. En muchas de las ocurrencias de este segundo uso podríamos interpretar que los amantes son tanto mujeres como hombres. Máxime cuando los ejemplos y advertencias —en los que se retoma el término ami - nos hablan de damas que maltratan a sus enamorados o de las que gozan con la sola palabra referida al amante; sin embargo, creemos que Lorris sigue la tradición trovadoresca en la que se emparejaban los amigos / amantes y las damas.

Dos son los tipos de amadores, de un lado los fingidos, de otro los verídicos y fieles. Amor execra a los primeros, quienes como ya decían los trovadores al evocar a los faus amanz o faus drus ${ }^{399}$ son orgullosos: "orgueilleus fet tot le contraire de ce que fins amant doit feire" (Rose, 2119 2120), elocuentes, aduladores, inconstantes y poco amigos del sufrimiento. En

${ }^{399}$ Cf. Dragonetti, L a technique poétique..., op. at., p. 23 y 71, entre otras. 
su descripción es de destacar la utilización del epíteto faus, del adjetivo en función de atributo losengeor y del verbo voloir, pues una de las principales características del que ama sinceramente es su incapacidad para actuar según él quisiera:

\author{
mes faus amanz content lor verve \\ si come il veulent, sanz peor; \\ icil sont fort losengeor
}

Rose, 2394 - 2396

Por el contrario aquellos amantes cuyo comportamiento corresponde a la confianza puesta en ellos son presentados sin que medie ningún adjetivo calificativo — por sus estados de ánimo y por sus sufrimientos los conoceremos—, ${ }^{400}$ o bien caracterizados por los epítetos loial (Rose, 1463 y 2318) y fin. Sin embargo, pese a lo que podríamos esperar por la reutilización de las convenciones corteses, ni a Lanzarote ni al enamorado de la rosa se les atribuye este adjetivo. Al segundo por estar en periodo de aprendizaje y no haber alcanzado aún la sutileza requerida merced a la aniquilación del instinto masculino y a la contención de los deseos sexuales una vez centrados en una sola hembra, a la vez y paradójicamente por el desposeimiento de sí mismo y por la plena asunción de las represiones sexuales:

et por ce que fins $\mathbf{a m a n z}$ soies, veil je et comant que tu aies en un seul leu tot ton cuer mis Rose, 2227 - 2229

La coherencia del relato de iniciación justifica el uso hecho por Lorris, toda vez que transcurrido casi un siglo desde que los trovadores se

${ }^{400}$ Cf. Rose, 2169 - 2171. 
otorgasen tal calificativo, al haberse modificado las relaciones e intereses de los diferentes grupos sociales —entendidos como estratos socio-económicos y como grupos de edad- y trastocado en su fundamento el ideal de mujer, las reelaboraciones literarias del amante han popularizado la ascesis y la han vaciado casi por completo de contenido al estar encaminada al matrimonio o cuando menos a la satisfacción de la libido. Chrétien no transita todavía por ese camino trillado porque es uno de los primeros en abrirlo, y de hecho su proximidad temporal y cultural con los trovadores le hacen distinguir entre el fin amant de la lírica y Lanzarote, el caballero enamorado, quien tan sólo puede imitar a aquel con sus sumisas palabras:

$$
\begin{aligned}
& \text { Ez vos Lancelot trespansé, } \\
& \text { se li respont molt belemant } \\
& \text { a meniere de fin amant: } \\
& \text { «Dame, certes, ce poise moi, } \\
& \text { ne je n’os demander por coi.» } \\
& \text { Charrete, } 3960 \text { - } 3964
\end{aligned}
$$

El narrador de Escoufle en estilo directo también identifica al fin amant con un cierta forma de hablar pero se trata ya de urbanidad, de un comportamiento social aprendido que debe permitir al que ama alcanzar la fama y la benevolencia necesarias entre los que rodean a la amada, y en absoluto de un sometimiento incondicional a la jurisdicción de la dama:

et sachiés que nus fins amans

ne dira ja riens qui desplace

a nului, n'en voie n'en place

Escoufle, $3746-3748$

En este roman encontramos también una expresión de nuevo cuño gracias a la combinación del sustantivo amant con douç, un adjetivo habitual 
en los sintagmas constituidos en torno a ami cuando funciona como vocativo. Esta ruptura de los moldes expresivos tradicionales, a la que se une la aparición del artículo posesivo sólo presente en nuestro corpus en el discurso directo de Iseo, quiere subrayar la sensualidad, el deleite del contacto físico recobrado por Aelis y Guillermo tras la primera separación de una noche, a la vez que se marcan las distancias con el ordenamiento cortesano:

$$
\begin{aligned}
& \text { Il n’i ot dame ne pucele } \\
& \text { fors une seule qui les garde } \\
& \text { par defors et qui se prent garde } \\
& \text { ke l'empereris ne demant } \\
& \text { cele qui tient sen douç amant } \\
& \text { entre ses bras et si le baise. }
\end{aligned}
$$$$
\text { Escoufle, } 3378 \text { - } 3383
$$

En función de sujeto los sintagmas que recogen la denominación amant en Rose — tan sólo hay otra ocurrencia en Escoufle, ya citadaencuadran algunos de los grandes tópicos que marcan la vida del seguidor de Eros, reformulados a menudo mediante verbos que requieren la aparición del mismo sustantivo en función de complemento de objeto indirecto:

a. El martirio, físico y psicológico, ${ }^{401}$ apenas dulcificado por el recuerdo de la amada y por la esperanza de lograr el encuentro sexual: "en quel guise ne coment pueent endurer cil amant les maus que vos m'avez contez?" (Rose, 2569 - 2571), "lors te vendront les aventures qui as amanz sont griés et dures” (Rose, 2255 - 2256),

Icil venirs, icil alers,
icil veilliers, icil pensers
fet aus amanz soz les drapiaus
durement amesgrir les piaus
Rose, $2529-2532$




\author{
Quant li amant plaint et soupire \\ et est en duel et en martire, \\ Douz Pensers vient a chief de piece, \\ qui l'ire et la dolor despiece \\ et a l'amant en son venir \\ fet de la joie souvenir \\ que Esperance li promet.
}

Rose, 2633 - 2639

b. La inestabilidad emocional expresada mediante parejas de antónimos, ya sean sustantivos como joie y toment: "il est ensi que li amant ont par eures joie et torment” (Rose, 2169 - 2170), ya adjetivos como douz y amer. "amant sentent les maus d'amer, une eure douz, autre eure amer" (Rose, 2171 - 2172).

c. El dispendio en agasajo de la amada y como pago a sus menudos favores eróticos: "il avient bien que li amant doignent dou lor plus largement que cil vilain entule et sot" (Rose, 2201 - 2203). Este último merece algún comentario, pues la virtud de dar, que en la tradición medieval quedaba en principio reservada a las relaciones entre señores y vasallos como medio para redistribuir la riqueza entre los grandes y para reforzar los lazos que los unían entre sí, muestra los cambios profundos que en el siglo XIII se producen en el trato entre hombres y mujeres inmersos en la economía dineraria y que ya hemos señalado en el caso de la princesa - burguesa Aelis. Mientras que Tristán e Iseo intercambian regalos cuyo valor es puramente sentimental y aún en E scoufle son las mujeres las que como muestra de su afecto y de su entrega regalan objetos simbólicos a sus amantes, Amor propone ya un pago por una simple sonrisa — donde quizás podemos leer lo más por lo menos—, aunque lo llame don y lo disimule tras la entrega del corazón del amante. De aquí a retomar las críticas ya antiguas sobre la venalidad femenina, que hemos visto perdurar hasta nuestros días, y a hacer un vicio femenino complementario de una virtud masculina sólo hay un paso, y Meun lo dará con suma naturalidad. 
Sobre estos esquemas conceptuales se erige la necesidad de observar una serie de reglas, la obediencia ciega a un código de conducta: "coment tu acompliras nuit et jor les comandemenz que je coment as fins amanz” (Rose, 2038 - 2040), cuyos emblemas son el verbo devoir (Rose, 2120) y el imperativo. Esta normativa debe conducir al amante hasta el paraíso, hasta la penetración en el templo constituído por el sexo de la mujer según la metáfora desarrollada por Meun y que Lorris expresa de forma más directa aunque menos fisiológica con la expresión avoir ses aviaus: ${ }^{402}$

Or t'ai dit coment n'en quel guise

amanz doit fere mon servise.

Or le fai donques, se tu viaus

de la belle avoir tes aviaus.

Rose, 2562 - 2566

Estos mandamientos, al parecer de naturaleza erógena no sólo para el hombre sino para la mujer contempladora de su vigor, pretenden alcanzar los mismos logros que Ovidio con sus consejos, pero aquí se insiste en el máximo esfuerzo mientras que el clásico había loado un desgaste mínimo de energías.

Las proposiciones subordinadas en las que se halla el sustantivo amant, muy abundantes fundamentalmente las relativas y completivas, hacen ostensible la voluntad didáctica de Rose, una de sus peculiaridades en comparación con los otros romans. En primer lugar las proposiciones completivas, entre las que catalogamos las interrogativas indirectas, dependen de verbos como savoir y aprendre: "si poroit savoir et aprendre quel duel ont li loial amant” (Rose, 1462 - 1463); “car bien saches qu'amors ne lesse sor fin amant color ne gresse" (Rose, 2535 - 2536), dire: "or t'ai dit coment n'en quel

402 Que significa según recoge F. Lecoy en su glosario a la edición de la obra: «jouir de ce que l’on désire», Rose, vol. III, p. 208. 
guise amanz doit fere mon servise" (Rose, 2563 - 2564) o desfendre. Todo lo que una mujer debía saber sobre sobre la naturaleza masculina, el instinto sexual y la reacción más sensata por más casta, se recoge en la prohibición de Castidad. Esta se basa en la experiencia más que en los cánones corteses que al parecer imponían un estricto cumplimiento de la lenta ascesis amorosa, incluso cuando la mujer, con el beso, había aceptado al suspirante y le había dado muestras de su afecto; y es que en el siglo XIII el deseo y el placer deben quedar supeditados a la preservación de la virginidad:

$$
\begin{aligned}
& \text { Ele me seut torjorz desfendre } \\
& \text { que du bessier congié ne doigne } \\
& \text { a nul amant qui m'en semoigne, } \\
& \text { car qui au bessier puet ateindre, } \\
& \text { a poine puet a tant remaindre. }
\end{aligned}
$$

Rose, 3382 - 3386

También son presentadas mediante construcciones impersonales que confieren a la realidad expresada un valor universal y atemporal: "Et totes voies covient vivre les amanz, qu'il lor est mestiers. Chascuns fuit la mort volentiers." (Rose, 2594 - 2596). 403

En cuanto a las relativas, nos muestran otros modos de aprendizaje del amor y de sus sufrimientos y otros maestros. Entre ellos los amantes experimentados: "Qui ne le set, si le demant a ceus qui sont loial amant." (Rose, 2317 - 2318), o de nuevo el gran iniciador, Amor: "si con je t'ai ci sarmoné, lors te vendront les aventures qui as amanz sont griés et dures" (Rose, 2254 - 1156). Así mismo, con este tipo de proposiciones se avisa a los amantes de la existencia y del grado de poder que poseen ciertas fuerzas psíquicas: "Beneoite soit Esperance, qui les amanz ensint avance" (Rose, 2615 - 2616), físicas o sociales para ayudar o tratar de impedir que el

403 Véanse también los versos 2169 - 2170 y 2201 - 2202 
enamorado haga realidad sus deseos. Entre las segundas, Venus, a la que rara vez mujer alguna ha logrado resistirse tras ser encendida con su llama, representa el apetito concupiscible de la hembra y consigue para el hombre lo que las súplicas, el servicio o la sumisión quizás nunca hubieran logrado: “mes Venus, qui torjorz guerroie Chasteé, me vint au secors. Ce est la mere au deu d'Amors, qui a secoru maint amant' (Rose, 3402 - 3405).

Ésta se enfrenta constantemente a las coacciones sociales, ya sean las construcciones morales figuradas por Castidad o bien la simple, aunque siempre nefasta maledicencia de los envidiosos y amargados que aquí encarna Male Bouche. Observamos cierto paralelismo al tiempo formal y semántico entre estos dos ejemplos por el uso del adjetivo indefinido maint que tan sólo se halla en estas ocurrencias:

Male Bouche, qui la covine

de mainz amanz pense et devine

et tot le mal qu'il set retret

$$
\text { Rose, } 3493-3495
$$

\begin{tabular}{lllllllll}
\hline FORMA & CA & BD & NV & RIMA & CA2 & NV2 & D & PERS \\
\hline amans & S & Escoufle & 3746 & acesmans & A & 3745 & D & Narrador \\
amans & S & Escoufle & 9019 & porveans & A & 9020 & N & Narrador \\
amant & S & Rose & 3242 & ament & V & 3241 & D & Franchise \\
amant & S & Charrete & 3962 & belemant & D & 3961 & N & Narrador \\
amant & S & Rose & 2570 & coment & D & 2569 & D & Amant \\
amant & S & Rose & 3312 & cortoisement & D & 3311 & D & Franchise \\
amant & S & Escoufle & 3382 & demant & V & 3381 & N & Narrador \\
amant & S & Rose & 2318 & demant & V & 2317 & D & Amour \\
amant & S & Escoufle & 4690 & dormant & T & 4689 & D & Aélis \\
amant & S & Tristan & 2800 & errant & D & 2799 & D & Iseut \\
amant & S & Rose & 3405 & flanbant & A & 3406 & N & Narrador \\
amant & S & Rose & 2201 & largement & D & 2202 & D & Amour \\
amant & S & Rose & 2169 & torment & S & 2170 & D & Amour \\
amant & S & Rose & 1463 & vilmant & D & 1464 & L & Écho \\
amanz & S & Rose & 2040 & comandemenz & S & 2039 & D & Amour \\
\hline
\end{tabular}

Tabla 52. Rimas del sustantivo amant referido al varón. 


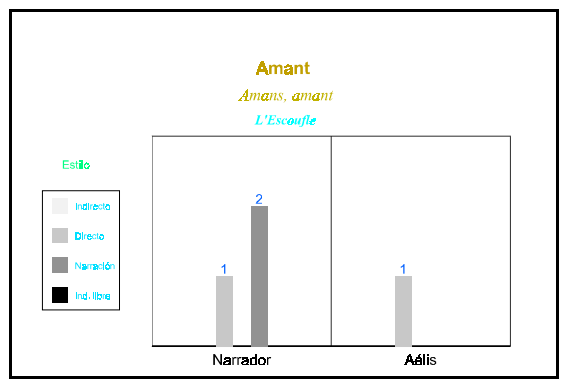

Fig. 57. Comportamiento estilístico del sustantivo amant referido al varón en Escoufle.

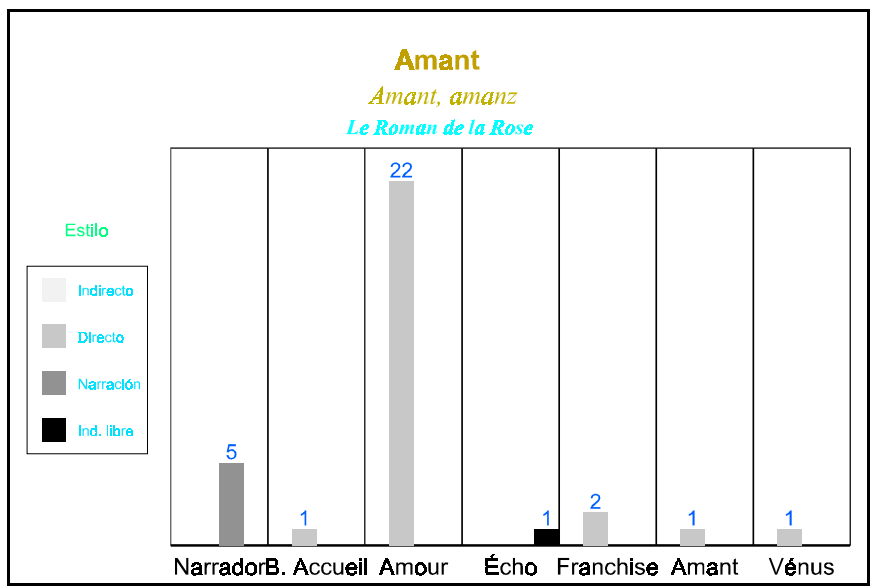

Fig. 58. Comportamiento estilístico del sustantivo amant referido al varón en Rose.

Las más de las ocurrencias del sustantivo amant en nuestro corpus adoptan un sentido general, ya sea como denominación de un colectivo caracterizado por los mismos estados de ánimo, ya como compendio de modos de actuar, cualidades y sentimientos, hecho que lo lleva a funcionar prácticamente como un adjetivo en el discurso directo de Aelis. Tan sólo en contadas ocasiones el narrador de E scoufle, los personajes alegóricos ayudantes en Rose o Iseo nombran de este modo al individuo concreto identificándolo inequívocamente mediante artículos posesivos o demostrativos.

\subsection{Compagnon.}

Este término aparece en tres de los romans relacionado con la temática amorosa, y se puede establecer la existencia de tres sentidos 
diferentes. En primer lugar denomina a los amigos que comparten aventuras y luchas, juegos y alegrías, a Lanzarote cuando de regreso a la corte es abrazado por Galván: "Or a grant joie, or est a eise, quant son conpaignon a trové" (Charrete, 6800 - 6801), a los acompañantes de Deduit: "les plus beles genz, ce sachiez, que vos ja mes nul leu truissiez, si sont li compaignon Deduit" (Rose, 613 - 615), a Guillermo, cuando siendo un niño llega al palacio imperial, sin que podamos arriesgarnos a ver una muy precoz atracción sexual, aunque sí debamos señalar la insistencia con la que Renart establece desde el primer momento la armonía entre Aelis y Guillermo, una armonía que quedará rota con la separación y la consiguiente ruptura de los lazos que los unían hasta llegar al loaus amoenus: 404

$$
\begin{aligned}
& \text { On enmaine l'enfant mangier } \\
& \text { en la chambre a la damoisele. } \\
& \text { Ml't l'en croist li cuers et oisele } \\
& \text { de çou qu'ele a tel compaignon. }
\end{aligned}
$$

Escoufle, 1962 - 1965

En segundo lugar adopta el sentido de confidente, de amigo curtido en amores que escucha al enamorado, lo anima y aconseja: "un compaig sege et celant” (Rose, 2673). Esta figura, que Amor recomienda al amante: “Amors me dit que je queïse un compaignon qui je deïse mon conseil tot outreement, ce m'osteroit de grant torment" (Rose, 3087 - 3090), personificará la experiencia masculina, una visión crítica y más bien cínica de las mujeres, de la moral sexual y del código cortés.

Por fin, con un contenido explícitamente sexual denomina al que ha compartido el lecho de una mujer y ha gozado de ella. Este sentido lo

Hé, Diex! ele avra ja souffraite
de serjant et de compaignon

Escoufle, 4652 - 4653 
encontramos únicamente en el discurso de Meleagant al acusar a Keu y a la reina de haber yacido juntos. Varios feómenos expresivos lo refuerzan: la alusión al momento más apropiado para la unión de los supuestos amantes mediante el adverbio enuit, la designación del lugar por excelencia del adulterio — la cama donde duerme la dama-, y el contexto en que aparece el sustantivo delit — que en sí mismo podía adoptar sentidos eróticos más atenuados-, en la rima con lit y con el adjetivo antepuesto tot que indica el grado del placer. El hecho de funcionar sintácticamente como complemento atributo y de estar construido sin artículo le confieren una función adjetiva que no poseían los usos señalados anteriormente:

\author{
Ensi m’ä̈st Dex et li sainz, \\ Kex li seneschaus fu conpainz \\ enuit la reïne, an son lit, \\ et de li ot tot son delit
}

Charrete, 4967 - 4970

De los emparejamientos al final de verso llamaremos la atención sobre la sistemática repetición en los textos del siglo XIII del sustantivo non. En ocasiones se utiliza de una forma excesivamente forzada, y por ello parece corroborar la hipótesis de que en la mayor parte de las ocurrencias, si exceptuamos la del discurso de Meleagant, la denominación compagnon funciona como una variante estilística de ami que evita las connotaciones eróticas que en este último observábamos.

\begin{tabular}{lllllllll}
\hline FORMA & CA & BD & NV & RIMA & CA2 & NV2 & D & PERS \\
\hline conpainz & S & Charrete & 4968 & sainz & S & 4967 & D & Méléagant \\
compaignon & S & Rose & 3094 & non & S & 3093 & N & Narrador \\
compaignon & S & Escoufle & 1965 & non & S & 1966 & N & Narrador \\
compaignon & S & Escoufle & 4653 & non & S & 4654 & N & Narrador \\
\hline
\end{tabular}

Tabla 53. Rimas del sustantivo compagnon. 


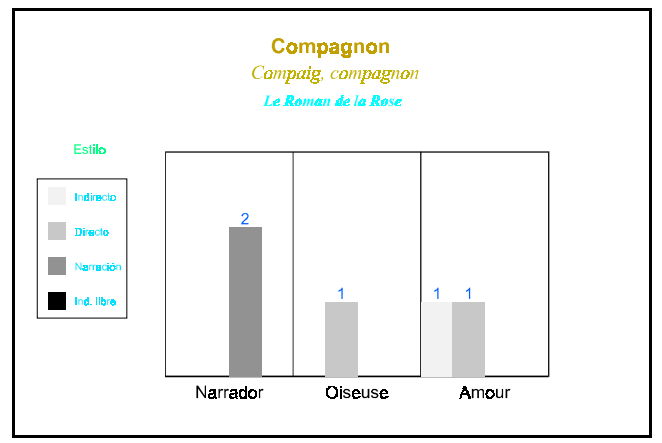

Fig. 59. Comportamiento estilístico del sustantivo compagnon en Rose.

\subsubsection{LOS AMANTES.}

Hemos podido comprobar que las construcciones copulativas, de manera especial cuando forman un sintagma complejo mediante la conjunción et, son el medio más habitual para presentarnos a los amantes como pareja. De hecho tan sólo el sustantivo amant asume este papel y ello en Tristan y en E scoufle ${ }^{405}$ donde se presta una mayor atención a la vida de la pareja, toda vez que en los otros dos romans los enamorados se encuentran rara vez juntos y muy excepcionalmente solos.

No obstante, existen diferencias notables en el tratamiento que de la denominación se hace en ambos textos. Béroul la utiliza en la narración de algunos de los acontecimientos que van a cambiar radicalmente la vida de los amantes. La lectura adivinatoria de su unión en el lecho del rey cuya consecuencia final será la vida en el Morrois: "A la lune bien vit josté erent

405 En este roman observamos una ocurrencia en plural del término rien para referirse también a la pareja reconstituyendo el valor ponderativo y excepcional que hemos señalado para las denominaciones individuales, al tiempo que se acentúa la perfecta conformidad física de los amantes:

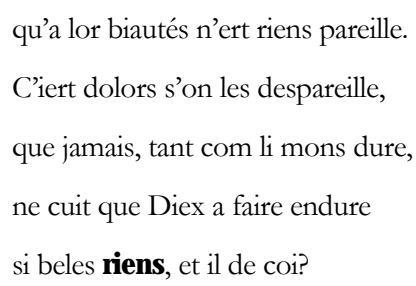


ensenble li dui amant." (Tristan, 736 - 738); el sueño espiado de los amantes en el bosque tras la desaparición de los efectos del filtro: "Eisi s'endorment li amant, ne pensent mal ne tant ne quant” (Tristan, 1829 - 1830); el viaje hasta la ermita de Ogrin que les permitirá volver a la corte: “tant ont erré qu'a l'ermitage vindrent ensenble li amant" (Tristan, 2291 - 2292). Las tres ocurrencias funcionan como sujeto y mientras que en dos de ellas se insiste en la unión o en la actividad conjunta mediante el adverbio ensemble, en la segunda, la desaparición de éste refuerza la idea de que algo los mantiene separados, aunque en el texto se deja abierta a la especulación la causa de un hecho poco corriente: el calor, el cansancio o el final del efecto del brebaje para los receptores del relato, la inexistencia del adulterio para el crédulo rey Marco.

Renart tan sólo recoge en la narración una alusión a los dos amantes en un sintagma preposicional, sin que exista como en Tristan una justificación temática y sí más bien relacionada con la composición rítmica y sonora: "se nus voloit la voie emprendre et la queste des .ii. amans" (Escoufle, 4188 4189). El resto de las ocurrencias las hallamos en el discurso directo de Guillermo y del propio narrador, siempre con un sentido general que apela a la experiencia del que escucha o bien que pretende instruir sacando breves consecuencias teóricas de la narración de las acciones de los personajes; junto a esto no podemos pasar por alto que mediante este sustantivo se identifica el comportamiento de las parejas estables fuera del matrimonio.

En el discurso directo del narrador apreciamos, por un lado, el uso sentencioso como un medio formal para pasar a otro tema, es decir, como un recurso discursivo para crear una transición; por otro, una cierta tendencia al didactismo, por el que los intelectuales del siglo XIII se muestran muy atraídos $^{406}$ y tras el que podemos ver el gran movimiento de predicación y enseñanza alentado por el papado desde finales del siglo XII.

\footnotetext{
406 Por lo que se refiere a la obra de Lorris y de su continuador Meun, Dufournet señala el deseo preponderante de enseñar aunque también pretendan agradar. Cf. Le dessein et la philosophie du Roman de la Rose, A da Litteraria, T. 23, n 3 - 4, p. 183.
} 
Guillermo, al utilizar el sintagma preposicional introducido por com, expresa, como ya veíamos para el sustantivo ami, la manera en la que habitualmente se comportan los amantes para hacerse agradables al otro y darse mutuo placer, conjugando ambos sentidos mediante el verbo deduire: "que que nous nous deduisions com amant en mainte maniere" (Escoufle, 7592 - 7593). Este verbo no es habitual en nuestro corpus aunque sí lo es el sustantivo deverbal deduit para nombrar el goce amoroso.

Precisamente las reflexiones del narrador surgirán en torno a esas sensaciones agradables producidas por el encuentro de los enamorados o por su evocación. Todas ellas están relacionadas con la necesidad de que se encuentren cerca el uno del otro y puedan a menudo reunirse para renovar los lazos que los unen: "k'il n'est joie se cele non de .ii. amans ki sont ensamble" (Escoufle, 5708 - 5709). Y sin duda alguna es el placer físico el que mejor puede atarlos. Esa es la consecuencia que saca de la minuciosa descripción del beso en la boca en el marco ideal del loaus amoenus, situación en la que una vez más Aelis asume el papel más activo y ayuda a la consolidación de la pareja:

\footnotetext{
Et sachiés bien, quant il avient

k'ou chief li met, qu'ele le baise:

Por ce que li baisiers li plaise, ele oevre si sa bele bouche que l'une langue a l'autre touche malgré les dens blans et serrés k’amors lor a si desserrés que li uns ne puet l'autre mordre. Bien doit si dous baisiers amordre .II. amans quant il sont ensamble.

Escoufle, 4334 - 4343
}

Muy al contrario la separación lleva al fausse amor, expresión de difícil interpretación pues por el contexto podemos entender que se trata del 
dolor producido por la pérdida de la amada pero también del desamor que surge del olvido. Nos decantamos más bien por el primer sentido pues, al abrir una puerta a la esperanza, reproduce un tema que quizás era ya tópico, la reconciliación, y en este caso el reencuentro, que hacen más dulces y agradables los placeres de la carne:

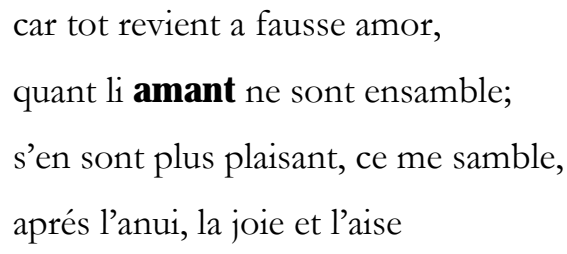

En estas tres intervenciones directas del narrador se observa la coincidencia casi absoluta de la construcción: el sustantivo amant es sujeto del verbo estre, ya sea de forma directa, ya por la intermediación de un relativo; y en dos de ellas se utiliza la subordinación temporal introducida por la conjunción quant. Todo ello parece avalar la impresión de que estos aforismos amorosos tenían más bien una función de transición o incluso de relleno y que en todo caso pretendían hacer, pese al tono adoptado, que la atención de los receptores volviese al tema principal tratado hasta ese momento.

\begin{tabular}{lllllllll}
\hline FORMA & CA & BD & NV & RIMA & CA2 & NV2 & D & PERS \\
\hline amans & S & Escoufle & 4189 & quans & A & 4190 & N & Narrador \\
amant & S & Tristan & 1829 & quant & D & 1830 & N & Narrador \\
amant & S & Tristan & 2291 & lisant & T & 2292 & N & Narrador \\
\hline
\end{tabular}

Tabla 54. Rimas del sustantivo amants referido a la pareja.

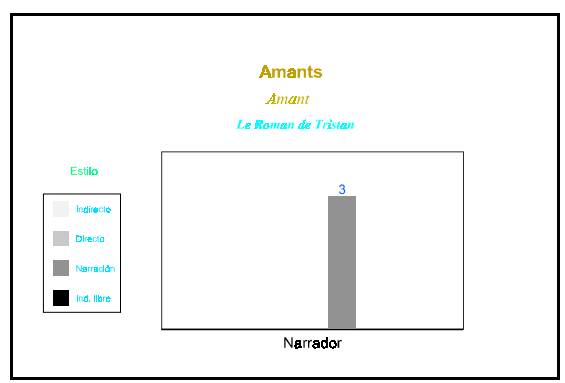

Fig. 60. Comportamiento estilístico del sustantivo amants referido a la pareja en Tristan. 


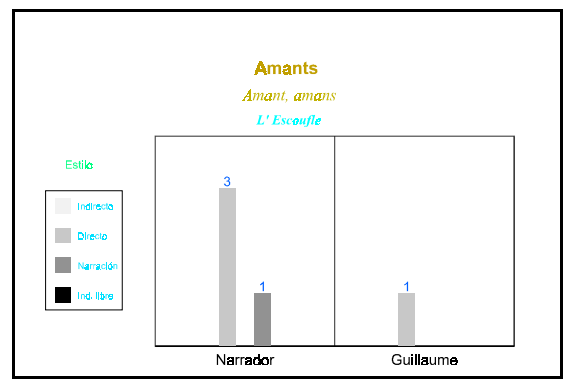

Fig. 61. Comportamiento estilístico del sustantivo amants referido a la pareja en Escoufle.

Por lo que se refiere a Tristan, tras comparar las apariciones en la rima y el comportamiento estilístico representado en el gráfico, podemos concluir que la elección de esta denominación se debe más a cuestiones formales que a una voluntad estilística y retórica. En la obra de Renart la utilización mayoritaria en el discurso directo del narrador, hecho muy excepcional a tenor de lo que hemos visto hasta ahora, hace inclinarse la balanza por la opción retórica, máxime si tenemos en cuenta que la denominación se adopta en función de un cambio tipológico en el discurso. 


\subsubsection{LA RELACIÓN ERÓTICA.}

Por lo que respecta a la organización de los términos de los que vamos a ocuparnos en esta parte del trabajo, siempre que lo consideremos necesario realizaremos dentro de cada uno de los cinco apartados principales una división lógica que los agrupe en función de las afinidades semánticas, tal y como hemos hecho en el capítulo consagrado a las denominaciones.

Por otro lado, aquí más que en la primera parte hemos llevado a cabo una drástica selección de los vocablos que en un principio podían ser analizados. Para ello hemos adoptado dos criterios combinados: la cantidad de ocurrencias encontradas en los textos relacionadas específicamente con uno de los temas abordados y su contribución al esclarecimiento de alguno de ellos, ya fuese por ser un término poco habitual en las imágenes tradicionales, por aportar nuevos matices o bien por ser de uso obligado.

En ocasiones los términos tratados podrían haber sido incluidos en más de un apartado. Optamos cuando esto ocurre por emplazarlos en función del sentido que consideramos más próximo a la expresión del erotismo en el corpus, si bien no pasamos por alto los otros sentidos que poseen, cuya relación es menos evidente pero no por ello menos necesaria para la construcción de la armazón erótico-amorosa del código caballeresco.

\subsubsection{El SENTIMIENTO AMOROSO Y LA PASIÓN.}

La exposición de los sentimientos de los amantes se nutre fundamentalmente de imágenes, temas y formas tradicionales, recurriendo a sustantivos y verbos que la literatura latina y la lírica trovadoresca habían consagrado, sin embargo, acude también a términos genéricos que sirven para dar realce o al contrario para encubrir la pasión o la actividad de conquista amorosa. 


\subsection{TÉRMINOS GENERALES.}

\subsection{1 «Afaire».}

En los textos del siglo XIII este sustantivo de naturaleza eminentemente eufemística enuncia la transición entre las situaciones precarias en que se encontraban los enamorados — tanto a Guillermo como al amante de Rose se les ha prohibido ver a sus amadas- y nuevas circunstancias que les ofrecen mejores perspectivas de satisfacer sus deseos, lo que se expresa mediante las locuciones comparativas aler bien / aler miex en presente de indicativo. Afaire adopta entonces la función de sujeto en proposiciones independientes e inaugura en el relato una nueva fase argumental, decisiva en el discurso narrativo de E scoufle pues preludia la fuga de los amantes: "Or va il mex en de amor li afaires qu'il n'avoit fait" (Escoufle, 3656 - 3657), menos espectacular en el discurso de Ami, ya que al amante de la rosa tan sólo se le permitirá contemplar a la amada, el primer paso en su nuevo camino de conquista: "Or vet, fet il, bien vostre afere. Encor vos sera debonaire Dangier." (Rose, 3191 - 3193).

Chrétien lo utiliza para hacer referencia a la pasión adúltera que podría dar origen a graves complicaciones sociales, en especial para la reina. Designa un arrebato amoroso que puede ser inventado por el obsesivo y quimérico Meleagant, lo que lleva a afaire a aparecer como complemento preposicional dependiente, en el discurso del verdadero amante y por lo tanto conocedor de los hechos, del verbo mescroire, que semánticamente implica no sólo la sospecha sino también la falsedad:

\footnotetext{
Ja ne vos an covient pleidier, fet Lanceloz, la ou je soie.

Ja Deu ne place qu'an mescroie ne vos ne lui de tel afeire.
}

Charrete, 4930 - 4933 
o bien es un ardor efectivo cuya ocultación exige un acto de la voluntad, que se traduce en una negación de la percepción social mediante el uso del imperfecto de subjuntivo del verbo aperçoivre:

\author{
li rois, li autre, qui la sont, \\ qui lor ialz espanduz i ont, \\ aparceüssent tost l'afeire, \\ s'ainsi, veant toz, volsist feire \\ tot si con li cuers le volsist.
}

Charrete, 6837 - 6841

Esta evocación de los sentimientos amorosos y de las manifestaciones espontáneas que de ellos se derivan, máxime cuando el acto carnal se ha consumado, está reclamando la complicidad del receptor de la obra que conoce el referente oculto a diferencia del conjunto de los personajes.

En E soufle el aspecto carnal, que estaba implícito en mayor o menor grado en las ocurrencias que hemos citado, se explicita y ocupa el conjunto del espacio significativo sin que los sentimientos ni el amor vehemente intervengan en absoluto, dando paso a los aspectos puramente dinásticos. El discurso del narrador utiliza el sustantivo para evocar en la noche de bodas del conde Ricardo el débito conyugal —aquí funciona como complemento de objeto directo de devoir-. Obligación que conlleva en su cumplimiento el ayuntamiento de los esposos, aunque en este caso se trata de una intervención exclusivamente masculina orientada a la procreación, en ella la mujer es un mero recipiente de la semilla por lo que llega sin transición hasta el alumbramiento de un heredero: "si com il son afaire dut, s'i joua tant qu'ele conçut .i. fil qui puis fu emperere" (Escoufle, 1751 - 1753).

La supresión de la ambigüedad inherente al término afaire se lleva a cabo en todos los casos que aquí nos ocupan mediante la anteposición de un 
determinante: ya sea tel, cuya capacidad determinativa parece derivar de la combinación de sus otras funciones como adjetivo y pronombre, lo que permite que haga referencia a elementos recogidos antes en el discurso a la vez que les suma un valor cualitativo; ya sea un artículo definido al que puede añadirse un complemento atributivo del nombre: "de amor li afaires" (Escoufle, 3656 - 3657); o bien un artículo posesivo que representa siempre a un poseedor masculino.

\begin{tabular}{lllllllll}
\hline FORMA & CA & BD & NV & RIMA & CA2 & NV2 & D & PERS \\
\hline afeire & S & Charrete & 4933 & feire & I & 4934 & D & Lancelot \\
afeire & S & Charrete & 6839 & feire & I & 6840 & N & Narrador \\
afere & S & Rose & 3191 & debonaire & S & 3192 & D & Ami \\
\hline
\end{tabular}

Tabla 55. Rimas del sustantivo «afaire».

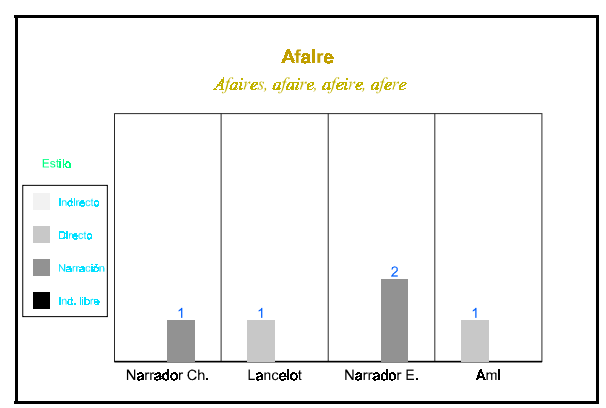

Fig. 62. Comportamiento estilístico del sustantivo «afaire» en el corpus.

Podemos considerar los imperativos formales como una de las causas fundamentales de la utilización del vocablo en nuestros textos, sin embargo, las rimas también ofrecen un apoyo a los matices que hemos observado. Así la asociación con el verbo feire refuerza la importancia del acto, de las manifestaciones del deseo y del coito, mientras que en Rose el feliz augurio de Ami se concentra en el adjetivo debonaire a menudo referido a la amable actitud de la enamorada que recibe con placer al amante. También queremos señalar en la obra de Renart la clara diferencia entre el referente carnal que caracteriza lo que se podría considerar el relato pre-cortés y el referente sentimental que da paso a los episodios más cercanos al modelo cortés aunque matizado por los cambios introducidos en el siglo XIII. 


\subsection{Aimery haïr.}

Las ocurrencias del verbo aimer en nuestro corpus se acomodan a una serie de esquemas a la vez formales y expresivos sujetos a muy ligeras modificaciones o excepciones. Estas peculiaridades del verbo que con mayor asiduidad sirve para hablar de los sentimientos amorosos, así como del contexto inmediato en que aparece, van a caracterizar cada una de las obras y nos permiten observar las notables diferencias que existen entre algunas de ellas y en menor medida la perduración de ciertas estructuras retomadas en los distintos romans.

En el texto de Béroul los amantes llegan casi a monopolizar el discurso amoroso y más concretamente el verbo que aquí estudiamos. Esto se debe a que constantemente se sienten forzados a justificar sus actuaciones antisociales y antifamiliares para intentar permanecer en la corte o reintegrarse a la vida social y procurar eludir el castigo por adulterio. Esta primera particularidad arrastra otras dos que están íntimamente ligadas. En primer lugar el verbo aimer se ve matizado, modificado axiológicamente mediante adverbios, formulación que llega a contaminar el discurso del rey Marco, del enano Frocin o del propio narrador: "se Tristran l'aime folement" (Tristan, 661), y con asiduidad por complementos preposicionales con valor modal o causal construidos en torno al sustantivo amor como núcleo de sintagma, modificado por adjetivos ya positivos: "que je ne l'aim de bone amor" (Tristan, 2327), ya negativos: "se il m’amast de fole amor" (Tristan, 496), "ne m'amot pas d'amor vilaine" (Tristan, 502). Excepcionalmente un interlocutor como el ermitaño puede provocar la desaparición del sustantivo amor en favor de otro como foi, sin duda mejor adaptado a las convicciones y al propio discurso del hombre de la Iglesia: "Sire, par foi, que ele m'aime en bone foi" (Tristan, 1381 - 1382). O bien puede encontrarse acompañado de sintagmas cuyo núcleo nominal posee un sentido claramente peyorativo: "par folie, sire Tristan, vos aie amé” (Tristan, 20 - 21), “qar tu penses que j’aim Tristrain par puterie et par anjen" (Tristan, 407 - 408). Como se puede 
observar, aun sin retomar todas las ocurrencias, prevalecen las expresiones negativas sobre las valoraciones positivas, debido fundamentalmente a que en su justificación los amantes recogen la creencia de los que les rodean para mejor mostrar cuán equivocada era ésta y cuán leales eran sus sentimientos para con las convenciones sociales. Estas combinaciones hacen que el verbo amer, que en principio habla de sentimientos considerados desde el punto de vista axiológico como buenos para el agente, adquiera un valor peyorativo, $\mathrm{y}$ que su significado abandone la esfera de la afectividad sentimental para pasar a la de la relación puramente física, restringiéndose y haciéndose sinónimo de «fornican» en algunos casos.

En segundo lugar la negación del verbo de la oración principal, de la oración subordinada en que aparece el verbo aimer, o la doble negación, es decir, tanto de la proposición principal como de la subordinada, son casi habituales para enfatizar la oposición entre las opiniones de los que les rodean y la apariencia o la realidad de su relación y de las causas de su amor: "vos n'entendez pas la raison: q'el m'aime, c'est par la poison” (Tristan, 1383 1384), "il ne m’aime pas, ne je lui, fors par un herbé” (Tristan, 1413 - 1414);

$$
\begin{aligned}
& \text { Tristran, certes, li rois ne set } \\
& \text { que por lui par vos aie ameit }
\end{aligned}
$$

Tristan, $69-70$

$$
\begin{aligned}
& \text { Ge ne di pas, a vostre entente, } \\
& \text { que de Tristran jor me repente, } \\
& \text { que je ne l'aim de bone amor } \\
& \text { et com amis, sanz desanor }
\end{aligned}
$$

Tristan, $2325-2328$

Y en el discurso del embaucado rey Marco para marcar el triunfo del engaño de los amantes: 


$$
\begin{aligned}
& \text { se il s'amasent folement, } \\
& \text { ja n’i eüsent vestement, } \\
& \text { entrë eus deus n'eüst espee } \\
& \text { Tristan, } 2007 \text { - } 2009
\end{aligned}
$$

La supremacía de esta voluntad probatoria trae consigo aún nuevas cualidades de las formas del verbo aimer:

- El presente de indicativo y el pretérito perfecto, de indicativo o de subjuntivo, dominan las intervenciones de los amantes y de los que los acusan. Estas formas actualizan la controversia de la primera parte del fragmento o bien ponen de relieve la fuerza del amor fruto del bebedizo mágico.

- Tanto la primera como la tercera personas del singular, habituales en el discurso de los amantes, sirven para hablar directa o indirectamente a terceros - el ermitaño o el propio rey Marco- de los sentimientos que los unen; de igual modo utilizan el pronombre de cortesía de segunda persona vos, o bien el pronombre tu pero precedido de la denominación sire. En cualquier caso nunca se hace uso del verbo aimer en la intimidad, de la que tan sólo poseemos fugaces resúmenes del narrador que prefiere la forma recíproca:407 “nule gent tant ne s'entramerent” (Tristan, 1791);

$$
\begin{aligned}
& \text { aspre vie meinent et dure: } \\
& \text { tant s'entraiment de bone amor } \\
& \text { l'un por l'autre ne sent dolor. }
\end{aligned}
$$

Tristan, $1364-1367$

El verbo aimer en Charrete adquiere un valor rotundo, sea positivo o negativo, se ama o no se ama en absoluto y nunca se deja una puerta abierta para que los sentimientos se modifiquen, aunque el discurso masculino

\footnotetext{
407 También encontramos una ocurrencia de esta forma en el discurso de los felones: "tes niés s'entraiment et Yseut" (Tristan, 607).
} 
mediatiza las posiciones de la mujer frente al amor. Sólo ésta llega a negar el verbo aimer, como hace la reina ante Bademagu al conceder el perdón para su hijo: "vostre fil, cui ge n’aim mie" (Charrete, 3791). Y en la negación es donde mejor podemos observar cómo las mujeres —equiparándose a los varones - mantienen siempre una independencia absoluta al decidir sobre sus sentimientos soslayando las presiones sociales y las coacciones individuales. En algunos contextos esto llega a traducirse en un cúmulo de recursos modalizantes — verbo mourir e invocación a la divinidad—y gramaticales —uso del condicional y del imperfecto de subjuntivo, adjetivo y adverbio negativos-:

$$
\begin{aligned}
& \text { que por rien amer nel porroie; } \\
& \text { si m'aïst Dex, einz me morroie } \\
& \text { que je l'amasse an nul androit. }
\end{aligned}
$$

Charrete, 1523 - 1525

La afirmación del amor femenino es indirecta —enunciada por el narrador o por Lanzarote—, hipotética: “s'ele m'amast, mes ami verai me clamast" (Charrete, 4367 - 4368), "se vos rien nule amez de cuer, dameisele" (Charrete, 1404 - 1405) — la expresión de cuer es la única que en esta obra matiza el sentido del verbo aimer con un valor superlativo, tal y como ya hemos comentado más arriba-; o negada en última instancia por los acontecimientos que presenta el relato, lo que ocurre con las doncellas del reino de Arturo al organizar el torneo de Noauz para encontrar a sus futuras parejas. ${ }^{408}$

\footnotetext{
408

De cels qui le feront noauz

ne tandront parole de rien, mes de ces qui le feront bien dient que les voldront amer
}

Charrete, 5370 - 5373 
Por el contrario los caballeros y aun el rey Arturo perseveran en sus sentimientos pese al rechazo femenino: “qu’il m'ainme et ne fet pas que sages" (Charrete, 1519), y aman a sus parejas legítimas, ilegítimas o ansiadas por encima de todo. De ahí los tiempos verbales más frecuentes, el presente y el imperfecto de indicativo, que expresan aquí la perduración del estado afectivo.

Lanzarote en esta línea y asumiendo el papel de perfecto amante cortés, deviene el espejo en el que deberán mirarse los amantes futuros y supera a los grandes enamorados de la tradición literaria:

$$
\begin{aligned}
& \text { donc le dut bien Lanceloz faire, } \\
& \text { qui plus ama que Piramus, } \\
& \text { s'onques nus hom pot amer plus } \\
& \text { Charrete, } 3802 \text { - } 3804
\end{aligned}
$$

Como observamos en este ejemplo, las construcciones comparativas y superlativas se hacen indispensables para realzar la pasión de los varones, y si aquí el elemento sobre el que gira la comparación es el propio amante, el sujeto, lo habitual es que sea el objeto amoroso, si bien siempre se toma como referencia al resto del género humano:

$$
\begin{aligned}
& \text { ne tant ne voel estre enorables } \\
& \text { que la rien que plus aim li doingne } \\
& \text { Charrete, } 3278 \text { - } 3279 \\
& \text { et por boens eürez se clainme, } \\
& \text { quant la rien voit que il plus ainme. }
\end{aligned}
$$

Charrete, $1547-1548$ 


$$
\begin{aligned}
& \text { Le roi Artus a Kex traï } \\
& \text { son seignor, qui tant le creoit } \\
& \text { que comandee li avoit } \\
& \text { la rien que plus ainme an cest monde }
\end{aligned}
$$

Charrete, 4854 - 4857

En la obra de Jean Renart dos son las características esenciales de los contextos en los que se inserta el verbo aimer, la acuñación de un sintagma preposicional en apariencia redundante que pretende con toda probabilidad evocar la perfección amorosa: "sachiés bien c'on ne l'en doit mie blasmer s'il aime par amors" (Escoufle, 3742 - 3743), "cis cuens ot totes bones mors, et s'ama toustans par amors" (Escoufle, 107 - 108), “cele qui m’ama par amours" (Escoufle, 7532); y en segundo lugar el valor intensivo que le otorgan tres tipos de expresiones:

- Las construcciones superlativas o comparativas de superioridad con apariencia de superlativas mediante los adverbios plus, plus ... que, ${ }^{409}$ miex o miex ... que, ${ }^{410}$ entre las que se incluyen las proposiciones de relativo cuyo antecedente es la denominación rien, ya tratadas con anterioridad. En ellas observamos dos rasgos diferenciales con respecto a Charrete, por un lado como segundo término de la comparación pueden entrar en juego el dinero y las joyas o bien el propio individuo emisor del discurso amoroso:

\footnotetext{
409 Tradicionalmente se había considerado que los términos introductores de la segunda parte de la comparación tales como que o come eran conjunciones. Sin embargo, creemos, siguiendo a Moignet y Soutet, que en las estructuras comparativas tienen una función adverbial especificando un grado en los planos cuantitativo o cualitativo como correlativos de adverbios o adjetivos comparativos, y como tales los hemos analizado en nuestros textos. Cf. O. Soutet, É tudes d'ancien et de moyen français. Paris: PUF, 1992, p. 73 y G. Moignet, op. at., p. 271 - 272.

se Diex de la riens que j'aim miex

me doinst joïr a nul jor mais
}

Escoufle, 4952 - 4953

aperçui je qu'ele amoit miex

moi tot seul que tos ceus del monde

Escoufle, 3162 - 3163 
jou l'aim plus que s'il me ploüst

tot l'or ne tot l'argent del monde

Escoufle, 3972 - 3973

j'amai ml't plus que les joiaus

l'amor: ce fu drois et raisons.

Escoufle, 7590 - 7591

«Sire, fait ele, ja vos ain ge

plus que mon cors et plus que m'ame.»

Escoufle, 2878 - 2879

Por otro se introduce en el esquema superlativo más habitual del que también tenemos varios ejemplos —objeto comparado/resto de la humanidad como segundo elemento de la comparación: "la rien el mont qu'il plus amot" (Escoufle, 6611)_, un cambio sustancial que ya se perfilaba en Charrete referido a Lanzarote pero allí en una estructura comparativa, de ahí que tengamos un nuevo esquema — sujeto comparado/resto de la humanidad—:

$$
\begin{aligned}
& \text { quant ele ot que cil la nomma } \\
& \text { qui plus l'aime que riens qui vive } \\
& \text { Escoufle, } 7686 \text { - } 7687 \\
& \text { quant j'entendoie a esgarder } \\
& \text { la rien el mont qui plus m'amot }
\end{aligned}
$$

Escoufle, 7628 - 7629

- La segunda fórmula intensiva utiliza los adverbios de cantidad tant: “Aelis qui n'en set mot que ce soit cil qui tant l'amot" (Escoufle, 7217 - 
7218), ${ }^{411}$ y moult:“ la pucele qui ml't l'amot” (Escoufle, 2540), o la construcción más habitual de las comparaciones de igualdad con los adverbios tant ... come, en la que observamos alguno de los fenómenos que acabamos de comentar, tal como la aparición del propio individuo en el segundo elemento de la comparación, un rasgo sin duda sintomático de los cambios operados en la mentalidad desde comienzos del siglo XIII. Pero si esto parece justificarlo no es menos cierto que, al menos en los ejemplos que aquí encontramos, este segundo término aparece devaluado por la mentira y el engaño. La ocurrencia citada más arriba se inserta en el discurso falaz de la emperatriz con el que engatusa a su esposo hasta yacer con él y conseguir romper el matrimonio entre Aelis y Guillermo. El segundo ejemplo lo hallamos en un discurso indirecto libre de Guillermo insertado en un monólogo de Aelis cuando piensa que su amante la ha abandonado:

\author{
Lasse! Il disoit qu'il m'amoit tant; \\ lasse! Il disoit j'ere sa dame; \\ lasse! Son cors ne riens fors s'ame \\ n'amoit il tant com il faisoit \\ moi seulement; por voir disoit. \\ Quant ses cuers frans n'ert o le dire
}

Escoufle, 5362 - $5367^{412}$

- Por último encontramos algunas expresiones que no utilizan los esquemas superlativos más habituales, como aimer sor. "que cil qu’ele amoit sor tos ceus de tout le mont" (Escoufle, 5247 - 5248), o la negación absoluta gracias al adverbio temporal mais y el adjetivo negativo nus, aunque se vea inmediatamente neutralizada por una referencia literaria al personaje de la

411 También en Escoufle, 2581, 7281, 7312 y 7685. En una ocasión tant refuerza al cualitativo fort: "tant fort les aime" (Escoufle, 601) para referirse al amor que siente el rey Marco por su esposa Iseo y su sobrino.

412 Véase también en Escoufle, 8370 - 8371. 
tradición bretona que marca en sus amores con Iseo una linea referencial permanente para el relato de Renart:

$$
\begin{aligned}
& \text { Or ñ } \mathbf{\text { nama }} \underline{\text { mais }} \text { en tel maniere } \\
& \text { nus hom ja; si fist viaus Tristrans. }
\end{aligned}
$$

Escoufle, 6352 - 6353

El único fenómeno que parecen tener en común los textos de nuestro corpus en cuanto al verbo aimer es la diferenciación entre un amor que sigue las reglas, aunque haya que tener en cuenta que éstas varían en cada uno de ellos y que Charrete se separa de este presupuesto al considerar el amor como un absoluto, y un amor que no las sigue o que no llega a alcanzar la perfección requerida. Guillaume de Lorris recurre como sus predecesores a un sintagma fijo para denominar el amor que alcanza el más alto grado y que como tal merece una recompensa. En este caso el propio verbo es el componente nuclear de la construcción, precedido del adverbio de modo bien, ya sea como núcleo del sintagma verbal: "li chevaliers fu biaus et genz et as armes bien acesmez et de s'amie bien amez" (Rose, 1246 - 1248), ya de un sintagma preposicional en infinitivo: "se cil qui tant ert tes amis en bien amer son cuer a mis" (Rose, 2685 - 2686), "je me veil loer ou blasmer au daerrain de bien amer' (Rose, 3077 - 3078).

La función didáctica de Rose y la concepción amorosa trovadoresca caracterizada por el sufrimiento amoroso y la sumisión del amante, corriente a la que formalmente adhiere el autor, determinan las peculiaridades que distinguen los usos del verbo aimer en este texto del siglo XIII, algunos de ellos coincidentes en lo expresivo pero divergentes en el nivel de la expresión.

Los sujetos indeterminados, muy escasamente representados en los otros textos, son habituales en el discurso narrativo de la primera parte del roman al situar las coordenadas espacio-temporales del relato y el proceso de enamoramiento, así como en el discurso del dios Amor y en el de Razón, e 
incluso en el de Ami. Esta conformidad retórica se ve compensada con la variedad de procedimientos formales. El pronombre relativo qui construido sin antecedente adquiere un valor indefinido y equivale a «cualquier hombre» o a «todo aquel que»: "qui en may n’aime” (Rose, 81), “qui amer veut, or i entende, que li romanz des or amende" (Rose, 2059 - 2060). Este relativo puede combinarse con el pronombre personal masculino de tercera persona con el mismo sentido indefinido: "qui ce qu'il aime plus regarde plus alume son cuer et larde” (Rose, 2333 - 2334), al que también encontramos en correlación con un pronombre indefinido negativo como nus: "ne cuidez pas que nus conoisse, s'il n'a amé, qu'est grant angoisse” (Rose, 2945 - 2946 ). El relativo qui puede retomar varios antecedentes con valor muy general a menudo precedidos por el adjetivo indefinido tout, ya sean sustantivos: "hons qui aime ne puet bien fere ne a nul preu dou monde entendre” (Rose, 3028 3029), “en icelui tens deliteus, que toute rien d'amer s'esfroie” (Rose, 84 - 85), o pronombres demostrativos: “toz celz qui mielz font a amer" (Rose, 1038),

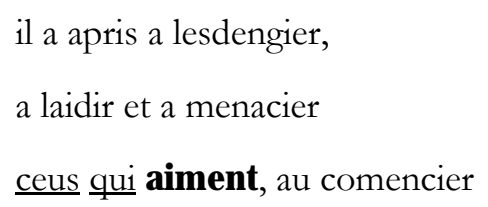

En el discurso del amante el efecto de indeterminación se consigue con la combinación de la metonimia particularizante y de la generalización, hace con ello referencia a los enamorados capaces de vencer cualquier obstáculo, y rogar así a su amada que no lo olvide ni con la distancia ni bajo las presiones morales y físicas a las que se ve sometida:

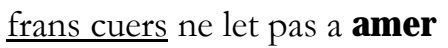 \\ por batre ne por mesamer \\ Rose, 3987 - 3988
}


Para el modelo de amante propuesto por Rose el hecho de ser amado se convierte no sólo en el justo premio por su sufrimiento y sus cualidades, sino en una virtud añadida que realza su prestigio y le hace merecedor de nuevos tributos y agasajos. Esta idea era en nuestra opinión aceptada desde el comienzo de la lírica cortés con la condición de que el sujeto fuera femenino, pero no la habíamos encontrado en nuestro corpus y mucho menos en relación con el varón. Tomemos como ejemplos a Lanzarote, por encontrarse teóricamente más cerca del modelo cortés, y a Guillermo por ser un personaje del siglo XIII. Las cualidades del primero no se multiplican tras la noche con la reina, a lo sumo lo encontramos menos distraído, y de Guillermo se ensalzan sus virtudes con fines matrimoniales más que amorosos. En Rose las construcciones pasivas nos permiten observar los diferentes pasos en esta marcha hacia el quietismo erótico, que canaliza el amor hacia la contemplación u otras actividades intelectuales alejándolo de los aspectos puramente físicos. El dios Amor, tomando como ejemplo a los enamorados novelescos, aconseja al amante utilizar sus habilidades guerreras y cortesanas para mejorar sus posibilidades de conquista:

$$
\begin{aligned}
& \text { et se tu sez lances brisier, } \\
& \text { tu t'en puez mout fere prisier; } \\
& \text { et s'aus armes es acesmez, } \\
& \text { par ce seras .x. tanz amez. }
\end{aligned}
$$

Se tu as la voiz clere et saine, tu ne doiz mie querre essoine

Rose, 2187 - 2192

Como podía esperarse, la diosa Venus proclama la simbiosis entre la belleza física, origen del placer de los sentidos, elemento al tiempo individual, intrínseco, no aprendido y ligado a la familia, con la virtud sentimental, es decir, el servicio y la fidelidad: 


$$
\begin{aligned}
& \text { qu'il sert et ainme en leauté, } \\
& \text { si a assez en lui biauté, } \\
& \text { por qu'il est dignes d'estre amez }
\end{aligned}
$$

Rose, 3429 - 3431

El amante de Cortesía, un joven caballero al que ya nos hemos referido por su naturaleza anacrónica, reúne los tres estadios: las cualidades sociales, guerreras y cortesanas, heredadas de los relatos del siglo XII, la perfección estética reivindicada durante el siglo XIII y por fin la cualidad de ser amado: "li chevaliers fu biaus et genz et as armes bien acesmez et de s'amie bien amez" (Rose, 1246 - 1248). El último umbral, el que conduce a la perfección gracias al amor del otro, lo franquea el narrador en su dedicatoria a la Rosa, bebiendo de nuevo de las fuentes más ortodoxas. ${ }^{413}$ Sus atributos no están en ella misma sino en los que la observan y la convierten en una entelequia, una abstracción a la que el autor - narrador rinde tributo con su obra, trabajo intelectual con el que espera quizá conquistar lo que con esfuerzos físicos había sido imposible:

$$
\begin{aligned}
& \text { la matire est et bone et nueve, } \\
& \text { or doint Dex qu'en gré le receve } \\
& \text { cele por qui je l'ai empris: } \\
& \text { c'est cele qui tant a de pris } \\
& \text { et tant est digne d'estre amee } \\
& \text { qu'el doit estre Rose clamee. }
\end{aligned}
$$$$
\text { Rose, } 39 \text { - } 44
$$

Es cierto que, como ya hemos apuntado más arriba, en Rose se retorna en cierta medida al origen literario de la idea del amor que con ciertas variaciones han adoptado los romans. Pero conviene que aclaremos aquí que el

\footnotetext{
${ }^{413}$ C. Nouvet en Les inter-dictions courtoises: le jeu des deux bouches, Romanic Review, vol. LXXVI, no 3 , p. 237, apunta que el discurso cortés en Rose pretende llegar a conseguir para el sujeto la dignidad de ser amado más que expresar su propio deseo.
} 
trabajo intelectual de un Guillaume de Lorris no se asemeja al arte poético de los trovadores. Y ello no solamente por su forma y las condiciones de difusión y recepción sino por la función social de la creación, por el papel que por su origen y por las circunstancias históricas asumían unos y otro, así como por las relaciones entre el enamorado y el sentimiento amoroso. Todo ello hace muy probable que Guillaume de Lorris esté más cerca en este sentido de Dante que de cualquier poeta occitano del siglo XII.

La tendencia a la abstracción sugerida por las dependencias que se establecían entre los enamorados y el amor se ve confirmada con el predominio del infinitivo del verbo aimer. Este puede funcionar como complemento de un adjetivo o de un sustantivo o formar perífrasis verbales con valor factitivo o modal: "qui amer veut, or i entende, que li romanz des or amende" (Rose, 2059 - 2060), esto último también expresado mediante el sustantivo volenté: “ci n'a mestier sens ne mesure, ci est d'amer volenté pure” (Rose, 1583 - 1584). La función del infinitivo en las perífrasis no podría determinarse con exactitud ya que puede considerarse como un objeto directo dependiente del verbo conjugado, o bien como el elemento nocional principal modificado por un auxiliar que aporta matices de diversa índole al verbo al tiempo que los indicios de persona, número, tiempo y modo. ${ }^{414}$ Las perífrases factitivas, en las que el infinitivo asume claramente el papel de complemento de objeto directo y son relativamente abundantes, nos muestran desde diferentes ángulos la indefensión y la subordinación del hombre o de la mujer ante los atributos del sexo opuesto en el proceso de enamoramiento: "Simpleice ot non, c'est la segonde, qui maint home par mi le monde et mainte dame a fet amer" (Rose, 1735 - 1737), ante el deseo y la pasión: "cil larz alume et fet flamer le feu qui fet les genz amer" (Rose, 2335 - 2336), o ante la propia fuerza del sentimiento amoroso: "s'Amors le fet par force amer' (Rose, 3247).

414 El problema lo plantea G. Moignet, op. at., p. 199 - 200. 
Dos adjetivos a los que podemos considerar antónimos, lache $\mathrm{y}$ engrés, ambos intensificados por un adverbio, reciben como complemento el infinitivo aimer. Representan las dos posturas que se enfrentan ejemplarmente en Rose, el hombre que se ama a sí mismo y desdeña el verdadero amor, el amor del otro, y aquel al que la presencia de la amada enardece física y espiritualmente, y le lleva según la filosofía amorosa del texto a olvidarse de sí mismo:

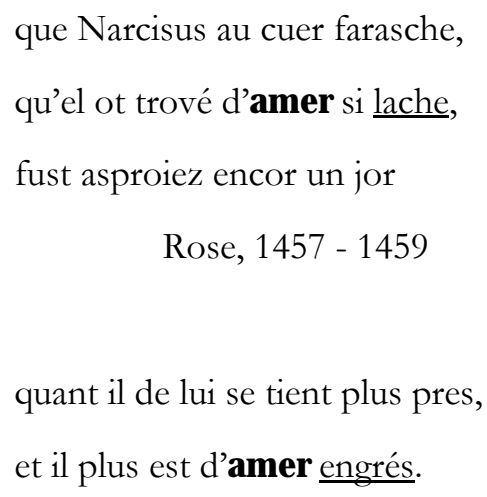

La finalidad didáctica de la novela aflora al observar el funcionamiento del infinitivo como complemento de sustantivo ya que se sitúa más cerca de la función nominal que de la acción verbal. El sintagma introducido por la preposición de puede equivaler a un sintagma nominal en el que se expresase el asunto sobre el que se tiene o no conocimiento: "onques hom rien d'amer ne sot cui il n'abelist a doner"' (Rose, 2204 - 2205). Siempre en un tono didáctico, el tema del sufrimiento amoroso se refleja mediante la reiteración de la locución mal d'amer en el discurso del dios Amor: "la nuit ensint te contendras et de repos petit prendras, s'onques le mal d'amer conui”" (Rose, 2491 - 2493) y en del narrador, con un carácter hiperbólico: "nes qu’em puet espuisier la mer, ne poroit nus les maus d'amer conter en romanz ne en livre" (Rose, 2591 - 2593) y contradictorio: "amant sentent les maus d'amer, une eure douz, autre eure amer” (Rose, 2171 - 2172), expresión en la que el infinitivo tiene la función de complemento atributivo del nombre. 
Como se puede observar en la tabla que presentamos a continuación, la importancia concedida al verbo aimer en nuestro corpus se halla reforzada por una posición privilegiada en el verso que permite a los autores jugar con las evocaciones sonoras y semánticas que ofrece la rima.

\begin{tabular}{|c|c|c|c|c|c|c|c|c|}
\hline FORMA & CA & BD & NV & RIMA & CA2 & NV2 & D & PERS \\
\hline aim & V & Escoufle & 3247 & haim & $\mathrm{S}$ & 3248 & $\mathrm{D}$ & Aélis \\
\hline aime & V & Rose & 81 & raime & $S$ & 82 & $\mathrm{~N}$ & Narrador \\
\hline aime & V & Escoufle & 601 & raime & $\mathrm{S}$ & 602 & $\mathrm{~N}$ & Narrador \\
\hline ainme & V & Charrete & 1548 & clainme & V & 1547 & I & Chevalier \\
\hline aint & V & Rose & 3986 & remaint & V & 3985 & $\mathrm{~L}$ & Amant \\
\hline ama & V & Escoufle & 7685 & nomma & V & 7686 & D & Guillaume \\
\hline amast & V & Charrete & 4367 & clamast & V & 4368 & D & Lancelot \\
\hline amast & V & Escoufle & 8252 & formast & V & 8251 & D & Chev/Clercs \\
\hline amee & $\mathrm{O}$ & Rose & 43 & clamee & $\mathrm{O}$ & 44 & D & Narrador \\
\hline amee & $\mathrm{O}$ & Escoufle & 2581 & pasmee & $\mathrm{O}$ & 2582 & D & Com. Gênes \\
\hline ameit & $\mathrm{O}$ & Tristan & 70 & set & V & 69 & D & Iseut \\
\hline amer & I & Rose & 2171 & amer & A & 2172 & D & Amour \\
\hline amer & I & Rose & 3465 & amer & A & 3468 & $\mathrm{~N}$ & Narrador \\
\hline amer & I & Rose & 1737 & aprimer & I & 1738 & $\mathrm{~N}$ & Narrador \\
\hline amer & I & Rose & 3078 & blasmer & I & 3077 & D & Amant \\
\hline amer & I & Rose & 3247 & blasmer & I & 3248 & D & Franchise \\
\hline amer & I & Charrete & 963 & clamer & I & 964 & $\mathrm{~N}$ & Narrador \\
\hline amer & I & Charrete & 5373 & crïer & I & 5374 & $\mathrm{~L}$ & Demoiselle \\
\hline amer & I & Rose & 2336 & flamer & I & 2335 & D & Amour \\
\hline amer & I & Rose & 1038 & losengier & I & 1039 & $\mathrm{~N}$ & Narrador \\
\hline amer & I & Rose & 2592 & mer & $\mathrm{S}$ & 2591 & $\mathrm{D}$ & Amour \\
\hline amer & I & Charrete & 6491 & mer & $\mathrm{S}$ & 6492 & D & Lancelot \\
\hline amer & I & Rose & 3987 & mesamer & I & 3988 & $\mathrm{~L}$ & Amant \\
\hline amez & $\mathrm{O}$ & Rose & 3431 & acesmez & $\mathrm{O}$ & 3432 & D & Vénus \\
\hline amez & $\mathrm{O}$ & Rose & 2190 & acesmez & $\mathrm{O}$ & 2189 & D & Amour \\
\hline amez & $\mathrm{O}$ & Rose & 1248 & acesmez & $\mathrm{O}$ & 1247 & $\mathrm{~N}$ & Narrador \\
\hline amé & $\mathrm{O}$ & Tristan & 79 & gré & S & 80 & $\mathrm{D}$ & Iseut \\
\hline amé & $\mathrm{O}$ & Tristan & 21 & loiauté & $\mathrm{S}$ & 22 & D & Iseut \\
\hline amés & V & Escoufle & 5911 & portés & V & 5912 & I & Gens \\
\hline amoit & V & Escoufle & 7281 & regretoit & V & 7282 & $\mathrm{~N}$ & Narrador \\
\hline amoit & V & Charrete & 1675 & tenoit & V & 1676 & $\mathrm{~N}$ & Narrador \\
\hline amot & V & Tristan & 2520 & esjot & V & 2519 & $\mathrm{~N}$ & Narrador \\
\hline amot & V & Escoufle & 2540 & mot & $\mathrm{S}$ & 2539 & $\mathrm{~N}$ & Narrador \\
\hline amot & V & Escoufle & 3385 & mot & $\mathrm{S}$ & 3386 & $\mathrm{~N}$ & Narrador \\
\hline amot & V & Escoufle & 5078 & mot & $\mathrm{S}$ & 5077 & $\mathrm{~N}$ & Narrador \\
\hline amot & V & Escoufle & 5552 & mot & $\mathrm{S}$ & 5551 & D & Aélis \\
\hline amot & V & Escoufle & 6611 & mot & $\mathrm{S}$ & 6612 & $\mathrm{~L}$ & Guillaume \\
\hline amot & V & Escoufle & 7218 & mot & $S$ & 7217 & $\mathrm{~N}$ & Narrador \\
\hline amot & V & Escoufle & 7629 & mot & $\mathrm{S}$ & 7630 & D & Guillaume \\
\hline amot & V & Rose & 2663 & $\operatorname{mot}$ & $\mathrm{S}$ & 2664 & $\mathrm{D}$ & Amour \\
\hline entramerent & $\mathrm{V}$ & Tristan & 1791 & $\begin{array}{l}\text { conpere } \\
\text { rent }\end{array}$ & V & 1792 & $\mathrm{~N}$ & Narrador \\
\hline
\end{tabular}

Tabla 56. Rimas del verbo aimer. 
Los textos del siglo XIII han aprovechado en este caso con más asiduidad los recursos que ofrece la rima, si bien con criterios diferentes. Lorris varía los emparejamientos aunque repite algunos de ellos como el de los participios amez / acesmez. Con esta rima establece una estrecha relación entre el verbo aimer en construcción pasiva con una de las innovaciones temáticas del siglo XIII, la importancia de la apariencia física, del ornato que contribuye al deseo. De igual modo, las combinaciones entre el infinitivo y el adjetivo amer o el verbo blasmer inciden en las problemáticas relaciones entre el sentimiento, el rechazo, la culpa y el dolor. En Escoufle, por el contrario, apenas se dan variaciones y la rima más abundante es la que se establece entre la tercera persona del imperfecto de indicativo, amot, y el sustantivo mot. Este acompaña en todos los casos a la negación de un verbo de dicción, dire, para expresar el despecho y el dolor, o de un verbo de conocimiento, savoir, con lo que se refuerza la incapacidad de los amantes para reconocerse o para encontrarse después de siete años de separación. De ahí que lo que en un principio podía parecernos un simple y fácil recurso formal pasa a convertirse en uno retórico.

La sintaxis proposicional nos da algunas pistas más sobre la construcción temática de los textos tomando como base el verbo aimer. Béroul lo presenta como núcleo verbal de subordinadas completivas y circunstanciales, hipotéticas y excepcionalmente causales: "a grant mervelle s'en esjot, qar sa feme forment amot" (Tristan, 2519 - 2520). Entre las primeras se encuentran las que dependen de los verbos penser, entendre en una perífrasis factitiva, y savoir en forma negativa: "li rois ne set que por lui par vos aie ameit" (Tristan, 69 - 70). En los tres casos el rey Marco es el sujeto y se refuerza la impresión de que el adulterio no es sino una opinión, una sospecha infundada de la corte y del marido. En la misma línea, si bien se intensifica la noción de irrealidad, hallamos las subordinadas hipotéticas, cuyos sujetos son, Tristan en el discurso de Iseo: “se il m'amast de fole amor, asez en veïsiez senblant" (Tristan, 496 - 497), o bien los dos amantes en el del 
marido: "s'il s'amasent de fol'amor, ci avoient asez leisor" (Tristan, 301 302). En ambos casos se expresa la acción de amar como un hecho contrario a la realidad, y ello merced a la modificación axiológica negativa que entrañarían las manifestaciones de índole carnal, y probablemente obscena. En las palabras premonitorias de Frocin se establece la misma relación lógica entre amor deshonesto y unión de los enamorados, pero en este caso el sistema hipotético y el enunciado performativo que lo precede indican la conexión necesaria entre el hecho enunciado en la subordinada y en la principal, sin que haya la menor duda sobre su realidad:

$$
\begin{aligned}
& \text { Deu te jur et la loi de Rome, } \\
& \text { se Tristran l'aime folement, } \\
& \text { a lui vendra a parlement }
\end{aligned}
$$$$
\text { Tristan, } 660-662
$$

Charrete recurre con más frecuencia a las subordinadas relativas, ya sean especificativas o explicativas, con el fin de precisar la relación de amor o de desamor entre el sujeto amoroso, generalmente sujeto de la subordinada, y el objeto representado por el pronombre relativo. A éstas se unen las subordinadas circunstanciales: causales, mediante las que se explican las causas reales del rechazo femenino o del insistente cortejo masculino: “mes m'amors li est an desfans, que por rien amer nel porroie" (Charrete, 1522 - 1523), "ce sai ge bien que il le panse, qu'il m'ainme et ne fet pas que sages" (Charrete, 1518 - 1519); y las hipotéticas en las que de nuevo se contrapone la realidad e intensidad del amor masculino frente a la posibilidad o la irrealidad del de las féminas.

En E scoufle las subordinadas relativas cuyo núcleo verbal es aimer son adjetivas especificativas en las que el relativo funciona a menudo como sujeto del verbo: "quant ele ot que cil la nomma qui plus l'aime que riens qui vive" (Escoufle, 7686 - 7687), aunque también se dan ejemplos en los que 
asume la función de complemento de objeto directo: "se Diex de la riens que j'aim miex me doinst joïr a nul jor mais” (Escoufle, 4952 - 4953). Las proposiciones relativas adjetivas sirven, sin hacer distingos entre el amante o la amada, para ponderar el amor, y es buena prueba de ello el hecho de que el verbo esté modificado por adverbios de cantidad que introducen un superlativo.

Las proposiciones subordinadas completivas, precedidas o no de la conjunción que, suelen depender de verbos de dicción como dire: "il disoit qu'il m'amoit tant" (Escoufle, 5362) y conter. "cil ne me menti mie ki me conta que vos amés" (Escoufle, 5910 - 5911); y en menor grado de verbos de conocimiento como savoir. "bien sai que il ne m'ama onques" (Escoufle, 3703); de percepción, como aperçoivre: ' $k$ ’a la douçor de ses biax iex aperçui je qu'ele amoit miex moi tot seul" (Escoufle, 3161 - 3163); o de creencia como esperer.

$$
\begin{aligned}
& \text { k'espoir ml't m'aime poi et prise } \\
& \text { et par li a ses pere prise } \\
& \text { de moi haïr ceste enresdie. }
\end{aligned}
$$

Escoufle, 3157 - 3159

En ellas observamos que, cuando el sujeto de la proposición principal es uno de los amantes, existe una clara tendencia hacia la disfunción entre la realidad de los hechos relatados, es decir, lo que el receptor sabe sobre las causas de los acontecimientos y particularmente de las separaciones de los enamorados, y las angustiosas causas que estos imaginan cuando culpan a su pareja de hipocresía en sus palabras o en sus acciones. Y ello en gran medida porque se potencia el papel del destino frente a los verdaderos motivos, sociales o individuales, que de hecho primaban en los romans estudiados del siglo XII. 
De las proposiciones subordinadas circunstanciales tan sólo encontramos ejemplos de proposiciones introducidas por la conjunción se. Exclusivamente una puede considerarse desde un punto de vista lógico como una condicional, en ella el verbo aimer aparece en imperfecto de subjuntivo y expresa una irrealidad que se ve contrarrestada por la negación. Gracias a ella Renart llama la atención sobre la necesidad del amor y del consentimiento para que una pareja llegue al matrimonio y pone de acuerdo en esta propagación de las normas eclesiales a los dos grupos dominantes, la pequeña nobleza y los clérigos:

$$
\begin{aligned}
& \text { cuidiés vous dont que s'el n'amast } \\
& \text { cest home, qu'il peüst avoir } \\
& \text { si bele feme? Nenil voir. }
\end{aligned}
$$$$
\text { Escoufle, } 8252 \text { - } 8254
$$

En los otros dos ejemplos se trata de la expresión de una concesión atenuada, con ella se pretende ensalzar el sentimiento amoroso salvando los prejuicios que deseaban relegarlo a un segundo plano por distraer las energías necesarias para el buen funcionamiento de la sociedad, especialmente entre los hombres, así como por minar los intereses matrimoniales de las familias. De hecho en el contexto inmediato se describe ya como una fuerza positiva que adorna y mejora a quienes la cultivan:

$$
\begin{aligned}
& \text { se je vos aim, ne vos em poist, } \\
& \text { car c'est une chose qui loist } \\
& \text { a moi, et a toutes les gens }
\end{aligned}
$$$$
\text { Escoufle, } 3433 \text { - } 3435
$$

sachiés bien c'on ne l'en doit mie

blasmer śil aime par amors

Escoufle, 3742 - 3743 
Las proposiciones relativas de Rose se reparten, como ya hemos podido observar, entre sustantivas, adjetivas relativas y un único ejemplo con valor circunstancial temporal: "en icelui tens deliteus, que toute rien d'amer s'esfroie" (Rose, 84 - 85). En cuanto a las subordinadas completivas, si no tenemos en cuenta los infinitivos precedidos de los verbos laissier o faire a los que ya hemos aludido más arriba, hallamos muy pocos ejemplos, en ellos la subordinada es dependiente de verbos de voluntad como vouloir. "Vos, veilliez que j'ain solement, autre chose ne vos demant" (Rose, 3163 - 3164) y garder: "gardez seviaus que li cuers m’aint" (Rose, 3986), así como de los verbos de conocimiento y percepción savoir y veoir, que se hallan coordinados para expresar la perfecta concordancia entre lo que observan los sentidos y las palabras del amante: "car vos savez bien et veez qu'il sert et ainme en leauté" (Rose, 3428 - 3429). El infinitivo precedido de la preposición en indica la finalidad dependiendo del verbo metre: "se cil qui tant ert tes amis en bien amer son cuer a mis” (Rose, 2685 - 2686).

La concesión introducida por se: “saches, je n'ai vers toi point d'ire et se tu aimes, moi que chaut?" (Rose, 3180 - 3181) que expresa la indiferencia o más bien el desprecio de Dangier hacia el enamorado y sus sufrimientos; la consecuencia del vano amor de Narciso expresada por la correlación tant ... que: "qu'il musa tant en la fontaine qu’il ama son ombre demainne" (Rose, 1491 - 1492); la causa introducida por la conjunción car. “car Equo, une haute dame, l'avoit amé plus que rien nee” (Rose, 1442 1443), o bien una explicación de la actitud perseverante del amante ante los obstáculos que le impiden seguir con su conquista: “je ne vos quier de ce lober, car j’ameré, puis qu’i me siet” (Rose, 3168 - 3169); así como la condición para conocer los dolores más intensos: "ne cuidez pas que nus conoisse, s'il n’a amé, qu'est grant angoisse” (Rose, 2945 - 2946), son las circunstancias expresadas en el texto de Lorris por las proposiciones subordinadas en las que se incluye el verbo aimer. 


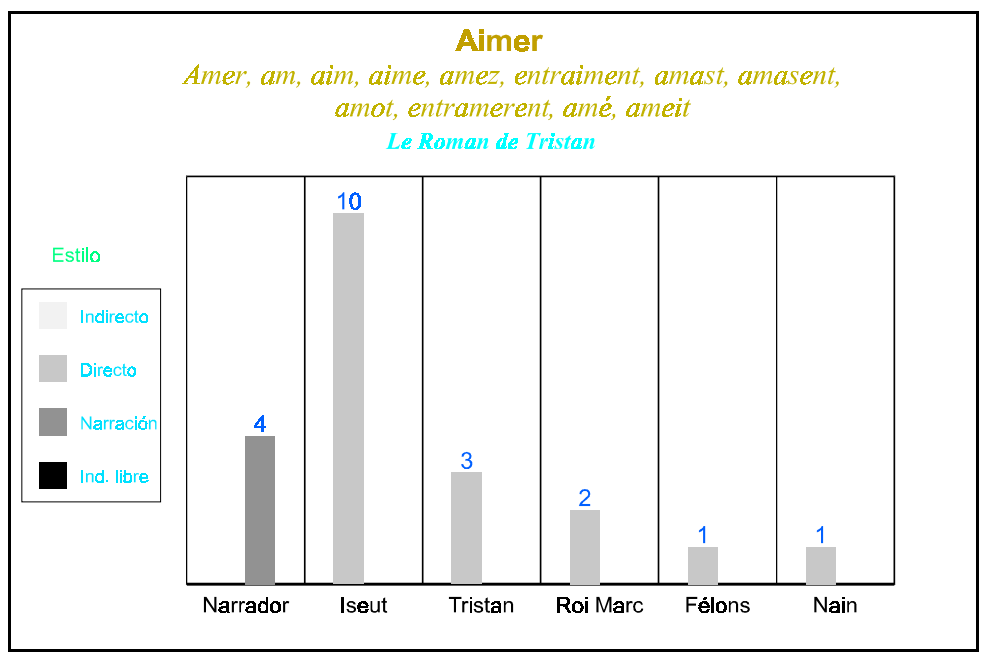

Fig. 63. Comportamiento estilístico del verbo aimer en Tristan.

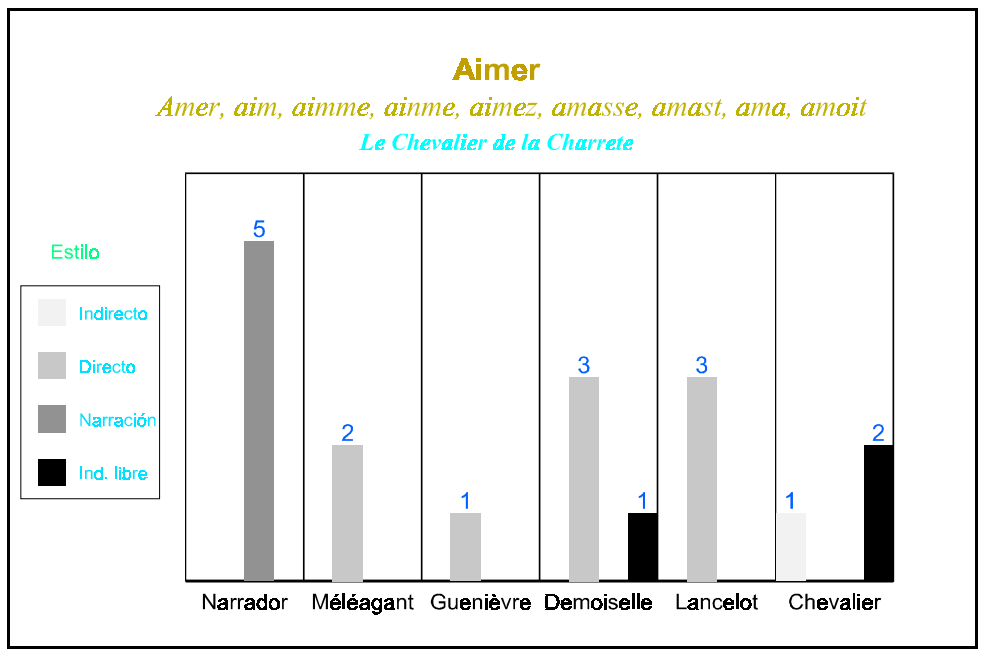

Fig. 64. Comportamiento estilístico del verbo aimer en Charrete. 


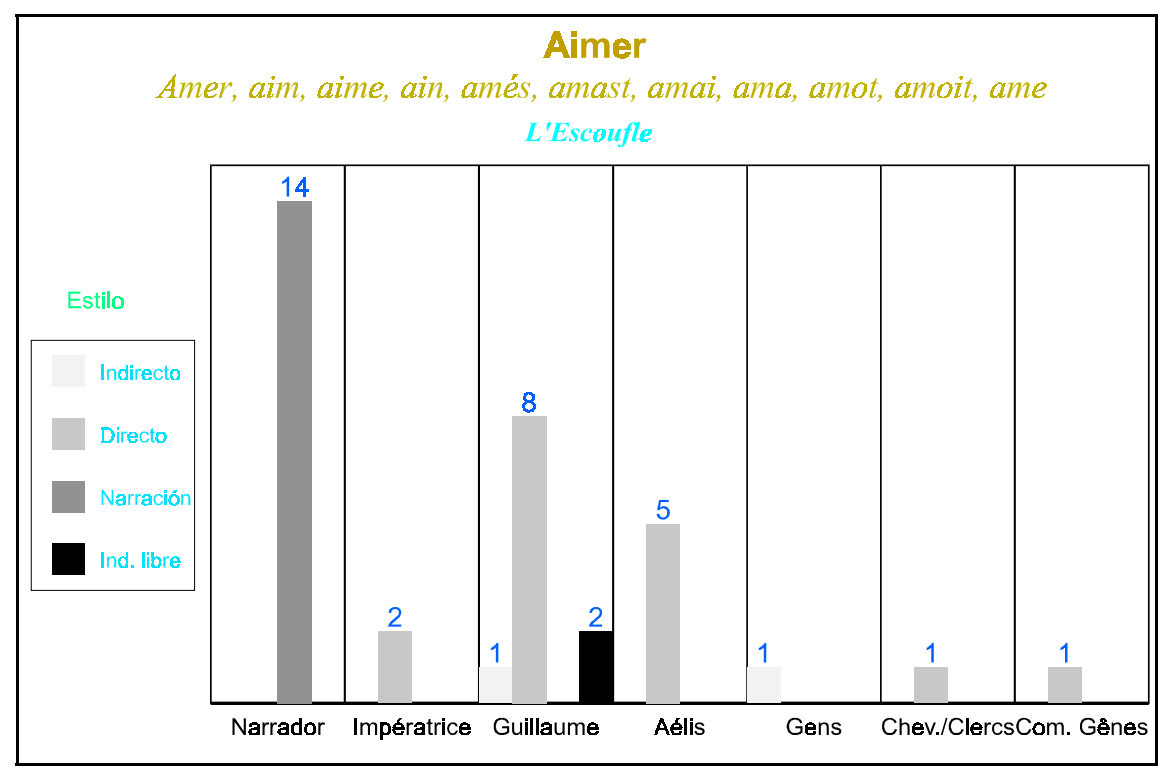

Fig. 65. Comportamiento estilístico del verbo aimer en Escoufle.

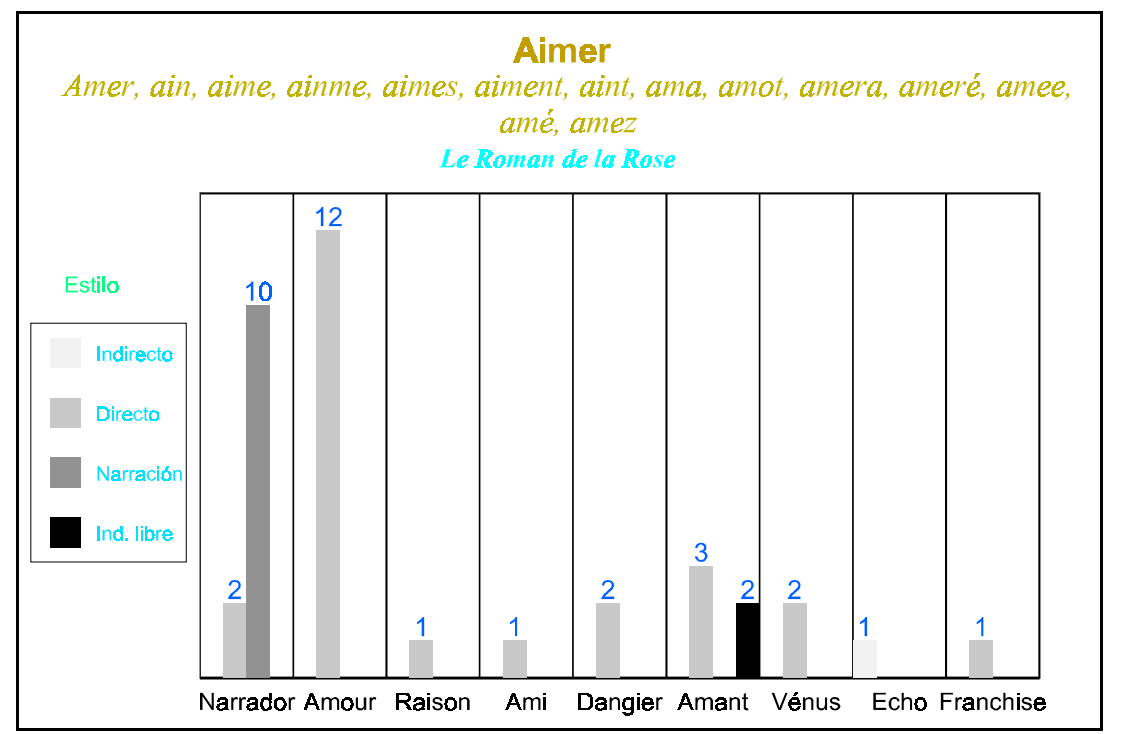

Fig. 66. Comportamiento estilístico del verbo aimer en Rose.

Los datos que nos muestran estos gráficos sirven para confirmar algunas de las afirmaciones expresadas con anterioridad sobre el uso del verbo aimer: la concentración de las ocurrencias en el discurso de Iseo, quien rige las intervenciones tendentes a contrarrestar la influencia que sobre su esposo tienen los barones felones, o bien la tendencia a la enseñanza prevaleciente en Rose a través de los discursos del dios Amor y del propio narrador en primera 
persona. En cuanto a Charrete y E scoufle creemos que merece destacarse la inclinación creciente a que sea el narrador el que recoja las vicisitudes amatorias, y en la obra de Renart la apropiación del discurso amoroso por parte de Guillermo. Si bien debemos precisar que las intervenciones del enamorado se concentran en el periodo que va desde su partida forzosa de la habitación de Aelis y su reencuentro con la amada y que en ellas dominan las construcciones superlativas incluidas en proposiciones de relativo.

Las ocurrencias del verbo haer de las que vamos a ocuparnos funcionan en realidad en la narración como variantes formales del verbo aimer, y son utilizadas, más que como un procedimiento retórico, para sustituir la fórmula afirmativa por una fórmula negativa más larga con la que rellenar el verso y conseguir una rima fácil con el sustantivo amie. Aunque no muy utilizada, esta fórmula, propia de los textos del siglo XIII, responde sistemáticamente al mismo patrón: se incluye en una proposición adjetiva de relativo y se recurre a un segundo adverbio negativo, mie, que permite la rima; por otra parte el antecedente es siempre un individuo femenino aunque sea un personaje alegórico. En Escoufle la proposiciones de relativo son especificativas, en una de ellas el relativo funciona como sujeto: "ml't le vit envoisiement la dame qui nel haoit mie" (Escoufle, 5832 - 5833), y en la otra como complemento de objeto directo: "et Guilliaume, le debounaire, et Aelis qu'il ne het mie" (Escoufle, 2092 - 2093). En Rose, por el contrario, es explicativa, y el relativo funciona como sujeto de la proposición subordinada: "Leesce, qui nou haoit mie" (Rose, 830). Su uso corrobora la preferencia de los autores del siglo XIII por las construcciones de relativo para hablarnos de la actividad sentimental así como de su propensión a acentuarla cuantitativamente. 


\subsection{Amoury amitié.}

Estos dos sustantivos, amour y amitié, no poseen ningún rasgo semántico ni gramatical que los diferencie, a no ser, como veremos, que uno y otro van precedidos de preposiciones diferentes en algunos usos como complementos, pero sin que ello varíe en absoluto su función. En todos los casos son intercambiables y tan sólo cuestiones puramente formales en relación con la medida del verso y con la rima parecen justificar la aparición de amitié en el corpus, a excepción de Charrete donde no se halla. Lo consideramos pues, una variante formal de tres sílabas que en Escoufle y en Rose se encuentra generalmente en la rima. Quizá su utilización no sea ajena al valor que los autores latinos medievales, como es el caso muy conocido de Alcuino, concedían a este término al denominar el elevadísimo sentimiento amoroso, aunque especialmente sensual, que mostraban hacia sus amantes masculinos. Esto le confiere por otra parte un origen culto que no creemos haya tenido ninguna influencia en la elección de nuestros autores frente a amour.

La vulneración de las normas socio-familiares y la ruptura de las leyes lingüísticas actúan mutuamente como causa y efecto en el texto de Béroul. En el caso de los términos amour y amitié, especialmente cuando funcionan como complemento directo de los verbos avoir y prendre, la transgresión lingüística tiene su origen en la ambigüedad. Ésta surge del conflicto permanente entre el adulterio — transgresión que está siempre presente en la mente de los que rodean a los amantes_ y la bigamia efectiva de la reina Iseo, que tan sólo los amantes aceptan como tal y el público receptor podía interpretar o intuir en función de los datos que aportaba la primera parte de la leyenda. En realidad se enfrentan dos formas de legalidad matrimonial que todavía coexistían en la época: por un lado los usos tradicionales en los que la entrega de la esposa por su familia al futuro esposo y el desvirgamiento constituían ya el vínculo familiar, a ello se une la voluntad 
de la Iglesia de implantar como elemento imprescindible para que el lazo matrimonial sea válido el mutuo consentimiento basado en el sentimiento amoroso; por otro lado se encuentran los nuevos ritos presididos por la Iglesia con los que se pretendía eliminar las antiguas costumbres mediante un control directo de los actos jurídicos por parte de los eclesiásticos. En el discurso directo de la reina el sentido ambiguo surge de la polivalencia en función de los receptores de algunos términos como seignor o de sintagmas como avoir pucelle, a los que ya nos hemos referido con anterioridad: "s'onques fors cil qui m'ot pucele out m'amistié encor nul jor!” (Tristan, 24 - 25), “que amor aie o home qu'o mon seignor" (Tristan, 37 - 38). Los receptores de estos enunciados poseen diferentes grados de conocimiento de lo acaecido anteriormente y por lo tanto comprenden o no el verdadero sentido del discurso. Por un lado se encuentra Tristán, para quien estas palabras son una declaración de amor. En el mismo nivel está el público de la obra, quien percibe también la triple infracción de la reina al haber degradado de hecho las instituciones matrimonial y dinástica, al hablar con total impunidad de ello, y por fin al engañar al marido con sus palabras haciéndole creer que él es el beneficiario de su amor. En un segundo nivel se encuentra, obviamente, el rey, quien cree poder dar un sentido bien definido a lo que es totalmente equívoco pues confía en la absoluta validez de los nuevos ritos y en último término en las apariencias. Por otra parte, en ambos contextos se prima la existencia del sentimiento amoroso, pero son precisamente las expresiones que introducen la ambigüedad discursiva las que permiten entrever el papel capital que junto a los sentimientos asume el contacto carnal entre hombre y mujer.

La alteración peyorativa mediante adjetivos, proposiciones de relativo o complementos circunstanciales de las estructuras formadas por avoir o prendre y el sustantivo amour como complemento de objeto directo, es una nueva fuente de equívoco lingüístico así como de justificación social. 
Está presente en el discurso indirecto libre de Iseo durante el juramento de la Blanca Landa y en el discurso directo de Tristan:

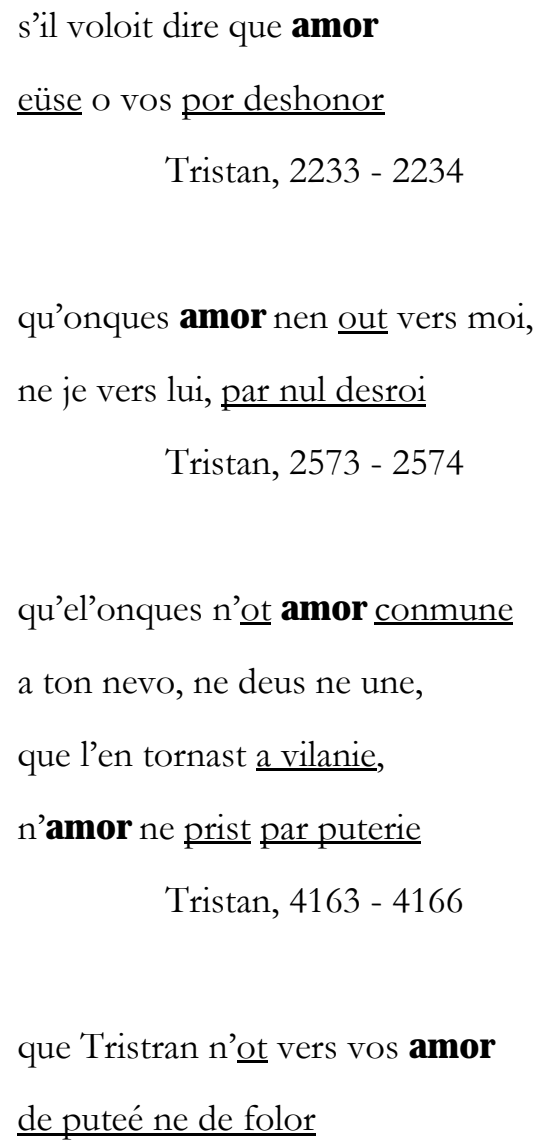

Cuando son modificados peyorativamente los sintagmas verbales, se plantean de nuevo dos niveles de comprensión de las relaciones entre Tristán e Iseo. Uno en el que se pone de relieve el fornicio, el ayuntamiento surgido de una atracción puramente física con el único fin de satisfacer el deseo y sin que intervenga la atracción afectiva. El otro pone en igualdad de condiciones las dos vertientes de las relaciones entre hombre y mujer y parte de la premisa de que la verdadera unión es la que nace del sentimiento compartido y del primer contacto sexual. Esta segunda comprensión permite a los amantes negar rotundamente la falta cometida contra las instituciones sociales y aun 
contra la moral, mientras que los que escuchan sus discursos se empecinan en el primer sentido.

Estas combinaciones sintácticas y expresivas desaparecen en el resto del corpus, donde el amor se nos muestra en su faceta más sentimental, en ocasiones podríamos decir incluso intelectual como en Charrete, y el venus es una consecuencia lógica e incluso necesaria del afecto. En dos ejemplos el sustantivo amor es complemento directo de avoir en la obra de Chrétien: durante la noche de amor, donde desaparece completamente el contenido carnal pero se conserva el emocional, hecho al que contribuye de forma decisiva el cambio de preposición con respecto a Tristan, puesto que frente a $\mathbf{0}$ y vers hallamos a, así como las formas de cuantificación: "et s'ele a lui grant amor ot et il .c. mile tanz a li" (Charrete, 4662 - 4663); y en las insinuantes palabras de la mujer del senescal cuando solicita el amor de Lanzarote a cambio de dejarle ir al torneo de Noauz: "que le retor me jureroiz et avoec m'aseüreroiz de vostre amor, que je l'avrai'" (Charrete, 5479 - 5481). En ellas se puede interpretar tanto una invitación a las relaciones sexuales inmediatas como a un cortejo más largo al estilo cortés, pero la dama libera inmediatamente a Lanzarote de su promesa al comprender que él ya ha entregado su corazón y su cuerpo.

Quizá la prelación de los sentimientos deba ser matizada para Rose pues observamos la primacía de la atracción física propia de los amores adolescentes, aunque es casi inmediatamente compensada por la acción del dios Amor y el desarrollo de las primeras manifestaciones del sentimiento amoroso. De hecho las tres obras - Charrete, E scoufle y Rose- poseen numerosos rasgos comunes: en lo que se refiere a los temas que rodean el amor, tales como el sufrimiento, las contradicciones, la oposición entre Amor y Razón o la fuerza irresistible que domina las acciones de los amantes, así como en lo que atañe a la expresión formal, por ejemplo, la abundancia de nexos adversativos y de complementos circunstanciales de causa. Sin embargo, no todas las obras utilizan estos recursos por igual y podremos 
observar cómo en alguna se da más importancia a uno frente a otro y cómo recurren a desarrollos secundarios con efectos temáticos y expresivos similares.

También se encuentran tratamientos diferentes de algunos motivos como ocurre con el del conocimiento del amor y de sus reglas, de las obligaciones que conlleva y de los derechos que otorga. En E scoufle el amor justifica el deseo de los amantes de permanecer juntos y de unirse en matrimonio, aunque desde el punto de vista del saber hacer Guillermo reconoce su incapacidad para engañar, para saltarse las normas sociales tal y como hacían Tristán e Iseo, y deberá ser Aelis quien escuche los consejos de Amor y busque las soluciones adecuadas. Ya ha quedado dicho que Rose es un texto iniciático en el que el amante aprende no sólo las normas teóricas sino también las alegrías y dolores del amor. Muy por encima de los otros héroes en lo que concierne a la sabiduría amorosa, Lanzarote no sólo es el perfecto caballero dispuesto a defender a los más débiles, entre los que en la obra se da preferencia a las mujeres, y capaz de defenderse a sí mismo de las ofensas de otros caballeros, sino que en su condición de perfecto amante, probablemente tras un esforzado aprendizaje, el corazón de Lanzarote ha sido elegido por el amor, lo que lo distingue de todos los demás caballeros:

$$
\begin{aligned}
& \text { car a toz autres cuers failli } \\
& \text { amors avers qu'au suen ne fist; } \\
& \text { mes an son cuer tote reprist } \\
& \text { amors, et fu si anterine } \\
& \text { qu'an toz autres cuers fu frarine }
\end{aligned}
$$

Charrete, 4664 - 4668

Por ello se permite analizar según la ética amorosa caballeresca lo que es conveniente o inconveniente en una determinada situación en la que se halla mezclado el sexo femenino y actuar en consecuencia. Pero no se queda 
Lanzarote ahí ya que juzga las actuaciones de los demás en situaciones similares o censura las posiciones que adoptan los que le rodean, aunque sea la reina misma. Se opone, en suma, como buen conocedor a los que desconocen todo del amor:

$$
\begin{aligned}
& \text { s'ai fet ce geu don an me blasme } \\
& \text { et de ma dolçor m'anertume, } \\
& \text { par foi, car tex est la costume } \\
& \text { a cez qui d'amor rien ne sevent } \\
& \text { et qui enor en honte levent }
\end{aligned}
$$$$
\text { Charrete, } 4382 \text { - } 4386
$$

onques amors bien ne conut

qui ce me torna a reproche

Charrete, 4354 - 4355

mes tant cuit je d'amor savoir, que ne me deüst mie avoir por ce plus vil, s'ele m'amast (..) ce deüst ele amor conter Charrete, 4365 - 4374 or sont cil d'amors non sachant qui ensi les vont despisant

Charrete, 4389 - 4390

El sometimiento violento al que el corazón de los amantes se ve forzado por el amor todopoderoso, se traduce en la aparición del sustantivo en función de sujeto de verbos en tercera o en primera persona que expresan 
mandato como comander, desfendre o justiser. "con cil qui force ne deffanse n'a vers amors qui le justise" (Charrete, 712 - 713), consejo como enorter y semondre: "mes amors est el cuer anclose qui li comande et semont" (Charrete, 372 - 373), ruego como prier o voluntad como voloir: “Amors le vialt et il i saut" (Charrete, 375). A menudo coordinados formando parejas, estos verbos adquieren sentidos muy similares y su unión refuerza la impresión de dominio de lo que en Charrete es ya una personificación: "amors le comande et vialt" (Charrete, 377), "il lait ce qu'amors li desfant et la ou ele vialt antant" (Charrete, 1241 - 1242), "Vilenie premierement, ce dist Amors, voel et conment que tu gerpisses" (Rose, 2074,1 - 2074,3). A esta serie hay que añadir el recurso a las perífrasis factitivas en las que Amor sigue siendo el sujeto y que añaden la obligatoriedad a la expresión de la acción verbal.415

La preferencia por el héroe de la carreta unida al enorme poder del amor tienen dos efectos principales en el comportamiento guerrero y amoroso de Lanzarote: se elimina la dispersión sentimental y en cierta forma el héroe se ve forzado a la fidelidad absoluta al dominar sus instintos mediante la condensación de las tendencias afectivas: "tot le fet en un leu ester amors, qui toz les cuers justise" (Charrete, 1232 - 1233), y como consecuencia de ello su fuerza y su orgullo caballerescos, impulsados por el acicate de la pasión reprimida, superan a sus contrincantes: "amors le cuer celui prisoit si que sor toz le justisoit et li donoit si grant orguel" (Charrete, 1237 - 1239). El amor llega a convertirse en Charrete en una fuerza benéfica para el caballero que le ayuda a superar todos los obstáculos y a mejorarse en la lucha: "et force et hardemanz li croist qu'amors li fet molt grant aïe" (Charrete, 3720 - 3721)

\footnotetext{
Amors et haïne mortex si granz qu'ainz ne fu encor tex, le font si fier et corageus
}

Charrete, 3725 - 3727

\footnotetext{
415 Especialmente en Rose. "s'Amors le fet par force amer" (Rose, 3247); "s'Amors le tient pris en ses giez et le fet a vos obeir" (Rose, 3260 - 3261).
} 
Otros caballeros, incluso paganos, también se ven impulsados a buscar la victoria en la batalla para honrar el amor de sus amigas: "L'amors s'amie li enorte k'il soit prex et frans et hardis" (Escoufle, 1164 - 1165). De igual modo aguijonea en su tarea intelectual al ya experto en amores y narrador de Rose y le insta a que comience su obra:

$$
\begin{aligned}
& \text { Or veil cel songe rimeer } \\
& \text { por vos cuers plus feire agueer, } \\
& \text { qu'Amors le me prie et comande } \\
& \text { Rose, } 31 \text { - } 33
\end{aligned}
$$

Sin embargo, en el caso del angustiado e inexperto Guillermo, ajeno a las luchas de los guerreros, el amor se hace más acuciante y se convierte en un yugo, en una fuerza negativa, que lo oprime y tortura como al amante de la rosa: "mout me grieve Amors et tormente" (Rose, 2450), ${ }^{416}$ "li damoisiax ne set que faire, k'amors le destraint et encauce" (Escoufle, 3202 - 3203), “ml't est cele amours de mal'aire ki si le travaille et ocist" (Escoufle, 6936 - 6937), al que priva de los rasgos que caracterizan al noble e incluso al ser humano: "or saciés que ml't fait amours qui si l'avile et despersone" (Escoufle, 6305 6306). Un proceso similar afectará a Narciso, pero en su caso, tras un profundo dolor provocado como en E scoufle por la imposibilidad de unirse al ser amado, desembocará en la muerte:

$$
\begin{aligned}
& \text { et tant le sot Amors destraindre } \\
& \text { et tant le fist plorer et plaindre } \\
& \text { qu'il li covint a rendre l'ame }
\end{aligned}
$$$$
\text { Rose, } 1439 \text { - } 1441
$$

Así pues, el dolor y las alegrías de los amantes dependen del poder y del capricho del amor que, en último término, se encuentra en el mismo nivel que el destino rigiendo sus encuentros y desencuentros: 
C'est Fortune ki le desvoie

et li diex d'amors qui n'a cure

k'il de si gentil creature

puist encore a la joie ataindre

Escoufle, 5160 - 5163

Esto es sobre todo válido para los varones en los textos del siglo XIII, donde se exacerba la sumisión a las fuerzas contradictorias de la pasión merced a la inexperiencia no sólo amorosa sino vital de los jóvenes héroes. En Tristan las penalidades, aunque tienen su origen en el amor, son más bien físicas — hambre, incomodidades y proximidad de la muerte en el suplicio-: "mot les avra amors pené: trois anz plainiers sofrirent peine, lor char pali et devint vaine" (Tristan, 2130 - 2132), y en Charrete se desarrolla un motivo metafórico tradicional que hemos estudiado con el verbo aimer, el amor es una herida en el corazón que puede agravarse en circunstancias adversas:

Amors molt sovant li escrieve

la plaie que feite li a;

onques anplastre n’i lia

Charrete, $1336-1338417$

Pero también la perspectiva de hallarse cerca de la amada puede convertirse en un bálsamo para las tremendas heridas que el paso del Puente de la Espada causa al héroe:

416 “Amors durement me tormente” (Rose, 2883), “Amors malement me jostice” (Rose, 3225).

417 Guillaume de Lorris recurre con asiduidad a esta imagen de la herida, principalmente gracias al sustantivo plaie o el verbo plaier que se adaptan a los motivos del dios arquero y cazador, llegando incluso a desarrollar una personificación:

$$
\begin{aligned}
& \text { Mout me destraint iceste plaie, } \\
& \text { qui me semont que je me traie } \\
& \text { vers le boton qui m'atalante. } \\
& \text { Rose, } 1777 \text { - } 1779
\end{aligned}
$$


mains et genolz et piez se blece, mes tot le rasoage et sainne

amors qui le conduist et mainne,

si li estoit a sofrir dolz

Charrete, 3112 - 3115

Los sufrimientos del amante, antes psicológicos que físicos, superan con creces según el dios Amor las peores enfermedades del cuerpo; 418 el dios anuncia al joven enamorado de la rosa días y noches de terribles padecimientos siempre en absoluta soledad para poder ocultar a los demás sus sentimientos: "les teniebres ou li cuers gist qui nuit et jor d'amors languist" (Rose, 2731 - 2732); y en efecto, llegará a desear la muerte al impedirle acercarse a la amada, no sólo a causa de las imposiciones sociales y el pudor femenino, sino también por los preceptos de un amor excesivamente exigente con sus fieles seguidores:

Que trop li fait Amors mal treire.

Il a tant mal que il n'eüst mestier de pis, s'il vos pleüst.

Rose, 3288 - 3290

Mas, de igual forma que el Amor produce dolor puede llevar la alegría a los enamorados al ofrecerles pequeños respiros en forma de esperanza, de recuerdos, de miradas o de besos, o al colmar por completo sus deseos y otorgarles el amor y el cuerpo de la amada:

mes se tant fait Amors que j’oie de m’amie enterine joie,

\footnotetext{
418

onques fievres n'eüs si males,

ne cotidianes ne quartes.

Bien avras, ainz que tu t'em partes,

les doulors d'amors essaïes
}

Rose, 2268 - 2271 
bien seront mi mal acheté!

Rose, 2451 - 2453

La relación del amor como ente próximo a una personificación con la heroína de E sooufle sufre una interesante modificación respecto de la que hemos observado con Guillermo. Deja de ser una fuerza opresiva para convertirse en un consejero que conversa y discute con ella, le ayuda a elegir un camino, a decidirse en los momentos de duda, incluso cuando aparece una perífrasis factitiva. ${ }^{419}$ De ahí que se reserven los verbos en los que se mantiene un sentido belico como abatre, somonter y boter amiere, ${ }^{420}$ para otros entes abstractos como la razón o el sentido común. Se nos muestra así Aelis como un ser más autónomo y quizá más próximo a las heroínas e incluso a los héroes de los romans del siglo XII. Buena prueba de ello son los verbos de los que el sustantivo amour es sujeto y el nombre de la joven o los pronombres que lo sustituyen son complemento directo o indirecto tales como escoler. "hardemens et amors l'escole" (Escoufle, 3946), dire o faire, ${ }^{421}$ e incluso oposer y boter con un sentido discursivo más de consejo para que venza la vergüenza y el pudor que de oposición argumentativa:

\section{Mais amours l'oposoit et boute, et dist: «C’est il, car li ceur seure!»}

Escoufle, $7602-7603$

Sentidos que, en el pleito entablado entre Razón y Amor en torno a la figura de Lanzarote, quedaban reservados para los verbos como chastier, anseigner y dire —matizado incluso gracias a la modalización introducida

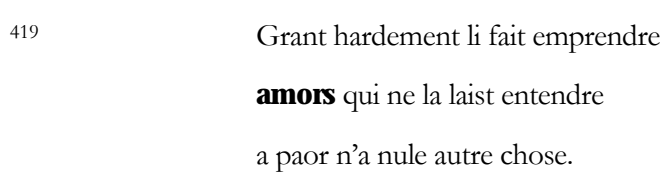

Escoufle, 3891 - 3893

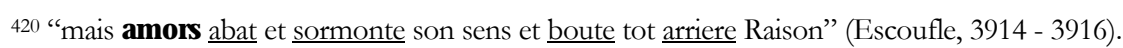


por el verbo oser-: “n'est pas el cuer, mes an la boche, Reisons qui ce dire li ose" (Charrete, 370 - 371) ${ }^{422}$, referidos a Razón, quien, como correspondía a su configuración arquetípica, debía conquistar mediante el discurso razonado y nunca mediante la imposición irracional que hemos visto correspondía al segundo. Esta batalla se convierte en un lugar común como muestra del inmenso poder del amor y lo observaremos gracias a las personificaciones de E scoufle. "ml't a grant bataille et envie entre amor et raison et sens" (Escoufle, 3928 - 3929), "Ne traient pas a unne corde sens et amours uniement" (Escoufle, 7564 - 7565), y a los personajes alegóricos de Rose. En este roman Razón y Amor ya no se enfrentan directamente en la mente y el corazón del héroe en un monólogo interior. Dada la supremacía del dios sobre los enamorados, solamente cuando éste ya ha desaparecido del relato y ante la desesperación del joven, Razón intenta convencer al amante de que su sumisión es una locura dolorosa que lo lleva a la enfermedad y a la angustia impidiéndole alcanzar la felicidad, el conocimiento y la vida honrada del trabajo o el estudio. De nuevo se recuperan las mismas o similares formas verbales en cuanto a su significado - dire, conseillier-, también acompañadas de un verbo modalizador: "Or te veil dire et conseillier que l'amor metes en oubli', (Rose, 3002 - 3003),

$$
\begin{aligned}
& \text { Or met l'amor en nonchaloir, } \\
& \text { qui te fait vivre, et non valoir, } \\
& \text { que la folie adés engraigne }
\end{aligned}
$$$$
\text { Rose, } 3047 \text { - } 3049
$$

\footnotetext{
421 "Fait amors: «Or avés vous tort, Aelys, que nel connoissiés." (Escoufle, 7656 - 7657).

422 Mes Reisons, qui d'amors se part,

li dit que del monter se gart,

si le chastie et si l'anseigne

Charrete, $365-367$
} 
También es un lugar común la visión del amor como un estado de ánimo contradictorio en el que se pasa de la calma y aun de la alegría al abatimiento y el dolor sin solución de continuidad, y en el que incluso este último puede hacerse placentero como ya ha quedado dicho en el caso del esforzado Lanzarote. Estas contradicciones son explotadas con intensidad por Guillaume de Lorris, ya sea mediante una sentencia en el discurso directo del narrador: "Amors se rechange sovent, il oint une eure, autre eure point, Amors n'est gueres en un point" (Rose, 3478 - 3480), o en la descripción de las flechas pre-alegóricas origen del enamoramiento. Es el caso para la denominada Bel Accueil que penetra con facilidad en el corazón del enamorado y acelera el proceso que lo llevará al cautiverio, pero al tiempo hace olvidar los primeros sinsabores con la aparición de la esperanza de la conquista o de los sentimientos compartidos:

$$
\begin{aligned}
& \text { Ele est aguë por percier, } \\
& \text { tranchant come rasoer d'acier, } \\
& \text { mes Amors avoit mout bien ointe } \\
& \text { d'oignement precieus la pointe, } \\
& \text { por ce qu'ele ne puist trop nuire } \\
& \text { Rose, } 1843 \text { - } 1847
\end{aligned}
$$

Ya en el discurso directo del dios Amor se nos presentan algunas de las ayudas que el enamorado recibe para soportar los sufrimientos amorosos. Éstas le deparan alguna alegría, como la esperanza, el oír hablar de la persona amada, las miradas tiernas y el recuerdo de una sonrisa o de una buena cara. ${ }^{423}$ Pero el narrador insiste en que su naturaleza inestable permanece y en que

\footnotetext{
423 Li premiers biens qui solaz face

ceus que li laz d'Amors enlace

est Douz Pensers, qui lor recorde

ce ou esperance s'acorde.
}

Rose, 2629 - 2632 
puede arrancar al amante de la felicidad cuando creía haber alcanzado su meta y obligarle a reanudar sus esfuerzos y a sufrir de nuevo:

\author{
mes Amors est si corageus \\ qu'il me toli tot en une eure, \\ quand je cuidai estre au deseure
}

Rose, 3950 - 3952

Tristan, Escoufle y de manera menos explícita Rose comparten otro tópico, que por el contrario desaparece en el texto de Chrétien. Se trata de la imposibilidad de fingir, de ocultar el amor a los que rodean a los amantes: "Ha! Dex, qui puet amor tenir, un an ou deus sanz descovrir? Car amors ne se puet celer" (Tristan, 573 - 575); "Il n'est riens qui vers amor puisse bareter ensi longement: li celers ne li valt noient" (Escoufle, 2000 - 2002). ${ }^{424}$ En todos los casos se observan pruebas corporales inequívocas, ya sean las miradas, el roce de los cuerpos, el tono de voz, la incapacidad oratoria o la debilidad y delgadez de los que no son correspondidos. Por el contrario Lanzarote y muy especialmente Ginebra consiguen refrenar sus instintos e incluso mostrarse a veces excesivamente distantes, lo que les permite guardar las apariencias y mantenerse en la corte sin sospechas y aun como modelos para damas y caballeros.

En cuanto a los aspectos formales, es decir, de composición de los versos, observamos el relieve que se da en la obra de Béroul a los aspectos negativos del amor, de igual modo que en Escoufle. También a la compleja relación del amor tristaniano con la sociedad y sus instituciones sin excluir siquiera la rima amor / loisor que nos habla de las imposiciones externas a los amantes. Por otra parte en este mismo texto la mayor parte de las rimas corresponden al sustantivo en función de complemento de objeto directo, mientras que en la única ocasión en la que se encuentra en la primera posición del verso funciona como sujeto. Escoufle y Charrete utilizan mucho más a

${ }^{424}$ Victoria del signo erótico puesta de relieve por Barthes en Fragments d'un discours amoureux. París: Seuil, 1977, p. 53. 
menudo la posición inicial del verso y siempre en función de sujeto de la proposición, aunque nos parece curiosa la escasez de rimas en la obra de Chrétien. Da la impresión de que el autor pretendía evitar cualquier asociación — tan sólo con enors, que realza el elevado papel que se concede al amor en el funcionamiento del grupo de la caballería- y cualquier posición relevante que no fuese la inicial. Situación compositiva que se reproduce casi de forma idéntica en Rose, aunque en esta obra con la particularidad de que el sustantivo amour queda relegado en muchas ocasiones de la primera posición del verso por su función de complemento del nombre en el sintagma nominal li diex d'amor.

\begin{tabular}{|c|c|c|c|c|c|c|c|c|}
\hline FORMA & CA & BD & NV & RIMA & CA2 & NV2 & D & PERS \\
\hline amor & $\mathrm{S}$ & Escoufle & 3655 & amor & $\mathrm{S}$ & 3656 & $\mathrm{~N}$ & Narrador \\
\hline amor & $\mathrm{S}$ & Escoufle & 3656 & amor & $\mathrm{S}$ & 3655 & $\mathrm{~N}$ & Narrador \\
\hline amor & $\mathrm{S}$ & Tristan & 2722 & anor & $\mathrm{S}$ & 2721 & D & Iseut \\
\hline amor & $\mathrm{S}$ & Escoufle & 1991 & color & $\mathrm{S}$ & 1992 & $\mathrm{~N}$ & Narrador \\
\hline amor & $\mathrm{S}$ & Tristan & 2327 & desanor & $\mathrm{S}$ & 2328 & D & Iseut \\
\hline amor & $S$ & Tristan & 2233 & deshonor & $\mathrm{S}$ & 2234 & D & Tristan \\
\hline amor & $\mathrm{S}$ & Tristan & 1365 & dolor & $\mathrm{S}$ & 1366 & $\mathrm{~N}$ & Narrador \\
\hline amor & $S$ & Escoufle & 4489 & empereor & $\mathrm{S}$ & 4490 & $\mathrm{D}$ & Aélis \\
\hline amor & $S$ & Tristan & 2218 & error & $\mathrm{S}$ & 2217 & $\mathrm{D}$ & Iseut \\
\hline amor & $S$ & Tristan & 4193 & folor & $S$ & 4194 & $\mathrm{~L}$ & Iseut \\
\hline amor & $\mathrm{S}$ & Escoufle & 3412 & honor & $\mathrm{S}$ & 3411 & D & Guillaume \\
\hline amor & $S$ & Rose & 1460 & jor & $\mathrm{S}$ & 1459 & I & Écho \\
\hline amor & $\mathrm{S}$ & Tristan & 301 & leisor & $\mathrm{S}$ & 302 & $\mathrm{D}$ & Roi Marc \\
\hline amor & $S$ & Tristan & 496 & loisor & $\mathrm{S}$ & 495 & $\mathrm{D}$ & Iseut \\
\hline amor & $S$ & Escoufle & 5166 & plor & $S$ & 5165 & $\mathrm{D}$ & Narrador \\
\hline amor & $\mathrm{S}$ & Tristan & 37 & seignor & $\mathrm{S}$ & 38 & D & Iseut \\
\hline amor & $\mathrm{S}$ & Tristan & 2416 & seignor & $\mathrm{S}$ & 2415 & D & Tristan \\
\hline amor & $\mathrm{S}$ & Escoufle & 6083 & seignour & $\mathrm{S}$ & 6084 & $\mathrm{~N}$ & Narrador \\
\hline amoreites & $\mathrm{S}$ & Rose & 878 & floreites & $\mathrm{S}$ & 877 & $\mathrm{~N}$ & Narrador \\
\hline amors & $\mathrm{S}$ & Charrete & 4370 & enors & $\mathrm{S}$ & 4369 & D & Lancelot \\
\hline amors & $\mathrm{S}$ & Escoufle & 8076 & jors & $\mathrm{S}$ & 8075 & $\mathrm{~N}$ & Narrador \\
\hline amors & $S$ & Escoufle & 108 & mors & $\mathrm{S}$ & 107 & $\mathrm{~N}$ & Narrador \\
\hline amors & $S$ & Escoufle & 3743 & mors & $\mathrm{S}$ & 3744 & $\mathrm{~N}$ & Narrador \\
\hline amors & $S$ & Escoufle & 4567 & mors & $\mathrm{S}$ & 4568 & $\mathrm{D}$ & Guillaume \\
\hline amors & $\mathrm{S}$ & Escoufle & 5121 & ors & $\mathrm{S}$ & 5122 & D & Guillaume \\
\hline amors & $S$ & Escoufle & 6365 & ors & $\mathrm{S}$ & 6366 & D & Narrador \\
\hline amors & $\mathrm{S}$ & Rose & 2660 & secors & $\mathrm{S}$ & 2659 & D & Amour \\
\hline amors & $\mathrm{S}$ & Rose & 3404 & secors & $\mathrm{S}$ & 3403 & $\mathrm{~N}$ & Narrador \\
\hline amour & $S$ & Escoufle & 7578 & flor & $S$ & 7577 & $\mathrm{D}$ & Guillaume \\
\hline amours & $\mathrm{S}$ & Escoufle & 6361 & dolors & $\mathrm{S}$ & 6362 & $\mathrm{~N}$ & Narrador \\
\hline amours & $\mathrm{S}$ & Escoufle & 6304 & jours & $\mathrm{S}$ & 6303 & $\mathrm{~N}$ & Narrador \\
\hline amours & $\mathrm{S}$ & Escoufle & 7532 & jours & $\mathrm{S}$ & 7531 & $\mathrm{D}$ & Guillaume \\
\hline
\end{tabular}

Tabla 57. Rimas del sustantivo amour. 


\begin{tabular}{lllllllll}
\hline FORMA & CA & BD & NV & RIMA & CA2 & NV2 & D & PERS \\
\hline amistié & S & Escoufle & 3482 & lié & A & 3481 & N & Narrador \\
amistié & S & Escoufle & 3466 & pitié & S & 3465 & D & Guillaume \\
amitié & S & Rose & 1201 & pitié & S & 1202 & N & Narrador \\
amitié & S & Rose & 2517 & pitié & S & 2518 & D & Amour \\
amitié & S & Rose & 2074.1 & pitié & S & 2074 & D & Amour \\
\hline
\end{tabular}

Tabla 58. Rimas del sustantivo amitié.

Junto a las funciones de complemento de objeto directo y de sujeto a las que ya hemos hecho referencia, las más abundantes de las desempeñadas por el sustantivo amour son las de complemento circunstancial, fundamentalmente de causa, y la de complemento atributivo del nombre introducido por la preposición de, muy a menudo con un valor especificativo o restrictivo -entre otros en el sintagma li diex d'amors presente minoritariamente en Escoufle pero que se repite constantemente en Rose“qui le boivre d'amor nos aporta ensenble a boivre" (Tristan, 2218 - 2219), “ou l'art d'amors est tote enclose" (Rose, 38), "les dances d'amors et les notes" (Rose, 493), o bien indicando la pertenencia incluso cuando no se trata de un nombe propio: "Or va il mex en de amor li afaires" (Escoufle, 3656 3657). En Charrete, donde el complemento de nombre desaparece, la preposición de introduce un sintagma dependiente de una forma verbal: "tant cuit je d'amor savoir" (Charrete, 4365), "d'amor rien ne sevent" (Charrete, 4385), “m’aseüreroiz de vostre amor” (Charrete, 5482 - 5483), “qui d’amors se part" (Charrete, 365), o bien de un adjetivo: "cil d'amors non sachant" (Charrete, 4389).

En la función de complemento de causa está particularmente presente en la obra de Renart, introducido por las proposiciones por, par, de: "ne fu il mors d'amours?" (Escoufle, 6361) o bien cuando se trata del sustantivo amitié precedido por en: “ele li prie en amistié” (Escoufle, 3482), aunque es evidente que el amor se muestra en todos los textos como la razón primordial por la que se mueven los amantes o los que se sienten atraídos por ellos, como las doncellas en Charrete o los caballeros y burgueses en E scoufle. 
“jusqu'a demain i serai por amor de vos” (Charrete, 4518 - 4519), “por l'amor la roïne Ysout" (Escoufle, 4619), ya que sirve como fundamento de sus promesas: “je vos pramet par fine amor" (Tristan, 2722), de sus ruegos y de los intercambios de objetos simbólicos: "Beau sire, por l'amor de moi, portez l'anel en vostre doi” (Tristan, 2709 - 2710), así como de las enseñanzas del dios Amor al amante de la rosa: "si te dirai que tu doiz faire por amor dou haut seintuaire" (Rose, 2521 - 2522) o de los sufrimientos de los enamorados frustrados: "qui fust destroiz por s'amitié" (Rose, 1201), "que reposer ne puez en lit por s'amitié”' (Rose, 2516 - 2517).

El análisis de la sintaxis proposicional muestra en primer lugar la abundancia del nexo adversativo mais en Charrete y en Rose. En general tiende a oponer dos puntos de vista y dos formas de actuar: los de Lanzarote al ocupar el lugar preferente en el lado del amor, y en Rose el comportamiento del verdadero amante frente al de los que nunca podrían llegar a serlo: “mes qui d'amors se velt pener, il se doit cointement mener" (Rose, 2121 - 2122); o bien introduce los argumentos de Amor en contra de Razón. En el roman de Lorris además refuerza la tesis del poderío del amor y la incapacidad de los que están bajo su férula para liberarse: “qu’il en a poines maintes tretes. Mes Amors ne veut consentir que il s'en puise repentir." (Rose, 3250 - 3252), o bien señala el momento en que Amor reanuda su caza interponiéndose entre el joven y la despreocupada dicha que embargaba sus sentidos al encontrarse cerca del capullo de rosa:

\footnotetext{
ja mes n'ert rien qui tant me plaise

come estre illec a sejor,

n'en queïsse partir nul jor.

Mes quant g'i oi esté grant piece,

li dex d'Amors, qui tot despiece

mon cors dont il a fet bersaut,

me redonne un novel asaut

Rose, 1812 - 1818
} 
Por lo que respecta a las proposiciones subordinadas en las que se incluye el sustantivo amour, el texto de Béroul nos ofrece fundamentalmente proposiciones completivas, que a excepción de un ejemplo en que el verbo introductor es acroire: "li font acroire (ce me senble) que nos amors jostent ensenble" (Tristan, 29 - 30), dependen de verbos de dicción como dire, están ligados al discurso como alegier y jurer o bien, aunque no estén claramente expresados, el contexto los suple como ocurre en el discurso indirecto libre de Iseo en la Blanca Landa:

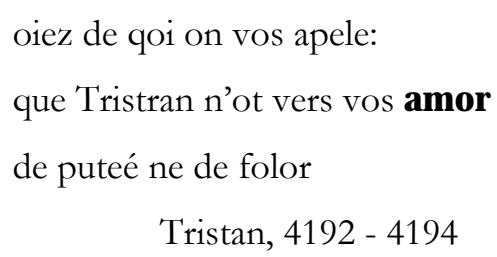

Del mismo modo que entre los complementos circunstanciales, la causa copa la expresión de las proposiciones subordinadas circunstanciales en las diferentes obras y se hace casi exclusiva en alguna de ellas. Chrétien utiliza las subordinadas causales para explicar las actitudes de los enamorados ya sea en el cortejo íntimo, en el campo de batalla o en el vagar del caballero enamorado; mientras que en Escoufle se prefiere mostrar las causas de las desdichas o del sufrimiento de los enamorados y especialmente de Guillermo. Guillaume de Lorris por su parte recurre a las proposiciones causales para explicar las razones del enamoramiento o de la escritura, así como de las acciones del enamorado.

\section{- Conjunción car.}

car a toz autres cuers failli

amors avers qu'au suen ne fist

Charrete, 4664 - 4665

car tot revient a fausse amor,

quant li amant ne sont ensamble

Escoufle, 5166 - 5167 
car Cupido, li filz Venus,

sema d'amors ici la graine

Rose, 1586 - 1587425

- Locución conjuntiva puis que [A dv. + $\mathbf{C}$ onj.]:

puis qu'amors le comande et vialt (Charrete, 377)

- Locución conjuntiva por ce que [Prep. + Pron. + C onj.]:

ml't en est abaissiés mes pris

por ce qu'il ert venus d'amors

Escoufle, 4566 - 4567

- Conjunción que, la más abundante:

et le plus bel sanblant li fet

que ele onques feire li puet,

que d'amors et del cuer li muet

d'amors vient qu'ele le conjot

Charrete, 4658 - 4661426

aperçui je qu'ele amoit miex

moi tot seul que tos ceus del monde,

que fine amors li areonde

tous les iex quant ele m'esgarde

Escoufle, 3162 - $3165^{427}$

425

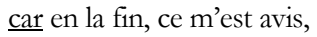

fera Amors de moi martir

Rose, $1834-1835$

426 "et force et hardemanz li croist qu'amors li fet molt grant aie" (Charrete, 3720 - 3721); "ne matiere ne lor failloit, qu'amors assez lor an bailloit" (Charrete, 4467 - 4468) 
si estuet il que j’i alasse,

qu'Amors, qui tote chose passe,

me donoit cuer et hardement

de feire son comandement

Rose, 1787 - $1790^{428}$

Las proposiciones subordinadas hipotéticas sirven en R ose para dar a conocer algunas de las reglas amorosas exponiéndolas como condiciones contrapuestas a los defectos que el amante debe evitar:

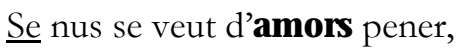

d'avarice trop bien se gart

Rose, 2206 - 2207

$\mathrm{Si}$ bien sus apariciones se concentran para volver a mostrar la absoluta dependencia del enamorado con respecto al amor, un sentimiento encorsetado por las estrictas normas de la cortesía a las que se unía la vigilante moral burguesa, y que hace que se desvanezca la capacidad de iniciativa que le daban su despreocupada inocencia y su deseo de descubrir nuevas sensaciones, aunque estuviesen coartados por la timidez propia del adolescente en un mundo del que desconoce las reglas y los peligros:

s'Amors veut ja que j'en garisse, que ja d'aillors ne quier que j'oie honor ne bien, santé ne joie.

$$
\text { Rose, } 3972 \text { - } 3974
$$

si n'avoie en nului fiance

fors ou diex d'Amors de l'avoir,

\footnotetext{
427 “Comment cuidiés vos je m'esjoie qui ai perdu si grant honor que tot mon cuer, tote m'amor ai mis en vos, sans traire arriere?” (Escoufle, 3410 - 3413)

428 "grant piece ai ilec demoré, qu’em Bel Acueil grant amor é et grant compaignie trovee" (Rose, 3361 $3363)$
} 
ainçois savoie bien de voir

que de l'avoir neant estoit,

s'Amors ne s'en entremetoit

Rose, 2758 - 2762

Así pues, el deseo de posesión y de felicidad aumenta a la par que la frustración - manifiesta en las negaciones-, en tanto que disminuyen sus posibilidades de conquista: "mar touchai la rose a mon vis et a mes ieuz et a ma bouche, s'Amors ne sueffre que g’i touche” (Rose, 3764 - 3766), y aunque a la postre ésta parecía encontrarse en el plan de la obra, el narrador anuncia que se hará gracias al esfuerzo del amor, es decir, de la sumisión, del sufrimiento físico y psíquico y quizás del esfuerzo intelectual y poético: "et li chastiaus riches et forz, qu'Amors prist puis par ses esforz" (Rose, 3485 3486), pero en modo alguno mediante los encuentros galantes, el contacto corporal y la alegría que presagiaban las primeras escenas del jardín de Deduit.

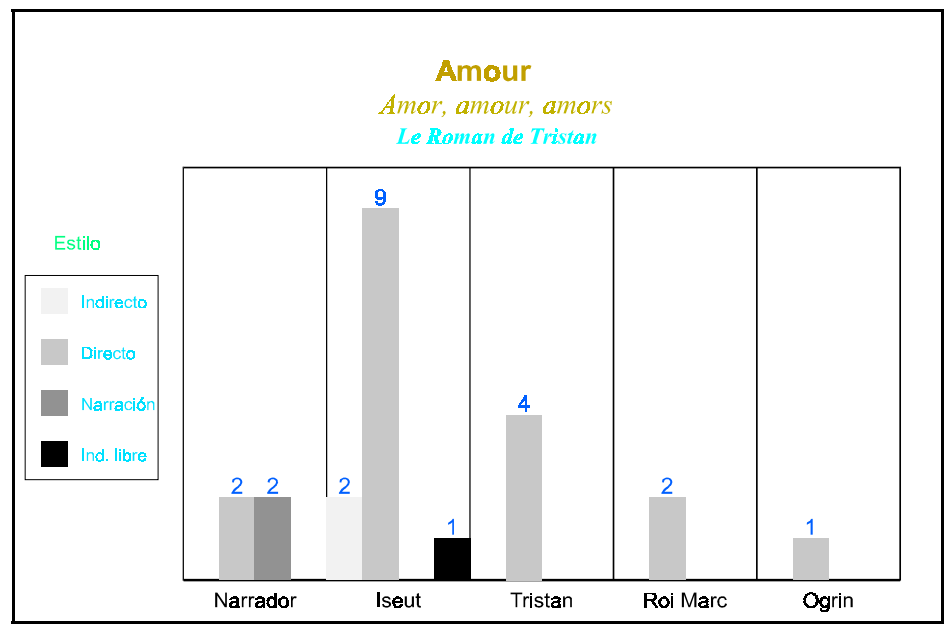

Fig. 67. Comportamiento estilístico del sustantivo amour en Tristan. 


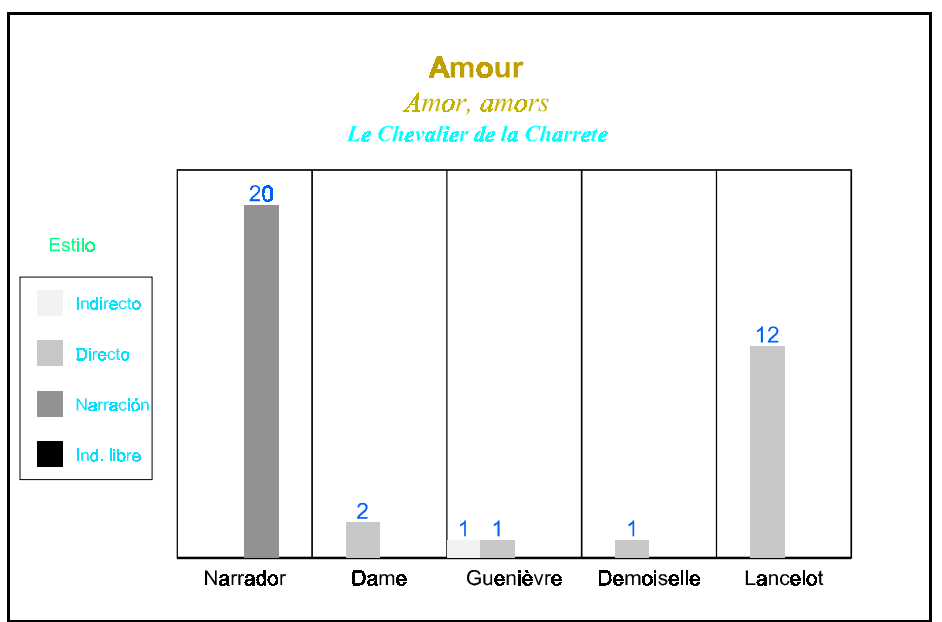

Fig. 68. Comportamiento estilístico del sustantivo amour en Charrete.

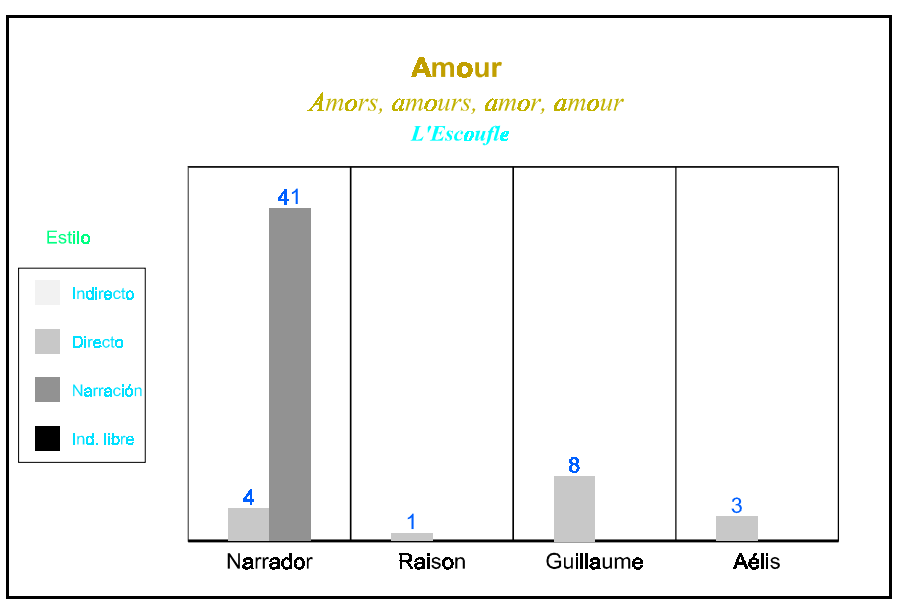

Fig. 69. Comportamiento estilístico del sustantivo amour en Escoufle.

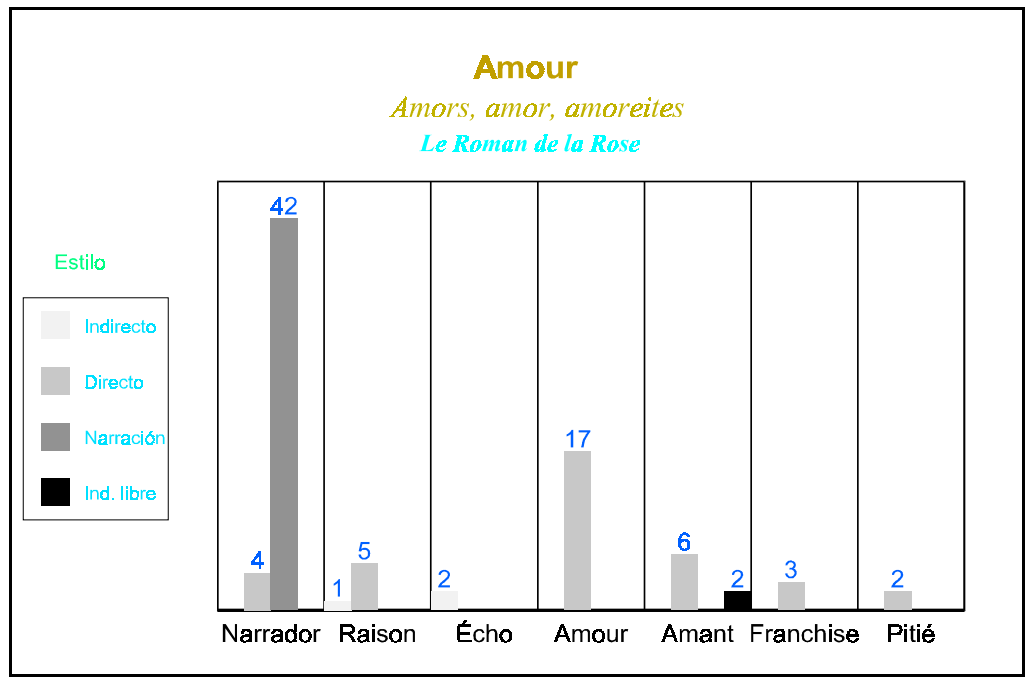

Fig. 70. Comportamiento estilístico del sustantivo amour en Rose. 


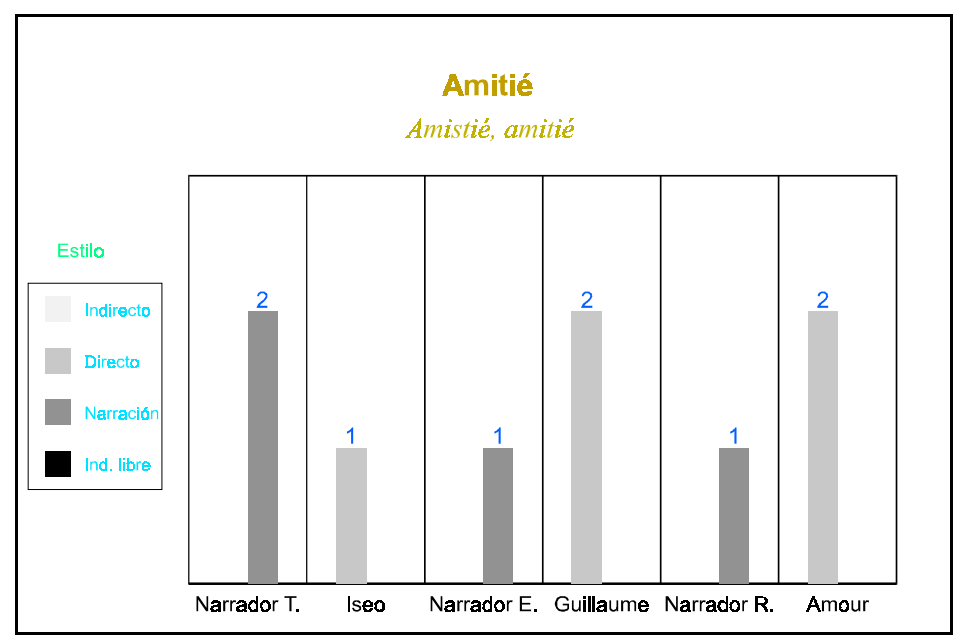

Fig. 71. Comportamiento estilístico del sustantivo amitié en el corpus.

Si excluimos el texto de Béroul, el resto del corpus tiende a ofrecer una visión analítica del sentimiento amoroso, de sus causas y de las consecuencias que tiene sobre la vida de los enamorados. Creemos que esto se ve reflejado en las ilustraciones precedentes pues, el narrador, incluso en mayor medida que para el verbo aimer, asume la voz principal y a ésta, completando su análisis, se suman la de Amor en Rose y las de los héroes enamorados Lanzarote y Guillermo. A ello tenemos que añadir dos fenómenos: en la obra de Lorris el narrador en primera persona adopta desde la distancia un doble papel y en general los narradores tienden a utilizar el discurso directo para implicar en su examen de la cuestión amorosa al receptor de la obra o bien para dar su opinión sobre las acciones de otros amantes literarios, algo poco habitual en otros contextos. Se nos puede objetar que el narrador de Tristan también adopta esta forma discursiva, de hecho de forma redundante al referirse en dos ocasiones a la imposibilidad de ocultar el amor, pero con ellas se agota el analizador. Por el contrario, siguiendo la misma pauta que con el verbo aimer, Iseo se hace cargo de la delicada estrategia que le permitirá a ella y a Tristán excusarse y apaciguar a la corte, al tiempo que astutamente reitera su amor por el joven caballero. 


\subsection{Rage.}

Representación de amor y deseo vehementes — de ahí la presencia de la rima corage tanto en Tristan como en Rose-, hallamos este sustantivo femenino en las obras del siglo XII con un sentido netamente peyorativo asociado a la pasión adúltera y a la irrefrenable ansia de goce, al loco amor de las reinas y sus caballeros. Béroul acude a este término para negar no sólo la relación que los felones utilizan como arma arrojadiza contra Tristán y la reina, sino la simple posibilidad del deseo, en este caso masculino, de que aquélla pudiera iniciarse: “onques n'oi talent de tel rage” (Tristan, 254). Por el contrario sirve para reafirmar la perturbadora inclinación de Ginebra hacia Lanzarote, aunque la razón le ayuda a refrenarla en presencia de la corte:

$$
\begin{aligned}
& \text { et se reisons ne li tolsist } \\
& \text { ce fol panser et cele rage, } \\
& \text { si veïssent tot son corage } \\
& \text { Charrete, } 6842 \text { - } 6844
\end{aligned}
$$

Tanto en Rose como en E scoufle desaparece la connotación negativa, aunque en ambos puede expresar el dolor y la rabia que sienten los amantes al verse separados de su pareja: "Douz Pensers ensint asoage la dolor d'amors et la rage" (Rose, 2651 - 2652). Renart utiliza rage en un fragmento prospectivo de la narración para expresar el contento, la alegría que produce el reencuentro así como el placer al que los enamorados se entregan en la primera noche de amor tras siete años de separación:

$$
\begin{aligned}
& \text { que cil plour a ris tourneront, } \\
& \text { que jou cuit bien qu'eles verront } \\
& \text { par tans en la cambre tel rage } \\
& \text { Escoufle, } 7671 \text { - } 7673
\end{aligned}
$$


Por su parte Lorris lo hace sinónimo de la irresistible y desmesurada inclinación que sienten los que acaban de enamorarse, una atracción fatal que los conduce hacia donde se halla el objeto de su deseo: “quant cele rage m'ot si pris, (...) vers les rosiers tantost me trés" (Rose, 1621 - 1623), que hace que cambie por completo su forma de pensar y de actuar — lo que se expresa mediante el adjetivo noveile- - que modifica sus deseos y les hace desechar la cordura y el buen juicio que los librarían de la locura a la que se ven empujados:

$$
\begin{aligned}
& \text { Ci sort as genz noveile rage, } \\
& \text { ici se changent li corage, } \\
& \text { ci n'a mestier sens ne mesure } \\
& \text { Rose, } 1581 \text { - } 1583
\end{aligned}
$$

Sintácticamente merece ser destacada la anteposición — siempre que en el contexto se aluda a amantes concretos- del adjetivo indefinido tel, con sentido deíctico en Tristan y como anuncio de una subordinada comparativa en Escoufle, o del artículo demostrativo cele con un valor anafórico. En cualquier caso queda excluida la indeterminación gracias a un adjetivo calificativo o a un artículo determinado, pues se trata de un sentimiento más fuerte que el denominado por el sustantivo amour, cuyo uso se podía extender a otros ámbitos en los que no interviniese la pareja.

\subsubsection{EL PODER DEL AMOR.}

La ya tópica fuerza del amor se manifiesta de diversos modos en nuestros textos: transfigurada en el engaño, la mentira y el disimulo propios de la naturaleza de Eros, se hace cómplice de los amantes frente a la sociedad coercitiva y moralista, y secundariamente se ofrece como un instrumento de conquista en Rose bajo la influencia de la tradición ovidiana; también es violencia, amenaza, sufrimiento físico y mental para los amantes. Esta cara 
monstruosa que puede llevar a la autodestrucción queda iluminada con mayor intensidad en la personificación creada por Lorris, quien recoge la tradición clásica, las formulaciones corteses y los sobrentendidos existentes en romans como Tristan. Este autor construye el personaje alegórico Amor como una institución en el sentido que Berrendonner da a este término, ${ }^{429}$ pues Amor es un elemento del relato cuya existencia se pone de manifiesto fundamentalmente por la aparición de discursos reglamentativos en los que se combinan la evaluación y la prescripción. Por otra parte, su poder queda justificado gracias a una indiscutible superioridad social que nace de las relaciones feudales y de su desarrollo económico e impositivo, y es en primera instancia ejercido mediante actos ilocutivos que se representan con imperativos o con verbos performativos explícitos; éstos quedan formulados a menudo de forma poco ortodoxa según las teorías que versan sobre la acción y el lenguaje cuando el narrador los recoge en su discurso, algo que sin embargo no es de extrañar si tenemos en cuenta que Amor es un avatar psicológico del erotismo masculino que el narrador - amante asume sin oposición.

\subsection{1 «Afolen», blesser y navrer.}

Estos verbos desarrollan en Rose el lugar común por el que el nacimiento del amor se concibe como una herida, en el caso del infinitivo afoler, sin efusión de sangre — sentido añadido que posee generalmente este verbo- Estamos ante la consecuencia lógica de la adopción de la figura alegórica del dios Amor, trasunto del romano Cupido, quien lanza la tercera flecha al corazón, cuando ya el daño es irreparable, mientras que las dos anteriores habían penetrado por los ojos: “si que par l'ueil ou cuer m’entra la saiete qui me navra” (Rose, 1741 - 1742). El discurso del narrador en primera persona acumula varios términos — esforcier, grever, pener, poine- que

${ }^{429}$ A. Berrendonner, É léments de pragmatique linguistique. París: Les Éditions de Minuit, 1982, p. 95, n. 3. 
abundan en este tema al tiempo que diversifican la expresión alternando los esfuerzos, la tenaz persecución del sentimiento por penetrar en el corazón del amante que había sido atraído físicamente con el dolor agudo que siente y le impide la huida:

\author{
Mes li archiers, qui mout s'esforce \\ de moi grever et mout se poine, \\ ne m'i let pas aler sanz poine, \\ ainz m'a fet, por mieuz afoler, \\ la tierce floiche ou cors voler, \\ que Cortoisie ert apelee. \\ Rose, 1760 - 1765
}

Las formas del verbo blesser sólo en Rose se utilizan para describir las causas del enamoramiento mediante una primera alusión a las flechas que Doux Regard lleva en su mano derecha: "Une de celes qui plus bleice rot non, ce m’est avis, Simpleice" (Rose, 939 - 940). Pero también reflejan las consecuencias físicas y mentales que el arraigo de este sentimiento produce. La presentación de la debilidad corporal del enamorado mediante una construcción que marca la analogía con un hombre herido, en la que el participio pasado bleciez funciona como un adjetivo: "foibles et vains come bleciez" (Rose, 1792), abre una fisura en la construcción metafórica del enamoramiento en forma de ataque del dios arquero al distinguir entre un herido real y uno simbólico. De hecho, la coordinación con el verbo nuire en el discurso de Amor refuerza el sentido figurado ya que prevalecen las nociones de daño moral, de tormento inmaterial. Este sufrimiento obligado funciona como una purificación ascética del deseo del amante con la finalidad principal de centrarlo en una sola mujer. Si soporta el dolor y se mantiene fiel, no sólo a su amada sino también al código amoroso, la recompensa será la cura, es decir la entrega afectiva y erótica: 
Aten et suefre la destrece

qui orendroit te nuit et blece,

car je sai bien par quel poison

tu seras trez a gairison.

Rose, 2029 - 2032

El verbo navrer en pretérito perfecto o pluscuamperfecto vuelve a otorgar el protagonismo, ya sea directo o metonímico, al dios Amor. En el discurso del narrador y del amante se recupera la imagen del arquero, principio y quizás fin de los sufrimientos del enamorado: "se vostre main, qui m’a navré, ne me done la guerison" (Rose, 1910 - 1911), y el relato del comienzo de su dolorosa pasión es utilizado para pedir a Bel Accueil la primera muestra de la aceptación del cortejo, el tan ansiado beso que debería inaugurar la intimidad de los jóvenes y el ascenso hacia la conquista de los sentimientos y del cuerpo de la mujer: "Lors ai pris cuer et hardement de dire Bel Acueil coment Amors m'avoit pris et navré” (Rose, 2867 - 2869).

\subsection{2 «Agaitien».}

Mediante este verbo se actualizan dos subconjuntos conceptuales que servían tradicionalmente para explicar el enamoramiento partiendo de la idea inicial de la caza. ${ }^{430}$ Por un lado se presenta un nuevo aspecto de la divinidad del amor, es un cazador que sigue a sus presas y espera el momento oportuno para herirlas: “et li dex d'Amors m’a seü endementieres aguetant con li vanieres qui atant que la beste en bon leu se meite" (Rose, 1418 - 1421). En el discurso de Aelis encontramos una variante de este predador, el amor es un pescador que lanza su anzuelo en busca de presas: "Amors nos a pris a son haim” (Escoufle, 3248). Por otro, el espejo maravilloso que se encuentra en el jardín de Deduit, con toda probabilidad los ojos femeninos que hechizan a los

430 Los troveros acudían con asiduidad a las imágenes de la caza, ya fuera caza con trampas, cetrería o caza mayor; véase en este sentido R. Dragonetti, op. ait., p. 211 - 212. 
que se acercan a mirarlos y que permiten espiar todas las promesas del jardín, es una trampa que ha atrapado a todos los que han osado mirarlo y en especial a los mejores, los más valientes, los mejor educados, es decir, aquéllos que merecen amar:

\author{
Maint vaillant home a mis a glaive \\ cil miroërs, car li plus saive, \\ li plus preu, li mieuz afetié \\ i sont tost pris et agaitié.
}

Rose, 1577 - 1580

Las formas del verbo también son significativas: mientras el participio presente, que funciona aquí como gerundio, se refiere al sujeto del verbo principal, el dios Amor, y completa la acción de aquél, el participio pasado forma parte de una construcción pasiva reforzada semánticamente por la coordinación de los sinónimos pris y agaitié, cuyo sujeto, pasivo, son los hombres enamorados, una masa de individuos incapaces pese a sus cualidades, o más bien debido a ellas, de hacer frente a la sagacidad de sus contrincantes: una abstracción y una sensación nacida del instinto.

\title{
3.2.2.1.2.3 Assailliry assaut.
}

La guerra es una metáfora ya tradicional en la literatura amatoria nutrida en esta época por los vínculos que se establecen entre el poder económico, social e ideológico y un estado de permanente belicosidad que afecta a todos los estratos y a todas las clases sociales. Guillaume de Lorris y Jean Renart se valen del sustantivo assaut para representar dos de las posibles variaciones eróticas. Ambos coinciden en la concepción lógica y formal del contexto al hacer depender el elemento nominal como complemento de objeto directo de verbos iterativos construidos con el prefijo re-, que se repite en E scoufle con el verbo remetre: 
- El recuerdo del amante del que ha sido separada, forma tópica del amor contrariado, refuerza en Aelis el deseo de poseerlo y la intensidad de su pasión. El narrador evoca por vez primera la abstracción personificada del amor, aunque en E scoufle no sea identificada como una divinidad: "Amors li refait .j. assaut ki li remet celui devant si bel, si preu, si avenant" (Escoufle, 3222 - 3224).

- El narrador de Rose continúa la descripción del proceso de fijación amorosa con un nuevo ataque del dios Amor que lanza otra flecha al corazón del amante:

li dex d'Amors, qui tot despiece mon cors dont il a fet bersaut, me redonne un novel asaut

Rose, 1816 - 1818

El verbo en construcción pasiva se utiliza en esta obra para mostrar la pugna entre las fuerzas instintivas y las fuerzas sociales para lograr la liberación o la represión sexual de las jóvenes:

Chasteez, qui dame doit estre et des roses et des boutons, ent asaillie de glotons si qu'ele avoit mestier d'aï; et Venus l'avoit envaïe Rose, 2830 - 2834

El discurso eclesiástico que preconizaba el control absoluto del sexo, y si cabe con mayor énfasis del sexo femenino, fue asimilado con suma facilidad por las capas intermedias de la burguesía, las más numerosas y, prestamente, se convirtió en uno de los pilares ideológicos de los pujantes grupos sociales residentes en las ciudades. En el fragmento citado 
observamos cómo se insiste, mediante las metáforas bélicas y el uso de la denominación injuriosa gloton, en dos aspectos: en el papel de víctima asumido por el valor que se había impuesto como la virtud familiar y social por excelencia, y en la necesidad de reforzar sus defensas para contrarrestar el indudable poder no sólo del instinto sino de la tradición, que todavía se mantenía entre las clases populares y aún en cierta medida entre la aristocracia y permitía una mayor libertad sexual.

\subsection{Commander y commandement.}

El amor cortés es en gran medida sometimiento simbólico masculino como compensación del sometimiento real y cotidiano en el que vivía la mujer. En los relatos cuya filiación remonta al amor trovadoresco la sumisión a las reglas del amor, personificado o no, y a la voluntad femenina son dominantes. Mientras que en E scoufle el verbo nos muestra más bien una cierta colaboración de los amantes, quienes, según el ámbito y la situación en los que se encuentran, son el elemento dominante o el dominado, aunque compensan este sometimiento coyuntural gracias a la comunión en el placer.

Además de estas consideraciones generales y de las que ya hemos realizado más arriba al analizar el comportamiento del sustantivo amour en cuanto fuerza irracional que marcaba la vida de los amantes, y particularmente en su forma personificada o alegórica en las que aparecía como sujeto del verbo comander, merece la pena que destaquemos algunos aspectos formales que caracterizan ambos términos.

En primer lugar, las construcciones duales en las que las formas del verbo aparecen coordinadas con las de otro verbo y que con ligeras modificaciones o permutas se mantienen en Charrete y Rose: comander / voloir. "amors le comande et vialt" (Charrete, 377), "et por ce que fins amanz soies, veil je et comant" (Rose, 2227 - 2228); comander / prier. "ele 
li comande et prie" (Charrete, 5878), "Amors le me prie et comande" (Rose, 33); comander / enchargier. "encor te comant et encharge" (Rose, 2543); baillier / comander. "avez bailliee et comandee l'amor" (Charrete, 5487 $5488)$.

En el último par de formas encontramos una variación sustancial con respecto a las anteriores: frente a construcciones activas en las que el verbo expresa la voluntad y el poder del sujeto, la dama o el amor, en el último emparejamiento se pone de relieve al contrario una situación de pasividad por parte del sujeto que se ha colocado bajo la tutela del ser amado al entregarle su amor. Una relación idéntica a la que se observa en otro episodio de Charrete en el que la constancia amorosa de Lanzarote se deduce de la sumisión de su corazón a la autoridad jerárquica de la amada. En este caso el participio pasado comandez funciona sintácticamente como atributo del verbo estre:

$$
\begin{aligned}
& \text { Li chevaliers n'a cuer que un } \\
& \text { et cil n'est mie ancor a lui, } \\
& \text { einz est comandez a autrui } \\
& \text { si qu'il nel puet aillors prester. }
\end{aligned}
$$

Charrete, $1228-1231$

La misma noción de fidelidad, de la que el dios Amor en una frase sentenciosa distingue las facetas física y afectiva, encarnada ésta también por el corazón, se establece mediante el sustantivo comande, que introducido por la preposición en funciona como complemento circunstancial del verbo avoir. "Il est assez sire dou cors qui a le cuer en sa comande" (Rose, 1994 - 1995).

Las ocurrencias del sustantivo comandement están siempre precedidas de un artículo posesivo de tercera: "son comandemant" (Charrete, 4392) o de segunda persona: “voz comandemenz” (Rose, 2043), a excepción de una que en el discurso del dios Amor se encuentra especificada 
mediante una frase de relativo con la aparición redundante del verbo comander en primera persona: "les comandemenz que je coment as fins amanz" (Rose, 2039 - 2040).

En el aspecto sintáctico hay que poner de relieve que el sustantivo funciona, si exceptuamos dos complementos circunstanciales introducidos por una preposición: “"or soit a son comandemant)" (Charrete, 4076), como complemento de objeto directo de verbos como faire: "ainz me sui penez longuement de fere son comandement” (Rose, 3213 - 3214) y acomplir. “et coment tu acompliras nuit et jor les comandemenz” (Rose, 2038 - 2039), que definen la actitud del amante; enchargier. "voz comandemenz m'enchargiez" (Rose, 2043), "li diex d'Amors lors m'encharja, tot issi com vos oroiz ja, mot a mot ses comandemenz” (Rose, 2055 - 2057), que recoge la actividad didáctica del dios Amor, y doter. "qui son comandemant ne dotent" (Charrete, 4392), que en forma negativa alude a la actitud desafiante de los que no aman. Por otro lado, en los ejemplos anteriores se advierten diferencias en el sentido de los sustantivos según se hallen en singular o en plural. En singular expresan el acto y el poder o el derecho de ordenar, mientras que el plural indica las reglas de conducta establecidas por la autoridad divina.

Las rimas nos muestran fundamentalmente la asociación en los tres textos de los términos que nos ocupan con formas del verbo demander, que significa según el contexto «pedin» o «preguntan». Con ello se redunda en la ligazón entre el acatamiento y la prepotencia dentro del triángulo formado por los amantes y los sentimientos, a lo que se sumaría en Rose el aspecto didáctico. 


\begin{tabular}{lllllllll}
\hline FORMA & CA & BD & NV & RIMA & CA2 & NV2 & D & PERS \\
\hline comande & V & Charrete & 4394 & amande & V & 4393 & D & Lancelot \\
comande & V & Rose & 33 & demande & V & 34 & D & Narrador \\
comande & S & Rose & 1995 & demande & V & 1996 & D & Amour \\
comande & V & Charrete & 5856 & mande & V & 5855 & D & Lancelot \\
comandee & O & Charrete & 5487 & demandee & O & 5488 & D & Dame \\
comandemant & S & Charrete & 4076 & estrangemant & D & 4075 & D & Lancelot \\
comandement & S & Rose & 1790 & hardement & S & 1789 & N & Narrador \\
comandement & S & Rose & 3214 & longuement & D & 3213 & N & Narrador \\
comandemenz & S & Rose & 2039 & amanz & S & 2040 & D & Amour \\
comandemenz & S & Rose & 2057 & romanz & S & 2058 & N & Narrador \\
comander & I & Rose & 3148 & amender & I & 3147 & D & Amant \\
comander & I & Charrete & 6593 & demander & I & 6594 & D & Lancelot \\
comandé & O & Rose & 2567 & demandé & O & 2568 & N & Narrador \\
comandoit & V & Rose & 1757 & tendoit & V & 1758 & N & Narrador \\
commande & V & Escoufle & 4321 & viande & S & 4322 & N & Narrador \\
commandé & O & Escoufle & 3665 & demandé & O & 3666 & N & Narrador \\
\hline
\end{tabular}

Tabla 59. Rimas del verbo commander y del sustantivo commandement.

En Rose la mayor parte de las proposiciones en las que encontramos el verbo commander o el sustantivo commandement son proposiciones principales, y casi en su totalidad el sujeto es el dios Amor. En cuanto a las proposiciones subordinadas, de nuevo destacan las circunstanciales que expresan la causa introducidas o no por una conjunción:

\author{
«Des qu'ele le comande, \\ li respont, la soe merci.» \\ Charrete, 5856 - 5857
}

- Or m'an puis a neant tenir,
fet la dame tot an rïant;
autrui, par le mien escïant,
avez bailliee et comandee
l'amor que vos ai demandee.

Charrete, 5483 - 5488

Las proposiciones relativas se caracterizan por tener antecedentes indeterminados, los pronombres neutros ce o quant, o bien por no tener 
antecedente, con lo que el propio relativo se convierte en un indefinido, ya sea qui o el compuesto quanque. En general este tipo de construcciones consolida la sensación de obediencia ciega de los amantes que evitan discernir entre lo que es conveniente o perjudicial para ellos:

\section{ja mes n’iert jorz que je ne face \\ quan que vos pleira comander}

Charrete, $6592-6593$

\section{il a bien fait tot a devise \\ quanque s'amie ot commandé}

Escoufle, 3664 - 3665

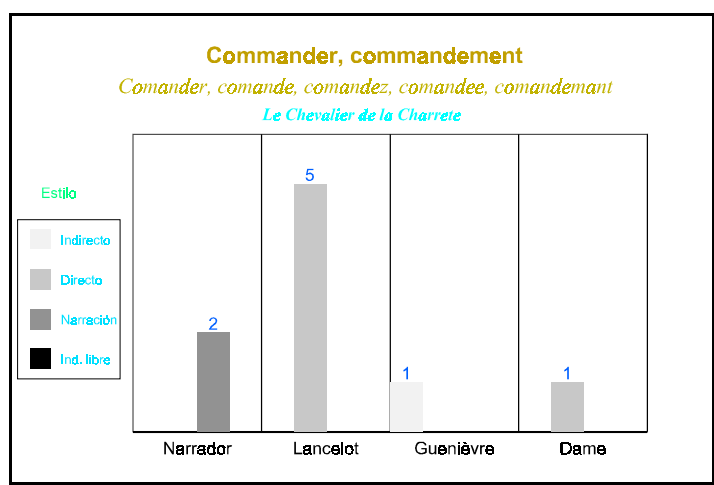

Fig. 72. Comportamiento estilístico del verbo commander y del sustantivo commandement en Charrete.

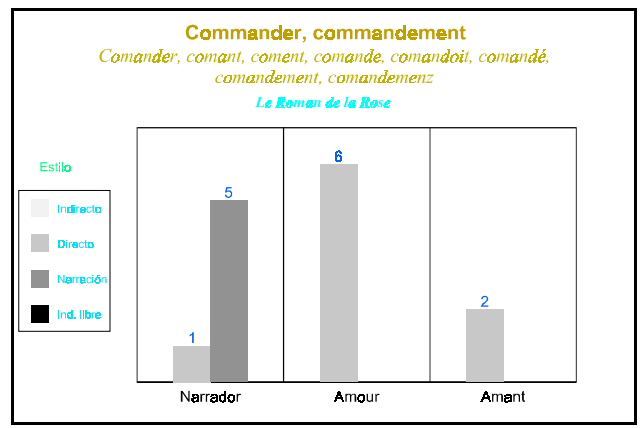

Fig. 73. Comportamiento estilístico del verbo commander y del sustantivo commandement en Rose. 
De nuevo comprobamos que las relaciones entre los enamorados difieren enormemente si consideramos por un lado las novelas Tristan y E scoufle y en el otro extremo Charrete y Rose. El papel jerárquico de la dama y del código se diluye en la lucha por la supervivencia de la pareja y de su felicidad en las primeras, mientras que los héroes masculinos creados por Chrétien y Lorris deben entregarse incondicionalmente a la búsqueda de la perfección amorosa, a los caprichos de la amada y a los imperiosos modelos sociales. Este comportamiento se refleja no sólo en el número de ocurrencias de estos términos que se hallan en cada obra, sino en la repartición discursiva. De hecho no existen en Tristan y tan sólo hay dos en la narración de E sooufle, por el contrario los amantes masculinos — de nuevo con la salvedad del narrador de Rose que cuenta aparentemente su propia experiencia- y los entes dominantes, la reina y especialmente el dios Amor, acaparan los diferentes usos del verbo commander y del sustantivo commandement.

\subsection{Enlacery «laz».}

El sustantivo invariable laz, que encontramos tanto en plural como en singular, desarrolla bajo una nueva perspectiva la metáfora del dios Amor cazador, quien tiende trampas para atrapar a los incautos jóvenes que desocupados e inocentes se acercan a sus dominios; en el ejemplo que presentamos a continuación la expresión se amplifica mezclando las formas tradicionales de la caza menor con artilugios más sofisticados, engins, que aseguran la efectividad:

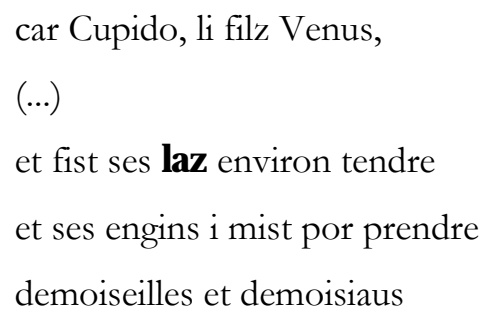


Pero, a diferencia de otras manifestacionse de esta imagen presentadas más arriba, este modo de captura se asocia con el placer y la alegría denotados por el sustantivo solaz con el que laz se empareja en la rima, aunque no acertamos a determinar si en este emparejamiento prima lo formal sobre lo expresivo o a la inversa. Es cierto que una vez que han caído en la trampa los retiene con el recuerdo del amante:

$$
\begin{aligned}
& \text { Li premiers biens qui solaz face } \\
& \text { ceus que li laz d'Amors enlace } \\
& \text { est Douz Pensers, qui lor recorde } \\
& \text { ce ou Esperance s'acorde. }
\end{aligned}
$$$$
\text { Rose, } 2629 \text { - } 2632
$$

Más poderosa aún es la visión de la amada para retener e incluso atar con más fuerza al amante caído en el artificio disimulado por el cazador, puesto que la contemplación de la belleza renovada de aquélla aumenta el placer pero también fija el deseo en ese único objeto; obsérvese la insistencia en esta idea gracias a la variante verbal lier - que encontramos en otros contextos para hablar de la acción de abrazar-, a la locución adverbial plus et plus, que indica a la vez superioridad y aumento progresivo del grado de intensidad, y el verbo estraindre del que depende como complemento de objeto directo el sustantivo laz:

$$
\begin{aligned}
& \text { et Amors plus et plus me lie } \\
& \text { de tant come ele est embelie, } \\
& \text { et tot adés estraint ses laz } \\
& \text { tant con je voi plus de solaz. } \\
& \text { Rose, } 3357 \text { - } 3360
\end{aligned}
$$

\begin{tabular}{lllllllll}
\hline FORMA & CA & BD & NV & RIMA & CA2 & NV2 & D & PERS \\
\hline enlace & V & Rose & 2630 & face & V & 2629 & D & Amour \\
laz & S & Rose & 2628 & solaz & S & 2627 & D & Amour \\
laz & S & Rose & 3359 & solaz & S & 3360 & N & Narrador \\
\hline
\end{tabular}

Tabla 60. Rimas del verbo enlacer y del sustantivo «laz». 
Además de las funciones de complemento directo y de sujeto que hemos visto en los ejemplos anteriores, el sustantivo funciona como complemento circunstancial locativo precedido por la preposición en dentro de sintagmas verbales cuyos núcleos son cheoir: "que maintenant ou laz cheï qui maint home a pris et trai" (Rose, 1611 - 1612) y estre: "trois autres biens, qui granz solaz font a ceus qui sont en mes laz” (Rose, 2627 - 2628).

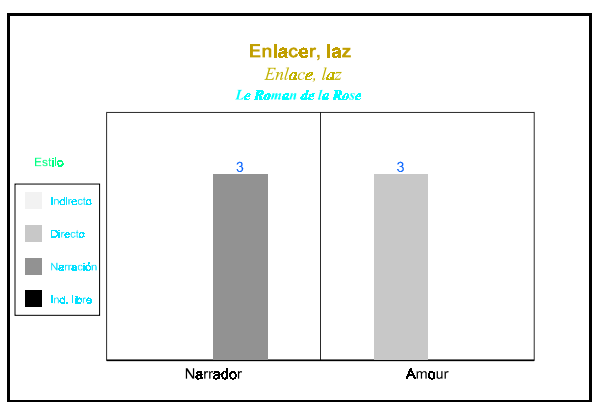

Fig. 74. Comportamiento estilístico del verbo enlacer y del sustantivo «laz» en Rose.

El pretérito perfecto con el que se nos narran el comienzo de las actividades cinegéticas del dios y el momento en que el amante - narrador cayó en el lazo tendido en torno a la fuente de Narciso se alterna con el presente de indicativo con un valor atemporal. Este es fundamental en la alocución de Amor y muestra de nuevo la validez universal de las reacciones de los jóvenes adolescentes en sus primeros encuentros con el sexo opuesto.

\subsection{LA ENTREGA Y EL SERVICIO.}

\subsection{Donner, don, «presanter» y présent.}

La acción de dar se torna bastante compleja en la narrativa cortés al mezclarse lo simbólico y lo real, planos que a su vez poseen diferentes niveles más o menos ligados al sentimiento o a lo puramente material. El foco de esta complejidad literaria se halla en el modo de intercambio de bienes en el seno 
de los grupos nobles del medievo, época en la que la dadivosidad ejemplar de los más ricos solapa una estrecha red de relaciones económicas y sociales que permiten el desarrollo de la vida feudal cotidiana, incluida la guerra.

Al funcionamiento general de los intercambios entre bienes y servicios, dádivas y cargas, en gran medida regulados por la tradición, deben añadirse dos elementos que son claves del desarrollo textual: el encumbramiento del sentimiento amoroso que mantiene unos lazos en ocasiones ambiguos con la unión física y, como consecuencia de lo anterior, la especialización de los intercambios entre seres de distinto sexo, otorgando por añadidura una primacía social, al menos teórica, al sexo femenino. Si bien es cierto que en los intercambios feudales esta relación también se dió, al menos en ciertas épocas y regiones donde las mujeres podían heredar las posesiones familiares y gobernarlas, cuando este hecho se producía, las mujeres no eran consideradas como tales sino como señores poseedores de un feudo.

En los textos, la entrega del afecto amoroso se simboliza mediante la rendición incondicional del corazón del amante: "qui en un leu met son cuer tout (...) Mes done le en don tot quite, si en avras greignor merite" (Rose, 2236 - 2242). Esta entrega puede a su vez ser sustituida mediante el regalo de un objeto, también marcadamente simbólico, como un anillo, un pendón: "sus la lance soit le penon dont la bele me fist le don" (Tristan, 3603 - 3604) o una limosnera. Sólo secundariamente o por añadidura se entrega el cuerpo, algo a lo que Charrete y Rose ponen más dificultades, sobre todo porque este don es femenino, aunque tan sólo se hace referencia explícita al beso: “m’otroia un bessier en dons" (Rose, 3457), preludio de la conquista del cuerpo y del sexo femenino. De ahí que en Rose el verbo doner adopte la forma negativa como marca de la represión del deseo y dependa de un verbo como defendre: "ele me seut torjorz desfendre que du bessier congié ne doigne” (Rose, 3382 3383). Por último y como en la anterior cesión, se obvía cualquier referencia a lo simbólico al regalar objetos o dinero, no sólo a la amada sino a su entorno, con el fin de conseguir el amor y el cuerpo de aquella: "a la pucele de l'ostel: 
un garnement li done tel qu'el die que tu es vaillanz", (Rose, 2545 -2547), o bien como pago por su compañía, sus labores y agasajos, lo que ocurre en el caso de Aelis y los hombres nobles y de la burguesía de Montepellier:

\author{
Et cil cui si bel oel ravisent \\ cuident estre ml't plus que conte, \\ il ne li donent pas a conte \\ les deniers; ml't croist et engraigne, \\ por ses joiaus et por s'ouvraigne
}

Escoufle, 5490 - 5494

De hecho, cada uno de estos actos de enajenación corresponde en los textos a un patrón de comportamiento erótico, masculino o femenino. El primero, en el que el corazón representa el servicio amoroso y el afecto, corresponde eminentemente al varón; mientras que el segundo, en que con un objeto valioso, ya sea por su valor intrínseco o sentimental, se puede suplir de manera figurada tanto al sentimiento amoroso como al ofrecimiento del cuerpo, conviene a las féminas: "par cest anel qui ml't est gens vos doins je mon cors et m'amor" (Escoufle, 4488 - 4489)

\footnotetext{
Que ke ma damoisele sist

lés moi sour l'erbe et sour la flor, iluec me fist don de s'amour par .j. anel d'or planteïs.
}

Escoufle, 7576 - 7579

En este punto se nos podría objetar que Tristán regala su perro a la reina Iseo como señal de amor y entrega física: "Husdent vos doins par drüerie" (Tristan, 2726); sin embargo, creemos que en este caso existe una razón probablemente más poderosa: el perro, que había demostrado un cariño obcecado por su amo y les había ayudado a sobrevivir en los tiempos difíciles 
del destierro, encarnaría sobre todo la protección del caballero una vez que este se ve obligado a abandonar la corte.

El tercero y el cuarto modos, como ya hemos apuntado, se reparten de forma excluyente entre mujeres y hombres. Respecto al abandono de los bienes del enamorado como pago secundario por un gesto de cariño, siempre tras la cesión de su corazón, el dios Amor insiste en que se trata de una de las virtudes necesarias del perfecto amante. Ésta reemplaza el arrojo guerrero y el tributo literario y hace perdurar la oposición con el villano: "il avient bien que li amant doignent dou lor plus largement que cil vilain entule et sot" (Rose, 2201 - 2203). El verbo devoir y el adverbio bien introducen la obligatoriedad y lo acuciante de la expresión destaca el movimiento económico unilateral como modo de conquista:

(... ) cil qui a por un regart ou por un ris douz et serin

douné son cuer tot enterin, doit bien aprés si riche don

doner ce qu'il a a bandon

Rose, 2208 - 2212

Chrétien recurre a un modelo de intercambio ligeramente diferente en el que al menos uno de los agentes no siente ninguna atracción, afectiva o física, hacia el otro. El don puede venir tanto del caballero como de una doncella o una dama y se pide o se exige una recompensa o guerredon, de ahí que este término aparezca a menudo en la rima en Charrete así como en los textos del siglo XIII en los que se adopta la misma expresión para trueques de diferente naturaleza. El varón aporta la ayuda y protección que sus artes guerreras pueden proporcionar, mientras que las mujeres ofrecen cobijo o la libertad para el caballero cautivo. El guerredon adquiere siempre un aspecto erótico-amoroso, unas veces explícito: "avoec moi vos coucheroiz, einsi le vos ofre et presant." (Charrete, 944 - 945), y otras más velado. En este último 
caso se encuentra la abnegada búsqueda de Lanzarote por parte de la hija del rey Bademagu, quien consigue la libertad del perfecto caballero y a la postre hace posible la culminación del relato con su victoria sobre el anti-héroe Meleagant:

$$
\begin{aligned}
& \text { Por ce don, et por ce servise } \\
& \text { me sui an ceste poinne mise: } \\
& \text { por ce vos metrai fors de ci. }
\end{aligned}
$$

Charrete, 6579 - 6581

La subversión del amor consiste en una entrega del otro a terceros, como es el caso de Iseo puesta en manos de los leprosos para que usen su cuerpo. Es éste un castigo en el que se reproduce la falta pero con unas consecuencias muy graves para la reina, de ahí que ella prefiera la muerte infamante, aunque relativamente rápida en la hoguera: “«Sire, merci! Ainz que m’i doignes, art moi ci.»" (Tristan, 1221 - 1222). Efectivamente se trataba de un castigo deshonroso por tres motivos: en primer lugar porque se suprimía la libertad de la mujer para elegir a sus compañeros sexuales, con lo que se reproducía a mayor escala el esquema matrimonial tradicional; en segundo lugar, porque la violación de la reina sería múltiple y reiterada, dada la creencia de que la enfermedad les aportaba un deseo sexual irrefrenable, y la convertiría en un suplicio continuado, algo de lo que se jacta el jefe de los leprosos: 'Veez, j’ai ci conpaignons cent: Yseut nos done, s'ert conmune. Paior fin dame n'ot mais une" (Tristan, 1192 - 1194); en tercer lugar porque la lepra, considerada una enfermedad de transmisión sexual y extremadamente contagiosa en la época, ${ }^{431}$ daba un aspecto muy desagradable a quienes la padecían en contraste con la belleza de Iseo y de su amante. De ahí probablemente que el tormento sea recordado por Tristán cuando pretende conseguir la rehabilitación social y sexual de la reina:

431 Véase a este respecto D. Jacquart y C. Thomasset, Sexualité et savoir médicl au Moyen Â ge. Paris: PUF, 1985 , p. $251-257$. 


\section{» Lors fu donnee la roïne \\ » as malades en decepline.}

Tristan, $2591-2592$

Ya hemos señalado más arriba la frecuencia con la que la mujer se convierte en moneda de cambio político o pago al esfuerzo del caballero, un motivo que se ha conservado en el folklore tal y como lo encontramos en la leyenda de Tristán, aquí reflejado en la forma pasiva del verbo doner.

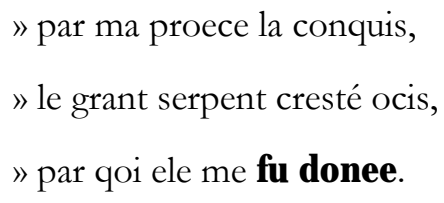

Tristan, $2559-2561$

El ropaje mítico que envolvía este episodio desaparece en Charrete, con los episodios del torneo de Noauz o de la devolución de la reina Ginebra a Lanzarote tras vencer a Meleagant, y en E scoufle al ofrecer el emperador la dama de Génova a su condestable: "il li a creanté qu’il li donra la riche dame” (Escoufle, 1680 - 1681). Sin embargo, se mantienen inalterados los usos que hacen de la mujer en la práctica un bien semoviente, con la ventaja de que, al menos en los relatos caballerescos, su disfrute llevaba aparejado el de otros bienes extremadamente preciados, la tierra, la fama, los honores y las alianzas.

Los juegos de repeticiones en los que se combinan distintas formas del verbo conjugado con el sustantivo don, que ya se inician en Tristan: “dorrez me vos tel don” (Tristan, 2723), en Rose añaden al valor retórico matices expresivos que pretenden reforzar la distinción entre un regalo mediante la fórmula doner en don y una donación interesada, aunque a la postre se mantiene siempre la figura de la amada como premio para la generosidad afectiva o pecuniaria: “done le en don tot quite” (Rose, 2241), 
mes de chose donee en dons
doit estre grant li guerredons

Rose, 2245 - 2246

La misma distinción se consigue mediante el uso de adverbios como quitement, volontiers ${ }^{432}$ o debonairement, adjetivos como quite, que pueden añadirse al recurso que acabamos de mencionar, o sintagmas nominales tales como a bele chiere:

\author{
donc le done tot quitement, \\ si le fai debonairemant, \\ car l'en doit chose avoir mout chiere \\ qui est donee a bele chiere
}

Rose, 2247 - 2250

El estudio de las rimas no nos ofrece más datos sobre el verbo doner y el sustantivo don aparte de la relación ya mencionada con guemedon. Sin embargo, las ocurrencias de presanter y de present se nos muestran en Charrete y en Escoufle como variantes formales que se hallan sistemáticamente en la rima formando parejas bien definidas de verbo y sustantivo.

\begin{tabular}{lllllllll}
\hline FORMA & CA & BD & NV & RIMA & CA2 & NV2 & D & PERS \\
\hline doigne & V & Rose & 3383 & semoigne & V & 3384 & D & Bel Accueil \\
doing & V & Rose & 2626 & besoing & S & 2625 & D & Amour \\
doingne & V & Charrete & 3279 & besoigne & S & 3280 & D & Méléagant \\
don & S & Rose & 2211 & bandon & S & 2212 & D & Amour \\
don & S & Charrete & 2799 & guerredon & S & 2800 & D & Demoiselle \\
don & S & Charrete & 6879 & guerredon & S & 6880 & D & Lancelot \\
don & S & Escoufle & 4500 & guerredon & S & 4499 & D & Guillaume \\
don & S & Tristan & 2723 & landon & S & 2724 & D & Iseut \\
don & S & Escoufle & 2136 & maison & S & 2135 & D & Empereur \\
don & S & Tristan & 3604 & penon & S & 3603 & D & Tristan \\
donastes & V & Charrete & 6574 & alastes & V & 6573 & D & Demoiselle \\
donastes & V & Tristan & 2392 & amenastes & V & 2391 & D & Ogrin l'ermite \\
donastes & V & Charrete & 4476 & sonastes & V & 4475 & D & Lancelot \\
& \multicolumn{2}{l}{ 432 "vos le } & me donastes molt volantiers" (Charrete, 6574- 6575). & & & \\
\end{tabular}




\begin{tabular}{lllllllll} 
done & V & Escoufle & 5497 & abandoune & V & 5498 & N & Narrador \\
donee & O & Tristan & 2561 & contree & S & 2562 & D & Tristan \\
donee & O & Charrete & 1679 & desirree & O & 1680 & D & Chevalier \\
donee & O & Rose & 2861 & nee & O & 2862 & N & Narrador \\
donees & O & Charrete & 6006 & mariees & O & 6005 & I & Demoiselle \\
doner & I & Tristan & 2216 & marïer & I & 2215 & D & Iseut \\
doner & I & Rose & 2205 & pener & I & 2206 & D & Amour \\
donés & O & Escoufle & 5875 & abandonés & O & 5876 & N & Narrador \\
donroit & V & Rose & 1445 & mouroit & V & 1446 & I & Écho \\
dons & S & Rose & 3457 & brandons & S & 3458 & N & Narrador \\
dons & S & Rose & 3373 & dons & D & 3374 & D & Amant \\
dons & D & Rose & 3374 & dons & S & 3373 & D & Amant \\
dons & S & Rose & 2245 & guerredons & S & 2246 & D & Amour \\
\hline
\end{tabular}

Tabla 61. Rimas del verbo donner y del sustantivo don.

\begin{tabular}{lllllllll}
\hline FORMA & CA & BD & NV & RIMA & CA2 & NV2 & D & PERS \\
\hline presant & V & Charrete & 945 & presant & S & 946 & D & Demoiselle \\
present & V & Escoufle & 5858 & present & S & 5857 & D & Dame Montpellier \\
presente & V & Escoufle & 4493 & entente & S & 4494 & N & Narrador \\
\hline
\end{tabular}

Tabla 62. Rimas del verbo «presanter» y del sustantivo présent.

Si exceptuamos E scoufle, los aspectos morfológicos y sintácticos del verbo doner ofrecen algunas particularidades que no habíamos podido observar hasta este momento, siendo de especial relieve el uso del subjuntivo, del imperativo y de la voz pasiva. Ésta se encuentra en los contextos en los que la mujer es objeto de una entrega, ya sea como premio al valor caballeresco: “qu'eles dient que s'an cestui ne se marient ne seront (...), n'a mari n'a seignor donees" (Charrete, 6003 - 6006) o como castigo, mientras que en la novela de Lorris se utiliza en una sentencia para otorgar a la fidelidad y la sinceridad amorosas un valor universal.

El imperativo en Tristan descubre la enajenación que se ha apoderado del rey Marco tras la infidelidad de la esposa y que le hace someterse a la voluntad del leproso, quien utiliza sistemáticamente esta forma: "Yseut nos done" (Tristan, 1193), "se la donez a nos meseaus" (Tristan, 1203). Chrétien lo inserta en el discurso del rey Bademagu, quien desea que su hijo Meleagant reconsidere la postura que contraviene las reglas de conducta del caballero y devuelva a la reina sin someterla de nuevo a los lances de una pugna entre soldados: 


$$
\begin{aligned}
& \text { que ce que il est venuz querre } \\
& \text { li done ainz qu'il le te demant } \\
& \text { Charrete, } 3204 \text { - } 3205
\end{aligned}
$$

En Rose se hace más habitual, si bien se concentra en la exposición de los mandamientos de Amor ${ }^{433}$ y en la arenga pronunciada por Venus para solicitar un beso que dé esperanza al amante, en la que recurre al tópico oollige virgo rosas tan apreciado por los goliardos:

$$
\begin{aligned}
& \text { Donez li, se vos m'en creez, } \\
& \text { car tant con vos plus atendroiz, } \\
& \text { tant, ce sachiez, de tens pardroiz. } \\
& \text { Rose, } 3452 \text { - } 3454
\end{aligned}
$$

El subjuntivo se encuentra en contextos habituales como núcleo de una subordinada completiva que depende de verbos de voluntad como defendre (Rose, 3382 - 3383) o voloir en forma negativa, lo que impide la actualización del proceso consecutivo: "ne tant ne voel estre enorables que la rien que plus aim li doingne" (Charrete, 3278 - 3279), de una completiva que actúa como sujeto de una locución que expresa la conveniencia como il avient (Rose, 2201 - 2202) o bien en una subordinada circunstancial comparativa en la que el subjuntivo precedido por ainz que $[\mathbf{A d v .}+$

C onj.] marca la preferencia: "Ainz que m'i doignes, art moi ci" (Tristan, 1222).

Las proposiciones independientes o principales las encontramos fundamentalmente en los discursos directos de los amantes, del dios Amor o de los enemigos de los enamorados en Tristan, mientras que tan sólo la narración de E sooufle acude excepcionalmente a ellas. Por lo que se refiere al resto de las subordinadas en las que se hallan el verbo doner o el sustantivo

433 Véase Rose 2241, 2247 y 2546. 
don, sobresalen por su número las proposiciones circunstanciales y las proposiciones relativas.

Las proposiciones circunstanciales expresan anterioridad en el tiempo: "quant la damoisele m'ot fait le don qui si ert bons et biaus" (Escoufle, 7578 - 7579), “quant tu avras ton cuer doné, (...) lors te vendront les aventures” (Rose, 2253 - 2255), o simultaneidad: “ne cuidiés pas c’on li eslise mauvais argent quant on li done" (Escoufle, 5496 - 5497); la consecuencia: "fei lui tel enor an ta terre, que ce que il est venuz querre li done ainz qu'il le te demant"' (Charrete, 3203 - 3205), o la causa (Rose, 1788 1789).

Por lo que se refiere a las proposiciones relativas conviene destacar la presencia de personajes femeninos como antecedentes. La relativa sirve para determinar en Charrete o en E scoufle la identidad de la mujer en relación con el don concreto solicitado u ofrecido al varón:

$$
\begin{aligned}
& \text { je sui cele qui vos rové } \\
& \text { quant au pont de l'espee alastes } \\
& \text { un don, et vos le me donastes } \\
& \text { molt volantiers quant jel vos quis }
\end{aligned}
$$

Charrete, 6572 - 6575

$$
\begin{aligned}
& \text { jou sui Aelis vostre amie } \\
& \text { qui vous donai l'anel ma mere }
\end{aligned}
$$

Escoufle, 7700 - 7701

Y en Rose para mostrar las especiales y precoces cualidades amorosas de Alegría, la joven enamorada de Deduit:

Leesce, qui nou haoit mie,

l'envoisie, la bien chantanz, 
que, des qu'el n'avoit que .vii. anz

de s'amor li dona l'otroi.

Rose, 830 - 833

En el resto de las proposiciones el antecedente suele ser un objeto que ha sido regalado: "de l'aumosniere et de l'anel k'ele li ot doné si bel” (Escoufle, 4502 - 4503), "si a culli une vert fueille vers le bouton, qu’i m’a donee" (Rose, 2860 - 2861), el propio amor: "et je ne pris le don un pois que l'en done desus son pois"' (Rose, 2251 - 2252), o bien la causa de la entrega de la mujer:

» par ma proece la conquis,

» le grant serpent cresté ocis,

" par qoi ele me fu donee.

Tristan, $5559-5561$

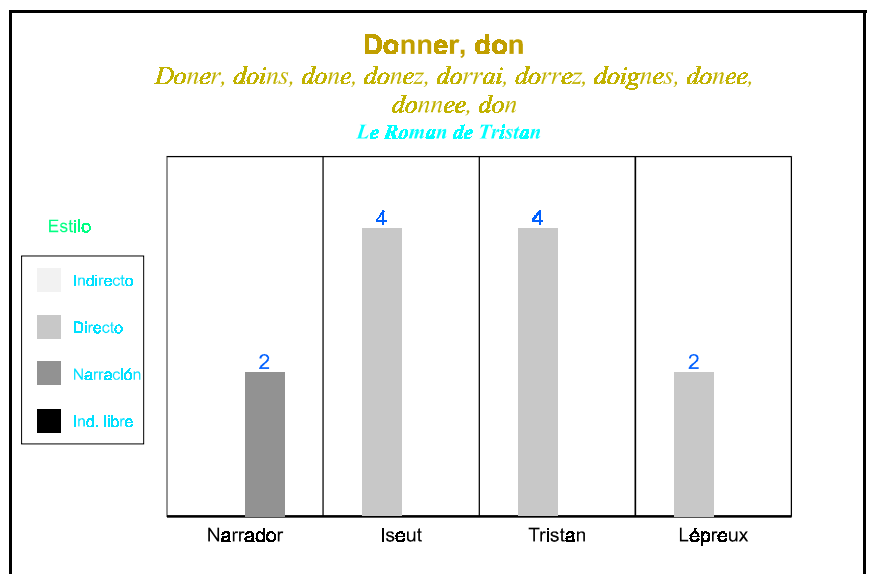

Fig. 75. Comportamiento estilístico del verbo donner y del sustantivo don en Tristan. 


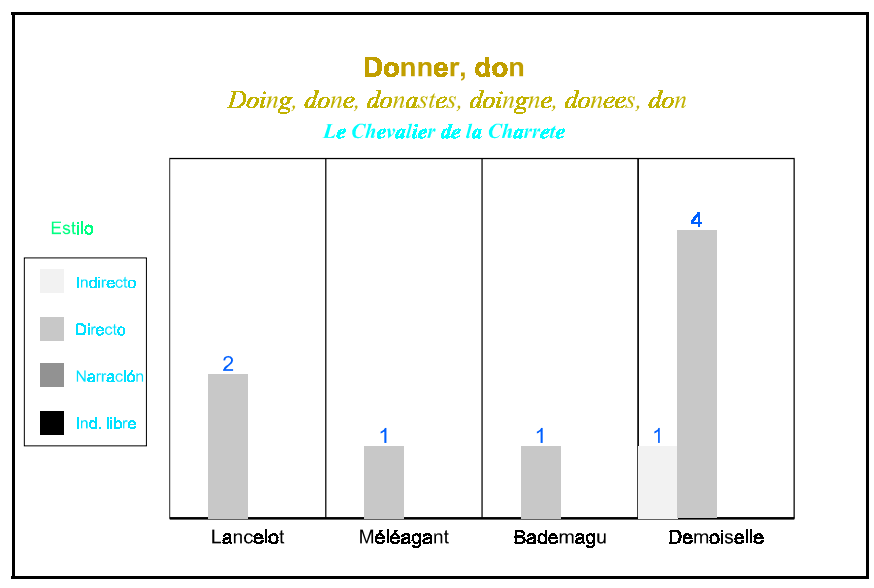

Fig. 76. Comportamiento estilístico del verbo donner y del sustantivo don en Charrete.

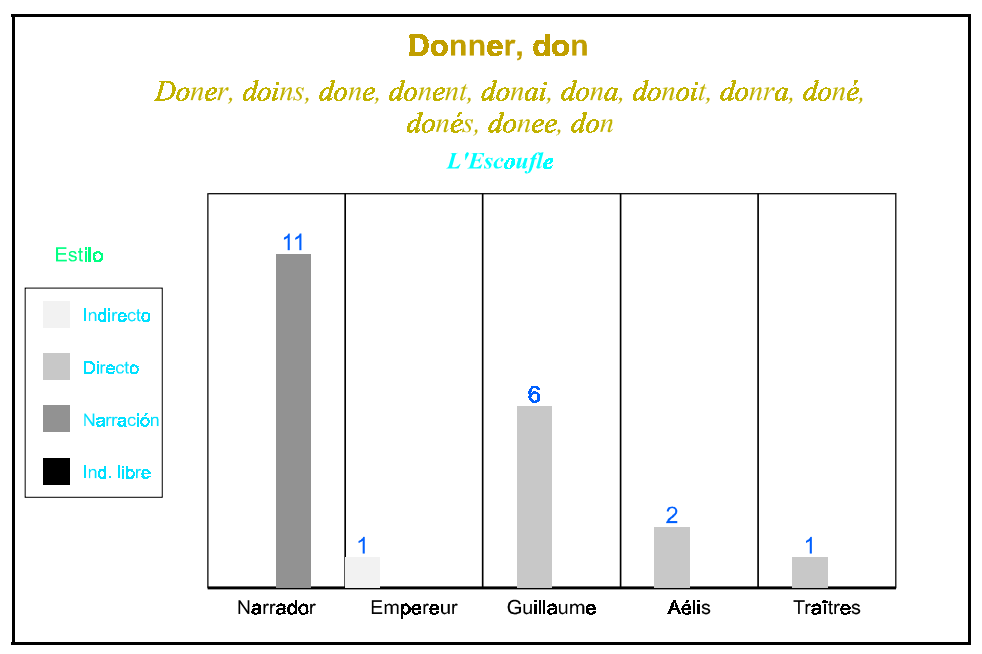

Fig. 77. Comportamiento estilístico del verbo donner y del sustantivo don en Escoufle.

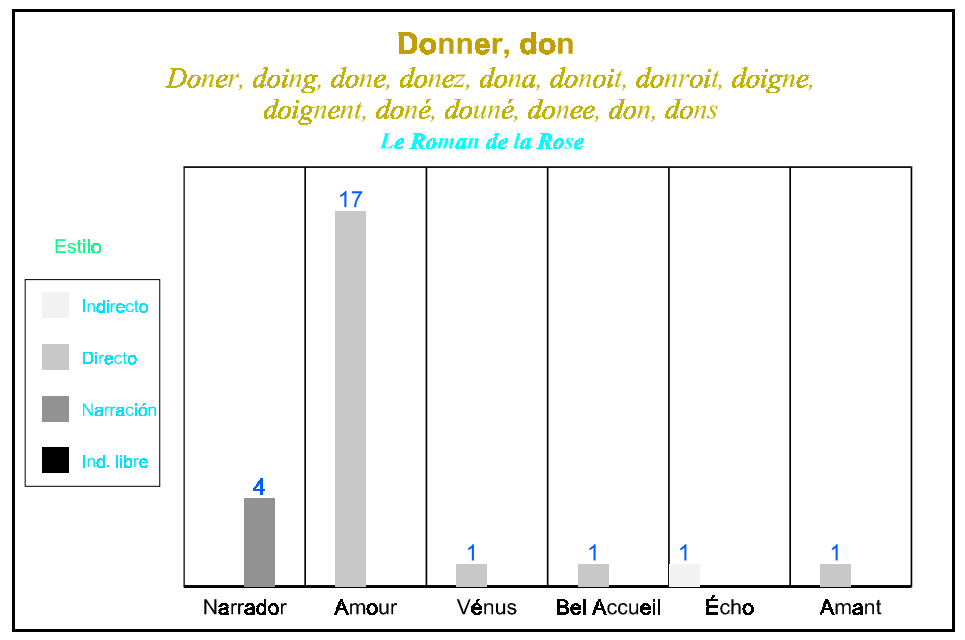

Fig. 78. Comportamiento estilístico del verbo donner y del sustantivo don en Rose. 
En el siglo XII el don que crea una obligación entre individuos de diferente sexo y el paso de la mujer de una mano a otra expresado por el verbo doner tienen una relativa importancia. Pero son los romans del siglo XIII los que, gracias a la donación de un bien simbólico, del corazón del amante o del cuerpo de la amada, pretenden salvar el amor y la pasión de las incipientes pero ya poderosas corrientes económicas que invadían todos los ámbitos de la vida. De ahí también que el verbo doner relacionado con el matrimonio quede relegado al discurso de los representantes de un orden que se denuncia al ir en contra del amor de los jóvenes, tal como ocurre en E soufle con el emperador y los cortesanos traidores. Sin embargo, Rose, más influido por la mentalidad mercantil, se debate entre la entrega incondicional y el pago por los favores eróticos, lo que da pie a Jean de Meun en su continuación para desarrollar en un tono sarcástico la venalidad femenina.

\subsection{Senvir y senvice.}

El amor según el código cortés es un servicio, una servidumbre que trastoca por completo el papel asumido tradicionalmente por ambos sexos. ${ }^{434}$ Este pilar básico de la retórica cortés, que según Guiraud es estrictamente platónico, ${ }^{435}$ aunque ya los trovadores utilizasen el término domnei tanto para denominar el cortejo como el juego erótico, se plasma en los romans, a excepción de Tristan, con diversos grados o matices que afectan tanto al verbo servir como al sustantivo service. Adoptan el sentido un tanto vago recogido en su diccionario de «faire la cour à une dame», pero expresan también la materialización erótica de la relación moral básica, particularmente en un uso recíproco del verbo durante los festejos celebrados tras la boda de Guillaume y de Aelis, periodo en el que las parejas se han dado mutua satisfacción a pesar de la oposición de los jalous:

434 De hecho ya Ovidio en su poesía había hecho prácticamente sinónimos los términos «amon» y «servicio», Cf. G. M. Cropp, op. at., p. 220. 
Ml't i ot solas et deduit:

ml't si sont bien servi trestuit, mais poi lor dona, ce lor samble.

Escoufle, 9025 - 9027

En la obra de Jean Renart — donde tan sólo escuchamos la voz del narrador- el servicio tanto masculino como femenino está constituido por acciones en atención de la amada y, excepcionalmente, del señor con el que la heroína mantiene una equívoca relación hecha de servidumbre y de sensualidad. Estas actividades resultan útiles, o cuando menos solazosas para los beneficiarios, ${ }^{436}$ y se puede identificar el servicio con un cortejo activo, de palabras y de hechos: "il la sent en dit et en fait de quanqu'il puet por li deduire" (Escoufle, 4508 - 4509), en el que se incluyen las caricias y agasajos propios del contacto amoroso. Cuando las atenciones son las del joven desconocido que ayuda a Aelis y se siente atraído por su belleza, el verbo senvir se halla modificado por los adverbios de modo debounairement y doucement intensificados por el adverbio $\mathbf{m l} \mathbf{t}$, con los que se pretende evitar cualquier sospecha de violencia y de contacto sexual: "ml't la sert debounairement" (Escoufle, 4791),

et si la sert ml't $\underline{\text { doucement, }}$

ml't li sot bien son mul restraindre

Escoufle, 4816 - 4817

Lanzarote sirve excepcionalmente a la reina: por ella llega a deshonrarse subiendo a la carreta, un envilecimiento que será infravalorado

435 Cf. P. Guiraud, op. at., p. 573 - 574.

436

$$
\begin{aligned}
& \text { Et quant il est avoec s'amie, } \\
& \text { ml't la set servir de biax dis, } \\
& \text { de dés, d'eschés, de gius partis. }
\end{aligned}
$$

Escoufle, 2026 - 2028 
por todos: "mes ma dame ne fu pas buens cist servises" (Charrete, 4376 4377). Desde luego no la sirve de la misma manera que a las jóvenes que halla en su camino y necesitan de su ayuda. Con ello se da a entender que el tributo caballeresco o guerrero a la dama en el que se pone en peligro la vida y el honor es el trasunto de un asiduo y paciente servicio sensual, cortesano, construido con hechos, sufrimientos y palabras: "sovant l'a servie et loiee" (Charrete, 3740). ${ }^{437}$ Más cercano al servicio caballeresco y por lo tanto alejado de los cánones corteses, es el que entendemos promete a la doncella que lo salva de la torre y a la que hace entrega de su cuerpo y de su corazón sin reticencias. Ya hemos abordado en otra ocasión este cambio en su actitud con respecto a las doncellas que había encontrado en su búsqueda de la reina. La modificación de la conducta podría ser atribuida a una formulación tópica del servicio de amor, aunque también podría entenderse como una mutación en el deseo de Lanzarote una vez que ha poseído a la reina, lo que lo desposeería del honroso título del más perfecto de los caballeros. Ambas interpretaciones serían imputables en cualquier caso a las notables alteraciones estilísticas y narrativas llevadas a cabo por el continuador de Chrétien:

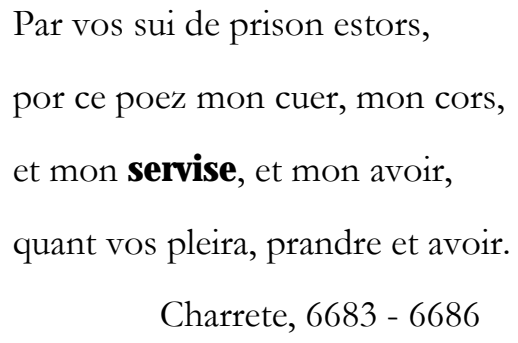

En Rose tan sólo expresan un cierto grado de sensualidad las ocurrencias que tienen por sujeto a Bel Accueil quien, nominalmente masculino, representa, sin embargo, la acogida femenina que atrae hacia sí al joven amante y le permite solazarse con su visión y compañía hasta que éste le pide un beso:

\footnotetext{
437 “Le service de l'amant n'est qu'un art d'attendre: pour arriver à ses fins, il doit non seulement «sofrii»» (patienter), «atendre» (espérer), mais supporter les souffrances, «enduren»”, R. Dragonetti, L a technique poétique..., op. at., p. 78.
} 
Bel Acueil m'ot mout bien servi

quant le bouton de si pres vi.

Rose, 2807 - 2808

et quant je voi qu'i ne me vee

ne son solaz ne son servise

une chose li ai requise

Rose, 3364 - 3366

La mayor parte de los usos del verbo y del sustantivo en esta obra establecen el servicio como tributo vasallático que debe el amante al dios Amor y que implica la obediencia, la fidelidad y el sacrificio a la pasión. Se relega a un segundo plano el sentido de cortejo en el que se incluye a todas las mujeres, como muestra de la atrofia social del código cortés: "Toutes fames ser et honore, en aus servir poine et labeure” (Rose, 2103 - 2104). De ahí que la incapacidad para la virtud, la abnegación y la constancia sirva para caracterizar a los que, villanos u orgullosos, quedarán excluidos del sentimiento amoroso, es decir, de los suplicios que darán paso a las mayores delicias:

vilains est fel et sanz pitié,

sanz Servise et sanz amitié

Rose, 2074,09 - 2074,10

et qui d'orgueil est entechiez,

il ne puet son cuer aploier

a servir ne a souploier.

Rose, 2116 - 2118

Se trata en definitiva de la transformación alegórica del primitivo «servicio de amor» de la retórica cortés dirigido a la dama, al que Guillaume de 
Lorris otorga una gran importancia en su obra como resumen de las obligaciones amorosas que impone Amor y a las que el amante está dispuesto a someterse:

$$
\begin{aligned}
& \text { Mes, par mon chief, or i para } \\
& \text { se tu de bon cuer serviras } \\
& \text { et coment tu acompliras } \\
& \text { nuit et jor les comandemenz } \\
& \text { Rose, } 2036 \text { - } 2039 \\
& \text { «Sire, fis je, grant talant é } \\
& \text { de fere vostre volenté; } \\
& \text { mes mon servise recevez } \\
& \text { en gré, foi que vos me devez. }
\end{aligned}
$$

Rose, 2011 - 2014

A ello se une que en el discurso de Venus, amor y servicio leales son presentados junto a la belleza y la juventud del enamorado como las virtudes que lo hacen digno de la entrega física de la amada: "qu'il sent et ainme en leauté" (Rose, 3429); y en el plano puramente formal la colocación casi constante en la última posición del verso de las formas verbales y del sustantivo que ahora tratamos.

\begin{tabular}{lllllllll}
\hline FORMA & CA & BD & NV & RIMA & CA2 & NV2 & D & PERS \\
\hline serve & V & Escoufle & 2377 & serve & V & 2378 & N & Narrador \\
serve & V & Rose & 2393 & verve & S & 2394 & D & Amour \\
servi & O & Rose & 2807 & vi & V & 2808 & N & Narrador \\
servi & O & Rose & 684 & vi & V & 683 & N & Narrador \\
servie & O & Charrete & 3951 & vie & S & 3952 & D & R. Bademagu \\
serviras & V & Rose & 2037 & acompliras & V & 2038 & D & Amour \\
servise & S & Rose & 1143 & devise & S & 1144 & N & Narrador \\
servise & S & Rose & 2789 & fointise & S & 2790 & D & Bel Accueil \\
servise & S & Rose & 2796 & franchise & S & 2795 & D & Amant \\
servise & S & Rose & 2564 & guise & S & 2563 & D & Amour \\
servise & S & Rose & 2016 & recreandise & S & 2015 & D & Amant \\
servise & S & Rose & 3365 & requise & O & 3366 & N & Narrador \\
\hline
\end{tabular}

Tabla 63. Rimas del verbo servir y del sustantivo service. 
La narración de las atenciones de Guillermo en el texto de Jean Renart prima el uso del verbo servir en tercera persona del singular del presente de indicativo en proposiciones independientes; mientras que en Rose predominan las proposiciones subordinadas completivas. En el discurso directo de Amor introducidas por se (Rose, 2036 - 2047) o coment: “or t'ai dit coment n'en quel guise amanz doit fere mon servise" (2563 - 2564) retoman el largo monólogo del dios y retan al amante a seguir sus preceptos. Algunas de ellas, dependientes de pares de verbos que indican percepción y conocimiento, expresan la progresiva comprensión de las nuevas sensaciones y sentimientos experimentados por el joven adolescente, o bien, refuerzan la argumentación de los personajes alegóricos que pretenden ayudarlo en su conquista:

$$
\begin{aligned}
& \text { et lores soi ge bien et vi } \\
& \text { qu'Oiseuse m'avoit bien servi }
\end{aligned}
$$

Rose, 683 - 684

$$
\begin{aligned}
& \text { car vos savez bien et veez } \\
& \text { qu'il sert et ainme en leauté } \\
& \text { Rose, } 3428 \text { - } 3429
\end{aligned}
$$

En ambos textos encontramos así mismo proposiciones subordinadas circunstanciales, temporales en E scoufle y causales en Rose:

- Las temporales, con estructuras muy similares, indican la simultaneidad introducidas por que que [C onj. + $\mathbf{C}$ onj.], y coinciden con los instantes previos a la separación y a la reunión de los amantes propiciadas por el encuentro con aves cuyo nombre da título a la obra. La similitud estructural acentúa los contrastes con respecto a la sensualidad de ambos amantes, frente al talante contemplativo de Guillermo cuando es todavía un niño se encuentra el roce carnal de Aelis, joven y bella aventurera: 
que qu'il la sert et il la garde,

uns escoufles, .j. lere, esgarde

Escoufle, 4543 - 4544

Que qu'ele le sert et tient nu,

fait li cuens: «Or m’est souvenu

de mes fauconniers et du mestre

Escoufle, 7065 - 7067

- Las causales introducidas por las conjunciones que o car justifican la amistosa acogida de Bel Accueil: “je ne m'en quier feire pleidier, car pres sui de vostre servise." (Rose, 2788 - 2789) o las palabras del amante ante su nuevo señor, a la vez deseoso de disfrutar de los placeres prometidos y temeroso de las pesadas cargas que su consecución conlleva:

nou di pas par recreandise,

que point ne dot vostre servise

Rose, 2015 - 2016

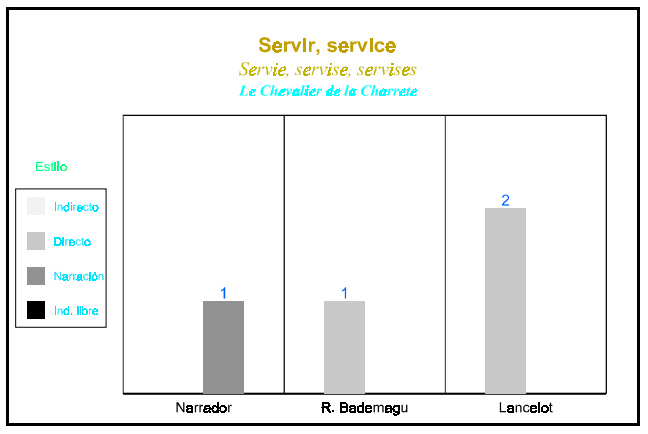

Fig. 79. Comportamiento estilístico del verbo servir y del sustantivo service en Charrete. 


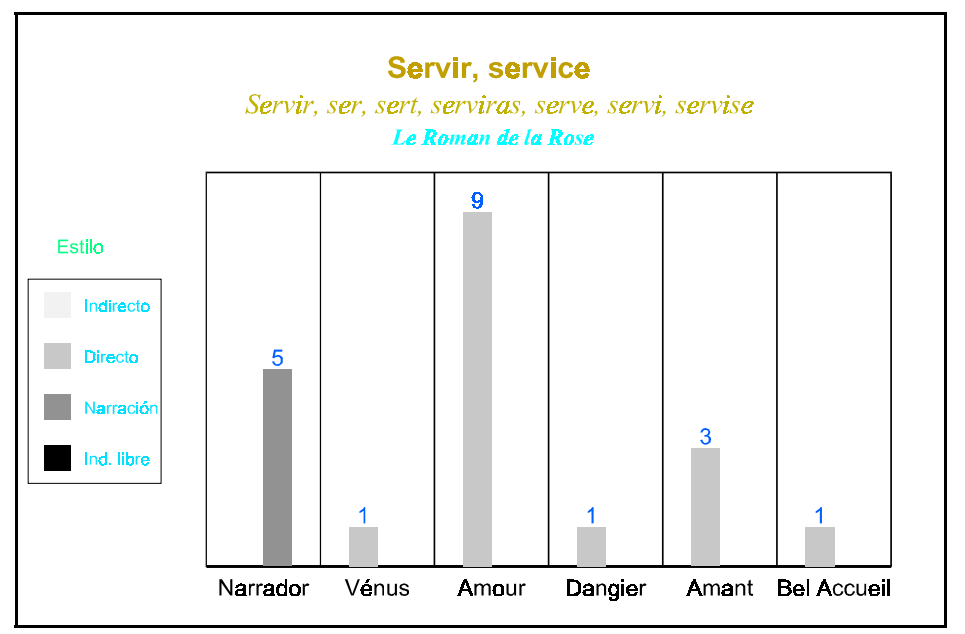

Fig. 80.Comportamiento estilístico del verbo servir y del sustantivo service en Rose.

Servir en nuestro corpus constituye la conjunción entre la expresión más genuina de la cortesía trovadoresca y de los lazos vasalláticos traspuestos a la relación erótica caballeresca. Probablemente esta sea la causa de que en la obra de Béroul no se halle y de que el servicio de los caballeros sea puramente feudal. Por el contrario observamos que a medida que ambos códigos se funden y tienden a adoptar formas carentes de su primitivo contenido los autores ponen más ahínco en hablar del servicio y sus características. De ahí los usos que nos muestran las ilustraciones precedentes así como las múltiples ocurrencias del verbo senvir en la narración de Escoufle, todo ello unido al incremento del sentido sexual tanto del verbo como del sustantivo.

\subsubsection{EL AMOR Y LA MUERTE.}

\subsection{Mouriry mort.}

Con frecuencia se ha hablado del movimiento trágico que caracterizaría al amor occidental y que lo conduce irremediablemente hacia la muerte de los amantes, lo que lo diferenciaría ostensiblemente del amor oriental y de sus formalizaciones literarias. Precisamente la leyenda de Tristán 
se aduce a menudo como ejemplo y texto inaugural de una larga tradición en la que Eros y Thanatos irían irremediablemente de la mano. Sin embargo, las ocurrencias del verbo monir que en la obra de Béroul encontramos relacionadas directamente con el amor son muy escasas, aunque dan muestra de una tendencia hacia la autodestrucción presente en todos los romans. La muerte se desea cuando se ha perdido al amante o cuando se le cree muerto, pero también como culminación del mal de amor por excelencia, del rechazo del otro, cuyo extremo serían Eco y Narciso:

$$
\begin{aligned}
& \text { quant ele s'oï escondire, } \\
& \text { si en ot tel duel et tel ire } \\
& \text { et le tint a si grant despit } \\
& \text { qu'ele fu morte sanz respit. }
\end{aligned}
$$$$
\text { Rose, } 1451 \text { - } 1454
$$

Las contradicciones propias de la retórica cortés hacen, empero, que Ginebra se debata entre su voluntad de morir una vez que cree desaparecido a Lanzarote y un deseo morboso de mantenerse en vida y sufrir el dolor provocado por su muerte, controversia formulada mediante un nexo adversativo y dos subordinadas comparativas en las que se oponen la vida a la muerte, el dolor al placer, y que nos recuerda la naturaleza «masoquista» del amor heredado de los trovadores:

\footnotetext{
Malveise est qui mialz vialt monir, que mal por son ami sofrir.

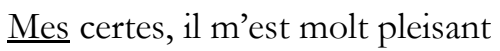
que j'en aille lonc duel feisant. Mialz voel vivre et sofrir les cos que morir et estre an repos.» Charrete, 4239 - 4244
} 
De manera más escueta y más cercana al tópico, personalizado gracias a los posesivos, el amante de Rose también se hace eco de los sentimientos contradictorios que le produce el deseo de la rosa: "ce est ma mort, ce est ma vie" (Rose, 2889).

Formalmente la atracción por la muerte se manifiesta en construcciones perifrásticas verbales formadas con los verbos voloir o pooir, subordinadas consecutivas: "g'i voudroie estre par covent que je monuse maintenant" (Rose, 2447 - 2448) o exceptivas: “de nule chose n'a envie fors que de monir en cele eure" (Escoufle, 4874 - 4875), y el recurso al futuro de indicativo y al condicional simple que expresan el fatal deseo o las condiciones de su ejecución. Deseo que es eminentemente masculino en las obras del siglo XII, mientras que se reparte entre ambos sexos en las del siglo XIII.

Las construcciones perifrásticas en las que interviene el verbo morir, al igual que el uso del futuro y del condicional o del sustantivo en función de complemento directo del verbo avoir, nos hablan de una cierta autonomía de los amantes o bien de una firme determinación ante las adversidades que se oponen a su amor. Es el caso de Tristán, quien plantea la reciprocidad en el fin de ambos, claramente marcada por los sintagmas preposicionales que se encuentran en el centro del mismo verso, y augura en cierta medida la conclusión de la leyenda: "En l'art por moi, por li momai” (Tristan, 988). Como también lo es de Aelis, quien proclama su firme deseo de morir ante la posibilidad de que sus esponsales se rompan: “c'est por noient u vos m’avrés u jou avrai par tans la mort.» (Escoufle, 3216 - 3217). Lorris cambia en gran medida estos planteamientos al hacer del enamorado un súbdito de Amor y borrando las íntimas conexiones que se establecían entre los amantes en los textos precedentes: “je vosdroie monir ençois qu'Amors m'eüst de fauseté ne de traïson aresté" (Rose, 3074 - 3076). El hecho de trastocar los nexos privilegiados que habían prevalecido hasta entonces entre la pareja de la novela caballeresca - ya fuesen de igualdad o de depencia del varón con respecto de la mujer, quien con su actitud o simplemente con su belleza podía 
ocasionar la muerte del amante real o simbólica: "la biautés de vostre cler vis m’a mort et destruit sans prier” (Escoufle, 3416 - 3417), “n'onques un mot ne me sonastes a po la mort ne m'an donastes" (Charrete, 4475 - 4476)—, 438 así como el hecho de colocar en un primer plano al amor y hacer un elemento externo dominante de lo que había sido un elemento afectivo interno o bien una abstracción configurada gracias a la suma de experiencias sentimentales individuales, acarrean también consecuencias en la sintaxis. La más interesante en este caso es la construcción del verbo en forma conjugada como núcleo de una proposición subordinada completiva dependiente de un verbo de voluntad cuyo sujeto es el dios Amor: "qu'Amors ne veut pas que je muire" (Rose, 1848).

El valor otorgado a la última posición del verso, especialmente en Rose, y la correspondencia con términos marcados negativamente como sofrir, menir, desconfort o nuire son los rasgos más sobresalientes que entresacamos de la tabla que ofrecemos a continuación.

\begin{tabular}{lllllllll}
\hline FORMA & CA & BD & NV & RIMA & CA2 & NV2 & D & PERS \\
\hline morir & I & Rose & 1507 & merir & I & 1508 & D & Narrador \\
morir & I & Charrete & 4239 & sofrir & I & 4240 & D & Guenièvre \\
morist & V & Rose & 1455 & requist & V & 1456 & N & Narrador \\
morrai & V & Tristan & 988 & eschapai & V & 987 & D & Tristan \\
morrai & V & Charrete & 4269 & porrai & V & 4270 & D & Lancelot \\
mors & O & Escoufle & 6383 & desconfors & S & 6384 & N & Narrador \\
mort & S & Rose & 2739 & confort & S & 2740 & D & Amour \\
mort & S & Rose & 4014 & desconfort & S & 4013 & L & Amant \\
mort & S & Escoufle & 3217 & mort & V & 3218 & D & Aélis \\
mouroit & V & Rose & 1446 & donroit & V & 1445 & I & Écho \\
muire & V & Charrete & 4231 & nuire & I & 4232 & D & Guenièvre \\
muire & V & Rose & 1848 & nuire & I & 1847 & N & Narrador \\
\hline
\end{tabular}

Tabla 64. Rimas del verbo mourir y del sustantivo mort.

\footnotetext{
${ }^{438}$ El propio Lorris recurre a esta relación en uno de los comentarios moralizantes en estilo directo del narrador:

Dames, cest essample aprenez,

qui vers vos amis mesprenez;

car se vos les lessiez morir,

Dex le vos savra bien merir.
} 


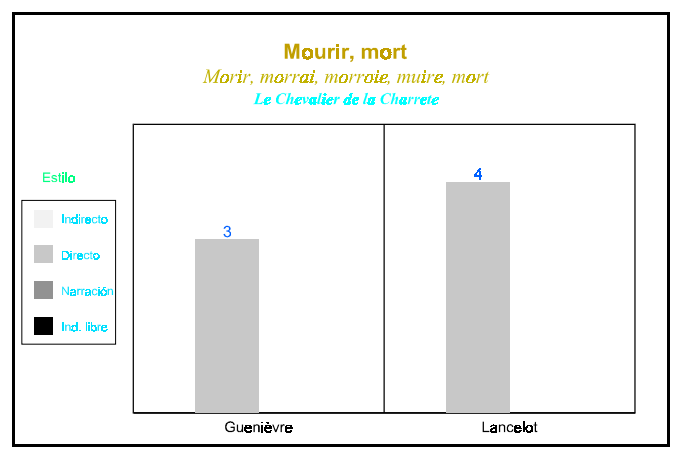

Fig. 81. Comportamiento estilístico del verbo mourir y del sustantivo mort en Charrete.

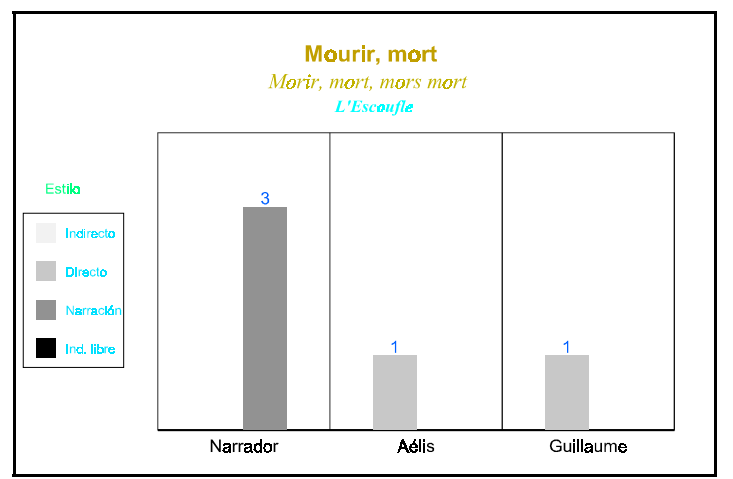

Fig. 82. Comportamiento estilístico del verbo mourir y del sustantivo mort en Escoufle.

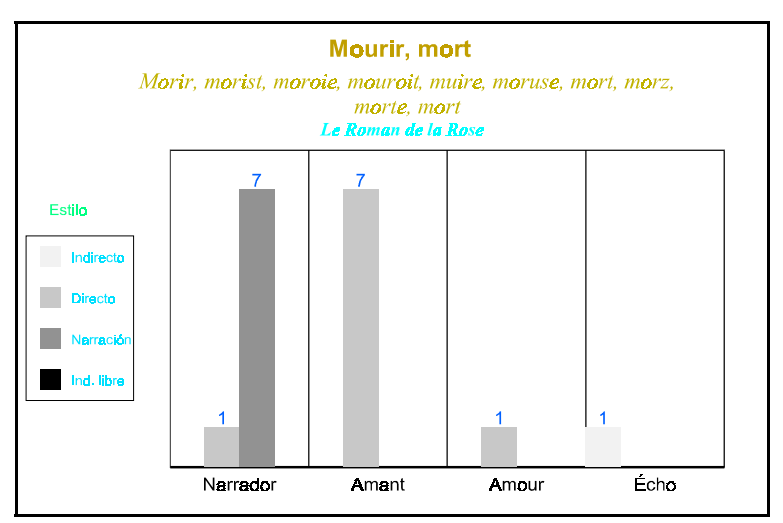

Fig. 83. Comportamiento estilístico del verbo mourir y del sustantivo mort en Rose.

Tan sólo el narrador de E scoufle desbanca a los enamorados en el uso del verbo monir y del sustantivo mort. En sus intervenciones muestra ejemplarmente con la historia de Píramo la incapacidad de los amantes para distinguir la apariencia de la realidad, una confusión que puede conducirlos hasta la enajenación y la tragedia, tal como les ocurrirá más tarde a Romeo y 
Julieta en la obra de Shakespeare. Con ello parece también querer romper con el inexcusable lazo entre el amor, el sexo y la muerte y apuesta por la vida aunque sea en condiciones precarias y fuera del refugio que para los hombres medievales ofrecían las férreas estructuras estamentales, algo que hasta el siglo XIII había sido considerado unánimemente como una muerte social.

\subsubsection{EL DESEO.}

\subsection{TÉRMINOSGENERALES.}

\subsection{1 «Atalanten», «entalanten», «talent» $y$ «talentos».}

Según recoge Greimas en su diccionario, el sustantivo talent denominaba en la época medieval — tal como ocurrirá con otros términos estudiados en este apartado- tanto el deseo como la voluntad, solamente compartida por los amantes en Tristan: "mandon au roi nostre talent" (Tristan, 2283), mientras que los verbos atalanter y entalanter, este último siempre en construcción pasiva en nuestro corpus, pueden significar tanto «gustan» como «inspirar deseo».439 En algunos contextos resulta difícil determinar cuál de los dos sentidos se impone al otro pues ambos son posibles, ambigüedad que favorece la evocación erótica por parte del receptor. De hecho el deseo surge naturalmente tras la percepción de un objeto agradable, movimiento casi imperceptible entre las sensaciones y la libido dibujado con maestría por Chrétien en la evocación del torneo de Noauz, ya que la gallardía de Lanzarote es apreciada por todas las doncellas casaderas y todas lo desean como esposo: "cil qui a totes atalante" (Charrete, 6014).

439 Op. at., p. 48, 227 y 618. 
En boca del rey Arturo hallamos, además el participio entalantez para expresar su firme determinación de obrar diligentemente para ayudar a la reina Iseo; de sus palabras colegimos que su entusiasmo político y guerrero nace de un vínculo entre Iseo y él mismo — cabeza del mundo caballeresco ideal- muy similar al que une a la dama con su fiel caballero, con lo que esto conlleva desde los puntos de vista bélico y erótico, aunque probablemente en un modo atenuado, el primero por delegación y el segundo por el acatamiento de las formas sociales inherente a la evolución de la cortesía:

\author{
vostre dame me salüez \\ de son demoine soudoier \\ qui vient a li por apaier. \\ Totes ferai ses volentez, \\ por lié serai entalentez. \\ El me porra mot avancier.
}

Tristan, $3540-3545$

El verbo atalanter, restringido en el corpus a Charrete y Rose y a la tercera persona del singular del presente de indicativo, escasamente tiene por sujeto al ser amado, ya que la función privilegiada para los enamorados es la de complemento de objeto indirecto. Como sujeto encontramos, junto a Lanzarote en el ejemplo citado, el capullo - doncella por el que suspira el amante de la rosa:

$$
\begin{aligned}
& \text { mout me destraint iceste plaie, } \\
& \text { qui me semont que je me traie } \\
& \text { vers le boton qui m'atalante. }
\end{aligned}
$$$$
\text { Rose, } 1777 \text { - } 1779
$$

En esta ocurrencia identificamos una atracción más fuerte que el simple deleite de los sentidos, pues el corazón y el cuerpo del enamorado son 
arrastrados por una fuerza que ahuyenta la debilidad y el dolor en que los ataques del arquero lo han sumido. De hecho tan sólo la primera flecha llamada Belleza correspondería a un estadio en el que únicamente estarían implicados los sentidos, en la narración alegórica la vista y el olfato, aunque ya se podría hablar de deseo físico, expresado por el participio entalantez: "se j'avoie avant esté dou bouton bien entalantez, lors fu graindre la volentez" (Rose, 1748 - 1750); sin embargo, tras la segunda, que representa la sencillez o naturalidad de la joven, y la tercera, Cortesía, la implicación es sentimental, y el deseo físico, que fácilmente podía desvanecerse, se transforma sin desaparecer hasta hacerse obsesivo y apremiante, fijándose de forma permanente en un solo objeto. Esto nos lleva a aventurar que Lorris no pretendía llegar a la simple consecución del cuerpo femenino como fin último del proceso de enamoramiento y conquista, sino a la conjunción sentimental y espiritual, cuya representación ideal era probablemente la unión de los cuerpos, a la que tendía la cortesía clásica.

Si excluimos los ejemplos citados, el sujeto del verbo atalanter — con un sentido aparentemente difuso pero que los contextos tienden a fijar dentro del ámbito del deseo erótico- son las maniobras proyectadas por el enamorado para acercarse a la dama, quien debe dar su aprobación, lo que implica su inserción en una proposición subordinada hipotética introducida por se: "śs'a la reïne atalante, avoec li leanz anterra: ja por les fers ne remanra" (Charrete, 4598 - 4600); o bien la entrega del cuerpo de una virgen que se ofrece en el lecho, pero que Lanzarote rechaza, hecho que marca las diferencias con el resto de los hombres: "mes ne pleist mie n'atalante quan qu'est bel, et gent a chascun” (Charrete, 1226 - 1227). La coordinación con el verbo pleire ${ }^{40}$ que podría apuntar hacia una construcción binaria con dos sinónimos, esquema muy habitual en los versos de esta época, muestra más bien la gradación, el paso del agrado al deseo al que nos hemos referido.

\footnotetext{
${ }^{440}$ Esta conjunción verbal está presente en otro ejemplo en el que sí son sinónimos: “des que il li siet; que quan que li plest m'atalante" (Charrete, 5892 - 5893).
} 
El sustantivo talent en la única ocurrencia en la que funciona como sujeto nos muestra la unión del deseo y del capricho femeninos, combinación propia de la dama cortés en su aspiración desmedida a probar la lealtad del enamorado:

$$
\begin{aligned}
& \text { Quant la reïne point n'an voit, } \\
& \text { talanz li prist qu'ele l'anvoit }
\end{aligned}
$$$$
\text { les rans cerchier tant qu'an le truisse. }
$$

Charrete, 5829 - 5831

Habitualmente lo encontramos en función de complemento de objeto directo. Depende de los verbos mander y dire - precedido por un artículo posesivo-, aporter. "ceste esperance le conforte et cuer et talant li aporte" (Rose, 2607 - 2608) y avoir —el más común-. Con este verbo la construcción sin determinantes, avoir talent de o avoir talent que, constituye una locución que permite situar al amante como sujeto activo del deseo, ya sea en un sentido vago, alejado de la posesión erótica, coordinado por ejemplo al sustantivo volonté: “qu’il n'a talant ne volanté d'emplastre querre ne de mire" (Charrete, 1340 - 1341), y asociado con las primeras sensaciones, imprecisas aunque imperiosas, que empujan al adolescente a internarse en el universo amoroso: “j”oi lors talant que le vergier alasse veoir et cerchier" (Rose, 1285 - 1286), o bien claramente impulsado por la sensualidad, que de nuevo se manifiesta como la mezcla de la percepción física y del sentimiento arraigado en el corazón, motor inequívoco del deseo, aquí puesto de relieve por el adjetivo con valor ponderativo tel:

se mi oil mon cuer ne convoient, je ne pris rien quen que il voient.

Doivent se il ci arester?

Nenil, mes aillent visiter

ce don li cuer a tel talant!

Rose, 2295 - 2299 
Dos aspectos formales con trascendencia en el sentido de estas locuciones merecen ser destacados, por una parte, la coordinación con otros sustantivos como cuer y el ya mencionado volonté formando un complemento doble, o bien la presencia de una proposición coordinada que podía ser calificada como redundante pero que aporta un cierto énfasis a la expresión:

a cui tu dies ton talant

et descuevres tot ton corage.

Rose, 2674 - 2675

En ambos casos el sentido de talent en el contexto se afianza gracias a dichas asociaciones. De igual modo, la negación de la locución determina la comprensión del deseo como deudor de la voluntad razonada, aunque paradójicamente también pueden encauzarla el instinto y la pasión, es decir, el anhelo de obtener placer, y excepcionalmente de darlo. Es el caso de Ginebra, quien se arrepiente del trato arisco a su amante que ha podido causarle la muerte y quiere enmendarse: “n'a mes talant que ele teigne atahine de nule chose" (Charrete, 4426 - 4427); también de Lanzarote, quien tras la noche de amor desearía no abandonar el lecho de su amada, quien tanto le place: "que la reïne tant li plest qu'il n'a talant que il la lest" (Charrete, 4695 - 4696). Pero es el amante de la rosa el que se deja llevar con mayor facilidad por la atracción que aquélla ejerce sobre sus sentidos y tan sólo las barreras sociales en forma de cardos y espinas logran detenerlo antes de que la tome por la fuerza: “et quant jou senti si fleirier, je n'oi talant de repairier, ainz m'en apressai por le prendre” (Rose, 1669 - 1671).

En Tristan y E scoufle encontramos algunos ejemplos de la capacidad de los amantes para controlar sus actos con independencia de los dictámenes del instinto: coinciden con la negación de los amores ilícitos, es decir, de aquéllos que excluyen el sentimiento y tienen por objeto el placer sensorial (Tristan, 30 - 31 y 253) y aun, en el caso de Aelis, el bienestar físico que le 
ofrecerían los hombres acomodados de la ciudad a cambio de una relación sexual a la que se hace una referencia apenas encubierta por las alusiones a la moral de la Iglesia y a los principios básicos que regían el funcionamiento de la sociedad estamental:

$$
\begin{aligned}
& \text { k'el n'a talent de chose faire } \\
& \text { ki doive a Damedieu desplaire, } \\
& \text { n'a s'ounor, n'a son haut lignage. }
\end{aligned}
$$

Escoufle, 4943 - 4945

En función de atributo el adjetivo talentos - cuyo sufijo se ha adaptado a la rima con la forma de origen provenzal jalos - no nos ofrece ninguna duda con respecto a su sentido erótico. Lanzarote, que contempla los cuerpos desnudos de una doncella y de su violador, no llega a excitarse y permanece indiferente ante el espectáculo que pretendía probar su control sobre la libido. Sale victorioso de la prueba pues en ningún momento siente deseos de poseer a la joven -obsérvese la acumulación de términos negativos, adverbios, ne, mie, y conjunciones, ne, estas últimas en una locución que indica la carencia absoluta, ne tant ne quant [C onj. + A dv. + Conj. + Adv.]—; es más, la doncella debe animarlo para que la libere de los que la están forzando y actúe como un caballero más que como un hombre enamorado, paralizado por una obsesión amorosa que no le permite interesarse por ninguna mujer que no sea la reina y por ninguna otra actividad que no sea la liberación de ésta:

$$
\begin{aligned}
& \text { si n'en ert mie talentos, } \\
& \text { ne tant ne quant n'an ert jalos } \\
& \text { Charrete, } 1085 \text { - } 1086
\end{aligned}
$$

Poco cabe decir en cuanto a las relaciones semánticas que se establecen en las rimas salvo por lo que se refiere al participio entalantez y el sustantivo volentez, una asociación paralela a la que hemos señalado al hablar 
del sustantivo talent. Sí merece destarcarse el hecho de que todas las formas verbales aparecen en la última posición del verso, quizá no tanto por la facilidad de la rima como por el empeño en mostrar la atracción que sienten los amantes y la fuerza del deseo.

\begin{tabular}{lllllllll}
\hline FORMA & CA & BD & NV & RIMA & CA2 & NV2 & D & PERS \\
\hline atalante & V & Charrete & 1226 & antante & S & 1225 & N & Narrador \\
atalante & V & Charrete & 6014 & gente & A & 6013 & N & Narrador \\
atalante & V & Charrete & 5893 & lante & A & 5894 & D & Lancelot \\
atalante & V & Rose & 2019 & presente & V & 2020 & D & Amant \\
atalante & V & Rose & 1779 & rapoente & V & 1780 & N & Narrador \\
atalante & V & Charrete & 4598 & vante & V & 4597 & I & Lancelot \\
entalantez & O & Rose & 1749 & volentez & S & 1750 & N & Narrador \\
entalentez & O & Tristan & 3544 & volentez & S & 3543 & D & Roi Arthur \\
talant & S & Rose & 2674 & celant & A & 2673 & D & Amour \\
talant & S & Rose & 2299 & lent & A & 2300 & D & Amant \\
talent & S & Tristan & 2283 & mandement & S & 2284 & D & Tristan \\
talent & S & Tristan & 31 & omnipotent & A & 32 & D & Iseut \\
talentos & A & Charrete & 1085 & jalos & A & 1086 & N & Narrador \\
\hline
\end{tabular}

Tabla 65. Rimas de los verbos «atalanter»y «entalanter», del sustantivo «talent»y del adjetivo «talentos».

Hallamos el sustantivo talent prioritariamente en oraciones independientes a excepción de dos proposiciones subordinadas de relativo, una de ellas introducida por el pronombre don (Rose, 2299) y la otra por el pronombre en caso régimen cui precedido por la preposición a (Rose, 2674). Es una muestra de la acumulación de las subordinadas en Rose, rasgo que comparte con Charrete, mientras que quedan excluidas, a excepción de una completiva en E scoufle, ${ }^{441}$ del resto del corpus.

En cuanto a las formas verbales que nos ocupan, ya hemos tenido ocasión de observar que los pronombres relativos que introducen las proposiciones subordinadas especificativas funcionan como sujeto, precedido por un demostrativo cuyo valor en principio indefinido se ve determinado por

441 Ançois li jure et escondit
k'el n'a talent de chose faire
Escoufle, $4942-4943$


la proposición subordinada: "cil qui a totes atalante" (Charrete, 6014), o por un sustantivo: "le boton qui m'atalante" (Rose, 1779).

Las proposiciones hipotéticas introducidas por la conjunción se: "se li servise n'atalante au seignor cui l'en le presente" (Rose, 2019 - 2020), ${ }^{442}$ y en menor medida las causales (Charrete, 1340) y las consecutivas (Charrete, 4696), en ambos casos introducidas por la conjunción que, conforman las proposiciones subordinadas circunstanciales.

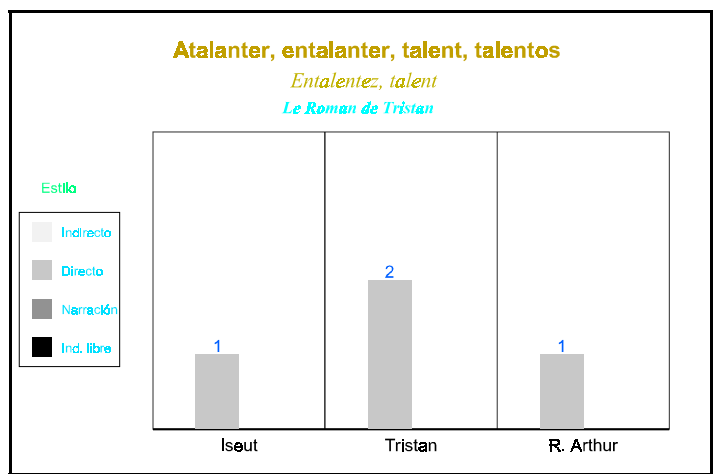

Fig. 84. Comportamiento estilístico de los verbos «atalanter»y «entalanter», del sustantivo «talent»y del adjetivo «talentos» en Tristan.

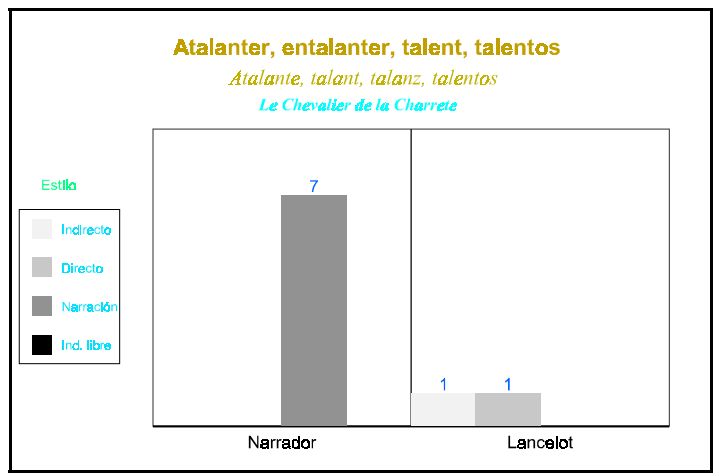

Fig. 85. Comportamiento estilístico del verbo «atalanter, del sustantivo «talent» y del adjetivo «talentos» en Charrete.

442 También Rose, 1748 - 1749 y Charrete, 4598. 


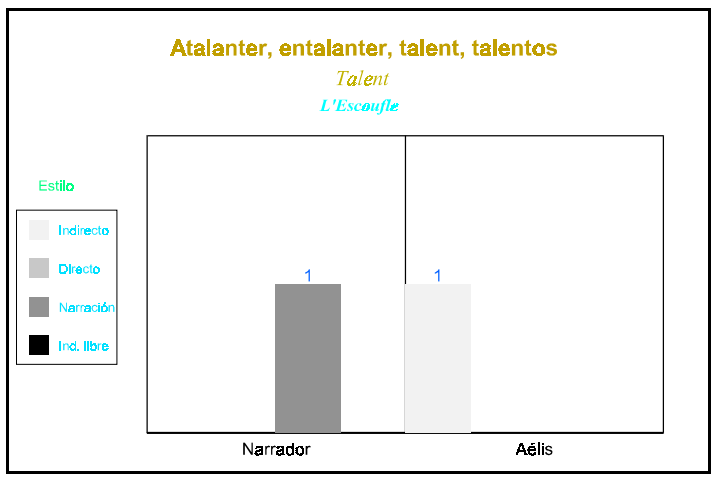

Fig. 86. Comportamiento estilístico de los verbos «atalanten» $\mathrm{y}$ «entalanter», del sustantivo «talent»y del adjetivo «talentos» en Escoufle.

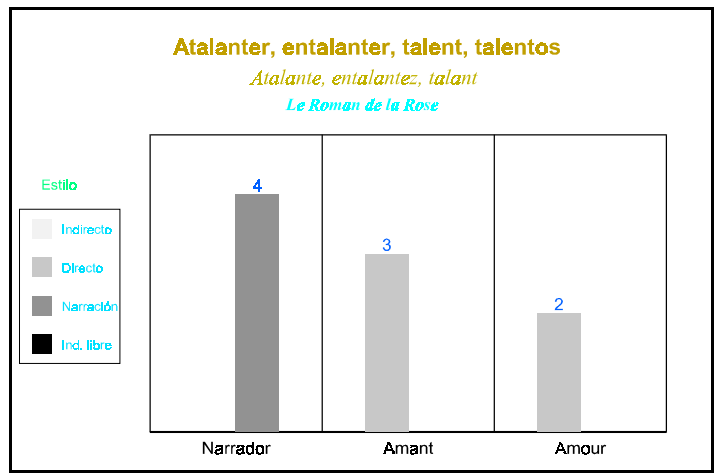

Fig. 87. Comportamiento estilístico de los verbos «atalanter» y «entalanter», del sustantivo «talent»y del adjetivo «talentos» en Rose.

Probablemente las consecuencias más notables que podemos extraer de la lectura de los gráficos precedentes sean: la coincidencia de las obras de Béroul y Renart en cuanto que las heroínas utilizan los vocablos que nos ocupan y que su uso en estas obras es menor frente a los textos de Chrétien o Lorris, quienes, por otra parte, dan un mayor protagonismo a la narración. En Charrete, texto en el que parecen analizarse las reacciones sentimentales desde el exterior, la desproporción es muy evidente, pero se armoniza en el texto del siglo XIII. En Rose el amante manifiesta sin recato sus deseos mientras descubre la atracción del sexo y no tiene conciencia clara de las prohibiciones que se le imponen, en lo que consideramos la primera fase de su enamoramiento. 


\subsection{2 «Baen $\mathbf{y}$ «beance».}

Independientemente del significado contextual de ambos términos, que va desde la intención de hacer algo hasta el deseo ardiente del amante excesivamente atraído por los placeres sexuales, Lorris les otorga dos valores opuestos, uno positivo y otro negativo. Dentro del primero se incluyen las aspiraciones, los anhelos, las intenciones: “mes ja mes jor n'avré beance de rien ou vos aiez grevance” (Rose, 3151 - 3152), así como los deseos del amante — de ahí las referencias al sustantivo cuer-, manifestados en los discursos de Amor, del narrador y del propio enamorado mediante el sustantivo beance o el verbo baer en pretérito imperfecto de indicativo: "mes vers le bouton me traioit li cuers, qui aillors ne beoit" (Rose, 1725 - 1726); a ellos se añade la opinión de Honte sobre las verdaderas intenciones de Bel Accueil al ofrecer su ayuda al adolescente que se acerca a las rosas, un fragmento en el que encontramos los ecos de las justificaciones de Tristan y de la reina Iseo. De hecho aquí también se enfrentan los motivos individuales, íntimos, relacionados con el sentimiento amoroso, en Rose sin atisbo de interpretación fraudulenta, representados por el pudor de la mujer joven, y las desmesuradas e inflexibles convenciones sociales encarnadas por la intransigente Jalousie:

mes certes je n'ai pas creance

que il ait eüe beance

de mauvestié ne de folie.

Rose, 3563 - 3565

Y también la imposición que el dios Amor hace del dolor como condición absolutamente necesaria para que los amantes puedan obtener un justo premio a su perseverancia, lo que se traduce en un despliegue de términos relacionados con la enfermedad y la cura en torno al sustantivo beance: guerir, guenison, plaie, doloir. El enamorado de la rosa acepta de 
buen grado los sufrimientos amorosos con la esperanza de lograr el trofeo anhelado, que no es otro que el goce pleno del objeto de sus deseos, la posesión sentimental y sexual del capullo - doncella:

\author{
Trestote autretele beance \\ a cil qu'Amors a en prison. \\ Il espoire sa guerison
}

Rose, 2604 - 2606

de mes plaies mout me dolui

et soi que guerir ne pooie

fors par le bouton ou j'avoie

tot mon cuer mis et ma beance;

si n'avoie en nului fiance

fors ou diex d'Amors de l'avoir

Rose, 2754 - 2759

En el extremo opuesto se encuentra la lectura que de esas mismas motivaciones hace el primer enemigo alegórico con el que se encuentra el amante, Dangier. ${ }^{443}$ Este atribuye a sus actitudes y palabras un sentido negativo, fruto del engaño y la mentira, sin otro origen posible que la simple concupiscencia del joven, al que cree deseoso de defraudar la confianza que Bel Accueil ha depositado en él, tal como explica mediante una proposición subordinada circunstancial de causa: "Vos fetes mal, se Dex me saut, qu'il bee a vostre nuisement” (Rose, 2912 - 2913), extremo en el que insiste al cambiar su interlocutor:

${ }^{443}$ En su intento de convencer al enamorado para que abandone la mesnada de Amor, Raison también utiliza el presente de indicativo del verbo baer para introducir las nefastas intenciones de Dangier:

car mout te bee durement

Dangier le fel a guerroier,

tu ne l'as mie a essaier.

Rose, 3008 - 3010 
Bel Acueil mal vos conoissoit

qui de vos servir s'angoissoit,

si le beez a conchier.

Rose, 2921 - 2923

En la misma línea se halla la recriminación de Bel Accueil ante el deseo excesivamente imperativo del amante de poseer a la doncella. Éste rompía no sólo con las normas sociales que prescribían la virginidad y el recato, sino con el reglamento de Amor que requería un cortejo largo y penoso: "Frere, vos beez a ce qui ne puet avenir" (Rose, 2892 - 2893); así como el contraataque dialéctico del enamorado para recuperar la confianza de Bel Accueil, minada por las amenazas, castigos y tergiversaciones de sus intenciones amorosas que los enemigos del amor han tejido en torno a la mujer:

Hé! Bel Acueil, ce sai de voir

qu'il vos beent a decevoir, et, se devient, si ont il fet

Rose, 4019 - 4021

Si observamos la construcción sintáctica en la que se inserta aquí el verbo baer, nos damos cuenta de que las proposiciones subordinadas completivas quedan reservadas para las defensas de los enamorados —el amante y la doncella representada por Honte- ante los ataques de sus contrincantes, y dependen de locuciones que expresan el conocimiento y más concretamente la creencia: savoir de voir y avoir creance (Rose, 3563), aunque esta última construida en negativo pues la estrategia debe ser diferente al oponer un argumento directo a los adversarios de Amor.

Como ocurría con el sustantivo talent, beance funciona sistemáticamente como complemento de objeto directo del verbo avoir, y en una ocasión de metre; con un sentido general si lo precede un indefinido 
como autretele o si no aparece marcado por ningún determinante, y con un valor particular antecedido por el artículo posesivo de primera persona, sin duda alguna referido al deseo erótico, que complementa al sentimiento amoroso encarnado por cuer. Ambos sustantivos se encuentran en una proposición subordinada de relativo introducida por el adverbio ou cuyo antecedente es bouton: "le bouton ou j'avoie tot mon cuer mis et ma beance" (Rose, 2756 - 2757). El mismo y lógico antecedente que encontramos para otra de las proposiciones de relativo, aunque en este caso el nexo relativo toma la forma habitual del pronombre régimen con preposición, un cambio que podemos atribuir a los imperativos del metro: "quant il me vit a li paler dou bouton a qui je beoie" (Rose, 3102 - 3103).444

\begin{tabular}{lllllllll}
\hline FORMA & CA & BD & NV & RIMA & CA2 & NV2 & D & PERS \\
\hline beance & S & Rose & 2604 & cheance & S & 2603 & D & Amour \\
beance & S & Rose & 2757 & fiance & S & 2758 & N & Narrador \\
beance & S & Rose & 3151 & grevance & S & 3152 & D & Amant \\
beance & S & Rose & 3564 & creance & S & 3563 & D & Honte \\
beez & V & Rose & 2892 & esfreez & O & 2891 & D & Bel Accueil \\
beoie & V & Rose & 3103 & comparroie & V & 3104 & I & Amant \\
beoit & V & Rose & 1726 & traioit & V & 1725 & N & Narrador \\
\hline
\end{tabular}

Tabla 66. Rimas del verbo «baer» y del sustantivo «beance» en Rose.

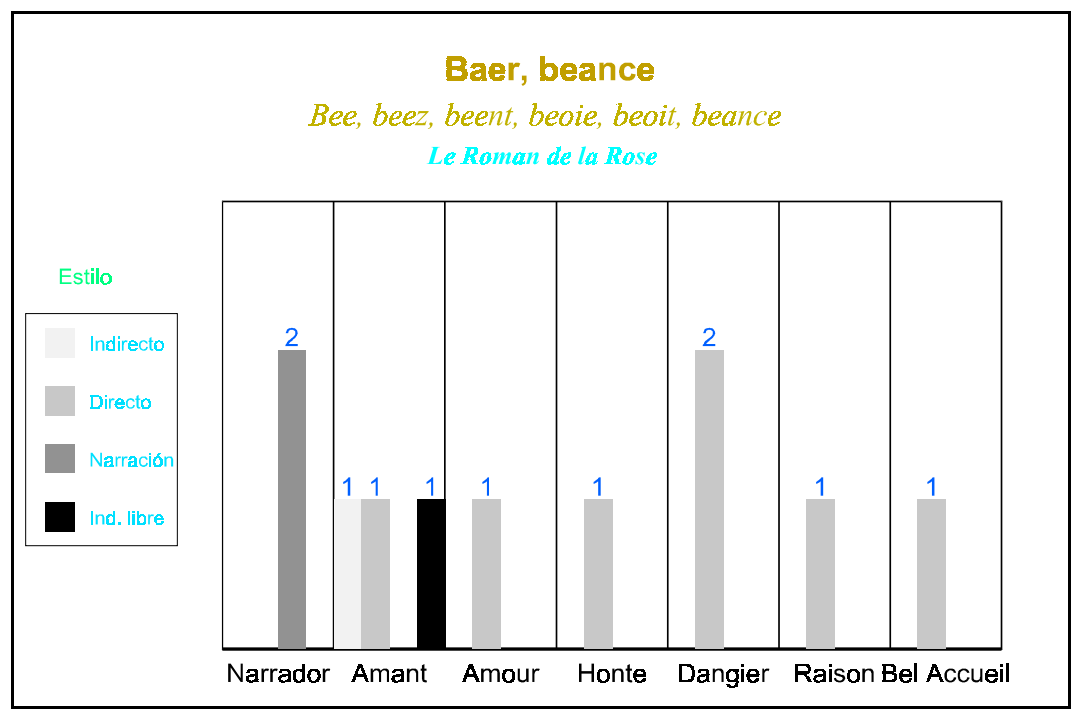

Fig. 88. Comportamiento estilístico del verbo «baen» y del sustantivo «beance» en Rose.

${ }^{444}$ Hasenohr advierte que el adverbio relativo ou cubriendo el área nocional del espacio expresada por las preposiciones en y a, tiene con frecuencia como antecedente un nombre de persona, en este caso bajo el manto de la alegoría, equivaliendo a a cui, op. at., p. 110 - 111. 
Los motivos formales parecen haber sido en gran medida determinantes para la elección de estas formas como alternativa a otros términos que en el corpus indican el deseo o la intención. Por una parte todas las formas del verbo baer utilizadas en el corpus son de dos sílabas, por otra, la aparición en la rima es mayoritaria, constante en lo referente al sustantivo beance, sin que los emparejamientos se repitan, por lo que podemos concluir que no existía una finalidad semántica en esas uniones. Sin embargo, no se puede pasar por alto el hecho de que, al igual que en el apartado precedente, la posición final de verso puede mostrar el interés que algunos autores, y particularmente Lorris, tienen en poner de relieve el deseo.

\subsection{Convoitery convoitise.}

El verbo covoitier y el sustantivo covoitise se nos muestran no sólo como variantes formales — se hallan siempre en la rima- sino como variantes expresivas de otros términos más utilizados en los textos de Chrétien y de Lorris. A ello se añade el hecho de que no existen posibles dudas sobre el sentido que adoptan en cada uno de los contextos pues se apela inequívocamente al deseo amoroso o al deseo carnal.

Se trata de concupiscencia en la narración en primera persona de Rose, donde el narrador evoca en presente de indicativo el exacerbado deseo que embargaba sus sentidos una vez que había acariciado y besado la rosa, es decir, una vez que había roto la barrera del contacto físico, algo que en la erótica cortés significaba la aceptación del enamorado, una invitación para que perseverase en su cortejo y el anuncio de nuevos y más intensos placeres:

$$
\begin{aligned}
& \text { se j'ai la savor essaie, } \\
& \text { tant est grainde la covoitise } \\
& \text { qui esprent mon cuer et atise }
\end{aligned}
$$$$
\text { Rose, } 3768 \text { - } 3770
$$ 
El participio pasado sustantivado que designa y caracteriza a uno de los caballeros participantes en el torneo de Noauz: "c'est Ignaures li covoitiez, li amoreus et li pleisanz" (Charrete, 5788 - 5789) completa en forma pasiva las cualidades del caballero cortesano, el ideal artúrico, de aquel que maneja las armas y que cultiva el amor y las artes cortesanas que lo hacen agradable a los de su clase, sean varones o mujeres, y por todo ello (aunque habría que suponerle también belleza física) es deseado, ¿como suspirante o amante de las damas, como compañero de armas y de juegos eróticos para sus iguales?. No sabríamos decirlo, pero, en cualquier caso, no como esposo, pues también será rechazado por las doncellas casaderas.

Las otras dos ocurrencias que se nos presentan en el corpus corresponden a un estadio incipiente o impreciso del deseo erótico. En Rose el amante anhela la cercanía y el trato agradable de aquélla a la que desea, un mínimo imprescindible para alimentar su esperanza, que se expresa mediante el superlativo absoluto en una proposición de relativo especificativa del sustantivo rien: "Bel Acueil li avez toloite, que c'est la rien que plus covoite" (Rose, 3281 - 3282). Mucho menos concreto en apariencia es el deseo de Lanzarote, pues se exterioriza por persona interpuesta mediante una fórmula desiderativa tópica en la que Dios es el sujeto del verbo doner en subjuntivo, ${ }^{445}$ que es utilizada como pago a su habilidad guerrera y como soborno para que cumpla la voluntad de la doncella que le habla. Sin embargo, contiene, y aun con insistencia gracias a la construcción comparativa en la que se incluye covoitier y a los dos versos posteriores que ofrecen una explicación premonitoria del deseo, todo aquello a lo que aspira el caballero en su errar: el honor de la victoria sobre el raptor de la reina y el amor de ésta, pues tal como

\footnotetext{
445 No existe unanimidad al considerar la forma que introduciendo este tipo de proposiciones independientes en subjuntivo. Nosotros la hemos clasificado como conjunción no por convencimiento, pues la explicación de Ménard sobre su origen final o consecutivo no nos satisface, tal como le ocurre a Soutet; sin embargo, la inclusión de una clase sui géneris que él llama «particule» y otros como Foulet «béquille» del subjuntivo, suponía una modificación de la clasificación tradicional poco operante pues no eran muchas las ocurrencias con las que nos íbamos a encontrar. Cf. O. Soutet, op. cit., p. 64 - 65.
} 
afirma Köhler, el combate está al servicio del amor ideal transmutado en fuerza que empuja a la aventura: 446

$$
\begin{aligned}
& \text { que Dex te doint joie et enor } \\
& \text { si grant con tu puez Covoitier, } \\
& \text { et si te doint bien esploitier } \\
& \text { de ce que tu as entrepris. }
\end{aligned}
$$

Charrete, $2826-2829$

\begin{tabular}{lllllllll}
\hline FORMA & CA & BD & NV & RIMA & CA2 & NV2 & D & PERS \\
\hline covoite & V & Rose & 3282 & toloite & O & 3281 & D & Pitié \\
covoitier & I & Charrete & 2827 & esploitier & I & 2828 & D & Demoiselle \\
covoitiez & O & Charrete & 5788 & mitiez & S & 5787 & D & Gens \\
covoitise & S & Rose & 3769 & atise & V & 3770 & N & Narrador \\
\hline
\end{tabular}

Tabla 67.Rimas del verbo convoiter y del sustantivo convoitise.

\subsection{4 «Corage».}

Derivado del sustantivo cor, «corazón», sede del alma y del espíritu, el sustantivo corage concentra en sí todas las disposiciones de aquellos, es decir, la intención, el deseo, el sentimiento, el pensamiento, la opinión o la voluntad, ${ }^{447}$ y puede hacer referencia al compendio de todas ellas, al carácter de un individuo: "Li valez fu joines et biaus, si estoit bien d'autel aage con s'amie, et d'autel courage” (Rose, 1274 - 1276), por lo que es más complejo esclarecer el sentido concreto que cada una de las ocurrencias adopta. De este modo, mientras la negativa de Aelis de revelar su origen y su nombre tal vez hiere los sentimientos del joven que la ayuda tras ser abandonada por Guillermo o quizás frustra sus deseos de entablar una relación más familiar:

\footnotetext{
4460 p. at., p. 81.

447 Los trovadores lo utilizaban como sinónimo de coeur, aunque poseía en general un sentido más complejo e intelectual que el monosílabo, "permettant d'exprimer un contraste entre le coeur, siège des désirs d'amour et la conscience dans laquelle le poète médite sur l'amour". G. M. Cropp, op. at., p. 263 , n. 28.
} 
"Ml't par li grieve en son corage por ce qu'il n'ot ainc mais veüe si bele riens" (Escoufle, 4810 - 4812), el espejo de la fuente de Narciso muda los proyectos, las intenciones nacidas del razonamiento, o bien los sentimientos, los deseos, en una palabra, las emociones de los que en él se miran:448

$$
\begin{aligned}
& \text { ici se changent li corage, } \\
& \text { ci n'a mestier sens ne mesure, } \\
& \text { ci est d'amer volenté pure }
\end{aligned}
$$$$
\text { Rose, } 1582 \text { - } 1584
$$

Béroul, además, ahonda en el debate entre el instinto y las convenciones sociales al aproximar el sentido del término a uno de los que posee actualmente, ya que Tristán apela a su fuerza moral con el deseo de reintegrar a la reina a la corte, quien recuperaría así el bienestar y la dignidad que merece:

$$
\begin{aligned}
& \text { A Deu, qui est sire du mont, } \\
& \text { cri ge merci, que il me donst } \\
& \text { itel corage que je lais } \\
& \text { a mon oncle sa feme en pais } \\
& \text { Tristan, } 2185 \text { - } 2188
\end{aligned}
$$

El sustantivo corage hace abiertamente referencia al deseo de la reina Ginebra, aunque reprimido y dominado por la razón, al volver Lanzarote a la corte de Arturo tras su cautiverio: "et se reisons ne li tolsist ce fol panser et cele rage, si veïssent tot son corage" (Charrete, 6842 - 6844); de igual modo que en los consejos de Amor para aliviar las penas del amante de la rosa: "a cui tu dies ton talant et descuevres tot ton corage" (Rose, 2674 2675). En ambos ejemplos se observa la misma construcción del sintagma nominal que funciona como complemento de objeto directo: [Adj.

\footnotetext{
448 A. Strubel propone la traducción «sentiments» para el término corage quedando así este verso: “c'est ici que les sentiments se transforment", opta por la opción que mejor se adapta al contexto posterior, aunque sigue persistiendo nuestra duda pues en los versos anteriores parece prefigurarse el sentido de
} 
Indefinido + Art. Posesivo + Sust.]. La construcción sintáctica o, por mejor decir, la formulación y recuperación de determinadas locuciones, se muestra como uno de los fenómenos determinantes en la construcción del sentido erótico en nuestro corpus. De este modo, en las obras del siglo XII, corage, que funciona como complemento de objeto directo del verbo avoir en construcción negativa, acompañado de un complemento atributivo de nombre introducido por la preposición de — que puede ser retomado por el adverbio en-, sirve sistemáticamente para que sean rechazadas las imputaciones de adulterio, de deseos y actos no ajustados a las normas, más habituales en Tristan. En este roman el rey Marco en tercera persona del plural intenta excusar a los amantes: "or sai je bien n'en ont corage" (Tristan, 305) e Iseo en primera persona del singular debe justificar sus encuentros con Tristan o su vuelta a la corte: "n'ai corage de drüerie qui tort a nule vilanie" (Tristan, 33 - 34), "qar ja corage de folie nen avrai je jor de ma vie" (Tristan, 2323 2324). También Ginebra debe defenderse de las acusaciones de Meleagant, quien encontraría en el fornicio de la reina con Keu la justificación para poseerla sexualmente, de ahí que ella insista en la capacidad de control sobre su cuerpo y en el rechazo del tópico de la mujer insaciable, dominada por el instinto sexual, sin capacidad para discriminar a sus parejas. En este caso, la reina, quien, a diferencia de Iseo, se halla en inferioridad, no sólo se siente empujada a justificarse a sí misma y descarta incluso cualquier inclinación futura por el senescal, sino que debe salvar el honor del caballero herido y poco hábil en sus argumentos, incapaz de defenderse y de protegerla:

$$
\begin{aligned}
& \text { et je ne regiet mie an foire } \\
& \text { mon cors, ne n'an faz livreison. } \\
& \text { Certes, Kex n'est mie tex hom } \\
& \text { qu'il me requeïst tel outrage, } \\
& \text { ne je n'en oi onques corage }
\end{aligned}
$$

«voluntad». Cf. Guillaume de Lorris et Jean de Meun, L e Roman de la Rose, A. Strubel (ed. y trad.). París: Librairie Générale Française, 1992, p. 127. 
del faire, ne ja ne l'avrai.

Charrete, 4842 - 4847

Junto a la función mayoritaria de complemento de objeto directo, el sustantivo asume la de complemento preposicional dependiente de un verbo: "et s'il vos vient, sire, a corage que me mandez rien par mesage" (Tristan, 2711 - 2712), "petit savroit a mon corage" (Tristan, 254). Y desde el punto de vista de la sintaxis oracional suele presentarse en proposiciones independientes o principales aunque encontramos ejemplos de subordinadas relativas: “a cui tu dies ton talant et descuevres tot ton corage" (Rose, 2674 - 2675), completivas (Tristan, 305 y 2186 - 2187) y circunstanciales hipotéticas: "Beaus amis douz, se ja corage vos ert venuz de repentir, or ne peüst mex avenir." (Tristan, $2270-2272$ ).

\begin{tabular}{lllllllll}
\hline FORMA & CA & BD & NV & RIMA & CA2 & NV2 & D & PERS \\
\hline corage & S & Rose & 2675 & avantage & S & 2676 & D & Amour \\
corage & S & Tristan & 2270 & boschage & S & 2269 & D & Iseut \\
corage & S & Escoufle & 4810 & lignage & S & 4809 & N & Narrador \\
corage & S & Tristan & 2711 & mesage & S & 2712 & D & Iseut \\
corage & S & Tristan & 305 & outrage & S & 306 & D & Roi Marc \\
corage & S & Charrete & 4846 & outrage & S & 4845 & D & Guenièvre \\
corage & S & Tristan & 254 & rage & S & 253 & D & Tristan \\
corage & S & Charrete & 6844 & rage & S & 6843 & N & Narrador \\
corage & S & Rose & 1582 & rage & S & 1581 & N & Narrador \\
courage & S & Rose & 1276 & aage & S & 1275 & N & Narrador \\
\hline
\end{tabular}

Tabla 68. Rimas del sustantivo «corage».

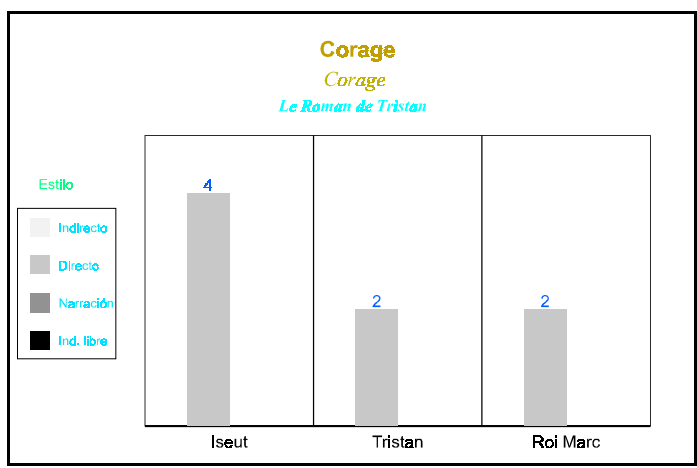

Fig. 89. Comportamiento estilístico del sustantivo «corage» en Tristan. 


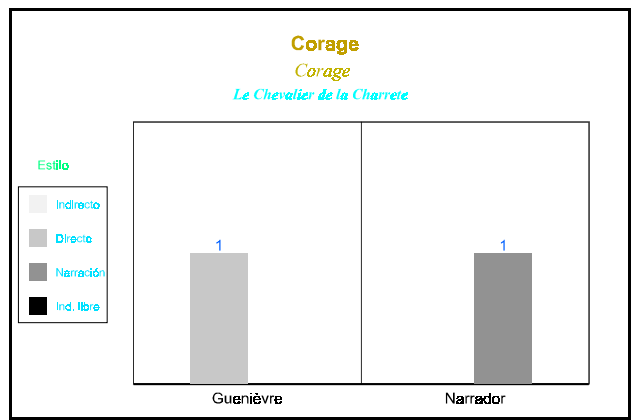

Fig. 90. Comportamiento estilístico del sustantiv «corage» en Charrete.

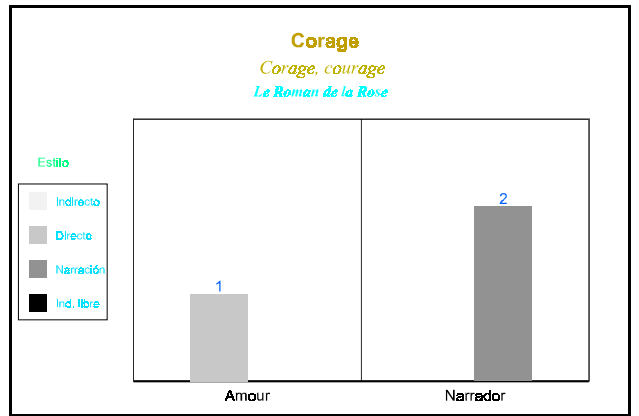

Fig. 91. Comportamiento estilístico del sustantiv «corage» en Rose.

Las rimas que se repiten en varias obras, con outrage y rage, ponen de manifiesto la estrecha relación entre el deseo erótico y la transgresión, ya sea de las reglas matrimoniales o de las que en un principio los moralistas eclesiásticos y posteriormente en el proceso de afirmación del individuo los defensores de la razón como elemento divino, intentaban imponer sobre el cuerpo y sus impulsos a duras penas controlables. Sin embargo, los usos de corage cuya relación es más estrecha con el apetito sexual se representan de forma negativa, mediante la sintaxis, la represión o la simple referencia verbal a un hipotético confidente.

\subsection{Désirery «desimant».}

El adolescente de Rose, antes de adentrarse en la parte más sensual de la ensoñación erótica, aspira a descubrir las nuevas diversiones que entrevé al salir de la infancia y, paradójicamente, pues es el protagonista de un sueño, se 
dirige intencionadamente, consciente de que existe una poderosa fuerza que lo empuja, en pos de los placeres desconocidos personificados por Deduit:

$$
\begin{aligned}
& \text { mes quant j'oi escouté un poi } \\
& \text { les oisiaus, tenir ne me poi } \\
& \text { qu'adonc Deduit voair n'alase, } \\
& \text { car a voair mout desirasse } \\
& \text { son contenement et son estre. }
\end{aligned}
$$$$
\text { Rose, } 707 \text { - } 711
$$

Tras la amena introducción en el mundo de la sensualidad adulta y la intervención del dios Amor, el verbo desirer se especializa, al igual que ocurre en Charrete, y pasa a denominar la tendencia consciente y suscitada por una mujer o por un hombre hacia los placeres sexuales. El adjetivo de origen verbal desimant en función de atributo es, de hecho, el medio utilizado por Chrétien para expresar el apetito sexual compartido de la reina y Lanzarote en el preludio de la noche de amor. Reciprocidad muy excepcional en este roman, que se pone de relieve gracias a un doble complemento preposicional en construcción coordinada paralela que ocupa un verso completo y al juego pronominal:

$$
\begin{aligned}
& \text { que molt estoient desirrant } \\
& \text { il de li et ele de lui. }
\end{aligned}
$$

Charrete, 4588 - 4589

Excepcionalidad que también concierne a la determinación del objeto deseado pues tanto en Rose como en Charrete hay una clara inclinación a mantenerlo indefinido. Lorris utiliza para ello proposiciones de relativo cuyo antecedente es el pronombre neutro ce: "je ne pris guieres tel gesir, quant je n'ai ce que je desir" (Rose, 2479 - 2480), “car je n’avré ja mes loisir de veoir ce que je desir" (Rose, 3747 - 3748), ambas en el discurso del amante por lo que aparece regularmente la primera persona del presente de indicativo. En la narración el pronombre neutro no remite a la persona amada sino a una 
acción, a una manifestación física del deseo, como en el caso de Narciso la posesión de su doble quimérico: "car quant il vit qu'il ne porroit acomplir ce qu'il desimit” (Rose, 1495 - 1496). Solamente en este caso desaparece la indeterminación al expresarse la acción, el don deseado, mediante un sustantivo que retoma el pronombre relativo: "adés me tarda li otroiz dou bessier que je desiroie" (Rose, 3400 - 3401).

Chrétien recurre igualmente a las proposiciones relativas pero el antecedente es el sustantivo chose, que, aunque menos utilizado en nuestro corpus, funciona como el sustantivo rien con un valor indefinido, modo de ocultación de la identidad de la dama según las normas de la cortesía, al que se suma un contexto ponderativo. En el discurso directo del caballero enamorado el verbo desirer en pretérito perfecto manifiesta la actualización de un deseo constante que cree por fin poder colmar al hallar a la doncella en un camino acompañada tan sólo por Lanzarote: “que Dex m’a la chose donee que j'ai toz jorz plus desimee" (Charrete, 1679 - 1680). En la narración, donde el condicional simple parece evocar la eventualidad en el pasado, ${ }^{449}$ chose figura a Ginebra, la fuente de inspiración erótica y guerrera del caballero: "trestorne soi et voit a mont la chose de trestot le mont que plus desimoit a veoir, as loges de la tor seoir." (Charrete, 3671 - 3674).

La inclusión en proposiciones subordinadas, ya sean las relativas que hemos señalado o bien proposiciones circunstanciales que introducen la noción de causa mediante la conjunción car (Rose, 710) o que: “d'un dolz salu l'a saluee. Et ele un autre tost li rant, que molt estoient desirrant" (Charrete, 4586 - 4588); así como la colocación en la rima — tan sólo hallamos un ejemplo en Charrete en el que el verbo se encuentra en el interior del verso- caracterizan al verbo y al adjetivo sintáctica y compositivamente.

\footnotetext{
${ }^{449}$ Véase para este uso de la forma en -roie la anotación que hace Ménard, op. dit., p. 145. En un principio habíamos interpretado este desconcertante empleo del verbo desirer en condicional como un inciso en estilo indirecto libre en el que se da la palabra a Lanzarote. Interpretación que descartamos tras consultar la obra de G. Hasenohr quien puntualiza que "la forme en -roie est caractéristique du discours indirect libre qui, situé dans le passé, vise l'avenir”, op. àt., p. 178.
} 


\begin{tabular}{lllllllll}
\hline FORMA & CA & BD & NV & RIMA & CA2 & NV2 & D & PERS \\
\hline Desir & V & Rose & 2480 & gesir & S & 2479 & D & Amant \\
Desir & V & Rose & 3748 & loisir & S & 3747 & L & Amant \\
Desirasse & V & Rose & 710 & alase & V & 709 & N & Narrador \\
Desiroie & V & Rose & 3401 & guerroie & V & 3402 & N & Narrador \\
Desiroit & V & Rose & 1496 & porroit & V & 1495 & N & Narrador \\
Desirrant & A & Charrete & 4588 & rant & V & 4587 & N & Narrador \\
Desirree & O & Charrete & 1680 & donee & O & 1679 & D & Chevalier \\
\hline
\end{tabular}

Tabla 69. Rimas del verbo désirer y del adjetivo «desirrant».

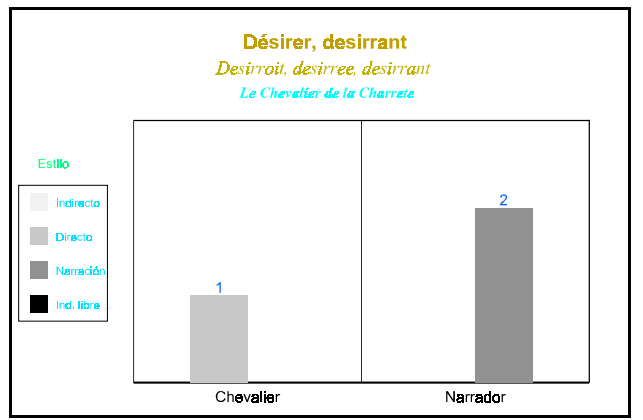

Fig. 92. Comportamiento estilístico del verbo désirer y del adjetivo «desirrant» en Charrete.

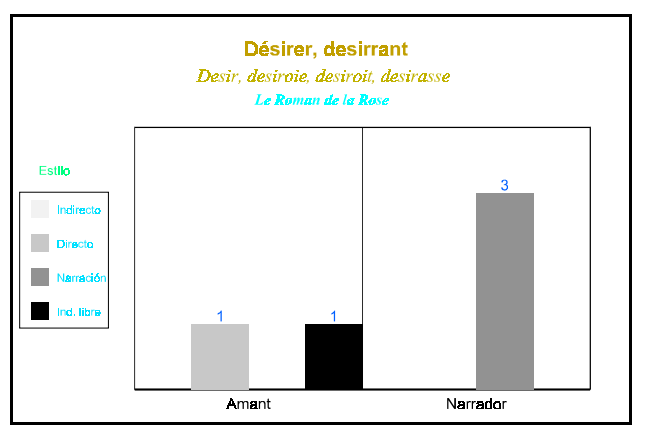

Fig. 93. Comportamiento estilístico del verbo désirer y del adjetivo «desirrant» en Rose.

Como ya ocurría con el verbo convoiter y con el sustantivo convoitise los términos claramente especializados en la expresión del deseo erótico quedan reservados en el corpus para los textos de Chrétien y de Lorris. En ellos la visión, el primer contacto físico que proporciona el beso o el goce de los cuerpos constituyen las principales etapas del cortejo y de la posesión prefigurados por desirer y desirrant. 


\subsection{Envie y «envieus».}

Si tomásemos en consideración la datación que propone Cropp, el siglo XV, para la adopción en francés del sentido de «deseo físico» para el sustantivo envie, o la definición que propone Greimas, ${ }^{450}$ donde se contemplan sólo la codicia y el odio, o el hecho de que se le conceda a lo sumo el sentido pasivo de «aquello que provoca el deseo», ${ }^{451}$ deberíamos excluir las ocurrencias que aparecen en Rose de envie y envieus. Sin embargo, probablemente influido por la lírica trovadoresca, descubrimos en el roman claras referencias al deseo, pese a que no resulte sencillo distinguir entre la concupiscencia y el deseo sublimado, menos imperioso, propio del amor cortés, pues ambos sentidos coexistían en antiguo provenzal. ${ }^{452}$

La atracción por los placeres recién descubiertos se traduce en el ansia de participar en el corro alegórico: "car de queroler, se j'ousasse, estoie envieus et sorpris" (Rose, 792 - 793), sin que podamos pasar por alto que en la vida real, desprovisto de su carga simbólica, también permitía que hombres y mujeres se conociesen y tocasen, compartiesen el baile y la diversión, en lo que podía ser el preludio de una relación más íntima como ocurrirá en el jardín de Deduit.

Envie, que funciona como complemento de objeto directo, y envieus en función de atributo jalonan el camino del joven desde la percepción de las primeras mujeres por las que se siente atraído: "choisi rosiers chargiez de roses (...) et lors m'en prist si grant envie” (Rose, 1614 1617). La apetencia de posesión carnal, inmediata y completa, de la doncella elegida, que se manifiesta en los primeros instantes del enamoramiento tras la acogida de la joven: "se le bouton ne me bailliez, (...) ce est ma mort, ce est ma vie, de nule rien n’ai plus envie.” (Rose, 2887 - 2890), deberá atemperarse y

\footnotetext{
450 Cf. A.-J. Greimas, op. cit., p. 235.

451 Ibid., p. 235 y F. Godefroy, L ex ique de l'ancien français. París: Honoré Champion, 1982, p. 186.

452 Cf. G.M. Cropp, op. at., p. 270.
} 
quedar reducida al deseo de besarla, que como hemos podido comprobar se repite obsesivamente en la obra ya que es el único contacto físico que le está permitido y aun éste a costa de grandes esfuerzos: "durement sui envieus d'avoir un baisier precieus de la rose qui soëf flaire" (Rose, 3369 - 3371).

El realce de la idea de deseo es habitual y se utilizan para ello dos recursos formales: los adverbios de intensidad durement o si con valor de superlativo absoluto: "le saintuaire precieus de quoi i sont si envieus." (Rose, 2711 - 2712), y la acumulación de términos negativos que subrayan la exclusividad: “de nule rien n'ai plus envie” (Rose, 2890).

\begin{tabular}{lllllllll}
\hline FORMA & CA & BD & NV & RIMA & CA2 & NV2 & D & PERS \\
\hline envie & S & Rose & 1617 & Pavie & S & 1618 & N & Narrador \\
envie & S & Rose & 2890 & vie & S & 2889 & D & Amant \\
envieus & A & Rose & 2712 & precieus & A & 2711 & D & Amour \\
envieus & A & Rose & 3369 & precieus & A & 3370 & D & Amant \\
\hline
\end{tabular}

Tabla 70. Rimas del sustantivo envie y del adjetivo «envieus».

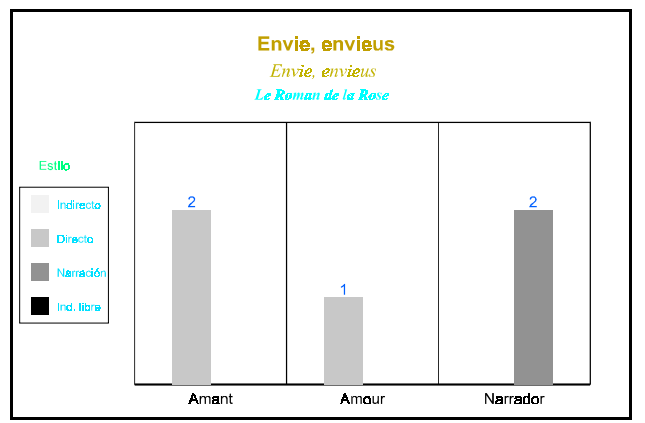

Fig. 94. Comportamiento estilístico del sustantivo envie y del adjetivo «envieus» en Rose.

La generalización del deseo masculino, el único al que hace referencia Lorris, se lleva a cabo en el discurso de Amor, donde la dama es representada mediante una metáfora de naturaleza religiosa, aunque el uso habitual de términos relacionados con la religión en los textos deudores del código cortés les confería un sentido profano e incluso galante. En cualquier caso creemos que predomina el deseo físico y, tanto en la narración como en el discurso del amante, el cuerpo de la mujer se muestra como la suprema aspiración masculina. 


\subsection{Vouloir, volonté y «vuel».}

El verbo voloir y los sustantivos voloir, volenté y vuel, que concentran las claves del discurso amoroso caballeresco, tienen una especial vigencia en las obras de Chrétien y Lorris, hecho que de nuevo nos induce a pensar cuando menos en una filiación común. En ambos textos hallamos los mismos sentidos: desde la voluntad de obligado cumplimiento que emana del discurso del dios Amor y de las damas corteses hasta el deseo de sometimiento absoluto de los amantes, pasando por el apetito de los placeres eróticos y por la denominación eufemística de la cópula como premio a la victoria de un guerrero sobre otro. También Tristan y E scoulle coinciden en un fenómeno esencial: las referencias al deseo compartido de los amantes que se expresa, además, en construcciones similares, tanto en el discurso indirecto libre del rey Marco en el que los receptores deben interpretar el sustantivo voloir en un sentido erótico, evidentemente alejado del que pretendía el emisor: "ainz lor laira la chanbre tot a lor voloir" (Tristan, 296 - 297), como en el más explícito del narrador de E sooufle.

$$
\begin{aligned}
& \text { Bien ont andui mis en la mine } \\
& \text { meres et parens et avoir } \\
& \text { por acomplir tot lor voloir. } \\
& \text { Escoufle, } 4050 \text { - } 4052
\end{aligned}
$$

Comenzaremos nuestro recorrido por el acatamiento del amante de la soberanía del amor y de sus exigentes preceptos, a los que deberá prestar toda su energía tanto para asimilarlos como para ponerlos en práctica sin error: "por ce sui en grant de l'aprendre que je n’i veil de rien mesprendre" ( Rose, 2047 - 2048). Es una entrega que remeda la sumisión del vasallo a su señor: "et se de moi vostre prison volez fere ne ne daigniez, ne m'en tieng pas a engigniez" (Rose, 1912 - 1914), haciéndolo depositario no sólo del cuerpo sino del corazón, sede de los sentimientos: "metre veil tot a devise cuer et cors en vostre devise" (Rose, 1916 - 1918). Está representada con asiduidad 
por la notable aparición de la primera persona del singular del presente de indicativo en el discurso directo de Amor. ${ }^{453} \mathrm{Al}$ reconocerle un poder divino todo depende de él, lo bueno y lo malo. Le procura los bálsamos que hacen el sufrimiento del enamorado más llevadero, como los dulces recuerdos de la amada, ${ }^{454}$ y el amante - siervo le otorga el derecho de vida y de muerte sobre su persona: "ne puis vivre jusqu'a demain, se n'est par vostre volenté” (Rose, 1906 - 1907).

Por si esto fuera poco el amante se encuentra a expensas de fenómenos psicológicos y sociales sobre los que le resulta difícil actuar: es absolutamente dependiente de fuerzas externas a la pareja que tratarán de impedir la proximidad corporal y la contemplación de la amada, y que llegan a traducirse en una aceptación de la angustia provocada por el distanciamiento personificado en Dangier: “je veil mieuz sosfrir ma mesaise que fere rien qui vos desplaise" (Rose, 3153 - 3154),

Vos, veilliez que j'ain solement, autre chose ne vos demant.

Rose, 3163 - 3164

A los yugos que atan al varón se añade en la obra de Lorris una obstinada dominación de la mujer por parte de la sociedad que le ha impuesto estrictas reglas de conducta, presididas por la castidad: “mes je n'osse por Chasteé vers qui je ne veus pas mesprendre” (Rose, 3380 - 3381). Se rompe así el modelo cortés en el que tan sólo existía la voluntad y el deseo de la

\footnotetext{
453 "et si i as tant gaaignié que je veil por ton avantage que tu me faces tost homage" (Rose, 1930 - 1932); "et te veil si a moi lier que tu ne me puisses nier ne promesse ne covenant" (Rose, 1969 - 1971); "mes de celui point ne me dout qui en un leu met son cuer tout. Por ce veil qu'en un leu le metes, mes gardes bien que ne le pretes" (Rose, 2235 - 2239).

454

ainz veut que j'aie aligement

por l'ointure de l'oignement,

qui ere toz de confort plains

Rose, 1849 - 1851
} 
mujer y particularmente de la dama, y en todo caso el intento de mantener sus amores en secreto para evitar habladurías y obstáculos, tal como queda reflejado en Charrete. En este roman a menudo el verbo voloir tiene como sujeto en las intervenciones dialogadas un pronombre de primera persona que representa a la reina o a una doncella: "que por ce que a gré vos vaigne voel ge molt bien que il se taigne." (Charrete, 3793 - 3794), ${ }^{455}$ y muy excepcionalmente en el discurso directo del narrador de Rose al referirse a su tributo literario, donde observamos una rehabilitación de la figura todopoderosa de la dama, lejana ya la época adolescente que recoge el relato:

$$
\begin{aligned}
& \text { a la bele, que Dex guerisse, } \\
& \text { qui le guerredon m'en rendra } \\
& \text { mieuz que nule, quant el voudra }
\end{aligned}
$$

$$
\text { Rose, } 3490 \text { - } 3492
$$

En esta obra, si exceptuamos este pasaje, se mantienen con regularidad las normas que facilitan el control de la pareja y en particular de la voluntad femenina, como la exigencia de que el cortejo sea muy largo y se quede en los primeros estadios, sin que ninguno de los componentes físicos intervengan; de este modo tan sólo se acepta de manera incondicional el primer servicio masculino, la palabra:

\footnotetext{
455 En menor medida en tercera persona en la narración, cf. Charrete, 5364 - 5365;

si dit: «Chascuns de vos me doit

un guerredon a mon gré randre,

quele ore que jel voldrai prandre;

gardez, ne l'obliez vos mie.»

Charrete, 704 - 707

- Lancelot, biax dolz amis chiers,

fet la pucele, jel vuel bien;

que vostre enor et vostre bien

vuel je par tot et ci et la.
}

Charrete, 6696 - 6699 


\begin{abstract}
- Dites, fet il, vostre voloir,
que ja ne m'en feroiz doloir

de chose que vos veilliez dire.
\end{abstract}

Rose, 2879 - 2881

Un contacto primordial que Ginebra había llegado a rechazar como castigo por las dudas que había mostrado el amante ante el sacrificio de su renombre social, ${ }^{456}$ y como muestra inequívoca de su poder sobre el varón. Medida extrema que llevará casi a la muerte a la dama y a su caballero, cuya voluntad queda sojuzgada por los preceptos corteses, lo que hará que pliegue gustosamente su actividad guerrera, fundamental en la vida pública caballeresca, a los deseos cambiantes y probatorios de la reina: "qu'il vialt si oltreemant feire trestot quan que vos li mandez" (Charrete, 5910 - 5911). Guillermo también desea agradar a su amada aunque ya no se siente obligado a ello; da así la imagen de un enamorado más común que pretende agasajarla y procurarle el placer de un descanso y una comida en un bello y tranquilo paraje, algo que debía repercutir también en su propio bienestar: "De tant la velt cil losengier k'il li otroie volentiers." (Escoufle, 4406 - 4407). En esta obra del siglo XIII donde los enamorados diluyen sutilmente los moldes de la cortesía ya especializada en los ritos prenupciales, las relaciones de los casados nos muestran en toda su virulencia los usos patriarcales que obligaban a la esposa a soportar todos los deseos del marido, incluido el cortejo de otra mujer casada: "et quant jou sueffre en tel maniere vostre volenté et ma honte" (Escoufle, 5920 - 5921), actividad que lo colocaba fuera de lugar, en el bando de los jóvenes: ${ }^{457}$ Con ello Renart pone de nuevo en entredicho la validez de los usos avalados por la costumbre e idealizados por la literatura

\footnotetext{
$456 \quad$ mes por lui grever et confondre,

ne li vialt un seul mot respondre,

einz est an une chanbre antree

Charrete, 3967 - 3969

${ }^{457}$ Cf. G. Duby, Mâle M oyen A ge..., op. at., p. 48.
} 
caballeresca, ya que los amores ilícitos de un hombre casado y de una dama no sólo rompían las normas genealógicas masculinas sino que, irónicamente, menospreciaban el valor erótico y social de la mujer casada a la que se pretendía ensalzar.

Las manifestaciones del deseo erótico son muy difusas en el caso de los varones y difícilmente reconocibles en el de las féminas, salvo en algunos contextos como el que recogemos a continuación de E scoufle y que ya hemos tratado en el anterior capítulo: "La damoisele velt qu'il face de li com de s'amie chiere." (Escoufle, 4046 - 4047).

Tanto Chrétien como Lorris se refieren al deseo de sus personajes masculinos aunque desde dos posiciones bien distintas que requieren modos de expresión diferentes. Así, mientras en la obra del siglo XII se plantea aquél como una meta conquistada, ya sea por la plena aceptación de la dama que acoge a Lanzarote en su lecho para llegar ambos al placer sexual:

$$
\begin{aligned}
& \text { Or a Lanceloz quan qu’il vialt } \\
& \text { quant la reïne an gré requialt } \\
& \text { sa conpaignie et son solaz }
\end{aligned}
$$

Charrete, 4669 - 4771

ya por las perspectivas que abre el encuentro de la amada para la plena satisfacción de la libido del caballero, quien podrá conquistarla y violarla si no logra obtener su cuerpo de otra forma:

or ai tote ma volanté,

quant en tel meniere vos truis

qu'avoec moi mener vos an puis

Charrete, 1576 - 1578 
En ambos casos observamos una construcción similar ya que el sustantivo volanté y el verbo voloir, integrado en una frase de relativo que retoma el indefinido quan, funcionan como complemento de objeto directo del verbo avoir, cuyo sujeto son los varones enamorados. Los dos comparten, además, la expresión de la totalidad, de la saciedad podríamos decir, mediante el adjetivo tote o la combinación de los pronombres antecedente y relativo, quan que.

Por el contrario en Rose, aunque son más claras las referencias al apetito sexual, éste todavía se encuentra en un período de desarrollo, de exacerbamiento, y consecuentemente de insatisfacción. En los dos ejemplos que encontramos, el sustantivo es sujeto del sintagma verbal que indica el progresivo aumento de las ansias del amante mediante el verbo croistre o la construcción atributiva con el adjetivo comparativo graindre:

$$
\begin{aligned}
& \text { et la volenté me croissoit } \\
& \text { tot jorz d'aler vers la rousete, } \\
& \text { qui mielz oloit que violeite } \\
& \text { Rose, } 1752-1754
\end{aligned}
$$

que se j'avoie avant esté dou bouton bien entalantez, lors fu graindre la volentez

$$
\text { Rose, } 1748 \text { - } 1750
$$

Como manifestación extrema del deseo masculino ajeno a las corrientes que pretendían la participación de la mujer en la relación sexual, se encuentra la expresión faire sa volentée ${ }^{458}$ que en Charrete es un modo eufemístico de denominar una violación. Esta expresión en la que el verbo

458 P. Guiraud recoge esta expresión con el significado de copular o como aclara posteriormente "disposer de... selon son bon plaisir", op. at., p. 636. 
faire y en menor grado el artículo posesivo muestran claramente la unilateralidad de la actividad erótica, se halla en contextos que señalan la falta de consideración y la brutalidad con las que era tratada la mujer. Gracias a ella se reproducen unos esquemas que en el imaginario masculino estaban probablemente amparados por los usos extremadamente violentos de la época:

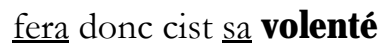 \\ de moi, veant tes ialz, a force? \\ Charrete, $1076-1077$
}

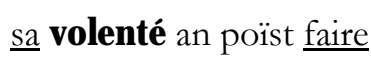

sanz honte et sanz blasme retraire

Charrete, 1315 - 1316

Amén de lo dicho para Escoufle, el deseo femenino se nos muestra tímidamente en Charrete. A medio camino entre la expresión de la voluntad y del deseo en el discurso de la reina al aceptar la entrada de Lanzarote en su habitación: “- Certes, fet ele, jel voel bien, mes voloirs pas ne vos detient” ( Charrete, 4616 - 4617), es en realidad deseo frustrado para las doncellas que pretenden conseguir al caballero que se obstina en su fidelidad y, por mucho que las doncellas manifiesten abiertamente su deseo de ser cortejadas o cuando menos de que se les preste alguna atención, él se muestra indiferente e incluso descortés:

$$
\begin{aligned}
& \text { et la pucele tote voie } \\
& \text { le chevalier de prés costoie, } \\
& \text { si le vialt feire a li antendre, } \\
& \text { et son non vialt de lui aprendre }
\end{aligned}
$$

Charrete, 1997 - 2000 
et lor volentez est comune

si qu'avoir le voldroit chascune

Charrete, 6015 - 6016

El análisis de la organización formal del texto nos muestra dos tendencias claras en la construcción. Por una parte, el hecho de privilegiar la primera parte del verso, especialmente la tercera o cuarta sílaba cuando se trata de una forma monosilábica del verbo voloir, aunque la aparición de la primera persona del presente de indicativo suele llevar consigo la colocación al comienzo del verso y la inversión del pronombre sujeto. ${ }^{459}$ Con ello se pone de relieve generalmente la voluntad del sujeto, sea la mujer o el dios Amor. Por otra parte, la frecuente colocación en la rima, más marcada en Charrete y Rose, donde, además, el número de ocurrencias consideradas es mucho mayor, tendencia que aumenta cuando se trata de uno de los sustantivos.

En cuanto a los enlaces que se establecen entre las formas que se hallan en la rima destacaremos únicamente la estrecha relación que se da entre el verbo voloir y el verbo doloir. A ésta se suman en una ocasión los sustantivos voel y duel, con toda probabilidad a causa de las coincidencias formales que la evolución desde la lengua latina les otorgaba. Desde el punto de vista semántico existen divergencias en función de la posición que los amantes adoptan respecto a sus sufrimientos. En E soufle el dolor aparece cuando se frustran los deseos del enamorado - excepcionalmente también en una ocasión en la obra de Chrétien en el discurso del caballero enamorado y no en el de Lanzarote- Mientras que en Charrete y en Rose el dolor, prácticamente omnipresente, queda mitigado o desaparece con la consecución del deseo pero también tras el acatamiento del código amoroso. 


\begin{tabular}{|c|c|c|c|c|c|c|c|c|}
\hline FORMA & CA & BD & NV & RIMA & CA2 & NV2 & D & PERS \\
\hline veille & $\mathrm{V}$ & Rose & 2859 & fueille & $\mathrm{S}$ & 2860 & $\mathrm{~N}$ & Narrador \\
\hline velt & $\mathrm{V}$ & Escoufle & 3153 & delt & $\mathrm{V}$ & 3154 & D & Guillaume \\
\hline veut & $\mathrm{V}$ & Escoufle & 5499 & eut & $\mathrm{H}$ & 5500 & $\mathrm{~N}$ & Narrador \\
\hline veut & $\mathrm{V}$ & Tristan & 2117 & Yseut & $\mathrm{S}$ & 2118 & D & Tristan \\
\hline vialt & V & Charrete & 377 & aquialt & $\mathrm{V}$ & 378 & $\mathrm{~N}$ & Narrador \\
\hline vialt & V & Charrete & 957 & dialt & $\mathrm{V}$ & 958 & $\mathrm{~N}$ & Narrador \\
\hline vialt & V & Charrete & 5357 & dialt & V & 5358 & $\mathrm{~N}$ & Narrador \\
\hline vialt & V & Charrete & 4669 & requialt & V & 4670 & $\mathrm{~N}$ & Narrador \\
\hline vialt & $\mathrm{V}$ & Charrete & 3985 & sialt & $\mathrm{V}$ & 3986 & D & Roi Bademagu \\
\hline vialt & V & Charrete & 2864 & vialt & V & 2863 & $\mathrm{~N}$ & Narrador \\
\hline viaus & V & Rose & 2565 & aviaus & $S$ & 2566 & D & Amour \\
\hline viaut & V & Rose & 2734 & diaut & V & 2733 & D & Amour \\
\hline voel & $\mathrm{S}$ & Escoufle & 5174 & duel & $\mathrm{S}$ & 5173 & $\mathrm{~N}$ & Narrador \\
\hline voil & V & Rose & 1894 & orgueil & $\mathrm{S}$ & 1893 & D & Amour \\
\hline volanté & $\mathrm{S}$ & Charrete & 1340 & santé & $\mathrm{S}$ & 1339 & $\mathrm{~N}$ & Narrador \\
\hline volanté & $\mathrm{S}$ & Charrete & 1576 & santé & $\mathrm{S}$ & 1575 & D & Chevalier \\
\hline voldroie & V & Charrete & 4503 & parleroie & V & 4504 & D & Lancelot \\
\hline voldroient & V & Charrete & 5364 & estoient & $\mathrm{E}$ & 5363 & I & Demoiselle \\
\hline voldroit & V & Charrete & 2929 & androit & D & 2930 & D & Demoiselle \\
\hline volentez & $\mathrm{S}$ & Rose & 3165 & consentez & $\mathrm{V}$ & 3166 & $\mathrm{D}$ & Amant \\
\hline volentez & $\mathrm{S}$ & Rose & 1750 & entalantez & $\mathrm{O}$ & 1749 & $\mathrm{~N}$ & Narrador \\
\hline volenté & $\mathrm{S}$ & Charrete & 966 & acreanté & $\mathrm{O}$ & 965 & $\mathrm{~N}$ & Narrador \\
\hline volenté & $\mathrm{S}$ & Charrete & 1076 & acreanté & $\mathrm{O}$ & 1075 & D & Demoiselle \\
\hline volenté & $\mathrm{S}$ & Rose & 3068 & denté & $\mathrm{O}$ & 3067 & D & Amant \\
\hline volenté & $\mathrm{S}$ & Rose & 3319 & denté & $\mathrm{O}$ & 3320 & D & Franchise \\
\hline volenté & $S$ & Rose & 2012 & é & $\mathrm{H}$ & 2011 & D & Amant \\
\hline volenté & $\mathrm{S}$ & Rose & 3132 & reconforté & $\mathrm{O}$ & 3131 & $\mathrm{~N}$ & Narrador \\
\hline volenté & $\mathrm{S}$ & Rose & 1907 & santé & $\mathrm{S}$ & 1908 & D & Amant \\
\hline voloie & V & Rose & 3754 & soloie & $\mathrm{V}$ & 3753 & $\mathrm{~N}$ & Narrador \\
\hline voloient & V & Charrete & 6053 & clamoient & $\mathrm{V}$ & 6054 & $\mathrm{~N}$ & Narrador \\
\hline voloir & $\mathrm{S}$ & Escoufle & 4052 & avoir & $\mathrm{S}$ & 4051 & $\mathrm{~N}$ & Narrador \\
\hline voloir & $\mathrm{S}$ & Rose & 1919 & doloir & I & 1920 & D & Amant \\
\hline voloir & $\mathrm{S}$ & Rose & 2879 & doloir & I & 2880 & D & Bel Accueil \\
\hline voloir & I & Escoufle & 1683 & remanoir & I & 1684 & $\mathrm{~N}$ & Narrador \\
\hline voloir & $\mathrm{S}$ & Tristan & 297 & savoir & I & 298 & $\mathrm{~L}$ & Roi Marc \\
\hline volsist & $\mathrm{V}$ & Charrete & 1318 & dist & $\mathrm{V}$ & 1317 & I & Demoiselle \\
\hline volsist & V & Charrete & 6841 & tolsist & $\mathrm{V}$ & 6842 & $\mathrm{~N}$ & Narrador \\
\hline voudra & V & Rose & 3492 & rendra & $\mathrm{V}$ & 3491 & D & Narrador \\
\hline voudroiz & V & Rose & 1902 & droiz & $\mathrm{S}$ & 1901 & D & Amant \\
\hline voudroiz & V & Rose & 3323 & droiz & S & 3324 & D & Bel Accueil \\
\hline vouloit & $\mathrm{V}$ & Rose & 1980 & toloit & $\mathrm{O}$ & 1979 & $\mathrm{D}$ & Amant \\
\hline vouz & $\mathrm{S}$ & Charrete & 6002 & prouz & A & 6001 & $\mathrm{~N}$ & Narrador \\
\hline vuel & $\mathrm{V}$ & Charrete & 1551 & duel & $\mathrm{V}$ & 1552 & $\mathrm{D}$ & Chevalier \\
\hline vuel & V & Charrete & 1240 & orguel & S & 1239 & $\mathrm{~N}$ & Narrador \\
\hline vuelle & $\mathrm{V}$ & Escoufle & 3191 & duelle & $\mathrm{V}$ & 3192 & $\mathrm{D}$ & Guillaume \\
\hline
\end{tabular}

Tabla 71. Rimas del verbo vouloir y de los sustantantivos volonté y «vuel».

459 Cf. Charrete, 3794 y 6699; Escoufle, 4406; Rose, 2228. 
Respecto de las características de las proposiciones en las que se hallan las formas del verbo voloir o los sustantivos volonté, voloir y vuel, señalaremos en primer lugar que son poco abundantes las subordinadas completivas. Por el contrario, el verbo voloir, que también funciona como auxiliar modalizante dentro de una perífrasis infinitiva, es a menudo el núcleo de una proposición principal de la que depende una subordinada completiva. Con mayor frecuencia encontramos subordinadas circunstanciales en las que se hallan insertos los términos que nos ocupan:

- Consecutivas:

Utilizadas en Charrete y Rose, están generalmente precedidas por el adverbio tant —en menor medida por el adverbio si-, y excepcionalmente desaparece la conjunción que. En las intervenciones dialogadas de Rose los adverbios introductores magnifican las virtudes y bondades del amante y del dios Amor que conllevan la concesión de bienes o la propia sumisión. Tan sólo en una ocasión en Charrete el adverbio pondera un adjetivo referido a Lanzarote, mientras que en el resto de las ocurrencias de ambos textos son modificadas formas verbales:

$$
\begin{aligned}
& \text { tant ai oï de vos bien dire } \\
& \text { que metre veil tot a devise } \\
& \text { cuer et cors en vostre devise } \\
& \text { Rose, } 1916 \text { - } 1918 \\
& \text { ançois a și mon cuer denté } \\
& \text { qu’i n'est fors qu'a sa volenté } \\
& \text { Rose, } 3067 \text { - } 3068 \\
& \text { espoir tant le puet ele amer, } \\
& \text { ne l'en voldra quite clamer. }
\end{aligned}
$$

Charrete, 963 - 964 
(...): «Dame, onques ne vi

nul chevalier tant deboneire,

qu'il vialt si oltreemant feire

Charrete, $5908-5910$

- Causales:

Utilizadas tanto para expresar la férrea voluntad del dios Amor: "mes ren toi, puis que je le voil, em pais et debonoirement” (Rose, 1894 - 1895) como el deseo de aprender las reglas amorosas en Rose (2047 - 2048) o de servir a la dama en E scoufle:

et ses amis a acosté

le soleil, qu'il li velt faire ombre

Escoufle, 4540 - 4541

- Temporales:

En Charrete la locución conjuntiva puis que [Adv. + C onj.] introduce regularmente la relación temporal de la principal con respecto a una acción anterior:

puis qu'il li ot acreanté

son voloir et sa volenté,

si l'en mainne jusqu'an un baile

Charrete, 965 - 967

En la obra de Lorris el término de los sufrimientos y el comienzo de los placeres queda fijado por el dios Amor con la locución conjuntiva tant que [A dv. + C onj.]: "la fin ne prendra ceste guere, tant que j'en veille la pes querre" (Rose, 2409 - 2410); mientras que la conjunción quant puede 
expresar no sólo la simultaneidad de dos acciones: “qui le guerredon m’en rendra mieuz que nule, quant el voudra” (Rose, 3491 - 3492) sino también su repetición:

$$
\begin{aligned}
& \text { et bien sachiez que tuit li membre } \\
& \text { me fremissent quant il me menbre } \\
& \text { de la rose que je soloie } \\
& \text { veoir de pres quant je voloie. }
\end{aligned}
$$

Rose, 3751 - 3754

\section{- Condicionales introducidas por se:}

Pueden, en un paréntesis, expresar el voluntario sometimiento a los mandatos del amor transcritos mediante el sustantivo voloir. "car, se ge faz vostre voloir, je ne me puis de rien doloir" (Rose, 1919 - 1920) o bien la condición necesaria para que el amante actúe con el verbo en tercera persona del singular y un pronombre sujeto singular generalmente femenino: “k'encore irai je, s'ele velt”' (Escoufle, 3153),

$$
\begin{aligned}
& \text { que ancor «au noauz» le face, } \\
& \text { s'avoir vialt l'amor et la grace } \\
& \text { la reïne, qu'ele li mande. }
\end{aligned}
$$

Charrete, 5853 - 5855

\section{- Condicionales restrictivas:}

Introducidas por la locución por quoi [Prep. + Pron.] seguida del subjuntivo, permiten excepcionalmente fijar al amante de la rosa ciertas condiciones para mantenerse dentro de las normas corteses, aunque exige bien poco, únicamente que lo dejen seguir amando, algo que es imposible evitar o prohibir: “que je de rien n’i mesprendré, por quoi vos me veilliez greer ce que vos ne poez veer.” (Rose, 3160 - 3162). 
- Comparativas de igualdad:

Introducidas por el adverbio com en relación con otro adverbio, tant o si, poseen como particularidad el hecho de que el sujeto del verbo voloir es siempre una mujer:

\author{
cascuns li baille et abandoune \\ de l'avoir tant com ele veut \\ Escoufle, 5498 - 5499 \\ et cil, des que il ne puet mialz, \\ l'otroie si com ele vialt, \\ de l'otroier li cuers li dialt \\ Charrete, 956 - 958
}

En cuanto a las proposiciones relativas en las que se inserta el verbo voloir, tan sólo Ami o el camuflado Lanzarote, al que se evoca mediante un demostrativo determinado por la frase de relativo, aparecen como antecedentes definidos: “quant celui n'ont qu'eles voloient, toz les autres quites clamoient" (Charrete, 5053 - 6054), “Amis, qui mon avancement vousist autresi bien con gié" (Rose, 3202 - 3203).

En Rose son mayoría las proposiciones que introducidas por el pronombre qui sin antecedente aclaran, en forma de máxima, las condiciones del contrato amoroso, como ya hemos observado al estudiar el verbo aimer. "Qui d'Amors veut fere son mestre, cortois et sanz orgueil doit estre" (Rose, $2217-2218) .460$

O bien, al igual que en Charrete o en Escoufle, las que tienen por antecedente un término indefinido, ya sean los pronombres rien: "se Diex ne

460 Véase también Rose, 2059 y 2121 - 2122 
m’aïe et ses sens jamais n'arai riens que je vuelle"(Escoufle, 3190 - 3191), 461 ce: "car li cuers de rien ne se diaut quant li oil voient ce qu'il viaut" (Rose, 2733 - 2734), o de forma más habitual quan, que refleja el compromiso ciego del enamorado con los dictados femeninos: "quan qu'ele voldra li promet et toz an son voloir se met" (Charrete, 633 - 634), o con las imposiciones del sentimiento amoroso, en sus aspectos personificado o alegórico: "quant por li me sanbloit enors a feire quan que vialt amors" (Charrete, 4369 - 4370)

\title{
vos poez quan que vos voudroiz
}

feire de moi, pendre ou tuer

Rose, 1902 - 1903

También se expresa de esto modo cómo la mujer se pliega a los deseos del amante una vez que las trabas externas han sido superadas:

\author{
- Je feré quen que vos voudroiz, \\ fet Bel Acueil, que il est droiz, \\ puis que Dangier l'a ostraié.
}

Rose, $3323-3325$

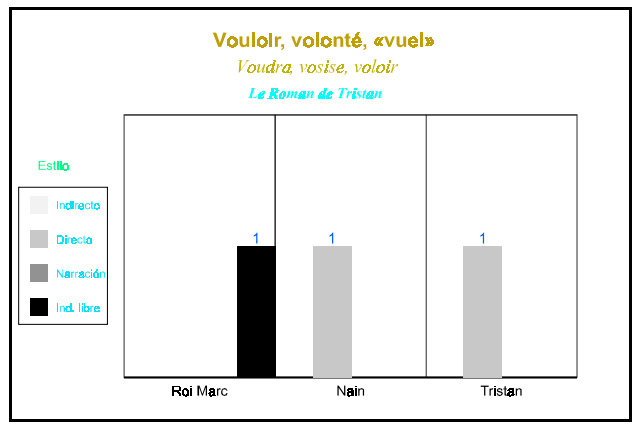

Fig. 95. Comportamiento estilístico del verbo vouloir y de los sustantivos volonté y «vuel» en Tristan.

461 También el sustantivo rien se encuentra como antecedente de algunas frases de relativo pero no las tratamos aquí pues ya las estudiamos en el capítulo precedente en el apartado consagrado a esta denominación. 


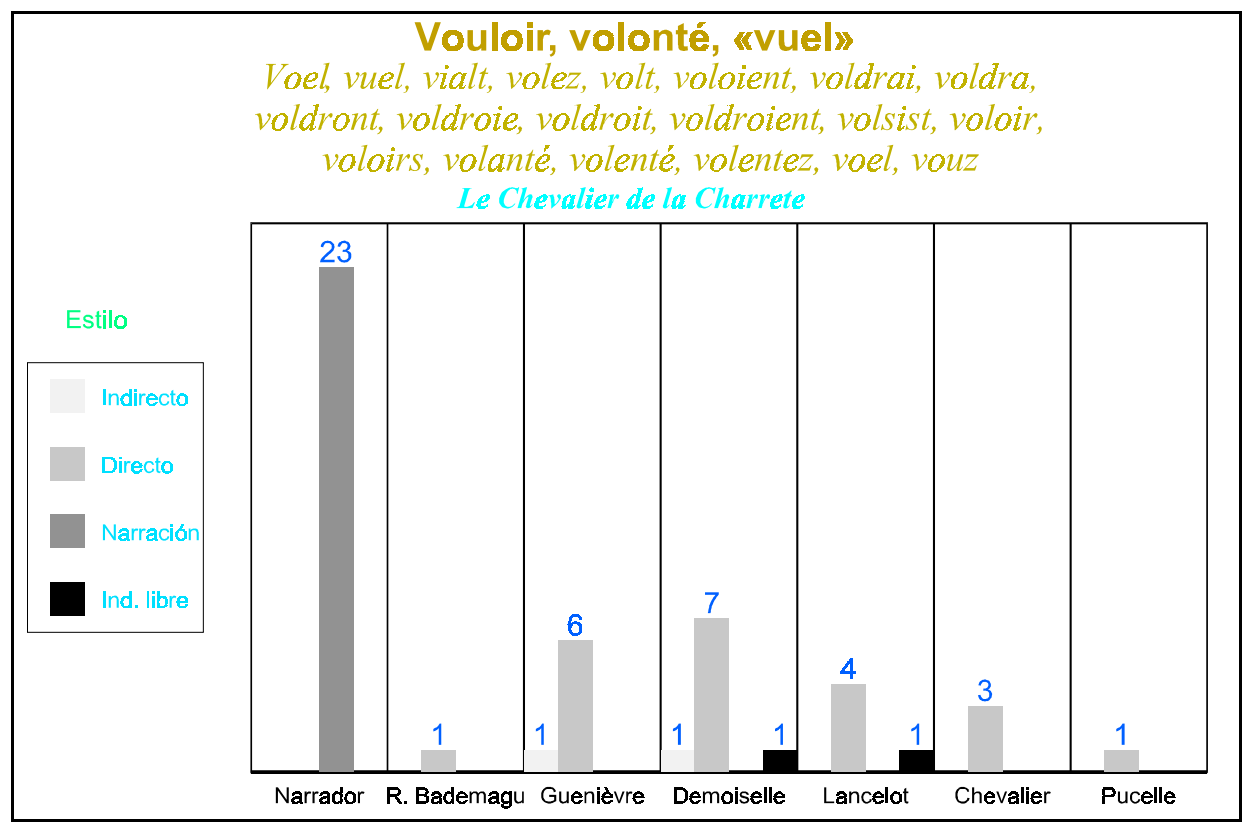

Fig. 96. Comportamiento estilístico del verbo vouloir y de los sustantivos volonté y «vuel» en Charrete.

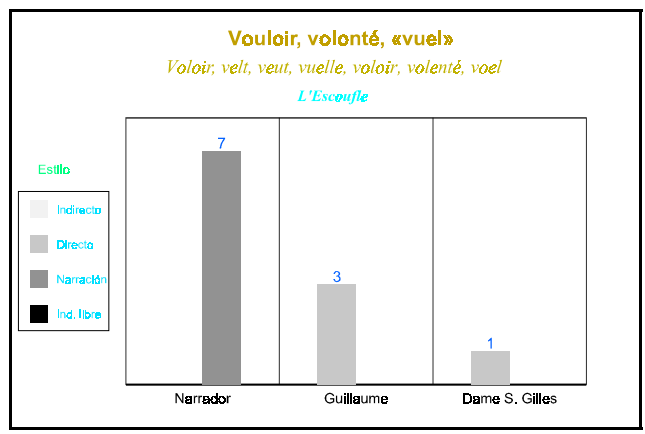

Fig. 97. Comportamiento estilístico del verbo vouloir y de los sustantivos volonté y «vuel» en Escoufle. 


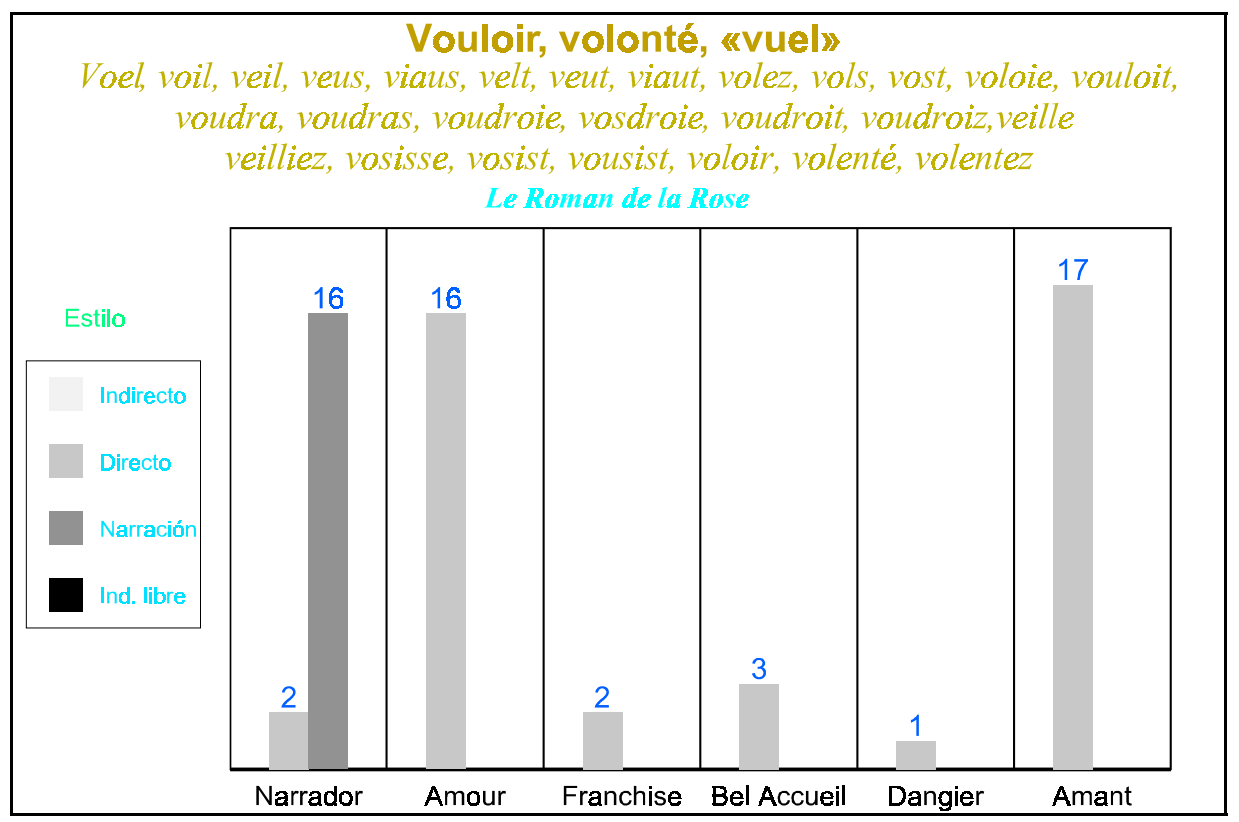

Fig. 98. Comportamiento estilístico del verbo vouloir y de los sustantivos volonté y «vuel» en Rose.

Pese a que en el texto de Chrétien se reconoce la igualdad de hombres y de mujeres ante el deseo carnal, ${ }^{462}$ tanto este autor como Lorris ocultan cuidadosamente las manifestaciones femeninas de aquél. Es cierto que, tal como nos muestran las ilustraciones que anteceden, la reina Ginebra y las doncellas del texto del siglo XII recurren frecuentemente en sus intervenciones a los términos que nos ocupan. Pero en ese caso quedan reservados para transcribir el dominio de la dama sobre el caballero respetuoso con las reglas corteses o bien las insinuaciones de un cortejo y el deseo de lograr un matrimonio, que por otra parte siempre serán fallidos para las que no han alcanzado el rango superior de la mujer casada. Más alejados de las ideas corteses, los romans de Béroul y de Renart dan una mayor importancia a los deseos compartidos y más concretamente en el caso de E soufle al deseo erótico femenino, del que se hace eco el narrador, frente al sometimiento voluntario del héroe masculino. En Rose los entes masculinos, el narrador, el amante, y aun el amor, al que sin duda podemos otorgarle tal género pues

${ }^{462}$ Cf. Charrete, 1758 - 1760. 
transcribe un código claramente destinado al varón, copan el discurso de la voluntad y el deseo.

\subsection{LAS IMÁGENES DEL FUEGO.}

El uso de los términos que recogemos a continuación, junto a otros menos relevantes con los que suelen establecer una relación de sinonimia o de gradación, a la vez que formalmente constituyen sintagmas dobles coordinados, responde a lo que Guiraud llama metáforas fundamentales de la lengua que han sido recuperadas por la literatura erótica. 463

\subsection{1 «Ardoin» y ardeur.}

El verbo es asociado a alumer y anflamer, se encuentra intensificado por el adverbio con valor absoluto plus y es parte integrante de frases en las que los enamorados son tomados a la vez como un conjunto coherente y como unidades que comparten las mismas sensaciones. En tercera persona del singular del presente de indicativo con un valor intemporal se integra en un discurso proverbial que pretende explicar las causas de la exacerbación de la pasión amorosa, enseñanza que en el discurso del dios Amor adquiere un tono de burla: "ce sevent tuit, sage et musart: qui plus est pres dou feu plus art” (Rose, 2345 - 2346). El pronombre relativo sujeto de la subordinada, la cual a su vez funciona como sujeto de la proposición cuyo núcleo es el verbo andoir, responde canónicamente al estilo sentencioso y evoca una persona indeterminada; lo mismo ocurre en el único ejemplo que hallamos en Charrete, donde debemos suponer que el verbo tiene un matiz factitivo, pues no es el enamorado el que se consume con su pasión, sino aquél que le impide cumplir sus deseos quien aviva el fuego del deseo:

463 P. Guiraud, op. cit., pássim. 
car qui blasme, bien le savez, son voloir a home n'a fame, plus en art et plus en anflame

Charrete, 1758 - 1760

En Tristan los sustantivos ardor y arson denominan la lujuria desatada que poseen los leprosos y que Tristán, simulando la enfermedad, recupera en su puesta en escena y en su discurso obsceno, construidos paródicamente como un calco del diálogo entablado entre Yvain, el jefe de los leprosos, y el rey Marco. Sintácticamente existe una gran similitud ya que en ambos fragmentos sintagmas nominales idénticos introducen una subordinada consecutiva, sin embargo se contrapone la maldad, el castigo sexual, a la benevolencia del que quiere apagar el fuego del deseo con vino:

$$
\begin{aligned}
& \text { Sire, en nos a si grant ardor } \\
& \text { soz ciel n'a dame qui un jor } \\
& \text { peüst soufrir nostre convers } \\
& \text { Tristan, } 1195-1197 \\
& \text { si grant arson a en son cors } \\
& \text { a poine l'en puet geter fors }
\end{aligned}
$$$$
\text { Tristan, } 3657-3658
$$

Lorris adopta el sustantivo ardure para ponerlo insistentemente en relación con los sufrimientos que la pasión provoca en el enamorado, así como con la inalterabilidad que sólo se agota con la muerte. Ya sea como sujeto del verbo estre o como núcleo de un sintagma preposicional, y siempre en posición final de verso, se halla rodeado por construcciones de la misma índole en las que se recoge la pena o la lucha en las que el amante se ve constantemente inmerso:

$$
\begin{aligned}
& \text { coment vit hom et coment dure } \\
& \text { qui est em poine et en ardure, }
\end{aligned}
$$


en duel, en soupirs et en lermes

Rose, 2573 - 2575

Lores seras en grant martire:

c'est la bataille, c'est l'ardure,

c'est li contanz qui tot jors dure

Rose, 2404 - 2406

\begin{tabular}{lllllllll}
\hline FORMA & CA & BD & NV & RIMA & CA2 & NV2 & D & PERS \\
\hline ardor & S & Tristan & 1195 & jor & S & 1196 & D & Lépreux \\
ardure & S & Rose & 2574 & dure & V & 2573 & D & Amant \\
ardure & S & Rose & 2405 & dure & V & 2406 & D & Amour \\
art & V & Rose & 2346 & musart & A & 2345 & D & Amour \\
\hline
\end{tabular}

Tabla 72. Rimas del verbo «ardoir» y del sustantivo ardeur.

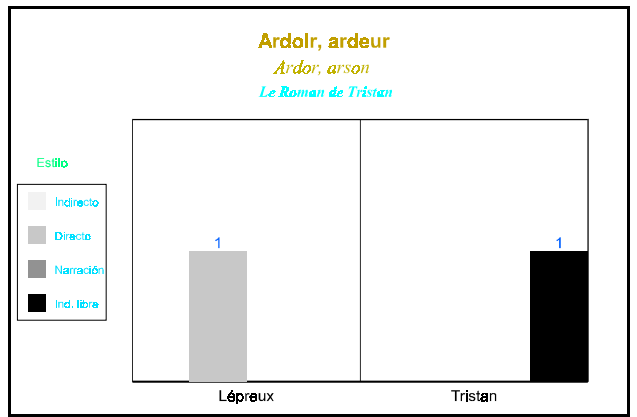

Fig. 99. Comportamiento estilístico del verbo «ardoir» y del sustantivo ardeur en Tristan.

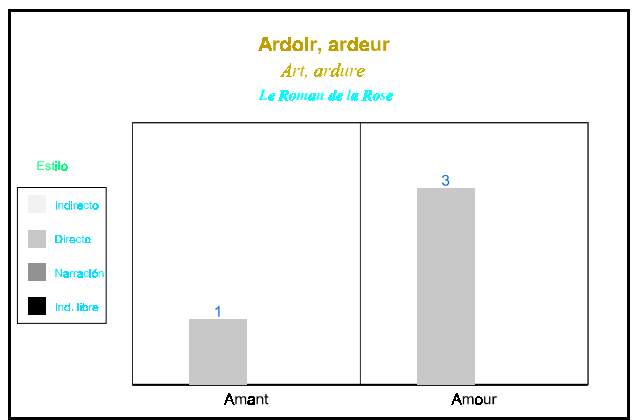

Fig. 100. Comportamiento estilístico del verbo «ardoir» y del sustantivo ardeur en Rose.

A excepción de Charrete, el contubernio del deseo expresado por ardoir o ardeur y de la enfermedad, sea metafórica o real, física o mental, es 
una amenaza para los amantes. Esta alianza descansa sobre las trabas que se imponen a la pasión, bien porque se considera ilícita, bien porque la preservación de la virginidad se sustenta artificialmente sobre un código en el que dolor y depuración son inseparables.

\subsection{Feu.}

Monopolizado por el discurso didáctico del dios Amor, el sustantivo feu encarna la imagen del deseo como un fenómeno obsesivo aunque también se identifica con el objeto de deseo, el origen de la pasión, por el que el enamorado se siente atraído y que es una fuente de calor permanente que renueva sus ansias. Funciona entonces como sujeto del verbo estre e introduce una definición compuesta por una proposición completiva cuyo núcleo verbal, remirer, describe la reiteración y el detenimiento que caracterizan la contemplación del ser amado, y por una proposición de relativo en la que se explica la función de la amada y en la que el verbo defrire en una locución factitiva recupera la idea del fuego. Dos son pues las fuentes ígneas complementarias que alimentan la pasión, la visión de la amada y ella misma:

$$
\begin{aligned}
& \text { li feus si est ce qu'i remire } \\
& \text { s'amie qui le fet defrire }
\end{aligned}
$$

$$
\text { Rose, } 2341-2342
$$

Esta idea de un fuego externo que lo abrasa se reproduce al funcionar feu como complemento de objeto directo de los verbos suivre: "Chascuns amanz suit par costume le feu qui l'art et qui l'alume” (Rose, 2337 2338) y sentir. "quant il le feu de plus pres sent, et il s'en vet plus apressant" (Rose, 2339 - 2340), contextos en los que se añaden nuevas fuerzas que obligan al amante a realizar dos movimientos complementarios, uno orbital y otro de aproximación en busca del contacto. 
En menor medida y también en función de complemento de objeto directo, feu se identifica con un fenómeno interno al propio amante, el deseo que nace: "cil larz alume et fet flamer le feu qui fet les genz amer" (Rose, 2335 - 2336), y que se renueva e intensifica a través de la vista:

$$
\begin{aligned}
& \text { et saches que dou regarder } \\
& \text { feras ton cuer frire et larder, } \\
& \text { et tot adés en regardant } \\
& \text { aviveras le feu ardant } \\
& \text { Rose, } 2329 \text { - } 2332
\end{aligned}
$$

La gran importancia que se les concede a los ojos en el nacimiento y perduración del sentimiento amoroso y el deseo, así como en la consecución del placer, tenía su fundamento en teorías médicas. Estas explicaban cómo el espíritu se dirigía al exterior a través del nervio óptico para percebir los objetos externos y los representaba después en la parte superior del alma. ${ }^{464}$

El hecho de que todas las ocurrencias se hallen agrupadas en unos pocos versos, de que exista un cúmulo de términos en torno al sustantivo que redundan en su significado, verbos: frire y larder, sustantivos, larz, o adjetivos deverbales como ardant, y de que se insista en que la visión del ser amado atrae y consume al enamorado como el fuego, producen la sensación de que el amante es como una mariposa nocturna que pese al peligro se empecina en revolotear en torno a la llama como si jugara con ella, aunque en realidad sea él el juguete del fuego - deseo, elemento universal e invariable según la naturaleza que le otorga la sistemática precedencia del artículo definido.

${ }^{464}$ Esta teoría elaborada por los médicos de Salerno está recogida en D. Jacquart y C. Thomasset, op. at., p. 115. 


\subsection{Flamber, flamme y flambant.}

El sustantivo flame es en Charrete el equivalente exacto de lo que será después el fuego en Rose, si bien Chrétien elimina el juego de repeticiones y la insistencia sinonímica que caracterizarán las alusiones al deseo en la obra de Lorris. Del mismo modo que para el amante dibujado por el dios Amor, el deseo de Lanzarote tiene su origen directo en la dama: "devant la reïne sa dame qui li a mis el cors la flame" (Charrete, 3749 - 3750), y aunque de distinta forma también el amante de la carreta es un elemento pasivo que recibe el impulso amoroso desde el exterior. La diferencia radica fundamentalmente en el papel que se nos da a entender representa la mujer, mientras que en Rose se trataba de un foco ígneo estable, indiferente al enamorado, quien por proximidad a la belleza veía germinar y crecer la pasión, en este caso el verbo metre otorga a la dama un papel activo, dominante.

Existen otros elementos comunes como la renovación e intensificación del anhelo amoroso ante la visión de la persona amada, que en el caso de Lanzarote incrementan su vigor y virtudes guerreras hasta lograr vencer a su adversario Meleagant:

$$
\begin{aligned}
& \text { por qu'il la va si regardant; } \\
& \text { et cele flame si ardant } \\
& \text { vers Meleagant le feisoit } \\
& \text { que par tot la ou li pleisoit } \\
& \text { le pooit mener et chacier! }
\end{aligned}
$$

Charrete, 3751 - 3755

También hay notables diferencias entre ambos textos ya que en Charrete se distingue entre el deseo amoroso genérico, para el que se utiliza el artículo definido, y la pasión amorosa propia de Lanzarote, introducida por el artículo demostrativo cele. Por otra parte, el cuerpo de Lanzarote se ve directamente implicado al unirse el deseo amoroso y el deseo erótico, 
simbiosis típica del modelo caballeresco: "qui li a mis el cors la flame" (Charrete, 3750), mientras que sólo el corazón del amante de la rosa, es decir, su espíritu, sufría sus embates.

En Rose el sustantivo flame y el adjetivo deverbal flanbant se presentan en clara oposición a feu ya que están reservados al deseo femenino, y más concretamente a la concupiscencia de las mujeres cuyo origen se halla en la diosa Venus y no en el amor. De modo que, pese a ser una ayuda imprescindible a las aspiraciones últimas de los amantes, el tratamiento es peyorativo, máxime si observamos los verbos que explicitaban los efectos del fuego, pues éste quemaba y consumía con una fuerza inusitada, purificadora, incluso cuando se trata del verbo flamer. "cil larz alume et fet flamer le feu qui fet les genz amer" (Rose, 2335 - 2336), mientras que la antorcha de Venus tan sólo calienta a las mujeres, es decir, las excita sexualmente:

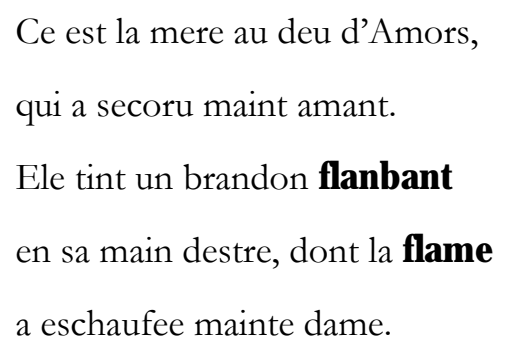

\begin{tabular}{lllllllll}
\hline FORMA & CA & BD & NV & RIMA & CA2 & NV2 & D & PERS \\
\hline flame & S & Charrete & 3750 & dame & S & 3749 & N & Narrador \\
flame & S & Rose & 3407 & dame & S & 3408 & N & Narrador \\
flamer & I & Rose & 2335 & amer & I & 2336 & D & Amour \\
flanbant & A & Rose & 3406 & amant & S & 3405 & N & Narrador \\
\hline
\end{tabular}

Tabla 73.Rimas del verbo flamber, del sustantivo flamme y del adjetivo flambant. 


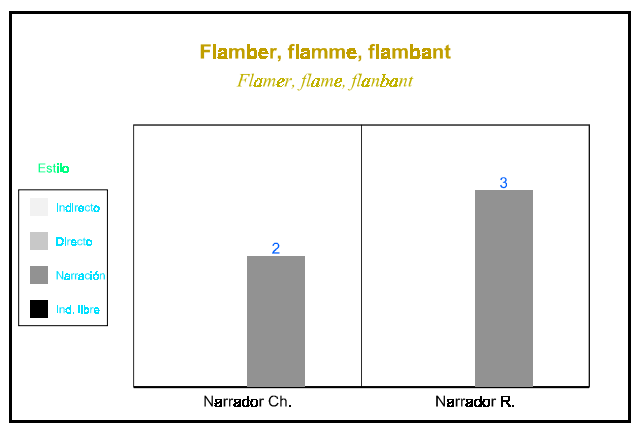

Fig. 101. Comportamiento estilístico del verbo flamber, del sustantivo flamme y del adjetivo flambant en Charrete y en Rose.

Una vez visto el uso específico que los textos hacen de estos términos no parece razonable atribuir su aparición en la rima a simples cuestiones formales. Conviene destacar el emparejamiento con términos que pertenecen al campo amoroso, aunque la relación con dame deba leerse de forma dispar en las dos obras dado el papel que cada autor otorga a la mujer en esos contextos: por un lado, es un foco de deseo que engrandece al hombre y, por otro, un ser dominado por el instinto capaz de satisfacer los deseos sexuales del varón.

\subsubsection{LA PERCEPCIÓN SEN SORIAL SIN CONTACTO FÍSICO.}

\subsection{EL ACERCAMIENTO Y LA PROXIMIDAD FÍSICA.}

\subsection{1 «Apressien», approcher, «aprismen» $\mathbf{y}$ «raprimen».}

La búsqueda de la proximidad física, de la presencia del otro, es uno de los móviles de los relatos al crear las claves del funcionamiento del engranaje erótico: los amantes se buscan porque se desean y en segunda instancia para impulsar su liberación frente a los que impiden su unión. Iseo y Tristán se reúnen en el jardín para amarse cuando la cámara les es vedada: 
“com ele aprisme son ami" (Tristan, 3), y el encuentro de amor frustrado, magistralmente interpretado y posteriormente reutilizado discursivamente por Iseo en su defensa, merced a la negación de la percepción que desdibuja las barreras entre realidad y apariencia: “ne veïstes qu'il m'aprismast ne mespreïst ne me baisast" (Tristan, 499 - 500), les ofrecerá la oportunidad de recuperar la perdida y tranquila intimidad. De igual modo, Aelis se impone un movimiento audaz, provechoso —en el encuentro evocado por Béroul la aproximación femenina es también positiva y práctica frente a la masculina, de Tristán y del rey—, que favorezca su unión con Guillermo: "Se mes sens a moi nel raprime, je ne voi comment il aviengne.” (Escoufle, 3256 - 3257).

Chrétien, por el contrario, recrea con el verbo aprochier encuentros inesperados, en el vagar de los caballeros o en el regreso a la corte tras la azarosa liberación de la reina. De ellos tan sólo los elementos masculinos, el caballero enamorado o el rey Arturo, pretenden sacar fruto desde el punto de vista erótico, unilateralidad que se insinúa en la alegría de ambos, frente al rechazo manifiesto de la doncella o al silencio cauto sobre la reina: "tant qu'a la cort vient la novele qui au roi Artus fu molt bele de la reïne qui aproiche” (Charrete, 5303 - 5305)

$$
\begin{aligned}
& \text { et por boens eürez se clainme, } \\
& \text { quant la rien voit que il plus ainme. } \\
& \text { Tot maintenant que il l'aproche, } \\
& \text { de cuer la salue et de boche } \\
& \text { Charrete, } 1547 \text { - } 1550
\end{aligned}
$$

El deseo masculino es el móvil fundamental de los movimientos de aproximación en Rose, que son siempre unidireccionales: “ainz m’en apressai por le prendre" (Rose, 1671). Nunca existe reciprocidad pues la mujer se muestra como un elemento estático, aunque excepcionalmente, y a riesgo de caer en la deshonra y de hacer fracasar el encuentro, puede estimularlo, papel 
que asume Bel Accueil. Tomaremos, sin embargo, la reiterada invitación transcrita en estilo indirecto con algo de recelo, pues se hará evidente que las intenciones del amante y las de la mujer distan mucho entre sí, ella desea el cortejo, la proximidad y el agasajo, el juego en el que intervienen sus compañeras, mientras que el adolescente interpretará sus insinuaciones como una entrega absoluta a la pasión:

\author{
Sovent me semont d'aprochier \\ vers le bouton et d'atouchier \\ au rousier qui estoit chargié.
}

Rose, 2855 - 2857

La sintaxis oracional nos depara pocas sorpresas: junto a dos proposiciones completivas, una introducida por la conjunción que (Tristan, 499), otra de infinitivo precedida por la preposición de (Rose, 2855), y una subordinada circunstancial hipotética (Escoufle, 3256), predominan las circunstanciales temporales que marcan la duración — esta noción aspectual se halla descrita también mediante la perífrasis aler + gerundio en la que el auxiliar mantiene su valor de verbo de movimiento: "quant il le feu de plus pres sent, et il s'en vet plus apressant" (Rose, 2339 - 2340)—, al mismo tiempo que la concomitancia del proceso de la subordinada y de la principal: “com ele aprisme son ami, oiez com el l'a devanci” (Tristan, 3 - 4) o bien la culminación del proceso expresado por las formas verbales que nos ocupan, tras el que se da paso al comienzo de otro transcrito en la proposición principal:

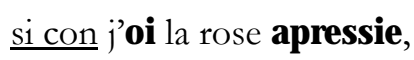

un poi la trovai engroisie

Rose, 3339 - 3340

tot maintenant que il l'aproche,

de cuer la salue et de boche

Charrete, 1549 - 1550 


\begin{tabular}{lllllllll}
\hline FORMA & CA & BD & NV & RIMA & CA2 & NV2 & D & PERS \\
\hline apressant & T & Rose & 2340 & sent & V & 2339 & D & Amour \\
apressie & O & Rose & 3339 & engroisie & O & 3340 & N & Narrador \\
aprismast & V & Tristan & 499 & baisast & V & 500 & D & Iseut \\
aproche & V & Charrete & 1549 & boche & S & 1550 & N & Narrador \\
aprochier & I & Rose & 2855 & atouchier & I & 2856 & I & Bel Accueil \\
aproiche & V & Charrete & 5305 & retoiche & V & 5306 & N & Narrador \\
raprime & V & Escoufle & 3256 & prime & S & 3255 & D & Aélis \\
\hline
\end{tabular}

Tabla 74. Rimas de los verbos «apressier», approcher, «aprismer»y «raprimer».

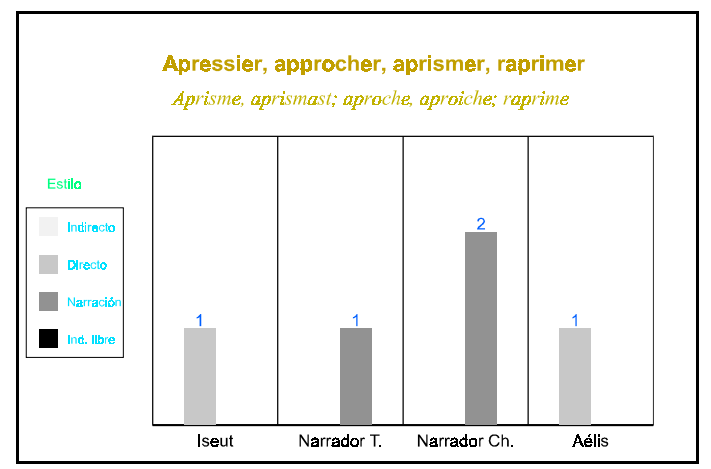

Fig. 102. Comportamiento estilístico de los verbos «apressier», approcher, «aprismer»y raprimer en Tristan, Charrete y Escoufle.

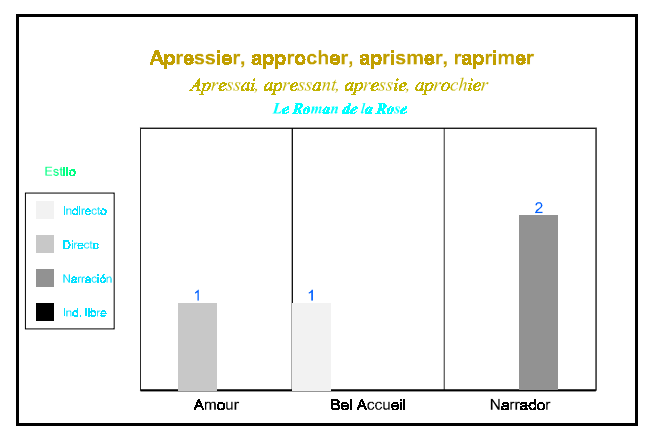

Fig. 103. Comportamiento estilístico de los verbos «apressier», approcher, «aprismer»y raprimer en Rose.

Los romans que dan la palabra a las féminas, Tristan y E soufle, y los que muestran esencialmente el punto de vista masculino en el momento del acercamiento y el primer contacto entre los sexos difieren así mismo en el modo de lograrlos. Los primeros ponen de relieve el uso de la inteligencia y de la sagacidad, mientras que en los segundos sólo juega la fortuna, la fuerza o la impulsividad del enamorado. 


\subsection{2 «Convoie» y convoi.}

Distinguimos dos realidades completamente diferentes significadas por el verbo y el sustantivo. En la más cercana al sentido actual se trata de acompañar físicamente, es decir, de ir un trecho del camino junto a alguien, sentido etimológico que se observa claramente en E scoufle al que se une la idea del agasajo de la amante: “jusc'au suel de l'uis le convoie” (Escoufle, 3642). Una muestra de afecto y consideración que está presente en otro pasaje de la obra en el que un cortejo de burgueses conduce fuera de la ciudad a la heroína y a su compañera, y en el que se ofrece de nuevo una ocasión a Aelis para mostrar su cortesía y su capacidad para captar la atención de cuantos la rodean:

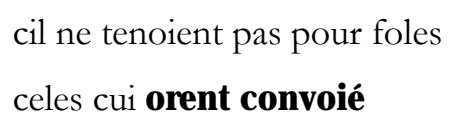

Escoufle, 6086 - 6087

li fix as bourjois cui els ont donés les joiaus qu’il ont pris sont monté es chevaus de pris, qui miels miels, por estre au Convoi Escoufle, 6060 - 6063

Aparentemente lo encontraremos también en Rose donde Bel Accueil lleva al amante junto al rosal del otro lado de la valla que le impedía acercarse: "et Bel Acueil me convoia” (Rose, 2803). Pero la construcción alegórica nos obliga a considerar un sentido segundo en el que la frase figura una invitación de la mujer, probablemente una mirada o una sonrisa que incita al amante a hacer caso omiso de los obstáculos personales o sociales.

En Tristan se inaugura ya un sentido figurado de convoier en el que tan sólo la mirada, representada metonímicamente por los ojos, sigue el 
alejamiento del amante, actividad que se convierte en una de las manifestaciones amorosas por excelencia: "Yseut o les euz le convoie" (Tristan, 2930), si bien aquí la preposición $\mathbf{0}$ mantiene al menos formalmente una conexión con el primer sentido que desaparecerá en las imágenes más elaboradas de Charrete y Rose. Chrétien refuerza los aspectos sentimentales al introducir el corazón en un plano inicial de igualdad con los ojos, equivalencia que pronto será superada por la supremacía de la víscera, del sentimiento sobre la sensación, al ser esta efímera y restringida debido a los impedimentos físicos y sociales:

des ialz et del cuer la convoie, mes as ialz fu corte la voie que trop estoit la chanbre pres

Charrete, 3971 - 3973

Lorris retoma la imagen y profundiza en las contradicciones que la disyunción entre lo físico y lo sentimental, ambos constituyentes del deseo, provocan en el amante. Añade para ello un tono de queja, por otra parte habitual en las intervenciones en estilo indirecto del amante arquetípico recuperadas por el dios Amor. Como también es común en este roman la reelaboración de un recurso retórico cortés, se adorna este motivo con juegos de palabras — veoir, aler- y repeticiones — cuer, oil, envoier, convoier, veoir-, en este caso aún más evidentes por afectar a los verbos en la rima:

quant la ou mes cuers est ne vois!

Mon cuer seul por quoi i envoi?

Adés i pens et rien n'en voi!

Quant je puis les ieuz envoier

aprés, por le cuer convoier,

se mi oil mon cuer ne convoient,

je ne pris rien quen que il voient.

Rose, 2290 - 2296 
Sin embargo, la principal innovación con respecto al fragmento de Charrete viene dada por la desaparición del ser amado y por el paso a un primer término del corazón. Éste se convierte así en el objeto que es o debería ser acompañado por la vista hasta hacer coincidir de nuevo ambas fuentes de deseo, autónomas de su objeto, al que se representa no ya mediante un pronombre personal sino mediante un adverbio, pues la mujer - entelequia es espacio conquistable o conquistado, no ya un ser. ¡Cuán lejos queda la sencilla pero emotiva separación de Tristán e Iseo!

La inalterable aparición de convoier y de convoi en la rima indica hasta qué punto pesaban los imperativos formales en su uso. Aunque esto no es obstáculo para que consideremos los emparejamientos léxicos como un recurso estilístico añadido, máxime si observamos el grado de recuperación de unas obras a otras. Esta se basa en el juego fácil de las formas derivadas y de las bases léxicas, así como en la relación con la visión, representada por el verbo voir y la interjección formada sobre éste.

\begin{tabular}{lllllllll}
\hline FORMA & CA & BD & NV & RIMA & CA2 & NV2 & D & PERS \\
\hline convoi & S & Escoufle & 6063 & avoi & L & 6064 & N & Narrador \\
convoia & V & Rose & 2803 & agrea & V & 2804 & N & Narrador \\
convoie & V & Tristan & 2930 & voie & S & 2929 & N & Narrador \\
convoie & V & Charrete & 3971 & voie & S & 3972 & N & Narrador \\
convoie & V & Escoufle & 3642 & voie & S & 3641 & N & Narrador \\
convoient & V & Rose & 2295 & voient & V & 2296 & I & Amant \\
convoier & I & Rose & 2294 & envoier & I & 2293 & D & Amant \\
convoié & O & Escoufle & 6087 & avoié & O & 6088 & N & Narrador \\
\hline
\end{tabular}

Tabla 75. Rimas del sustantivo convoi y del verbo «convoier».

El sustantivo convoi y el infinitivo convoier, que desempeña el papel de un sustantivo, cumplen funciones de complemento circunstancial, el primero expresa lugar: “por estre au convoi” (Escoufle, 6063) y el segundo la causa: "por le cuer convoier" (Rose, 2294). En cuanto a la sintaxis proposicional conviene destacar la supremacía de las oraciones independientes de las que tan sólo encontramos dos excepciones en Rose: una proposición subordinada circunstancial temporal introducida por quant (Rose, 2293 - 
2294) y otra hipotética precedida de la conjunción se (Rose, 2295); ambas contribuyen a la complejidad retórico-estructural del fragmento al que hemos hecho referencia.

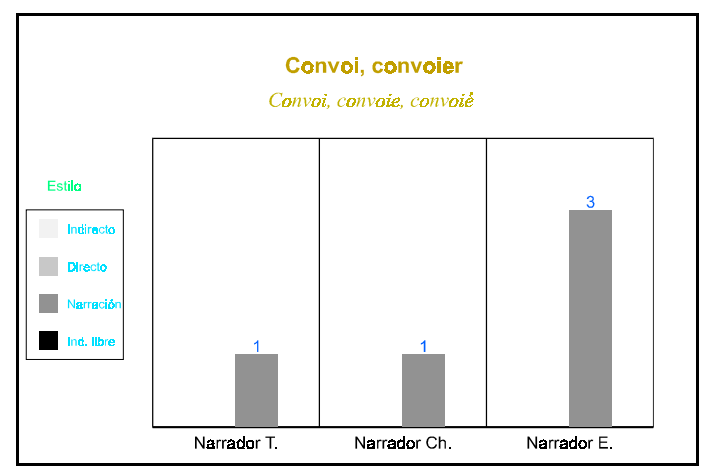

Fig. 104. Comportamiento estilístico del sustantivo convoi y del verbo «convoier» en Tristan, Charrete y Escoufle.

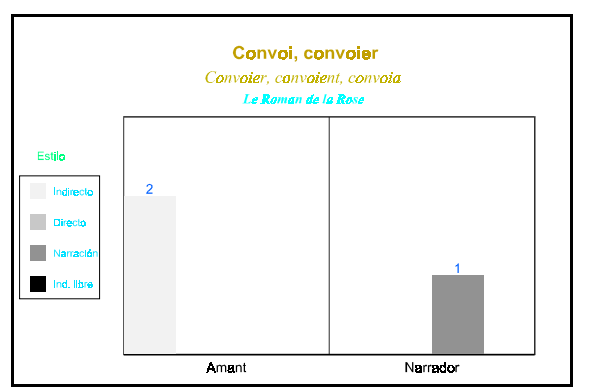

Fig. 105. Comportamiento estilístico del sustantivo convoi y del verbo «convoier» en Rose.

Los gráficos apuntan una cierta distancia en el uso estilístico de los términos. El primero señala la coincidencia en un cierto alejamiento con respecto a la historia, pues hallamos la voz del narrador en tercera persona como observador de las actividades de los dos amantes o cuando menos de uno de ellos y de los que lo rodean. El segundo pone en evidencia el paso a un primer plano del amante pese a que oculta varios desfases: vital y temporal en relación con el narrador en primera persona y vocal en el discurso generalizador referido a cualquier enamorado. 


\subsection{Veniry venue.}

Las ocurrencias del verbo y del sustantivo que hemos seleccionado indican el acercamiento de los amantes, y suelen expresar o preludiar la entrada en el espacio íntimo de la alcoba, recinto femenino por excelencia, y el juego amoroso. En Charrete podemos distinguir varias etapas en el venir que indican una aproximación progresiva hasta llegar al encuentro físico. Aunque con notables variaciones estas fases recuerdan, en un periodo reducido, las que debía superar el amante de la lírica: a. tímido agasajo a la amada que muestra su rechazo para endurecer la marcha de aquél; b. aceptación del servicio tras superar las duras pruebas impuestas - en nuestro caso un intento de suicidio-; c. conversación amorosa entre ambos y proximidad física aunque con impedimentos externos: "venez parler a moi a cele fenestre anquenuit" (Charrete, 4508 - 4509); d. veneración del cuerpo femenino y sumisión al deseo de la reina, lo que iniciará el juego sexual: “et puis vint au lit la reïne, si l'aore et se li ancline, car an nul cors saint ne croit tant" (Charrete, 4651 - 4653).

En Rose las fortificaciones simbólicas impiden a los amantes, y no sólo al protagonista del sueño, el paso de la primera etapa a la segunda, dificultades tanto más duras cuanto que la inexperiencia de los jóvenes y su desconocimiento de los códigos sociales y amorosos les habían deparado ya las primeras satisfacciones eróticas mediante el roce táctil y el beso:

si a bones portes coulanz

por fere ceus dehors dolanz

et por aus prendre et retenir

c'il osoient avant venir.

Enz ou mileu de la porprise

font une tor par grant mestrise

Rose, 3811 - 3816 
La conjunción entre los verbos venir y aler en Tristan y en E scoufle rememora también el contacto carnal y aún más lejos podríamos aventurar los movimientos de la penetración vaginal. En la primera de estas obras la evocación es inequívoca pues ya se nos ha dicho que los amantes aprovechan cualquier ocasión para manifestarse su amor y satisfacer su deseo del cuerpo del otro:

\author{
Li rois li a doné congié \\ d'estre a la chanbre: es le vos lié. \\ Tristran vait a la chanbre et vient; \\ nule cure li rois n'en tient
}

Tristan, $569-572$

En la novela del siglo XIII son los personajes que pretenden evitar la unión legal de los amantes los que introducen la sospecha de una relación que va más allá que la que realmente mantienen los jóvenes: “alons (...) en la cambre por le deffendre (...) qu'il i voise sans vos, ne viegne” (Escoufle, 2948 - 2951). En realidad los enamorados han aceptado plenamente los nuevos cánones del erotismo caballeresco que pretende mantener la virginidad hasta el matrimonio, un hecho que queda suficientemente claro al asumir Guillermo con total sumisión la prohibición del emperador de continuar con sus idas y venidas al gineceo: "ne jamais la ou ele soit ne sera tex qu'il voist ne viegne!" (Escoufle, 3068 - 3069).

La relación metonímica entre los movimientos del amante y la consumación del deseo es tan evidente que los felones los espían de forma reincidente en Tristan: "que tu voies la dedenz cler, qant il venra a lui parler" (Tristan, 4329 - 4330), ${ }^{465}$ que Iseo en su farsa bajo el pino, y también Ginebra, advierten a sus amantes de la posibilidad de un encuentro fortuito con un informador malintencionado que pondría en entredicho su honra y quizás sus

465 También en los versos 662 - 664, 704 - 706, 4291 - 4294 y 4411 - 4412. 
vidas: "grant poor ai que aucun home ne vos ait ci veü venir" (Tristan, 188 189), "quant vos vandroiz, si vos gardez que nule espie ne vos truisse" (Charrete, 4526 - 4527), y que el emperador prohíbe las venidas de Guillermo tras la ruptura del compromiso matrimonial que lo unía a Aelis:

$$
\begin{aligned}
& \text { je ne voel mais, por riens qui soit, } \\
& \text { que vos la ou ma fille soit } \\
& \text { venés sans moi puis hui cest jor. } \\
& \text { Je n'aim ne ne voel vo sejor } \\
& \text { en sa chambre desore mais. }
\end{aligned}
$$

Escoufle, 3017 - 3021

El enlace entre venir y la unión amorosa se hace aún más evidente si observamos los complementos que lo acompañan. En contadas ocasiones se trata de un espacio físico o de un objeto, como sería el caso del ejemplo precedente, de la habitación y de la cama de la reina Ginebra, o del recinto amurallado que encierra las rosas: "qui lesse un garçon desreé en nostre porprise venir por moi et li avilenir" (Rose, 3532 - 3534), y aun en estas ocasiones sabemos que el continente está por el contenido. Por el contrario se prefieren los seres animados — uno o los dos amantes introducidos por una preposición o un adverbio- o bien la conversación, uno de los primeros placeres aunque no tenemos por qué considerarlo uno de los más inocentes: "sovent vienent a parlement" (Tristan, 577); también puede darse la combinación de ambos, con lo que tenemos un doble complemento circunstancial:

- Venir + Prep. + Pron.: Es sin duda la construcción a la que más se recurre ya sea en tercera, en segunda o en primera persona, y puede, además, adoptar una forma recíproca, lo que lleva entonces al sujeto y al complemento a pasar de pronombre personal a pronombre indefinido: "se l'un a l'autre la nuit vient"' (Tristan, 705) 
par Perinis, un suen prochain,

avoit mandé que l'endemain

Tristran venist a lié matin

Tristan, 4347 - 4349

se Tristran l'aime folement,

a lui vendra a parlement

Tristan, $661-662^{466}$

rien fors vos ne me puet tenir

que bien ne puisse a vos venir

Charrete, 4609 - 4610

"el n'osera a moi venir" (Escoufle, 3186)

"et ele a lui ne fust venue?" (Charrete, 6826)

Lorris, en una escena extremadamente sensual en la que dos mujeres miman la danza erótica y actuan como iconos del deseo y de ciertos fantasmas tanto masculinos como femeninos, hace excepcionalmente uso de una construcción de este tipo, aquí recíproca, que no volverá a utilizar en su obra:

l'une venoit tot belement

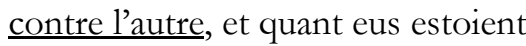

pres a pres, si s'entregetoient

les bouches qu'i vos fust avis

qu'eus s'entrebessoient au vis

Rose, $764-768$

466 También Tristán es el punto hacia el que tiende la reina en dos intervenciones gemelas: "que je a lui mais ne vendroie" (Tristan, 363) y "qar je a lui mais ne vendroie" (Tristan, 437). 
- Venir + Prep. + Denominación: Uso restringido a E sooufle. "tant est venus vers la pucele" (Escoufle, 3368), donde en el discurso de Amor, abstracción personificada que se dirige a la conciencia de Aelis, se identifica el espacio con el amante degradado y desterrado:

Fait Amors: «Bele et ja vendras

la desous a ton douç ami.»

Escoufle, 3948 - 3949

- Venir + encontre: Como la anterior esta construcción está tan sólo presente en E sooufle; el uso de este adverbio parece reservado a la expresión del sentimiento amoroso más que al preludio de un encuentro prohibido, ya sea entre los amantes que se reencuentran tras su separación o de la esposa hacia el esposo:

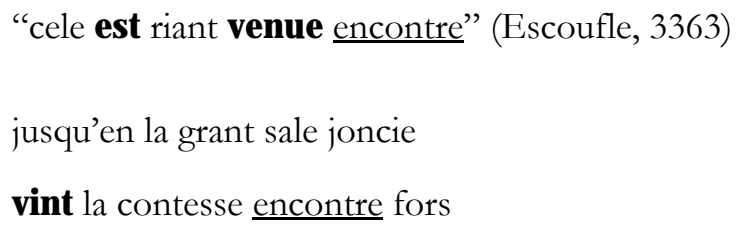

- Venir + ansamble: Se trata de una variante en la expresión de la reciprocidad del movimiento, si bien en Charrete adquiere un sentido más intenso al evocar la unión completa y sin trabas de los cuerpos:

de ce que ansanble ne vienent

lor poise molt a desmesure,

qu'il an blasment la ferreüre

Charrete, 4594 - 4596

au jor que il $i$ orent mis

vindrent ensamble al parlement

Escoufle, 5830 - 5831 
El recurso a la rima, muy abundante, apenas es utilizado en la evocación erótica a excepción de E scoufle y Charrete, en los que se recurre a sinónimos como avenir para evocar la reciprocidad del movimiento. Chrétien aprovecha la polisemia del verbo tenir. «retenen», «guardan», «mantenerse» O «coger de la mano»; mientras que Renart, al emparejar el sustantivo venue con el adjetivo nue, refuerza la relación claramente expresa en el contexto entre los términos que nos ocupan y el juego amoroso, representado en esta ocasión por las caricias al cuerpo desnudo de Aelis. Por el contrario en Rose las rimas con retenir y avilenir magnifican los obstáculos que se ponen al encuentro entre enamorados.

\begin{tabular}{lllllllll}
\hline FORMA & CA & BD & NVER & RIMA & CA2 & NV2 & D & PERS \\
\hline veingne & V & Charrete & 4425 & teigne & V & 4426 & N & Narrador \\
vendras & V & Escoufle & 3948 & dras & S & 3947 & D & Amour \\
vendroie & V & Tristan & 363 & parleroie & V & 364 & D & Iseut \\
vendroie & V & Tristan & 437 & parleroie & V & 438 & D & Iseut \\
venir & I & Charrete & 4515 & avenir & I & 4516 & D & Guenièvre \\
venir & I & Escoufle & 3186 & avenir & I & 3185 & D & Guillaume \\
venir & I & Rose & 3533 & avilenir & I & 3534 & D & Jalousie \\
venir & I & Tristan & 189 & ö̈r & I & 190 & D & Iseut \\
venir & I & Rose & 3814 & retenir & I & 3813 & N & Narrador \\
venir & I & Tristan & 4291 & tenir & I & 4292 & D & Félons \\
venir & I & Charrete & 4610 & tenir & I & 4609 & D & Lancelot \\
venir & I & Rose & 3842 & tenir & I & 3841 & N & Narrador \\
venist & V & Charrete & 4357 & apartenist & V & 4358 & D & Lancelot \\
venue & O & Charrete & 4578 & esternue & V & 4577 & N & Narrador \\
venue & S & Escoufle & 3027 & nue & A & 3028 & D & Guillaume \\
venue & O & Charrete & 6826 & venue & S & 6825 & N & Narrador \\
venuz & O & Tristan & 4412 & acoruz & O & 4411 & N & Narrador \\
vienent & V & Charrete & 4594 & tienent & V & 4593 & N & Narrador \\
vient & V & Charrete & 4575 & tient & V & 4576 & N & Narrador \\
vient & V & Tristan & 705 & tient & V & 706 & N & Narrador \\
vint & V & Tristan & 4409 & avint & V & 4410 & N & Narrador \\
vint & V & Charrete & 4198 & sovint & V & 4197 & D & Guenièvre \\
\hline
\end{tabular}

Tabla 76. Rimas del verbo venir y del sustantivo venue.

Las formas verbales aparecen en algunas proposiciones independientes, especialmente en las intervenciones en estilo directo de los personajes, entre las que destacamos el uso del imperativo en el discurso de Ginebra o del futuro en la autoritaria voz del Amor en Escoufle. También lo hacen en proposiciones principales, de forma preponderante en la narración, 
pero la subordinación, y especialmente la expresión de las circunstancias, sobresale en el análisis proposicional de los contextos en que se hallan venir y venue. A excepción de un ejemplo en Rose las proposiciones subordinadas circunstanciales se hallan tan sólo presentes en los textos del siglo XII.

- Temporales: Se indica mayoritariamente el tiempo en el que se producirá o en el que se produjo el acercamiento de los amantes mediante la conjunción quant: "que tu voies la dedenz cler, qant il venra a lui parler" (Tristan, $4329-4330)^{467}$

«Ha! Lasse! De coi me sovint, quant mes amis devant moi vint

Charrete, $4197-4198^{468}$

La conjunción tant que señala un proceso posterior al proceso principal, en el ejemplo que recogemos es presentado como efectivo pues el verbo aparece en indicativo; aquí cabe destacar, además, la aparente simetría de los movimientos de Lanzarote y Ginebra, sin embargo el caballero se halla en situación de inferioridad, pues debe correr en la oscuridad para esconderse aferrado a la ventana a la espera de su amante:

$$
\begin{aligned}
& \text { par cele fraite isnelemant } \\
& \text { s'an passe, et vet tant que il vient } \\
& \text { a la fenestre, et la se tient } \\
& \text { si coiz qu'il n'i tost, n'esternue, } \\
& \underline{\text { tant que la reïne est venue }}
\end{aligned}
$$

Charrete, 4574 - 4578

\footnotetext{
467 “quant vos vandroiz, si vos gardez que nule espie ne vos truisse." (Charrete, 4526 - 4527). 
- Hipotéticas: Reproducen las sospechas de los enemigos de los amantes en los textos en los que mayor importancia se les otorga, aunque con una notable diferencia: mientras que en Tristan se excluyen las dudas sobre las posibilidades de que la condición y por lo tanto el proceso de la principal se lleven a cabo, la introducción en Rose del auxiliar oser en la perífrasis verbal excluye en la práctica las opciones de los amantes. Esta diferencia probablemente es el resultado de los diferentes modos de vida que recrean los dos relatos, el feudal y el burgués, ya que la promiscuidad facilitada por la vida en común queda refrenada en la ciudad, donde se puede establecer una más estrecha vigilancia del gineceo.

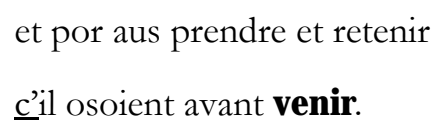

Tristan, 4288 - 4291

Se da la circunstancia añadida en el texto de Béroul de que todas las ocurrencias en contextos hipotéticos establecen la percepción visual como medio determinante de la culpabilidad de los amantes y de que se otorga a las 
pruebas así obtenidas absoluta credibilidad; frente a esto los amantes van a jugar, como ya hemos visto, con el lenguaje, instrumento más maleable y adaptable en un mundo ganado por las apariencias. Estas observaciones quedan corroboradas en las proposiciones completivas e infinitivas: "enuit verrez venir, par main" (Tristan, 4294); en dos de ellas la reina enseña sus cartas para vencer la represión de la corte: la duplicación de los discursos preñados de mendacidad: "et je li dis que grant folie avoit requis, que je a lui mais ne vendroie" (Tristan, 361 - 363) y la recreación en tono paródico de las convicciones más arraigadas entre sus contemporáneos para restarles su valor: “grant poor ai que aucun home ne vos ait ci veü venir" (Tristan, 188 - 189).

Las proposiciones subordinadas causales: "gar je a lui mais ne vendroie ne ja a vos n'en parleroie” (Tristan, 437 - 438), “je serai anz, et vos defors que ceanz ne porroiz venir" (Charrete, 4514 - 4515), y las finales: "rien fors vos ne me puet tenir que bien ne puisse a vos venir' (Charrete, 4609 4610), completan las subordinadas circunstanciales de las obras del siglo XII.

Chrétien reúne las proposiciones completivas en los episodios donde se muestran con mayor claridad los sentimientos y los deseos de la reina y de su caballero: "de ce que ansanble ne vienent lor poise molt a desmesure" (Charrete, 4594 - 4595), anhelantes ante la posibilidad de la unión que Ginebra había desbaratado y que sólo ella podrá recomponer: "et molt est la reïne tart que sa joie et ses amis veingne” (Charrete, 4424 - 4425). Son momentos excepcionales en un ambiente de continua ocultación por motivos no estrictamente situacionales pues también interviene la ideología amorosa cortés, que quedan reflejados no sólo en los verbos introductores, peser y tarder, sino también en los adverbios y las expresiones redundantes con valor adverbial, molt y a desmesure.

La misma concentración se da en E scoufle, donde la prohibición del espacio femenino al amante conlleva, además de la orden del rey introducida por el verbo voloir en construcción negativa (Escoufle, 3017 - 3019), la réplica 
y la petición de explicaciones por parte de un enamorado desconcertado y poco acostumbrado a las intrigas palaciegas, y ello mediante una interrogativa indirecta: "mais or me dites, s'il vos plaist, por coi vos dessiet ma venue" (Escoufle, 3026 - 3027); en ella el sustantivo venue cobra una doble importancia por ser sujeto de la proposición y por hallarse en la rima, y pone en evidencia mediante el verbo desseoir las contradicciones en las que caen los seniores por un apego excesivo a las convenciones sociales — fenómeno similar al observado en Tristan-.

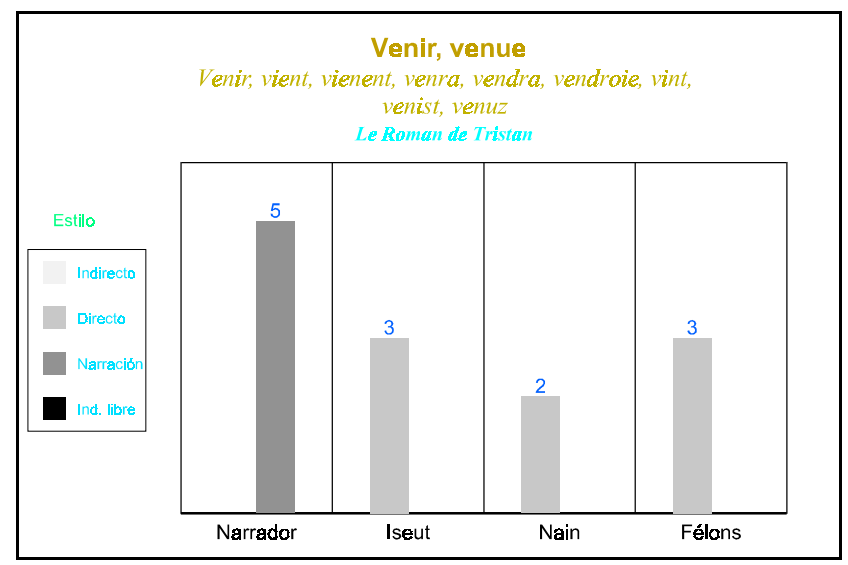

Fig. 106. Comportamiento estilístico del verbo venir y del sustantivo venue en Tristan.

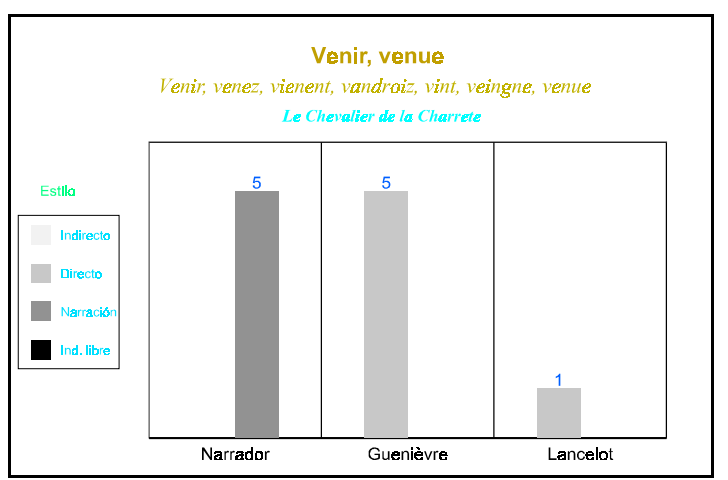

Fig. 107. Comportamiento estilístico del verbo venir y del sustantivo venue en Charrete. 


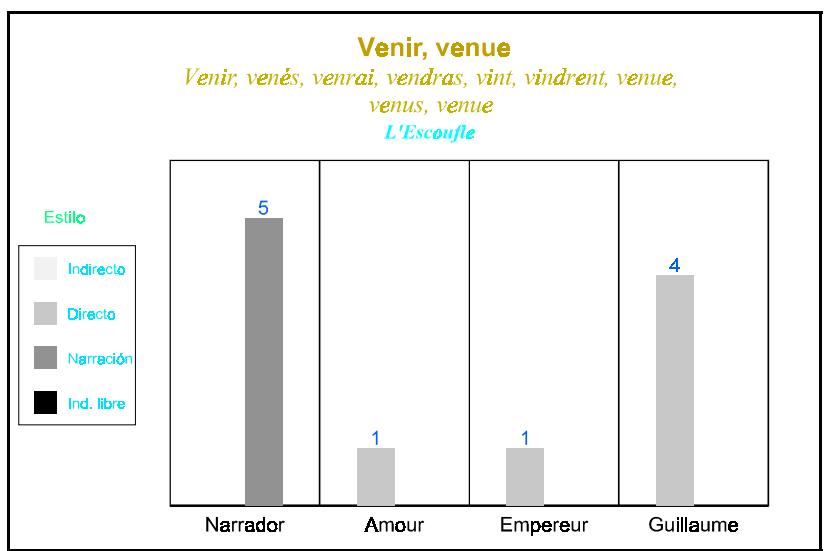

Fig. 108. Comportamiento estilístico del verbo venir y del sustantivo venue en Escoufle.

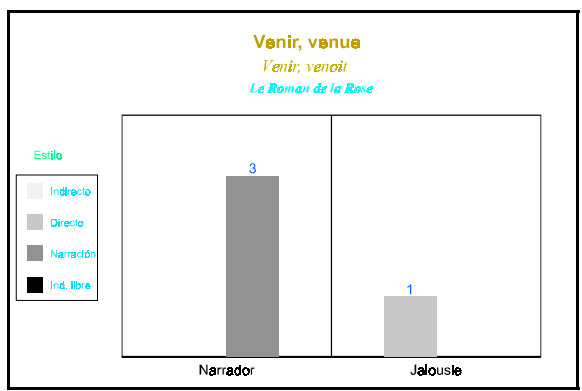

Fig. 109. Comportamiento estilístico del verbo venir y del sustantivo venue en Rose.

Los usos discursivos y narrativos muestran en gran medida la pugna entre dos formas de entender la realidad y la vida amorosa, la de los jóvenes y la de aquellos que pretenden imponer una moral social en la que no cabe la libertad para elegir a la pareja sexual. En Tristan ambas parecen oponerse en igualdad de condiciones, aunque la inteligencia del instinto contrarresta el apego a las apariencias; esta inclinación, tras haber contaminado al grupo juvenil, va a marcar en los otros relatos la mayor parte de los episodios decisivos desde un punto de vista narrativo, como el de la sangre en la cama de Ginebra o el de la desaparición de Guillermo. En Charrete prima la voluntad de la reina y el juego del cortejo cortés que gira en torno al verbo venir. Renart pone también de relieve la lucha de los jóvenes y deja espacio para mostrar la relación entre venir y el erotismo. Frente a ellos, Lorris hace que el fiel de la balanza se incline inequívocamente hacia las fuerzas contrarias al 
amor, cuyo visión es asumida por el propio narrador en un tono pesimista que excluye la rebeldía de los romans precedentes.

\subsection{LA PALABRA.}

En nuestros textos, oír hablar del amante, escuchar su voz susurrante cuando pronuncia dulces palabras o el nombre de la amada, percibir en primavera el melodioso canto de los pájaros mientras buscan a su pareja resulta placentero e induce al amor. No nos ocuparemos, sin embargo, de manera explícita de las sensaciones que experimenta el oyente por ser complementarias del decir amoroso y no aportar ningún dato de interés sobre los usos eróticos.

\subsection{1 «Aresnien».}

Es un verbo utilizado minoritariamente — tan sólo en Charrete y en Rose con una ocurrencia en el discurso del dios Amor-, sin embargo su uso es altamente significativo, en primer lugar por ilustrar los desequilibrios que afectan a la pareja cortés en la relación entre Ginebra y Lanzarote; en segundo lugar al poner de relieve la exclusividad amorosa que perturba el comportamiento social del caballero de la carreta y que le hace rechazar un discurso femenino, uso de la palabra que probablemente debemos identificar como un cortejo tras el intento fallido de hacer entrega del cuerpo. Con ello recupera la doncella las verdaderas armas femeninas tras haber utilizado los recursos tradicionalmente masculinos, la violencia y la atracción visual: "cele l'aresne, et il n'a cure de quan que ele l'aparole, einçois refuse sa parole" (Charrete, 1332 - 1334); y por fin, al mostrar la extrema timidez del verdadero enamorado en el uso de la palabra: “car onques cuer ne hardement n’eüs de li aressoner” (Rose, 2354 - 2355), fenómeno que podría reconocerse como síntoma natural de enamoramiento pero que deja al descubierto las 
contradicciones en las que, tras una notable evolución, entró la cortesía. Si el discurso elaborado pero sincero había sido el primer y mejor tributo del aspirante a enamorado, se había convertido tras una estricta sumisión combinada con la observación del natural, en un elemento tabú que quedaba reservado al sexo femenino hasta que la nueva ideología lo identificará con la aceptación del enamorado y lo vetará también para ellas.

La supremacía de la reina Ginebra se manifiesta gracias a la imposición de una férrea voluntad —el verbo voloir forma sistemáticamente perífrasis con aresnier-, que conlleva la negativa al uso de los sentidos y a la prerrogativa de la oralidad — se observa una acumulación de adverbios y de conjunciones coordinantes negativos- Cierra de este modo todo acceso al suspirante, y lo que sería quizás más importante teniendo en cuenta los preceptos de la cortesía y el supuesto cambio erótico que pretendía abanderar, impide la satisfacción de su propio deseo, ya sea en pretérito definido —el passé simple actual— en una proposición independiente: "por ce, voir, ne vos vos je pas ne aresnier ne esgarder" (Charrete, 4488 - 4489) o en presente en el discurso del Rey Bademagu como núcleo de una proposición subordinada completiva: “(...) «Lancelot, molt me mervoil que ce puet estre, et don ce muet, que la reïne ne vos puet veoir, n'aresnier ne vos vialt"' (Charrete, 3982 $-3985)$.

\subsection{Dire y «dit».}

Hemos recogido tan sólo una pequeña parte de las ocurrencias del verbo dire, eliminando prácticamente la totalidad de las utilizadas como verbo introductor del estilo directo en el discurso de los amantes, aunque hemos conservado dos ocurrencias de Charrete en las que el verbo posee un complemento de objeto: "lors dist cele sa volanté" (Charrete, 2796) o es modificado por un adverbio: "puis li dist amïablemant" (Charrete, 6679), 
elementos que nos permiten observar las relaciones entre Lanzarote y la doncella de la mula que lo salvará de su cautiverio. Por un lado el caballero acepta de inmediato su presencia y sus deseos, algo que había intentado rechazar sistemáticamente de sus anfitrionas, lo que podría quedar justificado por el aspecto decidido de la doncella y por su llegada en solitario; por otro, en el discurso de Lanzarote tras su liberación ya hemos señalado un cambio drástico en anteriores comentarios, pues las promesas — se reúne el verbo dire con el verbo prometre - reservadas a la dama, en su caso Ginebra, cambian de destinataria y adopta un tono que cuadraba poco con su rechazo del sexo femenino:

$$
\begin{aligned}
& \text { Se fors de ci me poez metre, } \\
& \text { por voir vos puis dire et prometre } \\
& \text { que je toz jorz mes serai vostres, } \\
& \text { si m'aïst sainz Pos li apostres }
\end{aligned}
$$

Charrete, $6587-6590$

Similar tratamiento han recibido las formas que preludian dentro de un discurso directo las palabras de otro personaje o las que han sido pronunciadas con anterioridad. Éstas pueden ser reproducidas ante terceros, y sobresale en este caso la recuperación discursiva del encuentro bajo el pino por parte de Iseo: “et je li dis que grant folie avoit requis" (Tristan, 361 - 362) —en cuya intencionalidad no volveremos a entrar-, o bien ser recogidas dentro de un monólogo, tal y como observamos en las quejas y reproches de Aelis al sentirse abandonada:

Lasse! Il disoit qu’il m'amoit tant; lasse! Il disoit j'ere sa dame

Escoufle, 5362 - 5363 
Estos versos son especialmente interesantes pues son muy pocas las ocasiones en las que se reproducen las palabras del homenaje y del cortejo amoroso y generalmente se nos ofrecen en estilo directo en la obra de Béroul o en la de Chrétien. Estos autores son más proclives a mostrar el tributo amoroso mediante hechos que mediante palabras, más propias de la poesía amatoria, y relegan el discurso al papel de instrumento secundario de la aquiescencia del caballero: "si li dist que molt volantiers, come cil qui est suens antiers" (Charrete, 5655 - 5656). En segundo lugar, resulta significativa la presencia del imperfecto de indicativo, aquí con un valor de repetición, para evocar un hecho habitual. Este contrastará en los versos siguientes con el pretérito definido que retoma la misma acción pero en un momento concreto, antes de la desaparición de Guillermo: “encor me dist il ore k'il m’estoit et sire et amis" (Escoufle, 4698 - 4699). Con el uso del imperfecto en la queja se representa con mayor intensidad el tópico desarrollado por los trovadores: los falsos amadores pronunciaban con facilidad palabras de amor que no respondían a sus sentimientos. Este motivo también se halla en el discurso del dios Amor de Rose para advertir del falso homenaje que será motivo de la ira y de la venganza divinas.

En el polo opuesto se desarrolla el tema del amante incapaz de articular sus discursos, uno de los primeros síntomas del enamoramiento: "ne soi que fere ne que dire" (Rose, 1721) y de exponer con claridad sus pensamientos a la dama o la doncella, o bien la variante del enamorado demasiado respetuoso como para atreverse a comunicarle a aquélla sus dudas y temores, máxime cuando se muestra esquiva y rechaza su homenaje o cuando se hallan en compañía de terceros, situación habitual en las cortes reflejadas en los textos del siglo XII y particularmente en Charrete: "mes je ne vos puis mie ci tot dire quan que ge voldroie" (Charrete, 4502 - 4503). El futuro como tiempo del acontecimiento, aunque el verbo dire se halle en infinitivo, y el futuro de indicativo como tiempo del discurso serán utilizados por Lorris en su roman. Con ellos asocia la incapacidad oratoria a ciertas 
disfunciones intelectuales, una de las ineludibles características que el dios menciona como signo del verdadero amor. Con la particularidad de que en este contexto discursivo la personalización mediante la segunda persona del singular está más cerca del pronóstico apoyado en la casuística que del mandamiento. Tan sólo escapa a esta particularidad el verso en el que advierte sobre la inexcusable decencia del discurso amoroso, del que debe quedar descartada cualquier referencia a los aspectos carnales, pues el mot de vilenie no es propio de los amantes corteses:

$$
\begin{aligned}
& \text { quant ta reison avras fenie } \\
& \text { sanz dire mot de vilenie, } \\
& \text { mout te tendras a conchié } \\
& \text { quant tu avras rien oublié } \\
& \text { qui te fust avenant a dire. }
\end{aligned}
$$

Rose, 2399 - 2403

\author{
et se tant te puez avancier \\ que ta resson comencier oses, \\ quant tu devras dire .iii. choses, \\ tu n'en diras mie les .ii., \\ tant seras vers li vergondeus \\ Rose, 2386 - 2390
}

Lo cierto es que la primera muestra de la aceptación del cortejo por parte femenina es la invitación a la palabra del enamorado, a quien da total libertad para solicitar de ella lo que desea:

- Dites, fet il, vostre voloir, que ja ne m'en feroiz doloir de chose que vos veilliez dire

Rose, 2879 - 2881 
Pero en este simple requerimiento de Bel Accueil se ocultan dos trampas nefastas: la primera de ellas para el modelo cortés no sólo del amor sino de la sociedad al trastocarse totalmente los papeles de la pareja anteponiendo la voluntad masculina sobre la femenina, que al menos para la reina y Lanzarote todavía se conservaba en Charrete. La segunda para el modelo naturalista regido por el instinto y sus impulsos no coartados, ya que este incentivo mal entendido impele al amante de la rosa a colmar sus deseos más allá de la vista y de la palabra mediante el tacto, el beso y aun la entrega de la virginidad, de ahí las expresiones granz privetez y gieus con las que se excluye un cortejo banal y el amante, que olvida la prohibición de Amor, se adentra en la esfera de la carnalidad: “j’avoie ja comencié a dire mes granz privetez a Bel Acueil, qui aprestez estoit de recevoir mes gieus" (Rose, 3946 3949), pero recibe a cambio el rechazo de la doncella, adoctrinada en la nueva moral de corte burgués, y la extrema vigilancia de las fuerzas externas en su celo por imponer modos de comportamiento diferentes como tapadera de un modelo nuevo de intercambio económico-sexual:

$$
\begin{aligned}
& \text { Lors s'en est Bel Acueil fuïz, } \\
& \text { et je remainz tot esbaïz, } \\
& \text { honteus et maz; si me repens } \\
& \text { dont onques dis ce que je pens. }
\end{aligned}
$$

Rose, 2935 - 2938

Renart, interesado por la tradición pero dispuesto a la innovación para salirse de los rígidos esquemas que la narrativa según el modelo cortés había impuesto, aporta la voz de la enamorada. Ésta había quedado recluida, si exceptuamos a algunas trovadoras, en la lírica tradicional, pero aquí pide a su amante que le muestre su amor con los besos y las caricias que a ambos satisfacen: "aprés mangier li dist qu'il baist son blont chief sor son dolç escors" (Escoufle, 4326 - 4327). En la reconstrucción que hace Guillermo del discurso amoroso de Aelis, las grandes y estereotipadas palabras del tributo 
masculino en torno al amor, al servicio cortés y a la relación mutua de dependencia, se tornan cariñosos y placenteros susurros en los que la combinación del artículo posesivo y de un adjetivo o de un sustantivo pretenden mostrar tan sólo su dulzura y su afecto:

$$
\begin{aligned}
& \text { a cui orrai je jamais dire } \\
& \text { mes doux, mes biax, mes cuers, mes sades? }
\end{aligned}
$$

Escoufle, 5142 - 5143

Más adelante, el encanto social atribuido a Aelis en su trato con los nobles y burgueses de Montpellier, será una combinación perfecta de belleza y simpatía, de amabilidad en el trato y de capacidad lúdica. Virtud variopinta en la que el don de relatar y recitar ocupa un lugar preponderante si nos atenemos a la insistencia con la que es mencionado: junto al verbo conter y a los sustantivos romans y contes, el sustantivo dis, que rima consigo mismo, es objeto directo del verbo dire:

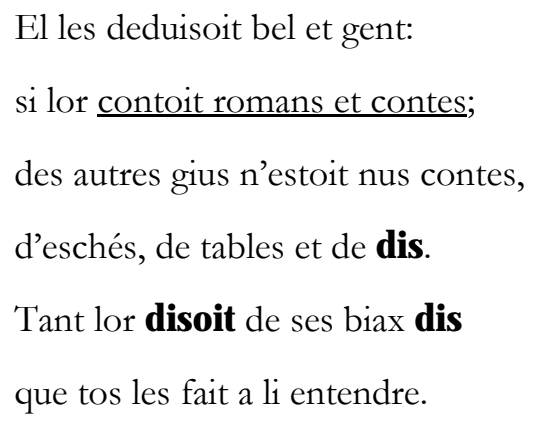

En la intimidad del gineceo estas actividades lúdicas servían para que Guillermo entretuviese a su enamorada y eran un componente más del servicio amoroso: "et quant il est avoec s'amie, ml't la set servir de biax dis, de dés, d'eschés, de gius partis" (Escoufle, 2026 - 2028), sin embargo, dentro del proceso general de divulgación de las actividades cortesanas y del modelo cortés, Aelis las extiende con una finalidad económica y como medio para 
alcanzar y mantener el prestigio social que su independencia no podía sino socavar.

El análisis de los sintagmas en los que se encuentra dire nos muestra cómo el verbo en infinitivo puede aparecer en perífrasis verbales, con valor modal - acompañado de pooir especialmente en Charrete para indicar la disposición de Lanzarote a mostrar sus sentimientos con respecto a la reina o la doncella de la mula en función de la situación— o temporal: “j’avoie ja comencié a dire" (Rose, 3946 - 3947). También adopta a menudo en los textos del siglo XIII la función de complemento preposicional con valor circunstancial: ya sea sustantivado mediante la anteposición del artículo determinado para expresar la acción de decir — mientras que el sustantivo dit se reserva para su resultado general o especializado- "quant ses cuers frans n'ert o le dire" (Escoufle, 5367) o con la función de un sustantivo pese a no aparecer determinado, construcción habitual en esta época: "si ne le li vost ostroier ne por dire ne por proier" (Rose, 1449 - 1450), ya como verbo acompañado de un complemento de objeto directo: "ke la dame li laist et sueffre son voloir sans dire folie" (Escoufle, 5926 - 5927). Siempre precedido de preposición puede funcionar como complemento de un adjetivo: "qui te fust avenant a dire" (Rose, 2403) o bien como régimen preposicional con un valor de complemento de finalidad: "lors ai pris cuer et hardement de dire Bel Acueil coment Amors m'avoit pris et navré” (Rose, 2868 - 2870). La notable presencia del infinitivo en estos textos sugiere que la acción escasamente determinada de dire es matizada por las acciones que expresan los verbos y sintagmas a los que acompaña, para poner de relieve la actitud del sujeto cuando es el mismo para ambos verbos o la oposición entre el sujeto de uno y otro.

Es también digno de reseñar el uso del imperativo, muy escaso o inexistente entre las formas verbales analizadas hasta ahora. A excepción de Tristan el resto de los textos recurren a este modo con distintos matices. Es 
raro encontrar un mandato claramente expreso: "et si li dites a consoil que «au noauz» que je li mant” (Charrete, 5644 - 5645) y se trata más bien de ruegos ya que el verbo suele ir acompañado de expresiones que modifican su intensidad, aunque se mantiene la intención de provocar un cambio en la situación descrita por el relato. Así ocurre en Charrete donde encontramos siempre a la reina como el foco del que emana cualquier posible variación, al controlar los mecanismos que animan el afán guerrero de Lanzarote así como las manifestaciones de sus sentimientos, lo que queda patente si observamos que el pronombre complemento de objeto indirecto hace siempre referencia al caballero enamorado. De ahí que el rey Bademagu suplique a la reina que haga valer su autoridad para salvar a su hijo de la ira del de la carreta, por lo que en realidad la verdadera orden, la de Ginebra, queda diferida, pero se halla implícita en la forma imperativa:

$$
\begin{aligned}
& \text { mes por moi, la vostre merci, } \\
& \text { li dites, car je vos an pri, } \\
& \text { qu'il se taigne de lui ferir } \\
& \quad \text { Charrete, } 3783 \text { - } 3785
\end{aligned}
$$

Lanzarote implora, de forma más parca pero con mayor patetismo el perdón de Ginebra por las faltas contra el amor cometidas en su búsqueda, y si en los dos ejemplos anteriores se ordenaba o pedía acometer un acto locutivo en una perspectiva ilocutiva, aquí se trata más bien de generar un acto perlocutivo:

$$
\begin{aligned}
& \text { et se vos ja le me devez } \\
& \text { pardoner, por Deu sel me dites }
\end{aligned}
$$

Charrete, 4496 - 4497

Similar estructura, formal y actancial, y la misma finalidad comunicativa se observan en la súplica del amante de la rosa dirigida a Bel 
Accueil, ya que lo que pide es el permiso para obtener un beso de la doncella, lo que a su vez, dada su impaciencia, equivaldría prácticamente a darlo y recibirlo:

\author{
Sire, por Dieu, dites moi dons \\ se il vos plest que je la bese
}

Rose, 3374 - 3375

En Rose hallamos otro ejemplo, al que ya hemos aludido con anterioridad, en el que más que un mandato se encierra una invitación de Bel Accueil para que el enamorado exprese sus deseos (Rose, 2879), mientras que en E sooufle el modo imperativo no guarda ningún vínculo con la autoridad al introducir una interrogación indirecta con un valor puramente retórico, que expresa ante Aelis el dolor, la desesperación y la impotencia de Guillermo cuando se ve expulsado del gineceo y privado de su compañía:

\author{
car me dites en quel maniere \\ je m'en porrai escaper vis
}

Escoufle, 3414 - 3415

De nuevo en los textos del siglo XIII, el sustantivo dis, las más de las veces acompañado del epíteto biaus, con el que se pone de relieve no sólo la belleza de las palabras o de los versos, sino su anclaje en el estilo noble, ejerce las funciones de complemento preposicional con sentido instrumental: “ml't la set servir de biax dis" (Escoufle, 2027) o expresa el modo: "ele ne fu nice n'onbrage, mes sage et antre, sanz outrage, de biaus respons et de biaus diz" (Rose, 1233 - 1235). Se halla también como aposición explicativa a un término más general, en este caso gius: “des autres gius n’estoit nus contes, d'eschés, de tables et de dis" (Escoufle, 5526 - 5527) o bien como complemento de objeto directo: "tant lor disoit de ses biax dis" (Escoufle, 5528), ejemplos estos en los que la preposición funciona como partitivo. 
Poco nos aportan las rimas desde el punto de vista semántico, sin embargo, la repetida aparición de las formas de dire o de dit en la última posición del verso nos obliga a pensar en una fuerte utilización retórica que se combina sin duda con la comodidad formal en la composición.

\begin{tabular}{lllllllll}
\hline FORMA & CA & BD & NV & RIMA & CA2 & NV2 & D & PERS \\
\hline dies & V & Rose & 2097 & ribaudies & S & 2098 & D & Amour \\
dire & I & Charrete & 4921 & desdire & I & 4922 & D & Guenièvre \\
dire & I & Escoufle & 5367 & ire & S & 5368 & D & Aélis \\
dire & I & Rose & 2403 & martire & S & 2404 & D & Amour \\
dire & I & Rose & 1721 & mire & S & 1722 & N & Narrador \\
dire & I & Charrete & 5444 & rire & I & 5443 & D & Dame \\
dire & I & Rose & 2881 & sire & S & 2882 & D & Bel Accueil \\
dire & I & Escoufle & 5142 & tire & S & 5141 & D & Guillaume \\
diroiz & V & Charrete & 5890 & porroiz & V & 5889 & D & Lancelot \\
dis & S & Escoufle & 5527 & dis & S & 5528 & N & Narrador \\
dis & S & Escoufle & 2027 & partis & O & 2028 & N & Narrador \\
dis & V & Tristan & 361 & requis & O & 362 & D & Iseut \\
disoit & V & Escoufle & 5366 & faisoit & V & 5365 & D & Aélis \\
dist & V & Rose & 2662 & esbaudist & V & 2661 & D & Amour \\
dist & V & Charrete & 1317 & volsist & V & 1318 & N & Narrador \\
dite & O & Charrete & 4681 & eslite & A & 4682 & D & Narrador \\
dite & O & Tristan & 477 & petite & A & 478 & D & Roi Marc \\
dites & V & Rose & 2794 & merites & S & 2793 & D & Amant \\
dites & V & Charrete & 4497 & quites & A & 4498 & D & Lancelot \\
diz & S & Rose & 1235 & desdiz & O & 1236 & N & Narrador \\
\hline
\end{tabular}

Tabla 77. Rimas del verbo dire y del sustantivo «dit».

La sintaxis y el contenido semántico de las proposiciones subordinadas en las que se incluye el verbo dire nos muestran curiosamente un predominio de las proposiciones completivas, ya sean infinitivas: "a cui orrai je jamais dire" (Escoufle, 5142), conjuntivas: "si me sovient que por ce dist une dame qui mout amot" (Rose, 2662 - 2663), "aprés gardes que tu ne dies ces orz moz ne ces ribaudies: ja por nomer vilainne chose ne doit ta bouche estre desclouse" (Rose, 2097 - 2100), o bien interrogativas indirectas introducidas por un pronombre interrogativo: "ne soi que fere ne que dire" (Rose, 1721) o por un adverbio: "ne sai coment dire l'osé” (Rose, 2459). Este dato, que podría resultar sorprendente si consideramos que habitualmente el verbo introduce una proposición completiva, nos instruye sobre el grado de influencia del discurso en los romans del siglo XIII y particularmente de un 
término muy general dentro de este conjunto semántico. Este vocablo sirve en gran medida para plantear los problemas a los que se enfrentan los enamorados cuando afrontan la difícil tarea de conquistar o de conservar las conquistas realizadas ya que deben guardar la justa medida entre la osadía verbal y la contención más exquisita y ajustada a los cánones de la cortesía.

En cuanto a las proposiciones subordinadas relativas, que solamente Lorris emplea, nos llama poderosamente la atención el hecho de que las referencias al discurso masculino representado por los antecedentes de los relativos son siempre imprecisas, probablemente en relación con la impotencia oratoria: "quant tu avras rien oublié qui te fust avenant a dire" (Rose, 2402 2403), y con la esperada utilización de los tópicos amorosos al uso, estrictamente encerrados en el marco del estilo y de los comportamientos corteses: "que ja ne m'en feroiz doloir de chose que vos veilliez dire" (Rose, 2880 - 2881). Por el contrario, el uso en singular del sustantivo bonté para denominar un acto, aquí discursivo, que es fruto de la amabilidad femenina, intensifica la asunción por parte de Bel Accueil de un discurso estrictamente reglado por una combinación de la cortesía y de las nuevas formas de relación heterosexual que permitían la palabra femenina pero desechaban los actos:

si vos rent graces et merites
de la bonté que vos me dites

Rose, 2793 - 2794

El discurso directo del narrador de Charrete nos aporta el único ejemplo de proposición subordinada circunstancial en los textos del siglo XII - aquí con un sentido causal-, que es especialmente interesante por dos motivos: el uso estilístico poco habitual en este roman y la construcción pasiva del verbo que parece imponer el silencio del ente narrativo, aunque la insistencia en la negación de la palabra sobre el ayuntamiento carnal coloca a éste en un primer plano erótico, al sobrepasar con la sugestión la capacidad descriptiva de la perfección del acto consumado entre Ginebra y Lanzarote: 
mes toz jorz iert par moi teüe,

qu'an conte ne doit estre dite.

Charrete, 4680 - 4681

Una articulación causal: "si me repens dont onques dis ce que je pens” (Rose, 2937 - 2938), una temporal: “quant ses cuers frans n’ert o le dire” (Escoufle, 5367), y finalmente una consecutiva: “qu'Amors m'avoit tant avancié que j’avoie ja comencié a dire” (Rose, 3945 - 3947), completan el panorama de las proposiciones subordinadas circunstanciales en los textos del siglo XIII.

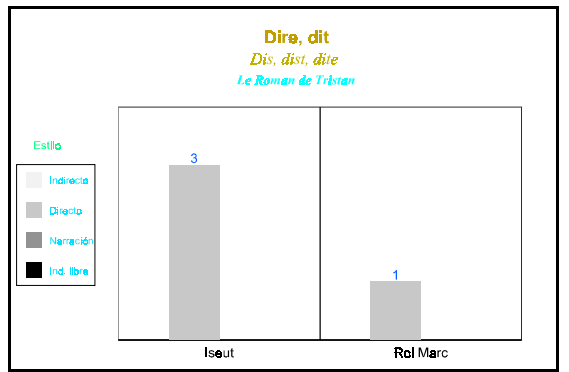

Fig. 110. Comportamiento estilístico del verbo dire y del sustantivo «dit» en Tristan.

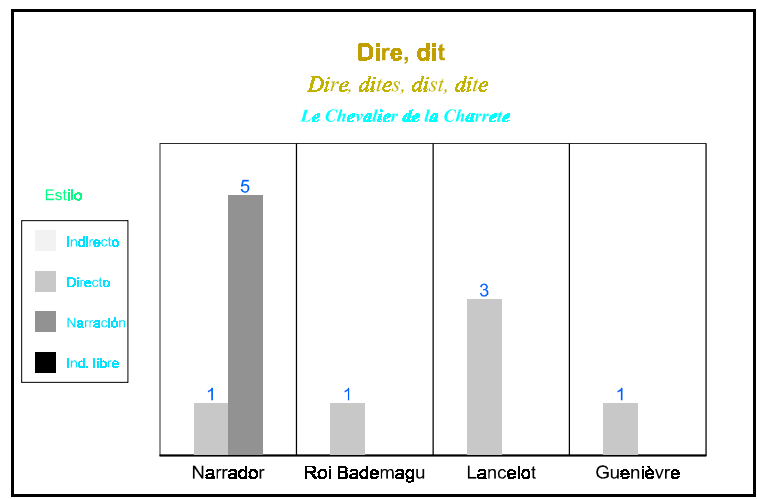

Fig. 111. Comportamiento estilístico del verbo dire y del sustantivo «dit» en Charrete. 


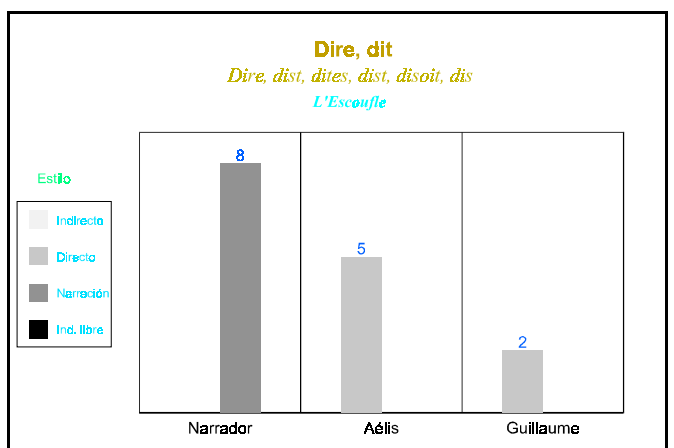

Fig. 112. Comportamiento estilístico del verbo dire y del sustantivo «dit» en Escoufle.

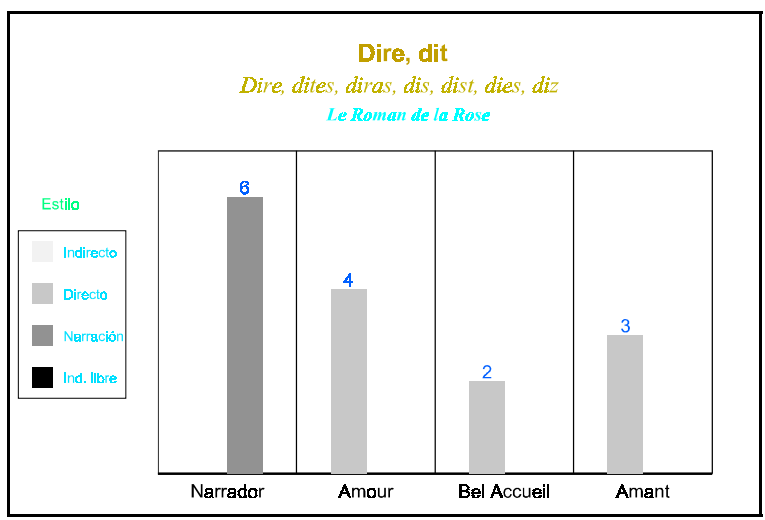

Fig. 113. Comportamiento estilístico del verbo dire y del sustantivo «dit» en Rose.

El eco domina las ocurrencias de dire en el texto de Béroul y de Renart: en el primero con un tono burlesco y en el segundo con un marcado componente dramático, con la particularidad de que es en estas obras donde las heroínas ocupan un lugar preminente en el decir, aunque en la última se abre paso a la voz del narrador, que ya había comenzado a imponerse en Charrete. Las reglas relativas a la conducta, ya sea en el hacer o en el decir, imperan en la elaboración de los contextos que incluyen el verbo dire y el sustantivo dit tanto en Charrete como en Rose, donde, por el contrario, los enamorados o las voces masculinas, incluida la del narrador, superan a las femeninas, y ello aun en el caso de Ginebra, quien domina con su palabra las actividades del enamorado. 


\title{
3.2.2.3.2.3 Parler, parole y «parlemant».
}

El verbo parler rara vez se presenta en una construcción en la que se exprese claramente la interacción. Cuando esto se produce se hallan formulaciones con el verbo en plural y reforzado por un adverbio como ensamble: "malgré sa mere, avons nos puis parlé ensamble" (Escoufle, 3720 - 3721), "puis parlerent a lor pleisir de quan que lor vint a pleisir" (Charrete, 4465 - 4466), o bien con un complemento introducido por la preposición $\mathbf{0}$ : "la ou son aise atent de parler o sa chiere drue" (Tristan, 4282 - 4283). En formas unidireccionales es utilizado como verbo intransitivo en Tristan, único caso en el que en algunos contextos podría ser concebido como sinónimo de dire, y probablemente como una variante formal de éste: "Iseut parla o grant sospir" (Tristan, 2694), "Yseut parla, qui n'ert pas fole" (Tristan, 2805); y muy a menudo como verbo transitivo indirecto seguido de la preposición de para introducir un complemento de persona: “qui de mon ami me parole. Si m'aïst Dex! I m'a garie qui m'en parle” (Rose, 2666 - 2668), "il vos a fait chanbres veer por moi: s'il or m'en ot parler' (Tristan, 175 - 176), o seguido de la preposición a con un complemento de persona, las más de las veces en forma pronominal como en los ejemplos precedentes: "Par foi, sire, grant tort avez, qui de tel chose a moi parlez" (Tristan, 163 - 164), "quant il me vit a li paler dou bouton a qui je beoie" (Rose, 3102 - 3103). Del uso de esta última construcción, muy abundante en el corpus, debemos inferir, casi sistemáticamente en los textos del siglo XII, que se trata de un diálogo entre los enamorados y no de una intervención individual en la que el interlocutor no tomaría la palabra:

\author{
A ton nevo parlai ersoir: \\ mot se conplaint com angoisos \\ Tristan, 432 - 433 \\ (...) Venez parler a moi \\ a cele fenestre anquenuit, \\ Charrete, 4508 - 4509
}


Adquiere, además, en ocasiones un valor eufemístico o si se prefiere metonímico, al evocar, más allá del simple intercambio discursivo, el contacto físico entre los amantes y quizás, sobre todo en las intervenciones de los que se oponen a los amores de los jóvenes, la unión sexual plena, uso que aún hoy se conserva para el verbo parler: ${ }^{469}$

$$
\begin{aligned}
& \text { que jamais tant que cist soit mestre } \\
& \text { de la chambre, n'en liu n'en l'estre } \\
& \text { qu'il puist a li parler sans gent, } \\
& \text { n'avrés chevalier ne sergant, }
\end{aligned}
$$

Escoufle, 2783 - 2786

y que, como observamos en el ejemplo precedente, se extiende desde Tristan al roman de Jean Renart, en especial gracias al sustantivo parlemant:

$$
\begin{aligned}
& \text { se Tristran l'aime folement, } \\
& \text { a lui vendra a parlement }
\end{aligned}
$$

Tristan, $661-662$

«Iseut, ma dame, grant merci

nos a Dex fait, qui ne menti,

qant il vos a fait desevrer

du parlement sanz plus outrer,

que li rois n'a chose veüe

qui ne puise estr'en bien tenue.

Tristan, $371-376$

qu'il convient afiner par tens

cest regart et cest parlement

Escoufle, 3460 - 3461

${ }^{469}$ Cf. P. Guiraud, op. at., p. 478. 
Este sustantivo se asocia sin ambages a términos que denominan el placer como joie y delis, ya sea para hablar de los encuentros entre amantes adúlteros o entre jóvenes prometidos en matrimonio:

\author{
quant la joie et li parlemens \\ ot assés duré par raison
}

Escoufle, 5884 - 5885

\author{
ainc puis ne furent a celee \\ lor parlemens ne lor delis \\ entre Guilliaume et Aelis
}

Escoufle, 2372 - 2374

En los romans del siglo XII este sustantivo también designa el diálogo cuando funciona como complemento de objeto directo o como complemento preposicional con valor circunstancial: “de vilenie ne d'enui ne tienent parlemant ne plet” (Charrete, 4590 - 4591). Es el único placer al que pueden acceder los amantes en presencia de la corte, aunque cuando las confidencias son demasiado habituales o cuando los testigos desaparecen: "au parlemant molt volentiers s'an alast, s'il fust anuitié" (Charrete, 4540 - 4541) y se hallan en la intimidad, sus encuentros se tornan altamente sospechosos y son una señal inequívoca de que existe una complicidad amorosa entre ellos. Sus palabras pasan así a ser un preludio de contactos más estrechos, lo que en Tristan da pie para la introducción de los felones en el relato. Obsérvese en el fragmento que reproducimos a continuación, el adverbio sovent, la construcción prepositiva par tot y el adjetivo indefinido maint, así como la coordinación en construcción distributiva de los sintagmas con un sentido modal a celé y voiant gent:

sovent vienent a parlement,

et a celé et voiant gent. 
Par tot ne püent aise atendre,

maint parlement lor estuet prendre

Tristan, $577-580$

La estrecha relación que se establece en los textos del siglo XII y en Rose entre el infinitivo parler y el sustantivo parole con verbos de audición, fundamentalmente oïr pero también escouter, es otra manifestación de las relaciones amorosas. También lo es de la influencia que terceras personas — formen éstas parte o no del triángulo amoroso surgido del adulteriopueden ejercer sobre las realizaciones discursivas de los enamorados. En Tristan se halla ligada con el conocimiento y con la ocultación de los verdaderos sentimientos que unen a los amantes; en esta obra parler funciona como núcleo de una proposición subordinada completiva de infinitivo: "quant out oï parler sa drue, sout que s'estoit aperceüe" (Tristan, 97 - 98) y el sustantivo como complemento de objeto directo: "li rois sout bien qu'el ot voir dit, les paroles totes oit”" (Tristan, 459 - 460). Chrétien, por su parte, la une a la obediencia ciega de Lanzarote que lo deja paralizado ante Meleagant: "la parole oï Lanceloz: (...) puis Lanceloz, por nule rien, nel tochast, ne ne se meüst, se il ocirre le deüst” (Charrete, 3805 - 3812), así como con el desprecio mostrado por Ginebra hacia el dubitativo caballero de la carreta negándose a escucharlo y a hablarle: 'mes ne li plest qu'ele me voie, ne qu'ele ma parole escolt" (Charrete, 3994 - 3995), un tema que se amplifica obsesivamente mediante verbos que expresan rechazo y negación como estrangier, veer o escondre: "ne vOZ paroles estrangier" (Charrete, 3988), "qu'ele sa parole, oiant toz, vos a vehee et escondite?" (Charrete, 4068 - 4069), "quant mon esgart et ma parole li veai”" (Charrete, 4201 - 4201). En estas ocurrencias es destacable el hecho de que el sustantivo parole vaya precedido de un artículo posesivo que individualiza la palabra e identifica de forma exclusiva el locutor con el amante. En Rose se asocia con uno de los grandes placeres de los enamorados no correspondidos o de los que se hallan lejos de sus amantes — se crea a partir de esta idea la denominación douz parler-, con la 
particularidad de que no se trata de una interacción entre los amantes, ni siquiera de un recuerdo de la palabra del otro, ${ }^{470}$ sino que se precisa la intervención de una tercera persona que ayuda a mantener el contacto, de un intermediario o de un confidente, personificado en Ami: "tu iras a li par confort et parleroiz endui ensemble de la bele qui ton cuer emble" (Rose, 2678 - 2680), que a la vez es signo de los obstáculos cada vez mayores a los que se enfrentan los amantes de la novela, probablemente en este caso como recuerdo de dos de las tradiciones de la lírica trovadoresca, por un lado el llamado amor de lonh, por otro la celebración y el tributo amorosos mediante la canción:

$$
\begin{aligned}
& \text { li autres biens est } \underline{\text { Douz }} \text { Palers, } \\
& \text { qui a fet a mainz bachelers } \\
& \text { et a maintes dame secors, } \\
& \text { car chascuns qui de ses amors } \\
& \text { ot paler toz s'en esbaudist } \\
& \text { Rose, } 2657 \text { - } 2661
\end{aligned}
$$

car au mains avras esperance, s'avras Douz Pensers sanz doutance, et Douz Parler et Douz Regart

$$
\text { Rose, } 2741 \text { - } 2743
$$

La anteposición de un sustantivo, al que parole y el infinitivo sustantivado quedan unidos por una relación de atribución formalizada mediante la preposición de, o bien de un adjetivo, ambos con un valor axiológico positivo, sirve para expresar la belleza y adecuación circunstancial del discurso: "a cascun comme a son seignour prent congié par beles paroles" (Escoufle, 6084 - 6085), elementos esenciales desde la óptica del relanzamiento narrativo tras un momento de crisis en los textos del siglo XIII. Con ellos los amantes consiguen atraer hacia sí fuerzas coadyuvantes, ya

\footnotetext{
470 Renart incluye excepcionalmente entre los recuerdos y pensamientos obsesivos dedicados a la amada, la rememoración de sus palabras, elemento que queda excluido en el resto del corpus: "la longe nuit degasta toute en penser et en recordant les paroles, le douç samblant” (Escoufle, 3176 - 3178).
} 
estuviesen predispuestas a ello, es el caso de la futura compañera de Aelis a la que se gana con lamentos, halagos, promesas y también con caricias y besos: "par la douçor de sa parole la conquiert" (Escoufle, 5290 - 5291), ya fuese uno de los engranajes de la compleja maquinaria psico-social de larga tradición, puesta a punto por Lorris para oponerla a la fuerza de la pasión y del instinto: "il se set bien amoloier par biau parler et souploier" (Rose, 3119 $3120)$.

De las rimas que presentamos a continuación destacaremos junto al gran número de ocurrencias que se hallan al final del verso, lo que, como para dire y dit, puede responder a dos motivos: la importancia otorgada a las muestras verbales de la relación erótica y la facilidad de emparejamiento formal, el nexo que se establece con la locura o más bien con la actuación poco congruente o inadecuada, representada por el adverbio folement, el adjetivo fole y el sustantivo foles en todo el corpus —asociación que no es exclusiva de la rima- Esta conformidad encierra, empero, dos posturas bien distintas. Por un lado se hallan Tristan y E scoufle: en ellos las mujeres actúan cuerdamente, es decir, en función de sus intereses, postura que aprueban tanto el narrador como los que las rodean, mientras que Tristán se comportará de forma incongruente, lo que pone en peligro la situación privilegiada en la que él mismo y la reina se encuentran para proseguir impunemente sus relaciones. Por el contrario, Chrétien y Lorris cuestionan mediante estos términos las actitudes de las féminas: en el examen de conciencia de la propia Ginebra, que ha truncado peligrosamente los lazos que la unían con su amante al negarle los únicos bienes a los que aquel aspiraba, la mirada y la palabra, también en el discurso denigrante para el sexo femenino de Male Bouche, en el que uno de los numerosos defectos de la mujer es el exceso verbal.

\begin{tabular}{lllllllll}
\hline FORMA & CA & BD & NV & RIMA & CA2 & NV2 & D & PERS \\
\hline paler & I & Rose & 3102 & aler & I & 3101 & I & Amant \\
palers & I & Rose & 2657 & bachelers & S & 2658 & D & Amour \\
parlemant & S & Charrete & 4531 & lieemant & D & 4532 & N & Narrador \\
parlemens & S & Escoufle & 5884 & mautalens & S & 5883 & N & Narrador \\
parlement & S & Escoufle & 3461 & comment & D & 3462 & D & Guillaume
\end{tabular}




\begin{tabular}{lllllllll} 
parlement & S & Escoufle & 7535 & comment & D & 7536 & D & Guillaume \\
parlement & S & Escoufle & 5831 & envoisiement & D & 5832 & N & Narrador \\
parlement & S & Tristan & 662 & folement & D & 661 & D & Nain \\
parlement & S & Tristan & 577 & gent & S & 578 & N & Narrador \\
parlement & S & Tristan & 471 & hautement & D & 472 & I & Roi Marc \\
parlement & S & Tristan & 2784 & longuement & D & 2783 & D & Tristan \\
parler & I & Tristan & 657 & aler & I & 658 & D & Nain \\
parler & I & Tristan & 446 & aquiter & I & 445 & D & Iseut \\
parler & I & Tristan & 4330 & cler & A & 4329 & D & Félons \\
parler & I & Tristan & 105 & crïer & I & 106 & D & Tristan \\
parler & I & Tristan & 1933 & per & S & 1934 & D & Roi Marc \\
parler & I & Tristan & 176 & veer & I & 175 & D & Iseut \\
parleroie & V & Charrete & 4504 & voldroie & V & 4503 & D & Lancelot \\
parleroit & V & Tristan & 697 & pooit & V & 698 & I & Tristan \\
parlez & V & Tristan & 164 & avez & H & 163 & D & Iseut \\
parole & S & Escoufle & 5290 & acole & V & 5289 & N & Narrador \\
parole & S & Charrete & 1334 & aparole & V & 1333 & N & Narrador \\
parole & V & Rose & 2666 & escole & S & 2665 & D & Dame \\
parole & S & Tristan & 178 & fole & A & 177 & D & Iseut \\
parole & S & Charrete & 4201 & fole & A & 4202 & D & Guenièvre \\
parole & V & Rose & 3573 & fole & A & 3574 & D & Honte \\
parole & V & Rose & 3890 & fole & A & 3889 & D & M. Bouche \\
parole & S & Escoufle & 8515 & vole & V & 8516 & N & Narrador \\
paroles & S & Escoufle & 6085 & foles & S & 6086 & N & Narrador \\
\hline
\end{tabular}

Tabla 78. Rimas del verbo parler y de los sustantivos «parlemant» y parole.

La discriminación de los diferentes tipos de proposiciones subordinadas en los que hallamos los tres términos que nos ocupan, nos muestra en primer lugar un claro predominio de las subordinadas completivas, así como una gran homogeneidad en lo que se refiere a las subordinadas circunstanciales, entre las que sobresalen las de contenido temporal. Tan sólo se da un caso de subordinada hipotética y otro de subordinada consecutiva. Ambas están en Charrete, donde se pone de manifiesto la extrañeza del rey Bademagu y del condestable Keu ante el comportamiento poco sociable de la reina Ginebra, presentando el primero la costumbre como condición de una actuación más adecuada, máxime ante las muestras de fidelidad y el sacrificio de Lanzarote, y el segundo la reacción desmedida de la reina.

qu'ele a vers vos $\underline{\text { i grant corroz }}$

qu'ele sa parole, oiant toz,

vos a vehee et escondite?

Charrete, 4067 - 4069 


$$
\begin{aligned}
& \text { s'ele onques a vos parler sialt, } \\
& \text { n'an deüst or feire dangier }
\end{aligned}
$$

Charrete, 3986 - 3987

- Temporales: No se hallan en Rose, y en el resto del corpus están introducidas mayoritariamente por la conjunción quant que expresa la contemporaneidad de las proposiciones principal y subordinada, aunque en ocasiones la primera no aparezca y deba sobreentenderse como una introducción del estilo directo: “quant la joie et li parlemens ot assés duré par raison" (Escoufle, 5884 - 5885),

$$
\begin{aligned}
& \text { Iseut, ma dame, grant merci } \\
& \text { nos a Dex fait, qui ne menti, } \\
& \text { qant il vos a fait desevrer }
\end{aligned}
$$$$
\text { du parlement sanz plus outrer }
$$

Tristan, $371-374$

quant mon esgart et ma parole

li veai, ne fis je que fole?

Charrete, 4201 - 4202

- Proposiciones subordinadas de relativo:

Son poco abundantes y se reparten entre las que poseen antecedentes indeterminados: "qui de mon ami me parole" (Rose, 2666), "la ou son aise atent de parler o sa chiere drue" (Tristan, 4282 - 4283) y las que tienen como antecedente un sustantivo como sire o garçons: "par foi, sire, grant tort avez, qui de tel chose a moi parlez" (Tristan, 163 - 164), “as garçons, qui por lui honir de parole le vont chuant” (Rose, 3614 - 3615). En estas últimas se presenta a los varones como elementos perturbadores del buen orden social y moral, si bien en el discurso directo de Iseo impera la 
disimulación y por lo tanto el doble sentido, la pura apariencia. Algo similar ocurre en el de Jalousie, quien con su celo represivo va excesivamente lejos en el menosprecio de los jóvenes, cuyos incipientes deseos sexuales sólo pueden responder al instinto no mitigado.

- Proposiciones subordinadas completivas:

- Infinitivas: Fundamentalmente dependientes de los verbos de audición: "car chascuns qui de ses amors ot paler toz s'en esbaudist" (Rose, 2660 - 2661), “il n'est nule qui ne se rie c'ele ot parler de lecherie” (Rose, 3885 - 3886), "s'il or m'en ot parler, bien me porroit tenir por fole" (Tristan, 176 177), también las hay tras otros verbos de percepción como veoir. "quant il me vit a li paler"' (Rose, 3102).

- Introducidas por la conjunción que dependen de verbos de conocimiento, de dicción o bien de locuciones verbales, que pueden expresar la injusticia o el comportamiento asocial de las mujeres en Charrete: " $n$ 'est mie droiz que cele teingne vers lui sa parole si chiere" (Charrete, 1554 - 1555), "sai que voudra a lui parler, por ceu que devra la aler" (Tristan, 657 - 658)

$$
\begin{aligned}
& \text { en son cuer dist qu'il parlemit } \\
& \text { a la roïne, s'il pooit, }
\end{aligned}
$$$$
\text { Tristan, } 697-698
$$

- Unidas a la principal, cuyo núcleo es un verbo de conocimiento, sin nexo conjuntivo:

$$
\begin{aligned}
& \text { et sachiés bien, malgré sa mere, } \\
& \text { avons nos puis parlé ensamble }
\end{aligned}
$$

Escoufle, 3720 - 3721

- Introducidas por el adverbio de modo comme supeditadas a un verbo de dicción: 
Or dit li rois a la roïne

conme le felon nain Frocine

out anoncié le parlement

Tristan, $469-471$

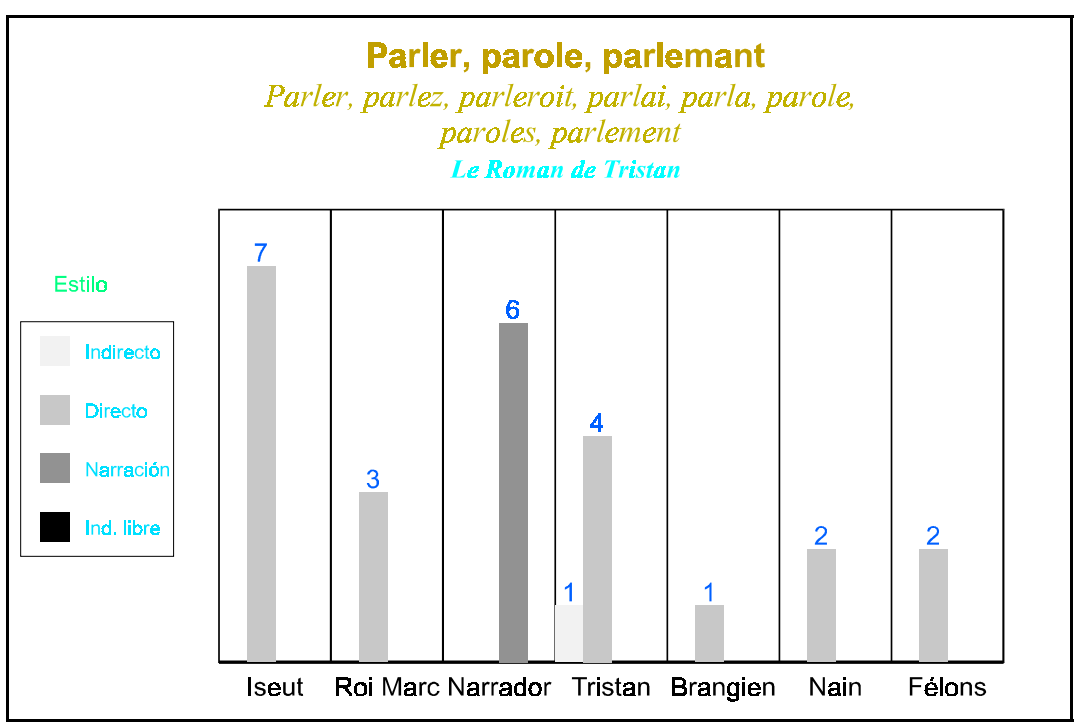

Fig. 114. Comportamiento estilístico del verbo parler y de los sustantivos parole y «parlemant» en Tristan.

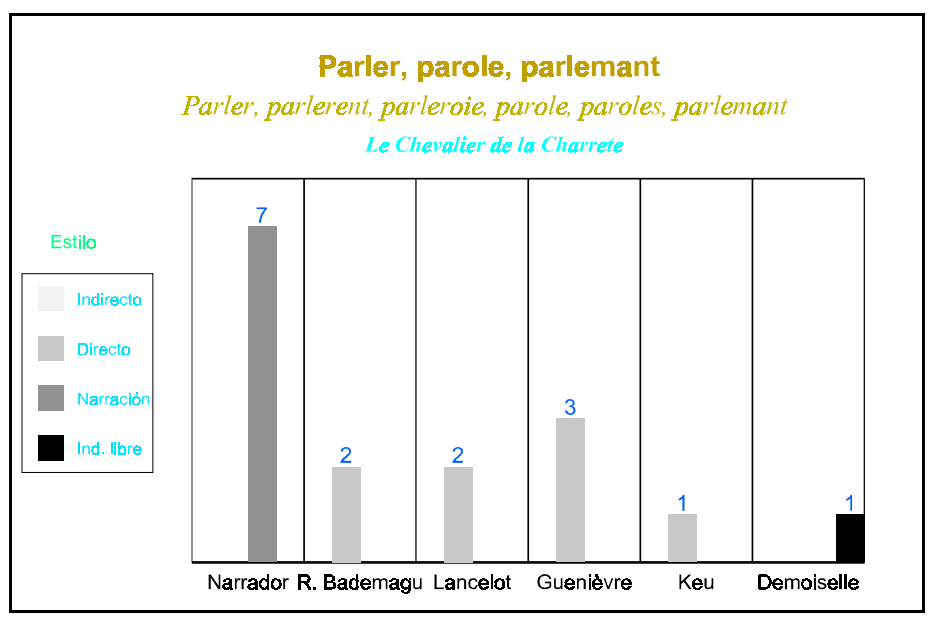

Fig. 115. Comportamiento estilístico del verbo parler y de los sustantivos parole y «parlemant» en Charrete. 


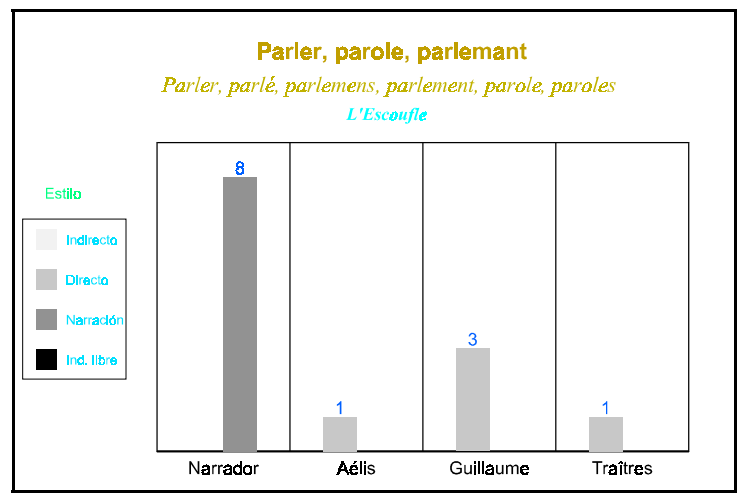

Fig. 116. Comportamiento estilístico del verbo parler y de los sustantivos parole y «parlemant» en Escoufle.

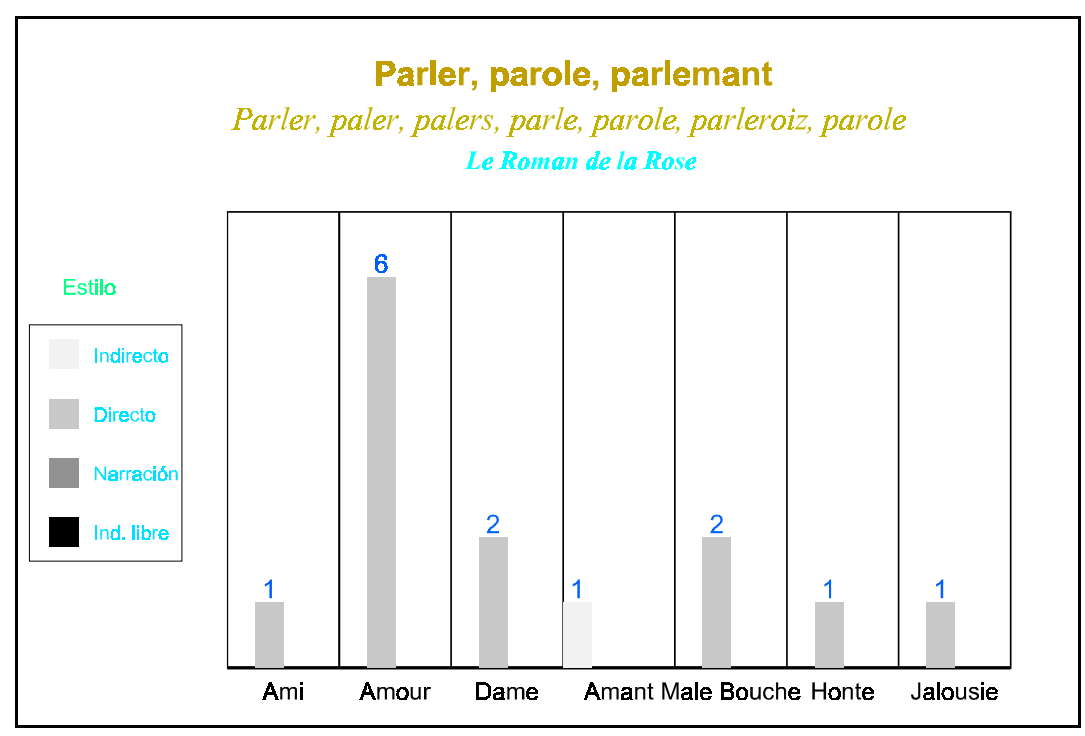

Fig. 117. Comportamiento estilístico del verbo parler y de los sustantivos parole y «parlemant» en Rose.

El comportamiento estilístico de parler, parole y parlemant confirma en gran medida las observaciones que habíamos hecho para los términos dire y dit, tales como el control del discurso por parte de la reina Iseo así como un papel creciente del narrador con la salvedad de Rose donde desaparece. Sin embargo, también aporta nuevas informaciones como la preferencia de estos términos sobre dire y dit en el discurso de Ginebra, a la inversa de lo que ocurre en el de Aelis, quien no olvidemos se hacía eco de los discursos de Guillermo. Este uso en Charrete podría resultar extraño, habida 
cuenta de que los términos que nos ocupan expresan la interacción, extrañeza que se disipa si tenemos en cuenta su concentración en los fragmentos de mayor intensidad amorosa, en los que se plantean y resuelven los conflictos entre los enamorados y en especial las contradicciones entre código y sentimientos en el fuero interno de la reina. Prevalece no obstante en todo el corpus la concepción de la palabra como integrante de la relación erótica: manifestación del deseo de Tristán y de Lanzarote mediante el uso del condicional; comienzo de las relaciones que podrán llevar al matrimonio entre las doncellas de la corte artúrica y los caballeros participantes en el torneo de Noauz: "De cels qui le feront noauz ne tandront parole de rien" (Charrete, 5370 - 5371); intervenciones de los personajes alegóricos contrarios a la unión amorosa en Rose para denigrar la palabra amorosa por estar relacionada con el engaño y la lujuria.

\subsection{Saluery salut.}

A la vez signo de un comportamiento conforme a las normas del trato social y de la existencia de una atracción erótica: "s'il avient chose que tu troves la bele ou point que tu la doives araisoner ne saluer" (Rose, 2379 2381), la especialización en cada uno de estos sentidos se transmite gracias al contexto inmediato en el que se hallan saluer y salu.

En Tristan permanece aparentemente en el ámbito de las normas de cortesía: "Iseut, la bele o les crins sors, contre lui lieve, sil salue" (Tristan, 4426 - 4427), mas la acción de la reina de levantarse y dirigirse hacia Tristán explicita una deferencia que sólo tiene su equivalente en el trato con el esposo, lo que pone de manifiesto la verdadera naturaleza del acto. En el otro extremo la ocurrencia del verbo saluer inserta en el marco del encuentro espiado, apela al patetismo fingido para acentuar el efecto de la farsa de la que el rey es espectador privilegiado y en la que se mantienen estrictamente dentro de las normas sociales imperantes: 
Atant s'en est Iseut tornee,

Tristran l'a plorant salüee

Tristan, $233-234$

Chrétien establece claramente las diferencias existentes entre uno y otro tipo de saludo, ya sea en la entrevista de la ventana, mediante un epíteto altamente expresivo desde el punto de vista erótico, al que se añade una construcción redundante en la que el sustantivo salu funciona como complemento preposicional con sentido instrumental del verbo saluer. "d'un dolz salu l'a saluee et ele un autre tost li rant" (Charrete, 4586 - 4587); ya sea gracias a la expresión de cuer que hemos relacionado claramente con el sentimiento amoroso: "tot maintenant que il l'aproche, de cuer la salue et de boche" (Charrete, 1549 - 1550). Frente a los afectuosos saludos de los enamorados, los de la doncella que acoge a Lanzarote y que posteriormente él custodia en el bosque responden al trato afable y correcto que una doncella instruida en las costumbres cortesanas debe mostrar. En el saludo a Lanzarote se ponen de manifiesto estas virtudes, coronadas por la moderación y la discreción: "la dameisele le salue come sage et bien afeitiee" (Charrete, 936 937), hecho que obliga a Lanzarote a tratarla en el mismo tono y con la misma deferencia, una actitud que cambiará ante las proposiciones sexuales de la doncella. Y aunque el saludo al pretendiente rechazado está motivado por el mismo acatamiento a las reglas, nos es presentado casi como una obligación con la que la mujer trata de evitar un contacto posterior, pese a que el enamorado lo toma como un avance en sus pretensiones:

molt a au chevalier valu, quant la pucele le salue, qui sa boche pas n'en palue ne ne li a neant costé.

Charrete, 1558 - 1561 
En Rose el saludo también alimenta la esperanza del enamorado y por ello no puede tratarse de un mero formulismo, fruto de una educada indiferencia, sino que debe dejar vislumbrar la acogida favorable del suspirante, por lo que son descritos mediante un epíteto como en Charrete. "se tu n'em peüses treire fors seulement un bel salu' (Rose, 2362 - 2363) o mediante un adverbio intensificado:

Bel Acueil au comencement me salua mout doucement et me mostra plus bel samblant que onques n'avoit fet devant

$$
\text { Rose, } 3327 \text { - } 3330
$$

\begin{tabular}{lllllllll}
\hline FORMA & CA & BD & NV & RIMA & CA2 & NV2 & D & PERS \\
\hline salu & S & Rose & 2363 & valu & O & 2364 & D & Amour \\
salue & V & Tristan & 4427 & nue & S & 4428 & N & Narrador \\
salue & V & Charrete & 1559 & palue & V & 1560 & N & Narrador \\
salue & V & Charrete & 936 & vestue & O & 935 & N & Narrador \\
saluee & O & Charrete & 4586 & ferree & O & 4585 & N & Narrador \\
saluiee & O & Tristan & 234 & tornee & O & 233 & N & Narrador \\
saluer & I & Rose & 2381 & muer & I & 2382 & D & Amour \\
\hline
\end{tabular}

Tabla 79. Rimas del verbo saluer y del sustantivo salut.

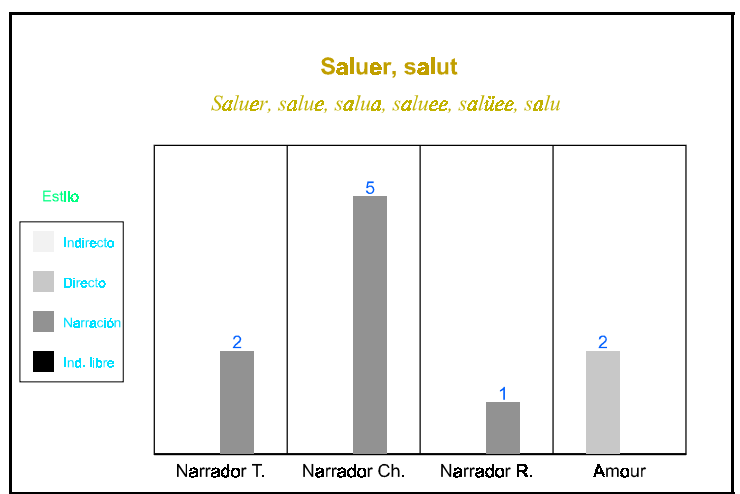

Fig. 118. Comportamiento estilístico del verbo saluer y del sustantivo salut en el corpus.

Fuertemente motivados por imperativos formales, como nos muestran las constantes apariciones en la rima, saluer y salu son 
fundamentalmente utilizados por los narradores de los romans del siglo XII para acentuar las características del trato entre hombres y mujeres. En Rose las ocurrencias que se hallan en el discurso directo del dios Amor vuelven a mostrar las dificultades del enamorado para entablar contacto con el objeto de sus deseos y comenzar así el camino hacia la conquista amorosa.

\subsection{LOS OJOS, LA MIRADA Y LAS SENSACIONES VISUALES.}

\subsection{1 «E sgarden», «esgart», «garden», «garde», regardery regard.}

Estos tres pares de formas pueden ser considerados sinónimos perfectos en la mayor parte de las ocurrencias, y con toda probabilidad el uso de un término u otro depende de la preferencia idiolectal a la que puede sumarse un uso regional o incluso una adaptación a las modas léxicas en un determinado momento. Bien es cierto que el verbo garder puede funcionar como una variante formal e incluso estilística, y en ocasiones resulta muy difícil determinar si los semas predominantes en un contexto definido son relativos a la visión o al hecho de guardar, de vigilar a una persona, algo relativamente habitual en algunos fragmentos de Escoufle como el que reproducimos a continuación:

$$
\begin{aligned}
& \text { mais la biautés et li visages } \\
& \text { de celi qu'il garde en dormant } \\
& \text { li vait si tot son sens emblant } \\
& \text { k'il en oublie l'aumosniere } \\
& \text { Escoufle, } 4530 \text { - } 4533
\end{aligned}
$$

Las múltiples situaciones eróticas en las que la vista puede intervenir son recogidas prácticamente en su totalidad en las abundantes ocurrencias de estos términos en el corpus, con la salvedad de Tristan. Las miradas de los 
enamorados para evidenciarse recíprocamente su amor; la contemplación atenta e incluso ensimismada de uno de ellos, generalmente el varón, del objeto de deseo; la visión individual o colectiva por parte de espectadores anónimos o declarados de la belleza, proezas y virtudes de uno de los miembros de la pareja o de ambos, y el espectáculo obsceno ofrecido en representación teatral a las miradas de la corte centradas en la reina Iseo y posteriormente en la pareja cuando atravesaba el Mal Paso: "tuit les gardent, et roi et conte" (Tristan, 3934); ${ }^{471}$ el placer de contemplarse uno mismo, rechazado al quebrantar los fundamentos de la relación erótica cortés: "que dedenz n'ousai esgarder, ainz comançai a coarder, que de Narcisus me sovint” (Rose, 1513 - 1515), o el de recibir una simple mirada de la amada: “mieuz vaut de li un regarz que d'autre li deduit entiers" (Rose, 2472 - 2473), lo que dará origen a Douz Regart, uno de los preciados dones que mantienen y aumentan el amor de los enamorados y que exige la permanencia junto a la amada o cuando menos separaciones poco prolongadas:

mes je te lo que tu te tiegnes

bien pres de li por Douz Regart,

que ses solaz trop ne te tart

Rose, 2704 - 2706

Se trate de voyeurisme involuntario, como el de Lanzarote impelido a presenciar la violación de una doncella sin que, dada su condición de perfecto amador, su libido se vea afectada, o de voyeurisme voluntario, como el del adolescente que contempla a Deduit y sus compañeros, ya esté codificado por

\footnotetext{
$471 \quad$ bien savoit que cil l'esgardoient

qui outre le Mal Pas estoient

Tristan, $3883-3884$

la roïne out mot grant esgart

de ceus qui sont de l'autre part

Tristan, 3899 - 3900
} 
unas supuestas normas de comportamiento cortesano: "ki es chambres s'amie garde les puceles qui font karoles!” (Escoufle, 2828 - 2829), ya sea furtivo, alevoso o censurador, o bien se trate de la dulce contemplación amorosa, no podemos desatender, aunque sea someramente, la implicación de los receptores de la obra. En su calidad de espectadores de una más o menos escueta representación del relato, sobre la que únicamente podemos aventurar conjeturas y que podía depender de la situación y cualidades escénicas del recitador, del marco, la ocasión o de la naturaleza del público al que se dirigía, eran blanco del enorme poder evocador de la voz, de las palabras y tal vez de los gestos. ${ }^{472} \mathrm{El}$ acto de transmisión textual pretendía exponerlos a la rememoración, debemos suponer placentera, de situaciones semejantes y aun más subidas de tono que hubiesen presenciado o vivido.

El prefijo entre- que refuerza la forma pronominal del verbo garder, o de otros tan expresivos como larder de los que el sustantivo regard es sujeto en E scoufle: "lor regart ont entrelardé parmi les fenestres des eus l'un cuer de l'autre" (Escoufle, 7820 - 7822), o bien la fórmula recíproca l'un l'autre en función sujeto: "l'un l'autre esgarde bonement" (Tristan, 2914), evocan cómo se miran mutuamente los enamorados en su afán por darse muestras de su pasión y son signo de complicidad ante la presencia de testigos indeseados que restringen las efusiones:

\author{
il s'entredechacent et boutent, \\ puis s'entregardent, que il doutent \\ l'apercevance de lor peres
}

Escoufle, 2097 - 2099

il s'entresgardent, si se tienent

de parler k'aucuns nes espit

Escoufle, 3980 - 3981

\footnotetext{
472 P. Zumthor indica, además, la importancia del contacto físico no sólo entre el recitador y su público sino entre los propios receptores. Cf. The Text and the Voice, N L H, vol. XVI, n 1, p. 75.
} 
Las miradas, puestas exclusivamente en el otro: "de l'esgarder onques ne fine, molt antentis" (Charrete, 562 - 563), la forma de los ojos, sin que puedan desdeñarse otros signos presentes en el rostro de los enamorados, revelan inequívocamente la pasión, contradiciendo a menudo sus actitudes y su discurso: "mais qui son vis et sa color et si esgardast ses biax ex, c'est la riens par k’il seüst miex li quex des nons li fust plus dols” (Escoufle, 1992 1995). Renart se muestra particularmente atento hacia estos detalles, especialmente en lo tocante a su heroína — mientras que Chrétien se inclina por Lanzarote-

que fine amors li areonde tous les iex quant ele m'esgarde.

Je m'en pris bien au partir garde

k'el les avoit tos en moi mis

Escoufle, 3164 - 3167

pero ya en Tristan hemos observado una prueba de ello gracias al adjetivo bonement que precede una alusión al enrojecimiento del rostro de la reina, avergonzada por la presencia de la corte tras tres años de ausencia, ella que había hecho gala de tanto desparpajo, y aún habría de hacerla en el futuro: "La roïne fu coloree, vergoigne avoit por l'asenblee" (Tristan, 2915 - 2916).

Y si la palabra quedaba vedada para ocultar los sentimientos amorosos o bien como signo de la angustia ante la separación: "cil l'esgarde, si ne dist mot, ains fremist et souspire et gient" (Escoufle, 3386 - 3387) para dejar hablar al cuerpo y a los ojos, estos últimos quedan como únicos protagonistas cuando un grupo de hombres se halla ante la suprema belleza de una doncella que supera a todas las demás. Se diría que este don tan valorado en el siglo XIII impone la contención, el refinamiento cortés en su más alto grado impidiendo otra manifestación del embelesamiento o del deseo que no sea la contemplación silenciosa, máximo tributo a la mujer, sin posibilidad de que sea engañoso. Progresivamente, y conforme Aelis recupera su posición 
privilegiada en la sociedad, la admiración ante sus cualidades físicas se extiende a la generalidad de las mujeres. Ya antes las damas nobles como la señora de Montpellier y la condesa de Saint Gilles la habían agasajado por este motivo, con lo que se equiparaban y aun superaban a los hombres de su rango. Ello no es óbice para que en el discurso del narrador se insista en el impacto que su belleza produce en los varones, de lo que podemos deducir su enorme atractivo sexual — fenómeno que se había pasado totalmente por alto en el caso de Iseo-, máxime cuando el verbo se halla en pasiva: "ml't est esgardee et prisie de ciaus de la cort Aelis" (Escoufle, 5646 - 5647), "Cel jor fu la bele Aelis ml't esgardee de maint home” (Escoufle, 8814 - 8815)

\footnotetext{
N'i a chevalier qui mot sont, ains l'esgardent a grant merveille
}

Escoufle, 5742 - 5743

cuidiés vous c'aucuns ne s'abuist

en esgardant bele Aelis?

Escoufle, 8212 - 8213

Guillermo, como varón, permanece ajeno a estos cambios ligados en el texto a la intervención de la Fortuna, y allí donde va recibe reiteradas muestras de admiración, compartida por hombres y mujeres, no sólo por sus habilidades, sino por su porte distinguido y su bello cuerpo, y ello aun cuando trabaja como un simple criado al servicio de un burgués:

«Cestui qui si est biaus et drois, font il, u trovastes vous, mestre?

Diex! Com il tient bien le pié destre

en l'estrier, et com il est gens!»

Plus l'esgardent tot seul les gens

que tous ciaus avoec qui il va

Escoufle, 6728 - 6733 
De igual modo, Lanzarote es el centro de todas las miradas, masculinas y femeninas, que preceden a la exclusiva elección de todas las doncellas. Pero en su caso prevalece el virtuosismo en el combate, como señalan el verbo feire, modificado por el adverbio bien en construcción intensiva, así como el sustantivo proesces en la alusión a la atención que le presta su compañero Galván, o los verbos vaincre y passer en construcción superlativa. Quedan muy difuminados sus atributos físicos y sobre todo sus facciones, en gran medida ocultos por el atuendo guerrero, pero también por el prisma ideológico - estético que determinaba el especial modo de ver en la literatura del siglo XII:

sel comance si bien a feire

que nus ne puet ses ialz retreire

de lui esgarder, ou qu'il soit

Charrete, 5623 - 5625

qu'a esgarder tant li pleisoit

les proesces que cil feisoit

Charrete, 5955 - 5956

que il a vaincuz et passez

trestoz les chevaliers del monde,

qu'il n'i a un qu'a lui s'aponde.»

Et les dameiseles disoient,

qui a mervoilles l'esgardoient,

que cil les tolt a marïer;

Charrete, 5990 - 5995

A excepción de Aelis en el momento de la separación o del reencuentro, ${ }^{473}$ y de Ginebra al observar las proezas de Lanzarote en lid con

\footnotetext{
473 Véase para el primero, además de los fragmentos citados el verso 3474 de E scoufle, y para el segundo momento Escoufle, 7427 - 7429.
} 
Meleagant o como anónimo y obediente caballero en el torneo de Noauz - en privado le niega el consuelo y el aliento de su mirada-, son los hombres los que contemplan con mayor asiduidad y fijeza a las mujeres amadas. Es el desarrollo lógico de la tesis de que toda realidad, y particularmente la corporeidad del sexo femenino, debe entrar por los ojos: ${ }^{474}$ "bien soela ses eus et peut Guilliaumes d'esgarder s'amie" (Escoufle, 7866 7867); "hui matin l'alai regarder an son lit" (Charrete, 4810 - 4811), “et totevoies s'arestoit, devant la reïne sa dame (...), por qu'il la va si regardant" (Charrete, 3748 - 3751). Una circunstancia para la que se prefieren el infinitivo o el participio presente con un valor temporal de continuidad, o bien el participio precedido de la preposición en que expresa el modo como en Rose. “et tot adés en regardant aviveras le feu ardant" (Rose, 2331 - 2332). Estas formas se asocian generalmente a otro valor de orden aspectual al situar una acción en curso con respecto a otra marcada temporalmente, circunstancias que se hallan fuertemente ligadas al deseo erótico, como prueban los términos con los que se emparejan en la rima pertenecientes al dominio del fuego. Y aun contemplan los varones alguno de los objetos que aquéllas utilizan en la vida cotidiana o una parte mínima de su cuerpo, dando paso a una veneración fetichista como la de Lanzarote, inexplicablemente atraído por un peine abandonado y los cabellos que en él han quedado prendidos. Chrétien acerca a los amantes mediante un proceso metonímico por el que el objeto poseído se toma por el poseedor y la parte es indicio de la totalidad ausente: "quant il le tint, molt longuemant l'esgarde, et les chevox remire" (Charrete, 1392 1393). Guillermo pasará su primera noche de exilio fuera de la cámara de Aelis mirando atentamente el edificio y la ventana de la habitación donde se encuentra la amada. Encontramos la misma pauta de transposición metonímica, pero aquí el continente está por el contenido: "s'est alés a une fenestre por regarder la sale et l'estre et la cambre ou s'amie maint"' (Escoufle, 3205 - 3207).

${ }^{474}$ Véase J. E. Ruiz Domenec, op. at., p. 55, donde retoma a Le Chapelain. 
En este punto resulta obligado que nos preguntemos cuál es la razón por la que tan sólo los hombres sienten aumentar su deseo y su pasión con la contemplación del cuerpo femenino y no a la inversa, especialmente en el texto de Lorris donde se magnifica el papel del varón, tal como ya hemos observado más arriba: "et saches que dou regarder feras ton cuer frire et larder” (Rose, 2329 - 2330), y ello pese a la generalización de la validez de algunas de sus afirmaciones mediante expresiones impersonales: "qui ce qu'il aime plus regarde plus alume son cuer et larde" (Rose, 2333 - 2334). Este hecho al que nos referimos responde con toda probabilidad a la observación de los fenómenos que diferencian las manifestaciones de la sexualidad de uno y otro género. Ello con la salvedad de que de la mujer, a la que los literatos varones del medievo parecen conocer muy poco salvo en contados casos, tan sólo podemos deducir por defecto cuáles son sus preferencias en lo relativo a la sensualidad. La vista sirve a los dos sexos como inicio de la pasión, de ahí el papel de acólito del personaje alegórico Douz Regarz, encargado de acompañar al dios Amor y de llevar los arcos y las flechas que, penetrando por los ojos y después por el corazón, harán surgir y perdurar el amor. ${ }^{475}$ Aunque en las féminas también interviene la palabra, el contacto cotidiano y el cortejo, amén de las caricias y los besos, todo lo cual se intuye por ejemplo en Rose. La vista es también el medio idóneo para que hombres y mujeres se demuestren su amor en el intercambio de miradas: "car lor regart sont tot commun" (Escoufle, 2003), aunque se da preferencia a la mirada femenina cuando no son recíprocas: "se je ne fuisse ses amis, cil dous regars ne peüst estre. Je vi son cuer a la fenestre de ses iex monter" (Escoufle, 3168 - 3171). Pese a ello las sensaciones visuales no tienen el mismo valor para hombres y mujeres, no

\footnotetext{
$475 \quad$ Delez lui ot un jovencel

qu'il fasoit estre ilec delez,

Douz Regart estoit apelez.

Icil bachelers regardoit

les queroles, et si gardoit

au dieu d'amors .ii. ars turquois

Rose, 904 - 909
} 
sólo en lo que se refiere a la excitación sexual mediante estímulos externos, sino en cuanto al incremento del sentimiento pasional que lleva a su vez a un aumento del deseo físico. Se podría decir que, al menos según los textos, la mujer mantiene intacta su pasión desde que ésta aparece, mientras que la del hombre se refuerza sin duda alguna con la visión del objeto amado.

De hecho, este es probablemente el mecanismo que permite atribuir un sentido sexual, casi podríamos decir obsceno, al verbo regarder en alguna de las ocurrencias del corpus. Este se convierte en la práctica en un sinónimo de «fornican» dentro del discurso directo del amenazante Meleagant, pues la mirada lleva emparejado el despertar del incontenible instinto sexual, de ahí la expresión mal gré suen, en la que se contienen la voluntad, la razón y las estrictas normas sociales que debían coartar la acción de Keu, pero que habrían sido arrinconadas y transgredidas por el apetito carnal:

$$
\begin{aligned}
& \text { mes enuit vos a regardee } \\
& \text { Kex, li seneschax, mal gré suen, } \\
& \text { s'a de vos eü tot son buen }
\end{aligned}
$$$$
\text { Charrete, } 4764 \text { - } 4766
$$

La mirada de la hembra también posee atribuciones obscenas en el discurso misógino de Male Bouche, pero a la inversa de la del macho se trata de un estímulo, de una provocación que pretende exacerbar las reacciones instintivas de aquel. Con ella se degrada a la animalidad a ambos sexos, aunque es más grave la caída de la mujer que se había mantenido, gracias a una igualdad o una superioridad promocionadas por la cortesía, en una posición privilegiada y estaba dotada de una cierta autonomía incluso para llevar la iniciativa en el juego amoroso. Lorris se hace eco de la concepción que la Iglesia tenía sobre los gestos femeninos que son en su mayoría “obscenos, inmorales y, en el mejor de los casos, peligrosos, imprudentes":476

\footnotetext{
476 Según las palabras utilizadas por Ruiz Domenec, op.at., p. 55.
} 


$$
\begin{aligned}
& \text { ceste est pute, ceste se farde, } \\
& \text { et ceste folement regarde, } \\
& \text { ceste est vilaine, ceste est fole } \\
& \text { Rose, } 3887 \text { - } 3889
\end{aligned}
$$

De este modo el autor de Rose, elimina esas prerrogativas y disimulado tras el parapeto de los enemigos del amor, ataca la libertad relativa que el sexo femenino había alcanzado al menos en un plano teórico, y siempre reservada claro está a los estratos nobles de la sociedad, lo que trae consigo la acumulación de adjetivos, sustantivos, verbos y adverbios en los que el valor insultante resulta no sólo del sentido del propio término sino de la simbiosis entre la particularización distributiva y la generalización.

Los únicos fenómenos destacables en lo que concierne a la morfosintaxis de los verbos que nos ocupan son, por un lado, la inexistencia de tiempos del futuro, aunque algunos contextos les confieren un sentido prospectivo. Tal es el caso de los vaticinios de Amor al joven amante de la rosa sobre el incremento del deseo sujeto a la acción de mirar. Por otro lado, el acaparamiento por el discurso narrativo de las formas verbales en presente y en imperfecto de indicativo, las más abundantes en el corpus, ya sea con un valor puntual o reiterativo, aunque en cualquier caso prima la intensidad de la mirada tanto de los amantes como de los espectadores ajenos a la pareja. Los infinitivos, precedidos generalmente de preposición, funcionan como complemento de objeto: "quant giete mes iex et avoi en vos regarder" (Escoufle, 3458 - 3459), “j’entendoie a esgarder la rien el mont qui plus m'amot" (Escoufle, 7628 - 7629), o circunstancial: "li tierz biens vient de regarder" (Escoufle, 2701), "lors s'an retorne a la fenestre por les chevaliers esgarder' (Charrete, 5916 - 5917).

En cuanto al funcionamiento sintáctico de los sustantivos objeto de nuestra atención, el complemento de objeto directo destaca claramente sobre el resto de las funciones. El sustantivo garde con esta función forma una 
locución junto al verbo prendre, que da un valor intensivo al hecho de mirar. Esta construcción coincide con momentos de crisis en los que los enamorados necesitan las fuerzas renovadas por la esperanza de futuros placeres que otorga la mirada de la amada, sea para continuar la lucha y vencer en el duelo que salvará del destierro a la reina y a las gentes de Logres, sea para comenzar el doloroso abandono del gineceo:

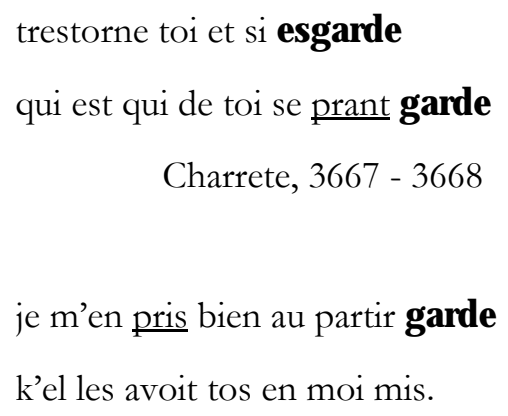

De entre las ocurrencias de los sustantivos esgart y regard merecen ser puestas de relieve las que se encuentran en contextos negativos, ya sea por el sentido del verbo al que complementan, ya sea por la aparición de adverbios y conjunciones de negación. Entre los primeros el verbo veer recoge la interdicción que Ginebra se impone para castigar al enamorado y que ella misma contempla como una transgresión de las normas que deben regir las relaciones amorosas tendentes a la obtención del placer: "quant mon esgart et ma parole li veai, ne fis je que fole?" (Charrete, 4201 - 4202), mientras que afiner intensifica la nueva situación en la que se hallan los enamorados de E scoufle, quienes creían tener toda la vida para permanecer juntos y amarse y deben al contrario poner un rápido fin a su aventurada cita: "qu’il convient afiner par tenscest regart et cest parlement” (Escoufle, 3460 - 3461). La negativa de Lanzarote a continuar con los tentadores juegos de seducción propuestos por la doncella que lo acoge en su castillo, implica necesariamente el rechazo de las sensaciones visuales, la concentración más que probable en la 
idealizada imagen de la dama y la más absoluta inmovilidad, hecho que se plasma gracias al cúmulo de adverbios y conjunciones de negación:

$$
\begin{array}{ll}
\underline{\text { n'onques ne torne son esgart }} & \text { C D D V J S } \\
\text { ne devers li ne d'autre part. } & \text { C R P C R A S }
\end{array}
$$

Charrete, $1221-1222$

Al elevado número de ocurrencias en la rima hay que sumar la repetición de muchas de ellas a lo largo de todo el corpus: en la asociación con la noción de deseo expresada mediante andoir o larder y, dentro del mismo ámbito nocional de la visión, cuando se combinan los tres pares de formas o bien cuando se juega con la polisemia de garder. Este fenómeno apunta hacia una fijación formal y semántica de los tópicos en torno a la visión dentro del

\begin{tabular}{|c|c|c|c|c|c|c|c|c|}
\hline FORMA & $\mathbf{C A}$ & BD & NV & RIMA & CA2 & NV2 & D & PERS \\
\hline esgarde & $\mathrm{V}$ & Charrete & 1181 & garde & $\mathrm{S}$ & 1182 & $\mathrm{~N}$ & Narrador \\
\hline esgarde & V & Charrete & 3667 & garde & S & 3668 & $\mathrm{D}$ & Pucelle \\
\hline esgarde & $\mathrm{V}$ & Escoufle & 3165 & garde & S & 3166 & D & Guillaume \\
\hline esgarde & $\mathrm{V}$ & Escoufle & 7427 & garde & S & 7428 & $\mathrm{~N}$ & Narrador \\
\hline esgarder & I & Rose & 1513 & coarder & I & 1514 & $\mathrm{~N}$ & Narrador \\
\hline esgarder & I & Charrete & 4489 & garder & I & 4490 & D & Guenièvre \\
\hline esgarder & I & Escoufle & 3140 & garder & I & 3139 & $\mathrm{D}$ & Guillaume \\
\hline esgarder & I & Escoufle & 7628 & garder & I & 7627 & D & Guillaume \\
\hline esgarder & I & Charrete & 5917 & tarder & I & 5918 & $\mathrm{~N}$ & Narrador \\
\hline esgardé & $\mathrm{O}$ & Escoufle & 7742 & gardé & $\mathrm{O}$ & 7741 & $\mathrm{~N}$ & Narrador \\
\hline esgardoient & V & Charrete & 5994 & disoient & $\mathrm{V}$ & 5993 & $\mathrm{~N}$ & Narrador \\
\hline esgardoient & $\mathrm{V}$ & Tristan & 3883 & estoient & $\mathrm{E}$ & 3884 & $\mathrm{~N}$ & Narrador \\
\hline esgart & $\mathrm{S}$ & Tristan & 3899 & part & S & 3900 & $\mathrm{~N}$ & Narrador \\
\hline esgart & S & Charrete & 1064 & part & S & 1063 & $\mathrm{~N}$ & Narrador \\
\hline esgart & S & Charrete & 1221 & part & S & 1222 & $\mathrm{~N}$ & Narrador \\
\hline garde & $S$ & Charrete & 3668 & esgarde & V & 3667 & D & Pucelle \\
\hline garde & $\mathrm{S}$ & Escoufle & 3166 & esgarde & V & 3165 & D & Guillaume \\
\hline garde & $\mathrm{V}$ & Escoufle & 4543 & esgarde & V & 4544 & $\mathrm{~N}$ & Narrador \\
\hline garde & V & Escoufle & 2827 & garde & V & 2828 & $\mathrm{~N}$ & Narrador \\
\hline regardant & $\mathrm{T}$ & Charrete & 3751 & ardant & A & 3752 & $\mathrm{~N}$ & Narrador \\
\hline regardant & $\mathrm{T}$ & Rose & 2331 & ardant & $\mathrm{A}$ & 2332 & D & Amour \\
\hline regarde & V & Rose & 3888 & farde & $\mathrm{V}$ & 3887 & D & M.Bouche \\
\hline regarde & V & Rose & 2333 & larde & $\mathrm{V}$ & 2334 & D & Amour \\
\hline regardee & $\mathrm{O}$ & Charrete & 4764 & gardee & $\mathrm{O}$ & 4763 & D & Méléagant \\
\hline regarder & I & Charrete & 4810 & garder & I & 4809 & D & Méléagant \\
\hline regarder & I & Rose & 2329 & larder & I & 2330 & D & Amour \\
\hline regarder & I & Rose & 2701 & tarder & I & 2702 & $\mathrm{D}$ & Amour \\
\hline
\end{tabular}
ámbito amoroso que ha sido heredada de la lírica. 


\begin{tabular}{lllllllll} 
regardoit & V & Rose & 907 & gardoit & V & 908 & N & Narrador \\
regart & S & Rose & 1303 & gart & V & 1304 & N & Narrador \\
regart & S & Rose & 2208 & gart & V & 2207 & D & Amour \\
regart & S & Rose & 2743 & gart & V & 2744 & D & Amour \\
regart & S & Rose & 921 & garz & S & 922 & N & Narrador \\
regart & S & Rose & 2705 & tart & V & 2706 & D & Amour \\
regarz & S & Rose & 2472 & garz & S & 2471 & D & Amant \\
\hline
\end{tabular}

Tabla 80. Rimas de los verbos «esgarder», «garder», regarder y de los sustantivos «esgart», «garde»y regard.

Los verbos de pensamiento como cuidier (Escoufle, 8212 - 8213), con el que el narrador reclama del público que saque sus propias conclusiones sobre la actitud de los que contemplan a la bella Aelis, y penser (Escoufle, 3459 - 3461), que refleja el tormento psicológico del enamorado ante la imposibilidad de continuar mirando a la amada, así como el de conocimiento, savoir (Tristan, 3883), introducen las proposiciones subordinadas completivas. Respecto a este último cada una de las ocurrencias muestra algunos aspectos claves de la personalidad y actitudes atribuidas a los personajes enamorados: a la sagacidad y sentido teatral de Iseo se opone el aturdimiento y embotamiento sensitivo de Lanzarote, mientras que el novicio de la rosa sigue el complejo aprendizaje del amor gracias al discurso doctoral del dios en el que el verbo savoir expresa la absoluta certeza sobre un fenómeno universal al tiempo que la imposición del conocimiento gracias al modo imperativo:

$$
\begin{aligned}
& \text { (... ) se il la savoit } \\
& \text { a la fenestre ou ele estoit, } \\
& \text { qu'ele l'esgandast ne veïst }
\end{aligned}
$$

Charrete, 3643 - 3645

$$
\begin{aligned}
& \text { et saches que dou regarder } \\
& \text { feras ton cuer frire et larder }
\end{aligned}
$$$$
\text { Rose, } 2329 \text { - } 2330
$$

En cuanto a las proposiciones de relativo resulta particularmente interesante el hecho de que los antecedentes sean en su gran mayoría mujeres 
que miran —el relativo es sujeto de la subordinada - o que son miradas — el pronombre funciona como complemento de objeto directo-, lo que las erige, como era de esperar, en el centro del universo sensual masculino. Pero si, a tenor de lo que hemos dicho anteriormente, parece lógico su papel pasivo y son los hombres los que las contemplan, resulta relativamente sorprendente su actividad, a la que otorgamos una función erógena no tanto para ellas como para el varón. Buena prueba de ello es Rose, donde el ser mirado se equipara en el proceso pasional al mirar, de ahí los reproches de Franchise a Bel Accueil: "Trop vos estes de cel amant, Bel Acueil, grant piece esloigniez, qui regarder ne le daigniez" (Rose, 3312 - 3314). Por ello tenemos nuestras reservas, al menos en lo que se refiere a nuestro corpus, con respecto a la opinión que mantiene Ruiz Domenec, quien considera que en general el amor heterosexual tiene su origen en la visión y en algunos romans la sexualidad femenina no es "entrega al roce por tacto u olor, es simplemente un acto emanado de la vista, del poder seductor del cuerpo masculino". ${ }^{477}$ A nuestro parecer el acto femenino de mirar concierne en última instancia a la sexualidad masculina, y si en algún caso la visión de un varón parece despertar el deseo en una mujer, no es por su belleza física sino por su maestría en las actividades caballerescas o cortesanas. En Charrete tanto las doncellas como Ginebra contemplan al héroe, pero mientras la mirada de la segunda tiene por objeto el placer inmediato de Lanzarote, las miradas apasionadas de las mujeres jóvenes, hacia las que el caballero se muestra totalmente indiferente, traspasan el ámbito intratextual y tienen por destinatarios reales a los receptores del roman, muchos de los cuales se sentían o deseaban sentirse identificados con el de la carreta, quien no atrae tanto por su físico como por su comportamiento: ${ }^{478}$

\footnotetext{
477 Ibid., p. 175.

478 En este sentido Zéraffa afirma que el roman caballeresco va dirigido a una audiencia de clérigos y nobles, un público que quiere poseer una literatura "qui les exprime et les justifie à la fois, et traduise ses conduites comme sa sensibilité", y que adopta una función psicosocial, la de la identificación con el héroe, Roman et société, op. at., p. 96 - 97.
} 


\author{
Et la pucele qui l'esgarde \\ dit: «Par mes ialz, vos n'avez garde \\ d'or en avant la ou ge soie.»
}

Charrete, 1181 - 1183

Et les dameiseles disoient,

qui a mervoilles l'esgandoient,

que cil les tolt a marier

Charrete, 5993 - 5995

Las proposiciones subordinadas circunstanciales con sentido temporal introducidas por quant jalonan la historia de Guillermo y Aelis. Delimitan el momento, coincidente con el de la mirada, en el que las huellas del enamoramiento se hacen patentes en la heroína (Escoufle, 3164 - 3165), aquél en el que el ensimismamiento contemplativo le impide a Guillermo percibir el peligro que se cierne sobre su vida en pareja: "quant j'entendoie a esgarder la rien el mont qui plus m’amot”' (Escoufle, 7628 - 7629), aquél en el que el varón es perfectamente consciente de la belleza de la amada y de la pérdida que la separación supone para él (Escoufle, 3458 - 3459), o por el contrario, al final de su búsqueda, el de la extrañeza al reencontrar la belleza de Aelis tras un duro periodo de incertidumbre y bajezas; con la particularidad de que en los dos últimos el verbo esgarder se empareja con penser, y se relaciona de este modo la sensación con la reflexión, aunque más bien deberíamos decir con el aturdimiento crónico del enamorado:

comment est ce que j’ai trouvé

celi u toute a esprouvé

nature quanqu'ele a de sens?

Quant plus l'esgart et plus i pens, tant me vient plus a grant merveille

Escoufle, 7769 - 7773 
El hecho de mirar es utilizado para explicar, mediante su inclusión en proposiciones subordinadas circunstanciales de contenido causal, las reacciones de los amantes: el rechazo frente a las tendencias narcisistas, a los placeres solitarios que alejarían al adolescente del aprendizaje del amor heterosexual: “je me suis trez un poi ensus, que dedenz n'ousai esgarder' (Rose, 1512 - 1513); la inusual distracción de Lanzarote en un combate crucial para recuperar el buen funcionamiento de la sociedad artúrica y para satisfacer sus más íntimos deseos eróticos: "et totevoies s'arestoit, (...) por qu'il la va si regardant” (Charrete, 3748 - 3751); o los intentos tendentes al fracaso de ocultar el amor que atenta contra los intereses dinásticos mediante engaños: “car lor regart sont tot commun” (Escoufle, 2003).

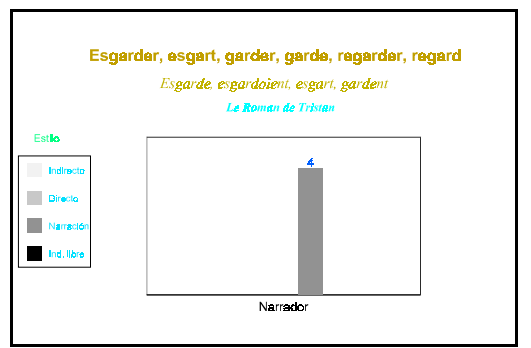

Fig. 119. Comportamiento estilístico de los verbos «esgarden», «garder», regarder y de los sustantivos «esgart», «garde» y regard en Tristan.

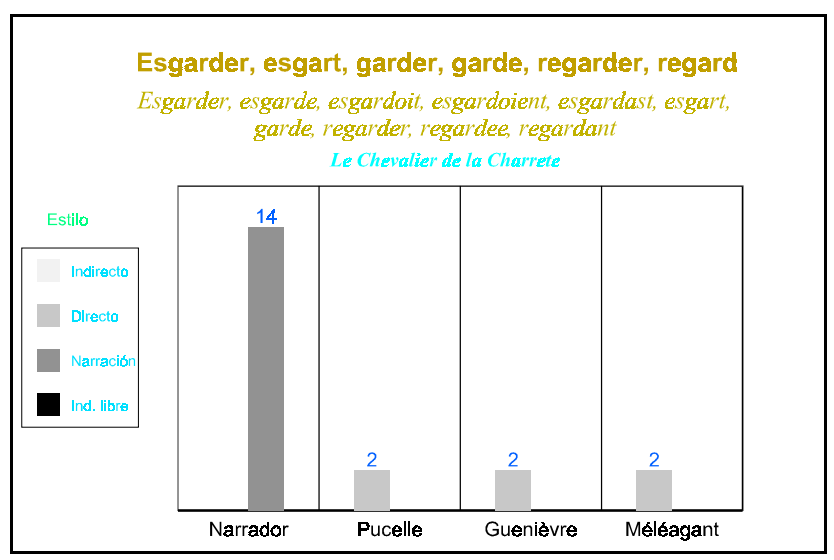

Fig. 120. Comportamiento estilístico de los verbos «esgarden», «garder», regarder y de los sustantivos «esgart», «garde»y regard en Charrete. 


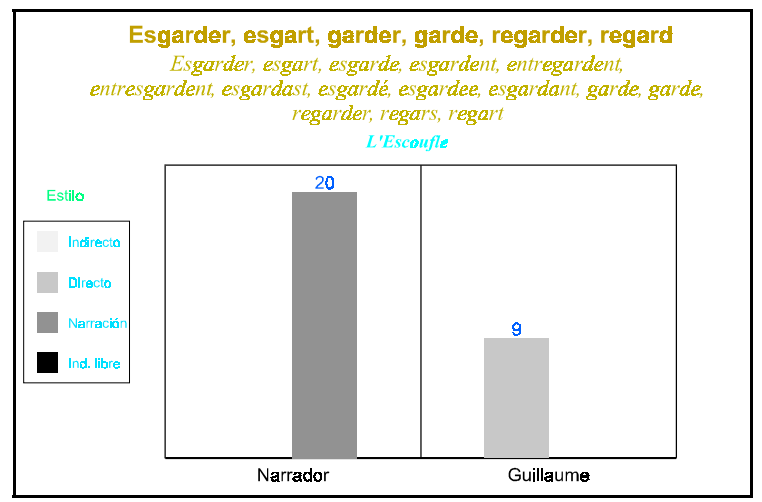

Fig. 121. Comportamiento estilístico de los verbos «esgarder», «garder», regarder y de los sustantivos «esgart», «garde» y regard en Escoufle.

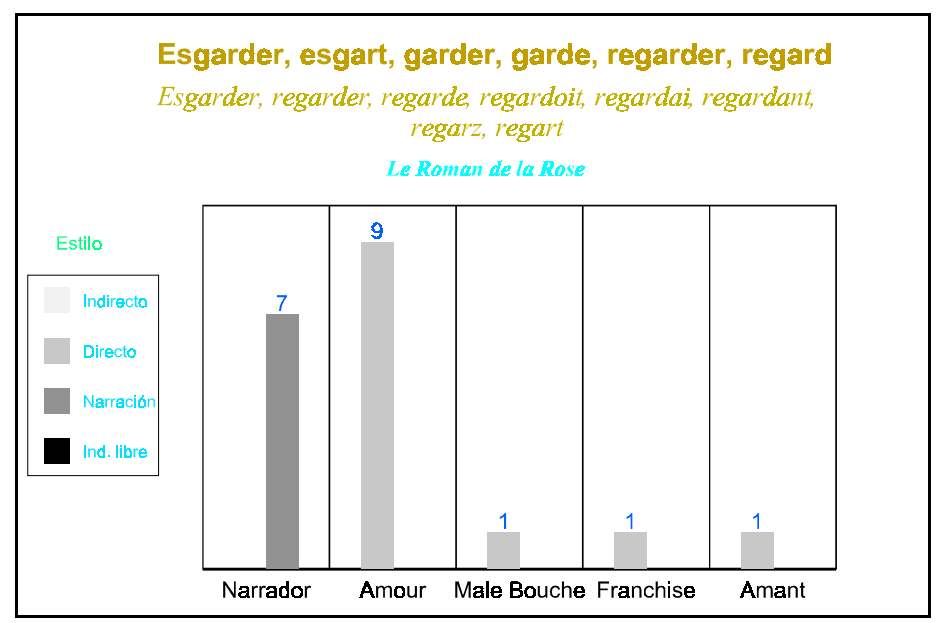

Fig. 122. Comportamiento estilístico de los verbos «esgarder», «garder», regarder y de los sustantivos «esgart», «garde» y regard en Rose.

Mirar y ser mirado, ofrecer cuerpo, acciones y pasiones, a un espectáculo íntimo o colectivo en el que actividad y pasividad se confunden, incluso cuando no se expresa la reciprocidad de las miradas, es un asunto narrativo más que discursivo. Tan sólo el narrador omnisciente está en situación de calibrar si el que es mirado es consciente de ello y por lo tanto mira a su vez. De ahí que incluso cuando el hecho de mirar es evocado en el discurso directo de uno de los personajes, como es el caso de Guillermo o de Ginebra, suele tratarse de una retrospección en la que relatan hechos acaecidos con anterioridad o bien de una transcripción de la acción que están 
realizando, lo que los convierte a su vez en narradores. El dios Amor actuará también como una segunda voz narrativa en Rose pero siempre con su afán didáctico refiriéndose al futuro.

\subsection{Mirery «remiren».}

En el corpus, tres son los rasgos fundamentales que caracterizan estos dos verbos en función de tres puntos de referencia. Y ello con independencia de que la forma prefijada exprese la intensificación del proceso, lo que de hecho produce una redundancia ya que la forma base mirer conserva el sentido «mirar atentamente» del étimo del latín popular*mirare, sin que ello sea un obstáculo para que se duplique el sentido mediante un complemento circunstancial de modo: “avoit .ii. pierres de cristal qu'a grant entente remirai" (Rose, 1536 - 1537).

Así pues, desde un punto de vista semántico, la selección en el paradigma de uno de estos verbos frente a las formas tratadas en el apartado anterior, aporta a la vez intensidad y duración al proceso de la contemplación.

En segundo lugar, si tomamos en consideración las relaciones contextuales, la elección de estas formas puede responder a la solución anterior como una variante estilística de esgander cuya acción es modificada por adverbios que suplen la noción de duración: "quant il le tint, $\underline{\text { molt }}$ longuemant l'esgarde, et les chevox remire” (Charrete, 1392 - 1393), o bien, en relación de proximidad con el término miroër — aunque puede estar ausente- tanto en Rose como en Escoufle, puede adquirir nuevos sentidos como «ver reflejado», «mirar en una superficie que devuelve la imagen», de los que surge otro, figurado y ponderativo, en la línea habitual de E scoufle, por el que Aelis se convierte en el modelo que inspira a la Belleza: "mais en vos en cui biautés mire" (Escoufle, 3456). En esta segunda opción debe ser incluida también la forma pronominal del verbo mirer, especialmente cuando se habla 
del miroër perilleus, de la fuente de la pasión en la que nace el amor, ya sea el de Narciso o el de aquel que contempla la belleza del otro sexo en sus aguas

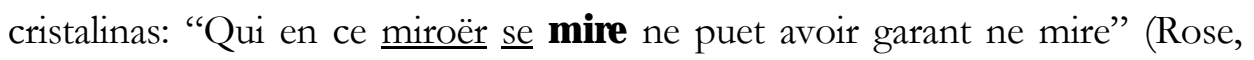
1573 - 1574). ${ }^{479}$

En tercer lugar estas formas se caracterizan por la especialización genérica de la mirada, pues si excluimos el ente abstracto Belleza, son sólo los varones los que contemplan, se contemplan o ven reflejado lo que es o será objeto de su deseo. Este puede ser fuente de placer en E scoufle gracias a una imagen comparativa en la que se produce la asociación explícita entre el bello rostro de la doncella y el espejo, y que describe su tersura, es decir, la limpieza, el lustre y la finura: "en sa veüe se peüst bien uns hom mirer" (Escoufle, 4812 - 4813), “on se peüst en sa colour com en .j. mireoir mirer” (Escoufle, 7620 7621). O ser origen del dolor en Rose, donde la contrucción en el seno del relato alegórico es más compleja al sustentarse en una metáfora por la que se identificarían los cristales incrustados en el fondo de la fuente y los ojos de la mujer. En ellos se hallan expuestas las delicias del jardín, es decir, los placeres del amor:

$$
\begin{aligned}
& \text { Mes de fort eure m’i miré. } \\
& \text { Las! Tant en ai puis soupiré! } \\
& \text { Cil miroërs m'a deceü }
\end{aligned}
$$$$
\text { Rose, } 1605 \text { - } 1607
$$

En cualquiera de los dos casos no podemos pasar por alto el proceso de «reificación» femenina en detrimento de su actividad amatoria, por el cual queda al servicio, especialmente en Rose, de la realización erótica del varón. También es sintomático el que se trate de los romans del siglo XIII, siglo en el que se diluye paulatina pero definitivamente la voluntad establecida por

\footnotetext{
${ }^{479} \mathrm{Y}$ ello porque sus aguas - cristales no reflejan el jardín, sino que lo revelan, es decir, descubren para el neófito las maravillas del amor. Cf. C. Nouvet, On The Way Toward Love, A merican Imago, vol. 50, $\mathrm{n}^{\circ}$ 3, p. 337.
} 
el imaginario cortés de armonización de los sexos. Se vuelve en gran medida a considerar a la mujer como un elemento complementario del hombre y, aunque quizá ya no es vista tan claramente como el lado oscuro de la época pre-cortés, se le hace retroceder en el proceso de individuación.

Dos características formales vienen a añadirse a las anteriores, por un lado la presencia en la rima o en su defecto en la primera posición del verso, situación poco habitual para una forma verbal y que es síntoma de la gran importancia que se otorga a mirer y remirer al ocupar estos dos lugares dominantes:

$$
\begin{aligned}
& \text { c'est li miroërs perilleus, } \\
& \text { ou Narcisus, li orgueilleus, } \\
& \text { mira sa face et ses ieuz vers } \\
& \text { Rose, } 1569-1571
\end{aligned}
$$

Por otro, la recurrencia de las proposiciones subordinadas relativas, que en E scoufle tienen como antecedente a Aelis y en Rose la fuente o los cristales, en cualquier caso el foco originario de la pasión amorosa, con la excepción de una proposición sin antecedente con la que se generaliza la relación entre la mirada y el enamoramiento (Rose, 1573 - 1574). Tan sólo hallamos otras dos proposiciones subordinadas, una completiva que funciona como sujeto de la principal: "li feus si est ce qu'i remire s'amie qui le fet defrire" (Rose, 2341 - 2342) y una circunstancial con valor final construida con un infinitivo: "adés me plot a demorer a la fontaine remirer et as cristaus" (Rose, 1601 - 1603), en las que se hace coincidir el deseo ardiente y el placer incipiente con la contemplación del sexo femenino. Todas las subordinadas tienen en común la separación de la mujer de la función de sujeto y la instrumentalización de su cuerpo y especialmente de su cara y de sus ojos con el fin de desarrollar o satisfacer la libido masculina. 


\begin{tabular}{lllllllll}
\hline FORMA & CA & BD & NV & RIMA & CA2 & NV2 & D & PERS \\
\hline mire & V & Escoufle & 3456 & dire & I & 3455 & D & Guillaume \\
mire & V & Rose & 1573 & mire & S & 1574 & N & Narrador \\
miré & V & Rose & 1605 & soupiré & O & 1606 & N & Narrador \\
mirer & I & Escoufle & 4813 & irer & I & 4814 & N & Narrador \\
mirer & I & Escoufle & 7621 & irer & I & 7622 & D & Guillaume \\
remirer & I & Rose & 1602 & demorer & I & 1601 & N & Narrador \\
remire & V & Charrete & 1393 & rire & I & 1394 & N & Narrador \\
remire & V & Rose & 2341 & defrire & I & 2342 & D & Amour \\
remirai & V & Rose & 1537 & dirai & V & 1538 & N & Narrador \\
\hline
\end{tabular}

Tabla 81. Rimas de los verbos mirer y «remirer».

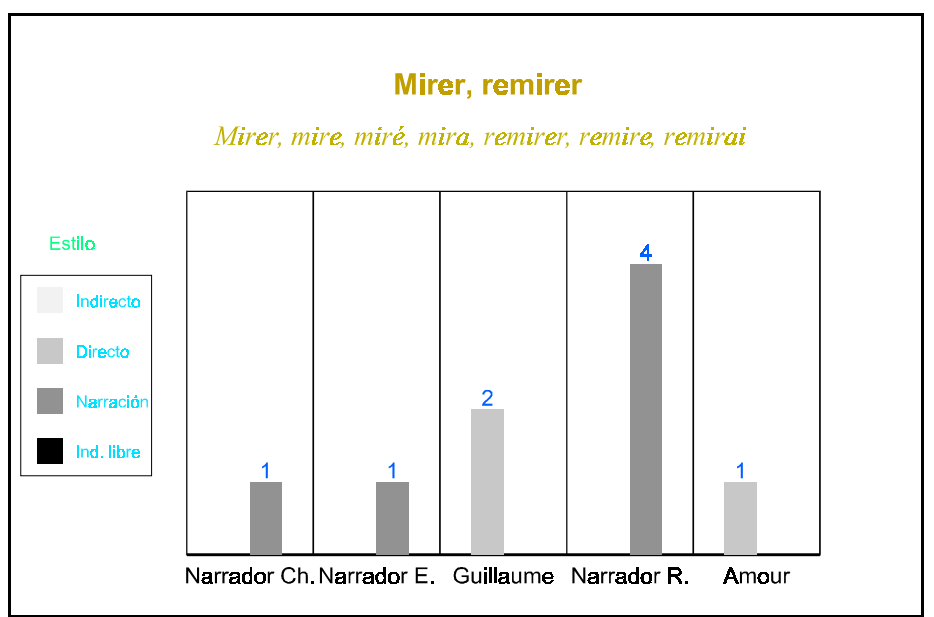

Fig. 123. Comportamiento estilístico de los verbos mirer y «remirer» en el corpus.

La interpretación de la realidad femenina y del origen de la pasión se torna gradualmente desde Charrete a Rose más dificultosa al abrirse una distancia cada vez mayor entre los que contemplan y el objeto de la contemplación. Un abismo creciente que se traduce en la complejidad de los procesos retóricos que intentan materializar estos conceptos, desde la metonimia hasta la composición metafórico-alegórica. Por otra parte, pese a que el comportamiento estilístico de estos dos verbos coincide por completo con el de los términos tratados en el apartado anterior, mirer y remirer aluden a un proceso no compatible con la reciprocidad, y observamos más bien un movimiento de reflexión en el que la mujer es la superficie inanimada en la que rebota la mirada. 


\subsection{0eil.}

Los ojos son los únicos órganos que permanecen en todas las descripciones de los aspectos físicos de los personajes, generalmente en plural, y ello tanto en el discurso del narrador como en las intervenciones directas de los personajes: "riche ert la robe et gent le cors: les eulz out vers, les cheveus sors" (Tristan, 2887 - 2888), "il avoit gros et vairs les $\mathbf{e x}$, le chief ot .j. poi crespe et bloi" (Escoufle, 7168 - 7169), "les chevels ot blondez et lons qui li bastoient as talons, nés ot bien fet, et ieuz et bouche” (Rose, 1007 - 1009). La tendencia hacia la individualización que advertimos durante el siglo XIII, y muy especialmente dentro del corpus en Rose, conlleva la diversificación y variación de los atributos de la parte visible de estos órganos. Esto se traduce formalmente en la renovación de los adjetivos, la multiplicación y combinación sintagmática de éstos mediante la coordinación o la distribución en epíteto y atributo, la utilización de participios presentes, y la comparación con elementos naturales diversos. Con ello, al color — siempre del mismo gris azulado, vario o cambiante como el halcón- se añadirá el tamaño o la forma, esta a menudo portavoz de las expresiones que se aprecian en el rostro y que son a su vez síntomas de la personalidad o del estado de ánimo. En segundo lugar la tendencia individualizadora comporta la combinación de los ojos con otros órganos y partes del rostro en los que antes no se reparaba como la nariz, el entrecejo, la frente, las cejas, las mejillas, el mentón o la boca, y aun como parte de la descripción se recurre a las sensaciones percibidas por otros sentidos como el gusto, el tacto o el olfato:

einçois ot nés lonc et tretiz,

euz vairs rianz, sorciz voutiz,

s'ot les cheveus blondez et lons

Rose, 1193 - 1195480

\footnotetext{
480 Insertamos aquí los múltiples retratos de los compañeros de Deduit en los que podemos observar las nuevas tendencias descriptivas: "front reluisant, sorciex votis; li entr'ieuz ne fu pas petis, ainz ert assez grant par mesure; le nés ot bien feit a droiture et les ieuz vers come faucons. Por feire envie a ces bricons, douce aleine ot et savoree" (Rose, 527 - 533); " la face avoit, con une pome, vermeille, et blanche tot entor; cointe fu et de bel ator; les ieuz ot vers, la bouche gente, et le nés bel par grant entente; cheveus ot blons, recercelez" (Rose, 802 - 807); "le front ot bel et plein, sanz fronce, les sorciz bruns et enarchiez, les ieuz gais et si envoisiez qu'il rioient torjors avant que la boucheite par covent" (Rose, 842 - 846)
} 
Parece inevitable que el cambio ideológico, que permitía la identificación de una criatura frente al resto de las de su especie, tuviese consecuencias directas sobre la percepción erótica del otro sexo y especialmente sobre la sensualidad de cada individuo, alimentada, además, por el recuerdo y la imaginación de rasgos más precisos evocados por el arte y la literatura. Y ello aunque no se subvertiese completamente el complejo sistema de los arquetipos descriptivos. Hemos de tener en cuenta, además, que, según ciertas teorías médicas medievales, ambas capacidades —recuerdo e imaginación — producían la excitación de la llamada virtud psíquica, que, a su vez, excitaba el hígado, éste el corazón y por fin, éste los órganos genitales y el deseo. ${ }^{481}$ De hecho Lorris se hace eco de esta relación que nosotros hemos establecido teóricamente entre la atención descriptiva a ciertos detalles anatómicos —especialmente aunque no únicamente del rostro-, la sobrevaloración del recuerdo y de la imagen del objeto de deseo, y la exaltación subsecuente del apetito sexual: “et a l'amant (...) fet de la joie souvenir que esperance li promet. Et aprés au devant li met les ieuz rianz, le nés tretiz, qui n'est trop granz ne trop petiz, et la boucheite coloree dont l'alaine est tant savoree, si li plest mout quant i li menbre de la biauté de chascun menbre.” (Rose, 2637 - 2643).

Las alusiones a los rasgos físicos básicos en los romans del siglo XIII, entre ellos los ojos, testimonian de la adecuación de los amantes al formar una pareja homogénea físicamente y en consecuencia moralmente: "ne trovast il .ij. si pareus de vis ne de bouche ne d'ex. Il samblent estre suer et frere" (Escoufle, 1945 - 1947). En E scoufle se desarrolla dentro de este subtema la tendencia a la ponderación, con la particularidad en este caso de que se supera la tradición representada por los ascendientes, un paso hacia la individualización matizada por la uniformidad de los amantes:

${ }^{481}$ Cf. D. Jacquart y C. Thomasset, op. at., p. 116. 


$$
\begin{aligned}
& \text { des biax } \mathbf{e x} \text { et des testes blondes } \\
& \text { et de cors, perent il bien estre } \\
& \text { li plus gentil de lor ancestre }
\end{aligned}
$$

Escoufle, 2108 - 2110

En otro orden de cosas, los órganos de la visión nos permiten conceptuar la corte como un complejo y variable grupo humano cuya cohesión en materia de relaciones entre los sexos surge, no sólo gracias a los combates ritualizados por el amor de las hembras o merced a las ceremonias de acogida de elementos externos que pronto se integran para permitir la exogamia, sino de la unanimidad en el enjuiciamiento de esas relaciones, valoración cuya base fenoménica son las percepciones visuales. Esto permite a Iseo hacer asumir a los ojos un papel equívoco, pues en principio debería sostener su causa ante la corte mediante un juramento oral, pero la reina los convierte en testigos legales, y los valida ante el esposo prefigurando la coartada visual a la que apelará en su discurso justificativo: “por ce m'est bel que cil i soient et mon deresne a lor eulz voient" (Tristan, 3255 - 3256). El rey Bademagu también apela a la comprobación visual de las pruebas que harían posible la acusación de adulterio contra Ginebra y Keu, y por lo tanto levantar el interdicto sobre el disfrute sexual de Meleagant enamorado de la reina: "le voir m'an aprendront mi oel” (Charrete, 4828).

Este espectáculo permanente de todos para todos, contrario a la esencia misma de la intimidad necesaria para las manifestaciones del sentimiento amoroso según la cortesía, máxime cuando se trata de un amor adúltero, justifica el disimulo con el que actúa Ginebra al ocultarse a los ávidos ojos de los cortesanos y del propio esposo:

$$
\begin{aligned}
& \text { li rois, li autre, qui la sont, } \\
& \text { qui lor ialz espanduz i ont, } \\
& \text { aparceüssent tost l'afeire }
\end{aligned}
$$

Charrete, 6837 - 6839 
En una construcción fija [[Part. Pres. + Art. pos.] + ialz] que expresa la circunstancia, y en la que el sustantivo funciona como sujeto del participio, las percepciones visuales se convierten en sustitutos de la actividad necesaria de un caballero ante un hecho que contraviene las reglas de la caballería, pero ante el que se muestra incapaz de actuar: "mes que bien li poist et despleise, vos an manrai, veant ses ialz” (Charrete, 1590 - 1591), o impasible al no afectar aparentemente a su empresa: "fera donc cist sa volenté de moi, veant tes ialz, a force?” (Charrete, 1076 - 1077), en ambos casos se adivina un matiz despectivo hacia lo que podría considerarse una contaminación de la corte y su voyeurisme, que incapacita para la acción caballeresca.

Existe una cuarta faceta testimonial de los ojos ya que, como hemos señalado anteriormente, pueden delatar los sentimientos de los amantes a quienes perciban sus miradas cómplices o los cambios que afectan a su forma (Escoufle, 1992 - 1995).

Pero los ojos en los romans son mucho más que un elemento recurrente con poder evocador en las descripciones, o que escaparates y sondas de las relaciones tribales, son una herramienta al servicio del amor, de la pareja o de uno de los amantes. Puerta de entrada del sentimiento amoroso y del deseo carnal, el enamoramiento según el relato alegórico de Guillaume de Lorris comienza cuando el dios Amor dispara la primera flecha que penetra por el centro del ojo hasta alcanzar el corazón del joven, quien siente inmediatamente los síntomas inequívocos del sentimiento amoroso: "par mi l'ueil m'a ou cuer mise sa saiete par grant roidor" (Rose, 1692 - 1693); tras esta primera flecha, cuyo nombre es Belleza, llegará una segunda llamada Dulzura, que seguirá el mismo camino antes de que el arquero comience a disparar directamente al pecho una vez que el daño es irreparable: "par l'ueil ou cuer m’entra la saiete qui me navra” (Rose, 1735 - 1736). Son, además, las únicas ocurrencias del sustantivo en singular. 
Se perfilan como el medio más adecuado para que los enamorados reafirmen su amor; esta garantía puede ser mutua y servir de mecanismo intermediario entre sus corazones, tal como ocurre en E sooufle, donde se hace hincapié en la reciprocidad mediante el artículo posesivo plural, el prefijo entre- y una construcción recíproca con variaciones sobre la habitual ya que en el primer segmento o bien se ha sustituido la combinación [A rt. def. +

Pron. indef.] por [A rt. def. + Art. indef.] o bien, un suple las dos funciones, lo que permite mantener la base nocional introduciendo un elemento nominal, cuer. "lor regart ont entrelardé parmi les fenestres des eus l'un cuer de l'autre" (Escoufle, 7820 - 7822). Puede ser también unidireccional como se observa en Charrete, una obra en la que la compenetración de los amantes se reserva a la noche de amor y a sus prolegómenos, que van precedidos por una acogida amable de la reina al mirar directamente al enamorado. Con esa mirada lo elige entre los demás individuos y acepta el tributo de su pasión y sufrimientos:

\author{
Lors ne lessa mie cheoir \\ la reïne ses ialz vers terre; \\ einz l'ala lieemant requerre, \\ si l'enora de son pooir \\ Charrete, 4460 - 4463
}

Los ojos mantienen el contacto en la separación, decidida por uno de ellos o impuesta para ambos: "Yseut o les euz le convoie" (Tristan, 2930), a la vez que son signo inequívoco de amor: "li oel li sont pres demi apetisié de fine angoisse" (Escoufle, 1998 - 1999), en Charrete y Rose generalmente asociados al corazón: “et Lanceloz jusqu'a l’antree des ialz et del cuer la convoie, mes as ialz fu corte la voie" (Charrete, 3970 - 3972), "li cuers (...) s'an est oltre aprés li passez, et li oil sont remés defors, plain de lermes, avoec le cors" (Charrete, 3976 - 3980). En la obra de Lorris podemos apreciar un desarrollo retórico excesivo de esta combinación y aun del contexto inmediato 
observado en Charrete como el verbo convoier, aunque esa hipertrofia bien podría responder al desarrollo temático de la obsesión amorosa como una enfermedad a la vez física y psíquica cuando el deseo se estanca sin que se pueda acceder al placer del contacto y aún menos del coito:

\author{
lors diras: «Diés! Con sui mauvois, \\ quant la ou mes cuers est ne vois! \\ Mon cuer seul por quoi i envoi? \\ Adés i pens et rien n'en voi! \\ Quant je puis les ieuz envoier \\ aprés, por le cuer convoier, \\ se mi oil mon cuer ne convoient
}

Rose, 2289 - 2295

La fijeza de la mirada, que entraña la inmovilización del héroe y el olvido de la lucha, se identifica con el grado superior en la escala de la pasión amorosa caballeresca alcanzada por Lanzarote: "ne se torna ne ne se mut de vers li ses ialz ne sa chiere, einz se desfandoit par derriere" (Charrete, 3676 3678). Igual significado adquiere la parálisis que afecta a los ojos del perfecto enamorado retratado por el dios Amor, aunque su amada sea aún más lejana e inalcanzable que la reina Ginebra y los síntomas de la pasión excesiva le sobrevengan con cada recuerdo, tal como antes le había ocurrido al de la carreta durante su búsqueda:

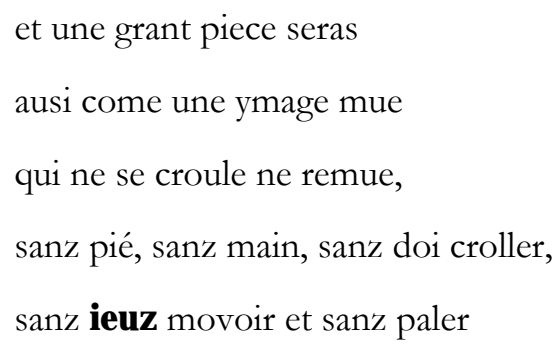


Los textos del siglo XIII van más lejos y hacen de los cambios casi imperceptibles en el aspecto de los ojos un indicio de placer erótico, así los del conde de Saint Gilles brillan al solazarse con su amada: "la doçors del solas qu'il ot li fait ses biax ex pontiier" (Escoufle, 5878 - 5879); o bien se les hace responsables del deleite del enamorado al poder contemplar lo que tanto ansiaban (Rose, 2709 - 2712). En este quehacer en el que los ojos son a la vez instrumentos y receptáculos del placer, ambos romans hacen funcionar el sustantivo eulz como complemento directo de los verbos soeler y pestre, con la particularidad de que ambos comparten una relación directa con la ingestión de alimentos, aunque el primero con el valor intensivo de «saciarse». $\mathrm{El}$ hecho de que los dos autores los utilicen en el mismo orden y de que el sujeto sea el enamorado, ya sea Guillermo, ya el amante de la rosa al que Amor en su función de segundo narrador prospectivo se dirige en segunda persona, nos hace pensar en una posible influencia de Renart sobre Lorris. También cabría la existencia de una fuente común no muy lejana en el tiempo, pues los dos verbos empiezan a utilizarse con los sentidos que les otorgamos en este contexto a finales del siglo XII para pestre y comienzos del XIII para soeler. Se trata por lo tanto de un sentido figurado de muy reciente creación en el que la subsistencia individual y aun el placer ligado a ella se asocian con los placeres que producen los mecanismos tendentes a la conservación de la especie. De hecho el verbo soûler en la expresión soûler sa volonté se mantiene con el sentido netamente sexual de «fornican»:482 "bien soela ses eus et peut Guilliaumes d'esgarder s'amie" (Escoufle, 7866 - 7867)

$$
\begin{aligned}
& \text { tu voudras mout ententis estre } \\
& \text { a tes ieuz } \underline{\text { saouler et pestre }}
\end{aligned}
$$$$
\text { Rose, } 2325 \text { - } 2326
$$

Las lágrimas o agua del corazón que mana de los ojos, son en E scoulle un signo inequívoco del dolor de los amantes ante su separación o ante la

482 Véase P. Guiraud, op.ait., p. 580. 
traición. Probablemente porque en el siglo XIII se admiten con mayor facilidad las manifestaciones abiertas de los sentimientos amorosos, contenidas anteriormente por las reglas del amor adulto y adúltero Lanzarote se le llenaban los ojos de lágrimas pero no lloraba (Charrete, 3979 3980)_. De hecho en este roman la esposa también llora al convencerse de que el marido ama a otra, no tanto por celos, sino por no sentirse correspondida en sus sentimientos, algo que parece revelar las modificaciones profundas en la consideración social respecto del matrimonio, que la Iglesia y probablemente la monarquía intentan promover, en especial dentro de las capas aristocráticas: "si durement li grieve et cuist k'a ses $\mathbf{e x}$ en vindrent les larmes” (Escoufle, 5906 - 5907)

\section{A cest penser li saut des $\mathbf{e x}$ \\ l'aigue du cuer aval la face \\ plus bele et plus clere que glace}

Escoufle, 4890 - $4892^{483}$

Las funciones sintácticas que asume el sustantivo en el corpus son fundamentalmente las de sujeto y las de complemento de objeto directo. En cuanto a la primera nos llaman poderosamente la atención dos aspectos, por un lado la gran variación verbal, por otro la escasa funcionalidad con verbos de percepción visual, tan sólo raviser y veoir toman este sustantivo como sujeto: "cil cui si bel oel ravisent" (Escoufle, 5490), si bien en el caso de veoir — circunscrito a los romans de Chrétien y Lorris— son más abundantes las ocurrencias que observamos gracias a la sustitución pronominal del sujeto en Rose, donde la acción de ver expresada mediante este verbo aparece esencialmente asociada al corazón, sede de los sentimientos: "li oil voient ce qu'il viaut" (Rose, 2734), "se mi oil (...), je ne pris rien quen que il voient" (Rose, 2295 - 2296). El semantismo del resto de los verbos expresa el estado transitorio de los órganos de la visión, en relación contextual con las

483 También en los versos 4750 - 4751 y 4818 - 4821. 
manifestaciones del amor, del dolor: "erent si oel moillié et de larmes et de suor” (Escoufle, 4750 - 4751), o del placer: apetisier (Escoufle, 1998 - 1999), pontiier (Escoufle, 5879), avoir bone encontre: "mout ont au matin bone

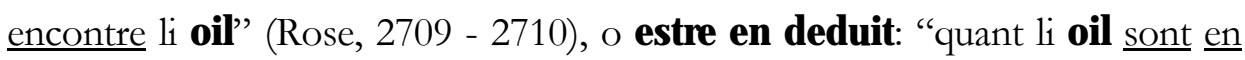
deduit" (Rose, 2717). La determinación, mediante un artículo definido para referirse a los ojos de los enamorados en general, distintiva de Rose, o mediante un artículo posesivo en Charrete y en E scoulle, en los que se nos habla de amantes concretos, caracteriza morfosintácticamente al sustantivo en esta función.

En cuanto a la función de complemento de objeto directo, los verbos de los que depende el sustantivo son menos variados y destaca el verbo avoir en pretérito definido o en imperfecto en las descripciones: "les eulz out vers” (Tristan, 2888), “einçois ot (...) euz vairs rianz” (Rose, 1193 1194), "il avoit gros et vairs les ex" (Escoufle, 7168), como vemos precedido o no de un artículo determinado, variación que parece deberse más bien a cuestiones formales que estilísticas. Un gran número de verbos cuyo contenido semántico no tiene en principio ninguna relación con la acción de mirar, al verse acompañados por el sustantivo eulz adoptan ese sentido con matices variados; tan sólo mirer escapa a esta premisa: “ou Narcisus, li orgueilleus, mira sa face et ses ieuz vers” (Rose, 1570 - 1571), sin embargo comparte con otros la capacidad de expresar una noción esencial en el corpus —a excepción de Tristan—, la larga contemplación, el hecho de mirar fijamente el objeto que se desea o que produce placer por su perfección, en Charrete esta idea se transcribe mediante la negación de verbos de movimiento: “ne se torna ne ne se mut de vers li ses ialz” (Charrete, 3676 - 3677), "lors ne lessa mie cheoir la reïne ses ialz vers terre" (Charrete, 4460 - 4461), "nus ne puet ses ialz retreire de lui esgarder" (Charrete, 5624 - 5625), por el contrario Lorris acude a las formas afirmativas toda vez que su amada es en extremo escurridiza: “je puis les ieuz envoier aprés, por le cuer convoier” (Rose, 2293 2294). En E scoufle son los verbos tenir y avoir, convenientemente aderezados 
por un adverbio de tiempo, toustans, y el participio pasado de aendre que intensifica la inmovilidad: "toustans li tenoit el visage ses iols $\underline{\text { aers }}$ bele Aelis" (Escoufle, 7404 - 7405), o por la fórmula s'a lui non [C onj. + Prep. +

Pron. + A dv.], que indica la exclusividad "el n'avoit les iols śa lui non" (Escoufle, 7429), los que sirven para exteriorizar la conmoción que produce en Aelis la visión de un desconocido en el que no reconoce a su enamorado pero por el que se siente profundamente atraída, acometida por deseos que habían quedado aletargados durante siete años. Un hecho que constituye una variante de la pasión única y obsesiva presente en los demás textos.

Por lo que hace a la sintaxis proposicional, cabe reseñar, junto a un gran número de proposiciones independientes, la escasez de proposiciones subordinadas completivas en las que hallamos el sustantivo.484 Las proposiciones subordinadas de relativo presentan múltiples antecedentes: aquellos que, sin ser identificados, rodean a la bella Aelis y pueden contemplarla —el pronombre sujeto qui no tiene antecedente (Escoufle, 1992 - 1993)_, o ser mirados por ella, en este caso la forma predicativa del pronombre relativo, cui, con la función de complemento directo se halla precedida por el pronombre demostrativo cil al que debemos considerar aquí simplemente como un elemento anafórico con la particularidad de diluir la concreción de los sustantivos a los que se refiere: "ele a lués droit la grace eüe des chevaliers, des damoisiaus. (...) Et cil cui si bel oel ravisent cuident estre ml't plus que conte" (Escoufle, 5486 - 5492); es este un fenómeno interesante pues pese a lo que en un principio se pudiese sospechar, la dilución tiene una finalidad valorizante, es decir, el varón sale supervalorado como individuo tras ser mirado por la mujer. Las lágrimas, definidas mediante la proposición de relativo: "l'aigue qui li descent des ex" (Escoufle, 4819) y los que pueblan la corte del rey Arturo (Charrete, 6837 - 6838) son retomados por pronombres sujeto, mientras que la fuente en la que se contempló Narciso deviene

${ }^{484}$ Tristan, 3255 - 3256 y Escoufle, 7428 - 7429. 
complemento circunstancial de lugar por mediación del relativo ou (Rose, 1569 - 1571).

Las proposiciones subordinadas circunstanciales expresan dos contenidos nocionales fundamentales, el tiempo y la consecuencia:

- Temporales:

La forma en -ant invariable, cuyo sujeto es ialz, y que equivale al moderno gerundio, introduce en Charrete la simultaneidad de las acciones de la principal y de la subordinada: "fera donc cist sa volenté de moi, veant tes ialz, a force?” (Charrete, 1076 - 1077); en Rose se acude más bien a la conjunción quant: "car li cuers de rien ne se diaut quant li oil voient ce qu'il viaut" (Rose, 2733 - 2734), "quant li oil sont en deduit, si sont si apris et si duit que seul ne sevent avoir joie" (Rose, 2717 - 2719), mientras que la conjunción que señala el punto en el que se realiza un proceso posterior — en este caso ver la mujer de sus sueños - al indicado en la proposición principal: "ne puet avoir garant ne mire que il tel chose as ieuz ne voie" (Rose, 1574 - 1575).

\section{- Consecutivas:}

Mediante las proposiciones consecutivas se introducen las reacciones físicas representadas por la actividad ocular, reflejo a su vez de una determinada actitud o sentimiento, provocados por las acciones de los enamorados o de los esposos, la conjunción que introduce la consecuencia se halla precedida entonces por el adverbio si que modifica intensivamente el sentido de otro adverbio: " $\underline{S i}$ durement li grieve et cuist $\underline{\text { k'a }}$ ses $\mathbf{e x}$ en vindrent les larmes" (Escoufle, 5906 - 5907); "sel comance si bien a feire que nus ne puet ses ialz retreire" (Charrete, 5623 - 5624). En Rose se trata más bien de explicar la destreza del dios Amor al conseguir introducir los nuevos sentimientos que atormentarán al amante de la rosa, de ahí el uso del adjetivo ponderativo tel que prefigura la subordinada: "et tret a moi par tel devise que par mi l'ueil m'a ou cuer mise sa saiete par grant roidor" (Rose, 1691 - 1693). 


\begin{tabular}{lllllllll}
\hline FORMA & CA & BD & NV & RIMA & CA2 & NV2 & D & PERS \\
\hline eus & S & Escoufle & 7821 & Yseus & S & 7822 & N & Narrador \\
ex & S & Escoufle & 1946 & pareus & A & 1945 & N & Narrador \\
ex & S & Escoufle & 1993 & miex & D & 1994 & N & Narrador \\
ex & S & Escoufle & 4819 & vermex & A & 4820 & N & Narrador \\
ex & S & Escoufle & 4890 & conseus & S & 4889 & N & Narrador \\
ex & S & Escoufle & 7168 & parex & A & 7167 & D & M. faucon. \\
oel & S & Charrete & 4828 & voel & V & 4827 & D & Roi Bademagu \\
ialz & S & Charrete & 1591 & mialz & S & 1592 & D & Chevalier \\
\hline
\end{tabular}

Tabla 82. Rimas del sustantivo oeil.

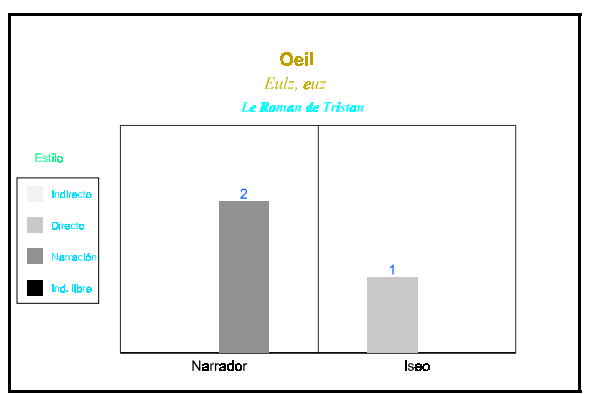

Fig. 124. Comportamiento estilístico del sustantivo oeil en Tristan.

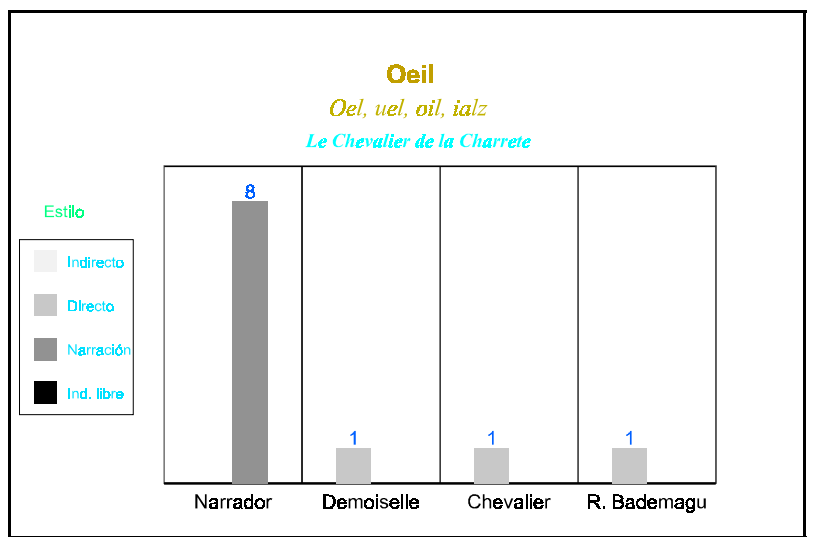

Fig. 125. Comportamiento estilístico del sustantivo oeil en Charrete.

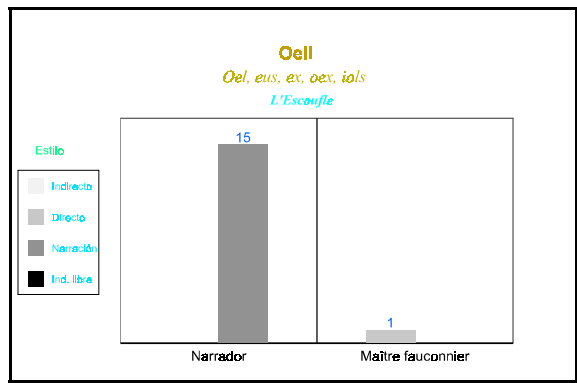

Fig. 126. Comportamiento estilístico del sustantivo oeil en Escoufle. 


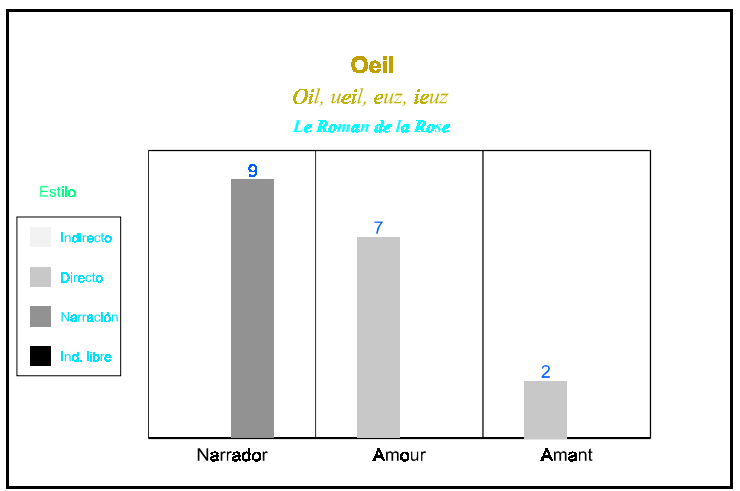

Fig. 127. Comportamiento estilístico del sustantivo oeil en Rose.

Prácticamente recluidos en el discurso narrativo, los ojos, órganos de la vista o partes visibles de sí mismos y de los párpados, pueden ayudar a los amantes mediante un complejo sistema de signos, en ocasiones involuntarios, que van desde la mirada fija hasta el movimiento rápido que indica el lugar en el que el enamorado podrá reunirse con la amada, o bien pueden traicionarlos, aunque los amantes adúlteros del siglo XII saben camuflar sus sentimientos y ocultan sus miradas como hacían con sus palabras, conscientes de que el grupo confía en la percepción visual para descubrir las relaciones antisociales. Los adolescentes que les suceden muestran una mayor candidez y dejan que los ojos expresen con intensidad sus sentimientos.

\subsection{Voir.}

El verbo veoir, al igual que los otros términos estudiados en este apartado, cumple la misión de mostrar cómo el erotismo se nutre de la visión del otro y cómo aquel a su vez alimenta el amor que va más allá de la corporeidad percibida, ${ }^{485}$ máxime en una sociedad patriarcal en la que priman las manifestaciones eróticas masculinas. En Escoufle se hace a la visión expresada mediante este verbo responsable de los celos, sentimiento doloroso provocado por el deseo de posesión exclusiva de la persona amada en

485 Véase esta distinción y el papel de los sentidos en O. Paz, L a llama doble. A mor y erotismo. Barcelona: Seix Barral, 1997, p. 33. 
Guillermo o por la sospecha de infidelidad, paradójicamente con el esposo legítimo, en el conde de Saint Gilles: “car g'istroie fors de mon sens se je veoie autre home avoir ceste honor et vos et l'avoir" (Escoufle, 3516 - 3518), "quant li quens vit avoir s'amie cele aumosniere (...) soupeçons et cuidiers l'enorte qu'ele voist canjant cest afaire" (Escoufle, 5834 - 5839).

Además, sus usos también se hacen eco de los temas a los que nos hemos referido con anterioridad, especialmente los tratados a propósito de eulz o de esgarder. Con éste comparte desde un punto de vista formal un derivado recíproco creado merced al prefijo entre-: “il s'entrevoient boinement si qu'il sont andui a cascun” (Escoufle, 1978 - 1979), si bien en este caso parece tratarse más bien de la armonía de los pensamientos antes que de un intercambio de miradas. Apunta el grado de afecto que los amantes se profesan y que los ha llevado al enamoramiento y el deseo, frente a los verbos tratados anteriormente, los cuales transcribían una manifestación física de la pasión. Como sinónimo de regarder en el discurso directo de Ginebra - puesto que la rememoración de la escena por parte del enamorado se debate entre este sentido y la recuperación de veoir de su contenido básico_ ${ }^{486}$ representa el primer escalón en la aceptación de los servicios de Lanzarote y de su acogida como amante, un paso frustrado por la exigente dama que se transmite mediante el uso del pretérito imperfecto de subjuntivo, forma que por su valor hipotético recoge a la vez la esperanza de Lanzarote, anunciada en el verbo de la proposición principal cuidier, y la negación del proceso en el pasado, ésta renovada en la perífrasis volitiva modificada por los adverbios de negación onques y ne:

et cuida que je li feïsse grant joie, et que je le veïsse, et onques veoir ne le vos

Charrete, 4211 - 4213

486 "mes ne li plest qu'ele me voie" (Charrete, 2994), "avant hier, quant vos me veïstes" (Charrete, 4474). 
Una fluctuación entre los dos sentidos, ver y mirar, que queda patente en otros contextos del roman y en especial cuando veoir y esgarder forman una estructura doble en el verso, construcción pleonástica habitual en la narrativa versificada: "se il la savoit a la fenestre ou ele estoit, qu'ele l'esgardast ne veïst" (Charrete, 3643 - 3645). De nuevo queda patente que mirar y ver, ser mirado y visto, ocupan en la obra de Chrétien un primer plano en las relaciones eróticas de la pareja, sin embargo existe una notable diferencia entre los sexos, para la mujer suele estar camuflado o cuando menos justificado por lo que podríamos tildar de obligaciones sociales, así Ginebra desea contemplar al guerrero que lucha por ella, pero solicita presenciar el combate desde un lugar privilegiado en su papel de reina cautiva que puede ser liberada al igual que sus súbditos:

$$
\begin{aligned}
& \text { la reïne qui li avoit } \\
& \text { la nuit proié qu'il la meïst } \\
& \text { an tel leu que ele veïst } \\
& \text { la bataille tot a bandon }
\end{aligned}
$$

Charrete, 3562 - 3565

Lanzarote, por el contrario, tiene una necesidad vital, difícilmente disimulable, de contemplar a la reina, "la chose de trestot le mont que plus desirroit a veoir" (Charrete, 3672 - 3673) para continuar su lucha y salir victorioso del encarnizado duelo con su contrincante, que lo es, no podemos olvidarlo, tanto en el plano social y bélico, como en el amoroso. Empujado a adaptar sus lances a la posición de observación de su amada le rinde un doble homenaje:

$$
\begin{aligned}
& \text { De tant que si pres l’i menoit } \\
& \text { qu'a remenoir li covenoit } \\
& \text { por ce qu'il ne la veïst pas } \\
& \text { se il alast avant un pas } \\
& \text { Charrete, } 3741 \text { - } 3744
\end{aligned}
$$


De esta adecuación entre homenaje visual y bélico podemos concluir que existe una notable diferencia entre los textos del siglo XII y los del siglo XIII, al haber observado en éstos la depuración de las formas caballerescocorteses, por un lado con el total abandono de la guerra entendida como lucha en torneo de múltiples caballeros en un recinto acotado. Éste, aunque en la realidad cumplía dos funciones, económica y técnica, y sólo secundariamente de prestigio social, que a su vez permitía conseguir nuevos ingresos, en las ficciones del siglo XII se había convertido — véase el torneo de Noauz- en un medio de conquista erótica y de ascenso social derivado de aquélla cuando se lograba un matrimonio ventajoso. Por otro lado, con la desaparición del duelo, de la batalla entre dos caballeros o entre dos ejércitos encabezados por su jefe supremo, concebidos en principio como una prueba de Dios. ${ }^{487}$ Tristán y Lanzarote ofrecen participar en un duelo o lo hacen efectivamente para salvar a sus amadas del oprobio, pero en Escoufle los caballeros sedentarios - tan sólo en la primera parte consagrada a las gestas del padre de Guillermo se nos habla de batallas — rinden exclusivamente un homenaje visual a la belleza femenina, al igual que el urbanizado héroe de Rose.

En el siglo XIII, además, el verbo veoir magnifica la contemplación de la belleza cuando el sujeto es el escogido grupo de la corte (Escoufle, 5592 - 5596) o el amante. Para éste actúa como una fuente de abundante placer — así lo atestiguan el verbo abelir y el adverbio que lo acompaña- y como un bálsamo contra el mal de amores, que es en gran medida carencia de la presencia de la amada -obsérvense el participio del verbo garir y el sustantivo maus - " "mout la verroie volentiers orendroites, se Diex m'aïst; gariz fust, c'un poi la veïst!"' (Rose, 2474 - 2476),

et durement m'abelisoit ce que jou veoie a bandon;

487 Véase la interesante exposición del nacimiento y evolución de ambas realidades durante los siglos XII y XIII en la obra de G. Duby, E I domingo de Bouvines. Madrid: Alianza, 1988, p. 102 - 161. 
s'en avoie grant guerredon,

que mes maus en entroblioie

Rose, $1806-1809^{488}$

Pero la contemplación se extiende también, y Renart insiste mucho en este detalle, a un público muy amplio, los habitantes de las ciudades, gentes ante las que la heroína, en este caso Aelis, pasea su palmito y su figura en una posición de superioridad física y social: "qu'ele vaut que cil la veïssent qui dui et dui des osteus issent”' (Escoufle, 8285 - 8286),

Il ne remest es osteus ame, ains s'en issent tuit, qui miex miex, pour veoir celi cui Ysiels ne sambla onques de biauté.

Escoufle, 8846 - 8849489

Para los ojos femeninos del siglo XIII también son las cualidades físicas observadas con la vista las que ocupan un lugar dominante, no tanto en el proceso de enamoramiento, como en el mantenimiento de la llama de la pasión, elemento crucial en Escoufle pues propicia la fuga de Aelis con su enamorado. Ello trae consigo que, a diferencia de Charrete, donde las

488 En A ucassin et N ioolette, M. Roques (ed.). Paris: Champion, 1982, donde la voluntad paródica lleva a constantes exageraciones, el adolescente enamorado, al cantar las alabanzas de su amada, afirma que la visión de la belleza de sus piernas había curado milagrosamente a un hombre:

$$
\begin{aligned}
& \text { si soulevas ton traïn } \\
& \text { et ton peliçon ermin, } \\
& \text { la cemisse de blanc lin, } \\
& \text { tant que ta ganbete vit: } \\
& \text { garis fu li pelerins } \\
& \text { et tos sains, ainc ne fu si } \\
& \qquad \mathrm{XI}, 22-28
\end{aligned}
$$

489 "qui le jour ne l'ot veüe ains puis ne vit si bele" (Escoufle, 8941 - 8942), "les fenestres, li huis, li bouge des ovreoirs erent tout plain de cels qui issent fors au plain pour veoir celi qui s'en va" (Escoufle, 8016 - 8019). 
doncellas consideran las excelentes aptitudes de Lanzarote para la lucha: "que bien orent veü comant il l'avoit fet premieremant" (Charrete, 5719 - 5720), “por ce que si adroit le voient" (Charrete, 6019), todas las cualidades de Guillermo pasen a formar parte de los atributos corporales que lo hacen agradable a la vista, incluso aquellas cuyo origen se hallaba en el comportamiento guerrero, como la designada por el adjetivo preu: "ki li remet celui devant si bel, si preu, si avenant com el l'avoit le jor veü’' (Escoufle, 3223 - 3225); una transposición que afecta también a las cualidades de Aelis: "Vostre douçors, vostre amistié, certes, mar vi jou, bele amie" (Escoufle, 3466 - 3467).

El gerundio veant cuando funciona en una proposición subordinada circunstancial no se agota en su combinación con eulz, ya que Chrétien lo utiliza con un pronombre en forma predicativa que actúa como sujeto, para redundar en la combinación entre voyeurisme e incapacidad caballeresca, como una alternativa estilística dentro del juego de las repeticiones que se adecúan al tono suplicante y angustioso de la doncella violada: "il me honira, veant toi" (Charrete, 1073). Es así mismo una alternativa, redundante ${ }^{490}$ o no, en la elaboración del tema de la corte como lugar privilegiado de observación de las relaciones de la pareja. Béroul lo opone en una construcción a la vez distributiva y acumulativa de dos términos introducidos por la conjunción et, con el fin de poner de manifiesto la incapacidad de los amantes para reprimir sus ansias de estar juntos, insistencia que llevará a una nueva crisis en la que se enfrentan sus intereses a los genealógicos y feudales: "sovent vienent a

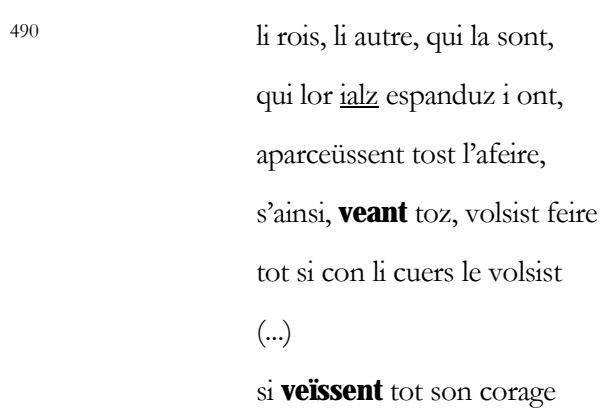


parlement, et a celé et voiant gent" (Tristan, 577 - 578), y que permite relanzar de nuevo el relato. En E scoufle la acción designada por este medio, así como el contacto físico subsecuente, se convierten en un instrumentento al servicio de la pareja: "voiant le conte et sa gent toute li court jeter ses bras au col" (Escoufle, 7692 - 7693). Guillermo y Aelis recuperan en un espacio social adecuado, el castillo del conde de Saint Gilles, y aun dentro de éste, en el espacio reducido e íntimo de la cámara - gineceo, la consideración erótica y legal que habían perdido en la cámara del palacio imperial; y si examinamos los dos escenas nos damos cuenta de que la segunda escena es una inversión de la primera: en primer lugar Aelis, quien, pese a conservar un gran protagonismo erótico por su juventud y su belleza, no reina en el recinto de Saint Gilles, ya que se encuentra supeditada a la condesa, una imagen amable de su propia madre y representante de la institución matrimonial, elemento clave del roman; en segundo lugar el varón que es el centro de la reunión y que recrea su cuerpo y su espíritu con el agradable y sensual servicio de las doncellas, es un señor, mientras que en Roma lo era el adolescente Guillermo, quien se conformaba con observar las gráciles danzas de las jóvenes; en tercer lugar y como consecuencia de lo anterior, es el joven el que penetra en el gineceo para desposeer al senior — trasunto del padre y hombre experimentado en los juegos eróticos y en los placeres - de sus prerrogativas, cuando en primera instancia había sido el emperador y sus cortesanos quienes lo habían echado; y por fin, en la separación el último contacto había sido visual, dominado por la mirada femenina que trataba de esconder sus sentimientos, frente al reconocimiento de Aelis mediante la visión y su traducción en una franca acogida que lleva aparejado el contacto físico en presencia de toda la corte.

En este sentido el cortejo de Deduit debe ser considerado como una secuela "sobreidealizada" de las cortes aristocráticas esbozadas en los romans caballerescos, por la despreocupación imperante, por la libertad con la que 
actúan los adolescentes que la componen ante sus compañeros de juegos eróticos, y por el ahínco con el que buscan el placer de los sentidos:

\author{
ses amis fu de lui privez \\ en tel guise qu'i la bessoit \\ toutes les foiz qu'il li plessoit,
}

voiant toz ceus de la querole

Rose, 1266 - 1269

Al igual que en Charrete, Lorris crea un espectador ajeno a los componentes del grupo consagrado al baile y los juegos sutilmente impregnados de erotismo. En aquel la figura del intruso voyeur está representada por un caballero de edad avanzada, padre de uno de ellos y señor de los jóvenes que desprecian a Lanzarote, quien asume el papel de testigo privilegiado y moderador en la lucha entre el caballero de la carreta y su enamorado hijo, y encarna por lo tanto la experiencia tanto en el plano erótico como en el guerrero. En la obra de Lorris, por el contrario, el extraño es el protagonista del sueño, cuyas peripecias relata el narrador en primera persona poniendo de relieve la inexperiencia y por consiguiente la capacidad de asombro y la irresistible atracción que sobre el adolescente ejercen la belleza y la sensualidad recién descubiertas:

$$
\begin{aligned}
& \text { mes nul jor mes ne me queïsse } \\
& \text { remuer tant con je veïsse } \\
& \text { cestes genz ainsi enforcier } \\
& \text { de queroler et de dancier } \\
& \text { Rose, } 771-774
\end{aligned}
$$

La articulación del sueño con los recursos alegóricos y la figura del narrador, que asume desde el conocimiento de la vida las primeras experiencias de la juventud, permite la inclusión natural de otros espectadores, 
los receptores de la obra, cuya presencia en el resto de los romans debía darse por hecha, pero a los que aquí se requiere insistentemente y con malicia mediante el verbo veoir. Bien es cierto que el pretérito imperfecto de subjuntivo en segunda persona del plural: "lors veïssiez quarole aler et gent mignotement baler" (Rose, 741 - 742), apela a la imaginación y a la rememoración de vivencias propias, pero estas no son menos útiles que la percepción ocular para estimular los sueños: “ainz les veïssiez entr'eus deus baisier come .ii. colombiaus" (Rose, 1272 - 1273). Cualquier detalle, como la presencia de unos simples músicos y su actuación, sirve para evocar la unión de hombres y mujeres en un ambiente desenfadado y festivo, asociando a la visión, las sensaciones auditivas y táctiles: “La veïssiez fleüteors et menestreus et jugleors" (Rose, 745 - 746).

Veoir puede adoptar un sentido eufemístico, pues la relación visual prefigura y contiene, aquí en menor grado que para regarder, contactos más íntimos entre los amantes, y ello aunque en el discurso de un determinado personaje, como por ejemplo en el del rey Marco, se pretenda descartar esta posibilidad: "Dame, veïs puis mon nevo?" (Tristan, 399). La respuesta de Iseo, en la que repite el verbo veoir y lo une a parler y estre en frases muy cortas, sin dejar el menor espacio para una explicación o una excusa, confirma su deseo de apartar toda sospecha de la mente del esposo al transcribir sucintamente la escena que él mismo había presenciado; pero, al mismo tiempo, para los que conocen el engaño, abre las puertas a una interpretación equívoca, pues saben que su compostura era una pose y que para los enamorados el estar juntos, el poder verse y hablarse aun en condiciones tan precarias es suficientemente gratificador, más áun si burlan al marido:

$$
\begin{aligned}
& \text { Gel vi et pus parlai a lui, } \\
& \text { o ton nevo soz cel pin fui. } \\
& \text { Or m'en oci, roi, se tu veus. } \\
& \text { Certes, gel vi. (...) }
\end{aligned}
$$$$
\text { Tristan, } 403 \text { - } 406
$$ 
El rey Bademagu, que se hace cargo de la seguridad de Ginebra, evita el contacto visual íntimo de los caballeros con ella - de ahí que acompañe a Lanzarote cuando éste se presenta ante la reina—, ${ }^{491}$ y especialmente las miradas de su propio hijo, pues quiere ante todo impedir la exacerbación del deseo de Meleagant y su más que probable violencia sexual para obtener el cuerpo de la reina: "que neïs veoir ne la lait son fil, qui molt an est dolanz, fors devant le comun des genz" (Charrete, 4054 - 4056). Sin embargo es Renart el que saca mayor partido del equívoco sentido del verbo cuando a Aelis se le ofrece la posibilidad de buscar alojamiento en una casa de la ciudad y no en una chabola de los arrabales: en ese contexto Isabel utiliza el verbo veoir, por supuesto menos con el sentido de «alojan» que con el gozar del cuerpo de la doncella que viaja sola, lo que provocará una inmediata intervención de Aelis para dejar bien clara su intención de mantener intacto su honor no ante los hombres, sino ante Dios:

$$
\begin{aligned}
& \text { borgois et clercs et chevaliers } \\
& \text { qui vos verront ml't volentiers, } \\
& \text { et vallés qui sient au change }
\end{aligned}
$$

Escoufle, 4933 - 4935

Lorris coincide en la asociación de la visión con el placer. Al hacerlo transgrede las normas semánticas de orden contextual que rigen la combinación de ciertos términos, pues hace funcionar el sustantivo solaz como complemento de objeto directo del verbo veoir. Crea de esta forma una fusión entre el objeto contemplado que produce placer y el placer erótico en sí mismo y da a entender que el paso de este goce tan simple a otros futuros y más gratificantes debiera hacerse fácilmente. Con ello se intensifica la sensación placentera pero también se establece una mayor dependencia que hará aún más insoportable el dolor del enamorado cuando no le sea posible seguir viendo: "et tot adés estraint ses laz tant con je voi plus de solaz" (Rose, 3359 - 3360).

491 Charrete, 3942 - 3943 y 4448 - 4451. 
La observación de la morfo-sintaxis de las formas del verbo veoir en el corpus nos presenta dos características importantes: por un lado el gran número de ocurrencias en pretérito anterior, tiempo que todavía no había sido desbancado por el pretérito pluscuamperfecto, pero que en el caso concreto de este verbo se hace más abundante de lo que hasta ahora hemos podido ver en el resto de los términos de la clase verbal. Tan sólo recogemos algunos ejemplos como muestra: "Isnelemant s'an vont par la ou la reïne orent veüe" (Charrete, 598 - 599), "qui le jour ne l'ot veüe ains puis ne vit si bele" (Escoufle, 8940 - 8941), “et vi qu'ele estoit puis creüe que quant je l'oi premiers veüe” (Rose, 3341 - 3342).

Por otro lado la gran cantidad de formas infinitivas nos ha hecho detenernos en las funciones que cumplen en el seno de la frase. En primer lugar hallamos algunos casos de infinitivo sustantivado gracias a un adjetivo: “et que adés ceste tor voies, que boen veoir et bel la fet" (Charrete, 3702 3703), o a un artículo, ya sea posesivo, ya determinado en contracción con una preposición: “de son veoir n'ai ge que faire” (Charrete, 3946), “et se tu te puez tant pener qu'au veoir puises asener" (Rose, 2323 - 2324). En segundo lugar, el infinitivo no determinado aparece a menudo precedido por una preposición. Las funciones que cumple en la proposición pueden ser muy variadas, complemento de objeto directo: "la chose de trestot le mont que plus desirroit a veoir" (Charrete, 3672 - 3673); complemento de un adjetivo: “de li veoir quidoit il estre ml't honerés” (Escoufle, 4826 - 4827); complemento circunstancial con valor final: "de cels qui issent fors au plain pour veoir celi qui s'en va” (Escoufle, 8018 - 8019); régimen preposicional de una locución verbal con valor final: “car je n'avré ja mes loisir de veoir ce que je desir" (Rose, 3747 - 3748). En último lugar, especialmente en Charrete, el infinitivo es el núcleo verbal de locuciones en las que el auxiliar es un verbo modal, como pooir. "quant il ne la pot veoir" (Charrete, 565), "que la reïne ne vos puet veoir" (Charrete, 3984 - 3985), "s'el me peüst encor veoir" (Escoufle, 3172), o voloir. "et onques veoir ne le vos" (Charrete, 4213). 
Son muy numerosas las ocurrencias del verbo que se encuentran al final de verso, sin embargo, y pese a que algunos términos se repiten aunque sea con distinta flexión, no parece que haya una voluntad clara por parte de los autores de crear asociaciones semánticas estables que refuercen el contenido de unas u otras formas, de esto podemos sacar la conclusión de que los imperativos formales se reducen a la voluntad de poner en relieve las formas del verbo veoir. Tan sólo creemos que merece la pena destacarse en cuanto a la conformación de los versos un fragmento de Rose, un discurso panegírico en estilo directo de Venus con el que pide un beso para el enamorado. Mediante la reiteración del imperativo —una ocurrencia en posición final de verso y otra en posición inicial— exige, no en vano se trata del avasallador instinto femenino, que la doncella observe el modo de ser y de actuar así como el agradable aspecto del adolescente:

car vos savez bien et veez

(...)

Veez come il est acesmez,

Rose, 3428 - 3433

\begin{tabular}{lllllllll}
\hline FORMA & CA & BD & NV & RIMA & CA2 & NV2 & D & PERS \\
\hline veez & V & Charrete & 1414 & creez & V & 1413 & D & Demoiselle \\
veez & V & Rose & 3428 & veez & O & 3427 & D & Vénus \\
veïsse & V & Charrete & 4212 & feïsse & V & 4211 & D & Guenièvre \\
veïsse & V & Rose & 772 & queïsse & V & 771 & N & Narrador \\
veïssent & V & Escoufle & 8285 & issent & V & 8286 & N & Narrador \\
veïst & V & Rose & 2476 & aïst & V & 2475 & D & Amant \\
veïst & V & Charrete & 3564 & meïst & V & 3563 & L & Guenièvre \\
veïst & V & Charrete & 3645 & preïst & V & 3646 & N & Narrador \\
veïstes & V & Charrete & 4474 & feïstes & V & 4473 & D & Lancelot \\
veïstes & V & Rose & 3316 & tristes & A & 3315 & D & Franchise \\
veïstes & V & Rose & 814 & vites & A & 813 & N & Narrador \\
veoir & I & Charrete & 565 & cheoir & I & 566 & N & Narrador \\
veoir & I & Charrete & 4459 & cheoir & I & 4460 & N & Narrador \\
veoir & I & Rose & 2713 & mechoair & I & 2714 & D & Amour \\
veoir & I & Escoufle & 3172 & savoir & I & 3171 & D & Guillaume \\
veoir & I & Charrete & 3673 & seoir & I & 3674 & N & Narrador \\
veoir & I & Charrete & 3943 & seoir & I & 3944 & D & Roi Bademagu \\
verras & V & Rose & 2328 & demoinras & V & 2327 & D & Amour \\
verras & V & Rose & 2347 & querras & V & 2348 & D & Amour
\end{tabular}




\begin{tabular}{|c|c|c|c|c|c|c|c|c|}
\hline veü & $\mathrm{O}$ & Rose & 2351 & deceü & $\mathrm{O}$ & 2352 & $\mathrm{D}$ & Amour \\
\hline veü & $\mathrm{O}$ & Rose & 2992 & deceü & $\mathrm{O}$ & 2991 & $\mathrm{D}$ & Raison \\
\hline veü & $\mathrm{O}$ & Escoufle & 3225 & eü & $\mathrm{O}$ & 3226 & $\mathrm{~N}$ & Narrador \\
\hline veü & $\mathrm{O}$ & Escoufle & 7407 & perdu & $\mathrm{O}$ & 7408 & $\mathrm{~N}$ & Narrador \\
\hline veü & $\mathrm{O}$ & Rose & 1417 & seü & $\mathrm{O}$ & 1418 & $\mathrm{~N}$ & Narrador \\
\hline veüe & $\mathrm{O}$ & Charrete & 599 & aconseüe & $\mathrm{O}$ & 600 & $\mathrm{~N}$ & Narrador \\
\hline veüe & $\mathrm{O}$ & Rose & 3342 & creüe & $\mathrm{O}$ & 3341 & $\mathrm{~N}$ & Narrador \\
\hline veüe & $\mathrm{O}$ & Escoufle & 1735 & eüe & $\mathrm{O}$ & 1736 & $\mathrm{~N}$ & Narrador \\
\hline veüe & $\mathrm{O}$ & Escoufle & 5485 & eüe & $\mathrm{O}$ & 5486 & $\mathrm{~N}$ & Narrador \\
\hline veüe & $\mathrm{O}$ & Escoufle & 5745 & eüe & $\mathrm{O}$ & 5746 & $\mathrm{~N}$ & Narrador \\
\hline veüe & $\mathrm{O}$ & Rose & 2368 & rue & $S$ & 2367 & $\mathrm{D}$ & Amour \\
\hline veüe & $\mathrm{O}$ & Escoufle & 3451 & seüe & $\mathrm{O}$ & 3452 & $\mathrm{D}$ & Guillaume \\
\hline veüe & $\mathrm{O}$ & Escoufle & 4811 & veüe & $\mathrm{S}$ & 4812 & $\mathrm{~N}$ & Narrador \\
\hline veüe & $\mathrm{O}$ & Escoufle & 8035 & veüie & $S$ & 8036 & $\mathrm{~N}$ & Narrador \\
\hline veüs & $\mathrm{O}$ & Escoufle & 7804 & connus & $\mathrm{O}$ & 7803 & $\mathrm{~N}$ & Narrador \\
\hline vi & V & Rose & 2808 & servi & $\mathrm{O}$ & 2807 & $\mathrm{~N}$ & Narrador \\
\hline virent & V & Escoufle & 8037 & eslirrent & V & 8038 & $\mathrm{~N}$ & Narrador \\
\hline virent & V & Charrete & 435 & firent & V & 436 & $\mathrm{~N}$ & Narrador \\
\hline voi & V & Escoufle & 3457 & avoi & V & 3458 & $\mathrm{D}$ & Guillaume \\
\hline voi & $\mathrm{V}$ & Rose & 2292 & envoi & $\mathrm{V}$ & 2291 & $\mathrm{D}$ & Amant \\
\hline voie & $\mathrm{V}$ & Tristan & 3311 & coie & A & 3312 & $\mathrm{D}$ & Iseut \\
\hline voie & V & Escoufle & 7992 & convoie & V & 7991 & $\mathrm{~N}$ & Narrador \\
\hline voie & V & Charrete & 3994 & gardoie & V & 3993 & $\mathrm{D}$ & Lancelot \\
\hline voie & V & Rose & 3207 & joie & $S$ & 3208 & $\mathrm{~N}$ & Narrador \\
\hline voie & V & Escoufle & 3117 & voie & $S$ & 3118 & $\mathrm{~N}$ & Narrador \\
\hline voie & V & Escoufle & 8676 & voie & S & 8675 & $\mathrm{~N}$ & Narrador \\
\hline voie & V & Rose & 1575 & voie & $S$ & 1576 & $\mathrm{~N}$ & Narrador \\
\hline voient & V & Rose & 2296 & convoient & $\mathrm{V}$ & 2295 & $\mathrm{D}$ & Amant \\
\hline voient & V & Charrete & 6019 & croient & V & 6020 & $\mathrm{~N}$ & Narrador \\
\hline voient & V & Rose & 2724 & envoient & V & 2723 & $\mathrm{D}$ & Amour \\
\hline voies & $\mathrm{V}$ & Charrete & 3702 & soies & $\mathrm{E}$ & 3701 & $\mathrm{D}$ & Pucelle \\
\hline voit & V & Charrete & 5829 & anvoit & $\mathrm{V}$ & 5830 & $\mathrm{~N}$ & Narrador \\
\hline voit & $\mathrm{V}$ & Escoufle & 4775 & avoit & $\mathrm{H}$ & 4776 & $\mathrm{~N}$ & Narrador \\
\hline
\end{tabular}

Tabla 83. Rimas del verbo voir.

Los verbos que introducen las proposiciones subordinadas completivas en las que se halla el verbo veoir son verbos de conocimiento como savoir. "se il la savoit (...) qu'ele l'esgardast ne veïst”' (Charrete, 3643 3645) y de pensamiento como cuidier. "cuida que je li feïsse grant joie, et que je le veïsse" (Charrete, 4211 - 4212), "ne cuit que nus hom voie si tres bele rien a cheval" (Escoufle, 7992 - 7993). Éstos expresan la esperanza de Lanzarote o la contagiosa convicción del narrador de E scoufle sobre la belleza de Aelis. También pueden transcribir, tal como hace le verbo laissier seguido de infinitivo, la autoridad del rey en una época en que la institución monárquica en connivencia con la Iglesia pretendía reforzar su posición e 
imponer unos determinados comportamientos sociales y por ende eróticos: "neïs veoir ne la lait son fil" (Charrete, 4054 - 4055). O bien expresan la voluntad femenina, contraviniendo las todavía vigentes reglas eclesiásticas así como las nuevas reglas adoptadas por la burguesía merced a voloir: "qu'ele vaut que cil la veïssent” (Escoufle, 8285), y con pleire: “mes ne li plest qu'ele me voie" (Charrete, 3994), que representa el capricho de la despótica dama del siglo XII.

Es la obra de Lorris la que con mayor asiduidad acude a las proposiciones de relativo. Sólamente hay tres proposiciones en Charrete, de ellas dos en las que el relativo funciona como complemento de objeto directo, retomando los cabellos o la persona de la reina, y el sujeto es el propio Lanzarote (Charrete, 1414, 3672 - 3673), y la tercera en la que el caballero que viene ante la reina para ser visto por ella es también sujeto de la visión gracias al relativo qui, aunque tal reciprocidad quedará rota por voluntad de Ginebra: "Dame, veez ci Lancelot, fet li rois, qui vos vient veoir" (Charrete, 3942 3943).

Cada uno de los roman del siglo XIII opta por diferentes construcciones según la función que adopta el pronombre relativo y el valor referencial del antecedente, siempre en el discurso narrativo o en el pseudonarrativo que caracteriza los vaticinios del dios Amor.

En Rose el pronombre relativo ejerce la función de complemento de objeto directo y con él el narrador en primera persona hace referencia explícita a la rosa: "la rose que je soloie veoir de pres" (Rose, 3753 - 3754). El dios Amor alude a conceptos abstractos como la belleza: "de la biauté que tu verras" (Rose, 2328), al aún indefinido objeto de deseo, acudiendo a una construcción de una gran vaguedad como la formada por el pronombre demostrativo ce y el pronombre relativo neutro que: "trestot le jor te sovendra de ce que tu avras veü” (Rose, 2350 - 2351), ${ }^{492}$ o bien a un lugar

492 “au cuer envoient noveles de ce que il voient” (Rose, 2723 - 2724) 
indeterminado de la ciudad en el que el amante había podido ver a la amada: “en la rue ou tu avras cele veüe” (Rose, 2367 - 2368).

En E scoufle el pronombre relativo es sistemáticamente sujeto y tiene como antecedentes a los hombres o los ciudadanos en general que observan la belleza de la heroína. Aunque puede aparecer algún relativo sin antecedente con el mismo valor generalizador que le hemos asignado más arriba (Escoufle, 8940 - 8941), es más habitual en los contextos en los que se encuentra veoir que se aluda a grandes conjuntos de personas: “qu'encore en ot mil a S. Gille qui ainc mais ne l'orent veüe" (Escoufle, 8034 - 8035). ${ }^{493}$

La visión se convierte en múltiples ocasiones en punto de referencia para explicitar las circunstancias como la causa, el tiempo, la condición o la consecuencia en las que se produce una determinada acción, expresada por una proposición principal o una subordinada de la que a su vez depende una proposición subordinada circunstancial. A continuación vamos a recoger algunos ejemplos de estos diferentes tipos aunque debemos señalar que la causa y la temporalidad acaparan la mayor parte de las ocurrencias. Esta última circunstancia llega a superponerse en algunos contextos concretos a la condición, pues la expresión de la temporalidad equivaldría a la suma de aquélla más una especificación del inicio del proceso. En otras ocasiones la polivalencia de la conjunción que impide determinar con precisión si se trata de un tipo u otro de expresión circunstancial, como en el siguiente ejemplo donde no podríamos decir si se trata de una nueva causa o de una determinación temporal: “car ses ombres l'avoit traï, qu’il cuida voair la figure d'un esfant bel a desmesure" (Rose, 1484 - 1486)

- Causales: Junto a la conjunción que, que puede sustituir en antiguo francés cualquier nexo conjuntivo: “que bien orent veü comant il l'avoit fet premieremant" (Charrete, 5719 - 5720), dos son los que destacan en la transcripción de la causa, car en Rose: “car je n’avré ja mes loisir de veoir ce

${ }^{493}$ Escoufle, 4933 - 4934, 8018 - 8019 y 8036 - 8037. 
que je desir" (Rose, 3747 - 3748), "char a voair mout desirasse son contenement et son estre” (Rose, 710 - 711), "Ne li devroit estre veez, car vos savez bien et veez qu'il sert et ainme en leauté” (Rose, 3427 - 3429), y la locución conjuntiva por ce que [Prep. + Pron. + C onj.] en E scoufle. “por ce qu’il n'ot ainc mais veüe si bele riens” (Escoufle, 4811 - 4812), de la que encontramos también una ocurrencia en Charrete. "si con s'ele fust ja s'espouse, por ce que si adroit le voient" (Charrete, 6018 - 6019). En la mayor parte de estos ejemplos se puede observar una coincidencia dentro del mismo roman en cuanto al subtema en torno al que se expresa la causa, lo que a su vez lleva consigo la repetición de ciertos términos o de ciertas construcciones circunstanciales, como desirer en Rose y las locuciones adverbiales ainc puis o ainc mais $[\mathbf{A d v} .+\mathbf{A d v}$.] en la obra de Renart. Chrétien pone de relieve las causas de la elección de Lanzarote por las doncellas, mientras que Renart vuelve a uno de sus temas preferidos, la extraordinaria belleza de Aelis que cautiva a quienes la contemplan: "ml't la en son cuer enamee por ce que si bele la voit" (Escoufle, 4774 - 4775), y les obliga a actuar ateniéndose a un estricto código de honor. También en relación con la visión de la belleza, amplía el tema de la comunión de los corazones:

$$
\begin{aligned}
& \text { pour ce qu'el n'ot ainc puis veü } \\
& \text { home qu'ele ot cestui perdu, } \\
& \text { que li seïst au cuer si bien }
\end{aligned}
$$$$
\text { Escoufle, } 7407 \text { - } 7409
$$

- Temporales: A las proposiciones cuyo núcleo verbal es el gerundio veant que ya hemos comentado, se suman en todo el corpus las que se hallan encabezadas por la conjunción quant para la expresión de la simultaneidad: "mais il le fait par lecherie, qant or verra passer s'amie" (Tristan, 3693 - 3694), si bien Chrétien utiliza también la locución conjuntiva tot maintenant que [Adv + Adv + Conj] que refuerza el sentido de instantaneidad, de coincidencia exacta en el comienzo de los procesos: "tot maintenant que eles 
virent mon seignor Gauvain, si li firent grant joie, et si le salüerent” (Charrete, 435 - 437),

\author{
quant la reïne point n'an voit, \\ talanz li prist qu'ele l'anvoit \\ les rans cerchier tant qu'an le truisse \\ Charrete, 5829 - 5831494 \\ quant j’oi veües les semblances \\ de ceus qui menoient les dances \\ Rose, 1283 - 1284495 \\ quant le mul ne li ne voit mie, \\ il s'esbahist et si se saigne \\ Escoufle, 5088 - 5089
}

La datación respecto a un proceso posterior mediante la locución tant que [A dv. + C onj.] la hallamos en Tristan: "gart moi l'argent, tant que le voie priveement, en chanbre coie" (Tristan, 3311 - 3312), mientras que en Escoufle o en Rose se presenta un proceso anterior ya sea mediante la conjunción que: "s’il onques but ne ne manga, kilil ne me vit" (Escoufle, 3253 - 3254) o de la locución des lores que [Prep. + Adv. + Conj.] mediante la que también se señala con cierta insistencia el comienzo del proceso: "mout a esté penssis et tristes des lores que vos nou veïstes" (Rose, 3315 - 3316).

- La expresión de la condición, tan sólo recogida en los textos del siglo XIII, aparece introducida por la conjunciones se o que: "gariz fust, ćun poi la veïst!" (Rose, 2476). Pueden expresar como la anterior un deseo irrealizable, un hecho irreal en el presente merced a la repetición del

494 “quant il ne la pot veoir, si se vost jus lessier cheoir" (Charrete, 565 - 566). 
imperfecto de subjuntivo en la prótasis y en la apódosis, o bien un hecho que el locutor considera posible en el futuro merced a la combinación de la forma en -roie con un imperfecto en la subordinada:

$$
\begin{aligned}
& \text { car g'istroie fors de mon sens } \\
& \text { se je veoie autre home avoir } \\
& \text { Escoufle, } 3516 \text { - } 3517
\end{aligned}
$$

- Consecutivas: Aunque la conjunción que introduce regularmente todas las proposiciones que encontramos en el corpus, no existe coincidencia en cuanto a las formas que en la proposición principal sirven para anunciar la expresión de la consecuencia. La importancia que se otorga en Charrete al espacio desde el que las mujeres nobles observan los combates entre caballeros, generalmente una torre, queda señalada por el adjetivo indefinido tel, éste acompaña al sustantivo que indica el lugar al que se hará referencia en la subordinada: "la nuit proié qu'il la meïst an tel leu que ele veïst la bataille tot a bandon" (Charrete, 3563 - 3565). Renart, atento en cualquier circunstancia a realzar la belleza de Aelis, recurre al adverbio intensivo si: "qu'ele est si bele a la candeille ćconques sa pers ne fu veüe" (Escoufle, 5744 - 5745). Mientras que el recién descubierto mundo del amor y del placer erótico llevan al joven adolescente a recorrer compulsivamente el jardín de Deduit para observar cada uno de sus rincones, cada una de sus posibilidades, lo que se expresa mediante la intensificación del verbo aler con el adverbio tant:

mes j'alai tant destre et senestre

que j'oi tot l'afere et tot l'estre

dou vergier cerchié et veü

$$
\text { Rose, } 1416 \text { - } 1417
$$

\footnotetext{
495 “et vi qu'ele estoit puis creüe que quant je l’oi premiers veüe” (Rose, 3341 - 3342), "Bel Acueil m’ot mout bien servi quant le bouton de si pres vi" (Rose, 2807 - 2808).
} 


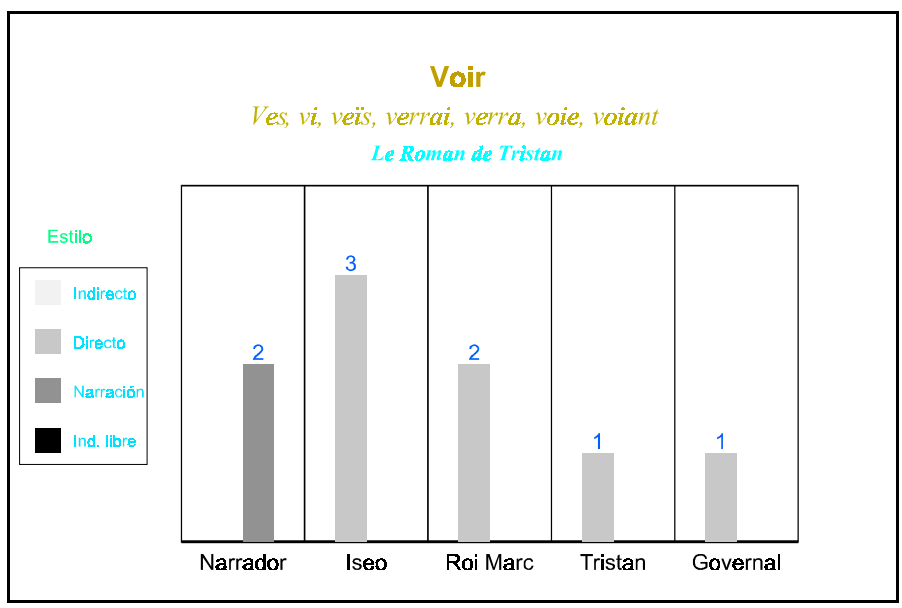

Fig. 128. Comportamiento estilístico del verbo voir en Tristan.

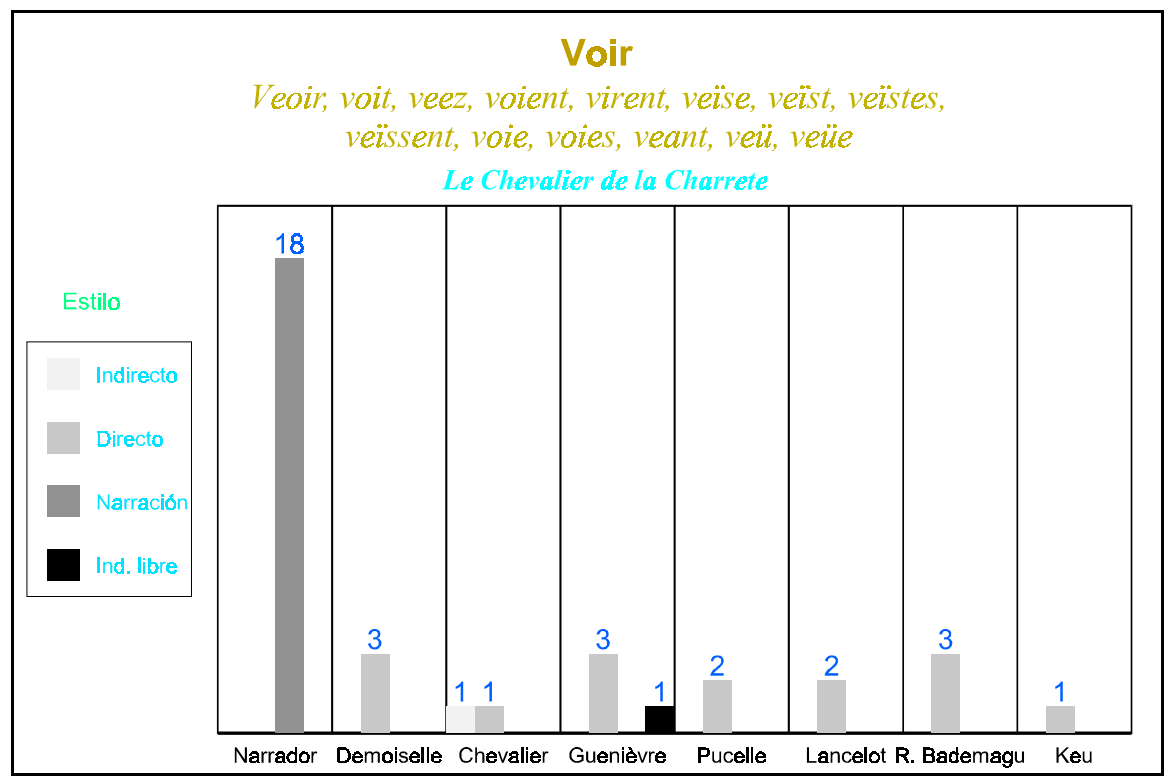

Fig. 129. Comportamiento estilístico del verbo voir en Charrete. 


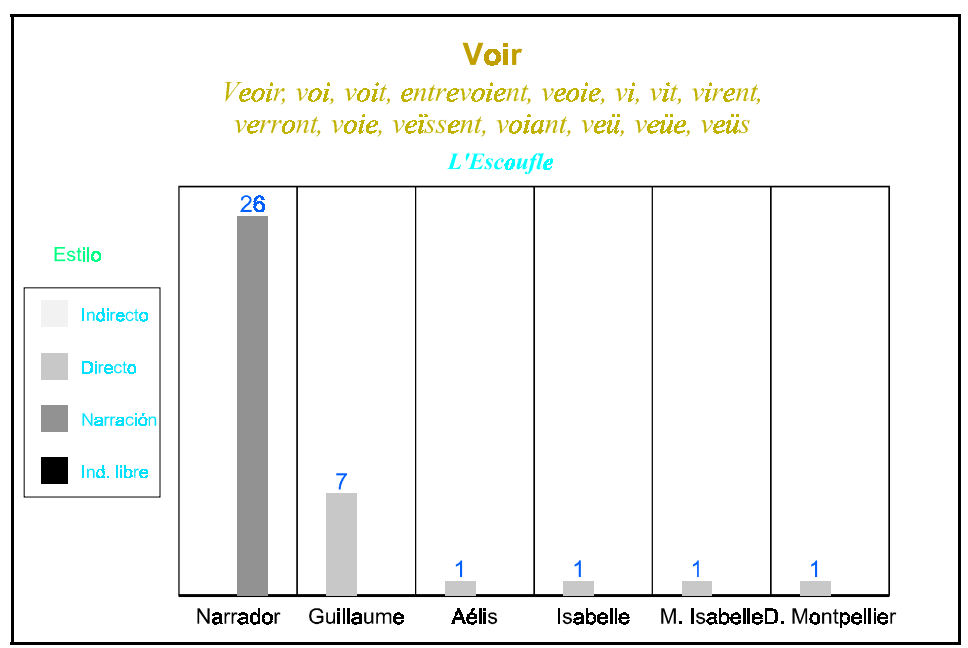

Fig. 130. Comportamiento estilístico del verbo voir en Escoufle.

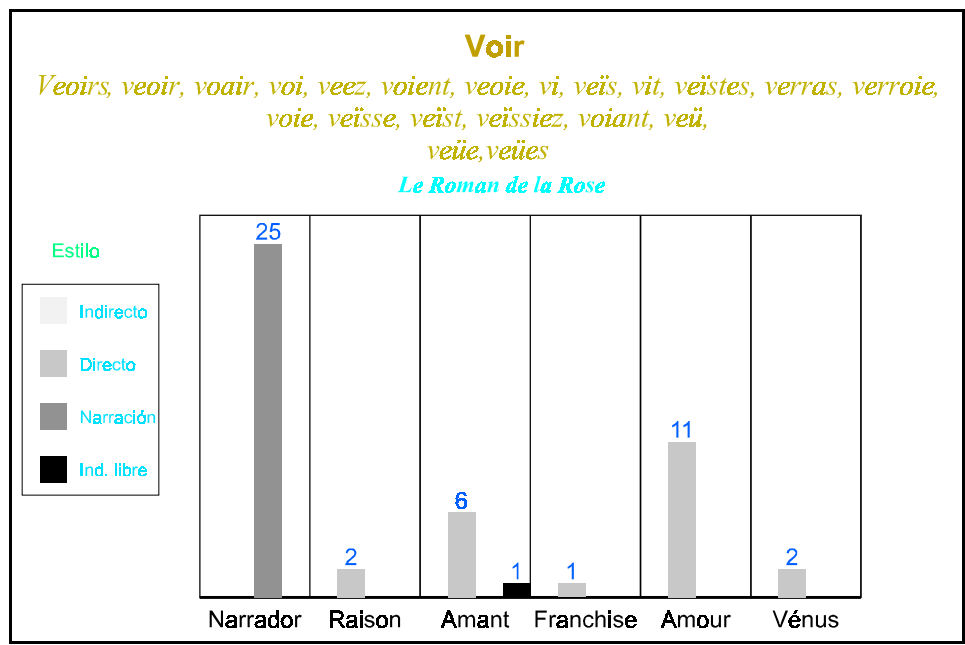

Fig. 131. Comportamiento estilístico del verbo voir en Rose.

Teniendo en cuenta los datos que recogen estos gráficos y en consonancia con los otros términos referidos a la percepción visual, observamos que el uso del verbo veoir se incrementa notablemente en los textos más influidos por la cortesía clásica. Se añade, empero, otro fenómeno digno de ser destacado: también E scoufle lo utiliza abundantemente pese a que ya hemos podido adscribirlo a una corriente más libre con respecto a la mencionada tendencia ideológico - estilística. Ésta hace por ejemplo que E scoufle y Tristan recurran a los sentidos que hemos calificado de eufemísticos, del mismo modo que Chrétien en el discurso del anti-héroe caballeresco Meleagant. 


\subsection{LAS SENSACIONES OLFATIVAS.}

\subsection{1 «Basme», flairer, odeur, «olen», «olent» y «soautume».}

Rose es el único roman que alude al sentido del olfato al desarrollar la metáfora de la rosa. Dos son los efectos destacables: sirve para la descripción y constituye uno de los elementos fundamentales en la elección de la rosa mujer y en el enamoramiento. Las sensaciones olfativas, ya tengan su origen en las agradables fragancias de los perfumes o en las primitivas y estimulantes feromonas, constituyen uno de los excitantes sexuales más poderosos, y el amante de la rosa no sólo se siente atraído por aquella cuyo exquisito olor supera al de las demás rosas - mujeres, sino que tras el beso, tres tipos de sensaciones que podríamos llamar secundarias en la literatura medieval, las olfativas, las táctiles, y las gustativas, se entremezclan para conquistar el cuerpo del amante. Su deseo y sus sentimientos se fijan definitiva y dolorosamente en ella sola, aunque el olor, como la visión, puede ser también un bálsamo que reduce los sufrimientos del enamorado.

El olor es una sensación poco elaborada retóricamente como fuente de la pasión: a diferencia de la visión y de los ojos que están conectados con el corazón, lugar de los sentimientos, el olfato se relaciona con las vísceras, con los impulsos irracionales, las necesidades fisiológicas y el instinto de procreación, lo que estaría en consonancia con estudios muy recientes acerca de la influencia que los olores corporales ejercen sobre la elección del partenaire sexual. ${ }^{496}$

Hechas estas consideraciones previas veamos cómo Lorris refleja formalmente las percepciones olfativas. Para ello establece y reproduce una

\footnotetext{
496 Dufournet, por el contrario, señala la relación del perfume con lo espiritual aunque no la justifica en L'amour d'un Roman de la Rose à l'autre (De Jean Renart à Guillaume de Lorris), A nnales U SB, Vol. XIX, $1989-1990$, p. 52.
} 
serie de esquemas sintácticos, que tienen, evidentemente, repercusiones semánticas:

- Los sustantivos funcionan como objeto directo o como sujeto de la proposición: “l'odor de lui entor espent” (Rose, 1666)

$$
\begin{aligned}
& \text { l'odor des roses savoree } \\
& \text { m'entra jusques en la coree } \\
& \text { Rose, } 1625 \text { - } 1626
\end{aligned}
$$

En el primer caso como complemento de los verbos espendre, rendre, eissir, avoir. "mes je passasse la cloisson mout volentiers por l'achoison dou bouton qui eut mieuz de basme" (Rose, 2765 - 2767), ${ }^{497}$ sentir, éste con la particularidad de que sus dos ocurrencias están en infinitivo, del que es sujeto el propio amante, y metre, que tampoco tiene por sujeto a la rosa o el capullo sino al beso del que el amante recuerda mejor el olor que la sensación táctil. Como sujeto lo son de los verbos entrer. "car une odor m'entra ou cors" (Rose, 3463), alegier. "li veoirs sanz plus et l'odors aligoit mout de mes doulors" (Rose, 1729 - 1730) y replenir. "La soautume qui en ist tote la place replenist" (Rose, 1667 - 1668).

- Se establecen relaciones de calificación axiológicamente positiva, entre un adjetivo y un sustantivo, entre un adverbio y un verbo o entre un adverbio y un adjetivo: "la rose qui soëf flaire" (Rose, 3371)

$$
\begin{aligned}
& \text { Mout bel me fu dont je estoie } \\
& \text { si pres que dou boton sentoie } \\
& \text { la douce odor qui en issoit }
\end{aligned}
$$$$
\text { Rose, } 1803 \text { - } 1805
$$

\footnotetext{
${ }^{497}$ Se trata de la única ocurrencia del sustantivo basme como sinónimo de odor, sentido que no posee actualmente ni poseía en la época medieval.
} 
bien est gariz qui tel flor baise,

qui est si sade et bien $\mathbf{~ o l e n z}$

Rose, 3468 - 3469

- Tanto las formas verbales como los sustantivos aparecen a menudo en construcciones comparativas: “tot jorz d'aler vers la rousete, qui mielz oloit que violeite" (Rose, 1753 - 1754), las cuales establecen siempre una relación de desigualdad en la que el capullo o la rosa que el amante ha elegido superan gracias a su agradable fragancia a las otras flores. También se hallan en construcciones superlativas: "dou bouton qui eut mieuz de basme" (Rose, 2767),

\author{
qui me mist une odor ou cors \\ assez plus douce que de basme \\ Rose, 3756 - 3757 \\ vers le bouton m'en vois errant \\ qui miaudre odor des autres rent
}

Rose, 2801 - 2802

- Como se ha podido observar en los ejemplos precedentes, las proposiciones subordinadas en las que encontramos estos términos son frecuentemente proposiciones relativas tanto determinativas: "je me començai lors a traire vers le bouton qui souëf flaire" (Rose, 1731 - 1732), como explicativas:

et quant du bessier me recors, qui me mist une odor ou cors assez plus douce que de basme, par un poi que je ne me pasme

Rose, 3754 - 3758 


\begin{tabular}{lllllllll}
\hline FORMA & CA & BD & NV & RIMA & CA2 & NV2 & D & PERS \\
\hline basme & S & Rose & 2767 & blasme & S & 2768 & N & Narrador \\
flaire & V & Rose & 3371 & desploire & I & 3372 & D & Amant \\
flaire & V & Rose & 1732 & traire & I & 1731 & N & Narrador \\
odors & S & Rose & 1729 & doulors & S & 1730 & N & Narrador \\
olenz & A & Rose & 3469 & dolenz & A & 3470 & N & Narrador \\
\hline
\end{tabular}

Tabla 84. Rimas del verbo flairer, del adjetivo «olent», y de los sustantivos odeur, «soautume»y «basme».

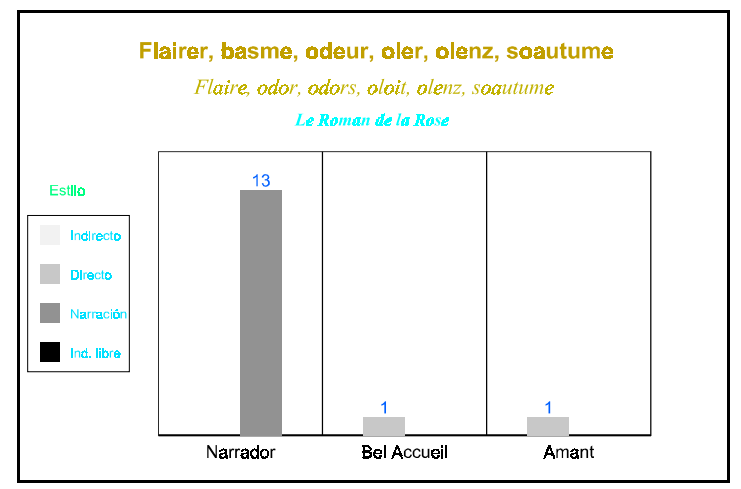

Fig. 132. Comportamiento estilístico de los sustantivos «basme», «soautume» y odeur, del adjetivo «olent» y de los verbos flairer y «oler» en Rose.

El perfume, el olor suave y agradable que se expande no sólo en el espacio sino en el tiempo - la mayor parte de las ocurrencias se hallan en el discurso del narrador en primera persona, el supuesto adulto que narra sus recuerdos-, y que, además, penetra en el cuerpo, en las entrañas del enamorado con más intensidad que las sustancias con las que se embalsama un cadaver, posee los poderes a la vez alienantes y calmantes de la percepción del cuerpo amado y deja al adolescente a merced de las flechas del dios Amor y de las contradicciones a las que se ve sometido al ser rechazado inmediatamente después de haber comenzado su conquista. 


\subsubsection{EL CONTACTO FÍSICO.}

\subsection{TÉRMINOS GENERALES.}

\subsection{Chair.}

El corpus recoge prácticamente todos los sentidos que actualmente posee este vocablo aplicado a los seres humanos. En primer lugar y en relación no tanto con el tacto como con la vista, representa el aspecto externo del cuerpo y de la piel, del que se atiende especialmente al color. Los estragos físicos ocasionados por el largo exilio en el bosque del Morrois nos muestran a los amantes delgados y pálidos, han perdido por lo tanto parte de su belleza y de los rasgos distintivos de las clases aristocráticas, mejor alimentadas que el resto de la población: "trois anz plainiers sofrirent peine, lor char pali et devint vaine" (Tristan, 2131 - 2132). En Rose hallamos la antítesis de esta somera descripción, no sólo por el magnífico y deseable aspecto de los personajes femeninos retratados al comienzo de la obra, sino por la relevancia que se otorga a la carne como elemento descriptivo, máxime al intervenir con más fuerza las sensaciones táctiles que los aspectos visuales. Junto a la blancura destacada por el verbo blancheoir y el contraste con el color de la ropa íntima, el adjetivo alise muestra la finura y suavidad de la piel en el primer ejemplo que recogemos, mientras que en el segundo al color intensamente rosado de la cara se une la extrema delicadeza de la piel:

s'avoit sa gorge descoverte

si que par outre la chemise

li blancheoit la char alise

Rose, 1170 - 1172 
el resembloit rose novele

de la color sus la char tendre,

que l'en li peüst tote fendre

a une petitete ronce

Rose, 838 - 841

Los rasgos que definen la carne jóven como primer término de una comparación de igualdad o de superioridad son de nuevo la delicadeza, la suavidad y la blandura: "la char plus tendre que poucins" (Rose, 526), "la char plus soëf que toison" (Rose, 538), "tendre ot la char come rosee" (Rose, 999). Estos elementos naturales que forman el segundo término de las comparaciones - el último se aparta de los anteriores y de las descripicones precedentes aportando una cierta irrealidad, una fragilidad feérica al retratocumplen dos objetivos entremezclados: acercar el jardín y sus habitantes a la cotidianeidad, ya que su extremada perfección los alejaba del común de los mortales, y acentuar la sensualidad mediante la valoración de las percepciones táctiles, en gran medida relegadas a un segundo plano pero que las reglas del cortejo cortés había llevado, al menos teóricamente, a una situación privilegiada. Todo ello sin olvidar que la diversificación de los rasgos descriptivos y por lo tanto eróticos correspondía en el siglo XIII a una revalorización del cuerpo como imagen de la belleza divina.

En plural en la obra de Béroul, el sustantivo char hace referencia a los cuerpos de los amantes separados por la espada y cubiertos con sus ropas, y en un segundo movimiento metonímico que se sitúa en el nivel simbólico debemos interpretar que remite también al instinto, al sexo: "Tristran se couche et trait s'espee, entre les deux chars l'a posee" (Tristan, 1805 - 1806). Adquiere el sentido de una locución adverbial poco habitual precedido por la preposición de e intensifica el valor sexual y peyorativo que posee el verbo adeser en Charrete. El rey Bademagu protege a la reina Ginebra, quien de forma excepcional se halla a salvo de las violencias sexuales a las que se 
encontraban sometidas las cautivas, siempre a merced de los beneficiarios del botín de guerra:

$$
\begin{aligned}
& \text { La reïne a boene prison } \\
& \text { que nus de char a li n'adoise, } \\
& \text { neïs mes filz cui molt an poise, } \\
& \text { qui avoec lui ça l'amena } \\
& \text { Charrete, } 3362 \text { - } 3365
\end{aligned}
$$

No menos explícito resulta uno de los contextos en los que encontramos char en el discurso directo de Guillermo: como más tarde evocará la propia Aelis, el amante reconoce que en sus relaciones prematrimoniales - habituales en la Edad Media y aun posteriormente en las capas populares de la sociedad—498 ha existido el contacto carnal, que ha acariciado el cuerpo desnudo de la amada aunque lo hace mediante una construcción negativa que más bien establece una salvedad: "Ainc voir ne senti sa char nue a sa honte, n'a son damage" (Escoufle, 3028 - 3029). En la confesión de estos contactos que coinciden con los ritos que debían preceder o sustituir al coito en las relaciones corteses, los sintagmas preposicionales con valor restrictivo a sa honte y a son damage podrían referirse más que a las caricias externas, a las penetraciones vaginales realizadas con los dedos o con el pene, que hubiesen causado daños en el himen y por lo tanto hubieran arremetido contra el valor ascendente de la virginidad. En cualquier caso Chrétien y Renart ponen de relieve el contacto con la carne desnuda — las dos ocurrencias de E scoufle se hallan seguidas del adjetivo nue- El contacto puede producirse con el cuerpo femenino o con una de sus partes, como en el ejemplo anterior, o con un objeto al que se le rinde o rendirá un culto fetichista, los cabellos de la reina Ginebra: “an son soing, pres del cuer, les fiche entre sa chemise et sa char' (Charrete, 1468 - 1469), o la limosnera que

${ }^{498}$ De hecho, hasta el concilio de Trento la unión sexual completa convertía a los prometidos en esposos. Cf. G. Duby y Ph. Ariès, De l'Europe féodale à la Renaissance, op. at., p. 137. 
Aelis regalará a su enamorado y que previamente se ha empapado con el sudor de su pecho: "li samis ert .j. poi sullens por ce qu'il ert a sa char nue" (Escoufle, 4476 - 4477).

La función sintáctica dominante de char es la de complemento de objeto directo pues es la más habitual en las descripciones de Rose, en las que depende del verbo avoir en pretérito definido, seguida por la de complemento preposicional, generalmente con valor circunstancial. Tan sólo dos ocurrencias funcionan como sujeto — ambas forman también parte de una descripción-, una seguida del verbo atributivo devenir en Tristan y otra como sujeto del verbo blancheoir en Rose.

En cuanto a la construcción de los versos, observamos que el sustantivo no está supeditado a las condiciones formales de la rima pues solamente una ocurrencia se halla en esta posición; sin embargo sí suele ocupar o bien la segunda posición del verso precedido del artículo determinado o bien la penúltima, seguido de un adjetivo.

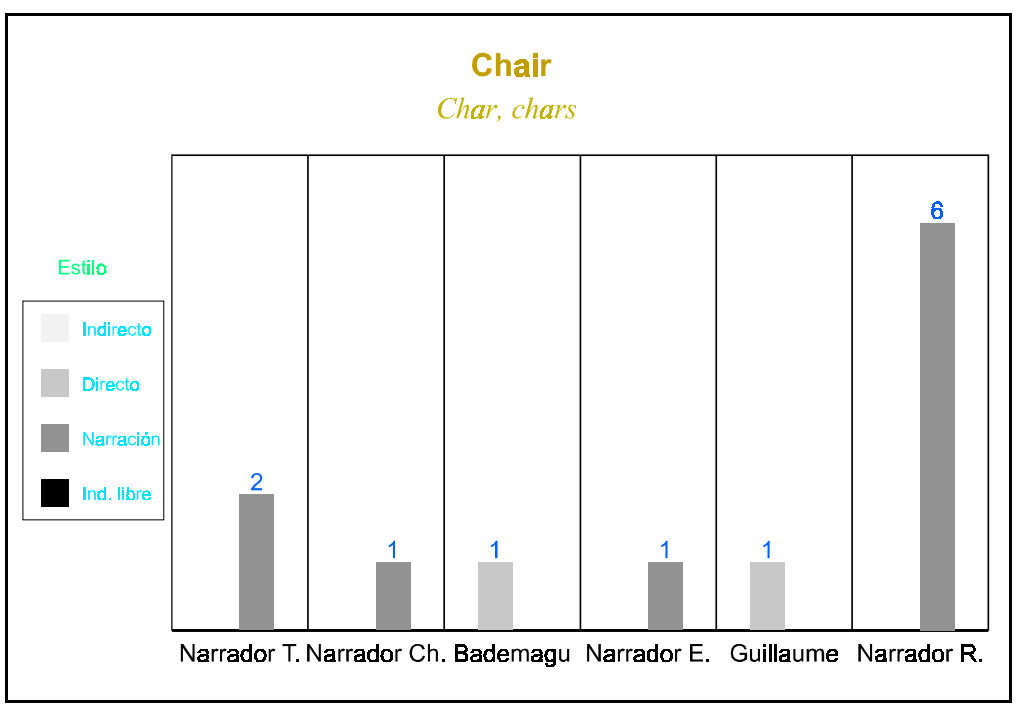

Fig. 133. Comportamiento estilístico del sustantivo chair en el corpus.

Las cualidades metonímicas y descriptivas del sustantivo tan sólo esbozadas en el siglo XII adquieren mayor intensidad en los romans del siglo 
posterior en los que el tacto, la vista o ambos a la vez, calibran y gozan del contacto. Las evocaciones eróticas se hallan restringidas al ámbito intradiegético hasta llegar a Rose. Pero Lorris, mediante las descripciones sometidas al prisma del voyeur - narrador, parece dirigirse más bien al ánimo de los receptores de la obra y los predispone a aceptar la sutil mezcla entre lo natural y lo simbólico, entre la perfección y la normalidad de lo cotidiano.

\subsection{2 «Adesen», «ajosten», «josten», assembler, rassembler $\mathbf{y}$ assemblée.}

A excepción de adeser y de algunas ocurrencias de asenbler, las otras formas verbales pueden ser consideradas como sinónimos cuya utilización depende de aspectos estilísticos y formales; de las formas prefijadas, tan sólo el sentido iterativo del prefijo re- se añade efectivamente al verbo asenbler tras la noche de amor entre Ginebra y Lanzarote: "del rasanbler n'est pas pris termes" (Charrete, 4704).

Adeser aparece exclusivamente en Charrete siempre en contextos antisociales que le otorgan un valor peyorativo — reforzado sistemáticamente por su rima con peser-, ya sea por la negativa del hombre a cumplir los deseos de la mujer, ya sea por evocar la violencia que atenta precisamente contra aquéllos. Puede expresar la acción de aproximarse hasta tocar el cuerpo femenino: "qu'il ne quiert a li adeser" (Charrete, 1247), en este caso requisito obligado para cumplir los deseos de la doncella que desearía ser poseída sexualmente por el caballero, quien debería ir más allá de las caricias con las que se cumplía el teórico assag de los trovadores. O bien, en tercera persona del singular del presente de indicativo, hacer referencia al contacto carnal, formulación en la que el sujeto es siempre el varón y el objeto la mujer, lo que se traduce sistemáticamente en la anteposición del complemento pronominal precedido de la preposición a: "quant nu a nu a li adoise" (Charrete, 1084). En este ejemplo el sintagma adverbial nu a nu [Adj. + Prep. + Adj.], 
que aquí implica la desnudez de los cuerpos, sentido que no era habitual, se carga de un alto contenido erótico al abundar en el contacto de las carnes del violador y de la mujer violada y en el consiguiente efecto sobre la percepción visual de Lanzarote y sobre la imaginación de los receptores de la obra.

La intimidad de los cuerpos o figuradamente de los sentimientos y de los deseos de los amantes: "que nos amors jostent ensenble" (Tristan, 30), se constituye gracias a la acumulación de adverbios de cantidad y de lugar: "a une dame de haut pris se fu de mout pres ajostez" (Rose, 990 - 991), y al adverbio de modo ensemble, que en su constante recurrencia, especialmente junto al verbo asenbler, confiere la carga sensual que el sentido denotativo de los verbos no parecía ofrecer. La cópula de Tristan y de la reina es evocada en los versos que preceden al verbo joster, y éste, reforzado adverbialmente, sirve para reproducir la escena en el discurso narrativo adoptando el punto de vista del adivino Frocín, hecho que hace evidente el contenido sexual de la expresión: "a la lune bien vit josté erent ensenble li dui amant" (Tristan, 736 738).

Por su parte asenbler tiene tres valores primordiales:

- Unirse físicamente: “mais amors est si porveans, qu'ele fait cascun a cascune asambler" (Escoufle, 9020 - 9022). Un acto siempre conflictivo en los romans, donde se presentan innumerables obstáculos y donde los escollos más difíciles son los hombres que voluntaria o involuntariamente estorban la voluntad de los amantes. En todos los casos la supremacía del amor — que se expresaba en el ejemplo precedente mediante la conjunción adversativa y la subordinada consecutiva-, personificado en Escoufle frente a los celosos felones o traducido en la férrea voluntad y en la fuerza física de Lanzarote, quien responde a los deseos de Ginebra, logrará el anhelado ayuntamiento tras salvar las dificultades que en el discurso de la reina se plasman en la forma negativa del verbo, en el condicional y en la proposición subordinada causal: 
Asanbler ne porriens nos,

qu'an ma chanbre, devant moi, gist

Kex, li seneschax (...)

Charrete, 4520 - 4522

- Reunirse pero sin que exista contacto físico, tal como ocurre en el encuentro espiado entre Tristán e Iseo: "s'un mot en puet li rois oïr que nos fuson ça asenblé" (Tristan, 190 - 191), o en el episodio de los amantes dormidos en el Morois, en el que el rey se muestra incapaz de distinguir entre la inocencia y la culpabilidad ante los signos contradictorios que se le ofrecen, ${ }^{499}$ y que, por una vez, tienen su origen más en el azar que en la voluntariedad de los amantes:

Les bouches furent pres asises, et neporquant si ot devises que n'asenbloient pas ensenble Tristan, 1823 - 1825

Los sustantivos assemblee y assemblement cumplen una función meramente substitutiva en los mismos contextos, si bien los determinantes y la función sintáctica en la proposición posibilitan algunos matices no despreciables desde el punto de vista de la presentación equívoca de los hechos. En la narración, assemblee se halla precedido del artículo definido, lo que identifica una determinada reunión frente a otras pero sin que se pueda colegir una clara diferenciación. El rey en el ejemplo que citamos se atiene a los postulados agustinianos sobre el referente, subordinando el plano lingüístico al conocimiento de los hechos mediante la vista —el sintagma nominal funciona como complemento de objeto directo del verbo veoir- si bien no elude el engaño pues unos y otro son falaces:

\footnotetext{
499 M. Bloch también remite a esta ambigüedad sígnica para ejemplificar el tema general del engaño puesto al servicio de la usurpación adúltera de la paternidad, op. àt., p. 246.
} 
$\mathrm{Li}$ rois qui sus en l'arbre estoit

out l'asenblee bien veüe

et la raison tote entendue.

Tristan, $258-260$

En el discurso directo del rey Marco, en el que la función del sustantivo es la de sujeto, la delimitación es más precisa al utilizar el artículo demostrativo, lo que hace que la reunión bajo el pino, tal como pretendían los amantes, sea considerada como un acontecimiento único sin precedentes ni posibles continuaciones: "Se feüst voir, ceste asenblee ne feüst pas issi finee." (Tristan, 299 - 300), de igual modo que cuando se alude a ella de nuevo en estilo indirecto mediante un artículo posesivo: "le fist monter por eus voier a lor asenblement" (Tristan, 473 - 474). En este caso se llega más lejos que en la narración al concluir el rey a partir de sus percepciones erróneas la mentira de sus consejeros, de ahí la combinación en la construcción hipotética del imperfecto y del pluscuamperfecto de subjuntivo. Algo similar ocurre en el fragmento del Morois, en el que se construye la hipótesis mediante dos imperfectos de subjuntivo. Estos marcan claramente que el locutor considera los hechos de la proposición hipotética como contrarios a la realidad, aunque se da un valor añadido al demostrativo, pues el rey no sólo identifica la escena en unas coordenadas temporales bien definidas, sino que la extrapola a los tres años transcurridos desde la huida del sobrino y de la esposa: "se il s'amasent folement, (...) autrement fust cest'asenblee” (Tristan, 2007 - 2010).

- En Escoufle, unir en matrimonio. De este sentido primordial se derivan otros como la preocupación por la continuación del linaje: "cele nuit sont couchié ensamble si com raisons et lois assamble" (Escoufle, 1747 1748) con la que se inaugura lo que podríamos llamar «las infancias» de Guillermo, o como la realización del ideal de pareja, elaborado en torno a la virginidad, la juventud y la igualdad, expresada mediante el sustantivo assamblee. Aquí la equiparación social es sustituida por la semejanza física, 
una transposición de las uniones hipergámicas que comienzan a celebrarse al final del siglo XII con el desarrollo de las estructuras de parentesco nobiliario que ponen fin a la vida errante de los jóvenes, y quizá también de los cada vez más frecuentes enlaces entre alta cuna y poderío económico. ${ }^{500}$

$$
\begin{aligned}
& \text { Del damoisel et d'Aelis } \\
& \text { estoit ml't bele l'assamblee, } \\
& \text { car se nature eüst emblee } \\
& \text { la grant biauté que lor dona }
\end{aligned}
$$

Escoufle, 2009 - 2011

Un ideal que toma como base el patrón familiar de la Iglesia y de las emergentes clases sociales. Modelo que valora la familia y arrincona el clan, de claro signo aristocrático. Éste estaba basado en el consentimiento mutuo y/o en la unitas carnis — de ésta tan sólo resta el término lis en el ejemplo que citamos a continuación-, y se impone formalmente mediante un sintagma simple o compuesto en función de sujeto que hace del matrimonio el núcleo constituyente de la unión de los amantes: “n'onques n'asambla lois ne lis .ii. ausi beles gens ensamle" (Escoufle, 8534 - 8535),

Si nos volst on ansdeus ansamble

asambler, si com lois assamble

les laies gens par mariaje

Escoufle, $7505-7507$

Sin embargo, las decisiones adoptadas por el emperador a favor y en contra del matrimonio de los adolescentes resultan contradictorias con lo que acabamos de decir al mostrar una clara tendencia a despreciar los modelos matrimoniales elaborados en el siglo XII por la Iglesia para volver al derecho feudal, el cual debía permitir una recuperación del control de las uniones por parte de los grupos familiares. Se trata en último término de despojar a los

${ }^{500}$ Cf. G. Duby, L es trois ordres...., op. at., p. 355 - 356. 
jóvenes de los derechos conquistados merced al discurso teológico y de restaurar el modelo aristocrático frente al de los grupos ciudadanos emergentes. A la vista de esto podría parecer que existen dentro de E scoufle profundas discordancias e incluso incoherencias; por el contrario, creemos que Renart pretende poner frente a frente las dos grandes tendencias de organización social que pugnan por imponerse a comienzos del siglo XIII, y aún ir más allá haciéndolas compatibles al final del roman, aunque como ya ha quedado dicho, todo ello repercuta muy negativamente en el valor que se otorga a los sentimientos y a la pasión.

Junto a las consecuencias psicológicas de la unión o de la frustración, que se expresan mediante la combinación de adeser y peser en posición final, y a los juegos de repeticiones entre el verbo assembler y el adverbio ensemble, algunas otras combinaciones resultan relevantes semánticamente: por un lado la rima con espee en Tristan con la que queda ligada la unión de los amantes a la autoridad y el poder en su vertiente castradora, incompatible con la pasión antisocial, por otro la combinación con emblee en E scoufle, muestra del movimiento dialéctico entre posibilidad e imposibilidad, entre voluntad individual y poderosas fuerzas exteriores como la Naturaleza o la Fortuna, aliadas no tanto con los amantes sino con los grupos que acaparan el poder.

\begin{tabular}{lllllllll}
\hline FORMA & CA & BD & NV & RIMA & CA2 & NV2 & D & PERS \\
\hline adeser & I & Charrete & 1247 & peser & I & 1248 & N & Narrador \\
adoise & V & Charrete & 1084 & poise & V & 1083 & N & Narrador \\
adoise & V & Charrete & 3363 & poise & V & 3364 & D & R. Bademagu \\
ajostez & O & Rose & 991 & biautez & S & 992 & N & Narrador \\
asenblee & S & Tristan & 11 & espee & S & 12 & D & Iseut \\
asenblee & S & Tristan & 2010 & espee & S & 2009 & D & Roi Marc \\
asenblee & S & Tristan & 299 & finee & O & 300 & D & Roi Marc \\
asenblé & O & Tristan & 191 & ré & S & 192 & D & Iseut \\
assamble & V & Escoufle & 7506 & ansamble & D & 7505 & D & Guillaume \\
assamble & V & Escoufle & 1748 & ensamble & D & 1747 & N & Narrador \\
assamblee & S & Escoufle & 2009 & emblee & O & 2010 & N & Narrador \\
assamblee & S & Escoufle & 7825 & emblee & O & 7826 & N & Narrador \\
jostee & O & Tristan & 1997 & espee & S & 1998 & N & Narrador \\
\hline
\end{tabular}

Tabla 85.Rimas de los verbos «adeser», «ajoster», «joster», assembler, rassembler y del sustantivo assemblée. 
En Escoufle y Charrete las proposiciones infinitivas actúan como subordinadas completivas de los verbos voloir: "si nos volst on ansdeus ansamble asambler" (Escoufle, 7505 - 7506) y faire: "ele fait cascun a cascune asambler" (Escoufle, 9021 - 9022). Esto nos hace de nuevo observar la dependencia de los amantes de fuerzas que se encuentran por encima de ellos, ya sean los seniores o el propio amor; también dependen de quenir. "ne ja plus ne li requerroit, qu'il ne quiert a li adeser' (Charrete, 1246 - 1247), verbo que pone de manifiesto la voluntad de Lanzarote de negarse a aceptar el placer de un cuerpo que no sea el de la amada. En Tristan, por el contrario, las subordinadas completivas van introducidas por la conjunción que y dependen de verbos como acroire: "li font acroire (...) que nos amors jostent ensenble" (Tristan, 29 - 30), que introduce — a falta del resto del roman al menos en el fragmento conservado - el tema de la facilidad con la que se puede influir sobre el rey.

Por lo que hace a las proposiciones subordinadas circunstanciales, en Charrete se recurre a las temporales: "s'en a grant honte et molt l'en poise quant nu a nu a li adoise” (Charrete, 1083 - 1084), aunque en este ejemplo también podemos apreciar un matiz causal, y las causales: "la reïne a boene prison que nus de char a li n'adoise" (Charrete, 3362 - 3363); en E sooufle se recurre a las consecutivas: ' $k$ 'ainc ne fu tant n'en bos n'en vile gardee par $\underline{s}$ grant destrece ḱlil, (...), n'assamblaissent malgré le roi” (Escoufle, 3124 3127), o a las que expresan la comparación introducidas por si com [A dv.

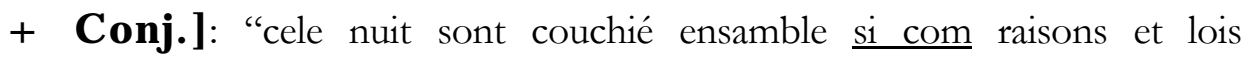
assamble" (Escoufle, 1747 - 1748), “si nos volst on ansdeus ansamble asambler, si com lois assamble les laies gens par mariaje” (Escoufle, 7505 7507). 


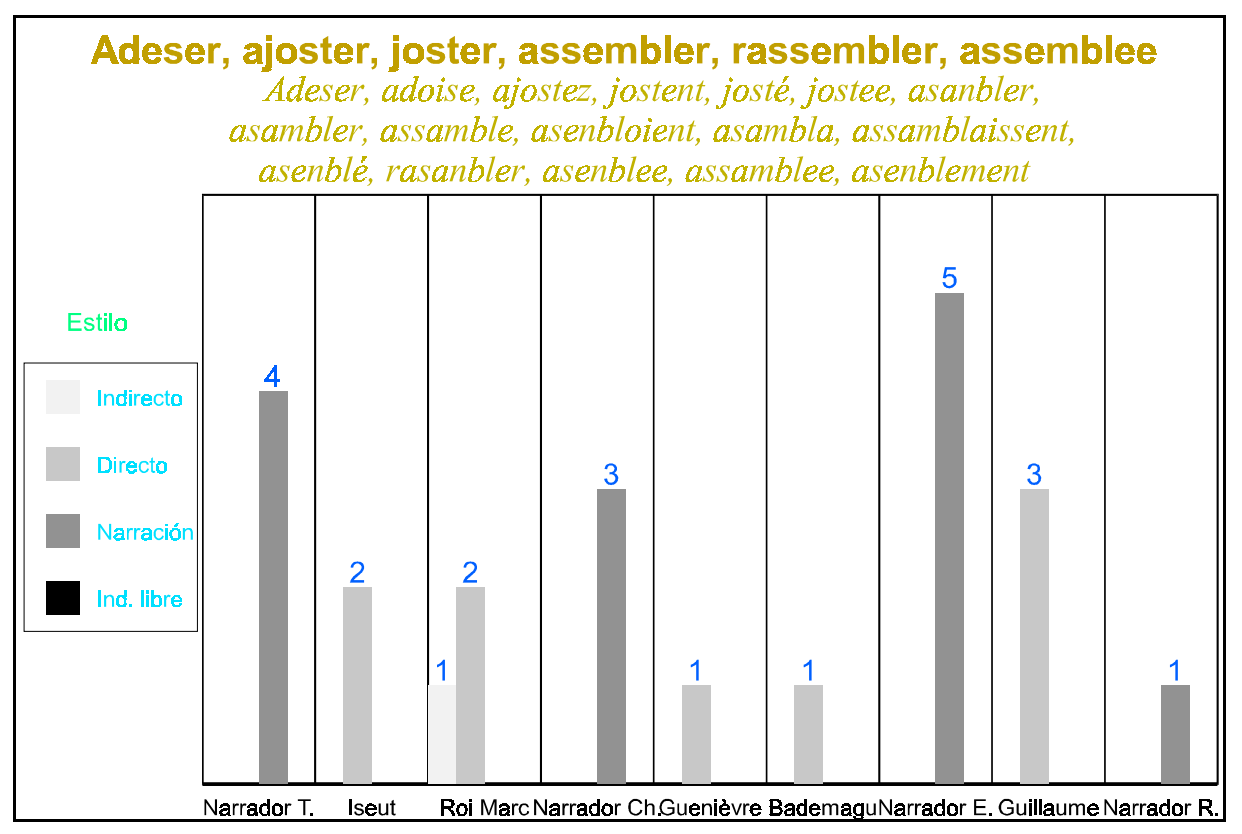

Fig. 134.Comportamiento estilístico de los verbos «adesen», «ajosten», «joster», assembler, rassembler y del sustantivo assemblée en el corpus.

De nuevo nos encontramos con el hecho de que el discurso narrativo se destaca en el uso de estos términos, y no solamente en las intervenciones de los entes narrativos por excelencia sino en las de algunos de los personajes que asumen temporalmente este papel. Es el caso de Guillermo, quien rememora los amores y las mañas de Tristán e Iseo para burlar la vigilancia del rey y de los felones o bien relata ante la corte de Saint Gilles las vicisitudes de su vida amorosa pasada. Frente a ellos, los discursos femeninos de los romans del siglo XII se ocupan de las circunstancias —consecuencias y obstáculos- que rodean la unión de los amantes. Mención aparte merecen las intervenciones en estilo directo del rey Marco, monólogos en los que se convence a sí mismo de la inocencia de los encuentros de los adúlteros. 


\subsection{Couchery gésir.}

Acostar, tenderse o estar acostado, son los sentidos que inicialmente se pueden atribuir a ambos verbos en el corpus. En un principio inocuos desde el punto de vista erótico, adquieren tradicionalmente un valor añadido de carácter metonímico eufemístico ${ }^{501}$ y pasan a expresar la acción de mantener relaciones sexuales, sentido que se conserva actualmente en la lengua familiar cuando el verbo coucher va acompañado de la preposición avec. La delimitación exacta de este último sentido en los romans puede ser muy evidente o bien debemos suponerla por el contexto, variable que puede hacer también que lo descartemos y que nos atengamos a una comprensión literal: "tu te coucheras en ton lit, ou tu avras poi de delit" (Rose, 2413 2414). Cuando los verbos poseen una connotación sexual evidente e implican necesariamente la unión carnal, la penetración y la emisión seminal, la construcción suele ser la siguiente: el amante o supuesto amante masculino es el sujeto del verbo y la mujer aparece como complemento preposicional introducido por a, o o avec. Asiduamente el núcleo del sintagma es un pronombre y muy excepcionalmente una denominación de las estudiadas en la primera parte de este trabajo precedida de un posesivo; cuando esta substitución se produce es un signo de respeto o de dilección: "il amast bien en .j. plus lait la nuit gesir avoec s'amie" (Escoufle, 3110 - 3111). La concepción de Honte, negativo burlesco de la de Jesucristo, en la que se hace incluso intervenir a la divinidad: "quant Dex ot Honte fete nestre" (Rose, 2829), confirma la validez de esta interpretación de la fórmula sintáctica: la ruptura del orden natural al no existir la cópula ni la inseminación - observaremos que la visión es suficiente, lo que nos recuerda la utilización metonímica que ya hemos señalado para los verbos que expresan tal percepción-, se traduce en una inversión del género del sujeto, aquí es Raison y no el varón:

${ }^{501}$ Cf. P. Guiraud, op. ait., p. 250 a propósito de coucher. 


$$
\begin{aligned}
& \text { et ses peres ot non Maufez, } \\
& \text { qui est si hideus et si lez } \\
& \text { c'onques a lui Reson ne jut, } \\
& \text { mes dou veoir Honte conçut }
\end{aligned}
$$$$
\text { Rose, } 2825 \text { - } 2828
$$

La falta del sintagma preposicional apunta en Rose a una extensión del significado del verbo que, además de al acto carnal en sentido estricto, pasaría a referirse a las caricias y juegos previos: "ausi i pooit l'en sa drue couchier come sus une coute" (Rose, 1392 - 1393).

En Tristan y E scoufle se presenta una opción cuya interpretación debe ser la misma. Se caracteriza por la presencia de la tercera persona del plural y tiene por sujeto a los amantes: "en la forest de Morrois sont, la nuit jurent desor un mont" (Tristan, 1275 - 1276) o a los esposos: "l'emperere et

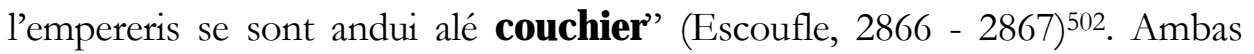
construcciones, la preposicional con sujeto masculino y la forma del plural, reforzada en este caso con el adverbio ensemble, coexisten en un mismo discurso en el que los nobles plantean al emperador la inconveniencia de que los futuros esposos compartan habitualmente el lecho y ponen especialmente de relieve el que sea por la noche, pues en la oscuridad, sin testigos que los coarten, los contactos sexuales plenos pueden prolongarse impunemente:

Encor le nos a on dit hui

k'il gisent toute nuit ensamble.

Est ce raisons? (...)

deveroit il estre creüs

k'il geüst avoec li par nuit?

Escoufle, 2820 - 2825

\footnotetext{
502 En este ejemplo nos referimos al sujeto lógico pues couchier funciona como complemento de destino del verbo aler.
} 
Excepcionalmente, la primera persona del plural en el discurso de Aelis introduce la escabrosa intimidad en la que va a vivir durante años con su compañera de viaje: "car par aventure girmons nos encore plus ensamble" (Escoufle, 5270 - 5271). Frente a esto llama la atención la inexistencia de formas del plural de Charrete y Rose.

En el texto de Béroul se nos presentan tres construcciones que coinciden en el alcance de la unión de los amantes. Cada uno de ellos es presentado por separado en un contexto muy próximo: "Yseut fu premire couchie; Tristran se couche et trait s'espee" (Tristan, 1804 - 1805); tan sólo Tristán es sujeto, aunque se da por hecho que se halla en compañía de Iseo mientras viven en el Morois: "Tristran se jut an la fullie" (Tristan, 1816); y por fin, los dos figuran como sujeto de coucher o de gesir. "Oez com il se sont couchiez" (Tristan, 1816). Estas ocurrencias ocupan la última parte del exilio del Morois, cuando el filtro ya ha perdido su efecto pasional o cuando está a punto de hacerlo, por lo que queda descartada la cópula pero se mantienen intactas las muestras de afecto: "Tristran gesoit en sa fullie, estroitement ot enbrachie la roïne" (Tristan, 1673 - 1675). Todas ellas tienen, además, en común su presencia en el discurso narrativo.

Por el contrario, el periodo cortesano entra de lleno en el modelo metonímico que es adoptado en el discurso de los personajes. La reina deberá acostarse con los leprosos, caracterizados por su furor sexual: "et l'estovra a nos couchier" (Tristan, 1206), también aquí la mujer es el sujeto del infinitivo en la perífrasis que expresa obligatoriedad; esta nueva inversión del esquema sintáctico típico refleja un desarreglo de las relaciones sexuales aún más grave que el propio adulterio. En estilo indirecto los felones narran al rey cómo los amantes ceden con frecuencia al imperioso deseo de ayuntarse y aturdidos por el placer no reparan en la presencia de testigos inoportunos: "et plusors foiz les ont veüz el lit roi Marc gesir toz nus" (Tristan, 593 - 594). La completa desnudez — habitual para dormir, tal como se nos muestra en Charrete una vez que la doncella abandona la compañía de Lanzarote y se acuesta sola: "si est 
an sa chanbre venue et si se couche tote nue" (Charrete, 1267 - 1268) - es muy significativa, porque al menos Tristán no se halla en el lecho que le corresponde, sino que está desafiando el poder social y sexual del señor compartiendo con él el tálamo y la esposa. En el discurso directo de Iseo se rememoran los momentos en que, fuera del recinto dominado por el monarca y sus nobles, los amantes se unían con total libertad en una cama hecha para servir al amor y a la pasión —obsérvese la suma de pronombres de primera persona del plural y del artículo posesivo— que se opone a la anterior, la del adulterio: "nos i geümes mainte nuit, en nostre lit que nos fist faire" (Tristan, 2820 - 2821).

Lanzarote y Meleagant se nos presentan de nuevo como dos polos opuestos y por ello irreconciliables en sus posturas ante el hecho de que un hombre y una mujer yazcan en el mismo lecho. El primero se inhibe ante la posibilidad de una aventura sexual, en un nuevo testimonio de su amor por la reina cuando se resiste al contacto con la doncella y ello aunque está obligado por una promesa que la cortesía le obliga a cumplir: "l'otroie si com ele vialt, de l'otroier li cuers li dialt, (...) molt avra au couchier tristesce" (Charrete, 957 - 960). Al actuar así corre el riesgo de seguir manchando su fama de caballero, aunque esto no llegará a ocurrir porque la a la postre comprensiva doncella sabe que anteponer la regla del amor monogámico a la del don contraignant es un rasgo que honra al caballero amador. Así ni uno ni otro se desnudan, ella tras haber observado su intachable comportamiento ante el simulacro de violación, aunque quizá utiliza una nueva estrategia de conquista al velar sus atractivos toda vez que la desnudez y la violencia no habían surtido efecto: "et la dameisele s'i couche, mes n'oste mie sa chemise" (Charrete, 1202 - 1203), él probablemente porque no desea que el instinto pueda traicionarlo, con lo que, además, invalida voluntariamente la que debía ser la prueba suprema del erotismo cortés:

et il se couche tot a tret, mes sa chemise pas ne tret, 
ne plus qu'ele ot la soe feite

Charrete, 1213 - 1215

Frente a Lanzarote se encuentra el modelo del caballero pre-cortés, atenazado por la libídine, quien sólo ve en la mujer, incluso en la que dice amar, un artefacto sexual capaz de unirse al hombre que encuentra más a mano, hecho que sólo le importa en la medida en la que él no puede disfrutar del mismo placer. La adopción de una lectura interesada de la observación visual, para la que se deja guiar por las apariencias al igual que el rey Marco, es, probablemente, un rasgo más de su apego hacia los usos y la ideología que la cortesía pretendía rechazar:

$$
\begin{aligned}
& \text { Enuit, ce dit, a Kex geü } \\
& \text { o moi, por ce qu'il a veü } \\
& \text { mes dras et les suens de sanc tainz }
\end{aligned}
$$

Charrete, 4923 - 4925

Veamos con más detalle cuáles son los medios que cada uno de los personajes implicados en ambos procesos utiliza para referirse a ellos, para lo que tendremos en cuenta también las intervenciones del narrador en las que se alude a una u otra postura. La primera observación es de orden estilístico: hay una clara preferencia por el verbo coucher en el episodio de la doncella, y ello tanto en el discurso narrativo como en el de los personajes, frente a la contraria por el verbo gesir en la escena de celos de Meleagant en la que los verbos que nos ocupan no se hallan nunca en las intervenciones del narrador.

Comenzaremos por la doncella, quien impone su derecho a disfrutar sexualmente del varón aprovechando su necesidad de cobijo nocturno; con mucha probabilidad Chrétien ha dado la vuelta a unas circunstancias que, de darse, debían ser más frecuentes al revés, incluso cuando las mujeres no viajesen solas, tal como vemos en E scoufle, donde la hospitalidad para con una doncella es equivalente a la entrega sexual. Este trueque de papeles nos coloca 
de nuevo ante el proceso de hiper-erotización de las aventuras caballerescas gracias a la recuperación interesada de algunos de los derechos presuntamente adquiridos por las mujeres con el movimiento cortés, consistentes en la libertad sexual y en la adopción de los patrones de comportamiento masculino. El verbo modal devoir, la formulación metonímica en la que el núcleo del complemento preposicional con valor circunstancial es aquí un pronombre de la primera persona del singular, lo que impide cualquier interpretación ambigua de los deseos de la doncella, y la construcción consecutiva itel ... que [Pron. + C onj.] que transcribe el chantaje, son los medios formales utilizados en el discurso directo de la hospitalaria doncella:

$$
\begin{aligned}
& \text { mes par itel herbergeroiz } \\
& \text { que avoec moi vos coucheroiz }
\end{aligned}
$$

Charrete, 943 - 944

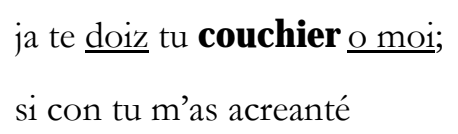

Lanzarote adopta por el contrario un papel totalmente pasivo en este episodio, en el plano temático al aceptar, aunque con disgusto, la oferta de su anfitriona y en el discursivo por su desvaído e ineficaz intento de evitar la para él temida y desagradable prueba. La única intervención en estilo directo se caracteriza por un sometimiento absoluto a la voluntad de la mujer, transcrito mediante la conjunción adversativa mes —ésta, más que expresar una objeción, pretende introducir una precisión que a él le parece indispensable pero que no tiene en absoluto un carácter vinculante- A mes se unen la construcción hipotética que contiene la fórmula de cortesía con el verbo pleire y la forma condicional del verbo sofrir. "mes, se vos pleisoit, del couchier me soferroie je molt bien" (Charrete, 952 - 953). El segundo paso, si 
bien finalmente resulta efectivo, no es tampoco muy decidido: tan sólo se aparta tímidamente para evitar la proximidad física y la peligrosa percepción visual de la doncella al quedar de espaldas, si bien mantiene su palabra de permanecer acostado junto a ella. De hecho en su intervención se encuentra la única ocurrencia de gesir de este episodio, probablemente para evitar cualquier confusión con couchier que posee en este fragmento el valor de gozar sexualmente: “einz s'an esloingne et gist anvers" (Charrete, 1217). Esta actitud pasiva tiene su correlato estilístico en la sistemática intervención de la vOZ narrativa retomando los mismos esquemas que había utilizado la doncella: sujeto masculino de coucher y complemento preposicional referido a la mujer - ya sea pronominal o nominal—, así como omnipresencia de la obligatoriedad, con el verbo devoir como auxiliar de la perífrasis infinitiva o mediante el sintagma preposicional par force:

$$
\begin{aligned}
& \text { et ce estoit meïsmes cele } \\
& \underline{\text { avoec cui couchier se devoit }}
\end{aligned}
$$$$
\text { Charrete, } 1060 \text { - } 1061
$$

par force covient que il s'aut

couchier avoec la dameisele:

covanz l'en semont et apele

Charrete, $1210-1212$

En clara oposición con lo que acabamos de exponer, el perfecto amador adopta un aire resuelto al desafiar a Meleagant para salvaguardar en combate el honor de la reina. También sus palabras se hacen categóricas cuando niega los amoríos de Ginebra y del senescal, tanto es así que se atreve a utilizar una forma performativa para referirse a hechos en los que en principio no debía estar implicado. En este caso se obvía de nuevo la construcción preposicional con la que se implicaría a la dama y se elige el adverbio pronominal $\mathbf{i}$ para referirse a la cama, espacio en el que se hallan los 
indicios del adulterio, la negación se refuerza, además, con una proposición coordinada en la que se expresa con el verbo sentir una progresión decreciente en el tipo de relaciones carnales sobre las que recaerían las sospechas de Meleagant, con lo que el esquema sintáctico del verso 4973 sería el siguiente: [C onj. (subordinante) + Pron. (sujeto masculino) + Adv. (negativo) + Adv. (pronominal) + Verbo + Conj. (negativa) + Adv. (negativo) + Pron. (complemento femenino) + Verbo]; ha de ser tomado en consideración, además, el hecho de que la conjunción de coordinación ne posee un fuerte valor negativo:

$$
\begin{aligned}
& \text { - Et je t'an lief come parjur, } \\
& \text { fet Lanceloz, et si rejur } \\
& \text { qu'il ñi jut ne ne la santi } \\
& \text { Charrete, } 4971 \text { - } 4973
\end{aligned}
$$

Mucho menos decidido y elocuente —con tan sólo la proposición hipotética introducia por se y el adverbio temporal onques, sin que medie ningún elemento negativo-, Keu, cuyo carácter recogido en la tradición artúrica es una mezcla de escasa inteligencia, bravuconería y pusilanimidad, si bien aquí está justificado por su lamentable estado físico y mental, pretende garantizar su inocencia apelando a la justicia suprema aunque sea a largo plazo; a ello añade un signo de distanciamiento personal al sustituir la forma pronominal, la más habitual, o una simple diferencia de rango social que se introduciría con el sustantivo reïne, por la denominación dame, que bajo el prisma de la cortesía implicaba un respeto absoluto también desde el punto de vista erótico:

ja Dex, quant de cest siegle irai, ne me face pardon a l'ame, se onques jui avoec ma dame

Charrete, 4860 - 4862 
En el otro lado de la balanza se halla Meleagant, el difamador y celoso enamorado, quien además de recurrir al patrón del sintagma preposicional añade una nueva variable temporal iterativa que agrava las supuestas relaciones adúlteras de la reina. Ésta, al retomar las palabras del calumniador, había escogido el adverbio enuit (Charrete, 4923 - 4924) para contrarrestar con el aspecto puntual la reiteración de la que se le acusa y que hallamos en relaciones como las de Tristán e Iseo y posteriormente de Guillermo y Aelis. Por otro lado se observa una marcada oposición entre el uso del presente en las intervenciones de Meleagant y los tiempos del pasado que figuran en el resto de los discursos:

$$
\begin{aligned}
& \text { (...) et si ai veü } \\
& \text { tant, que j’ai bien aparceü } \\
& \text { qu' } \underline{\text { avoec li gist Kex chasque nuit }} \\
& \text { Charrete, } 4811 \text { - } 4813 \\
& \text { car molt me vient a grant desdaing } \\
& \text { qant ele me het et despist, } \\
& \text { et Kex o li chasque nuit gist }
\end{aligned}
$$

Charrete, 4816 - 4818

Aunque nada nos dicen los emparejamientos que se establecen en la rima desde un punto de vista semántico, sí que resulta significativo el elevado número de apariciones de las forma de coucher y gesir al final de verso, posición de privilegio que se complementa con algunas ocurrencias al comienzo de verso.

\begin{tabular}{lllllllll}
\hline FORMA & CA & BD & NV & RIMA & CA2 & NV2 & D & PERS \\
\hline couche & V & Charrete & 1202 & couche & S & 1201 & N & Narrador \\
coucheroiz & V & Charrete & 944 & herbergeroiz & V & 943 & D & Demoiselle \\
couchie & O & Tristan & 1804 & jonchie & O & 1803 & N & Narrador \\
couchiee & O & Charrete & 1039 & dessiee & V & 1040 & D & Demoiselle \\
couchiee & O & Charrete & 4619 & meschiee & V & 4620 & D & Guenièvre \\
couchier & I & Charrete & 952 & chier & A & 951 & D & Lancelot \\
couchier & I & Escoufle & 2867 & chier & A & 2868 & N & Narrador \\
couchier & I & Tristan & 1206 & escouellier & S & 1205 & D & Lépreux \\
couchiez & O & Tristan & 1816 & chiet & V & 1815 & D & Narrador \\
\hline
\end{tabular}

Tabla 86. Rimas del verbo coucher. 


\begin{tabular}{lllllllll}
\hline FORMA & CA & BD & NV & RIMA & CA2 & NV2 & D & PERS \\
\hline geü & $\mathrm{O}$ & Escoufle & 5249 & ë̈ & $\mathrm{O}$ & 5250 & $\mathrm{~N}$ & Narrador \\
geï & $\mathrm{O}$ & Tristan & 1839 & seü & $\mathrm{O}$ & 1840 & $\mathrm{~N}$ & Narrador \\
geü & $\mathrm{O}$ & Charrete & 4923 & veü & $\mathrm{O}$ & 4924 & $\mathrm{D}$ & Guenièvre \\
gist & $\mathrm{V}$ & Charrete & 4818 & despist & $\mathrm{V}$ & 4817 & $\mathrm{D}$ & Méléagant \\
gist & $\mathrm{V}$ & Tristan & 1779 & ist & $\mathrm{V}$ & 1780 & $\mathrm{~N}$ & Narrador \\
gist & $\mathrm{V}$ & Rose & 2731 & languist & $\mathrm{V}$ & 2732 & $\mathrm{D}$ & Amour \\
jut & $\mathrm{V}$ & Rose & 2827 & conçut & $\mathrm{V}$ & 2828 & $\mathrm{~N}$ & Narrador \\
\hline
\end{tabular}

Tabla 87. Rimas del verbo gésir.

Varios son los rasgos que se pueden señalar de las proposiciones subordinadas completivas en las que encontramos gesir y coucher. En primer lugar la elaboración de interrogativas indirectas mediante los adverbios de modo com y comment, para referirse a la unión de Tristan e Iseo en su comienzo de exilio, tanto en el texto de Béroul como en la descripción de la composición figurativa que de la historia de los amantes se hace en E scoufle. “Oez com il se sont couchiez” (Tristan, 1816),

$$
\begin{aligned}
& \text { sor le corvecle estoit li lis } \\
& \underline{\text { comment il jurent en la roche }}
\end{aligned}
$$

Escoufle, 594 - 595

En segundo lugar, también en Tristan, la dependencia de una proposición principal en la que la voz narrativa se presenta en estilo directo utilizando una forma de imperativo atenuado dirigida a los receptores de la obra; en el ejemplo que presentamos a continuación destaca la desaparición del elemento conjuntivo que introduce este tipo de subordinadas:

$$
\begin{aligned}
& \text { et saciez de voir, sanz dotance, } \\
& \text { cele nuit jurent chiés l'ermite } \\
& \text { Tristan, } 1420 \text { - } 1421
\end{aligned}
$$

La clave temática de estos contextos se halla en la importancia que se concede al lugar en el que se unen los amantes durante su destierro en el Morois así como los gestos reveladores de la pasión liberada de la horma social. 
En tercer lugar, la dependencia de verbos de percepción como veoir o aperçoivre cuyos sujetos son los enemigos de los amantes: "et plusors foiz les ont veüz el lit roi Marc gesir toz nus” (Tristan, 593 - 594); “que j’ai bien aparceü qu'avoec li gist Kex chasque nuit" (Charrete, 4812 - 4813), a los que se suma el verbo de dicción dire también utilizado por los barones traidores en E scoufle para, haciéndose eco de los cotilleos de la corte, desacreditar el

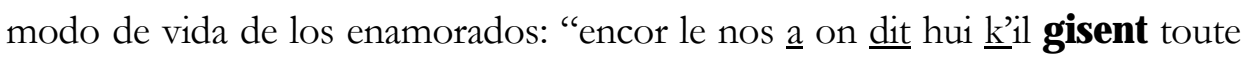
nuit ensamble" (Escoufle, 2820 - 2821) y poner en duda, mediante una interrogación retórica en la que el verbo croire en forma pasiva depende del verbo devoir en condicional, la confianza que el emperador había depositado en Guillermo por mor de sus virtudes y de las paternas: "deveroit il estre creüs k'il geüst avoec li par nuit?" (Escoufle, 2824 - 2825).

Tan sólo hemos recogido tres proposiciones subordinadas relativas, todas en los romans del siglo XII. En Charrete el antecedente es la doncella y el pronombre relativo se presenta en la forma régimen tónica precedida de la preposición avec: "et ce estoit meïsmes cele avoec cui couchier se devoit" (Charrete, 1060 - 1061). En Tristan por el contrario, las proposiciones subordinadas de relativo retoman los lugares en los que los amantes se refugian y se aman durante su destierro, los cuales representan la vida salvaje, sin comodidades, muy diferente a la palaciega, cuando ya está muy próximo el fin del efecto del filtro:

$$
\begin{aligned}
& \text { qui avoit trové lor fulliers } \\
& \text { ou il enent el bois geü } \\
& \text { Tristan, } 1838 \text { - } 1839
\end{aligned}
$$

Tristran de la loge ou il gist,

çaint s'espee, tot sol s'en ist

Tristan, $1779-1780$ 
Además de las citadas con anterioridad tan sólo pondremos de relieve algunas de las proposiciones subordinadas circunstanciales: una de sentido temporal introducida por quant en E scoufle, en la que se presenta la excepcional estancia en el mismo lecho del emperador y de la emperatriz como un subterfugio femenino con el que se crean las condiciones necesarias que la ayudarán a convencer al esposo: "quant il orent geü bras a bras longhement" (Escoufle, 2884 - 2885). En segundo lugar, las proposiciones subordinadas circunstanciales consecutivas que hallamos en Charrete. Se trata de dos proposiciones incluidas en los discursos directos de la doncella enamorada (Charrete, 943 - 944) y de la reina Ginebra. En ellas ambas imponen sus condiciones para que Lanzarote vea satisfechos sus deseos o quizá deberíamos decir sus necesidades, en un caso continuar la búsqueda de la reina tras una noche bajo techado y, en el otro, ser recibido en el lecho de la amada:

mes tant atandre vos covient

que an mon lit soie couchiee

Charrete, 4618 - 4619

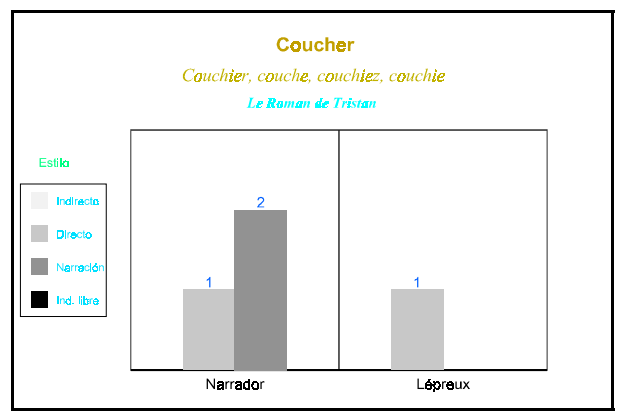

Fig. 135. Comportamiento estilístico del verbo coucher en Tristan. 


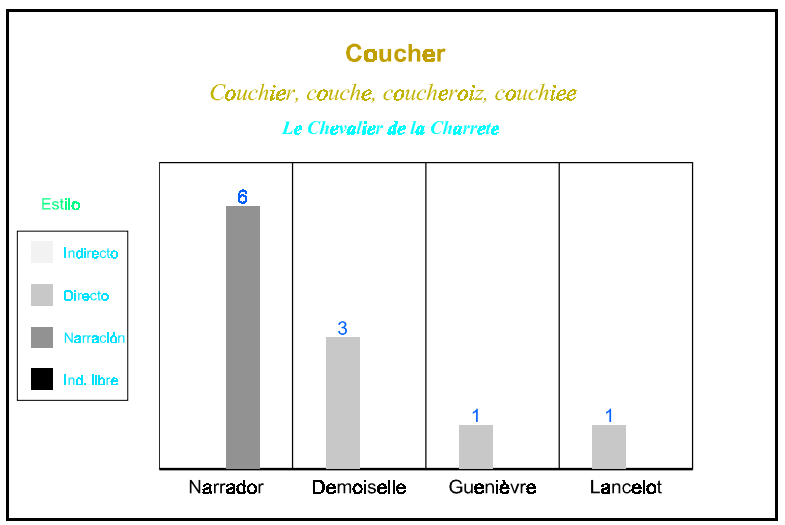

Fig. 136. Comportamiento estilístico del verbo coucher en Charrete.

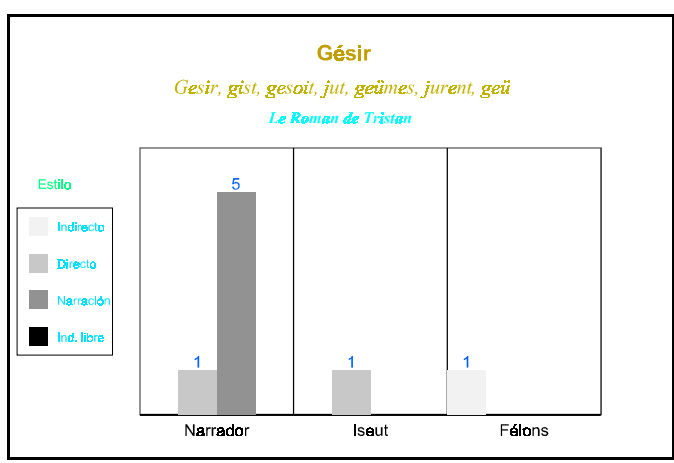

Fig. 137. Comportamiento estilístico del verbo gésir en Tristan.

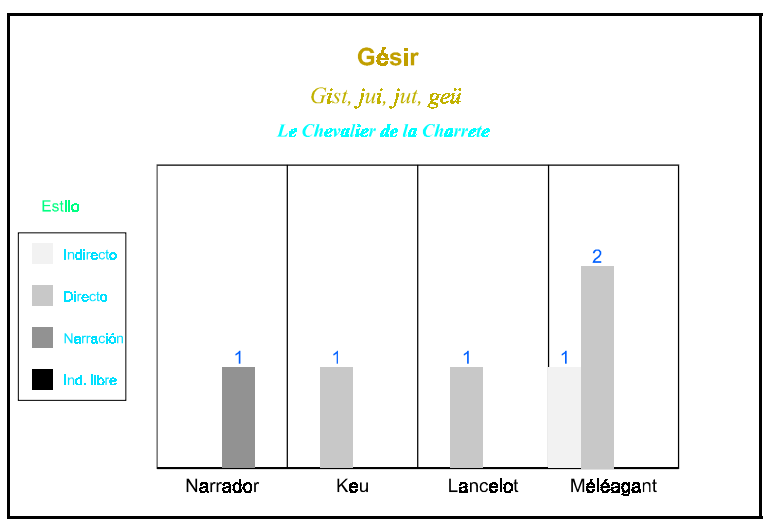

Fig. 138. Comportamiento estilístico del verbo gésir en Charrete. 


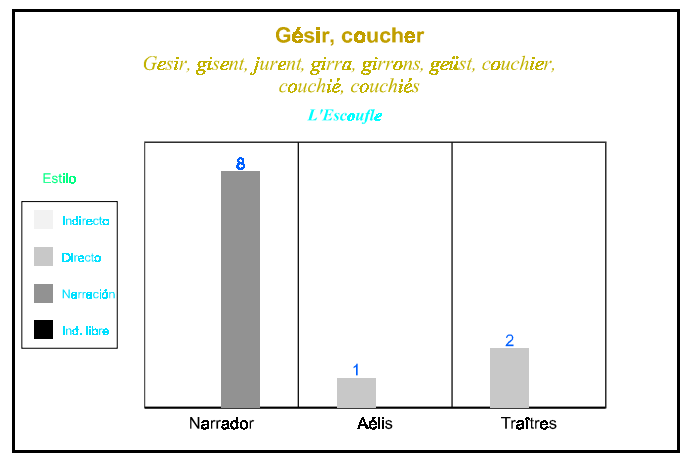

Fig. 139. Comportamiento estilístico de los verbos gésir y coucher en Escoufle.

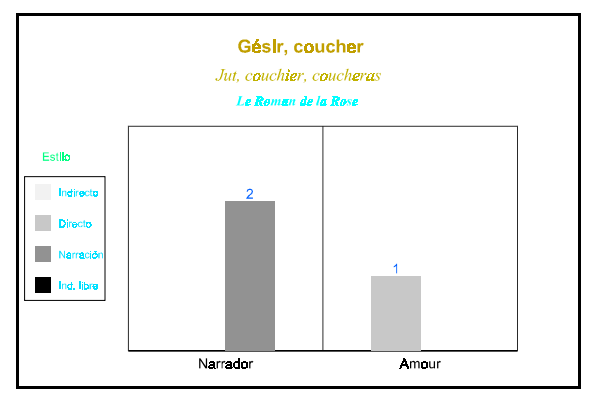

Fig. 140. Comportamiento estilístico de los verbos gésir y coucher en Rose.

La concentración episódica de las ocurrencias de los verbos gesir y coucher — si exceptuamos las escasas apariciones en Rose - es un indicador más de la gran carga de contenido sexual que poseen: siempre en la primera parte del relato en Tristan hasta la reintegración de la reina en la corte, de igual modo que en E scoufle, donde las encontramos hasta el momento en que Aelis encuentra a su compañera de aventuras, y aglutinadas en dos momentos muy concretos de la historia en Charrete en contraste con la noche de amor, fragmento en el que no hay ni una sola referencia a estos verbos. Este hecho lleva a nuestros autores a utilizarlos con un cierto comedimiento excepto cuando se enfrentan dos visiones opuestas de las relaciones amorosas: una «mal pensante» que corresponde a una ideología y a una actuación sexual que se pretende desterrar, que se considera anacrónica, y otra renovada, influida en mayor o menor medida por la cortesía, en la que el sentimiento amoroso y la unión carnal son inseparables. 


\subsection{Jouer y jeu.}

Si los juegos en Charrete y E scoufle, combinados habitualmente con el baile, son formas de contacto físico entre jóvenes o entre individuos de ambos sexos, los narradores se encargan de atenuar su sentido erótico y dejan adivinar una sensualidad latente acompañada de diversión. De igual modo, en Rose, texto en el que el verbo se halla en forma pronominal - construcción normal para muchos otros verbos sin que cambie su significado-, se identifica el juego de los pobladores del jardín de Deduit con el placer y la diversión —el verbo jouer se halla coordinado con solacier- Un placer ambiguo en el que no se puede determinar hasta qué punto intervienen las relaciones eróticas. Hace referencia a las actividades habituales de Oiseuse, quien junto a su imagen de heroína cortés posee todos los atributos de Venus, diosa de la lujuria: el peine, el espejo, la corona de rosas y el traje de color verde, ${ }^{503}$ y sirve para hablar de las relaciones entre el dueño del jardín y sus hermosos acompañantes: “a nule rien je n'entens qu'a moi jouer et solacier" (Rose, 584 - 585),

$$
\begin{aligned}
& \text { Il se jeue ilec et solace } \\
& \text { o ses genz, que plus bele place } \\
& \text { ne plus biau leu por soi jouer } \\
& \text { Rose, } 609 \text { - } 611
\end{aligned}
$$

A esta misma forma pronominal recurre Renart en el discurso narrativo para evocar el coito con una función procreativa en la que sólo parece intervenir y obtener el placer subsecuente el varón. En un contexto completamente desligado de la sensualidad, el esposo se atiene a la estricta observancia del débito matrimonial y de los intereses genealógicos que llegaban a coincidir en la ya anacrónica regulación sexual de la Iglesia: "si com il son afaire dut, śsi joua tant qu'ele conçut”' (Escoufle, 1751 - 1752). Se obvía

503 Retomamos a J.B. Friedman, L’iconographie de Vénus et de son miroir à la fin du Moyen âge, L 'érotisme au M oyen Â ge, B. Roy (ed.). Montreal: Éditions de L'Aurore, 1977, p. 76 - 7. 
aquí, pues, la conexión entre amor y juego, basada en la gratuidad de la acción si exceptuamos la finalidad de obtener placer y con ello liberarse, escapar a la realidad, ${ }^{504}$ una finalidad coincidente para ambos que ha fundamentado desde la época medieval hasta nuestros días la utilización de jeu y de jouer para hablar de los contactos sexuales. ${ }^{505}$

Según las palabras dirigidas en estilo directo por el narrador de Rose a los hipotéticos narratarios confundidos con los receptores de esta obra didáctica ${ }^{506}$ todo se incluye en el juego amoroso: desde el comportamiento del enamorado según las reglas de la cortesía impuestas por el dios Amor hasta la conquista y consumación del acto sexual — sólo anunciado en el texto de Lorris-. Esta intervención del narrador es a la vez una promesa y un acicate, en resumidas cuentas, una forma de hacer publicidad al roman inmediatamente antes de que el dios comience con la enumeración de las numerosas y poco alentadoras normas que sólo teóricamente permitirán al enamorado verse correspondido: "qui dou songe la fin ora, je vos di bien que il porra des jeus d'Amors assez aprendre" (Rose, 2065 - 2067). Jeu identifica los estados de plenitud, de felicidad y de alegría del amante, que según este código reformado es característica esencial de la cortesía: “c'est maladie mout cortoise, l'en en joe et rit et envoise" (Rose, 2167 - 2168), aunque siempre quedarán asociados a los periodos de sufrimiento, vaivén anímico que es característico de la enfermedad amorosa:

\footnotetext{
${ }^{504}$ Cf. R. Caillois quien, haciéndose eco de Benveniste, ha definido el juego como exaltación y liberación humanas en L'H omme et le sacré, op. at., p. 212 - 5.

505 Ibid., p. 399 y 402.

506 En la narración jeu se hace cortejo, servicio amoroso incipiente sin que podamos pensar en que haya ido más allá de la palabra y las miradas:

que j’avoie ja comencié

a dire mes granz privetez

a Bel Acueil, qui aprestez

estoit de recevoir mes gieus

Rose, 3946 - 3949
} 
Maus d'amer est mout corageus:

or est li amanz en ses geus,

or est destroiz, or se demente,

une eure pleure, autre eure chante.

Rose, 2173 - 2176

En E scoufle el componente sensual del juego de los amantes en el loaus amoenus queda fuera de toda duda, pero de nuevo la ambigüedad preside el uso del verbo ya que el acto de jugar se convierte en el umbral del sueño: "tout en jouant laste et soumaus fist endormir ma damoisele" (Escoufle, 7596 - 7597), debido tal vez al calor, el cansancio y la digestión, o más bien consecuencia del placer sexual obtenido. Chrétien es más explícito al ceñirse a las acepciones eróticas que después han permanecido en la lengua, y el juego, en vecindad con términos que nombran el placer - deport, joie y mervoille-, hace referencia no sólo a la cópula: "tant li est ses jeus dolz et buens (...) que il lor avint sanz mantir une joie et une mervoille" (Charrete, 4674 - 4677), sino también a los preámbulos preceptivos, con la particularidad de que en ambos casos y sólo en éstos de entre las ocurrencias escogidas el sustantivo funciona como sujeto:

$$
\begin{aligned}
& \text { qu'il n'i avroit geu ne deport, } \\
& \text { se li seneschax qui ci dort } \\
& \text { s'esveilloit ja por nostre noise } \\
& \text { Charrete, } 4621 \text { - } 4623
\end{aligned}
$$

En el primer ejemplo seguimos moviéndonos en el terreno pantanoso de la inconcreción en el que todos los textos sitúan los contactos carnales, y ello debido a la ambivalencia del pronombre personal de caso régimen con función de complemento indirecto, li, válido tanto para el masculino como para el femenino, así como del artículo posesivo que no distingue el género. En un principio las pautas generales observadas en el 
corpus nos llevarían a pensar que el elemento activo es Lanzarote y que el beneficiario del juego erótico es la reina, al eliminar la ambigüedad gracias a una comprensión intertextual de las relaciones entre los sexos. Sin embargo, el contexto inmediato y aun el contexto más amplio de este roman no nos permite ser tan tajantes en esta afirmación: la iniciativa desde la entrada de Lanzarote en la cámara la lleva la reina, mientras que del amante se realzan sus cualidades de perfecto enamorado, virtudes únicas que sólo puede poseer aquel que amor ha elegido entre todos los amantes para asentarse en su corazón.

Las funciones sintácticas del sustantivo y del infinitivo, a excepción de la de sujeto a la que hemos aludido, y de una ocurrencia en la que es complemento de objeto directo (Rose, 3949), están marcadas por su inclusión en un sintagma preposicional que puede actuar como régimen del verbo (Rose, 585) o como complemento circunstancial (Rose, 2174, 611 y 1265). En cuanto a las formas personales del verbo, todas están conjugadas en tercera persona del singular lo que nos lleva a concluir que siempre es un único personaje el que lleva el juego o el que se divierte aunque se especifique o sea absolutamente necesaria la presencia de la pareja o la compañía de otros. Rose, con valor intemporal, recurre al presente de indicativo, mientras que el único ejemplo de pretérito definido inaugura la historia de Guillermo.

Tres son los tipos de subordinadas circunstanciales que hallamos en el corpus — exclusivamente en Rose y Charrete-, las causales, las consecutivas: “qu'il n’i avroit geu ne deport” (Charrete, 4621) y las que expresan una excepción. Estas últimas están introducidas por la locución conjuntiva fors que [A dv. + $\mathbf{C}$ onj.] retomada con la conjunción que: "fors quilil est plains d'anvoiseüre et qu'il jeue a gent et parole" (Rose, 3572 - 3573). Las causales, tan sólo en la parte inicial de Rose, precedidas de las conjunciones que o car, pueden enunciar una causa de manera objetiva: "que a nule rien je n’entens qu'a moi jouer et solacier" (Rose, 584 - 585), “que plus bele place ne 
plus biau leu por soi jouer ne porroit il mie trover" (Rose, 610 - 612) o bien exponen una relación lógica e incontestable entre la causa y el efecto:

mes mout ert envoisie et gaie,

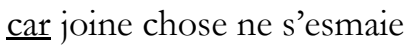

fors de jouer, bien le savez

Rose, $1263-1265$

\begin{tabular}{lllllllll}
\hline FORMA & CA & BD & NV & RIMA & CA2 & NV2 & D & PERS \\
\hline geus & S & Rose & 2174 & corageus & A & 2173 & D & Amour \\
gieus & S & Rose & 3949 & corageus & A & 3950 & N & Narrador \\
jouer & I & Rose & 611 & trover & I & 612 & D & Oiseuse \\
\hline
\end{tabular}

Tabla 88. Rimas del verbo jouer y del sustantivo jeu.

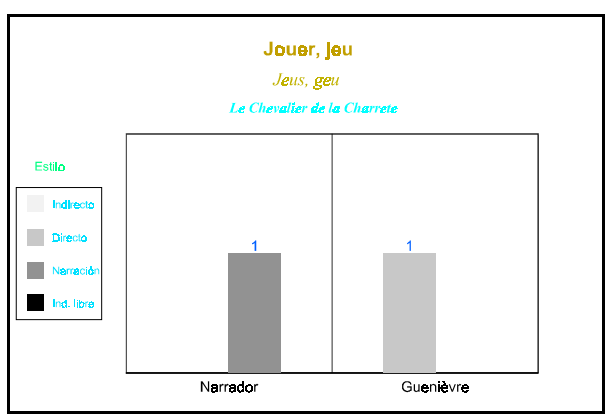

Fig. 141. Comportamiento estilístico del verbo jouer y del sustantivo jeu en Charrete.

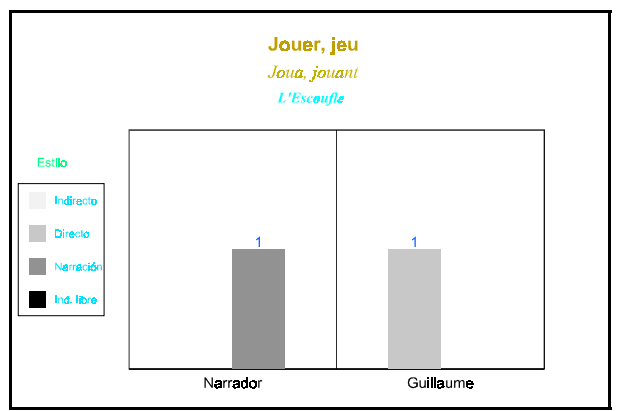

Fig. 142. Comportamiento estilístico del verbo jouer y del sustantivo jeu en Escoufle. 


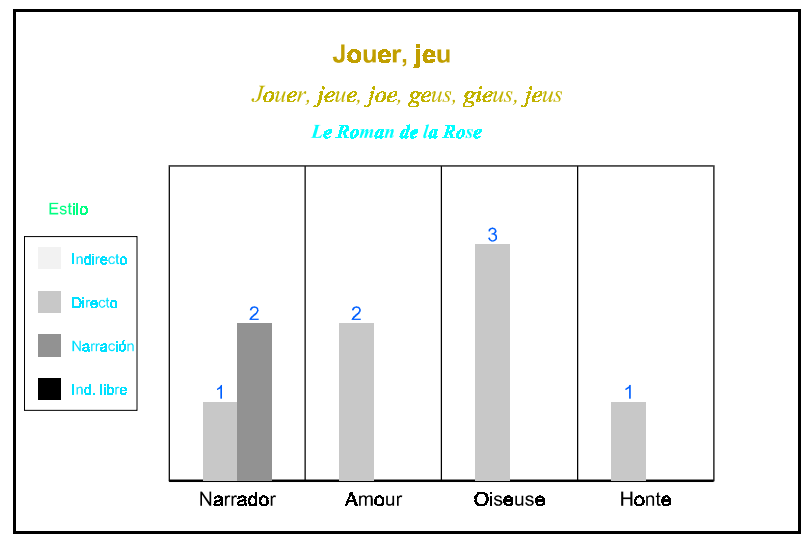

Fig. 143. Comportamiento estilístico del verbo jouer y del sustantivo jeu en Rose.

No cabe duda de que el juego es placer, fuera y dentro de la relación amorosa, y de que como tal puede contener desde la sensualidad más inocente y poco elaborada al coito y sus prolegómenos, por lo que los términos jeu y jouer llegan a aludir con crudeza al placer carnal no compartido; sin embargo, resulta paradójico el hecho de que en Rose, donde estos términos se utilizan con más asiduidad, se den dos fenómenos nada desdeñables. El primero, en relación con los habitantes del jardín de Deduit, sus seguidores y Bel Accueil, es la consideración únicamente de la parte inicial del espectro erótico, con una valoración positiva incluso por parte de un personaje perteneciente al bando opuesto al disfrute como es Honte. El segundo es la oposición que se establece entre aquéllos y el visitante enamorado, quien, pese a que se aprovecha escasamente de los beneficios del juego sensual, debe soportar en contrapartida los perjuicios ocasionados por la estricta regulación del juego amoroso sin poder atisbar la recompensa del acto sexual, lo que se traduce en una pérdida de la carga semántica del sustantivo.

\subsection{Sentir.}

Descartamos los sentidos que se hallan recogidos en el diccionario de francés antiguo de Greimas:507 "percevoir une odeur" y "éprouver un 507 0p. at., p. 591. 
sentiment", aunque de ambas acepciones tenemos algunos ejemplos en el corpus, especialmente en Rose; tampoco tomamos en consideración otra que aparece en los textos del siglo XII y que hace referencia al dolor, y más concretamente a su desaparición gracias al efecto medicinal que posee la presencia o la cercanía del amante y de la amada. Así pues, nos hemos atenido aquí a la expresión de una sensación proveniente del contacto físico: "ainc voir ne senti sa char nue a sa honte" (Escoufle, 3028 - 3029), aunque de Rose conservamos dos ocurrencias en las que la voluptuosidad se queda en un plano simbólico, y en ambos casos el fuego o los efluvios de la antorcha de Venus, metáforas del deseo masculino y femenino, empujan a los amantes a acercarse y en el segundo caso a conceder el beso: "quant il le feu de plus pres sent” (Rose, 2339), "Bel Acueil, qui senti l'eer du brandon” (Rose, 3455 3456).

Béroul reserva el verbo sentir para el discurso de Iseo. En él el verbo conserva su sentido primero, el de recibir información por vía sensorial de objetos sensibles, en este caso táctil, pero los objetos, que funcionan como complementos de objeto directo, deben tomarse en sentido metafórico y obsceno. La reina informa a la asamblea cortesana formada para escuchar su juramento de lo que ha conseguido tocar bajo las ropas del leproso - Tristán. La bolsa que pende de su cinturón a la que en pocos versos se nombra con dos sustantivos, — aloiere y sac — , cuyo contenido ha palpado y descrito con suma precisión - los dos versos consagrados a su inventario, el sustantivo viande y el adverbio bien lo muestran— no puede ser otra cosa que el cuerpo del amante y más concretamente sus genitales - la palabra sac conserva hoy este sentido, tanto para el sexo femenino como para el masculino—:508

soz sa chape senti sa guige.

Rois, s'aloiere n'apetiche:

508 Véase P. Guiraud, op. at., p. 560. 


$$
\begin{aligned}
& \text { les pains demiés et les entiers } \\
& \text { et les pieces et les quartiers } \\
& \text { ai bien parmié le sac sentu. } \\
& \text { Viande a, si est bien vestu. }
\end{aligned}
$$

Tristan, $3965-3970$

La osadía de la provocadora Iseo llega hasta dedicar a su esposo la minuciosa descripción y a manifestar que había conocido con anterioridad su capacidad de almacenamiento y por lo tanto su capacidad sexual. Esto nos lleva a recordar que Tristán había recurrido también a metáforas sexuales para hablar en el mismo lugar y con el mismo interlocutor de sus relaciones adúlteras.

En Charrete, el infinitivo sustantivado: "del beisier, et del santir" (Charrete, 4675) o el verbo conjugado en pretérito definido en una construcción negativa: “il n’i jut ne ne la santi” (Charrete, 4973), se refieren sin ambages al contacto de los cuerpos de dos individuos de distinto sexo durante el coito. En ambos se da la particularidad formal de que aparecen en construcciones pareadas con dos verbos cuyo contenido erótico tampoco deja lugar a dudas: gesir y beisier. $\mathrm{Si}$ nos atenemos al nivel estrictamente sintáctico, se hallan en igualdad por estar coordinados, aunque la posición final del verso concede un valor añadido al verbo sentir y pone de relieve o bien la regresión sensual entre ambos elementos con la construcción negativa o bien, en sentido opuesto, la intensificación de las sensaciones placenteras que preceden al orgasmo.

La primera persona del singular en los discursos de Iseo y Guillermo contrasta con la tercera persona que aparece en los fragmentos narrativos y discursivos de Rose y Charrete. Con ello se pone una vez más de manifiesto la tendencia de Béroul y Renart a dar la palabra a sus personajes para hablar de sus sentimientos y aquí de sus sensaciones. Por otro lado, mientras el presente de indicativo es utilizado por el dios Amor para hablar de sensaciones 
universales, en las que no interviene la variable temporal, los pretéritos definido y perfecto — combinados e indiferenciados en el discurso de Iseopueden referirse a un tiempo muy reciente en Tristan y Charrete, o bien el primero a un pasado remoto en la narración en primera persona de Rose.

\begin{tabular}{lllllllll}
\hline FORMA & CA & BD & NV & RIMA & CA2 & NV2 & D & PERS \\
\hline santi & V & Charrete & 4973 & manti & O & 4974 & D & Lancelot \\
santir & I & Charrete & 4675 & mantir & I & 4676 & N & Narrador \\
sent & V & Rose & 2339 & apressant & T & 2340 & D & Amour \\
sentu & O & Tristan & 3969 & vestu & O & 3970 & D & Iseut \\
\hline
\end{tabular}

Tabla 89. Rimas del verbo sentir.

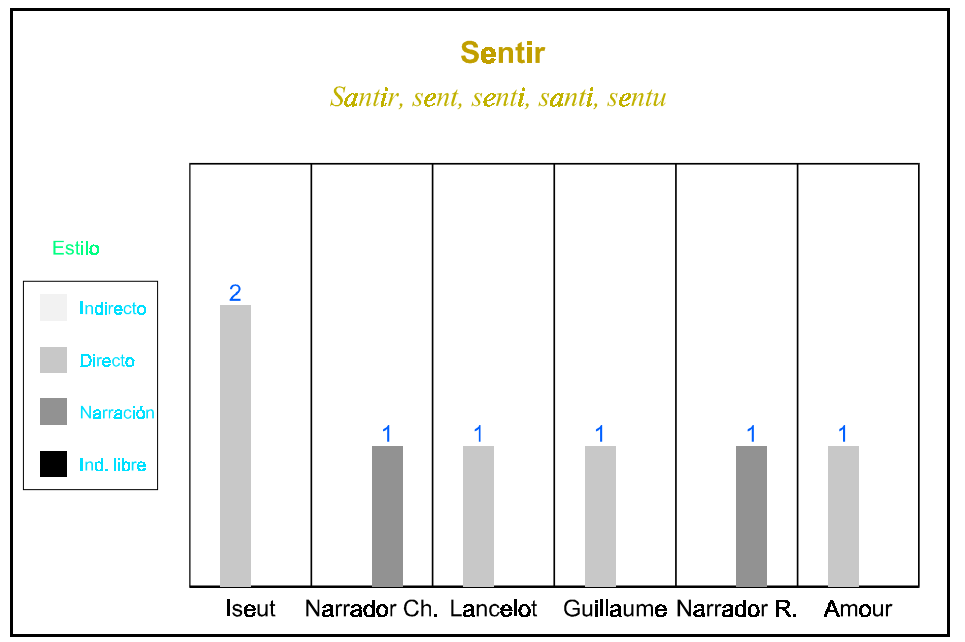

Fig. 144. Comportamiento estilístico del verbo sentir en el corpus.

Podemos agrupar las ocurrencias recogidas del verbo sentir en dos grandes grupos: las que se hallan en un contexto de provocación y causan en el interlocutor una reacción anímica, positiva en Tristan pues la interpretación de las palabras de Iseo trae la hilaridad de los reyes, negativa en E scoufle al levantar la ira del emperador, o una respuesta física, el combate entre caballeros en Charrete. En segundo lugar, las que preceden a un aumento significativo del contacto o del placer de los amantes. 


\subsection{Tenir.}

Hemos recogido dos usos, uno mediante el que se expesa un contacto táctil —en el que incluimos las formas recíprocas compuestas con el prefijo entre-: las manos o los brazos se convierten en receptáculo del cuerpo del otro: “il s'entretienent bras a bras" (Escoufle, 3369). Éste en ocasiones está desnudo o semidesnudo como en E scoufle. “que qu'ele le sert et tient nu" (Escoufle, 7065) o en Rose, con la salvedad de que en esta obra se trata de una ilusión: la construcción estre avis, que introduce la apariencia, la visión subjetiva, unida al futuro de indicativo tanto en la proposición principal como en la subordinada completiva, son las marcas de que la posesión del cuerpo desnudo durante la mortificante etapa del cortejo sólo puede ser un sueño que dejará más frustrado si cabe al enamorado: ${ }^{509}$

$$
\begin{aligned}
& \text { tel foiz sera qu'il t'ert avis } \\
& \text { que tu tendras cele au cler vis } \\
& \text { entre tes braz trestote nue }
\end{aligned}
$$$$
\text { Rose, } 2425 \text { - } 2427
$$

Frustración similar a la que siente la reina Ginebra cuando cree que su amante ha muerto sin que ella le haya demostrado su cariño acogiéndolo entre sus brazos: "se une foiz, ainz qu'il fust morz, l'eüsse antre mes braz tenu" (Charrete, 4226 - 4227). En este caso el pretérito pluscuamperfecto de subjuntivo nos sitúa a un tiempo en el pasado y en el presente: el momento de los remordimientos fundidos a los deseos irrealizables por irrealizados al haber sido voluntariamente ahogados, silenciados, bajo la presión del orgullo femenino, de la supremacía del sexo que, rompiendo con los moldes tradicionalmente patriarcales, se había arrogado los derechos que hasta entonces poseía el mundo masculino. Con ello Chrétien nos muestra el lado

509 La irrealidad del placer también es puesta de manifiesto por C. Nouvet, Les inter-dictions courtoises,op. at., p. 239. 
oscuro del código cortés, la conquista social por encima de la conquista del placer, de la identidad, de la identificación del propio cuerpo femenino, cuando en definitiva la primera debía ponerse al servicio de la segunda para comenzar la andadura de la quimérica igualdad entre los sexos.

El contacto puede ser negativo, y se deriva de él una posesión antinatural del cuerpo de uno de los amantes, una subversión del orden como la que atenta contra Iseo al quedar en poder de los leprosos: "fiert Yvain, qui Yseut tient" (Tristan, 1261), de la que es buena prueba el desprecio que muestra Tristán hacia estos personajes (Tristan, 1241), negándose incluso a combatir contra los lujuriosos parias para liberar a la reina, inactividad caballeresca que empuja a Governal a convertirse en el brazo ejecutor de su ira. Estas son las únicas ocurrencias recogidas en la obra de Béroul, pero el mismo contexto violento se perfila en Charrete, donde Lanzarote — no sin mucho dudar cuál era la postura que debía adoptar- decide intervenir para liberar a la doncella de su agresor, quien en este caso utiliza su fuerza no sólo en contra del orden estamental, sino del orden sexual instituido por la cortesía, el cual imponía la supremacía del sexo femenino y el fin de la violencia masculina que había forcejado tradicionalmente a las mujeres. La violación, que también entraña la desnudez femenina de cintura para abajo: "cil voit que molt vileinemant tenoit la dameisele cil descoverte jusqu'au nonbril"' (Charrete, 1080 - 1082), la parte menos noble pero con mayor fuerza para inflamar el instinto sexual, combina de este modo en el imaginario erótico de Charrete las percepciones táctiles y las visuales, la actividad agresiva y la inactividad del voyeur.

El segundo uso, en el que el verbo se presenta en forma reflexiva con el sentido de «permanecen», lo consideramos secundario ya que tan sólo deja espacio para el roce por la proximidad, aunque ésta implica un cierto grado de intimidad entre los amantes. Este es el segundo conjunto temático desarrollado mediante el verbo tenir en Rose en lo que concierne al amante, 
que puede ser hipotético: "quant il de lui se tient plus pres, et il plus est d'amer engrés" (Rose, 2343 - 2344) o concreto, y recibe los consejos del dios Amor:

$$
\begin{aligned}
& \text { mes je te lo que tu te tiegnes } \\
& \text { bien pres de li por Douz Regart, } \\
& \text { que ses solaz trop ne te tart } \\
& \text { Rose, } 2704 \text { - } 2706
\end{aligned}
$$

Por el contrario, en la parte introductoria, la que hace que el adolescente conciba la esperanza de alcanzar prontamente los favores de su amada, los personajes del cortejo de Deduit se nos muestran invariablemente unidos y presumiblemente dichosos: "Richece tint par mi la main un valet de grant biauté plain" (Rose, 1107 - 1108), "Largeice la vaillant, la sage, tint un chevalier dou lignage le bon roi Artu de Bretaigne" (Rose, 1173 - 1175).

La relación entre el bienestar de los amantes y la conjugación del verbo tenir en indicativo, presente o pasado y en tercera persona, del singular o del plural, se hace manifiesta en el corpus, si exceptuamos Tristan. Ya sea con una reja de por medio o en el lecho, tenir nos ofrece probablemente la primera ocasión de observar en Charrete cómo ambos amantes comparten una acción que les produce placer; en el primer caso, la reciprocidad expresada por el verbo no les permite llegar a la completa felicidad pues el contacto de las manos se les antoja insuficiente y desearían unir sus cuerpos. La unión se ha producido en la segunda ocurrencia, donde el sentido recíproco surge de proposiciones paralelas coordinadas por la conjunción copulativa et. La progresión entre las expresiones complementarias del verbo construidas a partir del sustantivo main y aquellas en las que se halla bras marca la modificación del contacto entre los amantes:

$$
\begin{aligned}
& \mathrm{Li} \text { uns pres de l'autre se tret } \\
& \text { et andui main a main se tienent }
\end{aligned}
$$

Charrete, 4592 - 4593 


$$
\begin{aligned}
& \text { quant il la tient antre ses braz } \\
& \text { et ele lui antre les suens }
\end{aligned}
$$

Charrete, 4672 - 4673

La reciprocidad es pues uno de los pilares sobre los que se asientan las ocurrencias del verbo tenir cuando se habla de dos amantes reconocidos, y podemos encontrar cualquiera de las posibles estructuras señaladas: el prefijo entre- en Escoufle. "or est la bataille apaisie de lor cuers quant il s'entretienent"' (Escoufle, 3978 - 2979), el verbo en forma recíproca o bien las construcciones coordinadas casi simétricas con una generalización en la segunda parte de la substitución pronominal: "Deduiz la tint par mi le doi a la querole, et ele lui.” (Rose, 834 - 835).

Excepcionalmente, en E scoufle, el verbo tenir posee un complemento de objeto de cosa como main y en este caso el sujeto es el amante, quien acaricia o abraza a la amada: "k'adés li tenoit cil au lés sa main ou a sa bele face” (Escoufle, 4044 - 4045), o bien un complemento preposicional con valor circunstancial cuando el sujeto es Aelis: "cele qui tient sen douç amant entre ses bras" (Escoufle, 3382 - 3383). Se puede observar de nuevo una conexión entre la iniciativa de cada uno de los amantes y el espacio social en la que se produce, al llevar éste aparejada una modificación de la asignación de papeles entre el elemento dominante y el dominado. Este esquema se reproduce en el mismo texto para presentar el contacto entre Aelis y el conde de Saint Gilles, si bien ya no se trata de mostrar las relaciones de poder sino más bien la oposición entre espacio privado y espacio público, femenino y masculino: ella lo tiene entre sus brazos en el gineceo: "la bele a la face vermeille qui tenoit la teste le conte" (Escoufle, 7176 - 7177), mientras que él la estrecha entre sus brazos a caballo — símbolo masculino y guerrero por excelencia — ante una abundante concurrencia cortesana y urbana: "il la tint puis une grant pose entre ses bras tut a cheval" (Escoufle, 8378 - 8379). En esta escena se implican todos los sentidos, algo que no ocurre muy a menudo, y la belleza, las voces, la proximidad de los cuerpos, el roce de los labios contradicen o más bien se 
convierten en excepción que confirma la regla de la supremacía de la sensualidad masculina.

El análisis de las proposiciones subordinadas nos muestra un cierto desequilibrio cuantitativo a favor de las proposiciones relativas — apenas hallamos proposiciones completivas-, las más de las veces determinativas, que son más abundantes en los textos del siglo XIII. Dentro de éstas predominan las que tienen al pronombre relativo como sujeto de la proposición, muy a menudo para explicar mediante la acción expresada por tenir el estado de ánimo descrito en la principal: “or n’est ele pas a malaise qui tient ce qu'ele plus amot" (Escoufle, 3384 - 3385); también se observan ejemplos en los que el pronombre relativo funciona como complemento, ya sea de objeto directo: "j'en cueillisse au moins une que je tenisse en ma main" (Rose, 1629 - 1631), ya de indirecto: "li cuens, cui cele tient tout nu" (Escoufle, 7102).

La consecuencia en E sooulle, con las construcciones correlativas tant ... que [A dv. + C onj.] que modifica una forma verbal: "tant est venus vers la pucele ḱlil s'entretienent bras a bras” (Escoufle, 3368 - 3369), y si ... que [Adv. + Conj.] que introduce una locución adverbial:

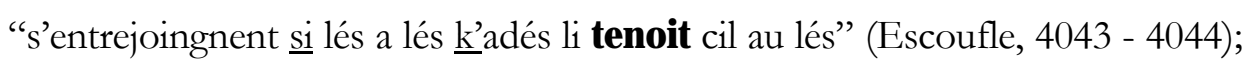
así como la simultaneidad temporal en todas las obras, introducida por la conjunción quant: “quant il s'entretienent" (Escoufle, 3979), "quant il la tient antre ses braz" (Charrete, 4672), "quant il de lui se tient plus pres" (Rose, 2343), o la locución conjuntiva que que [C onj. + C onj.]: "que qu'ele le sert et tient nu” (Escoufle, 7065), son los sentidos más asiduamente introducidos por las proposiciones subordinadas circunstanciales. El primer tipo describe un desplazamiento que permite a los amantes juntarse y tocarse; el segundo, si exceptuamos la proposición introducida por que que, y al igual que algunas de las subordinadas relativas, sitúa la confluencia entre el contacto y el placer erótico. 


\begin{tabular}{lllllllll}
\hline FORMA & CA & BD & NV & RIMA & CAT2 & NV2 & D & PERS \\
\hline entretienent & V & Escoufle & 3979 & tienent & V & 3980 & N & Narrador \\
tenisse & V & Rose & 1630 & cueillisse & V & 1629 & N & Narrador \\
tenu & O & Charrete & 4227 & nu & A & 4228 & D & Guenièvre \\
tiegnes & V & Rose & 2704 & loigtienes & A & 2703 & D & Amour \\
tienent & V & Charrete & 4593 & vienent & V & 4594 & N & Narrador \\
tient & V & Tristan & 1261 & vient & V & 1262 & N & Narrador \\
\hline
\end{tabular}

Tabla 90. Rimas del verbo tenir.

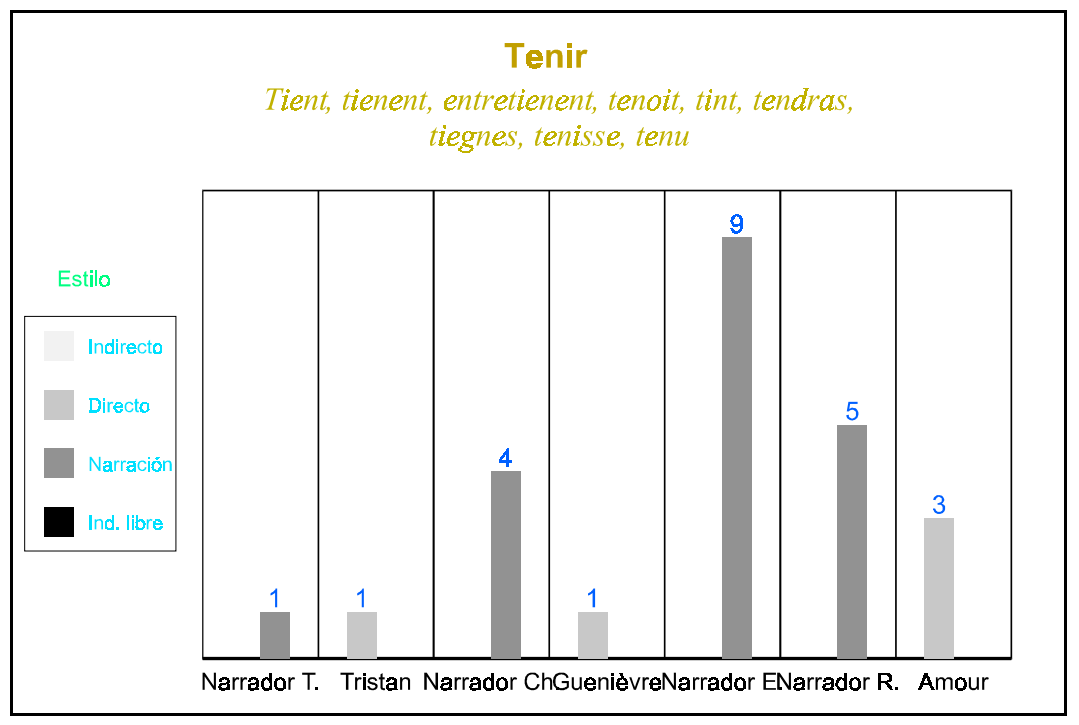

Fig. 145. Comportamiento estilístico del verbo tenir en el corpus.

El contraste entre la posibilidad más o menos lejana de tocar, de acariciar o de abrazar, y la realización de este anhelo universal entre los amantes tan sólo se manifiesta en Charrete y en Rose, de ahí el uso del subjuntivo o de proposiciones completivas dependientes de un verbo exhortativo. Por el contrario, la voz del narrador de E scoufle nos habla de la realización efectiva de la acción expresada por el verbo tenir y en consecuencia nos introduce en un universo en el que predomina la sensualidad de los encuentros y no la ilusión erótica, a la vez estimulante y frustratoria. 


\subsection{LOS BRAZOSY EL ABRAZO.}

\subsection{Bras.}

Los brazos con sus ademanes o su abandono expresan la intensidad del amor y del deseo. En la obra de Jean Renart muestran la importancia que se le concede al tacto así como a la belleza física, ya que muy a menudo el sustantivo va acompañado del epíteto biax, en las descripciones puras pero también al narrar cómo utiliza Aelis sus brazos: "La bele li a mis entor les flans ses .ij. biax bras" (Escoufle, 2364 - 2365).

Las descripciones físicas hacen intervenir este miembro de forma diferente en los siglos XII y XIII, sin que llegue a adquirir la importancia que tendrán las manos. Chrétien los utiliza para mostrar la gallardía y la fuerza de Méléagant antes de su combate contra Lanzarote, en compañía de otros miembros indispensables para la lucha a caballo y a pie propia de los duelos singulares entre caballeros: "et bien tailliez, de braz, de janbes, et de piez" (Charrete, 3541 - 3542). La armonía y belleza de las diferentes partes del cuerpo se someten al sentido práctico, y de hecho no se hace alusión alguna a los potenciales agentes creadores de dicha perfección -Dios o la Naturaleza - como ocurrirá en la descripción de Guillermo adolescente: "ml't ot biax bras et beles gemmes tex com li ot faites nature" (Escoufle, 2986 2987).

En Rose los brazos tienen un papel secundario y limitado a la narración de una fantasía, un deseo transferido a un tercer grado de hipótesis: expresado por el dios Amor, referido a un posible estado de alucinada desesperación y asociado a un cambio radical en las relaciones entre el amante y la amada. La palabra experimentada evoca un sueño probable motivado por el deseo frustrado de poseer el cuerpo femenino: 


$$
\begin{aligned}
& \text { tel foiz sera qu'il t'ert avis } \\
& \text { que tu tendras cele au cler vis } \\
& \text { entre tes braz trestote nue } \\
& \text { ausi con s'el fust devenue } \\
& \text { dou tot t'amie et ta compaigne }
\end{aligned}
$$

Rose, 2425 - 2429

También son evocados para expresar un anhelo, la muerte en los brazos de la amada, que podemos interpretar en sentido literal cargado de dramatismo o bien en uno figurado que aluda a la llamada pequeña muerte del orgasmo - la expresión conserva en la actualidad dicho sentido—:510 "la mort ne me greveroit mie, se ge moroie es braz m'amie" (Rose, 2449 - 2450). En este ejemplo, si tomamos la segunda interpretación, se coordinaría el eufemismo con una postura irónica y anticortés al dejar la puerta abierta a las relaciones sexuales con otras mujeres aunque quizá obtuviese un placer menor.

No es imaginario el encuentro de Lanzarote y Ginebra, quien lo había invitado a gozar de su voz, sus ojos y su presencia, de su boca y de los placeres de las sensaciones táctiles, pero que, una vez evitados los obstáculos que los separaban, lo recibe: "et la reïne li estant ses bras ancontre” (Charrete, 4654 - 4655) y estrecha con sus brazos atrayéndolo para que sienta su pecho y comience el juego sexual, tal y como la reina había deseado cuando lo creía muerto: "se une foiz, ainz qu'il fust morz, l'eüsse antre mes braz tenu" (Charrete, 4226 - 4227). Esta hipótesis irreal coincide con la que hemos señalado en Rose, y es destacable el hecho de que en ambos contextos se haga mención a la completa desnudez de los amantes como requisito para lograr el placer: "Certes, tot nu a nu, por ce que plus an fusse a eise" (Charrete, 4228 4229), un detalle realista visto a través del prisma de la imposibilidad que no aparece en los otros dos romans. Sin embargo no volvemos a encontrar en la

510 0p. dit., p. 190 y 457. 
obra de Chrétien ningún otro episodio en el que se nos hable de la existencia de un nexo físico entre los amantes, muy al contrario de lo que acontece en Tristan o en E scoufle, entre los que apenas existen diferencias, si tenemos en cuenta la expresión formal y el grado de reciprocidad con el que los amantes utilizan sus brazos para mostrar su pasión. En Escoufle la reciprocidad se manifiesta mediante la locución bras a bras, que puede estar reforzada por el prefijo verbal entre-: “il s'entretienent bras a bras” (Escoufle, 3369) o por una construcción pronominal de sentido recíproco: “li uns d'aus a l'autre abandoune ses bras et sa bouche et son vis" (Escoufle, 3618 - 3619). Béroul prefiere las acciones paralelas —obsérvese el prefijo iterativo del verbo avoir-, y es posible encontrar la causa de este fenómeno que se repite, de hecho lo hemos notado también en Charrete, en el modo de transmisión de la obra, probablemente más cercano al de las canciones de gesta frente a la probable lectura en voz alta del roman de Jean Renart, del que sin embargo no quedan excluidas las construcciones binarias reunidas por una conjunción copulativa:

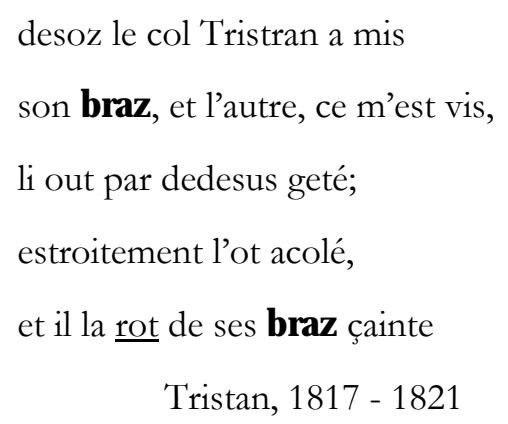

El análisis de los aspectos morfosintácticos en relación con los semánticos nos muestra varios fenómenos que no son independientes:

En primer lugar la tendencia en muchos contextos a describir una serie de gestos encadenados que van desde el acercamiento con los brazos extendidos de los amantes o el hecho de coger uno de ellos entre sus brazos al otro, hasta llegar al beso pasando por el abrazo. Muestras de amor que 
también se dan entre los esposos, aunque tal vez no sea casual que el rey Marco sólo actúe con tanta ternura cuando Iseo está inconsciente, momento en el que se permite abandonar por un instante el rígido y bochornoso papel de marido ultrajado: “entre ses braz l'en a levee, besie l'a et acolee” (Tristan, 3171 - 3172). El paradigma lo encontramos curiosamente en el reencuentro entre Lanzarote y Galván: "lors li vet ses braz estanduz, si l'acole, et salue, et beise" (Charrete, 6798 - 6799). Esto nos lleva en más de una ocasión a encontrarnos con una combinación redundante ya sea entre la acción expresada por un verbo acompañado de bras como complemento de objeto directo o como complemento circunstancial y el verbo que le sigue que designa el acto de abrazar: "ele li vait al col pendant ses biax bras, si l'acole et baise" (Escoufle, 5846 - 5847), ya sea, más claramente, al hacer depender el sustantivo de un verbo que significa «abrazar»: "vers soi l'atrait, des braz l'enbrace" (Tristan, 2804).

En segundo lugar la dependencia del sustantivo bras como complemento de tres verbos fundamentalmente - jeter, metre y tenirmientras que se hallan en franca minoría otros verbos como çaindre, ester, porter, pendre o estandre, entre los que también encontramos algunos más sugestivos desde el punto de vista erótico como lier y estraindre, que en E scoufle pueden estar ligados en la descripción progresiva de la acción de abrazar: "la pucele l'estraint et liede ses biaus bras et il des siens" (Escoufle, 7704 - 7705), abandouner, con el que se ahonda en la íntima confianza y en la búsqueda del placer de los adolescentes de E scoufle una vez que han pactado su fuga y creen poder alcanzar un futuro como pareja en la sociedad feudal escapando a las estrictas normas genealógicas que los separaban, o el propio monir, al que nos hemos referido más arriba. A pesar del predominio de los tres primeros no podemos por menos de poner de relieve la notable variedad de estas expresiones frente a algunas otras combinaciones verbales y nominales referidas en nuestro trabajo. 
En tercer lugar la sistemática adopción del sustantivo de dos funciones en la proposición, la de complemento directo: "et la reïne li estant ses bras ancontre, si l'anbrace” (Charrete, 4654 - 4655), "ele a son destre bras geté parmi l'emingaut du surcot le conte" (Escoufle, 7054 - 7056) y la de complemento circunstancial. En este caso puede expresar el modo con la preposición de: “des braz l'enbrace” (Tristan, 2804), el lugar: “ml't a poi en ses bras esté" (Escoufle, 3976) o ambas cosas a la vez, especialmente gracias a la preposición entre en Charrete y E sooufle: "il la tint puis une grant pose entre ses bras tut a cheval” (Escoufle, 8378 - 8379)

$$
\begin{aligned}
& \text { cele qui tient sen douç amant } \\
& \underline{\text { entre ses bras et si le baise }}
\end{aligned}
$$

Escoufle, 3382 - 3383

$$
\begin{aligned}
& \text { quant il la tient antre ses braz } \\
& \text { et ele lui antre les suens }
\end{aligned}
$$

Charrete, 4672 - 4673

Por su parte, el análisis de la sintaxis proposicional nos muestra un dominio de las proposiciones independientes o principales frente a algunos casos de subordinadas circunstanciales: temporales introducidas por quant, que hacen referencia a una acción que se prolonga en el tiempo y que precede a un cambio argumental en E scoufle al inmiscuirse la palabra, la voluntad y la sexualidad femeninas, por naturaleza negativas, en los ámbitos amoroso y genealógico que hasta ese momento habían convivido en armonía: "quant il orent geü bras a bras longhement” (Escoufle, 2884 - 2885). También indican la concomitancia de los procesos físicos y psíquicos del placer erótico en Charrete. "quant il la tient antre ses braz" (Charrete, 4672). Hipotéticas precedidas por la conjunción se y una consecutiva construida mediante la construcción tant ... que: “tant est venus vers la pucele k’il s'entretienent bras a bras" (Escoufle, 3368 - 3369), en la que por vez primera se alude al tema 
director de la historia de amor de Aelis y de Guillermo a partir de ese instante, los movimientos de separación y reencuentro consecutivos a la ruptura de la estabilidad vital y amorosa del gineceo, alteraciones en gran medida jalonadas por la presencia del sustantivo bras.

E scoufle es el único roman en el que el sustantivo bras está contenido en proposiciones relativas, con la particularidad de que el antecedente es siempre la heroína adolescente y el pronombre relativo funciona como sujeto tanto en los fragmentos descriptivos como en la narración o en el discurso del enamorado; no obstante, en ninguno de los casos se alude a ella mediante una denominación sustantiva y los términos antecedentes son pronombres —demostrativo o personal- o bien circunlocuciones superlativas, con ello se consigue un cierto alejamiento que parece compensar el protagonismo de la doncella en la actividad erótica:

cele qui tient sen douç amant

entre ses bras et si le baise

Escoufle, 3382 - 3383

Mais vous, fait il, qui m’avés mis

vo bras au col si doucement

Escoufle, 7696 - 7697

de la plus preus, de la plus france

qui tant estoit et bele et blance

et gente de bras et de mains

Escoufle, 3179 - 3181

\begin{tabular}{lllllllll}
\hline FORMA & CA & BD & NV & RIMA & CA2 & NV2 & D & PERS \\
\hline bras & S & Escoufle & 2365 & enbras & V & 2366 & N & Narrador \\
bras & S & Escoufle & 3369 & las & S & 3370 & N & Narrador \\
braz & S & Charrete & 4672 & solaz & S & 4671 & N & Narrador \\
\hline
\end{tabular}

Tabla 91. Rimas del sustantivo bras. 


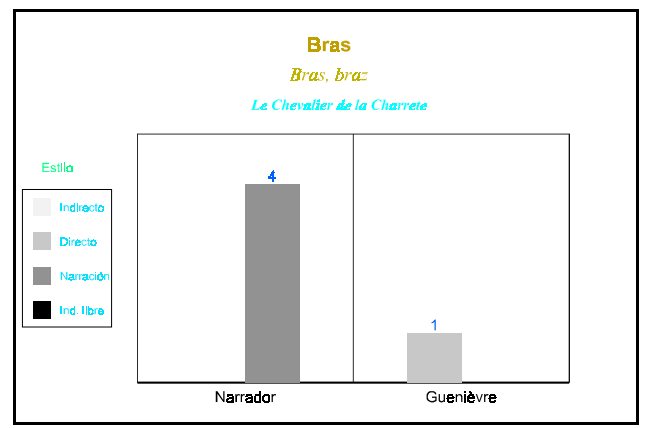

Fig. 146. Comportamiento estilístico del sustantivo bras en Charrete.

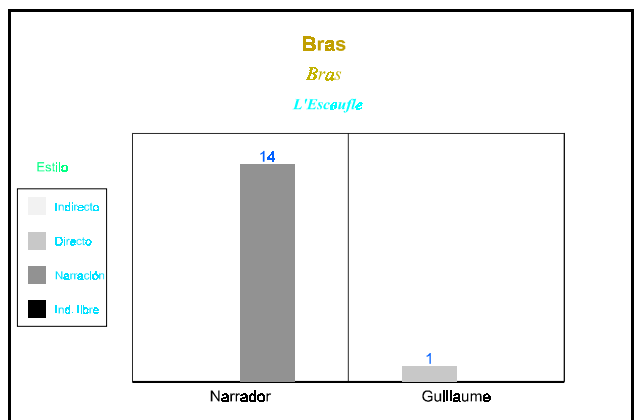

Fig. 147. Comportamiento estilístico del sustantivo bras en Escoufle.

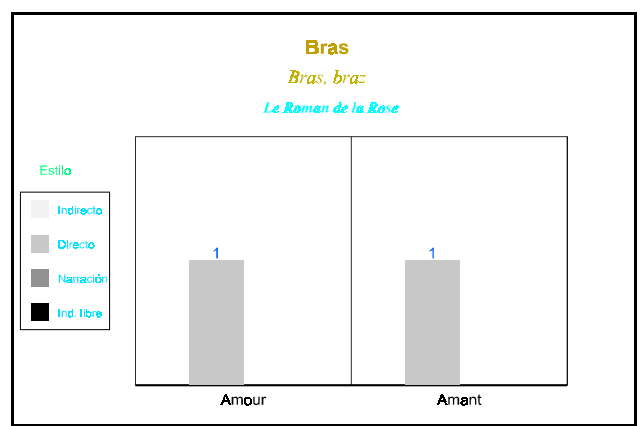

Fig. 148. Comportamiento estilístico del sustantivo bras en Rose.

Si bien escasas, las ocurrencias en la rima corroboran algunos de los aspectos formales y temáticos apuntados, en primer lugar la tendencia a la redundancia mediante la unión con verbos o sustantivos que expresan la acción de «abrazan» y la intimidad de los amantes, por otro la lógica relación con el placer sensual. Todo ello queda recogido en el discurso del narrador, incluido el roman de Béroul, lo que explica los verbos con sentido recíproco en tercera persona del plural o bien los artículos y adjetivos posesivos de tercera 
persona del singular. Las pocas intervenciones de los personajes enamorados se incluyen en contextos dominados por el aturdimiento, el distanciamiento y la muerte, lo que da lugar a una sensación agridulce, a una mezcla de melancolía y placer.

\subsection{2 «Acolen» y embrasser.}

Ambos verbos quedan excluidos de Rose y Chrétien dispone del verbo anbracier tan sólo en el momento en el que se inicia el juego amoroso al estrechar la reina contra su pecho a Lanzarote. Este hecho parece apuntar hacia una especialización de estas formas para hacer referencia a una intimidad continuada, una confianza que permite a los amantes gestos que escapan al furtivismo del texto alegórico y a la rapidez con la que Ginebra y Lanzarote pasan del alejamiento y el disimulo a la unión sexual completa. Ésta llega al entregarse con un único y prolongado abrazo, de ahí que el sentido del verbo anbracier sea retomado en la rima mediante lacier —es la única ocurrencia en el corpus si bien hemos tenido ocasión de observar algunos ejemplos del sustantivo laz en el apartado anterior- " "si l'anbrace, estroit pres de son piz le lace, si l'a lez li an son lit tret" (Charrete, 4655 - 4657). Por el contrario, los enamorados tristanianos, los adolescentes y amantes maduros de Escoufle se nos muestran a menudo abrazados, y esta acción está asociada con besar y estrechar entre los brazos: "si la baise, estraint et acole" (Escoufle, 5289). Por ello, cuando acoler o anbracier aparecen solos, podemos suponerles por extensión la acción de besar, sentido dominante en nuestros días para el segundo. Esto permite explicarnos en Tristan la insistencia con la que se describe la excepcional postura de los amantes al ser encontrados por el rey en la choza del Morois, abrazados pero sin juntar sus bocas.

En la alianza de acoler con baisier sobresale el hecho de que se impongan las razones formales para la distribución de ambos verbos en la primera o segunda parte del verso ya que no encontramos estructuras fijas, es 
más, incluso cuando la acción de besar se halla expresamente supeditada a la de abrazar, baisier puede estar en la parte inicial del verso para dejar acoler en la rima:

$$
\begin{aligned}
& \text { lors la preïst par bele bouche } \\
& \text { et la baisast, car ml't l'acole }
\end{aligned}
$$

Escoufle, 3548 - 3549

Renart, cuya preferencia por los gestos compartidos y por el prefijo entre- ya hemos señalado: "il s'entresont ml't doucement, au departir, entr'acolé" (Escoufle, 3632 - 3633), aprovecha la combinación de ambos términos para elaborar una nueva estructura recíproca con variación de los sujetos, con lo que resulta del todo evidente que ambos amantes se abrazan y besan mutuamente:

$$
\begin{aligned}
& \text { por le mangier ne remaint mie } \\
& \text { k'il ne l'acole et qu'el nel baist } \\
& \text { Escoufle, } 4324 \text { - } 4325
\end{aligned}
$$

Acabamos de referirnos a los amantes de los textos de Béroul y Renart pero no podemos pasar por alto el hecho de que estos verbos testimonian el amor del rey Marco hacia su esposa, siempre en períodos que preceden o suceden a encuentros que exculpan a los enamorados y sin que medie la reciprocidad característica de los abrazos de éstos: "Acole la, cent foiz la besse" (Tristan, 461), "besie l'a et acolee" (Tristan, 3172). Así mismo caracterizan la noche en la que el emperador y la emperatriz yacen juntos y en la que se fragua la separación de Aelis y de Guillermo: "L'empereris l'acole et baise et puis les ex et puis la face" (Escoufle, 2872 - 2873).

La preferencia por el presente de indicativo en el discurso narrativo sólo se abandona en Tristan durante la descripción del estrecho abrazo de los amantes dentro de la choza, pasando a utilizarse el pretérito pluscuamperfecto de indicativo: “estroitement l'ot acolé" (Tristan, 1820), “estroitement ot 
enbrachie la roïne" (Tristan, 1674 -1675). Con ello se supedita la actitud de los amantes a los acontecimientos posteriores, su descubrimiento y delación, ambos decisivos para su reintegración social. De hecho se reelaboran los fragmentos que acabamos de citar en presente y como una acción compartida, y el participio pasado adopta la función de complemento circunstancial: "en une loge de Morroi dorment estroitet enbrachiez" (Tristan, 1900 - 1901).

Las heroínas de Chrétien y de Jean Renart asumen el papel de sujeto activo en las acciones referidas por acoler y anbracier, con una notable diferencia, en el roman del siglo XIII la primera persona del singular de las intervenciones en estilo directo de Aelis se impone sobre las intervenciones narrativas en tercera persona: “- «Se jou l'acol et ce n'est il, jou arai honte” (Escoufle, 7554 - 7555)

$$
\begin{aligned}
& \text { «Di va! Biau frere, cui j’acol, } \\
& \text { estes vous donc li miens amis?» } \\
& \text { Escoufle, } 7694-7695
\end{aligned}
$$

Este papel activo de la mujer, al que ya nos hemos referido en innumerables ocasiones, se ve reforzado por la dependencia absoluta de Guillermo de su amada y de su iniciativa al expresar en voz pasiva su temor a no volver a ser abrazado tras su exilio del palacio imperial: "ce est del mains que jamais acolés n'en iere” (Escoufle, 3182 - 3183). Sin embargo, observamos un trasfondo común a ambas actitudes, un sometimiento consciente o inconsciente a las reglas que coartaban la libertad amorosa pretendida por la cortesía y en mayor grado por la corriente naturalista. No ya por la incondicional aceptación del tabú de la virginidad, sino por la represión de los impulsos amorosos, tanto más grave en el caso de Aelis cuanto que con el paso de los años su espontaneidad, su deseo de permanecer junto al amado o de buscarlo, se han ajado: se preocupa en exceso de los que la rodean y de las consecuencias que el hecho de abrazar a un desconocido que la atrae físicamente y que le recuerda a Guillermo podrían tener para ella y para su 
consideración en la corte del conde. Esta transformación se revela mediante lo que tiene toda la apariencia de ser una interrogación retórica, gracias a la proposición subordinada hipotética introducida por se y en mayor medida con la palabra honte, que se convierte en un elemento clave, pues al abandonar el palacio de su padre en compañía de su amante había desechado tal sentimiento al supeditarlo todo al deseo amoroso y a la pasión, y tan sólo al sentirse abandonada por Guillermo, es decir, al pensar en la unilateralidad de sus amores comienza a sentirse avergonzada por sus actos, no por ser amorales, sino por ir en contra de la construcción genealógica, tendencia que se agudiza progresivamente hasta el pasaje que nos ocupa.

\begin{tabular}{lllllllll}
\hline FORMA & CA & BD & NV & RIMA & CAT2 & NV2 & D & PERS \\
\hline acol & V & Escoufle & 7554 & col & S & 7553 & D & Aélis \\
acol & V & Escoufle & 7694 & col & S & 7693 & D & Aélis \\
acole & V & Escoufle & 3549 & parole & S & 3550 & N & Narrador \\
acole & V & Escoufle & 5289 & parole & S & 5290 & N & Narrador \\
acolee & O & Tristan & 3172 & levee & O & 3171 & N & Narrador \\
acolé & O & Escoufle & 3633 & escolé & O & 3634 & N & Narrador \\
acolé & O & Tristan & 1820 & geté & O & 1819 & N & Narrador \\
anbrace & V & Charrete & 4655 & lace & V & 4656 & N & Narrador \\
embrace & V & Escoufle & 3389 & face & S & 3390 & N & Narrador \\
enbrace & V & Tristan & 3184 & chace & S & 3183 & N & Narrador \\
enbrace & S & Tristan & 2804 & sace & V & 2803 & N & Narrador \\
enbrachie & O & Tristan & 1674 & fullie & S & 1673 & N & Narrador \\
enbrachiez & O & Tristan & 1901 & vengiez & O & 1902 & D & Félons \\
\hline
\end{tabular}

Tabla 92. Rimas de los verbos «acoler» y embrasser.

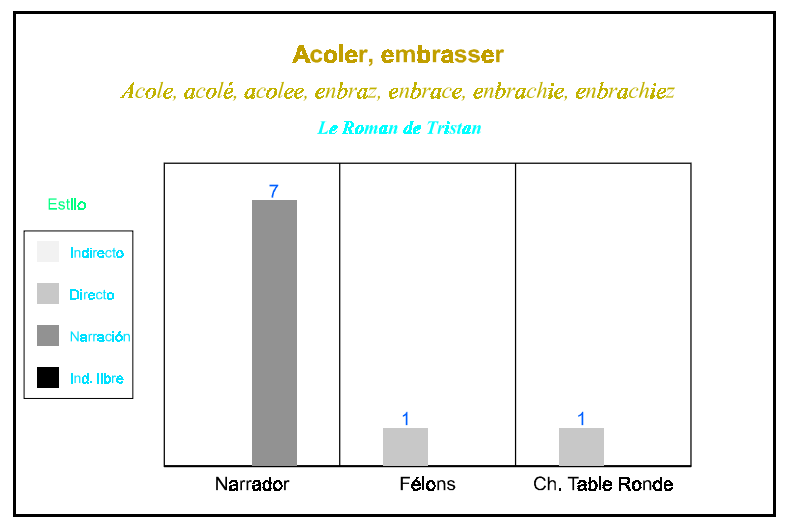

Fig. 149. Comportamiento estilístico de los verbos «acoler» y embrasser en Tristan. 


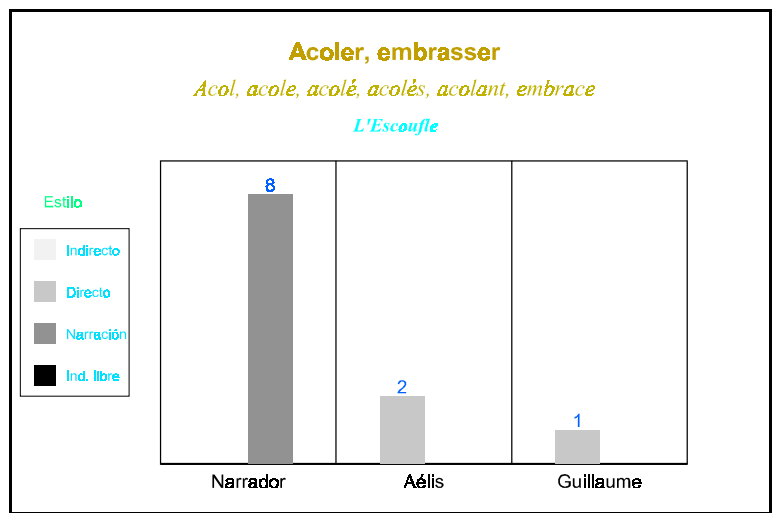

Fig. 150. Comportamiento estilístico de los verbos «acoler» y embrasser en Escoufle.

La distribución de las formas en los textos de Béroul y de Renart, así como la especialización en la rima de acoler y anbracier nos muestran las preferencias estilísticas y probablemente también las modificaciones diacrónicas en el uso de uno y otro término. Por otra parte, las construcciones sintácticas en las que se hallan estos verbos revelan una tendencia a la simplicidad sintáctica en el discurso narrativo, mientras que predomina su inserción en proposiciones subordinadas dentro del discurso directo de los personajes en el texto del siglo XIII.

\subsection{LA MANO, EL TACTO Y LAS CARICIAS.}

\subsection{Main.}

Organo del tacto y de la prensión, la mano se alza en protagonista del contacto sensual en E scoufle. Queda un tanto diluido su contenido erótico en los otros textos, incluso en algunas de las ocurrencias que complementan el verbo tenir o en las que hallamos el sintagma main a main para poner de relieve el comienzo de un proceso de unión física, ya sea deseada o no por ambos sexos, construcciones a las que recurre Chrétien. 511

511 Charrete, v. 1192 y 4593. 
Las manos sirven también para mostrar el respeto y el cariño del esposo: "pus est as piez le roi asise. Prist l'a la main, si l'en leva" (Tristan, 3156 - 3157), lo que coloca a la reina en una posición de igualdad pese a las continuas acusaciones y amenazas de los felones. Es esta una deferencia del varón situado en un nivel superior que se repetirá en E scoulle, donde el conde de Saint Gilles muestra su afecto y su preferencia por Aelis al conducirla de nuevo a la reunión cortesana. Este hecho prefigura el reconocimiento inminente de la elevada posición social de la doncella tras ser escuchada la historia de Guillermo: "par sa blance main la ra lors deduisant remenee au fu" (Escoufle, 7356 - 7357).

Las manos ayudan a establecer un compromiso privado entre los enamorados una vez rota la promesa de matrimonio en el ámbito genealógico:

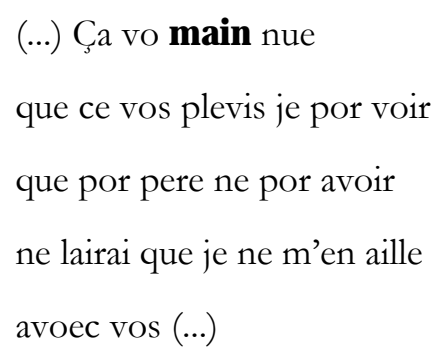

De igual modo, la mano del dios Amor al tomar la del adolescente supone la aceptación de su servicio y por lo tanto el comienzo de una relación pactada que debería llevar al enamorado a disfrutar de los bienes amorosos; observamos aquí una combinación de los valores expuestos hasta ahora: el inicio de un compromiso y la ratificación o el ascenso a un determinado nivel social, y más concretamente amoroso:

A ce mot vols bessier son pié, mes il m'a par mi la main pris et me dit: «Je t'ain mout et pris dont tu as respondu issi.

Rose, 1924 - 1927 
$\mathrm{Al}$ margen de las acciones que se ejecutan con ellas, las manos son unos de los miembros elegidos por los textos del siglo XIII para describir la belleza femenina. Se inaugura así en la estética occidental un canon que se mantendrá hasta nuestro siglo: el de la blancura del cuerpo y especialmente de las manos. En Escoufle se coloca el adjetivo de color como elemento singularizante junto a otros atributos generales y por otra parte redundantes entre sí: "qui tant estoit et bele et blance et gente de bras et de mains" (Escoufle, 3180 - 3181). Signo excluyente en dos direcciones, la de las razas orientales con las que se había entrado en contacto estrecho durante las cruzadas, con la consiguiente creación de un nuevo mito, el del extranjero y sus defectos, del que tenemos un claro ejemplo en $\mathrm{A}$ ucassin et $\mathrm{N}$ iolette, y la de las mujeres que trabajaban en los campos expuestas al sol, que se oponen no sólo a las mujeres nobles sino a las de las nuevas clases ascendentes de las ciudades. Tal como observamos en el retrato de Oiseuse, estas mujeres preservaban esta seña de identidad incluso durante sus diversiones al aire libre, y probablemente se impuso una nueva moda al adaptar una prenda de abrigo a las estaciones en las que el clima se mostraba benigno: "et por garder que ses mains blanches ne halassent, ot uns blans ganz" (Rose, 560 - 561). El canon de belleza reunido ineludiblemente con la pertenencia a una clase social privilegiada se extiende también a los varones como Guillermo cuyas manos son descritas por su enamorada con los mismos adjetivos a los que recurre el narrador. Aelis pone de relieve la blancura mediante un adverbio intensivo, la aparición en la rima y una construcción relativa que separa el adjetivo blanches del epíteto general beles, casi vaciado de su contenido por la constante utilización en los textos y particularmente en esta obra: "vos beles mains, qui si sont blanches" (Escoufle, 3285). Lorris, en el fino análisis de la casuística amorosa realizado gracias a los largos monólogos del dios Amor, atiende a los detalles que escapan al estereotipo descriptivo y pertenecen más bien a la vida cotidiana: pone en relación la belleza y, aunque no la nombre expresamente, la blancura, con la limpieza de las manos, de las uñas y de los dientes. Estos detalles realistas referidos al cuerpo de un individuo, y a la vez 
relevantes en los primeros contactos eróticos ya sea con la sola intervención de la vista o bien en una segunda fase en la que se llega al contacto manual o bucal, los textos del siglo XII y aun de comienzos del siglo XIII los pasan completamente por alto, y se convierten en una nueva manifestación de una vida relativamente ociosa:

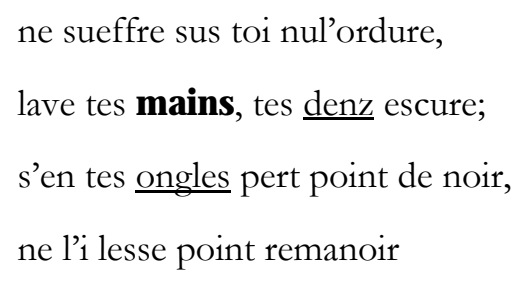

Junto a tenir, los verbos de los que el sustantivo depende más a menudo como complemento de objeto directo son prendre y metre. Con el primero, como ya hemos visto, las manos constituyen al tiempo un vínculo y un puente que permiten la reintegración de la mujer noble al puesto que le corresponde en la sociedad: el movimiento ascendente o del interior al exterior, siempre dentro del ámbito privado, corresponde a una reestructuración simbólica de las relaciones entre los sexos, que no entre los amantes. En segundo lugar, la combinación de prendre y main presenta la ternura del amante dentro de las convenciones del registro puramente amoroso; adquiere a la vez un valor metonímico al ser el primer paso en los juegos eróticos no descritos de los enamorados, máxime si tenemos en cuenta que el narrador acaba de referirse a la levedad de los pechos de la doncella: " $\mathrm{Li}$ damoisiax s'est acostés lés li, si l'a par la main prise” (Escoufle, 2322 - 2323). Tanto en Tristan como en E scoufle el sujeto de prendre es el varón, en Rose el pronombre sujeto es así mismo masculino pero al tratarse de Bel Accueil se hace referencia a una de las virtudes femeninas. Se inicia así un movimiento espacial contrario al que observábamos en E scoufle, de fuera hacia dentro, del espacio público, masculino, al espacio íntimo, femenino, al jardín prohibido dentro del jardín reservado para los elegidos, movimiento que de nuevo se 
duplica con una aceptación del enamorado que deja entrever el comienzo probable de una relación más estrecha entre ambos:

$$
\begin{aligned}
& \text { il m'a lores par la main pris } \\
& \text { por mener dedenz le porpris } \\
& \text { que Dangier m'avoit chalangié } \\
& \text { Rose, } 3331 \text { - } 3333
\end{aligned}
$$

Los contextos en los que se encuentra el verbo metre se nos presentan mucho más atractivos o prometedores — siempre en E scoufle y con la heroína como sujeto dentro del discurso narrativo o con el enamorado en el discurso directo de Aelis—, y ello en el sentido de que revelan gestos íntimos con los que las manos tocan o acarician partes del cuerpo femenino altamente sensibles a la excitación sexual. La propia Aelis, mojada por el sudor —otro fenómeno erógeno-, pasea su mano por su pecho hasta descubrir la limosnera destinada a Guillermo que había guardado junto al corazón: "La bele a mis por la suour sa main sous sa blanche chemise" (Escoufle, 4470 4471), o bien recuerda desnuda su intimidad con Guillermo y añora las caricias que recorrían su vientre y sus caderas, regiones anatómicas tan cercanas a los genitales que no podemos dejar de sospechar que de nuevo se apela a un recurso metonímico. Con ellas se da un cumplido repaso a las partes más sugestivas de un contacto carnal completo o casi completo, lo que, por otro lado, nos recuerda las representaciones figuradas primitivas de la tierra madre y la fertilidad en las que las mamas, las caderas y el vientre adquirían un tamaño desproporcionado con respecto al conjunto femenino que se reproducía: "tantes foïes avés mis vos beles mains, qui si sont blanches, a cest bel ventre et a ces hanches" (Escoufle, 3284 - 3286).

También al despertar de una apacible siesta precedida de los juegos amorosos a los que se entregaban tras su salida del palacio imperial intenta tocar a su amante desaparecido (Escoufle, 4648 - 4649). Éste había negado 
ante el padre cualquier gesto libidinoso, poniendo gran cuidado en no nombrar ninguna parte del cuerpo de la doncella y sustituirla por una prenda íntima. Recupera, además, una de las fórmulas más habituales en el texto de Béroul para dar por engañado al senior, aquí el padre, allí el marido: la dependencia de la proposición subordinada completiva de un verbo de conocimiento reforzado por el adverbio bien para expresar la certeza absoluta. En este caso el sustantivo main ya no es objeto, sino sujeto, con ello queda personalizada, adquiere vida propia, y el verbo ya no es metre sino muchier, «esconden», sin duda marcado negativamente por el gesto furtivo, la ocultación, que van asociados a la contravención de las normas sociales: "Bien saciés que ma mains ne s'ose muchier sous son bliaut de Sire" (Escoufle, 3036 - 3037). Lo mismo ocurre en Rose con el verbo tendre: en los contextos en los que se halla alude a un gesto que, además de hacerse a escondidas, une el simple contacto físico a la posible posesión de la flor - doncella — de ahí la construcción subordinada hipotética con Se- "por ceus espier et sorprendre qu'il voit au roses la main tendre” (Rose, 2815 - 2816)

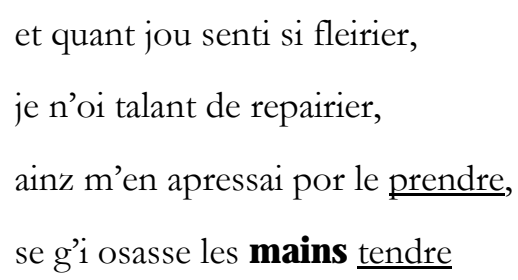

La otra función privilegiada de los sintagmas en los que encontramos main es la de complemento circunstancial, si bien no es fácil determinar las etiquetas semánticas que convienen a cada uno de ellos: el modo en Charrete. "an la sale an vont maint a main” (Charrete, 1192), "je ne porrai avenir a vos, fors de boche ou de main" (Charrete, 4516 - 4517), "et andui main a main se tienent" (Charrete, 4593); el modo o el instrumento en Tristan, E scoufle y Rose. “tel gent vos tienent entre mains" (Tristan, 1241), “ains l'ataste a sa souef main" (Escoufle, 2913), "si l'a par la main prise” (Escoufle, 2323), "ki par la 
main les maine amont" (Escoufle, 5607), "par sa blance main la ra lors deduisant remenee au fu” (Escoufle, 7356 - 7357), “mes il m’a par mi la main pris” (Rose, 1925), “il m’a lores par la main pris” (Rose, 3331); el lugar en Rose: “en ma main por l'odor sentir” (Rose, 1631).

\begin{tabular}{lllllllll}
\hline FORMA & CA & BD & NV & RIMA & CA2 & NV2 & D & PERS \\
\hline main & S & Charrete & 4517 & demain & D & 4518 & D & Guenièvre \\
main & S & Escoufle & 2913 & demain & S & 2914 & N & Narrador \\
main & S & Charrete & 1192 & main & V & 1191 & N & Narrador \\
main & S & Escoufle & 4648 & main & D & 4647 & N & Narrador \\
main & S & Rose & 1107 & plain & A & 1108 & N & Narrador \\
mains & S & Tristan & 1241 & certains & A & 1242 & D & Tristan \\
mains & S & Escoufle & 3181 & mains & D & 3182 & N & Narrador \\
mains & S & Escoufle & 4441 & mains & D & 4442 & N & Narrador \\
\hline
\end{tabular}

Tabla 93. Rimas del sustantivo main.

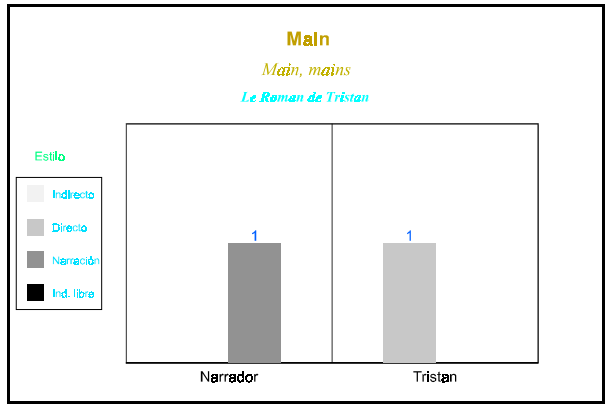

Fig. 151. Comportamiento estilístico del sustantivo main en Tristan.

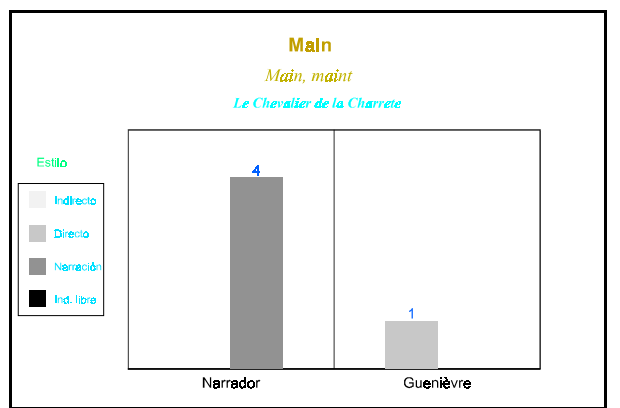

Fig. 152. Comportamiento estilístico del sustantivo main en Charrete. 


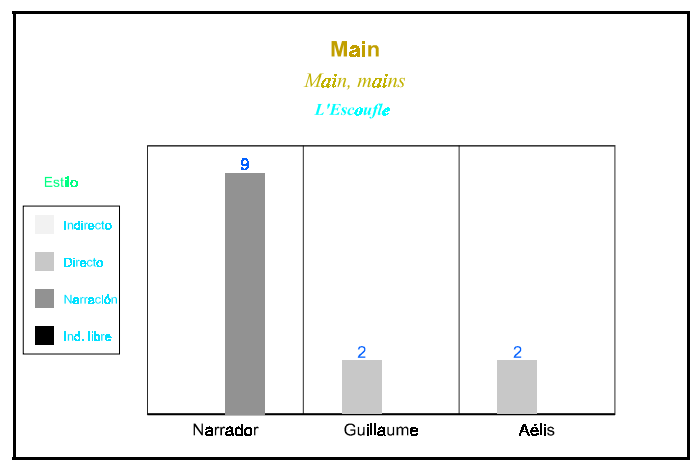

Fig. 153. Comportamiento estilístico del sustantivo main en Escoufle.

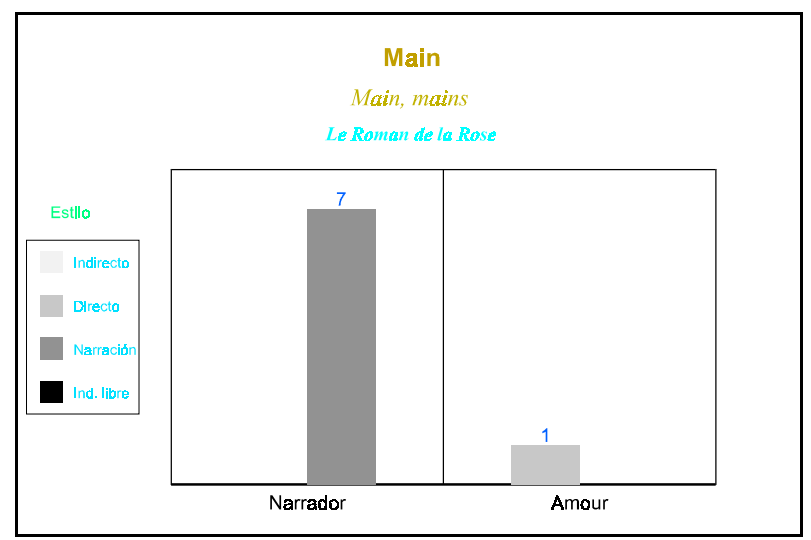

Fig. 154. Comportamiento estilístico del sustantivo main en Rose.

Con la sola excepción del discurso preceptivo del dios Amor en Rose, la caracterización estilística del corpus por lo que respecta al sustantivo main es completamente regular: a la voz, generalmente dominante del narrador y cuyo peso aumenta notablemente en el siglo XIII, se une la de uno o la de los dos amantes, y ello incluso en el texto de Lorris donde el narrador en primera persona resulta ser el doble maduro y experimentado del joven adolescente enamorado por primera vez. Sea en un discurso o en otro, la predominancia de los complementos circunstanciales de modo y/o instrumento otorga un papel de intermediario a las manos en dos sentidos: uno social, aunque estrechamente relacionado con las relaciones entre los géneros y secundariamente con el erotismo, y otro indudablemente sensual, que, aunque no de forma exclusiva pues los narradores recurren igualmente a él, descubrimos en los discursos directos de Ginebra y de Aelis, mientras que Guillermo lo niega y del narrador de Rose tan sólo oímos el deseo. 


\subsection{2 «Atasten», tâter, toucher, attouchery tact.}

Tan sólo presentes en los textos del siglo XIII, los verbos ataster y taster y el sustantivo tast, cuyo origen se halla en la forma del bajo latín tastare, procedente de una clásica taxare, intensiva con respecto a tangere, se hallan asociados bien a la suavidad de las manos que acarician: "ains l'ataste a sa souef main" (Escoufle, 2913), bien a la piel aterciopelada, tersa y suave del cuello femenino, que invita al contacto sensual: "polis ert et soés au tast" (Rose, 542). Constituye ésta una curiosa incursión en la sensibilidad táctil cuando todas las sensaciones descritas habían apelado a la visión de un bello cuerpo femenino, o bien a la intensidad de las caricias manuales: "tasté mon cors en tos sens" (Escoufle, 3287). Con ella se designa por eufemismo el contacto sexual en el que no se llega al coito e incluso con toda probabilidad la masturbación de la heroína, y sirve para expresar el grado de intimidad entre Aelis y Guillermo, quienes se daban placer según los preceptos corteses salvaguardando el valor en alza en el siglo XIII.

El verbo atochier, que en la actualidad posee los sentidos de acariciar, rozar y más concretamente de acariciar sexualmente, nos suministra valiosa información sobre el conflicto que afecta a la libido masculina, y si cabe en mayor medida a la de un enamoradizo adolescente, que compromete su afección al código cortés cimentado en la estricta monogamia: el joven de Rose se siente atraído por un único capullo - doncella, pero ante la cercanía de otras mujeres desearía poder gozar del contacto con ellas; es más, la inclusión de este pasaje en el discurso indirecto de Bel Accueil parece indicar la reciprocidad de las féminas, quienes ofrecerían sus encantos para atraerlo y gozar así del sutil roce entre los cuerpos:

$$
\begin{aligned}
& \text { sovent me semont d'aprochier } \\
& \text { vers le bouton et d'atouchier } \\
& \text { au rousier qui estoit chargié }
\end{aligned}
$$

Rose, 2855 - 2857 
Así pues, las formas procedentes de la otra raíz generadora de términos con este sentido en francés, ya sea *toccare o *tudicare, apenas se hallan en relación con las manos o con la suavidad del tacto, por el contrario hacen una referencia indeterminada al contacto de dos cuerpos: "de tochier a li molt se gueite, einz s'an esloingne" (Charrete, 1216 - 1217) o bien a las caricias efectuadas con otros órganos, eminentemente con los labios o los ojos, un uso que se conservará hasta el siglo XVII. En Charrete, un contexto negativo revela la abstención del contacto con otra mujer que no sea Ginebra, mientras que las caricias hechas con los ojos los hacen participar, más allá de la visión, en las sensaciones táctiles junto a la boca, la frente y la cara. Al descubrir los cabellos de la esposa de Arturo el arrebato fetichista de Lanzarote lo lleva a venerarlos con un fervor excesivo, una desviación sexual que nos describe así Chrétien:

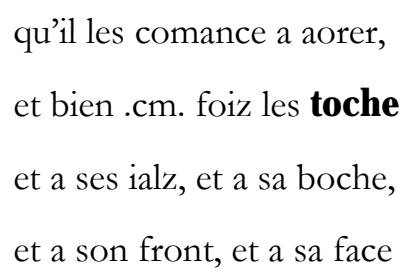

Charrete, 1462 - 1465

También el amante de la rosa había rozado una vez los pétalos con su cara, sus ojos y su boca y, desesperado al ver que Amor no le permite tocarla de nuevo, se queja amargamente y desea la muerte. Podemos observar la gran semejanza existente entre las construcciones preposicionales con valor circunstancial en uno y otro texto, aunque las diferencias sean notables desde el punto de vista erótico: mientras que Ginebra no llega a conocer la reacción de Lanzarote, la amada del siglo XIII había percibido la sensación táctil producida por las caricias del amante, con la consiguiente y más que probable estimulación erótica, pese a que luego, ya sea por motivos estrictamente sociales o de ética amorosa, rechace nuevos agasajos:

Mar touchai la rose a mon vis

et a mes ieuz et a ma bouche, 
s'Amors ne sueffre que g'i touche

Rose, 3764 - 3766

La unión de los labios transcribe mediante el verbo tochier la aceptación del homenaje por parte del dios Amor en un remedo de la ceremonia de compromiso del servicio mutuo feudal, aunque se pone de relieve la importancia de la ascendencia en un momento de profundos cambios sociales. Si en esta época las relaciones sociales entre varones ligados por un feudo no dejaban ningún espacio para el ascenso de las clases no caballerescas, no ocurría lo mismo en términos genealógicos, pues la burguesía adinerada comienza a introducir a sus hijas en el seno de las clases nobles mediante el matrimonio, sin embargo, se sigue excluyendo a los campesinos o a los grupos poco favorecidos de las ciudades:

$$
\begin{aligned}
& \text { que je veil por ton avantage } \\
& \text { que tu me faces tost homage. } \\
& \text { Si me besseras en la bouche, } \\
& \text { ou onques nus vilains ne touche. } \\
& \text { Je n’i lesse mie touchier } \\
& \text { chascun vilain, chascun porchier } \\
& \text { Rose, } 1931 \text { - } 1936
\end{aligned}
$$

De igual modo, en E scoufle el verbo tochier establece una estrecha relación con el beso, y es éste el único texto en el que se nos describe un beso con lengua. A la vez apasionado y tímido, recoge la intensidad del amor de los adolescentes quienes, pese a su inocencia, se dejan llevar por las reacciones instintivas que les llevan a abrir los labios y a separar los dientes. De todas formas es interesante el hecho de que a la vez, de forma más complementaria que contradictoria con lo que acabamos de afirmar, se aluda a Aelis como la que lleva de nuevo la iniciativa en la relación erótica y persigue intencionadamente con sus acciones proporcionar placer a su amante: 
por ce que li baisiers li plaise,

ele oevre si sa bele bouche

que l'une langue a l'autre touche

malgré les dens blans et serrés

k'amors lor a si desserrés

Escoufle, 4336 - 4340

Otros deleites sensuales atestiguan el indudable deslizamiento hacia una integración del cuerpo vivo, voluptuoso, en el seno del texto noble: la boca y los labios de Aelis y de Guillermo comparten la comida y la saliva mezclando el placer gastronómico y el placer erótico. Es de nuevo la amada la que le ofrece al amante su porción de comida después de haber mordido, todo ello sin que se atisbe ninguna reminiscencia de los bocados que expulsaron al hombre y a la mujer del Paraíso:

$$
\begin{aligned}
& \text { Ne li rent pas tant ne demi } \\
& \text { de savour ne poivres ne seus, } \\
& \text { comme faisoit la grans douceurs } \\
& \text { de la ou les levres touchierent }
\end{aligned}
$$

Escoufle, 4452 - 4455

Las proposiciones subordinadas completivas cuyo núcleo es tochier, dependientes de verbos como lessier (Rose, 1935) o soufrir cuyos sujetos poseen un rango superior al del amante de Rose y por lo tanto pueden imponerle su voluntad, se caracterizan por estar insertas en un contexto negativo con lo que expresan una interdicción: "avecques ceus est Male Boche, qui ne sueffre que nus i toche" (Rose, 3017 - 3018), "s'Amors ne sueffre que g’i touche tot de rechief autre foïe" (Rose, 3766 - 3767). Las sensaciones táctiles le están vedadas por lo que se imposibilita su progresión en la obtención de los placeres eróticos. Pero también, si nos situamos en el lado de la mujer, se hace inviable una de las principales, si no la más 
importante fuente de placer sexual para ella, con lo que se está retornando de hecho a la época pre-cortés en la que la satisfacción sexual femenina no debía en ningún caso llegar a colmarse.

Las dos proposiciones subordinadas relativas en las que se encuentran las formas que aquí estudiamos están introducidas por el adverbio ou, que como es preceptivo retoma un antecedente que indica el lugar. Éste puede ser simbólico como los labios del dios Amor (Rose, 1933 - 1934) o bien ser una porción de un elemento de la realidad, en este caso el manjar con el que Aelis obsequia a su enamorado: "la ou les levres touchierent ki a la plus bele bouche ierent" (Escoufle, 4455 - 4456).

\begin{tabular}{lllllllll}
\hline FORMA & CA & BD & NV & RIMA & CA2 & NV2 & D & PERS \\
\hline atouchier & I & Rose & 2856 & aprochier & I & 2855 & I & Bel Accueil \\
tast & S & Rose & 542 & portast & V & 541 & N & Narrador \\
toche & V & Charrete & 1463 & boche & S & 1464 & N & Narrador \\
toche & V & Rose & 3018 & Boche & S & 3017 & D & Raison \\
touche & V & Escoufle & 4338 & bouche & S & 4337 & N & Narrador \\
touche & V & Rose & 1010 & bouche & S & 1009 & N & Narrador \\
touche & V & Rose & 1934 & bouche & S & 1933 & D & Amour \\
touche & $\mathrm{V}$ & Rose & 3766 & bouche & S & 3765 & L & Amant \\
touchierent & V & Escoufle & 4455 & ierent & E & 4456 & N & Narrador \\
\hline
\end{tabular}

Tabla 94. Rimas de los verbos «ataster», tâter, toucher, attoucher y del sustantivo tact.

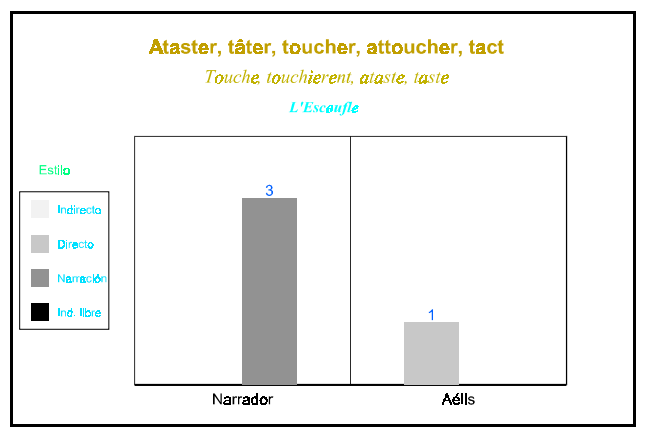

Fig. 155. Comportamiento estilístico de los verbos «ataster», tâter, toucher, attoucher y del sustantivo tact en Escoufle. 


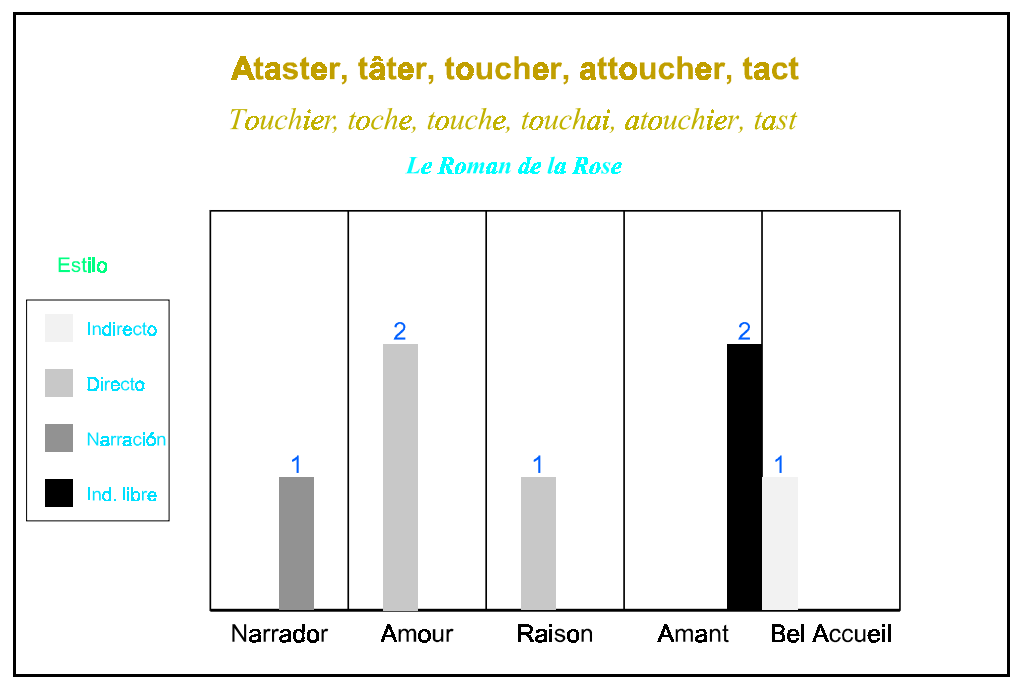

Fig. 156. Comportamiento estilístico de los verbos «atasten», tâter, toucher, attoucher y del sustantivo tact en Rose.

La casi exclusiva relación entre las sensaciones táctiles expresadas con el verbo tochier y los labios o el interior de la boca, se halla magníficamente documentada por la asociación en la rima con la forma bouche, y ello pese a que en una de las ocurrencias se haga referencia al personaje alegórico que perjudica a los enamorados difundiendo sus amores y evitando cualquier posible contacto. En otro orden de cosas, la utilización de los términos por parte de los diferentes entes discursivos nos muestra una discordancia entre Charrete y E scoufle frente a Rose: en los primeros, con un número menor de ocurrencias, se da un dominio claro del narrador y se describen las sensaciones táctiles y aun gustativas sin que haya una implicación directa de la sensualidad de los personajes, si exceptuamos claro está la sugestiva intervención de Aelis; en el otro extremo se encuentra el texto de Lorris, no tanto por ofrecernos la sensualidad en las intervenciones de los personajes, sino por su capacidad para substraer los fenómenos eróticos de la vida, convirtiéndolos en meras entelequias que adoptan la dudosa forma de recuerdos idealizados, la de deseos difícilmente realizables o bien expresamente prohibidos. 


\subsection{LA BOCA Y EL BESO.}

\subsection{Bouche.}

Los usos erótico-amorosos que se otorgan a la boca en nuestro corpus son tres. Derivan de los sentidos habituales que puede adoptar el sustantivo, y es posible establecer entre ellos una gradación según la sensualidad evocada.

En primer lugar y con un valor atenuado se nos presenta en su calidad de órgano de la palabra, uso principal en la obra de Chrétien y secundario en la de Lorris, pero inexistente en los otros textos a excepción de una ocurrencia en E sooufle. Este sentido queda, además, asociado gracias a la rima en las obras de Chrétien y de Renart con un posible uso negativo del lenguaje y del cuerpo, ajeno a la cortesía, al emparejarse con reproche.

En segundo lugar, bouche denomina el conjunto de los dos labios y se integra o bien en las descripciones físicas de los personajes dibujadas en exclusiva en los textos del siglo XIII, o bien como instrumento de las sensaciones táctiles en el mismo plano que otras partes de la cara. En este caso se puede establecer una relación inmediata con el beso o excluirla, tal como hemos visto al ocuparnos del verbo tochier. "et bien .cm. foiz les toche et a ses ialz, et a sa boche, et a son front, et a sa face" (Charrete, 1463 - 1465), "mar touchai la rose a mon vis et a mes ieuz et a ma bouche" (Rose, 3764 3765)

se je baise les ex, sa bouche, cui fais je tort de ceste chose?

Escoufle, 3034 - 3035

En este caso las rimas se hacen con formas del presente de indicativo de los verbos tochier y aprochier, asociaciones en las que coinciden todos los romans a excepción de Tristan. 
Por último se identifica con la cavidad en la que se hallan la lengua y los dientes y que comunica con los aparatos digestivo y respiratorio, un recinto en el que se unen íntimamente los cuerpos y al que no se alude directamente si exceptuamos la obra de Renart: "ele oevre si sa bele bouche que l'une langue a l'autre touche" (Escoufle, 4337 - 4338).

Tan sólo la ambigüedad de una de las ocurrencias del término en el discurso directo de Ginebra escapa a esta clasificación. Resulta muy difícil determinar si el contacto al que se refiere la reina cuando cita a su enamorado deberá ser puramente verbal, si sus labios podrán acariciarse y besarse pese a la separación impuesta por los barrotes de la ventana o bien, si podrán unir sus bocas abiertas en besos más acordes con la pasión compartida que les llevará finalmente a ayuntarse en el lecho: "ne je ne porrai avenir a vos, fors de boche ou de main" (Charrete, 4516 - 4517).

En los textos más influenciados por la cortesía, el uso del órgano de la palabra es un ingrediente capital del código ético-amoroso, sea en manifestaciones prácticas, insertas en las peripecias del relato y características de la obra de Chrétien, sea en un plano teórico, propio del discurso doctrinal del dios Amor. El contacto verbal entre hombre y mujer es en Charrete un signo de la asimilación de las reglas de urbanidad fomentadas por la cortesía. La incitación sexual, que probablemente subyacía o se suponía hasta la época pre-trovadoresca en las intervenciones verbales femeninas - puesta en relación por el verbo paluer con la suciedad, con la impureza de las relaciones puramente carnales: "quant la pucele le salue, qui sa boche pas n'en palue" (Chrétien, 1559 - 1560)—, permanece intacta entre algunos varones como el caballero desdeñado, mientras que la mujer ha asumido sin reticencias las nuevas ideas. Este hecho es del todo natural si tenemos en cuenta que la liberaban de la exclusión social y de la violencia sexual derivadas respectivamente del silencio o del discurso, e iban aún más lejos al convertirse en el instrumento principal del nuevo poder erótico-amoroso concedido a las féminas: 
N'est mie droiz que cele teingne

vers lui sa parole si chiere

que ele ne li rande arriere,

au moins de boche, son salu.

Charrete, 1554 - 1557

Como observamos en este ejemplo, el sustantivo en función de complemento circunstancial introducido por las preposiciones en o de duplica su capacidad expresiva al operar también en el plano metafórico en oposición o como complemento del corazón, sede del estado afectivo: "de cuer la salue et de boche" (Charrete, 1550). De este modo las palabras pueden ser signo de los verdaderos sentimientos amorosos o de las obligaciones inexcusables del amante leal, al margen de la actividad reflexiva en gran medida condicionada por la vida en comunidad, lo que en relación con Lanzarote se representa en el discurso del amor personificado. También pueden ir contra ellos, cuando las palabras están dictadas por los prejuicios individuales y colectivos: "n'est pas el cuer, mes an la boche, Reisons qui ce dire li ose" (Charrete, 370 - 371).

La tendencia hacia la universalización de ciertos preceptos corteses que fomentan una convivencia menos agreste, más civilizada que la imperante en la Alta Edad Media, se ha consolidado en el siglo XIII cuando menos en el plano teórico. Y ello en gran medida gracias al desarrollo de la vida ciudadana, la inclusión de la nobleza en este ámbito y el incremento lógico de las relaciones en el seno de los grupos sociales debido a la bonanza económica y sanitaria y a un relativo control de la violencia que había dificultado hasta entonces los viajes y los contactos. El amante de este siglo evitará, como Guillermo, las habladurías, las blasfemias y los reproches (Escoufle, 2042 2045), es decir, se comportará como un perfecto cortesano. De ahí también que Lorris lleve más lejos que Chrétien las obligaciones de los enamorados, y el que cumple escuetamente las reglas impuestas por el dios Amor bien podría haber sido identificado en el siglo XII como el más perfecto de los amantes. 
Teniendo en cuenta tan sólo las relaciones discursivas expresadas mediante el sustantivo bouche, al amante de la rosa se le exige no sólo que salude a las damas sino que devuelva prestamente a todos el saludo (Rose, 2093 - 2096), se censura por otro lado abiertamente la alusión a cosas y tal vez acciones que se han convertido en tabú, muy probablemente en relación con la actividad sexual y escatológica, con lo que el uso de ciertos términos queda como signo de la pertenencia a un grupo social bajo, no identificable con la cortesía, separación que se observará por ejemplo en la división genérica de los textos literarios:

$$
\begin{aligned}
& \text { ja por nomer vilainne chose } \\
& \text { ne doit ta bouche estre desclouse. } \\
& \text { Je ne tien pas a cortois home } \\
& \text { qui orde chose et laide nome }
\end{aligned}
$$$$
\text { Rose, } 2099 \text { - } 2102
$$

La boca no está presente en las descripciones de los romans del siglo XII y escasamente en Escoufle, donde se inserta en una construcción ponderativa en la que el consabido adjetivo bele precede al sustantivo: "de la ou les levres touchierent ki a la plus bele bouche ierent" (Escoufle, 4455 4456). Esta pobreza descriptiva se debe probablemente a dos motivos conectados entre sí: la boca contiene un gran potencial sensual a la vez que ofrece una mayor variedad de formas y movimientos que otras partes del rostro, incluidos los ojos, y por lo tanto es altamente individualizante y, en segundo lugar, es la abertura que pone en contacto el interior con el exterior y en la que se pueden mezclar los fluidos corporales de los amantes. Con el beso se puede evocar, aun sin entrar en los contactos bucogenitales, la unión completa de los sexos, que, de hecho, se da por sentada tras este primer contacto. Se toma por el contrario como una prueba irrefutable de la inocencia de los amantes el que, hallándose juntos y solos, permanezcan separados sus cuerpos y especialmente sus bocas: "la bouche o l'autre n'ert jostee" (Tristan, 1997), "les bouches furent pres asises, et neporquant si ot devises que n'asenbloient pas ensenble" (Tristan, 1823 - 1825). En estos 
ejemplos la función sujeto del sustantivo así como la utilización del artículo definido en lugar del artículo posesivo —este último es común en los textos y acorde con el uso que aún hoy se hace en francés-, acrecientan la sensación de que existe una focalización sobre esta parte del cuerpo. Ésta le da una autonomía erótica que no poseían otros órganos como los ojos o las manos y que le hace adquirir su virtud testimonial.

En Rose la boca forma parte de las que podemos considerar detalladas descripciones de la cara de los acompañantes de Deduit. Detalladas si las comparamos con los otros textos del corpus y aun con la mayor parte de las obras de esta época, lo que formalmente conlleva un encadenamiento de sustantivos en función de complemento de objeto directo del verbo avoir seguidos de uno o más adjetivos: "les ieuz ot vers, la bouche gente, et le nés bel par grant entente" (Rose, 805 - 806). Sin embargo, no se aportan elementos estrictamente individualizantes pues las características de los atributos mencionados son excesivamente generales, mas no por ello preñados de sensualidad como los labios pequeños y gordezuelos de Oiseuse "la bouche petite et grossete" (Rose, 535). Las formas del diminutivo del sustantivo y de los adjetivos: "ele ot la bouche petiteite" (Rose, 849), podrían quedar justificadas por la juventud de los personajes, pero deben añadirse causas formales a su uso como el número de sílabas para completar el verso o la rima. Más estrechamente relacionadas que las anteriores con la capacidad amatoria y con la excitación sexual son las cualidades de la boca de la amada, evocación de Amor en la que se da por sentado que el amante ya ha probado su sabor en sus besos: "et la boucheite coloree dont l'alaine est tant savoree" (Rose, 2643 - 2644); o bien los atributos de la del amante, descritos por la diosa Venus, en cuyo discurso el argumento negativo responde a una estrategia psicológica, al igual que el verbo de opinión, por la que se sugiere, se invita al descubrimiento del goce y se evita la imposición, siempre perniciosa en amores: "qu'il a, ce cuit, mout douce aleine et sa bouche n'est pas vilaine" (Rose, 3445 - 3444). En ambos casos el sentido del olfato, más vinculado a la 
realidad vivida y a un trato más íntimo se une a las referencias visuales, sin duda más habituales en los textos.

"Lors la preïst par bele bouche et la baisast, car ml't l'acole" (Escoufle, 3548 - 3549), "li uns d'aus a l'autre abandoune ses bras et sa bouche et son vis" (Escoufle, 3618 - 3619). El inusual adjetivo bele en función adverbial delante de bouche, los verbos abandouner, prendre y el redundante baiser, son muestras de la fuerza de la pasión que une a los amantes de Escoufle antes de huir del palacio. Con la salvedad de que el imperfecto de subjuntivo de los verbos citados en lugar del esperado pretérito definido nos obligue a considerar una reducción de la intensidad en beneficio del deseo. Pero la pasión no puede evitar que Aelis y Guillermo cedan a las convenciones sociales, a una unión reglada que les permita reintegrarse en el cuerpo social aristocrático. Las muestras de afecto preceden un anuncio o un refuerzo de las relaciones que se derivan de su enlace, cuando ya se sienten conde y condesa o se conciertan para huir. Por el contrario, lejos ya del palacio, en medio de la acogedora naturaleza del locus amoenus, más propicia al placer que el propio gineceo, el beso con lengua tendrá como única finalidad el placer. De hecho la despreocupación y el ensimismamiento contemplativo que se derivan de él van a provocar la separación de los amantes y el aplazamiento sine die de la concertación matrimonial.

\begin{tabular}{|c|c|c|c|c|c|c|c|c|}
\hline FORMA & CA & BD & NV & RIMA & CA2 & NV2 & D & PERS \\
\hline boche & $\mathrm{S}$ & Charrete & 1550 & aproche & $\mathrm{V}$ & 1549 & $\mathrm{~N}$ & Narrador \\
\hline boche & $\mathrm{S}$ & Charrete & 370 & reproche & $\mathrm{S}$ & 369 & $\mathrm{~N}$ & Narrador \\
\hline boche & $\mathrm{S}$ & Charrete & 4356 & reproche & $\mathrm{S}$ & 4355 & D & Lancelot \\
\hline boche & $S$ & Charrete & 1464 & toche & V & 1463 & $\mathrm{~N}$ & Narrador \\
\hline bouche & $\mathrm{S}$ & Escoufle & 3548 & aproche & V & 3547 & $\mathrm{~N}$ & Narrador \\
\hline bouche & $\mathrm{S}$ & Escoufle & 3034 & reproce & $\mathrm{S}$ & 3033 & D & Guillaume \\
\hline bouche & $\mathrm{S}$ & Escoufle & 2043 & reproche & $\mathrm{S}$ & 2044 & $\mathrm{~N}$ & Narrador \\
\hline bouche & $\mathrm{S}$ & Escoufle & 4337 & touche & V & 4338 & $\mathrm{~N}$ & Narrador \\
\hline bouche & S & Rose & 1009 & touche & V & 1010 & $\mathrm{~N}$ & Narrador \\
\hline bouche & $\mathrm{S}$ & Rose & 1933 & touche & V & 1934 & D & Amour \\
\hline bouche & $\mathrm{S}$ & Rose & 3765 & touche & V & 3766 & $\mathrm{~L}$ & Amant \\
\hline bouchete & $\mathrm{S}$ & Rose & 1482 & nete & A & 1481 & $\mathrm{~N}$ & Narrador \\
\hline
\end{tabular}

Tabla 95. Rimas del sustantivo bouche. 


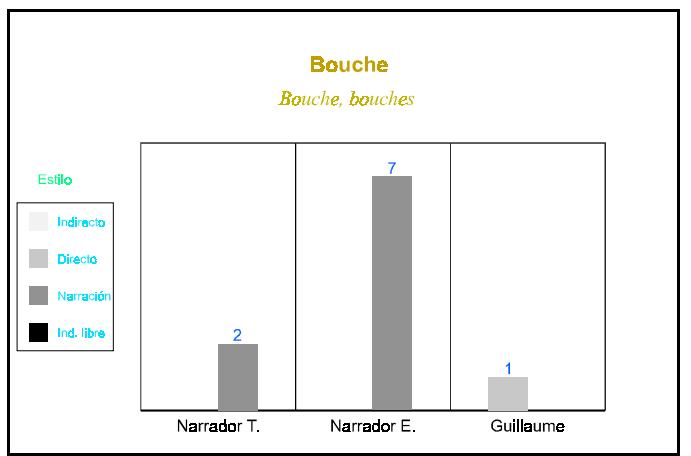

Fig. 157.Comportamiento estilístico del sustantivo bouche en Tristan y Escoufle.

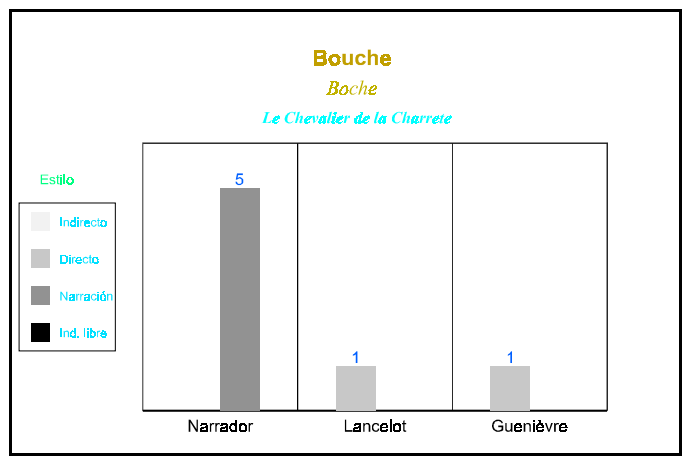

Fig. 158.Comportamiento estilístico del sustantivo bouche en Charrete.

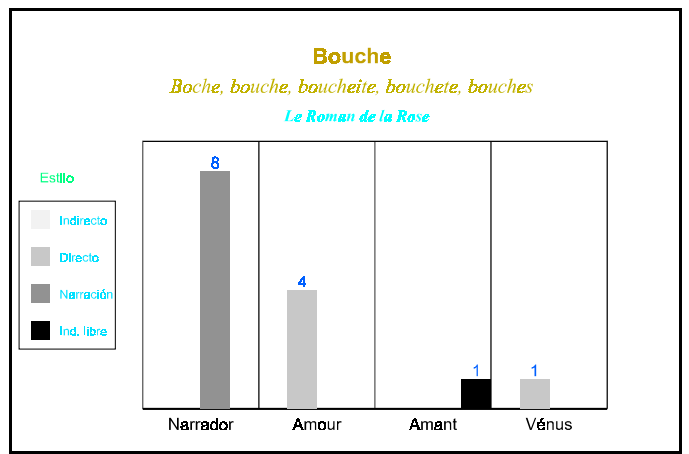

Fig. 159.Comportamiento estilístico del sustantivo bouche en Rose.

Si hacemos abstracción del por definición inevitable uso de la boca en el beso, actividad erótica que estudiaremos a continuación, el recurso al sustantivo bouche puede ser calificado como poco relevante en nuestro corpus por mucho que Chrétien se haga eco de la hipérbole amatoria inaugurada por Catulo. El discurso narrativo dominante la asocia casi 
inevitablemente a otras partes del cuerpo con las que comparte el juego sensual, la relega al ámbito manierista del discurso cortesano o bien la dispone en las descripciones más o menos alejadas de los arquetipos literarios, con una función sensual indudable pero secundaria. Tan sólo su utilización pseudojurídica como sello de pactos amorosos o como prueba fehaciente de actividad erótica, colocan la boca en un primer plano, lo que de hecho la lleva a la posición de sujeto proposicional, pero es éste un muy pobre papel para la que en sentido literal o figurado es la puerta al interior del otro y al placer.

\subsection{Baiser.}

La acción de besar en Tristan se presenta como el indicio más claro de que existen relaciones sexuales adúlteras, de hecho ya en antiguo provenzal baizar podía significar «mantener relaciones sexuales con una dama». De este modo encontramos baiser coordinado en una construcción triple a un verbo que expresa un movimiento de aproximación del que se deriva un contacto, $\mathrm{y}$ a otro que comporta un claro sentido peyorativo, mesprendre; la colocación de este último en posición intermedia refuerza el razonamiento negativo del que la reina extrae una consecuencia no tanto de orden amoroso como de índole moral y jurídica, siempre adaptándose a la lógica patriarcal del rey Marco para quien Tristán debía llevar la iniciativa en las acciones sucesivas y culpables designadas por aprismier y baiser. "ne veïstes qu'il m’aprismast ne mespreïst ne me baisast. Bien senble ce chose certaine: ne m'amot pas d'amor vilaine." (Tristan, 499 - 502).

Tal y como hemos apuntado para el sustantivo bouche, en el espacio cortesano del siglo XIII, el palacio del emperador, alejado de las cortes transgresoras del siglo precedente en las que nació y creció la cortesía y en el que imperan los designios de la patrilinearidad, los besos de la esposa o del amante no adulterino, que deberían parecernos irreprochables, se cargan de los aspectos negativos que tradicionalmente la ideología masculina había 
impuesto a la mujer, vana, mentirosa, artera, interesada, traicionera, como al amor, asocial, desintegrador, igualitario. Las estrategias para caracterizar estos comportamientos en este primer ámbito, opuesto a la naturaleza, al espacio exterior en el que los amantes gozarán de la libertad necesaria para amarse y practicar el sexo, son diversas pero tienden a subrayar las disonancias entre amor, unión física y matrimonio. En ambos casos sólo uno de los miembros de la pareja lleva la iniciativa en la acción de besar. El beso en estos contextos, ya sea explícita o implícitamente, es considerado como el comienzo del contacto carnal que terminará en el coito, de naturaleza negativa aquí por no ceñirse a las normas que imponían la supremacía masculina y paterna sobre la esposa y el pretendiente. Más arriba hemos señalado cómo el discurso narrativo descubre las malas artes de la emperatriz para conseguir lo que desea de su esposo. Aquí sólo nos haremos eco de la acción de besar que está aparentemente cargada de ternura e incluso de recato, sin siquiera rozar la boca del esposo, y consagra los ojos, que ya veíamos aparecer en las caricias de Lanzarote a los cabellos de la reina Ginebra, como un elemento básico en las sensaciones táctiles: "l'empereris l'acole et baise et puis les ex et puis la face” (Escoufle, 2872 - 2873), y que Guillermo retoma en su discurso para unirlos a la boca, reducto del amor extramatrimonial, asaltado su discurso por la culpa: "Se je baise les ex, sa bouche, cui fais je tort de ceste chose?" (Escoufle, 3034 - 3035). Tampoco escapan a la sospecha la entrega y la espontaneidad de Aelis, quien como Iseo y Ginebra lleva la iniciativa en los períodos de transgresión, ${ }^{512}$ y la heroína oculta sus efusivos abrazos y besos a las miradas indiscretas de los cortesanos y de los padres, remedos de las antiguas figuras de los felones y de los esposos celosos: "cele li fait des siens .j. las entor le col, puis si le baise" (Escoufle, 3370 - 3371).

Fuera ya del contexto palaciego Renart mantiene a la mujer, sea Aelis o la dama de Montpellier, como sujeto de la acción de besar, para lo que prefiere las formas pronominales a las denominaciones sustantivas. Este

512 “cele qui tient sen douç amant entre ses bras et si le baise.” (Escoufle, 3382 - 3383). 
hecho no hace sino confirmar el protagonismo femenino en el conjunto de las relaciones eróticas y la inmersión de este acto, generalmente de carácter culminativo, en un proceso más complejo constituido por donaciones, abrazos y caricias o promesas, construido mediante formas coordinadas y en proposiciones independientes. Esta supremacia queda también avalada en las proposiciones subordinadas de relativo en las que el pronombre sujeto representa a Aelis: "cele qui tient sen douç amant entre ses bras et si le baise" (Escoufle, 3382 - 3383), "tuit servent Guilliaume et onourent et la pucele qui le baise” (Escoufle, 7730 - 7731). Ello no es obstáculo para que los varones las besen, por propia iniciativa o a petición de la amada: la única ocurrencia de imperativo se encuentra en el discurso directo de la dama de Montpellier: "baisiés moi" (Escoufle, 5852) y el subjuntivo del verbo expresa en el discurso indirecto los deseos de Aelis: "aprés mangier li dist qu'il baist son blont chief sor son dolç escors” (Escoufle, 4326 - 4327); y ellos, Guillermo y el conde de Saint Gilles, se muestran incluso más efusivos emulando, como ya había hecho Lanzarote, al amante catuliano: ${ }^{513}$

$$
\begin{aligned}
& \text { ml't a poi en ses bras esté } \\
& \text { quant il ne l'a .c. fois baisie }
\end{aligned}
$$

Escoufle, 3976 - 3977

$$
\begin{aligned}
& \text { Li quens la baise pres a pres } \\
& \text { plus de .x. fois tout en montant }
\end{aligned}
$$

Escoufle, 8368 - 8369

Tristan, E scoufle y Rose coinciden en la utilización de construcciones recíprocas aunque pueden diferir temática y formalmente. En los casos de coordinación y substitución pronominal, que se da al menos en el segundo miembro de la construcción, el varón ocupa siempre la primera posición:

513 También el rey Marco había manifestado hiperbólicamente su amor por la reina: "Acole la, cent foiz la besse" (Tristan, 461) 
“iluec le baise et ele lui” (Escoufle, 3643), "cil la baise a unne alenee plus de .c. fois, et ele lui” (Escoufle, 7734 - 7735); “Tristran en bese la roïne, et ele lui, par la saisine" (Tristan, 2731 - 2732). En la obra de Renart estos besos marcan la separación y el reencuentro de los enamorados, en Tristan a la separación se une la promesa de fidelidad y ayuda sellada por la entrega de regalos y reforzada mediante el sustantivo saisine perteneciente al léxico feudal. Las formas prefijadas del roman de Béroul y de Rose tienen en común la referencia a acciones no realizadas, ilusorias — de ahí, en los fragmentos que citamos a continuación, el uso del imperfecto de subjuntivo del verbo veoir y de la construcción impersonal que introduce la apariencia y su efecto en la percepción del observador- Acciones que tranquilizan al esposo borrando sus sospechas sobre las actividades eróticas del sobrino y la esposa o bien acrecientan en el joven los deseos difusos de la primera adolescencia y el placer derivado del voyeurismo: "ci avoient asez leisor, bien les veïse entrebaisier" (Tristan, 302 - 303)

$$
\begin{aligned}
& \text { l'une venoit tot belement } \\
& \text { contre l'autre, et quant eus estoient } \\
& \text { pres a pres, si s'entregetoient } \\
& \text { les bouches qu'i vos fust avis } \\
& \text { qu'eus s'entrebessoient ou vis }
\end{aligned}
$$$$
\text { Rose, } 764-768
$$

La obra de Lorris, en la que el beso se convierte en el elemento clave del caminar erótico del aspirante a enamorado así como de la amada, puede dividirse en dos grandes partes: en la primera los besos se dan y se reciben con suma facilidad, los amantes del círculo de Deduit se besan para mostrarse su amor con toda naturalidad, libres de toda traba moral o social y, a diferencia de E scoufle, la acción de besar no es un eslabón más de la actividad erótica sino que es exclusiva y por lo tanto recoge en sí todas las demás: 


$$
\begin{aligned}
& \text { ses amis fu de lui privez } \\
& \text { en tel guise qu'i la bessoit } \\
& \text { toutes les foiz qu'il li plessoit } \\
& \text { Rose, } 1266 \text { - } 1268 \\
& \text { ele ot la bouche petiteite } \\
& \text { et por beisier son ami prete } \\
& \text { Rose, } 849 \text { - } 850
\end{aligned}
$$

ainz les veïssiez entr'eus deus

baisier come .ii. colombiaus

Rose, 1272 - 1273

De forma similar en Charrete la unión carnal de los amantes, cuyo efecto es un placer raramente alcanzado, se resume en dos acciones, santir, que interpretamos en relación con el tacto y baiser. "tant li est ses jeus dolz et buens, et del beisier, et del santir" (Charrete, 4674 - 4675). En esta primera parte los besos también pueden ser simbólicos como los que unen al amante y al dios Amor, ${ }^{514}$ o como el beso fetichista que el maestro aconseja al enamorado no correspondido, basado en una relación metonímica entre continente y contenido: "au revenir la porte baise" (Rose, 2524). Se caracteriza formalmente por haberse utilizado en ella exclusivamente las formas del verbo baiser, mientras que en la segunda parte se combinan el

Si me besseras en la bouche Rose, 1931 - 1933

Atant devins ses hom mains jointes, et sachiez que mout me fis cointes dont sa bouche baisa la moie Rose, 1953 - 1955 
verbo y el sustantivo deverbal. En ésta todo gira en torno a la consecución de un beso de la rosa, un beso acordado y no robado, pues los besos furtivos escapaban a la reglamentación cortés y no podían preceder la entrega de la amada y el yacer de los cuerpos. Frente a los amantes consagrados del jardín y a los héroes de los otros romans, el enamorado de la rosa trata de conseguir un único beso. Se trata de un beso ritual, la esencia de las relaciones amorosas corteses, la clave de la aceptación del enamorado cuando es consentido por la amada y que es síntoma de su entrega y por lo tanto de la futura unión carnal de los amantes: "sire, por Dieu, dites moi dons se il vos plest que je la bese" (Rose, 3374 - 3375). De este hecho fundamental se deriva el uso dominante del sustantivo deverbal por oposición a la generalidad e indeterminación de la acción expresada por el verbo. En el discurso del amante y de la diosa Venus el sustantivo está precedido por un artículo indefinido — que puede aparecer acompañado y precisado por el adjetivo seul: "Mes se, sanz plus, d'un seul bessier me deignoit la bele aasier" (Rose, 2463 - 2464)_, con lo que proclama junto a la sujeción al dominio de Amor, es decir, la contención del instinto, lo razonable de su petición; la agregación de adjetivos sobrepone nuevos matices, como la del adjetivo precieus, que expresa una valoración extrema por parte del enamorado: "Sire, fi ge, sachiez de voir, que durement sui envieus d'avoir un baisier precieus de la rose qui soëf flaire” (Rose, 3368 3371), o la de doucereus que en el discurso de Venus implica de antemano a la amada y le muestra el camino hacia el placer: "Por quoi vos fetes vos, biau sire, vers cest amant si dangereus d'avoir un bessier doucereus?" (Rose, 3424 - 3426). El sustantivo también puede estar precedido por un artículo definido o por la contracción de éste con las preposiciones a o de. La aparición de estas construcciones nos muestra hasta qué punto el beso es concebido como un ritual, un contacto iniciático y único, lo que no es óbice para que otros besos sigan a este primero, máxime durante el ayuntamiento carnal tal y como

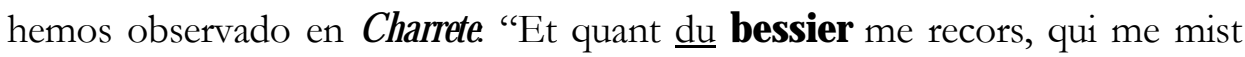
une odor ou cors assez plus douce que de basme” (Rose, 3755 - 3757). Por otro lado, en el texto de Lorris se insiste en el respeto absoluto hacia la 
voluntad de la mujer, que no está libre sin embargo de sufrir los embates del instinto reproductor o de la impuesta castidad, y ello gracias a la repetición del verbo otroier o de algún sinónimo como greer, acompañados por el sustantivo baiser en función de complemento directo: "se le bessier li otroiez, mout est en lui bien emploiez" (Rose, 3441 - 3442), “bien est, ce m’est avis, mesure que uns beisiers li soit greez” (Rose, 3450 - 3451), o bien del sustantivo otroiz modificado por un complemento preposicional: "adés me tarda li otroiz dou bessier que je desiroie" (Rose, 3400 - 3401), aquí desde la óptica del enamorado quien deja la acción para la fémina. La locución doner congié a la que se une el sustantivo mediante una preposición, supone desde la perspectiva femenina al tiempo su consentimiento y la iniciativa masculina en la acción de besar:

Ele me seut torjorz desfendre que du bessier congié ne doigne a nul amant qui m'en semoigne Rose, 3382 - 3384

Las dos posturas enfrentadas figuradas por Venus y por Castidad desarrollan dos tópicos bien representados en la literatura amorosa y particularmente en la medieval. La primera, a la postre victoriosa, recupera junto a la innovadora imagen higiénica y estética del amante, la temática latina del «collige virgo rosas» que los goliardos habían tratado magistralmente en sus composiciones. $\mathrm{Al}$ menos en un principio parece que es el argumento del aprovechamiento gozoso de la juventud en los placeres eróticos lo que decide a la mujer, ${ }^{515}$ ya atraída por la apariencia física del muchacho, a concederle la llave del cortejo. La otra postura, en principio bien arraigada en el espíritu de

\footnotetext{
$515 \quad$ Donez li, se vos m'en creez,

car tant con vos plus atendroiz,

tant, ce sachiez, de tens pardroiz.

Rose, 3452 - 3454
} 
la doncella merced a lo que se nos antoja una sistemática repetición de consignas morales pero que quedará desbancada, se hace eco de una concepción tradicional y misógina. Ésta desprecia la potestad que la cortesía había concedido a la mujer de obrar por reflexión y elección y hace del beso no una puerta que ella abre a voluntad, sino un agujero por el que se introducen sin permiso los inmoderados deseos masculinos para unirse a la naturaleza incontinente de la mujer. Como muestra del desarrollo literario de este tema citaremos sólo la conversación que mantienen Perceval y el caballero Orgulloso de la Landa, en la que éste, además de despreciar al hombre que no aprovecha la ocasión de poseer sexualmente a la mujer de la que ha recibido o a la que ha robado un beso, muestra a ésta defendiéndose sin convicción ante la violación pues, desde un punto de vista misógino y machista que todavía hoy perdura, desea ser vencida y penetrada:

$$
\begin{aligned}
& \text { Quant il la beisa maugré suen, } \\
& \text { n'an fist il aprés toto son buen? } \\
& \text { Oil, ce ne cresra ja nus } \\
& \text { qu'il la beisast sanz fere plus, } \\
& \text { que l'une chose l'autre atret. } \\
& \text { Qui beise fame et plus n'i fet, } \\
& \text { qant il sont seul a seul andui, } \\
& \text { dons cuit ge qu'il remaint an lui. } \\
& \text { Fame qui sa boche abandone } \\
& \text { le soreplus de legier done, } \\
& \text { s'est qui a certes le demantt16 }
\end{aligned}
$$

Observaremos que tanto este fragmento de Chrétien como el de Lorris que reproducimos a continuación adoptan una forma impersonal propia de las expresiones sentenciosas, aunque en lo que atañe al desarrollo

516 Chrétien de Troyes, L e onte du G raal (Perceval), F. Lecoy (ed.). París: Honoré Champion, 1975, v. 3837 3847. 
temático, la obra del siglo XII pone el mayor énfasis en la actitud lujuriosa de la mujer mientras que la del siglo XIII, menos belicosa y dando la palabra a aquélla, concede todo el protagonismo al varón, sin dejar lugar al reproche:

$$
\begin{gathered}
\text { car qui au bessier puet ateindre } \\
\text { a poine puet a tant remaindre } \\
\text { Rose, } 3382 \text { - } 3386
\end{gathered}
$$

De cuanto hemos dicho podemos concluir que tampoco en esta ocasión Lorris se ciñe a la lógica cortés pues ninguna de las dos posiciones encontradas toman en consideración el albedrío de la mujer, el poder que había adquirido para imponer sus intereses sensuales y aun sociales sobre la libido masculina o su capacidad para domeñar su propio instinto, de hecho hace que se impongan por encima de cualquier razonamiento e incluso del llamamiento a gozar del propio cuerpo, los impulsos no aprendidos ni reflexivos materializados en el calor de la antorcha de la diosa del amor:

$$
\begin{aligned}
& \text { Bel Acueil, qui senti l'eer } \\
& \text { du brandon, sanz plus deloer, } \\
& \text { m'otroia un bessier en dons, } \\
& \text { tant fist Venus et ses brandons } \\
& \text { Rose, } 3455 \text { - } 3458
\end{aligned}
$$

Las ocurrencias verbales de esta segunda fase del relato se hallan inmersas en fragmentos preñados de añoranza y melancolía pues el narrador amante evoca el beso a la rosa y las penalidades posteriores. Las encontramos bien en un contexto generalizador introducida la proposición por un pronombre relativo con valor indefinido, en una mezcla de identificación y alejamiento tanto existencial como temporal favorecida por el estilo directo: "bien est gariz qui tel flor baise, qui est si sade et bien olenz" (Rose, 3468 3469), o bien en una proposición subordinada temporal introducida por la locución puis que [Adv. + $\mathbf{C}$ onj.] que sitúa la acción de besar en el comienzo de sus sufrimientos: 


$$
\begin{aligned}
& \text { Et ne por quant j'ai mainz anuiz } \\
& \text { sosferz et maintes males nuiz } \\
& \text { puis que j'oi la rose besie } \\
& \text { Rose, } 3473 \text { - } 3475
\end{aligned}
$$

Proposiciones temporales ${ }^{517}$ e hipotéticas: “Or n’en aiés dont pas envie se jou la bés pour faire feste" (Escoufle, 6140 - 6141), "mes se, sanz plus, d'un seul bessier me deignoit la bele aasier" (Rose, 2463 - 2464), dominan la expresión del acto de besar y ello exclusivamente en los romans del siglo XIII. Quedan descartadas las circunstancias en las obras del siglo XII, en las que el beso apenas queda subordinado a otros actos o al menos, no se establece una subordinación formal que lo colocaría en una posición secundaria.

El significado y las relaciones sintagmáticas de los verbos introductores de las proposiciones subordinadas completivas desvelan otros aspectos asociados en el corpus a la acción de besar. Así en Tristan hallamos el verbo veoir en imperfecto de subjuntivo, ya que el sujeto, el rey Marco, se fia de las engañosas apariencias que ocultan a sus ojos los besos de los amantes: "bien les veïse entrebaisier" (Tristan, 303), "ne veïstes qu'il m’aprismast ne mespreïst ne me baisast” (Tristan, 499 - 500). En E scoufle y en Rose los verbos de conocimiento y de percepción, sea esta real o aparente, tienen por sujeto a los narratarios, un medio para implicar a los sujetos de la recepción en el universo erótico recreado:

et sachiés bien, quant il avient k'ou chief li met, qu'ele le baise

Escoufle, 4334 - 4335

ainz les veïssiez entr'eus deus

baisier come .ii. colombiaus

Rose, 1272 - 1273

517 Escoufle, 3977; Rose, 3475 y 3755. 


$$
\begin{aligned}
& \text { (...) et quant eus estoient } \\
& \text { pres a pres, si s'entregetoient } \\
& \text { les bouches qu'i vos fust avis } \\
& \text { qu'eus s'entrebessoient ou vis }
\end{aligned}
$$

$$
\text { Rose, } 764 \text { - } 768
$$

En la obra de Lorris los verbos desfendre: "ele me seut torjorz desfendre que du bessier congié ne doigne" (Rose, 3382 - 3383) y plaire en una interrogativa indirecta: "dites moi dons se il vos plest que je la bese" (Rose, 3374 - 3375) presentan la represión surgida en dos frentes: el que se desarrolla tras el enquilosamiento de las maneras corteses, liberadoras de la sexualidad en su comienzo pero coercitivas según las doctrinas expuestas durante el siglo XIII, y el que sirve de trinchera a la pacata moral burguesa frente a cualquier forma de sensualidad, sea dentro o fuera del matrimonio, si se exceptúa el placer ofrecido por las meretrices al comerciar con su cuerpo.

\begin{tabular}{lllllllll}
\hline FORMA & CA & BD & NV & RIMA & CA2 & NV2 & D & PERS \\
\hline baisast & V & Tristan & 500 & aprismast & V & 499 & D & Iseut \\
baise & V & Rose & 3468 & aaise & A & 3467 & D & Narrador \\
baise & V & Escoufle & 2872 & aise & S & 2871 & N & Narrador \\
baise & V & Escoufle & 3371 & aise & S & 3372 & N & Narrador \\
baise & V & Escoufle & 5847 & aise & S & 5848 & N & Narrador \\
baise & V & Escoufle & 7731 & aise & A & 7732 & N & Narrador \\
baise & V & Rose & 2524 & aise & S & 2523 & D & Amour \\
baise & V & Escoufle & 3383 & malaise & S & 3384 & N & Narrador \\
baise & V & Escoufle & 4335 & plaise & V & 4336 & D & Narrador \\
baisie & O & Escoufle & 3977 & apaisie & O & 3978 & N & Narrador \\
baist & V & Escoufle & 4326 & baist & V & 4325 & I & Aélis \\
beise & V & Charrete & 6799 & eise & S & 6800 & N & Narrador \\
beisoit & V & Charrete & 6830 & sivoit & V & 6829 & N & Narrador \\
bese & V & Rose & 3375 & plaise & V & 3376 & D & Amant \\
besie & O & Rose & 3475 & apesie & O & 3476 & N & Narrador \\
besse & V & Tristan & 461 & tese & V & 462 & N & Narrador \\
bessier & S & Rose & 2463 & aasier & I & 2464 & D & Amant \\
bessoit & V & Rose & 1267 & plessoit & V & 1268 & N & Narrador \\
entrebaisier & I & Tristan & 303 & gramoier & I & 304 & D & Roi Marc \\
\hline
\end{tabular}

Tabla 96. Rimas del verbo y del sustantivo baiser. 


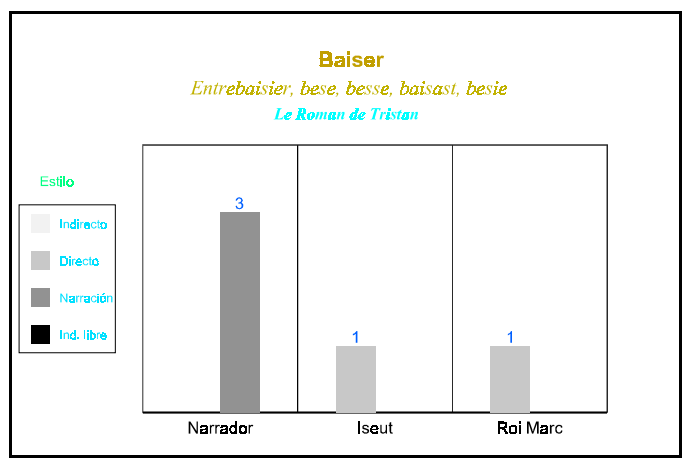

Fig. 160.Comportamiento estilístico del verbo y del sustantivo baiser en Tristan.

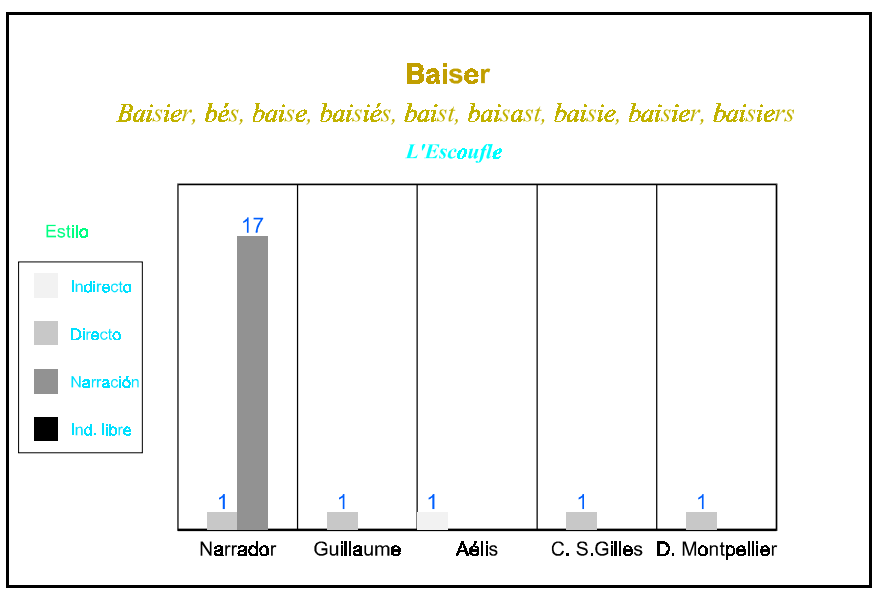

Fig. 161.Comportamiento estilístico del verbo y del sustantivo baiser en Escoufle.

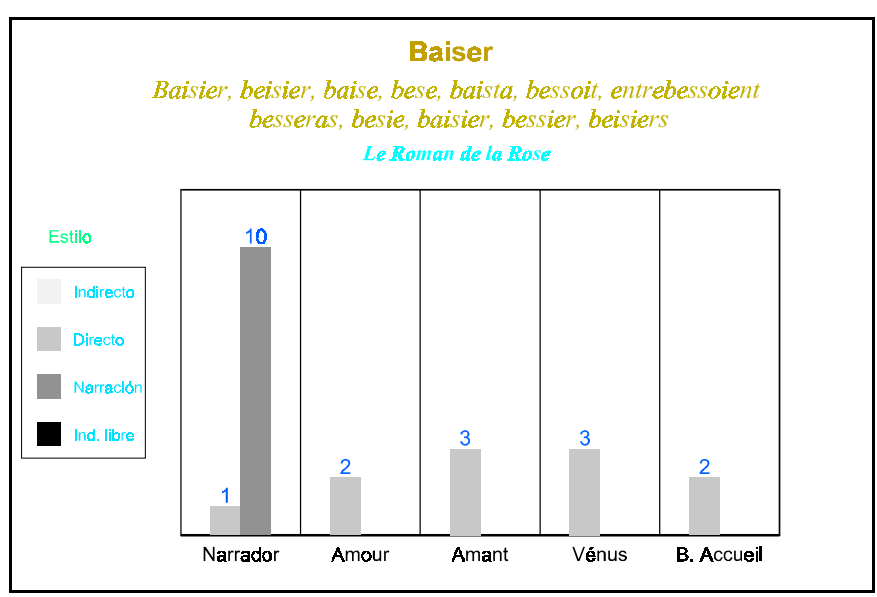

Fig. 162.Comportamiento estilístico del verbo y del sustantivo baiser en Rose. 
Las rimas con el sustantivo y el adjetivo aaise y los verbos aasier y plaire confirman formalmente los lazos entre el beso y el placer, pero esta relación no es tan directa como pudiera parecer. De hecho, el interdicto que pesa sobre el beso en Rose refrena el despertar femenino al deseo y potencia la aquiescencia para con la sexualidad masculina que se impone como acción condenando a la mujer a la inactividad sexual, obligada a asumir su instinto sin poder elegir. La guerra entre moral e instinto en esta obra del siglo XIII esconde una regresión de las relaciones entre los sexos con respecto a los modos caballerescos de hechuras corteses que ejemplifica Charrete, obra en la que el beso se hace sinónimo de ayuntamiento carnal. También con respecto a las tendencias naturalistas de E scoufle en las que la fusión de ambos sexos y aun la primacia de la mujer busca la perfección de las sensaciones eróticas compartidas.

\subsubsection{EL PLACER.}

El placer sexual ligado a la satisfacción de una necesidad física de origen instintivo y que, en su transcripción literaria, aspira a devenir placer intelectual induciendo al goce carnal de los receptores, es el fin último de la actividad erótica. Sin embargo, es tan sutil su expresión novelada que se hace casi imposible de aprehender. Todos los autores lo callan o lo ocultan bajo la apariencia de términos cuyo significado denotativo sólo se refiere tangencialmente a él, como los que nombran la alegría, la diversión o la comodidad. Nociones de las que evidentemente se puede derivar mediante un proceso metonímico de causa - efecto en determinados contextos en los que a menudo se hace alusión a otras sensaciones físicas placenteras.

Por otra parte, tal como señala Guiraud, al orgasmo se le concede siempre un valor positivo —no así a la eyaculación-. De ahí que sea expresado mediante metáforas abstractas, a las que a menudo se añade la 
intensificación extrema, ya porque ésta se halla en el propio sentido de la construcción metafórica, ya sea mediante la conjunción de adjetivos o adverbios. ${ }^{518}$

Muchos de estos términos como joie, deduit o solaz se encontraban habitualmente en la poesía de los trovadores y de los troveros, y conservan de la lírica los sentidos equívocos o difícilmente definibles en contexto. Este hecho, así como el secretismo con que se trata el placer erótico, nos han llevado a desechar algunos términos por su tangencialidad extrema o bien porque sus escasísimas ocurrencias aparecen en combinación con otros vocablos que sí trataremos en las páginas que siguen.

\subsubsection{1 «AASIER», AISE Y «AISEMENT».}

En el corpus, siempre en un estilo escueto, con frases breves en las que no se deja espacio para la calificación adjetiva y apenas para la adverbial, estos términos hacen referencia a los placeres sensuales que ofrece el contacto físico entre los amantes o entre hombres y mujeres en general. Las caricias y los besos son a menudo asociados al descanso y a la comida, como ocurre en la cámara del castillo de Saint Gilles durante las veladas en las que el conde se rodea de las doncellas que sirven a su esposa: "si s'en va la jus avoec eles mangier son fruit et aaisier" (Escoufle, 7022 - 7023). ${ }^{519}$

Béroul opone los sufrimientos del destierro a los placeres que mutuamente se dan los amantes y probablemente se esconde tras el sustantivo aaisement el goce producido por las relaciones sexuales completas: "bien orent lor aaisement" (Tristan, 1786), sensaciones capaces de compensar las carencias y las penalidades, las necesidades insatisfechas y la falta de armonía

\footnotetext{
518 Cf. P. Guiraud, op. at., p. 56 - 57.

${ }^{519} \mathrm{G}$. Duby y Ph. Ariès recogen el uso placentero que hacen los seniores del lugar en el que por miedo a su sexualidad quedaban relegadas las mujeres. Cf. De l'Europe féodale à la Renaissance, op. at., p. 88.
} 
en sus actividades vitales y sociales. Conviene que llamemos la atención sobre el uso del plural tanto del verbo, que implica una actividad compartida al igual que el artículo posesivo, como del sustantivo, signo no tanto de una realidad diversa como de una multiplicación de los actos placenteros para ambos, cantidad que unida a la calidad se expresan mediante el adverbio bien.

Pero, habitualmente, los placeres así denominados son unidireccionales: parten de la mujer para ser disfrutados por el varón. Y observamos notables diferencias entre los otros textos ya que responden a una intención positiva en E scoufle y Charrete, incluso cuando se trata de un mero deseo, frente a la frustración manifiesta en Rose. Ginebra desearía haber ofrecido su cuerpo desnudo a Lanzarote, contacto supremo que paradójicamente queda diluido por el uso del adverbio comparativo plus pero que llegará a producirse, por ello podemos considerar el pasaje que citamos a continuación como un anuncio de acontecimientos futuros al quedar desvelados para el receptor los verdaderos sentimientos y deseos de la reina: "Certes, tot nu a nu, por ce que plus an fusse a eise" (Charrete, 4228 - 4229). En E scoufle el estilo directo de la narración recupera un lugar común al que también se referirá el dios Amor en Rose-el placer es mayor cuanto mayor es el sufrimiento para alcanzarlo_:520 "s'en sont plus plaisant, ce me samble, aprés l'anui, la joie et l'aise" (Escoufle, 5168 - 5169). No es desdeñable en este

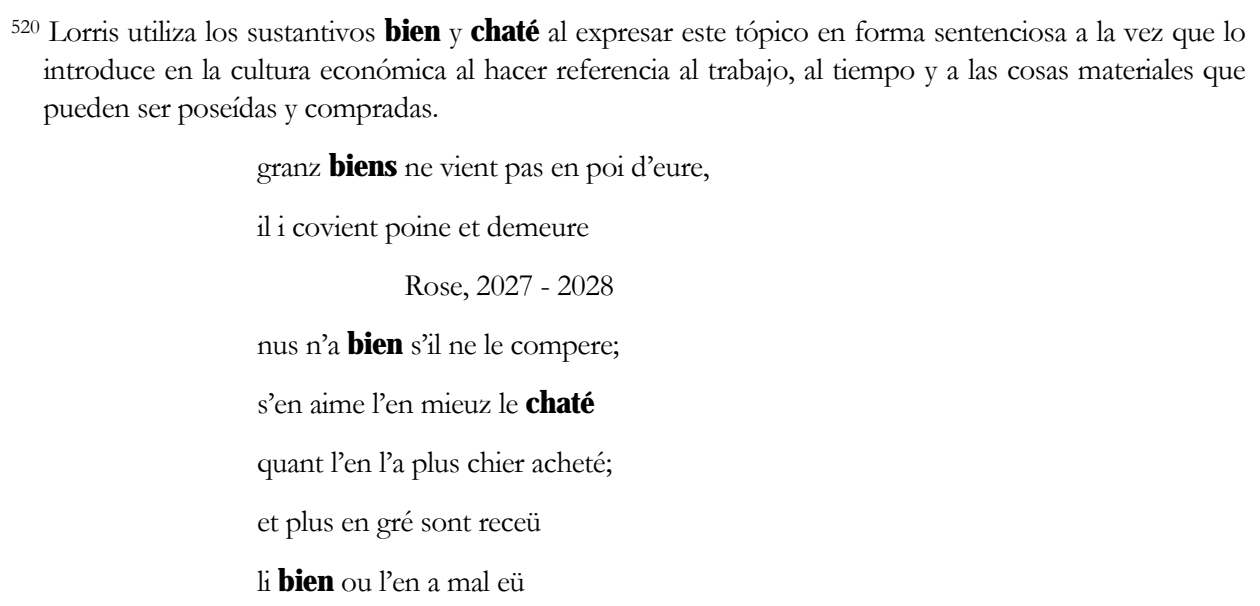


vaticinio de los placeres que en ese punto del relato se les niegan a los enamorados la acumulación de términos referidos al deleite —el adjetivo plaisant y los sustantivo joie y aise-, así como la reaparición del adverbio plus, aquí plenamente comparativo. Por el contrario, el poco esperanzado amante de la rosa se conformaría con un beso de la amada para aliviar sus sufrimientos: "Mes se, sanz plus, d'un seul bessier me deignoit la bele aasier" (Rose, 2463 - 2464), y los supuestos emitidos por Amor están presididos por la negación de las dos estructuras básicas en las que podemos encontrar el sustantivo: como complemento preposicional con valor modal cuando depende del verbo estre: "⿺辶a mes a aise ne serai” (Rose, 2304), y en este caso es suficiente para el enamorado tener algún indicio de la proximidad de la amada para alcanzar el placer, y como complemento de objeto directo del verbo avoir, con lo que se niega la posibilidad de actualización de las sensaciones placenteras: "por amor dou haut seintuaire de quoi tu ne puez avoir aise" (Rose, 2522 - 2523).

\begin{tabular}{lllllllll}
\hline FORMA & CA & BD & NV & RIMA & CA2 & NV2 & D & PERS \\
\hline aaisement & S & Tristan & 1786 & sent & V & 1785 & N & Narrador \\
aaisier & I & Escoufle & 7023 & soulacier & I & 7024 & N & Narrador \\
aasier & I & Rose & 2464 & bessier & S & 2463 & D & Amant \\
aise & S & Rose & 2523 & baise & V & 2524 & D & Amour \\
aise & S & Escoufle & 5169 & malaise & S & 5170 & D & Narrador \\
eise & S & Charrete & 4229 & malveise & A & 4230 & D & Guenièvre \\
eise & S & Charrete & 4469 & pleise & V & 4470 & N & Narrador \\
\hline
\end{tabular}

Tabla 97. Rimas del verbo «aasier»y de los sustantivos aise y «aisement».

La insatisfacción y la privación, ligadas inexorablemente al deseo que precede a la hipotética consecución del placer, tiñen algunos contextos en los que aparecen los términos que nos ocupan, con la aportación de las rimas con malveise y malaise. Sin embargo, es más habitual hallarlos al comienzo de un espacio narrativo mínimo consagrado a las agradables sensaciones derivadas del contacto físico entre los sexos para expresar preferentemente las circunstancias - tiempo y condición- en las que aquéllas pudieran producirse. 


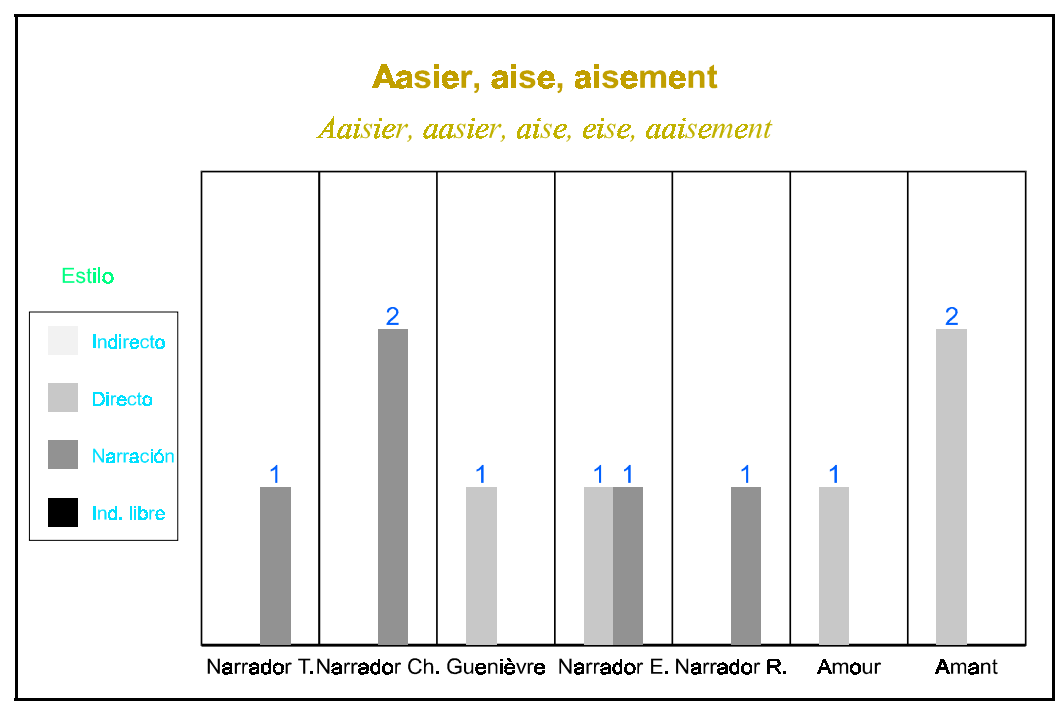

Fig. 163. Comportamiento estilístico del verbo «aasier» y de los sustantivos aise y «aisement» en el corpus.

\subsection{BIEN.}

Lorris es el único que, a nuestro parecer, utiliza el sustantivo bien para referirse al placer o por mejor decir a los placeres derivados del encuentro amoroso: las menudas alegrías que mantienen vivo al amante al tiempo que alimentan su pasión: “je t’ai conté sanz mentir les biens qui pueent garantir les amanz et garder de mort" (Rose, 2737 - 2739) y el placer físico de la unión. A este alude el dios Amor de soslayo para despertar la curiosidad del que lo desconoce todo del amor heterosexual y de sus voluptuosos goces, mientras que de las primeras hace una detallada enumeración en la que las construcciones atributivas paralelas ponen de relieve la voluntad didáctica de la descripción: "li premiers biens (...) est Douz Pensers" (Rose, 2629 - 2631), "Li autres biens est Douz Palers" (Rose, 2657), "Li tierz biens vient de regarder, c'est Douz Regart” (Rose, 2700 - 2701). Esta presentación descompensada respeta la tradición del texto cortés y de su estilo noble dejando que sea la realidad extraliteraria la que trabaje en la imaginación de los receptores en función de su experiencia. 
En algunas ocurrencias es difícil determinar si el sustantivo se refiere al placer físico a la vez que inmaterial que proporcionan el amor y el sexo o bien hace referencia a las cosas materiales ajenas a las relaciones entre los sexos: “que ja d'aillors ne quier que j’oie honor ne bien, santé ne joie" (Rose, 3973 - 3974), máxime cuando el sustantivo joie se halla en el mismo verso. En el ejemplo que acabamos de citar nos inclinamos por la segunda opción, pues en una estructura muy cuidada se encuentran en el primer hemistiquio los términos de referencia social, abstracto el primero, concreto el segundo, mientras que en el segundo hemistiquio aparecen los términos relacionados con el individuo en orden inverso a los anteriores.

Hechas estas reflexiones vamos a basar el análisis del sustantivo en ciertos fenómenos formales, algunos puramente sintácticos, otros retóricos, aunque siempre de naturaleza sintagmática. En primer lugar, y por defecto, la excepcionalidad de la rima de bien en este roman, frente a la mayor parte de los términos que nos ocupan en este apartado, tal como hemos podido apreciar para los vocablos aaisier y aise cuyo uso al final del verso era preferente.

En segundo lugar, la conexión mediante conjunción coordinante - et y con mayor asiduidad ne al hallarse también este vocablo en contextos negativos - con términos que en principio podríamos considerar sinónimos como joie: "je n'oi bien ne joie onques puis que Bel Acueil fu em prison" (3966 - 3967), pero que en esta combinación parecen ofrecer una gradación en la que bien expresaría una satisfacción menor, o bien con vocablos antónimos como angoisse: "qu'ele ot des biens et de l'angoisse que Amors a ses gens depart en sa jonece bien sa part" (Rose, 3908,02 - 3908,04).

La función más habitual del sustantivo bien es la de complemento de objeto directo. Depende de verbos como doner. "et aveques ce je te doing trois autres biens" (Rose, 2626 - 2627), avoir o vendre, también de prester y acheter, que se hallan en construcciones secundarias pues sus complementos 
de objeto directo son formalmente un pronombre relativo cuyo antecedente es bien y el pronombre personal les. Todos ellos señalan la voluntad de mantener el vínculo de lo inmaterial con lo material aunque no existe ambigüedad respecto del referente del sustantivo. No obstante, establecen anclajes simbólicos para el poder del amor diferentes pero complementarios si tenemos en cuenta la tradición y las nuevas tendencias. Mientras vendre, prester y acheter se asientan en los terrenos de la nueva economía, más acordes con la realidad ciudadana del siglo XIII que las viejas fórmulas, no se renuncia a éstas al evocar la donación, sistema de reparto de bienes típicamente feudal:

Amors me set ore bien vendre

les biens que il m'avoit pretez.

Jes cuidoie avoir achetez;

or les me vent tot de rechief

Rose, 3924 - 3927

Por su parte, el verbo avoir introduce al enamorado en el ámbito de lo desconocido, de lo inexplicado, de lo que parece quedar fuera del poder de Amor y que intuimos se encuentra ya en los dominios de Venus: los placeres, cuya cuantificación se reitera mediante la doble construcción comparativa, que no dependen del buen conformar del amante mantenido siempre a distancia, sino de la voluntad de la amada que se entrega para ser poseída, y de hecho se cambian el pasado y el presente por el futuro, siempre incierto: “qu'autre biens, qui ne sont pas mendres, mes greignor, avras ça avant" (Rose, 2746 2747).

En último lugar, las intervenciones en estilo directo de Amor y aun la del amante en estilo indirecto libre, que emana y sirve de conclusión narrativa a las anteriores, se caracterizan por la colocación del sustantivo bien como antecedente de una frase de relativo. El pronombre es sujeto en el primer caso y complemento de objeto en el segundo: "les biens que il m'avoit pretez” (Rose, 3925) 
trois autres biens, qui granz solaz

font a ceus qui sont en mes laz

Rose, 2627 - 2628

Li premiers biens qui solaz face

ceus que li laz d'amors enlace

Rose, 2629 - 2630

car je t’ai conté sanz mentir

les biens qui pueent garantir

les amanz et garder de mort

Rose, $2737-2739$

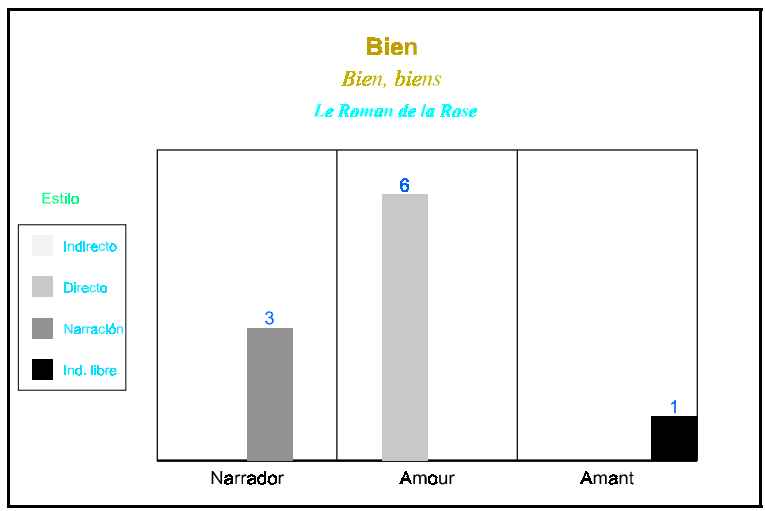

Fig. 164. Comportamiento estilístico del sustantivo bien en Rose.

La inclusión preferente en proposiciones principales, el hecho de verse acompañado por proposiciones de relativo y la presentación secuencial de los placeres, caracterizan las ocurrencias de bien en el discurso didáctico del dios Amor. El discurso narrativo se decanta por las construcciones binarias en las que predominan el carácter poco definido de los placeres eróticos o las tradicionales contradicciones que hacen inconfundible al amor, y especialmente al amor cortés o amor de los jóvenes. 


\subsubsection{3 «DEDUIRE»Y DÉDUIT.}

Tanto el verbo como el sustantivo poseen gran variedad de sentidos y aun de matices que van desde sentir alegría, ya sea por el canto de los pájaros o por el atuendo que hace más agraciado al joven amante (Rose, 2417 - 2418), hasta gozar del juego amoroso, que se puede ofrecer como servicio a la dama: "Il sont entré por aus deduire en la cambre qui ml't fu bele" (Escoufle, 3376 3377), "il la sert en dit et en fait de quanqu'il puet por li deduire”" (Escoufle, 4508 - 4509). También denominan la diversión que se ofrece a los invitados de una boda o de una coronación: "tos li deduis estoit laiens" (Escoufle, 1714), “on ne set en cel liu aler c'on ne truist deduit de .c. pars” (Escoufle, 9002 9003) o bien las distracciones mezcla de veladas literarias, recitales musicales y feria de joyería, aderezadas con el atractivo físico de Aelis: “or n’est il deduis se cil non que d'estre o la france pucele" (Escoufle, 5476 - 5477). En resumen, las actividades cortesanas que el dios Amor aconseja practicar a su pupilo para agradar a todos y muy especialmente a las mujeres:

$$
\begin{aligned}
& \text { Se tu sez nul bel deduit fere } \\
& \text { par quoi tu puisses a gent plere, } \\
& \text { je te comant que tu le faces. } \\
& \text { Rose, } 2177 \text { - } 2179
\end{aligned}
$$

El presente de indicativo en el discurso directo de Ginebra, reforzado por el verbo deporter también en construcción pronominal, nombra el morboso placer que le produce el dolor por la supuesta muerte de su enamorado, con lo que se llevan al extremo las contradicciones amorosas tradicionales que los trovadores habían glorificado y que encontraremos hasta en la mística:

quant je a rien ne me deport

s'es max non, que je trai por lui?

Quant après sa mort m'i dedui

Charrete, 4234 - 4236 
Así mismo, como eufemismo tradicional, ${ }^{521}$ sirve deduit, modificado por el adjetivo entier, para designar el placer producido por el coito. Es un uso excepcional y se hace en un contexto a la vez negativo e irreal, y aun diríamos hipócrita, pues se trata del segundo término de una comparación en la que los nimios placeres sospechados más que obtenidos por el amante de la rosa son mayores que el orgasmo con otra mujer que de hecho nunca ha tenido: "que mieuz vaut de li un regarz que d'autre li deduit entiers" (Rose, 2472 - 2473), siempre en la línea de los dictados del dios Amor, de las reglas tradicionales de la cortesía, que pese a todo se ven calladamente minadas por la frustración apenas disimulada y el deseo de ir más allá, de besar, de tocar y de poseer a la mujer amada.

En E scoufle el infinitivo precedido de la preposición por adquiere la función de complemento circunstancial con sentido final —excepcionalmente también sin preposición: "Venés ent, douce amie ciere, fait li cuens, deduire la fors" (Escoufle, 7354 - 7355)—. Puede regir a su vez un complemento pronominal en función de objeto directo, referido a la pareja dentro del palacio imperial o a la amada durante su huida; también se encuentra la construcción sin el complemento del infinitivo y con un sentido reflexivo para hablar de la fuente de la diversión y del placer, que no podía ser otra sino Aelis: "Tuit li clerc et li chevalier o li sont por deduire adés" (Escoufle, 5944 5945), y en Rose con un sentido más sensual y abierto al ofrecerse a cualquier mujer la promesa de gozar de la bella boca del enamorado de la rosa:

\author{
ainz semble estre fete a estuire \\ por solacier et por deduire \\ Rose, 3445 - 3446
}

${ }^{521}$ Cf. P. Guiraud, op. at., p. 274. 
Las preposiciones por y a con el mismo sentido final ${ }^{522}$ introducen sintagmas nominales en los que el sustantivo precedido por el artículo definido o posesivo adquiere un valor general equivalente al sentido expresado por el infinitivo: “Tot ont atorné au deduit”" (Escoufle, 4053). Si del hedonista conde sabemos que el diálogo con sus servidores, la comida o el descanso entre las doncellas, forman parte de esos placeres, aunque tan sólo se nos deja adivinar que las relaciones con las jóvenes van más allá de la simple compañía: “aprés souper quant li cuens vint en la cambre por son deduit" (Escoufle, 7030 - 7031), queda siempre sin explicar cómo se produce el placer, qué hacen los adolescentes enamorados para alcanzarlo: "Sovent lor est li jors trop cors por le solas, por le deduit" (Escoufle, 4328 - 4329). Tan sólo se nos aclara gracias al artículo posesivo plural, construcción muy poco habitual, que se trata en su caso de placeres compartidos: "Quant li enfant ont le jor fait lor deduit au bos ou au plain (...) le jor estoit lor deduis tex" (Escoufle, 4346 4352).

El sustantivo funciona a menudo como sujeto de la proposición. Este hecho, que en un principio nos había sorprendido, está justificado por el valor muy general que adquiere al servir como un crisol que funde y purifica las más diversas actividades de diversión, sin olvidar las que inspira el amor cuando se encuentran jóvenes de distinto sexo en circunstancias festivas como la coronación de Guillermo y Aelis: "Ml't i ot solas et deduit" (Escoufle, 9025). En este caso las acciones se caracterizan por una cierta autonomía con respecto a los individuos que las ejecutan, y, por otra parte, las diversiones son siempre multitudinarias, implican al grupo cortesano en su conjunto: "Tout joant falent li deduit quant les gens s'en vont as osteus" (Escoufle, 7854 7855), "Grant noise i font li estrument par le palais et li deduit" (Escoufle, 8990 - 8991). Como podemos observar en los ejemplos citados, dos son las combinaciones sintácticas que sirven para recrear la unanimidad y la

\footnotetext{
522 Excepcionalmente el sintagma preposicional puede expresar la causa: "tot a oublié la mesaise li damoisiax por le deduit" (Escoufle, 7744 - 7745).
} 
independencia de los placeres: una construcción impersonal que implica la desaparición de cualquier elemento determinante con la salvedad de los adjetivos indefinidos $\mathbf{m l} \mathbf{t}$ o tel que magnifican la cantidad y calidad y que pueden ir acompañados de la preposición de: "Il n'avoit a Monpellier tel ne de soulas ne de deduit" (Escoufle, 5518 - 5519), y en el caso de verbos personales la precesión del artículo definido plural.

Como complemento de objeto directo podemos encuadrarlo en dos grandes conjuntos. Se refiere por un lado al goce sexual de uno o de los dos amantes, y se construye sistemáticamente con el verbo avoir. "Molt ot de joie et de deduit Lanceloz, tote cele nuit" (Charrete, 4685 - 4686), "Ml't orent deduit par engien" (Escoufle, 3136), "Li dui qui tot le deduit ont" (Escoufle, 3630), ejemplos en los que se hace patente la diferencia entre el texto caballeresco-cortés ortodoxo como es Charrete y la heterodoxia que hallamos en Escoufle, tanto en el discurso narrativo como en el eco intertextual al referirse Guillermo a Tristán y a la reina, si bien todos coinciden al poner de relieve mediante los adjetivos indefinidos ml't y tot la magnitud del placer. Por otro lado, en relación con un grupo variopinto de verbos, el sustantivo deduit pasa a nombrar ese conjunto de placeres de naturaleza indefinida, entre los que no debemos descartar algún ingrediente erótico, que hemos definido como cortesanos y en los que los héroes enamorados son meros instrumentos para terceros, ello con verbos como prisier. "son afaitement, son deduit prisent ml't cil qui l'ont hantee" (Escoufle, 5536 - 5537) y aimer. "s'il ert hom qui amast delit, ne chiens ne oisiaus ne deduit" (Escoufle, 6526 6527); o bien aquellos que no distinguen a los amantes del resto de los mortales. A veces se incluye también a los receptores de la obra, al tiempo testigos y actores como en el caso de trover: "on ne set en cel liu aler c'on ne truist deduit" (Escoufle, 9002 - 9003) y de veoir. "car tel joie ne tel deduit ne vit mes hom, si com je cuit” (Rose, 473 - 474). Mención aparte merece faire pues incorporaremos la ocurrencia de Rose: "Se tu sez nul bel deduit fere" (Rose, 2177) a este segundo grupo, mientras que en E soufle la balanza parece 
inclinarse hacia el lado del juego erótico pues probablemente todos los pasatiempos del viaje convergen para aplacar los deseos de los adolescentes y avivar el fuego de la pasión: "Quant li enfant ont le jor fait lor deduit au bos ou au plain" (Escoufle, 4346 - 4347).

La construcción de los versos prima la aparición en la rima de deduire y deduit por lo que podemos suponerle un gran peso al aspecto puramente formal. Este hecho se ve reforzado por la coordinación con sintagmas paralelos que contienen los sustantivos joie y solaz o el verbo solacier y que se encuentran sistemáticamente en la primera parte del verso. En el aspecto semántico merecen ser puestas de relieve dos de las combinaciones en la rima: por una lado la relación con el sustantivo nuit, el tiempo que tradicionalmente se considera más adecuado al amor, a la unión sexual de los amantes y por lo tanto al placer erótico, una relación que no deja de entrañar un aspecto negativo, pues la oscuridad y la noche también se asocian con lo prohibido y lo maligno, con el pecado en suma; por otro lado, y en estrecha relación con lo que acabamos de escribir, la combinación con términos a priori negativos como destruire, nuire y enuier, si no fuera porque la mayor parte de los contextos en los que se hallan desmienten este valor primario.

\begin{tabular}{lllllllll}
\hline FORMA & CA & BD & NV & RIMA & CA2 & NV2 & D & PERS \\
\hline dedui & V & Charrete & 4236 & lui & P & 4235 & D & Guenièvre \\
deduire & I & Rose & 2147 & destruire & I & 2148 & D & Amour \\
deduire & I & Rose & 3446 & estuire & S & 3445 & D & Vénus \\
deduire & I & Escoufle & 3376 & nuire & I & 3375 & N & Narrador \\
deduire & I & Escoufle & 4509 & nuire & I & 4510 & N & Narrador \\
deduis & S & Escoufle & 7060 & cuis & O & 7059 & N & Narrador \\
deduisant & T & Escoufle & 7058 & devant & S & 7057 & N & Narrador \\
deduisent & V & Escoufle & 9017 & visent & V & 9018 & N & Narrador \\
deduisions & V & Escoufle & 7592 & raisons & S & 7591 & D & Guillaume \\
deduit & S & Escoufle & 4053 & anuit & V & 4054 & N & Narrador \\
deduit & S & Escoufle & 7745 & anuit & V & 7746 & N & Narrador \\
deduit & S & Rose & 615 & conduit & V & 616 & D & Oiseuse \\
deduit & S & Rose & 2994 & conduit & O & 2993 & D & Raison \\
deduit & S & Escoufle & 6527 & cuit & V & 6528 & D & Guillaume
\end{tabular}




\begin{tabular}{lllllllll} 
deduit & $\mathrm{S}$ & Rose & 473 & cuit & $\mathrm{V}$ & 474 & $\mathrm{~N}$ & Narrador \\
deduit & $\mathrm{S}$ & Escoufle & 767 & duit & $\mathrm{A}$ & 768 & $\mathrm{~N}$ & Narrador \\
deduit & $\mathrm{S}$ & Escoufle & 5536 & duit & $\mathrm{V}$ & 5535 & $\mathrm{~N}$ & Narrador \\
deduit & $\mathrm{S}$ & Rose & 2717 & duit & $\mathrm{A}$ & 2718 & $\mathrm{D}$ & Amour \\
deduit & $\mathrm{S}$ & Escoufle & 7031 & fruit & $\mathrm{S}$ & 7032 & $\mathrm{~N}$ & Narrador \\
deduit & $\mathrm{S}$ & Charrete & 4685 & nuit & $\mathrm{S}$ & 4686 & $\mathrm{~N}$ & Narrador \\
deduit & $\mathrm{S}$ & Escoufle & 4329 & nuit & $\mathrm{S}$ & 4330 & $\mathrm{~N}$ & Narrador \\
deduit & $\mathrm{S}$ & Escoufle & 4413 & nuit & $\mathrm{V}$ & 4414 & $\mathrm{~N}$ & Narrador \\
deduit & $\mathrm{S}$ & Escoufle & 6408 & nuit & $\mathrm{S}$ & 6407 & $\mathrm{~N}$ & Narrador \\
deduit & $\mathrm{S}$ & Escoufle & 7017 & nuit & $\mathrm{S}$ & 7018 & $\mathrm{~N}$ & Narrador \\
deduit & $\mathrm{S}$ & Escoufle & 7854 & nuit & $\mathrm{S}$ & 7853 & $\mathrm{~N}$ & Narrador \\
deduit & $\mathrm{S}$ & Escoufle & 9025 & trestuit & $\mathrm{P}$ & 9026 & $\mathrm{~N}$ & Narrador \\
deduit & $\mathrm{S}$ & Escoufle & 8991 & uit & $\mathrm{N}$ & 8992 & $\mathrm{~N}$ & Narrador \\
deduit & $\mathrm{S}$ & Escoufle & 5519 & viii & $\mathrm{N}$ & 5520 & $\mathrm{~N}$ & Narrador \\
\hline
\end{tabular}

Tabla 98. Rimas del verbo deduire y del sustantivo déduit.

Junto a un gran número de proposiciones principales $\mathrm{e}$ independientes, encontramos los términos deduire y deduit en algunas subordinadas adjetivas entre las que destacan en E scoufle aquellas cuyo relativo sujeto retoma a los individuos beneficiarios del placer: "li .xv. jor furent ml't court a ciaus qui laiens se deduisent" (Escoufle, 9016 - 9017), mientras que en el único ejemplo de Rose el pronombre sujeto se refiere a uno de los guías alegóricos que introducen al adolescente en los deleites del amor: "Oiseuse m'avoit bien servi, qui m'avoit en ce deduit mis" (Rose, 684 - 685). Contrastan de nuevo entre ambas obras la actividad de los amantes incluso adolescentes frente a la pasividad del aprendiz de las formas corteses. Son sin embargo las subordinadas circunstanciales aquellas en las que encontramos con mayor asiduidad deduire y deduit — causales (Rose, 473 - 474), hipotéticas (Rose, 2177), comparativas (Rose, 2472 - 2473)—, si bien sólo se repiten las temporales que expresan la simultaneidad de los procesos de la principal y de la subordinada introducidas por quant: "aprés souper quant li cuens vint en la cambre por son deduit" (Escoufle, 7030 - 7031), “quant li oil sont en deduit" (Rose, 2717) y por que que: "que qu'il atent en deduisant" (Escoufle, 7058), "que que nous nous deduisions com amant en mainte maniere" (Escoufle, 7592 - 7593). 


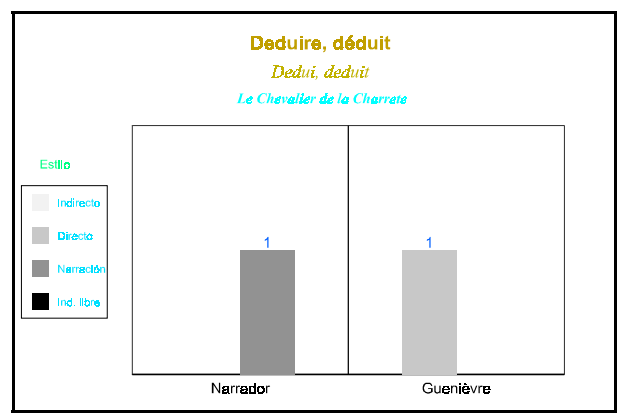

Fig. 165. Comportamiento estilístico del verbo «deduire» y del sustantivo déduit en Charrete.

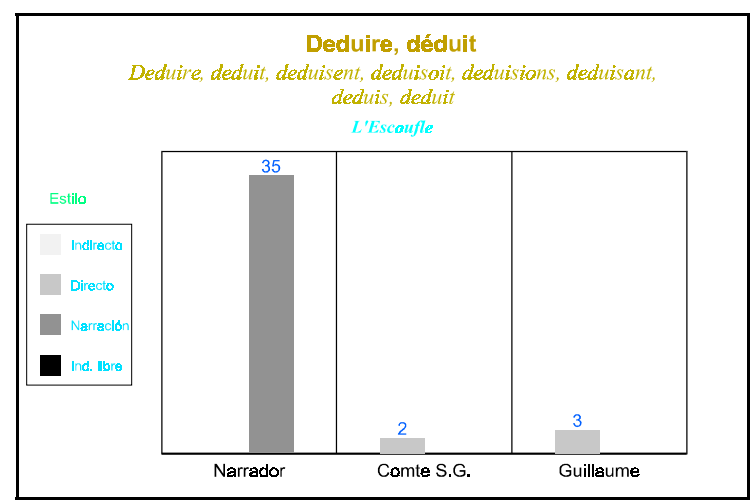

Fig. 166. Comportamiento estilístico del verbo «deduire» y del sustantivo déduit en Escoufle.

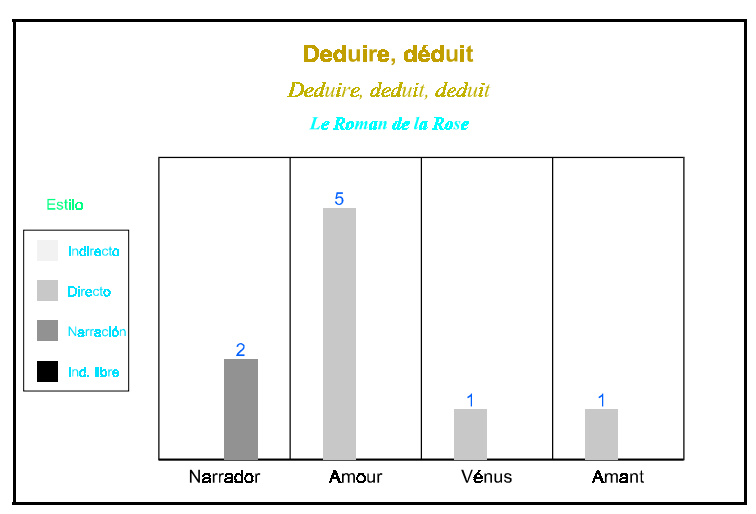

Fig. 167. Comportamiento estilístico del verbo «deduire» y del sustantivo déduit en Rose.

Apenas representados en Charrete, deduire y deduit se encuentran sobre todo en Escoufle con un sentido positivo que no llega a contradecirse siquiera con la aparente dualidad entre los aspectos positivos y negativos de las 
combinaciones en la rima, y que por el contrario se ve reforzado dentro del propio verso mediante la combinación sinonímica. El placer nombrado por estos términos, cuya consecución es la finalidad de muchas de las actividades descritas en los textos, es el goce del varón y en menor grado de la pareja. De hecho, el discurso masculino ya sea del narrador o de los personajes acapara todas las ocurrencias con la salvedad de las intervenciones de Ginebra y Venus, la primera se recrea en el placer masoquista y la diosa del amor evoca tan sólo la posibilidad del goce carnal.

\subsubsection{4 «DELITER», «DELITABLE»Y «DELIT».}

El adjetivo delitable, habitual en las descripciones del locus amoenus tanto en E scoufle como en Rose, expresa la capacidad para producir placer del sustantivo al que acompaña. Alterna con la forma deliteus, ésta puramente descriptiva, estática, frente al proceso dinámico expresado por delitable que se establece entre los sentidos y el lugar calificado para influir en los órganos del placer humano, produciendo o incrementando el goce erótico:

$$
\begin{aligned}
& \text { et sachiez que je cuidai estre } \\
& \text { por voir em paradis terrestre: } \\
& \text { tant estoit li leus delitables, } \\
& \text { qu’i sembloit estre esperitables } \\
& \text { Rose, } 633 \text { - } 636
\end{aligned}
$$

Fuera de las descripciones espaciales Lorris utiliza el adjetivo, tanto en constucción atributiva como unido al nombre sin cópula, para otorgar a la imaginación y la memoria, así como a la percepción visual, las más altas cualidades eróticas. Las tres son en sí mismas deleitables y a la vez promueven el desarrollo del deseo obsesivo, placentero y doloroso, tal y como conviene al erotismo cortés, pues la segunda será a todas luces insuficiente para calmar el apetito masculino y las primeras se presentan explícitamente como un engaño, 
ya que la unión física no es más que la consecuencia de un desarreglo mental que además aleja de la ortodoxia al representarse el amante vívidamente el coito sin que la amada lo haya aceptado:

\author{
tant con tu iras foloiant \\ en la pensee delitable \\ ou il n'a que mençonge et fable \\ Rose, 2432 - 2434
}

car il est mout as amoreus

delitables et savoreus

Rose, 2707 - 2708

Chrétien, por el contrario, reserva este adjetivo en construcción superlativa para calificar el intenso y extraordinario placer producido por la cópula sexual: "des joies fu la plus eslite et la plus delitable” (Charrete, 4682 4683) y es éste el único medio para describir una actividad cuyos pormenores deben quedar ocultos en el texto noble. Esta prohibición a la que se somete queda, sin embargo, compensada por las insistentes alusiones a la necesidad de callar, que tienen como finalidad conseguir la estimulación erótica de los que escuchan el relato. Podríamos de hecho decir que frente a la exposición pornográfica que estaría totalmente fuera de lugar, el texto caballeresco recurre a la negación de la palabra mediante la palabra. Con los verbos taisir, celer y dire en forma negativa ${ }^{523}$ logra el efecto erótico deseado entre sus receptores a la vez que mantiene a sus personajes nobles en el ámbito de lo

mes toz jorz iert par moi teüe,
qu'an conte 뜨 doit estre dite.
Des joies fu la plus eslite
et la plus delitable cele
que li contes nos test et cele

Charrete, 4680 - 4684 
bello y de lo puro, pues la cópula en el caso de Lanzarote y de la reina debería ser la lógica y última consecuencia de un amor depurado en el que el cuerpo es dominado por los sentimientos y doblegado por el dolor físico y psíquico. No hay rastro, sin embargo, en esta justificación narrativa de las imposiciones morales que hallaremos en textos del final de la Edad Media como el A madís de G aula. ${ }^{524}$

La actividad sexual en la que queda implícito el coito tan sólo se nombra mediante el sustantivo delit en los textos del siglo XII: "trop a son delit entent" (Tristan, 734), “et de li ot tot son delit” (Charrete, 4970), obra esta última donde se considera como en Rose el deleite en toda su extensión aunque el adjetivo tot tenga un valor menos definido que el adjetivo antier. Por su parte, Renart, al reservar el término a los placeres eróticos de los jóvenes antes del matrimonio, y Lorris, al referirse a los menudos placeres previos al encuentro sexual o a los simplemente imaginados por el amante en su delirio, descartan la penetración.

Sin embargo, Escoufle se aparta de todos los demás, centrados obcecadamente en el varón, al tener en cuenta no sólo el deleite compartido de los enamorados, sino de nuevo el goce de la heroína. La consideración de la pareja conlleva formalmente junto a la tercera persona del plural del verbo avoir, con el que el sustantivo mantiene una relación de complemento de objeto directo: "ml't ont soulas, ml't ont delis" (Escoufle, 4294) y el pronombre personal complemento de tercera persona plural, el uso del artículo posesivo plural que desbanca al artículo posesivo singular que veíamos en los ejemplos citados, con todo ello Renart insiste en la perfecta comunión de los placeres:

\footnotetext{
${ }^{524} \mathrm{Y}$ que podemos observar en este fragmento del capítulo XII del libro I: "Galaor folgó con la donzella aquella noche a su plazer, y sin que más aquí vos sea recontado, porque en los autos semejantes, que a buena conciencia ni a virtud no son conformes, con razón deve hombre por ellos ligeramente passar, teniéndolos en aquel pequeño grado que merescen ser tenidos". Citamos por la edición de Juan Bautista Avalle-Arce: Garci Rodríguez de Montalvo, A madís de G aula. Madrid: Espasa Calpe, 1991.
} 
Ainc puis ne furent a celee

lor parlemens ne lor delis

entre Guilliaume et Aelis.

Tot lor delit sont mais commun

Escoufle, 2372 - 2375

Pero si exceptuamos las ocurrencias ya citadas que son minoritarias, ¿cuáles son los placeres identificados mediante el sustantivo delit, y que haremos extensivos al verbo deliter siempre en forma pronominal que hallamos en Charrete Tanto para los varones como para las féminas, son los producidos por la visión del amante: “et tant se delite con s’il m’avoit ja tote quite" (Charrete, 1527 - 1528), "toustans li tenoit el visage ses iols aers bele Aelis. Or estoit ce tous ses delis" (Escoufle, 7404 - 7406), “et durement m'abelisoit ce que jou veoie a bandon; que mes maus en entroblioie por le delit et por la joie" (Rose, 1806 - 1810). Con una notable diferencia entre el punto de vista masculino y femenino, desde el primero se tiende a considerar los placeres que aún están por venir y de los que este primero es un agradable anticipo; en su forma femenina el placer de la visión sirve para reforzar la dependencia monogámica para la que se educaba a la mujer y de la que presuntamente la cortesía la liberaba, ya que el placer viene del reconocimiento de la imagen de su amante en las formas masculinas percibidas. Esta forma de control de la sexualidad femenina, que se observa por ejemplo en los cuentos donde la heroína espera a su príncipe azul, creemos que sigue plenamente vigente como un modelo social asumido inconscientemente, con la salvedad de que la ideología burguesa lo extendió parcialmente al varón en el período post-matrimonial.

En segundo lugar interviene la capacidad intelectiva que hace surgir el placer gracias al recuerdo de la persona amada. Se distinguen las formas de indicativo de Charrete, indicio de la actualización, frente al subjuntivo y la 
construcción hipotética, un nuevo exponente de la inexperiencia del adolescente que justifica el planteamiento teorizante de Lorris:

$$
\begin{aligned}
& \text { et cil qui se delite et pest } \\
& \text { de son panser qui molt li plest } \\
& \text { Charrete, } 1361 \text { - } 1362 \\
& \text { je ne serai ja si dolenz, } \\
& \text { s'i m'en sovient, que je ne saie } \\
& \text { toz plains de delit et de joie. }
\end{aligned}
$$

Rose, 3470 - 3472

Por fin, el contacto fetichista con una parte del cuerpo venerado: "et cil se delite et deporte es chevox qu'il a en son saing”' (Charrete, 1498 - 1499) o con una prenda que lo hubiese rozado:

$$
\begin{aligned}
& \text { tant de solas, tant de delit } \\
& \text { com ele ot si fu des linceus }
\end{aligned}
$$

Escoufle, 5246 - 5247

En cuanto a las rimas, las del adjetivo muestran en Rose la dificultad para distinguir entre realidad y mentira, dos aspectos del discurso en general, del sueño que enmarca el relato y de los placeres que describe en particular. Las del sustantivo establecen dos relaciones semánticas básicas: una con el que es al tiempo sujeto y objeto del placer, individual o compartido, la heroína de E scoufle, la otra con el lugar por excelencia del ayuntamiento carnal. Es esta obra la que mayor partido saca a la posición final del sustantivo poniéndolo de relieve hasta el momento en que los amantes recuperan su lugar en la sociedad y la identidad sexual que podríamos llamar oficial. Esta rima con lit es utilizada, además, en los romans del siglo XIII para señalar la oposición entre el placer de la unión con la amada y la frustración del amante que yace solo. 


\begin{tabular}{lllllllll}
\hline FORMA & CA & BD & NV & RIMA & CA2 & NV2 & D & PERS \\
\hline delis & S & Escoufle & 2373 & Aelis & S & 2374 & N & Narrador \\
delis & S & Escoufle & 7406 & Aelis & S & 7405 & N & Narrador \\
delis & S & Escoufle & 4294 & lis & S & 4293 & N & Narrador \\
delit & S & Charrete & 4970 & lit & S & 4969 & D & Méléagant \\
delit & S & Escoufle & 3199 & lit & S & 3200 & D & Guillaume \\
delit & S & Escoufle & 5246 & lit & S & 5245 & N & Narrador \\
delit & S & Escoufle & 5400 & lit & S & 5399 & N & Narrador \\
delit & S & Escoufle & 5515 & lit & S & 5516 & N & Narrador \\
delit & S & Rose & 2414 & lit & S & 2413 & D & Amour \\
delitable & A & Rose & 1410 & fable & S & 1409 & N & Narrador \\
delitable & A & Rose & 2433 & fable & S & 2434 & D & Amour \\
delitables & A & Rose & 635 & esperitables & A & 636 & N & Narrador \\
delite & V & Charrete & 2792 & parfite & A & 2791 & D & Demoiselle \\
delite & V & Charrete & 1527 & quite & A & 1528 & D & Demoiselle \\
\hline
\end{tabular}

Tabla 99. Rimas del verbo «deliter», del adjetivo «delitable» y del sustantivo «delit».

Las proposiciones subordinadas de relativo pueden aquí clasificarse en función del antecedente y su valor referencial. Por un lado se encuentran las que tienen por antecedente el lugar donde se producen los placeres, la cámara: "viaus la chambre u ele sejorne (...) cui je suel estre a tel joie et a delit" (Escoufle, 3196 - 3199) o el lecho: "tu te coucheras en ton lit, ou tu avras poi de delit” (Rose, 2413 - 2414); por otro aquellas cuyo antecedente es el sujeto varón que obtiene placer: "et cil qui se delite et pest de son panser" (Charrete, 1361 - 1362); en tercer lugar las que tienen como antecedente a la mujer considerada como motor del placer aunque a un tiempo sea presentada como un mero objeto ya que todo el proceso se realiza en el cuerpo y en los órganos afectivos del hombre, en este caso Lanzarote: "de la rien qui plus te delite" (Charrete, 2792).

La consecuencia establecida mediante la correlación si ... que [A dv. + C onj.] (Rose, 3470 - 3472), la causa introducida por las conjunciones car. "qar trop a son delit entent” (Tristan, 734), (Rose, 2707 2708) o que: "que mes maus en entroblioie por le delit et por la joie" (Rose, 1809 -1810), y la simultaneidad de los procesos indicada por la locución tant com [A dv. + C onj.]: "et avras joie de noiant tant con tu iras foloiant en la pensee delitable" (Rose, 2431 - 2433), son las circunstancias expresadas mediante proposiciones subordinadas, más abundantes en el texto de Lorris. 


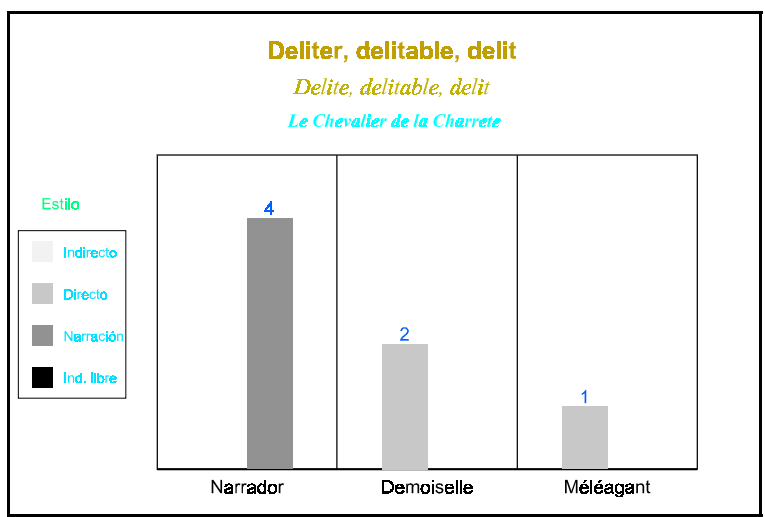

Fig. 168. Comportamiento estilístico del verbo «deliter», del adjetivo «delitable»y del sustantivo «delit» en Charrete.

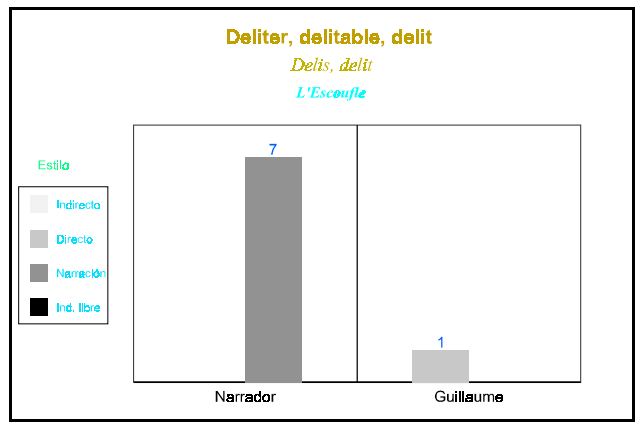

Fig. 169. Comportamiento estilístico del verbo «deliter», del adjetivo «delitable»y del sustantivo «delit» en Escoufle.

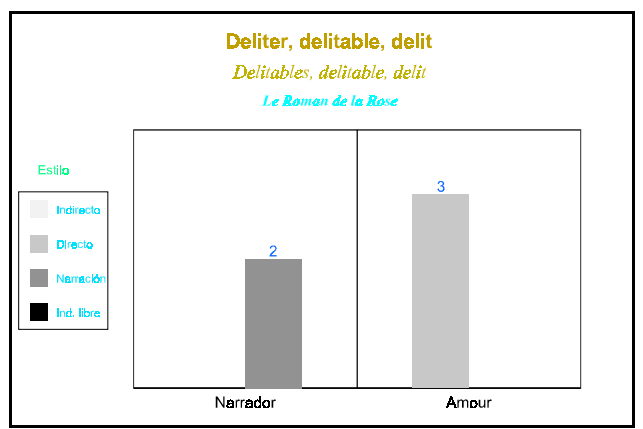

Fig. 170. Comportamiento estilístico del verbo «deliter», del adjetivo «delitable» y del sustantivo «delit» en Rose.

Ciertos fenómenos formales y semánticos alinean estos términos con el resto de los tratados hasta ahora en relación con el goce carnal: las construcciones binarias con vocablos sinónimos o que aportan apenas un leve 
matiz al sentido de deliter, delit y delitable, la adjunción de superlativos y ponderativos, y la insistente negación del placer que se produce en algunos fragmentos de los romans del siglo XIII. A estas concordancias se añade el hecho de la supremacía del varón, también en lo concerniente a las entidades discursivas, si bien aquí contrarrestada por los placeres compartidos de los amantes en E sooufle y por la consideración de la mujer como sujeto del placer.

\subsection{JOUIR Y JOIE.}

La joie según el modelo de la canción de gesta se correspondía con "una excitación feroz, con una exaltación bestial no alejada del wut de la tradición germánica pagana, el furor, el tranœ guerrero", 525 pero se reconvirtió con la lírica trovadoresca en una estado de euforia amorosa que llevará al sustantivo a expresar el placer. Ya en latín clásico el neutro GAUDIUM podía adquirir los sentidos de «contento», «satisfacción», «gozo», «alegría», «placer de los sentidos», y particularmente el plural GAUDIA indicaba los placeres sensuales del amor, por ejemplo en Ovidio; 526 y no siempre en nuestros textos, donde a menudo se busca la ambigüedad al tratar las relaciones extramatrimoniales, es fácil delimitar entre este ramillete de acepciones la expresión de la alegría, de la felicidad y del placer de los sentidos o carnal. Así, en el discurso de la taimada Iseo tras la desaparición de los efectos del filtro, podemos interpretar el deseo del bienestar cortesano que habían perdido, pero también la recuperación y perduración con nuevos engaños de sus amores en un ambiente más favorable: "consel nos doroit honorable, par qoi a joie pardurable porron ancore bien venir" (Tristan, 2275 - 2277). Renart construye de otra forma la ambigüedad referencial al colocar el sustantivo en una intersección temática: "nule joie ne puet ataindre a celi qui est en la court" (Escoufle, 9014 - 9015). Designa de este modo en el discurso narrativo el

\footnotetext{
${ }^{525}$ F. Cardini, El guerrero y el caballero, en El hombre medieval, J. Le Goff (ed.). Madrid: Alianza, 1990, p. 93.

${ }^{526}$ G.C. Cropp, op. at., p. 338.
} 
regocijo de los que se entregan a los juegos cortesanos, hace referencia a las actividades caballerescas con causa amorosa a las que el narrador acaba de aludir, y a la vez alude al placer sensual y carnal que proporcionan a los nuevos enamorados los incesantes, furtivos y satisfactorios encuentros.

También el uso metafórico del sustantivo que se observa en Lorris para describir la época privameral, con su vegetación exuberante, las flores recientemente abiertas y los cantos nupciales de los pájaros, discurso que reproduce los motivos habituales de las canciones, juega con todos los sentidos mencionados para conseguir no sólo crear el marco idóneo en el que situar su sueño erótico sino alentar el deseo retomando los tópicos que cantaban el placer consumado en el lenguaje enigmático de los poetas:

$$
\begin{aligned}
& \text { qu'en may estoie, ce sonjoie, } \\
& \text { el tens enmoreus, plain de joie, } \\
& \text { el tens ou toute rien s'esgaie }
\end{aligned}
$$$$
\text { Rose, } 47 \text { - } 49527
$$

Más significativa aún es en Rose la extensión referencial del sustantivo, inexistente en los otros textos, a partir de una operación metonímica novedosa con respecto a las que hemos señalado hasta este momento al ser aquí de efecto - causa. Con ella se designa a la amada mediante el placer que produce en el enamorado, y se pone de relieve también la intención posesiva y la unidireccionalidad mediante el artículo posesivo de segunda persona singular:

$$
\begin{aligned}
& \text { tant con ta joie einsi verras, } \\
& \text { ja mes movoir ne t'en querras }
\end{aligned}
$$

Rose, 2347 - 2348

\footnotetext{
${ }^{527}$ La benignidad meteorológica y el nacimiento del amor combinados en el adjetivo enmoreus se unen a la belleza de la naturaleza para caracterizar todo el fragmento descriptivo hasta alcanzar la lógica y obligada consecuencia sentimental entre los jóvenes humanos: "lors estuet joines genz entendre a estre gais et amoreus por le tens bel et doucereus. Mout a dur cuer qui en may n'aime, quant il ot chanter sus la raime as oisiaus les douz chans piteus." (Rose, $78-83$ ).
} 
Los contextos en los que el sustantivo adquiere el sentido de «agasajo»y, en combinación con el verbo faire al que complementa como objeto directo, el de «agasajan», quedan determinados por las contradicciones, los desencuentros en los que la cortesía incurre frente a las reacciones naturales de los enamorados en una situación de inocencia y de abstracción con respecto de los tabúes e imperativos sociales, situación que, por otra parte, es presumiblemente irreal y utópica. Especialmente vivaz en Charrete, este uso resume el homenaje táctil que rinde Lanzarote a los cabellos de la reina cuando está ausente: “n'est joie nule qu’il n'an face" (Charrete, 1466) y caracteriza en negativo las reacciones hipócritas de Ginebra en presencia de testigos (Charrete, 6824 - 6833) o, con una intención punitiva desproporcionada, una refinada crueldad que bien podríamos calificar como sado-masoquismo psicológico avant la lettre.

et cuida que je li feïsse grant joie, et que je le veïsse, et onques veoir ne le vos, ne li fu ce donc mortex cos?

Charrete, 4211 - 4214

Atemperada la doctrina a los amores adolescentes, mucho menos corrosivos para el orden social que los adúlteros, la joie de Guillermo ante los preciosos regalos de la amada expresa, aquí en presencia de esta, su obsequiosa sujeción a la voluntad de Aelis, su veneración y su disposición a servirle y complacerle como buen amante: "qui donc li veïst joie faire de l'aumosniere et de l'anel" (Escoufle, 4502 - 4503).

Bien es verdad que el origen sexual del deleite se identifica claramente en la única ocurrencia que hemos seleccionado del infinitivo jö̈r "se Diex de la riens que j’aim miex me doinst joïr a nul jor mais" (Escoufle, 4952 - 4953). Esta construcción desiderativa recuerda otras que en Charrete también se ponen en boca de una doncella, si bien el placer se pretende 
puramente sentimental, aunque bien pudiera ser que tras el corazón del amante se escondiese el receptáculo del placer sexual. Esto podría quedar formalmente confirmado por la calificación ponderativa —en este caso adjetiva como en la descripción del orgasmo de Lanzarote y de Ginebra (Charrete, 4682 - 4684) pero también la encontramos bajo el aspecto de una proposición de relativo-, ya que dicha calificación es un recurso habitual como hemos visto al tratar los términos precedentes y tendremos ocasión de observar más adelante:

$$
\begin{aligned}
& \text { dist la pucele: «Dex te mete, } \\
& \text { chevaliers, joie el cuer parfite, } \\
& \text { de la rien qui plus te delite }
\end{aligned}
$$

Charrete, 2790 - $2792^{528}$

Sin equívocos joie identifica en algunas de sus ocurrencias el encuentro final, la cópula, deseada vehementemente por los amantes: "se tant fait amors que j'oie de m'amie enterine joie” (Rose, 2453 - 2454) y cuya promesa les permite seguir sufriendo: "Esperance li fet souffrir les maus, dont nus ne set le conte, por la joie qui .c. tanz monte” (Rose, 2610 - 2612). Es el placer supremo según el modelo caballeresco, aunque también placer raro y exiguo que no hace justicia según Razón a los padecimientos con los que se paga. En este discurso moralizante la insistencia en su excepcionalidad y en su brevedad es el indicio que nos permite identificar el orgasmo como referente del sustantivo:

$$
\begin{aligned}
& \text { La poine en est desmesuree, } \\
& \text { et la joie a corte duree. } \\
& \text { Qui joie en a, petit li dure, } \\
& \text { et de l'avoir est aventure }
\end{aligned}
$$

Rose, 3035 - 3038

\footnotetext{
${ }^{528}$ En otro ejemplo la referencia al placer sexual viene dada por la combinación del adjetivo grant y de la construcción desiderativa: "tes cuers si grant joie ait de la rien que il plus voldroit" (Charrete, 2928 2929), ya que este adjetivo es bastante habitual en compañía de joie y por ello casi inexpresivo.
} 
Si la combinación con el verbo faire permitía determinar un sentido preciso y repetido de índole erótica aunque no estuviese relacionado con la cópula, la dependencia sintáctica mayoritaria como complemento de objeto del verbo avoir, observada en la segunda ocurrencia del fragmento que acabamos de citar, nos devuelve a la imprecisión peculiar del sustantivo. Ésta es puesta de relieve por el carácter conclusivo y sintético de numerosas frases, intercaladas incluso en fragmentos alejados de la temática amorosa, o bien por el papel de transición narrativa entre dos episodios del relato, rasgos estos que son comunes a todos los textos pero más habituales en los del siglo XIII: ${ }^{529}$ “molt ot de joie et de deduit Lanceloz, tote cele nuit" (Charrete, 4685 - 4686), “il sambloit estre fors del sens, tant ot de joie et de liece” (Escoufle, 7706 7707),

$$
\begin{aligned}
& \text { Or s'en vait a Saint Gile arriere. } \\
& \text { Ml't ot li quens joie a cel jor; } \\
& \text { il ne fait en nul lieu sejor } \\
& \text { dusqu'il vient arriere en maison }
\end{aligned}
$$

Escoufle, 5894 - 5897

$$
\begin{aligned}
& \text { a la haie que Dangier garde } \\
& \text { sui retornez, que mout me tarde } \\
& \text { que je le boton au moins voie, } \\
& \text { des qu'avoir n'en puis autre joie. } \\
& \text { Rose, } 3205 \text { - } 3208
\end{aligned}
$$

No cabe duda de que los sintagmas preposicionales nos aportan nuevos aspectos del amplio concepto de placer expresado por joie en la literatura caballeresca. Los introducidos por la preposición por que indica la instrumentalización en beneficio del amante convierten la joie, esencialmente en Rose, no sólo en un fin en sí misma sino en la tabla de salvación frente al

${ }^{529}$ Excepción hecha de Tristan donde tan sólo hallamos en una ocasión el término joie. 
sufrimiento amoroso: "mes maus en entroblioie por le delit et por la joie" (Rose, 1809 - 1810),

$$
\begin{aligned}
& \text { por la joie covient lors } \\
& \text { que li cuer oblit ses dolors } \\
& \text { et les teniebres ou il ere }
\end{aligned}
$$$$
\text { Rose, } 2725 \text { - } 2727
$$

Pero el dolor puede volver, toda vez que los placeres sensuales son efímeros y dejan al amante más desamparado que antes de haber gozado de ellos, con lo que la joie se convierte en la causa del tormento:

$$
\begin{aligned}
& \text { que je sui a plus grant meschief } \\
& \text { por la joie que j’ai perdue } \\
& \text { que s'onques ne l'eüse eue } \\
& \text { Rose, } 3928 \text { - } 3930
\end{aligned}
$$

Mientras, en la obra de Renart, los sintagmas preposicionales nos hablan del placentero comportamiento de los amantes, orientado hacia la amada en el caso del jóven, más egoísta el del señor que mantiene relaciones sexuales fuera del matrimonio: "com jou l'en menoie a grant joie" (Escoufle, 7567), “de joie s'est abandonés a voloir tot quanque li plot” (Escoufle, 5876 5877).

El análisis de la sintaxis proposicional pone de manifiesto una clara tendencia a la aparición de los términos tratados en proposiciones subordinadas, que siguen, además, una serie de pautas relativamente estables en lo formal y en lo semántico.

Las proposiciones subordinadas circunstanciales se reparten entre causales, consecutivas y temporales. Entre las primeras, introducidas por que y des que [Prep. + C onj.] prevalecen los contextos en los que se reúnen 
el sufrimiento y la felicidad o el placer: "que li diax por la joie fine" (Charrete,

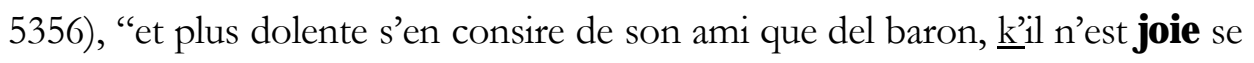
cele non de .ii. amans ki sont ensamble" (Escoufle, 5706 - 5709)

je n'oi bien ne joie onques puis

que Bel Acueil fu em prison,

que ma joie et ma guerison

est toute en li et en la rose

Rose, 3966 - 3969

El estilo sentencioso de las intervenciones narrativas en Charrete y en E scoufle contrastan con la formulación personal de Rose al plañer el alejamiento de la amada y la excesiva moderación en los placeres sensuales, obligado a conformarse con el parco deleite que produce la visión distante del objeto de deseo: "que je le boton au moins voie, des qu'avoir n'en puis autre joie" (Rose, 3207 - 3208).

Tan sólo al comienzo de la obra, cuando ni el deseo ni el amor se habían adueñado todavía de su cuerpo, la alegría es independiente del padecimiento y el narrador se contagia del ambiente al descubrir un nuevo medio, unas sensaciones y un comportamiento desconocidos o, por mejor decir, ignorados hasta ese instante. Muestra su gratitud de igual modo que los elementos naturales, aunque la proposición introducida por car deja un regusto de justificación que casa mal con la inconsciencia, con la naturalidad del supuesto adolescente:

$$
\begin{aligned}
& \text { je l'en seüse mout bon gré, } \\
& \text { car tel joie ne tel deduit } \\
& \text { ne vit mes hom (...) } \\
& \text { Rose, } 472 \text { - } 474
\end{aligned}
$$


Las proposiciones con sentido consecutivo en las que el adverbio introductor modifica formas adjetivas, ya sea tant o si, presentan la consecuencia, es decir, el placer, como un hecho que ya se ha producido — la voluptuosidad de la cópula entre Lanzarote y la reina-, o bien como un fenómeno general independiente de las condiciones particulares del enamoramiento, la relación entre los órganos de la vista y el corazón, sede de los sentimientos amorosos:

$$
\begin{aligned}
& \text { tant li est ses jeus dolz et buens, } \\
& \text { et del beisier, et del santir, } \\
& \text { que il lor avint sanz mantir } \\
& \text { une joie et une mervoille } \\
& \text { Charrete, } 4674 \text { - } 4678
\end{aligned}
$$

$$
\begin{aligned}
& \text { et quant li oil sont en deduit, }
\end{aligned}
$$

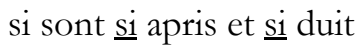

$$
\begin{aligned}
& \text { que seul ne sevent avoir joie }
\end{aligned}
$$

Rose, 2717 - 2719

Por el contrario, cuando el adverbio tant modifica la acción expresada en la proposición principal, la consecuencia, en este caso el coito, se busca, se desea, pero no se ha alcanzado todavía y el verbo avoir se construye regularmente en subjuntivo: “mes se tant fait Amors que j'oie de m'amie enterine joie" (Rose, 2451 - 2452).

Las conjunciones quant o tant $\mathbf{c o m}$ [Adv. + $\mathbf{C}$ onj.] sitúan temporalmente el placer con respecto a la movilidad de los enamorados: el hombre que mantiene relaciones sexuales fuera del lecho conyugal debe separse de su amante una vez consumado el acto sexual: "quant la joie et li parlemens ot assés duré par raison” (Escoufle, 5884 - 5885), mientras que el enamorado cortés, que no ha podido pasar de los primeros estadios de la 
conquista, se siente incapaz de abandonar el lugar en el que se halla la amada: “tant con ta joie einsi verras, ja mes movoir ne t'en querras" (Rose, 2347 2348). En E scoufle la locución ains que [A dv. + C onj.] contrapone de nuevo penalidades y felicidad, aquí en el tiempo, al señalar la consecución de ésta como un proceso posterior que seguirá a una depuración clásica dentro de la literatura amorosa:

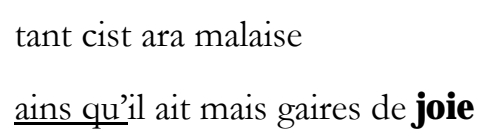

Escoufle, 5170 - 5171

En cuanto a las proposiciones subordinadas relativas, llaman especialmente nuestra atención las introducidas en Rose y en Charrete por el adverbio relativo dont que contiene el valor de la preposición de: "et te menbre de la douce eure dont la joie tant te demeure" (Rose, 2225 - 226); en ellas se repite la construcción avoir joie de que presenta el origen del disfrute. Éste puede ser una doncella — prevalecen en este caso los contextos negativos - o la acogida del amante entre los vasallos de Amor mediante el beso: “ce fu ce dont j’oi greignor joie” (Rose, 1956), “j’ai mis mon cuer en tel leu dont ja n'avré joie ne preu” (Rose, 2469 - 2470), "la riens que je plus vuel, don moins ai joie, et plus me duel" (Charrete, 1551 - 1552).

Junto a los verbos de conocimiento, que pueden poner de manifiesto el conocimiento que las mujeres en general, y las doncellas en particular, tenían de las manifestaciones de la sexualidad masculina: “je sai bien qu'il a or androit si grant joie" (Charrete, 1526 - 1527), los verbos introductores de proposiciones completivas mejor documentados son los que expresan el deseo o la voluntad. El deseo de los amantes, negado o planteado solamente como probable en el futuro mediante el núcleo verbal de la subordinada en subjuntivo: "que ja d'aillors ne quier que j'oie honor ne bien, santé ne joie" (Rose, 3973 - 3974), “cuida que je li feïsse grant joie” (Charrete, 4211 - 4212). 
En el último ejemplo, el verbo cuidier adquiere sentido desiderativo al encontrarse el pensamiento del caballero de la carreta dominado por la ciega atracción que sobre él ejerce la dama; por su parte, el apetito sexual de la amante se traduce en una construcción impersonal con respecto a la que la proposición subordinada funciona como sujeto: "et molt est la reïne tart que sa joie et ses amis veingne" (Charrete, 4424 - 4425). Por lo que se refiere a la voluntad, es la de entes abstractos que la construcción literaria pone en el camino de los enamorados: "se Diex de la riens que j'aim miex me doinst joïr a nul jor mais" (Escoufle, 4952 - 4953), pero que a menudo responden a las normas sociales o a los apetitos disfrazados de sentimientos amorosos y que en el relato son determinantes para la unión, como la personificación del dios Amor en E scoufle, en este caso se marcan la distancia y la objetividad mediante la locución introductora, y el subjuntivo en la subordinada responde a la negación del verbo principal:

et li diex d'amors qui n'a cure

k'il de si gentil creature

puist encore a la joie ataindre

Escoufle, $5161-5163$

\begin{tabular}{lllllllll}
\hline FORMA & CA & BD & NV & RIMA & CA2 & NV2 & D & PERS \\
\hline joie & S & Tristan & 3696 & bloie & A & 3695 & N & Narrador \\
joie & S & Rose & 1810 & entroblioie & V & 1809 & N & Narrador \\
joie & S & Escoufle & 3409 & esjoie & V & 3410 & D & Guillaume \\
joie & S & Escoufle & 5171 & esjoie & V & 5172 & D & Narrador \\
joie & S & Rose & 2719 & esjoie & V & 2720 & D & Amour \\
joie & S & Rose & 1956 & moie & A & 1955 & N & Narrador \\
joie & S & Escoufle & 7567 & montjoie & S & 7568 & D & Guillaume \\
joie & S & Charrete & 1677 & oie & V & 1678 & D & Chevalier \\
joie & S & Rose & 3974 & oie & H & 3973 & N & Narrador \\
joie & S & Rose & 24522 & oie & H & 2452 & D & Amant \\
joie & S & Rose & 3472 & saie & E & 3471 & N & Narrador \\
joie & S & Escoufle & 4857 & savoie & V & 4858 & D & Valet \\
joie & S & Rose & 48 & sonjoie & V & 47 & N & Narrador \\
joie & S & Rose & 3208 & voie & V & 3207 & N & Narrador \\
\hline
\end{tabular}

Tabla 100. Rimas del sustantivo joie. 


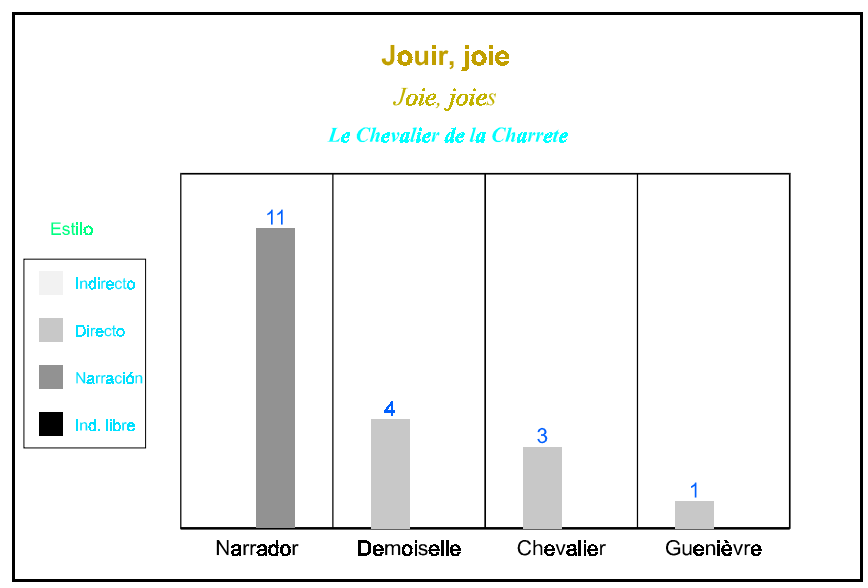

Fig. 171. Comportamiento estilístico del verbo jouir y del sustantivo joie en Charrete.

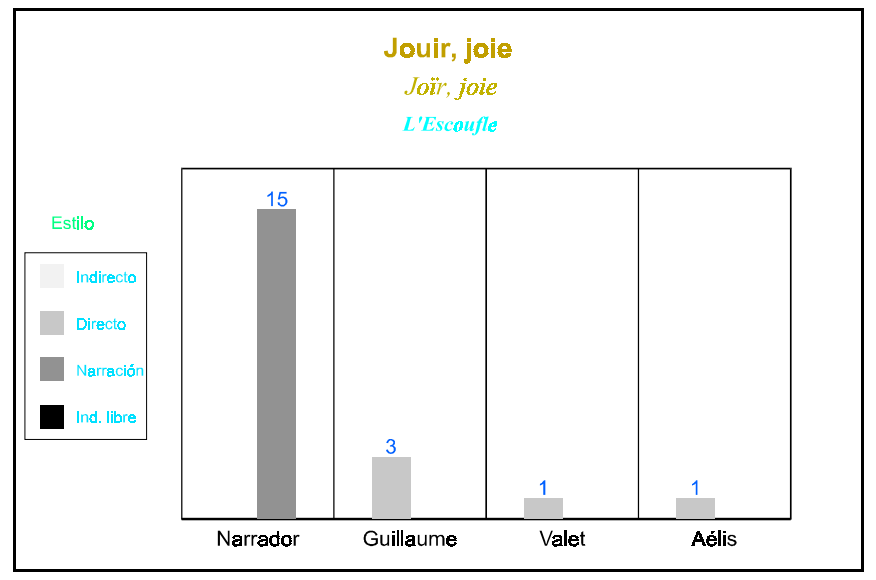

Fig. 172. Comportamiento estilístico del verbo jouir y del sustantivo joie en Escoufle.

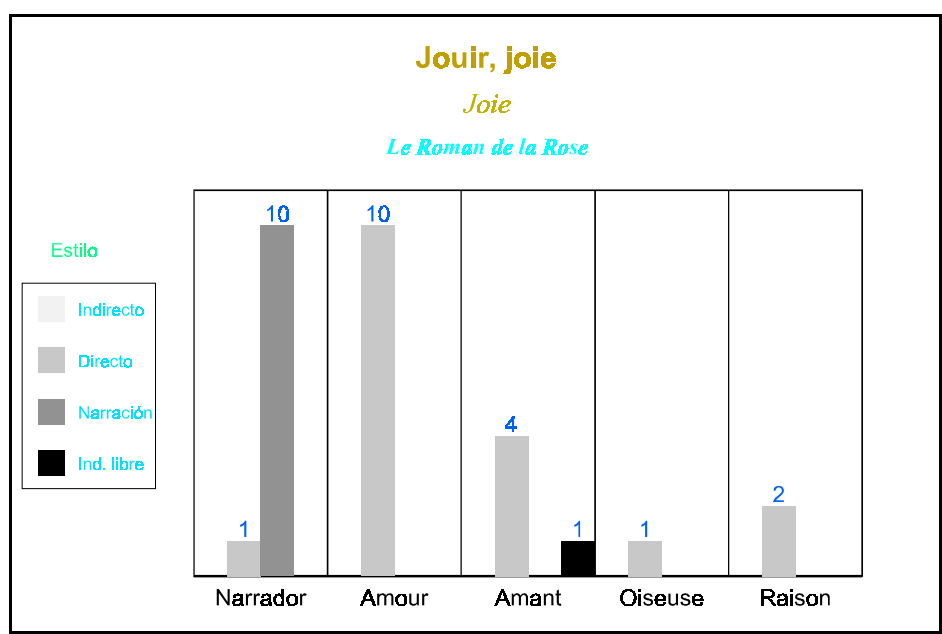

Fig. 173. Comportamiento estilístico del verbo jouir y del sustantivo joie en Rose. 
El uso constante de adverbios como tant o molt realzan la cantidad y pretenden colocar en un primer plano los fenómenos puramente instintivos, naturales, el deseo y por encima de todo la voluptuosidad, frente a la construcción social del sentimiento amoroso, que lo hace esencialmente doloroso. Con la exaltación de la sensualidad se pretende que los amantes sobrelleven el dolor en los textos más próximos a la doctrina cortés o lo superen como en E scoufle. Estos llamamientos a la concupiscencia fuera del lecho conyugal contrastan con las manifestaciones del pensamiento racional que aboga por la supresión de ambos, voluptuosidad y amor. El discurso de la razón se emparenta con el modo de vida monástico y, dado que la procreación es necesaria so pena de caer en el pensamiento herético, recupera el pensamiento tradicional de la Iglesia.

\subsection{SOLACIER Y «SOLAZ».}

El término clásico solacium que significaba en un principio «consolación», «alivio», llegó a denominar, como más tarde los términos medievales, la alegría y el placer. Paulatinamente se acentuó el componente sensual y en latín medieval designó el placer producido por el encuentro sexual. Paralelamente a la evolución del sentido citado se desarrolla otro a partir del sentido de «conversación», que llega a indicar la participación en la vida cortesana, la diversión y el espíritu social como se observa en los tratados occitanos sobre el amor cortés. 530

Según Guiraud, quien recoge en su diccionario ejemplos de estos términos hasta el siglo XV, solacier significa «copulan» así como avoir o prendre le solaz, término que significa «coito», 531 tal y como observamos excepcionalmente en E sooufle: "la doçors del solas qu'il ot li fait ses biax ex

\footnotetext{
${ }^{530}$ Cf. G. M. Cropp, op.at., p. 334, quien se hace eco de las descripciones de André le Chapelain de los «solatia» de la parte superior y de la parte inferior del cuerpo.

531 P. Guiraud, op. at., p. 577.
} 
pontiier". En este ejemplo el sustantivo del que depende solaz en calidad de complemento atributivo, la reacción física involuntaria, y finalmente el comentario posterior en estilo directo del narrador, quien implica en el desciframiento de estos versos a los receptores de la obra que ya conocen los deleites del amor, nos dan las claves del sentido sexual. Sin embargo, en nuestro corpus apenas podemos percibir claramente este sentido aunque probablemente se halle intencionadamente unido, mezclado a otros de los que acabamos de recoger. Por otro lado, la unión en el mismo verso con otros términos tratados en este apartado puede matizar su alcance sexual.

Sin representación en Tristan, y mucho más abundantes en los textos del siglo XIII, en un principio se podrían excluir o bien tratar como marginales las ocurrencias en las que no se habla de las relaciones entre un hombre y una mujer. Sin embargo, el placer que dan Aelis y Guillermo a quienes se encuentran con ellos es sin duda un mérito erótico, un atractivo más que se une a la belleza física y moral, a sus habilidades manuales y cortesanas, para aumentar su prestigio al hacerlos más deseables. Al mismo tiempo se prepara la reconciliación al igualarlos de nuevo por sus cualidades como se había hecho durante su infancia. El verbo y el sustantivo componen así la conclusión de la etopeya en los episodios del relato en los que se hallan separados: "Ml't le savoit bien Soulacier la pucele bele Aelis" (Escoufle, 7024 - 7025), “ml't ont cier son Soulas eü” (Escoufle, 7004). También la diversión de los que están en el jardín de Deduit es una preparación al amor, un preludio de éste y por lo tanto es parte del ceremonial erótico:

\footnotetext{
Maintes foiz por esbanoier se vient en cest leu ombroier Deduiz et les genz qui le sievent, qui en joie et en Solaz vivent
}

$$
\text { Rose, } 601 \text { - } 604
$$


Dicho esto, quizá las combinaciones en el plano sintagmático sean los fenómenos más significativos en el análisis de solacier y solaz: en primer lugar las agrupaciones binarias con otros términos, sean sinónimos o bien pertenecientes al campo de las relaciones sociales y en particular corteses, y en segundo lugar las relaciones sintácticas. Comenzaremos por la coordinación con vocablos que adquieren un sentido idéntico o muy similar en contexto, y que aportan apenas un ligero matiz: el verbo en Rose se combina con jouer en forma reflexiva cuando se hace referencia a la diversión, que no excluye la sensualidad, y ocupa la segunda posición en el verso: "il se jeue ilec et solace o ses genz" (Rose, 609 - 610), “que a nule rien je n'entens qu'a moi jouer et solacier" (Rose, 584 - 585); en la descripción de la boca del adolescente, la unión con deduire (Rose, 3445 - 3446) implica la voluptuosidad al invitar Venus a la mujer a gozar del cuerpo masculino, formalmente se invierte el orden con respecto a la estructura anterior. Las combinaciones del sustantivo, en las que tanto se halla en el primer hemistiquio como en el segundo, se llevan a cabo en Rose con joie (Rose, 604), en E scoufle con delit (Escoufle, 5246, 5400), y más a menudo con deduit. En estos contextos puede adoptar los dos sentidos más generales a los que aludíamos: el placer sensual que se dan los enamorados mutuamente o la diversión, el placer más difuso de una compañía agradable que ofrece Aelis a los hombres y mujeres que la rodean:

$$
\begin{aligned}
& \text { Sovent lor est li jors trop cors } \\
& \text { por le solas, por le deduit } \\
& \text { Escoufle, } 4328 \text { - } 4329
\end{aligned}
$$

ses Soulas, ses deduis envoise celes et ceus qui sont laiens

Escoufle, 7044 - 7045

La coordinación del sustantivo con términos que se refieren al ámbito de las relaciones sociales en general y cortesanas en particular 
- compagnie, druenie y service - , característica de Charrete y Rose, pone de manifiesto diversos aspectos de la morfología del relato de Chrétien y de la evolución de la cortesía en el roman, reflejo a su vez de las mutaciones que sufren las relaciones heterosexuales. La estructura episódica de Charrete se basa en la repetición e inversión de situaciones y construcciones formales con las que se pone el acento en la ascesis erótica de Lanzarote para alcanzar el éxtasis, el orgasmo junto a la reina. Veamos los dos ejemplos en los que solaz se une a compagnie y en los que la colocación inversa de la pareja de sustantivos y su aparición en la rima, con vilenie y con braz respectivamente, contribuye a delimitar el sentido plenamente sexual de solaz, negativo uno y positivo el otro:

$$
\begin{aligned}
& \text { ne cuit mie que molt vos pleise } \\
& \text { mes solaz, ne ma conpaignie } \\
& \text { Charrete, } 1252-1253 \\
& \text { quant la reïne an gré requialt } \\
& \text { sa conpaignie et son solaz } \\
& \text { Charrete, } 4670-4671
\end{aligned}
$$

Frente al discurso de la doncella en estilo directo que apuntala la distancia entre ambos personajes, está la intervención del narrador que integra la actitud de los amantes, la receptividad de la mujer y el agasajo del enamorado. Si ambos ejemplos enuncian el deseo por medio de las formas verbales, en el primero se niega el deseo masculino rompiéndose con las tradiciones eróticas: las que seguían imperando en la vida real pese a la cortesía y en las que el macho debía responder a cualquier ofrecimiento de la hembra, y las propias de la cortesía en su vertiente lírica en las que solía ser el amante varón el que deseaba a la mujer y se ofrecía a ella, habitualmente para ser rechazado; en el segundo se recoge una de las expresiones de deseo de la reina, de hecho las únicas de las que se nos habla pues Lanzarote sólo sirve y se humilla pero no manifiesta su apetito, se pliega al de la reina. 
Tampoco Lorris se ciñe en las combinaciones con druerie y service a los cánones corteses: aunque en estos casos el sentido carnal no esté actualizado y más bien se trata de manifestaciones del cortejo, éstas parten de las mujeres y no del varón, extremo paradójico sobre todo para el segundo vocablo máxime si tenemos en cuenta que el hombre no parece corresponder en el contexto inmediato a tales muestras de cortesía y de amor como ocurría por ejemplo en Tristan: 532

$$
\begin{aligned}
& \text { Par druerie et par Solaz } \\
& \text { li ot s'amie fet chapel } \\
& \text { de roses, qui mout li sist bel } \\
& \text { Rose, } 826 \text { - } 828 \\
& \text { et quant je voi qu'i ne me vee } \\
& \text { ne son Solaz ne son } \underline{\text { servise }} \\
& \text { Rose, } 3364-3365
\end{aligned}
$$

Al funcionar como sujeto de la proposición solaz va seguido por el verbo avoir en su forma impersonal cuando se presenta el placer de muchos, siempre en Escoufle, donde se diversifican los ambientes, el palacio imperial (Escoufle, 9025) o la ciudad de Montpellier (Escoufle, 5518 - 5519), mientras en Rose lo acompañan los verbos tarder. "mes je te lo que tu te tiegnes bien pres de li por Douz Regart, que ses Solaz trop ne te tart" (Rose, 2703 - 2705) o doubler, al enumerar el dios Amor los placeres acumulados de los que puede disfrutar un amante leal: “encor vait ce solaz doublant, quant d'un ris

\begin{tabular}{l}
\hline 532 qant ce vendra au departir, \\
ge vos dorrai ma drüerie, \\
vos moi la vostre, bele amie \\
Tristan, 2686-2688 \\
(...) la moie amie, \\
Husdent vos doins par drüerie \\
Tristan, 2725 - 2726
\end{tabular}


ou d'un biau sanblant li menbre" (Rose, 2647 - 2649). El resto de las ocurrencias acompañan verbos como plaire "mais plus plaisoit encor as gens ses biax soulas; ses biax samblans" (Escoufle, 744 - 745) ${ }^{533}$ y envoisier (Escoufle, 7043 - 7044), que excepto en Charrete implican también el placer colectivo ante la capacidad de agradar, de satisfacer, y que poseen tanto Aelis como el conde Ricardo, padre de Guillermo.

Por lo que respecta a su funcionamiento como complemento de objeto directo depende del ya habitual verbo avoir, como la mayor parte de los vocablos tratados en este apartado, y que aquí se halla exclusivamente en E sooufle, ${ }^{334}$ así como de la locución avoir cier. "ml't ont cier son soulas eü et ml't lor poise qu'il remaint" (Escoufle, 7004 - 7005). Chrétien en la ya comentada relación con requenir (Charrete, 4670 - 4671) rompe la trayectoria del placer observada hasta ahora que iba de la mujer hacia el varón. En Rose encontramos en el discurso directo de Amor una estructura repetida en torno a faire: "trois autres biens, qui granz solaz font a ceus qui sont en mes laz. Li premiers biens qui solaz face ceus que li laz d'Amors enlace" (Rose, 2627 2630), y en el del narrador en primera persona los verbos veoir. "tant con je voi plus de solaz” (Rose, 3360) y veer. “et quant je voi qu’i ne me vee ne son

\footnotetext{
533 También los versos 1252 - 1253 ya citados de Charrete.

534

tant de solas, tant de delit

com ele ot si fu des linceus

Escoufle, 5246 - 5247

ml't ont soulas, ml't ont delis,

n'est deduis ne riens qui lor faille

Escoufle, 4294 - 4295

tant de Soulas, tant de delit

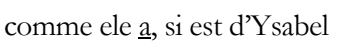

Escoufle, 5400 - 5401

onques n'ot soulas ne deduit

fors de tant qu'el li rementoit

la rien dont il plus li estoit

Escoufle, 6408 - 6410
} 
solaz ne son servise” (Rose, 3364 - 3365). Como vemos, la atracción, la plena felicidad y la voluptuosidad implícitas en los contextos que mencionábamos de Charrete y Escoufle contrastan con la atenuación de las connotaciones sexuales en Rose.

\begin{tabular}{lllllllll}
\hline FORMA & CA & BD & NV & RIMA & CA2 & NV2 & D & PERS \\
\hline solace & V & Rose & 609 & place & S & 610 & D & Oiseuse \\
solacier & I & Rose & 585 & trecier & I & 586 & D & Oiseuse \\
solaz & S & Charrete & 4671 & braz & S & 4672 & N & Narrador \\
solaz & S & Rose & 826 & laz & S & 825 & N & Narrador \\
solaz & S & Rose & 2627 & laz & S & 2628 & D & Amour \\
solaz & S & Rose & 3360 & laz & S & 3359 & N & Narrador \\
soulacier & I & Escoufle & 7024 & aaisier & I & 7023 & N & Narrador \\
\hline
\end{tabular}

Tabla 101. Rimas del verbo solacier y del sustantivo «solaz».

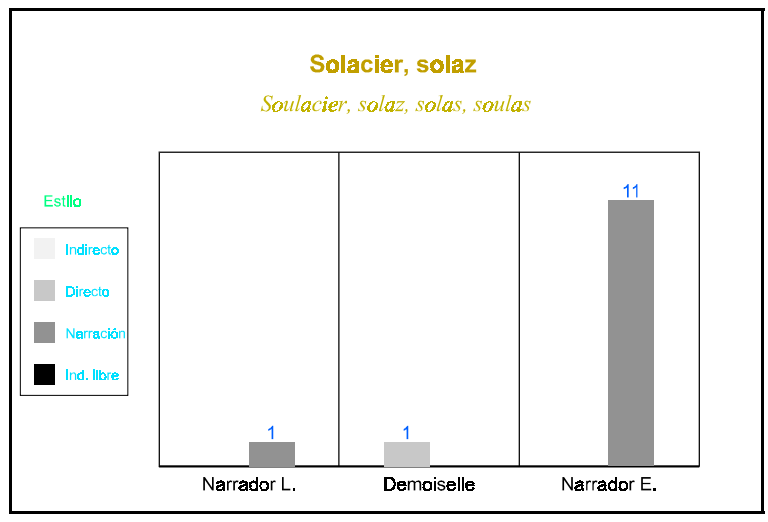

Fig. 174. Comportamiento estilístico del verbo solacier y del sustantivo «solaz» en Charrete y Escoufle.

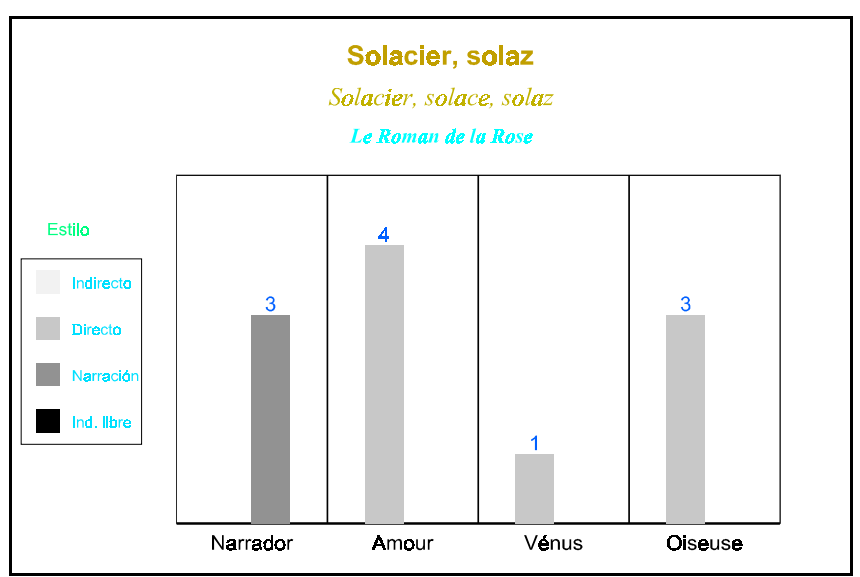

Fig. 175. Comportamiento estilístico del verbo solacier y del sustantivo «solaz» en Rose. 
Las proposiciones relativas introducidas por qui $y$ las circunstanciales temporales coinciden, respectivamente, con las construcciones comentadas en deliter y joie por su forma y por su aporte a la elaboración del discurso erótico —incluyendo los aspectos retóricos y narrativos - Las rimas con términos potencialmente voluptuosos en las que participan solacier y solaz subrayan, de manera poco habitual en este capítulo si exceptuamos los vocablos deliter y delit, la relación del placer con los sentidos, en particular con el tacto. 



\section{CONCLUSIONES.}

Al finalizar nuestro recorrido por las manifestaciones del erotismo noble que nos ofrecen los cuatro romans, creemos conveniente revisar en primer lugar los cambios que el género novelesco trae consigo con respecto a la lírica, ya que en ella tienen su origen buena parte de los códigos de comportamiento amoroso observados, así como su transcripción artística. Algunas de estas alteraciones son capitales para la expresión del erotismo caballeresco al permitir las remodelaciones en el nivel superficial la consagración literaria de evoluciones profundas, que se habían producido o se estaban llevando a cabo todavía en lo social y en lo ideológico.

En primer lugar, la utilización del narrador en tercera persona permite diversificar la presentación de las acciones y de los sentimientos y sobre todo, la inclusión más o menos velada de detalles relacionados con la sexualidad y el placer, reservando los más escabrosos para las alocuciones de los personajes marcados negativamente, avatares en ocasiones muy distantes de los jalous. Por ello, entre otras posibles causas que no se excluyen entre sí, la recuperación de la voz del amador en primera persona tiene como consecuencia lógica una elaboración segunda del relato mediante el recurso al sueño y a la alegoría, sin pasar por alto la narración de los recuerdos de juventud: tres medios para conseguir un distanciamiento del individuo, todavía no liberado por completo de las fuerzas ideológicas que lo mantenían en el seno del conjunto social. Procedimientos que sustituyen al alambique retórico de la metáfora distorsionante o del estático juego de oposiciones a los que la vOz primitiva de la lírica recurría para velar los sentimientos, deseos y pasiones.

Las intervenciones del narrador en estilo directo, identificado probablemente con el recitador en el acto de transmisión oral, sirven para 
establecer una relación directa con el narratario y con el oyente aprovechando sus conocimientos teóricos y experimentales sobre los asuntos amorosos y carnales a menudo dejados en suspenso según las normas del género. De este modo, evocación e imaginación consiguen hacer participar al receptor directamente en la historia y que el relato pueda cumplir una de sus funciones básicas: la actualización del deseo erótico.

La diversificación de los personajes «nobles»: héroes, heroínas, coadyuvantes o comparsas, da pábulo a la confrontación de diversos modos de entender las relaciones entre hombres y mujeres, y permite recurrir a la cantidad para enardecer al receptor; lo cual no impide que en sus discursos se mantenga un estilo acorde con el género y con el carácter especular de las aventuras sentimentales en las que intervienen. Sin embargo, conviene distinguir, por una parte, los intercambios discursivos y, por otra, los monólogos — los diálogos de abstracciones personificadas pueden ser considerados equivalentes- Estos últimos reproducen los anhelos y frustraciones íntimos y, en menor grado, las controversias genealógicas, conservando en gran medida el tono y el estilo, aunque amplificado, de las composiciones del trobar leu que se caracteriza por las contradicciones insolubles y la incapacidad para la acción. En cuanto a los intercambios dialógicos, se observan notables diferencias entre los que llevan a cabo individuos del mismo sexo y aquellos en los que intervienen hombres y mujeres. Éstos se hallan casi invariablemente ritualizados, plagados de fórmulas de cortesía, de epítetos y de denominaciones de carácter social o amoroso, y dejan sólo en contadas ocasiones que salgan a la luz las referencias al deseo o a la unión sexual, que, como hemos dicho, quedan acotadas en el discurso narrativo.

A nuestro juicio, el roman medieval cumple dos funciones principales desde el punto de vista social: la de divertir a sus receptores, distrayéndolos de la cruda realidad y en ocasiones haciéndolos reír; y en segundo lugar la de 
modelar la realidad social ayudando a la cohesión del grupo y al desarrollo y asentamiento de ciertas instituciones como el matrimonio o la familia, acompasando para ello los moldes más tradicionales con ciertas ideas renovadoras. Por tales razones se vale de la combinación de tipos — grupos de personas caracterizados social e ideológicamente, $y$, deberíamos añadir, en función de su comportamiento erótico— $\mathrm{y}$ de prototipos — seres ejemplares por sus cualidades o vicios-.

Pese a que el renacimiento humanista del siglo XII fuerza la primera ruptura del hombre con la divinidad y pone unas sólidas bases para el antropocentrismo victorioso del siglo siguiente, la realidad no puede concebirse sin referencias implícitas o explícitas a la divinidad creadora, de igual modo que los individuos no tienen razón de ser fuera del conjunto social y del estamento al que pertenecen.

La presencia de bellas mujeres que aman, seducen o intentan seducir al héroe permite reflejar la perfección divina. Se combina así el recurso que la novela ofrece: la aparición de personajes figurados — diferentes por su aspecto como, principalmente, por sus actos-, con la influencia del modo cortés de amar y de expresar el amor, que recurre a la creación de un ser virtual construido en torno a la añoranza y mediante la recuperación sonora y retórica, y que convierte así a la mujer, a la amada, generalmente identificada como dama, en un ser que participa de la Belleza y llena de gozo al que lo contempla y ama. Parecería lógico que aquella se hallase en el centro del universo erótico en el que predomina nominalmente la sumisión generalizada a la amada — de ahí que la denominación dame modifique su espectro significativo para alcanzar a las solteras en el siglo XIII debido a la superposición temprana del sentido amoroso sobre el social-, sin embargo, el tono irónico, la sintaxis subordinante en la que destaca la insistencia en la posesión o el valor sensual concedido a la cantidad y a la indeterminación, mediatizan el papel preponderante que este vocablo otorgaba a la mujer. Ésta, 
cuando es identificada con el nombre de reina, aunque se nos muestren sus deseos y sentimientos y sea el motor del relato, se halla implicada en todo cuanto tiene que ver con el honor masculino y con el correcto funcionamiento de la corte. Es objeto de deseo y de intercambio en un mundo dominado por el hombre y la fuerza guerrera, y aparece ante nosotros como un personaje contradictorio: es esposa y amante adúltera, somete a su enamorado pero está sometida a la voluntad del resto de los varones, está lejana y casi indefensa, y, mujer al fin, no se verá libre de la inevitable asociación con la falta sexual. Por el contrario, a pesar de su aparente papel complementario durante el siglo XII, en Charrete las doncellas pasan a un primer plano diegético y erótico tanto por sus atractivos dones y su elevado número como por su capacidad para instigar o mitigar los ardores caballerescos, no en vano la denominación demoiselle se sitúa en posiciones de privilegio en la sintaxis y en la versificación.

Poco cuenta el aspecto físico del varón, su aspiración a la perfección se manifiesta en su actitud amorosa, el rechazo de todo deseo biunívoco, su fuerza, su valentía - con la correspondiente transposición del vocabulario feudal al vocabulario amoroso como observamos en las denominaciones homme y vassal-, y aun en su capacidad para el engaño y el disimulo, componentes indisolubles del erotismo caballeresco del siglo XII. La tendencia a la supervalorización de la capacidad guerrera y amatoria de los varones adultos, tal como vemos en los contextos en los que se insertan los sustantivos homme y chevalier, se traduce formalmente en la abundancia de las más diversas formas de calificación y especialmente de construcciones ponderativas, entre las que predominan las comparativas y superlativas. Estos esquemas los encontramos en Charrete, $y$, con significativas variantes expresivas, en los textos del siglo XIII en torno a verbos del registro amoroso como amer para poner de relieve la intensidad pasional masculina.

La figura del consumado amador caballeresco así dibujada y los ardientes deseos que inspira a las féminas nos llevan a concluir que, en la obra 
de Chrétien, la transposición manierista de la fin' amors es un mero instrumento para mostrar la vinculación entre adulterio y soltería como un modelo complejo y depurado, aunque anacrónico, de comportamiento social noble. La renuncia a las virtudes sociales, entre las que se incluyen las amatorias, por parte de Meleagant y el papel secundario del rey Arturo, en contraste con la socarronería con la que es tratado el rey Marco, parecen avalar la voluntad modélica del texto más allá de las relaciones entre los sexos.

En los romans del siglo XIII observamos dos formas de comportamiento social y erótico divergentes, aunque presentan ciertas coincidencias: ambos exaltan la belleza física de las mujeres y de los adolescentes enamorados, elemento esencial de una nueva forma de erotismo que permite el desarrollo de percepciones y sensaciones desdeñadas u ocultas en el siglo precedente; en segundo lugar, ambos otorgan el privilegio del amor a los púberes, más inexpertos, menos proclives a racionalizar y dominar sus apetitos que sus predecesores y más expuestos a las dolorosas contradicciones de la pasión y del código amoroso; y por último, coinciden al insertar la iniciación en un viaje, a la vez movimiento físico e interior. En la obra de Renart se nos presenta el modelo propuesto por los grupos aristocráticos que ya no precisan seguir sublimando los excesos belicosos y sexuales de los jóvenes solteros, y que utilizan el atractivo ideal de una vida cortesana en la que se conjugan un refinado comportamiento y un incruento ascenso social para asentar la nueva organización nobiliaria basada en las alianzas matrimoniales. Por su parte, las minorías intelectuales, que gozan del prestigio de las universidades y de la fuerza de las corporaciones, recrean los refinamientos amorosos de las cortes meridionales en los moldes de la didáctica y del clasicismo; con ello intentan dotarse de un renombre por el que ya pugnaban en sus composiciones los estudiantes vagabundos del siglo XII. En ambos modelos el varón es el elemento dominante pues, tanto si consideramos las relaciones de la pareja, como la capacidad de excitar sexualmente, el papel de las mujeres jóvenes tiene menor relevancia en 
comparación con el de las damas y el de las doncellas en las obras del siglo XII. De hecho, aunque las vírgenes han accedido teóricamente al primer nivel erótico asentándose como el objeto de deseo canónico, la denominación demoiselle ocupa un lugar secundario que refleja una dependencia casi absoluta con respecto a la voluntad y a las acciones del varón. Su aspecto físico, la belleza que se exhibe y contempla, así como su entrega sentimental y física predominan en el discurso narrativo y en el de los personajes. Es cierto que en numerosas ocasiones hemos argumentado una cierta prepotencia y un aumento de la actividad social y erótica de la heroína de E sooufle, algo que sin duda permite establecer una cierta filiación respecto de Ginebra y en mayor medida de Iseo. Sin embargo, gran parte de este trastocamiento se lleva a cabo en un período de desclasamiento que culmina con la reintegración en el orden erótico y genealógico construido en torno a la autoridad masculina, el matrimonio y la entrega de la virginidad al esposo.

La unión conyugal no solamente se asienta sobre los lazos entre sexo y poder sino que a la vez los consolida - aunque, como observamos en el caso del término seigneur, éstos casi siempre se hallan velados, lo que explica que el matrimonio esté muy escasamente relacionado de forma explícita con el encuentro carnal- La institución matrimonial se revela en los romans como un eficaz instrumento de control social y sexual en manos de la nobleza feudal y cortesana, con la particularidad de que en la cadena de sumisiones el eslabón más reforzado es el que sujeta a la mujer, dejando apenas un resquicio a la igualdad en el uso del sustantivo per en Tristan. La rigidez de esta institución según el modelo mejorado por la Iglesia medieval concuerda con las construcciones fijas que conceden a los términos femme y mollier el sentido restringido de esposa. De hecho la introducción de un elemento ajeno a las expresiones habituales se pone en relación con el placer carnal y el engaño, aspectos negativos de la naturaleza femenina según la concepción eclesial que parecen asumidos plenamente en la mentalidad popular y que salen inevitablemente a la luz como contrapunto de la perfección física y amatoria 
de las heroínas, sean el prototipo de amada cortés o de la joven virgen casadera. En este caso y siempre que, en la narración o en el discurso de los personajes, encontramos mensajes marcadamente misóginos, estos adoptan una expresión aforística, con lo que el recurso a la generalización cubre la degradación del mito femenino.

El amor compartido queda excluido de la relación matrimonial, no sólo en las obras en las que se trata el adulterio sino también en E scoufle, roman en el que la pasión queda reservada a la época prenupcial; sin embargo, tampoco los amantes como pareja salen mejor parados. Por un lado, en el uso retórico y estilístico de la denominación plural amanz destacan la generalización y la voluntad didáctica —algo muy similar ocurre con el singular de este término en Rose-, por otro, los contextos en los que aparecen los sustantivos que hacen referencia a uno de los dos enamorados suelen poner de relieve la superioridad de uno de ellos. Aunque esta afirmación tiene un valor general en el corpus, el tratamiento que cada obra da a ciertos topoi corteses, como el sometimiento a la dama o a la estricta normativa amorosa, permite matizarla y poner de manifiesto las afinidades que existen entre las obras por lo que se refiere a las relaciones de pareja: en un extremo se hallan los romans que adoptan la tradición trovadoresca, Charrete y Rose, en los que la sumisión del amante no puede tener fisuras, en el otro, Tristan y Escoufle recurren en menor medida a ellos y optan por dar alternativamente la supremacía al amante o a la amada, en una difícil búsqueda del equilibrio entre ambos sexos que alimente la unión y la felicidad de la pareja.

El mito femenino al que aludíamos queda sólo en apariencia a salvo con la utilización del término amoroso amie, que al igual que el masculino ami está generalmente marcado por la posesión. Este sustantivo tiene una triple función: la de contaminar los vocablos que perteneciendo a otros ámbitos se sitúan junto a él, la de derribar las barreras sociales, y la de 
establecer los márgenes entre los que se sitúa la relación erótica, desde la vaguedad en los azarosos encuentros de los caballeros artúricos con las mujeres núbiles en Charrete, hasta la concreción del deseo unívoco de los jóvenes hacia las reinas adúlteras, las herederas o las hijas de la burguesía que les son vedadas. Por otra parte, a diferencia de la drue que es invariablemente la amante apasionada, la mujer que goza y da placer, un sueño lejano y poco recomendable en el siglo XIII, tras lo que podríamos denominar censura cortés, la amiga se nos presenta como la causa eficiente de la actividad del enamorado. Sin embargo, la subordinación sintáctica del término, relegado a las funciones de complemento, pone de manifiesto una vez más la supremacía masculina — de la que tan sólo Aelis escapa durante buena parte de la historia-, y le deja apenas un cierto control del espacio cerrado, interior, en el que el amante intentará penetrar. Por su parte, el amigo, causa y fin de las acciones de la amada pero en raras ocasiones sujeto de acciones amorosas, es también el beneficiario de la expresividad afectiva de la fémina. Ésta se manifiesta gracias a la diversidad e intensidad de uso del sustantivo ami en función de vocativo o de aposición al vocativo, acompañado de uno o varios adjetivos, especialmente en Tristan y E scoufle. La integridad de la figura del amigo, intrínsecamente contraria a la normalidad patrilinear, aunque ésta paradójicamente la utilice, queda cuestionada directa o indirectamente en las obras de Chrétien y de Renart: al dudar la amada sobre su identidad, al plantearse una gradación en la calidad de las acciones y actitudes de los enamorados $y$, al evocarse la denostada figura del falso amigo. La rigurosa dualidad de Rose, emanante de las fuentes provenzales, eliminará cualquier alternativa a la abyección o a la perfección del amador. Este hecho consagrará la tendencia observada en el corpus a tratar el sustantivo amant como una denominación colectiva o tipológica, puesta aquí al servicio del didacticismo que alterna el ejemplo y la normativa con el fin de conseguir el placer de la unión sexual, siempre que sea con el máximo esfuerzo, pues al texto noble le será muy difícil abandonar el modo ascético impuesto por el cristianismo, fuera éste ortodoxo o herético. 
Los nombres propios de los héroes y heroínas nos permiten corroborar algunas de las conclusiones precedentes y apuntar otras. El de Iseo es utilizado con fines subversivos: la alteración del orden social, la perturbación de las jerarquías y el trastorno de los valores morales ligados al adulterio o al incesto son tan manifiestos como lo es la subversión de algunos principios de la cortesía. Por su parte el de Tristán, asociado a menudo sintácticamente con el rey y los barones de la corte, se relaciona con la traición y con sus consecuencias para ambos amantes. Sin embargo, en el discurso de la reina es el emblema de un modo novedoso de amar en el que contacto sexual y sentimientos amorosos se unen indisolublemente. Por ello, y por el papel otorgado a la mujer, podemos afirmar que, si bien en muchos aspectos el relato de Béroul se halla a años luz de los cánones corteses, comparte y aun sobrepasa los presupuestos básicos sobre los que se asienta teóricamente el erotismo nacido en las cortes del sur.

La búsqueda de Ginebra, que todo el relato tiende a sublimar poniéndola en relación con el restablecimiento del orden social y sexual, está unida contextualmente con las tendencias predadoras de los jóvenes guerreros en busca de riquezas y placer, temibles costumbres que los señores habían erradicado con la ayuda de la Iglesia. Por ello el entronque con la tradición trovadoresca en el uso del nombre propio de la reina parece una simple formalidad frente a la profunda huella que ha dejado en el de Lanzarote. La paradójica pasividad del héroe enamorado unida al prolongado anonimato y a los vocativos en el discurso de las mujeres delatan una feminización simbólica que, junto a la pericia y fuerza del feroz caballero, da origen invariablemente al deseo de aquellas.

De lo que acabamos de formular podemos deducir un nexo entre las dos obras del siglo XII: ambas erigen al héroe enamorado como el sujeto erótico por excelencia. Para él se adoptan y acomodan las nuevas tendencias amorosas provenientes del Sur en sus aspectos más problemáticos para la sociedad aristocrática, a la vez que se hacen compatibles con el placer carnal 
que impone el patrón novelesco. Desde esta perspectiva las reinas adúlteras asumen un papel meramente instrumental poniendo su discurso al servicio de la construcción dinámica del modelo de amante caballeresco.

Renart, que se hace eco al comienzo del siglo XIII de muy diferentes tendencias ideológicas y estéticas, particularmente en el terreno que nos interesa, el de las relaciones entre los sexos y su institucionalización, trivializa la utilización del nombre propio de la amada, gracias a la adopción de esquemas retóricos fijos, probablemente un reflejo de la lírica popular. Para hacerlo tiene como excusa el lugar privilegiado concedido a la heroína en su historia. Por otro lado, se atiene al modo cortés gracias a la veneración del amante aunque rompe con el modelo de pensamiento realista al adoptar un culto renovado del individuo propio del siglo XIII, al que el género novelesco contribuye sin duda alguna. En el nombre del anti-héroe Guillermo confluyen dos problemas mayores en la elaboración de la imagen social nobiliaria de esta época, la preocupación por la subversión genealógica y la plena incorporación de los jóvenes a la vida social y política, que se manifiesta por su integración en funciones sintácticas subordinadas como complemento de objeto o formando parte de proposiciones dependientes, y en el otro extremo la modelización del que puede ser un nuevo tipo de amante, el amante cortesano en el que no quedan trazas del caballero pero para el que se respetan los modos discursivos corteses.

En Rose los nombres asignados a los elementos de la pareja recogen tanto la tradición trovadoresca como la caballeresca. Por un lado el amante es el que desea y conquista, el que recuerda, sufre y goza, el que recibe las enseñanzas teóricas y los consejos prácticos, es, en definitiva, el que ama, el sujeto erótico; por el otro, la mujer, capullo o rosa, representa el objeto de deseo en sus dos vertientes, el deseo intelectual, sublimado, por su perfección y lejanía, y el deseo físico concentrado en su cuerpo y su sexo. 
Relato de la iniciación erótica de un adolescente y compendio de las tendencias amorosas que lo preceden, el roman de Lorris muestra la evolución de la sensualidad de aquel a la vez que adapta los modelos de amada desarrollados en el siglo XII y comienzos del siguiente. La penosa tarea de conquista de la joven núbil, de la rosa a la que desea tocar y besar, se llevará a cabo en un universo concéntrico, encerrado en el sueño alegórico en el que se oponen el bien y el mal, aunque éstos se hallen en diferentes ámbitos según se considere el relato desde la óptica erótica o moralista, según adoptemos la perspectiva de los enamorados y del instinto o de la sociedad y sus normas variables y por definición coercitivas. La voluntad del amante, aparentemente independiente, se encuentra siempre supeditada a una fuerza externa y superior, por ello Amor aparece como la personificación de los sentimientos inexplicables según la razón, producto de la actividad sensitiva, pero que se pretenden ajenos al puro instinto sexual que correspondería a la naturaleza animal. Por ello también la identificación entre el narrador y el amante se hace bajo los auspicios de esta divinidad pagana que doblega las voluntades, y no sólo obliga a amar sino que también obliga a escribir — en Charrete y en E scoufle se multiplicaba el ardor guerrero de los caballeros acicateados por la pasión—. De esta forma la novela se hace eco del germen de la fin' amors. Como en ella, la mujer amada no es sino una causa secundaria de la escritura $y$, aunque sea presentada explícitamente como la receptora por excelencia de la novela, se encuentra en el mismo plano que los hipotéticos receptores de la obra para cuyo deleite será compuesta. En cualquier caso el viaje alegórico y la composición literaria persiguen dos objetivos distintos aunque relacionados: conseguir el amor y el cuerpo de la rosa. El segundo pretende el placer y está relacionado con el fin último de la obra al que aludíamos, el primero se mueve en un segundo plano de abstracción y le permitirá al amante alcanzar la perfección amatoria al armonizar su esencia como sujeto amoroso y su existencia como objeto amado. Con ello se perfecciona en favor del varón el esquema dual de la lírica trovadoresca y se culmina un proceso que podía observarse en sus primeros estadios ya en Lanzarote. Las diferencias 
fundamentales con este último radican en la naturaleza de las relaciones interpersonales: en Charrete predomina el modo feudal basado en la multiplicación de los contactos eróticos con elementos de ambos sexos y de diferentes grupos sociales y de edad; en Rose prima el modelo burgués, la unidad mononuclear, la pareja que dará paso a una familia en un sentido restringido.

Si tomamos en consideración dos de las características esenciales del texto de contenido erótico: su naturaleza profundamente antisocial, con el consiguiente predominio del engaño, de la ocultación y de la mentira —aunque a excepción de Charrete todos los textos invocan la imposibilidad de encubrir las manifestaciones corpóreas del deseo-, y su intencionalidad transgresiva del orden sexual instituido, que se puede manifestar a través del incesto, la bigamia, el adulterio, la violación, el ataque a la voluntad paterna y real o el trastorno del lenguaje instituido, debemos dar constancia de una evolución negativa que culmina con Lorris. El amante de Rose es adoctrinado para utilizar el engaño en su conquista, pero el fraude recae sobre su pareja; Guillermo y Aelis desafían al emperador pero ni mienten ni lo provocan verbalmente, sólo disimulan sus planes, y conviven sin transgredir el tabú de la virginidad. Chrétien se vale de muchos de los quebrantamientos citados pero desdeña el juego lingüístico con fines eróticos en el discurso de sus personajes. Béroul aprovecha todos los recursos — evoca incluso la violación múltiple en el episodio de los leprosos—, y con particular maestría los que le ofrece el lenguaje. En su roman la palabra pública es el gran obstáculo erótico, por un lado en la tradición trovadoresca con las denuncias de los felones al marido, y por otro, en los encuentros espiados de los amantes o en el juramento de Iseo. Esto lo lleva a utilizar un segundo nivel textual que responde a los juegos de la vOz, con referencias narrativas explícitas - Iseo atraviesa el vado sobre Tristan, identificado ante el auditor como tal—o bien, implícitas u ocultas en el propio mensaje y que el auditorio debía descifrar gracias a su conocimiento de las relaciones adúlteras. El autor transforma los mensajes textuales de tal 
forma que aparecen dos planos de significación claramente diferenciados, uno con valor social y otro con valor individual o para la pareja: las reiteradas justificaciones de los amantes esconden alusiones a la unión carnal, que rayan con la obscenidad, y los juegos de palabras ocultos entre el discurso aparentemente formal y de disculpa preludian el falso juramento de Iseo. Sin duda, el público medieval, avezado a descubrir los mensajes ocultos del texto, apreciaba la habilidad de los amantes ante el cornudo celoso. Estos recursos parecen eclipsarse con la desaparición de los efectos del filtro tras su período de influencia puramente física, pero las mismas claves son retomadas ante la asamblea nobiliaria de la Blanca Landa. A diferencia de otros textos como el Roman de Renart o el Roman de la Rose de Meun en los que la relación entre palabra y sexualidad se hace explícita, en Tristan se oculta el nexo necesario entre palabra y erotismo. No utiliza para ello los medios extremos de los que se sirven los movimientos poéticos deconstructivos, como la negación del uso coherente de palabras y frases que llevaría a lo informe, el discurso no se convierte en negación de la enunciación, pero sí deviene denuncia del sentido único, del código y de los grupos de poder que los sostienen. Se rinde culto al desafío, a la subversión, aunque no al acto gratuito sino al acto creador de la comunicación múltiple.

El roman de Chrétien y las novelas del siglo XIII coinciden en ofrecer una visión analítica del sentimiento amoroso y lo presentan como la causa de las alegrías y sufrimientos de los amantes, de sus acciones, promesas y ruegos; comparten una tendencia a la abstracción que se plasma en la personificación del amor y en su enfrentamiento con los enamorados; y dejan un espacio mínimo a la pasión desordenada que se expresa con el sustantivo rage. Renart y particularmente Lorris construyen el discurso sobre el amor engarzando motivos tradicionales, sin embargo, la maestría y originalidad con las que tratan algunos recursos temáticos y formales consiguen aportarles nueva vida: sobresalen en E scoufle las extrañas aventuras de los enamorados adolescentes en su vagar por el espacio físico y social, las diferentes técnicas de 
ponderación o el recurso a la intertextualidad con fines didácticos; mientras que en Rose son ante todo los juegos con los entramados pre-alegórico y alegórico los que permiten la renovación de los topoi. Ésta se fundamenta en la pericia con la que Lorris maneja el léxico, tal como observamos, por ejemplo, en el apartado consagrado al poder del amor, con el uso de sinónimos o con la acumulación de términos con pequeñas variaciones de sentido.

Si bien sería una reducción excesiva hacer del amor un simple intercambio de bienes, servicios, sensaciones y fluidos, la reciprocidad efectiva o anhelada no deja de ser uno de los pilares sobre el que se asientan algunos de los motivos esenciales del erotismo caballeresco. Los amantes entregan su corazón, su capacidad guerrera, sus sufrimientos, su cuerpo o preciados y escogidos objetos simbólicos en señal de pasión, de amor compartido, de mutua complacencia y promesa de ayuda. En el siglo XII estas actividades tienen como modelo las formas económicas feudales: dons y guerredons se acomodan a un ritmo lento de servicios en los que no ha penetrado el sistema pecuniario; en el siglo siguiente se les sumarán los regalos y aun los sobornos con el fin bien definido de conseguir con rapidez el amor y el cuerpo femeninos. Sin embargo, de forma paradójica, Lorris y sobre todo Jean Renart, aumentarán en cantidad las alusiones a los presentes —incluidas las construcciones redundantes del tipo doner en don— así como la calidad de los servicios desinteresados de los enamorados. La que según las propias palabras de Renart es la trama central de Escoufle, se inicia y llega a su fin merced a la sobrevaloración del trueque de objetos y servicios: las insignificantes atenciones con que el amante satisfecho y despreocupado paga el rico don de la amada y que darán pie a la separación, se convierten en un largo calvario, que incluye el desclasamiento y el embrutecimiento, el trabajo manual y el ahorro, adversidades y pesadumbres al final de las cuales el deseo, la cólera y la impotencia estallan en una sucesión de gestos inusitados y violentos fruto de la locura, que, aunque transitoria, será el sacrificio supremo del enamorado y permitirá su reunión con Aelis. 
Las diferentes formas del deseo, casi siempre obsesivo, ya sea femenino - mortal o concupiscente según Lorris—, masculino, mutuo, sublimado o sexual, comparten en su expresión la tendencia general a velar las manifestaciones eróticas, aunque en ocasiones se observan fenómenos contradictorios como ocurre al ponerlo de relieve en la posición final del verso. Las técnicas de ocultación a las que se acude más asiduamente son: la representación estereotipada — hipertrófica en la denominación rien referida a la mujer - del deseo, de la pasión y de la belleza de la que aquellos emanan, y en segundo lugar la dispersión y la fragmentación de la expresión por el uso de muchos términos con pocas ocurrencias, vocablos que, por añadidura, suelen poseer un espectro significativo muy amplio y dan pie a la ambigüedad, escasamente subsanada por el contexto. Así, es difícil determinar si envie se refiere al apetito sexual o al deseo dominado y sublimado de la lírica cortés, o si corage son las intenciones razonadas o los sentimientos de los enamorados. Tan sólo algunos como covoitier y desirer se refieren claramente y sin excepción al deseo amoroso y carnal, con la particularidad de que únicamente Charrete y Rose los utilizan. Estas prácticas que acabamos de mencionar son comunes a la mayor parte de las manifestaciones eróticas, pero hemos recogido otras que son propias de las representaciones del deseo en el corpus: la tendencia a la indeterminación de su objeto por la utilización de proposiciones relativas cuyos antecedentes son indefinidos en las obras de Chrétien y de Lorris; el aplazamiento sine die de su satisfacción por una figuración hipotética en el discurso del dios Amor o por hallarse en una fase de desarrollo en la narración de Rose; las evocaciones por persona interpuesta, ya sea una doncella o un confidente; la negación de los apetitos carnales. Esta última tendencia, cuyas motivaciones profundas son sociales, tiene dos elaboraciones en el corpus: una primaria en Tristan al formular negativamente las expresiones avoir talent o avoir corage — aunque la ironía que caracteriza la obra posibilita una doble interpretación-, y una segunda en Charrete y Rose por la codificación cortés que sublima la contención y la univocidad con 
efectos erógenos y de conquista, tras la que quedan ocultos los verdaderos motivos, la ruptura de la pratrilinearidad y las regulaciones familiares.

Impelidos por el deseo, los amantes desafían las prohibiciones que traban su unión. El éxito es menor cuanto más apego muestran a la regulación cortés, y a menudo sólo el corazón de los enamorados puede penetrar en el gineceo con la amada, acompañamiento simbólico que los deja indudablemente insatisfechos. En el otro extremo, la firmeza y la inteligencia de Aelis y de Iseo, quien sacará provecho de la morbosa inclinación de los seniores por las apariencias, consiguen mejores resultados al reabrir para sus amantes el espacio vedado de la cámara, tanto más estrechamente vigilada por los felones cuanto que se trata de una representación metonímica del cuerpo femenino. Las idas y venidas de los amantes, que remedan en un nuevo recurso atenuativo los movimientos del coito, se convertirán en el eje central del discurso reprobatorio del emperador y de los traidores en Escoufle, obsesionados por la preservación de la virginidad.

La voz originaria de los relatos es masculina, caracterizada por su apego a la tradición y a las normas que regían la sociedad patriarcal, y en el caso extremo de Rose el monopolio del discurso varonil se rompe casi exclusivamente para dar paso al lado negativo de la feminidad, manifestación de la misoginia. A pesar de que en el resto de los romans pocas mujeres toman la palabra, hemos observado en las intervenciones femeninas algunas características dignas de mención: la capacidad que posee Iseo de jugar con los elementos lingüísticos y extra-lingüísticos de la comunicación para mostrar su amor a Tristán y mantener una aparente fidelidad al rey; la intensa dominación ejercida por Ginebra sobre Lanzarote mediante el discurso, formal o amoroso, y mediante su complementario, el silencio; por fin, la habilidad con la que Aelis utiliza las formas afectivas y los discursos recreativos para encandilar a hombres y mujeres, recurso que le será negado una vez restablecido el orden genealógico. Las palabras de la heroína de Escoufle, rememoradas por su enamorado, son el mejor ejemplo en el corpus del lenguaje amoroso como 
forma de contacto físico, expediente al que acudirán las doncellas de Charrete ante la ineficacia de los medios tradicionalmente masculinos para conquistar a Lanzarote. De hecho, el verbo parler y el sustantivo parlemant equivalen como eufemismo a los encuentros amorosos y a la unión sexual en el discurso narrativo y en el de los grupos que se oponen a los amantes. También los vocativos, además de funcionar como transición conversacional, sirven al juego amoroso: la elección de uno u otro, su reiteración y su variación balizan el encuentro apasionado o la ternura que preceden a la unión física, los temores ante el peligro social o ante la posible pérdida de interés erótico, la racionalización de la pasión y el recuerdo del amante.

Por otra parte, el discurso sobre el decir amoroso, que llega progresivamente a estar acaparado por los entes narrativos, es un excelente indicador de la evolución del modelo cortés y de las contradicciones que genera la mezcla entre los modos trovadoresco y caballeresco de amar. El sincero y elaborado discurso primigenio, tributo digno del amante y de la amada, queda relegado tras las acusaciones a los falsos amantes, por lo que el caballero deberá permanecer mudo ante aquella cuya voluntad lo domina, pero también sordo a las palabras de las doncellas que le ofrecen su amor y su cuerpo. El discurso - acción pasa de este modo durante un corto periodo de tiempo al dominio de las féminas para terminar desapareciendo con ellas del primer plano erótico. Una vez recuperado por el varón, tal como vemos en Rose, se le otorga el papel de instrumento secundario y falaz, especialmente adecuado para la conquista del mismo modo que muchos otros recursos.

El hecho de que las historias de amor de nuestro corpus se asienten sobre los impedimentos a la pasión, y los enamorados hallen en los ojos a sus mejores aliados para burlar la vigilancia social y para consolarse ante la frialdad de la amada o la distancia física, no podría explicar el relieve que se da a las percepciones visuales y a la mirada en las relaciones amorosas. Este interés responde esencialmente a un motivo de índole erótica: el papel básico representado por la visión para la libido masculina. De esta causa se derivan 
otras tres: la aceptación por parte de los moralistas de la erótica visual, el nexo que algunos médicos establecían entre la visión, el deseo y el placer, y el modo en que el enunciado con finalidad erógena implica al receptor, despierta sus recuerdos, sus fantasmas y en general su deseo. En este sentido resulta ejemplar el marco onírico en que Rose injiere la conquista de la mujer deseada, al establecer una relación estable entre lo narrado, la forma alegórica y los receptores del enunciado, para lo que la utilización del verbo voir se convierte en un recurso clave. Este verbo, que introduce una percepción subjetiva y ambigua en la descripción del modo de aprehensión del sueño, presenta al narrador como espectador de su propio sueño, lo que supone una identificación con la experiencia que los que leerán o escucharán la obra tienen de las representaciones oníricas, reavivando así su conciencia de soñadores eróticos. Las imágenes visuales transformadas por el texto en sensaciones auditivas son el duplicado de las percibidas por los receptores y deben provocar una imagen visual interna, manifestación de su propia imaginación erótica, de naturaleza similar al sueño y por lo tanto realizable. De ahí que la exposición de la ensoñación erótica, intimidad revelada que debería permanecer oculta, no pretenda ser justificada con las razones tradicionales, morales o didácticas, sino por su representación de la realidad humana percibida por los sentidos. De hecho, la validez universal de lo enunciado, por la implicación del receptor, de sus percepciones, de su memoria y de su imaginación, adquiere mayor peso que el argumento de autoridad, que también es invocado según los principios de la retórica.

Pero los sujetos que miran, el modo de mirar y los atributos percibidos no son homogéneos en nuestro corpus. La contemplación del objeto de deseo es casi siempre una actividad masculina y la visión sólo es erógena para el varón, cuando mira y cuando es mirado. Por otro lado, el ensimismamiento apasionado de Lanzarote ante la reina se torna admiración generalizada por la belleza de Aelis, tanto más apreciada cuanto más cerca se encuentra de recuperar su posición social inicial. También la belleza física de 
Guillermo y de los acompañantes de Deduit destierra la atracción que ejercían la fuerza y la gallardía del de la carreta sobre doncellas y caballeros. Y mientras el mirar masculino puede equivaler a la posesión carnal de la fémina — tan sólo Iseo es sujeto de veoir con un sentido equívoco-, al decir de las malas lenguas la mirada femenina se carga de obscenas invitaciones al ayuntamiento. Tampoco los ojos, órganos insoslayables en la descripción física y en el contacto amoroso, escapan a los cambios. Frente a la uniformidad que los caracteriza en los romans del siglo XII, sus variados atributos contribuyen a la individualización de los personajes en el siglo posterior. Renart y Lorris harán de ellos ventanas, no sólo de la pasión sino también del dolor y del placer, mientras que en Tristan y Charrete los enamorados —a excepción de Lanzarote— sabían utilizarlos a su favor y ocultar las miradas delatoras.

Las cualidades descriptivas de los términos char, braz, main o bouche, sustantivos con los que se alude a los contactos táctiles entre los amantes, quedan apenas esbozadas en el siglo XII, pero se fijan en el siglo siguiente con un afán individualizador y de evocación sensual en la que se unen el tacto y la visión, con especial intensidad en Rose. Las manos y la boca tienen dos funciones en las relaciones intersexuales, una sensual y otra ritual - sirven de nexo entre los espacios dominados por uno y otro sexo o bien sellan los pactos amorosos-, mientras que char prevalece cuando se trata de hacer referencia a las violencias que se infligían a las mujeres que eran botín de guerra, a los ritos corteses transformados en ritos prematrimoniales en E scoufle o al ayuntamiento carnal, capacidad metonímica y eufemística que comparte con todos las formas, verbales o sustantivas, que denominan el contacto físico entre los amantes. Éste quedará caracterizado por la aparición de innumerables obstáculos que los héroes deberán salvar hasta consumar su unión, en el plano estilístico, por el control narrativo, y en el formal, por la abundancia y diversidad de las construcciones recíprocas. En cuanto a las formas verbales que expresan las sensaciones táctiles, se distinguen esencialmente por reforzar sus sentidos denotativos, a menudo poco 
relacionados con la sensualidad, mediante expresiones adverbiales de cantidad o de modo y, en segundo lugar, por especializarse gracias a las connotaciones que les confieren los contextos en los que se encuentran. De este modo, adeser $y$ tenir pueden nombrar los contactos que subvierten el orden sexual o son manifiestamente anticorteses; anbracier y acoler hacen referencia a una intimidad continuada y se hallan asociados a la acción de besar aunque no se halle explícita. Taster denomina las caricias y la masturbación femenina, placeres permitidos por la cortesía clásica, mientras que toucher sirve para las acciones en las que no intervienen las manos, como las caricias con los ojos y la cara o la unión de las lenguas en el excepcional beso de Aelis y Guillermo. Coucher y gesir se aplican a las relaciones sexuales que implican la penetración y la emisión seminal, especialmente cuando van acompañados de una preposición que indica compañía, o bien cuando en Tristan y E scoufle el verbo está en plural y el sujeto son los componentes de la pareja. Estos dos verbos, que son poco habituales y están concentrados en situaciones muy concretas, suelen ponerse al servicio del enfrentamiento entre dos formas de entender las relaciones heterosexuales: una en la que no se concibe el amor y otra en la que se unen los sentimientos y el instinto. También los términos que hacen referencia al juego, inagotable fuente de sensaciones y de placer, extienden su sentido hasta abarcar todo el proceso de enamoramiento, cortejo y unión física, y denominan el coito en los romans de Chrétien y Renart.

El beso, excepcional en los amores de Lanzarote, es clave en el resto de las obras: estrecha los lazos entre los amantes, es una manifestación emblemática de la pasión que atenta contra el poder genealógico y un paso fundamental en el camino hacia la unión carnal a la que también llega a sustituir. El valor ritual del beso al que aspira el amante de la rosa y la batalla dialéctica que enfrenta al instinto contra la moral así lo confirman. Sin embargo, los argumentos de los enemigos del amor y de Venus, junto a la multiplicación de los interdictos que evitan el placer de ambos sexos y a la reducción a formas intelectuales de los fenómenos eróticos, implican una 
ruptura con la tendencia a la armonización del deseo y de la satisfacción sexual de hombres y mujeres iniciada por los trovadores. Pero no es de extrañar, pues ya en Charrete imperaba la ilusión, el ansia irrealizable o irrealizada de tocar, de abrazar y acariciar, de obtener placer o de darlo.

Las escasas y tangenciales alusiones al goce carnal en el texto noble resultan ser un índice de las actitudes básicas que ante el erotismo adoptan los autores — que no identificamos con los autores empíricos—, así como de su puesta en ejecución literaria. Hallamos en un principio dos posiciones divergentes: de un lado, los romans adscritos a la tradición cortés se caracterizan por proponer un placer unidireccional, que parte de la mujer para hacer sujeto de las sensaciones al varón, por hacer gozar con el dolor y dar al sufrimiento origen en el placer, por hacer converger todas las acciones y los menudos placeres de los enamorados hacia el momento culminante del coito, hacia una única cópula — no realizada en Rose - y, en último lugar, por someterse al poder, al que Lanzarote dará estabilidad y con el que el amante de la rosa tratará de congraciarse. Por otro lado, Tristan y E scoufle, más cercanos a la corriente naturalista, enuncian el placer común e incluso el goce de la mujer aunque en el roman del siglo XIII se preserve su virginidad. En ellos su disfrute es efectivo y repetido y se formula en indicativo, el sufrimiento es un elemento externo de origen social, que puede aplazar el placer pero nunca darlo, y por último, y pese a la reconciliación final con el poder en la obra de Renart, la búsqueda del placer conlleva la subversión del orden genealógico y social. 



\section{BIBLIOGRAFÍA.}

\section{GENERALES.}

\subsection{INFORMÁTICA.}

BYERS, R.A., Introduoción a las bases de datos on dBA SE III PL U S. Madrid: McGraw-Hill, 1988.

\subsection{LINGÜÍSTICA.}

BAtANy, J., Français médiéval. Tex tes choisis, commentaires linguistiques, commentaires littéraires, chronologie phonétique. París: Bordas, 1972.

BENVENiste, E., L'appareil formel de l'énonciation, L angages, n 17,1970 , pp. 12 - 18.

BRUNOT, F., H istoire de la langue française des origines à 1900. T.I. de l'époque latine à la Renaissance. J. Batany (ed.). París: Armand Colin, 1966.

BÜHLER, H., Sprachbarrieren und Schulanfang. E ine pragmalinguistische U ntersuchung des Sprechens von Sechs- bis A chtjährigen. Weinheim, 1972.

Cerquiglini, B., E loge de la variante. H istoire critique de la philologie. París: Seuil, 1989.

L a parole médiévale. D iscours, syntaxe, tex te. París: Minuit, 1981.

DEEs, A., A tlas des formes linguistiques des tex tes littéraires de l'ancien francais. Tubinga: Max Niemeyer, 1987.

— Dialectes et scriptae à l'époque de l'ancien français, Revue de L inguistique Romane, vol. 49, 1985, pp. 87 - 117.

DelBEy, A., Expliquer. Justifier. Grammaire et poétique de la cause en ancien français, Médiévales, $n^{\circ}$ 9, 1985, pp. 35 - 54.

DiEZ, F., G rammaire des L angues Romanes. Ginebra/Marsella: Slatkine/Laffitte Reprints, 3 vol., 1973.

Gresillon, A. y Maingueneau, D., Polyphonie, proverbe et détournement, L angages, $\mathrm{n}^{\circ}$ 73, 1984, pp. 112 - 125.

LANLY, A., Fiches de philologie française. París: Bordas, 1984.

MARCHELlO-Nizia, Ch., D ire le vrai: l'adverbe SI en français médiéval. Ginebra: Droz, 1985.

MORris, Ch., Signos, lenguaje y conducta. Buenos Aires: Losada, 1962.

Nyrop, K., G rammaire historique de la langue française. T. II. M orphologie. T. III. F ormation des mots. T. IV. Sémantique. T. V. Syntax e, noms et pronoms. T. VI. Syntax e: particules et verbes. Copenhague: Glydendal, 1930 - 1968. 
Ogden, C. K. y Richards, J. A., E I significado del significado. Buenos Aires: Paidós, 1964.

PERreT, D., Les appellatifs (analyse lexicale et actes de parole), L angages, $\mathrm{n}^{\circ}$ 17, 1970, pp. 112 - 118.

Picoche, J. y MARCHELlo-Nizia, Ch., H istoire de la langue française. París: Nathan, 1989.

Pope, M. K., From L atin to modern F rench. W ith especial consideration of A ngloN orman. Phonology and morphology. Manchester: University Press, 1934.

StRawson, P. F., Phrase et acte de parole, L angages, no 17, 1970, pp. 19 - 33.

TEILGARD LAUGESEN, A., Quelques formules de salutation en ancien français, Revue Romane. M élanges Paul H oybye, n 1-2, vol. VIII, 1973, pp. $143-150$.

\subsubsection{DICCIONARIOS.}

LE GRA ND LA ROUSSE DE LA LA N GUE FRA N ÇA ISE. París: Larousse. 7 vol., 1971-1978.

TRÉ SOR D E LA LA N G UE FRA N ÇA ISE .París: Klincksieck, 1971-1986.

LE PE TIT ROBE RT. D ictionnaire alphabétique et analogique de la langue française. A. Rey y J. Rey-Debove (eds.). París: Le Robert, 1985.

DICTION NA IRE HISTORIQUE DE LA LA NGUE FRA NÇA ISE. A. Rey (dir.). París: Le Robert, 1992.

D ICCIONA RIO DE LA LENG UA E SPA Ñ OLA . Madrid: Real Academia Española, 1992.

Bloch, O. y WARTBurG, W. vON, D ictionnaire étymologique de la langue française. París: PUF, 1975.

CASARES, J., D iocionario ideológico de la lengua española. Barcelona: Gustavo Gili, 1992.

Dauzat, A., Dubois, J. y MitTerand, H., N ouveau D idionnaire étymologique et historique. París: Larousse, 1964.

Godefroy, F., L ex ique de l'ancien français. J. Bonnard y A. Salmon (eds.). París: Honoré Champion, 1982.

_ D ictionnaire de l'ancienne langue française et de tous ses dialectes du IX e au X V e sièle. París: Librairie des Sciences et des Arts. 10 vol., 1937.

Greimas, A.-J., D ictionnaire de l'ancien français jusqu'au milieu du X IV e sièdle. París: Larousse, 1980.

LEWANDOWski, T., D iocionario de lingüística. Madrid: Cátedra, 1992.

Moliner, M., D iccionario de uso del español. Madrid: Gredos, 1986.

PiCOCHE, J., D ictionnaire étymologique du français. París: Le Robert, 1987.

ROBERT, P., L e grand R obert de la L angue F rançaise - D ictionnaire alphabétique et analogique de la langue française. París: Le Robert. 6 vol., 1978.

TOBleR, A. y LOMmatzsch, E., A ltfranzösisches W örterbuch. Berlín/Wiesbaden,1936 sg..

WALKER, D. C., D ictionnaire inverse de l'ancien français. Ottawa: Université d'Ottawa, 1982. 


\subsubsection{LÉXICO.}

Adams, J. N., The latin sex ual vocabulary. Baltimore: The John Hopkins University Press, 1982.

Andrieux, N., Une ville devenue désir: la Prise d'Orange et la transformation du motif printanier, Mélanges de langue et de littérature médiévales offerts à A liœ Planche. A nnales de la Faculté des L ettres et Sciences humaines de N iœ. París: Les Belles Lettres, 1984, vol. 1, pp. 21 - 32.

Aragón FernándeZ, M. A., Campos semánticos y recurrencia léxica en la narrativa francesa del siglo XII, M edioevo romanz0, vol. III, 1976, pp. $66-84$.

BRuCKER, Ch., «Sage» et «sagesse» au M oyen A ge (X IIe et X IIIe sièdes). É tude historique, sémantique et stylistique. Ginebra: Droz, 1987.

Burgess, G. S., Etude sur le terme cortois dans le français du XIIe siècle, Travaux de L inguistique et de Philologie, vol. XXXI, 1993, pp. 195 - 210.

Cropp, G. M., L e vocabulaire courtois des troubadours de l'époque dassique. Ginebra: Droz, 1975.

Chaurand, J., Introduction à l'histoire du vocabulaire français. París: Bordas, 1977.

DuCHACEK, O., Esquisse du champ conceptuel de la beauté dans le français du XIIIe siècle, Mélanges de Philologie R omane offerts à Charles C amproux. Montpellier: C.E.O., 1978, pp. 287 - 98.

Grisay, A., LAVIS, G. y Dubois-StAsse, M., L es dénominations de la femme dans les anciens tex tes littéraires français. Gembloux: Duculot, 1969.

GUIRAUD, P., «La joie d'amour» (analyse étymologique), H ommage à Jean 0 minus. A nnales de la Faculté des $\mathrm{L}$ ettres et Sciences humaines de N iœ. París: Les Belles Lettres, 1979, pp. 37 - 40.

HACKETT, M., Ire, courroux et leurs dérivés en ancien français et en provençal, M élanges offerts à F elix L ecoy. París: Champion, 1973, pp. $168-180$.

Hollyman, K. J., L e D éveloppement du vocabulaire féodal en Franœ pendant le H aut M oyen Â ge. Ginebra: Slatkine Reprints, 1957.

KAWAGUCHI, Y., Systèmes distincts, fluctuations ou variantes graphiques en ancien champenois, $\mathrm{L}$ a $\mathrm{L}$ inguistique, $\mathrm{n}^{\circ} 2$, vol. 23, 1987, pp. 87 - 98.

KLEIBER, G., L e mot «ire» en ancien français (X Ie - X IIIe siècles). E ssai d'analyse sémantique. París: Klincksieck, 1978.

LAVIS, G., Contribution à l'histoire du vocabulaire français: D emander dans les anciens textes littéraires (XIIe - XVe s.), Travaux de L inguistique et de Littérature, no 1, vol. XXII, 1984, pp. 95 - 160.

L 'ex pression de l'affectivité dans la poésie lyrique française du M oyen A ge (X IIe X IIIe s.) É tude sémantique et stylistique du réseau lex ical «joie - dolor». París: Les Belles Lettres, 1972.

Love, N., The vocative adjectives biaus, dous and chiers in Old French, L ingvisticae Investigationes, $\mathrm{n}^{\circ}$ 2, vol. IX, 1985, pp. 307 - 19.

Matoré, G., L e vocabulaire et la société médiévale. París: PUF, 1985. 
Remarques sur Beau et Beauté en Ancien Français, É tudes de L angue et de L ittérature françaises offertes à A ndré L anly. Nancy: Université Nancy II, 1980, pp. 225 - 32.

PiCOCHE, J., Le verbe aimer et sa famille dans les Chroniques de Froissart, M élanges de langue et de littérature offerts à A lice Planche. A nnales de la Faculté des L ettres et Scienoes humaines de N iœ. M. Accarie y A. Queffélec (eds.). París: Les Belles Lettres, 1984, pp. 371 - 78.

Tilander, G., L ex ique du Roman de Renart. París: Honoré Champion, 1971.

VENDLER, Z., Les performatifs en perspective, L angages, no 17,1970 , pp. 73 $-90$.

\subsubsection{MORFOSINTAXIS.}

ANDrieux, N. y BAUMGarTner, E., Systèmes morphologiques de l'ancien français. L e verbe. Burdeos: Bière, 1983.

Bonnard, H. y RÉGNIER, C., Petite grammaire de l'ancien français. París: Magnard, 1989.

Brunot, F. y Bruneau, Ch., Précis de grammaire historique de la langue française. París: Masson, 1969.

BURIDANT, C., Les particules séparées en ancien français, Romanistique $\mathrm{G}$ ermanistique. U ne confrontation. C. Buridant (ed.). Estrasburgo: Universités de Strasbourg, 1987, pp. 165 - 204.

DEEs, A., É tude sur l'évolution des démonstratifs en ancien et moyen français. Groninga: Wolters, 1971.

EPSTEIN, R., L'article défini en ancien français: l'expression de la subjectivité, L angue F rançaise, no 107, 1995, pp. 58 - 72.

FOUCHÉ, P., M orphologie historique du français. L e verbe. París: Klincksieck, 1967.

Foulet, L., Petite syntax e de l'ancien francais. París: Honoré Champion, 1974.

Graeme-Ritchie, R.L., Recherches sur la syntax e de la onjonction "que" dans l'ancien français depuis les origines jusqu'au commencement du X IIIe siède. París: Champion, 1907.

HERMAN, J., La formation du système roman des conjonctions de subordination. Berlín: Akademie Verlag, 1963.

Herslund, M., Problèmes de syntaxe de l'ancien français. Compléments datifs et génitifs. Copenhague: Akademisk Forlag, 1980.

IMBS, P., L es propositions temporelles en ancien français. L a détermination du moment. París: Les Belles Lettres, 1956.

JONAs, P., L es systèmes comparatifs à deux termes en ancien français. Bruselas: Éditions de l'Université, 1971.

KLEIBER, G., L'opposition CIST/CIL en ancien français ou Comment analyser les démonstratifs?, Romanistique - $\mathrm{G}$ ermanistique. U ne confrontation. C. Buridant (ed.). Estrasburgo: Universités de Strasbourg, 1984, pp. 269 - 95. 
_ L'opposition détérminé/indéterminé: les articles en ancien français, M élanges de langue et de littératures médiévales offerts à A liœ Planche. A nnales de la F acculté des L ettres et Scienoes humaines de $\mathrm{N}$ iœ. M. Accarie y A. Queffélec (eds.). París: Les Belles Lettres, 1986, pp. 247 - 61.

Kukenheim, L., G rammaire historique de la langue francaise. L es Parties du discours. Leyde: Universitaire Pers, 1967.

— $\mathrm{G}$ rammaire historique de la langue française. L es syntagmes. Leyde: Universitaire Pers, 1968.

LA ChausséE, F. de, Initiation à la morphologie historique de l'ancien français. París: Klincksieck, 1977.

LANLY, A., M orphologie historique des verbes français. París: Bordas, 1977.

LEPELLEY, R., Déterminants et détermination des substantifs en ancien français. Etude portant sur les vers 3632 à 3736 du Roman de G uillaume de D ole, L 'information G rammaticale, vol. IV, 1980, pp. 27 31.

MarChello-Nizia, Ch., La position de l'objet dans l'évolution du français, A ctes du X X e C ongrès International de L inguistique et Philologie Romanes. Tomo I, Sección I - L a phrase. Tubinga: A. Francke, 1993, pp. 453 64.

— La composition du groupe nominal sujet en ancien français (1150 1250), M élanges offerts à F elix L ecoy. París: Champion, 1973, pp. 385 99.

MÉNARD, Ph., Syntax e de l'ancien français. Burdeos: Bière, 1976.

Moignet, G., Ancien français si/se, Travaux de Linguistique et de Littérature, $\mathrm{n}^{\circ}$ 1, vol. XV, 1977, pp. 267 - 89.

$\mathrm{G}$ rammaire de l'ancien français. París: Klincksieck, 1984.

Mora Millán, M. L., El concepto de adverbio, su aplicación a los elementos que integran la clase del «adverbe de phrase», A nales de Filología Francesa, no 5, 1993, pp. 129 - 40.

NORDAHL, H., Superlatif absolu et structures séquentielles en ancien français, Mélanges de Philologie R omane offerts à Charles $\mathrm{C}$ amproux . Montpellier: C.E.O., 1978, pp. 439 - 50.

Picoche, J., Précis de M orphologie historique. París: Nathan, 1979.

PotTier, B., À propos des classes syntaxiques, Modèles L inguistiques, $\mathrm{n}^{\circ} 1$, vol. 8, 1986, pp. 77 - 84 .

RAYNAUd DE LAGE, G., Introduction à l'ancien français. G. Hasenohr (ed.). París: SEDES, 1990.

— Manuel pratique d'ancien français. París: Picard, 1978.

SNEyders De VoGel, K., Syntax e historique du français. Groninga: J.-B. Wolters, 1927.

Soutet, O., É tudes d'ancien et de moyen français. París: PUF, 1992.

L a concession en français, des origines au X V Ie siède. Tome 1: Problèmes généraux. L es tours prépositionnels. Ginebra: Droz, 1990. 
STANOVAÏA, L., Sur la déclinaison bicasuelle en ancien français (point de vue scriptologique), Travaux de L inguistique et de Philologie, vol. XXXI, 1993, pp. $163-83$.

STÉFANINI, J., L a voix pronominale en ancien et en moyen français. Gap: Ophrys, 1962.

WOLEDGE, B., «La flors» et «la flor». La déclinaison des féminins chez Chrétien de Troyes, M élanges de Philologie et de L ittératures romanes offerts à Jeanne W athelet-W illem. M arche Romane. J. De Caluwé (ed.). Lieja: Université de Liège, 1978, pp. 717 - 40.

ZINK, G., M orphologie du français médiéval. París: PUF, 1994.

_ L 'ancien français (X Ie - X IIIe siède). París: PUF, 1990.

\subsection{TEORÍA E HISTORIA LITERARIA.}

BEZzolA, R. R., L es origines et la formation de la L ittérature courtoise en 0 cadent. 500 - 1200. Ginebra: Slatkine Reprints, 1984.

BOuRneuf, R. y Ouellet, R., L a novela. Barcelona: Ariel, 1981.

CAsas Fernández, F. de, La lírica, H istoria de la L iteratura Francesa. J. del Prado (coord.). Madrid: Cátedra, 1994, pp. 145 - 78.

Cirlot Valenzuela, V., La materia cortesana, H istoria de la Literatura franoesa. J. del Prado (coord.). Madrid: Cátedra, 1994, pp. 80 - 99.

CurTius, E., L iteratura europea y E dad M edia latina. Tomo I y II. México: Fondo de Cultura Económica, 1981 - 1984.

Dronke, P., M edieval L atin and the Rise of E uropean L ove L yric. 2 vols. Oxford: Clarendon Press, 1968.

FAral, E., L es A rts Poétiques du X IIe et X IIIe siècle. Recherches et documents sur la technique littéraire du M oyen A ge. París: Champion, 1924.

HucheT, J.-Ch., L’amor de lonh du grammairien, Médiévales, nº 9, 1985, pp. 64 $-79$.

Jauss, H. R., Pour une esthétique de la réception. París: Gallimard, 1978.

Littérature médiévale et théorie des genres, Poétique, nº 1, 1970, pp. 79 $-99$.

— Littérature médiévale et expérience esthétique, Poétique, no 31, 1977, pp. 322 - 36.

Jodogne, O., La personnalité de l'écrivain d'oil du XIIe au XIVe siècle, L 'humanisme médiéval dans les littératures romanes du X IIe au X IV e siède.

A. Fourrier (ed.). París: Klincksieck, 1964, pp. 87 - 106.

JunG, M.-R., É tudes sur le poème allégorique en France au M oyen A ge. Berna: FranKe, 1971.

LEWIS, C. S., The A llegory of L ove: A Study in Medieval Tradition. Londres: Oxford University Press, 1959.

Marrou, H.-I., L es troubadours. París: Seuil, 1971.

MichA, A., D idtionnaire des L ettres francaise: le M oyen Â ge. París: Fayard, 1964.

REIS, C., F undamentos y técnicas del análisis literario. Madrid: Gredos, 1981.

RiffATERRE, M., L'intertexte inconnu, L ittérature, nº 41, 1981, pp. 4 - 7. 
Rodríguez, J. C., T eoría et historia de la produoción ideológica. L as primeras literaturas burguesas. Madrid: Akal, 1974.

Rosier, I., La théorie médiévale des Modes de signifier, L angages, $\mathrm{n}^{\circ}$ 65, 1982, pp. 117 - 28.

RYCHNER, J., D u «Saint A lex is» à F rançois V illon. E tudes de littérature médiévale. Ginebra: Droz, 1985.

Segre, C., Principios de análisis del tex to literario. Barcelona: Crítica, 1985.

STOCK, B., Medieval Literacy, Linguistic Theory, and Social Organization, N L H, no 1, vol. XVI, 1984, pp. 13 - 29.

Trannoy, P., Le jardin d'amour dans le D e A more d'André le Chapelain, Senefiance, no 28, 1990, pp. 373 - 88.

Zumthor, P., L angue, tex te, énigme. París: Seuil, 1975.

_ L L L ettre et la voix. D e la «litterature» médiévale. París: Editions du Seuil, 1987.

\subsubsection{RETÓRICA Y NARRATIVA.}

Authier-Revuz, J., Hétérogénéité(s) énonciative(s), L angages, nº 73, 1984, pp. 98 - 111.

BAL, M., T eoría de la narrativa (una introducción a la narratología). Madrid: Cátedra, 1985.

BÄUmL, F. H., Medieval Texts and the Two Theories of Oral-Formulaic Composition: A Proposal for a Third Theory, N L H, n ${ }^{\circ}$ 1, vol. XVI, 1984, pp. 31 - 49.

BLOCH, R. H., E tymologie et généalogie. U ne anthropologie littéraire du M oyen A ge français. París: Seuil, 1989.

BOURNEUF, R., L'organisation de l'espace dans le roman, É tudes L ittéraires, $\mathrm{n}^{\mathrm{o}}$ 1, vol. III, 1970, pp. 77 - 94.

Tubinga: A. Francke, 1993, pp. 213 - 24.

CALDARINI, E., Un lieu du roman médiéval: le verger, CA IE F, vol. XXXIV, 1982, pp. 7 - 23 / $245-6$.

CArmona, F., El roman lírio medieval. Murcia: PPU, 1988.

CERQUiglini, B., La parole étrange, L angue F rancaise, no 40, 1978, pp. 83 98.

Le style indirect libre et la modernité, Langages, no 73, 1984, pp. 7 - 16.

CorTÉs ZaBOrras, C., Análisis del código espacial en un texto narrativo del siglo XIII, A ctas del IV Simposio internacional de la A sociación andaluza de Semiótica. Pilar Moraleda García y Ascensión Sánchez Fernández (eds.). Córdoba: Universidad de Córdoba, 1992 (microfichas).

DragonetTI, R., L e mirage des sources, l'art du faux dans le roman médiéval. París: Seuil, 1987.

— L a technique poétique des trouvères dans la chanson courtoise. Contribution à l'étude de la rhétorique médiévale. Ginebra: Slatkine Reprints, 1979.

L e G ai savoir dans la rhétorique courtoise. París: Seuil, 1982. 
DugGan, J. J., Oral Performance of Romance in Medieval France, C ontinuations: E ssays on M edieval French L iterature and L anguage. N. J. Lacy y G. Torrini-Roblin (eds.). Birmingham: Summa, 1989, pp. 51 61.

DuprIEZ, B., G RA D U S. L es procédés littéraires (D ictionnaire). París: UGE. 10/18, 1990.

FOURRIER, A., L e C ourant réaliste dans le roman courtois en France au M oyen A ge. Tome I: les débuts (X IIe siède). París: Nizet, 1960.

GALlaIs, P., Littérature et médiatisation. Réflexions sur la genèse du genre romanesque, É tudes littéraires, vol. IV, 1971, pp. 39 - 73.

García Gual, C., Primeras novelas europeas. Madrid: Istmo, 1974.

GuiETTE, J., Symbolisme et senefiance au Moyen Âge, F orme et senefianœ. E tudes médiévales. J.Dufournet, M.de Grève, H. Braet (eds.). Ginebra: Droz, 1978, pp. 33 - 60.

_ Observations sur l'âge courtois, F orme et senefiance. É tudes médiévales. J.Dufournet, M.de Grève y H. Braet (eds.). Ginebra: Droz, 1978, pp. $57-72$.

HAIDU, P., Narrativity and language in some XIIth century romance, Y ale French Studies, nº 51, 1975, pp. 133 - 46.

Hamon, Ph., Qu'est-ce qu'une description?, Poétique, nº 12, 1972, pp. 465 85.

Hicks, E., Le signe et l'interdit, E t c'est la fin pour quoy sommes ensemble. H ommage à Jean D ufournet. T ome II. J.-C. Aubailly, E. Baumgartner, F. Dubost, L. Dulac y M. Faure (eds.). París: Honoré Champion, 1993, pp. 739 - 46.

HuCHET, J.-Ch., L e roman médiéval. París: PUF, 1984.

JACQUESSON, F., Le désordre et la structure. Sur la syllabe médiévale, Médiévales, $\mathrm{n}^{\circ}$ 1, 1982, pp. .

Joris, P.-M., L'étoile sibylline, Médiévales, no 11, 1986, pp. 49 - 65.

LintVELT, J., E ssai de typologie narrative. L e "point de vue". T héorie et analyse. París: Librairie José Corti, 1981.

MARNETTE, S., Réflexions sur le discours indirect libre en français médiéval, Romania, no 1 - 2, vol. CXIV, 1996, pp. 1 - 49.

MÉNARD, Ph., La déclaration amoureuse dans la littérature arthurienne au XIIIe siècle, CCM, vol. XIII, 1970, pp. 33 - 42.

Morier, H., D ictionnaire de poétique et de rhétorique. París: PUF, 1961.

OLLIER, M.-L., Discours intérieur et temporalité: l'adverbe OR en récit, L e nombre du temps en hommage à Paul Z umthor. París: Champion, 1988, pp. $201-17$.

Utopie et roman arthurien, CCM, vol. XXVII, 1984, pp. 223 - 32.

OLLIER, M.-L., Le présent du récit. Temporalité et roman en vers, L angue Française, no 40, 1978, pp. 99 - 112.

ONG, W. J., Orality, Literacy, and Medieval Textualization, N L H, n ${ }^{\circ}$ 1, vol. XVI, 1984, pp. 1 - 12.

PAYEN, J.-Ch., Figures féminines dans le roman médiéval français, E ntretiens sur la Renaissance du X IIe siècle. D écades du œntre culturel international de 
Cerisy-la-Salle. M. de Gandillac, E. de Jeauneau (dir.). París/La Haya: Mouton, 1968, pp. 407 - 36.

POIRION, D., Théorie et pratique du style au Moyen Age: le sublime et la merveille, Revue d'H istoire L ittéraire de la Franœ, no 1, vol. LXXXVI, 1986, pp. 15 - 32.

REENEN, P. y VAN SCHOSLER, L., SI "thématique" en ancien et moyen français - discours direct, A ctes du X X e Congrès International de L inguistique et Philologie R omanes. Tomo I, Sección I - L a phrase. Tubinga: A. Francke, 1993, pp. 617 - 28.

RICARD, F., Le décor romanesque, E tudes F rançaises, no 4, vol. VIII, 1972, pp. $343-62$.

RIFFATERRE, M., Intertextuality vs. Hypertextuality, N L H, no 4, vol. XXV, 1994, pp. 779 - 88.

Rodríguez DE Montalvo, G., A madís de G aula, 2 vol. Juan Bautista Avalle-Arce (ed.). Madrid: Espasa Calpe, 1991.

RYCHNER, J., L a narration des sentiments, des pensées et des disoours dans quelques oeuvres des X IIe et X IIIe siècles. Ginebra: Droz, 1990.

Spearing, A. C., The Medieval Poet as Voyeur, The Olde D aunce. L ove, Friendship, Sex, and M arriage in the M edieval W orld. R.R. Edwards y S. Spector (eds.). Albany: State University of New York Press, 1991, pp. 57 - 86.

Spitzer, L., É tudes de style. París: Gallimard, 1970.

StANESCO, M., Sous le masque de Lancelot. Du comportement romanesque au Moyen Age, Poétique, no 61, vol. XVI, 1985, pp. 23 - 34.

Stone, G. B., The Insistence of the Body in the Old French Fabliau E stormi, E x emplaria, no 2, vol. 2, October 1990, pp. 449 - 73.

Todorov, T., Poétique de la prose -choix, suivi de- $\mathrm{N}$ ouvelles recherches sur le récit. París: Seuil, 1980.

Vinaver, E., A la recherche d'une poétique médiévale. París: Nizet, 1970.

VinCEnsini, J.-J., Procédés d'«esthétisation» et formes de l'«esthétique» dans la narration médiévale, A ctes du X X e C ongrès International de L inguistique et Philologie Romanes. Tomo V, Sección VIII - L 'art narratif aux X IIe et X IIIe sièdes. Tubinga: A. Francke, 1993, pp. 415 - 26.

VITZ, E. B., Desire and causality in medieval narrative, Romanic Review, $\mathrm{n}^{\circ} 3$, vol. LXXI, 1980, pp. 213 - 43.

ZÉrAFFA, M., Roman et société. París: PUF, 1976.

ZumTHOR, P., Le champ du romanesque, E urope, no 642, 1982, pp. 27 - 35.

_ L L angue et techniques poétiques à l'époque romane (X Ie - X IIIe sièdes). París: Klincksieck, 1963.

_ L L poésie et la voix dans la civilisation médiévale. París: PUF, 1984.

E ssai de poétique médiévale. París: Seuil, 1972.

—_ Intertextualité et mouvance, Littérature, no 41, 1981, pp. 8 - 16.

— The Text and the Voice, N L H, no 1, vol. XVI, pp. $67-92$. 


\section{HISTORIA, SOCIEDAD E IDEOLOGÍA.}

H istoire mondiale de la Femme. T. II: D e l'0 ocident des C eltes à la Renaissanœ. P. Grimal (dir.). París: Nouvelle Librairie de France, 1966.

$\mathrm{H}$ istoria de las ideologías. I.L os mundos divinos (H asta el siglo V III) y D e la Iglesia al E stado (Siglos IX al X V II). François Chatelet (dir.). Madrid: Zero, 1978.

ArIÈs, Ph., Saint Paul et la chair, Communications, no 35, 1982, pp. 34 - 6.

_ L'amour dans le mariage, Communications, no 35, 1982, pp. 116 - 22.

AZCÁRATE RISTORI, J. M., La mujer en el arte medieval español: introducción, A das del Coloquio $\mathrm{H}$ ispano-Franós «L a condición de la mujer en la E dad M edia». Madrid: Universidad Complutense, 1986, pp. 403 6.

BLOCH, R. H., Medieval Misogyny, Representations, nº 20, 1987, pp. 1 - 24.

BLumstein, A. K., Misogyny and Idealization in the Courtly Romanœ. Bonn: Bouvier, 1977.

BOKLUND, K., On the spatial and cultural characteristics of courtly romance, Semiotica, vol. 20, 1977, pp. 1 - 37.

Boswell, J., Christianisme, T oléranœ sociale et H omosex ualité. L es homosex uels en E urope occidentale des débuts de l'ère chrétienne au X IV e siècle. París: Gallimard, 1985.

Brenon, A., L es femmes cathares. París: Perrin, 1992.

Brundage, J. A., L aw, Sex, and Christian Society in M edieval E urope. Chicago/Londres: The University of Chicago Press, 1987.

Bullough, V. L., The Subordinate Sex. A H istory of A ttitudes towards W omen. Nueva York: Penguin Books, 1974.

CALIN, W., Contre la fin' amor? Contre la femme? Une relecture de textes du Moyen Age, Courtly L iterature: culture and ontex t. K. Busby y E. Kooper (eds.). Amsterdam/Filadelfia: John Benjamins, 1990, pp. 61 $-82$.

CARré, Y., L e Baiser sur la bouche au M oyen A ge. Rites, symboles, mentalités à travers les tex tes et les images, X Ie - X V e sièdes. París: Le Léopard d'Or, 1993.

CÁtedra GARCÍA, P., La mujer en el sermón medieval (a través de textos españoles), A ctas del C oloquio $\mathrm{H}$ ispano-Franoés «L a condición de la mujer en la E dad M edia». Madrid: Universidad Complutense, 1986, pp. 39 - 50.

Clark, E. A., "Adam's Only Companion": Augustine and the Early Christian Debate on Marriage, The Olde D aunœ. L ove, Friendship, Sex, and Marriage in the Medieval W orld. R. R. Edwards y S. Spector (eds.). Albany: State University of New York Press, 1991, pp. 15 - 31.

Coppin, J., A mour et mariage dans la littérature française du N ord au M oyen A ge. París: D’Argences, 1961.

Courtemanche, A., Ecriture Historique sur les Femmes du Moyen Age: L'exemple de Manosque, A tlantis, $n^{\circ}$ 2, vol. 10, 1985, pp. 47 - 64. 
D'Alverny, M.-T., Comment les théologiens et les philosophes voient la femme, C CM . A ctes du olloque «L a femme dans les civilisations des X e X IIIe sièdes», no 2 - 3, vol. XX, 1977, pp. 105 - 29.

DAvY, M.-M., Initiation à la symbolique romane (X IIe siècle). París: Flammarion, 1988.

DeCRET, F., Mani et la tradition manichéenne. París: Seuil, 1974.

Delumeau, J., L e péché et la peur. L a culpabilisation en 0 ccident, X IIIe- X V IIIe sièdes. París: Fayard, 1983.

DeluZ, Ch., Le jardin médiéval, lieu d'intimité, Senefianœ, nº 28, 1990, pp. $97-108$.

Dronke, P., W omen W riters of the Middle A ges. Cambridge: Cambridge University Press, 1984.

DuBy, G., L e chevalier, la femme et le prêtre. París: Hachette, 1981.

_ M âle M oyen A ge. D e l'amour et autres essais. París: Flammarion, 1988. L es trois ordres ou l'imaginaire du féodalisme. París: Gallimard, 1978. Saint Bernard, l'art cistercien. París: Flammarion, 1979.

Duby, G. y ArIES, Ph., De l'Europe féodale à la Renaissance, H istoire de la vie privée. G. Duby (dir.). París: Seuil, 1985.

ELLIS, D. S., The Merchant's Wife's tale: Language, Sex, and Commerce in Margery Kempe and in Chaucer, E x emplaria, $\mathrm{n}^{\circ}$ 2, vol. 2, 1990, pp. $595-626$.

FIRPO, A., Las concubinas reales en la Baja Edad Media castellana, A das del Coloquio $\mathrm{H}$ ispano-Franoés "L a condición de la mujer en la $\mathrm{E}$ dad M edia». Madrid: Universidad Complutense, 1986, pp. 333 - 42.

FLANDRIN, J.-L., La vie sexuelle des gens mariés dans l'ancienne société:de la doctrine de l'Eglise à la réalité des comportements, C ommunications, $\mathrm{n}^{\circ}$ 35, 1982, pp. $103-15$.

_ Un temps pour embrasser. A ux origines de la morale sex uelle occidentale (V Ie X Ie siède). París: Seuil, 1983.

L e sex e et l'0 ocident. É volution des attitudes et des comportements. París: Seuil, 1981.

— La réglementation du commerce conjugal dans les pénitentiels: Réflexion sur ses effets possibles et son application, A ctas del Coloquio H ispano-Francés «L a condición de la mujer en la E dad M edia». Madrid: Universidad Complutense, 1986, pp. 85 - 96.

FLORI, J., Aristocratie et valeurs «chevaleresques» dans la seconde moitié du XIIe siècle. L'exemple des lais de Marie de France, L e M oyen A ge, $\mathrm{n}^{\circ}$ 1, vol. XCVI, 1990, pp. 35 - 65.

FoCILLON, H., A rt d'O ccident. L e M oyen Â ge roman. L e M oyen Â ge gothique. París: Armand Colin, 1987.

Fossier, R., La femme dans les sociétés occidentales, CCM . A ctes du colloque «L a Femme dans les divilisations des X e - X IIIe sièdes», n 2 - 3, vol. XX, 1977, pp. 93 - 104.

Gourevitch, A. J., L es C atégories de la culture médiévale. París: Gallimard, 1983. 
Gourevitch, D., L e mal d'être femme. L a femme et la médecine dans la Rome antique. París: Les Belles Lettres, 1984.

Jacquart, D. y Thomasset, C., Sex ualité et savoir médical au M oyen A ge. París: PUF, 1985.

JACQUART, D., La maladie et le remède d'amour dans quelques écrits médicaux du Moyen Age, A ctes du Colloque «A mour, Mariage et transgressions au M oyen A ge». Göppingen: Kümmerle Verlag, 1984, pp. $93-101$.

JAVELET, R., L'amour spirituel face à l'amour courtois, E ntretiens sur la Renaissance du X IIe siède. D écades du centre curturel international de C erisyla-Salle. M. de Gangillac et E. de Jeauneau (dir.). París/La Haya: Mouton, 1968, pp. 309 - 46.

KÖHLER, E., L 'aventure chevaleresque. Idéal et réalité dans le roman courtois. París: Gallimard, 1974.

KOOPER, E., Loving the Unequal Equal: Medieval Theologians and Marital Affection, The Olde D aunce. L ove, Friendship, Sex, and M arriage in the M edieval W orld. R. R. Edwards y S. Spector (eds.). Albany: State University of New York Press, 1991, pp. 44 - 56.

LABAL, P., L os cátaros: herejía y crisis social. Barcelona: Grijalbo Mondadori, 1995.

LAFONT, R., Oncles et neveux, E t d'est la fin pour quoy sommes ensemble. H ommage à Jean D ufournet. Tome II. J.-C. Aubailly, E. Baumgartner, F. Dubost, L. Dulac y M. Faure (eds.). París: Honoré Champion, 1993, pp. 839 - 54.

LANGLOIS, Ch.-V., L a vie en France au M oyen A ge. D e la fin du X IIe au milieu du $\mathrm{X}$ IV e siècle. T omo I: D 'après les romans mondains du temps. París/Ginebra: Slatkine Reprints, 1981.

_ _ L a V ie en Franc au M oyen A ge de la fin du X IIe siède au milieu du X IV e siècle. T omo II: D 'après les moralistes du temps. París/Ginebra: Slatkine Reprints, 1984.

LE Bras, G., Le Mariage dans la théologie et le droit de l'Eglise du XIe au XIIIe siècles, CCM , n 2, vol. XI, 1968, pp. 191 - 202.

LE Goff, J., L es intellectuels au M oyen Â ge. París: Seuil, 1985.

_ L o maravilloso y lo cotidiano en el 0 ccidente medieval. Barcelona: Gedisa, 1985.

LECLERCQ, J., L e mariage vu par les moines au X IIe siède. París: Éditions du Cerf, 1983.

__ L 'amour vu par les moines au X IIe siède. París: Éditions du Cerf, 1983. L a F emme et les femmes dans l'oeuvre de saint Bernard. París: Téqui, 1983.

LEJEUNE-DeHousse, R., La femme dans les littératures française et occitane du XIe au XIIIe siècle, CCM . A ctes du colloque «L a femme dans les civilisations des X e - X IIIe sièdes», no 2, vol. XX, 1977, pp. 201 - 17.

LÉVI-STRAuss, C., L es structures élémentaires de la parenté. París: Mouton, 1968.

LOT-Borodine, M., D e l'amour profane à l'amour sacré. É tudes de psychologie sentimentale au M oyen A ge. París: Nizet, 1979. 
MarChello-Nizia, Ch., Amour courtois, société masculine et figures du pouvoir, A nnales E.S.C., nº 6, 1981, pp. 969 - 82.

MCCASH, J. H., Mutual Love as a Medieval Ideal, Courtly L iterature: culture and context. K. Busby y E. Kooper (eds.). Amsterdam/Filadelfia: John Benjamins, 1990, pp. 429 - 38.

MÉtral, M.-O., L e M ariage. L es hésitations de l'0 ocident. París: AubierMontaigne, 1977.

Metz, R., Le statut de la femme en droit canonique médiéval, L a F emme. Recueils de la Société Jean Bodin, vol. X II, n. 2. Bruselas: Société Jean Bodin, 1962, pp. 59 - 113.

Morali-Daninos, A., H istoire des relations sex uelles. París: PUF, 1980.

NeLLI, R., L a vie quotidienne des C athares du L anguedoc au X IIIe siècle. París: Hachette, 1984.

NoOnan, J. T., Contraœption et mariage. É volution ou contradiction dans la pensée chrétienne. París: Editions du Cerf, 1969.

PAYEN, J.-Ch., Le clos et l'ouvert dans la littérature médiévale et les problèmes de la communication (éléments d'une problématique), Perspectives médiévales, $n^{\circ}$ 2, 1976, pp. 61 - 72.

Payer, P.-J., Sex and the Penitencials, the development of a sex ual code. 550 - 1150. Toronto: University of Toronto Press, 1984.

Pernoud, R., L a femme au temps des cathédrales. París: Stock, 1984.

PouCHELLE, M.-Ch., Le corps féminin et ses paradoxes: l'imaginaire de l'intériorité dans les écrits médicaux et religieux (XIIe - XIVe siècles), A ctas del Coloquio $\mathrm{H}$ ispano-Franoés «L a condición de la mujer en la E dad M edia». Madrid: Universidad Complutense, 1986, pp. 315 - 32.

— C orps et chirurgie à l'apogée du M oyen A ge: savoir et imaginaire du corps chez $\mathrm{H}$ enri de M ondeville, chirurgien de P hilippe le Bel. París: SEDES, 1983.

Power, E., M edieval W omen. M. M. Postan (ed.). Cambridge: University Press, 1975.

Regnier-Bohler, D., Femme $\backslash$ Faute $\backslash$ Fantasme, A ctas del Coloquio H ispano-Franós «L a condición de la mujer en la E dad M edia». Madrid: Universidad Complutense, 1986, pp. 475 - 500.

_ Le corps mis à nu: valeur symbolique et perception individuelle et sociale du corps nu dans les récits du Moyen Age, E urope, nº 654, 1983, pp. $51-61$.

Rey-Flaud, H., L e C harivari: les rituels fondamentaux de la sexualité. París: Payot, 1985.

Rivera Garretas, M.-M., Formas femeninas de sexualidad en la Europa prefeudal y feudal, $\mathrm{H}$ ijas de A frodita. L a sex ualidad femenina en los pueblos del M editerráneo. A. Pérez Jiménez y G. Cruz Andreotti (eds.). Madrid: Ediciones Clásicas, 1995, pp. 215 - 39.

RODRíGUEZ GIL, M., Las posibilidades de actuación jurídico-privadas de la mujer soltera medieval, A ctas del C oloquio $\mathrm{H}$ ispano-Francés «L a condición de la mujer en la E dad M edia». Madrid: Universidad Complutense, 1986, pp. 107 - 20. 
Rossiaud, J., Prostitution, sexualité, société dans les villes françaises au XVe siècle, Communications, ${ }^{\circ}$ 35, 1982, pp. 68 - 83.

Rousselle, A., Porneia. D e la maîtrise du corps à la privation sensorielle, IIe - IV e siècle de l'ère chrétienne. París: PUF, 1983.

RousseT, P., L'émotivité à l'époque romane, CC M , nº 2, vol. II, 1959, pp. $53-67$.

RuCQuOI, A., Historia de un tópico: La mujer en la Edad Media, H istoria 16, $\mathrm{n}^{\circ} 21$, enero 1978 .

Ruiz DomenEC, J. E., M ujeres ante la identidad (siglo X II). Bellaterra: Publicacions de la Universitat Autònoma, 1986.

— Littérature et Société médiévale: vision d'ensemble, L e M oyen A ge, $\mathrm{n}^{\circ}$ 1, vol. 88, 1982, pp. 77 - 114.

_ La mujer en la sociedad aristocrática de los siglos XII y XIII, A das del Coloquio $\mathrm{H}$ ispano-Franós «L a condición de la mujer en la $\mathrm{E}$ dad M edia». Madrid: Universidad Complutense, 1986, pp. 379 - 402.

SchмiтT, J.-C., L a raison des gestes dans l'0 ocident médiéval. París: Gallimard, 1990.

SheEHAN, M. A., Maritalis Affectio Revisited, The Olde D aunœ. L ove, Friendship, Sex, and M arriage in the M edieval W orld. R. R. Edwards y S. Spector (eds.). Albany: State University of New York Press, 1991, pp. 32 - 43.

Simonnot, Ph., L e sex e et l'économie ou la monnaie des sentiments. París: J-C. Lattès, 1985.

Sot, M., Mépris du monde et résistance du corps aux XIe et XIIe siècles, M édiévales, vol. VIII, 1985, pp. 6 - 17.

Thomasset, C., La femme au Moyen Age. Les composantes fondamentales de sa représentation: immunité, impunité, 0 rnicar, vol. 22 - 23, 1981, pp. $223-38$.

VincenT-CAssy, M., Péchés de femmes à la fin du Moyen Age, A das del Coloquio H ispano-Franós «L a condición de la mujer en la E dad M edia». Madrid: Universidad Complutense, 1986, pp. 501 - 18.

Wade Labarge, M., L a mujer en la E dad M edia. Madrid: Nerea, 1988.

\subsection{EROTISMO.}

Alberoni, F., L 'érotisme. París: Ramsay, 1987.

AtKIns, J., Sex in Literature. The erotique impulse in L iterature. Vol. III: The

M edieval E x perience. Londres: John Calder, 1978.

BARTHES, R., Fragments d'un discours amoureux. París: Seuil, 1977.

Bataille, G., L'érotisme. París: Minuit, 1985.

— L es larmes d'E ros. París: 10\18, 1985.

BAudrillard, J., D e la seduoción. Madrid: Cátedra, 1986.

Bermejo, J. M., L a vida amorosa en la época de los trovadores. Madrid: Temas de Hoy, 1996. 
BLOCH, R. H., The Arthurian Fabliau and the Poetics of Virginity, Continuations: E ssays on M edieval French L iterature and L anguage. N. J. Lacy y G. Torrini-Roblin (eds.). Birmingham: Summa, 1989, pp. 231 $-49$.

Blue, A., E l Beso. D e lo metafísion a lo erótion. Barcelona: Kairós, 1998.

Bologne, J.-C., H istoire de la pudeur. París: France Loisirs, 1986.

BowDen, B., The art of Courtly Copulation, M edievalia et $\mathrm{H}$ umanistica, $\mathrm{n}^{\circ}$ 9, 1979, pp. $67-85$.

BRAult, J., Le secret d'amour dans la lyrique courtoise, L 'érotisme au M oyen âge. E tudes présentées au IIIe C olloque de l'Institut d'E tudes médiévales. B. Roy (dir.). Montreal: Editions de l'Aurore, 1977, pp. 23 - 33.

BRÜCKMANN, J. y Couchman, J., Du «Cantique des Cantiques» aux «Carmina Burana»: amour sacré et amour érotique, L 'érotisme au M oyen âge. E tudes présentées au IIIe C olloque de l'Institut d'E tudes médiévales. Bruno Roy (dir.). Montreal: Editions de l'Aurore, 1977, pp. 37 - 50.

CORTÉs ZABORRAs, C., «Cortoisie fere». Une approche au L ai de l'O mbre, A nales de filología francesa, $n^{\circ}$ 3, 1989, pp. 19 - 31.

CHANDÈs, G., Amour, mariage et transgressions dans «le Bel Inconnu» à la lumière de la psychologie analytique, $\mathrm{A}$ ctes du Colloque «A mour, mariage et transgressions au M oyen A ge». Göppingen: Kümmerle Verlag, 1984, pp. $325-33$.

Cheverny, J., Sex ologie de l'0 ocident. París: Hachette, 1976.

Chlvmsky, M., Esthéticité, érotisme et pornographie, Rérue d’E sthétique, no 1-2, 1978, pp. 191 - 213.

DinZELBACHER, P., Pour une histoire de l'amour au moyen âge, L e M oyen Â ge, no 2, 1987, pp. 223 - 40.

DragonetTI, R., Trois motifs de la lyrique courtoise confrontés avec les Arts d'aimer (Contribution à l'étude de la thématologie courtoise), L a musique et les lettres. É tudes de littérature médiévale. Ginebra: Droz, 1986, pp. 125 - 68.

— Aux origines de l'amour courtois: La poétique amoureuse de Guillaume IX d'Aquitaine, L a musique et les lettres. É tudes de littérature médiévale. Ginebra: Droz, 1986, pp. 169 - 200.

ELSEN, C., H omo eroticus. París: Gallimard, 1953.

ESPINOSA SANSANO, $\mathrm{M}^{\mathrm{a}} \mathrm{D}$., El erotismo y lo anti-cortés como fuente de humor, los trovadores, A nales de Filología francesa, n 3, 1989, pp. 61 71.

FEHER, M., L'amour le plus éprouvant, Magazine littéraire, no 267 - 268, 1989, pp. 18 - 21.

FERRANTE, J. M., Male fantasy and female reality in courtly literature, W omen's Studies, vol. 11, 1984, pp. 67 - 97.

Foucault, M., H istoria de la sex ualidad. 1. L a voluntad de saber. Madrid: Siglo XXI, 1987.

Fox, R., Les conditions de l'évolution sexuelle, Communications, nº 35, 1982, pp. 2 - 13.

FrappIER, J., A mour courtois et Table Ronde. Ginebra: Droz, 1973. 
- Vues sur les conceptions courtoises dans les littératures d'oc et d'oil au XIIe siècle, CCM, no 2, vol. II, 1959, pp. 135 - 56.

Freud, S., Psicoanálisis aplicado y técnica psicoanalítica. Madrid: Alianza, 1974.

FrIEDMAN, L. J., «Gradus amoris», Romanœ Philology, vol. 19, 1965-1966, pp. $167-77$.

Furber, D. y Callahan, A., E rotic L ove in L iterature F rom M edieval L egend to Romantic Illusion. Troy: The Whitston Publishing Company, 1982.

García Calvo, A., Los dos sexos y el sexo: las razones de la irracionalidad, Filosofía y sex ualidad. F. Savater (ed.). Barcelona: Anagrama, 1988, pp. $29-54$.

GrIVEL, M., La place d'amour, L e Réait amoureux. C olloque de C erisy. Seyssel: Champ Vallon, 1984, pp. 102 - 18.

Guiraud, P., D ictionnaire historique, stylistique, rhétorique, étymologique de la littérature érotique. París: Payot, 1978.

HARF LANCNER, L., Le Val sans Retour ou la prise du pouvoir par les femmes, A ctes du Colloque «A mour,mariage et transgressions au M oyen A ge». Göppingen: Kümmerle Verlag, 1984, pp. 185 - 93.

HuCHET, J.-Ch., L 'amour discourtois: L a «F in' A mors» chez les premiers troubadours. Toulouse: Privat, 1987.

— La voix d'Héloïse, R omance $\mathrm{N}$ otes. «C ourtly ideology and W oman's place in medieval French Literature», no 3, vol. XXV, 1985, pp. 271 - 87.

— De la perversion en littérature, Poétique, $\mathrm{n}^{\circ}$ 71, vol. XVIII, 1987, pp. $271-90$.

Huot, S., Seduction and Sublimation: Christine de Pizan, Jean de Meun and Dante, Romanœ N otes, no 3, vol. XXV, 1985, pp. 361 - 73.

JEAY, M., Sur quelques coutumes sexuelles du Moyen âge, L 'É rotisme au M oyen A ge. E tudes présentées au IIIe C olloque de l'Institut d'É tudes médiévales. B. Roy (dir.). Montreal: Editions de l'Aurore, 1977, pp. 125 - 39.

JimÉnEZ, M., L'agonie d'Eros. Spectacle et Spéculation, Revue d'E sthétique, no 1 - 2, 1978, pp. 214 - 28.

KARnEIN, A., La réception du D e A more de André le Chapelain au XIIIe siècle, Romania, vol. CII, 1981, pp. 324 - 51.

— Le D e A more et l'enseignement de l'amour dans la littérature française médiévale, Romania, vol. CII, 1981, pp. 502 - 37.

KELLER, H.-E., De l'amour dans le Roman de Brut, Continuations: E ssays on M edieval French L iterature and L anguage. N. J. Lacy y G. Torrini-Roblin (eds.). Birmingham: Summa, 1989, pp. 63 - 81.

KELLERMANN, W., L'éclosion du lyrisme occidental: l'amour vénération, E ntretiens sur la Renaissance du X IIe siècle. D écades du centre culturel international de C erisy-la-Salle. M. de Gandillac y E. de Jeauneau (dir.). París/La Haya: Mouton, 1968, pp. 373 - 405.

KENDRICK, L., The G ame of L ove: Troubadour W ordplay. Berkeley: University of California Press, 1988. 
Kerdelhue, A., Scènes de la vie conjugale du Chevalier au Cygne, A des du colloque «A mour, mariage et transgressions au M oyen A ge». Göppingen:

Kümmerle Verlag, 1984, pp. 103 - 21.

Kristeva, J., H istoires d'amour. París: Denoël, 1983.

LAFONT, R., L e chevalier et son désir. París: Kimé, 1992.

LARMAT, J., Le corps et le langage dans Flamenca, Raz0, nº 2, 1981, pp. 29 42.

LAZAR, M., A mour courtois et fin' amors dans la littérature du X IIe siède. París: Klincksieck, 1964.

Le Chapelain, A., T raité de l'amour ourtois. C. Buridant (ed.). París: Klincksieck, 1974.

LeCERCLE, J.-L., L 'amour de l'idéal au réel. París: Bordas, 1971.

Leupin, A., Le sexe dans la langue: la dévoration. Sur Du c., fabliau du XIIIe siècle, de Gautier Le Leu, Poétique, nº 45, vol. XII, 1981, pp. 91 $-110$.

LORCIN, M. T., L'expression corporelle dans les fabliaux français, Raz0, $\mathrm{n}^{\circ}$ 2, 1981, pp. $43-50$.

Marcuse, H., E ros y Civilización. Barcelona: Seix Barral, 1969.

MARTín, S., El Sexo Sentido, El Independiente, «L ibros», no 52, 7 - III - 91, p. 33.

MoI, T., Desire in Language: Andreas Capellanus and the Controversy of Courtly Love, M edieval Literature: Criticism, Ideology and H istory. D. Aers (ed.). Brighton: The Harvester Press, 1986, pp. 11 - 33.

NeLLI, R., É rotique et aivilisations. París: Weber, 1972.

_ L 'érotique des troubadours. París: UGE, 1974.

L 'amour et les mythes du coeur, suivi de L e corps féminin et l'imaginaire. París: Hachette, 1975.

Ovide, L'art d'aimer. París: Gallimard, 1988.

L es Remèdes à l'amour. París: Gallimard, 1988.

PAstre, J.-M., Par delà le bien et le mal ou l'adultère dans les fabliaux allemands, A ctes du Colloque «A mour,mariage et transgressions au M oyen A ge». Göppingen: Kümmerle Verlag, 1984, pp. 389 - 401.

PAYEN, J.-Ch., Un ensenhamen trop précoce. L 'A rt d'A imer d'André le Chapelain, Mittelalterbilder aus neuer Perspek tive. D isk ussionsantösse zur amour courtois, Subjek tivität in der D ichtung und Strategien der E rzählens. Munich: W.Fink, 1985, pp. 43 - 58.

PAYEN, J.-Ch. y LEgROS, H., La femme et la nuit ou recherches sur le thème de l'échange amoureux dans la littérature courtoise, Senefianœ. M élanges Pierre Jonin, pp. 215 - 25.

PAZ, O., L a llama doble. A mor y erotismo. Barcelona: Seix Barral, 1997.

Rey-Flaud, H., L a N évrose courtoise. París: Navarin, 1983.

RINGGER, K., La biche blanche et le chevalier ou les avatars d'Eros et d'Agapé, Corps écrit, nº 6, 1983, pp. 149 - 58.

Rougemont, D. de, L 'A mour et l'0 ocident. París: Plon, 1979.

Ruiz Domenec, J. E., L a mujer que mira. Crónicas de la cultura cortés. Barcelona: Quaderns Crema, 1986. 
STRASSER, I., Mariage, amour et adultère dans les fabliaux, A ctes du colloque «A mour,mariage et transgressions au M oyen A ge». G öppinger A rbeiten zur G ermanistik. Göppingen: Kümmerle Verlag, 1984, pp. 425 - 30.

VAnCE, E., Love's Concordance: The Poetics of Desire and the Joy of the Text, D iacritics, $\mathrm{n}^{\circ} 5,1975$, pp. 40 - 52.

Victorio, J., E l amor y el erotismo en la L iteratura M edieval. Madrid: Editora Nacional, 1983.

WARD, J., The Nature of Heterosexuality, H eterosex uality. G. E. Hanscombe y M. Humphries (eds.). Londres: GMP Publishers, 1987, pp. 145 69.

YOURCENAR, M., Sur quelques thèmes érotiques et mystiques de la GitaGovinda, L e temps, ce grand saulpteur. París: Gallimard, 1983, pp. 115 28.

ZÉRAFFA, M., Érotique / Esthétique, Rérue d'E sthétique, nº 1 - 2, 1978, pp. $107-25$.

ZINK, M., La tristesse du coeur dans le «Livre du Cuer d'Amours espris» de René d'Anjou, L e Récit amoureux. Colloque de C erisy. Seyssel: Champ Vallon, 1984, pp. 22 - 38.

\section{FILOSOFÍA Y ESTÉTICA.}

BRUYNE, E. de, É tudes d'E sthétique médiévale. Tomo III. Ginebra: Slatkine Reprints, 1975.

Coomaraswamy, A. K., T eoría medieval de la belleza. Palma de Mallorca: José J. de Olañeta, 1987.

Chydenius, J., La théorie du symbolisme médiéval, Poétique, nº 23, 1975 , pp. 322 - 41

Hirsch, Ch., E l árbol. Barcelona: Plaza y Janés, 1989.

\section{PARTICULARES.}

\subsection{BÉ ROUL Y LE ROMANDE TRISTAN.}

BARTEAU, F., L es romans de Tristan et Y seut. Introduction à une lecture plurielle. París: Larousse Université, 1973.

BATANY, J., Imaginaire et grammaire du mythe: les systèmes hypothétiques chez Béroul, A ctes du olloque «T ristan et Iseut, mythe européen et mondial». Göppingen: Kümmerle Verlag, 1987, pp. 7 - 19.

Béroul, L e Roman de Tristan. Poème du X IIe siède. Ernest Muret (ed.); 4e édition revue par L. M. Defourques. París: Honoré Champion. CFMA, 1982.

Tristán et Iseo. R. Ruiz Capellán (ed. y trad.). Madrid: Cátedra, 1985. 
Burns, E. J., How Lovers Lie Together: Infidelity and Fictive Discourse in the Roman de Tristan, Tristania, $\mathrm{n}^{\circ}$ 2, vol. 8, 1983, pp. 15 - 30.

Busby, K., Le Tristan de Béroul en tant qu'intertexte, C ontinuations: E ssays on M edieval French L iterature and L anguage in $\mathrm{H}$ onor of John L. G rigsby. Birmingham: Summa, 1989, pp. 19 - 37.

Chernack Zovic, N., L es espaces de la transgression dans le Tristan de Beroul (tesis). Cambridge: Harvard University, 1989.

Dubuis, R., D ru et D rüerie dans le Tristan de Béroul, Senefianœ. Mélanges Pierre Jonin, $\mathrm{n}^{\circ}$ 7, 1979, pp. $223-31$.

Dussol, É., À propos du Tristan de Béroul: Du mensonge des hommes au silence de Dieu, E $t$ c'est la fin pour quoy sommes ensemble. H ommage à Jean D ufournet. Tome II. J.-C. Aubailly; E. Baumgartner; F. Dubost; L. Dulac; M. Faure (eds.). París: Champion, 1993, pp. 525 - 33.

Ferroul, Y., La passion selon Tristan et Iseut, E t c'est la fin pour quoy sommes ensemble. H ommage à Jean D ufournet. T ome II. J.-C. Aubailly; E. Baumgartner; F. Dubost; L. Dulac; M. Faure (eds.). París: Champion, 1993 , pp. $571-8$.

FrAPPIER, J., Structure et sens du Tristan, version commune, version courtoise, CCM , no 4, vol. VI, 1963, pp. 441 - 54.

GATES, L. D., Precisions on the use of irony in Béroul's «Tristan», Tristania, vol. XIV, 1993, pp. 15 - 29.

GeHAnne, D., Le vocabulaire amoureux dans les Tristans, Médiévales, no 3 , 1983, pp. $68-75$.

GIDDEY, J.-L., Effets du philtre, efforts du verbe dans le Tristan de Béroul, É tudes de L ettres, vol. 2 - 3, 1987, pp. 105 - 12.

GoutTeBroze, J.-G., Tristan ou l'inceste impose, Tristan et Iseut, mythe européen et mondial. A des du colloque. Göppingen: Kümmerle Verlag, 1987, pp. 127 - 38.

JOHNSON, Ph., «Dolor, dolent» et «soi doloir»: le vocabulaire de la douleur et la conception de l'amour selon Béroul et Thomas, Romanœ Philology, vol. XXVI, 1972 - 73, pp. 546 - 54.

JONIN, P., L es personnages féminins dans les romans français de Tristan au X IIe siède. É tude des influenoes contemporaines. Gap: Ophrys, 1958.

_ L La ruse d'Yseut dans le Tristan de Béroul, $\mathrm{H}$ ommage au doyen É tienne G ros. Gap: Ophrys, 1959, pp. 77 - 84.

Kakar, S. y Munder Ross, J., L es Pièges de l'amour érotique. París: PUF, 1987.

LARMAT, J., La religion et les passions dans le Tristan de Béroul, M élanges de Philologie et de L ittératures romanes offerts à Jeanne W athelet-W illem. M arche Romane. Jacques De Caluwé (ed.). Lieja: Université de Liège, 1978, pp. $327-45$.

LE GeNTIL, P., La légende de Tristan vue par Béroul et Thomas. Essai d'interprétation, Romanœ Philology, vol. VII, 1953 - 1954, pp. 111 - 29.

LEGROS, H., Du verger royal au jardin d'amour: mort et transfiguration du locus amoenus (d'après Tristan de Béroul et Cligès), Senefiance, $\mathrm{n}^{\circ}$ 28, 1990, pp. $215-34$. 
LEJEUnE-DeHOusSE, R., Les «influences contemporaines» dans les romans français de Tristan au XIIe siècle, L e M oyen A ge, 1960, pp. 143 - 62.

OlLIER, M.-L., Le statut de la vérité et du mensonge dans le Tristan de Béroul, Tristan et Iseut, mythe européen et mondial.. Göppingen: Kümmerle Verlag, 1987, pp. 298 - 318.

— Le péché selon Yseut dans le Tristan de Béroul, Courtly Literature: culture and contex t. K. Busby y E. Kooper (eds.). Amsterdam/Filadelfia: John Benjamins, 1990, pp. 465 - 82.

OrTIZ, L., E l sueño de la pasión. Barcelona: Planeta, 1997.

PAYEN, J.-Ch., Ordre moral et subversion politique dans le Tristan de Béroul, M élanges offerts à Jeanne L ods. C ollection de l'É oole N ormale Supérieure de Jeunes F illes. París, 1978, pp. 473 - 84.

_ Irréalisme et crédibilité dans le Tristan de Béroul, M élanges de Philologie et de L ittératures romanes offerts à Jeanne W athelet-W illem. M arche Romane. J. De Caluwé (ed.). Lieja: Université de Liège, 1978, pp. 465 - 75.

PITTS, B. A., The Path of Memory: Imagination and Repetition in Béroul's Roman de Tristan, Romance Q uarterly, no 1, vol. 37, 1990, pp. 3 - 17.

POIRION, D., Tristan: du mythe antique au symbole médiéval, Résurgenoes. Mythe et littérature à l'âge du symbole (X IIe siède). París: PUF, 1986, pp. $79-97$.

— Le Tristan de Béroul: récit, légende et mythe, L 'Information L ittéraire, ${ }^{\circ}$ 5, vol. XXVI, 1974, pp. 199 - 207.

REISS, L. H., Tristan and Isolt and the Medieval Ideal of Friendship, Romanœ Q uarterly, no 2, vol. XXXIII, 1986, pp. 131 - 7.

REY-FLAud, H., «Teste» et «chef» dans le T ristan de Béroul, M élanges de Philologie R omane offets à Charles Camproux. Montpellier: C.E.O., 1978, Tomo I, pp. 451 - 58.

SARgENT-BAUR, B. N., Between Fabliau and Romance: Love and Rivalry in Beroul's Tristran, Romania, $\mathrm{n}^{\circ} 2$ - 3, vol. CV, 1984, pp. 292 - 311.

_ La dimension morale dans le Roman de Tristan de Béroul, CCM, vol. XXXI, 1988, pp. 49 - 56.

Subrenat, J., Sur le climat social, moral, religieux du Tristan de Béroul, L e M oyen A ge, no 2, vol. 82, 1976, pp. 219 - 61.

VITZ, E. B., Orality, literacy and the early Tristan material: Beroul, Thomas, Marie de France, Romanic Review, no 3, vol. LXXVIII, 1987, pp. 299 310.

Wallenbrock, C., Ambiguity in the Symbolic Elements in Beroul's Tristan, Tristania, vol. XIV, 1993, pp. 129 - 38.

Wright, L., "Burning" and Leprosy in Old French, M edium A evum, no 1, vol. 56, 1987, pp. 101 - 11.

YLLERA, A., «Amoun», «amistié» en las novelas de Tristan en verso. Un aspecto del vocabulario afectivo de Béroul y Thomas, Filología M oderna, no 63 - 64, vol. XVIII, 1978, pp. 271 - 99. 


\subsection{CHRÉTIEN DE TROYESY SU OBRA.}

ACCARIE, M., L'éternel départ de Lancelot. Roman clos et roman ouvert chez Chrétien de Troyes, M élanges de langue et de littérature médiévales offerts à A liœ Planche. A nnales de la F aculté des L ettres et Sciences humaines de N iœ. París: Les Belles Lettres, 1984, pp. 1 - 19.

_ Guenièvre et son chevalier de la charrete: l'orgasme des anges, E t c'est la fin pour quoy sommes ensemble. H ommage à Jean D ufournet. Tome I. J.-C. Aubailly, E. Baumgartner, F. Dubost, L. Dulac y M. Faure (eds.). París: Honoré Champion, 1993, pp. 46 - 54.

Beltrami, P. G., Chrétien de Troyes, l'amour, l'adultère. Remarques sur le «Chevalier de la Charrete», A ctes du X IV e Congrès international arthurien. V ol. I. Rennes: Presses Universitaires, 1985, pp. 59 - 69.

Bezzola, R. R., L e Sens de l'aventure et de l'amour. Chrétien de Troyes. París: La Jeune Parque, 1947.

Bouvier-AjAm, M., Chrétien de Troyes dans son temps, E urope, no 642, 1982, pp. 16 - 26.

Colas, L., Chrétien de Troyes: le corps et le geste, E urope, nº 642, 1982, pp. $105-13$.

ColBy, A., The Portrait in twelth-œntury F rench Literature. A n ex ample of the stylistic originality of Chrétien de Troyes. Ginebra: Droz, 1965.

CHANDĖs, G., L e serpent, la femme et l'épée. Recherches sur l'imagination symbolique d'un romancier médiéval: C hrétien de Troyes. Amsterdam: Rodopi, 1986.

_ Recherches sur l'imagerie des eaux dans l'oeuvre de Chrétien de Troyes, C CM, vol. XIX, 1976, pp. 151 - 64.

Chaurand, J., Quelques réflexions sur l'hyperbole dans L e C hevalier de la Charrete, M élanges offerts à Felix L ecoy. París: Champion, 1973, pp. 43 53.

CHÊNERIE, M.-L., L e C hevalier errant dans les romans arthuriens en vers des X IIe et X IIIe sièdes. Ginebra: Droz, 1986.

DAuphiné, J., Le thème de l'amour dans le conte du Graal, E urope, no 642, 1982, pp. $115-20$.

DRAGONETTI, R., Le vent de l'aventure dans Y vain ou le Chevalier au Lion de Chrétien de Troyes, L e M oyen A ge, no 3 - 4, vol. XCVI, 1990, pp. 435 $-62$.

Duplat, A., Étude stylistique des formules de salutation chez Chrétien de Troyes, T ravaux de Linguistique et de L ittérature, n 1, vol. XIII, 1975, pp. $107-43$.

_ Étude stylistique des apostrophes adressées aux personnages féminins dans les romans de Chrétien de Troyes, CCM, vol. XVII, 1974, pp. 129 - 52.

FrAPPIER, J., Le prologue du Chevalier de la Charrete et son interprétation, Romania, vol. XCIII, 1972, pp. 337 - 77.

Chrétien de Troyes. París: Hatier, 1957.

Freeman, M. A., Transpositions structurelles et intertextualité: Le Cligès de Chrétien, L ittérature, n 41, 1981, pp. 50 - 61. 
GaLlais, P., D ialectique du récit médiéval. Chrétien de Troyes et l'hex agone logique. Amsterdam: Rodopi, 1982.

— Méléagant et la contradiction, A ctes du oolloque «L ancelot». D.

Buschinger (ed.). Göppingen: Kümmerle Verlag, 1984, pp. 39 - 49.

Galdien, S., L a C onception sentimentale de C hrétien de Troyes. París: Nizet, 1975.

GARCía GuAL, C., H istoria del rey A rturo y de los nobles y errantes caballeros de la Tabla Redonda. Madrid: Alianza Editorial, 1984.

Gravdal, K., Chrétien de Troyes, Gratian, and the Medieval Romance of Sexual Violence, Signs: Journal of W omen in Culture and Society, $\mathrm{n}^{\circ} 3$, vol. 17, 1992 , pp. $558-85$.

HANnING, R. W., Love and Power in the Twelfth Century, with Special Reference to Chrétien de Troyes and Marie de France, The Olde D aunce. L ove, Friendship, Sex, and Marriage in the M edieval W orld. R. R. Edwards y S. Spector (eds.). Albany: State University of New York Press, 1991, pp. 87 - 103.

JONIN, P., L'espace et le temps de la nuit dans les romans de Chrétien de Troyes, M élanges de langue et de littérature médiévales offerts à A liœ Planche. A nnales de la Faculté des L ettres et Sciences humaines de $\mathrm{N}$ ice. París: Les Belles Lettres, pp. 235 - 46.

Kelly, D., Chrétien de Troyes: The Narrator and His Art, The R omances of Chrétien de Troyes. A Symposium. D. Kelly (ed.). Lexington: French Forum, 1985, pp. 13 - 47.

— The Logic of the Imagination in Chrétien de Troyes, The Sower and his Seed. E ssays on C hrétien de Troyes. R. T. Pickens (ed.). Lexington: French Forum, 1983, pp. 9 - 30.

KÖHLER, E., Le rôle de la «coutume» dans les romans de Chrétien de Troyes, Romania, vol. LXXXI, 1960, pp. 386 - 97.

LEFAY-TOURY, M.-N., L a tentation du suicide dans le roman français du X IIe siède. París: Fayard, 1979.

Lot-Borodine, M., L a femme et l'amour au X Ile siède d'après les poèmes de Chrétien de Troyes. Ginebra: Slatkine Reprints, 1967.

Love, N., Why tu, rather than vous, in Chrétien de Troyes' L e Chevalier de la Charrete?, L ingvisticae Investigationes, $\mathrm{n}^{\circ}$ 1, vol. XI, 1987, pp. 115 - 27.

Maddox, D., The Awakening: A Key Motif in Chrétien's Romances, The Sower and his Seed. E ssays on Chrétien de Troyes. R. T. Pickens (ed.). Lexington: French Forum, 1983, pp. 31 - 51.

— The A rthurian Romances of $\mathrm{C}$ hrétien de Troyes. 0 nœ and future fictions. Cambridge: Cambridge University Press, 1991.

Martineau GENiEYs, Ch., De Lancelot à Tristan, ou plutôt d'Iseut aux Blanches Mains à la demoiselle entreprenante: la preuve par la chair, T ristan et Iseut, mythe europén et mondial.. Göppingen: Kümmerle Verlag, 1986, pp. 252 - 61.

MelHado White, S., Lancelot's Beds: Styles of Courtly Intimacy, The Sower and his Seed. E ssays on C hrétien de Troyes. R. T. Pickens (ed.). Lexington: French Forum, 1983, pp. 116 - 26. 
Molle, J. V., Le réalisme des cérémonies et des conventions sociales dans le L ancelot de Chrétien de Troyes, A ctes du C olloque «L anoelot». D.

Buschinger (ed.). Göppingen: Kümmerle Verlag, 1984, pp. 117 - 34.

Monson, D. A., La «surenchère» chez Chrétien de Troyes, Poétique, nº 70, vol. XVIII, 1987, pp. 231 - 46.

MoyA, M.-H., Les couleurs dans la structure narrative du L anœlot, Sénéfianœ, $\mathrm{n}^{\circ} 24,1988$, pp. $275-83$.

PAYEN, J.-Ch., Lancelot contre Tristan: la conjuration d'un mythe subversif (Réflexions sur l'idéogie romanesque au Moyen Age), M élanges Pierre L e G entil. París: SEDES, 1973, pp. 617 - 32.

POIRION, D., Symbole et conjointure du roman: Chrétien de Troyes, Résurgences. M ythe et littérature à l'âge du symbole (X IIe siède). París: PUF, 1986, pp. 135 - 87.

RAABE, P., Chrétien's L anœlot and the Sublimity of Adultery, U niversity of Toronto Q uarterly, no 2, vol. 57, 1987/8, pp. 259 - 69.

RIBARD, J., Les Romans de Chrétien de Troyes sont-ils allégoriques?, CA IE F, vol. XXVIII, 1976, pp. 7 - 20.

Chrétien de Troyes, L e C hevalier de la Charrette. E ssai d'interprétation symbolique. París: Nizet, 1972.

SALY, A., L'épisode du pré aux jeux dans le C hevalier de la Charrette, A ctes du Colloque «L anœlot». Danielle Buschinger (ed.). Göppingen: Kümmerle Verlag, 1984, pp. 191 - 7.

__ La demoiselle "esforciee" dans le roman arthurien, A des du Colloque «A mour, mariage et transgressions au M oyen A ge». Göppingen: Kümmerle Verlag, 1984, pp. 215 - 24.

SZABICS, I., Les visages de l'amour dans les romans de Chrétien de Troyes, A cta litteraria A cademiae scientarum hungaricae, no 3 - 4, vol. XXXII, 1990, pp. 221 - 32.

TOMARYN BrUCKNER, M., Le Chevalier de la Charrette (Lancelot), The Romanœes of Chrétien de Troyes. A Symposium. D. Kelly (ed.). Lexington: French Forum, 1985, pp. 132 - 81.

VANCE, E., Le combat érotique chez Chrétien de Troyes. De la figure à la forme, Poétique, no 12, vol. III, 1972, pp. 544 - 71.

VERCHÈre, Ch., Du mépris à la méprise: l'impossible retour de Lancelot du Lac, CC M, no 2, vol. XXV, 1982, pp. 129 - 37.

VoICU, M., La description chez Chrétien de Troyes: lecture des signes, "effet de réel" ou "effet de texte", A ctes du X X e C ongrès International de L inguistique et Philologie Romanes. Tomo V, Sección VIII - L 'art narratif aux X IIe et X IIIe sièdes. Tubinga: A. Francke, 1993, pp. 429 42.

WALTER, Ph., Lancelot, l'archange apocryphe (reminiscences et re-écriture dans le C hevalier de la Charrette), L ancelot. A ctes du colloque «L ancelot». Danielle Buschinger (ed.). Göppingen: Kümmerle Verlag, 1984, pp. $225-38$.

Williamson, J. B., Suicide and adultery in L e C hevalier de la Charrete, M élanges offerts à Jeanne L ods. París: E.N.S., 1978, pp. 571 - 87. 


\subsection{JEAN RENART Y L'ESCOUFLE.}

BlakeSLEE, M. R., Les allusions aux romans de Tristan dans l'oeuvre de Jean Renart: études des sources, A ctes du Colloque «Tristan et Iseut, mythe europén et mondial». Göppingen: Kümmerle Verlag, 1987, pp. 42 $-58$.

CORTÉs ZABOrRAs, C., Jean Renart. L'Humanisme dans les romans aristocratiques du XIIIe siècle; une esthétique nouvelle, E studios humanístioos en homenaje a L uis C ortés V ázquez. R. Dengler Gassin (ed.). Salamanca: Universidad de Salamanca, 1991, vol. I, pp. 147 - 59.

DiLLER, G. T., L 'E scoufle. Une aventurière dans le roman courtois, L e M oyen A ge, no 1, vol. 85, 1979, pp. 33 - 43.

LARmat, J., La morale de Jean Renart dans le L ai de l'ombre, M élanges de Philologie Romane offerts à Charles C amproux (I). Montpellier: C.E.O., 1978, pp. 407 - 16.

Lejeune-DeHousse, R., L 'oeuvre de Jean Renart. C ontribution à l'étude du genre romanesque au M oyen A ge. París: Droz, 1935.

_ Le personnage d'Aélis dans le Roman de l'E scoufle de Jean Renart, Mélanges offerts à Jeanne L ods. París: E.N.S., 1978, pp. 378 - 92.

Poirion, D., Fonction de l'imaginaire dans L'E scoufle, Mélanges Charles Foulon (I). 1980, pp. 287 - 93.

Renart, J., L e R oman de la R ose ou de G uillaume de D ole. Félix Lecoy (ed.). París: Honoré Champion, 1979.

— L 'E scoufle. Franklin Sweetser (ed.). París/Ginebra: Droz, 1974.

ZINK, M., R oman rose et rose rouge. París: Nizet, 1979.

\subsection{LE ROMAN DE LA ROSE, GUILLAUME DE LORRIS.}

ACCARIE, M., La vie n'est pas un songe. Théorie et pratique chez Guillaume de Lorris, C ontemporary R eadings of M edieval L iterature. G. Mermier (ed.). Ann Arbor: University of Michigan, 1989, pp. 115 - 42.

Agamben, G., N arcisse. Stanze: Christian Bourgeois éditeur, 1981.

BAtAny, J., Paradigmes lexicaux et structures littéraires au Moyen Age, Revue d'H istoire L ittéraire de la Franœ, 1970, pp. 819 - 35.

— Miniature, allégorie, idéologie: «Oiseuse» et la mystique monacale récupérée par la «classe de loisir», É tudes sur le Roman de la R ose de $\mathrm{G}$ uillaume de L orris. J. Dufournet (ed.). París: Honoré Champion, 1984, pp. 7 - 36.

_ A pproches du «Roman de la R ose». París: Bordas, 1973.

BAUMgartNer, E., «L'Absente de tous bouquets...», É tudes sur le Roman de la Rose de G uillaume de L orris. J. Dufournet (ed.). París: Honoré Champion, 1984, pp. 37 - 52.

DragonetTI, R., Specchi d'amore «il romanzo della rosa e il fiore», L a musique et les lettres. É tudes de littérature médiévale. Ginebra: Droz, pp. 399 - 418. 
Dufournet, J., Le dessein et la philosophie du Roman de la Rose, A da L itteraria A cademiae Scientiarum H ungaricae, $\mathrm{n}^{\circ} 3$ - 4, vol. XXIII, 1981, pp. 177 - 214.

_ L'amour d'un Roman de la R ose à l'autre (de Jean Renart à Guillaume de Lorris), A nnales U SB, vol. XIX, 1989 - 1990, pp. 51 - 9.

FrappIER, J., Le thème de la lumière de la Chanson de Roland au Roman de la Rose, $\mathrm{H}$ istoire, mythes et symboles. E tudes de littérature francaise. Ginebra: Droz, 1976, pp. 181 - 98.

Friedman, J. B., L'iconographie de Vénus et de son miroir à la fin du Moyen âge, L 'érotisme au M oyen A ge. É tudes présentées au IIIe C olloque de l'Institut d'E tudes médiévales. Bruno Roy (dir.). Montreal: Editions de l'Aurore, 1977, pp. 53 - 82.

GAGNÉ, J., L'érotisme dans la musique médiévale, L 'érotisme au M oyen A ge. E tudes présentées au IIIe C olloque de l'Institut d'É tudes médiévales. Bruno Roy (dir.). Montreal: Éditions de L'Aurore, 1977, pp. 85 - 107.

GunN, A. M. F., The M irror of L ove. A reinterpretation of «T he R omance of the Rose». Lubbock: Texas Tech Press, 1952.

HICKS, E., La mise en prose des formes allégoriques: hypostase et récit chez Guillaume de Lorris, É tudes sur le Roman de la Rose de G uillaume de L orris. J. Dufournet (ed.). París: Honoré Champion, 1984, pp. 53 81.

JAUSS, H. R., La transformation de la forme allégorique entre 1180 et 1240: d'Alain de Lille à Guillaume de Lorris, L 'H umanisme médiéval dans les littératures romanes du X IIe au X IV e siède. A. Fourrier (ed.). París: Klincksieck, 1964, pp. 107 - 46.

Kamenetz, G., La Promenade d'Amant comme expérience mystique, É tudes sur le Roman de la R ose de G uillaume de L orris. J. Dufournet (ed.). París: Honoré Champion, 1984, pp. 83 - 104.

KAY, S., Sexual knowledge: the once and future texts of the Romanœ of the Rose, T ex tuality and sex uality. Reading theories and practioes. Judith Still y Michael Worton (eds.). Manchester/Nueva York: Manchester University Press, 1993, pp. 69 - 86.

KELLY, D., Du narcisse des poètes à la rose des amants: le jeu de la vérité chez Guillaume de Lorris, E t c'est la fin pour quoy sommes ensemble. H ommage à Jean D ufournet. Tome II. J.-C. Aubailly, E. Baumgartner, F. Dubost, L. Dulac y M. Faure (eds.). París: Honoré Champion, 1993, pp. $793-800$.

KÖHLER, E., Narcisse, la fontaine d'Amour et Guillaume de Lorris, L 'H umanisme médiéval dans les littératures romanes du X IIe au X IV e sièdle. A. Fourrier (ed.). París: Klincksieck, 1964, pp. 147 - 66.

Larmat, J., Le jardin de Déduit dans le Roman de la Rose de Guillaume de Lorris, Mélanges de langue et de littérature médiévales offerts à A liœ Planche. A nnales de la Faculté des L ettres et Scienos humaines de N iœ. París: Les Belles Lettres, 1984, pp. 263 - 72. 
Lejeune-Dehousse, R., À propos de la structure du Roman de la Rose de Guillaume de Lorris, M élanges offerts à F elix L ecoy. París: Champion, 1973, pp. $315-48$.

Lorris, G. y DE Meun, J., L e Roman de la Rose. Tomo I. F. Lecoy (ed.). París: Honoré Champion. CFMA, 1983.

— L e Roman de la Rose. Tomo III. F. Lecoy (ed.). París: Honoré Champion. CFMA, 1982.

Louis, R., L e Roman de la Rose. E ssai d'interprétation de l'allégorie érotique. París: Champion, 1974.

NouveT, C., Les inter-dictions courtoises: le jeu des deux bouches, Romanic Review, n 3, vol. LXXVI, 1985, pp. 233 - 50.

— On The Way Toward Love, A merican Imago, no 3, vol. 50, 1993, pp. $325-51$.

NykroG, P., L 'amour et la rose. L e G rand D essein de Jean de M eun. Lexington: French Forum Publishers, 1986.

PAYEN, J.-Ch., L'espace et le temps dans le Roman de la Rose, É tudes de L angue et de L ittérature françaises offertes à A ndré L anly. Nancy: Université Nancy II, 1980, pp. 287 - 99.

__ L'Art d'aimer chez Guillaume de Lorris, É tudes sur le Roman de la Rose de G uillaume de L orris. J. Dufournet (ed.). París: Honoré Champion, 1984, pp. 105 - 44.

PoIrion, D., L e Roman de la Rose. París: Hatier, 1973.

- Les mots et les choses selon Jean de Meun, L 'Information littéraire, $n^{\circ} 1$, vol. XXVI, 1974, pp. 7 - 11.

RIBARD, J., Introduction à une étude polysémique du Roman de la Rose de Guillaume de Lorris, M élanges offerts à F elix L ecoy. París: Champion, 1973, pp. 519 - 28.

SASAKI, S., Le jardin et son estre dans L e Roman de la Rose et dans L e dit dou L yon, CA IE F, vol. XXXIV, 1982, pp. 25 - 37.

STRuBEL, A., L'allégorisation du verger courtois, Senefianœ, n² 28, 1990, pp. $343-58$.

_ Écriture du songe et mise en oeuvre de la senefiance dans le Roman de la Rose de Guillaume de Lorris, É tudes sur le Roman de la Rose de $\mathrm{G}$ uillaume de L orris. J. Dufournet (ed.). París: Honoré Champion, 1984, pp. 145 - 79.

UITTI, K.D., Understanding Guillaume de Lorris: the truth of the couple in Guillaume's R omance of the Rose, C ontemporary Readings of M edieval Literature. G. Mermier (ed.). Ann Arbor: University of Michigan, 1989, pp. $51-70$.

VITZ, E. B., The I of the Roman de la Rose, G enre, vol. VI, 1973, pp. 49 - 75.

ZumThor, P., De Guillaume de Lorris à Jean de Meung, M élanges offerts à

Felix L ecoy. París: Champion, 1973, pp. 609 - 20. 